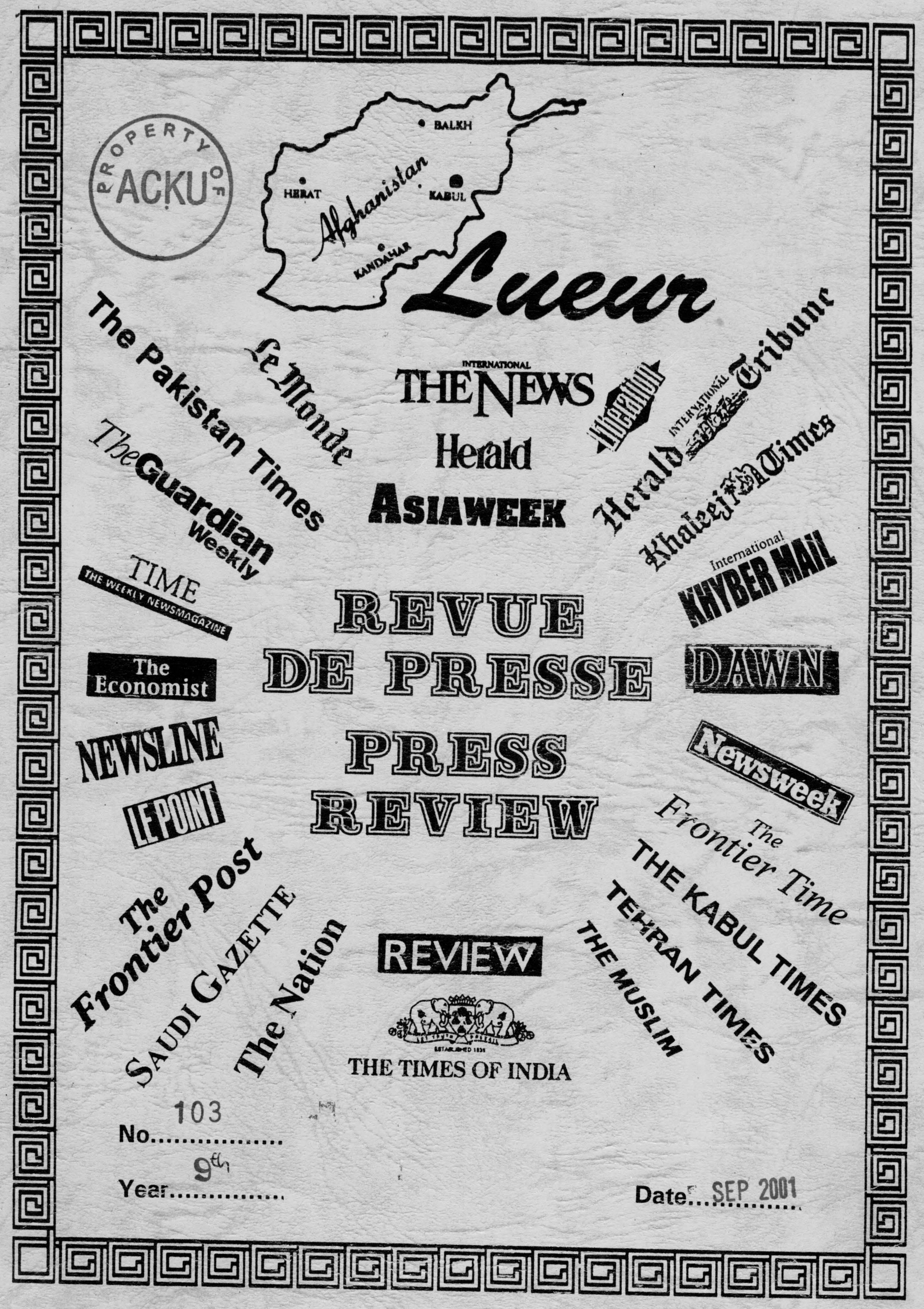




\section{REVUE DE PRESSE No! 03 PRESS REVIEW No}

Cette Revue de Presse rassemble sur une base mensuelle et hebdomadaire les principales informations concernant l'actualité en Afghanistan à partir des quotidiens suivants de langue anglaise : The Pakistan Times, Tehran Times, The Times of India, Statesman, The News, Khyber Mail, The Nation, Dawn, Pakistan Observer, Khaleej Times, Herald Tribune, Friday Times, ... ainsi que The Kabul Times publié à Kaboul, en Afghanistan.

Les articles relatifs à l'Afghanistan dans les mensuels ou magazines tels que : Diplomat, Competitor, Herald, Newsweek, Time, Asia Weck, The Economist, The Guardian, Newsline, Press Review, New York Times ou dans toute autre publication en anglais sont également inclus. Par ailleurs, cette Revue mensuelle comporte une annexe française dans la deuxièment partie de document.

Nous avons volontairement opté pour une classification simple : les articles sont presentés par quotidien et par jour, toujours dans le mème ordre chronologique d'utilisation facile.

L'équipe de "LUEUR" (association culturelle afghane responsable du PCFA, Programme Culturel Franco-Afghan et du CPA à Kaboul, Centre Pédagogique Afghan) a le plaisir de vous proposer cette revue de presse et souhaite qu'elle soit une source supplémentaire d'informations sur la situation en Afghanistan.

Vous trouverez un index thématique en début de document ainsi qu'un index alphabétique en fin de document.

$* * * * * * * * * * * * * * * * * * * * * * *$

The Press Review collects, on a monthly or a weekly basis, the main news items concerning Afghanistan found in the daily newspapers namely, The Pakistan Times, Tehran Times, The Times of India, Statesman, The News, Khyber Mail, The Nation, Dawn, Pakistan Observer, Khaleej Times, Herald Tribune, Friday Times,.. . as well as The Kabul Times, published in Kabul, Afghanistan. Our Press Review also comprises French news.

Any articles relating to Afghanistan published in the monthly or the weekly publications such as Diplomat, Competitor, Herald, Newsweek, Time, Asia Week, The Economist, The Guardian, Newsline, Press Review, New York Times and others are also included

Articles and new items are presented chronogically and by newspaper. In order to further facilitate the use of Press Review all items are listed in a thematic index at the beginning of the review and an alphabetical index at the end. I

The team of the Afghan Cultural Association "LUEUR" hopes that this issue of Press Review will provide an additional source of data on the situation in Afghanistan.

Pour de plus amples informations :

For further details :

LUEUR

-c/o PCFA, C27, Spinzar Plaza, Jamrud Road, Jehangirabad, UPO Box 1460, University Town, Peshawar, PAKISTAN -c/o CPA Kaboul, H.30 St.4, Shar-e-Naw, Post Box. 1644

Kabul - AFGHANISTAN. 


\title{
INDEX THEMATIQUE/THEMATIC INDEX
}

\section{DOMESTIC AFFAIRS 1] Political Aspects}

\begin{abstract}
1a) - Afghan leaders: 2, 10, 66, 130, 133, 162, 167, 171, $174,181,183,184,191,192,193,195,200,201,202,203$, $204,206,207,208,209,215,216,217,218,219,224,228$, $230,232,265,266,268,268,269,272,278,280,281,285$, $287,299,300,308,309,311,315,316,329,324,326,328$, $331,333,337,340,346,347,354,358,363,367,368,373$, $379,381,385,387,388,391,396,403,422-424,448,451$, $454,455,460,461,463,468,469,475,480,481,506,509$, $510,517,524,526,529,532,533,537,538,541,552,555$.

1b) - Kabul: 5, 7, 83, 144, 145, 149, 151, 152, 173, 194, $211,218,224,226,230,232,283,286,287,333,341,360$, $376,380,388,399,400,403,463,477,509,516,526,537$, 560 .

1c)- Situation in the provinces: $34,38,61,62,111,161$, $162,175,184,212,213,276,319,325,326,329,351,354$, $355,372,431-433,449,456,457,461,530,547,558$.

1d)-Peace prospects: 36, 178 .

1e)- Interference: $36,112,135$.
\end{abstract}

\section{2] Civil Society}

2a)- Refugees: $1,3,4,5,6,89,10,12,14,19,20,21$, $26,27,28,29,31,33,34,35,36,37,39,40,41,55,56$, $63,75,76,77,78,85,87,95,96,97,105,108,111,116$, $117,134,136,137,139,143,146,153,154,155,158,169$, $170,172,173,174,175,180,204,205,211,212,269,277$, $306,307,330,345,347,371,377,389,400,428,446,468$, $476,477,510,527,528,529,537,545,552,559,560$.

2b) - Health: 139, 149 . 
2c)- Women: 5, 337, 378, 452, 478, 558 .

2d)-Comments: $7,11,12,13,14,18,22,23,24,41,42$, $43-45,46,47,48,49-53,56,57,58,64,65,68,69,70$, $72-75,78,79,93,94,95,97-101,102,103,104,113,114$, $115,117-124,125,, 126,127,159,160165,166,186,187$, $188,189,190,195,196,197,198,199,200,214,215,221$, $225,236,237,238-241,245-249,263,264,300-303,305$, $306,312,313,314,315,335,360,365,366,402,404,405$, $406,407,408,409,410,411,412,413,414,415,416,419$, $420,421,433-438,439-442,443,444,456,457,469,470$, $478,479,481,482,483,484,485,486,487,488,489,490$, $492,493,494,495-500,501-503,504,505,512,513,514$, $515,516,542,543,555,556,557$.

2e)- Terrorists: 210, 272, 273, 299, 300, 353, 362, 372, $375,383,394,419,420,421,451$.

2f) - Terrorism: 353, 358, 367 .

2g)-Drugs: 1, 25, 32, 34, 39, 62, 63, 83, 148, 174, 231.

2h) - Smuggling: 1, 32, 34, 62, 174, 231.

2i)-Education: 5, 182 .

2j)- Fighting: 83, 109, 111, 140, 162, 164, 172.

2k) - Trading: 142, 147, 234.

21)-Killing: 1, 61, 85, 111, 163, 173, 213.

2m) - Bombing: $38,136,167,200,201,202,275,450$.

2n)- Demining: 213, 540 .

20)- Children: 158, 452, 465.

2p) - P.O.Ws: $177,183,372$.

2q)-Sanctions: 138

2r)-Drought: 24,146 .

2s)-Execution: 128, 133 . 
2t)- Explosion: 157, 171, 173, 218, 226, 340 .

2u)- Culture: 182,337 .

2v)- Sports: 378,527 .

\section{FOREIGN RELATIONS 1] Regional Affairs}

1a)-Pakistan: 3, 148, 158, 185, 195, 216, 227, 268, 271, $275,278,282,286,290,291,292,310,332,336,369,371$, $386,401,431-433,450,452,460,471,473,474,491,530$, 557 .

1b) - Iran: $35,62,146,177,217,229,330,379,388,461$, $462,522$.

1c) - Kashmir: 377,491 .

1d)- India: $229,269,310,318,347,363,379,398,461$, $466,471$.

1e)- Tajikistan: 224, 271, 281, 326, 380, 451.

1f) -' China: $185,320,321,333,344,395,398$.

Ig)-Uzbekistan: 293, 294, 447, 477 .

\section{2] Arab countries}

2a)- Saudi Arabia: 137, 448, 462, 539.

2b) - U.A.E: 283, 427, 428, 446, 510 .

2c)- Kuwait: $38,424,425,426$.

2d)- Greece: 62, 190. 


\section{3] Others countries}

3a) - United States of America: 9, 33, 83, 109, 176, 179, $180,191,210,211,212,213,214,217,220,222,228,229$, $231,233,242,243,244,245,249,250,251,252,253-256$, $257,258,259,260,261,268,269,270,271,273,274,281$, $282,283,286,287,288,289,290,291,292,293,294,295$, $296,297,298,300-303,304,308,309,310,317,321,322$, $323,328,330,332,334,338,339,340,341,343,344,346$, $347,353,359,361,362,363,367,369,398,399,401,403$, $404,416,417,418,422-424,429,430,431,439-442,445$, $447,448,449,450451,452,459,463,465,467,468,469$, $475,477,491,507,508,509,511,517,520,522,526,527$, $534,539,541,543,545,549,550,553,559,561,562$.

3b)-Russia: 161, 175, 195, 229, 273, 337, 342, 352, 353, $356,378,461,467,468,475,476,521,528,555$.

$3 c)-$ U.K: 71, 72, 180, 231, 351, 355, 454, 520, 529, 546.

3d)- Germany: 382 .

3e)-France: 71, 72, 76, 112, 148, 185, 191, 193, 206, 207, 208.

3f)- Japan: 345 .

$3 g)$ - Australia: 2, 10, 12, 15, 31, 36, 37, 39, 40, 76, 77, $78,81,82,102,108,111,134,150,153,154,155,156$, $204,205,206,273,306,307$.

3h) - Indonesia: 4, 164, 375 .

3i) - Norway: $8,81,82$.

3j)- Newzerland: 15, 28, 29, 34, 37, 55, 56, 80, 81, 87, $105,116,117,150,233,277,477$.

3k)- East Timor: 37. 
31)- Turkey: 395, 398, 404, 448.

\section{4] International relations}

4 a) - United Nations: 4, 10, 26, 27, 28, 29, 40, 58, 59, 84, $109,130,131,138,141,149,152,174,178,180,220,223$, $227,233,269,276,308,316,321,322,323,353,359,364$, $374,379,390,395,430,431,446,460,474,475,509,530$, 540,554 .

4b) - U.N.H.C.R: 1, 3，6，8，9，29，33，41，63，75, 76,137, $174,345,400,445$.

4 C) - I.C.R.C: 109, 223, 268, 334, 363 .

4 d) - W.H.O: 148,389 .

4 e) - W.F.P: 8, 30, 135, 141, 348, 359, 390, 430, 474, 475.

$4 f)$ - Human Rights: 146, 149, 164, 194, 424, 425, 426.

$4 \mathrm{~g})$ - Aids: 4, 6, 7, 8, 84, 141, 183, 223, 428, 518.

4 h) - O.I.C: 386,387

$4 i)-$ Aids : 


\section{From our correspondent}

ISLAMABAD - Pakistan yesterday denied it was deporting any Afghan refugees living in Jalozai and Shamshatoo camps outside Peshawar city of the North-West Frontier Province.

Foreign Office spokesman Riaz Muhaminad Khan siid at a news briefing that Pakistan was not deporting any of the refugees in the Jalozai or Shamshatoo camps where the UNHCR and Pakistani officials were carrying out a joint screening.

At the same time, he said, Pakistan was not in a position to accept any further influx of Afghan refugees who were mosily economic imigrants. "We have repeatedly requested the United Nattions and orher international organisations that relief should he provided to displaced Afghans inside their country."

The spokesman said that reliet should he provided in alreas controlled by the opposition Northern Alliance as well in areass ruled by Talcban government "so that these displaced Afghans do not leave their country in search of food and other relief."

Mr Riaz Khan said Palkistan had heen host to the largest relugee population in the world for more than two decades now. At present. he said. the Afghan refugees in Pakistan numbered close to 2.5 million.

Since last September, he said.

Pakistan had received close to 200.0100 tefugees mostly hecause of drought and extreme economic hardships in that country. "We are not in a position to receive and lake care of further influx of $\mathrm{Al}$ ghan refugees.

"This position should be understood by the international community against the backdrop of what you see on the television screen where a country, the size of a continent. defends its right to turn back a ship carrying Afghan asylum-seekers from its territorial waters."

The spokesman also referred to a recent article contributed by the chief of the UNHCR to a British newspaper in which he said how could he ask "Pakistan to accept more refugees when some industrialist countries treat asylumseekers as plague rats."

Answering a question about Pakistan's role in resolving a row over the detention of eight Western aid workers in Afghanistan on charges of promoting Christianity, the spokesman said: "Pakistan is doing whatever it could and will do whatever it can so that this problem is amicably resolved."

Responding to a question about the proposed deployment of UN monitors to oversee implementation of anti-Taleban sanctions by the UN Security Council, he said: "No monitors have arrived in Pakistan." He said the Security Council had held a closed-door meeting in New York on August 28 in which, according to a statement, it considered efforts being made by the secretary-general 10 bring an end to the conflict in Afghanistan, promote peace and rehabilitation in that country.

The UN body, he said, also emphasised the centrality of the UN role in peace efforts and encouraged the secretary-gèneral's special envoy to continue his efforts in this regard.

"Pakistan supports the decision of the Security Council. We have always supported the UN efforts to bring Afghan conflict to an early end."

In response to another question, the spokesman reiterated that the screening was being carried out for the refugees already living in Jalozai and Shamshatoo camps while Pakistan was not in a position to accept any more refugees.

Asked whether the Afghan families deported a couple of days ago from Peshawar were newly arrived, he cited some Press reports which said these were new arrivals.

When asked if any Pakistani was on board the Norwegian ship stranded in Christmas island. he said that according to Press reports most of the asylum-seckers wer Afghans. However, he added. there might be some Pakistanis and people from other South Asian countries among these stranded people.

\section{Talehan close offices of two aid groups}

KABUII. - Afghanistan's ruling Talchin closed the offices of two more Christian relief organisations yesterday after accusing them of links with aid workers detained on chitges of promoting Christianity.

Talchan security officials said they hard closed the offices of US based International Assistance Mission (IAM) and Serve on the orders of the foreign ministry.

"No one is left here and we are not allowed to let any foreigner in. All foreigners left this morning after we closed their offices," saic at Taleban guard.

Twenty-four staff members of the German-based Christian aid group Shelter Now International (SNI) four Germans, two AusMalians, Iwo Americans and 16 Alghans, were jailed in early August on charges of proselytising.

Foreign Minister Wakil Ahmed Muttawakil said there had been complaints about IAM and Serve. The atuthorities, therefore, deemed it necessitry to close them and tell their staff to leave Afghanistan. Taleban officials said privately they had not made any arrests. Reuter

\section{Smugglers killed}

DUSHANBI: - Russian guards manning the border between Tajikistan and Afghanistan killed ninc drug smugglers trying to cross the frontier overnight and seized more than $200 \mathrm{~kg}$ of drugs, officials said yesterday. A horder guard spokesman said five drug rumers had heen shot dead in a clash wittr" guards from the Pyand/haskovo unit.

Around $150 \mathrm{~kg}$ of heroin were later recovered from the scene Guards also shot four smugglers Reuters 


\section{Aid workers' fifth} week in Taliban custody

KABUL: Eight foreign Christian aid workers started their fifth week in detention in Afghanistan on Friday as the ruling Taliban Islamic militia remained "vasive about their fate.

Foreign affairs ministry official Mullah Abdul Rahman Ahmad Hotak told AFP the delained aid workers were at the mercy of Taliban supreme leader Mullah Mohammad Omar, despite plans for a trial in an Islamic court.

"Naturally the initial resolution will be passed by the court, then that will be presented to the Leader of the Faithful (Omar)," the ministry's consulate chief said. "He can make the final decision within the framework of his authority, under Islamic law."

Pressed to outline the charges against the two Americans, two Australians and four Germans who were arrested for allegedly preaching Christianity, Hotak took refuge in a vague notion of Sharia law. "No other expedicncy is considered to be higher than the implementation of Sharia," or Islamic law, he said, without explaining what that meant for the foreign aid workers in Taliban custody.
Kabul-based officials have been reluctant to provide any more details until their secretive leader, who rarely leaves the militia's southern stronghold of Kandahar, has outlined his thoughts on the issue.

The foreigners, as well as 16 Afghans arrested with them, were staff of German-based group Shelter Now, whose operation in Afghanistan was closed after the arrests between August 3 and 5 .

The Taliban has refused to explain the charges or the likely punishment. Afghans found guilty of renouncing Islam or inviting Muslims to convert to another religion face the death penalty, but the punishment for foreigners is likely to be less.

Meanwhile, diplomats and parents representing the two young American women in custody were holed up at the United Nations guesthouse here Friday, a holiday in the deeply Muslim country.

An Australian diplomat visited the two Australian prisoners on Thursday morning but the others have not been seen since the only previous consular visit on Monday, when all were found to be in good health. - AFP

\section{Indonesia urges Australia to take asylum seekers}

JAKARTA: Indonesia on Friday pressed neighbouring Australia to accept tlie 4:33 mostly Afghan asylum seckers stranded in the Indian Ocean for nearly a week and rejected Canberra's suggestions it should take them.

The Australian government has refused to accept the refugees who were rescued near Christmas Island last Sunday from their sinking wooden boat as they tried to sneak into the country from Indonesia.

The Norwegian cargo ship which rescued them has been their home since and so far only New Zealand and tiny East Timor have shown any interest in acting as a temporary host. "We urge Australia for humanitarian rea sons to accept (them)," Defence Minister Matori Abdul Djalil told reporters.

Australia has stood by its tough stance to refuse entry of the asylum seekers whom it accuses of trying to jump the queue of those entering the country through legal channels. Indonesia has also refused to accept them.

Officials from the two countries and Norway are due to hold talks later in the day in Geneva to try to end the standoff. - Reuters

\section{Australian Muslims slam}

\section{government over boat-people}

SYDNEY: An Australian Muslim day. group has condemned the government's refusal to accept hundreds of mostly Afghan asylum seckers stranded on a ship in the Indian Ocean, labelling the use of troops to repel the boat-people as "mediaeval".

The Australian Federation of Islamic Councils said Prime Minister John Howard's rejection of over 400 boat-people, many women and children, lacked compassion.

The sick and exhausted asylum seekers have now spent six days on the Norwegian freighter Tampa since they were rescued from a sinking Indonesian ferry on Sun-
In a statement, the council said it "expresses its decpest concern at the plight of asylum seekers". "The decision by our government to use the SAS (Special Air Services) force to drive the ship, with it. human (argo, out of Australian waters smacks of the mentality of the mediaeval age and absolutely devoid of human compassion," it said.

Crack Australian troops boarded the Tampa on Wednesday after it entered Australian territorial waters around Christmas Island in the Indian Ocearr. The troops seized control of the ship, but the captain has steadfastly refused to move his ship back into international waters. The Tampa now sits a few kilometres off Christmas Island.

The Islamic Councils urged Howard not to be driven by preelection pressure in deciding the fate of the boat-people. "We urge the government of Australia not to be guided by the political expediency to gain popularity for the impending election," they said.

More than 9() per cent of Middle East boal-people, mainly Afghans and Iraqis, who have arrived in Australia in recent years have been granted refugee status. - Reuters 


\section{Shifting refugees}

$\mathrm{T}$ he alleged forced deportation of abcut 150 Afghan asylum seekers by the Afghan Commissionerate to Afghanistan a few days ago, as reported by our correspondents in Thursday's issue has led to the suspension of screening of refugees in protest by the UN High Commissioner for Refugees (UNHCR). A spokesman of the UNHCR described the action as 'incomprehensible' and in breach of an agreement between the organisation and Pakistan government on

According to the report, the Commissionerate officials took some 28 different families of Afghan refugees from the makeshift Jalozai camp on pretext of shifting them to the better Shamshatoo camp and instead transported them to Torkham, where they were handed over to the Taliban authorities. These refugees belong to the northern Afghan province of Juzejan which has greatly suffered the ravages of the ongoing civil war. The action taken on orders of the provincial governor according to an official of the Afghan Commissionerate, comes at a time when relations had improved somewhat between the Pakistan and the UNHCR after a period of serious disagreements.

The latest flood of refugees that sought asylum in Pakistan in the wake of a sudden increase in the tempo of fighting and the prolonged drought had forced the government to stop all entry of refugees into Pakistan. Islamabad took the position that it already housed too many Afghan refugees and had no further capacity to look after more. It was only after high level negotiations between Pakistan government and the UNHCR that an understanding was reached which allowed the entry of Afghan refugees and their screening by officials of Pakistan and the UNHCR to determine their correct status. The screening was intended to sift out the refugees who would accept voluntary repatriation to Afghanistan and those who would opt to stay in Pakistan. Over 180,000 refugees have entered Pakistan in the current inflow causing much disquiet to the government which does not consider that all of them are genuine asylum seekers.

It is not clear under what circumstances the 28 families were taken to Torkham and what was their current status, but it has certainly not helped the somewhat tenuous relations between the UNHCR and the government. The spokesman of the world body said the decision to deport 28 newly arrived families from Jalozai on Tuesday is unfortunate and regrettable.' The manner in which the refugees were moved to Afghanistan, if true, is particularly distressing and calls for a thorough inquiry. Although Pakistan has a strong case about its refusal to accept any more refugees but there has to be an acceptable method to implement decisions without causing em-
barrassment.

\section{Pakistan says it has limited influence on Taliban}

MOSCOW: Pakistan says its failure-to dissuade the militia from destroying Bamian Buddha statues:showed its limited influence od them.

In an interview to Russian daily 'vremya novostyei', Pak istan Ambassador to Russia Iftikhar Murshed, also described the Taliban as moderate.

! ${ }^{4} T$ The present day taliban are not the one in 1995, they are much moderate," Murshed said. "Talk to the Taliban about terrorism, they would say that they themselves are its victims.

They would also tell you that thetr interests are limited within the country and do not want to invade Pakistan, Uzbekistan or China," he said.

$\therefore$ Referring to the international outcry over the demolition of Bamian Buddhas, he asked "Why the world did not deplore the destzuction of Babari Mosque by Hindu fundamentalists?"

iStating that Pakistan had con demned the destruction, he said his lcountry's failure to dissuade the Taliban regime from destroying the Buddhas should be seen ass the "proof of islamabad's lim. ited influence" over the Taliban regime.

sMurshed also referred to Pakistan President Pervez Musharraf's remarks in a recent intervilew with a Russian newspaper that India was proposing to have a thissile defence shield similar to US National Missile Defence (NMD) and said this would escalate nuclear arms race in the subcontinent.

"Any violation of stability in angy part of the globe is not a positive:development," Murshed said when asked about Pakistan's stance in case China boosted its. Iluclear arsenal if the US de. cictes to abrogate the ABM Treaty. $\rightarrow$ NNI 


\section{Indonesia donates $\$ 10,000$ humanitarian aid for Afghans \\ Giving details of projects to \\ mat said. \\ 10.}

\section{Kamran Haider \\ ISLAMABAD: Indonesian govern- ment on Friday donated $\$ 10,000$ for the humanitarian assistance of drought and war-stricken Afghan people. \\ Islamabad-based Indonesian ambassador Jack Said Gaffar presented a cheque of donation to the office of the United $\mathrm{Na}$ - tions Coordinator for Afghaniśtan here. \\ Gaffar noted that the govern- ment and the people of Indonesia expressed their sympathies with the Afghan people, in this time of tremendous difficulty, adding that "people of my country prays for peace in Afghanistan." \\ UN official said the funds will be channelled into the small- scale emergency assistance pro- gramme in the UNOCHA. "The amoun will be used in Herat, where currently approximately 200,000 displaced Afghans have been living in six camps," he} said.

\section{Afghans} be financed through this amount, the UN diplomat said the funds will be used to employ displaced persons to produce quilts, allow ing them to earn money and at the same time protect other displaced families, who might otherwise freeze in winter.

Appreciating the support of Indonesian government for poor Afghans, the UN Coordinator for Afghanistan Mike Sackett said the contributions to meet the needs of the Afghan people at this point in time are almost overwhelming as these are essential to be able to provide nonfood items to the hundreds of thousands of displaced inside Afghanistan. "We will be sure the money, is put to good use," he said. "It.(contribution) serves as a strong signal that humanitarian assistance to the people of Afghanistan through the United Nations comes on behalf of all member states, including over fifty Islamic countries," UN diplo-
In 2000 and 2001, factional conflict and worst drought in living memory have triggered the new displacement of approxl: mately 900,000 Afghans in var. ous areas insid Afghanist Sackett said adding that estimates of Afghans stranded in vil:lages, who are too poor event $t \delta^{\text {r }}$ pay for transport, vary between i' one and two million.

The people of Afghanistan gre: facing the most serious humath tarian crisis in the history of the country. The aid community thas appealed for over US\$ 283 Thilp: lion for Afghanistan in 2001 is:

According to UN statistics, \$ 114 million have been pledged, or $40 \%$ of funds needed. "Severe' funding shortfalls are affecingl programmes in human rightsa water and sanitation, minemen tion, coordination, refugee repa: triation, and most activities aimed at rehabilitation, ester cially agriculture," IJN (o)-ord nator said.

\section{everything for a better life}

PESHAWAR: War, oppression and drought are forcing Afghans to risk their lives in desperate bids at freedom, but most only make it as far as neighbouring Iran and Pakistan, aid workers and police say.

Virtually none of the 180,000 Afghan refugees who have poured into squalid camps near Peshawar over the past 12 months will ever get to Western countries like Australia, a place they could not even imagine.

Hundreds have perished since September last year in the Jallozai camp on the outskirts of Peshawar, a sea of plastic tents on a treeless plain where children die of diarrhea in summer and exposure in winter.

These are the poorest of the poor, subsistence farmers with only a few hundred rupees (five dollars) to their names, who are prepared to live in ab- ject misery because they have nowhere (')se to go. So who are the Afghans risking their lives with Indonesian smug. glers to sail on unseaworthy boats to Australia?

Aid workers said smuggling gangs based here target Afghans with money, or at least the assets to pay for travel documents and guides farniliar with the complex routes to Europe, the Middle East and Australia. These would include people with property or businesses in the main Afghan towns of Herat, Kabul, and Kandahar, or members of powerful military and political elites from the days before the Taliban militia seized power in 1996.

"They are usually people who have relatives outside and they are people who can get money, so therefore they would probably come from urban enviromments," said one senior atal worker who deals with the refugees here. "They are also people who do not have much time aild can't wait to get out," perhaps because they are in immediate danger, he added.

Most would not have applied for official UN refugee status, preferring instead to live in Pakistan illegally so they would not be missed when they left, he said.

The aid worker did not want to be identified for fear of the powerful smuggling gangs who make their business from the two million registered Afghan refugees, and possibly as many illegal immigrants, in Pakistan.

A public servant in Kabul told AFP that his brother migrated legally to Australia a year ago, using connections with a cousin who had lived in Sydney for 12 years. "Our family was very lucky as we had our cousin in Australia. Actually he 
The News International, Saturday, Septembre 1, 1901

helped and sponsored Nemattullah and got him to Australia," said Abdullah, 32 , who works in the education ministry.

"My brother sends a good amount of money to us every two months and now we can live a much better life here."

He said those without connections in the West were prepared to sell their houses or property to send one male family member abroad in the hope they will find work and send some of their earnings home.

"One person is quite enough. It's much better for people to sell their properties here and send their sons abroad," ne said. "Some people were - used to a luxurious life here in Kabul but now, because of some problems and other reasons in our society, they can't have that kind of life, so they leave."

Despite the new arrivals, most Afghans in Pakistan, whether legal or illegal, are long-term residents dating back to the Soviet invasion of Afghanistan in 1979. Since the Soviets withdrew in 1989 , the country's political and economic institutions have been destroyed by factional infighting between powerful warlords and the civil war since 1996.

The older refugee camps in Pakistan look more like settled villages of traditional mud houses, with thriving markets and businesses, and children who have never seen Afghanistan or the troubles there.

But while the vast majority of refugees remain extremely poor, some families have made enough money in

Pakistan to pay for the chance of a better life elsewhere.

The cost can vary from around 800,000 rupees ( 12,000 dollars) to a million, which includes documents and transport to the destination, police said. Once there, they have to apply for refugee status or live illegally.

The route they take is complex and varied, according to Pakistani police who say they are powerless to stop Afghans with valid travel documents leaving the country.

"Once they leave Pakistan on proper documents their agents have contacts with international gangs of human smugglers," said a Pakistani police source in Peshawar. "Initially a small amount is paid here and the rest of the money is delivered only when the person safely arrives at the chosen destination."

Another police officer complained: "We have no authority to check these Afghans whom we know will disappear after leaving Pakistan. From Pakistan they generally travel on valid passports and valid visas."
Sources close to the smugglers, who often front as travel agents, said organised groups in Pakistan arranged legitimate visas for places like Dubai, Indonesia, Jordan, Malaysia, Syria and Turkey. Once there, they begin the secret journey to the West, involving dan-

gerous overland treks, sometimes oni foot at night over mountain passes, or: on flimsy boats across the Indian Ocean!'

Europe is still the favoured destina: tion. According to United Nations fig. ures, Austria, Germany, the Netherlands and the United Kingdom received almost 70 per cent of Afghan asylum applicat tions worldwide last year. Australia äc:counted for only 3.7 per cent.

An Indonesian embassy spokesman' in Islamabad said Afghans were onty given visas if they had letters of recommendation, or at least 2,000 dollars in travelers cheques plus bank statement's over six months. "We issue visas when all these requirements are fulfilled, oth:erwise we don't," he said.

An airport official with a major Gulf airline in Pakistan said it was routine procedure to issue transit visas for Dubai. "We are bound to give transit facilities to our passengers whichever nas tionality they represent. It is not our problem if they try to change their dofi: uments at Dubai," he said. He also re; quested anonymity out of fear of the gangs, adding: "I'm married with two; sons".

"The question is, when such people. are caught and deported back to Pak istan, why don't the concerned agencies investigate them? We are not a cripse agency we are just a commercial organisation." - AFP

\section{Police asked to arrest killers of Afghan doctor

$$
\text { Bureau Report }
$$

PESHAWAR: Relatives of the dẹceased Dr Karima Mobeen have asked the Frontier police to arrest killers of the doctor ạnd bring them to justice. They said that such a crime was ironifoll which took place in the neärt of Peshawar in which a professional and educated Af'ghan national was killed.

In a press statement, the relatives said that the killing of the doctor was a national loss and șet back for Afghan women working for the rights of women.

They said that she was planhing to establish a charity hosfital to provide health cover to the poor and hapless Afghans, specially, women, but could not achieve her goal. Quran Khwani will be held for the departed soul at her residence in Phase' $B$,' Hayatabad on Saturday (today).

\section{Taliban guards foil sabotage bid at Kabul varsity}

\section{Our correspondent}

JALLOZAI: Taliban security personnel foiled a terrorism attempt at Kabul University Medical College by arresting an accused along with a bomb, says reports reaching
here.

The accused, a fourth year medical student at the university, was caught red-handed when he was planting the device near the office of Dean faculty of medical. He belongs to Khwaja Musafir village of Paghman province. Hundreds of students were present at the time of the attempt, who had come to see their results.

The Taliban security forces have arrested another student,

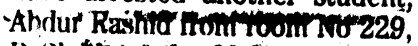
D)-Block of the Muloes atostel,

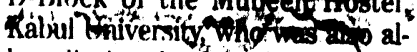
legedly involved in the atrempt. Abdur Rashid also belong to Paghman and was a first year student at the lslamic Law Faculty.

Interestingly all students named Abdur Rashid have gone under ground following the incident.

Presently 12,000 students are studying at the university. The attompt to detonate a bomb at the university premises has caused panic among the students. 


\section{The Frontier Post saturday, september , , 2001 Two aid agencies
offices closed}

Monitoring Report

KABUL : Afghanistan 's ruling Taliban on Friday closed the offices of two Christian aid organisations because of link: with aid workers detained on charges of promoting Christianity.

Tuliban security officials said they had closed the offices of US -based International Assistance Mission (IAM) and Serve on orders issued by the foreign ministry. "No one is left here and we are not allowed to let any foreigners in. All foreigners left Friday morning afier we closed their offices," said a Taliban guard.

Twenty-four members of the German-based Christian aid group Shelter Now International (SNI), including eight forcigncrs, were jailed early in August on charges of proselytising. The Taliban could impose death sentences for converting from Islam or encouraging someone to convert. but they have said the punishment will be decided by Taliban supreme leader Mullah Mohammad Omar.

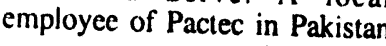

IAM has been operating in Afghanistan since 1965 and most of its foreign staff came in family groups. It operated some sanitary and health projects. Forcign ministry seals were stamped on the gates of the two offices but there was no word as to where their foreign staff had gone.

Taliban officials privately said they had not made any arrests but had given a three-day ultimatum to the foreigners to leave Afghanistan. Both organisations draw their support from churches. The Taliban said they had found links of co-operation with SNI.

"They were involved in those unacceptable activities and had relations with the SNI," said one Taliban official. He added that the offices of the two agencies would be closed across the country.

Pactec, an American NGO that provides air and communications support to other aid agencies, pulled out its foreign staff following the closure of IAM and Serve. A local

\section{UNHCR suspends screening of refugees}

said their operations would be crippled by the closure of IAM because it provided them logistic and ground support in Afghanistan.

Pactec operated flights to different Afghan cities and towns from Peshawar, the capital of North West Frontier Province of Pakistan.

The parents of two American women in detention with six other foreigners in Kabul were due to meet their daughters later on Friday, only their second meeting since their arrival in Kabul on Monday.

On Thursday, only the Australian diplomat was allowed to meet the two detained Australians. The Taliban have ruled out a pardon. saying all those arrested; including four Germans and 16 Afghan staff knew they were violating a strict ban on proselytising. The arrests followed months of worsening ties between the Taliban and foreign aid groups helping millions of impoverished Afghans cope with more than two decades of war and a decvastating drought.
ISLAMABAD (APP): The United Nations suspended its participation in the screening of Afghan refugees in Pakistan on Friday, saying the government had broken an agreement by taking refugees back to Afghanistan after saying they were going to a nearby camp.

"We are temporarily suspending our participation in the screening process." Yusuf Hassan, spokesman for the UN High Commissioner for Refugees, said..

"We consider this a clear breach of our agreement with the govemment."

Hassan said the UNHC.R had confirmed reports that about 28 Afghan families had been lured on to government trucks on Wednesday by the promise that they were being taken from Jallozai; a makeshift refugec camp famed for its appalling conditions -- to another wellequipped refugee camp.

The UNHCR official said they had confirmed that the approximately 145 people, many of them from northern Afghanistan that remains outside Taliban control, were handed over to Taliban authorities at the Pakistan border.

The UNHCR-government agreement to screen Afghan refugecs in Jallozai and other camps was reached in early August after protracted negotiations because of the conflicting goals of the two sides.

Pakistan, alarmed at the influx of about 200,000 Afghan refugees over the last year that has raised the total number of Afghans in the country to around two million, has refused to accept more and wants many of those already in the country to go home.

The UNHCR, whose mandate is to protect refugees, wants to ensure that those with legitimate rights to seek refuge,- such as fear of persecution -- are not returned to Afghanistan against their will.

Under the agreement, joint UNHCR and government teams were supposed to interview refugees to determine whether they wanted to return to Afghanistan or had legitimate claims to remain in Pakistan.

The UNHCR says there are now about two million Afghans in Pakistan, 1.6 million in Iran and others scattered about the world. Their country has been destroyed by more than two decades of war and in recent years, by drought. 


\section{The Frontier Post Saturday, September 1, 2001}

\section{In the line of fire}

T seems that the Taliban versus the world tussle is getting worse. as can be found in the UN Security Council's condemnation of the Taliban on account of their alleged support to terrorism: It scolded them for refusing to hand over Osama Bin Laden and failing to comply with its resolutions. It also took umbrage at their handling of human rights issues, particularly with reference to women's non-accessibility to education and jobs. Referring to the detention of aid workers, it lamented the hurdles created by them in the provision of international relief and assistance to the people in Afghanistan.

Though the Security Council is well acquainted with the Taliban and their style of governance, it was Mr Kofi Annan's report on Afghanistan that prompted it to scoff at them yet again. However, it acknowledged the cradication of poppy cultivation caused by a decree issued by Mulla Omer. In this regard, it expressed its support for the efforts by the Afghan Support Group and Six plus Two to rehabilitate former poppy cultivators. The Security Council called upon the parties involved in the fratricidal conflict to resume talks for the formation of a broadbased government in Afghanistan. It also pleaded for a central role for the UN in the peace process.

The Taliban never cease to draw international concern, and flak. The reason being the difference of perceptions between the Taliban and the world about terrorism and as a corollary of it Osama Bin Laden. Both sides have contradictory views on other issues as well, such as human rights. While the Taliban continue to cling to their peculiar interpretation of religious injections, the world thinks that with a bit of arm twisting it could inculcate in them some 'rationalism'. This wedge is widening because sticking to their respective positions both are unable to find a middle way.

Resultantly, the world continues to hold them as sponsor of terrorism and promoter of obscurantism and retrogression. The Taliban, on the other hand, accuse the world of deliberately adopting this line of attack in order to undermine the independent character of the people of Afghanistan and to forestall Islamic renaissance. Incidentally, this view is shared by many in Pakistan. This is why Pakistan is perceived to be wielding considerable influence over the Taliban. Pakistan, therefore, invariably comes into focus whenever a move is contemplated against the Taliban. Read with the report that the US is poised to launch another commando adventure to get Osama and the Security Council's condemnation becomes doubly ominous for Pakistan. These developments could be a prelude to further tension between the Taliban and the world minus its few friends including Pakistan.

To make them adhere to resolutions 1333 and 1267, more international pressure could be exerted on them that could ricochet off to produce dynamo reaction in Pakistan and other regional countries. Considering the dice loaded against them, the Taliban should come to grips with certain some realities staring in their face. First, struck by drought and curbs the people of Afghanistan need aid and relief, which is not possible if internathey have fewer friends to be obstructed and frightened. Second, they have fewer friends who too are finding it extremely difficult to present their case in the wake of their irrational attitude toward women and minorities. They should, therefore, make an honest appraisal of their conduct if they want to cultivate international support and ward off further punitive measures.

For its part, the international community should attempt to engage the Taliban rather than isolating them to the point of desperation. In this respect, their offer of Osama's trial in a third country under Islamic jurisprudence should be considered. To achieve a broad-based government in Afghanistan, it is important that the countries covertly influencing events in that country - Should immediately withdraw in the interest of peace in the
whole region.

\section{No arrests, aid workers leave Kabul}

\section{Monitoring Report}

KABUL: No arrests were made and it is helioved the foreign aid workers of the two organiza. tions have left the country.

Also, six foreign workers of Partners in Aviation and Communications Technology. an IAM-affiliated group - left their offices in the city early Friday, telling a guard that it was "too dangerous to remain."

The IAM expatriates, all volunteers, lived in Afghanistan with their families. They lived in some of the country's poorest neighbourhoods, without electricity or running water.

They were known as a missionary organization. There wos only one expatriate worker with SERVE, a group that also works with Afghan refugees in Pakistan. Like Shelter Now international, eight of whose foreign aid workers are being held by the Taliban, SERVE also was accused in the early 1990 s of trying to convert Afghan refugees to Christianity.

\section{Arafat asks Taliban to release aid workers}

KANDAHAR (Online): Palestinian leader Yasser Arafat is having a message delivered to Taliban that asks for the release of two American aid workers accused of preaching Christianity, according to the Afghan Foreign Minis: $: y$.

Ahmed Salman, the Palestinian ambassador to Pakistan, arrived in Kandahar on an International Committee of the Red Cross flight carrying a message from Arafat to Taliban supreme leader Mullah Mohammed Omar, asking for the release of the Americans, reports CNN.

The eight members of the Shelter Now International assistance group -- two Americans, four Germans and two Australians -- are charged by the Taliban of attempting to convert Muslims to Christianity, an act considered illegal by the strict Islamic group. 


\section{Norway willing to take some asylum seekers}

OSLO (Agencies): Norway said on Friday it was willing to take in some of the more than 400 asylum seekers crammed onto a Norwegian freighter off Australia and that it would meet Australia and Indonesia to try to end the standoff.

Norwegian Foreign Minister Thorbjoem Jagland dismissed an offer from UNadministered East Timor to take in the mostly Afghan refugees, saying East Timor was too poor to cope.

He said that officials from Australia, Norway and Indonesia were to meet in Geneva on Friday at the offices of the UN High Commissioner for Refugees (UNHCR). New Zealand. which has offered to help, would also attend.

"We will contribute if requested by the UNHCR," Jagland told reporters, without saying how many refugees it would accept. "Norway is a humanitarian country and one of a dozen nations which will always help the UNHCR.by taking people."

'I don't think there will be a solution today but in the near future," he said after briefing Norwegian parliamentary leaders on the three-nation standoff over the 433 mostly Afghan refugees.

The Norwegian-registered Tampa is off Australia's remote Christmas Island after picking up the asylum seekers on Sunday from a sinking ferry that had set out from Indonesia.

Norway, Australia and Indonesia have said they do not want the refugees.
Jagland said the UNHCR would present its view of the issue and "possibly put forward a propocil." Norway has not previotsly said it would be willing to take any of the refugees.

Jagland reiterated Norway's view that Australia had prime responsibility. "These people are on Australian territory and Australia has to take responsibility, in cooperation with the High Commissioner for Refugees," he said.

He said he spoke to Australian Foreign Minister Alexander Downer earlier on Friday. "The foreign minister of Australia indicated a solution," he said, without giving details. "I said we're willing to contribute provided that they take responsibility for the people on the vessel."

\section{The Nation}

\section{WFP starts food aid at Afghan-Tajik border}

\section{By Cllocla Zaidi}

ISLAMABAD - UN World Food Programme has started another round of food distribution to hundreds of destitute Afghans who have been stranded on the Afghan-Tajik border for more than 10 months.

According to WFP official sources, it has to overcome many hurdles to access the war-torn and drought stricken Afghans, who have fled the fighting between the Taliban and the opposition forces last year to an island in the river Pyanj, which is also the border with Tajikistan.

Since February 2001, WFP has been able to provide 65 tons of food aid to about 1.500 poor people on this island.
This week, WFP assisted by French NGO, Agency for Technical Cooperation and Development( ACTED), hopes to distribute another 23 tons of food aid among them.

Ismail Omar, Officer Incharge of WFP operations to assist about one million poor Tajiks, said that this operation has been particularly difficult, though the number of people are much smaller as compared to hundreds and thousands of drought stricken people that WFP has been struggling to help in Tajikistan. Access to this area always remains a problem for them.

In early August, the Afghans on the island had to survive 10) days on meager food ration because the aid workers were not given entry.

Since last October, over 80,000 people have been displaced because of fighting within Takhar and Badakhshan provinces in north-east Afghanistan including about $10,(0)()$ people who moved to the border area.

WFP is running an emergency operation to help 3.8 million poor people throughout Afghanistan to avoid starvation due to a long and devastating cycle of drought and civil war.

They include more than 700,000 people who have been displaced by the war and conflict over the past two years. 


\section{The Nation}

SATURDAY, AUGUST 1, 2001

\section{Repatriation of Afghan refugees in progress}

\section{From Our Correspondent}

PESHAWAK - Déspite suspension of major screening process of Afghian Refugees on the part of United Nation High Commission for Refugees (UNHCR) ats a mark of protest against forcible deportation of some refugee families, the repatriation of Afghan refugees on volunteer basis is still in progress as at least five Alghan families are crossing the border every week.

It is pertinent to mention here that Nasir Bagh Refugee canı wals the biggest hurdle in the waly of the NWFP Government in connection with construction of Regi $L_{\text {al }}$ Ima Housing Scheme for which the provincial government had directed the residents to vacate the camp up to October, 1.200)। at which the refugees residing in the camp instead of shifting io (1/her camps situated at the outskirts of Peshawar preferred to go hack 10 their country.

The Nasir Bagh Camp, where about 70,000 Afghan are living out of which a large number are shifting to their country as the repatri ation process commenced since July, 2001 in which at least five families are leaving the camp in different convoys every week.

In this connection the UNHCR has established its specific centre at Nasir Bagh Camp where Refiigees are interviewed who wish to return to their country on voluntarily basis and are registered for repatriation. According to an official working in the said centre. a convory is constituted on every Wednesdiy and each convoy is based on at lealst 250 families which crossed the border under the supervision of UNHCR representatives after the ir thorough scrutiny.

\section{US diplomats meet NWFP governor}

PLSIIAWAR (SANA) - A delegattion of US Diplomats called upon the NWFP Governor Lt. (icn. (r) Syed Iftikhar Hussain Shah at (iovernor's House here on liriday.

The delegation led by US Consul Mr. David J. Katz included Mr. Jon Danilowicz Incharge Drug section of US Consulate and Mr. Bob Traister. Provincial Secretary Ilome Mr. Abdul Karim Qassoria and Political Agency Khyber Agency Dr. Fida Mohammad Wazir were also present on the occasion.

Tilking to members of the US delegation, the Governor reiterated resolve of the government tha the target of zero level achieved in poppy cultivation would be maintained in Frontier Province and tribial areals of the comntry.

The Covernor, however stressied the need for construction of aceess roads to those in-aceessible areas where the cultivation of poppy needed to be eradicated.

He satid that the trend of growing poppy in those areas could be combrolled provided those were hrought at pall with the other de. veloped areas of the country. He also stressed the need for joint efforts of Donor Agencies and the governinent in this respect.

During his visits of the tribal arreas. the Governor said. he has wit- nessed a keen interest among the people of these areas for development and added that majority of the tribal people kept on demanding for provision of facilities for education, health, drinking water and communication ctc. which, he added was a good omen.

He said the law and order situation could also be controlled when if the tribal areas of were developed.

Regarding Khyber Area Development Project. the Governor said that all possible efforts were be ing made in this respect.

The (iovernor also) ordered that the minimum possible staff should be employed and the non-developmental expenditures should not be incurred.

Regarding the screening process of Alghinl Refugees. the Governor saicl that lhi: prictice aimed at determining the real as well as un real Refugees. He said that all those who did not come under the definition of Refugees would be sent back to their country.

The (iovernor, on this occasion, dispelled the impression that the Alghan citizens had migrated to Pakistan as a result of their differences with the policies of their government. They were actually commuting to and from Afghanistan from time to time, the Governor maintained. 


\section{The Nation}

\section{Hekmatyar's follies}

\section{led to Afghan conflict-II}

Little before, late Dr. Najib UIlah's willingness for transfer of power to UN interim Council, under the UN supervision in early 1992, Hekmatyar was the first one who not only rejected the plan but mysteriously left Peshawar for somewhere inside Afghanistan to get. in power through military ways. And his such adventure resulted in an era of in-fighting for power and authorities and Afghans are still paying for such act of Hekmatyar. He opposed joining of the efforts here in Peshawar for a consensus amongst the IUAM about the future set up which had concluded with signing of the Peshawar Accord on April 22, 1992 last. Hizbe Islami of Hekmatyar which had in share the office of Prime Minister but Gulbadin Hekmatyar

refused to work with former $\mathrm{Af}$ ghan presidents Prof. Sibghat UIlah Mujaddadi and Prof. Burhanuddin Rabbani: First he wals reluctant to recognise the Peshatwar Accord and later on he was persuaded by high ranking authorities from all three leading Muslim countries like Pakistan. Siludi Arab and Iran to accept it. And first he nominated his party's Ustad Fareed and later on become himself Prime Minister of Afghanistun but instead of entering Kabul and occupying his office he stayed aw:ly in Charsiab, to South of Kabul from where he was forcibly ejected by Taliban on March 10, 1996.

Since his ejection from Charsiab in March 1996, Hekmatyar is staying in Islamic Republic of Iran and like past he changes his st:all.

es on the issues of Afghanistan. Sometimes he praises Talibain for restoration of peace in their controlted areas but on contrary he expresses sympathies with his Jehadic colleagues who have formed the Northern Opposition Alliance. sometimes, he barks lle political

\section{Situationer}

From Shamim Shahid

solution to the conflict but just for restoration of friendly ties with old hosts from Pakistan, he advocates a coalition between Talibaan and Mujahideen parties. On one hand he supports the Cyprus moot which is trying for convening a meeting of the Loya Jirga but at the same time he opposes the

Rome, Italy similar initiatives. Instead of realising Mujahideen and communist leadership like Babrak Karmal, Hafeez Ullah Amin, Dr. Najib Ullah and Noor Mohammad Taraki's own mistakes, Hekmätyar says" former king Mohammad Zahir Shah is responsible for the ongoing unrest and bloodshed in Afghanistan.

Whatever may be the future ambitions of Engineer Gulbadin Hekmatyar but it is crystal clear that most of the Afghans are disappointed by fighting and bloodshed first on the name of communist revolution, and secondly in the name of imposed civil war. Afghans. who suffered a lot on the slogans of Communism and ethnicism are now desirous for an end to every sort of bloodshed and de-

struction in Afghanistan which is possible through declaring an international reconciliation as suggested by moderate Afghan lead. er Pir Syed Ahmad Gillani, Peshawar based Shura-i-Tafahum and several other regional and international forums even by United Nations, $6+2$, United States and Organisation of the Islamic Countries.

Engineer Hekmatyar who is still respected for his heroic role in Afghan Jehad needs to honour wishes and expectations of the masses who are desirous for an era of peace and stability and re-integration with each others rather than opposing the proposed meeting of Loya Jirga and opposing the person of former king Mohammad Zahir Shah.

DAWN SATURDAY, SEPTEMBER 1, 2001

\section{UN move to help asylum seekers}

SYDNEY, Aug 31: The crisis of 460 asylum seekers aboard the Norwegian ship Tampa is expected to end soon, and if every thing goes according to plan, the asylum seekers will be allowed to disembark temporarily at Christmas Island for humanitarian reasons.

Norway's ambassador to Australia visited the ship this evening and confirmed after meeting, each asylum seeker, that except for a few Sri Lankans, all the asylum seekers are Afghans.

The Australian Government has softened its earlier position and is now seriously considering a three-point plan by the UN High Commissioner for Refugees that was submitted to Australia, Norway and Indonesia.

Accordin,s, to the plan, the asylum seekers will disembark at Christmas Island and then be screened either on Australian soil or elsewhere, to determine which were genuine refugees and which are economic migrants. The plan also proposes to transfer asylum seekers to other countries either for fur. ther screening or resettlement.

Australia has back tracked from its proposal to send 460 asylum seekers to East Timor for screening. Foreign Minister Alexander Downer gave this proposal today but said a few hours later that asylum seekers on Tampa will not be screened by the UN in Fast Timor. 


\section{DAWNGALLERY SATURDAY, SEPTEMBER 1, 2001}
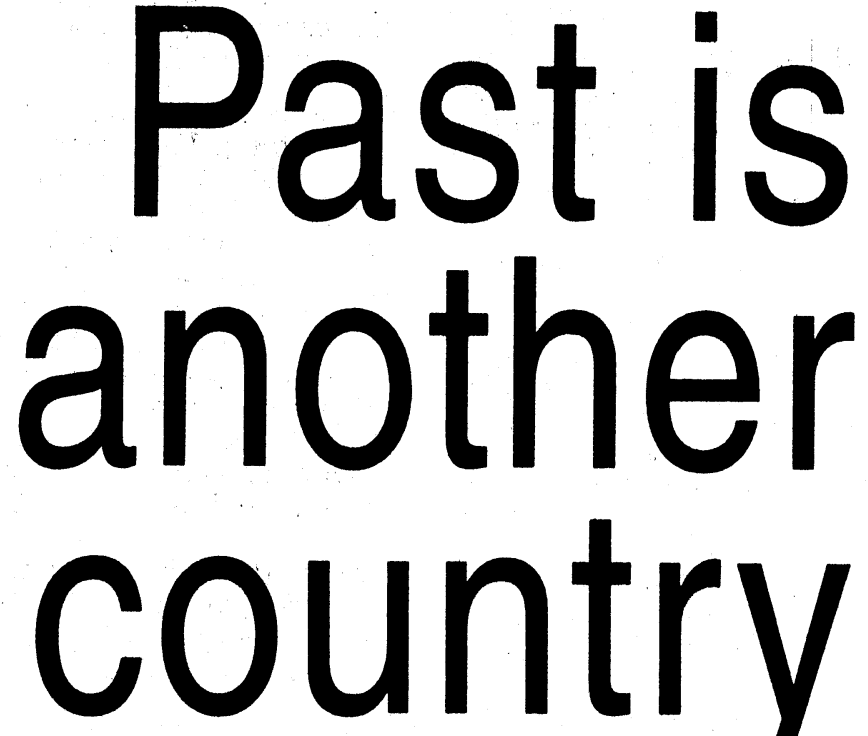

By Asif Nooranl

$\mathrm{H}$ e paints from sketches and photographs, but most of ten he paints from memory because the subject of most of his paintings - his motherland, Afghanistan - is deeply etched on his mind, even though he hasn't been there since he took refuge in Pakistan in 1993.

Abdul Shakour Khesravi is exhibiting for the first time in Karachi, at the Majmua Art

Gallery. He left Afghanistan in 1993 when the Mujahideen conquered Kabul. "But things were still not so bad back then, there was no ban on the performing or fine arts. It was just that no exhibitions were being held and the art material - paints, brushes, canvas and paper had become very expensive, so I came to your country," he says. Khesravi, 37, has since lived with his wife and children in Islamabad.

One is struck by the vibrant colours that he uses. If he were to paint the present day Afghanistan, he would perhaps need only two colours - grey and black. "Why don't you go to Afghanistan?" someone asks him. "I don't have any suicidal tendencies. They'll kill me. There is no room for any kind of art in present-day Afghanistan," he says.
After a pause, he drifts down memory lane: "Those were the days. The Kabul University had classes of fine arts and even music. The faculty of fine arts was very impressive. We used to have painting and sculpture exhibitions regularly. I took part in a number of competitions and often went home with prizes and trophies. I am proud to have been a student at that department."

"The fine arts department closed down soon after the Taliban took over Kabul," he laments. "How come you can't communicate in Urdu?" I query. "I don't interact much with people. I spend most of my time painting," says the Persian speaking artist. In Karachi, his nephew acts as his interpreter.

Khesravi's paintings, however, cut across all linguistic barriers. They are highly articulate. Barring three - one that shows a building in ruins, another which portrays a father and a child, with fear and hunger writ on their faces, and the third, which shows the disfigured statues of the Bamiyan Buddhas. The remaining 56 paintings show lively people, the lovely landscapes and busy streets of Afghanistan, as they once used to be.

His subjects on display include gypsies, both men and women, who move with camels.
They are called karavane-shoterha. Then there are the Hazara and Turkmen women, hookah smoking Uzbeks, a young man from Nuristan - the erstwhile Kafiristan - a Pashto musician, a bahishti (water carrier), and a patragar (ceramic utensil-repairer). There is action and pace in the two paintings which show the popular game of buzkashi in progress: The players are all on horseback, their energies direct. ed towards snatching the inflated body of a dead goat from the rival team. These are oil on can: vas.

Khesravi has also done two highly impressionistic paintings on the hand-made paper that someone had brought from Nepal for Mehreen Elahi, the curator of Majmua. His works on display are in both impressionistic and realistic styles. He seems to be at ease with both the genres.

Khesravi also does abstract paintings and calligraphies in

Persian and Arabic. He uses a wide variety of media: oil, watercolour, pencil, pen, chalk and pastels. "All these are just means to an end," he says. "What matters is that I paint the past. I don't often paint the present."

He exhibits his works in Islamabad at Nageen Hyat's gallery, Nomad. Foreigners, he claims, buy his paintings more than the locals. His work is by no means very pricey. The paintings on display at Majmua range from $R s 5,000$ to Rs7,500.

Thanks to his brother, who has settled down in the US, Khesrar's paintings have been displayed there at a number of solo and group exhibitions. These include the solo exhibi tion at the World Institution on

Disability in Oakland, California (1997) and the exhibition at the Balch Institute for Fthnic Studies in Philadelphia. 


\section{Annan welcomes Australia plan for stranded refugees \\ eral KAN - UN Secretary Gen-} eral Kofi Annan welcomed yesterday a compromise by Australia to transport hundreds of asylum seekers stranded on a Norwegian ship to New Zealand and the Patcific Island of Nauru.

"We accept the compromise and I hope the process can be completed as soon as possible," $\mathrm{Mr}$ Annan told a news conference here, where he was attending a UN conference on racism in South Africa.

Asked whether Australia had acted wrongly by refusing to allow the asylum seekers onto its territory, Mr Annan said: "I would have preferred that Australia accepted them in the first place. Under the United Nations convention the first port of call is responsible for processing asylum seekers."

"And it doesn't give comfort that men, women and children are still stranded on that ship," he added.

Under intense international pressure, Australia managed to patch together a diplomatic solution (o) resolve a six-day stalemate over the fate of the mainly Afghan boat people whom Australia and Indonesia have flatly refused to accept. Australia said earlier yesterday it had reached agreement with the governments of New Zealand and Nauru on processing the 433 passengers rescued last Sunday by the cargo ship Tampa from their sinking Indonesian ferry.

Australian Prime Minister John Howard said in Sydney the asylum seekers would be transferred to non-Australian ship at sea in the next few days and taken to. New Zealand and Nauru without setting foot on Australian soil.

The Tampa is currently lying off Christmas Island in the Indian Ocean some $350 \mathrm{~km}$ south of Indonesia and $1,500 \mathrm{~km}$ west of the Australian mainland

Meanwhile in Geneva representatives of Australia, Norway, Indonesia and New Zealand resumed talks on Saturday at the UNHCR on the plight of the Afghan refugees stranded on a boat in Aüstralian territory.

The talks, which began around 11:00am are scheduled to last two or three hours, a spokesman for the UNHCR said.

But he expressed a wish to know more about an Australian plan announced overnight which would see the refugees taken to New Zealand and the Pacific island state of Nauru. "A plan has been announced by Australia, we know this only through media sources and we want to know more about it," he said.

"At first glance, we prefer our own plan which sees the refugees disembarking at Christmas Island (Australian territory) where their request for asylum will be examined before they are conveyed to a third country," he added.

He said that taking the refugees to Nauru, more than $6,000 \mathrm{~km}$ away, would be problematic.

The accord foresees that around 150 refugees, mainly women and children, would be taken in by New Zealand, and 300 others would be taken to Nauru, where their requests for asylum would be assessed.

The refugees have been stranded on the Norwegian freighter Tampe since last Sunday, when they were rescued from a sinking Indonesian vessel. - Reuters, AFP
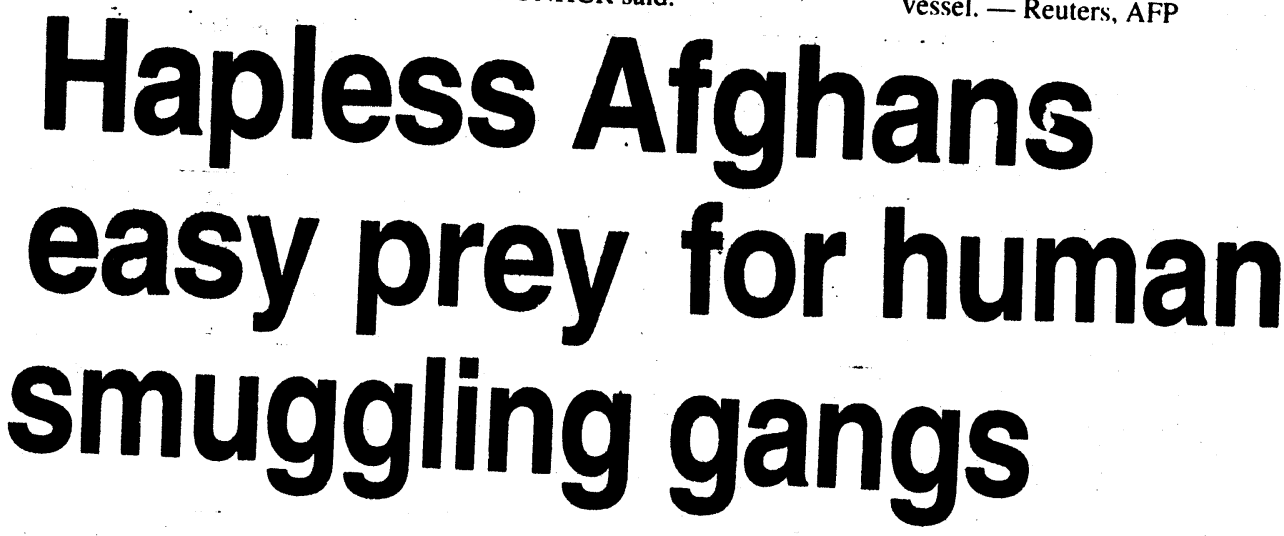

BY RORY MCCARTHY, JoHN AgLionby \& PATRICK BARKHAM

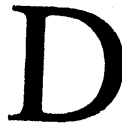

EEP in the maze of teeming bazaars to the north of Peshawar, where they sell stolen televisions, large blocks of hashish and cheap Kalashnikov assault rifles, is a new breed of travel agents. Their business is discreet, effective and illegal. and the profits are enormous.

One young, bearded Afghan agent slips away from his office above a row of paint shops and, sitting nervously in the back of a car, slowly starts to talk about his work as a kachakbar, a refugee smuggler.

Just a few weeks ago the hundreds of Afghan refugees now stranded on the Tampa cargo ship.off Christmas Island in Australian waters sat in secret in Peshawar and met smugglers just like him. They borrowed a small fortune from their relatives and signed contracts which promised to whisk them away from the squalid refugee camps of Pakistan's North West Frontier and deposit them in front of an Australian immigration desk.

The smuggler said the going rate was 


\section{$\$ 12,000$ per person.}

The journey begins in Afghanistan, where in the past two decades more than six million people have left their country to escape war. Hundreds of thousands more have poured out in the last year in a sudden exodus to flee a new burst of fighting, a vicious drought and the ever more brutal Taleban regime. They stream across the border at the Khyber Pass with no passports and in the refugee camps around $\mathrm{Pe}$ shawar quickly meet the kachakbar agents who fill them with promises of a new life in the west.

The refugee smuggling business is a sophisticated, well-oiled operation. Most smugglers have a travel agent's licence and senior contacts among the Pakistani authorities. Prices vary depending on the destination and the ease of the journey. The smugglers take a handsome 40 per cent profit.

For most Afghan families the cost of escape is crippling. One father, Mohammad, who lives in a camp in Peshawar, has just sent his 15 year-old son through a smuggler to London. It was a cheap ticket, and $£ 6,000$ was all the family could afford. The journey took one year and 14 days.

"I know he went to Iran and then I think he went to Russia but I don't know how he got to London. I don't even know what kind of passport he has now. What kind of journey is that to send a 15-year-old boy on?" he asks in broken English.

"We simply didn't have a choice. The house we had in Kabul for 100 years we sold to send my son to England to study. We sold a house that we didn't want to sell even for a million dollars. If you knew the difficulties of the Afghans, you would cry."

The Afghans on board the Tampa would have deposited the fee with a third person, usually a money changer who will only pay the smuggler once the refugee telephones to confirm safe arrival.

For two days the refugees practise their stories. "We tell them to say they come from a

part of Afghanistan ruled by the Taleban and that the Taleban have imposed all these laws and created serious problems," said the smuggler. "Most people are genuine cases but some of them are not even Afghans, they are Pakistanis, Kashmiris, even Chechens. People in the West don't know the difference."

At Karachi airport, officials are bribed and refugees bound for Australia board flights to Jakarta, Kuala Lumpur or Singapore. A smuggler's agent flies with them and just before they reach immigration he takes their passports and disappears.

Suddenly the Afghans drop into a foreign world filled with Iraqis, Sri Lankans, Pakistanis and refugees from across the globe desperate to reach Australia. Most head to the Indonesian island of Lombok to wait for the final crossing, many get no further.

A year ago Awarli left Iraq with his wife, three children and mother-in-law. They crossed into Pakistan, flew to the Malaysian capital Kuala Lumpur and were taken to the west coast by a smuggler. They thought they would be travelling alone but when they reached the coast the converted fishing boat already ful

"There were 17 of us," he said. "We were put on a small boat, only about six metres long. It was dark, the weather was bad. We knew that it was dangerous on the boat but what can we do? We need our freedom." They were lucky and made it to Medan, a city in north Sumatra. Many others have perished attempting to cross the Malacca Strait on boats that are overcrowded and barely seaworthy. They then went by bus to Jakarta and waited in a backpackers' hotel, eating at the McDonald's restaurant directly opposite the UN building.

"We were then told there was a boat for us so we went to sout'! Java coast," Awarli said. "But we have no luck. The first boat never arrived and the second boat had to turn back" So they moved east, first to the city of Surabaya and then on to Bali. But still no boat."

"Then we were told of possibility on Lombok so we come here and get arrested." The entire journey has cost $\$ 20,000$ and now the family are holed up in the Nusantara I guesthouse in Lombok along with 126 other illegal migrants waiting to be processed by the UN High Commissioner for Refugees (UNHCR).

"Our money is almost gone and also our hope," Awarli said. "We know not what will happen to us."

\section{$\mathrm{S}$}

CE the people smuggling business took off a year ago, 492 asylum seekers have been caught in Indonesia and classified by.the UN$\mathrm{HCR}$ as refugees. But only 19 have been found new homes. Another 632 asylum seekers who were arrested did not qualify as refugees and so are given nothing and live in squalid detention centres.

Lombok is an increasingly popular jumping off post for Australia, according to the local pölice spokeswoman, Assistant Commander Sri Budi Pangistuti. "We have caught 251 people this year," she said, "and most have been in the last few months. The vast majority are from Iraq and Afghanistan."

It is easy to see why so many take the risk.

Australia's minister of immigration, Philip Ruddock, said recently that only 14 per cent of the Afghans assessed in Indonesia were given refugee status while the corresponding figure for Australia was more than 80 per cent.

Indonesian police are catching only a fraction of illegal migrants. Awarli said there were about 300 people in his groun. "I know no where the others are now," he said, adding with a sudden flash of humour, "and I know not where I will be next month."

From Indonesia a small but steady stream of boats ferries asylum seekers to Australia's beautiful and desolate northern beaches. More than 4,000 made it in the past year alone and more are expected in the coming months as the
weather improves.

Most of the vessels are tiny antiquated fish ing boats or inter-island ferries like the $20 \mathrm{~m}$ boat from which the 433 asylum seekers were rescued by the Tampa on Sunday night. Two such ships sank when they were caught in the 
Khaleej Times, Sunday, September 2, 2001

aftermath of Cyclone Sam last December, drowning 167 asylum seekers from the Middle East. Australian authorities believe up to 400 other migrants have drowned this year.

$\mathrm{T}$ HE goal of the refugee smugglers is not to complete the hazardous three-day crossing to mainland Australia undetected, but to be picked up by the authorities at one of the country's remote territorial outposts - either Christmas Island, 970 miles west of the mainland, or Ashmore Reef, a scattering of small sandy atolls 200 miles from Australia's north west coast.

Most of the sailors are young Indonesians, perhaps unaware of the 20-year prison sentences that avvait them if they are caught. For the asylum seekers, the arduous journey from their homes ands in a hot, remote detention centre in the Australian outback. Australia is the only devizloped country to lock up those who apply for: asylum.

Once arrested, asylum seekers are flown to the three most isolated of Australia's six detention centre's, Port Hedland, Curtin and Woomera, where they are interviewed and searched. "Unless people start burning buildings, we don't have an idea of what is going on in Curtin or Woomera," says Graham Thom of Amnesty Intırnational.

Most wait many more months in a labyrinthine process: of appeals. More than 80 per cent are eventually found to be genuine refugees and yet the government regularly leaves unfilled its humanitarian quotas. Last year 2,040 unfilled places from the resettlement programme were carried over to the next year.

Yet life in the new world is not quite as the Afghans imagined when they sat in Peshawar listening to the gilded promises of the smugglers. Refugees like Rahmon, a native of Panjsher Valley, in opposition territory in Afghanistan, who now works in a factory in Sydney, are granted only three-year temporary protection visas. They cannot get access to full benefits, they have no right to English language classes and they cannot bring over the families they have left behind. It will take months to pay back their relatives and most simply melt away into the ethnic ghettos of industrial Sydney or Melbourne. - Guardian New's Service

\section{Refugee boat to nowhere}

AUSTRALIA'S paranoia is best exemplified by the hysteria over the Norwegian cargo ship Tampa doing the right thing to rescue .438 refugees on the high seas between Australia and Indonesia. These unfortunate refugees might have drowned but for the humanitarian act of the ship's captain. Indeed, he steered his ship to the rescue site after receiving an Australian signal and guidance; as of today, the fate of the boat people hangs in the balance despite asylum offers by New Zealand Nauru. There is a long-standing and widespread fear in Australia of being swamped by boat people. Mostly, the fear has centred round Asian 'hordes' descending from Australia's north: the age-old yellow peril theory which is short hand for all kinds of Asians fleeing poverty, overcrowding and political persecution and heading towards Australia's vast spaces. Instead, we now have Afghan and Middle Eastern refugees. Although they have numbered only about 11,000 in the last decade, but this has been enough to validate for Australia its long-dreamt nightmare. Worse still, they are mostly Muslims who fit all the dangerous stereotypes in the Australian imagination. Canberra is, therefore, keen to send a message to the world that Australia is not a 'soft touch' or an easy target for refugees.

There is a feeling too that Indonesia is facilitating the refugee inflow as a payback of sorts for Australia's role in East Timor. The hard evidence for this is lacking. But Canberra would like Jakarta to prove its bona fides by, first, preventing the refugees from boarding for Australia and, second, if that fails, to mind them on its territory with Australian financial and infrastructure aid. To some degree, the Indonesian police is doing this on a local basis. But Jakarta is refusing to be involved at a policy level. Prime Minister John Howard is also playing domestic politics on the refugee issue. The government is facing an election later this year and indications are that it might lose. It is, therefore, banking on the highly emotive issue of refugees, with 80 to 90 per cent people rooting for Howard's tough policy of turning away refugees with force, if necessary. Indeed, there is so much callousness around that some people won't mind if the refugees were drowned and fed to sharks to deter future arrivals. Sending the military to secure the Norwegian ship is the desperate act of an electorally vulnerable government. Listening to government officials talking of safeguarding the country's territorial integrity looked like Australia was under attack by a Norwegian cargo ship. 


\title{
WOSHINGTON TIMES
}

SEPTEMBER 2,2001

\section{Fretful residents follow plight of refugees}

\author{
By Kathy Gannon
}

\section{ASSOCIATED PRESS}

KABUL, Afghanistan -- The Afghans stranded last week in the Pacific are among many who are fleeing Afghanistan, leaving their goods for sale in shops.

"I don't know where they have gone. Maybe they are on that ship," said Habibullah, the owner of one store.

Like many others in Afghanistan, he is paying close attention to diplomatic efforts over the Norwegian cargo ship moored off an Australian island with 460 persons on board, most of them Afghans.

For six days, Australian Prime Minister John Howard has refused to let the stranded migrants disembark on Australian territory, saying he wanted to show their smugglers that his country will not tolerate the illegal trade.

Yesterday, New Zealand and the tiny Pacific island republic of Nauru agreed to - accept the migrants. Those in New Zealand found to be genuine refugees will be allowed to apply for residency there, while refugees in Nauru will be resettled in third countries -- including Australia.

Ove Thorsheim, Norway's ambassador to Australia, said the migrants were exhausted and dehydrated after weeks or months on the run, but firm about their goal.

"They are very determined to come to Australia," he said after boarding the boat Friday. "Nowhere else will do."

Back home in Afghanistan -- an impoverished, war-torn country ruled since 1996 by the strictly Islamic Taliban militia -- those left behind tuned into radio broadcasts to follow the saga of their stranded compatriots.

"What choices do they have? They didn't risk their lives for nothing. Look around at this country. There is nothing left for our children," said Mohammed Akram, a former school teacher.

His daughter also was a teacher but is now unemployed because of a Taliban rule prohibiting women from working and girls from attending school. Women also must wear the billowing burqa, which hides them completely except for a mesh opening 
over their eyes, their only window on the outside world.

Music, movies, television, photography and most forms of light entertainment are

Afghanistan, already ravaged by civil war, also is suffering from the worst drought on record. About 4 million Afghans facing death by starvation, the United
Nations says.

"I would leave here tomorrow, if I could," said Nasim Nawabi, a former pilot who now makes less than $\$ 1$ a day as a porter. "Life is too hard -- no jobs, no food,
no life."

Afghans already make up the world's largest refugee population, according to the United Nations, which calls Afghanistan a "humanitarian catastrophe." There Iran.

Those two countries are suffering from "asylum fatigue," said Yusuf Hassan of the U.N. High Commissioner for Refugees office in Pakistan.

"Afghans are no longer welcome. The outside world is indifferent toward the sufferings of Afghans, and there are little opportunities for legal resettlement," he

\section{LOS ANǴELES TIMES}

\section{DEPTEMBER 2,2001}

\section{Staffs of 2 Aid Groups Start Afghan Pullout}

KABUL, Afghanistan -- Foreign staff members of two Christian humanitarian aid organizations began pulling out of Afghanistan on Saturday, a day after the ruling Taliban issued an ultimatum for their expulsion and raided their offices.

"Some have already gone, and the rest of us are making final preparations for leaving in the face of the Taliban's notification," said a staff member of the International Assistance Mission, who declined to be identified.

Those who left have gone by road to neighboring Pakistan, he said. The Taliban on Friday said all foreign staff of the International Assistance Mission and Serve, which have operations in several key cities, must leave the country within $\mathbf{7 2}$ hours.

The Taliban has not explained the reason for the order but said the decision followed frequent reports and complaints about the activities of the two 
organizations.

The Taliban said no foreign staff members of the two agencies were arrested.

But Western sources said four British nationals working for the International Assistance Mission in the western city of Herat and several unidentified foreigners in the eastern city of Jalalabad had been detained. "I have heard about the arrest too," the International Assistance Mission staff
member said.

He said the Taliban gave no clarification for its decision, and privately some Taliban sources said the move was made after the fundamentalist Islamic militia found that the International Assistance Mission and Serve had links to another Christian relief group called Shelter Now International, whose staff members have been charged with proselytizing.

Twenty-four staff members of the German-based Shelter Now, consisting of two Americans, four Germans, two Australians and 16 Afghans, were jailed last month on charges of proselytizing.

The arrests followed months of worsening ties between the Taliban and foreign aid - groups helping millions of impoverished Afghans cope with more than two decades of war and a devastating drought.

\section{Chicago Tribune}

\section{SEPTEMBER 2,2001}

\section{Taliban expels 2 dozen aid workers}

KABUL, AFGHANISTAN -- About two dozen foreign aid workers traveled a dusty, war-ruined road out of Afghanistan on Saturday, expelled by the Taliban for allegedly preaching Christianity in this devoutly Muslim nation.

The expulsions came as the parents of two U.S. women also accused of proselytizing met for a second time with their jailed daughters. They said the women, Dayna Curry and Heather Mercer, were still in good spirits as they awaited their trial. Two Germans and four Australians also are to be tried.

The workers expelled Saturday were from the international aid organization SERVE and the U.S.-based International Assistance Mission.

They were ordered out of the country but were not tried for their alleged activities. 


\title{
^WEEKEND Australian
}

\section{Afghan consul criticises Howard}

\author{
From AAP \\ September 02, 2001
}

THE Afghanistan consul to Australia today accused Prime Minister John Howard of trying to save face and make electoral gains with his Pacific solution for the 438 stranded asylum seekers.

Yesterday Mr Howard announced a solution to the stand-off which involves New Zealand taking 150 women, children and families from the Tampa and the remaining mostly male asylum seekers being sent to Nauru, $6000 \mathrm{~km}$ away.

But Mahmoud Saikal from the Canberra Consulate of the Islamic State of Afghanistan said it was not a long-term solution to the problem.

"The current breakthrough formula is a short-term solution, designed for face saving and perhaps electoral gains in Áustralia," Mr Saikal said in a statement.

While he welcomed the news of the solution to the problem, Mr Saikal said Mr Howard's actions would damage Australia's international reputation.

"We feel Prime Minister John Howard's refusal to accept the United Nations' plan, allowing the asylum seekers to land at Christmas Island before being processed, will tarnish Australia's image and international reputation," Mr Saikal said.

The 438 mostly Afghan asylum seekers have been stranded on the Norwegian freighter the Tampa off Christmas Island after the wooden ferry they were travelling to Australia in sank last week.

Mr Saikal said he appreciated the humanitarian gesture of New Zealand Prime Minister Helen Clark.

"By accommodating our homeless and stranded children and mothers, New Zealand has placed herself in the hearts of the Afghan people," he said in a statement.

And while he thanked the Nauru president Rene Harris for his support, Mr Saikal was not supportive of the plan to send some of the asylum seekers to the small Pacific island.

"Shipping more than 300 asylum seekers to the tiny and distant Nauru Island involves excessive cost," he said.

"I am sure Nauru has neither the resources nor the experience to handle a 2.5 per cent increase in its population and process hundreds of applications.

"I am not fully convinced the decision is the best for all concerned."

Mr Saikal suggested a better solution would be for sympathetic countries to assist 
financially in relocating the refugees back to the non-Taliban controlled areas in

He also appealed to New Zealand to accept more of the asylum seekers.

\section{SUNDAY MAIL}

02sep01

\section{Taliban move detained foreigners \\ From AFP}

THE Taliban authorities have moved eight foreign aid workers, including two Australians, detained for allegedly preaching Christianity in Afghanistan to an unknown place, guards at the detention centre have said.

The detainees were transferred late yesterday from Kabul's juvenile correction centre to an unknown place, Taliban guards at the gate of the detention centre said.

Diana Thomas and Peter Bunch from Western Australia have been held in detention in Kabul since early August, along with two Americans, four Germans and 16 Afghan colleagues. They all worked for the German-based Shelter Now International.

A Taliban guard said the ruling militia's religious police came at about $8 \mathrm{pm}$ yesterday (0100 AEST Sunday) and took them away. He gave no further details.

Taliban Foreign Minister Wakil Ahmad Mutawakel yesterday said investigations into the case were about to be concluded and the aid workers would soon be brought to trial.

\section{THE STAR}

Sep. 2, 2001

\section{Muslims also to blame for Afghan refugee mess}

Haroon Siddiqui

- Australia deserved to be condemned for refusing to take a boatload of 434 mostly Afghan asylum seekers. History will judge it as harshly as it did Canada for turning back 376 Sikhs from the West Coast way back in 1914. But the Islamic world ought not to escape its share of the blame. 
Not only did Indonesia, the largest Muslim nation, refuse them entry. Not one of the - 55 members of the Organization of Islamic Conference offered to take them. More tellingly, they did not want to go to any one of them. They preferred to take their chances in the much-maligned West, prompted no doubt by better economic prospects but perhaps also the knowledge that life can be cheap in Muslim societies and human rights often non-existent.

The Islamic world has also been silent on two related moral issues:

The decision of the ruling Taliban in Afghanistan to charge eight aid workers, along with their 16 Afghan employees, for preaching Christianity and, then, treating the foreigners far better than the fellow Afghans who haven't been heard from since
their arrest.

The conviction in neighbouring Pakistan of a teacher on charges of blasphemy, for allegedly insulting the Prophet Muhammad.

Let's take these one by one, starting with the floating human cargo off the Aussie coast.

The world agrees that the Taliban are abominable. They oppress their own people, especially women. They have killed hundreds of minority Shi'ite Muslims. Yet when a few dozen desperate Afghans turn up in Australian waters, Prime Minister John Howard calls them "bogus refugees" and queue-jumpers! If the Afghans are not genuine refugees, who is?

It is said he took the tough stand because anti-refugee sentiment is running high in his electorate and he faces an election this fall.

But that surely is not the whole truth.

Rather it is that the world, especially the West, has refused to face up to the fact that so long as we continue to ignore and isolate Afghanistan, we shall not escape its fallout.

Conditions there are so wretched - following 22 years of war, two years of American-led economic sanctions and four years of drought - that more than 1 million people face starvation and hundreds of children are already dead.

The Aussie stance is particularly shameful.

An immigrant nation, of boatloads of criminals, at that, at its beginnings, which used the Sydney Olympics to market itself as a land of diversity and tolerance, takes far fewer refugees than its huge size and sparse population of 19 million would suggest. In the first three months of this year, it took in 2,386, comparcu to 21,054 in Germany, 17,000 in Britain, 15,000 in the United States and about 10,000 in Canada. It also treats them badly, holding them in detention centres in the remote outback until their cases are decided, in months or years.

There are uncanny parallels between Howard's deployment of troops against the 
refugee-laden Norwegian freighter, the Tampa, and our own prime minister Robert Borden's against the Japanese freighter, Komagata Maru, when it anchored in Burrard Inlet on May 23, 1914, carrying mostly Sikhs, economic migrants all.

They were not allowed to disembark for two months, during which time one passenger died and many became sick. When 160 armed policemen aboard a port vessel failed to budge the freighter, Borden ordered a gunboat to escort it out to sea on July 23. After Hong Kong and Singapore refused entry, the passengers reached India where British police killed 26 and jailed many for five years.

That was then, the Aussie inhumanity is now.

Intolerance of a different sort is on display, from both Muslims and Christians, in Kabul.

There the Taliban are holding two Americans, two Australians and four Germans for proselytizing. Ostensibly aid workers of a German non-governmental organization, they are part of a Christian group, Vision for Asia, and carried CDs, audiotapes and pamphlets on conversion translated into local languages.

What were they doing breaking the local law against conversions? They had, in fact, been warned by United Nations officials but in their Christian zeal continued to entice the starving with a loaf of bread and a word about Jesus.

According to the Red Cross, visiting diplomats and relatives, they are being well looked after and will likely be let go. But their local workers may face death.

Besides, the general conduct of the Taliban has repelled more Afghans and others from Islam than any misguided missionaries can ever hope to pick off, as noted by Hamid Algar, professor of Islamic studies at the University of California, Berkeley, in an interview Friday.

Across the Afghan border in Pakistan, the Blasphemy Law continues to cause grief. Whatever the arguments about the law, itself - it is no different than the one in Britain - it is often either misused by segments of the majority Muslims against Christian and other minorities to settle persoral and property disputes, or it is misapplied, as happened recently.

A professor told his class that Muhammad was not a Muslim until age 40 when he received Allah's revelations. To non-Muslims, it may seem a statement of the obvious. But, as in thtological matters anywhere, it is more complicated. Tradition has it that Muhammad was always a muslim, one who submitted (to the will of God). He did not ever worship idols or engage in rebellion against God.

That this is yot a central point in the oyerall scheme of Islam did not deter someone from filing a complaint of $\mathrm{k}$ lower cout finding him guilty. He faces death. Even if such sentences are rarely carried out, they violate not just the spirit of the faith but also the practices of the Prophet and the majority of the divine words of the Qur'an enjoining humane behaviour. 


\section{CHICAGO SUN TIMES}

September 2, 2001

\section{Think Taliban intolerant? Look at a federal court}

\section{BY NEIL STEINBERG SUN-TIMES COLUMNIST}

The Taliban are always in the news, forcing Hindus to wear yellow and hounding Christians and such, not because Afghanistan particularly interests Americans--it is small, poor, and far away--but because we enjoy a burst of ego gratification at such stories. "Look at these people," we tisk-tisk, "chasing women with sticks. How
medieval."

Then we do exactly the same thing, in our own way.

Grab a Taliban off the street and ask why women shouldn't work or be educated and he will patiently explain to you that women who work are whores, and would you want your wife or sister to be a whore?

Makes all the sense in the world to him.

Go to Florida and ask U.S. District Judge James Lawrence King why gays can't adopt children and he will say--actually, he did say, Thursday--that there is insufficient evidence that "homosexual families are equivalently stable, are able to provide proper gender identification or are no more socially stigmatizing than married heterosexual families."

Makes all the sense in the world to him. Nevertheless, this is not only nonsense, but nonsense so knotted it can't be dismissed in a single, Gordian slash, but must be broken up into component parts of buncom.

Let's start with "equivalently stable!" To what? Heterosexual families? Puh-leeze. Half the couples divorce and another big chunk of parents never marry in the first place. Adoptive couples are so hard to find that, in moral Florida, 25 percent of kids adopted go to unmarried adults, whom I suppose are "stable" in that they won't split in two, but do not otherwise meet the supposed mom-and-dad-and-Fido ideal.

This is not to say that gay couples cannot be dysfunctional, abusive, short-lived-enjoying all the woes afflicting straight couples. They are after all--the Florida ruling notwithstanding--human. But to argue that they are somehow a special breed of instability is not science, it's bias (and don't forget that we withhold the sanctity of marriage from them, deeming them not worthy of that, either. Maybe if we let them wed, they'd be more stable, assuming they aren't now, which I don't). 
"Equivalently stable" reminds me of one of my favorite Peanuts cartoons, where
Charlie Brown corners Linus and lectures him that if he doesn't give up his blanket
he'll never become a happy, well-adjusted child. When Charlie finishes haranguing,
Linus removes his thumb from his mouth and coolly delivers a shattering put down:
"Like you?"

On to "proper gender identification." Don't gay men shave? Play football? Drink beer? If you must have straight parents to become properly straight, let me ask you
this: Where do gays come from? Eggs?

I'm not a scientist, but the the idea that you get your sexuality from your folks is laughable. The wildest girls I knew in my younger years had sprung from repressive American Gothic backgrounds and went nuts once the cage was flung open. People
follow the own urgings.

My father is a swell guy, and I took many traits from him--reading the New Yorker, gobbling that colorful geometric English licorice--but he wasn't exactly the Welcome Wagon for the glories of heterosexuality. Whose is? Dads are the guys arguing while you're trying to get the car keys to go out and be heterosexual. I probably would have become gay to spite him, were being gay something you decide to do, which it's
not.

Finally, the topper: "No more socially stigmatizing than married heterosexual families." In a world where John Wayne Bobbitt, Marv Albert and Bill Clinton walk around, heads held high, I would argue that the concept of social stigma has very little currency. Are we now forming law based on social stigma? They didn't strip Rick Sutcliffe of his citizenship when he blew that fifth game against the Padres, did they?

I think the invocation of stigma shows just how rooted in 19th century thinking (if not 13 th century thinking) the Florida judge's logic is--not to single out Florida; there are similar laws in Mississippi and Utah. These decisions are being made by people who have never met gays and don't want to. They cling to their prejudices, and don't want to know that gays can be devoted spouses and parents. They may not be ideal, but who is? I have no doubt in my mind that, if my wife and I were hit by a bus, and my boys had to be raised either by the Mormon Tabernacle Choir or the Gay Men's Glee Club, I'd choose the Glee Club in a heartbeat. At least my boys $\downarrow$. wouldn't have to go door to door, trying to win converts (though gay missionaries are amusing to imagine: "Hello sir, might I offer you this free videotape of 'Queer as Folk'?')

Prejudice always has reasons, and they always persuade those who believe them. I wish I could bring back an average man from 1901, to explain why women of course should never vote--feminine weakness--nor blacks be educated (smaller brains, see?), nor the Irish allowed into polite society, being so dirty, and drunken, and having all those kids ...

Those arguments are hollow lies now, but they weren't then, and 100 years from 
now, I guarantee you, people will look back on this legal wrangling over whether gays are full human beings in the eyes of the law with the same head-shaking disbelief we extend toward the bigotries of the past. I wish I was going to be around to see it--no, I take that back. I am so certain that society will get there that I don't need to be there. It'll happen. Dignity is a powerful drug, and once people taste a sip of it, you can't snatch the bottle back again.

\section{FINANCIAL TIMES}

September 22001

\section{Drought and conflict fuel Afghan exodus}

By Farhan Bokhari in Islamabad

A crackdown on aid workers' activities by Afghanistan's Taliban regime and the controversy surrounding the Tampa - a Norwegian vessel carrying mostly Afghan asylum seekers off the Australian coast - are the most recent signs of the crisis facing the country's $22 \mathrm{~m}$ population, western relief officials said.

Poverty has intensified in the past year, which has seen one of the worst droughts in recent years to hit Afghanistan, forcing up to $1 \mathrm{~m}$ people to leave their homes in search of food. In addition, the country, which has seen unending conflict since the Soviet invasion of 1979 , has faced fighting this summer between the Taliban and their main opponents, the Northern Alliance.

Most refugees have headed towards Pakistan and Iran, where the combined Afghan refugee population is estimated to be in excess of $4.5 \mathrm{~m}$.

But a small minority with the means to pay travel agents who specialise in forged documents, have chosen to travel further.

According to Lt Gen Kamal Matinuddin, a former Pakistani military commander who has written extensively on Afghanistan: "Afghans are now more desperate to leave their country than ever before. The push from asylum seekers will only grow in future."

In recent months, there have been other examples of increased Taliban pressure on the relief operation upon which many Afghans rely. "There is nothing such as a diplomatic immunity left in Afghanistan any more. The Taliban can send their guards to check our food stocks if they want to," said one UN official. 

But diplomats acknowledge that the west cannot afford to abandon Afghanistan
completely, not only because of fears over militants from the country spreading to
neighbouring regions, but also because of concern over asylum. Council's sanctions on arms supplies to the Taliban has already sparked anger
among militants in Pakistan.

Lt Gen Matinuddin warns: "The deadlock over Afghanistan will continue and the Taliban will remain defiant. That's even at the cost of more Afghans leaving their
country," he says.

* Taliban rulers said yesterday they might hold an open trial of eight western aid workers on the charge of promoting Christianity, but $16^{\circ}$ Afghans arrested with them would be tried separately, Reuters adds from Kabul.

\section{The Irish Times}

02/09/2001

\section{Taliban renew ban on poppy growing in Afghanistan}

The leader of Afghanistan's ruling Taliban militia has renewed his ban on the cultivation of state run Radio Shariat.

Taliban supreme leader Mullah Mohammad Omar in a statement broadcast over the radio said Afghan farmers should strictly obey the decree which last year banned the production
of opium throughout Afghanistan. land, adding that in case of violation the Taliban authorities would destroy the crop.

Those violating the decree will be given severe punishment, it said but gave no details.

Mullah Omar last year declared that opium growing was un-Islamic and must be stopped. Taliban officials say the decree has been successfully implemented in areas under the
militia's rule.

Until last year Afghanistan was the world's largest producer of opium, which is harvested from poppy buds and forms the raw ingredient of heroin.

US Assistant Secretary of State Christina Rocca last month pledged 1.5 million dollars to help UN drug-control efforts in Afghanistan in response to the Taliban militia's ban on
poppy cultivation. 
"We welcome the Taliban's enforcement of the ban and hope it will be sustained," the Bush administration's senior policy-maker for South Asia said during her visit to Pakistan. The Taliban seized Kabul in 1996 and controls most of the country with a strict brand of
Islamic law.

AFP

\title{
Toronto Star \\ $9 / 2 / 01$ \\ Muslims also to blame for Afghan refugee mess
}

\author{
Haroon Siddiqui \\ EDITORIAL PAGE EDITOR EMERITUS
}

Australia deserved to be condemned for refusing to take a boatload of 434 mostly Afghan asylum seekers. History will judge it as harshly as it did Canada for turning back 376 Sikhs from the West Coast way back in 1914. But the Islamic world ought not to escape its share of the blame. Not only did Indonesia, the largest Muslim nation, refuse them entry. Not one of the 55 members of the Organization of Islamic Conference offered to take them. More tellingly, they did not want to go to any one of them. They preferred to take their chances in the much-maligned West, prompted no doubt by better economic prospects but perhaps also the knowledge that life can be cheap in Muslim societies and human rights often non-existent.

The Islamic world has also been silent on two related moral issues:

The decision of the ruling Taliban in Afghanistan to charge eight aid workers, along with their 16 Afghan employees, for preaching Christianity and, then, treating the foreigners far better than the fellow Afghans who haven't been heard from since their arrest.

The conviction in neighbouring Pakistan of a teacher on charges of blasphemy, for allegedly insulting the Prophet Muhammad.

Let's take these one by one, starting with the floating human cargo off the Aussie

The world agrees that the Taliban are abominable. They oppress their own people, especially women. They have killed hundreds of minority Shi'ite Muslims. Yet when a few dozen desperate Afghans turn up in Australian waters, Prime Minister John Howard calls them "bogus refugees" and queue-jumpers! If the Afghans are not genuine refugees, who is?

It is said he took the tough stand because anti-refugee sentiment is running high in his electorate and he faces an election this fall.

But that surely is not the whole truth.

Rather it is that the world, especially the West, has refused to face up to the fact that 
so long as we continue to ignore and isolate Afghanistan, we shall not escape its fallout.

Conditions there are so wretched - following 22 years of war, two years of American-led economic sanctions and four years of drought - that more than 1 million people face starvation and hundreds of children are already dead.

The Aussie stance is particularly shameful.

An immigrant nation, of boatloads of criminals, at that, at its beginnings, which used the Sydney Olympics to market itself as a land of diversity and tolerance, takes

- far fewer refugees than its huge size and sparse population of 19 million would suggest. In the first three months of this year, it took in 2,386, compared to 21,054 in Germany, 17,000 in Britain, 15,000 in the United States and about 10,000 in Canada. It also treats them badly, holding them in detention centres in the remote outback until their cases are decided, in months or years.

There are uncanny parallels between Howard's deployment of troops against the refugee-laden Norwegian freighter, the Tampa, and our own prime minister Robert Borden's against the Japanese freighter, Komagata Maru, when it anchored in Burrard Inlet on May 23, 1914, carrying mostly Sikhs, economic migrants all.

They were not allowed to disembark for two months, during which time one passenger died and many became sick. When 160 armed policemen aboard a port vessel failed to budge the freighter, Borden ordered a gunboat to escort it out to sea on July 23. After Hong Kong and Singapore refused entry, the passengers reached India where British police killed 26 and jailed many for five years.

That was then, the Aussie inhumanity is now.

Intolerance of a different sort is on display, from both Muslims and Christians, in Kabul.

There the Taliban are holding two Americans, two Australians and four Germans for proselytizing. Ostensibly aid workers of a German non-governmental organization, they are part of a Christian group, Vision for Asia, and carried CDs, audiotapes and pamphlets on conversion translated into local languages.

What were they doing breaking the local law against conversions? They had, in fact, been warned by United Nations officials but in their Christian zeal continued to entice the starving with a loaf of bread and a word about Jesus.

According to the Red Cross, visiting diplomats and relatives, they are being well looked after and will likely be let go. But their local workers may face death.

Besides, the general conduct of the Taliban has repelled more Afghans and others from Islam than any misguided missionaries can ever hope to pick off, as noted by Hamid Algar, professor of Islamic studies at the University of California, Berkeley, in an interview Friday. 
Across the Afghan border in Pakistan, the Blasphemy Law continues to cause grief. Whatever the arguments about the law itself - it is no different than the one in Britain - it is often either misused by ségments of the majority Muslims against Christian and other minorities to settle personal and property disputes, or it is misapplied, as happened recently.

A professor told his class that Muhammad was not a Muslim until age 40 when he received Allah's revelations. To non-Muslims, it may seem a statement of the obvious. But, as in theological matters anywhere, it is more complicated. Tradition has it that Muhammad was always a muslim, one who submitted (to the will of God). He did not ever worship idols or engage in rebellion against God.

That this is not a central point in the overall scheme of Islam did not deter someone from filing a complaint or a lower court finding him guilty. He faces death. Even if such sentences are rarely carried out, they violate not just the spirit of the faith but also the practices of the Prophet and the majority of the divine words of the Qur'an enjoining humane behaviour.

\title{
Queensland Newspapers \\ Afghan consul criticises Howard
}

\author{
From AAP \\ $02 \operatorname{sep} 01$
}

THE Afghanistan consul to Australia today accused Prime Minister John Howard of trying to save face and make electoral gains with his Pacific solution for the 438 stranded asylum seekers. Yesterday Mr Howard announced a solution to the standoff which involves New Zealand taking 150 women, children and families from the Tampa and the remaining mostly male asylum seekers being sent to Nauru, $6000 \mathrm{~km}$ away. But Mahmoud Saikal from the Canberra Consulate of the Islamic State of Afghanistan said it was not a long-term solution to the problem.

"The current breakthrough formula is a short-term solution, designed for face saving and perhaps electoral gains in Australia," Mr Saikal said in a statement.

While he welcomed the news of the solution to the problem, Mr Saikal said Mr Howard's actions would damage Australia's international reputation.

"We feel Prime Minister John Howard's refusal to accept the United Nations' plan, allowing the asylum seekers to land at Christmas Island before being processed, will tarnish Australia's image and international reputation," Mr Saikal said.

The 438 mostly Afghan asylum seckers have been stranded on the Norwegian freighter the Tampa off Christmas Island after the wooden ferry they were travelling to Australia in sank last week.

Mr Saikal said he appreciated the humanitarian gesture of New Zealand Prime Minister Helen Clark. 
"By accommodating our homeless and stranded children and mothers, New Zealand has placed herself in the hearts of the Afghan people," he said in a statement.

And while he thanked the Nauru president Rene Harris for his support, Mr Saikal was not supportive of the plan to send some of the asylum seekers to the small Pacific island.

"Shipping more than 300 asylum seekers to the tiny and distant Nauru Island involves excessive cost," he said.

"I am sure Nauru has neither the resources nor the experience to handle a 2.5 per cent increase in its population and process hundreds of applications.

"I am not fully convinced the decision is the best for all concerned."

Mr Saikal suggested a better solution would be for sympathetic countries to assist financially in relocating the refugees back to the non-Taliban controlled areas in Afghanistan.

He also appealed to New Zealand to accept more of the asylum seekers.

The News International

September 2, 2001

\section{UNHCR restarts screening tomorrow}

ISLAMABAD: The United Nations refugee body said Saturday it will restart a drive to verify the status of tens of thousands of Afghans in northern Pakistan after assurances from the government that it won't deport any more refugees.

Joint teams of the UN body and Pakistani officials were conducting t. interviews to determine whether these Afghans deserve refugee status.

The United Nations High Commissioner for Refugees susprnded interviewing more than 130,000 Afghans in two major camps in NWFP on Friday to protest against the deportation of about 150
Afghans - many of them children.

"We will restart the screening process from Monday as the government has assured that no deportation will take place until the exercise is completed by December or so," Yusuf Hassan, spokesman for the UN refugee body in the capital Islamabad, told The Associated Press.

The screening exercise was being carried out for more than 70,000 Afghans living in Nasir Bagh camp on the outskirts of Peshawar and about 60,000 Afghans in Jallozai camp.

On Thursday, the United Nations had arcused Pakistan of vio- lating the agreement by deporting the Afghans - a charge denied by Islamabad, which said only the newly arrived refugees were pushed back to their country.

But on Saturday Shafqat Shah, a senior Pakistani official, expressed concern over the plight of Afghans and assured that refugees at Jallozai and Nasir Bagh camps won't be deported, Hassan said.

Pakistan, where more than 2 million Afghans have been living for more than two decades, has closed its border with Afghanistan, saying that its fragile economy is not in a position to afford the influx of new refugees.-AP 


\section{Expelled aid workers leave Kabul 'IAM, SERVE involved in preaching Christianity'}

KABUL: Expelled foreign aid workers left Afghanistan on Saturday, ending 36 years of work in this poor country by one aid organization, which the Afghan foreign minister said was preaching Christianity.

Also Saturday the parents of two American women jailed in here on similar charges visited their daughters for a second time.

The Taliban shut down the US based International Assistanc $\because$ Mission (IAM), which began its work in Afghanistan in 1965, on Friday. Its 50 mostly American workers were expelled.

Also closed was the interna tional aid organization SERVE, which provided solar-powered appliances such as ovens and operated other shelter and health-related aid projects. No arrests were made, but their offices and homes were sealed and armed Taliban stood guard outside.

"We found evidence that they were involved in preaching Christianity," the Afghan's Foreign Minister Wakil Ahmed Muttawakil told The Associated Press in a telephone interview from the Taliban headquarters in southern Kandahar.

He did not elaborate on the evidence. Their expulsion was apparentiy the result of the Taliban's ongoing investigation into charges of preaching Christianity against the
German-based Christian group Shelter Now International.

The Taliban will put on trial eight foreign aid workers of shelter Now International, who were arrested nearly one month ago along with their 16 Afghan staff.

"The investigation will soon be finished and the trial will be soon," said Muttawakil, without giving a date. He also said that no other aid organizations are expected to be implicated in proselytising, including the World Food Programme, which the Taliban had earlier said was suspicious.

"During the investigation we found no evidence against WFP" said Muttawakil. Considered a serious crime in devoutly Muslim Afghanistan, the penalty for proselytising is jail and expulsion for a foreigner and death for an Afghan.

The Shelter Now International which has frightened Afghan employees of Western organizations and made most foreigners suspicious to many Afghans - began on August 3.

On that day two American women, Dayna Curry and Heather Mercer of Shelter Now International, were arrested at the home of an Afghan family, which is strictly forbidden under Taliban rules. The Taliban accused the two women of teaching Afghans about Christianity, a serious crime.
Two days later, on August 5, Taliban troops seized offices and. homes of other Shelter Now Inter national employees, arrested six more foreigners and 16 . Afghar staff. They displayed compact discs, boxe's of Bibles and otber Christian literature translated local languages they said were seized from the Shelter Now International offices.

While no formal charges: have been filed, the seizures laviehed the Taliban onto a sweeping investigation of other organizations.

International Assistance Mission (LAM), which operates eve hospitals, clinics and runs; several other food-related brogrammes in different pants of the comintry, was nervous from the outsct of the Taliban's investigation.

Considered a missionary orga. nization, LAM foreign and Afghan workers privately said they were worried that they would be the next international aid group to be targeted. Many of the Af'ghan staff of IAM had been stayinis at home fearing arrest by the Taliban, who have not allowed anyone to visit the arrested Afghan workers of Shelter Now International

A senior Taliban official told that at least some of the 16 Afghan employees of Shelter Now will be sentenced either to life in jail or death.-AP

\section{WFP distributes food among: refugees on Tajik border

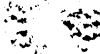

ISLAMABAD: The United Nations World Food Programme (WFP) has said it had started delivery of food to hundreds of Afghans stranded for the last 10 months on an island near the border with Tajikistan

"The World Food Programme has to overcome many hurdles to access the war and drought-stricken Afghans who fled the fighting between the Taliban and the opposition forces last year to an island in the river Pyanj," a WFP statement said.

The river is on the border with Tajikistan. Some
1,500 people, mostly from the northern protese are stranded on the island and food is delivered to them throught Tajikistan. Dushanbe has officialy is fused to accept any Afghan refugee for morg; thana: year.

The WFP said it had distributed 65 tonnes to this group of displaced Afghans since Februato

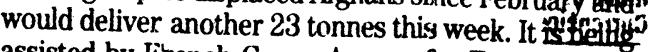
assisted by French Group Agency for Technical Oo: operation and Development (ACTED. - Reuters 
The News on Sunday

September 2, 2001

\section{Asylum seekers cling to Australia dream}

CHRISTMAS ISLAND: Hundreds of asylum seekers at the centre of an international standoff at sea clung to their dream of a new life in Australia on Saturday as the world community racked its brains over what to do with them.

The United Nations High Commissioner for Refugees (UNHCR) reported "broad support" on Friday for its plan to end their plight after a day of informal talks in Geneva involving officials from Australia, Norway, Indonesia and New Zealand.

UNHCR spokesman Ron Redmond said the representatives would pursue efforts to reach a solution on Saturday.

With the Geneva-based agency pressing Australia to let the 433 mostly Afghan boat people land on Christmas Island as an initial, temporary measure, the asylum seekers themselves wrote to Australian Prime Minister John Howard.

Norway's ambassador to Australia, who visited the ship off Christmas Island on Friday and left with the letter for Howard, spoke of miserable conditions aboard the Tampa.

"There is little water and limited food," Ove Thorshein told reporters after spending nearly six hours on the ship. "Sanitation is unsatisfactory."

But he added that the asylum seekers - men, women and children plucked from a sinking ferry by the Norwegian freighter on Sunday were determined to reach Aus.

\section{Threaten to go on hunger strike}

NUSAKAMBANGAN ISLAND: Detained for two weeks after being shipwrecked on a notorious Indonesian prison island, 138 Afghan refugees Saturday threatened to go on a hunger strike unless their demands for political asylum were agreed to by the United Nations.

The refugees were sailing for Australia's Christmas Island from Indonesia last month when their rickety boat sank in a storm. A mother and child drowned. The others managed to swim to the shores of nearby Nusakambangan Island.

"We will go on a hunger strike on Monday unless we ar - ed to leave this place," said Abdul Rashid, 34, a dentist who said he was fleeing political persecution by the Taliban. "No one is listening to us or helping us."-AP

tralian territory. "They said they would go nowhere but Australia," he said.

Norway's Prime Minister Jens Soltenberg said on Friday his country could takc in some of the asylum seekers prosvided that Australia lets them land and "accepts its responsibilities".

Earlier, Norwegian Foreign Minister Thorbjoern Jagland dismissed an offer from UN-adminis- tered East Timor to provide a temporary refuge, saying it was too poor to cope.

"East Timor is out of the question," he said, adding that he had discussed the idea with UN Secretary-General Kofi Annan.

"It's meaningless to shove these problems onto one of the world's poorest countries."

The asylum seekers have be come an election issue in Australia a country built on immigration and which accepted tens of thousands of boat people from Vietnam and other parts of Asia in the 1970 s and $1980 \mathrm{~s}$. With the government denouncing illegal immigrants as queue jumpers, Australian troops stormed the Tampa on Wednesday as it entered Australian waters to prevent anyone from trying to reach land. The troops have remained on board the ship.

The UNHCR's three-point plan calls for Australia to allow the boat people to land on Christmas Island, which is closer to Indonesia than continental Australia.

"The plan would begin with first, temporary disembarkation for humanitarian reasons on Christmas Island...The people have been aboard far too long and that island $\therefore$ the most logical place to go for the time being," Redmond said.

Under the plan, the UNHCR would then screen passengers to determine genuine asylum seekers, who would be transferred to third countries for further screening or resettlement.-Reuters 


\section{Nine dead, drugs seized in Tajik border clashes}

DUSHANBE: Russian guards manning the border between Tajikistan and Afghanistan killed nine drug smugglers trying to cross the frontier overnight and seized more than $200 \mathrm{~kg}$ of drugs, officials said.

A border guard spokesman told Reuters that five drug runners had been shot dead in a clash with guards from the Pyandzhskovo unit. Around $150 \mathrm{~kg}$ of heroin were later recovered from the scene.

In a separate incident further along the border, Russian guards shot four drug smugglers as they tried to sneak into Tajikistan, the border guard press service said.
The press service said $46 \mathrm{~kg}$ of drugs, including $39 \mathrm{~kg}$ of heroin were confiscated. A further $15 \mathrm{~kg}$ of drugs were seized in a third clash during which the smugglers escaped back across the border.

The seized narcotics would be destroyed in the presence of the head of the Russian border guards, the spokesman said. Since the start of the year, Russian border guards have seized 4.5 tonnes of drugs, including 1.9 tonnes of heroin.

Central Asia is a major export route for illicit drugs produced in Afghanistan for Western markets. - Reuters

\section{Taliban unlikely to oblige Arafat}

\section{Rahimullah Yusufzai}

PESHAWAR: The Taliban are un likely to oblige Palestinian president Yasser Arafat this time by releasing the eight foreigners detained on charges of proselytizing on his recommendation in case they listen to advice from Osama bin Laden and his Afghanistan-based Arab followers.

Bin Laden and his men weren't happy when the Taliban agreed to release several Iranian prisoners following Arafat's intervention in the summer of 1998. The Taliban had seized the Iranians, mostly truck drivers, when they captured Mazar-i-Sharif and other areas in northern Afghanistan.

Dr Ayman al-Zawahiri, leader of the Islamic Jehad group of Egypt and a close aide of bin Laden, told this correspondent during a meeting near Kandahar, southwestern Afghanistan, at that time that the Taliban should have freed the Iranian prisoners on the recommendation of the Palestinian Islamic party, Hamas, instead of obliging Arafat.

He explained: "Bin Laden and all of us felt the Taliban should have given this credit to Hamas and its leader Shaikh Ahmad Yassin rather than Arafat. The Hamas would have grown in stature and earned the goodwill of Iran and other Islamic countries if the Taliban had released the Iranian prisoners on Shaikh Yassin's request."

Al-Zawahiri, who like bin Laden is wanted by the US government on terrorism charg.s, argued that Arafat is a stooge of the West and no longer fit to lead the Palestinians. However, he felt the Taliban had agreed to release the Iranians on Arafat's request because of their strong support and sympathy for the Palestinian cause.

Bin Laden, al-Zawahiri and their Afghanistan-based Arab followers would be perturbed again by the arrival of Arafat's emissary Ahmad Abdur Razzaq Salman, who is also the Palestinian ambassador in Pakistan, in Kandahar. Newsparer reports said ambassador Salman met Afghan foreign minister and Taliban leader Wakil Ahmad Mutawwakil in Kandahar on Thursday to urge him to show leniency toward the four German, two American and two Australian staffers of the Christian aid group, Shelter Now International, who were jailed in Kabul early in August on charges of proselytizing the Afghans. The reports

quoted Taliban sources in Kandahar as saying that the Palestinian. ambassador requested the re-. lease of the foreign aid workers because it would earn goodwill for the Taliban and show the tolerant face of Islam. However, the sources felt the Taliban were unlikely to heed the request by the Palestinian diplomat.

One would also have to wait to see if Taliban supreme leader Mulla Mohammad Omar agrees to grant an audience to ambassador Salman. The ambassador appears to be keen to meet Omar because he knows that the latter makes all final decisions in Afghanistan.

In fact, Omar's decision to meet any non-Afghan increases the importance of that person in Taliban eyes. By not meeting the Palestinian ambassador, Omar may be keen to send the message that Arafat has no role in the issue concerning the detained aid workers.

Besides, it could also provide an indication as to where Taliban sympathies lay in Palestine. Though there is no evidence to suggest that the Taliban and the Hamas have forged any ties, it is possible that the two hardline Islamic groups share some of their hatred for Israel and its American and Western patrons.

This indeed would be happy news for bin Laden and his supporters. 


\section{The News on Sunday}

September 2, 2001

\section{US actress visited Afghan camps on UNHCR's invitation}

ISLAMABAD: US actress Angelina Jolie visited Pakistan on the invitation of the United Nations High Commission for Refugees (UNHCR) to visit Afghan refugee camps in NWFP and Balochistan last week, says a press release.

Prior to coming to Pakistan, she visited Africa (Sierria Leone and Tanzania) and Cambodia to know the plight of refugees there. After her departure from Pakistan she left for Geneva where she was formally appointed as the goodwill ambassador of the UNHCR.

During her visit to Pakistan she also called on Minister for Kashmir Affairs, Northern Areas and States and Frontier Regions, Abbas Sarfraz Khan. The minister briefed her about the sufferings of the Afghan refugees. He stressed the need for enhanced role of the international community in general and the UN and its agencies in particular for rehabilitation of Afghan refugees in their country.

He appreciated the efforts of the UNHCR and expressed hope that with their support the acress would be able to play an important role in not only increasing awareness of the plight of Afghan refugees internationally but also raising much needed funds for them.

Ms Jolie, while expressing concern over the sufferings of the Afghan refugees said that she is fully committed to the cause of refugees all over the world. She expressed her desire to raise the issue of refugees at international level, particularly among the youth.

The minister presented a book to Ms Jolie on the Northern Areas of Pakistan.

\section{The Frơntier Post}

Sunday, September 2, 2001

\section{Refugee influx}

HERE can be no dispute with the foreign office spokesman's contention that Pakistan can take no more influx of Afghan refugees. For well over two decades, it has hosted a huge population of these people, at one time crossing the four million mark. Even a prosperous nation would have found its well of hospitality going dry on having to host such a large refugee population for such a long time. Even now, there are over two million Afghans still living here. Another 200.000 have freshly arrived. Pakistan, meanwhile, is stuck in its own economic woes. Obviously, it cannot shoulder any further refugee burden, more so when international assistance for relief has dwindled to a trickle.

Surely, this constraint of Pakistan is not lost upon others. However, there are more humane and dignified ways to cope with this difficult situation than have been in evidence of late. In recent days, there have been reports that refugees are being forcibly repatriated to Afghanistan. Just a few days back, it was reported that 132 refugees were tricked into leaving this country. They were told they were being shifted from Jallozai camp to a better abode. Instead, they were handed over to the Taliban officials at the border. The UNHCR people have met the unfortunate souls at Jalalabad, where they are presently housed. They come from the Tajik ethnic minority of northem Afghanistan, currently in the throes of civil strife, and include. apart from sick and malnourished persons, several children whose families are left behind in the camp.

In protest at their deportation, the UNHCR has suspended the refugee screening process. The agency has termed it a breach of its ..:eement with the Pakistan government for screening of the Sugees, which stipulates no deportation from the Jallozai and Nasir Bagh camps while this process is on. For resuming the task, the agency wants an assurance from the government that such a deportation will not be repeated

Knee-jerk responses must be eschewed. Though not being a signatory to the Geneva Convention on refugees, Pakistan has hosted the Afghan refugees for years. It has earned a good name worldwide for this. If it doesn't abide by those conventions now, when refugees from northern Afghanistan are trying to get in, its reputation will be badly sullied for obvious reasons. It can ill-afford this, especially when it is already being pilloried in diverse ways for its friendship with the Taliban.

For hosting the Afghan refugees in such large numbers and for so long. Pakistan has come to enjoy a popular sentiment of goodwill in Atghanistan. If A tghans from as far away as northern Afgha:istan travel down to Pakistan instead of a nearby bordering state for refuge, it reflects as much their own desperation as their trust in this country to be a triendly and secure abode for shelter. For this popular sentiment of trust and goodwill among the Afghans, the people of this country have paid enormous costs in multiple ways. Their sacrifices should not be frittered away' by thoughtless actions.

Nor should it be forgotten that forced expulsions are no solution to the problem. Instead, these would lead to complications impossible to deal with. Pakistan shares a long, porous border with Afghanistan, which no army or border security force can plug completely. Repatriation by stealth would prompt an uncontrollable influx of refugees through this border, with unpredictable consequences.

The best course is to be pragmatic. Humanitarian problems can have only humanitarian solutions. The government must give the required assurance to the UNHCR for the screening process to resume. 


\section{The Frontier Post}

Sunday, September 2, 2001

\section{Howard allows refugees to apply for asylum}

SYDNEY (Online): Australian Prime Minister John Howard has announced a deal which would allow more than 400 refugees stranded on a Norwegian ship to land and apply for asylum.

Under the deal, the people will be taken to New Zealand and the Pacific Island state of Nauru, where their application claims would be processed, BBC reports Saturday said. Australia will meet the costs of the operation, and has agreed to take some of the refugees, if their claims are judged genuine.

Mr Howard's government has been firmly opposed to allowing the refugees to land and apply for asylum in Australia. Public opinion in Australia has largely supported Mr lloward's position.

"This does not involve the people being taken onto Christmas Island or any other Australian territory." said Mr Howard.

He added that Australia would step up military patrols, by sea and air, of the ocean between it and Indonesia, with immediate effect.

The 438 asylum seekers on board the Norwegian ship Tampa will be split into two groups. Women, children and families - a group numbering about 150 - will be taken to New Zealand, where their asylum claims will be assessed. If successful, the applicants will be allowed to stay there as part of the country's annual refugee quota. "New Zealand will be working closely with Australia and the United Nations High Commission for Refugees to arrange transhipment of the refugees to New Zcaland," said New Zealand Pritr. Minister Helen Clark.

\section{Taliban attack on Ghore repulsed}

ISLAMABAD (NNI): The Northern Alliance said that Taliban launched a surprise attack against their troops on the border between Ghore and Badghis, but retreated after 20 of their fighters were killed and 30 taken prisoner.

Three junior opposition commanders were also killed in fighting.

In a related development, more than 90 commanders from Ghore, Badghis and Herat provinces held a meeting in Ghore to discuss ways of coordinating their activities against the Taliban militiamen. Ismail Khan chaired the meeting.

Reports from Bamyan say that the Taliban continue to demolish houses outside the provincial capital. An opposition source told Payam-e-Mujahid Weekly that the Taliban, who had earlier burned houses in Shahidan and Shebarto regions of Bamyan Province, are now tearing down their walls using bulldozers.

\section{Afghan national convicted for drug trafficking F.P. Report}

PESHAWAR: The Additional District and Session Judge Khalid Badshah on Saturday convicted the accused Anwer Khan on charges of drug-trafficking for four and a half years rigorous imprisonment and Rs 30,000 fine.

The convicted, an Afghan refugee, was arrested by the Hashtnagri Police on G.T Road on December 23, 2000 with 4500 grams hashish. The verdict also contains that if the convict would not able to pay the fine he would be jailed for further three months.
UIN issues stern warning to Taliban UNITED NATIONS (Online): UN Secretary General Kofi Annan has warned the Taliban against detention of aid workers, saying their action could seriously affect international humanitarian assistance to Afghanistan. The detention and expulsion of aid workers "may bring to an end their (aid ayencies) assistance and activities in Afghanistan." a spokesman quoting Annan said. 


\section{The Frontier Post}

\section{Sunday, September 2, 2001}

Iran says Taliban raising tension along borders

\section{UNITED} NATIONS

(Agencies): Iran complained to the United Nations that Afghanistan's ruling Taliban had raised tensions in the region by deploying soldiers along their border and seizing an Iranian border kiosk.

Tehran had set up the border kiosk at the Dogharun crossing point in northeastern Iran to check on movements by nationals of both countries, Tranian envoy Mohammad Hasan Fadaifard said in a letter to UN secretary-general Kofi Annan.

But aliban soldiers entered Iran on Aug. 27 and returned to Afghanistan with the kiosk, Fadaifard said, demanding its return and expressing concern about the incident.

"At the present time, armed forces of the Taiban, still deployed on the rder strip, have created ser. - stensions in the area," he sa:

"The continus:un of such practice will jeopardize peace and tranquillity in the two countries' border areas." he said, asserting Tehran's "legitimate right to defend its security and its international borders."

The conservative Islamic Taliban movement, which controls, most of Afghanistan and draws its strength from the majority Sunni Muslim sect, accuses largely Shiite Iran of supporting Afghanistan's opposition alliance, which is fighting Taliban rule.

Iran denies backing the opposition but still recognizes ousted President Burhanuddin Rabbani, whose forces were driven by the Taliban from the capital Kabul in 1996.

Flooded by hundreds of thousands of Afghan refugees who have fled their homes to escape 21 years of war and the worst drought in 30 years, Iran has started deporting Afghanis, accusing many of drug dealing.

Iran lies on the main drug transit route from Afghanistan and Pakistan to lucrative markets in Europe and the oil-rich Arab states.

The government has used thousands of troops in an effort to seal its eastern borders and spent $\$ 20$ million last year to fight drug trafficking along its 590-mile border with Afghanistan.

\section{Khatami slams Taliban admirers} TEHRAN: Iranian President Mohammad Khatami hit out at hardline clerics on Saturday for expressing admiration for strict punishments decreed by the Taliban in Afghanistan.

"The Taliban, whom we always curse, have managed to restore security for their people. Why cannot we do the same?" said Qorbanali Dorri Najafabadi during Friday prayers in Tehran.

"Such people who took the podium in Friday's prayers sug. gesting envy for the Taliban have insulted the late imam (Khomeini) and their stance is unacceptable," the official IRNA news agency quoted Khatami as telling a news conference from which foreign reporters were barred.

"We chose neither Talibanbased security, nor Talibanbased Islam," he said.

He called for greater cooperation between his government, the judiciary and parliament. He hoped greater freedom of the press could be fostered in his second term. - Reuters

\section{The Statesman simaly, Seperemerer, 2001}

\section{Govt asked to restrict Afghan refugees to camps}

Statesman Report

BALAMBAT: Residents of the locality have demanded of the provincial government to ban the free movement of Afghan refugees and restrict them to their camps in Timergara and other parts of the province.

In a statement, general councillor from Balambat Mohammad Ibrahim and other notables of the area complained that the locals were facing numerous problems due to the presence of Afghan refugees everywhere in Timergara.
They said that the high number of refugees in various parts of NWFP has resulted in the upsurge in crimes adding that only by banning the free movement of Afghan people rampant lawlessness could be controlled.

Swoop against jihadis flayed: Senior vice president Tehrik-i-Istiqlal Rehmat Khan Wardag has termed crackdown against the Jihadi outfits as a cruel and imprudent act of military governmelit.

He stated this while addressing newsmen here during his visit to Dir. He said the Jihadi outfits have waged a crusade against the elements bent upon destabilising our motherland.

$\mathrm{He}$ termed the military government's act as an unwise decision, adding that it would strengthen only the hands of enemy. He asked the government to review its policy towards Jihadi organisations.

He recalled that only Jihadi outfits were responsible for the disintegration of the erstwhile Soviet Union; adding that the treatment meted out to the heroes of Afghan war was deplorable. 


\section{KHYBER $M_{A I L \text { September 02,2001 }}$}

\section{Australia and}

\section{Afghan refugees}

A ustralia's refusal to take in the 460 or so Afghan refugees currently crammed on a Norwegian cargo the world off Christmas Island is drawing fire from across stand are coming fire and the appeals to reconsider its rights coming not just from idealistic groups and human rights organizations, but also from hardheaded politicians - some of them leaders of countries that are favorite destinations of asylum seekers. Australia has legitimate fears about the effects of holding its doors open to all those who want to come. There is no doubt that those fears must be addressed. However, the time to discuss them is not when 400 -odd sick and hungry people, women and children among them, are waiting on board a cargo ship that is not equipped to carry passengers. The key question here is that of responsibility. Who is responsible for the refugees? Indonesia in whose waters they were picked up, or Norway where the Tampa is registered or Australia? Mary Robertson, the UN High Commissioner for Refugees, has pointed out, as the international law stands now, it is Australia that is primarily responsible for them. The Geneva Convention on Refugees, to which it is a signatory, states that refugees must be provided for at the nearest port Christmas Island is that nearest port.

The standoff is partly politics. Prime Minister John Howard wants to play the tough guy in the hope that Australians will like it. There is an election on the horizon and he is not seen as strong. The Australians do like it Opinion polls suggest that a staggering 98 percent of them support his hard line. Perhaps that is not so surprising: although Australia has accepted immigrants from all over the world, there is a strong redneck tradition running through Australian society - as indigenous Aborigines still know to their cost. Immigrants and refugees who are not white or willing to accept total assimilation into Australia's Westernized culture are regarded with suspicion. Prime Minister Howard tries to justify his stand on the grounds that if he.lets the Afghans in, it will send a signal to all those other Afghan refugees in camps in Iran and Pakistan, not to mention the millions of would-be economic migrants elsewhere in the world, that the country is a pushover, that all they have to do is arrive on its doorstep looking pathetic and desperate and they will be let in. There is without doubt a numbers issue: there are hundreds of thousands of displaced persons within Afghanistan and a further three-and-a-half million in refugee camps in Iran and Pakistan. Many might indeed want to head to a life of freedom, safety and comfort

But there is more to this than a mere fear of numbers. If the boat people had been white Europeans, they would have been welcomed with open arms. Australia may be today a limits. It is a multicult but its multiculturalism has decided and Westerm a malticulturalism thatic secular, materialic unusual and col. If it means interesting ethnic restaurants, ing and music, that is most acceptable. Anything with dancsuch as a different lifestyle acceptable. Anything more such as a different lifestyle and a faith, rigorously maintained; that is seen as a threat. This is the reality behind Australia's opposition to the Afghan refugees.

\section{The Nation}

SEPTEMBER 2, 2001

\section{Afghan lawyers seek UNSC intervention for Afghan solution}

\section{From Our Correspondent}

PESHAWAR - The Peshawar based Lawyers Association have demanded early involvement of the Security Council not only for supporting the peace initiatives but also for finding out ways and means for an end to every sort of foreign interferences in affairs of Afghanistan.

Through a letter addressed to UNO Secretary General by Prof. Qazi Gul Rehman, President of the association has praised the UNO Secretary General for his recent proposal regarding involvement of the Security Council for an early solution to the conflict which is possible with involvement of all the involved countries in the peace process. "The principle problem of the existing case originate from its foreign dimension ( foreign interferences). Afghans have realised that the foreign interference is the main cause for continued bloodshed and destruction in Afghanistan and it could only be resolved by the Security Council"

Legitimacy of ADC questioned

Meanwhile, Former Afghan Minister and chief of Ghor tribe from Central Afghanistan Abdul Qadar Imami has questioned legitimacy of the Afghanistan Defence Council and said that it will not only be considered a naked interference in affairs of that country but even it is an act to curb its sovereignty and solidarity.

As a result of in-fighting, he added, Afghanistan has been converted into ruins while millions of its people have lost their lives and majority of the remaining are now scattered all over the world. 
The Nation

SEPTEMBER 2, 2001
THE PAKISTAN TIMES

Saturday, September 1, 2001

\section{Asylum: court ruling throws new doubt}

\section{CHRISTMAS ISLAND,} Australia (AFP) - New Zealand and Nauru Saturday agreed to take in 438 refugees stranded on a Norwegian freighter in the Indian Ocean, handing Australia a way out of the week-old crisis over their fate.

But the face-saving deal was thrown into doubt on Saturday night when an Atstralian Federal court issued an injunction preventing the ship from leaving Australian waters until it had ruled on whether the refugees should be allowed to land in Australia.

Australian Prime Minister John Howard had earlier announced that the the boat people would be split into two groups, with 150 to be accepted by Wellington and the remainder to have claims for refugee status assessed on the tiny Pacific island of Nauru.

The court ruling casting doubt on this solution came in response to an application from the Victorian Council for Civil Liberties for the refugees to be allowed to disembark at Australia's Indian Ocean territory of Christmas Island.

Theasylumseekershavebeenliving on the deck of the freighter, theTampa for almost a week after Australia refused to accept them. The Tampa is currently anchored four nautical miles off Christmas Island.

The asylum seekers were plucked from the sea by the Tampa's crew last Sunday after captain Arne Rinnan was alerted to their plight aboard a sinking Indonesian vessel by Australian maritime authorities.

\section{4 nations in talks over plight of Afghan refugees}

GENEVA (AFP)

Representatives of Australia, Norway, Indonesia and New Zealand resumed talks Saturday at the UNHCR on the plight of the Afghan refugees stranded on a boat in Australian territory.

The talks, which began around 11:00 am (0900 GMT), are scheduled to last two or three hours, a spikesman for the UN High Commissioner for Refugees said.

But a spokesman for the UNHCR expressed a wish to know more about an Australian plan announced overnight which would see the refugees taken to New Zealand and the Pacitic island state of Nauru.

"A plan has been announced by Australia; we know this only through media sources and we want to know more about it," he
said.

"At first glance, we prefer our own plan which sees the refugees disembarking at Christmas Island (Australian territory) where their request for asylum will be examined before they are conveyed to a third country," he added.

\section{We'll take them, East Timor says}

DILI: East Timor-one of the world's poorest countries, not yet independent and barely recovered from devastating violence-has offered temporary refuge to the asylum seekers stranded off Christmas Island.

The offer came as Australia, Norway and Indonesia squabbled over the people on the Tampa.

"We are a small player. If we can be the solution to this problem, of course we'll make ourselves available," said Jose Ramos Horta, East Timor's de facto foreign minister.

His offer came a day after Australian Foreign Minister Alexander Downer contacted the head of the UN administration in East Timor, Sergio Vieira de Mello, to discuss the possibility of the territory providing temporary shelter to the boat people.

Last night, however, $\mathrm{Mr}$ de Mello said he had received a second call from Mr Downer, this time saying East Timor was no longer an option, meaning that it would not be considered as a processing centre for the asylum seekers.

Mr Downer's initial approach came on Thursday, the day East Timorese voted in their first democratic election, two years to the day after they voted for independence from Indonesia.

East Timor is still recovering from massive devastation inflicted by Indonesian Armybacked militias in 1999 after the independence vote.

More than 500,000 East Timorese were displaced in :1999, including an estimated $-300,000$ forcibly deported to West Timor where up to 80,000 remain as refugees in militia-controlled camps.

Norway's Foreign Minister 'Thorbjoern Jagland dismissed the idea. "East Timor is out of the question," he said. "It's meaningless to shove these problems on to one of the world's poorest countries."

Mr Ramos Horta said his offer was conditional on the international community paying the costs of sheltering the boat people and that they 'stayed for a limited time. But he said any request for assistance from Australia or the UN High Commissioner for Refugees would be received favorably.

"Australia holds primary responsibility with Indonesia to address this issue, but we are friends of Australia: And, we have also been refugees "there," Mr Ramos Horta said. He made the comments after consulting independence leader Jose "Xanana" Gusmao, Fretilin party leader Mari Alkatiri and Bishop Carlos Belo.- PTR 


\section{Pakistanis, Afghans arrested in Kuwait}

\section{By Our Correspondent}

KUWAIT CITY, Sept 1: The Kuwait coastguards have arrested two Pakistanis and nine Afghans as they were trying to enter Kuwait illegally, reported Arabic daily Al Watan.

The coastguards were on a routine patrol in Al Jalea area when they intercepted a boat carrying Pakistanis and Afghans. All the accused were arrested and their case was sent to the interior ministry for further investigation. The boat was coming from Iran.

Kuwait in recent days had imposed a ban on issuance of visas to Pakistanis and Afghans due to fear of terrorist attacks on US interests.

\section{Taliban jets bomb opposition bases}

i $y$ is
KABUL: Forces of the Taliban's movement launched a new offensive against its opponents north of the capital Kabul on Sunday, gaining high ground and some posts near a disused airbase, Taliban sources said.

But a spokesman for the opposition forces said the Taliban movement's troops were quickly repulsed except for one post after the pre-dawn attack, which was backed by aerial bombing on opposition bunkers.

Taliban sources in Kabul said its soldiers gained some high ground and several posts near the Bagram air base, where the forces of main opposition commander Ahmad Shah Masood have dug in after being driven from power and out of Kabul in 1996.

Bagram served as a major air base for Soviet forces during their occupation of Afghanistan in the 1980s but has been in disuse in recent years after changing hands between rival forces several times.

Clashes also broke out in the Khoja Ghar district of Takhar province in the northeast, close to the Tajik border, they said.

The Taliban controls Afghanistan's main towns and roads, while the opposition is estimated to control about, 10 percent of the war-torn country. 2it

Masood, a legendary guerrilla commander during the Soviet occupation and a former idefence minister, remains the Taliban's main obstacle to gaining total control of Afghanistan. $\quad \therefore \ldots$

Opposition spokesman Mohammad Habeel told Reuters:by satellite telephone from the areat the Taliban attack was concentrated on the so-called New Road east of Bagram, some $50 \mathrm{~km}$ north of Kabul.

Taliban forces captured some opposition posts initially, but lost all but one later, he said: "Our men are now trying to get this post back from them," he said.

Taliban jet fighters pounded opposition positions "as" well as residential areas of toharikar and Kapisa further 'roith of Bagram on the Shomfáf plain, which leads to Masog Panjsher valley stroffighold, he added. "sith:":

Masood's forces sufferced several setbacks at the hand of the Taliban last year. This year fighting has spread into some isolated areas in the centre and northo the country. - Reuters

\section{Opposition commaniders clash in Badakhshän

KABUL: A number of residential that a fierce clash bas recently houses were damaged as a result taken place between ffrmander of mutual clashes between Pir Muhammad and sommander the commanders of the Northern Hassan's men in Takhtse Tawan Alliance in the suburb of area of Badakhshan province northern province of leaving a number of 5 sidential Badakhshan. The rebel forces have also looted goods of the people of the area.

Quoting a reliable source Bakhtar news agency reports
The report said that ilashes are still continuing ands, number of supporters of the commanders have also been killed. - Sana 


\section{HRCP resents Afghans deportation}

\section{Bureau Report}

PESHAWAR: The forced and arbitrary deportation of 28 Afghan refugee families from Jalozai camp has created deep concern and indignation not only among refugee population but also among all those who believe in human rights, civilised behaviour and rule of law.

The chairman Human Rights Commission of Pakistan, Afrasiab Khattak, in a statement on Sunday said that 28 families of Afghan refugees were bundled in official trucks on the pretext that they were being taken to another refugee camp. The whole operation was conducted with such high-handedness that some members of the aforementioned families were left behind as the families were given no time to properly assemble. After leaving Jalozai the refugees discovered that instead of going to another camp, they were being taken to Torkham for being pushed out from Pakistan. The fact that at least eight families of the deported the Afghans consisted of refugees who were recently screened by the joint teams of government of Pakistan and UNHCR and declared to be genuine refugees makes the whole thing outrageous.

The HRCP chairman posed a question as to what is the message government of Pakistan wants to convey? Does it want to say that the ongoing process of screening of Afghan refugees is just eyewash and the real purpose is to throw refugees out in total violation of international customary law and the law of the land. While opposing the forced and arbitrary deportation of refugees and demanding an end to it, the HRCP chief appealed to the international community to come forward help refugee population in Pakistan. He said it was crystal clear Pakistan could not cope with the crisis alone.

\section{FC recover hashish, bombs}

QUETTA: Frontier Corps Balochistan seized $47 \mathrm{~kg}$ of hashish, two mortar bombs and five rounds of rocket launcher from general area Aza near PakAfghan border on Saturday.
An FC press release said the drugs and ammunition were recovered after thorough search of the area following a tip-off.

These items were found hidden under stones. - APP

\section{Australia slammed over asylum seeker saga}

asylum seekers to New Zealand

SYDNEY: Afghanistan's opposition government accused Prime Minister John Howard Sunday of trying make political capital with his $\mathrm{Pa}$ cific solution for the 438 asylum seekers stranded in the Indian Ocean.

Mahmoud Saikal, from the Canberra Consulate of the Islamic State of Afghanistan, said Australia's proposal to send 150 of the and the rest to the island state of Nauru was not a long-term solution.

The consulate represents the opposition forces headed by former president Burhanuddin Rabbani, who still hold the Afghan seat at the United Nations despite only controlling a small section of the country. Australia recognises his goveriment rather than the Tal- iban regime.

"The current breakthrough formula is a short-term solution, designed for face saving and perhaps electoral gains in Australia," Saikal said in a statement.

Saikal suggested a better solution would be for sympathetic countries to assist financially in relocating the refugees back to the non-Taliban controlled areas of Afghanistan.

And while he welcomed news of a solution to the problem, Saikal said Howard's actions would damage Australia's international repu-

tation.

"We feel Prime Minister John Howard's refusal to aecept the United Nations' plan, dllawing the asylum seekers to land at Christmas Island before beingoptocessed, will tarnish Australia's image and international reputation," he added.

The mostly Afghano asylum seekers have been stranded on the Norwegian freighter Tarnè since it rescued them from theit sinking wooden ferry off Indortesiálast Sunday. U $2 \pi j 6$ :

Saikal said he appreciated the humanitarian gesture of New Zealand Prime Ministê Helen Clark. of $14 i^{n}: \mathrm{i}$ :

"By accommodatin 'our' homeless and stranded chithreit and mothers, New Zealand fitas placed herself in the hearts of the Afghan people," hè said.

He thanked the Nadirt president Rene Harris for his support, but said: "Shipping more thati 300 asylum seekers to the tiny dind distant Nauru Island involves excessive cost."

"I am sure Nauru has nélither the resources nor the experience to handle a 2.5 percent increse sn its population and process hindreds of applications. "I am not fin fix convinced the decision is the fest for all concerned." Ausir. agreed to meet all the costs involved. - AFP are aunde 


\section{The Frontier Post}

Monday, September 3,2001.

\section{Australian court verdict complicatés refugees issue} ISLAMABAD (Agencies):- Society in Australia, Dr, Kofi Annan has welcomed the proposal of New Zealand and Nauru that they are ready to accept the asylum seekers who have been waiting for their fate aboard a Norwegian cargo ship near the Christmas Island of Australia. But on the other hand, an Australian court has said that the Australian gov: ernment cannot send the asylurn seekers from the Australian Ocean to anywhere else.

Under the accord, New Zealand would scrutinize only those refugees who have families while Nauru government has accepted responsibility for the remaining refugees. Kofi Annan has called for immediate implementation of the accord on the stranded asylum seekers But the head of the Afghans

\section{The Statesman} Khaliq Fazal who closely watches the affairs in the region says that the court decision has further complicated the crisis

"The Australian Federal Court has made the decision contrary to the decision of the Australian Prime Minister with the New Zealand and Nauru government about the shifting of these refugees. The court said that these people could not be shifted from the Norwegian ship and the Norwegian Ship itself cannot move from the Christmas Island." Fazal told the BBC.

Asked would the Australian government file an appeal in the court against the Federal Court Judgement. Fazal said that the Australian government can tile an appeal in the Supreme Court but it would require some time.

\section{JUI threatens to kill UN monitors}

\section{- S atesman Report}

QUETTA: Jamiat Ulema-iIslam (F) on Sunday vowed to take up arms against the UN monitors for ensuring enforcement of sanctions against Afghanistan.

JUI's central secretary general Maulana Abdul Ghafoor Haideri addressing a press conference at his residence here said: "We want to make it clear that they will not be allowed and

\section{fate," he said.} The JUI $(F)$, which is considered quite close to Taliban Islamic movement, has always stood up against any internation-
Suppose, the Australian government files and appeal against the verdict of the Federal Court or move the Supreme Court, it would need another 48: hours, he added.

Fazal said that the New Zealand government is accepting such a large number of the refugees for the first time. The government brought change in its policy because the Australian government and Prime Minister made a serious request as the New Zealand government as the Australian government was faced with a big problem by deciding that it would not accept the 438 people. That is why, New Zealand and Nauru came to its rescue and help.

According to the Norwegian Ambassador, the asylum seekers are gradually suffering from psychological problems whereas their health is good.

Maulana Ghafoor asked Pakistan government not to accept the UN resolution and allow its land to be used against another Islamic emirate.

He also said that most of the UN decisions were anti-Islam, therefore Muslim states should take notice.

The JUI secretary general also accused the N(j()s of spreading Christianity in the country's most poor populace. "They take benefit of poor people's problems and in return for food and other essentials covert them to other religions.", 


\section{KMI Report \\ PESHAWAR:} UNHCR and Pakistan resume screening of Afghan refugees in two camps near Peshawar on Monday (September 3) after suspending it over a controversy with the government over deportations.

The olfice of the United Nations High Commissioner for Refugees (UNHCR) has taken this decision after it gets assurances from Pakistan that no more Afghans would be deported during the screening process.

The UNHCR suspended its participation in the screening of Afghan relugees on Friday, claiming Pakistan had broken an agreement by sereding refugees io

\section{Afghanistan.}

Pakistani foreign office spokesman Riaz Ahmed Khan denied reports that Afghan refugees have been thrown out. He said only new arrivals had been returned to Afghanistan and that Pakistan was not in a position to accept new refugees from the war-torn country

The UNHCR will resume the joint sereening process in Jalozai and Nasir Bagh tollowing a meeting with senior Pakistan officials during which the question of deportations was discussed and resolved, a UNHCR statement has said.

UNIICR spokesman Yusuf Hassan said yesterday that the UNHCR had contirmed reports that about 28 Alghan families had been deported and handed over to Taliban authorities at Torkham border. They were taken from Jalozai refugee camp.

The agreement between the UNHCR and Pakistan under which the joint screening programme began calls for Afghans found to be in need of protection to be granted a temporary legal statús to reside in Pakistan. They will be transferred to the refugee camps and will be helped by the UNHCR.

Afghans whose cases are rejected will have the right to appeal, but once a tinal decision is made, they would have to return home. Particularly vulnerable rejected persons will be allowed to remain in Pakistan until con- ditions in their villages improve, the UNHCR statement added.

The UNHCR-Pakistan agreement to screen Afghan refugees in Jallozai and other camps was reached in early August after protracted talks because of the two sides' conflicting goals.

Pakistan refuses to accept new Atghan refugees, saying it already hosts more then two million and does not have the resources to cater for more. The UNHCR confirms there are now about two million Afghans in Pakistan, 1.6 million in Iran and others scattered around the world. Their country has been derastated by more than 1110 decades of war and, in recent ycars, by drought.

The Nation MONDAY, SEPTEMBER 3, 2001

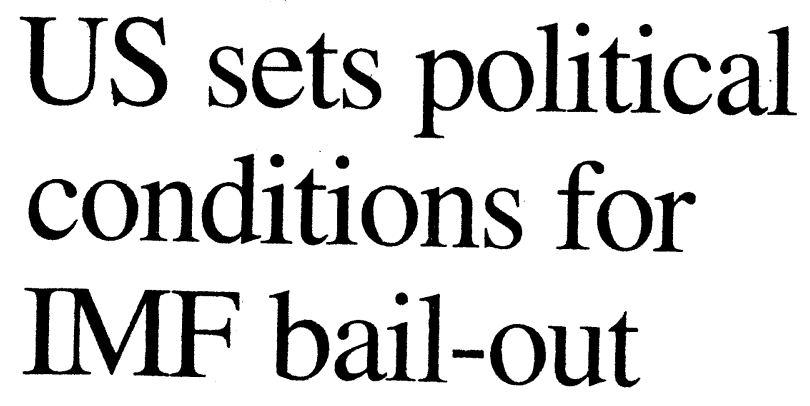

\section{Conditions include change in Afghan policy: Acceptance of UN Monitors: Check on jehadi forces: Freeze of N-plan}

ISLAMABAD - Pakistan is under considerable pressure from the US to accept certain political conditions in return for an IMF bail-out package needed to end its present financial worries, reliable diplomatic sources told The Nation Sunday.

"The biggest issue is Pakistan's Afghan policy," sources close to both the international financial institutions and top Pakistani officials said. One of the biggest economies of the world, the US, holds majority shares in the IMF and greatly influences the Fund's decisions through the

Federal Treasury to fulfil Washington's political agenda.

The unofficial set of political conditions includes a change in Pakistan's policy on Taliban government, help in getting Osama bin Laden, acceptance of UNSC monitors on Afghanistan. reining in of jehadi organisations, freezing of the nuclear and missile programmes, and improvement of relations with India.

A senior US Embassy official in Islamabad, when contacted, denied having knowledge of any such conditions. "In all earnest, I do not have any comment on 
this," the official said.

Pakistan has already taken steps to pacify some of the US concerns, the sources said. The recently applied ban on jehadi organisations to collect funds for jehad in Kashmir, and the acceptance of controversial monitors on Afghanistan are the most important steps taken by the government. "The government has also moved in the 'positive' direction on Pakistan's nuclear and missile programmes as significant measures have already been taken to address the US concerns," the sources said without giving any details.

Senior Pakistani officials denied such reports. :No such issues have been discussed."

Diplomatic sources close to the international financial institutions, and senior

Pakistani officials dealing with the financial and foreign affairs privately confess the existence of US pressure on Pakistan for compliance with a non-economic agenda given by Washington.

"There has been a constant pressure on Pakistan for the last few years," the sources said, adding "next three months are very important for Pakistan to prove that it means business."
Despite a "solid macroeconomic performance" by Pakistan during the last fiscal year, the IMF is still reluctant to commit a medium-term, multi-billion dollars Poverty Reduction and Growth Facility "The US has been using the IMF as a too to serve its political purposes," a senior diplomat said. "In cases such as South Africa, the IMF tool was used for positive ends, but in other cases, the purpose might be different."

Knowledgeable circles believe that despite the implementation of a painful reforms programme dictated by the $\mathrm{IMF}$, any deviation by Pakistan on political conditions will make it difficult for Islamabad to get the PRGF, which means the expensive Stand By Arrangement will be extended. "If the SBA continues, Pakistan will go straight into an economic straitjacket as SBA is an anti-growth programme," sources said.

In October last year, former US Secretary of State, Madeleine Albright, had written a letter to Foreign Minister Abdus Sattar setting political conditions to end $\mathrm{Pa}$ kistan's financial worries. At that time, the US priorities included the reining in of jehadis, checking the cross-border terrorism, and signing of the CTBT.

\section{Scotland THIOSCOTSMAN.CO.UR}

\section{i $\quad 3 / 9 / 2001$ \\ Protest at refugees' detention centre}

\section{Gethin Chamberlain and John Staples}

DOZENS of protesters yesterday gathered outside Scotland's first detention centre for asylum seekers yesterday on the eve of its opening.

Dungavel Detention Centre in South Lanarkshire is due to begin taking refugees in the next few days and is expected to house up to $\mathbf{1 5 0}$ people while their applications are processed.

But around 60 campaigners protested at the privately run building yesterday 
afternoon demanding that it remains closed.

The demonstration came as homeless charities expressed deep concerns to The Scotsman that Glasgow Asylum seekers attempting to escape the racial tensions in Sighthill could end up in hostels or on the streets.

Once a refugee's application to remain in Britain is accepted, they have just 14 days to quit accommodation paid for by the government.

While Glasgow City Council says they can remain in the flats and become local authority tenants, it is widely believed that many will be desperate to escape in the hope of finding places where they are not at risk of violence and intimidation.

The demonstration came as David Blunkett, the Home Secretary, asked France to close a controversial refugee camp near the entrance to the Channel Tunnel amid growing concerns over the number of immigrants trying to get into Britain.

The Red Cross camp at Sangatte houses around 1,200 refugees, mainly Afghanis, Iranians, Iraqi and Turkish Kurds, most of them desperate to get across the Channel to Britain.

On Saturday night French police intercepted 100 asylum seekers as they were about to enter the tunnel. Passenger services through the tunnel were delayed for several hours and freight services were suspended overnight after the group was caught inside the Eurotunnel compound at Coquelles, north of Calais.

The attempt came just three days after 44 asylum seekers managed to walk seven miles along the tunnel before they were eventually stopped. The following night another 80 tried to repeat the feat. They had all been living in the camp at Sangatte, which is just half a mile from the tunnel entrance.

Yesterday the Home Office confirmed that Mr Blunkett had spoken to the French government about the problems associated with the Sangatte camp.

A spokesman said: "Ultimately the camp's location is a matter for the French, although we do believe its location is not helping the situation at the Eurotunnel at Coquelles."

Mr Blunkett is reported to have told the French interior minister Daniel Vaillant that the camp "was not helping" Britain combat the problem of illegal immigration.

Eurotunnel, which operates the tunnel and which faces the threat of sizeable fines for cvery illegal immigrant who gets through, has begun legal action in the French courts in an attempt to force Sangatte's closure.

The company is struggling to cope with a tide of refugees determined to get across the Channel by whatever means they can. Those who fail simply try again the next 
night.

Eurotunnel has spent $£ 3$ million on high-tech security in a bid to keep out illegal
immigrants trying to get to Britain

The tunnel operator has installed 20 miles of high perimeter fences topped with razor wire round the terminal. It employs 160 full-time security guards and dog $-n$

monitor the perimeter.

Infra-red cameras are positioned at various locations around the terminal to spot hiding immigrants and freight services are checked with hand-held carbon dioxide
monitors to find stowaways.

The immigrants have taken to attempting to storm the terminal in large groups to

Dramatic television pictures of Saturday night's attempt showed dozens of asylum seekers scaling embankments, breaching security fences and swarming along the
track towards the tunnel entrance.

Some of the men threw stones at a passing train, but they were halted by the presence of another train which had stopped in the mouth of the tunnel. The group were eventually herded on to buses and driven back to the camp at Sangatte.

A Eurotunnel spokeswoman later said: "They are breaching the perimeter fences all the time and tend to come in large groups of 100-150 people, which can be intimidating for our security guards." Those caught on Saturday night were arrested peacefully, but the incident caused
delays in the rail service.

Thousands of illegal immigrants try to cross into Britain from France every year, running a gauntlet of barbed wire and guard dogs to stow away on cross-channel trains or trucks.

Britain ranks seventh among European Union countries as a target for asylum seekers, with 97,860 applications in 2000 , according to the UN High Commissioner
for Refugees. Yesterday morning another 40 illegal immigrants were found in the back of a lorry
at the port of Dover, in Kent.

Police said the asylum seekers included 39 Sri Lankans and an Indian. Most were adults, but among the human cargo was an eight-year-old child and two teenagers.

A police spokeswoman said the asylum seekers were detained after immigration 
officers at Dover's eastern docks stopped a German lorry which had arrived on a cross-Channel ferry from Calais.

She said: "When the back doors of the 7.5-tonne box lorry were opened at first it appeared to contain only furniture, but a closer inspection revealed the presence of the immigrants.

"With the help of customs officers the group was taken off the lorry and was being held at the port's detention centre."

One of the asylum seekers was taken to the William Harvey Hospital, in Ashford, suffering from heat exhaustion, but was taken back to Dover after treatment.

A 29-year-old German lorry driver has been arrested on suspicion of smuggling people and was in custody at Dover police station for questioning.

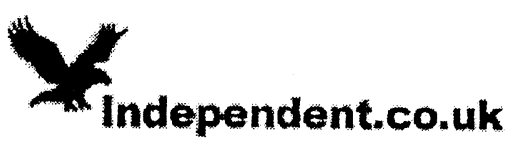

3 September ,2001

\section{It may look idyllic, but what will 300 Afghans make of Nauru, a speck in the Pacific Ocean?}

By Kathy Marks in Sydney

"Are they coming here?" asked the receptionist at the Hotel Menen in Nauru, sounding breathless with excitement. "We have many rooms free at the moment."

The impending arrival of 310 asylum-seekers has sent a frisson through Nauru, a tiny speck in the South Pacific. Visitors are a rare commodity, because Nauru has no tourist attractions and just one export: bird droppings. For the island's $\mathbf{1 2 , 0 0 0}$ people, the prospect of refugees from Afghanistan is positively exotic.

Quite what the Afghans will make of Nauru, a polluted lunar landscape ravaged by a century of phosphate mining, is anyone's guess.

When they fled a repressive regime, desperate for a better future, they could scarcely have predicted what lay in store. Shipwreck on the high seas. Salvation by kindly Norwegians. The arrival of SAS commandos in full combat gear. Utter rejection by Australia, the country that embodied their aspirations, and which has treated them like pariahs. 
Now, after a week languishing aboard the Norwegian freighter MS Tampa in the Indian Ocean, with the Australian territory of Christmas Island shimmering tantalisingly on the horizon, the asylum-seekers are about to embark on yet another leg of their odyssey.

Pending the result of court action in Melbourne, they are to be shipped to Papua New Guinea by an Australian Navy troop carrier and then flown to Nauru or - in the case of 150 of them - to New Zealand. Once their claims have been processed, those deemed genuine will be resettled by several nations including Australia, Norway and New Zealand.

Such are the lengths to which the Australian Prime Minister, John Howard, is prepared to go in order to make a point. The point being that refugees are not welcome in Australia if they pay a fortune to "people smugglers", board unseaworthy vessels and risk life and limb to turn up here uninvited. They must go through the proper channels or, preferably, not come at all.

Never mind that there is little prospect of that message getting through to the next wave of people packing their bags in Kabul, Baghdad and Islamabad. In order to keep the Tampa's passengers at bay, Mr Howard was prepared to pick a fight with Norway, that most inoffensive of nations, fall out with Indonesia, Australia's powerful northern neighbour, and risk censure by the UN.

His obduracy could yet backfire. Until last weekend, the polls showed overwhelming support for his hardline stance. Now, public opinion is more evenly divided - not, the anecdotal evidence suggests, because Australians have been overcome by a sudden attack of compassion, but because they are unhappy about the damage to their international standing.

The horse-trading in recent days has been humiliating, with the government twisting arms around the region to persuade its allies - particularly those in receipt of Australian aid - to take pregnant women and children off its hands. Even the fledgling nation of East Timor was asked, just one day after its long-suffering people had voted in their first free election. East Timor's leaders agreed - what else could they do? But so scathing was the reaction elsewhere that Australia abandoned the idea.

So to New Zealand, which can always be relied upon to do the decent thing, and to Nauru, a former British colony that needs the hard cash Australia is offering. But not yet, because lawyers for the asylum-seekers have secured a Federal Court injunction that prevents them from being removed until the court has ruled on whether they should be allowed to land in Australia.

In a bizarre twist, the Tampa's captain, Arne Rinnen - one of the few people to emerge well from this whole sorry saga - and two SAS soldiers are scheduled to give evidence by telephone after the hearing resumes today. Mr Rinnen rescued the Afghans from a sinking Indonesian ferry and has been a vociferous advocate for their welfare. 
Lawyers for the Victorian Civil Liberties Council argue that the asylum-seckers are within Australian jurisdiction and should be brought ashore so they can claim refugee status. The lawyers also argue that they are being unlawfully detained by the SAS troops, who boarded the Tampa after it tried to sail to Christmas Island.

The legal action is likely to delay their transfer to the HMAS Manoora, an amphibious troop ship, by several days. An appeal is expected if the ruling is against

The decision to send most of the Tampa's occupants to Nauru was condemned by the UN Secretary General, Kofi Annan, who said that they would be better off on Christmas Island, and by Norway, whose Foreign Minister, Thorbjoern Jagland, called it inhumane. There was further embarrassment for Australia yesterday when the British tycoon Richard Branson, visiting Australia to launch a new route for his low-cost airline, Virgin Blue, offered to fly a plane to Christmas Island to pick up the asylum-seekers. The offer was declined, through gritted teeth, by the Australian
Foreign Minister, Alexander Downer.

The Afghans will spend up to six months on Nauru, but not at the Hotel Menen, one of its two hotels. Australian officials plan to set up a tent city to accommodate them.

Nauru is described by Lonely Planet's guidebook as "a wasteland of mind-boggling proportions". With most of the island uninhabitable because of environmental devastation, the population clings to a narrow coastal strip. Electricity is rationed to two hours a day and drinking water is imported from Australia. Nauru's singleplane airline was recently grounded as unsafe. Nauruans also have famously poor
health, with high rates of heart disease, cancer and diabetes.

The island's rich phosphate deposits, extracted from guano, or fossilised bird droppings, once gave Nauruans the world's second highest per capita income. But they invested their money unwisely, their industry is in sharp decline and the country - also notorious as an international money-laundering centre - is close to
bankruptcy.

Like many South Pacific nations, Nauru is also being engulfed by rising tides as a result of global warming. Some Australians speculated yesterday that the arrival of 300 extra souls would make the island disappear beneath the waves.

The Island

Where is it?

The $8.5 \mathrm{sq}$ mile island is in the middle of the Pacific, just south of the Equator. History?

Once a British colony, it was named Pleasant Island by European explorers. With a population of 12,000 , Nauru is now the world's smallest republic. 


\title{
Economy?
}

Vast wealth was created over the past century by mining high-grade phosphate 1,000 years worth of fossilised bird droppings. Reserves are expected to run out by 2003 so government turned to offshore banking. The US says Nauru is implicated in tax evasion and money-laundering.

Investment?

Most of the mining wealth went on importing processed food and sugary drinks. Today the island is broke and cannot even afford to import petrol.

\section{Health?}

The islanders, once hunters and fishermen, gained a taste for the carbohydrate-high western diet. Now 45 per cent of them have Type 2 diabetes. Life expectancy is 57 for men and 65

for women.

Tourism?

Few tourists go to Nauru. Mining left a weed-strewn lunar landscape.

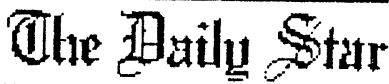

Prepared by onirhan

Mon. September 03, 2001

\section{Taliban move aid workers to an unknown place}

\author{
AFP, Kabul
}

The Taliban authorities have moved eight foreign aid workers detained for allegedly preaching Christianity in Afghanistan to an unknown place, guards at the detention centre here said Sunday.

The detainees were transferred late Saturday from Kabul's juvenile correction centre, the guards said.

The aid workers -- two Australians, two Americans and four Germans -- from the German-based Shelter Now were arrested in early August along with 16 Afghan colleagues.

A Taliban guard said the ruling militia's religious police came at about 8:00 p.m. 
(1500 GMT) and took them away. He gave no further details.

Taliban Foreign Minister Wakil Ahmad Mutawakel Saturday said investigations into the case were about to be concluded and the aid workers would soon be brought to trial.

Taliban authorities on Saturday allowed the parents of two American aid workers to meet their detained daughters for the second time in a week.

Red Cross officials were granted permission to visit the foreigners August 26 while Pakistan-based diplomats representing the detainees were also allowed access on Monday.

The US, Australian and German diplomats, staying at a UN guesthouse in Kabul, were awaiting Taliban permission for another meeting with their countrymen.

Australian diplomat Alastar Adams visited the two Australian prisoners on Thursday but the others have not been seen since Monday, when all were found to ${ }^{\circ}$ be in good health.

Meanwhile, the trial of eight foreign aid workers detained for preaching Christianity in Afghanistan will be held in open court and observers will be allowed to monitor the proceedings, the ruling Taliban's foreign minister said Sunday.

\section{the \\ Monday 3 September 2001 \\ When darkness descends}

By PAUL MCGEOUGH

IT'S early evening in the Cockha valley and a silvery crescent moon hangs in a rosewater sky.

Teenagers play volleyball, a family threshes grain in the fields and, alone on a rock in the river, a wizened old man kneels and faces Mecca for his evening prayers.

These are the rare snatches of time when you forget that Afghanistan is one of the worst places to live on God's earth. These are the glimpses of a rural idyll that has been engulfed by a combination of war and drought that started more than 20 years ago.

This country is wrecked and withered. Everywhere there are signs of the tyranny of the Taliban - the ruthless orphans of war, the fundamentalist graduates of the narrow-minded madrassa religious schools who have built a society that has no soul, no joy.

In the warm land where the pistachio and pomegranate grow, Afghans are confronted daily by a brutalising regime that dangles the bodies of its opponents 
from city lamp-posts as a lesson to others; that forbids children to fly kites because they are not supposed to have fun.

Listen. A mean wind whips through the mud-brick emptiness of the ghost villages of the north. Entire communities - from ancient $t$ Herat in the far west to Asadabad, tucked into the creases of the mighty Hindu Kush in the east - have vanished as first fighting, and now famine, stalk the land.

As you drive the tracks that pass for roads, family groups merge in and out of the incessant clouds of dust, turbans wrapped tightly against the grit. A few are on camels, some are on donkeys and horses, many walk. All are united in their poverty and their misery.

In the first year of the drought, they sold their sheep and cattle. Last year they bartered their tools and donkeys. Finally, as they confronted the failure of this year's rains, they ate the seed that was to ripen as the next crops. Only then did they take to the roads. They are still walking away.

But there is even worse, much worse, and it is enough to make any parent desperate to find a new life for themselves and their children.

When the tales from the battlefields are pieced together, it becomes clear that Afghanistan's Taliban regime is acting out its own version of Slobodan Milosovic's ethnic cleansing.

Religious bigotry is the fire in the belly of many of its fighters as they push through swathes of country, clearing out minority Hazara, Uzbek and Tajik communities. Civilians are burned alive, whipped with len ls of electric cable and mutilated with knives and bayonets. They are massacred by the hundred, occasionally by the thousand.

Mountain farmers and their families are strafed from hand-me-down Soviet helicopter gunships. Tanks are lined up on hilltops to lob shells among civilian farmers in the hope of making them abandon their pastures.

In some hideous cases, victims of the Taliban are being skinned and their bodies put on public display as a warning to others. And witnesses have told how Taliban fighters have sometimes daubed themselves in the blood of their victims before turning to Mecca to pray.

A foreign observer who has spent much time in these traumatised communities told me: "They want all Afghans to know that when they walk down the street any Talib they pass is capable of turning on them and inflicting severe pain.

"Unfortunately, the shock of what is happening here is being masked by a sense of 'This is all that Afghans are good for' and 'Aren't they just a bunch of warring factions?' No one has seriously confronted the Taliban on what they are doing."

THE mercury has climbed to 50 degrees today, but now the intense heat is easing as dusk settles on a sweeping curve in the River Panj, which forms part of 


\section{Afghanistan's northern border.}

Yet the respite may be too late for Marcuarh, whose six-month-old daughter seems to be dying. The child lies limp on a ragged pillow, her only comfort a tiny mosquito net. Only the faintest breathing moves her weary lungs and her matchstick limbs
seem useless.

The young mother is distraught and, at the same time, resigned to what seems to be inevitable. "She is dying and what can I do? It's better that way - we have no food for her and I have no breast milk because I have not eaten for days."

Jeahon Shorhatangis, who makes a few dollars translating for rare foreign visitors, screams in frustration as he tours this makeshift camp for the internally displaced at Khoja Bahauddin, near the front line in north-eastern Takhar province. "People are dying every day from disease. There is not enough food, there is not enough medicine, not enough sanitation".

Shorhatangis is a 26-year-old whose dreams of study have been shattered by the crisis that has dogged Afghanistan since he was a toddler. Standing on a rise above the camp, he says: "Look at it ... The world reacted in Zaire and the UN helped the people of Kosovo and East Timor. Why will they not do more for these people?"

The camp was set up 11 months ago, when the first of about 8000 families who now live here began to abandon their villages to the south. The early arrivals suffered last winter, with its bitter temperatures and several falls of snow, and now all of them are bracing for another winter of hunger and exposure.

Day after day, 90-year-old Bidy Mohamad lies under a stretched sheet of plastic, his only home since the Taliban ran him out of the village of Khwagaghar this year. He says that they broke his bones when they beat him and that his only supply of food is in the corner of his tent - a pile of grass gathered from the nearby floodplains.

Qar Bambee says she is 55 years old but she looks about 80. She has been lying on the ground, as I found her, for the past three months. Her story is as simple and as appalling as the rest. "I have eaten nothing except grass today. My husband is dead and I don't know where my only daughter is."

Most of the refugees said they had eaten only once - and meagrely - during the day. As I arrived in the camp, some of the children were getting their only rations for the day: a handful of ground grain and stale bread, served to them dry in the colorful little hats that they wear; or what looked like a burnt Anzac biscuit - a lot of ground grass mixed with a small amount of flour which then was cooked in a drop of oil.
The taste was revolting.

Hatam Big, 60, tugged at the front of his grey traditional dress as he ran a shaky finger around the edge of the palm of his hand to indicate the size of the piece of bread that was all he had eaten for the day. Angrily waving his hands in the air, he said: "Now we are talking about going back to the village, into the arms of the Taliban. All they can do is kill us ... and that would be better than life here. We have 
nothing to lose."

French aid group Medecins Sans Frontieres has put a water tank and latrines in the camp, but nothing will make this mess of plastic and canvas habitable. Local aid workers concede that not enough food is getting through, but there is no money to buy more before the World Food Program's next scheduled distribution of flour, sugar and cooking oil - which is to be sometime "soon".

Afghanistan has none of the institutions of state taken so much for granted by those who live in First World democracies. Emerging from the ashes of wars that started long before the Taliban's literal pursuit of the seventh century society of the prophet Mohammed, Afghans suffer an education system that is skewed to fundamentalism and to block half of the population - its women.

Their health system favors the other half of the population - the men - and it could not function without the jury-rigged intervention of United Nations agencies and non-government organisations from across the world.

The Afghans are victims of a legal system that has few basic rights and little forensic skills. Instead, it functions on knee-jerk findings of guilt and the irreversible punishments of stoning, flogging, amputation and execution.

This is a country in which a barely educated band of schoolyard bullies is in control. Afghanistan scholar Dr William Maley describes the Taliban as "perhaps the most fiercely anti-modernist movement in any Asian country since the Boxer Rebellion".

So political opponents disappear; adulterers are lashed in public or stoned to death; homosexuals are executed by having a wall topple on them; and those who cannot recite their prayers or who trim their beards to less than fist-length are beaten by the thuggish foot-soldiers of the Ministry for the Prevention of Vice and the Promotion of Virtue (PVPV).

Academic and press freedom do not exist. The Taliban this year threatened to make members of the minority Hindu community identify themselves by wearing a piece of yellow cloth and the Taliban incurred the wrath of the world when it destroyed the ancient Buddha statues at Bamiyan.

The middle-classes have fled and the few with an education are being shunned. They see the destruction of the education system as one of their worst fates and the spectre of future generations of illiteracy troubles them deeply.

"There is a total loss of hope," said an engineer planning his own disappearance from Afghanistan. "Two years ago many of the Afghan middle class still saw a future for themselves, even with the Taliban in control. But what they desperately want is to be able to educate their children.

"Now they see that it will be 10 or 20 years before there is substantial change. They will not wait that long."

Villagers and townspeople across the country live in fear of their sons of fighting age 
being rounded up to be used as cannon fodder. A UNICEF study of children in Kabul, the Afghan capital that has been destroyed by war, found that most children had been confronted by violence and that few of them had any expectation of surviving.

Two-thirds had seen people die or the scattering of body parts that followed rocket attacks; 90 per cent suffered from nightmares and acute anxiety; and more than 70 per cent had lost a family member and no longer trusted adults.

The violence of war, the privations of drought and the outright ugliness of life under the Taliban have destroyed any sense of a normal upbringing or future for children in a country in which about half the population is teenage or younger.

With no sign of a break in the drought and the fighting at a stalemate, the PVPV puts huge energy into maintaining the ban on music and movies, on VCRs and audio cassettes.

Dotting the landscape are peculiar, grey-black trees that glisten in the sun. But come closer and they mark the Taliban's roadside checkpoints. It turns out that the "trees" are posts festooned with thousands of metres of cassette tape which has been ripped from the tape recorders of motorists who thought them could ignore the Taliban ban on music.

Even love cannot escape this misery. Before the emergence of the Taliban in the mid-1990s, the youngsters of Mazar-e-Sharif, in the far north, had for centuries gathered with great devotion at the tomb of the beautiful Rabia Balkhi, the first woman poet of Islam.

They came to pray for success in their love affairs because of the mediaeval tragedy that befell the poet - her brother slashed her wrists after she slept with a slave lover; she died, but not before writing her last poem in her own blood.

When the Taliban captured Mazar-e-Sharif in 1998, the tomb was forbidden to the young lovers of Afghanistan.

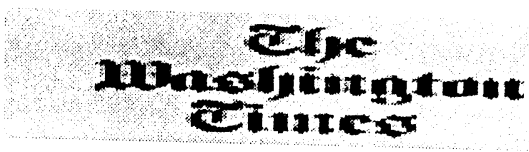

3 September 2001

\section{Open trial considered for aid workers}

KABUL, Afghanistan -- The nation's Taliban rulers said yesterday they might hold an open trial of eight Western aid workers held on charges of promoting
Christianity.

"It is expected that the trial will be an open one and the investigation of their case is 
almost complete," said the movement's foreign minister, Wakil Ahmad Muttawakil. He could not give a date for the trial of two American, four German and two Australian workers of the German-based relief agency Shelter Now International. But other Taliban sources said it was expected to begin later this week.

\section{NEwS}

INTERACTIVE

3 September,2001

\section{Taliban to lodge aid worker case}

AFGHANISTAN's ruling Taliban militia is to formally lodge its case against eight foreigners detained for allegedly preaching Christianity, the country's foreign minister said.

Two Australians, Diana Thomas and Peter Bunch from Western Australia, are _ being held in detention in Kabul, along with two Americans, four Germans and 16 Afghan colleagues.

Taliban Foreign Minister Wakil Ahmed Mutawakel told the news agency AFP the religious police had finished their investigations and the legal proceedings were about to begin.

"The investigation conducted by the ministry for the promotion of virtue and the prevention of vice has been completed and their file will be handed over to the court today," he said.

He said that once the case was officially lodged it would be up to the court to decide how and when to proceed.

The foreign minister did not say when the detainees would apppear before the court.

Mr Mutawakel said over the weekend they would receive proper legal representation and diplomats would be able to monitor the trial in an "open court" run according to the militia's strict brand of Sharia law.

The maximum penalty for Afghans áccused of inviting Muslims to adopt another faith is death, but the punishment for foreigners is likely to be less severe.

The Taliban has refused to further explain the charges despite repeated requests from Pakistani-based diplomats who are waiting in Kabul for the case to begin.

All the detained workers were employed by the German-based Christian organisation, Shelter Now International.

Mr Muttawakil said the foreign workers and Afghans would be tried 
separately.

Relatives of the Afghan employees fear their family members will be hanged.

Twelve-year-old Amjad, whose father gave Pashtu language lessons to the foreign workers of Shelter Now International, has seen his father only once since his arrest.

A mechanic at a local car repair shop in Kabul, Amjad wept as he asked: "What will we do if my father is hanged?"

A senior Taliban official said it is expected that some of the 16 jailed Afghan employees will be given either life in prison or the death penalty.

Since the Shelter Now International drama began on August 3, the Taliban has expelled two other Christian organisations alleging they too were involved in proselytising.

The Taliban has displayed boxes of Bibles and other Christian material they said they confiscated from the offices of Shelter Now International in Kabul. The Bibles and other literature had all been translated into Afghanistan's local languages.

MONDAY, SEPTEMBER 03, 2001 THE TIMES OF INDIA

\section{Afghan asylum seekers could be NZ queue jumpers}

WELLINGTON: An Afghan refugee said on Monday he fears his orphaned nephew's resettlement in New Zealand will be delayed by the arrival of 150 asylum seekers rescued by a Norwegian cargo ship.

New Zealand on Saturday agreed to take 150 Afghan refugees stranded on the freighter the Tampa off Christmas Island, guarantecing them places in a queue of 750 places in New Zealand's annual allotment of UN-approved refugees.

Najibullah Lafraie, a former foreign minister in war- and drought-ravaged Afghanistan, said he was worried about how news of the likely delay for other refugees would affect the psychological health of his dead brother's son, Hikmatullah Noor Ebad, one of about two million Afghan refugees in Pakistan.

Noor Ebad's mother died in April 1999 and his father a year later. Their three children were split between family members with Lafraie given responsibility for 17-year-old Hikmatullah.

"He needs to have a home...it's more than a year and he's still waiting and I'm 
worried about his social and psychological health," Lafraie said.

The 433 asylum seekers on the freighter, most of them from Afghanistan, were rescued from a leaky Indonesian boat on their way to Australia on August 26.

But Australia has refused to let them in, calling them queue jumpers and arguing that accepting them would give the impression Australia was an easy destination for illegal migrants.

While the tiny Pacific island Republic of Nauru has offered to process the bulk of the refugees, New Zealand is so far the only country to pledge to take some for resettlement -- prompting Opposition politicians to criticise the decision for crowding out others.

Lafraie, who spent 11 months in hiding in the Afghan capital Kabul before fleeing to Pakistan and then on to New Zealand, said despite the possible delay for others, he süpported New Zealand's humanitarian position.

"Although my own nephew would have to wait longer, I sympathise with these people (on the cargo ship).

"Just to turn them away because of this (queue jumping) argument -- I think it would be very unfair."

A spokesman for the New Zealand Immigration Service said it was too early to conclude that the Tampa asylum seekers would delay the entry of other refugees to New Zealand.

( REUTERS )

MONDAY, SEPTEMBER 03, 2001 THE TIMES OF INDIA

\section{Taliban complete proselytizing probe; trial next}

KABUL: The Taliban on Monday said they have completed their investigation into charges of preaching Christianity against eight jailed foreign aid workers and all that remains is the trial.

The secretive Taliban have not said when the trial will be held, but the Foreign Minister Wakil Ahmed Muttawakil says it will be open.

In the Afghan capital of Kabul there were some suggestions that it could begin later on Monday, but the Taliban have refused to give any indications. 
For the parents of the two American women, Dayna Curry, 29, and Heather Mercer, 24, the wait has been long and uncertain. Curry's mother, Nancy Cassell of Thompson's Station, Tennessee, and Mercer's father, John, of Vienna, Virginia have been in Kabul exactly one week and have twice seen their children.

"We just want to bring them home," Mercer told reporters after his second visit with his daughter which took place on Saturday at the Reform School for delinquent Afghan children, where the eight aid workers have been held since their arrest four weeks ago.

Three Western diplomats from the United States, Germany and Australia also are in the Afghan capital to monitor the situation.

All employed by the German-based Christian organization, Shelter Now International, the eight foreigners -- two Americans, four Germans and two Australians, were arrested along with 16 Afghan workers.

Muttawakil said the foreign workers and Afghans will be tried separately.

Under Taliban law the penalty for proselytizing is jail and expulsion for foreigners and death for an Afghan.

There is a gread deal of fear among the relatives of the Afghan employees of Shelter Now International that their family members will be hanged.

Twelve-year-old Amjad, whose father gave Pashtu-language lessons to the foreign workers of Shelter Now International, has seen his father only once since his arrest.

A mechanic at a local car repair shop in Kabul, Amjad wept.

"What will we do if my father is hanged?"

A senior Taliban official said it's expected that some of the $\mathbf{1 6}$ jailed Afghan employees of Shelter Now International will be given either life in prison or the
death penalty.

Since the Shelter Now International drama began on Aug., 3, the Taliban have expelled two other Christian organizations alleging they too were involved in
proselytizing.

The Taliban have displayed boxes of Bibles and other Christian material they confiscated from the offices of Shelter Now International in Kabul. The Bibles and other literature had all been translated into Afghanistan's local languages.

The ongoing investigation as well as the fear among Afghans that the local staff of Shelter Now International could face long prison sentences or death has made Afghans working for Western aid organizations nervous. 
International aid workers say their Afghan workers are afraid to be seen in public with them. They say that some complain of harassment by the authorities and by other Afghans, who threaten to tell the authorities that they are flirting with Christianity in many cases because they covet their jobs.

In poor Afghanistan a job with an international aid organization is prized because the average salary is barely dlrs 4 , most people do not have work and millions of people are dependent on global assistance, like the U.N. World Food Program, to survive.

The other six foreign aid workers being held have been identified by the Taliban as Germans, George Taubmann, Margrit Stebnar, Kati Jelinek and Silke Duerrkopf; and Australians, Peter Bunch and Diana Thomas.( AP )

\section{UN wants fair trial of Afghan-held. aid workers}

KABUL: The United Nations on Sunday called for a fair trial of all 24 foreign and Afghan aid workers detained by Afghanistan's Taliban rulers on the charge of
promoting Christianity. The trial by an Islamic court is expected to begin later this week after the Taliban authorities said on Saturday an investigation of eight foreign and 16 Afghan workers of the German-based Shelter Now International (SNI) agency was almost over.

"The UN wants a fair trial of these people on the basis of justice," said a UN official who declined to be identified.

He said the United Nations wanted an early resolution of the case, which began when the radical Islamic Taliban movement arrested the SNI staff early last month and shut down the agency's offices in the war-torn country.

The Taliban authorities say they have strong evidence that SNI's foreign staff -- four Germans, two Americans and two Australians -- were involved in trying to convert Afghan Muslims to Christianity but had no proof any conversions were actually made. The SNI denies the charge.

Taliban sources said they expected the country's Supreme Court to begin the trial any time this week and the movement's reclusive supreme leader, Mullah 
Mohammad Omar, would make the final decision about the punishment.

A decree issued by Omar early this year prescribed the death penalty for Afghan Muslims converting to another religion, but the punishment for foreigners found

"We are more concerned about the Afghan staff of SNI and we wish the Taliban to UN official told Reuters.

He also said the United Nations was relieved by a Taliban announcement that no other foreign aid group was suspected of involvement with the SNI in the alleged conversion attempts.

"We are happy about it and hopeful of a normal working atmosphere with the authorities on the basis of the memorandum of understanding which we have with them," the UN official said.

Staff of two agencies leave In a related development, all foreign staff of two Christian humanitarian groups -- International Assistance Mission (IAM) and Serve -- have left Afghanistan after the Taliban closed down their operations on Friday and ordered them to leave by Monday morning, Western sources in Kabul said.

They said the Taliban had also freed four IAM foreign staff members who were arrested in the western city of Herat along with several others in the eastern city of Jalalabad on Friday.

The Taliban have not explained the reason for their expulsion but say the decision followed frequent reports and complaints about the activities of the two organisations.

A Pakistan-based Afghan news services on Saturday quoted Taliban Foreign Minister Wakil Ahmed Muttawakil as assuring other relief organisations that no other foreign aid group was under scrutiny for preaching Christianity.

The Afghan Islamic Press also quoted him as saying by telephone from the southern city of Kandahar that the investigation of the detained SNI staff would be over "in the next few days" and then their case would be sent to court.

Three Pakistan-based Western diplomats have been in Kabul since Monday last week to meet their detained nationals, ensure their welfare and ultimately to seek
their release.

The Taliban allowed a US diplomat along with relatives to visit two detained American women for more than three and a half hours on Saturday but in the
presence of local officials. 
The News International, Tuesday, September 4, 2001

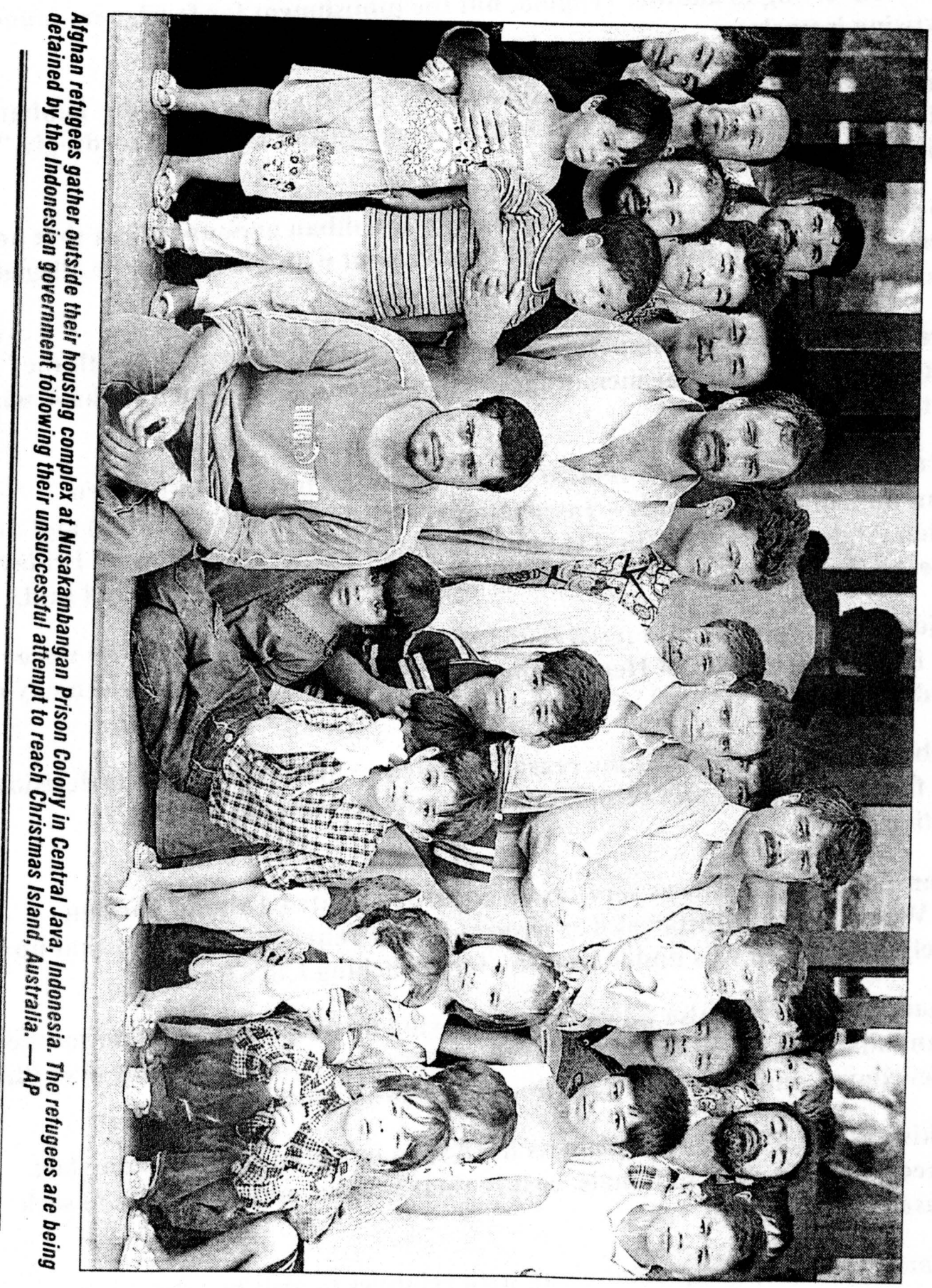




\section{Thousands of Afghans deprived of help, says official}

ISLAMABAD: The closure of three aid agencies by the Taliban movement because of suspicion they were promoting Christianity may deprive hundreds of thousands of people of badly needed help.

The International Assistance Mission (IAM), closed by the Taliban on Friday, said in a statement it was seriously concerned about the impact on relief work after it was shut and their foreign staffs was given 72 hours to get out of the country.

"IAM is very concerned about the effects of this action both on local staff and programme beneficiaries."

"Hundreds of thousands of people will be deprived vital assistance at this critical times the aid agency said in a statemert on Monday.

IAM and Serve, thedther NGO ordered shut by the Taliban on Friday, both operated across Afghanistan.

The Taliban closed down the German Christian relief agency Shelter Now International (SNI) in early August and arrested 24 staff eight of them foreigners - accusing them of using aid to promote Christianity among Muslim Afghans.

IAM, which is backed by churches and many international donor agencies, said it had always respected and honoured the laws of Afghanistan and it was stunned by its sudden closure.

"IAM is still committed to the mutually agreed protocols with the Islamic Emirate of Afghanistan. IAM also remains committed to work towards the alleviation of human suffering and the development of Afghanistan," it said.

Motivated "oy a Christian faithbased concern for the poor (IAM) has servitu people of Afghanistan working alongside Afghans in the fields of health, economic development, and education and rehabilita- tion for 35 years," it said.

The United Nations and dozens of non-governmental organisations (NGOs) are providing crucial aid to impoverished Afghanistan, whose economy is in ruins and infrastructure destroyed by more than 20 years of war.

The worst drought in living memory and conflict between the Taliban and opposition Northern Alliance forces have made matters worse for Afghans and close to a million people have left their homes in the last two years.

Foreign aid agencies deliver basic food, shelter and medical services, besides providing rare job opportunities.

But the Taliban view several Christian-based aid groups suspiciously.

The eight - four Germans, two Australians and two Americans have been held in Kabul and were granted limited access to diplomats

\section{4 killed, 13 injured as missiles hit Taloqan}

\section{Bureau Report}

PESHAWAR: Four persons were killed and 13 others injured when fighters affiliated with the Afghan Northern Alliance allegedly fired missiles on Taloqan city, capital of Takhar province on Monday, Afghanistan's official news agency Bakhtar reported.

The report said that several missiles were rained on the city from the nearby mountains controlled by the opposition forces loyal to former Afghan defence minister Alumad Shah Misoond, from their countries last week.

The eight are expected to receive an open trial, but their 16 Afghan colleagues would be tried separately.

Recent Taliban actions have cast a pall of gloom on the aid community, with workers, both foreign and Afghan, saying they felt insecure.

Punishment for proselytising can include the death sentence and the Afghan aid workers are at greater risk as contact with foreigners can make them suspicious in the eyes of the Taliban.

Taliban Foreign Minister Wakil Ahmed Muttawakil said on'Saturday no other foreign aid groups were under scrutiny for preaching.

"Other NGOs are not underscrutiny...I want other NGOs to work without any fear in Afghanistart and Taliban will support them if they do not violate our laws, "AIP quoted him as saying. Reuters which hit three homses inside the city.

Bakltar reported that four persons were killed inside a house owned by nne Ilaji Gül Aqha. killing four members of the same family while two other missiles hit houses in the nearby vicinity causing injuries to 13 people. including a woman.

It is to be recalled that Taliban and the opposition forces are locked in fierce fighting in Takhar province as well as north of Kabul these days, inflicting material and hurnar losses on both sides. 


\section{0 immigrants held on Greek island}

KOS-Greece: Forty Afghan would be immigrants were detained on this island late Sunday after crossing illegally in a wooden fishing boat from the nearby coast of Turkey, authorities said.

The immigrants - including 11 children and eight women - were all in good health, the merchant marine ministry said.

The boat's captain, who said he also was from Afghanistan, was arrested. Tens of thousands of peuple from Asia, eastern Burope and the Middle East cross illegally into European Union-member Greece every year, typically heading to Greek islands close to Turker's coast.

The number of Afghans arriving on Greek shores has risen steadily this year. With their country devastated by war and drought, Afghans make up the world's largest refugee population, with 3.7 million having fled to other countries according to the United Nations. - AP

\section{Law, order situation reviewed}

KABUL: The Afghan High Security Commission discussed law and order situation in the country.

The commission went into session in Kabul with the Deputy Administrative Chief of the Council of Minister, Mulla Muhammad Hassan Akhund in the chair.

Bakhtar News Agency reports

that the meeting held in depth review on law and order situation in Afghanistan. The meeting made necessary decisions and communicated them to the departments and oficials concerned. Two teams were constituted to visit Maidan Wardag and Bamiyan to obtain information about

\section{The Frontier Post}

\section{Tuesday, September 4, 2001}

\section{Ex Iranián}

\section{minister lauds}

\section{Taliban}

KABUL

(Agerieies): Addressing Juma congregation in Tehran, the former Iranian Information Minister termed the Taliban administration as a model for enforcing Islamic Shariah i letter and spirit and restoring peace in war-ravaged Afghanistan.

Bakhtar News Agency reports that the former Iranian Information Minister, Qurban Ali in his Juma sermon criticised Khatami government for its failure to meet the requirements of the Iranian people and society. He said that Islamic Emirate of Afghanistan has succeeded in restoring complete peace and security in its controlled areas and enforcing Islamic
Shariah in the country at a

\section{Police seize $298 \mathrm{~kg}$ of narcotics}

TEHRAN (IRNA): Police have seized over 298 kilos of narcotics in the central province of Isfahan over the past week in two separate operations, an informed source said.

He said that some $99-\mathrm{kg}$ of hashish was seized from two traffickers in a shoot-out in the southern part of the province.

In another shoot-out, 199 $\mathrm{kg}$ of opium residue was seized from another smug. gler, he added.

Meanwhile, police in upper border Khorássan province killed Sunday an armed Afghan who, along with four more, had illegally sneaked across the Iranian border.

A large amount of ammunition, including an AK47 assault rifle and several hand grenades were also seized from the bandits, police said.

Iran imposes death penalty for all those convicted of possessing more than 30 grams of heroin or five kilos (11 pounds) of opium.

Iran is a major route for smuggling drugs from Afghanistan and Pakistan to markets in the Persian Gulf, Europe and beyond: Opium, heroin, hashish and morphine are hauled through the country and single busts involving a ton or more of illicit drugs are not uncommon.

During the last Iranian cal. endar year which ended March 20, police seized 5.5 tons of heroin in the country. 


\section{The Frontier Post}

Tuesday, September 4, 2001

\section{Afghans warned of poppy cultivation}

KABUL (NNI): The Taliban government in Afghanistan has again directed the Afghans not to cultivate poppy as a ban imposed by the authorities on poppy cultivation remains in force.

In an edict issued here, the authorities said it is reminding the people at the beginning of poppy cultivation season that the orders would remain in force.

The edict appreciated that the Afghan people accepted the decree with great sincerity and devotion, which the world community had not expected at all. No one cultivated poppy in the area under the control of the Taliban.?

"Now when the poppy cultivation season approaches, the Islamic Emirate in pursuance of last year decree once again calls on the countrymen to strictly abide by the last year edict banning poppy cultivation in the country. If anybody was found violating the decree by cultivating poppy, he would be awánded stern punishment besides destructipn the poppy

\section{1,000 Afghans leave for home voluntarily Himid-yaya \\ PESHAWAR: The screening of} Afghan refugees in Nasir Bagh and Jalozai gaths gain restarted after."a tong delibera. tions between Government of Pakistan and UNHCR officials, while more than one thousands more refugees voluntarily leave here for homeland on Monday. "i".

The spokesman of UNHCR confided in. The Frontier Post that both Government of Pakistan and. UNHCR agreed to restart screening in both Nasir Bagh and Jalozai camps forthwith and on Monday (yesterday) several families were interviewed in both samps. The official furthen informed that 203 families in 46 trucks voluntarily, repotriated to Afghanistan and most of them belonged to Lugas Laghman cities.

He further iblofmed that Today (Tuesday)' some faroilies would be shifted froth Jalozai camp to 'Shamshtét camp where they would be properly settled.

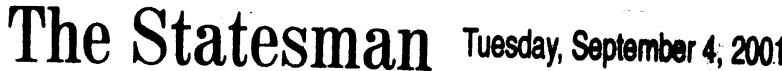

\section{5pc Afghans likely to be screened out}

Statesman Report

PESHAWAR: Commi-
ssioner Afghan Refugees
Nacem. Khan Monday said
almost 75 per cent Afghans
residing in Pakistan are not gen-
uine refugees and they will have
to leave the country once the
screening process is completed.
He said that the Afghans
deported last week had entered
Pakistan illegally and the gov-
crnment would do so again if the
need arose.
"Those were illegal immi-

"Those were illegal immi- grants and their deportation was not illegal.

Muhammad Naeem was briefing newsmen at Nasirbagh refugee settlement on the resumption of screening programme, which was earlier postponed by the UNHCR.

Pakistan is committed to send back every Afghan national who enters the country illegally and in violation of its law, he said.

Muhammad Naeem Khan said since there is no life threat and founded fear of persecution in Afghanistan, therefore, any one trying to illegally enter Pakistan would be deported to Afghanistan.

The

Afghan Commissionerate chief said that 75 per cent Afghans are not qualifying for refugee status and

they would be repatriated to their country if screened out in the ongoing screening process. He said that those, who would be screened in, would be accommodated at Shamshatu refugee camp and they would be provided protection.

He said that Pakistan honoures and respects intemational norms and any one. who enters the country lawfully, is afforded full protection and facilities. 


\section{The Statesman Tuestay, Sepelember 4, 2001}

Muhammad Nacem ciaimed that life in Afghanistan is morit

safe and the Afghan families, who had returned to their country, are living peace there.

To a question about the appeals against the non-gen;ine refugee status Muhammad Nacem said that after the decision of joint teams such appeals remain illogical. Afghan refugecs are being repatriated duc to the financial condition of Pakistan as it could not bear the burden of such a huge population of aliens.

He said that Iran repatriated 4500 Afghan refugees daily, but there was no one to make hue and cry against the decision.

He said that the Afghan Commisionrate was working on a plan to extend the screening process to other settlements of the refugees also.

The Alghan govermment has also pledged assistance to the repatriated Afghan families and wants the donor agencies to provide assistance (1) Afghan D)Ps inside Afghanistan, he salld.

Peter Nickolus, in charge of the UNHCR screening teams, also spoke to the journalists on this occasion.

$\mathrm{Hc}$ alleged that 28 afghan refugec farnilies were repatriated in violation of the agreement reached between the government of Pakistan and UN refugee agency that's why the UNHCR had put off the sereening process.

He said SAFRON then gave the assurance that no steps would be taken against the agreed rules, therefore the screening was being resumed.

He said that the screening should be held in an active and dynamic manner and only those Afghan nationals, who arc screened out, should be repatriated.

Peter disagreed with the commissioner and said the Ministry of State and Fronticr Regions had admitted that deportation was a mistake and it would not happen again. He stressed under the agreement the government could not deport Afghans from Jallozai and Shamshatu camps during the screening process.

\section{The SNI row}

$\mathrm{t}$ is now over a month but the furious controversy sparked by the arrest of functionaries of a foreign aid group in Kabul continues unabated. According to reports, the Afghan government has completed the investigations and the two Australians, two Americans and four Germans will now be put in the dock to be tried on charges of spreading Christianity under a humanitarian guise. The Taliban authorities insist they have solid evidence to substantiate the accusations. While the case appears to be on the threshold of court proceedings the Kabul administration has shut down offices of two more non-governmental foreign groups in the capital for alleged links with the banned Shelter Now (SNI) outfit. The groups had been operating before the advent of the Taliban movement and its ascendancy in the war-torn country. No doubt, the Islamic militia has been subjected to mounting external pressures for a variety of reasons. The trend to isolate the Taliban government as well as the liberal and one-sided use of sanctions against it has complicated matters. A policy of engagement would have been the right pelicy to sort out the issues through talks and encourage a peace process. Pakistan has rightly and consistently advocated this in order to promote reconciliation in the troubled land. Despite their grievances, the government in Kabul needs to do some rethinking regarding the issue of the detained aid workers and consider adopting a softer line. It has already allowed diplomats, Red Cross officials and relatives to visit the capital and meet with the detainees, which was a positive decision. By and large, the visitors have expressed satisfaction that the detained persons were being treated well.

Irrespective of the merits of the case, it is necessary to take into account the clemency appeals that have been made by members of the international community. The Taliban authorities have sufficiently put across their strong sentiment and viewpoint on the issue of proselytising in the deeply religious society. The message has certainly been well understood by all outsiders who are expected to pay more attention to complying with local traditions, customs and laws. It is time to move to cool down things. Mulla Mohammad Omar should use his ultimate authority to defuse the crisis on humanitarian grounds before the case goes to the court. The clemency appeals are a sign of appreciation of the strong views and feelings in Afghanistan concerning missionary activities. A positive response will send a'good signal abroad. Pakistan has also expressed the hope that an amicable solution to the problem will emerge and the Foreign Office last week said Islamabad was doing whatever it could in this regard. The Taliban leadership may consider giving due consideration to suggestions that the detained people be forgiven and allowed to leave in order to bring the unhappy episode to an end. It is also in the overall
iriterest of the edouhtry! ". 


\section{$K_{\text {HYBER }} M_{\text {ALL September 04, 2001 }}$}

\section{Taliban's obduracy}

7 he way forcign -aid workers are being cxpelled from Afghanistan by ruling Taliban is yet another manifestation of their obduracy and misplaced arrogance. Taking shclter behind Islam for each and every action on their part establishes the fact that they have made this universal religion as a shield for legitimising whatever they do, no matter right or wrong. They blame a particular European NGO for preaching Christianity among Afghans in the garb of its humanitarian activitics, and since then they are raising a storm by expelling dozens of foreign aid workers from Afghanistan every day. Some of the workers of Shelter Now International, the NGO blamed for promoting Christianity are facing trial alongwith some of Afghans, but this issuc is bcing made an excuse for wholesale deportation of foreign aid workers.

If Taliban think they were doing something against Ilslam, the matter could have been settled in a normai way without blowing it up out of proportions. We are not to defend the said NGO accused of promoting Christianity by cxploiting miscry of unfortunate Afghan pcople much hit by fratricidal war, natural calamity and UN sanctions. But what the Taliban are doing in their interpretation of Islam in the context of promotion of Christianity involving personnel of an aid agency, is beyond comprehension of an average Muslim. Islam is a very libcral, enlightened faith with universal appeal, and perhaps Taliban know it but they are seemingly accustomed to make and treat everything by their own version of Islam. Does it suit them to thrive on a mad warfare within their own country and with their own Muslim countryinen? Is Islam not against human bloodshed and human suffering? Taliban should first look at what they are doing in utter disregard of what Islam teaches and preaches.

The socalled custodians of Islam should first put their own house in order and minimise suffering of millions of their own countrymen including those who have abandoned their hearth to cscape war, and taken refuge outside their homeland in much sub human conditions. Playing up with religion has become obsession with Kabul's Taliban rulcts. But Islam, instead they are hurting its real message and appeal not only in the eyes of Muslims but the teeming non-Muslims as well.

\section{The Nation}

SEPTEMBER 4, 2001

KABUL (AFP) - Afghanistan's Taliban militia on Monday charged eight foreign aid workers with several crimes including preaching Christianity and formally began legal proceedings against them, the justice minister said.

We have submitted the file to the Supreme Court, Justice Minister Mullah Nooruddin Turabi, a close aide to Taliban leader Mullah Mohammed Omar and one of the most powerful figures in the Islamic regime, told the agency.

There are so many charges against them but the main one is preaching an abolished religion.

A foreign ministry statement later Monday said the relevant files were officially submitted to the Supreme Court in order to make the final decision.

Trial starts today: The trial of aid workers will start today, the ruling Taliban militia's top judge said.

In the first phase of the trial, the court will study the report about the case compiled by Taliban authorities, the Supreme Court'schief judge Mawlawi Noor Mohammed Saqib told the agency late Monday. At the first phase of the trial complete information will be collected, he said adding that a fair resolution would be passed in the light of that information, Sharia law and the vylid iegulations. 


\section{The Nation}

SEPTEMBER 4, 20)1

\section{Rift surfaces in Taliban over internal issues}

\section{From Shamim Shahid}

PESHAWAR - Amidst facing worst kind of isolation in the comity of nations, the Taliban administration in Afghanistan seems to have developed serious internal differences over certain issues particularly the increasing influence of Arab militants in the internal affaires of Afghanistan.

These differences are not new, however, got intensified immediately after the death of late Mullah Rabbani as well as giving key statis to Arab national Osama Bin Laden and his Uzbek aide Juma Namangani in defence affairs of the country.

The information gathered by The Nation link the differences among the Taliban ranks also to the murder of former Army Chief Mullah Abdul Ghafoor commonly known as Mullah Burjan who had a soft comer for late Dr Najibullah. In 1996. he made efforts to provide protection to Dr Najibullah who took refuge in the United Nations compound. However, Mullah Burjan was later murdered reportedly for his intention to provide protection to Najibullah. This resulted in serious differences amongst the Taliban administration.

Later, late Mullah Rabbani and sitting Interior Minister Mullah Abdul Razzaq were tipped to have some role in the murder of Mullah Burjan.

However, Taliban soldiers loyal to Mullah Burjan later poisoned
Mullah Rabbani to death while Mullah Abdul Razzaq is still facing life threats.

Most recently, after the death of Mullah Rabbani, his younger brother Mullah Ahmad Rabbani was made General Commander and was assigned the task to lead armed forces on war fronts of Takhar province. However, he developed differences with Governor of Takhar Qari Ahmad Ullah which led to the removal of $\mathrm{Ah}$ mad Rabbani.

Now acting President and Prime Minister of Afghanistan, Mullah Mohammad Hassan Akhund, Maulvi Abdul Kabeer and Mullah Abdul Razzaq were on the list of their substitutes.

The insiders informed that recently Mullah Abdul Razzaq was deprived of his power regarding postings and transfers of 'Governors. Likewise, Mullah Abdul Razzaq was also deprived of his other powers by Mullah Mohammad Hassan and Maulvi Kabeer, who are considered most confidants of Mullah Omer.

Afghanistan's Defence Minister Mullah Obaid Ullah Akhund is unhappy over the increasing involvement of the Arab and Uzbek militants in his department. At present, Osama Bin Laden is reportedly empowered to supervise the military operations being carried out by his Uzbek associate Juma Namangani. 


\section{DAWN, September 4, 2001}

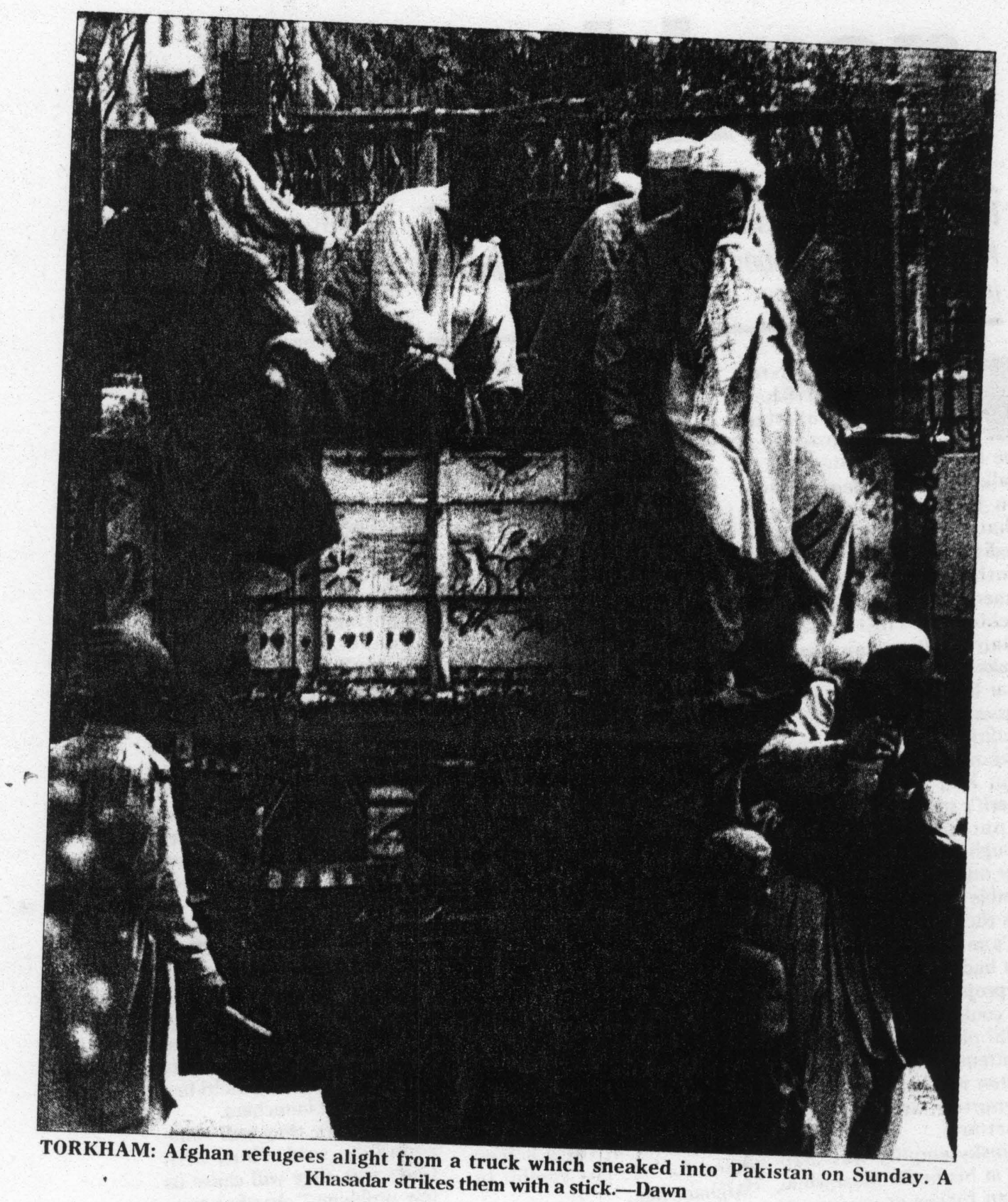




\section{DAWN, September 4, 2001}
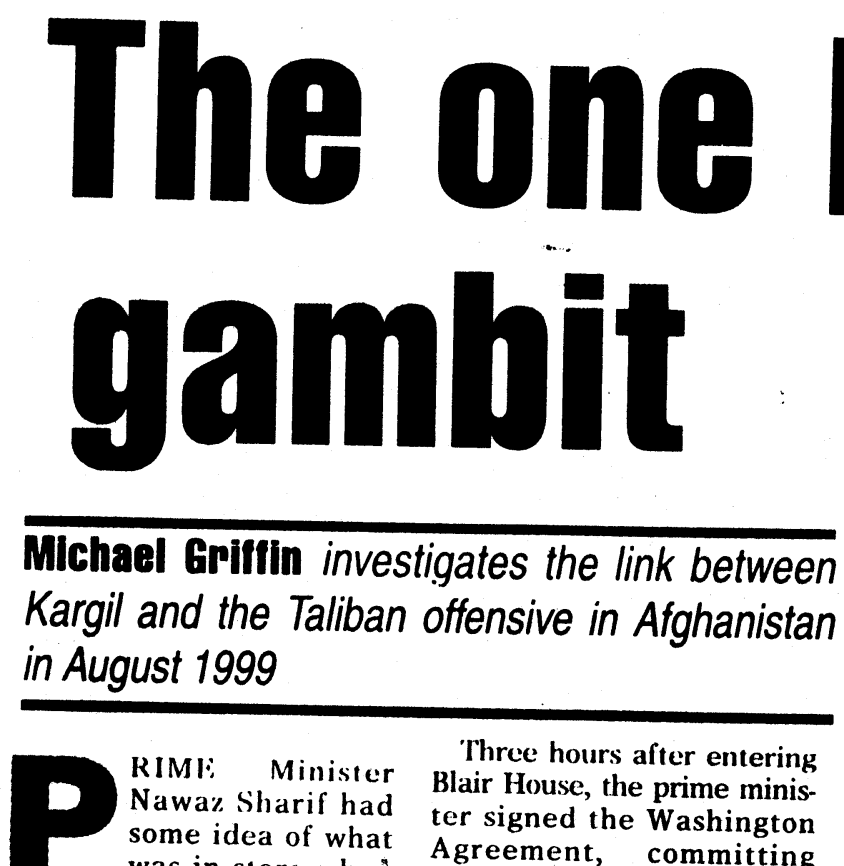

RIMI: Minister Nawaz Sharif had some idea of what was in store wher he flew into Washington for talks with President Clinton on July 4 , the very morning that Osama bin Iaden was rediscovered to the world. Not until much later would it emerge what had transpired behind the closed doors of Blair House, for nothing leaked out and Sharif denied that bin Laden was ever discussed. At home - in the best traditions of Pakistani policymaking - the Kargil incur. sion had briefly restored Sharifs star at the real risk of a nuclear confrontation, though what possible advantage might accrue from such a gamble remained obscure, as was the identity of the country's military organization that had been responsible for the project.

It could, after all, have been an ISI ploy to distract domestic attention abroad, much as Clinton was believed to have attempted at Khost and Khartoum, when the Lewinsky enquiry was snap. ping at his heels. Meanwhile, Indian forces at great cost were gradually winkling the 'mujahideen' out of their positions above the SrinagarKargil road. Sharif had asked for the meeting with Clinton; it is unlikely he relished its outcome.
Three hours after entering Blair House, the prime minisAgreement, committing Islamabad to the immediate withdrawal of its forces from beyond the Iline of Control and the signing of the Comprehensive Test Ban Treaty by the end of the year. No such concessions were wrung from India, whose moral right to occupy ed, rather than held up to international condemnation, while the latter's first play of the nuclear card a year earlier entirely escaped US censure.

With one stroke of the pen, Sharif inflicted lasting damage on the nation's prestige and his own ability to rule. He flew home to a country on the edge of mutiny, with army leaders threatening to withdraw support and the opposition united on the streets in their demands for his resignation. He did not return entirely empty-handed, however: in exchange for capitulating over Kargil, Sharif had won Pakistan's military a free hand for one last gambit in Nighanistan.

Two days after the Washington Agreement,

President Clinton announced sanctions against the Taliban, freczing $\$ 400,000$ in assets held by the national airline in US banks and a further $\$ 24$ ter signed the Washington Kashmir was thus consolidat-

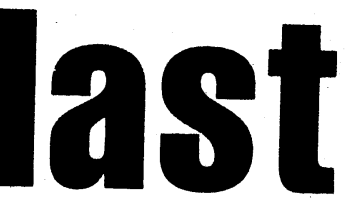

million in conventional trade. The boycott was as symbolic for the one country, whose largest export was illegal opium, as it was for the other, whose chief import from Afghanistan was heroin. With no more forthright US condemnation of the thousands of Pakistani and Arab fighters mustering at Rishkor, the Taliban protectors of bin Laden and Brigade 055 received the go-ahead to unleash the campaign which, it was fervently hoped, would finally put paid to Massoud.

There had been sporadic fighting in Samangan, Kunduz, Balkh and the Shomali Plain since the collapse of the Ashgabat agreement in the spring, but this was little more than jockeying for advantage in the onslaught to come. The Northern Alliance still held four provinces - Parwan, Kapisa, Takhar and Badakhshan - and was well-

supplied with weapons from across the Amu Darya. From his command post in the Panjshir valley in June, Massoud owned to 20,000 available troops and a journalist saw rows of recently acquired tanks and multi-barrelled rocket launchers.

"We know they will come soon," he said, "but, with God's will, they will cause us few problems." Another traveller one month later remarked on the valley's 'well-nourished and carefree children ... living an a diet of peaches, apples, apricots, honey, nan bread and yogurt'. In mid-July, the UN sum. moned the $6+2$ members to 
Tashkent in a last ditch attempt to avert the approaching battle, extracting 'firm assurances' from the Taliban that it would not attack and a joint agreement from neighbouring countries 'not to provide military sup. port to any Afghan party and to prevent the use of their territories for such purposes'. With utter predictability, the storm broke a week later.

At midnight on July 28 , the Taliban launched three simultaneous thrusts against the enemy at Tagab, east of Kabul; eastwards from Kunduz to Takhar; and into the 80-mile long expanse of wheatfields and orchards that make up the fruitful Shomali Plain. As in previous years, the objectives were to drive Massoud out of missile range of Kabul, to lock him in the Panjshir valley and knock out his supply lines from Tajikistan through Taloqan.

But the strength and coordination of the 1999 campaign surprised analysts, who noted the Taliban's three-to-one numerical superiority and the fact that the shock tactic of a rapid advance in pick-ups the Taliban's preferred mode of attack - had been replaced by stolid infantry movements, reinforced with tanks and artillery. Tagab and Najrab in Kapisa fell swiftly. On July 30 , a force with 30 tanks captured Barikab Hill overlooking Bagram and the air-base fell after a fierce battle. "It was loud, very hot fighting," said a witness, "par-

ticularly before dawn."

After three days, the number of dead was set at 1,000 and the bodies of Massoud's men littered the road to Bagram. The loss of the base, a thorn in the side of the Taliban since the fall of Kabul in 1996, was a massive boost to morale. Charikar, Jabal Saraj and Gulbahar all fell without resistance on August 2, Massoud having withdrawn to the Panjshir valley after dynamiting the entrance to delay pursuit.

From the north came other promising news. On August 3,

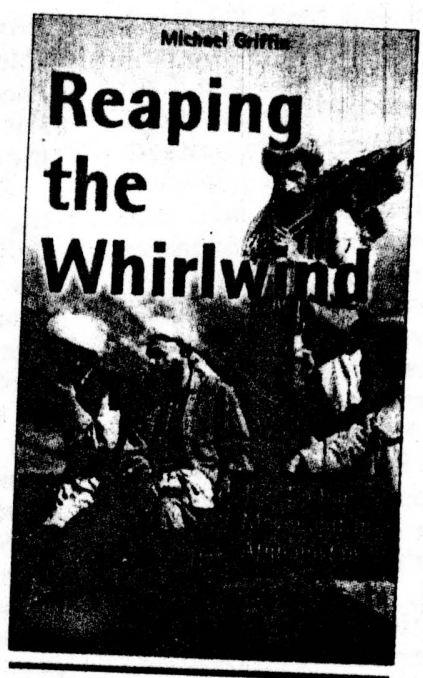

These are excerpts from Reaping the whirlwind: the Taliban movement in Afghanistan By Michael Griffin

Pluto Press, London

Distributed in Pakistan by

Vanguard Books,

45 The Mall, Lahore

Tel: 042-7243783

Email: vbl@brain.net.pk ISBN 0-7453-1274-8

283pp. $\{14.95$

Taliban forces captured Sher Khan Bandar, the river port across from the Tajik border which underpinned the opposition supply line. Massoud was again boxed in his lair, but keeping him there, or eliminating him completely, would demand graver sacrifices. "Two men with Kalashnikovs could hold the

passes," said a Western observer. "So it really boils down to whether the Taliban can throw men at Massoud faster than he can kill them."

The Taliban had made an alternative plan to their soldiers dying in droves. On August 4 came the first report of what proved to be an exodus from the Shomali Plain with people heading for shelter either to Kabul or the Panjshir valley itself. According to agency estimates, 100,000 were on the move, though the opposition put the figure as high as
25,000. At Bamian in 1998, the locals had fled out of fear of Taliban reprisals, but the Tajik inhabitants of Shomali were simply herded out en masse to prevent Massoud ever again relying on the fat of their land.

Six thousand Taliban and their Pakistani allies were allotted the task of clearing the district of Massoud sympathisers, 'killing wantonly emptying entire towns, machine-gunning livestock, sawing down fruit trees, blasting apart irrigation canals'. They shot anyone young enough to be a soldier. A spokesman said the Taliban trucked 1,800 families to the grim Sar Shahi refugee camp outside Jalalabad for 'their own protection'; it was a 'temporary measure' to prevent civilians being caught in the crossfire during the anticipated counter-attack; they had only

\section{dynamited the canals to} stop their use as trenches.

During August 8.12, 55,000 refugees streamed down the Old Road to Kabul. On August 15, the UN accused the Taliban of waging a 'scorched earth war', without surrendering to the blunter, miore candid description of 'ethnic cleansing. "Families speak of whole villagee being burned to the ground," said the UN, "and crops set on fire to prevent them mov. ing back to this once-fertile valley." Nor did they spare the mulberries, whose fruit had sustained Afghans through hard winter for centuries.

The trauma of such losses became evident only in October. Among a group of displaced Tajilks in Bararak north of Jalalabad, a reporter stumbled across an old woman who had been sobbing inconsolably for two months, fingering a red flower embroidered on a pink cloth. No one was quite sure what her story had been....

On August 4, Massoud launched a counter-attack from the mouths of the 
Panjishir and Salang valleys, retaking Charikar in the early hours, literally as the Taliban slept. He had announced carty in the cam. paign that any captured non-Afghans would be exe cuted and many 'Taliban' prisonera were Elaughtered by the displiced men of Shomnli, who had rallied to Massoad in an attempt to win back theff homes. An allience polocitivin put the number of Taliban doad at 500 , including a Intigen number of Pakistanis and Arabs, rising to $1,000 \mathrm{bs}$ the end of the two-meek offensive.

On Auguat 6, Kabul was back within rocbeting range and Bagam surrounded, its fall : to Massoud all but inevitable. Two daje Inter, allied troops mere reported to be closing in on Tagab and Najrab; while fighting continued at the northern port of Sher Khoin Bandar. On August 8, Mullah Mohammad Oraar appealed to the heads of Pakistani madressah to declare a 10 day holiday $s 0$ that students could cross the border to handle security in Kabul, freeing more seasoned troops to bolster the Taliban's collapaing frontlines. More than 2,000 started for the capital over the next two days. Meanwhile, the Tajik population continued to stream out of the contested zones, with 200,000 leaving by 30 August, more than half of them bound for the relative sanctuary of the Panjshir valley. With history at their backs, 12,000 also found temporary respite in the grounds of the old Soviet embassy in Kabul.

The fighting soon sub. sided to its usual level of

- low intensity, mostly to Massoud's small advantage, but August remained a month of anxious anticipation elsewhere. Afghans searched the sloies for signs either of a fresh US attack to commemorate the first anniversary of the East African embassy boübings, or a second Tomahawk strike, perhaps at Jalalabad, to eliminate the man who had escaped vengeance at Khost. ...

Four days after the Khat anniversary, at $10 \mathrm{pm}$ on August 24, a broken-down fuel truck, parked close to Mullah Mohammad Omar's home in Kandahar, exploded, damaging buildings up to one kilometre 'away. The mullah miraculoutly sur. vived, but among the 40 fatalities were two of his brothers, a brother-in-lawi, fourteen members of his bodyguard, six police, three civil servants and, interestingly, six Arab nationals. One of his sons was injured. Most Afghans immediately suspected 'America', but the US denied any connection to the bombs, which were hidden in fuel drums by the perpetrators who escaped hours before the blast.

Pakistan and the so-called moderate faction of the Taliban could equally have been to blame, for Mullah Mohammad Omar had demonstrated clearly in the preceding weeks both his inability to win the war and an absolute refusal to sue for peace. In public, the mullah accused no one, calling the assassination attempt an 'act of terrorism' but, privately, he suspected the hand of Iran, and 70 Shias were rounded up for interrogntion'.

Coming so socen fifter the Kargil fiasco, the spoiling of Pakistan's ambitions in Afghanistan by Massoud and his ragtag army of mountain fighters was as humbling, as it wes public. Indeed, the scourging of the Shomali Plain seemed more the reaction of an injured conventional power than any domestic faction, for the latter were inured to the thin pickings of an Afghan victory' end in thrall to the fiat of destiny and the abiding consolation of patience.

For the first time since the mysterious rise of the Taliban five years before, the UN finally came clean about the movement's foreign support. "These thousands of young people are not fighting a foreign invasion force as it was when the Russians were there," said Special Envoy Lakhdar Brahimi. "They are taking sides in a local conflict." But he was silent as to whether these 'young people' had ever worn Pakistani uni. forms.

Switching to its civilian hat, Islamabad quickly offered in mid-August to mediate a fresh round of talles between the Afghans, and mission was sent to meet Massoud's representatives in Dushanbe. It was led, impudently, by a middle-ranking official in Pakistan's Interior Ministry, an office dealing with local law and order, not foreign relations. The alliance rejected its overtures on Auguet 24.

Michael Grilin is a widelytravelled freelance writer and journalist. He has worked as an information consultant for Unicef in Afghanistan and is the associate editor of Index on censorship 
The Aictu Hork Eimes

September 3, 2001

\section{Britain Faces Flurry of Illegal Migrants Using Channel Tunnel}

BY ALAN COWELL

ONDON, Sept. 2 - In one of the most audacious attempts yet to evade Britain's immigration restrictions, a group of about 100 people apparently attempted a mass dash late Saturday night toward the Channel Tunnel from France, the French police said today.

They were intereepted by French security personnel.

It was the third attempt this week by migrants to use the rail link underneath the English Channel, and it showed the perils they are prepared to face to seek sanctuary. Once in the narrow tunnels, they apparently hope to stow away on the rail cars for the 32-mile trip under the channel.

As on the previous oceasions, the would-be asylum seckers had left a Red C'ross

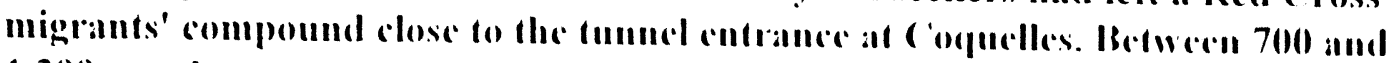
1,200 people are cared for there, most of them having managed lo enter tiurope by clandestinc routes from Irag, Afghanistan, Turkey and Iran.

The pressure from would-be immigrants, conomic refuges and political asylum seckers plays into an emotional political debate in Britain. It pits a frayed tradition of hospitality against louder voices demanding harsher measures to bar access to all but genuine asylum seckers.

Ann Widdecombe, the opposition Conservatives' spokeswoman on immigration, for instance, said today that "the fact is the asylum system has been out of control ever since this government" came into office in 1997 and that there were no "serious deterrents" to discourage those secking to enter Britain.

"The biggest difficulty, of course, is that there is no sanction that the French government is taking against those people who try night after night," said Gwyn Prosser, a government legislator from Dover.

But the British authorities said today that back in July, Ilome Secretary David Blunkett, asked France to move the camp at Sangatte, near Coquelles. Many people being held there have said openly that they want to reach Britain either by stowing away on trucks or ferries or by making their way through the tunnel. 
Last year, 97,860 migrants applied for permission to remain in Britain, according to the United Nations high commissioner for refugees.

But a report today from the Center for Policy Studies, a rightist research organization, said the true number of illegal immigrants last year was 400,000 . The Conservatives say Tony Blair's Labor government is viewed as a "soft touch" because of its relatively liberal policies toward asylum seckers.

Eurotunnel, the British-French company that operates the Channel Tunnel, has also pressed to have the French migrants' camp closed.

Just in the last week, a group of 44 migrants was found walking in the tunnel. $A$ day later, on Thursday, a group of about 80 people was caught trying to break into the terminal at Coquelles.

The group seized on Saturday was in the terminal but had not actually entered the tunnel, the French police said. Passenger and freight services were halted for several hours.

Early today, in a separate incident, about 40 Sri Lankans and Indians were found hiding in a German truck arriving at Dover by ferry from Calais, France, the police said.

Many illegal immigrants rely on unscrupulous brokers to get them into Britain. Once they have evaded immigration controls, they are fres to seck asylum. The Sunday Times reported today that its reporters had found Britain's defenses easy to breach after they crossed the channel at night on small boats chartered by peoplesmugglers and swam the last few hundred yards to shore.

\section{THE GLOBE AND MAII}

Monday, September 03

\section{Australian navy ship taking boat people to port}

\section{Reuters News Agency}

Christmas Island, Australia - An Australian navy troop carrier transferred 433 asylum seekers from a Norwegian freighter on Monday and is now on its way to Papua New Guinea, the next stage of their odyssey.

But the completion of the transfer, off Australia's Christmas Island, did not mean that the asylum crisis was over.

The Federal Court, sitting in Melbourne, still has to rule in a case that may yet force 
the government of Prime Minister John Howard to aceept the mostly Afghan boat people it has steadfastly refused to allow onto Australian soil.

"All the refugees are off the boat," Hans Christian Bangsmoen, spokesman for the freighter's owners Wallenius Wilhelmsen, told Reuters in Oslo. He said there were no reports of injuries during disembarkation.

"The Manoora set sail overnight and is now on its way to Papua New Guinea," a spokesman for Mr. Howard told Reuters. He said Australian authorities would check the vessel for any stowaways and complete other formalities. The Norwegian Foreign Ministry said 34 Australian soldiers were aboard the ship.

Harbourmaster Don O'Donnell said four translators would board the Manoora at daybreak Tuesday before it sailed.

From Papua New Guinea, the asylum seckers will be flown to New Zealand or the Pacific island of Nauru, which have agreed to take them while their asylum requests
are processed.

The transfer from the Norwegian freighter Tampa took place in Flying Fish Cove, about one nautical mile off the island's northern coast. The refugees were moved in groups of about 30 , wearing new red lifejackets.

The Manoora was farther out to sea and obscured by the much larger Tampa, which was acting as a windbreak while the Australian troops ferried the refugees between the ships on high-speed Zodiac inflatable boats as southwesterly winds gusted up to 20 knots and created choppy seas.

Norwegian ambassador Ove Thorshein was taken to the Tampa after the asylum seckers were removed, and sources said he would sail with it to its original destination of Singapore.

The Tampa was expected to sail Monday night, and Christmas Island locals were planning to send it off with some fireworks as a tribute to the captain and crew.

The Zodiac used to ferry Mr. Thorshein returned to shore with four Indonesians who were crew of the boat the asylum seekers were rescued from by the Tampa on August 26.

The four were taken to the Christmas Island police station, where, an Australia Federal Police spokesman said, they will be charged Tuesday with immigration offecnces.

Police sources said there was a fifth Indonesian crewman, but his whereabouts was not yet known.

The asylum seekers have been stranded off Christmas Island for eight days since their rescue. Indonesia and Australia have refused to aceept them and denied responsibility for them. 
A court agreement between Australia and civil-liberties lawyers stipulates that the boat people cannot be forced to leave the Manoora until the court decides whether Australia's rejection of the asylum seckers was lawful.

If the government loses, the boat people could still make it to Australia within days, although the government is expected to appeal an unfavourable ruling.

Federal Court judge Tony North said he hoped to make his ruling before the Manoora reached Port Moresby in six to 10 days. The case was adjourned until 10:15 a.m. local time Tuesday, with a ruling not expected until Wednesday.

On Sunday, Australia announced a South Pacific solution, with Nauru agreeing to take 283 and New Zealand 150. Australia will bear the cost of Nauru's processing the boat people.

UN Secretary-General Kofi Annan said the plan to ship the asylum seekers to New Zealand and Nauru was acceptable.

Australian officials have arrived in Nauru, an 2-square-kilometre island with about 12,000 people, to prepare for the asylum seekers who are expected to be housed in tents.

Nauru said it could take three months to process the boat people's refugee claims. Legitimate refuges can then apply for settlement in another country, including Australia. New Zealand will house their intake in an Auckland refugee center.

Hundreds of thousands of Afghans have fled conflict and the strict Islamic rule of Afghanistan's Taliban. Many live in crowded refugec camps in Pakistan, where they wait for refugec applications to be processed.

The asylum seckers have lived in cramped conditions with makeshift facilities on the Tampa. The Manoora, an amphibious transport ship, is designed to carry 450 troops, $180 \mathrm{crew}$, as well as vehicles, landing craft and four helicopters.

It also has a hospital with several operating theatres.

"It is frequently at sea for weeks on end with hundreds of troops, so the conditions on it are much better than the conditions on Tampa," Mr. Ioward told reporters.

The stand-off in the Indian Ocean has already cost an estimated \$20-million (\$16million Canadian), more than it would have cost to detain the boat people for more than a year.

Yet Mr. Howard may still emerge a political winner from the crisis just months before a tough end-of-year election, with voters applauding his refusal to accept the asylum seckers.

About 5,000 illegal immigrants arrive in Australia cach year - a big jump from the 600 of a decade ago - and the issue has become a political hotpoint. 
Packages containing bullets and detonators were sent to Parliament on Monday addressed to politicians critical of the government's rejection of the asylum seekers, Australian Broadcasting Corporation television reported.

The ABC said the packages were sent to Labor Opposition leader Kim Beazley; Natasha Stott Despoja, leader of the small Democrats Party; and Greens senator Bob Brown. Police said they were meant to intimidate not injure.

\section{THE IRISH TSIMES}

Tuesday, September 4, 2001

\section{The Afghan Refugees}

The Australian move to ship over 400 Afghan refugees to Papua New Guinea began in earnest last night despite court actions and international outrage. Few people have fled their homeland in such numbers as the Afghans. Since the Soviet invasion of Afghanistan in 1979, more than six million people have tried to escape wars, civil strife and a succession of oppressive governments. Those conflicts and the brutal policies of the Taliban regime in Kabul have been compounded by a devastating drought that has lasted for years.

If Australia was a destiny that symbolised some hope for Western-style justice and compassion on the part of those flecing Afghanistan, then that hope has been sadly dashed. The harsh treatment of the foreign aid workers who were recently arrested in Afghanistan has served to draw Western attention once again to the plight of those who live under the Taliban. In Afghanistan today, basic liberties, including the freedom of spech and freedom of religion, are denied, wem are not allowed to work, male unemployment is rife, adult literacy is just 30 per cent and life expectancy is only 45 years.

Complaints about the reign of terror in Afghanistan must ring hollow when Western governments refuse to deal compassionately with those who manage to flee the Taliban. And complaints in Australia and Europe about the numbers of refugees belie the facts. Although 150,000 Afghans have applied for asylum in Europe in the last decade, the real burden is being borne by Afghanistan's neighbours. According to the United Nations High Commissioner for Refugees, the largest numbers of Afghan refugees are in Pakistan, where they total two million, and Iran, where there are a further 1.6 million.

The eight foreign aid workers who are going on trial in Kabul accused of preaching 
Christianity, include two Australians. They have been denied consular or family visits for most of their time in detention. Undoubtedly the Taliban will argue that it has acted within its own harsh interpretation of Islamic law. The Australian government says it too has been acting within the law. But it is a law that serves a large section of xenophobic voters while failing to meet the neeus of those already denied basic human rights.

The lack of compassion in both Afghanistan and Australia in recent weeks must be condemned internationally. But Australia must also be judged by Western standards of justice, decency, democracy and fair play.

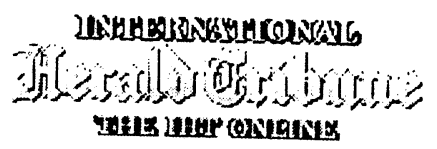

Tuesday, September 4, 2001

\section{France to Open 2d Migrant Center}

BAILLEUL, France France pressed ahead Monday with plans to open a second camp for asylum seekers near the Channel Tunnel despite mounting concerns that the move would lead to more migrants' arriving Britain. . Bailleul's mayor, Jean Delobel, said town officials had been asked to consider opening a camp to ease overcrowding at the center in Sangatte, which houses about 1,200 refugees, most of them from Iraq, Iran and Afghanistan. .The facility in Bailleul would be set up near a psychiatric hospital and be run by the Red Cross, which also operates the Sangatte center. The Bailleul camp would house as many as 200 asylum seekers, Mr. Delobel said.

Ehe Airtu Hork Times

September 4, 2001

\section{High Public Support for Australian Leader's Refugee Stance}

\section{By THE ASSOCIATED PRESS}

CHRISTMAS ISLAND, Australia (AP) -- For nine days, Prime Minister John Howard faced a barrage of international criticism for refusing to let a boatload of refugees enter Australia. But opinion polls Tuesday showed Australians overwhelmingly supported his hard-line stance.

As a warship carrying the 433 refugees steamed away, the four Indonesians accused 
of trying to sneak them into Australia were arraigned Monday night on charges of people-smuggling. They face up to 20 years in prison if convicted. They were
ordered held in Perth.

During the standoff, Howard ordered 50 commandos to take control of the Norwegian cargo ship the Tampa when it defied an order banning it from entering Australian waters off remote Christmas Island with the refugees, most of them from
Afghanistan.

The refugees were transferred Monday to the naval troop carrier HMAS Manoora, which began a weeklong voyage to Papua New Guinea. From there, the refugees will be flown to New Zealand and the tiny Pacific republic of Nauru where their asylum
applications will be processed.

A national A.C. Nielsen poll of 2,058 voters found 77 percent agreed with Howard's

- firm policy and 74 percent approved of how he handled the affair. Howard has said he wanted to send a message that Australia is not an easy destination for smugglers.

"Support for the policy is across the board, it is supporters of all the parties, supporters in all the age groups," said John Stirton, Nielsen's chief pollster.

A Newspoll of 1,148 voters found 50 percent supported turning back all boats and 38 percent some boats. Only 9 percent thought all should be allowed in.

Howard's approval rating jumped 10 points, the biggest increase since he introduced tough gun control laws after a shooting massacre in 1996.

Neither poll published a margin of error.

The prime minister, whose conservative government faces a seneral election before year's end, welcomed the support, but denied he had pandered to public sentiment.

"I did not do this for poll reasons, I did it because I thought it was right," he said.

But criticism kept coming from overseas about the Australian plan to send the refugees to New Zealand and Nauru.

Australia's refusal to take in the refugees, who were stranded for days on the deck of the Norwegian container ship without food or medical care, set a troubling precedent, critics said.

"We are concerned and we have expressed our concern almost ad nauseam for the past week," said U.N. High Commissioner for Refugees spokesman Ron Redmond. "UNHCR would have preferred another solution to this. Our option would have been first to put them ashore on Christmas Island, at least temporarily."

Redmond said Australia's stand may discourage other ships from rescuing refugees and said Howard's refusal to accept the refugees sent a poor message to impoverished nations closer to conflict zones which are forced to take in hundreds of thousands of refugees. 
In Melbourne, a federal court challenge to the legality of Australia's decision to turn away the migrants continued Tuesday.

The challenge, by civil rights lawyers, is expected to last at least two days. If the court rules that the government acted illegally in turning away the boat people, they will be brought to Australia to have their asylum applications processed.

The government has said it would appeal such a decision.

Government lawyer David Bennett told the court Australia has the right to protect its borders and said the refugees brought their problems on themselves by ordering the Norwegian ship's captain to sail to Australia.

\section{Ehe Ainu Hork Eintes}

September 4, 2001

\section{Taking On the Taliban, From Here}

To the Editor:

Karl F. Inderfurth ("Teaching the Taliban About Human Rights," Op-Ed, Aug. 29) suggests that Taliban extremists might be best persuaded toward observing basic human rights by their fellow Islamic governments.

This issue also gives American Muslim groups an opportunity to dispel what they feel are unfair public perceptions of Muslims. Yet these groups have failed to make an impression on the public with any significant condemnations of the persecution of Christians, Jews and Hindus in Pakistan, Sudan and other countries under Muslim law.

Nor have they been outspoken on the death sentence declared this summer by a Muslim cleric in Jordan on the writer Khalid Duran, who lives in the United States, for a book on Islam he wrote that was commissioned by the American Jewish Committee.

As groups like the American Muslim Alliance become more involved in American - political life, they could enhance their political presence and American interfaith amity by speaking up against oppression wherever it appears.

(Msgr.) HARRY J. BYRNE

New York, Aug. 30, 2001

To the Editor:

Karl F. Inderfurth ("Teaching the Taliban About Human Rights," Op-Ed, Aug. 29) 
is right that the Taliban should be set straight by the Muslim countries that recognize them as the legitimate rulers of Afghanistan.

It is hard to explain to those not of the Islamic faith just how deeply painful the Taliban's barbaric actions are to Muslims everywhere. For Muslims, it is an added responsibility to set the record straight on the depth of the Koran's teachings on tolerance, spirituality, scholarship and respect for women.

But the darkness and cruel nature of the deeds of the Taliban make it equally incumbent on the entire world and, notably, the major powers to apply any leverage that can expediently fight the spread of the Taliban's brand of order.

SANOBER Q. HAIDER

Princeton Jct., N.J., Aug. 30, 2001

To the Editor:

Karl F. Inderfurth ("Teaching the Taliban About Human Rights," Op-Ed, Aug. 29) is right that Muslims and Islamic governments should condemn the Taliban's perversion of Islam in Afghanistan. But this should not let the rest of the world off the hook. Five years ago, the Taliban took over Kabul and prohibited women from attending school, working or going outside without a close male relative. Women have been beaten, imprisoned and killed for violating the draconian decrees.

The United States should do more to pressure Pakistan, Saudi Arabia and the United Arab Emirates to withdraw their support and recognition of the brutal militia's regime. America should provide more humanitagia's assistance to nongovernment organizations both inside Afghanistan and in the countries to which millions of refugees have fled.

International outery from Muslims and non-Muslims alike is necessary to restore women's rights, human rights and religious freedom in Afghanistan.

\section{ELEANOR SMEAL}

President, Feminist

Majority Foundation

Arlington, Va., Aug. 30, 2001 


\section{Ehr Aictu Hork Eimes}

September 4, 2001

\section{EU Maps Strategy to Develop Ties with Asia}

By REUTERS

BRUSSELS (Reuters) - The European Union set out a strategy on Tuesday for strengthening its presence in Asia, a region where it has traditionally been overshadowed by the United States.

A policy document adopted by the EU's executive Commission on Tuesday calls for the EU to strengthen its engagement with Asia in the political and security fields over the next decade, increase trade and investment ties and step up efforts to promote democracy and fight poverty in Asia.

"We must focus on strengthening the EU's political and economic presence across the region and raising this to a level commensurate with the growing global weight of an enlarged EU," the document said, referring to negotiations under way which could add 12 new countries to the EU's 15 members.

The Commission paper deals with a vast area of 3.3 billion people ranging over

The Commission adopted the document -- which must still be endorsed by EU governments -- on the eve of an EU-China summit in Brussels.

The United States has huge political, military and economic influence in Asia, far outweighing the EU.

Some EU leaders see EU-Asia as the weak link in a global triangle binding the United States, EU and Asia and want to step up Europe's ties with the region.

The Commission sounded a potentially controversial note by saying it would welcome a greater Asian voice in the Asia-Europe Meeting (ASEM), a cooperative forum that currently includes the $\mathrm{EU}$ and 10 Asian countries.

The Commission suggested the body could be expanded to take in countries on the Indian sub-continent as well as Australia and New Zealand.

SECURITY ROLE

Malaysian Foreign Minister Syed Hamid Albar said in October last year that if Australia and New Zealand became members of ASEM, they would have to join on 
the European, rather than the Asian, side of the organization.

On security issues, the Commission said the EU should play a more pro-active role in regional forums, support conflict prevention and seek closer cooperation with Asia on issues such as immigration and arms trafficking.

The EU should aim to develop cconomic relations with Asian countries by working to improve market aceess and investment conditions on both sides.

"We should in addition encourage Asia to take maximum advantage of the new possibilities offered by the curo," the Commission said, alluding to the euro's potential as a trading and reserve currency.

Noting tensions between India and Pakistan, the Commission said the EU should be ready to adopt a more assertive and forward-looking approach to its policy dialogue a with the key countries in the region.

"An early restoration of parliamentary democracy in Pakistan will be a prime factor in paving the way for enhanced cooperation with that country," it said.

Noting China's growing economic power, the Commission said the EU should seek to engage China further in the international community, through a stronger political dialogue.

It said the EU should encourage South Korea to push ahead with economic reforms and support reconciliation between North and South Korea.

\section{Deutsche Presse Agentur}

Tuesday, 4 September 2001

\section{Australia wriggles under Taliban wrath}

By SII) ASIBI RI SYDNEY - In the 1960s Australian backpackers followed the hippie trail through South East Asia,
India and on to Afghanistan.

The brutality of the Taliban has since reversed the direction of the traffic with locals impelled down a pipeline that once brought mop-headed Australians.

A few of the Afghans streaming out of their benighted country, grubby copies of the Lonely Planet travel guide in their hands, are making it all the way to Indonesia 
where they take to flimsy boats for the passage to Australia.

Many of them don't make it that far. Stranded in Indochina, in the Indonesian archipelago, they join the skint and unwanted dregs of an Afghan diaspora.

One in four of the world's refugees are Afghans. About half of those seeking asylum in Australia are Afghans. All but 22 of the 460 boat people waiting to be taken off a Norwegian freighter at Christmas Island are Afghans.

Since April about 8,000 Afghans have sought asylum in Australia - a tiny fraction of those knocking on doors worldwide.

Australian officials say as many as 5,000 more are stuck in Indonesia, waiting for good weather or better boats to attempt the crossing.

In countries like Germany, which received 100,000 refugees last year, people can't fathom why Australians are so uncharitable, why so much money is being spent to shoo away so few people.

Some Australians share their indignation.

Bob Brown, a member of parliament for the Greens, complains that the money spent so far keeping hundreds of refugees aboard a Norwegian freighter would have been enough to airlift thousands from squalid camps in Pakistan.

He reckons it absurd that the government is spending more money keeping Afghans

- "out of Australia than it does on keeping them in Pakistan's refugec camps.

Government officials talk of sending a strong message to people smugglers and those Afghans they often con into parting with their life's savings.

Foreign Minister Alexander Downer, who will travel to Jakarta with two other ministers to seck help in choking off the flow of asylum seckers, said "Australia should break the back of these syndicates and I don't think you're going to do that by being weak".

Like other Australians, he worries that successful outcomes for those aboard the Norwegian freighter will be an inspiration for the 1.2 million Afghans in Pakistani refugee camps.

He says Australia will be seen as an easy mark and there will ile a stampede down the quandam hippie trail.

But, at often 10,000 US dollars a pop, passages to Australia don't come cheap. There's no flood, only a trickle. 


\section{Fighting erupts in north of Kabul}

ISLAMABAD: Fighting involving tanks and heavy weapons erupted Tuesday north of the Afghan capital near the opposition stronghold of the Panjshir valley, a report said.

The Taliban militia captured Khanqah and Sang-e-borda areas in the southwest of Mahmud-i-Raqi, capital of Kapisa province, around 70 kilometres north of Kabul, the Afghan Islamic Press reported.

The Pakistan-based private news agency said the Taliban and opposition forces loyal to commander Ahmad Shah Masood were using mortars, tanks and other heavy weapons.- AFP

\section{Taliban deploy anti-aircraft guns at borders}

CHAMAN: Taliban administration has beefed up security measures and deployed missiles along the borders besides sealing them. Anti-aircraft guns have also been deployed in the interior all over Afghanistan.

According to a report, these measures were taken to overcome situation emerging due to deployment of foreign observers along the Afghan borders.

It may be recalled that Afghan supreme leader Mulla Muhammad Omar Mujahid had already ordered shooting any foreign observer seen along Afghan borders. The troops equipped with modern weapons such as missiles and rockets have also been reinforced.

Taliban commandoes are keeping strict vigil along the borders and are ready to meet any situation.

According to reports pouring in here from Afghanistan, anger prevails among Afghan population against the US.-PPI

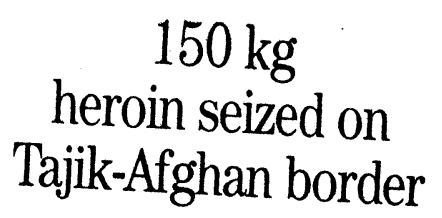

DUSHANBE: Russian border guards deployed in Tajikistan seized $150 \mathrm{~kg}$ of heroin early on Tuesday after an armed clash with a gang trying to smuggle the drug in from Afghanistan, a border guards spokesman said.

The gang dropped six bags of narcotics after border guards at the Moskovsky border point in southern Tajikistan and gunfire erupted, the spokesman said, stopped them.

The gang retreated into Afghanistan. No casualties were reported. In a similar incident last week, Russian border guards killed nine armed smugglers and seized $200 \mathrm{~kg}$ of heroin at a neighbouring border point.

Tajikistan, ravaged by years of civil war, has become a transit route for Afghan drugs making their way to Russia and western Europe via sparsely populated Central Asia.

Russia keeps thousands of servicemen in Tajikistan who help guard its remote, mountainous border with Afghanistan under a formal agreement with the Dushanbe government. -Reuters

AP: Russian border guards intercepted 4.4 metric tons of drugs on the border between Tajikistan and Afghanistan in the first eight months of this year, a guards' commander said.
No demand for Egyptian cleric release: Zaeef.

ISLAMABAD; The Taliban Tuesday said they are not studying any US offer to free two jailed American aid workers in lieu of the release of Egyptian cleric Sheikh Omar Abdur Rahman, who is imprisoned in an American jail.

The American are among eight foreign workers of Germany-based shelter now international NGO charged with preaching Christianity. "It is not Taliban policy to demand the release of any one and free another person in lieu of that," Afghan ambassador in Pakistan Mulla Abdul Salam Zaeef said.

Mulla Zaeef was commenting on a report by Afghanistan-based correspondent of Al-jazeera, that Taliban are studying a proposal to free two women workers arrested by Taliban last month for preaching Christianity.

Al-jazeera reports that some sources are trying to secure a deal for the release of two Americans women from Taliban detention and the release of Sheikh Omar Abdur Rahman, leader of Al-jama'a Islami
of Egypt.

"We have not arrested aid workers for any bargain. They will be tried in court under Islamic shariah," the Taliban ambassador said. - NNI 


\section{The Frontier Post wednesday, September 5, 2001}

\section{Local workers to have defence

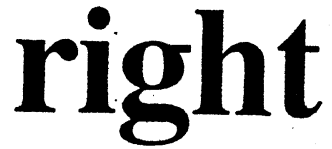

Government in Afghanistan and cases of foreign aid owrkers, Mullah Zaeef said that Afghan government had constituted a Commission to probe into the case of the people arrested on the charges of preaching Christianity in the country. The investigation has now been completed. "We have received a written statement, which says that the investigation has been completed after which the case was referred to the court" he added.

About the procedure of the trial, the Afghan Foreign Minister said there is Islamic decisions are made in accordance with Islamic system and Shariah. The case of the accused had been sent to the Supreme Court of Afghanistan. The court would make a just decision on this case.

He avoided giving any detail about possible sentence to the aid workers involved in preaching Christianity. To a question about Taliban Chief's pardon to the foreign aid workers. Zaeef said, "it depends on him whether or not, he would pardon them"

About investigations into the

\section{poised to quit \\ Afghanistan in food aid row}

NEW DELHI (Agencies):The United Nations will pull its vital aid workers out of Afghanistan if the Taliban continues to threaten them and to bar women from taking part in a desperately needed food programme, the head of its mission to Afghanistan has said.

Erick de Mul, the head of the mission, said: "I told the Taliban: If you want to fight the whole world, if you want to fight with 184 member states of the UN, that's your choice; but don't expect us to do that. There are conditions under which we can operate and if they're not acceptable to them, then we'll have to close down."

The already tense relationship between the Taliban and the aid community on which the country depends has grown increasingly worse in the last month. Two weeks ago, the feared religious police beat up doctors and workers at a new Italian-run hospital for war wounded in Kabul. Foreign aid workers in Kabul have been threatened.

It is no longer safe for them to walk on the streets and aid agencies have been prevented from reaching thousands of starving refugees in the Hazarajat region of central Afghanistan. The final straw. though, for the UN has been the Taliban's refusal to allow a long-overdue survey of poor households for the bread distribution programme.

Almost 300,000 people queue up every day outside bakeries in the capital for subsidised bread, but the UN says that in the last five years the scheme has become "totally rotten and corrupt" with bread no longer reaching the poorest families. These include those headed by thousands of war widows whom the Taliban have forcibly prevented from earning a living.

The Taliban have banned men from entering non-family households where women might be present, so only women can carry out the survey. But as women are not allowed to work anywhere other than in a hospital, they, too, are effectively banned from conducting the survey.

The atmosphere between non-Muslims and the feared religious police from the Ministry for the Prevention of . Vice and the Promotion of Virtue has grown increasingly menacing in recent weeks. First they ordered Afghanistan's tiny Hindu and Sikh population to year yellow identity tags
20 religious police, brandishing Kalashnikovs, forced their way into a newly-opened 100-bed hospital for war victims and accused the male and female staff of having lunch together and talking to each other.

The 200 Afghan and nine international staff from the Italian aid agency Emergency. who insisted that the male and female sections of the canteen had been separated by a curtain. were pushed on to the floor, a Finnish doctor was whipped and three Afghan staff were beaten up and thrown in prison.

About $\mathbf{4 0}$ patients, half of whom were children suffering from burn and landmine. injuries, were either sent to other hospitals or discharged and the hospital is now closed. If the UN and other agencies end all or even some of their programmes in Afghanistan, the result will be catastrophic. Last year government and nongovernment aid agencies spent some a total of $£ 420,000$ daily in Afghanistan and the amount is expected to rise to $£ 560,000$ this year. The Taliban provides: no funds for the local population, the country is entirely dependept on foreigu aid. A bout 600,000 to joges are on the brink of staryat o w wheris 


\section{The Frontier Post}

Wednesday, September 5, 2001

\section{Film on Afghan refugees wins distinction}

KABUL (Agencies): Iranian helmer Majid Majidi scored an unprecedented Grand Prix hat trick at the Montreal World Film Festival on Monday. picking up his third consecutive Grand Prix of the Americas for best film.

Majidi won for "Baran," a tale of Afghan refugees in Iran. sharing the honor with "Abandoned" (Torzok), a grim autobiographical story of childhood from Hungarian director Arpad Sopsits.

Majidi won the Grand Prix for "The Colour of Paradise" in 1999 and "The Children of Heaven" in 1997, which went on to garner an Oscar nomination. One of Iran's best-known filmmakers, his pictures have done solid art-house business around the world.

The awards for the Montreal World Film Festival were handed out at a ceremony

\section{$K_{\text {HYBER }} M_{\text {AIL }}$}

\section{Taliban asked}

\section{to release aid \\ workers}

\section{KMI Report}

PESHAWAR: District

Peshawar Organizer of National Awami Party Pakistan (NAPP), has appealed to ruling Taliban of Afghanistan to release the aid workers of Shelter Now International (SNI) on Humanitarian basis and in the interest of the people of Afghanistan, says a press release issued here on Tilesday.

He said that Taliban should think before taking any step agamst these workers because Australia, USA and Germany are taking part in the rehabilitation of the Afghan refugees. He further that recently 124 million dollars have been spent by the different US agencies for the Afghan refugees in Pakistan.
Monday night in Montreal. The fest kicked off Aug. 23.

The Special Grand Prix of the jury. the second prize, was given to "Son of the Bride" (El Hijo de la Novia), a chronicle of a depressed middle-aged guy. from Argentine helmer Juan Jose Campanella. "Son of the Bride" also took home the award for best Latin American Fature.

Germany's Oliver tor for "The Experiment" (Das Experiment), a disturbing story of a psychological experiment gone wrong.

The award for best actress was given to Sandrine Kiberlain, Nicole Garcia and Mathilde Seigner, the three lead thesps in Gallic helmer Claude Miller's dark thriller 'Betty Fischer and Other Stories" (Betty Fischer et Autres Histoires).

\section{September 05, 2001}

\section{Minister visits carpet industry at Jalozai}

From Our Correspondent

P'ABBI: NWlPP Minister for Industrics (Bats (ihani visited ear?et industry at Jaloza: Alghan refugees camp.

He was informed that $80 \%$ Afghan refugees has been carning bread by making carpet which is famous all around the world.

He was told that these carpets are exported through lixport Promotion Bureau and bring hand some moner to the country he was further told these earpets were preferred orer Iranian and lurkish earpets because it is made of hand. Hirschibiegel won as best direc-

\section{NA claims killing of 50 Taliban \\ Monitoring Report}

PESHAWAR: Afghan opposition Northern Alliance has claimed killing 50 Taliban in renewed war in Kapisa province.

A spokesman for the Afghan opposition, Muhammad Habeel told the BBC that Taliban carried out attacks on eastern flank of Bagram air base and Sang-eBreed and Khan Aqa areas in Kapisa.

Taliban made some advance in the beginning of the offensive and captured some posts in Bagram air base area but the Mujahideen repulsed them, he claimed.

$\mathrm{He}$ said that when the Taliban's operations did not yield any result, they subjected residential areas of Panjsher and Kapisa to bombings killings a number of civilians. 
DAWN WEDNESDAY, SEPTEMBER 5, 2001

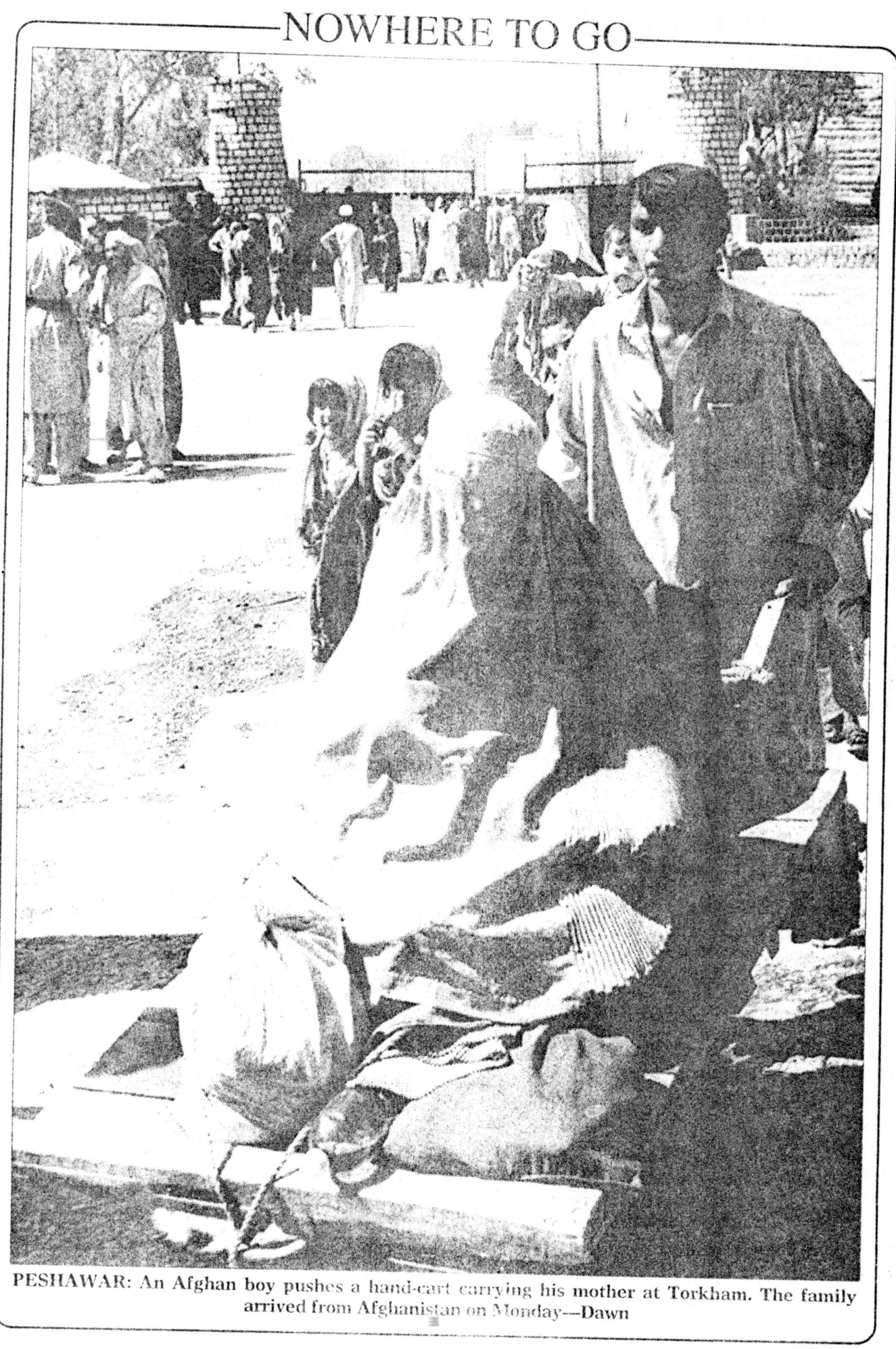




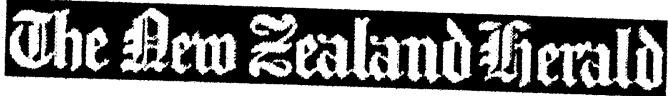

Wednesday September 05, 2001

\section{Local Afghans ready to help}

\subsubsection{By JOSIE CLARKE}

Interpreters and doctors from Auckland's Afghan community have offered to help Government agencies care for the 150 Tampa asylum-seekers.

Auckland Refugee Council members and representatives of the Afghanistan community met on Sunday and again last night to discuss New Zealand's offer to take asylum-seekers from the Norwegian ship.

Refugee Council president Dr Nagalingam Rasalingam said the refugee community would rally to help the Afghans once they reached New Zealand.

At least 25 bilingual interpreters and two doctors had offered their services. The doctors were unregistered in New Zealand but were willing to help with administration, Dr Rasalingam said.

"The strength of the family unit is of very great importance to these asylum-seekers, so to meet people from their own land will be a very great help."

He said that certainly some among the 150 asylum-seekers would be traumatised. Some could be suffering from malnutrition and the pregnant women would need urgent medical
checks.

Statistics showed at least 20 to 30 per cent of refugees were likely to suffer post-traumatic stress disorder.

The Mangere centre is prepared for the asylum-seekers.

Immigration Service spokesman lan Smith said there would be a degree of control, depending on how many asylum-seekers arrived at the centre and what groups they were in.

"Minimal [security] is our thinking, but that is still to be determined."

The National Party leader, Jenny Shipley, has said she believed the asylum-seekers should be housed in a sectioned-off area of a prison to ensure the safety of New Zealanders.

But Dr Rasalingam said the Mangere centre had been recognised globally and commended for its facilities, and he had concerns about any extra security measures.

"We don't know how many of the 150 people have been severely traumatised already, and that trauma could be reactivated if they were put into prison systems.

"We don't want women or children going into prisons with other people caught up in their own issues."

He was confident that processes already in place, especially programmes at the Refugees 
and Survivors Centres in Auckland and Wellington, would cope.

Mr Smith said the Immigration Service would consider all offers of help from members of the Afghan community and pass them on to relevant agencies.

\section{th. NEWG \\ INTERactive \\ 05sep01 \\ Death an option for foreigners: Taliban}

\section{From AFP}

EIGHT foreign aid workers on trial in Afghanistan for allegedly preaching Noor Mohammad Saqib has if found guilty, Taliban chief justice Mawlawi

He told the Afghan Islamic Press the punishment would fit the alleged crime and the death penalty was an option if the eight foreigners were found
guilty.

Diana Thomas and Peter Bunch from Western Australia are on trial in Kabul with two Americans and four Germans.

\section{IIF.jighm.2II \\ Wednesday 5 September 2001 \\ Aid worker trial begins in secret}

The cousin of one of the Australian aid workers charged with spreading Christianity in Afghanistan has travelled to the troubled country to offer his
support.

The trial of West Australians Diana Thomas and Peter Bunch, four Germans, two Americans and 16 Afghanis arrested by the religious police of the ruling Taliban last month, began yesterday.

But Australian officials have yet to be informed about the trial or about specific details of the charges.

"We need to ensure that the detainees understand what is happening to them, that they are aware of what facilities might be available to them," Australian consul Alastar Adams told ABC radio. 


\section{Diplomats still in the dark}

Nor have the Taliban revealed where they are keeping detainees after moving them
on the weekend. Nine court judges are believed to have met in a closed session for four hours despite
promising it would be open to the public.

Afghanistan Chief Justice Noor Mohamed Saqib would not say when the defendants would be called to the court, but they would be able to defend themselves, and a lawyer would be provided if they wanted one. Mr Bunch's cousin Nicholas Evans flew in from his home in India to offer support
during the trial.

"If my visit provides one modicum of comfort to the family then it will have been worthwhile," Mr Evans told ABC radio.

The Taliban enforces a strict version of Islam and may impose the death penalty on Afghan Muslims who convert to another religion.

Those who encourage them to do so may also face execution.

The foreigners are likely to be deported if convicted.

\section{THE TIMES}

\section{Taleban tries foreign aid workers in closed court}

\section{FROM ZAHID HUSSAIN IN KARACHI}

EIGHT foreign aid workers went on trial before a closed Islamic court in Afghanistan yesterday facing charges of preaching Christianity.

Despite the Taleban authorities' promise to hold an open trial, journalists and diplomats were not allowed to observe the proceedings against the eight, who have been held in Kabul for the past month, with 16 Afghans.

The court, which consists of the Chief Justice and 14 senior Islamic clerics, met for four hours and examined the evidence without the accused or their counsellor present.

"The trial proceedings started today, but we can't say how long it would take as it depends on the pace of the gathering of reliable evidence and the reasons for a verdict," Noor Muhammad Saqib, the Chief Justice, said. "We will review the 
previous interrogation (files) and if needs be will want fresh questioning, too ... We want this issue to be resolved fairly."

He added that the accused would be allowed to defend themselves, either through a lawyer or individually.

The evidence, including Bibles, videos and audiotapes and files from the religious police, had been handed over to the Supreme Court.

All those arrested on August 5 worked for Shelter Now International, a Germanbased Christian relief group. The detained foreigners - four Germans, two Americans and two Australians - were allowed visitors only last week.

The Taleban closed two more Christian relief organisations last week and ordered their expatriate workers to leave, saying that they had also used aid to entice Muslims to become Christians.

The Chief Justice said that the Supreme Court was canvassing clerics and judges all over Afghanistan to decide whether to hold an open trial.Under a law passed last year, the punishment for preaching any religion other than Islam is death.

Nothing is known about the fate of the 16 Afghan workers who are also being held.

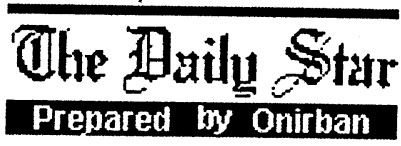

Wed. September 05, 2001

\title{
Taliban try 8 foreigners behind closed doors
}

\author{
AFP, Kabul
}

The trial of eight foreigners charged with preaching the "abolished religion" of Christianity in Taliban-ruled Afghanistan began behind closed doors yesterday.

Supreme Court chief justice Mawlawi Noor Mohammad Saqib promised a fair trial after meeting fellow judges and Islamic scholars for several hours earlier in the day.

"The trial has begun today. How long it will take, it is not clear," Saqib told reporters at the court in central Kabul.

"They are innocent unless they are proven guilty. For the court, they are just 
accused who are yet to be proven guilty."

He said details of the proceedings were still being worked out and the accused - two Americans, two Australians and four Germans - had not yet appeared before the
court.

"They will be given a full chance to defend themselves and say whatever they want. If we find it necessary during the course of the trial to call any of the detainees, we will call them," said Saqib, flanked by a group of 15 Islamic scholars.

"In many countries the accused are given the right to have lawyers. We do not consider that necessary. However, if they are unable to (defend themselves) we will have no objection to them hiring legal assistance."

Taliban Foreign Minister Wakil Ahmed Mutawakel had earlier promised that the trial would be "open", with diplomats and journalist allowed to attend.

But Saqib said "judges will decide whether the proceedings will be open".

The eight aid workers, plus 16 Afghan colleagues at German-based Shelter Now International, were arrested early last month and have been in detention in Kabul ever since.

The hardline Islamic militia, which rules most of Afghanistan, has refused to rule out the death penalty.

Australian, US and German diplomats, who have been in Kabul for the past week, have asked to monitor the trial, which is unprecedented under the fundamentalist militia's unique brand of Islamic Sharia law.

"As consuls, we are very concerned to ensure that the detainees here get the correct advice from the Afghan authorities, about the process and what charges they are facing," Australian diplomat Alastar Adams told AFP.

The accused are Americans Heather Mercer and Dana Curry, Australians Diana Thomas and Peter Bunch and Germans George Taubmann, Silke Duerrkopf, Margrit Stebner and Kati Jelinek.

It is the first time foreigners have been charged with preaching Christianity in Afghanistan and the trial will put the secretive Islamic militia's legal system under an international spotlight.

Police files were presented to the Supreme Court Monday at the end of a month of investigations in which police confiscated Afghan-language Bibles and thousands of computer disks with Christian content.

Shelter Now has denied its staff were involved in missionary work. The Taliban claim to have written confessions from the detainees.

Once a verdict is reached, it will be passed to reclusive Taliban leader Mullah Mohammad Omar for a final decision. 


\section{BUSINESSDAY}

05 September 2001

\section{Aid workers' trial begins in Kabul}

KABUL The trial of eight foreigners charged with preaching the "abolished religion" of Christianity in Taliban-ruled Afghanistan began behind closed doors yesterday.

Supreme Court chief justice Mawlawi Noor Mohammad Saqib promised a fair trial after meeting fellow judges and Islamic scholars for several hours earlier in the day.

"The trial has begun today. How long it will take, it is not clear," Saqib told reporters.

"They are innocent unless they are proven guilty. For the court, they are just accused who are yet to be proven guilty." He said details of the proceedings were still being worked out and the accused two Americans, two Australians and four Germans had not yet appeared
before the court.

"They will be given a full chance to defend themselves and say whatever they want. If we find it necessary during the course of the trial to call any of the detainees, we will call them," said Saqib.

"However, if they are unable to (defend themselves) we will have no objection to them hiring legal assistance."

Taliban Foreign Minister Wakil Ahmed Mutawakel had earlier promised that the trial would be "open", with diplomats and journalist allowed to attend. But Saqib said "judges will decide whether the proceedings will be open".

The eight aid workers, plus 16 Afghan colleagues at German-based Shelter Now International, were arrested early last month and have been in detention ever since. The hardline Islamic militia, which rules most of Afghanistan, has refused to rule out the death penalty.

Australian, US and German diplomats, who have been in Kabul for the past week, have asked to monitor the trial, which is unprecedented under the fundamentalist militia's unique brand of Islamic Sharia law. Sapa-AFP. 


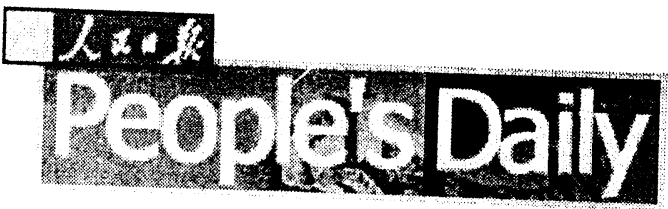

Wednesday, September 05, 2001

\section{Trial of Eight Aid Workers in Afghanistan to Start Today}

The trial of eight foreign aid workers charged with preaching Christianity in Afghanistan will start in Kabul Wednesday.

The ruling Taliban militia's top judge says in the first phase of the trial, the court will study the report about the case compiled by Taliban authorities.

Chief judge Mawlawi Noor Mohammad Saqib says a "fair resolution" will be passed in light of that information, Islamic Sharia law and the valid regulations.

The Taliban has charged the aid workers with several crimes including preaching Christianity.

The two Americans, two Australians and four German from the German based Shelter Now group were arrested early last month.

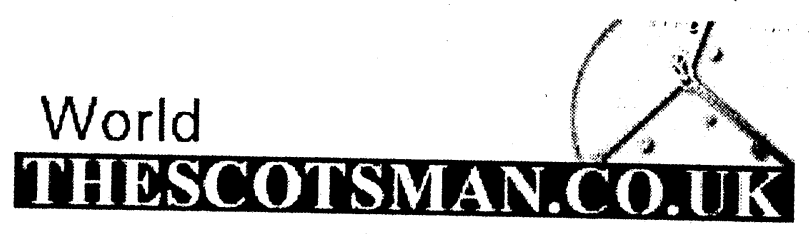

\section{September,2001 \\ Taleban trial of Christians starts}

Rory McCarthy In Islamabad

JUDGES from Afghanistan's hardline Taleban regime began hearing a trial yesterday for eight foreign aid workers accused of spreading Christianity, in one of the biggest showdowns between the isolated regime and the Western world.

The Taleban's chief justice, Noor Mohammed Saqib, met in private with 14 Islamic cleries to consider the case of the two Americans, two Australians and four Germans who were arrested a month ago. All worked for Shelter Now International, a German-based Christian aid agency.

Talebar police have also arrested 16 of the Shelter Now Afghan staff, including drivers and gardeners, who will face trial later and who risk being sentenced to 
death under Islamic sharia law if they are found to have converted from Islam.

Although senior Taleban officials had promised that the trial would be open to diplomats and journalists yesterday's hearing was held in private in Kabul's supreme court. It is not clear how long the trial will take or how severe the sentence could be.

"It will be a fair trial whereby the accused will be given the chance to speak and defend themselves without any compulsion or fear," said Mr Saqib. He said the foreigners would be given lawyers. "It is a matter of concern for the whole Islamic world, not just the Islamic Emirate of Afghanistan."

The Taleban appear already to have ignored a new decree they issued in June which said foreigners caught proselytising should be jailed for up to ten days and then deported. It is clear some hardline elements within the regime want to impose a much stricter punishment as a sign of control over westerners in Afghanistan and defiance to the international community as a whole.

Mullah Mohammad Omar, the one-eyed supreme leader of the Taleban, will make the final decision about sentencing.

Two of the parents of the US women from Shelter Now are in Kabul and have visited their daughters, Dayna Curry, 29, and Heather Mercer, 24. But they were not allowed to watch the court hearing yesterday.

During the trial the Taleban judges will produce evidence which the head of the feared religious police said was "as clear as the sun". The first two women arrested were caught in the house of an Afghan family showing a film"about the life of Jesus. It is forbidden for foreigners to visit Afghans in their homes.

Bibles in the local languages Pashto and Dari, music cassettes and video discs were taken from the Shelter Now offices, along with a book, Sharing Your Christian Faith with Muslims.

A Shelter Now office in Pakistan was closed a decade ago after clerics accused it of trying to convert Afghan refugees. Shelter Now has denied its staff in Kabul were proselytising and said the material in the office was for personal use only.

Two other Christian groups, International Assistance Mission (IAM) and Serve, were also ordered to close their operations in Afghanistan at the weekend. IAM had worked in the country for more than 35 years on health care projects, including two eye hospitals.

Much of the Taleban's resentment of Western aid agencies may also come from their opposition to what remains of Kabul's richer, better educated élite. The Taleban were poor religious students who emerged from madrassahs, mosque schools, along the border with Pakistan in 1994. One element of their movement was 

to destroy the Kabul élite, which they believed did not play a big enough role in
resisting the Soviet occupation of the 1980 s.

"Now it is the peasants and the rural people who have the power and the weapons," said the aid worker. "They don't like Afghans who work for NGOs [non-

governmental organisations] because they are better educated, they have money and

The trial is the first time foreigners have been in a Taleban court since March 1997 when two French aid workers were accused of immoral conduct after allowing their male and female Afghan staff to eat lunch together. The two were held in jail for 26 days and then, after a one-hour trial, were deported.

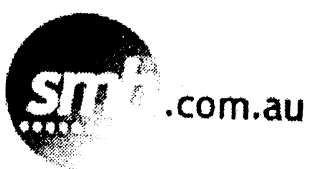

Wednesday, September 5, 2001

\section{'Now we think, absolutely, we will die'}

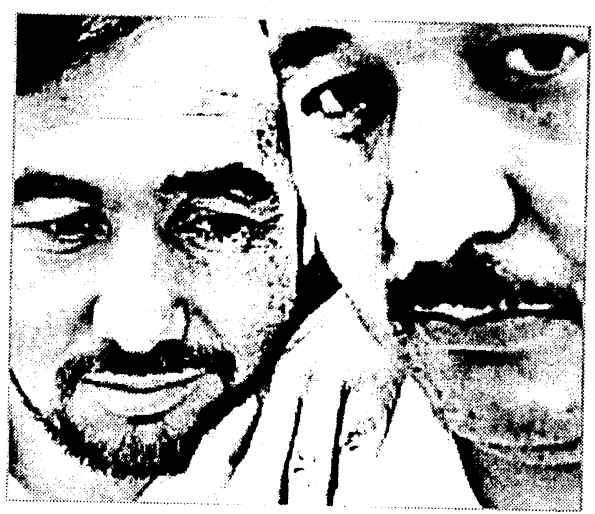

'We are are here not for travel and leistrrely recreation'... two of the men, unwilling to give their names, who came by boats in the hope of a new life. Andrew Clennell spoke to two refugees, now living in the community, who came to Australia by boat. They recount those journeys.

The Afghan man came on a boat from Indonesia early last year. He has been granted a temporary protection visa after spending months in a detention centre. He did not want to give

his name. 
"It was as horrible an experience as living under the rule of the Taliban when I was forced to leave my country. At every moment, we faced life danger. The situationi threatened our lives, a very small fishing boat with very primitive equipment, we were about 100 people in a very slow [boat|.

"We travelled for eight continual days to arrive in Australian water. The people smugglers told me, 'You go a few kilometres by this boat and then you go by a big boat.' |We| didn't see another boat. Several times, we faced our fate and we believed we may not reach Australian territorial waters.

"We were very close to Australian water when the boat broke down and water came in and everyone shouted, 'It is going to sink,' and people [were/ jumping to bail out the water - at that time it was $11 \mathrm{pm}$, the Australian Navy arrived and they checked everything and they asked us to go back. We told them, 'The boat is sinking.'

"[We told them], 'We are here not for travel and leisurely recreation. We escape from our life, we can't go back.' [When] they couldn't take us and ask us to go back, everyone was very shocked and very sad.

"This happened twice. We stayed there during the night. At the early morning they came back and took us." All through the night they had to bail water out of the boat, he said.

THE other man came by boat from Indonesia in 1999 . He, too, has now been granted a temporary protection visa. Like his fellow Afghan, he would not give his name.

"We were in the ocean 16 days. Five or six days we faced death. A big wave with a small boat. Five times, six times, we said, 'We will not be alive.' Especially one night in the afternoon after 16 days, we saw some light in Ashmore Reef. We saw a big light. We thought, 'Maybe, this is Australia. Let's go to that light,' and we became happy. We didn't understand that light is for dangerous area. Big light.

"The weather has become dark. The storm has come. We didn't understand ... the light. For that reason, don't come to this area, this is a dangerous area.

"Our boat had an accident on the rock. All of us become so worried about this, we catch each other and cry. There's not any option, no alternative. The boat, it turned back from that way we come out from the inside of the ocean. Again wave is coming.

"We went back and stayed there, the storm is coming. We turned off the boat. In the early morning we start in a new direction.

"One aircraft is coming very low. Then planes surrounded us about $4 \mathrm{pm}$. At $4 \mathrm{pm}$ the Navy is coming there. They discussed with us, they said, 'Everything's OK, here's some food, here's some fuel.' They told us, 'Go back.' At that time when they said, 'Go back', everything we had ourselves and what they gave us, we threw into 
the ocean.

"We believe that what we threw into the ocean, they will come back.

"But they disappeared. When they disappeared we became frightened. We have nothing, fuel, food, everything to get out of the ocean. Now we think absolutely we
will die. "We spend one night in the ocean ... At 5 o'clock in the morning ... the Navy again comes. This time when the Navy are there, they take our boat."

A 25-hour flight to the detention centre followed.

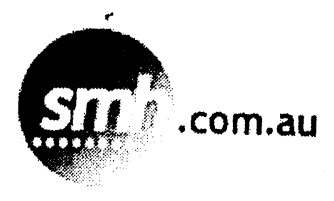

Wednesday, September 5, 2001

\section{Into the hands of strangers}

Kuala Lumpur is the funnel through which thousands of Afghans pass on the way to Indonesia and a boat to the ultimate goal of Australia. Mark Baker reports on the 'agents' who manage the transits.

The plane is half an hour late. In the vast arrival hall of Kuala Lumpur International Airport the milling crowd awaiting Iran Air Flight IR840 grows impatient. Among the usual throng of travellers' families and friends, hotel greeters and taxi touts, there are some who look obviously out of place: swarthy Middle Eastern faces amid the sea of Malays, Chinese and Europeans.

Four Iraqi men who had earlier huddled over burgers and coffee in the nearby fastfood restaurant now move into position around the glass arrival doors and the adjacent windows with views along the two concourses that lead from the customs hall. Each is armed with a mobile phone, into which they talk in endless, furtive monologues.

The leader wears tight jeans, stacked sports shoes and a white Versace T-shirt stretched across his ample girth. There is lots of chunky gold jewellery of the kind that advertises a fast-buck fortune, while the craggy, unshaven face betrays a harder past. As the first passengers begin to appear, he moves quickly between his 
spotters whispering clipped instructions.

At first it seems the people they are awaiting have missed the flight as most of the passengers and the last of the crew come and go. Then, finally, they appear, more than an hour after the plane from Tehran arrived. There are three large family groups, about 20 people in all. They look frightened, bewildered and exhausted their nervousness marking them out, as conspicuously as the battered suitcases and . bursting plastic bags in which they carry their meagre possessions, to be refugees on the move.

The women in simple head scarves slowly push their baggage trolleys towards the doors into the arrival hall, followed by their teenage daughters and younger sons. The smallest children clutch pathetically to the hems of their mothers' heavy overcoats, coats needed in the chill mountains of Afghanistan but sadly incongruous in the tropics.

There is just one man among the group, a short and balding Iranian who steps forward to hand a locked chrome attache case to the leader of the Iraqi team. As soon as they pass through the arrival doors, the families are briskly and brusquely ushered to seats in a quiet corner of the terminal building to await their transportation to cheap city hotels.

At 11pm on a humid Tuesday, "The Pipeline" has emptied another tide of human misery on the next stage of the long and perilous voyage towards the hope of a new life in Australia, or the hopelessness of internment, rejection and eventual repatriation.

Malaysia is the funnel through which most of the thousands of asylum seekers from Afghanistan, Iraq and Iran now pass on their way to Indonesia and the boats that will ultimately carry them across the Timor Sea and the Indian Ocean to wash up on Australia's northern coastline.

Each week flights from Iran, Pakistan, Dubai and other Middle Eastern ports are landing hundreds of passengers whose destination is Australia and who take advantage of Malaysia's policy of visa-free access for visitors from most fellow Islamic countries. With a one-month "social visit" entry that can be automatically extended for another month, there is time to regroup and arrange papers, often forged, for the onward journey to Indonesia.

In Kuala Lumpur the travellers stay at a range of seedy budget hotels like the Mexico, a notorious haunt of prostitutes and drug dealers, the Best Otel, where rooms can be rented by the hour, and the International Hotel in grimy Chow Kit district, near the Pakistan mosque and the shopfront stalls that sell discount ferry tickets to Indonesia.

From ports scattered along the western seaboard of peninsular Malaysia, a one or two-hour ferry ride to Indonesian Sumatra can cost as little as \$20. The most 
popular departure points are the old Portuguese town of Melaka, the southern fishing village of Kukup and the city of Johor Bahru, across the causeway from
Singapore.

The "agents" who manage the Afghani transit passengers include Pakistanis, Iraqis, Iranians and local Chinese who operate with impunity in a culture of endemic corruption in the police force and immigration bureaucracy. Violence and intimidation are currencies of the trade. The Australian Immigration Department was recently forced to recall some of its undercover "compliance officers", who monitor Malaysia's ports and airports in conjunction with locally based Australian Federal Police, after they received death threats.

The majority of those fleeing the worsening repression under Afghanistan's Taliban regime are shepherded by these gangs, many of whom are part of well-organised people smuggling syndicates with networks that stretch from the border refugee camps in Iran and Pakistan, through Middle East capitals and Kuala Lumpur, and on to Jakarta and the coastal ports of the Indonesian archipelago, where ramshackle flotillas are assembled for the treacherous passage to Australia.

Some asylum seckers pay as much as $\$ 40,000$ for the full journey - a lot of money but still less than the sums charged for an illegal passage to Western Europe or North America. Many other travellers who have limited resources bribe and beg their way down the pipeline and often are stranded along the way when the money runs out, or are cheated by middle meń more unscrupulous than the rest.

Increasingly, the flight of Afghans is ending in Malaysia, where welfare agencies are called in to assist people who are destitute and desperate.

While most of the Afghan asylum seekers are urban, middle-class people, many well-educated professionals, the notion that they are a class of rich immigration queue jumpers seriously misrepresents the reality. The truth of international migration is that wealthy exiles have choices for resettlement, while those prepared to risk their lives in perilous ocean crossings to reach freedom almost invariably are people whose options have run out; people ready to gamble whatever resources they can muster on the chance of a new start for themselves and their children in the West.

With Australia so far accepting about 90 per cent of the Afghan boat people for resettlement as genuine refugees - albeit after lengthy detention in grim transit camps while their cases are processed - it is a gamble an increasing number of people are prepared to make. And the problem is likely to get worse.

Australia's refugee crisis is a sideshow compared with the explosion in illegal migration and people trafficking around the world, and particularly across Asia, over the past few years. The era of globalisation and mass international travel has made it much easier for people to flee poverty and oppression and made it increasingly difficult, if not impossible, for governments to control their borders. 
In Malaysia, authorities now estimate there are as many as 1 million illegal migrants among a total population of less than 24 million. Private agencies reckon the true syndicates operating out of .

The problem has grown worse in recent months with the economic downturn which has forced tens of thousands of legitimate migrant workers out of work and into hiding to avoid repatriation to their countries. In a new twist, groups assisting displaced migrant workers say hundreds are being lured into paying thousands of dollars to travel to Indonesia with the false promise of an easy passage on to Australia and guaranteed employment.

In a desperate effort to try to bring illegal migration under control, the Malaysian Government last month amended the country's Immigration Act to provide imprisonment and canings for illegal migrant workers and employers who engage

But despite their problems, Malaysian authorities are continuing to resist pressure from Australia to tighten visa access for travellers from Afghanistan and other Middle East countries. The Malaysians argue that any move to restrict visa access would be bad for business and tourism.

That view may change with growing signs that people-trafficking syndicates are starting to forge links with international drug smugglers, and evidence that increasing numbers of Afghan asylum seekers bound for Australia are being stranded in Malaysia.

Tenaganita, a private aid group that assists migrant workers, is helping to provide assistance to more than $\mathbf{4 0}$ destitute Afghans stranded in Kuala Lumpur after they ran out of money or were abandoned by the syndicates that brought them to the country. Dozens more are being helped by ABIM, an Islamic youth group founded by the jailed former deputy prime minister, Anwar Ibrahim.

"We try to give food and shelter, or just to be a friend to these people who have nothing and are in a really desperate situation," says Tenaganita's program coordinator, Aegile Fernandez.

Among those the agency is helping is a young Afghan widow who fled Kabul with eight children after her husband and all the other adult males in her extended family were killed in the civil war. Stranded in Kuala Lumpur for more than six months, the family lives in a squalid single room surviving on charity handouts. Their application for refugee status was rejected by the United Nations High Commissioner for Refugees because they did not have adequate identity papers.

"It is pitiful to see them. They don't have enough food to eat, their clothes are like rags and now the mother is ill with diabetes," says Fernandez. "These are people 
who have fled a real crisis situation in their home states and the world must come to their aid. Western countries have to be prepared to accept more of these people. How can you blame them when they suffer so much and their recruiters get off scotfree? 'These people have become the victims."

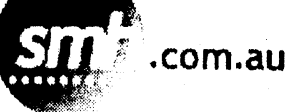

Wednesday, September 5, 2001

\section{'Put Afghans to work' call earns swift rebuke}

\section{By Greg Roberts}

The president of Nauru, Mr Rene Harris, has rebuked his government's senior law officer for claiming that asylum seekers aboard HMAS Manoora will be put to work immediately on public infrastructure projects upon their arrival in the island nation.

The plan, outlined by Nauru's Solicitor-Cieneral and former (iold Coast solicitor, Ms Kerry Smith, in the Gold Coast Bulletin, caused outrage among civil liberties groups yesterday.

Ms Smith said the Nauru Government was hastily preparing legislation to ensure the legality of the plan, adding that the first projects would be the construction of a gymnasium and a swimming pool. This would help them "regain fitness".

"The island lacks infrastructure and this is the perfect opportunity to build the island up," she told the newspaper. "Why should we have these people holed up in a detention centre where they will only get sick and demotivated? They could be out in the community doing something positive."

However, Mr Harris said Ms Smith's plan had not been discussed with him and it could not be tạken seriously.

"Any claims to the effect of those outlined in the story have not been canvassed by the Government and do not represent the views of the Government," he said.

"The first any of us knew about this misunderstanding was when we read the story." 
Mr Harris told the Herald that the boat people could be in Nauru for up to three months. His office said the number of asylum seekers entering Nauru would be 283 .

- He said a centre to be funded by Australia for the boat people would be fully equipped with all required accommodation, sanitary, medical and leisure facilities. A spokesman for the Immigration Minister, Mr Ruddock, said the work plan is not referred to in the draft memorandum of understanding agreed to by Nauru and Australia. "This has not been discussed with Australia," he said.

Cash-strapped Nauru is the world's smallest republic, with its population of 13,000 living in an area of just 21 square kilometres. Australia has promised to meet all the costs to Nauru of accommodating and
processing the asylum seekers. Ms Smith, who is based in Nauru House in Melbourne, declined to return calls
yesterday.

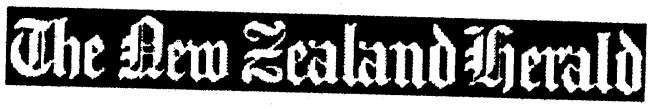

Wednesday September 05, 2001

\section{Dialogue: Watch out for poor huddled masses}

\section{BY COLIN JAMES}

Winston Peters is on to a good thing, ch? Asian refugees will stop the greyhairs getting operations. Worth a few votes, that.

Except that this time he starts from the pits of micro-support, not the trampoline of rising stardom, as with Asian migrants in 1995-96. And he is up against a Prime Minister who, unlike Jim Bolger, is cogent with the media. 
Helen Clark pointed out that our annual refugee quota is 750 and the 150 Afghanis (and Pakistanis?) will be within that number. By giving priority to families, she reduces the likelihood of add-ons later. Moreover, to catch the "knowledge wave" we need migrants (though she omitted our bad record in gi'sing non-whites jobs).

And in case you think she is opening floodgates, note that our quota - in place when Peters was Deputy Prime Minister - is less than half Australia's, adjusted for population. We're hardly angels of mercy down in our distant, empty little corner of
the world.

On the plus side for our humanitarian image is our peacekeeping and peacemaking round the world - and Clark has dedicated our armed forces to that work.

But in foreign aid we skimp. Thirty years ago a Labour Government nurtured an ideal of 1 per cent of GDP. Today's Labour-led Government gives less than a
quarter of that.

Next week, aid minister Matt Robson will announce a major redirection of aid, to focus on our needy South Pacific neighbours and not spread crumbs around 63 countries as now.

The Ministry of Foreign Affairs and Trade's aid division will be made semiautonomous, serviced by the ministry but with permanent, professional staff reporting direct to Robson. Ministers say this sequestration of two-fifths of the ministry's budget has had it in a tizz.

Aid will henceforth be a policy item in its own right, assessed not by foreign policy objectives but by whether it is effective in helping recipient countries towards self-
sustainability.

This fits better the message on Monday from Jean-Claude Faure, chairman of the OECD's development assistance committee, to the ministry and non-government aid
organisations.

Faure argues a shared self-interest in rich and poor nations in ensuring that poor nations can join the globalised economy. In the past couple of decades the gap between rich and poor nations has been growing.

If the rich want a secure world, they will need to build the poor's economic, social, political, governance and "civil society" capacity to make their way in the world.

Poor nations are not just pitiable. Theý are also, Faure says, a source of conflict dangerous, spillover conflict.

-

The Taleban's persecuted and misgoverned Afghanistan is a prime example. The human disaster of a displacel population nearly equal to this country's makes a terrible point. 
Clark called on Saturday for urgent international efforts to deal with the refugees. But that would just attack a symptom.

At the root of such disasters, an unofficial but high-powered International Commission on Intervention and State Sovereignty under former Australian Foreign Minister Gareth Evans will report this month, is a failure of states in their "responsibility to protect" their citizens' basic human rights. But in the event of such failures, Evans' commission will say, the responsibility
passes to other states to intervenc.

But in what circumstances? Under what criteria? Who can legitimately take part? What can outsiders legitimately do and does that include pre-emptive measures
beyond aid? Who decides?

And how is consensus, the usual procedure in multilateral international matters, to be reached on this touchiest of issues for states jealous of sovereignty? Evans' commission has wrestled with these tangled conundrums.

Most probably the world will ignore Evans and lurch into more disasters, more tidal waves of refugees, more Tampas.

Add to that the globalisation of work and the migration it stimulates (don't we know it?) and this century is shaping up as one of large movements of people.

If so, we won't escape these waves of intruders, any more than the Maori could hope to escape 19th-century European colonising expansion. And these migrant waves will cause periodic political convulsions - as Mr l'eters' little-Kiwi speech has conveniently reminded us. 


\section{The fem :}

Wednesday September 05, 2001

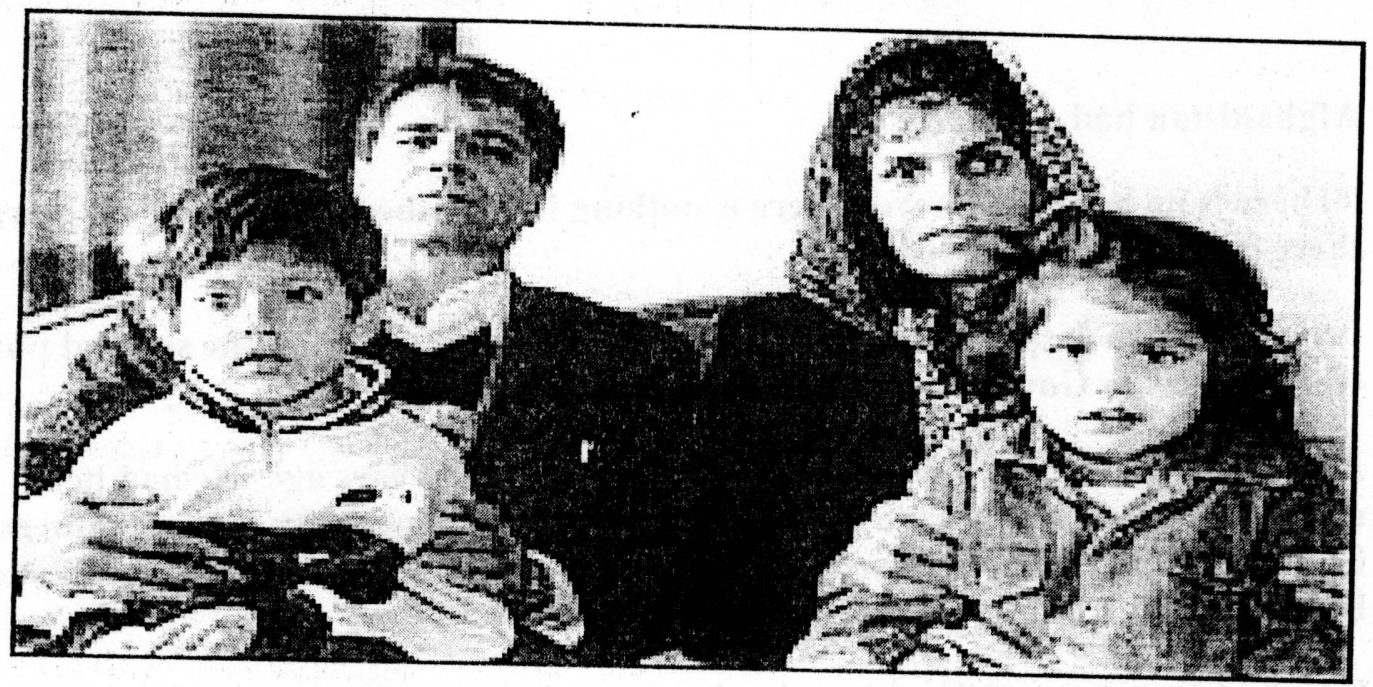

Abdul Hamid and Belqis Wakili with two of their children, Majid, aged 6 (left), and Deba, 3. Picture / Peter Meecham

\section{Taleban horror haunts couple}

05.09.2001 By SHENAGH GLEESON

Life is not easy for Abdul Hamid and Belqis Wakili.

The Afghan couple may have found asylum in New Zealand but both the past and the future still worry them.

Abdul Hamid's nights are ruined by dreams of being tortured by the Taleban and he receives counselling to help rebuild his confidence. Belqis vividly remembers months of fear for his safety and for her three children.

- They live on a benefit and neither have any hope of working in their professions of lawyer and university lecturer until their English improves.

But no matter how difficult life in their small Mt Roskill house is, they know there are worse off.

For nine days they agonised over the fate of their compatriots stranded off the coast of Australia on board a container ship which rescued them from a sinking boat. Now they just hope they will get safely to Papua New Guinea and then on to New Zealand and Nauru. 
Afghanistan had no choice.

"There is no hope any more. There is nothing left for them. They have no power, there is no school, no freedom."

People were so desperate they were willing to risk their lives on the sea and put their trust in foreign Governments.

Abdul Hamid fled from Kabul about three and a half years ago. He had been arrested by the Taleban, placed in a windowless container with up to 30 others, and beaten with an electric cable every night. He watched an elderly man die after a beating.

He said his crime was that he spoke the wrong language, Persian instead of Pashto. The Pakistan-backed Taleban targets northern Afghans who speak Persian.

After 19 days of near starvation, a Pashto-speaking neighbour paid for Abdul Hamid's secret release. His shin bone broken, his legs swollen, his sight impaired from beatings, he eventually made his way over a mountain pass to Peshawar in Pakistan.

A relative looked after him, got treatment for his injuries and arranged a flight to New Zealand. Immigration officials checked his injuries and history and gave him asylum and permission to bring his wife and children to join him.

The couple like New Zealand and are proud that their eldest son "sounds like a Kiwi". They look forward to working and watching their children grow up in a safe and friendly environment.

They are grateful that New Zealand is also giving the same chance to 150 of the refugees who were stranded on the Tampa. They believe they should be thoroughly screened when they get here but think there is little chance there are any terrorists and criminals among them.

"The people who are escaping are innocent people," Abdul Hamid said. "The Taleban are the terrorists. Osama bin Laden and his followers, who are being - " sheltered by the Taleban, are the people who are dangerous." 


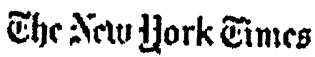

September 5, 2001

\section{Taliban Trial of Christian Aid Workers Continues}

By REUTERS

KABUL (Reuters) - Judges and Islamic clerics under Afghanistan's Supreme Court on Wednesday began a second day of deliberations in the ruling Taliban's trial of eight foreign aid workers accused of promoting Christianity.

"The deliberation and work on their case entered its second day. We want to continue this regularly and can't say how long it will last," Chief Justice Noor Mohammad Saqib told Reuters.

He promised to deal with the case on a fair basis and stressed the four Germans, two Americans and two Australians would be allowed to defend themselves both during the process and when the final verdict was announced.

Twenty-four staff from the German-based Christian relief agency Shelter Now International (SNI) -- the foreigners and 16 Afghan colleagues -- were arrested more than four weeks ago on charges that could carry the death penalty.

There was no indication the accused had yet been called to appear and it was not clear if or when diplomats, family members or reporters would be allowed in to observe the trial. 
The News International, Thursday, September 6, 2001

\section{Australian court to rule by weekend on refugees}

SYDNEY: A judge said Wedmesday he expected to rule by Friday in a case brought by rights groups challenging Australia's decision to bar entry to a group of asylum seckers.

Federal Court judge Tony North adjourned the case Wednesday following final sub. missions from the government. and from civil liberties lawyers seeking a court order to bring the asylum seckers to Australia for processing aş refugees.

More than 430 asylum secekers, who were taken off the freighter Tampa on Monday, were on their way to Papua New Guinea on Wednesday in the relattive comfort of the well-equipperl Australian troopship Manoora.

From Papua New (iuinea they will fly to New Zealand and the Pacific island of Nauru as part of Canberra's plan to prevent them setting foot in Australiat.

However, if the court rules the Australian government acted unlawfully in denying them acress, they may be refurned to Australia.

The Manoora is not experted to reach Port Moresby until Sunday when the verdict will be known.

However, North's ruling may not end the case because if it. goes against the government, an appeal to a full bench of the ferderal Court is almost certain to be lodged.

The Federal Court has a history of ruling against the government on issues concerning refugees, so the case may not. end there either. It may go to the High Court which has an equally long history of overturning ver-

\section{Helicopters to take Afghan asylum-seekers to PNG}

PORT MORESBY: Authorities here said Wednesday the unwanted 400 asylum-seekers bound for Papua New Guinea could be flown by heli-
copter from an Australian troop at Port Moresby's airport.
.

Foreign Minister John

mum security and surveillance of the bont perplan would provide maxi-

The mainly Afghan 434 ce of the boat people.

ing Indonesian boat last month and spers were rescued from a sinktainer ship off Christmas Isth and spent a week on a Norwegian coninternational pressure to let them the Australian government defied

They are pressure to let them land.

They are now being shipped on the HMAS Manoora to PNG before lum will be assessed.

"Not one singsed.

made for their onward will be allowed ashore outside of arrangements of the asylum seekers be allowed to realand and Nauru, nor will any Moresty during their be allowed to roam around the city of Port

"Our preference is for the in Papua New Guinea," Pundari said. (o)ters from the Manoor the asylum seekers to be up-lifted by heli-

Both PN(i's founding Prime Minister Sir Minternational Airport." position forcign affairs spoke Minister Sir Michael Somare and Optralia's request to transfer the refugees in PNG apposed to Ausrefingees maly try to jump ship aud seek refugee On Sunday, Prime Minister Sir Mekere Morautat in PNG.

to Prime Minister Jolun Howard's Mekere Morauta said he had agreed 6) Prime Minister John Howard's request that PNG be used as a trans-

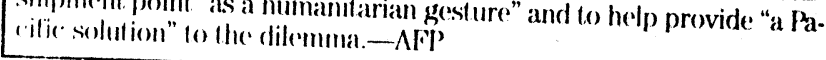

dicts of llec Federal court.

Four Indonesians, who had berll on the Tampa after being rescued along with the refugees OII August 26, are now in custody onl Christmas lsland - an AusIralian territory in the Indian ()ceall - on people smuggling rhatges which carry a maximum 2()-ycar jail sentence.

Phree senior Australian ministers left for Indonesia on Wednesdiay for lalks with their counterparts in Jakarta on illegal immigration and people smug. gling, officials said.

Immigration Minister Philip
Ruddock, Defence Minister Peter Reith and Foreign Minister Alexander Downer will try to push Indonesia to be more co-operative in the battle to stem the now of boatpeople.

Australia blames Indonesia for not preventing the refugee exodus and for refusing to allow the Tampa boatpeople to return to Indonesia where they started their journey.

Australia will also seek the extradition of at least six known suspects believed to be in charge of the people smuggling rings.- 


\section{Taliban threaten to ban UN, ICRC flights}

ISLAMABAD: Taliban have warned that they may not allow the United Nations and International Committee of the Red Cross (ICRC) to use the Afghan airspace if no heed was paid to the great headships being experienced by the Afghan Civil Aviation ministry due to the UN sanctions.

"If Afghanistan could take mea. sures to provide protection to more than 33 foreign flights then the international community should also compensate the losses being faced by afghan civil aviation ministry, "Taliban Civil Aviation Minister, Mullah Mansur told the VOG.

He said that his ministry and

\section{Warring factions urged to stop fighting}

PESHAWAR: The Council for Understanding and National Unity of Afghanistan commonly known as Shura-e-Tafahum (ST) welcoming the United Nation's initiatives to host an indirect dialogue among the Afghans at Geneva on September 10 has stressed on making such a step more representative rather then focusing on few groups.

The ST in its meeting held with its President Hayatullah in chair, discussed in depth current Afghanistan situation. Brig (retd) Mohammadullah Shuaib, Helman Ghaznavi, Abdul Wahab Yousafzai, Engineer Said Ahmad, Engineer Ziggar Ahmazai, Abdullah Ghamkhor, Eng Mehboob, Siad Karimul Haq, Zahir. Khan Jabbarkhel, Ali Gul Khan, Faiz Mohammad Nayab, Shehtzdat Masud atid Syed Hussain Waez attended the meeting.

The participants termed the dialogue a positive step, saying it would find a negotiated solution to the conflict. They said Geneva indirect talks should be made direct as well as representatives. It expressed concern over the ongoing fighting and confrontation in Afghanistan and urged the warring factions to announce an immediate ceasefire, as continuation of fighting is not in the interest of the country and people. the Ariana Airline were facing great economic and technieal difficulties due to the UNSC sanctions.

He further said that his ministry could face great complications if the acquisition of funds was not made available by easing the UN curbs against Afghanistan.

He said that Taliban would ab-

The Afghan airline was the major source of air lifting life saving drugs and meeting the Afghan with their relatives, he said.

The UN Security Council sanctions against the Taliban in January this year directly affected the Afghan Ariana Airlines.-Sana

\section{Taliban set up commission to regulate NGOs}

KABUL: Afghanistan's ruling Taliban Wednesday formed a commission to monitor the operations of non governmental organisations (NGOs) in the country, the official radio said.

The commission will study the workings of all foreign NGOs and make recommendations to bring their activities "in line with the Islamic values and existing laws and regulations of the Islamic Emirate of Afghanistan," the radio said. The broadcast said the decision was taken during a routine meeting of Taliban ministers here.

The commission will include Foreign Minister Wakil Ahmed Mutawakel, Deputy Minister of Taliban's ministry for promoting virtue and preventing vice, Salim Haqqani and Public Affairs Minister Saaduddin Saeed.-AFP solutely not be responsible for it.

\section{Call to trade US-jailed Sheikh for held workers}

CAIRO: The family of a jailed leader in the United States said Wednesday it had proposed his release for that of eight foreigners held in Afghanistan, in letters addressed to Washington and Kabul.

A wife of jailed Sheikh Omar Abdel Rahman has written to President George W Bush and the Taliban leadership to "urge them to agree to such an exchange $e^{n}$ because of her husband's poor health, the Sheikh's son Abdullah
told AFP.

Sheikh Omar was sentenced to life in prison in January 1996 in New York for the deadly bombing of the World Trade Centre, while eight foreigners were arrested recently in Afghanistan accused of preaching Christianity.

The eight, including two Americans, could be hânged if found guilty, Taliban leaders have said.

Montasser al-Zayat, a lawyer for the Egyptian group Jamaa Islamiya, whose spiritual leader is Sheikh Omar, also confirmed the swap had been proposed.

Jamaa Islamiya officially declared it had stopped using violence in March 1999, but southern Egypt remains under tight security because of the continued Islamist presence and large number of local tourist sites.

Abdullah said his mother, Aisha Abdel Rahman, the first of the Sheikh's two wives, sent the letters to Sheikh Omar's lawyer in the United States, former US attorney general Ramsey Clark. He did not give the date they were sent.

Clark is to transmit the letters to US officials and representatives of the Taliban, he added.

"In her letter to the Taliban, my mother urges them to agree to this exchange, applying the principles of Islam in which a Muslim who stops the suffering of another Muslim will be rewarded by God," Abdullah said.

"Such an exchange must only take place after the trial of the eight humanitarian workers," according to Abdullah, who is a researcher in Islamic theology at the University of Al-Azhar in Cairo. -AFP 


\section{The Frontier Post}

Thursday, September 6, 2001

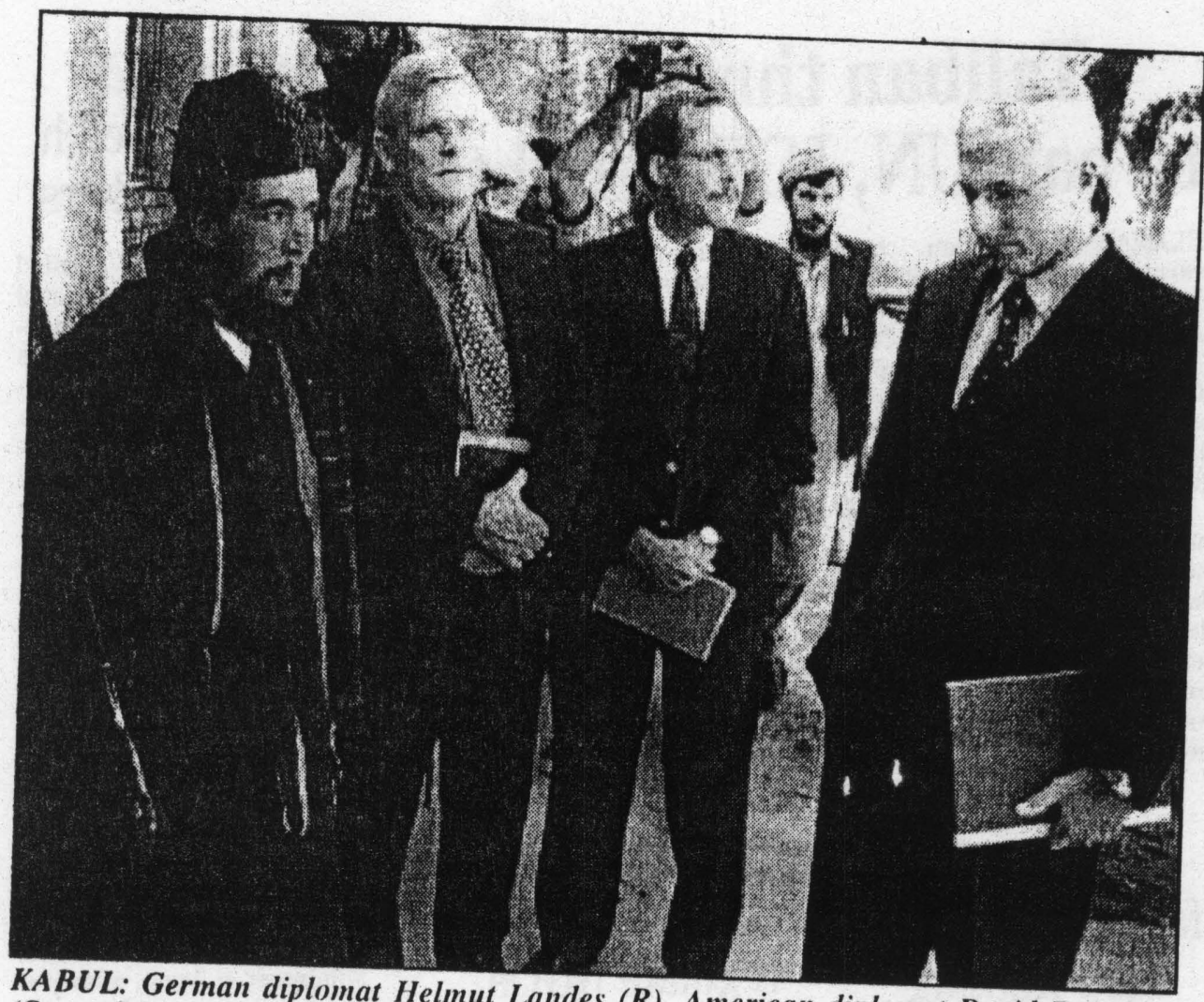

(Second-R) and Supreme Court in Kabul on Wednesday

\section{Taliban may execute foreign aid workers}

ISLAMABAD (NNI): A senior Taliban official has warned that foreign aid workers on trial in Afghanistan on charges of preaching Christianity could be executed.

Afghan chief justice Maulvi Noor Mohammad Saqib has been quoted as saying that if the eight accused were found guilty. they would be punished according to Islamic law. reports the BBC.

"We will punish them according to the laws they have broken," he said. "If they have broken the law and should be hanged, then we will punish them like that."

Saqib said the accused, who were all working for the German-based Shelter Now organisation. would be allowed to have foreign. nonMuslim lawyers. The trial hegan in Kabul on Tuesday behind closed doors.

Diplomats who sought a meeting with the chief justice to clarify the legal proceedings were turned away from the court building without explanation. Saqib said the diplomats would be contacted when it was deemed necessary, adding that the court had still not decided whether to allow independent observers into the trial. The diplomats continued to demand information about the trial.

"We want to know what's going on," said Australian consul Alastar Adams. "It's too bad that we have been kept completely in the dark about the trial."

Four of the aid workers are Germans, two American and two Australian. Sixteen Afghan nationals were also arrested in connection with the allega- tions. The foreigners face a number of charges, but will chiefly be tried on the accusation that they preached a banned religion.

Saqib has not said when the aid workers will be called to court. Bibles and other Christian materials allegedly seized from the homes and offices of the detainees, who all worked for the German-based Shelter Now International, are being scrutinised.

The Taliban's supreme leader, Mullah Mohammad Omar, is expected to have the last word on the penalty. No one has previously been tried for preaching Christianity as far as Afghans can recall, and this is the first time the Taliban have put any non-Muslim foreigners on trial for any charges. The Afghan defendants are to be tried at a later date. 


\title{
The Frontier Post
}

\author{
Thursday, September 6, 2001
}

\section{Shipment of refugees to PNG starts}

\section{CHRISTMAS}

ISLAND

(Agencies): The Australian move to ship over 400 Afghan refugees to Papua New Guinea began in earnest last night despite court actions and international outrage. Few people have fled their homeland in such numbers as the Afghans. Since the Soviet invasion of Afghanistan in 1979, more than six million people have tried to escape wars, civil strife and a succession of oppressive govermments.

Those conflicts and the brutal policies of the Taliban regime in Kabul have been compounded by a devastating drought that has lasted for years.

If Australia was a destiny that symbolised some hope for Western-style justice and compassion on the part of those fleeing Afghanistan, then that hope has been sadly dashed. The harsh treatment of the foreign aid workers who were recently arrested in Afghanistan has served to draw Western attention once again to the plight of those who live under the Taliban.

In Afghanistan today, basic liberties, including the freedom of speech and freedom of religion, are denied, women are not allowed to work, male unemployment is rife, adult literacy is just 30 per cent and life expectancy is only 45 years.

Complaints about the reign of terror in Afghanistan must ring hollow when Western governments refuse to deal compassionately with those who man. age to flee the Taliban. And complaints in Australia and Europe about the numbers of refugees belie the facts. Although 150,000 Afghans have applied for asylum in Europe in the last decade, the real burden is being borne by Afghanistan's neighbours.

\section{IOM staff, 3 interpreters join migrants}

CHRISTMAS

ISLAND

(Agencies): A team of four colnternational Organisation for Migration (IOM) operalions staff and three Dari/Pashto interpreters, including two women, has joined the 434 migrants iboard the Australian troopship HMAS Manoora.

The ship sailed from Chrisimas Island for Port Moresby, Papua New Guinea, alter themigrants were iranslerred to the Manoora from the Norwegian container ship the Tampa. According to IOM's Richard Danziger, who observed the operation, the transfer "was very carefully planned by the Australian Defence Forces, calm and went well."

The voyage is expected to take about seven days. En route, the IOM team will register and inform the migrants about their situation. An IOM medical team is expected to join the HMAS Manoora from Darwin later this week.

A second four-person leam, headed by Iolnternational Organisation for Migration's Manila-based Regional Representative, has arrived on the Pacific island state of Nauru to work with the authorities there to prepare for the arrival of the inigrants.

In Port Moresby, the group is expected to transfer (o) International Organisation lor Migration (IOM) chartered filights either to Nauru (1) 10 New Zealand, where their asylum claims will be assessed. New Zealand has agrced to take 150 of the group, including families with children.

\section{4 killed in rockets attack on Taloqan F P Report}

PESHAWAR: "̈̈t east four people were killed and 14 others wounded in a rockets attack on Taloqan the capital of northeastern Afghan province of Takhar.

Bakhtar News Agency reports that the opposition Northern Alliance forces fired two rockets on residential areas of Taloqan City at a time when the people were offering Maghrib prayers on
Sunday.

The first rocket landed at the residence of one Haji Gul Aqa killing four people and injuring thirteen others. The second rocket hit the residence of another dweller of Talogan injuring a woman. The rockets attack has caused great material losses as well.

The people of Talogan have strongly condemned the elements behind the tragic incident and their Russian masters and reiterated their support to the Islamic Emirate of Afghanistan, the agency said.

\section{Afghan, Palestinian envoys discuss ME situation}

KABUL (Agencies): The Afghan Ambassador Mulla Abdul Salam Zaeef, met with the Falestinian Ambassador in the Afghan Embassy in Islamabad and exchanged vicws on the outcome of the latter visit to Afghanistan. The Palestinian envoy spoke about the criminal and brutal acts of Israel. The Afghan envoy declared full support of the people and Islamic Emirate of Afghanistan with the people of Palestine.

\section{Fierce fighting rages in Kapisa}

KABUL (Agencies): Fierce fighting is raging between the Taliban and the opposition in northern Afghan province of Kapisa, reports Radio Tehran. The broadcast said that Taliban have captured some areas in the province. The rival factions are reportedly using tanks, artillery and other heavy weapons, the broadeast said. The N A spokesman claimed killing 50 Tiliban in Kinisa province. The Taliban have not yet commented on the opposition's claim. 


\section{Pakistanis set up 75 units in Afghanistan}

\section{By Our Staff Reporter}

KARACHI, Sept 5: Pakistani businessmen have set up at least 75 units, mainly textile factories, engineering and flour mills, in Kabul, Kandhar, Herat and Jalalabad.

This was stated by Consul General of Islamic Emirate of Afghanistan, Mawlawi Rahmatullah Kakazada while talking to newsmen at Karachi Chamber of Commerce and industry (KCCI) on Wednesday.

$\mathrm{He}$, however, did not disclose the actual amount of total investment made by Pakistani businessmen in Afghanistan. "I don't have the figures right now but it is definitely in millions of dollars," he said adding more industries by Pakistanis are being set up in Afghanistan.

He said roughly over 100 units, having old technology, owned by Afghans currently exist in his country as most of the industries were destroyed after Russian invasion.

He lambasted the foreign media for portraying a negative image of his country vis-a-vis law and order there. "Afghanistan is currently very peaceful and being run under Sharia. There is no law and order problem," he said.

He appreciated the initiative - taken by some banks in Pakistan to start Islamic banking and invited those banks to initiate this operation in Afghanistan. He said talks were under way with some leading banks of Pakistan in this regard but declined to give the names of these banks.

Earlier, in his address, he called for setting up a PakAfghan Trade Council under the banner of KCCI to foster trade between the two countries in an effective manner particularly through land routes.

He invited a KCCI delegation to visit Afghanistan and hold talks with the government officials for setting up the council. He said if a Pakistani enters into a joint venture with an Afghan, his government will provide com- plete protection to the project.

Furthermore, foreign investors have been allowed to bring in 100 per cent individual investment. The land can be bought on the lease of 80-100 years at the rate of 10,000 Afghanis (or Rs 7) per square foot. Similarly, he said power rates range between Rs 2.50-3.00 per unit for industries with no tax and surcharge. The government also provides three-year, five-year and sevenyear tax exemption to different categories of industries. A $50 \mathrm{~kg}$

cement bag is available at Rs 50 , he said.

Rahmatullah said industrialists can export freely and there is no restriction of importing raw material. Textile mills can easily be set up as some cities have ample cotton production and are currently exporting cotton to Pakistan.

Prospects of joint ventures are also bright in setting up match factories as wood is available in abundance. Oil refinery can easily be set up as petrol is being produced in Afghanistan.

On smuggling, he said some unscrupulous elements and khepias are active in Dubai in destroying the PakistanAfghanistan trade agreement by dumping cheaper goods in Pakistan through illegal chan. nels.

The consul general dispelled the impression that the Afghan government has prohibited women from getting education.

He urged the governments of both the countries to be united on one stand under the present conditions "as our goals and destination are same."

A member of KCCI, Saifullah Paracha said that there is a big scope of setting up industries for making fans, sewing machines and cycle in Afghanistan.

\section{Afghan shot at}

LILLE (France), Sept 5: An unidentified assailant shot and wounded an young Afghan man from the French Sangatte refugee camp, a staging post for asylum seekers that has fuelled tension between Paris and London.

The 18-year-old took a bullet in the leg near the hip in an attack which happened overnight between the camp and the entry to the Channel Tunnel crossing from northern France to Britain.-Reuters 


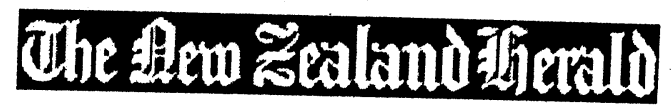

Thursday September 06, 2001

\section{Dialogue: Afghans have proved to be diligent citizens}

06.09.2001 The Afghan asylum-seekers from the Tampa will make better citizens
than some recent immigrants of dubious than some recent immigrants of dubious background, writes TERRY DIBBLE*.

I was in Australia when the MV Tampa arrived at Christmas Island with its load of - mostly Afghan refugees. The public protest against allowing those people refuge in Australia was both strident and overwhelming.

It was a relief to hear the news from Helen Clark that New Zealand would accept 150 of the asylum-seekers. Her statement was in marked contrast to the intolerant approach of the Australian Prime Minister, John Howard.

Since the mid-1980s I have sponsored many Afghans as refugees to New Zealand and continue to do so. They have proved themselves to be very good citizens. With one or two minor exceptions, they are law-abiding, diligent and keen to make a contribution to the welfare of New Zealand.

In some cases, adults have had difficulty in finding work because qualifications are not recognised. Language difficulties are another hurdle.

Their children have been quick to grasp the opportunity of acquiring an education. Many are now gaining tertiary qualifications and finding good jobs. The families recognise the advantages available to their children and make the most of the opportunities.

They are only too well aware of the drastic situation that steadily worsens in Afghanistan, one of the poorest countries in the world. The poverty is exacerbated by chronic drought that has brought malnutrition to many areas.

Twenty years of war have brought their own misery. Guerrilla warfare against invading Soviet troops has been followed by civil war since the withdrawal of those troops. No invader has ever been able to permanently subdue the Afghans. They have repelled every attempt to colonise them.

New Zealand supported them by boycotting the Moscow Olympics in 1980 in protest against the Soviet invasion of Afghanistan.

The withdrawal left a politically destabilised nation ripe for internal conflict. The Taleban, the rulers in much of Afghanistan, show many of the hallmarks of the Khmer Rouge under Pol Pot in Cambodia. What little of the economy that survived 
the Soviets has been destroyed.

Women are forbidden to work and girls are not given education. The schools for boys follow a narrow curriculum dominated by Islamic studies.

Medical facilities are scarce and under-resourced. Most Afghans live in the countryside where they survive on what they grow. Drought means starvation.

Understandably, Afghans see no hope in their own land and flec. There are some 3.2 million Afghan refugees in Pakistan alone. They live in squalor.

For these people, there is no queue they can join to find asylum elsewhere. Only a minute number will be processed for settlement in another country, unless they have a relative or other contact who can intercede on their behalf.

Those on the Tampa took the only course open to desperate people. They are not queue-jumpers; there was no queue for them to join.

They will have scraped together whatever money they could in a do-or-die bid to find some future for themselves and their families. Because they have been the victims of extortion all their lives, they will not be aware that paying over money for documents and unauthorised passage is illegal. It is simply user-pays in a corrupt environment. They have never known anything different.

Many may well have been involved in armed conflict. 'They come to countries such as ours to get away from war. They want to live in peace to give their children health, education and a stable life.

In the 1980s, bringing Afghan refugees into New Zealand met cooperation from the Immigration Service. However, in the early 1990s it suddenly became much more difficult. They were declared to be refugees from Afghanistin to Pakistan, but not from Pakistan to New Zealand.

The only classification available for entry to New Zealand was on humanitarian grounds. The criteria were mental or physical trauma. Poverty was specifically excluded as a reason to migrate.

Meanwhile, our immigration door was opened wide to anyone who could assemble enough cash to qualify for entry. No probing questions were asked as to how the money was acquired.

As a consequence, many people of dubious background have gained residency. It is no coincidence that we now have a special police Asian crime unit.

There is no reason to believe that the people on the Tampa will be any less valuable as citizens in our country than the Afghans who are here. The boat people have shown considerable initiative in getting themselves from the remote regions of Afghanistan to the shores of Australia. They will use the same resourcefulness to add value to our own society. 
For the Australians, the issue of migrants arriving on leaky vessels is a problem that needs resolution. There needs to be negotiation with Indonesia to establish a more
orderly process, even for the good of the refugees themselves.

In the longer term, putting strategies in place to reduce the gap between the affluent and poor countries will be the surest way to achieve an orderly process of migration.

It is an anomaly that once people are given refugee status and accepted into Australia, they are treated much better than refugees coming to New Zealand. I trust that the willingness of the New Zealand Government to come to the assistance of the people on the Tampa will be backed up by appropriate assistance to help them to integrate into this country.

Such investment will be returned many times by the industry and ingenuity of grateful residents.

* Father Terry Dibble, of Grey Lynn, is a Catholic priest.

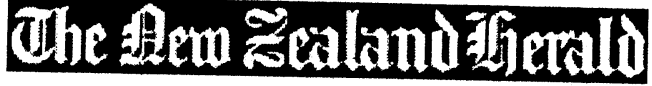

Thursday September 06, 2001

\section{Taleban blocks envoy inquiry}

KABUL - Afghanistan's Taleban has denied Western diplomats access to the trial of eight foreign aid workers accused of promoting Christianity.

But the chief justice said the accused - four Germans, two Americans and two Australians- could hire foreign lawyers.

Judges and Islamic scholars under Afghanistan's Supreme Court went into their second day of deliberations over the trial.

Chief Justice Noor Mohammad Saqib said he did not know how long the trial would last, but the Pakistan Afghan Islam Press (AIP) quoted him as saying the detainees could hire foreign, non-Muslim lawyers.

"We want to continue this regularly and can't say how long it will last," Saqib said.

Twenty-four staff of the German-based Christian relicf agency Shelter Now International - the foreigners and 16 Afghan colleagues - were arrested more than four weeks ago on charges that could carry the death penalty.

It was not known if the 16 Afghans, who are expected to be tried separately, would be called to give evidence.

The three diplomats, from Germany, Australia and the United States, arrived 
uninvited at the court.

They waited in the street for around 30 minutes before leaving, saying they would make another attempt to meet the chief justice.

Australian diplomat Alistair Adams said there had been no contact with the Taleban over the case since last week.

"An explanation of what is happening in this case ... we have no official word at
all," he said.

AIP quoted Saqib as saying the punishment would be decided under Islamic Sharia law, and would fit the crime.

"If the crime is worthy of imprisonment they will be imprisoned, if the crime is worthy of hanging, they will be hanged," he said.

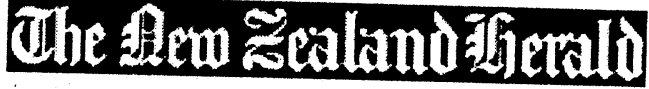

Thursday September 06, 2001

\section{Shipley gets a broadside on refugee}

\section{By SHENAGH GLEESON}

Opposition Leader Jenny Shipley is not fit to hold office after her "totally unfounded" attack on Afghan refugec Dr Najibullah Lafraie, says one of Australia's experts on Afghanistan.

Professor William Maley said from Canberra yesterday that it was preposterous for the National Party leader to say that Dr Lafraic was a guerrilla leader and possibly a danger to New Zealand.

Dr Lafraie was approved by the United Nations High Commissioner for Refugees for settlement in New Zealand a year ago.

He works part-time for the Immigration Service in Christchurch.

Professor Maley, who is an associate professor of politics at the Australian Defence Force Academy and chairman of the Australian Refugec Council, said he had known Dr Lafraie for more than 10 years.

Dr Lafraic had a PhD from the University of Hawaii and was one of the besteducated Afghan men of his generation.

Professor Maley, who saw Dr Lafraie several times when he was a Government minister in Kabul, said he was the least militaristic of men.: "lie's a thinker. I doubt he would know one end of a gun from another." 
He had not been involved in fighting, let alone terrorism, either during the Jihad, or holy war, against the Soviet invaders or after the war.

Professor Maley said Mrs Shipley was wrong in alleging Dr Lafraie had been refused refugee status in Australia in 1999. Authorities declined an application for him to go there under a special humanitarian programme on a misunderstanding that he had been accepted by another country.

Mrs Shipley had clearly not done her homework and had attacked Dr Lafraie for shallow political motives. "It is utterly preposterous and raises questions about whether she ought to be in public office."

Mrs Shipley last night said the information on Dr Lafraie was independently sourced and she did not intend to debate the case with Professor Maley.

The issue remained that New Zealanders had to be assured there was effective screening of asylum-seekers.

Meanwhile, the Australian troop ship Manoora is making steady progress on its journey to Port Moresby, Papua New Guinea, with 434 asylum- seekers taken from the container ship, Tampa.

The boat people are reported to be doing well. From Port Moresby 150 will be flown to Auckland where they will assessed.

A group of 137 refugees from Thailand, Iraq, Iran and Afghanistan, who began arriving in Auckland this week, will move out of the Mangere Reception Centre to a defence facility at Whangaparaoa when the 150 arrive.

The remaining 284 boat people from the Manoora will go to Nauru, where President Rene Harris says the Afghan asylum-seekers will not be put to work as labourers. Nauru's Melbourne-based solicitor-general, Kerry Smith, had raised the idea of putting them to work.

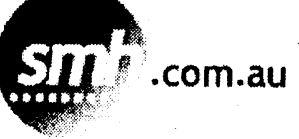

Thursday. September 6, 2001

\section{Bin Laden 'building a foreign legion'}

By Rory McCarthy in Islamabad

Arab fighters funded by the Saudi terrorist Osama bin Laden have become increasingly influential within Afghanistan's Taliban movement and are building a 

foreign legion to extend the regime's hardline vision of Isląm, aid workers and
analysts say.

Rising numbers of Arab mercenaries have flooded into the country this year, taking part in civilian massacres against minority Shia Muslim communities in Hazarajat, central Afghanistan, in the first months of the year.

"Clearly there is a long-term project to build a political and military movement that is seriously expansionist," a senior aid worker in Kaloul said.

"Osama bin Laden and his faction are one of the guiding influences in the movement. They want Afghanistan to be a sanctuary to all those Muslims who reject 'false' notions of sovereignty and want to revive the Khilafah."

Since seizing Kabul five years ago the Taliban have imposed a brutal police state in their effort to build the Khilafah, the ultimate Sharia law government for the Islamic world.

But the arrival of foreign fighters has sparked a dispute within the movement between internationalist elements, who are happy to welcome the fighters and their money, and those loyal to Afghanistan's defiant history of nationalism, who resent the foreignèrs.

The internationalists' efforts have been bankrolled by bin Laden, who is wanted by the United States for the 1998 bombings of two US embassies in east Africa that killed 224 people. His closeness with the reclusive Taliban leader, Mullah Mohammad Omar, has grown, and their project has been the driving force behind increasingly hardline, misogynistic policies and a growing harassment of Western aid groups.

A new school curriculum that cut classes in arts and sciences in fivour of Islamic and Arabic-language subjects was issued in March. In the same month the two towering Buddhas at Bamiyan, the greatest symbol of Afghanistan's long preIslamic history, were destroyed. A rising number of Islamic aid agencies, at least one of which is believed to be funded by bin Laden, have set up offices in Kabul.

"There is a project to build up a foreign legion," the aid worker said. "The Western presence here is alien to that. If these people come into the ascendancy then clearly sooner or later they will get rid of all the Westerners."

Analysts believe there are up to $\mathbf{1 2 , 0 0 0}$ foreigners - a quarter of the movement's $-$ military force - fighting with the Taliban.

The Taliban are believed to run camps where they train Chechen fighters, Pakistani sectarian extremists and soldiers from the Islamic Movement of Uzbekistan. Bin Laden and his supporters are believed by many to be the power behind the Taliban throne.

The Taliban have refused to hand bin Laden to the US for trial, despite two years of 


\section{UN sanctions.}

"Osama bin Laden came as a mujahid [holy warrior]," said the Taliban Information Minister, Mr Qadratullah Jamal. "He is a very calm man and he respects Islamic law. He is a good man, and he doesn't want to harm anyone." The Guardian

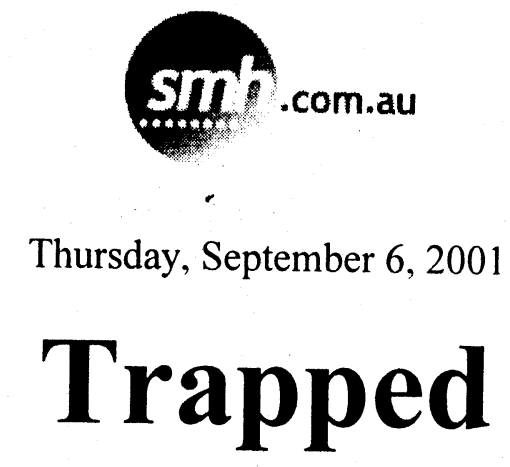

Refugees heading for Australia end in limbo in Indonesia. Pirates and possible drowning await them at sea, while on land they are imprisoned. Lindsay Murdoch reports.

The smugglers' plan went like clockwork. Paid up asylum seekers were flown in small groups from Pakistan to Jakarta, transiting in Bangkok, Singapore or Kuala Lumpur.

There was little fear of their fake Indonesian visas and Afghan passports being rejected in Jakarta, which has one of the most corrupt airports. The smugglers even paid for special passes so they could wait inside the customs area and arrange for their clients to be processed in a side room and not have to wait in queues like other new arrivals.

Faizullah, a shopkeeper, was happy with the service he got for the $\$$ US12,000 $(\$ 23,000)$ he had paid to smugglers in the Afghan capital Kabul, the Pakistan city of Lahore and Jakarta to bring his pregnant wife Fatima and their two children to Australia.

One of the smugglers even travelled with them, making sure nothing went wrong during the trip to Indonesia, but keeping his distance. "He told us to ignore him," Faizullah says. "In Jakarta another man, a Pakistani, was waiting for us at the airport. He took us to a rented house and told us not to talk to any neighbours, stay inside and wait until he came to take us on the final leg of the trip."

Over several months the smugglers, from one of six major people-smuggling syndicates operating in Indonesia, had parked clients, who had paid them more than \$US700,000, in safe houses across Jakarta and its outlying suburbs.

Abdul Rashid Matin, a 35-year-old nurse from Kabul, was surprised the arrangements went so smoothly for himself, his wife and four children. In Pakistan he was even shown a photograph of the smuggler who would be waiting for him 
among the teeming faces of taxi drivers and con artists who tout for business at Jakarta airport.

"The smugglers fulfilled every promise until the time we stepped on to the boat," Matin says. "That's when we realised we had been left to a terrible fate."

It was almost dark by the time the smugglers had collected 138 people from the safe houses and brought them to a port on the southern coast of Java (the smugglers warned their clients not to reveal the location).

There was no time to properly check out the KM Harapan Jaya II because the tide was moving fast, the smugglers said, and the police might come. But they were to find out later the boat's hull was rotting, there were no working pumps or life jackets as the smugglers had promised, and it would have been overcrowded if only a dozen had boarded, let alone 138 .

As the boat chugged out to sea a couple of teenagers who had picked up basic Bahasa Indonesia while staying at their safe house learnt from the four Indonesian crew that the trip to Christmas Island was expected to take seven days and seven nights. The smugglers had told them 30 hours.

But there was barely time to digest that news. The boat hit the rocks off Nusa Kembangan, Indonesia's "Devil's Island", in the early hours of the morning. When water started to fill the hull, the asylum seekers tried to bail it out with their hands. Said Sakhi, 20, fell into the sea as waves washed over them. "For God's sake help me," he screamed before slipping away and drowning.

Fatima, 20, clutched her baby, Murtaza Roni, who had been born in Indonesia 2 months earlier.

But as the boat split into pieces she lost her grip and the baby fell into the water. "We could see him. But nobody could reach him," says Abdul Rashid Matin. "The rest of us managed to get ashore and then we found the body. It was a huge shock to all of us."

Three weeks later, Fatima sits on the concrete floor of a dormitory in the jail on Nusa Kembangan, her sad eyes only looking downward, the look of shame and despair. She has not spoken for days.

"We had to come even though we lost our baby," says husband Faizullah, 24. "In Afghanistan the Taliban was going to kill me because I refused to fight for them. But I feel now that if I could stay anywhere in the world it would not make up for the loss of our baby."

Many of the hundreds of asylum seekers from Iran, Iraq, Pakistan, Afghanistan and other countries who are stranded in Indonesia have similar horror stories.

Boats carrying hundreds of people have sunk, drowning all aboard. Like the Vietnamese boat people before them, the new asylum seckers trying to reach Australia have been the targets of modern-day pirates and rapists and the victims of 
cruel smugglers.

- And Indonesian authorities have at times helped push boats out to sea, knowing they are not seaworthy and the passengers' chances of survival only slim, some survivors say.

THE survivors of the KM Harapan Jaya II and hundreds of other asylum seekers who have failed to reach Australia are unwelcome in Indonesia, where authorities are becoming increasingly impatient with them.

When they are caught, Indonesia's policy is to place them in "quarantine" - usually a jail compound with criminals or at a guarded hostel or cheap hotel pending assessment of their status by the United Nations High Commissioner for Refugees.

But they often escape, or are allowed to walk away by officials fed up with them. Their only option then is to try to arrange passage with other smugglers.

Even if they are assessed to be refugees, third countries including Australia have been slow to accept them, leaving Indonesia, a country struggling with its $\mathbf{1 . 5}$ million internally displaced people, with the burden of coping with the rapidly growing numbers.

Lukmiardi, a senior official at Indonesia's Justice Ministry, says that placing all the asylum seekers in quarantine is proving impossible "given that their numbers are reaching into the thousands and are likely to increase". He urges the building of proper detention facilities. "to convey the message that Indonesia is not a transit point for illegal migrants".

Tensions are running high on Nusa Kembangan, the prison island off the central Java city of Cilacap that houses some of Indonesia's most notorious criminals, including Bob Hasan, the one-time golfing partier of the former dictator Socharto.

"Our job is to provide security for Indonesian criminals, not foreigners," says Djono, a guard on the island that has been a prison since the Dutch colonial era. "The presence of these people is a big problem for us."

Abdul Rashid Matin, the nurse from Kabul, speaks for the group of survivors, many of whom are unwell because of the lack of food and water, and the primitive conditions on the island.

"As you are Australians please report to your country that we are suffering and appreciate very much your humanitarian program," he tells the Herald.

"You have taken in many Afghans before. We know that. We hope you will please help us."

Abdul Ghani, 20, presses to the front of the group. "Please can you tell us. Should we stay here or escape? Please tell us. We are desperate."

THE presence of refugees who share houses in Indonesian cities, towns or villages 
has often caused problems in the local communities, including gang fights.

Some asylum seekers turn violent. When 33 Iraqi people were caught arriving on North Sumatra recently, two men cut their chests open and a mother threw her baby to the ground to protest being taken to a local immigration shelter instead of Jakarta.

Gira Prawijaya, the head of the police foreign monitoring office on Lombok, where several hundred Iraqi and Afghan asylum seckers have been staying, says the situation has become intolerable: "They [the asylum seckers] are so outrageous. They come to this country with fake passports but act like nobles, demanding first class facilities and services."

Often those in immigration shelters go on hunger strikes. A few have sewn up their mouths or cut their tongues to protest the refusal of Indonesian authorities to take them to Jakarta where smugglers are easily found, usually in the city's biggest McDonald's after 9pm every day.

An Indonesian policeman who worked undercover for months in an international squad funded by Australia to track the smugglers says each syndicate has a field coordinator for each country who employs hotel providers, boats and crews, the producers of passports and visas and travel agents. He says network members are usually of Arab descent.

The two best-known syndicate bosses are Pakistani. They fly first or business class, _. use at least four aliases and always travel with four to six bodyguards. "They are - very dangerous, deceitful, untouchable," says the policeman, who asked not to named.

While drug smugglers face execution in Indonesia and possessing a firearm can send a person to jail for 20 years, the laws covering people smuggling are vague and untested.

One syndicate boss, known as Captain Bram, who was recently in Cambodia with 241 Afghan and Pakistan people trying to get to Australia, has often been arrested in Indonesia but is always released because of the lack of evidence.

"Money talks," the policeman says.

Smugglers often meet clients openly in the jails and immigration shelters. "The syndicates work very secretly and are hard to infiltrate," the policeman says. "Jobs are given on a need to know basis." .

The policeman says the operation, from the start until the asylum seckers board a boat for the last leg of the journey, is sophisticated and highly professional.

Passports are usually genuine, but the names and visas fake.

He says the asylum seekers are told to destroy their travel documents when they arrive in Indonesia by either plane or boat from Malaysia, which has emerged as the people smuggling hub because the country allows visa-free entry for people from 
most Muslim countries. Without proof of where they are from, asylum seekers cannot be sent home.

There are two main sea routes out of Indonesia. One is through the eastern islands to the tiny, uninhabited Ashmore Reef 200 kilometres north-west of the Australian mainland.

The smugglers know that if their cargo reaches there, Australian Navy and Coastwatch patrols will carry them to immigration authorities.

The other route to Christmas Island is faster but more risky because of the notoriously rough seas that can blow up at any time.

On Nusa Kembangan, the Afghan survivors have been told by prison guards and workers about the drama involving the people on the Tampa and how they were plucked from their sinking boat off Christmas Island.

"If we get another another chance to go, we will go," sayg A'dul Ghani. "Those people aboard are being taken to be resettled in a third country. That is all we are asking for ourselves."

\section{On file: untold tragedies of refugees}

Files held by Australian officials in Jakarta and Canberra reveal how dozens of attempts to reach Australia's shores have ended in tragedy. But the Federal Government refused a request from the Herald to allow access to the files to publicise the true stories as a warning to others not to attempt the treacherous voyage.

The Government has instead spent millions of dollars on a widely criticised documentary that is a joke among the asylum seckers.

The slick documentary warns viewers that should they try to illegally to enter Australian waters they risk drowning in giant mid-ocean whirlpools or tropical storms, being eaten by sharks, mauled by giant crocodiles, bitten by snakes or left languishing in dusty refugee camps in the middle of the Simpson Desert.

"These people are not fools," says a United Nations official in Jakarta. "They can see through the propaganda."

Figures supplied by Indonesia's Directorate Ciencral of Immigration show that as of July, 439 foreigners in Indonesia had been granted refugec status, 557 were being assessed, and 737 had unclear status.

But as well as these people, officials predict several thousand more asylum seekers are in Indonesia at any time. "About 84 per ent of those granted refugec status are from Iraq," says Rachmat Tanjung, the head of the Foreigners Supervisory Coordination Office at the Directorate General of Immigration.

Tanjung says that one of the biggest problems is the breakdown of the refugec 
assessment system because third countries are shirking their commitments to accept those found to have a fear of persecution if they were to return home.

"Migrants go to any length to reach even the outer shore of the destination country [Australia] because they believe it would be much easier to fight for refugee status if they have already arrived on their dreamland," he says.

While refugees wait for their applications to be considered, the International Organisation for Migration gives them \$US50 (\$96) a month. Australia provides the money.

\section{Detainees can hire lawyers: Taliban}

KABUL: Afghanistan's ruling Taliban on Wednesday denied Western diplomats access to a court where eight foreign aid workers are on trial for promoting

- Christianity, but the chicf justice said the defendants could hire foreign lawyers.

Judges and Islamic scholars under Afghanistan's Supreme Court completed their second day of deliberations over the trial and Chief Justice Noor Mohammad Saqib said the aid workers would be sentenced according to Islamic Sharia law.

"If the crime is worthy of imprisonment they will be imprisoned, if the crime is worthy of hanging, they will be hanged," Pakistan Afghan Islam Press quoted him as saying.

Three Islamabad-based Western diplomats in Kabul, frustrated at the lack of information about the case, were denied entry to the Supreme Court after arriving uninvited in a bid to meet the chief justice.

Saqib told reporters he did not know how long the trial process would last, but AIP quoted him as saying the detainees could hire foreign, non-Muslim lawyers.

"Nothing will be said about the final punishment before a final verdict," he said.

"The trial is continuing and going very fast."

Saqib promised to deal with the case on a fair basis and stressed that the four Germans, two Amerieans and two Australians would be allowed to defend 
themselves.

"They have the complete right to defend themselves in court. If they want to use a lawyer we have no objection," AIP quoted him as saying. "They can even bring in
foreign, non-Muslim lawyers to defend themselves."

Twenty-four staff of the German-based Christian relief agency Shelter Now International (SNI) -- the foreigners and 16 Afghan colleagues -- were arrested more than four weeks ago. It was unclear whether the 16 Afghans, who are expected'to ine tried separately,
would be called to give evidence.

The trial process under the hardline Islamic movement remained unclear and despite repeated requests from diplomats and journalists since the case began no Taliban officials have been either willing or able to clearly outline procedures.

Added to this Taliban statements have been inconsistent with officials often
contradicting each other.

The diplomats from Germany, Australia and the United States, secking to protect the interests of their nationals, arrived uninvited at the court.

Clearly frustrated as they waited in the street for around $\mathbf{3 0}$ minutes, they left saying they would make another attempt to meet the chief justice through the foreign ministry.

Australian diplomat Alistair Adams said there had been no contact with the Taliban over the case since last week.

"An explanation of the judicial process, what is happening in this case, we have no official word at all," he said. "We have some idea from press reports that the case has commenced, we have had no official advice up to this point."

In Washington, a U.S. State Department official called for a fair trial.

"We call upon the Taliban to ensure the proceedings follow the rule of law and are fair and transparent," said the official, who declined to be identifie!.!.

AIP quoted Saqib as saying the punishment would accord with the crime. The Taliban say supreme leader Mullah Mohammad Omar has the final say no matter what the court decides.

There was no indication the accused had yet been called to appear and it was not clear if or when diplomats, family members or reporters would be allowed in to observe the trial. 
Saqib told AIP it was not necessary for anybody besides the accused to attend court.

"However, in case the judges and the religious scholars feel it necessary for anybody $-\infty$

else to attend court proceedings they will be allowed," he said.

The Taliban say they have strong evidence that SNI's foreign staff were involved in trying to convert Afghan Muslims to Christianity but had no proof any conversions were actually made. SNI says its staff are told not to proselytise.

The Taliban have also evicted the foreign staff of two other Christian humanitarian groups -- International Assistance Mission and Serve -- saying they were connected with SNI.

Recognised as a legitimate government by just three countries, the Taliban rule about 95 percent of Afghanistan and want to establish a purist Islamic state.

Their strict interpretation of Islam has often earned them international condemnation, especially for human rights abuses and the destruction of the country's pre-Islamic heritage.

\section{Dhe Courier-mail}

()6 September 20()1

\section{Taliban issues death warning \\ Is/amabad}

EIGHT foreign aid workers on trial in Afghanistän for allegedly preaching Christianity could be hanged if found guilty, Taliban Chief Justice Mawlawi Noor Mohammad Saqib said yesterday.

He told the Afghan Islamic Press that the punishment would fit the alleged crime and the death penalty was an option if the eight foreigners were found guilty.

Diana Thomas and Peter Bunch from Western Australia are on trial in Kabul with two Americans and four Germans.

"We will punish them according to the laws they have broken. If they have broken the law and should be hanged then we will punish them like that," Mr Saqib said.

The aid workers were arrested, along with 16 Afghans, more than four weeks ago, but the charges and likely punishment have not been fully explained.

The Taliban Supreme Court began the trial behind closed doors on Tuesday despite 
earlier promises from Taliban ministers that diplomats and journalists would be allowed to observe the proceedings.

American, Australian and German diplomats arrived at the Supreme Court building in Kabul yesterday in a bid to meet Mr Saqib and clarify the legal process, but they were turned away.

Diplomats were barred from entering the building and were told their presence would be requested when it was deemed necessary.

Australian consul Alastar Adams said the envoys were being "kept in the dark" and demanded to know how the Taliban planned to proceed with the trial.

"We want to know what's going on," he said outside the court. "It's too bad that we have been kept completely in the dark about the trial, which we understand has started."

"We have been waiting patiently for more than a week now and none of the Taliban officials have responded to our pleas."

For 30 minutes, the diplomats waited outside the Supreme Court building in the heart of Kabul surrounded by journalists and armed Taliban soldiers.

Inside the building, the Chief Justice met his fellow judges and decided now was not the time to meet the diplomats.

He did not give any explanation. Frustrated, the diplomats departed.

- "Please pass on the message to the Chief Justice that we need to know the procedure, so we can pass it on or have it passed on to the detainees," Mr Adams told Taliban officials.

"We are not here to interfere with the legal process, but rather to understand the procedure."

The Western diplomats said that as consular officers their job was to advise their nationals on the legalities of their trial.

But for much of the past week the diplomats have been unable to meet any Taliban official.

Agence France-Presse/Associated Press. 


\section{THE IRISH T, TIMES}

Thursday, September 6, 2001

\section{Judge tells aid workers they may be executed}

The Taliban's chief justice yesterday warned that eight foreigners on trial for preaching Christianity in Afghanistan could be hanged if found guilty.

Mr Mawlawi Noor Mohammad Saqib spoke on the second day of the trial of the two Americans, two Australians and four Germans.

"We will give them punishment according to Islamic law, whether imprisonment or hanging," he told the Pakistan-based news agency Afghan Islamic Press (AIP).

"We will punish them according to the laws they have broken. If they have broken the law and should be hanged then we will punish them like that."

The aid workers were arrested along with 16 Afghan colleagues more than four weeks ago, but the charges and likely punishment have not been fully explained. The Afghans are likely to face a separate legal process.

At the end of the second day of deliberations between judges and senior Islamic scholars, which constitutes a trial in Taliban-ruled Afghanistan, Mr Saqib reiterated that the accused were innocent until proven guilty.

"The punishment will be decided by the highly qualified judges and ulemas (scholars) and only if the accused are proven guilty," he said in a statement. $-n$

He said the trial would be fair, although in a speech at a mosque on August 10th he called for "exemplary punishment" to "end such un-Islamic practice by any foreign group in Afghanistan".

Mr Saqib said the court had not decided whether to allow independent monitoring of the trial. But he said the foreigners could hire lawyers if they wished.

The son of a jailed Islamist leader in the US said yesterday his family had proposed his release in exchange for the aid workers.

The wife of Mr Sheikh Omar Abdel Rahman, who was jailed for the World Trade Center bombing, sent letters to the US president and the Taliban leadership to agree to such an exchange, he said. 


\title{
BUSINESSDAY
}

Thursday 06 September 2001

\section{Diplomats are not allowed ataid workers' court hearing}

\begin{abstract}
Afghanistan's chief justice says the defendants may hire foreign lawyers
\end{abstract}
KABUL Afghanistan's ruling Taliban denied western diplomats access yesterday to a court where eight foreign aid workers are on trial for promoting Christianity, but the chief justice said the defendants could hire foreign lawyers.

Judges and Islamic scholars under Afghanistan's Supreme Court completed their second day of deliberation over the trial and chief justice Noor Mohammad Saqib said the aid workers would be sentenced according to Islamic sharia law.

"If the crime is worthy of imprisonment they will be imprisoned, if the crime is worthy of hanging, they will be hanged," he said.

Three Islamabad-based western diplomats in Kabul, frustrated at the lack of information about the case, were denied entry to the supreme court after arriving uninvited in a bid to meet the chief justice.

"The trial is continuing and going very fast." Saqib promised to deal with the case on a fair basis and stressed that the four Germans, two Americans and two Australians would be allowed to defend themselves. "They have the complete right to defend themselves in court. If they want to use a lawyer we have no objection," the Pakistan Afghan Islam Press (AIP) quoted him as saying. "They can even bring in foreign, non-Muslim lawyers to defend themselves."

Twenty-four staff of the Germanbased Christian relief agency Shelter Now International (SNI) the foreigners and $16 \mathrm{Afghan}$ colleagues were arrested more than four weeks ago.

The diplomats from Germany, Australia and the US, seeking to protect the interests of their nationals, arrived uninvited at the court. Clearly frustrated as they waited in the street for around $\mathbf{3 0}$ minutes, they left saying they would make another attempt to meet the chief justice through the foreign ministry.

Australian diplomat Alistair Adams said there had been no contact with the Taliban over the case since last week. 
In Washington a US state department official called for a fair trial.

The Taliban say supreme leader Mullah Mohammad Omar has the final say, no matter what the court decides. There was no indication the accused had yet been called to appear and it was not clear if or when diplomats, family members or reporters would be allowed in to observe the trial.

Saqib told AIP it was not necessary for anybody besides the accused to attend court. "However, in case the judges and the religious scholars feel it necessary for anybody else to attend court proceedings they will be allowed," he said.

The Taliban say they have strong evidence that SNI's foreign staff were involved in trying to convert Afghan Muslims to Christianity but had no proof any conversions were actually made. SNI says its staff are told not to proselytise.

The Taliban have also evicted the foreign staff of two other Christian humanitarian groups International Assistance Mission and Serve saying they were connected with SNI.

Recognised as a legitimate government by just three countries, the Taliban rule about $95 \%$ of Afghanistan and want to establish a purist Islamic state.

Their strict interpretation of Islam has often earned them international condemnation. Reuters.

THE TELEGRAPH

Thursday 6 September 2001

\section{Aid workers trial judge wants a guilty verdict}

By Ahmed Rashid in Lahore

CHRISTIAN aid workers facing capital charges in Afghanistan are being tried by a judge who has already demanded an "exemplary" punishment.

In a speech at a mosque last month, Taliban Chief Justice Mullah Noor Mohammed Saqib called for a guilty verdict against eight Western captives and 16 Afghans accused of converting Muslims to Christianity in order to "end such un-Islamic practice by any foreign group in Afghanistan".

Mullah Saqib insisted yesterday that he was overseeing a fair trial. The foreigners were innocent until proven guilty and would be tried according to the Sharia Islamic law. He said: "The punishment will be decided by tlie highly qualified 
judges and ullema [Islamic scholars], and only if the accused are guilty."

Although the court said the two Amerieans, two Australians and four Germans could use their own lawyers, the hearings have been held in secret. Foreign diplomats have been refused access .

Australian consul Alistair Adams said: "We want to know what's going on. We have been waiting patiently for more than a week now and none of the Taliban officials has responded to our pleas."

Mullah Saqib said: "We will punish them according to the law they have broken. If they have broken the law and should be hanged, then we will punish them like that."

The chief justice is heading a 14-man bench of Taliban judges trying the members of the Christian aid agency Shelter Now International, which has been shut by the Taliban .

Despite the trial, the judges have said that Taliban leader Mullah Mohammed Omar will eventually decide their fate. But a Western diplomat said: "The Taliban appear to be making up the law as they go. Anyway, the final decision will be a political one rather than on the merits of the case."

The aid workers are now virtual hostages in a wider game aimed at stalling Western and United Nations pressure on the radical Islamic movement, as well as an assertion of hard-line elements against moderates within the Taliban.

The Taliban appear determined to drag out the trial to frustrate key Western policy measures this month. In the coming weeks the UN Security Council was expected to send 15 technical experts to enforce its arms ban.

They were to be mostly stationed on the Pakistan-Afghanistan border, as Pakistan remains the main weapons supplier to the Taliban. Iowever both Pakistani Islamic extremists and the Taliban have vowed to kill them. Western diplomats said the UN is certain to defer the move while the crisis persists.

The Bush administration had also been expected to announce a tougher policy after the Taliban refused to extradite the Saudi terrorist Osama Bin Laden. With two Americans among the hostages, Washington will have little choice but to delay.

Both America and the $\mathrm{EU}$ are moving closer to backing a proposal to call a Loya Jirga - or grand tribal council - by former Afghan King Zahir Shah, living in exile in Rome. This is supported by the anti-Taliban alliance led by Ahmad Shah Masud, which controls 10 per cent of the north east of the country and most of the population.

However, the Taliban are bitterly opposed to it. They belong to the Pashtun ethnic group from the south and, until the Pashtun rise against them, their grip on power will be unshakeable. There is now a move by Pashtun commanders to raise a 
National Resistance Army in support of the Loya Jirga.

\section{GULF $\quad$ NEWS}

Thursday, September 06, 2001

\section{Riyadh rejects mediation calls in Afghan crisis}

Riyadh |By Our Correspondent

Saudi Arabia has turned down requests from several countries and humanitarian organisations to mediate with Afghanistan's Taliban government to release eight foreign aid workers who were arrested more than four weeks ago for allegedly preaching Christianity, said a senior Saudi official.

The official, who asked not to be named, told Gulf News that his country had received several requests, through diplomatic channels and direct contacts with senior officials, to intervene with the Taliban government to release the detained Westerners, but Saudi Arabia had turned down all these requests.

"Saudi Arabia severed relations with the Taliban several years ago for adopting a pro-terrorism policy and hosting a number of terrorists led by (Osama bin Laden. Taliban still refuses to abandon this policy," the official said.

"Saudi Arabia's intervention in this case is rejected by Shariah law as Islam bans the preaching of any other religion among members of the Muslim society. As such, those foreigners who used the cover of a relief agency to preach Christianity, must be tried in accordance with the Islamic Shariah," noted the official.

The detained Westerners could be hanged if found guilty, Taliban chief justice, Mawlawi Noor Mohammad Saqib, said yesterday.

The official branded the detainees as enemies of Islam and Muslims as they had gone to Afghanistan, which is a Muslim country, to urge its citizens to convert from Islam and embrace Christianity, and exploited the poverty prevailing there.

He observed that the Taliban had provided those missionaries with a fair trial and if they are found guilty, they will undoubtedly be hanged according to the Islamic Shariah. "The same penalty will be applicable to the Afghans who converted from Islam to Christianity if they refuse to come back to Islam." 


\section{the gem.all \\ Thursday 6 September 2001 \\ Taliban may push for hanging}

By SIMON JOHANSON with agencies

Two Australians and six other foreigners on trial in Afghanistan for preaching Christianity could be hanged if found guilty, the Taliban said yesterday.

The chilling warning comes a day after foreign minister Alexander Downer vowed to get the two West Australian aid workers released.

In an interview with a Pakistani Islamic news agency, the Taliban's chief justice Mawlawi Noor Mohammad Saqib gave the clearest indication so far execution was an option under the militia's radical brand of Islamic law.

"We will give them punishment according to Islamic law, whether imprisonment or hanging," he told the private news agency, Afghan Islamic Press.

"We will punish them according to the laws they have broken. If they have broken the law and should be hanged then we will punish them like that," he said.

A spokeswoman for the Department of Foreign Affairs said an Australian official met with the Afghanistan ambassador to Pakistan yesterday and gave him a joint letter from the US, Australian and German governments expressing strong concern the detainees be allowed aceess to legal representation and translating services.

"He also expressed our concern and dișappointment at the continued lack of official information from the Taliban," the spokeswoman said.

Initial deliberations on the trial of the two Americans, four Germans and Australians, Diana Thomas and Peter Bunch, began two days ago.

"We understand the foreign detainees have not appeared in court yet," the spokeswoman said. 


\section{THE PAKISTAN TIMES}

Thursday, September 6, 2001

\section{Helicopters to take Afghan asylum-seekers to PNG}

PORT MORESBY: Authorities here said Wednesday the unwanted 400 asylum-seekers bound for Papua New Guinea could be flown by helicopter from an Australian troop ship directly to outward-bound planes at Port Moresby's airport.

Foreign Minister John Pundari said the plan would provide maximum security and surveillance of the boat people.

The mainly Afghan 434 asylum-seekers were rescued from a sinking Indonesian boat last month iand spent a week on a Norwegian container ship off Christmas Island while the Australian government defied international pressure to let them land.

They are now being shipped on the HMAS Manoora to PNG before being flown to Nauru and New Zealand, where their demands for asylum will be assessed.

"Not one single soul will be allowed ashore outside of ar- rangements made for their onward journey to New Zealand and Nauru, nor will any of the asylum seekers be allowed to roam around the city of Port Moresby during their transit time in Papua New Guinea,"

"Our preference is for the asylum seekers to be up-lifted by helicopters from the Manoora directly to Jacksons International Airport."

Both PNG's founding Prime Minister Sir Michael Somare and Opposition foreign:affairs: spokesman Michael, Nali, are opi. posed to Australia's reqest to transfer the refugees in PNG.

Nali warned the refugees may try to jump ship and seek refugee status in PNG.

On Sunday, Prime Minister Sir Mekere Morauta said he had agreed to Prime Minister John Howard's request that PNG be used as a trans-shipment point "as a humanitarian gesture" and to help provide "a Pacific sotution" to the dilemma.-AFP Pundari said,

The News International, Friday, September 7, 2001

\section{Loya Jirga}

\section{Bureau hoport}

PESHAWAR: The Council of Understanding for National Unity of Afghanistan (CUNUA) has supported the convening of emergency Loya Jirga and the Rome peace process, claiming the former monarch Zahir Shah was the only personality to unite all Afghans.

Speaking at a news conference here on Thursday, president of CUNUA Haji Hayatullah said his organisation was working for restoration of peace in
Oula Ghamkhoor, Saeed Karimul Haq, Engineer Mahboob, Zahir Khan Jabarkhel, Saeed Osman, Wakil Abdul Wahab Khan, Dr

Sadiq Abdul Ghaffar Shuja and their supporters were present on this occasion.

Haji Hayatullah said millions of Afghans were martyred, hundred of thousands were disabled, and millions were forced to leave their homes and many more fleeing homes now. He said the entire world was well aware of the deteriorating condition of helpless Afghains.

Hayatullah said they were supporting the èmergency Loya Jirga (grand assembly) being convened by former Afghan king Zahir Shah because he reined Afghanistan for 40 years. During his tenure, peace, security, democracy and development prevailed. He said Zahir Shah was free from lingual, ethnic, ideological, political and regional discriminations.

He said the Rome Peace Process under the leadership of the former king insisted on convening the emergency Loya Jirga and political system of Afghans choice. It, he said was an extensive movement towards the right of self-determination. He said the tribal leaders, ulema, party leaders, scholars, the elite and jihadi commanders and also men and women alike have the right to participate in the Rome process

as a non-party entity.

"The Rome peace process is not preparing any front against any one nor it believes in war. It is a movement of peace to relieve Afghans from the intra-Afghan conflict and foreign intervention," he added.

The CUNUA president said all Afghans wanted peaceful co-existence, brotherhood and equality with all neighbours. They were fed up with the puppet government in Afghanistan. He said the RPP is a reality, which work for a friendly government in order to deny foreign intervention and prevent puppet governments.

The CUNUA, he said had been supporting all peace initiatives, cooperated with UN envoys. He said Frances Vendrell was trying to convene a meeting in Geneva 


\section{The Frontier Post Friday, September 7, 2001}

- - to unite and coordinate the Rome, Cyprus and Bonn efforts and the UN will facilitate the negotiations but the world should know the former king was the only personality to unite all Afghans.

Hayatullah said 53 Afghan councils, parties and political organisations had amalgamated in CUNUA but the UN envoy has ignored it though being the largest peace movement.

\section{WFP issues emergency appeal for Afghanistan}

ISLAMABAD (PPI): The United Nations World Food Programme today launched an appeal for a US\$151-million emergency operation to save millions of people in Afghanistan from starvation due to a long

"There is evidence of widespread pre-famine conditions due to a severe food crisis caused by the worst drought in decades and an armed conflict well into its third decade. Without more food aid many lives could be in danger;" said Gerard van Dijk, WFP representative to Afghanistan. "Some Afghans, especially in the central parts of the country, have reportedly eaten poisonous grass that caused paralysis and many displaced pedple in the northern provinces have been eating meals of locusts mixed with animal fodder." Because of soaring needs in Afghanistan WFP stepped up food distribution under a \$76-million operation that was originally planned to help feed 3.8 million people until March 2002. As the food stocks for this operation will be exhausted much sognet, WFP is launching this newa operation to help about 5.5 million potople using more than 366,000 tons of food over 12 months starting in November.

\section{Pakistan not interfering in Afghanistan:

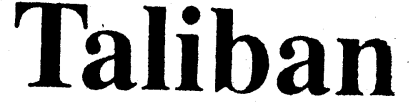

ISLAMABAD (NNi): Ruling Taliban in Afghanistan have rejected the allegations that Pakistan was extending any military support to them. Those who level such allegations are still lost in the past when pro-Pakistan organisations were active in Afghanistan. They say that geo-strategic situation does not allow Pakistan to waste its energies in Afghanistan while confronting hostile neighbour in the east.

A spokesman of Taliban goverriturent, Maulvi Abdul Hai Mutmaen told VOA that even during the days of fight against Soviet aggression. Pakistan was just a source of supply of American arms 10 the organisation fighting against the US rival.

"One will have to keep the historic background in view as to whether or not they are involved in the situation. Pakistan has a strong enemy. like India and big rival like Iran in its neighbour, it cannot afford to spend its intelligence and military energy somewhere else. This is a fact. Pakistan has never been an aggressive country during its fifty years history" Mutmaen remarked.

The Taliban spokesman said that international observers are also of the view that Pakistan is neither an aggressor nor has committed aggression. Pakistan has spent all of its intelligence and military energy on Kashmir. "The problem is that those who do not understand the issue has been viewing the Pakistan's presence form the old angle i.e. the Jihad days" he added.

"During the Jihad, the Afghan had been rendering sacrifice for the sake of Allah Alnighty. The United States had been providing military and economic assistance to the Afghans to defeat its big rival. The American themselves had not been providing these assistance and Pakistan was a source for it. For instance. now when the Russians are providing assistance to our opponents, they do so through Tajikistan" the Taliban spokesman said.

"At that time, the Pakistani intelligence and other forces were being busy in the process and the United States was bearing all the economic expenditures. Every kind of military and economic assistance was being provided by the United States and Pakistan was just a source of it. Pakistan itself was unable to directly involve itself in the issue" Maulvi Mutmaen recalled.

The Taliban official said. "in fact at that time we ourselves witnessed that hundreds of vehicles were heing loaded with weapons in Peshawar and sent to Jalalabad and from Quetta to Kandahar. But whẹn the Russians pulled out of Afghanistan and the United States stopped its assistance, some Jihadi organizations and Pakistani authorities had been enjoying very close relations, which produced adverse results".

He accused that some important weapons like Singer missiles, which the Afghan Mujahideen had obtained from Pakistan were repurchased by Pakistan from the Afghan commanders. Pakistan was purchasing tanks at scrap's prices. Let me say that the military maps of Afghanistan had also been provided to Pakistan by some of the organizations.

"These organizations and Pakistan had heen enjoying very cordial relations. These organizatlons were in power in Afghanistan before the emergence of the Taliban. Now some people tell us that military supplies were continuing to Afghanistan form Pakistan at that time. The people who are not fully aware of the Afghan issue largely name Pakisian in this regard" he remarked. 


\section{The Frontier Post}

Friday, September 7, 2001

\section{Afghan Support \\ Group meets in capital \\ ble members of Afghan society and affect those}

ISLAMABAD: Representatives of 16 countries that are financing humanitarian assistance in Afghanistan met in Islamabad this week to discuss the humanitarian crisis in that country.

The meeting on this occasion in statement said that the donor countries represented in the Afghanistan Support Group remain very concerned by the ongoing detention of the 24 aid workers of Shelter Now International (SNI).

Moreover, they are alarmed at the closing down of all offices and operations as well as the expulsion of the staff of International Assistance Mission (IAM) and Serve on August 31.2001. these organizations were active in the fields of eye surgery and the provisions of primary health care.

The closure of their offices and the confiscation of medical and other official equipment will have a very negative impact on the most vulnera-

5,200 Afghans nabbed in Zabol in 6 months

ZABOL(Agencies): Police have arrested a total of 5,280 Atghan migrants trying to sneak into the country through this castem border city since March, a source with the local police said.

Hamid-Reza Mehrabi siad that the detained Afghans were later deported after undergoing judicial proceedings. Iran is home to one of the world's largest refugee population caused by a long drawn-out war plaguing Afghanistan. neighboring

The massive intlux of Afghan refugees into Iran has, however, become increasingly burden. some to the Iranian government because of the high unemployment, low investment; as well as

- a crippling drought that has hit the country for a third consecu. tive year.

A joint program with the UNHCR has repatriated tens of thousands of Afghans amid accusations from members of the Iranian parliament that they are taking badly needed jobs away from Iranian nationals.

Mehrabi also said 23 drug traffickers were arrested and some 468 kilograms of narcotic drugs were seized. who are most in need of help.

Donor countries reiterated their demand of August 13 for an expeditious resolution of the SNI case and the release of detained aid workers. The arrest of aid workers and the closure of agencies has posed serious threat to the future of the relief work carried out by the international community for the sake of the Afghan people.

Donor countries are dismayed at the constant deterioration of working conditions for the aid community: They applauded the dedication of aid workers of all international organisations and non-government organisations in carrying out their humanitarian work for the people of

Donor countries have called upon the Afghan authorities to allow the aid community to carry out its mandate, as previously agreed on various occasions, in an enabling environment ensuring adequate conditions of security.

\section{KHYBER $M$ Taliban office damaged in bomb blast}

By Ziaul Haq

PESHAWAR: An explosive devise went off outside the Taliban office cum hospital here in the posh area University Town, causing partial damaging of boundary wall of the office. However, no causality was reported.

"It was around 6:00 a.m when explosion occurred outside the office" informed Maulvi Abdul Haq an official of the office. He said, the boundary-wall of the office was partially damaged. No person was hurt, he added. When inquired whom they blame for this act, he replied, at the moment it was not possible to name anyone.

"What message they want to give through this act, we don't know" he maintained. He told, in the office, they treat those ailing Afghans. who were referred to us from Kabul. When explosion took place, there were 25 patients in the hospital, he informed.

However the Police Station University lown lodged the First Information Report (FIR) and started the investigation. An officer in the Police Station informed that the matter was relerred to bomb disposable squad to ascertain the nature of the device (dynamite or other explosive material). No one ivas charged in the lilR, he added.

It is worth mentioning here that explosion took place outside the Taliban office, when trail of eight aid workers four are German, two American and two Australian arrested in connection of allegation for preaching Christianity in Alghanistan has begun 


\section{The Statesman Friday, Seplember r, 2001}

\section{UNHCR arranges 4,500 tents for displaced Afghans \\ Statesman Report}

PESHAWAR

UNHCR has arranged The

tents

tents for providing shelter to 27,000 drought, hunger and war-affected people of the northern and central parts of Afghanistan.

A press release issued here said that Yuasaku Hanyu, the deputy chief of the UNHCR mission in Afghanistan, on Tuesday presented 3,500 tents to the representatives of the International Organisation for Migration, International Rescue Committee and Peace Winds of Japan in Mazar-iSharif.

The UN refugees agency

\section{Riyadh rejects mediation calls}

From Our Correspondent

RIYADH: Saudi Arabia has rejected calls for mediating with the Afghan government the release of foreign aid workers associated with a German-based Christian NGO called Shelter Now Intemational. The SNI staffers, detained more than a month earlier for allegedly preaching Christianity, went on trial this week.

A newspaper report claimed here on Thursday that Saudi Arabia had received requests through diplomatic channels and direct contacts from several countries and humanitarian organisations for playing a role in negotiating the release of the Western aid workers.

"But the Saudi governmen has turned down all these requests," the Gulf News reported, quoting a senior official. who requested anonymity. He argued that the relations of the Arab kingdom, one of the few nations that recognise the Taliban government, with Kabul had been strained over the Osama bin Ladin issue.

The report added that the Saudi Arabia snapped relations delivered 1,000 tents in Kabul for the people displaced in the central parts of Afghanistan.

For helping the recently returned Afghans to start afresh and reintegrate, the UNHCR would provide them with shelter and potable water.

It had already assisted 3,000 people to re-build their homes and begin the construction of 72 shallow wells.

The press release added that the UNHCR had distributed blankets, medicines, kitchen sets, tea leaves, clothes and buckets among the returnees in the northern region.

2 engines derail after collision : Two engines of

with the Taliban several years ago for "adopting a pro-terrorism policy and hosting a number of terrorists led by Osama bin Laden. Taliban still refuse to abandon this policy," the official said.

"Saudi Arabia's intervention in this case is rejected by Shariah law as Islam bans the preaching of any other religion among members of the Muslim society. As such, those foreigners who used the cover of a relief agency $t)$ preach Christianity, must he tried in accordance with the Islamic Shariah," noted the official.

The official branded the detainces as the enemies of Islam and Muslims as they had gone to Afghanistan, which is a Muslim country, to urge its citizens to convert from Islam and embrace Christianity, and exploited the poverty prevailing there.

He observed that the Taliban had provided those missionaries with a fair trial and if they are found guilty, they will undoubtedly be hanged according to the Islamic Shariah. "The same penalty will be applicable to the Afghans who converted from Islam to Christianity if they refuse to come back to Islam."
Pakistan Railway collided here in the congested Nauthia area here.

According to details, the engine of Khushal Express was on its way to the locomotive shed when another engine appeared on the same track coming from the shunting yard.

The engines bearing 8036 and 8305 numbers collided in Nauthia and both were reportedly derailed.

The railway officials said that the drivers of the both the engines were suspended.

The engines were damaged but there was no causality. One of the engines had recently been brought from Risalpur factory. 


\section{The Nation}

SEPTEMBER 7, 2001

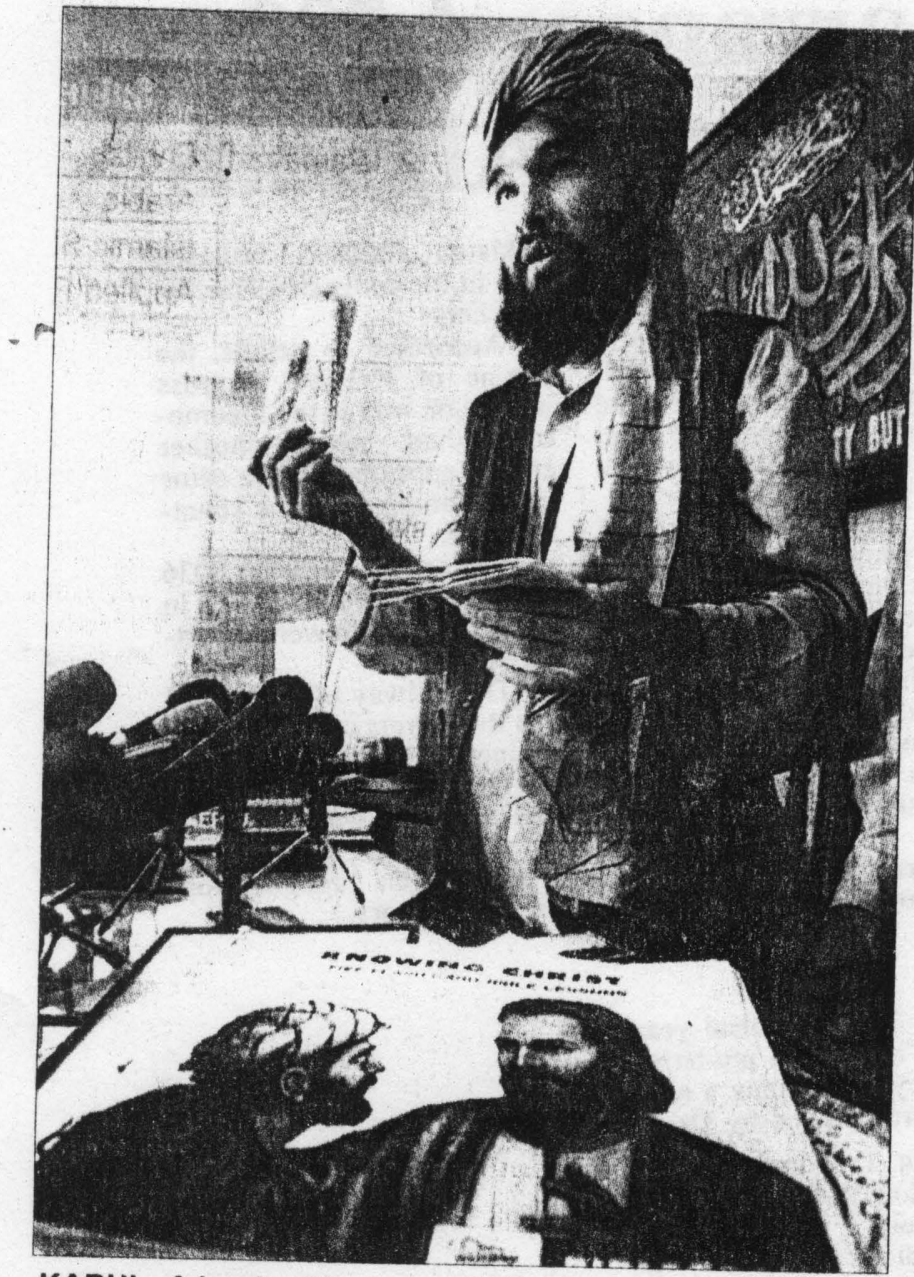

KABUL: A book with a cover picture of Jesus Christ with a follower (bottom) is displayed as Syed Rahmatullah Hashmi, a Taliban foreign ministry official, show to the press here on Thursday.-AFP

\section{Wakil promises aid workers 'open trial'}

\section{Taliban threaten to close Afghan skies}

KABUL (AFP) - Afghanistan's ruling Taliban militia on Thursday repeated threats to declare its skies unsafe and off-limits to international flights in protest at UN aviation sanctions.

Foreign Minister Wakil Ahmed Mutawakel said that all international flights over Afghanistan, with some 'rare' exceptions, would be stopped unless the United Nations released funds from frozen aviation accounts.
Afghanistan is one of the shortest routes for all international flights to cross from one continent to the other.

The UN Security Council has banned international flights by state-run Afghan Ariana Airlines except for humanitarian reasons as part of sanctions imposed over the Taliban's refusal to extradite Osama bin Laden.

Other international airlines are also prevented from landing in or taking off from Afghanistan.

$\mathrm{UN}$ and Red Cross planes are exempted from the sanctions along with all humanitarian and most

diplomatic flights. Overflights are not affected.

Revenues generated from overflight fees and aviation taxes are deposited in Taliban accounts which have been frozen as part of the sanctions.

'Our goal is not to ban flights or UN flights, our goal is that the funds that are being paid for overflights should be given to our government,' Mutawakel said.

'Because th: money is seized so there is no way out - we have to ban their flights from Afghanistan.'

Meanwhile, a minister of Afghanistan's Taliban militia Thursday promised an 'open trial' of eight foreigners accused of preaching Christianity as the Supreme Court met for the third day behind closed doors.

But senior oflicials with the Islamic militia issued conflicting statements as relatives and diplomats representing the two Americans, two Australians and four Germans waited desperately for answers.

Foreign Minister Wakil Ahmed Mutawakel said the foreigners would appear in court during the 'second phase' of the trial, when diplomats, relatives and journalists would also be allowed to attend. 'That might take place very soon ... it will be an open trial,' he told journalists at a press conference here.

'The process of scrutinising the investigation files is continuing in the court.
He said the move would affect ee for the Red Cross flights, which ferry crucial humanitarian aid into the war-torn country, one of the poorest in the world.

We are considering banning international flights over Afghanistan, the foreign minister told a press conference.

The sanctions are not only affecting us but also the international community in general because 


\title{
THE WASHINGTON TIMES \\ September08,2001 \\ Pakistan razes homes to drive out Afghans
}

\author{
By Rory McCarthy
}

THE WASHINGTON TIMES
PAGHMAN, Afghanistan -- Pakistan's military government has begun bulldozing the
homes of Afghan refugees and forcing them back to a drought-stricken, war-torn
homeland they fled

years ago. In the past two months, more than 11,000 Afghan refugees have been forced out of the camps in northern Pakistan.

Some have fled the region entirely, like the 438 refugees recently stranded on a ship that was denied entry into Australia. But most have been forced back to Afghanistan, to villages destroyed during years of civil
war.

Rahimullah Habibi fled with his family from the advancing Soviet army as it invaded

They settled in a refugee camp in the border area of northwest Pakistan and over time accumulated savings to build a small mud-brick home, only to be forced out by Pakistan's army.

"They came and they destroyed my home [in Pakistan] with a bulldozer," Mr. Habibi said. "My house had eight rooms and everything was destroyed, just ruined.

"They told us we should repatriate. They call it 'voluntary repatriation,' but that is a lie. It is false. They gave us no choice."

He spoke outside tattered canvas tents set up in the ruins of the family's former village, expressing fear of life under Afghanistan's brutal Taliban regime.

Conditions in Afghanistan rarely have been worse than they are today: Civil war still rages in the central and northern provinces, three years of drought have dried most farmland to dust and, with little health care or education, poverty worsens by the day. Pakistan's military regime has made no secret of its distaste for Afghan refugees.

In November, Pakistan closed its border crossing in the Khyber Pass to new arrivals, a harbinger of the present campaign to force refugees to leave their adopted homes. Last week, authorities loaded 132 refugees from the squalid Jalozai camp, near Peshawar, onto a bus and told them they were being moved to a better camp nearby. Instead, they were driven to the border and forcibly evicted.

In Mr. Habibi's case, what happened was slightly less direct. He and his family first came to the Nasir Bagh refugee camp near Peshawar two decades ago, while a war raged against a Soviet occupation army.

In the camp area, "there was nothing, no water," he said. "Whatever savings we had, we spent. We found jobs doing laboring work."

Eventually, the family saved enough money to buy a house and set up a transportation business, running buses between the Pakistani cities of Peshawar and Lahore.

Every year, family members discussed whether it was time to return to their home in Afghanistan. And every year they decided to stay in Pakistan, where at least there was 
work and a school nearby for the boys, although not the girls.

Then in July, Pakistan's government decided to clear the Nasir Bagh camp to build a housing project.

The bulldozers came and no alternative land was offered to the refugees.

Along with four other families totaling 30 persons, Mr. Habibi rented two trucks at $\$ 100$ each.

They all set out for home with what remained of their belongings.

The Office of the U.N. High Commissioner for Refugees gave each family the equivalent of $\$ 100$, a plastic sheet and 650 pounds of wheat.

They drove for eight hours from the border to Afghanistan's capital, Kabul, then further west. They passed che kpoints where the Taliban regime has hung streams of cassette tape from poles as a warning that music and dancing are banned.

The family finally arrived in Paghman, where they once had a large house with a green field and their own well. Nothing was left but rubble and a mud wall riddled with bullet holes.

"When we arrived, everybody was crying. Everything had been destroyed," Mr. Habibi said.

He now must rush to build a new house before the winter cold makes tent living unbearable for his children.

Even so, he is luckier than some.

Among the refugees deported last week were elderly women and young children, some of whose families were still in Jalozai and came from a village in Sang Charak on the northern front lines.

They were all from the Tajik ethnic minority, which is loathed by the ethnic Pashtuns that dominate the Taliban regime.

The Office of the U.N. High Commissioner for Refugees described the move as "incomprehensible" and immediately suspended a screening program it has run in Pakistan to look at new refugee arrivals.

The U.N. agency believes thousands more Afghans have been deported in similar ways in recent months.

Pakistan, which says it is struggling to cope with the burden of the 2 million Afghans now living in Pakistan, denies it is forcing long-term residents to leave.

"Only the newly arrived Afghans were deported," said Mohammed Riaz Khan, a Foreign

Ministry spokesman.

Peopale Daily

Saturday, September 08, 2001

Heavy Fighting Erupts in Northeastern Afghanistan

A series of multi-prong attacks has been launched by the Alghan United Fiont in the northeastern Takhar province in a bid to lay siege to Taloqan, the Taliban-controlled provincial capital, a report reaching here said on Friday, September 7.

Quoting an official of the Afghan United Front, the report that "vast areas were captured from Taliban forces in Chal and Eshkamesh districts and heavy casualties inflicted on Taliban." 
It's estimated that more than 130 Taliban fighters were either killed or injured, and more than 70 were captured.

The Taliban has not confirmed the reports yet, but Payam-e- Mujahed news service from inside Afghanistan in its daily bulletin said that large quantities of arms, ammunition and several vehicles were captured.

\section{SATURDAY, SEP'TEMBER 08, 2001 THE TIMES OF INDIA}

\section{EU aid commissioner to visit Afghanistan, Pakistan}

BRUSSELS: Poul Nielson, the European Union's humanitarian aid commissioner, goes to Afghanistan and Pakistan next week to inspect Afghan refugee camps, and meet members of the Taliban, the $\Lambda$ gighan opposition and the Pakistani government.

The September 12-19 trip is designed to show the EU's "continuing support for the Afghan people", the European Commission, the bloc's executive arm, said on Friday. Some 700,000 Afghans have fled their homes and are in camps on the fringes of cities and over 4.5 million are in neighbouring countries, making Afghanistan's refugee population the biggest in the world, the Commission said in a statement.

"A whole generation of Afghans has known nothing but conflict and drought," said Nielson.

"The European Commission has been providing substantial, continuous relief... I am going there to ensure the continued flow of aid to those in need."

Nielson is due to meet Pakistan's foreign minister Abdul Sattar and the minister for refugees Sarfraz Khan.

$\mathrm{He}$ is also scheduled to meet representatives of Afghanistan's Northern Alliance opposition and the ruling Taliban, which has imposed a unique and extremely strict brand of Islamic law in Afghanistan.

The EU has been severely critical of the Taliban for its treatment of women, minorities and foreign aid workers and its religious intolerance. Brussels has also criticised Pakistan for supporting the Taliban.

On Thursday France voiced deep concern on Thursday at attempts by the Taliban to hinder humanitarian aid agencies working in Afghanistan, where some five million people depend on food aid, according to the UN's Food and Agriculture Organisation and the World Food Programme.

Nielson said delivering relief supplies was "not an easy task" for the non-governmental agencies (NGOs) through which the EU channels its aid.

The Commission said the 15-member EU has provided some 400 million euros (358 million dollars) in humanitarian aid to Aighanistan.

It said Nielson would use his trip "to underline the humanitarian principles to which all parties in the conflict should adhere ... to allow free humanitarian access to people in need and the obligation to guarantec the security and independence of humanitarian actors as they carry out their tasks". 


\section{Businessmen misused incentives: Musharraf}

\section{Addresses Workers Welfare Board; seeks guarantee against smuggling to open land route to Afghanistan, CARs; slams barring of women from polling votes and contesting polls}

\begin{abstract}
Behroz Khan
PESHAWAR: President Gen. Pervez Musharraf on Friday said that misuse of the incentives by businessmen was not only the reason behind the collapse of GadoonAmazai Industrial Estate but the same was now obstructing trade activity with Afghanistan and Central Asian States.

"Give me the assurance that concessions will not $b^{\prime}$ misused to encourage smuggli, ${ }_{t,}$ we are ready to allow the land route trade with Afghanistan and the Central Asia," said the President while addressing a function at the Nishtar Hall Peshawar in the evening.

President Gen. Pervez Musharraf was the chief guest at a ceremony organised by Workers Welfare Board NWFP in which allotment letters of 200 family flats were handed over to workers and Jahez Fund and scholarships were distributed among their children.
\end{abstract}

The comments came in reply to the points raised by President Sarhad Chamber of Commerce and Industry Khizar Hayat in his speech, who said that land route trade was allowed with neighbouring countries from Sindh, Balochistan and Punjab, but only Frontier has been deprived of the opportunity. The president along with his wife, Sehba Musharraf, cabinet members is on a two-day visit to the province. NWFP Governor, Syed Iftikhar Hussain Shah and Corps Commander Peshawar, Ehsanul Haq, were accompanying the president.

The development of Gawadar Port, the president said, was part of the long term planning of the government to pull trade and business from Afghanistan and CAR to turn the country as the centre of business activity in the region. Gen. Pervez Musharraf said that restriction on certain items has been lifted and further improvement would be brought in the trade policy in regard to restoration of trade links with these countries.

"We are not ashamed of any thing. This is a matter of shame for those involved in the smug. gling of items back to the country through skipping export duties. Be that the trade with Afghanistan or the exploitation of duty free im- port of machinery and raw material for the collapsed GadoonAmazai Industrial estate," remarked the President.

He was reacting to a single man's remarks from the audience, who shouted "shame, shame" during Khizar Hayat's speech, after the SCCI president mentioned about the cold shoulder attitude of Federal Minister for Trade and Commerce Razaq Dawood. The SCCI president said that no action has been taken on complaints made by the business community of the province in regard to opening the land route trade with Afghanistan.

Gen. Pervez Musharraf assured that details of the ban items would be reviewed and the complaints would be removed. "Either remove him, if you don't like someone, or trust those, who want to deliver for the betterment of the country", the president said. 


\section{Our correspondent}

JALLOZAI, Nowshera: Fifteen Afghan families, rejected in the ongoing screening process, have been trucked in the NLC vehicles and sent back to Afghanistan under the supervision of Afghan commissionerates officials.

During the ten days the screening teams have interviewed a total of 329 families. Out of this 243 families were declared as genuine, while the 86 families were rejected completely. All the 243 were transported to a much-established Shamshatoo camp near Peshawar. In Shamshatoo camp the refugees are provided full facilities including food, shelter and education and health facilities.

On the other hand the government the other day sent 15 families out of the total rejected 86 back to Afghanistan. All the fifteen families were first taken to the security office and kept there for about three hours.

Area commander told this scribe that after failure in the screening test, as per policy, these families were supposed to be sent back to Afghanistan

within 24 hours. These people could not be set free in the camp otherwise they would run away and create problems for the security officials. Most of the refugees after failing in the screening test prefer to go back to Afghanistan voluntarily.

It is to be noted that contrary to the expectations of the UNHCR the screening process continued is very slow for the last ten days.

When the screening team leader Vicky Tannant was asked. that the screening process was too slow and if it remained so the duration of one year would lapse on interviewing 12,000 families. She said in future they would try to speed it up as it was the beginning and the both the officials and refugees are not familiar with the process.

Meanwhile, the NWFP gov- ernment has removed the Additional Commissioner of Refugees Rehabilitation Col (Retd) Abdul Hafiz from the screening pro. gramme. Hafiz has attained the age of retirement and the gov: ernment was also suspecting that he was safeguarding the interest of UNHCR instead of the government of Pakistan.

Three months back an US na. tional Afghan lady, who donated some 1,800 tents for the refugees, accused $\mathrm{Col} \mathrm{Hafiz}$ of stopping her from distributing the tents among the genuine and forced her to give them to the corrupt refugees and area commanders.

According to some reports Col Hafiz was also involved in the embezzlement of millions of ru. pees along with the representatives of the refugees and area: commanders. Presently, secrets: agencies are also investigating:
the case.

It is worth mentioning that the records of donations and relief goods provided by the different organisation during last year is destroyed by the area commanders.

A man, whose names is stated to be Raja, has donated 3,000 tents to the refugees of Jallozai camp, but not a single tent was provided to the refugees. It is very interesting that the former area commander and representa. tive of the camp are not willing to give the address or telephone number of the Raja.

\section{Aid workers'}

\section{trial in recess for} weekly holiday

KABUL: The trial of eight foreign aid workers detained in Afghanistan on charges of preaching Christianity went into recess for a weekly holiday i.e. Friday, prolonging the agonising wait for families and diplomats.

The Supreme Court is due to resume the trial behind closed doors on Saturday but it is still unclear when the two Americans, two Australians and four Germans will be asked to appear.

Diplomats and family members were holed up at a United Nations guesthouse in war-torn Kabul, while government offices were closed and officials from the fundamentalist Islamic militia went about their Friday prayers.

US Ambassador to Pakistan Wendy Chamberlain joined her counterparts from Australia and Germany in making the request, which has been a consistent US demand, by letter. "The letter asked for a commitment from the Taliban that the detainees would have legal representation and interpreters at the trial and that consular access would be resumed," said State Department spokesman Richard Boucher. "So far there's been no response."

French foreign ministry spokesman Francois Rivasseau said in Paris the case was another example of the Taliban's "hindrance" of vital relief organisations despite a humanitarian crisis in the country. "Even though the aim of such organisations is to reduce the suffering of victims of conflict, they are running into growing hostility from the Taliban authorities," he said.

"This hindrance of their role is making an already catastrophic situation worse." Diplomats said the relatives, parents of the two American women and a cousin of the Australian man, were allowed to meet the prisoners at an undisclosed location Thursday.

"The parents held an hour-long meeting with their daughters and also saw other detainees and passed on to them whatever they knew about the beginning of the trial," US Consul David Donahue told AFP Friday. "I think that their (the relatives') biggest concern is that there is nothing that is said or reported that would in any way offend the local authorities or make them less positive and helpful in resolving the issue."

United Nations special envoy to Afghanistan Francesc Vendrell to 


\section{The Frontier Post Saturdays Soptember 8, 2001}

Thursday met Taliban Deputy Foreign Minister Abdul Jalil and requested the prisoners be allowed mote frequent visits from doctors and relatives, UN officials said.

He told reporters that diplomats and relatives should be allowed to observe the trial. "I hope the trial is open. It should be a public trial to show the world that it conforms to norms (of justice)," he said. - AFP

\section{Taliban attack}

\section{repulsed in}

\section{north of Kalui}

ISL AMABAD (NNI): Two attacks by the Taliban south and east of Bagram air base have been repulsed by the opposition United Front, a spokesman for the opposition northern alliance has said.

r. In a recent pre-dawn attack. the Taliban succeeded in capturing three outposts, but they were forced to retreat when the rival forces launched a counter attack. said spokesman Mohammad Eshaq in a statement, received here Friday.

Two days later, a similar attack by the Taliban was repulsed in Shokhi, east of Bagram air base.

Failing to gain any ground in Takhar, the Taliban are trying to test the resolve of the Mujahideen north of Kabul. North of Kabul is the second major fighting front against the Taliban militiamen," Eshaq. said.

said, The attacks might also be aimed at forcing the opposition alliance from the Shemali Plateau, who have gone to the North to fight in Takhar, back to their home base. Due to shortages in manpower and logistics, the Taliban are not able to launch sim : ? taneous attacks against the rivals in both Takhar and north of Kabul," the spokesman said.

\section{Peshawar blast}

$T$

HE bomb explosion outside the Taliban's political office in the posh University Town of Peshawar; an area that houses mostly foreign aid workers, carries a potential overtone to it that should set the authorities worrying. Following the UN sanctions imposed on Taliban-ruled Afghanistan, the office had been converted into a hospital for casualties from the civil war. When the explosion occurred, more than 80 patients were reportedly in the hospital complex. Fortunately though, no loss of life has been reported. Though the hand and the motivation behind the blast are yet to be identified; one guess is that it is linked to Afghanistan's fratricidal war between the Taliban and their Northern Alliance opponents. Unless proved otherwise by an investigation, that would remain very much a strong possibility, bringing with it the perturbing tiding that the Afghan civil strife has at last hit our soil as well.

Already, the country is enmeshed in innumerable difficulties and problems of its own, with the bad law and order situation being at the top. Lawlessness, violence and terrorism are not only playing havoc with the lives and properties of our people, they are also hurting the efforts for economic revival. For its economic recovery, the country needs the vitality of massive investments, especially foreign. That support is not forthcoming, mainly due to the ugly law and order situation. Were the Afghan civil strife also to spill over to this land, the entrepreneurial class would be completely frightened away, undoing all the calculations for the country's economic rejuvenation.

Even otherwise, the civil strife in Afghanistan is creating untold difficulties for Pakistan. For its friendship with the Taliban, its people are being made to pay a heavy price in diverse ways. Apart from a besmirched image internationally, domestically they are being confronted menacingly by a spiralling religious extremism, fuelled by the example from across the Durand Line.

Should the fratricidal fracas of the Afghans spill over to Pakistan's soil, that would multiply our travails on many an account. The country could be engulfed by a furious wave of violence and bloodletting; lives and properties would be exposed to greater insecurity and perils; the process of economic development would become all the more uncertain; and Pàkistan's image abroad would get a still severer battering. That eventuality has to be averted at all costs.

The blast must, therefore, be thoroughly investigated to identify the perpetrators. If it turns out, as suspected, to be a spillover of the Afghan civil strife, every measure should be taken to nip it in the bud effectively. In no event should our soil be allowed to become the battleground for the wars of others. 


\section{The Fröntier Post saturday, September 8, 2001}

\section{Islamic NGOs replacing Western
in Kabul}

KABUL (Agencies): Before giving away five freshly baked pieces of bread, Atta Mohammed carciully studied the soiled white card offered up by a small boy. The bread was cooked at a bakery run by Al-Rasheed Trust, the largest of several new Islamic charities to open in Afghanistan. The boy, Hamid, is the son of a government worker who likely earns less than $\$ 4$ a month.

"In just four months, Kabul's Jañdscape has changed: White signs emblazoned with the name of the Pakistani-based Al. Raslieed Trust have suddenly appeared on every other street. Most aid reoipients ate meagerly paid govermment servants.

In an advertisement beseeching the faithful for money, Al-Rasheed Trust asks: "When will the Islamic world wake up for Islam?" "If there exists just one Islamic non-government organization (NGO), then there is no need for other NGOs to come here," said Naim Safi of the Taliban Information Ministry.

After five years of virtual Taliban control of Afghanistan, it is only now that Islamic-charities have begun to arrive here in significant numbers. Their proliferation coincides with an attempt by the Taliban to impose comtrols on international - mostly Western - aid organizations.

Thís year, the Taliban have ordered every aid organization, including the

Uniled Nations, to submit a list of Afghan and foreign employees; to detail their projects; and to explain their finances. The Taliban also have threatened to take over some groups and shut
down others.

Recenlly, authorities closed three Western aid groups on charges of preaching Christianity - a serious crime in this Muslim nation - arresting eight foreign and 16 Afghan workers. Tyo of the foreign aid workers now on trial are Americans. The arrests of the Afghans terrorised other local aid workers, who fear they will be accused of flirting with Christianity - a crime that can carry the death penalty.

Some Western aid workers worry the Taliban are trying to force out international aid groups. "If they can bring in the Islamic NGOs and kick us out they would be happy because we are a pain, we complain about human rights, we are witnesses," said an international aid worker, who spoke on condition of anonymity for fear of reprisals.

Some of the new Islarnic organizations are secretive and refuse interviews: AlRasheed Trust has links with the militant group Jaish-e-Mohammed and its radical leader, Masood Azhar is one of three. men freed from Indian jails in 1999 in exchangc for a hijacked Indian plane and. its passengers. Two other groups - Al

Akhtar Trust and Al Mujahedeen Trúst are Pakistani-based NGOs

Al Akhtar is building mosques an repairing a military hospital fn Kandahar. the Taliban headquarters. It is building a university for men and a mosque for women. But no schools will be built for women, says Mohammed Mazhar, the Pakistani head of the organization: Al Mujahedeen Trust was started by the leader of Jamiat Ulemae Islam (JUI), Fazilur Rehmian, who has campaigned in Pakjstan against intermational aid organisations, accusing them of flouting tradition and trying to liberate women.

When there is Wafaa Organization for Humanitarian Work; run on donations from Arab countries, particularly Saudi Arabia. The head of the organization refuses to speak to women. It operates health and education programs in Kabul.

Not all new Islamic charities espousc the same strict version of Islam practiced by the Taliban. The Canadian Relief Foundation, an Islamic group based in Canada, came here last November.

"The whole idea is to bring NGOs representing the Muslims of North America and Europe to Afghanistan." said Fadil Dillman, a Canadian who heads the Canadian Relicf Foundation in Kabul. "I think this will lead really toward the improvement of the image of 


\section{The Frontier Post}

Saturday, September 8, 2001

NDIMA calls for

convening

PESHAWAR (PPI): National Defender Islamic Movement of Afghanistan (NDIMA) has rejected the Taliban government at Afghanistan and demanded an emergency Loya Jirga under the leadership of former King Zahir Shah.

"Loya Jirga is the only solution to the Afghanistan problem and the Afghans have the right to convene an emergency Loya Jirga according to their traditions," said by Shan Bacha Shinwari, chairman, NDIMA while addressing a seminar on 'practical ways for convening Loya Jirga" here al a local hotel on Friday.

The seminar was largely attended among others Atghan leaders by Syed Ishaq Gilani, Pir Haidri, Prol. Alticullah Pachwak, Siddiqullah Mujaddai, Imami Ghawri and Darya Khan Afridi.

Shan Bacha Shinwari, strong supporter of Rome Peace

Process, said on this occasion

\section{Afghan illegal imigrants jailed}

GENAVEH (Agencies): Twenty seven Afghan and one Iranian migrants have been jailed in this southern city of Iran after they failed to pay the cash fine imposed on them, an informed source said.

"The detainees, arrested while heading for Kuwait aboard two boats, were arrested Wednesday night, tried, and sentenced to. pay one million rials in cash fine," the unnamed source said. adding, "they were sent to jail as they failed to pay the fine."

A joint program with the UN High Commissioner of Refugees has repatriated tens of thousands of Afghans amid accusations from members of the Iranian parliament that they are taking badly needed jobs away from Iranian natıonals. that the people of Afghanistan have ho more time to waste in wars now he appealed this scaltered nation to become unite and solve all their problems through traditional Loya Jirga.

The chairman asked on this occasion to the neighboring countries to help the Afghan people in solving their 23 years long dispute and put an end to the forcign interference in the Afghan problem.

Pir Syed lshay Gilani said while addressing the seminar that for the establishment of a national Islamic government in Afghanistan the people of Afghanistan should forgot the past grievances and enmitics and might be united for this sacred cause.

He said that wars have given them only poverty, disease and deaths now he said that it was the proper time to solve the problems though table talks and through traditional Loya Jirga.

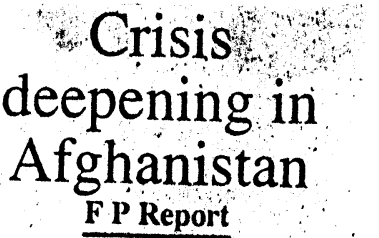

PESHAWAR: The Office of the UN Coordinator for Afghanistan has prepared an update on the plans and needs of the assistance community to respond to drought, conflict and displacement. in Afghanistan. Human suffering in Afghanistan thas largely outstripped the capacity and resources of the aid community due to both the magnitude and the depth of the crisis

The catastrophe is a gradually cumulative hunjanitarian disaster of enormous proportions. Confifet, drought, dis-. placement, grinding poverty and human rights abuses add up to a deadly combination.

Despitc a well thought out strategy adopted last ycar, it has been impossible for the aid community to respond to the extent necessary in all areas of the country. The aid community has not hes the resources, the capacity...... sonnel to do so.

\section{The Statesman}

Saturday, September 8, 2001.

\section{Afghan leaders stress Loya Jirga}

Statesman Report

PESHAWAR: Citing foreign interference as the main reason for the on-going civil war in Afghanistan, the chief of the Milli Mubazireen Afghanistan. Shan Bacha Shinwari. Friday said that the Afghan people should themselves decide the fate of their motherland.

Addressing a mecting of various Afghan groups at a local hotel, Shan Baacha said that Loya Jirga was the only way to restore peace in the war-ravaged country.

The Mill Mubazireen chic urged the neighboring countries to make efforts for the establishment of a national government in Kabul, which was acceptable to all the groups.

He emphasized that a real representative government would also be in the interest of all the neighboring countries.

He observed that the continued war had gifted the Afghans with hunger, poverty and deprivation, adding millions of the countrymen were forced to take refuge in the neighbouring countries where they were living a miserable life.

The Afghan leader called upon the warring factions to shun their differences in the larger interest of their people and work collectively for the rehabilitation of their war-ravaged country.

Another Afghan leader, Pir Syed Ishaq Gilani in his address said that presently 45 movements were active in Afghanistan and almost all the leaders were striving for restoration of peace in the country. He maintained that the Afghan people were passing through a critical juncture of their history as poverty and war had shattered their hopes, adding the continued war had played havoc with the economic and social structure of the country.

He also stressed that Loya Jirga should be convened so ihat all the Afghan groups could si together and solve the decadelong issuc.

Imami Ghauri, Sadiq ul Mujadedi. Ajmal Suhail. Sarira Sharif, Altiqullah and other Afghan leaders also spolke on the occasion 
The urged upon all the warring groups to give up their difference and Kelp restore peace in their country.

They also backed the convening of the Loya Jirga and said that in the present circumstances it was the best option to negotiate and settle the issue once for all.

\section{The Statesman}

Saturday, September 8, 2001

\section{Businessmen want land route export to Afghanistan \\ By F.M. Shakil}

PESHAWAR: The local business community belicved that an unrestricted land route export to Afghanistan was much more benclicial for the NWFP than the cultivation of tea and commissioning of small hydro stations in the province.

During his visit to the provincial metropolises on Friday, a group of key industrialists have reportedly briefed President General Pervez Musharraf on this count.

The president was understood to have informed that the local businessmen have felt aggrieved over the persistent denial of the federal government to budge over the land route issue.

The

president was informed that apart from the deleterious implications of ban on the industrial and business potential of the province, the stubborn attitude of the central government vis-à-vis land route export was going to create a sense of deprivation in the local population.

$A$ random approach to a number of business and indus. trial luminaries revealed that the local business community did not see eye to eyc with the government on its hydropower policy.

Given the end-result of WAPDA's bickering with the NWFP on the net hydropower profit, most of the businessmen were averse to

the establishment of more and more hydro stations in the province, which they claimed would hardly benefit the local communities. The business leaders recalled that the NWFP-based business organisations had repeatedly demanded deregulation of power tariff so as to offset the impacts of petroleum deregulation.

The business community believed that the land route trade with the neighbouring countries could fetch a billion dollars annually to the government kitty.

They claimed that the ban on the land route export in one way or other had proved damaging for the local trade and industry. Being away from the only seaport of the country, they said, the land route facility was the only feasible consideration of a meaningful investment in the NWFP.

Most of the local industrialists think that the establishment of Export Processing Zone (EPZ) at Risalpur would be a futile exercise unless the government withdraws restriction on export to Afghanistan.

Hinting at the growing cxport to the neighbouring country mostly from Iran. China and Far Eastern countries, they lamented that the lopsided government policies have kept them from a healthy competition.

The official circles do not think that the businessmen plea has any valid ground. They fear that the goods sent through the land route arrangement to Afghanistan often smuggle back in the local market.

This was precisely the reason that the federal government had also turned down a set of safeguards suggested by the NWFP industry department and twice relaxed the procedure to include some more items in the exportable item list.

These measures have not fulfilled the demands of the local industry. The business leaders did not approve of these steps and termed them as cosmetic, calling for the unbridle export through the land route to Afghanistan and onward to Central Asian Republics.

"On the one hand the government is encouraging investment in Afghanistan, planning to establish utility stores in major cities of the war-torn country and spending billion of rupee on the improvement of infrastructure but on the other hand they persistently denied land route export facilities to the local industrialists and businessmen," ręmarked an industrialist. 


\title{
The Statesman
}

\author{
Saturday, September 8, 2001
}

\section{Pakis \\ From Nasir Jaffry}

ISLAMABAD: Pakislan Friday assured to extend all possible assistance to the World Health Organization (WHO) in its efforts to eradicate poppy cultivation in the war-shattered Afghanistan.

"We will certainly help the UN body in its efforts to cradicate poppy cultivation in nighbouring Afghanistan as the drive will have positive impact in Pakistan as well in terms of the elimination of trafficking and consumption of drugs," Food and Agriculture Minister Khair Muhammad Junejo told The Statesman here.

Junejo, who had a mecting with a five-member delegation of WHO, headed by its regional Director Dr. Hussain A.Gezairy, said: "We have already reached an understanding to the effect with WHO".

The UN body wanted Pakistan's assistance and technical know-how in the war on poppy cultivation in Afghanistan and crop substitution through provision of seeds to farmers in the war-hit country.

When asked about the implementation strategy to provide assistance to WHO, he said officials in his ministry would shortly hold series of mcetings with the WHO representative in Pakistan to finalise all modalitics as well as ways and means to commence assistance process.

Pakistani experts will also organıse kind of technical courses for the farmers under aegis of the WHO. cnabling then! to

\section{$K_{\text {HYBER }} M_{A I L}$}

\section{September 08, 2001}

\section{France urges Taliban to \\ stop hindering aid work \\ ISI.AMABAD (NNI):} grow altcrnate crops, Juncjo said, adding that the programme will be launched shortly.

Asked what types of seeds would be provided to the farmers, the Junejo said the ministry would provide seeds for alternate crops and vegetables to WHO, which would be distributed among the farmers in Afghanistan

He said he told the Regional Director of WHO that his ministry would also coordinate with the UN body in reaching farmers of the remote arcas for provision of health services, adding that farmers health and their productivity are closely connected and have deep bearing on each other

Referring to country's agriculture policy, he informed Gezairy that it primarily focused on growing of hygienically sound agricultural products. He said corporate farming was a step towards standardization of agriculture and would have far reaching impact on human health.

The minister maintained that corporate farmers also enjoyed facility of using information technology and other hi-tech methods with better management, enabling them to make optimal use of resources.

Asked if Pakistan's assistance to the farmers in Afghanistan would not hamper in view of UN sanctions on that country, Juncjo said that the assistance fell under jurisdiction of humanitarian activities. adding that the assistance will be provided to the farmer under the acgis of WHO.
France has expressed its (leep eoneern orer ditticullies of aid workers in Alehanistan and called on the laliban to stop hindering the actions of the agencies and humanitarian I:gos.

"The trial in Kabul of sev. eral Aighan and foreign members of the NGO Sheller now reflects the in which the N(jO's are forced 10 lyork in Alghanistan," a French cmbassy Islamabad statement quoted french Foreign Ministry spokesman as sayang.

"Whereas the objective of the NGO's is to alleviate the suffering of people affected by the continuing fighting, they lace growing hostility from the Taliban authorities. increasiligl! difiicult climatc 


\section{The Nation SATURDAY, SEPTEMBER 8, 2001}

\section{UN warns Taliban of human cost to ban flights}

\section{By Javed Rana}

ISLAMABAD - Linited Vations on Priday in sharp reaction to the Taliban militia's threats to han UN flights amid controversy of the detention of foreign aid workers said, "flight operations is crucial to maintain urgently needed humanitarian assistance to the Afghan people."

The latest warning by UN is being seen as an attempt to convince Taliban militia that any move to ban UN flight operations to Afghanistan entails a heavy risk of cut-off of major source of food and medical supply to the worst drought hit people of war torn country.

An announcement by the Office of the United Nations Co-ordinator for Afghanistan said, "The service provides essential transport for staff of the United $\mathrm{Na}$ tions, NGOs, donors, and highlevel officials. In late August, Flight Operations ferried a delegation of high-level Pakistani officials to Kabul, Herat, Mazar and Jalalabad so that they could witness first hand the severity of the situation in Afghanistan and the magnitude of international assistance.

The Pakistani mission characterised the visit as extremely productive and said that they benefited greatly from the visit to the

camps for displaced persons in Afghanistan".

Since 1991, the Office of the Co-ordinator has been responsible for UN aircraft operations in support of United Nations activities in Afghanistan. The aircraft constitute a most reliable air link to Afghanistan and have a 100 per cent safety record during the entire duration of their operations, the announcement added.

The operating base for the aircraft is Islamabad. Flight Operations have flown approximately 60,000 passengers and transported almost 1,600 metric tons of hu- tratrilatiati cafgo ith its terryedf operation.

It runs regular flights to all major airports in Afghanistan, Dushanbe, Tajikistan and other lociations throughout the region as required, the statement observed.

UN Flight Operations are indispensable to United Nations work in Afghanistan, particularly its humanitarian operations, because of the topography and poor infrastructure of the country. At times, various areas are almost entirely inaccessible except by air. Due to terrain and poor roads, other areas are much farther, than they appear on the map:

For example, to reach Mazar from Islamabad would require

five days of driving -one way. Morcover, in initial emergency operations, such as those in response to earthquakes, flights are the only way to get in, staff and essential supplies when they are needed, the st th ement said.

Apart from ilying the normal monthly schedule to various destinations inside Afghanistan, Flight Operations also undertakes relocations, relief flights, and medical evacuations. In case of a life threatening accident Flight Operations either scrambles a stand by plane or dixerts scheduled flights to the nearest usable airstrip to carry out a medical evacuation to a hospital in Pakistan.

In January this year, Flight $O p$ erations saved the life of an Afghan de-miner, when a landmine blew up in his face.

Without the timely rescue, the de-miner would have died, the statement recalled.

The task of Flight Operations is eased by the excellent co-operation extended by the Government of Pakistan, including the Civil Aviation Authority, and local allthorities in Afghanistan. They provide various facilities, includ. ing clearances and landing permission, even on short notice, the stitcment concludes.

\section{Kabul hospitals face shortage of medicines}

\section{From Our Correspondent}

PESHAWAR - The tough UN sanctions are having negative effects on every aspect of the Afghan society. The hospitals of the country are faced with acute shortage of medicines, including life-saving drugs.

According to credible sources in the hospitals, particularly those situated in the capital city of Kabul, due to shortage of medicines, the patients are being given half of the prescribed doze.

For the poverty-ridde'n population of Afghanistan, it is increasingly becoming difficult to get medicines, and now it is required to buy most of them from the open markets on inflated rates, added the sources.

The Charsad Bistar Hosptal (400-bed military hospital) in Kabul, treating a majority of the Taliban injured in the war, is experiencing a deficiency of drugs as well.

Due to the UN sanctions, it has become extremely difficult for the country to meet its raw material needs.

An Arab charity organization has sent some assistance in the form of laboratory equipment and medicines to Kabul-based hospitals a feiv days back, yet it is still unable to meet the demands. 
Khaleej'Times, Monday, September 3, 2001

\section{Boat people hearing adjourned by

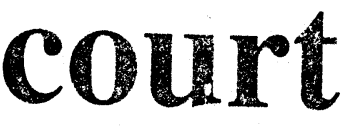

SYDNEY - An Australian court adjourned a hearing late yesterday into whether Australia acted illegally in barring entry to hundreds of mostly Afghan refugees stranded on a Norwegian container ship for more than a week.

The adjournment until today stalled Australia's plans to move the 433 asylum seekers from the ship onto an Australian navy troop carrier so they could be taken to Papua New Guinea.

From Port Moresby, they are to be put on planes for New Zealand and the tiny Pacific island of Nauru under a solution hammered out by Australian Prime Minister John Howard.

Mr Howard steadfastly refuses to allow the asylum seekers to land on Australian soil despite growing condemnation from the United Nations, Norway and human rights groups.

The Norwegian freighter Tampa rescued the asylum seekers from a sinking Indonesian ferry on hip four days ago when it moved isto Australia territorial waters off Christmas Island.

Nauru has agreed to take 283 of the boat people and New Zealand 150 while their asylum requests are processed. Australian media reported Federal Court Justice Tony North had ordered the hearing to resume today.

An injunction against moving the asylum seekers or the freighter Tampa from its position off
Australia's Christmas Island in the Indian Ocean remains in place.

The court has been asked to rule on whether the boat people had been unlawfully detained and if they had the right to apply for refugee status in Australia. The injunction against moving the asylum seckers was imposed on Friday.

The hearing in Melbourne was triggered by an application by the Victoria state Council for Civil Liberties.

The Tampa is lying in Australian waters close to Christmas Island, which is $340 \mathrm{~km}$ south of Indonesia and $1,500 \mathrm{~km}$ west of the Australian mainland as the asylum seekers began their second week on board with only the most rudimentary facilities.

Earlier yesterday $\mathrm{Mr}$ Howard said Papua New Guinea had agreed to allow more than 400 asylum seekers stranded on a cargo ship off Christmas Island to be transferred to capital Port Moresby by an Australian troop ship before leaving for New Zealand and Nauru.

The troop ship HMAS Manoora, which can carry 450 troops, arrived near Christmas Island yesterday afternoon, amid feverish activity by army helicopters which are ferrying supplies including hundreds of life jackets to the ship, floating near the Tampa.

"An agreement has been reached with the government of PNG for the trans-shipment of the people from the Tampa through Port Moresby and then via aircraft to both Nauru and New Zealand," Mr Howard told reporters in Sydney.

"The proposal is that the people should be transferred from the Tampa to the amphibious troop ship Manoora which is a very large vessel capable of travelling for $6,000 \mathrm{~km}$," he said.

Helicopters have been shuttling between the island's airport and the Manoura, picking up palettes loaded by soldiers with water. rations, tarpaulins, life jackets and other supplies, and ferrying them to the frigate. Officials on Wednesday had said the Arunta had been dispatched.

"I am told by the chief of the defence force, through the defense minister, that as I speak the Manoora is ready to take people on board," he said.

"The idea is that they should be transferred to the Manoora then the Manoora will sail to Port Moresby, they will then be transferred to aircraft that will take them to Nauru and to New Zealand.

$\mathrm{Mr}$ Howard said officials from the immigration and other government departments were on their way to Nauru, a tiny Pacific island state northeast of Australia, to set up tent facilities to receive the asylum seekers.

About 150 will be tken to New Zealand and the remainder to Nauru. - AP, Reuters 
Khaleej Times, Wędnesday, September 5, 2001

Kabul judge promises fair trial of aid workers

KABUI. -- The trial of eight foreigners charged with preaching Christianity in Afghanistan began behind closed doors yesterday.

Supreme Court Chicf Justice Mawlawi Noor Mohammad Sayib promised a fair trial after mecting fellow judges and Islamic scholars for several hours carlier in the day.

"The trial has begun todaly. How long it will take, it is not clear," Justice Saqib told reporters at llie court in central Kabul.

"They are innocent unless they are proven guilty. Fior the court, they are just accused who are yet to be proven guilty."

He said details of the proceedings were still being worked out and the accused - two Americans, two Australians and four Germans - had not yet appeared before the court.

"They will be given a full chance to defend themselves and say whatever they want. If we find it necessary during the course of the trial to call any of the detainees, we will call them," said Justice Saqib, flanked by a group of 15 Islamic scholars. "In many countries the accused are given the right to have lawyers. We do not consider that necessary.

"However, if they are unable to (defend themselves) we will have no objection to them hiring legal assistance."

Afghanistan Foreign Minister Wakil Ahmed Mutawakel had earlier promised that the trial would be "open", with diplomats and journalist allowed to attend.

But Justice Saqib said "judges will decide whether the proceedings will be open".

The eight aid workers were arrested early last month and have been in detention in Kabul ever since. - AFP
Khaleej Times, Friday,

September 7, 20)1

Taleban threaten
to close skies over Afghanistan

KABUL - Afghanistan's ruling Taleban yesterday repeated threats to declare its skies unsafe and offlimits to international flights in protest at UN aviation sanctions.

Foreign Minister Wakil Alımed Mutawakel said that all internalional flights over Afghanistan, with some "rare" exceptions, would be stopped unless the United Nations released funds from frozen aviation accounts.

He said the move would affect all UN and International Committee for the Red Cross flights, which ferry crucial humanitarian aid into the war-torn country, one of the poorest in the world.

"We are considering banning international flights over Afghanistan," the foreign minister told a

\section{Press conference.}

"The sanctions are not only affecting us but also the international community in general because Afghanistan is one of the shortest routes for all international flights to cross from one continent to the other,"

The UN Security Council has banned international flights by state-run Afghan Ariana Airlines except for humanitarian reasons as part of sanctions imposed over the Taleban's refusal to extradite Saudi dissident Osama bin Laden.

Other international airlines are also prevented from landing in or taking off from Afghanistan.

UN and Red Cross planes are exempted from the sanctions along with all humanitarian and most diplomatic flights. Overflights are not affected. Revenues generated from overflight fees and aviation taxes are deposited in Taleban accounts which have been frozen as part of the sanctions.

"Our goal is not to ban flights or UN flights, our goal is that the funds that are being paid for overflights should be given to our government," Mutawakel said.

"Because that money is seized so there is no way out - we have to ban their flights from Afghanistan."

Taleban Aviation Minister Mullah Akhtar Mohammad last week said the militia would declare its Airlines was reimbursed revenue lost due to the sanctions. - AFP skies "dangeróus" unless Ariana 


\section{Kabul trial due to resume today}

KABUL - The trial of eight for- aid workers' detention and the eign aid workers detained in Af- Taleban's closure of two Christian ghanistan on charges of preaching relief groups last week.

Christianity went into recess for a weekly holiday yesterday, prolonging the agonising wait for families and diplomats.

"The arrest of aid workers and the closure of agencies pose serious threats to the future of relicf work carried out by the interna-

The Supreme Court is due to resume the trial behind closed doors today but it is still unclear when the two Americans, two Australians and four Germans will be asked to appear.

They have not been officially informed of the proceedings. which began on Tuesday, or given legal representation to help defend themselve's against charges which may carry a maximum penalty of death.

tional community for the sake of Afghan people." the ASG said in a statement.

French foreign ministry spokesman Francois Rivasseau said in Paris the Taleban were guilty of 'growing hostility' towards relief organisalions despite a humanitarian crisis in the country.

Diplomats said the relatives, parents of the two American women and a cousin of the Australian man, were allowed to meet

Diplomats and family members were holed up at a United Nations guesthouse in war-torn Kabul, while government offices were closed and officials from the Taleban went about their Friday prayers.

The Taleban have come under fire from the concerned governments and leading donors for its treatment of the aid workers, who were running food and shelter projects before their arrest in carly August.

Washington issued a new call on the Taleban to permit legal representation and provide interpreters for the aid workers.

US Ambassador to Pakistan Wendy Chamberlain joined her counterparts from Australia and Germany in making the request, which has been a consistent US demand, by letter.

"The letter asked for a commitment from the Taleban that the cletainees would have legal representation and interpreters at the trial and that consular access would be resumed," said Statc Department spokesman Richard Boucher.

"So far there's been no response."

Some 15 donor comntries in the Afghan Support Ciroup (ASCi) said they were 'very concerned' at the the prisoners at an undisclosed location on Thursday.

"The parents held an hour-long meeting with their daughters and also saw other detainees and passed on to thein whatever they knew about the beginning of the trial," US consul David Donahue told AFP yesterday.

"I think that their (the rclatives') biggest concern is that there is nothing that is said or reported that would in any way offend the local authorities or make them less positive and helpful in resolving the issue."

United Nations special envoy to Afghanistan Francesc Vendrell on Thursday met Afghan Deputy Foreign Minister Abdul Jalil and requested the prisoners be allowed more frequent visits from doctors and relatives, UN officials said.

Afghan Foreign Minister Wakil Ahmed Muttawakil said on Thursday the foreigners would appear in court during the 'second phase' of the trial, when diplomats, relatives and journalists would also be allowed to attend.

But Chief Justice Mawlawi Noor Mohammad Sacit told stateruin Radio Shariat that no decision had heen laken regarding permis. sion for dipiomats to observe the trial. - AFP 


\section{Adrift and Unwanted}

\section{A Norwegian ship saves 438 asylum seekers-and triggers an ugly diplomatic row over their fate}

\section{BY DANIEL WILLIAMS}

A SAILOR SINCE HE WAS 15 AND NOW ON the verge of retirement, Arne Rinnan might have been excused for thinking he could negotiate any challenge the sea could toss up. But as the graying Norwegian skipfer steered his red freighter, the Tampa, across the Indian Ocean en route to Singapore last week, he sailed into a storm to shake any captain's confidence.

A call from Australian rescue authorities alerted Rinnan to a sinking wooden ferry $140 \mathrm{~km}$ northwest of Christmas Island, a tiny, remote Australian territory $320 \mathrm{~km}$ south of Java. When the Tampa reached the doomed vessel at dusk on Aug. 26, the scene stunned the captain and his crew: waiting to clamber aboard the Tampa were 438 asylum seekers-men, women and childrenbelieved to be from Afghanistan, Pakistan and Sri Lanka.

Having found them in Indonesia's sea-rescue zone, Rinnan intended to take them to the nearest Indonesian port. But this plan alarmed his new passengers, five of whom confronted him and, according to Rinnan, demanded that he head for Christmas Island or "any western country." The skipper appeased them-and steered his ship into an international incident. "The situation is calm," Rinnan told Time from the Tampa at the end of a swirling week of diplomatic mancuvering involving three nations. "The refugee men have litted their hunger strike and their morale and physical condition have improved."

As the Tampa powered for four hours through rough seas, Rimnan, 61, had no inkling that in Australia - that vast and prosperous island continent that hosted the 2000 Olympics with such charm-illegal immigrants, 4,000 of whom have arrived by boat this year, have become a white-hot political issue. Despite a line in the country's national anthem that declares, "For those who've come across the seas/ We've boundless plains to share," opinion polls indicate that most Australians are prepared to share only with legal migrants. Just days before the Tampa's rescue, the Federal Government announced it would build three more detention centers for illegal entrants. Prime Minister John Howard, determined that

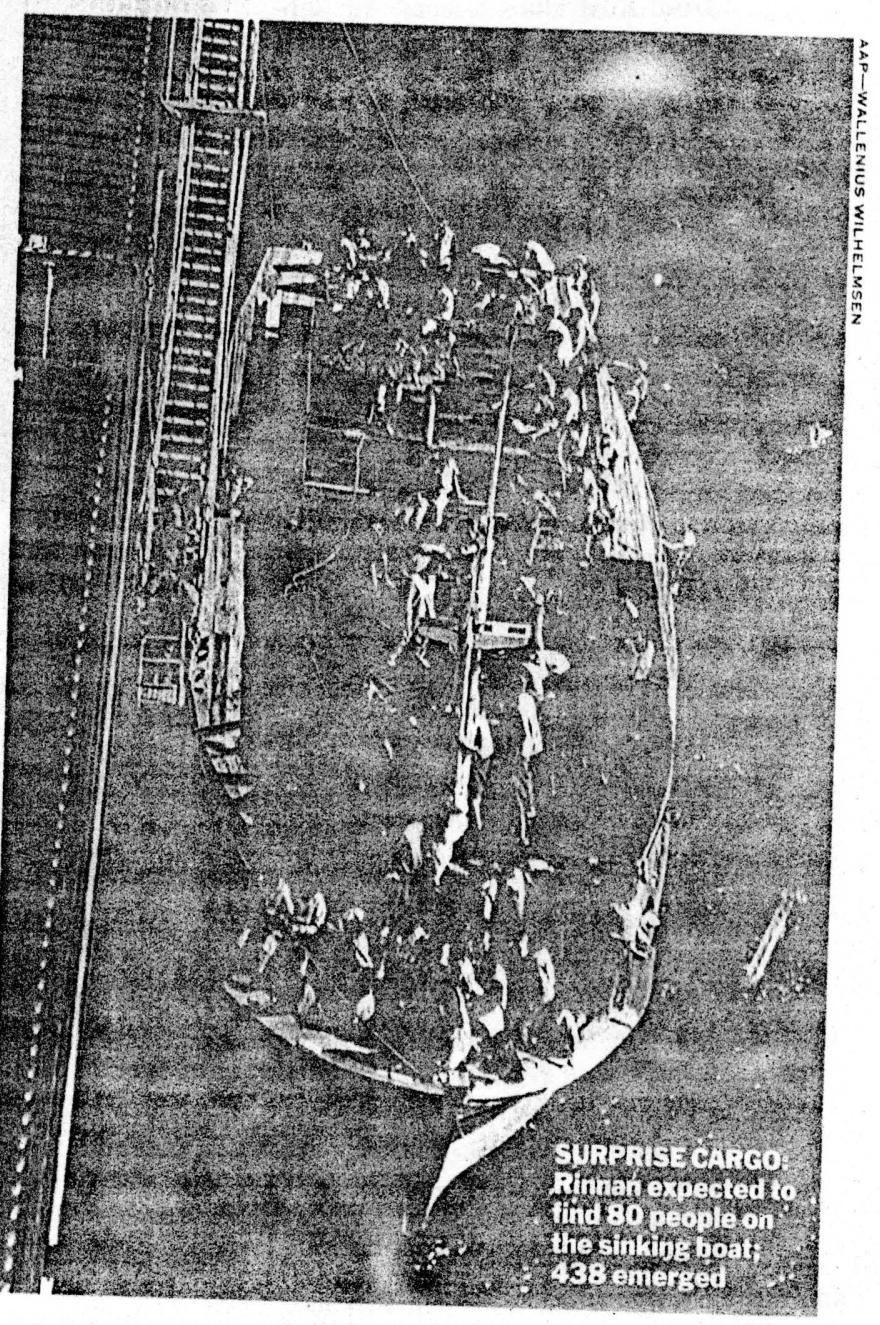

asylum seekers should cease to regard Australia as a "soft option," wals about to draw a line-right in the path of the Tampa-and trigger a standoff in which issues of national sovereignty, international law and human decency would blur and collide.

Told that Australia would not accept his ship, Rinnan halted it $20 \mathrm{~km}$ from Christmas Island, outside Australian waters. There it stayed for more than two days as Australia, 
Norway and Indonesia bickered over responsibility for the passengers. Says a spokesman for immigration minister Philip Ruddock: "The Australian government is not about rewarding people who exert duress on the captains of ships." Meanwhile, a frustrated Rinnan surveyed from his bridge the mass of humanity on the deck below. The male asylum seekers had begun a hunger strike, and the captain believed many in the group-including two pregnant womenneeded medical help. By early afternoon on Aug. 29, Rinnan had made up his mind: defying Australian orders, he began moving toward Christmas Island.

The Tampa was within $8 \mathrm{~km}$ of shore when it was intercepted by troops from Australia's Special Air Service regiment. At week's end, armed SAS members remained on board, with Rinnan still in nominal command. But negotiations between Australia and her neighbors had produced a breakthrough: Howard announced that, without ever setting foot on Australian soil, the refugees would be transferred to another boat and taken to New Zealand (which would accept 150 'rusbands, wives and children), while the remaining 288 men would begin a $6,000-\mathrm{km}$ voyage to Nauru, one of the world's smallest nations. Rinnan says he and his crew are in good spirits: "The Australian troops are behaving and being polite."

Canberra argues that Christmas Island was ill-equipped to moor the bulky Tampa; Jakarta should have done more, since most of the refugee boats come via Indonesia. Jakarta bristles. "Matters might have worked out better," says Indonesia's ambassador to Australia, Sudjadnan Parnohadiningrat, "had friendly discussion been sought first."

Rinnan's Oslo-based colleagues at shipping line Wallenius Wilhelmsen scoff at any suggestion that he panicked in making a dash for shore. "Not Arne," a company spokesman says. "A calmer man has never sailed the seas." The crisis raises many old questions about refugees, the brutal regimes that create them, and the responsibilities of nations that have the resources to help them. But on the high seas, a new question will surface in every mariner's mind the next time their ship) receives a distress signal: What am I getting myself into if I save these people?

\section{Far Eastern Economic Review September 13, 2001}

\section{Saudi Shuffle May Signal Policy Shift}

King Fahd's appointment of his brother Prince Nawaf bin Abdulaziz as Saudi Arabia's new foreign intelligence chief is being watched as a sign that Riyadh will adopt tougher policies toward militant Islamic movements and leaders in Asia, including wanted Saudi terrorist leader Osama bin Laden. The prince was named on September I to replace the monarch's nephew, Prince Turki al-Faisal bin Abdulaziz, as head of the General Intelligence department. Turki, who had headed

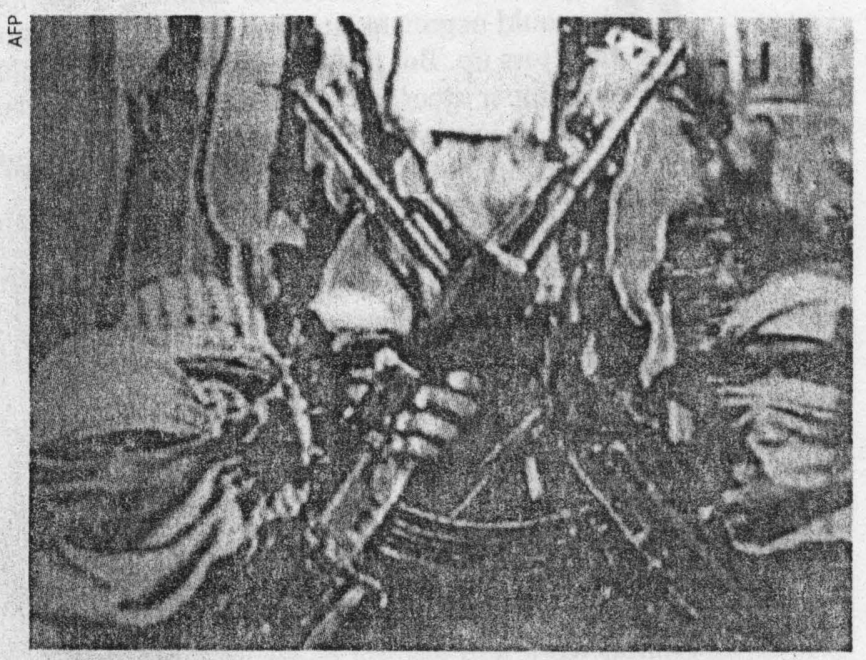

NEW TACK: Will the new Saudi intelligence chief act against bin Laden and his followers in Afghanistan, such as these fighters?

the agency since 1977 , was a key ally of the United States in aiding Afghan resistance fighters against the Soviet occupation in the I980s. His departure will likely affect policy toward the ruling Taliban in Afghanistan, the anti-government Islamic Movement of Uzbekistan and other militant Sunni Islam movements that General Intelligence has backed, diplomats say. It may mean greater cooperation with the Central Intelligence Agency of the United States and a toughening attitude toward bin Laden, who is sheltered by the Taliban, the envoys add. To date, the Saudis have maintained that bin Laden is no longer their problem as they have revoked his citizenship. But the CIA has repeatedly asked for the General Intelligence. department's help in apprehending bin Laden. 
Far Eastern Economic Review September 13. 2001

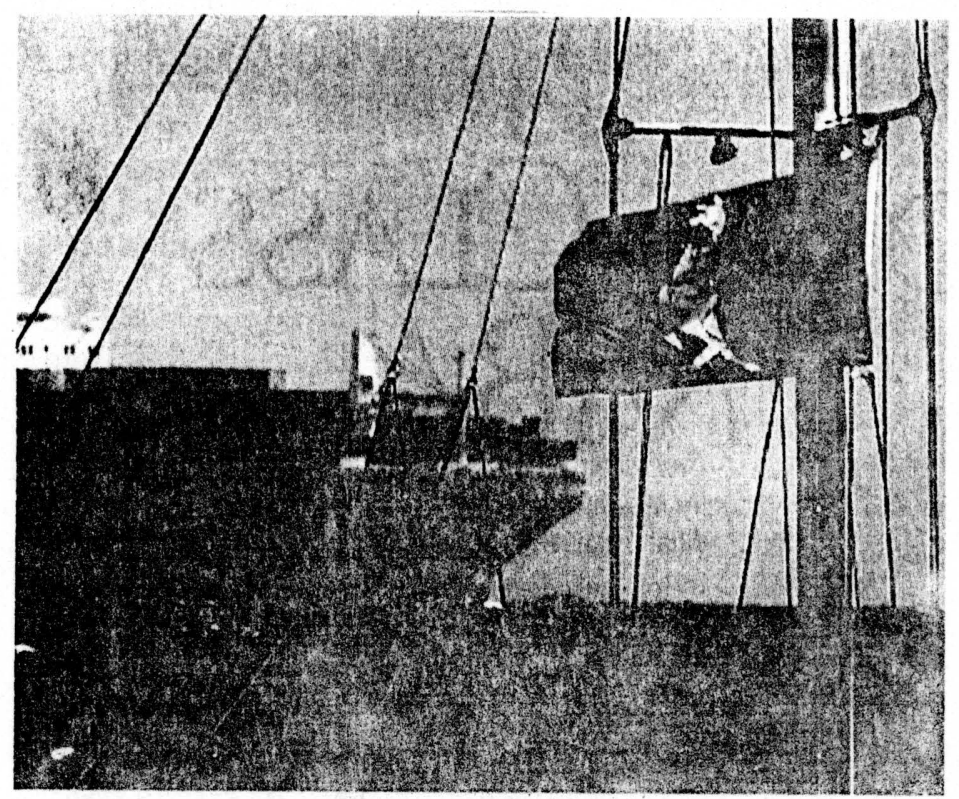

AUSTRALIAN DEFIANCE: A boxing kangaroo sees off the Tampa

Australia

\section{To Turn a Tide}

Prime Minister John Howard blocks hundreds of asylum seekers, but plenty more are still out there

\section{By John McBeth/JAKARTA}

IT'S A HARD QUESTION for Jakarta to answer: How 433 Afghan and Pakistani asylum seekers boarded a ferry in the southern Sumatra port of Lampung and headed into the Indian Ocean without official knowledge. But when the vessel sank and the refugees were picked up by a Norwegian ship that headed into Australian waters, Prime Minister John Howard found himself in a heated exchange with Norway and the United Nations-and at risk of re-opening old wounds with Jakarta.

Relying on neighbourhood generosity and strong public support, Howard finally managed to broker a deal with New Zealand and the tiny Pacific island of Nauru to act as processing centres for the asylum seekers, who had languished aboard the container ship Tampa off Australia's remote Christmas Island for more than a week.

The arrangement allowed Howard to maintain his stand of denying entry to a tide of queue jumpers paying peoplesmugglers $\$ 10,000$ to $\$ 15,000$ each to filter them through Indonesia or Malaysia. And in a sign that Australia's fragile relationship with Jakarta appears to have survived, Indonesia raised no objection to an Australian naval blockade against new arrivals.

With six detention camps overflowing with 3,500 Iraqis, Iranians, Afghans and Pakistanis posing as Afghans, officials said Australia couldn't take more. About I,700 asylum seek- 
ers landed in August, the largest number of boat arrivals since November 1999. According to Australian intelligence reports, as many as 5,000 are waiting in Indonesia, including 1,500 ready to set sail in the next two weeks.

Indonesian President Megawati Sukarnoputri ruffled diplomatic feathers by declining to take phone calls from Howard during the crisis. Seeking a longer-term solution to the whole problem, Australian Foreign Minister Alexander Downer, Immigration Minister Philip Ruddock and Defence Minister Peter Reith were ordered to Jakarta.

They hoped to build on a 1997 memorandum of understanding and a protocol signed last year under which police anti-people smuggling task forces were established in Jakarta, West Java, Bali, Lombok and the West Timor cap. ital of Kupang. Top of Canberra's priority list: better customs and immigration enforcement, particularly at airports in Jakarta, Bali and Lombok-where foreign asylum seekers frequently land with fraudulent Indonesian visas:

Under fire from United Nations Secretary-General Kofi Annan, UN High Commissioner for Human Rights Mary Robinson and Norwegian officials, Howard openly accused Indonesia and Malaysia of not doing enough. Diplomats criticize the failure of authorities to arrest leaders of people-smuggling networks and say that for every Indonesian official trying to stop the trade, others are being paid to turn a blind eye.

Indonesia's muted response was probably due in large part to Foreign Minister Hassan Wirayuda, a polished career diplomat who has brought a sense of professionalism to Indonesian diplomacy lacking under former President Abdurrah. man Wahid's administration. Well aware of the rift between Jakarta and Canberra over East Timor in 1999, Wirayuda was careful to ensure that this latest refugee problem did not degenerate into a new shouting match. "Our country," he noted, "is like a huge house without a perimeter fence."

\section{"The ONLY MESSAGE THEY WILL GET IS that this group was unlucky"}

\section{RAYMOND HALL, UN REFUgEE AGENCY, JAKARTA}

Indeed, while police have had recent success in stopping asylum seekers leaving West Timor and elsewhere in eastern Indonesia, smugglers have now shifted operations back to Java and Sumatra. Says one Indonesian official: "We feel we're as much a victim in all this as anyone else. If Australia wants to blockade, we don't want to make it an issue."

In the first such operation, three Australian frigates, two landing ships, patrol craft and P-3 Orion reconnaissance aircrafi set up a picket line as close as 38 kilometres 10 java's southern coast and stretching from southeast Sumatra to Indonesia's border with East Timor. But will prospective queue jumpers get the message from Howard? Raymond Ilall, the regional representative of the United Nations High Commissioner for Refugeres, doesn't think so. "The only message they will get," he predicts, "is that this group was unlucky." $\equiv$ 


\section{Sattar warns against isolation of Taliban}

ISLAMABAD, Sept 7: The Taliban should be engaged rather than shunned if the world community wants to help bring peace and stability to Afghanistan, Foreign Minister Abdus sattar said on Friday.

"They (Afghans) jealously guard their own independence, and they will, therefore, resent any interference or intervention in their affairs," Abdul Sattar said in an intervicw with Reuters Television.

"It has been our view that a policy of engagement with the government of Afghanistan is better than a policy that seeks to isolate them and push them against a wall," he added.

Mr Sattar said it wa: wrong to assume that Pakistan had any influence with the Taliban.

He also said the sanctions were flawed because the arms embargo did not apply to the Northern Alliance, commanded by Ahmad Shah Masood.

"The sanctions that are imposed are one-sided...This policy needs to be reviewed in our view so that it is both a constraint and an incentive for all parties within Afghanistan to engage in peaceful settlements."

The foreign minister said the $6+2$ grouping - Afghanistan's neighbours Pakistan, Iran,
China, Turkmenistan, Tajikistan and Uzbekistan together with the United States and Russia was due to meet later this month or next in New York.

"The $6+2$ in particular should refrain from providing military supplies and assistance for mili. tary purposes to any of the fighting parties in Afghanistan," he said.

"We hope that the logic of this view will ultimately prevail and the world community will engage with the government of Afghanistan as it does with the ('Taliban's) opposition."

Mr Sattar said Pakistan had suffered because of the continuing strife in Afghanistan. It had received more than two million Afghan refugees, imposing a serious economic burden, and the war and sanctions prevented Pakistan from using key trade routes to Central Asia, he added.

But he said Pakistan had been able to intervene on behalf of Western countries seeking access to eight detained foreign aid workers accused by the Taliban of promoting Christianity.

"We played a role of interces sion, of contact, conveying the request of the foreign embassies to the government of Afghanistan for visas for visits, etcetera," he said-Reuters

\section{Seven injured in Afghan ministry blast}

KAIBULL: Al least seven people were injured in an explosion Saturday at the Taliban Interior Ministry building, officials said.

"Three people were injured seriously while four others sustained minor injuries in the explosion," a ministry official said. He said the explosion occurred around midday in a toilet in the criminal investigation department but he could not confirm whether it was caused by a bomb or some other explosive material.- $\mathrm{AFP}$

\section{Afghan \\ commissionerate denies report \\ Bureau Report}

PESHAWAR: A spokesman of the Afghan Commissionerate NWFP has contradicted a news item appearing in the The News on Saturday in which baseless allegations have been levelled against the senior officer of the Commissionerate.

It is clarified that Col (retd) Abdul Hafeez is looking after the affairs of screening process with sincerity and utmost satisfaction of the Afghan Commissionerate.

He was never involved in any embezzlement of funds and is considered as the most honest and efficient officer of Afghan Commissionerate NWFP.

\section{Meeting}

KABUL: A meeting of the governors and commanders of the northern Afghan provinces has evolved strategy for launching a major onslaught on the only opposition held northern province of Badakhshan.-Sana 
The News on Sunday

September 9, 2001

\section{Pakistan calls for} proper documentation of Arab-Afghans

\section{Umer Farooq}

ISLAMABAD: Pakistan has advised the Taliban government to make proper documentation of Arab-Afghans living in Afghanistan who sometimes travel on Afghan passports.

In some cases these ArabAfghans are living in Afghanistan without valid visas that creates doubts among Arab states, the sources said. The Taliban authorities are said to have accepted the advice of Pakistani government. However, they have Pakistani officials that are issuing visa on plain paper that sometime becomes necemary to protect these Arub). Afghans from unnecessary harassment.

The Taliban authorities have agreed to make proper documentation of the Arab-Afghans living is Afghanistan.

Most of these Arab-Afghans tinterositighanistan during the days of Soviet occupation with the support of their governments. However, after the withdrawal of
Soviet force they decided to stay back fearing prosecution at home. The Taliban regime adopted these Arab-Afghans after they took control most of the Afghanistan area.

The northern Arab countries have always complained about the presence of their nationals on Afghan soil and have used different tools to get them back. Some of them have even signed extradition treaties with Pakistan. In late eighties, Pakistan had extradited some Arab nationals to their native countries.

Recently the Taliban authorities have assured the Arab countries that none of thene ArabAfghans will be allowed to use Afghan soll against any brotherly Muslim country.

In the past northern Arab countries like Tunisia. Algeria and Libya have conveyed their tuneasiness over the presence of their na-

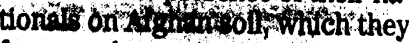
fear may be getting military trainings in the alleged training camps in Afghanistan.

\section{Afghan refugees' children becoming drug addicts}

QUETTA: A suryey of non-governmental organisations shows that some Afghan refugee children in Pakistan particularly in the Balochistan province are being made drug addicts for their sexual exploitation, reports BBC.

The local authorities have so far not taken any considerable steps to rescue the refugees' children and make arrangements for their education. A large number of them have been deprived of education.

Like other parts of Pakistan, a large number of $A$ ghtan children are busy in various tough jobs to earn bread for their families in
Quetta. Most of the children are collecting papers on roads. A number of children work during night to make money. But some culprits have gradually made these children drug addicts to sexually exploit them.

The report adds that fathers of most of these children have died in the Aghan war. One Adam Khan who along with his children collect papers on roads said that no faither would ever wants his children to remain deprived of education but the economic: problems have

forced the children to do job. He said that nobody helps them. He said that his son has also become drug addict but he can do nothing. There is no government centre in Quetta to save the Afghan children form drugs.

However, an international organisation, Save the Children has opened some centres for their education and sports where these children are happily getting education.

An official of a Balochistan Children Rights Organisation, Muhammad Hashmi Kakar said that the government had devised a plan for the rehabilitation of the Afghan drug addict children. He said that besides the rehabilitation, these children would be imparted technical education and training. He said that these children would become useful citizens after getting education at these centres.

The head of a non-goveriumental organisation for children rights, Azam advocate has strongly criticised the Pakistan government and said had the government discharged its responsibility, the Afghan children would not have become drug addicts.-Sina 


\section{Sanctions against}

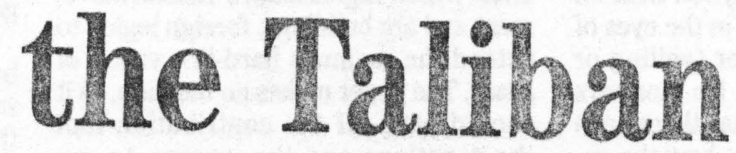

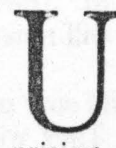

nder Resolution 1363 of 30 th July 2001, the Security Coun cil has decreed that a 20 person team of monitors, com prising a five-man headquarters component and a 15 person field component, "Sanctions Enforcement Support Team"(SEST), -to be stationed in the countries bordering on the area of Afghanistan controlled by the Talibanwill be deployed "in full consultation and close cooperation" of the countries concerned to (a) to monitor the implementation of the measures imposed by resolutions 1267 (1999) and 1333 (2000); (b) to offer assistance to States bordering the territory of Afghanistan under Taliban control and other States, as appropriate, to increase their capacity regarding the implementation of the measures imposed by resolutions 1267 (1999) and 1333 (2000); ..." The measures imposed under the earlier resolutions have been succinctly described in the present resolution as being "the fields of arms embargoes, counter-terrorism and related legislation and, in view of the link to the purchase of arms and financing of terrorism, money loundering, financial transactions and arug trafficking".

This resolution, like the previous resolutions on Afghanistan, has been adopted under Chapter VII of the UN Charter. The implementation of resolutions adopted under this Chapter is mandatory for all member states. Pakistan's was the lone voice of protest raised against the adoption of this and previous resolutions, which singled out the Taliban administration for sanctions and left untouched the question of arms supplies and other assistance to the other factions in Afghanistan.

The Security Council is not unaware of the fact that such assistance is being provided and that unilateral sanctions, even if they bring about the overthrow of the Taliban-and this is unlikely-only re- tards the prospects for a negotiated peace. In April 2000, the President of the Security Council, in a statement on Afghanistan said, The Security Council reiterates that outside interference in the internal affairs of Afghanistan, including the involvement of foreign combatants and military personnel and the supply of weapons and other materials used in the conflict, should cease immediately. It calls upon all States to take resolute measures to prohibit their military personnel from planning and participating in combat operations in Afghanistan, and immediately to withdraw their personnel and to assure that the supply of ammunition and other war-making materials is halted. The Council expresses its deep concern at the continuing involvement in the fighting in Afghanistan, on the side of the Taliban forces, of thousands of non-Afghan nationals". It went on to say "The Security Council welcomes the renewed commitment of members of the Six plus Two group to contribute to a peaceful resolution of the Afghan conflict in support of the efforts of the United Nations, and urges the members of the group and the Afghan parties to implement the Tashkent Declaration...particularly the agreement of members of the group not to provide military support to any Afghan party and to prevent the use of their territories for such purposes". (The $6+2$ is the grouping of all Afghanistan's neighbours- Pakistan, Iran, Tajikistan, Turkmenistan, Uzbekistan, China- and the United States and Russia).

How far this commitment has been honoured by the other neighbours of Afghanistan is apparent from a report prepared by Human Rights Watch and published in July this year which states "In October 1998, a large train shipment of weapons and ammunitions en route from Mashhad, Iran, to United Front forces in Afghanistan was intercepted in Kyrgyzstan. (See Appendix I.). Accord-
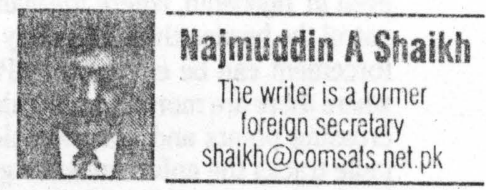

ing to an inventory of the contents of the train drawn up by the Kyrgyz MNB (the successor agency to the KGB in Kyrgyzstan), these weapons from Iran included $100 \mathrm{~mm}$ and $115 \mathrm{~mm}$ tank ammunition for the T-55 and T-62 tanks, respectively; YM-II antitank mines; D-30 $122 \mathrm{~mm}$ towed howitzers and ammunition; $122 \mathrm{~mm}$ rockets for the BM-2I and BM-21V "Grad" multiple-rocket launch systems; $120 \mathrm{~mm}$ mortar bombs; rockets for RPG-7 rocket-propelled grenade launchers; F-1 hand grenades; and $7.62 \mathrm{~mm}$ rifle ammunition... This part of the report has been quoted verbatim only to illustrate the wide variety of arms that have been shipped.

$r$ he report goes on to add that the public disclosure of this shipment probably came about only because of a lack of coordination between the Kyrgyz customs and the Kyrgyz Foreign Office, which had given the nod to the Iranians but failed to inform the Customs. The Customs chief was subsequently dismissed. The report quoted above, makes it clear that while supply routes have now shrunk, Afghanistan's Central Asian neighbours have all cooperated in getting Iranian and Russian arms supplies to the Northern Alliance even if they have not supplied arms themselves.

Of course the report makes similar and even more damning charges against Pakistan but the point is that all of Afghanistan's neighbours have contravened solemn commitments that they have made and none can claim any credibility for their assertion that they are seeking to bring about a negotiated settlement in Afghanistan. 
The News September 9, 2001

These are the facts but that is not how the United Nations Security Council has chosen to view them. The axe has fallen squarely on the Taliban alone and will, perhaps, unfortunately fall next on the one country, identified in the eyes of the world as the supporter (willing or otherwise) of the Taliban. No monitors have yet been posted nor has there been any public statement about how the cooperation of Afghanistan's neighbours is to be enlisted or how they are to be provided assistance in strengthening their capacity for enforcing the sanctions. There are assessments, however, that even in Tajikistan, where Russian forces patrol the border, there is no way the enforcement can be effective. In Pakistan where there are more than 200 identified crossing points and innumerable other mule tracks the enforcement is going to be simply impossible.

In the meanwhile there have been statements by supporters of the Taliban in Pakistan that they will not allow UN monitors on Pak territory and that the sense of outrage about one-sided sanctions is particularly strong in the tribal areas where the Pakistan government's writ is difficult to implement even at the best of times. In these circumstances one can visualise that the monitors who come to Pakistan will have to be provided local security on a rather large and expensive scale. The UN may foot the bill and it will be horrendous, but for the Pakistan government it will be the heavy political burden, which cannot be quananed in monetary terms, which will pose the biggest problem.

Inside Afghanistan the situation has only deteriorated further. There are reports that the outrageous action of the aid workers, carrying proselytizing material into Afghanistan apparently for distribution along with aid, has strengthened the hands of those Taliban who adyocate an expulsion of all westerners from Afghanistan. A report in the

\section{'American women on trial wanted to help poor'}

VIENNA: A Virginia woman on trial in Afghanistan for allegedly preaching Christianity has never made a secret of her faith, friends and neighbours say.
"Guardian"(5th Sep'01), normally a sober paper says that "Arab fighters funded by the Saudi terrorist Osama bin Laden have become increasingly influential within Afghanistan's Taliban movement and are building a foreign legion to extend the regime's hard-line vision of Islam, The paper makes no mention, as it should have, of the contribution that the sanctions and the unwise, to say the least, activities of the "Shelter Now" aid workers have made to this development.

On the misery front the United $\mathrm{Na}$ tions Coordinator on Afghanistan has apparently issued a document in which it is said that among the Taliban those who favour the expulsion of western aid workers are in the ascendancy and that "There is no question that the delivery of humanitarian aid is deliberately being made more difficult by some elements of the authorities." It also highlights the fact that in response to the appeal for $\$ 332$ million for aid to Afghanistan the international cornmunity has pledged only $\$ 142$ million. There are 900,000 internally displaced people in Afghanistan and the number is likely to rise to $1 \mathrm{mil}$ lion by the end of the year. About 500,000 people derived their livelihood from opiurn cultivation, which yielded an income of $\$ 100$ million. Now with wheat being a poor substitute many of these people will also abandon their villages and join the ranks of the displaced, unless aid and seeds etc are provided to them to persuade them to stay in their homes.

There appears to be little prospect of any further aid being pledged. The Afghan people suffer under an oppressive regime, an cpportunistic opposition, covetous neighbours whose agendas have little to do with the interests of the Afghan people and an international community with a one-point agenda. Only further misery lies in store for these proud people.
Heather Mercer, 24, who is from this Washington suburb, is one of eight Westerners - two of them Americans - on trial in Kabul on charges of trying to proselytise
Muslims.

Mercer's friends in Virginia have been reluctant to talk about the case, afraid of upsetting the closed-door court hearings or angering the Taliban.

"She had very strong beliefs, but it was never something she would push on people," said friend and classmate Tarah Grant. "She went out of the way to find people who were quiet and didn't have any friends and made friends with them."

In her high school yearbook, Mercer quoted lsaiah 40: "Those who hope in the Lord will renew

their strength. They will soar on wings like eagles. ... They will walk and not be faint."

After high school, Mercer attended Baylor University, majored in German and became heavily involved at Antioch Community Church in Waco, Texas.

"Heather in particular loves the poor," said Antioch's associate pator, the Rev Jeff Abshier. "She was very compassionate and al. ways looked to those who were suffering. She in particular wanted to go and help those people."

The other American under arrest, Dayna Curry, 29, also attended Baylor. She grew up in the Nashville, Tennessee, area.

Curry's stepmother, Sue Fuller, said Curry went to Afghanistan to help the nation's women. The Taliban do not allow women to attend school beyond age eight.

"She just really has a heart for the people there who are oppressed," she said. -AP 


\section{Russian forces}

put on alert

DUSHANBE (Agencies): Fighting between Afghanistan's Northern Alliance and the Taliban militia has moved within a submachine-gun burst distance of the border with Tajikistan.

Sources said that intensive tank and artillery shelling was going on in front of the stretch in charge of the Pyandzh border detachment, forcing Russian border guards to take shelter in their defensive facilities.

The Russian troops, which guard Tajikistan's border with Alghanistan, have been put on alert.

. Meanwhile, a spokesman for the opposition norther alliance has claimed.that two attacks by the Taliban south and east of Bagram air base have been repulsed by the opposition Northern Alliance.

In a recent predawn attack, the Taliban succeeded in cap- turing three outposts, but they were forced to retreat when the rival forces launched a counter attack, said spokesman Mohammad Eshaq in a statement, received here Friday.

Two days later, a similar attack by the Taliban was repulsed in Shokhi, east of Bagram air base.

"Failing to gain any ground in Takhar, the Taliban are trying to test the resolve of the Mujahideen north of Kabul. North of Kabul is the second major fighting front against the Taliban militiamen," Eshaq said.

"The attacks might also be aimed at forcing the opposition alliance from the Shemali Plateau, who have gone to the North to fight in Takhar, back to their home base. Due to shortages in manpower and logistics, the Taliban are not able to launch simultaneous attacks against the rivals in both Takhar and north of Kabul," the spokesman said.

He said the strategy of engaging the Taliban in several fronts to prevent the concentration of their troops in one front seems to be working well. "Escalation of fighting in Ghore, Badghis, Bamyan and Samangan has also resulted in the dispersion of the Taliban's forces in a vast area with poor communication lines".

He said the tough resistance put up by the Front forces in the two major fronts and engaging the enemy in several secondary fronts have deprived the Taliben of any significant military victory during thein spring and fall cumpaigns.

"Military experts believe that the in the remaining fighting months, the Taliban will not be able score any major victory," he said.

\section{Chief Justice urges citizens to stay away from non-Muslims}

KABUL (Agencies): The chief justice of Afghanistan's Supreme Court, who is hearing the case of eight foreign aid workers charged with preaching Christianity, warned Afghans to stay away from non-Muslims, who he saic! are out to destroy their faith.

Stop your relationship with the kafir (unbeliever). The friendship with the kafir is forbidden," Chicf Justice Noor Mohammed Saqib told hundreds of worshippers at Kabul's largest mosque. Pulc-Khishti, during the Friday congregation.

Saqib warned Muslims that some international aid organizations uscd charity as a means to propagate Christianity. He specifically referred to Shelter Now International, the Christian aid group that employs the two Americans. four Germans and two Australians who have been jailed for allegedly proselytizing.

During Friday's sermon in the ancient mosque. Saqib warned the faithful to look carefully at any reading material received from foreigners.

$\because$ If you find any book that is suspicious, quickly inforn the Islamio Emirate of Afghanistan," said the chief justice. He warned that thousands of Bibles were being circulated in this poor nation.

In a nation ravaged by more than two decades of war and the worst drought in living memory, Saqib said some. international charities are using the offer of assistance to lure Muslims to Christianity.

"Some NGOs (nongovernment organizations) under the pretense of helping Alghans are using their charity for evil, to preach Christianity," said Saqib.

However, he also told
Muslims that the eight foreign aid workers had not been convicted and "I promise you, their chse will be dealt with fairly."

Saqib then went on to list some of the evidence that he and the 14 other justices of the Supreme Court were revir. :ing. He did not say what punishment would be handed out if they were found guilty.

For an Afghan who converts to Christianity, the penalty is death. An earlier edict said a foreigner who proselytized would be jailed and expelled.

But Foreign Minister Wakil Ahmed Muttawakil said the other day that under Islam there was no minimum or maximum penalty for a foreigner proven to have been preaching another religion. The final decision will rest with the Taliban's leader Mullah Mohammed Omar. 


\title{
The Frontier Post
}

\author{
September 9,2001
}

\section{Taliban claim gains in fierce fighting}

KABUL (Reuters) - our troops to move up toward Afghanistan ruling Taliban claimed on Saturday to have driven opposition fighters from two districts northeast of the capital Kabul alter several days of heavy clashes.

Taliban officials said they took control of the Shokhi and Khan Aqa districts in Kapisa province, 70 miles northeast of Kabul in a rugged region leading north toward the Panjshier vallcy.

Panjster valley is the stronghold of the opposition Northern Alliance' led by veteran guerrilla Ahmad Shah Masood.

"The capiure of these two areas is of high importance for us as it gives casy access for
Panjsher. We have broken the opposition line of defense," a Taliban official told Reuters in Kabul.

There was no independent claim, but opposition sources said all Taliban attacks had been repulsed since the fighting began on Wednesday.

"The Taliban report is baseless. We have foiled all their offensives and have dealt heavy casualties to them," Bismillah Khan, one of Masood's top commanders, lold Reuters by satellite telephione from a location to the north of Kabul.

"During the fighting, the Taliban have lost more than 70 of their fighters despite their confirmation of the Taliban repeated aerial attacks mostly aimed at civilian areas." he added.

He described the fighting as infense and said opposition castalties were limited to a few dead and wounded.

The Taliban control around 95 percent of Afghanistan and Masood, who holds areas in the northeast, center and north of the country, is their last serious opponent.

The hardline Islamists overran key Masood bases in the northeastern province of Takhar close to the Tajikistan border last year and since then have been trying to dislodge the opposition from Takhar town, through which they still have a supply line from Tajikistan.

\section{Panjsher Valley offers magnificent hospitality}

PANJSHIR VALLEY (NNI): Hyper capitalists of the world, unite: the best place on earth for a G-8 or World Trade Organization meeting - away from volcanic anti-globalization protests - is the Panjshir Valley, the Afghan Shangri-La.

No hitchhiking. You can only get to the Panjshir by Russian military helicopter.

The Panjshir is a natural fortress: a lush green valley surrounded by sheer rock face. There are no crowds, no Big Macs, no symbols of corporate greed. Ti:e Panjshir offers magnificent hospitality, pure mountain air, pristine rivers and immaculate landscapes filled with artsy intrusions ("Still life with tank" is the great Afghan contribution to modern art). But bring your own Bordeaux and Brie: the menu is a little too biased toward mutton kebab, reports Asia Times.

In the unlikely event that Afghanistan's civil war between the Islamic Emirate (the Taliban) and the Islamic State of Afghanistan comes to an end, the best market positioning for the Panjshir Valley would be as the Epitome of the Asian Shangri-La. To top it all, the Panjshir (tive lions) boasts a resident liton, unrivaled both in charismand righteous freedom struggle credentials: Ahmad Shah Masoud, Mujahiddin Number One, victor over the Soviet Red Army, bete noire of the Taliban and vice president of the Islamic State of Afghanistan.

He lives in a sprawling mansion on top of a hill. He has dozens of bodyguards. He moves around by private helicopter, and on the spot by a black Toyota $4 \times 4$ with tinted windows (although he's no druy dealer). He drives women wild. Ahmad Shah Masoud - the Che Guevara of the Hindu Kush - is nothing less than the CEO of the Panjshir:

As the heart of the Afghan resistance against the Taliban, visitors to the Panjshir expect to confront countless intimations of war - from the rumble of military helicopters to the conceptual art of accumulated destroyed tanks and armored carriers. Mujahiddin or not, almost anyone carries a kalashnikov. But there is also a semblance of "norma!" life, at least by Afghan standards.

The chaikhanas (teashops) are lively, the bazaars are stocked with products from Iran, Pakistan and most of all China. Kids, who don't appear to be undernots:shed, swim in the Panjshir River. Peasants harvest wheat. And unlike Talibun-controlled areas, girls actually go to school.

Almost every family exbibits a photo of a benevolent "Saint" Masoud in their visitors' room, but underneath there are always the inevitable few photos of dead relatives, killed during the years of war. 


\section{The Frontier Post}

Sunday, September 9, 2001

\section{SNI converted thousands to Christianity? \\ Naveed Miraj}

ISLAMABAD: By the time Afghanistan's ruling Taliban militia expclled marching orders to evangelical relief organization Shelter Now International (SNI), it had already won upwards of thousands converts from among Muslim Afghans, sources close to the Taliban claimed during an exchange with The Frontier Post.

"The Taliban authorities were stunned when they stumbled on the silent revolution underway in one of the world's most zealously religious societies", said a diplomat in the know.

However, the information could not be confirmed from independent sources.

Shelter Now was order id to close down its offices in Kabul on August 4 after Taliban officials said it was involved in efforts to covert Muslims to Christianity. At the same time, the extremist militia had arrested 24 SNI staff, eight of them foreign nationals including six women, and 16 Afghans.

The Afghan authorities had also claimed seizure from the custody of arrested workers of materials used to spread Christianity, including a Gospel in English, another book in Dari, two storybooks for Christian children in English and Dari, and two computers and CDs allegedly used to exhibit films on Christianity.

Shelter Now International began as a respons to the 1979 invasion of Afghanistan by the Soviet Union.

Headquartered in Oshkosh, Wisconsin, USA and with support offices in Australia and Spain it is a member of America's Association of Evangelical Relief Organizations (AERDO), and is registered with the United States Agency for International Development (USAID).

Shelter Now was founded after "millions of Afghan refugees flooded into Pakistan and Iran" by evangelists Thor and Debi Armstrong with a small team of volunters, who came to Peshawar, Pakistan to help meet the needs of sheltering Afghan refugee families.

SNI's stated purpose is to "respond quickly and with compassion to those who as a result of war, persecution or natural disaster are homeless and in desperate need of shelter and in doing so to be instruments of God's love for all people

But the operations of the organisation are not limited to Afghanistan anymore. In 1991, when the Gulf War:sent millions of Kurds fleeing from their homes, SNI responded and eventually helped rebuild over 10,000 homes for Iragi
Kurds.

Since then SNI has responded to the needs of refugees and displaced people in many. other countries including: Tajikistan, Angola, Burundi Kosovo, Macedonia, Western Sahara, Albania, Noghen Afghanistan and Sri Lanka. A Sholter Now continues to have an office in Peshawar, Its Afghanistan operations were man aged with the help of field offices in Kabul

\section{KHYBER $M_{\text {AIL }}$}

\section{Northern alliance claims}

\section{killing 128 Taliban}

KMI Afghan Desk

PISSHAWAR: Reports from Alghanistan speak of sporadic lighting. The opposition sats that they hate intlicted heary losses on the Taliban in lighling in Northern Alghanistan. Howerer, BIBC: reports that the Talihian and independent somees have not yet confirmed.
There have been conflicting reports about the results of the fighting between the warring lactions in Alghanistan. However, reports said that the rival factions have clashed in lshk-e-Mishk and Chal areas of Takhar and Khawaja (ilar area neal lajik border. The (1)penculs cham lo hasc lilled one hundred and lwenty eight Taliban and arrested eighty five others but they said that there is no change in the frontline positions. The opponents have also reported fighting in Badghis and Kapisa provinces.

The Northern Alliance sourees said that lighting is also going on in the sumounding of Tilloyin. These someses said that laliban bombed Dasht-c-Kala in Takhar provinee, Khawaja Bahauddin and Panjshir during the past 


\section{Doing business with Central Asia}

\section{By Profithalid Mahmud}

TO join the Shanghai Cooperation Organization (SCO) may well be Pakistan's best bet for doing business with Central Asia. The ECO is a deadwood, more cere monial than a functional mechanism for expansion of economic ties, while it has little potential for bridging the gap in the vast area of political divergence among its members. Pakistan's presence in Central Asia has hitherto been marginal, a far cry from the need to establish a trading route and an economic partnership.

Afghanistan has indeed been the stumbling block. Peace and stability in Afghanistan is a prerequisite for an opening to the north. But the Taliban also have to outgrow their obscurantism and fixation with a medieval mode of functioning in order to secure international recognition as the de jure government in Kabul.

Pakistan has paid a heavy political price for its Afghan policy. 'slamabad is widely seen as the patron-saint of the Kabul regime and therefore charged with connivance, if not sponsorship of what is termed 'international terrorism.' Needless to say, Pakistan has had to incur the displeasure of Russia, China, and the Central Asian republics, albeit it had the good fortune of averting the doomsday scenario in diplomatic isolation, despite a concerted campaign by New Delhi for declaring Pakistan a 'rogue state'.

Thanks to the 'all-weather friendship', the Taliban irritant has not seriously affected Sino-Palistan ties. The Chinese were sagacious enough to distance them lves from the USled moves to browbeat the -Taliban into submission. Pursuing a policy of engagement rather than containment, they were able to use Pakistan's good offices to establith a communication channel with the Taliban. From all accounts they were assured by the Taliban that they wbufd not let septaratist elements' from Xinjiang province use the Afghan territory for training or other support activities.

However, there has been no let-up in the Russian hostility. Moscow has had second thoughts about mending fences with Pakistan following President Putin's special envoy's visit to Islamabad last year. The hope that the visit may lead to an improvement in relations between the two countries has been belied. For whatever reason the Russians see Pakistan as a 'collaborator' and not a 'mod. erator' in the Afghan context.

Pakistan's access to Central Asia has been blocked by the Taliban factor. But its bid to establish durable ties has also suffered from other limitations. It was wrong to assume that the 'Islamic factor' will be a cementing force. As subsequent devel-

opments proved, religion is not the right wavelength for communicating with the newly-independent Muslim states in Central Asia. To wean them away from Russian influence is beyond Pakistan's power and ingenuity and is therefore not worth trying for the present. The Central Asian countries have some serious divergence of perceptions and interests with Russia and do not wish to be relegated to a client states' status. The West, the US in particular, has also been trying to woo them with a measure of success. Some observers are inclined to believe that the Central Asian states are quite happy performing the balancing act between Moscow and
Washington.

Interestingly, Uzbekistan did not join the other Central Asian states in the 'Shanghai Five' process until it sought an observer status in it and then joined the Shanghai Cooperation Organization (SCO) as its sixth member in June. This year. The explanation given is that it does

not have a common border either with Russia or with China, and therefore had no interest in participating in an endeavour aimed at resolving border issues. However, Uzbekistan also entertained the aspiration of playing a leadership role in Central Asia, was in contention with Kazakhstan, and keen to ward off the Russian tutelage by hobnobbing with the US. It was not unitll 1998 when' Islamic extremist elements resorted to arined action in that country that the Uzbek leadership saw the need for a common platform to combat what the Chinese termed the 'three evils' - ethnic sepa. ratism, religious extremism and international terrorism.

The SCO has now set up an anti-terrorist centre in Bishkek, the capital of Kyrghyzstan to coordinate efforts for regional security. The sources of threat are manifold but the Taliban regime in Afghanistan would be on top of the list as the closest neighbour committed to offering support and assistance to 'Islamic warriors'. The Indians will be.only too happy to collaborate with any campaign against Islamic militants in order to drive home the message that together with the Taliban-ruled Afghanistan, Pakistan is the main force behind the rise and

spread of religious extremism in the region. They have been trying hard to project the Kashmiri freedom fighters as 'terrorists' sponsored by Pakistan, and asking the whole world, including China, to join hands with them in fighting the threat of Islamic militancy. No wonder they have of late been focusing their pro- 
paganda on the Kashmiri militants' supposed Afghan connection.

If Pakistan can manage to get into the $\mathrm{SCO}$, it would perhaps be the best security arrangement available to it under the circumstances. Apart from breaking Pakistan's diplomatic isolation in the region, it would take the steam out of the efforts to bracket Pakistan with religious extremist forces. The forum will also offer an opportunity to dispel Russia's fears and suspicions, neutralize its hostility and sort out issues of discord with it in a climate of mutual trust and understanding. The SCO may in due course also prove helpful in resolving the Afghan problem, first as a discussion forum for evolving a common approach, and then as a collective mechanism to negotiate a final settlement with the Kabul regime. Howsoever farfetched the idea may seem at the moment, in corporating Afghanistan into the SCO should be consid. ered an achievable goal.

Pakistan's long cherished desire to establish trade links with Central Asia and provide the land-locked countries an easy access to warm waters of the Arabian Sea can be fulfilled through the membership of the SCO. The Central Asian states were components of a well integrated economic system in the Soviet era. They are still reliant on one another, more so on Russia for economic management and security. The Chinese are extremely careful not to let the Russians have the misgiv. ings that they are trying to replace the Russian influence in Central Asia. The success of the SCO to secure support for eco. nomic cooperation has been largely because of the Central Asian states' perception that Russia and ching are working together and fiot competing with each other. Therefore, the lesson for Pakistan is to follow the Chinese example and not try to bypass Russia in a bid to promote economic ties with Central Asia.

Regional security is yet the number one issue on the SCO's agenda. Economic development is in its initial stages, although it has great potential to harness Central Asia's rich resources and usher in an era of progress and prosperity in the region. Pakistan can play a crucial role in the process by establishing the shortest and the cheapest route for exports from Central Asia. The plan to develop Gwadar as a deep-sea port is a timely initiative and the Chinese assistance in building it a happy development for Pakistan to make a new beginning towards its economic salvation. 


\title{
Afghan Resistance Leader Massoud Injured in Suicide Bombing Attack
}

\author{
By (Omar Samad \\ Azadi Afghan Radio
}

WASIIIN(;TON, September 9, 2001 - $\Lambda$ AR - Veteran Afghan resistance leader and chief of the United Front anti-Taliban forees, Ahmad Shah Massoud, was injured Sunday afternoon following a suicide bombing attack in northern Afghanistan, which resulted in three deaths, including an Afghan official and two alleged Arabs posing as journalists, who carried out the assassination attempt.

Massoud's aide and a UF leader, Yunus Qanooni, told Azadi Afghan Radio that the "wounds are not life-threatening," as the commander was flown to neighboring Tajikistan for treatment.

Assem Suhail, a spokesman for the 49-year-old Afghan military leader, was killed in the incident, and Afghan Ambassador to New Dehli, Massoud Khalili, who was accompanying Massoud at that time, was also injured. There is no update about Khalili's condition.

Qanooni said that the two perpetrators, claiming to be journalists, either detonated a booby-trapped hand-held camera or an explosive charge that was presumably strapped to one of the men was detonated by remote control by the second man. The nationality of the two bombers has not been determined yet.

UF sources told AAR that the two bombers had traveled to Parwan and Kapisa provinces prior to mecting Massoud near Khwaja Bahaudin in Takhar, and met with other UF leaders, including head of the UN-recognized Islamic State, Prof. Burhanudin Rabani and his ally Prof. A. R. Rasul Sayaf.

Thousands of Arab and Pakistani extremists allied with the Taliban and Ossama Bin Laden are fighting in Afghanistan to capture territory held by Massoud, who is also Defense Minister in the UN-recognized Islamic State of Afghanistan, ousted by the Pakistani-backed Taliban from Kabul in 1996. Massoud has accused the Taliban - who enjoy Islamabad's military and political support - and extremist foreign militants in Afghanistan of aggression, civilian atrocities and grave human rights violations.

The UF alliance headed by Massoud also includes Ismacl K'han, Haji Abdul Qadeer, Ustad Khalili, S. Hussein Anwari, Bismillah Khan and other veterans of the anti- Sovict occupation $A$ fghan resistance in the $1980 \mathrm{~s}$, who are now fighting against Taliban domination of the country. Abdul Rashid Dostum, an Afghan (zbek leader is also part of the alliance.

Massoud and the ISA leadership, headed by Rabani, have sought a political dialogue with the Taliban or advocated elections or a traditional grand assembly to reflect the political will of the Afghan people, but the Taliban and their backers 
have rejected negotiations or a democratic solution insisting on an Islamic Emirate headed by Mullah Omar. |Azadi Afghan Radio|

\section{The Toronto Star}

S(p): 9. 200)

\section{Afghan workers from Christian group arrested}

KABUL, Afghanistan (AP) - As the trial of eight foreign aid workers accused of proselytizing entered its fifth day Sunday, the ruling Taliban was accused of jailing 35 Afghan employees of another ('hristian aid organization.

The Afghans were employed by International Assistance Mission, a self-declared Christian aid organization, that was shut down more than a week ago in this devoutly Muslim country.

They were arrested Thursday after obeying a Taliban directive to pick up their salaries at the planning ministry, which is responsible for foreign aid organizations, other aid workers said on condition of anonymity.

The Taliban have not commented on the arrests, even to confirm them, and it was not immediately clear if the IAM employees were picked up for questioning or if the Taliban plan to press charges.

The punishment for an Afghan Muslim who either converts to or preaches another religion is death. The punishment for a foreigner caught proselytizing is jail and expulsion.

One American aid worker said the Afghan staff probably took the risk of picking up their salaries because they were desperate for the money.

Afghans working for foreign aid organizations have been nervous since the arrest last month of the eight foreign aid workers of Shelter Now International, along with 16 Afghan employees of the same organization.

The foreign aid workers - two Americans, four (iermans and two Australians did not appear in court Sunday. Supreme Court judges spent day five of the trial behind doors, sifting through evidence.

Chief Justice Noor Mohammed Sacpib said it was "premature" to discuss punishment for eight arcign aid workers who pleaded not guilty Saturday during their first court appearance. 
They said they were unaware of the charges against them and had been kept in virtual isolation since their arrests in early August.

The 16 Afghan employees of Shelter Now, a German-based Christian organization, have not been seen in public since their arrest and will be tried separately. "All I want is my father back," said 14-year-old Ajmal, whose father, Arsalan, was
arrested.

Ajmal, who like most Afghans uses only one name, makes 70 cents a week working as a mechanic. He is the oldest of six children and now the sole wage earner.

"How can I feed my family? My father is innocent," he said. "He only worked for them for 10 days when he was arrested."

Soon after the Shelter Now arrests, the Taliban closed the local offices IAM and SERVE, both self-declared Christian groups, expelling their expatriate workers on charges they too were trying to convert Muslims to Christianity. The aid groups have denied the allegations.

Last week the foreign ministry displayed Christian material allegedly confiscated from IAM offices in Kabul. One of the documents allegedly said the aim of IAM was to "strengthen the Christian church in Afghanistan."

Increasingly Afghans in Kabul are afraid to be seen with foreigners for fear of being branded a convert.

On Friday in the city's largest mosque, Saqib, who also is an Islamic cleric, warned the faithful to stay away from foreigners, saying friendship with them was against Islam.

He accused some aid organizations of using charity to lure Afghans to Christianity.

\title{
The Courier-mlail
}

\author{
10sep01
}

\section{Kudos for answering refugees' call}

Tom Frewen, in Wellington

\section{"THERE is nobody in New Zealand."}

It couldn't be true but I was not about to argue with the only human being I encountered during 10 frustrating minutes lost inside the new American Express telephone answering service.

- What the customer service representative in the Sydney call centre really meant was 
that there was nobody in the credit card company's NZ office on weekends.

I would have to wait until Monday. Very sorry. Goodbye.

That was on Saturday, a couple of days after the Prime Minister, Helen Clark, offered homes in NZ to 150 of the more than 400 asylum seekers on the Norwegian freighter Tampa, then still in Australian waters off Christmas Island.

Politically, the gesture looked brave, even foolhardy. Just under 90 per cent of a record 27,000 respondents to a television program poll paid a dollar to say No to NZ taking any refugees off the Tampa.

But that was later revealed to be only the redneck kneejerk response. A more scientific survey showed opinion much more evenly divided.

Then, as the All Blacks stumbled to last-minute defeat by the Wallabies at Stadium Australia, messages of congratulations and gratitude began arriving in Wellington from all over the world.

Australian Prime Minister John Howard called Ms Clark to thank her while Queensland Premier Peter Beattie described her as "a great prime minister".

Afghanistan's consul in Australia, Mahmoud Saikal, said her humanitarian gesture was appreciated.

"By accommodating our homeless and stranded children and mothers, New Zealand has placed herself in the hearts of the Afghan people," he said.

And in South Africa attending a United Nations conference on racism, NZ AttorneyGeneral Margaret Wilson reported favourable comment from many delegates.

. ANZ is frequently perceived by people outside the Pacific as being "down under" and part of Australia. Ms Clark's offer distinguished New Zealanders as being not only separate and different but also more friendly and generous than their colonial cousins.

Former prime minister Jenny Shipley found herself wrong-footed this week when the Government announced the appointment of her National party predecessor, Jim Bolger, as chairman of its new state-owned People's Bank which has been established with \$NZ80 million (\$A64 million) of taxpayer funding and scheduled to open next year.

And by the time the bank opens for business, the 150 Tampa refugess will have learned just enough English to work in its call centre which, on current globalisation trends, will probably be in Kabul. 


\section{Masud wounded in blast during interview}

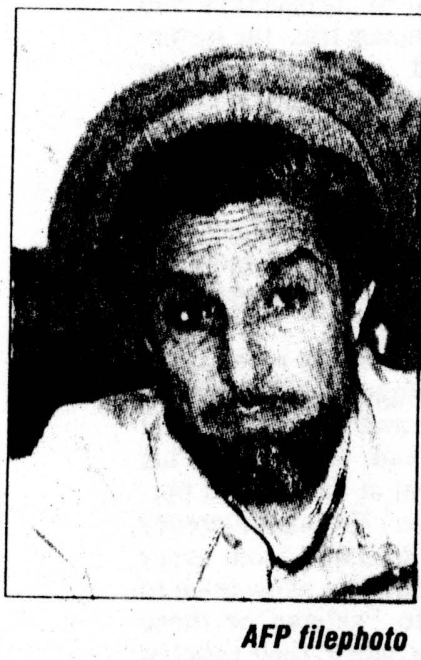

DUSHANBE: Afghan opposition commander Ahmad Shah Masud was wounded Sunday in northern Afghanistan when a bomb concealed in a video camera went off while he was being interviewed by a group of journalists, a source at the Afghan embassy in Dushanbe told AFP.

The incident, which happened at his heavily-guarded residence in Khwaja Bahauddin, killed an official from Masud's opposition forces and wounded Masud in the leg, the source added.

"This afternoon, Masud gave an interview in his office to a group of Arab journalists who arrived from

Kabul. When the camera started filming, it exploded. It looks like a bomb had been concealed in it," the source said.

The 49-year-old leader of the armed resistance to Afg'.anistan's ruling Taliban was "feeling fine," he added. The journalists, whose nationality and number the Afghan diplomat did not specify, were detained. Earlier, the Interfax news agency reported, also citing an Afghan embassy source in the Tajik capital, that Masud had been wounded when his vehicle was hit by an explosion near the frontline. The ITAR-TASS news agency cited military sources in Dushanbe as saying that the blast had been trig. gered by a landmine.
The Taliban Islamic militia captured Kabul in 1996, and now controls most of the country. But Masud's forces, a loose coalition of mainly ethnic Uzbek and Tajik commanders, continue to resist the Taliban in the far north of the warravaged country. The Taliban administration is recognized only by Pakistan, Saudi Arabia and the United Arab Emirates. - AFP

\section{Taliban arrest dozens of Christian workers}

KABUL: The ruling Taliban arrested dozens of Afghan employees of one banished Christian-based aid organizations, while the trial of eight foreign aid workers of another aid group ended its fifth day Sunday.

The arrested Afghan workers were employees of International Assistance Mission (IAM), a self-declared Christian aid organisation, that was shut down more than one week ago. The foreign staff, who were mostly American, were expelled. The Taliban accused both IAM and SERVE - another newly outlawed Christian-based organization - of preaching Christianity.

Last week the foreign ministry displayed Christian material translated into local languages allegedly confiscated from IAM offices in Kabul. As well an IAM constitution was circulated saying the aim of IAM was to "strengthen the Christian church in Afghanistan."

The 35 Afghan IAM employees now in jail were had obeyed a Taliban directive to pick up their salaries at the planning ministry, which is responsible for foreign aid organizations. But when they went to collect their salaries they were arrested. It wasn't imınediately clear whether the Afghan staff were picked up for questioning or whether the Taliban plan to lay charges. So far, the Taliban have not commented on the arrests, even to confirm them.

One American aid worker speaking on condition of anonymity said the Afghan staff probably took the risk of picking up their salaries because they were desperate for the money. She added that one of her local workers had been arrested because he had previously worked for IAM. Afghans working for foreign aid organizations have been nervous since the episode with the Christian aid group, Shelter Now International, occurred last month in which eight foreign and 16 Afghan staff were arrested.

On Friday in the city's largest mosque, Saqib, who also is an Islamic cleric, warned the faithful to stay away from foreigners, saying friendship with them was against Islam. He accused some aid organizations of using charity to lure Afghans to Christianity.

Meanwhile, on Sunday, the three Western diplomats from Aus-

tralia, United States and Germany, as well as the parents of the two jailed American women, Dayna Curry, 29 and Heather Mercer, 24, went to the foreign ministry to request greater access to the aid workers. "We asked for a meeting to with all eight detainees and the three consular officers to allow us to sit down and discuss their legal options," said David Donahue, consul-general at the U.S. Embassy in neighbouring Pakistan.

The consular officials say they are investigating legal options available to their nationals, including a legal advisor or lawyers either from Afghanistan or elsewhere. There is one suggestion that at least one lawyer should be a Per-

sian speaker, familiar with the local legal system, said Donahue.

But first he said the consular officials need to meet their imprisoned nationals to discuss with them their options. It's not clear how long their trial will last, but Saqib said the aid workers must now decide whether they want a lawyer or whether they will defend themselves.

Curry's mother, Nancy Cassell of Thompson's Station, Tennessee and Heather Mercer's father, John, of Vienna, Virginia also went to the Taliban's foreign ministry and submitted a written request to see their children again. They said they are hoping for a reply on Monday. $-\mathrm{AP}$ 


\section{Afghan rivals locked in heavy fighting}

KABUL: The Taliban movement. and opposition forces of Alumad Shah Masond were locked in intense clashes on Sunday on the main road leading out of the capital, Afghan sources said.

They said both sides bombarded each other's positions with heavy weapons on the plains of Shomali on the so-called Old Road, some $25 \mathrm{~km}$ north of the Taliban-held Kabul.

Witnesses in the area said Taliban forces broke the opposition lines during an overnight offensive lasting several hours but retreated after dawn.

"We could hear constantly salvoes of rockets landing and being fired in the early hours of the morning," one witness said.

Taliban jet fighters were seen on Sunday morning heading towards Shomali, which lies on the main road to Panjsher valley, Masood's native stronghold.

Opposition sources say that over the past several days the Taliban have stepped up their attacks on several directions leading to the twisting valley, which has been under partial siege since the Taliban ousted Masood from power in 1996. But they said the opposition forces were bracing for a counter-attack. -Reuters

NNI adds: The Taliban suffered heavy casualties south of Takhar's provincial capital, Taloqan, but there was no major change in front line positions, an opposition spokesman has said.

More than 135 Taliban were killed and 75 captured in a predawn operation launched by the opposition forces on Taliban positions in Eshkamesh and Chal districts of Takhar Province, spokesinan Mohammad Eshaq said. Mullah Rahmatullah Sangaryar, a prominent Taliban commander, was wounded in the attacks.

Payam-e-Mujahid Weekly reported that the alliance forcres seized 50 Kạlashonikov rifles, 23 PK machine guns, three ZPU-1 machine guns, two $82 \mathrm{~mm}$ recoilless rifles, $19 \mathrm{RPG}$ rocket launchers, two truck-mounted ZSU-23 machine guns, one $82 \mathrm{~mm}$ mortar, two pickup trucks and 10 wircless communication sets. The opposition forces lost four men and more than 10 of their fighters were wounded.

The Taliban jets bombed residential areas in Khuram, south of Samangan's provincial capital, Aibak, wounding six people and destroying three houses. In a separate incident, more than $30 \mathrm{Tal}$. iban fighters were killed or wounded in the Safid Kotal area, west of Aibak, when two trucks carrying them hit land mines.

Eshaq said four local commanders were arrested recently by the Taliban in Samangan on charges of establishing contacts with the alliance forces. These arrests have resulted in the defection of more local Taliban commanders to the opposition. Two local commanders by the name of Naik Mohammad and Shair Jan defected to the anti-Taliban alliance along with 50 of their fighters.

\section{Family seeks police} protection from refugees

PESHAWAR: A Pakistani national, living in Gharibabad Peshawar, has asked Peshawar police to provide protection to him and his family members from his neighbouring Afghan refugees.

The family of Khitab) (iul, an employee of PTCL posted in Islamabad, was attacked by two Afghim refugees, Bacha and Mustafa and their other relatives, seriously: injuring his wife. A case was registered at Shaheen Town Police Station, on August 8, 2001. However, the cul- prits are still at large, threatening his family members. The Pakistani nationals said that as he performs his duty in Islamabad and his family lives in Peshawar he is always concerned about the welfare of his family, particularly his chiddren.

He has also fears that the ab)sconding culprits might harm or abduct auy of fanily members and flee to. Afghianistan. He lias assked Pzshawar police to arrest the culprits so that he could perform his official duty with peace of mind. - NNI

\section{Afghans complain of extortion at private checkpost \\ Bureau Report}

PESHAWAR: The political administration seems helpless to stop an influential and powerful person in its jurisdiction who collects money from the incoming and outgoing Afghan refugees without any justification.

He has made check post at Khwaizai, about 40 kilometers away from Ghalanai, in Mohmand agency to facilitate himself while getting gratifications.

An elder of the recently returned refugee family disclosed to The News that the influential person had established his check post at Pak-Afghan border, "Garo" Mohmand agency and get Rs 2,000 from every Afghan family to allow them to enter into Pakistan or those who repatriate to their country. "Those who avoid giving him gratification is fined ranging from Rs $5,00,000$ to one million. He has his private jail to put those into it who avoid giv. ing him money," the elder complained.

He appealed to the NWFP Governor to probe into the case and get the helpless people rid of the on going injustices. He alleged that the political administration was also hands in gloves with the powerful people. 


\section{The Frontien Rost}

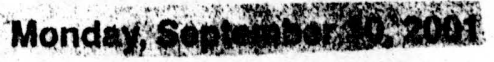

\section{Kabul residents face prolonged power shedding}

\section{Our correspondent}

KABUL: The people of Kabul are faced with numerous hardships due to more than 12 hours power load-shedding everyday for the last several weeks as business activity has come to a standstill in various parts of the city.

It is to be noted that the Taliban government provide electricity to the residents of Kabul on nominal charges despite the fact that the government is facing financial problems. Taliban restored the electricity lines within short time simc: they took control of the capital in September 1996, which had been damaged in the factional fighting among different groups of mujahideen.

Farida, a city dweller said that the people were faced with hardships because they are poor and could not afford additional expenses to arrange firewood and kerosene oil.

However, officials of the electricity department said that loadshedding was due to shortage of water as Kabul has not received enough rains due to prolonged dry spell.

\section{Afghans killed in Iran}

TEHRAN: Three Afghan bandits were killed in clashes with the security forces in Iran's northeastern Khorassan province, the daily Qods newspaper reported Sunday.

An official from the Taybod neighbourhood was quoted by the paper as saying "these bandits who entered Iranian territory to carry out kidnappings were killed after five hours of clashes."

Quantities of drugs, a rocket launcher and two guns were seized during the operation.

Three other Afghans were killed Thursday on the province's horder with Afghanistan.-AFP

\section{Taliban deny bomb blast report}

KABLL: Taliban authorities in Afghanistan have denied the reports of a bomb blast in the Interior Ministry building in Kabul, reports BBC.

The spokesman for the Taliban has rejected the reports but other officials and eyewitnesses have been quoted as saying that few people have been wounded in the explosion. The bomb blast took place in the Criminal Investigation Centre of the Ministry. SANA

\section{Taliban bar journalists from leaving hotel}

KABUL, A gencies): Afghanistan's Taliban authorities early on Sunday barred foreign journalists and photographers from leaving their hotel tor takin: pelures of eight foreigners on trial for preaching Christianity, ofticials said,

The journalists are holed up in Kabul's intercontinental Hotel and the officials are not allowing them to leave, they said.

The authorities have also detancel official Afghan interpreters of the journalists for "not preventing" them from laking pictures when the supreme court resumed the tral of eight forcign aid workers on Saturday.

"We will take a decision about them later," a foreign ministry official said.

The Taliban authorities have put all foreign journalists and photographers in the intercontinental Hotel. The reporters haye been asked to always travel with a regimeappointed interpreter.

The authorities Saturday expressed anger as some journalists took pictures and made video films when the detained aid workers appeared in the stipreme coutt for the first time since their arrest in carly August on charges of propagating Christianity.

Sources said the Taliban who have banned the taking of pictures, searched rooms for cameras, films and videos. They detained the interpreters for lailing to prevent the foreigners from taking pictures. 


\section{The Frontier Post}

Monday, September 10, 2001

\section{Omar Abdel-Rahman Taliban's likely choice}

KABUL (Agencies): The foreign minister of Afghanistan's ruling Talition ats atued ounday sagtat lide hald-fine movement might consider swapping eight detained foreign aid workers for an Islamic militant jatled in the United States.

But Wakil Ahmad Muttawakil, quoted in the Taliban's Shariat Daily, stressed that the trial of the aid workers, accused of promoting Christianity, would first have (i) be completed.

The authorities and responsibles of the Islamic Emirate (of Afghanistan) will deliberate about such a request, and after consideration and research, a decision will be taken," he was quoted ds saying. "But above all we need to wait for the decision of the Supreme Court (in the (rial)," he added.

Islamist sources outside
Afghanistan said last week the Taliban might be willing to stee the eight wid watkers if Wastingers allowed the diling Sheikh Omar Abdel-Rahman. jailed for life for planning guerrilla attacks, to go to Afghanistan.

Relatives of the blind Muslim cleric said they had written letters to both the hardline Islamist Taliban and the State Department in Washington. Four Germans, two Australians and two Americans, all trom Germanbased Christian relief agency Shelter Now International (SNI) were arrested with 16 Afghan colleagues five weeks ago on charges that could carry the death penalty.

Judges completed the fifth day of the trial Sunday. The detainees appeared for the first and only fime so far on Saturday arfd said they were innocent of proselytizing.
Muttawakil said the Taliban had not received an official reforrest for the propesed prisoner swap.

We have heard this news (exchange) through the media that his family has asked the leadership of the Islamic Emirate and similarty proposed to the American authorities," he said.

"First we should wait for the decision of the Supreme Court of the Islamic Emirate of Afghanistan and the American authorities have not contacted us in this regard." he added. "The request requires clarification and comprehension. We have not been in touch with the Americans about this."

Sheikh Omar, the spiritual leader of Egypt's main militant group a-Gama's al-Islamiya (Islamic Group), was convict: ed in 1995 of plotting to blow up the World Trade Center and bamb the Untied Nations.

\section{UN struggles to cope with refugee surge in HK}

HONG KONG (Agencies): A rise in global refugees has led to an escalation in the number of asylum-seekers arriving in Hong Kong, leaving cash-strapped UN representatives battling to cope, a report said Sunday.

The number of refugees arriv: ing in the former British colony has soared from 50 a year over the past three years to 100 a month this year, according the United Nations High Commissioner for Refugees (UNHCR).

Civil unrest and wars in Pakistan, Afghanistan and Sri Lanka contributed to the surge in numbers, the UNHICR said.

"Everybody believes there are no more refugees, because they are not visible. But we have had an influx this year from all over the world," UNHCR sub-office head Daniela Cicchella lold the Simdix Morning Post.

\section{Afghanistan's stability vital: Kharrazi}

TASHKENT (Agencies): Visiting Iranian Foreign Minister Kamal Kharrazi here highlighted the need for safeguarding the stability in Central Asia, particularly in Afghanistan and Tajikistan. whose stability, he said, would guarantee regional security and economic development.

Kharrazi who was speaking at Uzbek economy and democracy college qualified religious extremism, drug trafficking. organized crime and illegal immigration as major factors threatening Central Asian and the Caucasian security, saying such threats are mainly rooted in the war-torn Afghanistan and similar "crisis centers."

He said that the encounter of superpower's various interests in Central Asia is the most complicated and sensitive fac- tor undermining the security in the region.

"The insatiable greed of superpowers, the existence of current conflicts, aild the formation of extremist groups in the countries of the region have all provided common interests for these states to launch cooperation in different enterprises." Kharrazi saij.

Kharrazi called on the Central Asian states to resolutely exploit their joint capabilities to materialize economic objectives, to attain a political stability, and to forge ahead with campaigns to thwart the threats endangering the security of the region.

Kharrazi was in Kyrgyzstan Wednesday, where he dis. cussed the situation in Alghanistan and regional security with oflicials. 


\section{The Frontier Post Monday, September 10, 2001}

\section{Taliban suffer casualties in Takhar province}

ISLAMABAD (NNI): The Taliban suffered heavy casualties south of Takhar's provincial capital, Taloqan, but there was no major change in front line positions, an opposition spokesman has said.

More than 135 Taliban were killed and 75 captured in a predawn operation launched by the opposition forces: on Taliban positions in Eslikamesh and Chal districts of Takhar Province, spokesman Mohammad Eshaq said. Mullah Rahmatullah Sangaryar, a prominent Taliban commander, was wounded in the attacks.

Payam-e-Mujahid Weekly reported that the alliance forces seized 50 Kalashnikov rifles, 23 PK machine guns, three ZPU-1 machine guns. two $82 \mathrm{~mm}$ recoilless rifles, 19 RPG rocket launchers, two truck-mounted ZSU-23 machine guns, one $82 \mathrm{~mm}$ mortar, two pickup trucks and 10 wireless communication sets. The opposition forces lost four men and more than 10 of their fighters were wourded.

The Taliban jets bombed residential areas in Khuram, south of Samangan's provincial capital, Aibak, wounding six people and destroying three houses. In a separate incident, more than 30 Taliban fighters were killed or wounded in the Safid Kotal area, west of Aibak, when two trucks carrying them hit land mines.

Eshaq said four local commanders were arrested recent- ly by the Taliban in Samangan on charges of establishing contacts with the alliance forces. These arrests have resulted in the defection of more local Taliban commanders to the opposition. Two local commanders by the name of Naik Mohammad and Shair Jan defected to the antiTaliban alliance along with 50 of their fighters.

The Taliban's attacks on Qades and Jawand districts, Badghis Province, were repulsed. Three Talibanwere captured by the opposition forces. The alliance troops succeeded in liberating the Afry area west of Saghar District in Ghore Province. The opposition forces captured five Taliban soldiers in the fighting for control of Saghar.

\section{FBI launches} - campaign to capture Osama

ISLAMABAD (Online): The $\mathrm{FBl}$ is circulating "wanted" notices in Pakistan for Saudi dissident Osama bin Laden via matchboxes according to Sunday's Parade magazine.

The matchboxes carry Bin Laden's photograph and an announcement in Arabic advertising a reward for information leading to his capture. The matchbooks/specify a 500,000 dollar reward, but it's a printing error, and the reward is actually 5 million-dollar, Parade said.

The matchboxes, which show bin laden in a turban with a moustache and a heavy beard, have been distributed in Pakistan since February 2000. Parade said.u's

The FBP is following the example of the $\mathrm{ClA}$, which used the same matchbox campaign in Afghanistan, Parade said.

\section{Cultural concert for refugees in Moscow}

MOSCOW (Agencies): An international conference and music concert was held in Muscow for different refugees' sncieties with the support and collaboration of the UNHCR, French, Italian Welfare Society and Afghans Centre. The conference was aimed at bringing about cultural closeness and consensus among different refugee societies, reports $B B C$. $A$ joint conference for different refugees was held for the first time in Moscow. Refugees of different countries attended it. It was aimed at bringing in cultural closeness among different refugees and avoiding confrontation among different cultures. The conference discussed the issue and papers were read out in the conference.

One minute silence was observed in respect of a Nigerian refugee who was recently killed by the Russian nationalists. Very rough treatment is meted out to the Black and Wheatish people in Russia. This problem does exist and the refugees are facing lot of problems in Russia. 


\section{The Statesman Monday, september 10, 2001}

\section{Osama plans more attacks on US: NYT}

\section{By Sadaqat Jan}

PESHAWAR: Saudi dissident Osama bin Laden, sheltered by Taliban as their 'guest,' has recently outlined new 'terrorist plots' against his principal enemies, the United States and Israel, the New York Times reported Sunday.

"He promises an intensified holy war that includes aid to Palestinians fighting Israel - an important shift in emphasis," the paper said, quoting intelligence analysts.

In recent years, in a series of violent attacks, Osama's main focus has been on driving American forces out of the Arabian Peninsula, the report claimed. The alleged terrorist, as shown in a video footage, was reading a poem at the wedding of his son earlier this year at an undisclosed location inside Afghanistan.

In the video, the New York Times said, Osama devised plans for an expansion of his

terrorist training operations in Afghanistan, saying that the Taliban had built an ideal, purified Islamic state that provides the perfect base for a worldwide holy war against 'infidels.'

According to the paper, intelligence officials who have analysed the tape now say it features the fullest exposition yet of the billionaire's views as well as his terrorist strategy, and thus provides a rough road map of where his organization; Al-Qaeda, is headed.

"With his mockery of American power, bin Laden seems to be almost taunting the United States: FBI investigators believe that he was behind the bombings of the World Trade Center bombing in 1993, in Saudi Arabia in 1995 and 1996, American embassies in east Africa in 1998 and the Cole attack. However, the US has so far found no way of containing him, it continued.

After nearly a year, the report says,

American investigators have been unable to trace the Cole plot beyond six men arrested in Aden for assisting the bombers. The man thought to have directed the attack for $\mathrm{Al}$ Qaeda, Muhammad al-Harazi, is believed to have fled to Afghanistan.

Now, despite a $\$ 5$ million American reward for his capture, multiple indictments in American courts and a cruise missile strike on his camps in Afghanistan in 1998 that he narrowly escaped. bin Laden is threatening still more at s. He tells followers that there is nothing to fear from the United States and that their faith - and their willingness to die - is enough to neutralise America's military might.

"A year or two ago, after the missile attacks on Afghanistan, there were people in

Washington saying bin Laden was in a box," said Peter Bergen, a Washington-based writer who interviewed him in Afghanistan in

1997. "But if he's in a box, he's a jack-in-a- box. He as much of a threat as he ever was."

The erstwhile veteran of the Afghian war is written about in these words: In the verses, read out at the wedding of his oldest son earlier this year, Osama declares his purpose - killing Americans and Jews - more starkly than ever. Proudly, he salutes the suicide bombing of the American destroyer Cole in the Yemeni port of Aden last October in which 17 American sailors died, and promises more attacks.

"The victory of Yemen will continue," he says. Shots of the Cole listing in Aden harbor after the attack, and of the Americans being carried in flag-covered coffins - and a simulation of the bombing, complete with a blinding flash - are played in the tape's opening and closing sequences

The shots are taken from American television coverage, and accompanied by what seems like a gloating brutality. "Their limbs were scattered everywhere," Mr. bin Laden says.

The verses also celebrate what Mr. bin Laden describes as the futility of American military might. "In Aden, our brothers rose and destroyed the mighty destroyer, a ship so powerful it spreads fear wherever it sails," Mr. bin Laden says, over images of the Cole.

"But as it moves through the water, toward the small boat bobbing in the water, it is sailing to its own destruction, drawn by the illusion of its own power."

In the Cole attack, two Arabspeaking suicide bombers blew a gaping hole in the destroyer at the waterline with an explosives laden skiff, causing $\$ 250$ million

damage. While Mr. bin Laden, on the tape, stops short of saying he ordered the strike, he effectively confirms what the FBI suspected from the outset: that it was a bin Laden operation.

Another sign of the freedoms Mr. bin Laden appears to enjoy are the tape passages showing his followers engaging in combat training, including firing heavy weapons and storming buildings, at a location identified as the "al-Faroog camp." Some recruits appear little more than 11 or 12 . In one scene, Mr. bin Laden himself is seen crouching to fire a Klashnikov rifle.

Much of the tape focuses on the current upheaval in Israel and the Palestinian territories. What is not clear, say intelligence experts, is whether Mr. bin Laden plans to mount direct attacks on Israeli targets, or whether he is firing fol-

lowers' passions for attacks elsewhere. "Our brothers in Palestine are waiting for you anxiously, and expect you to strike at America and Israel," Mr. bin Laden says. "God's earth is wide and their interests are everywhere."

Vincent Cannistraro, former head of counter-terrorist operations for the Central Intelligence Agency, who reviewed the tape, stressed Osama's warnings of new attacks should be taken seriously. "The intifada has clearly focused his attention on the Palestinian problem, which he sees in holy war terms - the Palestinians being oppressed by the Israelis, in ways that are only possible because of the support they get from the United States," he said.

"This has reinforced his opinion about the United States and its policies in the whole of the Middle East. It sharpens his instincts for attack." 


\section{The Statesman Monday, Seplember 10, 2001}

\section{Taliban may mull swap of prisoners}

- nab more aid workers

KABUL:

Afghanistan

Foreign Minister Wakil Ahmad Muttawakil said Sunday his government might consider swapping eight detained foreign aid workers for an Islamic religious leader jailed in the United States.

The Taliban arrested dozens of Afghan employees of banished Christian-based aid organisations on Sunday. They have been nervous since the episode with the Christian aid group, ... Shelter .. Now International, occurred last month in which eight foreign and 16 Afghan staff were arrested.

The eight foreign aid work ers of SNI - two Americans, four Germans and two Australians, are currently on trial in the Supreme Court for allegedly Christianity in Afghanistan.

Muttawakil, quoted in Afghanistan's Shariat Daily, stressed that prisoner swapping would only be considered after completion of the trial.

Sources

outside Afghanistan said last week the Taliban might be willing to free the eight aid workers if Washington allowed the ailing Sheikh Omar Abdel-Rahman, jailed for life for planning guerrilla attacks, to go to Afghanistan

Muttawakil said the Taliban had not received an official request for the proposed prisoner swap. "We have heard this news (exchange) through the media that his family has asked the leadership of the Islamic Emirate of Afghanistan and similarly proposed to the American authorities," he said.

"The request requires clarification and comprehension. We have not been in touch with the Americans about this."

Sheikh Omar, the spiritual leader of Egypt's main group AGama's al-Islamiya (Islamic Group), was convicted in 1995 of plotting to blow up the World Trade Centre and bomb the United Nations.
- The Afghan workers arrested on Sunday were employees of International Assistance Mission (IAM), a self-declared Christian aid organisation, that was shut down more than one week ago.

The foreign staff, mostly American, was expelled. The Taliban accused both IAM and SERVE - another newly outlawed Christian-based organisation - of preaching Christianity.

It wasn't immediately clear whether the Afghan staff was picked up for questioning or whether the Taliban planned to lay charges. So far Taliban have not commented on the arrests, not even confirmed.

The Taliban early Sunday barred foreign journalists and photographers from leaving their hotel for taking pictures of eight foreigners on trial for preaching Christianity, officials said. - Agencies

\section{Afghan SC} resumes aid workers' trial

From Sayed Salahuddin

KABUL: The Supreme Court of Afghanistan said Sunday it was awaiting word from eight foreign aid workers on how they want to defend themselves against the charge of promoting Christianity.

During their first appearance a day earlier, the court gave them papers asking them how they would like to conduct their defence against the accusation.

"We are waiting for them to send the inquiry papers (with reply) to the court," Chief Justice Noor Mohammad Saqib said.

The detainees pleaded innocent when they appeared in court, but Saqib said they would not appear when the court resumes hearing for the fifth day on Sunday. "If they don't (reply) we will go and receive it from them. They will not appear before the court for handing over the papers," the Chief Justice said, adding that it was also not clear when the accused would appear before the court in future.

Reporters were barred from the proceedings on the fifth day of the trial and the Chief Justice said the accused had not been called. "We have started our deliberations of the case," Chief Justice Noor Mohammad Saqib told Reuters.

The diplomats are seeking regular consular access to the detainees and have said they will write to the court about this. "After reading their petition, we will make a decision about this issue too," Saqib said on Sunday.

"They can meet provided their visit is based on the principles of this country. Their job is consular affairs and they can't represent the accused," he remarked.

There was no indication how long the case would last and the diplomats said the legal process remained clouded in uncertainty. - Reuters 


\section{The Nation MONDAY, SEPTEMBER 10, 2001}

\section{UN peace initiatives and Afghan conflict}

PESHAWAR - United Nations is going to repeat the April. 10, 1988 experience of indirect mediation amongst the Afghans and their supporters through a gathering at Geneva Monday (today) to initiate efforts aimed at resolving the conflict through table talks and negotiations.

United Nations idea of indirect talks amongst the Afghans could lead to further division and hatred amongst them and is most likely to meet the ends of former accords.

After Soviet invasion in 1979 , the UN initiated indirect Geneva Talks between Pakistan and Afghanistan along with their supporters like United States and former Soviet Union. Former Secretary General of UN Perez De Cuellar as a special UN representative Secretary General started

indirect talks. Later on Perez De Cuellar was replaced by Diego Cardovez when the former became Secretary General and the latter his special representative on Afghanistan. Cardovez visited the region for several time and succeeded in brokering the Geneva Accord between Pakistan and Afghanistan on April 10, 1988.

Geneva Accord paved the way for withdrawal of Soviet troops from Afghanistan but failed to ensure peace and stability in that country. Afghanistan and its people faced another era of internal civil war and hostilities after. Soviet withdrawal. UN ignored the major party i.e. former Mujahideen groups in the talks and the agreements which were opposed by these leaders, majority of whom now living in Iran and other Central Asian Republics.

Cardovez's plan of transfer of power from late Najibullah to a 15-member UN Council was sabotaged at eleventh hour by war lords like Ahmad Shah Masud, Gen. Rashid Dostam, Gen. Baba Jan, Gen. Momin and others. UN representative Francis Venderrel and Afghan elders

\section{Situationer}

\section{Rfrom Shamim Shahld}

continued efforts

to find out a nego-

tiated solution to

the conflict.

The present UN

Envoy for Afghanistan Francis

Venderrel without keeping in mind the failure of his predecessors like Diego Cardovez and others, is going to start another series of indirect talks at Geneva on Monday (today). But this time, he has ignored Pakistan and Russian Federation in the indirect talks. He has only invited the delegates

from Iran who support the Cyprus Conference, to influence former King Mohammad Zahir Shah's Rome Peace Process and Germany who at hosted a session of Intra-Afghan dialogue at Bonn. Beside the hosts and patronisers, members of all three moots have also been invited to express their point of view in the indirect talks, second of its kind regarding Afghanistan.

Former king Mohammad Zahir Shah who is in Italy since 1973 , suggested convening a meeting of the proposed Loya Jirga for the first time when former Soviet Union invaded Afghanistan and empowered late Babrak Karmal as president of the country. However, with the passage of time he as

well as his scattered supporters have continued such a stance and formally in 1997 they decided to take practical in connection with their peace plan. The plan was named Rome Peace Process. But on the other hand, Hizbe Islami of Gulbadin Hekmatyar which opposes the demand for Loya Jirga, convened a meeting at Cyprus. Majority of the participants were earlier associated with Hizbe Is- lami and other hardliners and the Iranian government is reportedly contributing a lot in hospitality of the delegates.

Now the UNO according to Francis Venderrel's strategy has decided to unify all these initiatives and had arranged indirect talks amongst them.

But like Diego Cardovez, he has again ignored some important parties to the conflict. These parties

include the two main warring factions Talibaan and Northern Alliance and several others including scattered but ideologically united stalwarts of the former ruling Watan Party, three major moderate Jehadic groups and certain Peshawar based Afghan Shura's and groups.

Francis Venderrel by creating such divisions among the Afghans would further complicate the already tense situation in Afghanistan. Instead of hosting gatherings at Geneva and other Western cities, UN needs to arrange broad based direct talks amongst the Afghans in the region if it is not possible inside Afghanistan. And only the implementation of Loya Jirga proposal is the proper way for pulling Afghanistan and its people out of 23 year long internal fighting and hostilities. 


\section{The Nation MONDAY, SEPTEMBER 10, 2001}

\section{Afghan conundrum}

SINCE the arrest of eight members of a Western charity group "Shelter Now" in Afghanistan on charges of preaching. Christianity, the standoff between Kabul and the West has taken an ominous turn. The trial of the detainees has started, triggering concern in world capitals about its outcome. Foreign Minister Abdul Sattar's warning to the world community not to deepen the Taliban's isolation thus makes eminent sense. Since the imposition of UN sanctions, aside from the curbs slapped by the US and its partners, living conditions in the war-ravaged country have taken a nosedive. The combination of drought and civil war have taken a cruel toll. The recent UN move to station monitors on the Pak-Afghan border to monitor compliance with the Security Council sanctions seems to have further hardened the Taliban's resolve not to succumb to such pressure, one manifestation of which was Kabul's refusal of the Western diplomats' request to see the detained aid workers. The UN has meanwhile warned Kabul not to carry out its threat to ban overflights, as it would hit distribution of humanitarian aid. The logjam is threatening to
get worse.

At the core of the standoff lies the Taliban's refusal to agree to a Westsponsored broad-based government at Kabul, expel or hand over Saudi dissident Osama bin Laden to the US, soften their policies on women, and wind up alleged training camps of jehadis on Afghan soil. In fact, curbing transnational "terrorism" has been made an important plank of US foreign policy in the region. What has apparently stiffened the Taliban's resolve not to dilute their position is the ruthless tightening of the screw by the US and its allies. The clamping of tough sanctions on the Taliban government, and the provision of clandestine aid to the Northern Alliance has further ruffled feathers in Kabul. For them, the bias is too pronounced to be ignored.

The Afghans have already paid a steep price for the West's proxy war, the last battle of the Cold War. The subsequent civil war and the world community's callous neglect further embittered the Afghans. As exhorted by Abdul Sattar, the international community, instead of isolating Kabul, should engage it in constructively. The Afghans are already at the end of their tether; driving them against the wall won't be good for anybody.

\section{Taliban asked to release aid workers}

\section{From Our Correspondent}

PESHAWAR - Haji Hayatullah President of the Peshawar based Council for Understanding and National Unity (CUNUA) has asked the Taliban leadership to release the eight foreigner aid workers being tried for preaching Christianity in Afghanistan and deport them to their native countries. He said the step will be beneficial for the country.

"Islam is the religion of patience and tolerance, therefore, Taliban leadership needs to treat them according to Shariah," he remarked while informally talking to The Nation here in Peshawar on Sunday. Haji Hayatullah said that foreign NGOs, particularly from the western world have contributed a lot for the welfare and relief of war stricken Afghans. 


\section{Asylum seekers flood Britain}

\section{By Qamar Ahmed}

LONDON, Sept 9: Britain is fast becoming a reasonably safe haven for asylum seekers, illegal immigrants and refugees. Most of them brought into the country with the help of travel agents and people who specialize in the movement of the human cargo.

A lot of money is involved in this business and a lot of money to be made for them as desperate people in search of a better life and escape persecution attempt to come to a country where they are assured of a shelter and social security.

In recent times a bulk of them have come to Britain as refugees after the crisis in the Balkans where Milosevic and his Serbian bandits murdered many Kosovan, Bosnian and Croatian muslims families in the name of ethnic cleansing.

Well to do Afghans are the second in number of those with refugee status followed by the Kurdish people from Iraq. Persecution by the Taliban government and Iraqi zealots had caused their exodus from their country of birth.

People from Pakistan, India and Bangladesh come in the later category and little in number compared to the Afghans, Kurds and Iraqis.

Risking life by swimming the Channel and walking under the waves through the Channel Tunnels, and risking exploitation and also arrest and inhuman conditions of infamous Oakington detention centre in Britain they have braved the odds to enter Britain.

Only a couple of days ago nearly 40 people were apprehended when they entered the Euro-tunnel to walk through it into the Kent coast. Which attracted an uproar in both France and in England.

Humanitarian organizations have already recorded their protest over the treatment given by the British Home office to asylum seekers, refugees and illegal immigrants. Once they enter Britain and apply for asylum, they are put in a detention centre till their hearing and are not allowed to work for six months. Instead of cash they are handed over vouchers to buy food which barely enough for them to have a square meal for them or for their children.

\section{Engaging the Taliban}

THE foreign minister's plea that neither of the warring parties should be supplied with arms deserves to be heeded by all those interested in peace in Afghanistan. Speaking on Russian television, $\mathrm{Mr}$ Abdul Sattar observed that the sanctions were flawed, because they did not apply to the Northern Alliance. This one-sided ban did not help the cause of peace; instead, the UN sanctions enabled the alliance led by Ahmad Shah Masoud to continue to receive arms and, thus, pursue their war against the Taliban irrespective of the consequences for the people. The foreign minister's observations should be seen against the backdrop of the US-inspired UN sanctions, which have in no way advanced the cause of peace or made the Taliban change their policies. The civil war continues as before, causing more miseries to the people.
Devastated by both war and drought, the hapless people have no choice but to suffer in silence or to head for safety, and there is only one direction in which they head - Pakistan. On its part, Pakistan has done all that can possibly be done to help the Afghan refugees. There is, however, a limit to Pakistan's resources - and patience.

On the other hand, the US and Russia pursue punitive policies without taking into account the long-term consequences for Afghanistan and its neighbours. Russia, it is now becoming increasingly clear, is overplaying the bogey of terrorism. Whatever the bizarre nature of the Taliban's repressive and obscurantist policies, no one in his right mind would believe that the rulers of an impoverished and troubled country have nothing else to do but to export their brand of Islam to a country as far away as Russia. Nor are the rulers of Afghanistan's neighbours in Central Asia averse to exploiting the bogey of a fundamentalist

threat to crush political opposition at home. For Russia also, the entire Taliban-related phenomenon provides it with a ready pretext for keeping a military presence in some of the CIS countries.

For America, the aim is to so force the Taliban to hand over Osama bin Ladin to it. That is where the State Department is wrong. No matter what the pressure, the Afghans, a proud people, are not going to succumb. The British and Russians have learnt this to their cost. If the Americans want Osama to try him for alleged acts of terrorism, then it is through negotiations with Kabul that a satisfactory solution can be reached. Sanctions on the Taliban and military aid to their enemies are not going 


\title{
The Fronitier Post
}

\author{
Tuesday, September 11, 2001
}

to make Kabul surrender. The proper course for the Americans would be to engage the Taliban instead of trying to isolate them from the rest of the world. One hopes that the six plus two talks in New York later this month would take a realistic view of the situation. Clearly, sanctions must be lifted, the arms embargo should be applied to both sides, and the two encouraged to end the civil war and begin negotiations for a broad-based government acceptable to all sections of the people of Afghanistan.

This is also time for the Taliban to review their domestic policies which have drawn worldwide censure. Their insistence on imposing their brand of Islam on the people, their harsh treatment of women, and their cultural policies, as seen in what they did to Afghanistan's cultural heritage, have served to cast Islam and Taliban in a bad light. The Taliban should note that it is not the nonMuslim world alone that is aghast at their policies; even the Muslim world at large has turned its back on them. It is time the Taliban decided to open up a bit.

\section{Attack on Masood}

$\mathrm{R}$

EPORTS from Afghanistan say: the Lion of Panjsher, Ahmiad Shah Masond, has been injured in an attempted - assassination. The man whose name is synonymous with the undefeated resistance to Soviet occupation of his country, and who is leading the Northern Alliance's war against the Taliban, was hurt by a bomb placed in a video camera that a group of so-called Arab journalists were carrying to interview. him. The bomb exploded as soon as the camera started filming. One of Masood's bodyguards died on the spot, along with two of the 'journalists'. Another was detained. The extent and seriousness of Masood's injuries are not yet known. Rumours, however, have already started swirling about his death.

The finger of suspicion would naturally point first and foremost towards the ruling party in Kabul being behind the attempted assassination. What other actors are involved, from within or outside 'Af'ghanistan, will perhaps only be known with the passage of time, if at all. The Taliban, and arguably their main backers, the military regime in Pakistan, may have cause for elation at the injury to, or even death of the redoubtable Ahmad Shah Masood. But the long term repercussions of any such development, either of his incapacitation or demise, are still too difficult to assess so close to the event.

If Masood is forced to leave the battlefield or dies, a chapter of the Afghan resistance and civil war would come to a close. The fallout of his death for the situation in-Afghanistan is bound to be critical. It may yet be too early (0) say, bat some consequences suggest themselves almost immediately. The first is the choosing of a successor for Masood. The internal dynamic of his resistance group is not too well known. It is not clear, therefore, whether Masood has already named a successor or not. In any case, the next leader may or may not enjoy the prestige or command the loyalty that Masood does. Rivalries could conceivably break out, which would obviously weaken the resistance.

The Northern Alliance too, given that there is really no replacement for Masood who could command the same respect, could fracture or even disintegrate. The Northern. Alliance had been strengthened of late by the return of the Uzbek warlord Rashid Dostum from self-imposed exile, as well as the reactivation of the western front after the ex-governor of Herat, Ismael Khan, miraculously escaped from Taliban captivity and found his way to Iran. Whatever plans were being drawn up to take pressure off the Panjsher valley by drawing Taliban forces away towards the Mazar-e-Sharif (the Uzbek. stronghold) or Heart fronts, must now be clouded in uncertainty.

If the Taliban attempt to take advantage of this 'coup' and mount a major offensive against Másood's forces, it is not certain whether in his absence, his men will be able to stave off such an attack. If not, there could conceivably be a retreat of some if not all of his forces across the border into Tajikistan. With Russian troops guarding that frontier against the spillover of the Afghan civil war onto Tajikistan's soil, the reception the retreating fighters may receive is also in the realm of the conjectural. Tajikistan's official and unofficial sympathies with their co-ethnic brother Masood notwithstanding, they may not welcome hosting one side of the fratricidal strife for fear of 'hot pursuit' by the Taliban across the border.

The regional players who were backing the Northern Alliance have no doubt received a severe setback to their plans. Russia and some of the Central Asian republics will be worried about the implications of a weakening or collapse of the Northern Alliance for the chances of the militant fundamentalist movements that have sprung up in the region and all the way to Chechnya, being strengthened by these developments. Even China, despite its diplomatic overtures and offers of economic cooperation to the Taliban lately, may be pondering the effect on the Muslim separatist movement in Xinjiang. 
Overall, the internal Afghan, the regional, and the wider scenario is bound to undergo an enormous change in the event of Masood's departure. The apprehension is that even if the Taliban succeed finally in gaining an outright military victory over their rivals, instability will continue if not exacerbate because of redoubled efforts by the regional and other players to resist the Taliban's export of their brand of fundamentalism to other countries of the region. This is a fate that seems destined to haunt the area for the foreseeable future, no matter what happens to Masood.

\section{The Frontier Post Tuesday, September 11, 2001}

\section{Music and music education \\ F.P̈. Report \\ In Peshawar, there is a real}

PESHAWAR: Music accompanies every human milestone. from baby naming till death. One can find it every where around him; the chirping birds, the flowing streams, the blowing winds and even the thumping of our hearts has a musical rhythm in it. Music, with its sedatory effect, attracts people all over the world and is no doubt an international language.

However. music in itself is a vast knowledge and it is for this reason that a large number of academies and even universities all over the world are imparting musical education and training in various musical instruments.

Those being trained include both the amateur and the professionals. In our country, especially in Punjab music academies can be seen In this respect, our province is lagging behind. Because of some cultural, social and economical compulsions of our people, musical education is not being provided in its true fervour. death of such musical academies, however, individuals do impart the training of specific musical instruments. The most popular instruments among the people of this area are Rabab, Saarinda, Sitar and flute. These instruments are played on special occasions and in some of the areas, thes

lovers have benefited from his academy, "Irfan Musical Centre", which is among the few numbered ones in Peshawar. Ustaad Ehsan has been imparting musical education for the last 30 years in Pakistan, India and Afghanistan and it is since 1992 that he is in Peshawar.

At present he is training more than hundred students in his academy Ustaad Ehsan says that youngsters are really interested in this rich art and they have the talent also but what is needed is to provide them with proper guidance and training.

Besides those entering this filed as a profession, músic is a good and healthy pastime

are even a part of their culture.

Ustaad Ehsan Irfan is also among those masters of this art who are imparting the musical education to its lovers/mongers. The proverb, "Jack of all and master of none", can be proved wrong in his case as he plays five musical instruments, i.e. Rabab, Sitar, Sarod, Tabla and keyboard, and is the master of all. Hundreds of music. you relief from the woes and you relief from the woes and lot of research is being carried out on the medicinal and therapeutic roles of music. However, it is no doubt a delightful, enjoyable and ravishing way for people to reduce the stress response in a manner that leads us to positive psychological and biological changes. 


\section{The Frontier Post}

Tuesday, September 11, 2001

\section{Taliban, opposition swap prisoners \\ F. P Report}

PESHAWAR: Afghanistan's ruling Taliban militia and the Northern Alliance forces have exchanged imprisoned commanders in Suri Pul province. 3. According to details, Taliban militia has released commanders Amir Mohammad and Amanullah of Mazar-1-Sharif belonging to Ahmad Shah Masood-backed Northern Alliance in exchange for its two commanders, Abdul Karim and Abdur Razzaq. The swap of the commanders was carried out in the protince of Suri Pul:

All the four commanders had been arrested during the fighting in Suri Pul province sometimes back.

it is worth-noting that both the commanders of the Taliban side belong to Kandahar Province and are very strong supporters of Taliban regime.

Germany seeks Pak help for release of aid workers

ISLAMABAD (NNI):

Germany has reportedly asked Pakistan to extend its help in the release of the four detained German aid workers who have been arrested by the Taliban along with two Americans and two Australian on the charge of preaching Christianity in Afghanistan.

- Voice of A merica quoted a report published in a German journal as saying that a special German envoy has met the head of the Pakistani ISI and discussed the issue in Tslamabad.

42. However, the German officials did not confirm the meeting but said they will continue their efforts to find out ways for the release of these arrested German aid workers.

\section{Suicide bombers killed in attack on Masood}

ISLAMABAD (NNI): TWo alleged Arabs, posing as journalists and carried out the assassination attempt on the life of veteran Afglian resistance leader and chief of the United Front anti-Taliban forces, Ahmad Shat Massoud, Sunday were killed, a Unifed Front (UF) leader has said.

Massoud's aide and a UF leader, Yunus Qanooni, told Azadi Afghan Radio that the "wounds are not life-threatening." as the commander was flown to neighboring Tajikistan for treatment. Assem Suhail, a spokesman for the 49-year-old Afghan military leader, was killed in the incident, and Afghan Ambassador to New Dehli, Massoud Khalili, who was accompanying Massoud at that time, was also injured. There is no update aboult Khalili's condition.

Qanooni said that the two perpetrators, claiming to be journalists, cither detonated a booby-trapped hand-held camera or an explosive charge that was presumably strapped to one of the men was detonated by remote control by the second man. The nationality of the two bombers has not been determined yet.

UF sources said that the two bombers had traveled to Parwan and Kapisa provinces prior to meeting Massoud near Khwaja Bahaudin in Takhar, and met with other UF leaders, including head of the ousted Afghan government Prof Burhanudin Rabani and his ally Prof, Abdur Rab Rasul Sayat.

Opposition claims that several Arabs are allied with the Taliban and are fighting in Afghanistan to capture territory held by Massoud, who had been Defense Minister in the government, ousted by the Taliban from Kabul in 1996

The UF alliance headed by Massoud also includes Ismael Khan, Haji Abdul Qadeer, Ustad Khalili, S. Hussein Anwari. Bismillah Khan and other former veterans of the anti-Soviet occupation Afghan resistance in the 1980s, who are now fighting against Taliban. Abdul Rashid Dostum, an Afghan Uzbek leader is also part of the alliance.

\section{EC approves grant for CARE Afghanistan}

\section{FP Report}

PESHAWAR: The European commission has approved a grant of Euro 3,300,000 for CARE Afghanistan lo support the security of livelihood for Afghan returnees (SoLAR) project. The overall objective of the project is to enhance the social and economic situation of vulnerable local comimunities' thereby encouraging and facilitating the durable reintegration of returnees and internally displaced persons.

The funding will specifically. assist 30,000 rural households in targeted areas of eastern and southeastern Afghanistan to improve their agricultural infrastructure, improve market roads and increase water supply. In addition the project will focus on supporting the most vulnerable, often landles households with income gencration projects. The project started on July 1, 2001 and will continue until 30th June 2003.

CARE Afghanistan established its operations in 1961. The first projects focused on medical training and improving health care services. The 1979 Soviet invasion and civil war that followed made it necessary for CARE to suspend operations from 1980 until 1989. CARE's main office is located in Peshawar, Pakistan with six sub-offices in Afghanistan. 


\section{The Frontier Post tuesday, September 11, 2001}

\section{Taliban launch major offensive in Parwan}

KABUL (Agencies): Ruling Taliban in Afghanistan have launched a major offensive against their opponents in Parwan province and claimed that their forces had captured some areas from the opposition forces.

According to-Radio Tehran, the Taliban forces were backed by tanks and warplates during the attack. Taliban sources were quoted as saying that their forces had captured strategio high ground from opposition forces in the vicinity of Bagram airbase. A Talibań official said the capturing of high grouind would enable Taliban artillery to hit most of the areas under opposition control. - On the other hand clashes between Taliban and North.
Alliance forces have also occurred in Khawaja Ghar and Chal Ulâswalis in Northerinte Afghanistan. However, there are no reports whether any of the sides have

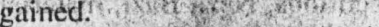

Meanwhile, Afghanistan's ruling Taliban movement -and opposition forces were locked in intense clashes on the main road leading out of the capital, Afghan sources said :

They said both sides bom barded each other's positions with heavy weaporis on the plains of Shomali on the socalled Old Road, some $25-\mathrm{km}$ (15 miles) north of Kabul. There were no further details on the fighting from either side.

Witnesses in the area said opposition lines during an overnight offensive lasting several hours but retrcated after dawn.

"We could hear constantly salvoe: of rockets landing and being fired in the early hours of the morning," one witness said.

Taliban jet fighters were seen heading towards Shomali, which lies on the main road to Panjsher valley, Masood's native stronghold.

Opposition sources say that over the past several days the Taliban have stepped up their attacks on several directions leading to the twisting valley, which has been under partial siege since the Taliban ousted Masood from power in 1996. But they said the opposition forces were bracing for Taliban forces broke the a counter-attack.

\section{Putin, Rakhmanov discuss \\ for 12 . situation in Afghanistan}

KABUL (Agencies): Russian Pahjsher valley stronghold were President Vladimir Putin spoke Monday to Tajikistan's President Imomali Rakhmonov dbout Afghanistan, the Kremlin said.

The heads of state discussed the current situation in Afghanistan in the light of the activisation of terrorist activity of extremist groups," the Kremlin statement said. It made no reference to Masood, whose forces control-regions bordering Tajikistan, which survived its own devastating civil war in the 1990 s and fears a Taliban advance to its borders.

Masood's anti-Taliban alliance is officially led by President Burhanuddin Rabbani, who was driven from Kabul in 1996 but is still recognized by the United Nations as Afglanistan's legitimate leader. Soviet forces repeatedly failed to crush Masood during the 1980 s. Today he is the driving force behind the opposition to Taliban rule.

Annual attacks on hís repulsed and the became a romantic figure in the West. After appearing near defeat a year ago, he has ikept Taliban attacks dotted across the northern thali of the country. Itar-Tass quoted inspecified sources in its report from Tajikistan's capital Dushanbe. In Tajikistan, the. Afghan embassy, which is under Masood's control, said Masood was still in Afghanistan receiving treatment. It too said there was no concern for his condjtion. There were two Arab journalists with him for an inter. view at his office in Khoja Bahauddin (Takhar province)," said the Panjsher valley secretary, who asked not to be named.

One of them had attached explosive devices on his body and blew himself up as a suicide bomber or devotee," he added. "This person got killed on the spot along with a colleague of us and Masood himself rereived forces off balance by guerrilla injuries on his leg, hand and chest. The wounds are minor ones " he said.

The secretary said Masood's guards opened fire and killed the second Arab. He said they had not determined the nationalities or affiliation of the would-be assassins. Masood's forces control the northeast of Afghanistan and are fighting the Taliban north of the capital Kabul, on the route toward the Panjsher valley, the commander's native stronghold.

Taliban chief spokesman Abdul Hai Mutmaen told Reuters that the Taliban were not behind the assassination attempt. "We are not involved in the incident. If we were, we would have proudly said that because he is our enemy," Mutmaen said.

The attack on Masood came a day after a powerful blast in the capital Kabul wounded an unknown number of people inside the hard-line Islamist Taliban's interior ministry. 


\section{The Frontier Post Tuesday, September 11, 2001}

\section{Situation in Afghanistan dominates Pak-French talks}

Fakhar-ur-Rehman

ISLAMABAD : While Pakistan and France agreed on Monday to further consolidate the existing bilateral friendly relations, situation in Afghanistan dominated the parleys held between delegations of the two sides led by Loic Hennekinne, Secretary General of the French Ministry of Foreign Affuirs and Foreign Secretary Inam ul Haque.

Sources at the Foreign Office told The Frontier Post, the situation in Afghanistan was figured during the talks in length and reterence was made to the reported incident of assassination attempt on Ahmed Shah Masood".

According to a Foreign Office press, release during the consultations, the entire gamut of Pakistan-France bilateral relations in the political, economic, commercial, cultural, etc. aspects was reviewed in detail.

The French side was briefed on Pakistan's regional perspective, including relations with India, the: Kashmir dispute and Afghanistan.

Hennekinne apprised the Pakistan side of the French perception of South Asia, situation in Europe and French ties with

the European countries. Detailed discussion also took place on Pakistan's interaction with the European Union.

The French side was led by Mr.Loic Hennekinne, Secretary General of the French Ministry of Foreign Affairs. Foreign Secretary Inam ul Haque headed the Pakistan delegation to the talks.

The government announced programme to return the country to the democracy was also discussed which according what the government press release said was lauded by the French side. dominates Pak-French talks

"The French side welcomed the policies of the government for the return to democracy by October 2002 , particularly the August 14 announcement of the roadmap" said the Foreign office statement.

French Secretary General also appreciated efforts of the government aimed at revival of economy. The two sides decided to further enhance the level of bilateral cooperation in all spheres.

They expressed their keen desire to maintain regular contact with each other to augment the existing friendly relations:

Earlier, the French Secretary General called on the President. During the meeting, the "President emphasized the importance Pakistán attached to its long standing and friendly relations with France.

The French Secretary General underline Pakistan's geo-strategic location and recognized Pakistan as a vital factor of stability in the region.

Hennekinne also called on the Foreign Minister, during which Mr. Abdul Sattar focused on Pakistan's relations with France and underscored the need to strengthen them further.

He also briefed the French delegation on the situation in Afghanistan and the Agra Summit.

Secretary General Hennekinne was accompanied by a delegation of senior officials from the French Foreign Office comprising: Mr. Dominique Girard,Director General for Asia and Oceania; Mr. .Hughes Pernet, Director Generalfor Eastern Europe; Mr. Bruce Bourdon, Desk Officer for Pakistan; Mr.Yannick Girard, Ambassador of France and officials of the French Embassy in Islamabad.

\section{Taliban, China sign MoU \\ F P Report}

PESHAWAR: The Afghan Ministry of Mining and Industries signed a memorandum of understanding with the Chinese economic and techni, cal cooperation delegation here. The memorandum calls for promoting economic and technical cooperation between the two countries.

The Afghan Minister for Mining and Industries Mulla Mohammad Ishaqi met the vis: iting Chinese economic and technical cooperation delegation and discussed matters of bilateral interest.

During the meeting the two sides explored ways and meins of expanding technical and economic cooperation between the two countries in the mining and industrial sector. Later the two sides signed a memorandum of understanding calling for technical and economic cooperation between the Taliban and of China. 
Fridagfimes

Aug 31-Sept 6, 2001

\title{
Gulf flesh-traders recruit
} women from NWFP

\author{
Iqbal Khattak \\ says Pakistani and Afghan girls end up in five-star hotels \\ in Dubai
}

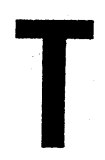

he North West Frontier Province is witnessing a steady rise in cases of women trafficking for prostitution purposes, reveal surveys done by some NGOs. While the majority of the girls forced into the trade is Afghan, the number of native girls is also on the rise.

Last year, a survey conducted by Aurat Foundation, an NGO working on women's rights, brought to surface 39 cases of women trafficking in the NWFP. However, the Foundation spokesperson told TFT the survey was not comprehensive. "It is extremely difficult to unearth all such cases for a host of reasons," she says.

Investigations confirm that Peshawar, Chitral, Swabi, Mardan, Charsadda, Swat and Bannu districts top the list in the sale and purchase of girls as young as 13-yearolds. While some are taken to the Punjab after being "married off" and abused, in most cases they end up in the Gulf states for prostitution purposes.

Sources say the seriousness of the situation can be gauged from the fact that a top intelligence agency has been asked to conduct investigations into the business. As recently as August 16, the police arrested an Afghan girl and her pimp at Peshawar airport after being tipped off by this agency.

The man, Murtaza Wasee, is a resident of Saadat Colony in Karachi and has been booked on the charge trafficking young girls. Misbahuddin, the coordinator of Citizen Action Committee for Women's Rights in Charsadda district, told TFT that last

year two cases were reported when girls sold out to parties in the Punjab fled their captors and came back. This year, three other cases of girls trafficked to Punjab have been reported in the district.

In some instances, interested parties take advantage of the poverty of the parents and the tradition among some tribes of selling off girls for a price. Some reported cases reveal the girls were married off to one person who then used them to entertain other customers.

In the federally administered Mohmand Agency, brokers have traditionally organized a fair where parents bring their girls and the clients pick them up on the basis of beauty, age and such other factors. The fair was declared illegal a few years back but it continues on the sly in many areas of the Agency.

"Parents bring their daughters to the fair where buyers pick up the best merchandise," a source at Ghalanai, headquarters of Mohmand Agency, told TFT earlier this month.

A 'Situational Analysis' on trafficking of Women and Children in Pakistan by ActionAid Pakistan says the issue is grave and complex and needs to be addressed at various levels. The report says Pakistan is the destination point for girls being trafficked into the country from Bangladesh, Burma,

Afghanistan and the Central Asian States. It is also the transit point for girls brought in from Far East Asia and Bangladesh before being smuggled into the Gulf states. The report also says the country has become a recruiting ground for Pakistani and Afghan girls who are bought here and taken to the United Arab Emirates and Saudi Arabia.

Police officials confirm these findings. A senior police officer from the Crimes Branch told TFT that scores of Afghan girls are trafficked to five-star hotels in Dubai every month. "Dubai is where girls from various countries, including Eastern Europe and Russia, end up," he said. This fact was confirmed by TFT last year during a brief stay by one of its reporters at one of the 


\section{Fridan fimes Aug 31-Sept 6, 2001}

five-start hotels in Dubai. The hotel's discotheque was teeming with girls who were being picked up by clients.

In the case of girls trafficked from NWFP, the passports are prepared at Darra Adamkhel located in the Orakzai Agency on Peshawar-Kohat Road. Darra is also famous for arms manufacture and smuggling.

Sources in Kabul told TFT that most upper-class Afghan women in that city have taken to prostitution since falling upon bad days. "Of course, the trade goes on surreptitiously. It's the same situation in Herat and the Mazar," he said.

Senior police officers admit the trafficking cannot go on without the collusion of certain law enforcement officials. "There are many factors involved here. Of course there is the element of corruption. But there is also the element of poverty and greed of the parents who are prepared to accept money from unknown people and marry off their daughters to strangers. There is nothing the police can do if it looks like a lawful wedding," says a senior officer.

\section{Walk the walk on Afghanistan}

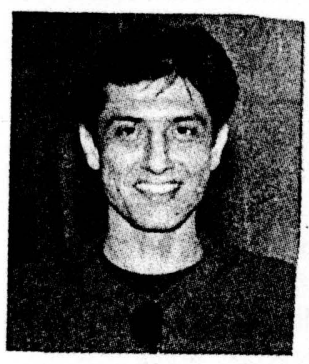

Ejaz Haider

viys if the Taliban wre not sensitive to P'akistan's interests, why must Islamabad keep sticking its neck out for them

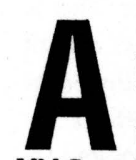

II religious parties and most political parties have rejected the placing of United Nations monitors in Pakistan to oversee the implementation of the UN Security Council sanctions against the Taliban regime. The sanctions have been put under UNSC resolutions 1267 and 1333, passed on 15 October 1999 and 19 December 2000, respectively. The placing of the monitors itself in Pakistan and other countries around Afghanistan is being done under the UNSC resolution 1363, which was passed on 30 July 2001.

The rejection came during a religio-political parties' meeting in Islamabad on August 26. What course should the government adopt? Should it go along with the sentiment and reject the UNSC resolutions, taking a snapshot view of the situation or should it take a holistic view of its Afghan policy?

Pakistan's Afghan policy needs a serious review. A common argument in its support relates to interference in Afghanistan from other regional and global actors on the side of antiTaliban forces. Since Pakistan has sided with the Taliban in the struggle for power within Afghanistan, the argument inevitably leads to the following corollary: anti-Taliban forces are anti-Pakistan forces and therefore Taliban, by keeping them at bay, are fighting Pakistan's battle in that country. Moreover, after being at it for so long Pakistan cannot be expected to simply walk away leaving the arena open for other contenders.

Something needs to be said about this argument. A review would obviously entail costs not so much because of itself as because of a bad policy that has gone on for so long. Similarly, the costs of what is being done are all too obvious. One can count innumerable acts by the Taliban since the militia emerged in October 1994 to prove that they are no one's protégé. Islamabad has said on various occasions that its leverage with the militia has serious limitations. If empirical evidence and Islamabad's assertions are accepted, then one must ask the question of what is in it for Pakistan? Pakistan needs to be clear on whether it can or cannot exercise leverage over the Taliban. If it cannot, then it makes no sense to carry on with them.

It is no secret that the policy has marginalised Pakistan. The militia, like previous Afghan governments, refuses to accept the sanctity of the Durand Line. Support to the Taliban has adversely affected Pakistan's Kashmir policy, and the Taliban's penetration into Pakistani society threatens the country's social fabric with serious disruption. 
Consider the strategic aspect. Pakistan wants a "friendly" government in Kabul, one that it can control. Apparently, that also translates into the much talked-about strategic depth, a concept that steadily shaped up during the Afghan war. Pakistan can reach the Central Asia Republics through Afghanistan, and, finally, it can get the "friendly" government in Kabul to accept the Durand Line that forms the border between the two countries.

\section{Pakistan's present stand of opposing the resolutions but going along with them is sensible. There is no need for Islamabad to carry the Taliban cross if it does not translate into any meaningful gains for it. The Taliban must be told that there are no free lunches here and that if they want Pakistan's support they will have to . respect Pakistan's interests}

None of this has happened, or is likely to happen. Instead of influencing Afghanistan in any meaningful way, the Pakistani society, or at least large sections of it, is under threat of being influenced by the Afghan ethos. That process can be seen already at work. Pakistan has failed to reach out to the CARs, most of whom fear the Taliban. On the economic front, while Afghanistan continues to plague Pakistan's economy in several ways, there is hardly any trade going on between Pakistan and the CARs.

No matter how one looks at it there is only the flip side to this policy. The "friendly" government in Kabul has cost Pakistan its relations with Iran and the CARs. It has made it that much more difficult for Pakistan to reach out to Moscow. It has allowed India to propagate the linkage between Kashmir and Afghanistan and pass off the freedom struggle in Kashmir as acts of fundamentalist terrorism. And, it provides the one area where China has expressed its reservations on a number of occasions. The proponents point out that Pakistan should have fought off these resolutions and got China involved. The fact is that Islamabad did give a fight. That it did not succeed is a measure of how unpopular the policy has become internationally. China abstained from the vote, which is significant not because it did not put its weight behind the pow- ers pushing the resolution through, but because it did not deem it fit to put its weight squarely behind Pakistan and veto the resolution.

Should Pakistan then move away from Afghanistan? Yes, and no. It may not walk away from Afghanistan but it must from the Taliban. The militia must be told who is the boss and if its refuses to bite, it must be made to pay for it. Real diplomacy is about creating a situation where moving away from the Taliban or forcing them to concede to Pakistan's will does not automatically result in losing all our eggs. This means serious policy review rather than just parroting off known talking points ad nauseam. If Pakistan is prepared to walk the walk it can still manage the situation. It must reach out to Iran. Previously, it refuse to take Iran seri-

ously; now Iran holds better cards at least in terms of international support if not the ground situation. In any case, Pakistan has to place itself in a position of importance once again.

The review must also focus on the internal costs Pakistan is accumulating with this policy. These costs are being dismissed and that is a huge mistake. The proponents argue that the UNSC is acting in a very partial manner. That is true. But why is it that Pakistan, today, cannot stop it from doing so? The Taliban are the problem and Pakistan is in no position to offer a solution, which makes it a part of the problem. If all the assumptions about the policy as it stands are correct then why should Pakistan be going down with Afghanistan? Surely, Pakistan's policy is supposed to advance Pakistan's interests rather than Taliban's interests. That, apparently, is not how some of the proponents look at it.

Finally, Pakistan's present stand of opposing the resolutions but going along with them is sensible. There is no need for Islamabad to carry the Taliban cross if it does not translate into any meaningful gains for it. The Taliban must be told that there are no free lunches here and that if they want Pakistan's support they will have to respect Pakistan's interests. It is only by getting into a position of power vis-àvis the militia that Pakistan can still hope to interest the world. 


\title{
Fridgaffimes Aug 31-Sept 6, 2001
}

\section{Could Taliban deny consular access to SNI detainees?}

\author{
Ahmer Bilal Soofi \\ says there is no provision in international law that compels any \\ state to allow access to foreign nationals
}

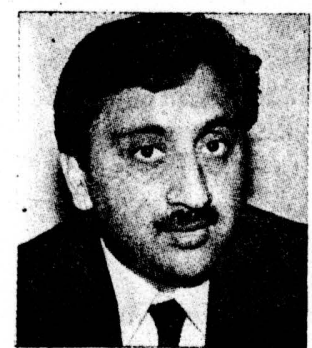

While the Taliban government has finally allowed diplomats from the US, ricrmany and AusIfalia to meet their detained nationals working for Shelter Now International (SNI) and accused of proselytizing, it had earlier denied consular access to the detainees. This article purports to look into the issue of consular access in light of international law and determine whether the Taliban were acting in violation of any IL provisions.

Facts of the case: The SNI does not represent any formal UN organization and is one of the many NGOs working in Afghanistan. Therefore, the SNI staff is not entitled to diplomatic immunity or privileges. The staff, excluding the Afghans hired by the SNI, comprises foreign nationals. On the face of it, they were found propagating Christianity. The charge, if true, is an offence under the Taliban law and Kabul shut down the organisation and took some of the staff into custody.

Due to sanctions and other political reasons, by and large, all embassies in Afghanistan have been shut down. The Pakistan mission is perhaps one of the few missions left operating in Afghanistan. Except for three countries the international community does not recognise the Taliban government. The nearest missions and embassies are in Islamabad. Given these facts, the legal issue is whether the detainees had a right of access to their envoys? Or, conversely, did diplomats have a right to meet their detained nationals in Kabul?
What does the law say? The basic international law in this regard is codified in the Vienna Convention on Diplomatic Immunity 1961. It enlists several exemptions from domestic laws to diplomatic missions and also provides several other privileges to diplomats.

However, the law does not provide any option or any facility to a diplomatic mission as a matter of right to have access to its nationals who might be detained in the host country under domestic law. Access can be had only if the host-state so allows it as an act of courtesy. Consider a concrete example. In Pakistan, several foreign nationals are routinely tried under various offences, which range from drug charges to illegal entry. The foreign missions of these nationals cannot as a matter of right meet the detainees. However, there are many instances in which such access has been granted as a matter of courtesy. Even in the Councilor and Privileges Act in Pakistan, which is a domestic legislation, no such right has been given to the detainees.

The proposition in relation to Afghanistan: As mentioned, the SNI volunteers are not diplomats, merely nationals of some foreign countries. Under international law the Taliban government is under no obligation to allow envoys to meet the detainees. Neither is there any domestic legislation to provide

such passage. The closest to such an arguable position is Article 46 of the 1961 Vienna Convention, which speaks about the temporary protection of the interests of the third state and its nationals. But again it cannot be interpreted as displacing a valid national legislative criminal process. It is thus clear that in so far as the framework of law is concerned, it is difficult to find an authority for the diplomats' right to see their detained nationals.

Access to ICRC: Interestingly enough, the Taliban did allow representatives of the International Committee of the Red Cross (ICRC) to meet the detainees. The ICRC, as per its own statute, can seek or render assistance to 
any state even in a situation of internal strife. It has been a state practice that given the neutral status of the ICRC, most of the states or non-state actors in control of territories where conflict is in process, do provide access to the

" ICRC. The Taliban appear to recognise the same principal and have allowed access to the ICRC to meet the detainees.

Courtesy argument: The only argument being advanced so far is that it is an issue of state courtesy. To this extent the point can be taken. States have practiced acts of courtesy in various situations, even when there are no legal binding obligations in a situation. There are several examples of this where on purely humanitarian grounds or as a gesture of goodwill, such assistance was rendered to the other state. However, given the fact that the UN has slapped sanctions on the Taliban Regime, there was little likelihood that they would express any gesture of goodwill towards the world community. On the other hand, they have responded shrewdly by initially declining consular access to detai- nees. Having made the point, they have decided to extend the courtesy to the envoys and allowed them access to the detainees.

The issue of recognition: On the one hand, the Taliban Regime is being denied recognition formally and legally whereas on the other hand they are being engaged directly at the state level. In one of my previous comments, I made it quite clear that by reaching out to the Taliban, the world community has in fact recognised them. Engagement of the Taliban in this episode is additional proof that they are the actual controlling authorities of Afghanistan. This implies recognising them as the legitimate regime.

Rationality of law: It is an altogether a separate argument to question the legality or vires of the law under which the Taliban wish to punish the SNI volunteers. Generally, it is recognised that the fundamental right of practicing religion would not be complete unless the ancillary right to preach is also recognised. However, if such a specific right is provided in any international instrument it needs to be seen whether Afghanistan is a party to that instrument and whether the Taliban are the legal successors to that obligation.

The writer is an expert in international law.

\section{Greece detains 46 Afghan immigrants}

ATHENS: Greek authorities said on Monday they had detained 46 Afghan illegal immigrants trying to reach the eastern Aegean island of Kos, a few kilometres off the Turkish coast.

$\because$ The Merchant Marine Ministry said the Afghanis, including five women and 12 children, were intercepted off the coast of the isFand in a wooden fishing boat. The latest arrests bring to 114 the fumber detained in the past 36 hours. On Sunday, the coast guards detained 68 Afghan immigrants, including 10 women and 16 children.

Hundreds of illegal immigrants and several smugglers have been Wetained on Kos over the past two Teks.

E. Thousands of illegal immigrants from Asia, Africa and EastEin Europe cross illegally into Greece every year either via its horthern border or by sea, hoping eventually to reach other European destinations.- Reuters 


\section{KHYRER $M_{\text {AIL }}$ Tuesday, September 11, 2001}

\section{France condemns attack on Masood}

ISLAMABAD (NNI): France Monday condemned attack against the Commander of Northern Alliance $\mathrm{Mr}$. Ahmad Shah Masood and described it as a terrorist act.

The visiting lineleh Secretary General for foreign Allairs $\mathrm{Mr}$. Loic Hennekinne addressing a news enference in Islamabad said that France has always condemned the acts of terrorism.

To a question Mr. Loic Ilennekinne said there is perecption gap between Pakistan and the Western countries about Alghanistan.

"Western world tend to think that it is possible for Pakistan to exert some kind of influence on Taliban government because of relations and proximity with Alghanistan". He said it is thinking in Europe that Pakistan may have some moderating. impact on Aighanistan. However he said Pakistani leaders.informed him that it is not the case and Taliban have their own thinking. The Pakistani leaders emphasised that it is the responsibility of international community not to isolate but assist $\triangle$ fghanistan and talks with the Taliban.

The French oflicial was of the view that Western world still thinks that if a government is able to talk with Taliban, it is Pakistan. He said France has a Charge 'd Aflaires for Aighanistan based in Islamabad. France has been having contacts with all Afghan groups including the Taliban, Northem Alliance and those in exile. He said it is imperative to bring people around and try for a broadbased government in Kabul.

He strongly urged India and Pakistan to lind a solution of lhe kashmir dispule through dialogue and peaceful means. He said his country was encouraged by lhe Aera sum. mit and has taken a note of the face that the leaders of both Pakistan and lndia will be mecling in New York later this month. "It is unfortunale that since 1947 India and Pakistan hare nol been able lo resolve the Kashmir problem," he said.

Asked to eomment on a free hand given by the Indiain government to oecupation forces in Kashmir to suppress tho lieedom struggle, he said France condemns human rights violations in any part of the world.

Replying (o) a question, he said linance as an active $m \mathrm{~cm}$ ber of the IMI: will support the idea ol granting poverty reduction and growth facility loan to Pakistan by the IMl:

He described his meetings with lhe President (ieneral Perve\% Musharral and the foreign Minister Mr. Abdul Sattar as very lriendly and usefiil. Ile said durine his formal talks will foreign Secretary Mr. Inamul Hac lhey had indepth exchange of views on bilateral relations, internal sitllation in Pakistan, crucial regional and international issuses like siluation in Aighanistan, sccurity in Soull Asia, bilateral relations between Pakistan and India and between Pakistan and the European Union.

He said there was a mutual desite on both sides to further eement and develop the existing ties between Palkistan and lirance. He said his country values its relations wili Pakistan and considers it a very important country in the region and a major lactor of stability in this part of the world.

Ile said stability and prosperity of Pakistan is important for security and stability of South $\Lambda$ sia.

The french secretary General ior Foreign Aftairs said Pakistan and his country had been having very good political dialogue, economic and linancial relations and eontacts in the field of defenee ind armaments.

Ile said during his meetings in Islamabad. he was briefed about the road map announced by President Pervez Musharraf on the 14 th of $\Lambda$ ugust as well as about the local government elections. He said France also took note of all the reforms undertaken by the present govcrnment. He said his country is also watching the road map announced by the President and considers the local government elections as a beginning of that process.

\section{US says Afghan opp leader killed WASHINGTON: Afghan opposition leader Ahmad Shah Masood was killed Sunday in a suicide bombing carried out in northern Afghanistan by individuals claiming to members of the media, a US official said. "That's our understanding as well," said the official when asked about reports that Masood was killed in a bomb- ing in northern Afghanistan. The official, who spoke on condition of anonymity, said "some individuals who por- trayed themsevels as mem- bers of the media conducted the suicide bombing which apparently killed Masood as well." - Agencies}




\section{The Statesman Tuesday, Spplember 11,2001}

\section{Masood unconscious; aide, two Arabs dead}

\section{Taliban deny involvement in suicide bomb attack}

\begin{abstract}
By Imtiaz
PESHAWAR: Afghan warlord Ahmad Shah Masood, who Sunday sustained life-threatening head injuries is said to be unconscious and in serious condition following a suicide bombing attack.
\end{abstract}

Sources in Northern Afghanistan told The Statesman that Ahmad Shah Masood had received injuries in legs and had an emergency surgery after a suicide bomb attack by two Arabs in the disguise of journalists in his heavily-guarded Khawaja Bahauddin residence. Besides suicide bombers one of the close aides of Masood, Azim Sohail Khan was killed while Masood Khalili, another senior leader of the Northern Alliance, also injured critically in the attack. Ahmed Shah Masood, sources said, was rushed to a Tajik hospital across the border.

"Both the journalists, who happened to be Arab nationals and got Belgian passports also killed during the attack," the sources said.

Some Peshawar-based Afghan sources told The Statesman that Masood died of serious wounds while some of the international news agencies have also released reports that Ahmad Shah, who was getting treatment, breathed his last, early Monday. But the reports could not be confirmed from any independent sources.

Sources claimed that for the last few months, Masood was in close touch with an American lobby, working on 'get Osama', mission.

Sources said that during the last two months, he held a series of meetings with some senior CIA officials in Tajikistan. The American lobby, the source said, wanted to get Ahmad Shah Masood favour against Osama Ben Ladin.

The suicidal bombers were alleged to be members of the

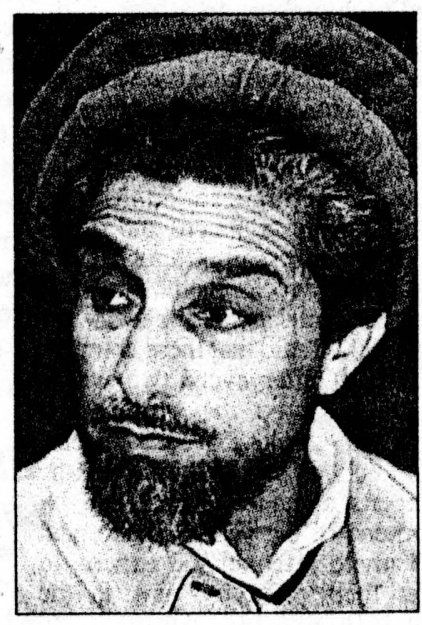

Osama's group based in Afghanistan. "In fact they are all Arab nationals, but possessed passports and nationalities of other countries, the sources told The Statesman.

Agencies add: The loss of Masood would devastate the opposition, already a fractured collection of groups who fought each other when they ruled much of Afghanistan for four years until the Taliban took control in September 1996.

Opposition accused the

Taliban of sending the suicide bombers into Masood's territory while Taliban militia Monday dismissed allegations it was behind an assassination attempt against opposition commander Ahmad Shah Masood. Foreign Minister Wakil Ahmed Mutawakel said Taliban had heard about the suicide bombing at Masood's office in northeastern Afghanistan through the media.

"Masood was our enemy on the frontlines but we are not involved in this," he said. "If we had carried such an attempt on his life we would have already announced it."

The opposition had originally said Masood only suffered leg wounds; however, Ahmed Wali, Masood's brother and the opposition's ambassador in Britain, said the injuries were more serious.

The most serious injuries were head wounds caused by shrapnel. Masood also suffered wounds to his leg and hands.

Since the suicide bombing Sunday afternoon, there have been conflicting reports about the extent of Masood's injuries, with the Russian news agency Itar-Tass reporting his death.

According to Wali, the suicide bombers were traveling on Belgian passports, with a multiple Pakistani visa issued by the Pakistan embassy in London.

"The whole thing was organised by Pakistanis and some Arab circles, that was for sure," Wali said.

According to Khan, the explosion happened soon after the interview began on Sunday around $4 \mathrm{pm}$ at Masood's base in Khawaja Bahauddin in northern Afghanistan's Takhar province.

The two bombers were welcomed into opposition territory as journalists. They first conducted interviews with opposition soldiers in Shomali, about 30 miles north of Kabul, then were taken to meet Masood, Khan said.

The bomb was either hidden in the vedio camera or concealed around the waist of one of the bombers, said Mehrab Mastan, the opposition's ambassador in Paris.

Mastan said the interview was conducted in the office of Suhail, the spokesman. The two journalists and Suhail were sitting at one end of the room, with Masood several feet away. 
Pak-India talks on Kashmir must continue

\section{Osama stumbling} block to ties with Afghanistan: France By Our Staff Reporter

ISLAMABAD - France Monday said the issue of extradition of Osama bin Laden was the biggest stumbling block to the normalisation of relations between Afghanistan's ruling Taliban and the western countries.

"The UN sanctions are aimed at the activities of Osama bin Lad en;" Loic Hennekinne, the visiting French Foreign Secretary told a Press conference here while replying to a question as why did France support unilateral UN sanctions on Afghanistan which were not imposed on opposition Northern Alliance.

Earlier, the French Foreign Secretary had claimed that France, being a developed country, con-

demned all kinds of terrorism and the violations of human rights without any discrimination. $\mathrm{He}$ said the terrorist activities either by Taliban or Northern Alliance were condemnable. He said France also condemned human rights viola. tions either by Indian forces in Jammu and Kashmir or anyone else.

Hennekinne was on a one-day visit to Pakistan to discuss annual bilateral issues between the two countries. During his stay in Islamabad he met Pakistan President General Pervez Musharraf and Foreign Minister Abdus Sattar. He also held bilateral talks with his Pakistani counterpart Inam-ulHaq.

During the meetings both the sides discussed present government's policies for the return to democracy by October 2002, and the roadmap unfolded by the government on August 14. To a question he said that France, being a democratic country, would support rule of democracy all over the world but certain countries, due to specific reasons, had to modify the system.
During the talks between the Foreign Secretaries, the whole range of Pakistan-France bilateral relations in the political, economwere reviewed. Pakistan briefed France about its regional perspective, including relations with India, the Kashmir dispute and Afghanistan. stan side of the French perception of South Asia, situation in Europe and French ties with the European countries.

Detailed discussion also took place on Pakistan's interaction with the European Union.

An official statement issued by the government said the French side had welcomed the policies of the government.

Earlier, the French Secretary General called on the President. During the meeting, the President emphasized the importance Pakistan attached to its long standing and friendly relations with France.

The French Secretary General underlined Pakistan's geo-strategic location and recognized Pakistan as a vital factor of stability in the region.

Hennekinne also called on the Foreign Minister, during which Abdul Sattar focused on Pakistan's relations with France and underscored the need to strengthen them further. He also briefed the French delegation on the situation in Afghanistan and the Agra summit.

Hennekinne was accompanied by a delegation of senior officials from the French Foreign Office comprising Dominique Girard, Director General for Asia and Oceania, Hughes Pernet, Director General for Eastern Europe, Bruce Bourdon, Desk Officer for Pakistan, Yannick Girard, Ambassador of France and officials of the French Embassy in Islamabad. ic, commercial, and cultural areas

Hennekinne apprised the Paki-
Loic Hennekinne, Secretary General Ministry of Foreign Affairs France has urged upon India and Pakiştan to continue the process of dialogue for finding a negotiated settlement of Kashmir dis pute.

"We are encouraged by Musharraf-Vajpayee meeting in Agra in July last and hope that this process of dialogue will continue," he said.

\section{Benazir condemns attack on Masood}

ISLAMABAD (PPI) - Former Premier and PPP Chairperson Ms Benazir Bhutto has criticised the attack on Afghan leader Ahmad Shah Masood.Pakistan's former Premier has expressed concern for the well being of the Afghan leader. Ahmad Shah Masood was injured when a bomb concealed in a video camer ! went off when two journalists came to visit him.

Masood was hospitalised with a leg injury and is recovering. Bhutto nominated former High Commissioner to UK Wajid Shamsul Hasan to contact the Afghan Representative in London to convey her concern.

Bhutto said that the Pakistan Peoples Party and people of Pakistan are pained by the sufferings of the Afghan people which spanred more than two decades.

She said the PPP had been calling that negotiations be held between the different Afghan parties with a view to building a safe and peaceful Afghanistan. 


\section{THE PAKISTAN TIMES}

Tuesday September 11, 2001

\section{Trial resumes in Kabul as diplomats seek access}

KABUL: The trial of eight foreign aid workers charged with preaching Christianity in Taliban-ruled Afghanistan resumed for the sixth day Monday as diplomats awaited permission to visit them.

Judges and religious leaders were examining evidence against the two Americans, two Australians and four Germans at the Supreme Court, but Chief Justice Mawlawi Noor Mohammad Saqib did not attend, Taliban officials said.

"The trial is continuing without Saqib," an official said.
Court spokesman Agha Habibur Rehman said the foreign ministry had not yet granted permission for diplomats to meet the detainees, who appeared in court Saturday and were told to consider hiring lawyers.

"We will take up the matter when we formally receive intimation from the foreign ministry for permission," he told AFP. Diplomats said they made another request for regular consular access during a meeting with foreign ministry officials on Sunday and were waiting for a response. They are desperate to keep the captivies informed of the legal proceredings against them and help them organise a defence.

The allegations may icarry a maximim penalty of death under the fundamentalist Taliban militia's puritanica./ brand of Sharia law. but this exact charges have not been explained. Th: foreigners protested their innocence during their only court appsearance Saturday and complained they had not been given a chance to defend themselves. - AFP

\section{\$10m deal for asylum seekers}

\section{By Ashraf Shad}

SYDNEY, Sept 10: The Australian government has signed a deal with tiny Pacific nation of Nauru under which more than $600 \mathrm{Afghans}$ and Iraqi asylum seekers would be provided shelter in the Pacific state in return for an aid package worth US\$10 million.

The deal was signed by Australian Defence Minister Peter Reith and President Rene Harris of Nauru on Monday.

Under the deal, Australia will give immediate help to Nauru, which has a population of 12,000 , in fuel supplies and power generation and provide debt relief.

However, the Human Rights groups have criticized the Australian government for turning Nauru into a large detention centre. There are about 670 asylum seekers on board Australian naval ship HMAS Manoora more than 430 than the Norwegian ship Tampa, while 237 were picked up in international waters on the weekend.

Manoora is heading towards Papua New Guinea and is expected to reach there later this week. Once the ship arrives at Port Moresby, the asylum seekers will be transported to Nauru and New Zealand, provided a court in Melbourne gives judgment in favour of the Australian government.

The court was expected to give its verdict on Monday but officials informed in the morning that it was not ready to announce the decision today (Monday).
Although the court did not say when a decision will be made, it is widely believed the judgment could come as early as tomor. row.

The court had allowed the government to move the asylum seekers from the Norwegian ship to Manoora on the condition that asylum seekers will be brought back to Australia if court rules in favour of them.

The petition is filed by a civil liberty group that wants the refugee status of the asylum seekers to be assessed in Australi... If court decides that the asylum seekers have the right to have their refugee applications heard in Australia, the Naval ship may be ordered to come back. 


\section{Russian agency claims Masood} is dead

DUSHANBE, Sept 10: Afghan opposition sources on Monday scotched a rumour that top commander Ahmad Shah Masood had died after an assassination attempt by Arab suicide bombers allegedly linked to Osama bin Laden.

"He is recovering from his injuries," a source at the Afghan government-in-exile's embassy in Dushanbe said.

The official added that Masood, seen as the last bulwark against the Taliban, was in Afghanistan but would not give details.

Russia's ITAR-TASS news agency reported earlier, citing unidentified sources in Dushanbe, that the opposition commander had "died before reaching hospital".

Tajikistan is used as a supply base by Masood, whose forces are based a short helicopter ride across the border in northern Afghanistan.

A Masood spokesman also earlier said the 49-year-old ethnic Tajik was "thank God, in good health", despite serious wounds to his foot, affirming that he had spoken to him through a wireless on Monday morning.

Spokesman Waisuddin Salik said by satellite phone from northern Afghanistan that the two Arabs were killed along with Masood's interpreter and personal assistant Assem Suhail.

Masood commands a loose coalition of forces who are fighting the Taliban, which control most of Afghanistan.

A spokesman for the Northern Alliance on Monday alleged that the Taliban and Osama bin Laden were behind the attempted assassination of commander Ahmad Shah Masood. -AFP

\section{The changing profile of Pakistan's Taliban policy}

\section{By Syed Talat Hussain}

SLOWLY, but steadily the profile of Pakistan's policy towards the Taliban is changing. From a deep, multi-dimensional engagement meant to back the Taliban as the most desirous option in the context of a stable Afghanistan on its porous $2,430 \mathrm{kms}$ long north-western border, Pakistan's interaction with the Taliban has acquired a certain aloofness, even coldness.

The argument that "the
Taliban are our best bet" once very popular in the corridors of policy-making in Islamabad when the group led by Mulla Umar took over Kabul - is losing its pith. More and more voices are heard in favour of maintaining a "fair distance from the Taliban" and of keeping them at "an arm's length."

The definition of the strategic goals that Pakistan once wanted to achieve in Afghanistan - having a friendly regime in Kabul controlling all of Afghanistan to the exclusion of all alien influences like that of Iran and the former Soviet Central Asian republics - is also a subject of serious rethinking. While the game of fighting competing influences is still going on, Islamabad is equally concerned about blocking the debilitating blow-back effects of Afghanistan's persistent civil strife.

A complex interplay of global and regional considerations have brought about a change in Pakistan's attitude towards the Taliban.

Internationally, the Taliban have lost a lot of diplomatic ground. Their support in the international community has dwindled considerably. Their origi- 
nal strengths - deweaponizing Afghanistan, ensuring law and order and providing quick justice - have lost appeal and attraction for the outside world, which now perceives the Taliban as a warring faction in control of a territory but with out the ability to govern it efficiently and effectively.

This changed perception of the world of the Taliban has thrown up a complex set of diplomatic problems for Pakistan.

When the Taliban had just taken over Kabul and in the flush of victory were seen to be poised to overrun the remaining foothold of the Northern Alliance in the country's nonPushtoon north, Pakistan could present them as the only force capable of restoring peace and stability in Afghanistan. Another seeming virtue that the Taliban had - and Pakistan argued their case on that count with the international community - was that they could also clear the path to the treasure trove of Central Asia to the world's multination. als. Former interior minister, $\mathrm{Lt}$ General (retd) Naseerullah Babar, was the proponent of this idea of projecting the Taliban as the clearing force on the path to Central Asia and creating a passage for good business. To a considerable degree, this proposition found favour with some foreign powers, which were quite willing to see the Taliban in a somewhat better light than now because then they had in mind the question of a land route for access to the markets that lay beyond Afghanistan.

At one time the Taliban came

quite close to gaining a total victory, but despite their best efforts, they failed to achieve it. The Northern Alliance even in its most disorganized form, has shown a remarkable capacity for resilience and survival, thanks largely to the generous support it has received from its backers in Europe and Russia.

The only value and the use that the Taliban could serve for the world - stabilizing Afghanistan - now looks increasingly remote. This has brought forth with a vengeance all the issues on which the inter. national community has always had reservations, but held them back in the hope that the Afghanistan's new force may be able to resolve the country's problem of violence and strife. That is why human rights, terrorism, drugs, and the Taliban's interpretation of Islamic laws and Shariah, are the concerns that now determine the general attitude to the Taliban regime in Kabul. Partly, this attitude is reflected in the United Nations

Resolutions 1267, 1333, and now 1363.

The first two resolutions are an unqualified condemnation of the Taliban and are a direct signal to them that if they did not change their conduct and handed over of Osama bin Laden, accused by the United States of carrying out a systematic terrorism campaign against its national and global interests, they will suffer the consequences of economic and military sanctions imposed against them. The third resolution, passed in July 2001 goes a step further and, besides reiterating the need for continuing restrictions on the Taliban, proposes a mechanism to monitor how effectively these curbs are being enforced.

The political and diplomatic significance of these resolutions has not been lost on Pakistan. From their previous status of being seen and helped as a possible solution to Afghanistan's fratricidal civil war, the Taliban have become something of a liability in the eyes of large sections of Pakistanis, thanks largely to the Kabul government's extremist policies and its harsh treatment of women, young Afghans, religious minorities and, in some cases, western aid workers.

It is this globalization of the campaign against the Taliban and its related consequences for Pakistan, one of the only three countries in the world to have recognized their regime in Kabul, that have had a deep impact on the traditionally sympathetic attitude and policies of the country's ruling establishment towards them. Pakistan has been, quite literally, forced by the changing global diplo.

matic climate vis-a-vis the Taliban to reconsider its support for them. Far from being of any help, they are increasingly seen to have become a political liability and a diplomatic embarrassment for Pakistan.

For instance one of the most often-used arguments that the defenders of the Taliban among the policy-makers in Islamabad always put forward was that of "clout". The Taliban are a group that listens to Pakistan and can be influenced by its advice, ran the argument. It is unclear how these pro-Taliban circles intended to use this capital to Pakistan's advantage, but still they were always ready to put forward this justification for backing the Taliban regime regardless of other considerations.

A series of events and developments systematically shattered this myth. The occasions on which the Taliban said 'no' to Pakistan are far more than when they said 'yes'. The destruction of the statues of the Buddha in Bamiyan is one case in point. Total lack of cooperation with Pakistan on handing over sectarian criminals hiding in Afghanistan is another. Pakistan has also been unable to influence the Taliban to show flexibility in dealing with international aid agencies and workers, particularly those representing the United Nations aid agencies, is yet another.

Now in the lingering crisis over the eight detained American German and Australian workers, repeated requests from Pakistan not to play up the issue have fallen on deaf ears. There are many other cases where Pakistan's counsel for restraint, moderation and flexibility to the Taliban regime has gone unheeded. These include the question of winding up of training centres for Islamic militants in Afghanistan, allowing the Afghan soil to be used as a staging post as well as a sanctuary by the so-called holy warriors widely suspected to be engaged in stirring up troubles in Central Asian states and elsewhere in the region.

All this has raised questions about the justification for being supportive of the Taliban government in an unquestioning spirit. The experience has also diminished the perceived utility of the Taliban in the larger con- 
text of Pakistan's foreign policy, which at this point is focused on cultivating the international community and not alienating it unnecessarily.

However, it is too early yet to know for sure whether current revision of Pakistan's engage ment with the Taliban will result in a reversal of Islamabad's policies towards the ruling militia in
Afghanistan. A degree of modification is a likelier possibility. But there is no mistaking the fact that the Taliban in the current global international setting are not the most desired option Pakistan wants to have in Afghanistan. It is engaged with them for lack of a better alterna. tive. It is this revision of the costs and benefits of a strong
pro-Taliban tilt in Pakistan's regional policies that is believed to have provided an appropriate setting for a growing number of sceptics in policy-making circles in Islamabad to come out in favour of a substantive - rather than one of tone and key change in Pakistan's pro-Taliban policy.

\section{The Guardian \\ Conversion theory \\ Faisal Bodi \\ Saturday September 8, 2001}

I believe it was Mahatma Gandhi who coined the term "rice Christians" to denote those Indians who had converted to the Cross for material gain. By then, of course, colonial missionaries had long known that food was a more effective inducement to the poor and illiterate than the blunderbuss. If the charges levelled against the eight western aid workers in Afghanistan hold any water, their methods have changed little in $\mathbf{5 0}$ years.

The eight are awaiting trial - and possibly jail - for preaching Christianity to Afghanistan's majority Muslim population. Sixteen of their subjects reportedly face the death penalty for converting to Christianity, or, more properly, for apostasising from Islam.

Death seems a draconian penalty for conversion, especially for people who are probably little more than economic converts, nominal Christians at best. The prospect of them as the Taliban's latest victims has given new ammunition to those ever eager to decry the intolerance of a compulsive faith.

Western commentators would not hold up the throat-cutting Chetniks as an example of normative Christian practice; they should not do the same with the Taliban. The rag-tag militia which bans women's education and compels men to grow beards has never been a glowing advertisement for Islam. If that has been forgotten here, so have the arguments about freedom of religion rehearsed ad nauseam during the Rushdie saga.

Islam's stand on the matter is almost unequivocal. The religious texts of the Shariah do not prescribe ań penalty for apostasy, let alone capital punishment. Throughout the Prophet's lifetime, and that of his four successors, no-one was strung up for changing religion. In the course of Muslim history, the penalty has been sparingly applied to those found guilty of high treason, an offence in which conversion often combined with plotting against the security of Muslim states. 
There are, indeed, many explicit statements upholding freedom of faith, most fam- ously the Koranic verse, "There shall be no compulsion in religion". In his book, Freedom Of Expression In Islam, the Afghan scholar of Islamic jurisprudence, Muhammad Hashim Kamali, cites a string of Islamic authorities, modern and classical, who concur that penalising conversion violates the essential pre-requisite for religious belief, freedom of conscience. After all, a forced faith is no faith at all.

The Taliban have also drawn much ire for the charge of proselytising levelled against the aid workers. Islam stands accused of being a defensive faith, using the threat of punitive sanction to protect its shaky beliefs. A confident faith, it is said, would be capable of withstanding any assault on its values.

The argument has it takers, but I am not convinced by modern Muslim apologists that the freedom to propagate enjoyed by Muslims in democratic western societies should be offered to non-Muslims by Muslim societies, even as the satellite age and the internet make such laws hard to enforce. The tectonic plates of two world views are in such mighty collision here that it is futile to try to reconcile them.

Although Salman Rushdie's crime was not proselytising but blasphemy, it is relevant to the issue. The author was accused of deliberately profaning Islamic sanctities. For both offences, a punishment, of varying orders, is prescribed for the same reason: to protect the truth. Make no mistake about it, Islam is an absolutist faith. Unlike postChristian democracies, which recognise multiple truths, Islam regards truth as absolute and inviolable, not a relative and shifting idea. Like all precious things, the truth needs protecting. The alternative is to see your sacred articles become a matter of abuse and ridicule, something Christianity has got used to in the age of Scorsese's The Last Temptation Of Christ and Madonna's Like A Prayer. Allowing others to attack your sensibilities, or giving them a free hand to transplant them, is a sign of surrender and weakness, not of strength.

Here the Taliban are on less tenuous ground. Afghanistan is not alone in banning proselytisation; even liberal countries like Malaysia have such statutes. There is no harm in allowing believers of other faiths to practise their religion, but the line has to be drawn at spreading it to those who already have the truth. The difference is not between a more tolerant western society and a less tolerant Islamic one, but between two irreconcilable views of truth.

The author Shabbir Akhtar wrote after the Rushdie affair that "beliefsystems, like biological organisms, must be fortified against external attack." For Muslims, that Islam does this is a matter of pride, not shame.

- Faisal Bodi is a British Muslim writer 


\title{
The Moscow Times
}

Tuesday, Sep. 11, 2001

\section{Taliban's Main Opponent Feared Dead}

\author{
By Syed Salahuddin
}

\section{Reuters}

KABUL, Afghanistan -- The fate of Afghan guerrilla leader Ahmad Shah Masood was uncertain Monday after an assassination attempt that his spokesmen said had caused only minor injuries but which U.S. officials believe killed him. Masood's spokesmen both inside and outside Afghanistan denied a report from Russia's Itar-Tass news agency that the man who has proved the chief obstacle to Taliban hopes of ruling the whole country had been killed in Sunday's blast, and said he was receiving treatment for minor chest, hand and leg wounds. But a U.S. official in Washington later said Masood, who acquired fame as a legendary fighter against the Soviet occupation of Afghanistan in the 1980s, was believed dead. "We believe he's dead," the U.S. official said on condition of anonymity, without giving further details about the basis for the assertion. With the Taliban authorities themselves denying involvement in the attack, Masood's precise whereabouts were unclear. "He is fine and in good health," a secretary for Masood said from the opposition stronghold in the Panjsher valley. He said an assassin posing as a television journalist had blown himself up after gaining access to Masood's office in northern Afghanistan. Presumably, the explosive was hidden in the man's camera. "We have nothing to worry about his condition," the secretary said, adding that Masood was in neighboring Tajikistan. Other members of the opposition movement said that the 48-yearold guerrilla commander was still in Afgkanistan. In Moscow, the Kremlin said President Vladimir Putin spoke to Tajik President Emomali Rakhmonov about Afghanistan on Monday, the day after the attack on Masood. But it did not refer to Masood, whose forces control regions bordering Tajikistan, which survived its own devastating civil war in the 1990s and fears a Taliban advance to its borders. Masood's anti-Taliban alliance is officially led by President Burhanuddin Rabbani, who was driven from Kabul in 1996 but is recognized by the United Nations as Afghanistan's leader. Sayed Najibullah Hashimi, a spokesman for Rabbani, said Rabbani had met Masood and had found him in good health. "Masood is in one of his bases in Takhar after minor injuries were treated," Hashimi said, adding that Masood Khalili, the movement's ambassador to India, had been seriously wounded in the attack and had been operated on in a hospital. Masood's spokesman in France, Mehrabodin Masstan, said there had been a dozen attempts on Masood's life in the past 20 years. "Between now and tomorrow I believe our chief will reappear and give an interview. However, the doctor has told him not move today," he said, quoting colleagues inside Afghanistan. Soviet forces repeatedly failed to crush Masood during the 1980s. Today he is the driving force behind the opposition to Taliban rule. Annual attacks on his Panjsher valley stronghold were repulsed and he became a romantic figure in the West. After appearing near defeat a year ago, he has kept Taliban forces off balance with guerrilla attacks dotted across the northern half of the country. Itar-Tass quoted unspecified sources in its report from Tajikistan's capital Dushanbe. In Tajikistan, the Afghan embassy, which is under Masood's control, said Masood was still 
in Afghanistan receiving treatment. It too said there was no concern for his condition. The Panjsher valley secretary said one of two Arab journalists interviewing Masood had blown himself up. "This person got killed on the spot along with a colleague of ours and Masood himself received injuries on his leg, hand and chest. The wounds are minor ones," he said. The secretary, who asked not to be named, said Masood's guards shot dead the second attacker, identified only as an Arab. They had not determined the nationalities or affiliation of the would-be assassins. Masood's forces control the northeast of Afghanistan and are fighting the Taliban north of the capital Kabul, on the route towards the Panjsher valley, the commander's native stronghold. Taliban chief spokesman Abdul Hai Mutmaen said that the Taliban were not behind the assassination attempt. "We are not involved in the incident. If we were, we would have proudly said that because he is our enemy," Mutmaen said. The attack on Masood came a day after a powerful blast in the capital Kabul wounded an unknown number of people inside the hard-line Islamist Taliban's interior ministry. No one has claimed responsibility, but the Taliban have blamed previous Kabul blasts on Masood. The opposition says they are the work of dissidents within the Taliban. Kabul is in the spotlight for the Taliban trial of foreign aid workers accused of promoting Christianity. The detainees -- four Germans, two Australians and two Americans -- were arrested more than five weeks ago on charges that could carry the death penalty. They made their first appearance in court Saturday and denied proselytizing. The Taliban government, recognized only by Pakistan, Saudi Arabia and the United Arab Emirates, has been widely accused of human rights abuses in enforcing its austere version of Islam. The Taliban are rooted in the majority Pashtun group, while Masood is a member of the minority ethnic Tajiks and has drawn strength from minorities that feel threatened by the Pashtun drive for dominance.

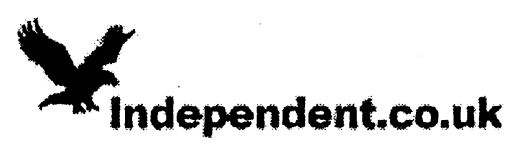

11 September 2001

\section{'Lion of Panjshir' reported killed in suicide bombing}

Taliban poised to take total control of the war-torn country and claim international recognition after attack on famed guerrilla leader

\section{By Peter Popham in Delhi}

The man who represents the last bulwark of resistance against Afghanistan's Taliban regime was reported by Russian and American sources last night to have been killed by two suicide bombers.

Ahmed Shah Masood is the almost legendary guerrilla leader who held out for years against the might of the Soviet Union in his mountain headquarters in the Panjshir 
Valley, north-east of the capital, Kabul, gaining the title "the Lion of Panjshir" in the process. He survived to see the Soviet Union routed, he survived the internecine warfare between rival Mujahideen groups that followed. He has defied a dozen attempts on his life, and some followers were claiming his injuries were minor.

His brother, Ahmed Wali, who is the ambassador of the official but powerless Afghan regime to Britain, told reporters yesterday: "The doctor says it will be 10 or 12 hours before we know. His condition is stabilising but he is still unconscious."

But if Masood is dead, it is not merely one brave guerrilla who will have passed away. The last real opposition to the Taliban would have been removed. Already the regime controls 95 per cent of the country, although it is recognised as legitimate by only three other states. The incessant flow of refugees across Afghanistan's borders belies the claim that it has brought any real peace to the land it rules. With Masood removed, the rest of the world would somehow have to come to terms with the fact that the most fanatical Islamic zealots in the world were on the verge of achieving legitimacy.

Masood, aged 48 or 49, sustained head injuries on Sunday afternoon when two Arab visitors posing as journalists detonated a bomb in his office in his Afghan headquarters. The bomb was either inside the visitors' video camera or strapped round the waist of one of them. They gained access on the pretext of interviewing him. Both Arabs died and an aide of Masood's was also reported to have been killed.

The Taliban denied having any role in the attack. Its chief spokesman, Abdul Hai Mutmaen, told Reuters: "We are not involved in the incident. If we were, we would have proudly said that because he is our enemy." Mr Wali said: "The whole thing was organised by Pakistanis and some Arab circles, that was for sure." Pakistan and Saudi Arabia have been the most loyal allies of the Taliban since the regime rose to power. And it is the Taliban which will gain immeasurably if Masood dies.

Masood was an engineering student in Kabul in 1979 when the Russians invaded. Mustering his lightly armed guerrilla force in his home base high up in the Panjshir Valley, he repelled wave after wave of attacks, gaining a legendary reputation both among his men and far beyond Afghanistan. By 1989 the Russians had gone; three years later Masood, who had established a power base at Taliqan, close to the border with Tajikistan, became one of the most powerful men in the country when his ally Burhanuddin Rabbani became acting president of the newly inaugurated Islamic State of Afghanistan, and Masood became his minister of defence.

But although the Russians were long gone, Afghanistan's mayhem was only just getting under way. As far as the United Nations is concerned, Rabbani is still the President of Afghanistan, and Masood is, or was till yesterday, his Defence Minister. But that became a polite fiction seven years ago, when the new state was torn to pieces by bitterly feuding Mujahideen. Masood, ethnically a Tajik like Rabbani, was in effect just one warlord among a batch of them, each scrabbling for the power and wealth of his own fiefdom. Afghanistan's national identity, never very robust, was 
smashed into pieces.

Into this vacuum of state power roared the Taliban, drawn from exiles of the country's Pushtun majority who had been schooled in Islamic fundamentalism in primitive schools in Pakistan, fuelled by the funds of Pakistan and Saudi Arabia. Masood was forced back into the sort of role he had played during the war against the Soviet Union. A brilliant tactician, a moderate Muslim, he has outlasted all his rivals and until yesterday at least was the only one left fighting.

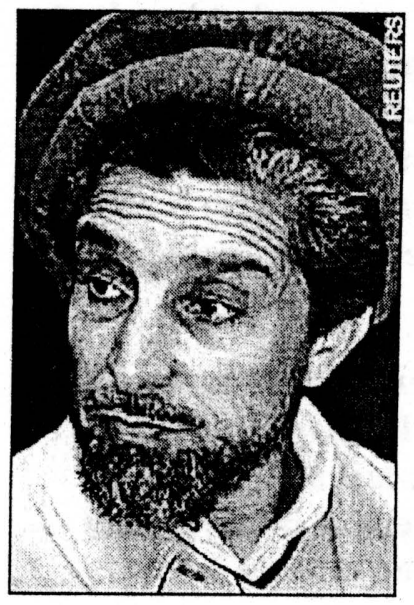

Ahmad Shah Massoud:

attackers posing as

television journalists

detonated a bomb

while interviewing him

\title{
THE TELEGRAPH
}

$11 / 09 / 2001$

\section{Massoud had aura and assurance that set him apart}

\author{
By Sandy Gall
}

I FIRST met Massoud in 1982 when the Russians were bombing the Panjshir, his home valley 100 miles north-east of Kabul. 
We had walked in from the Pakistan border for 12 days and had arrived at a village called Tanbonnah. Some of the trees were shattered by bomb blasts and a deep green pool in the river below was in fact a bomb crater.

About 7.30 next morning a small group of men came through the trees towards the house. One, in front, flat Chitrali cap on the back of his head, khaki combat jacket and trousers and black Russian boots, was Massoud.

He had an air of authority and assurance. He was 28. I was aware even then of an aura, a mystique, that seemed to set him apart. As I shook his hand, I noticed above all his eyes, quick and intelligent.

A Russian jet whined overhead and immediately Massoud and his entourage walked to the shelter of the house and we all sat down.

Massoud sat in the corner rapidly reading letters and messages and equally rapidly writing replies. He had no radio and messages went by runner.

Afterwards he talked to the assembled locals. He struck me as a good listener. At the end of each conversation he would say a few words as if giving instructions. There was never any argument.

It was several days before we saw Massoud again. By this time we had seen the Russians bombing all around us and a few days later the Russian ground attack started.

Massoud told us the Russians' tanks and infantry were only just down the valley and we had to hurry. We climbed up the steep side of a mountain and crawled inside a small cave.

Massoud appeared eventually and joined us, not at all put out by the Russian advance, reeling off facts and figures. He left soon afterwards to supervise the battle.

During the long hours until we made contact with Massoud again his brother Yahya told me his story.

The son of an Afghan colonel, he had always wanted to be a soldier, but after studying at the Istiqlal Lycee in Kabul he enrolled in the Polytechnic to study engineering.

In 1975 , when he was 21 , he took part in a failed coup and had to flee to Pakistan, where he was trained by the army in guerrilla warfare.

Early in 1979 before the Russian invasion, Massoud returned to Kabul and went underground. In June that year he left for his native Panjshir and by the time the Russians invaded in December he had already formed a resistance movement to fight the Afghan Communist government.

By December 1982 he had survived five Russian offensives, had built up a guerrilla 
army of 300 and was beginning to get British help. He even came to Britain to be taught mountain warfare:by the British Army.

Years later I travelled into Kabul with him on top of a Russian APC manned by fearsome-looking Uzbeks. On the outskirts of Kabul the convoy stopped and everyone got out to pray.

Even on that day, perhaps the greatest of his life, he spent an hour before the final drive into Kabul talking about the war.

Kabul turned out to be a poisoned chalice with too much infighting and dissension among the alliance partners. In the end in 1996 Massoud was forced to withdraw by the Taliban, their army heavily supported by Pakistan and Saudi Arabia.

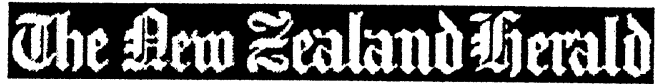 \\ Australia fends off another refugee boat}

\subsubsection{1}

CANBERRA - Australia has rejected another boat carrying asylum seekers from Indonesia which has ran aground off a remote reef, northwest of Darwin.

Australia has already rejected two vessels carrying a total of 680 mainly Afghani boat people in the past two weeks.

On Monday Australia struck a deal with the tiny Pacific island of Nauru to take the bulk of them in return for diesel.

A spokesman for Immigration Minister Philip Ruddock said navy surveillance, reinforced in waters between Australia and Indonesia last week, spotted a third boat late on Monday.

"'The Royal Australian Navy is providing assistance to the boat to render it seaworthy to return to international waters," the spokesman said.

The group would then be encouraged to return to Indonesia, he said.

Should that fail, its passengers could also be sent to Nauru, Foreign Minister Alexander Downer told the Australian Associated Press.

Indonesia has said it would turn away the asylum seekers. 
The boat, carrying around 130 people, ran aground off the remote Ashmore Reef, northwest of Darwin in the Indian Ocean, this morning.

Ashmore Reef and the remote Australian territory of Christmas Island are the favoured drop-off points for boatloads of asylum seekers who pay people smugglers for passage to Australia.

Mr Downer told Australia's Channel Seven there were actions the Government could take to stop those aboard the boat landing in Australia.

"The more we can ensure that these people don't get to Australia and get processed elsewhere then the end the message will get through to those who wish to buy these passages to Australia," he said.

\section{KYODO NEWS JAPAN \\ 2001/09/11 \\ Court rules Australian gov't treatment of boat people illegal}

SYDNEY, Sept. 11, Kyodo - The Australian government illegally detained over 400 asylum seekers who were stranded on a Norwegian freighter off Christmas Island for over a week after being rescued at sea, the federal court ruled Tuesday. Judge Tony North told the court in Melbourne the 433 asylum seekers rescued by the freighter Tampa, who are currently en route to Papua New Guinea on a navy troop carrier, must be returned to the Australian mainland.

North gave the government a deadline of Friday 5 p.m. to release them, unless an appeal is lodged with the federal court by the government resulting in a different ruling.

The Tampa rescued the $\mathbf{4 3 3}$ mostly Afghani asylum seekers from a sinking Indonesian vessel on Aug. 26, but was refused entry to Christmas Island, a remote Australian territory in the Indian Ocean, when it arrived there the next day.

When the Tampa defied orders and entered Australian territorial waters on Aug. 29, it was boarded by armed troops. The government later struck deals with New Zealand and Nauru to accept the asylum seekers and hear their refugee claims.

North said the civil liberties groups that initiated the legal action had proven that the government illegally detained the asylum seekers by directing troops to board the Tampa and by determining their future with no consultation.

"In my view, the evidence...demonstrates that (the government) was committed to retaining control of the fate of the rescuees in all respects," he said. 
"They procured the closing of the harbor so the rescuees would be isolated, they did not allow communication with the rescuees, they did not consult with them about the arrangements being made for their physical relocation or future plans."

"After the arrangements were made, the fact was announced to them, apparently. not in their native language, but no effort was made to determine whether the rescuees desired to accept the arrangements."

"An ancient power of the court is to protect people against detention without lawful authority."

Attorney General Daryl Williams' office said the federal government would appeal the decision after considering the judgment.

Immigration Minister Philip Ruddock said the government had acted legally in its handling of the asylum-seeker standoff.

"We disagree very strongly (with the ruling)," he said. "We believe that the decisions that were taken all through this...have been lawful."

Meanwhile, Defense Minister Peter Reith said earlier Tuesday an Australian navy boat is attempting to turn back an Indonesian fishing boat carrying 130 most Afghani asylum seekers that has run aground on a reef off Australia's northwest coast -- inside Australian waters but outside Australia's migration zone in which a valid application for refugee status can only be made.

Reith said the navy was providing assistance to the vessel with the aim of making it seaworthy so that it could return to international waters.

Australia also blocked entry over the weekend to another 237 asylum seekers who were intercepted on another Indonesian vessel in international waters.

\title{
France condemns attack on Masood
}

\author{
Islamabad, Sept 10, IRNA
}

France Monday condemned attack on the commander of Afghanistan's United Front Ahmad Shah Masood and described it as a terrorist act. The visiting French Secretary General for Foreign Affairs Mr. Loic Hennekinne addressing a news conference in Islamabad said that France has always condemned the acts of terrorism. To a question Mr. Loic Hennekinne said there is perception gap between Pakistan and the Western countries about Afghanistan. "Western world tend to think that it is possible for Pakistan to exert some kind of influence on Taliban because of relations and proximity with Afghanistan". He said the notion in Europe is that Pakistan may have some moderating impact on Afghanistan. However he said Pakistani leaders informed him that it is not the case and Taliban have their 
own ideas. Pakistani leaders emphasized that it is the responsibility of international community not to isolate but assist Afghanistan and engage in talks with the Taliban. The French official was of the view that Western world still thinks that if a government is able to talk with Taliban, it is Pakistan. He said France has a charge d'affaires for Afghanistan based in Islamabad. France has been having contacts with all Afghan groups including the Taliban, United Front and those in exile.

He said it is imperative to bring people around and try for a broad-based government in Kabul. He strongly urged India and Pakistan to find a solution to the Kashmir dispute through dialogue and peaceful means. He said his country was encouraged by the Agra summit and has taken a note of the fact that the leaders of both Pakistan and India will be meeting in New York later this month. "It is unfortunate that since 1947 India and Pakistan have not been able to resolve the Kashmir problem," he said. Asked to comment on a free hand given by the Indian government to forces in Kashmir to suppress the freedom struggle, he said France condemns human rights violations in any part of the world. Replying to a question, he said France as an active member of the International Monetary Fund will support the idea of granting poverty reduction and growth facility loan to Pakistan by the IMF. He described his meetings with the President General Pervez Musharraf and the Foreign Minister Abdul Sattar as very friendly and useful.

He said during his formal talks with Foreign Secretary Mr. Inamul Haq they had in-depth exchange of views on bilateral relations, internal situation in Pakistan, crucial regional and international issues like situation in Afghanistan, security in South Asia, bilateral relations between Pakistan and India and between Pakistan and the European Union. He said there was a mutual desire on both sides to further cement and develop the existing ties between Pakistan and France. He said his country values its relations with Pakistan and considers it a very important country in the region and a major factor of stability in this part of the world. He said stability and prosperity of Pakistan is important for security and stability of South Asia. He said during his meetings in Islamabad, he was briefed about the road map announced by President Pervez Musharraf on August 14 as well as about the local government elections. He said France also took note of all the reforms undertaken by the present government. He said his country is also watching the road map announced by the President and considers the local government elections as a beginning of that process. He said France noted some positive aspects in local government elections in Pakistan and reservation of one third seats for women. TK422/AH End ::irna 19:20 


\section{Masood might be taken to France for medical treatment}

Islamabad, Sept. 10, IRNA

Afghan sources in Pakistan say Afghan commander, Ahmad Shah Masood might be taken to France via Tajikistan, for medical treatment. Masood was injured in a bomb explosion in Khwaja Bahauddin district of Takhar province on Sunday night. Later there were reports that the injured commander of the United Islamic Front has been flown to Dushanbe for medical treatment. Rumours also flouted here that he had been killed in the blast. However, sources close to the United front rejected these rumours. "I contacted the office of Professor Burhanuddin Rabbani just today, where people close to the Afghan President denied the reports," the source said. No group has so far accepted responsiblity for the bomb attack on the veteran Afghan commander, but United Front sources have put the blame for the attack on Taliban and Osama bin Laden. AHM/422/RR End ::irna 18:17

$\underline{C N N}$

\section{Massoud is alive, says brother}

September 11, 2001 Posted: 12:33 PM HKT (0433 GMT)

LONDON (CNN) -- Conflicting reports are circulating regarding whether the leader of Afghanistan's opposition to the ruling Taliban, Ahmed Shah Massoud, is still alive.

Ahmed Wali Massoud told CNN his brother is recovering from wounds suffered in an assassination attempt Sunday that left him unconscious for at least 10 hours.

But U.S. officials say they have reliable information that Massoud was killed in the attack.

A spokesman for Massoud's Northern Alliance, the anti-Taliban alliance in northern Afghanistan, said the rebel commander was being interviewed by two Arab journalists when their television camera exploded, killing the journalists and an aide to Massoud.

Massoud's right leg was severely wounded, two pieces of shrapnel lodged in his head, his face was burned and his fingers were injured, his brother said.

He said the attack left his brother unconscious for 10 to 15 hours, fueling speculation about his death.

"That is one of the reasons why there was so much confusion," he told CNN. "Until the last couple of hours, me myself, as his brother, didn't know his condition." 


\section{Better situation}

The rebel commander was taken to a Tajikistan hospital, where he is now able to eat and talk, his brother said in a telephone interview from his London home. "He's in a much better situation now."

He added that he hasn't spoken with his brother, but said he learned about his condition from hospital representatives and other relatives who have visited him.

Aides to the Northern Alliance also said Massoud survived the attack.

U.S. officials placed the organization headed by fugitive terrorist leader Osama bin Laden high on the list of suspects in the attack.

If Massoud is dead, the U.S. officials said, there may be a period of infighting among commanders of his alliance that would help the Taliban strengthen their hold on the country.

Taliban claim no involvement

Taliban officials said they played no role in the assassination attempt and gave no indication that they believe he is dead.

U.S. officials say the two journalists involved in the assassination attempt were Algerians. Other Algerians have been connected in testimony in U.S. courts with bin Laden, who is based in Afghanistan, presumably under the protection of the Taliban.

A spokesman for Massoud, who gave his name only as Nasser, said earlier that Massoud received injuries to his head, one arm and one leg.

Nasser said an adviser in Massoud's foreign ministry, Engineer Mohammed Amir Sohail, was killed and his ambassador to India, Masood Khalili, was wounded.

Massoud, a former defense minister under the deposed government of President Burhanuddin Rabbani, fled to the hills of northern Afghanistan after the Taliban Islamic militia captured Kabul in 1996.

The Taliban control about 95 percent of Afghanistan's territory and engage in frequent clashes with the coalition of ethnic Uzbek and Tajik commanders that make up Massoud's forces.

--CNN National Security Correspondent David Ensor contributed to this report. 
The News International, Wednesday, September 12, 2001

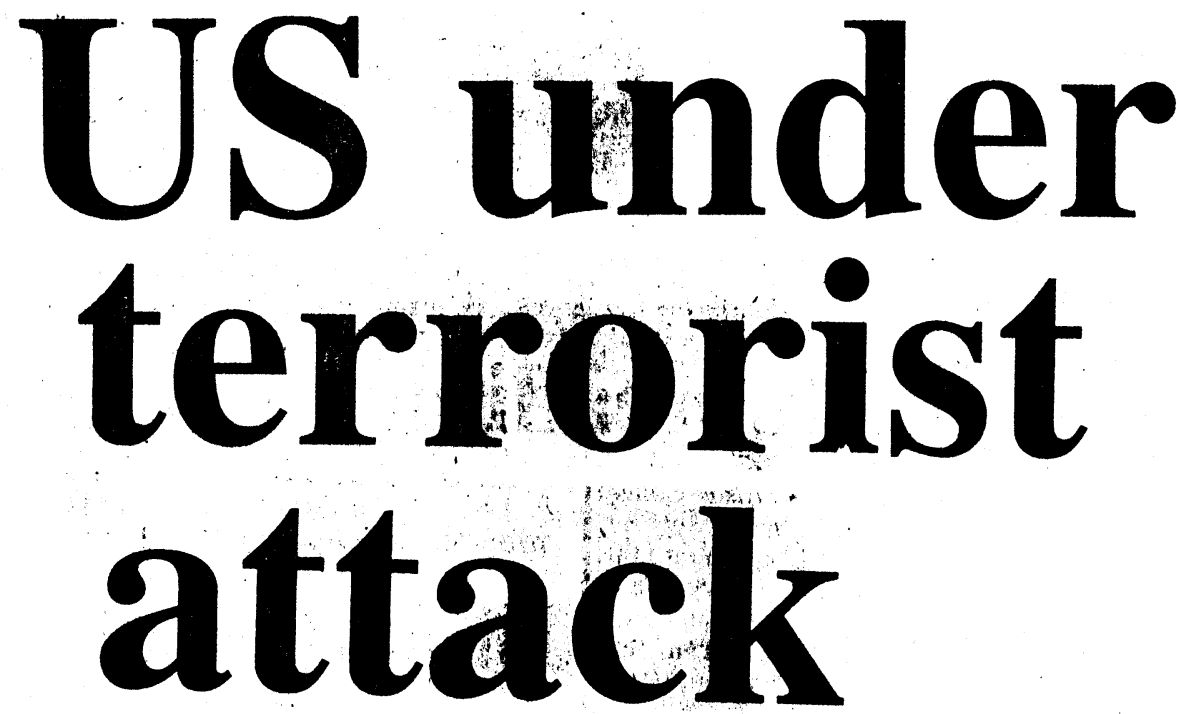

\section{Thousands killed}

\section{Pentagon in flames}

None claims responsibility

\section{Bush vows to retaliate}

World expresses shock; air space sealed; Trade Center demolished; Osama being targeted; US attack on Afghanistan feared; Taliban deny involvement
10,000 feared dead in New York alone

NDW ,ORK: No official toll has been established so far following Tuesday's wave of terrorist attacks in the United States but thousands of people may have lost their lives.

Speaking on Fox television Jim Moran, a Democratic member of the US House of Representatives, said authorities were expecting a death toll for New York alone of 10,000 .

NBC television spoke of thousands of victims but the New York Police Department declined to confirm that repoit to AFP.

Sada adds: According to another report the projected death toll in New York following the attacks on the twin towers of the World Trade Center Tuesiday rose to 5,000 , according to hospital estimates.

Another 7,000 people have been brought to city hospitals with injuries ranging from critical to smoke inhalation and shock, doctors said.

\section{US to blame jihadis, Osama for attack: Sami}

\begin{abstract}
Our correspondont
NOWSHERA: Chief of his own faction of Jamiatul Ulema-e-Islam Maulana Samiul Haq has feared that the US would shift the burden of terrorist attack in New York and Washington on jihadi groups, Tal-
\end{abstract}

iban and Osama bin Laden.

In a press release he said the

US suffered bectuise Allah almighty had listened to the cries of the oppressed.

He said the US was committing excesses against Muslims in Libya Iraq, Afghanistan, Bosnia and
Palestine. He, however, did not rule out involvement of US regime itself in this act to unleash another reign of terror against Muslims.

Meanwhile, Samiul Haq asked for Khatm-e-Quran and Nawafil at Darul Uloom Haqqania for salvetion of the Ummah. 


\section{Attacks bear bin} Laden's signature:
US senator

Our correspondent

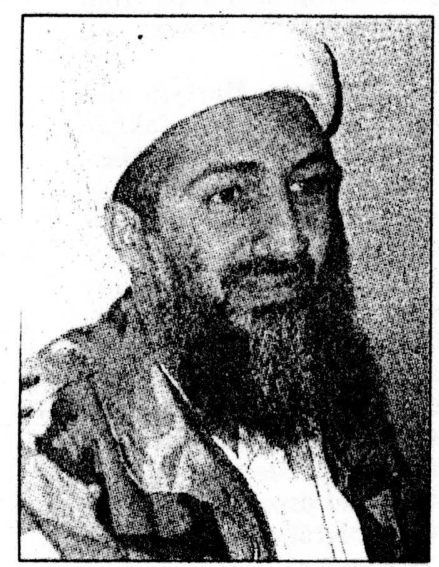

NEW YORK: Influential US Senator Orrin Hatch has said that Tuesday's attacks bear Osama bin Laden's signature.

Talking to the media, he said Pakistan must be urged to be more cooperative in handing over of Osama bin Laden.

\section{Pak military leaders meet}

ISLAMABAD: Senior military leaders of Pakistan continued their discussions until late on Tuesday night to discuss the New York bombings and its implications, sources said.

The leadership discussed the possible implications of the attack for Pakistan and the region, especially in view of the cruise missile attack by the US on Afghanistan in the past.

Special meetings were also held in the GHQ, Naval Headquarters and Air headquarters.

President Pervez Musharraf also met with the three service chiefs. An emergency meeting was also held at the Foreign Office. Jang-News service
The retired Commander of Natoi, General Wesley Clark has also blamed Osama for these attacks. In the wake of these statements from American leaders, Pakistan will come under tremendous pressure for its friendly overtures to the Taliban.

Meanwhile, claim by a Palestinian organization for these attacks has not diminished the number of statements pointing fingers at Osama bin Laden.

In either case, Muslim terrorists are being pointed out as the responsible element of these unthinkable organised terrorist attacks.

Taliban Foreign Minister Wakil A Mutawakil in a directly televised News Conference, denied any involvement in these attacks. $\mathrm{He}$ criticised and condemned all forms of terrorism.

American wire service AP is being quoted that followers of Osama bin Laden had warned few. days ago about a "Huge and unprecedented" attack on America.

The news agency has quoted a
London based Arab journalist for hearing such claims from the followers of Osama bin Laden.

Meanwhile President Bush has decided not to return to Washing. ton and has landed in Louisiana for safety reasons.

AFP adds: Saudi dissident Osama bin Laden warned three weeks ago of "a big attack" against the United States, according to the editor of the Londonbased Al-Quds daily Tuesday, citing "very good sources."

He said the series of terrorist strikes in New York and Washington earlier Tuesday were "definitely the work of Islamic fundamentalism." "It is well-orchestrated and well-organized," the editor, Abdel-Bari Atwan, told AFP, adding that the attacks could be the work of a "consortium" of Islamic groups.

Atwan, who is reputed to have good contacts with bin Laden's organisation, said: "Very good sources told me three weeks ago that he is planning for a big attack against American personnel and interests and maybe this is the outcome of it."

\section{EC grants 3.3m euros for refugees}

\section{Bureau Report}

PESHAWAR: The European Commission approved a grant of 3.3 million Euros to develop social and economic conditions of the local communities, encouraging durable reintegration of returning Afghan refugees and internally displaced individuals, said a press release here.

The funding would be used for a project called Security of Livelihood for Afghan Returnees (SOLAR) of CARE Afghanistan, an NGO working inside Afghanistan since 1961 . 


\section{EU commissioner starts visit today}

\section{Our correspondent}

ISLAMABAD: The European Union is expected to urge the Taliban as well as the Northern Alliance for the free movement of the aid workers in drought and war-torn country.

Poul Nieloson, European Union Commissioner for Development Aid, who is visiting Pakistan and Afghanistan from today, is expected to meet representatives of both the Northern Alliance and the Taliban. He will use the opportunity to underline the humanitarian principles to which all parties to the conflict should adhere.

Kurt Juul, Ambassador of the European Commission's delegation in Islamabad, while briefing a news conference in Islamabad, said these are the requirements to allow free humanitarian access to people in need and the obligation to guarantee the security and independence of humanitarian actors as they carry out their tasks of evaluating needs and implementing relief operations.

He said the aid provided by ECHO is governed solely by humanitarian principles and is channelled impartially to those most in need, wherever they are located, regardless of their reli- gious or political convictions, ethnicity or gender.

He did not give a clear answer when asked if commissioner Nielson would discuss closure of humanitarian agencies in Afghanistan by the Taliban militia. "Commissioner Nielson will be able to tell you more when he comes back from Afghanistan," he said. Nielson will be addressing a press conference in Islamabad on September 18.

Kurt said Nielson's will be coming on a humanitarian mission and the focus during the visit will be on men in distress. He said the Commissioner wants to ensure free flow of aid to those in need. Nielson will start his mission in Pakistan, holding meeting with Foreign Minister Abdul Sattar and other Pakistani officials. He will also meet United Nations agencies and Non-Governmental Organisations (NGOs).

Since last year ECHO has significantly increased its support for the victims of the fighting and the drought. For 2001 , it allocated funding of 23.5 million Europe, channelled through its operational partners, for food security, health, water, sanitation, de-mininig and other emergency relief projects $t a r$ geted at displaced people. Over 25 NGOs are currently implementing ECHO projects.

\section{Taliban seek}

\section{emergency aid for Takhar refugees}

ISLAMABAD: The Afghan government has urged the international relief organizations and agencies to provide emergency humanitarian assistance to the refugees being displaced from Takhar province by fighting and drought.

The Chairman Martyrs and Refugees Affairs of Takhar province, Mulla Mohammad Hussain said that the process of migration of the refugees from the opposition controlled areas to Takhar province has been increasing day by day to escape atrocities and drought.

He said that the migration process from different parts of Takhar province to the provincial capital has speeded up due to atrocities and drought. He said that mass migration of the people is continuing.

The Afghan official added that so far over 5500 families have migrated from Takhar and a number of them have been accommodated in Taloqan city's Baharak area and surrounding of Taloqan.

He said that they are extending every possible assistance to the new refugees but the resources in hands could not meet the refugees' requirements. -NNI

\section{US attack on Afghanistan may provoke Islamists}

\section{Analysis \\ Rahimullah Yusufzai}

PESHAWAR: By hastily condemning the acts of terrorism that shook the US on Monday, Pakistan and Afghanistan's ruling Taliban wisely tried to distance themselves from those who sponsored the bombings of the Pentagon in Washington and New York's World Trade Centre.

However, the question is whether the US government, panicky after the embarrassing attacks on its defence headquarters and commercial nerve-centre, would be satisfied with the strong denials coming out of Kabul and Islamabad. Everybody knows that Islamabad is bracketed with Kabu

due to Pakistan's close ties with the Taliban. Therefore; Pakistan risks being pressured if and when the US decides to punish the Taliban for harbouring Osama bin Laden.

President Bush and the American media have already concluded that the attacks were acts of terrorism and amounted to the declaration of war on the US. An effort is on to identify the attackers and some American television channels were telecasting interviews with terrorism experts and diplomats who suspected bin Laden's hand in the bombings.

The Taliban, they alleged were also responsible for the attacks because they gave refuge to bin Laden and refused to expel him from Afghanistan even after repeated demands by the UN Security Council. The message being sent out was that the Taliban cannot escape responsibility 
The NewS International, Wednesday, September 12, 2001

for bin Laden's actions.

In fact, the US government officials had conveyed such a message to the Taliban several months ago. The message was loud and clear - that the Taliban would have to bear responsibility for any future terrorist attack against the US by bin Laden and

his men.

Fear had gripped Kandahar, spiritual capital of the Taliban and hometown of their supreme leader Mulla Mohammad Omar, on a number of occasions following media reports of a likelihood of another US attack on Afghanistan. The first US strike against Afghanistan was in retaliation to the August 1998 bombings of American embassies in Kenya and Tanzaria and was launched only 12 days after the attacks on the US missions.

The situation is far more serious now because the US as the world's only superpower cannot afford to be seen as weak and vulnerable. It . would want to strike back forcefully to punish the attackers and their supporters and deter,future bombers.

There seems little doubt that the devastating terrorist attacks in New York and Washington were a reaction to the pro-Israel policy of the US government in the Middle East. The free hand given to Israel to kill and uproot Palestinians and destroy their homes has been fuelling anger and frustration not only against Tel Aviv but also the US. It is certain that the US won't change its policy concerning Israel and Palestine in the wake of the ter-

rorist attacks. Whether under the Democrats or the Republicans, the US is heavily committed in favour of Israel and balancing this policy by granting at least some rights to the hapless Palestinians appears unlikely in the near future.

President Clinton had wasted no time in ordering a cruise missile attack on Afghanistan on August 20,1998 following the bombing of the US embassies in: East Africa. One reason for his haste was to draw attention away from his much-publicized sexual. affairs with the young White House intern Monica Lewinsky. President Bush too would be

under pressure, though not for reasons which forced Clinton's hand, to attack Afghanistan. Such an attack may not harm bin Laden but it would definitely have apolitical fallout and could fuel protests in both Afghanistan and Pakistan and provoke Islamist forces to adopt a tougher anti-US stance. Pakistan, already a much sanctioned country and no longer in American good books compared to India, would also have to brace itself for further hostility from Washington until it agrees to abandon the Taliban and facilitate US plans to get bin Laden.

\section{0 militiamen killed in landmine blast}

KABUL: At least 30 Taliban were killed and many wounded when their two trucks hit a landmine in Sufaid Kotal in northern Afghan province of Samangon, reports Radio Tehran.

Fighting between the Taliban and the opposition Northern Alliance is continuing in north of Kabul. The alliance sources said that the clashes are going on in the old road area, north of Kabul and Taliban's jet fighters have bombed residential areas in north of Kabul. The sources said that a number of Taliban were killed and wounded during clashes in Takhar.

They said that a number of military equipment were also seized from the Taliban. The sources said that fighting between the rival factions is still raging in north of Kabul. -Sana

Reuters adds: The Taliban movement launched a major offensive north of the capital on Monday night, one day after a suicide bomber tried to kill their key

\section{Work on Kabul- Jalalabad highway continues}

ISLAMABAD: Construction work on the Kabul-Jalalabad highway is in progress and for this purpose sophisticated road construction machinery has been imported to ensure the construction of the said highway according to international standard.-NNI military opponent, anti-Taliban sources said.

Opposition sources with Ma. sood's forces said the Taliban of fensive was concentrating on two fronts leading to his stronghold and birthplace in the Panjsher valley, $120 \mathrm{~km}$ north of Kabul.

The Taliban forces were striking at the so-called Old Road, some $25 \mathrm{~km}$ north of Kabul, and in Kapisa province to the northeast, they added.

"They have not gained anything from the attacks. We have foiled them all and there are heavy casualties on both sides," an opposition official said by satellite phone.

Kabul residents could hear the roar of Taliban jet fighters - left behind by the Soviet forces Masood fought in the 1980s - making regular runs north of Kabul and the explosions of artillery shells.

The Taliban, who forced Masood from Kabul in 1996,currently controls all but a northern five percent of the country. 


\section{Afghan envoy denies Osama hand}

ISLAMABAD: Afghanistan's ruling Taliban Tuesday denied that Saudi dissident Osama bin Laden had played any role in a series of apparent terrorist attacks in the United States.

The Taliban militia's ambassador to Pakistan Abdul Salam Zaeef condemned the attacks and said he hoped the perpetrators would be quickly brought to justice.

"Osama is only a person he does not have the facilities to carry out such activities," he told a news conference. "We want to tell the American people that Afghanistan feels their pain. We hope the terrorists are caught and brought to justice."

Zaeef said it would be a "big mistake" for the United States to attack bin Laden's interests in Afghànistan, where he has been harboured as an honoured guest of the Taliban militia.-AFP

Reuters adds from Kabul: Afghanistan's ruling Taliban Tuesday said Saudi dissident Osama bin Laden was not responsible for the attacks on the United States.

"What happened in the United States was not a job of ordinary people. It could have been the work of governments. Osama bin Laden cannot do this work, neither us," a Taliban spokesman, Abdul Hai Mutmaen, told Reuters from the southern city of Kandahar.

"We are not supporting terrorism. Osama does not have the capability. We condemn this. "This could have been the act of either internal enemies of the United States or its major rivals. Osama cannot do this work," he added.

In Geneva, the UN envoy for Afghanistan said that if Washington believed the World Trade Center attacks were related to terror suspect Osama bin Laden, it would have "incalculable consequences" for Afghanistan, where the Saudi exile is believed to live.

But Francesc Vendrell also told
Reuters that he hoped there were no Afghan links to the attacks in which two hijacked planes crashed into the twin towers on the tip of Manhattan island and another plane smashed into the -Pentagon in Washington.

He was speaking in an interview at the United Nations' European headquarters in Geneva after chairing three-day talks between diplomats from Iran, Germany', Italy and the United States about the situation in war-torn Afghanistan.

"If these terrorist acts were to be seen by the US government to be related to any activities on the part of bin Laden or with people associated with Afghanistan cur. rently or in the past, it could have incalculable consequences, "Ven:drell told Reuters.

"Obviously, we would then be in a totally different ball game in Afghanistan," he added. "I hope; of course these actions are not at all linked with anyone in Afghanistan."

\section{Great game to control Afghanistan goes on}

ISLAMABAD: It has been one of the world's poorest areas for centuries, an arid, mountainous land with a dearth of natural resources and a climate that swings from baking heat to subzero winters.

But, just as the British and Russians in the 19th century played out their "Great Game" for control, a new group of countries are vying for influence in Afghanistan. The same accidents of geography that contribute to their poverty have placed Afghans at the crossroads of Central Asia.

In the new version of the Great Game, outside forces have lined up on opposite sides in the cam. paign by the Taliban movement to win total control.

The Sunday attack on key op- position leader Ahmad Shah Masood, which appears to have left him seriously wounded - some say dead - must have pleased the Taliban and alarmed those trying to halt them.

"One of the key factors in the Afghan issue is everyone wants to get in the kitchen yet everyone should stay out," said S Frederick

Starr of the Johns Hopkins School of Advanced International Studies in Washington.

"If there's anything that we should've learned from the last two centuries it is that outsiders screwing around in Afghan politics always come out badly," said Starr, who is chairman of the school's Central Asia-Caucasus Institute.
Despite Pakistan's continual denial of a role in the fighting unlike the 1980 s when it was openly the base for attacks on the Soviet-backed regime in Kabul - it finds few believers.

"They are there and they are a reality. Since we have common borders with them we cannot have any other policy than engaging with whoever is in charge in Afghanistan," Pakistani military leader General Pervez Musharraf justified his country's backing during an interview in July.

Beyond Pakistan, the Taliban have few friends. Saudi Arabia and United Arab Emirates are the only other countries to recognise the Taliban as the legal government, 
The News International, Wednesday, September 12, 2001

but they have not joined Pakistan in maintaining embassies in Kabul.

Turkmenistan, which still dreams of exporting its vast natural gas reserves to the teeming subcontinent via a pipeline across Afghanistan, has been the only Central Asian neighbour to keep firmly neutral in the civil war.

But the Taliban have private supporters who may have deep pockets similar to Osama bin Laden, the multi-millionaire Saudi dissident. This year the United Nations has reported a marked increase in the number of Arabs in the capital, often taking residences in the best areas. Links to the Gulf are underlined by the decision of Qatar's Al Jazeera television, with Taliban blessing, to open a bureau with their own transmission facilities in Afghanistan.

On the opposite side, the Northern Alliance - which is united mainly by antipathy to the Taliban - is backed financially and militarily by several countries.

Iran threatened to mass troops on the border in one confrontation with the Taliban.

Tajikistan and Uzbekistan both fear the export of Taliban fundamentalism. That is also a fear for China, which has tried to suppress unrest in its remote western regions, which touch Afghanistan.

Russian not only wants to keep Taliban ideas out of their former empire in Central Asia, but also is angered that Chechen fighters battling their continued rule in Chechnya are being trained inside Afghanistan.

India, which is joining Russia, Iran, Turkmenistan and Uzbekistan at a meeting expected soon in the Tajik capital, is likely most interested in diverting Pakistan from their conflict over Kashmir to the protracted struggle in Afghanistan.

The United States may have a more complicated agenda. It sees opportunities in Central Asia, with vast oil and gas deposits, and a longer-term rival is not the Taliban but the old colonial power in the Kremlin.

In the mid-1990s, even as the Taliban expanded, a US company explored the idea of building a pipeline across Afghanistan. The US commercial need for a stable government controlling Afghanistan mirrored Pakistan's interest in securing a safe trade route into Central Asia.

"The first step is not trade but the second one is," Starr told Reuters.

However, even US officials will admit that US policy on Afghanistan has become hostage to bin Laden. By protecting a man who Washington has described as their greatest enemy, the Taliban have made their own image little better.

Officially, Washington's position is to call for a broad-based government in Afghanistan to end the fighting that has gone on since even before the Soviet invasion of 1979.

Diplomats

covering Afghanistan are convinced the Taliban cannot impose their rule throughout the country; if the current opposition collapsed over something like the death of Masood, new unrest would appear in a country where large minorities come from different tribes than the Taliban.

But equally, no one expects the current opposition nominally led by President Burhannudin Rabbani to roll back the Taliban. Rabbani's period of rule in Kabul, with Masood as his defence minister, was as brutal and chaotic as the rest of the past two decades.

"I don't see any way in which there will be an absence of conflict unless there is a way of representing all of the national and ethnic groups," said Roy Allison of Britain's Royal Institute for International Affairs.

Unlike the United Nations, which recognises the government of Rabbani, Washington has never recognised any faction as the legal rulers.

That has reinforced the belief of diplomats in Islamabad that Washington, in its longer-term interests in Central Asia, would deal with the Taliban if they hand over bin Laden who could target the interests of the United States or its allies like Israel. -Reuters

\section{Osama denies hand}

\section{in attack on Masud}

\begin{abstract}
Behroz Khan
PESHAWAR: Saudi dissident Osama bin Laden has denied involvement in the suicide attack on former Afghan defence minister Ahmad Shah Masud and said his organisation would never indulge itself in internal conflicts among warring Afghan groups.
\end{abstract}

"We reject any such impression and news reports involving Al-Qaida in the murderous attack on Ahmad Shah Masud. No one affiliated with our organisation has carried out the attack," sources close to Osama bin Laden told The News on Tuesday.

The source, a known Afghan, who often speaks to the press on behalf of Osama bin Laden, specially visited The News Peshawar Bureau to convey the message from the Afghanistan-based alleged terrorist, who is wanted to the United States on charges of involvement in the bombing of American embassies in Kenya and Tanzania in 1998.

"I have always tried my level best to mediate between the Taliban and the opposition and convince both sides to resolve their differences through dialogue. This latest fighting between the warring sides is a matter of extreme concern for me," the source quoted Osama bin Laden as saying.

The Pashto speaking Afghan, on condition of anonymity, said Osama was concerned about the escalation of fighting in Afghanistan because of the situation in the Middle East, especially the killing of Palestinian children at the hands of Jews.

"Palestinian children are the victims of atrocities and cruelties unleashed by Jews with the patronage of the United States, " he 
quoted Osama bin Laden as saying and added that Shiekh, a reference to Osama bin Laden, said that the world kept mum on the situation in which, armless children throw stones on the Israeli soldiers while in reply receive bullets. "The cruelties of Israelis are unbearable", the source quoted Osama as reacting to the ongoing uprising in Palestine. The Afghan had left Afghanistan early in the morning and was not aware of the terrorist attacks in the US, as his remarks were only Masud-specific.

"The great Islamic state of Afghanistan will be able to help Palestinians and the suppressed Kashmiri people if factional fighting is brought to an end in Afghanistan," Osama commented on the infighting among different Afghan groups. Osama bin Laden, who took refuge in Afghanistan in

\title{
The Frontier Post:
}

\author{
Wednesday, September 12, 2001
}

\section{Pakistan flays life attempt on Masood}

Fakhar-ur-Rehman

ISLAMABAD : Pakistan on Tuesday strongly condemned an assassination attempt on a main commander of the anti Taliban opposition Ahmed Shah Masood who was reportedly injüred severely in a bornb blast on Sunday while he was giving an interview to some Arab journalists.

The spokesman for Foreign Office in a statement on Tuesday said that " Pakistan strongly has condemned the assassination attempt on Commander Ahmed shah Masood, leader of the Shoorae-Nizar of the Northern Afghanistan, in which he reportedly received serious injuries".

The spokesman said that Pakistan was opposed to violence' in Afghanistan, which may be aggravated by such acts
1995, has given allegiance to Talban supreme leader Mulla Muhammad Omar and pledged to follow him as Amirul Momineen. The source said that Osama has always wished to play conciliatory role in bringing the Afghan factons to negotiating table but has not been able to assume the role host of factors.

It is to be noted that Ahmad hasud had sought world help against Taliban and the alged terrorist, Osama bin Laden, which the sources believe annoyed the Saudi born multi-milionaire and was not on good the leadership of the Masud. The source said that linking every Arab with Osama was wrong and had no justification because several extremist Arab groups rather hated the Saudi dissident because of his ideology.

\section{of terrorism}

He said that Pakistan wants to see peace return to that war ravaged country and political solution to the on going is found." Pakistan desires to see peace and national reconciliation in Afghanistan where people have long suffered the ravages of foreign military intervention followed by more than a decade of civil strife", the spokesman added.

The statement was devoid of comment on the reported allegation on Pakistan's involvement in an assassination attempt on Ahmed Shah Masood. While the confusion continued to muffled exact condition of Ahmed Shah Masood, sources told the Frontier Poot that he was under treatment in nospital at a place inside Afghanistan. " he maybe under treatment at Karyab in the north of Afghanistan".

\section{Afghan opposition headless without Masood}

ISLAMABAD (Agencies): The extent of Afghan opposition commander Ahmad Shah Masood's injuries following a failed assassination bid could have far-reaching consequences for the civil war, analysts said Monday.

Masood was in hospitál somewhere in opposition-controlled northern Afghanistan or neighbouring Tajikistan after two Arab men posing as journalists exploded a bomb during a meeting in his office on Sunday.

Opposition sources have said the former defence minister's injuries are not life threatening, but the two bombers as well as an opnosition spokesman were killed in the blast.

Analysts said the Taliban could take advantage of the opposition : commander's absence to launch fresh attacks in the northeast or the Panjshir Valley, Masood's traditional stronghold and support base.

The veteran commander, who held Soviet forces at bay for 10 years during the $1979-89$ occupation, is famous for leading battles from the frontlines and holding the fragile opposition alliance together with deft diplomacy.

His loss, even if just for a few weeks while he recovers in hospital, would be a major blow to the opposition as the summer fighting season nears its traditionally bloody close.

The resistance has always been a motley alliance of former encmies and turncoats, incluuing warlords' from the Uzbek, Hazara and Masood's Tajik ethhic minorities.

But without Masood's leadership, and the contacts he enjoys with allies among the international community, analysts said it could be in danger of crumbling as it has several times before.

Ex-communist general and Uzbek warlord Abdul Rashid Dostam -. at various times over the past 10 years both an enemy and an ally of Masood's -. rejoined the alliance as recently as April after a period in exile following defeat at the hands of the Taliban. 


\section{The Frontier Post Wednesday, September 12, 2001}

He has launched a fe w minor attacks in his heartland of northern Balkh province since his return, but has failed to seriously trouble the Taliban, which seized Kabul in 1996.

In central Bamiyan province, the opposition alliance consists of Shiite Hazara forces led by the Hezbe-Wahdat, a group which helped reduce much of Kabul to rubble when Masood was defence minister in the early 1990.

\section{Masood is safe, alive, claim allies}

DUSHANBE (PPI): Allies of Afghan Commander Ahmed Shah Masood have claimed that he is still alive.

They have rejected reports of his death, terming them as false. A diplomat of Professor Burhanuddin Rabbani government in Tajikistan, Mahiyuddin Mehdi has said that Commander Ahmed Shah Masood is now recovering.

Commander Masood sustained injuries in a suicidal assassination attempt at his base in Khawaja Baha ddin in Takhar province on Monday.

Mehdi said that the assailants who had posed themselves as journalists had arrived in the area from the Taliban's controlled area and after waiting for some time, had got the permission to interview Masood.

In an interview to $\mathrm{BBC}$ Mehdi told that Commander Masood is safe and alive. He said that the latest reports are that Commander Masood held telephonic conversations with Dushanbe based staff of the northern alliance.

Masood has reportedly issued necessary orders to the embassy staff in Tajik capital.

Commander Masood also met with some Commanders and officials of the opposition northern alliance last night.

$\mathrm{He}$ added that Masood is safe and sound and would appear soon in the media.

Meanwhile source close to Ahmed Shaih Masood said that investigations are underway to ascertain the identity of the two men killed in the incidents.

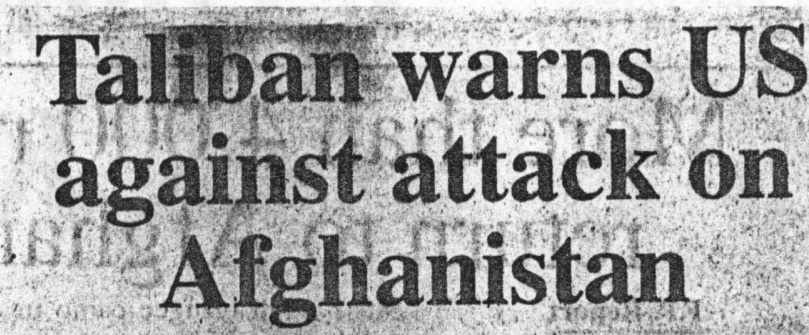

Fakhar-ur-Rehman

ISLAMABAD : The ruling

Taliban authorities in Afghanistan while strongly condemning loss of life and destruction caused by a series of unprecedented act of terrorism on Tuesday in New York and Washington warned the Bush administration that any attack on Afghanistan will be a big mistake.

Afghan enyoy to Pakistan Maulvi Abdus Salaam Zacef addressing a press conference in Islamabad on Tuesday night said " the incident which took now in Washington and New York and which caused destruction and killings we strongly condemn it and investigation

\section{Iran condemins Masood} assassination bid

TEHRAN (Agencies): Iran strongly condemned on Tuesday the assassination attempt on Ahmad Shah Masood, the main guerrilla enemy of Afghanistan's ruling Taliban movement, state television said. Uncertainty surrounds the fate of Masood, 48, who was the target of an assassination attempt in northern Afghanistan on Sunday by two Arab suicide should be carried against those brought them to justice' Zaeef said "w saudi dissident act of terrorism as we en under control all his comcomplicated one in whic no facility to carry out such activity".

To ariother query he said "we do not expect from US to take such a speedy and thoughtless action without completing the investigation in to the case. An attack will be a big mistake".
Three Afghans nabbed in Capital

ISLAMABAD (Online): Golra police have rounded up three illegal Afghan immigrants from the city under 14 Foreigners Act.

According to Police sources, Murad Khan was apprehended from G-11/1, Faiz Khan from G$10 / 4$ and Waheed Khan from F$11 / 2$ for not possessing sufficient documents.

During a separate operation in jurisdiction of Golra police station, a large quantity of illicit weapnns were seized from three perşons, Shahid ullah, Amanullah and Abdullah hailing from Bajor agency. Kohsar police station meanwhile registered a case against one Omer Khan, working as driver with the United Nations. 
The Statesman Wednesday, September 12, 2001

\section{Kabul urged to restore democracy}

GENEVA: Iran and Western powers including the United States urged Afghanistan's rulers on Tuesday to restore democracy, saying a military solution to the country's internal strife was unacceptable.

In a statement after three days of talks under United Nations auspices, diplomats from Germany, Iran, Italy and the United States condemned Sunday's terrorist atlack on opposition leader Ahmad Shah Masood as "a new escalation of the Afghan conflict".

The fate of Masood was unclear after a suicide bomb attack at his office in northern Afghanistan.

Francesc Vendrell, the UN special envoy for Afghanistan, told a news briefing after chairing the talks: "All I can say is that Commander Masood suffered a terrorist attack against his life. This was a kind of suicide attack reportedly by people of Arab origin. His health is in danger."

Asked whether the assassination bid and a fresh Taliban offensive north of Kabul had led to a more dangerous situation in the war-torn country, Vendrell replied simply: "I agree."

Sources in Masood's alliance insist that he survived the attack and said forces of the purist Islamic Taliban h.d begun a drive to dislodge his fighters from positions north of the capital Kabul. Other reports have said the bomb killed Masood.

"If it is true that he was killed, it would be a severe blow. There isn't anyone else with the charisma or personality," said one diplomat close to the talks.

"It would be an opportunity for the Taliban to try to push forward during the period of uncertainty," the diplomal added. The Taliban has denicd involvement in the allack.

The statement said the diplomats at the Geneva lalks had agreed that "a military solution is neither possible nor indeed acceptable and called for genuine negotiations leading io a durable cease - lire and a dialoguce among all Afghan factions and groups in order to end the conllict in Afghanistan." - Reuters

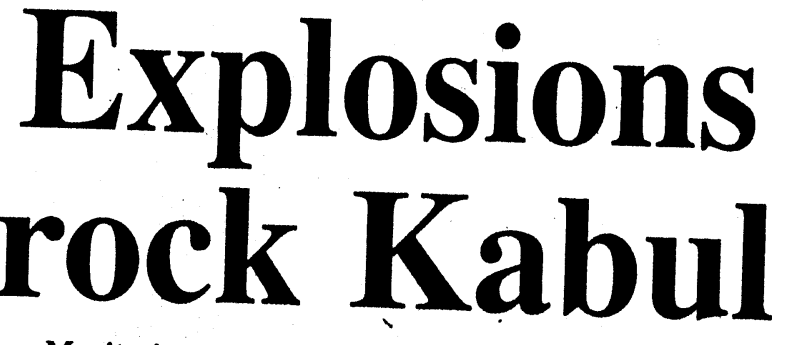

\section{Monitoring Report}

PESHAWAR: Hours after the massive terrorist strikes in New York and Washington, explosions rocked the Afghan capital of Kabul early Wednesday.

A CNN report monitored here said that explosions could be heard north of Kabul in the vicinity of the airport. Large plumes of smoke were also seen, the network added.

According to the report, the explosions began around 2:30 a.m. and came in rapid succession, seconds apart, making buildings shudder. They were reported after a string of explanations from Taliban's top leadership that alleged Saudi terrorist Osama bin Laden had no link to the acts of terrorism that hit the US early Tuesday morning.

There were no sounds of airplanes or anti-aircraft fire. The ruling militia officials could not be reached at the airport.

The CNN, however, quoted an unnamed US official as saying that the United States isn't attacking Afghanistan as of 6 p.m Tuesday night. He saia the fighting in Kabul appears to be rocket attacks by Afghan rebels opposing the Taliban in response to the attack on opposition commander Ahmed Shah Masood over the weekend.

The explosions were in the direction of the front line where Taliban soldier are lined up against opposition forces. Fighting in that area has increased in recent but this would be first major assault by opposition forces so close to the capital.

The White House has denied ordering attacks on Kabul and said it was part of Afghanistan's civil war.

Taliban ambassador Abdus Salam Zaeef told SADA in Islamabad that the attack had been carried out by the US. "It is an American attack," he said, ruling out a reprisal offensive by the main opposition Northern 


\section{Masood's fate shrouded in mystery}

KABUI, Sept 11: The Taliban launched a fresh push against rival forces in the north on Tuesday as mystery surrounded the fate of their main rival, Ahmad Shah Masood following Sunday's suicide bomb attack.

With the Taliban themselves denying any role in the assalssination allempt on Masood, his opposition alliance reported a fresh push by Taliban forces to dislodge its fighters from positions north of Kabul.

The sound of fighting could clearly be heard in the city on Tuesday.

Iran's state-run television announced that neighbours who remain wary of the Taliban and its influence in the region would meet soon in Dushanbe, capital of Tajikistan.

Masood, 48, was the target of two Arab suicide bombers posing as journalists in his office in northern Afghanistan.

Members of his alliance both inside and outside the country say he was wounded in the blast, but insist he is recovering. Other reports suggest that he died in the blast.

"Masood is still under treatment in a hospital in neighbour. ing Tajikistan," Bismilla! Khin, one of Masood's top comman. ders said over satellite phone from a location to the north of Kabul.

Another alliance of ficial, Sayed Najibullah Hashimi, speaking from its capital of Faizabad in the northeast, told a similar story.

He blamed Sunday's blast on the Taliban and Osama bin laden.

The Taliban have denied involvement and had no immediate comment on liuesday's offensive -- which followed several days of heavy clashes with Masood's forces in the same area.

Khan said that it focused on two main roads to the south of Panjsher valley, Masood's stronghold and his nat ive valley.

The Taliban attacks, which involved a large number of troops and aerial bombard. ments, had failed with dozens of Taliban fighters killed, he added.

CONFLICTING REPORTS: Most opposition sources said that Masood was in Tajikistan.

Ahmed Wali Masood, Masood's brother, told CNN from London that the guerilla commander had survived with a seriously wounded right leg, two pieces of shrapnel lodged in his head, burns to his face and injuries to his fingers.

"Now he can communicate, but of course not frequently. He can communicate from time to time," he said.

The Russian newspaper Kommersant said on Tuesday that Masood was being treated by Russian military doctors in Tajikistan, but the report drew a swift denial from a Russian military spokesman in the former Soviet republic.

The alliance's deputy ambassador in Tajikistan said Masood was still in Afghanistan.

The Russian news agency ITAR-TASS and the British Broadcasting Corporation, how. ever, quoted sources in central Asia as saying that Masood had been killed.

The BBC said Gen Fahim,
Masood's intelligence chief, had replaced him.

US officials satid privately on Monday that intelligence reports indicated Masood, who first made his name fighting the Soviet occupation of Afghanistan in the 1980s, was deald.

But the official US line was that his fate was unclear.

Sunday's attack on Masood came one day after a bomb wounded several people inside the interior ministry in Kabul.

"We are not involved in the (Masood) incident. If we were, we would have proudly said that because he is our enemy," Taliban chief spokesman Abdul Hai Mutmaen said on Monday.

CURRENCY: In Kabul, the embattled Afghani currency rose against the dollar on reports that Masood may have died, money dealers said.

"The Afghani wias traded for 71,500 against one dollar before the reports while it is now sold for 68,600 ," a dealer said.

DIPLOMACY: Afghanistan was the subject of diplomatic exchanges on Monday.

In Moscow, the Kremlin said Russian President Vladimir Putin discussed it with Tajikistan President Imomali Rakhmonov.

In Geneva, non-warring Afghan factions held U.N.-sponsored talks with German, Iranian, Italian and US diplomats.

Iranian television said representatives from Iran, Russia, Tajikistan, India and Uzbekistan would meet soon in Dushanbe. -Reuters 


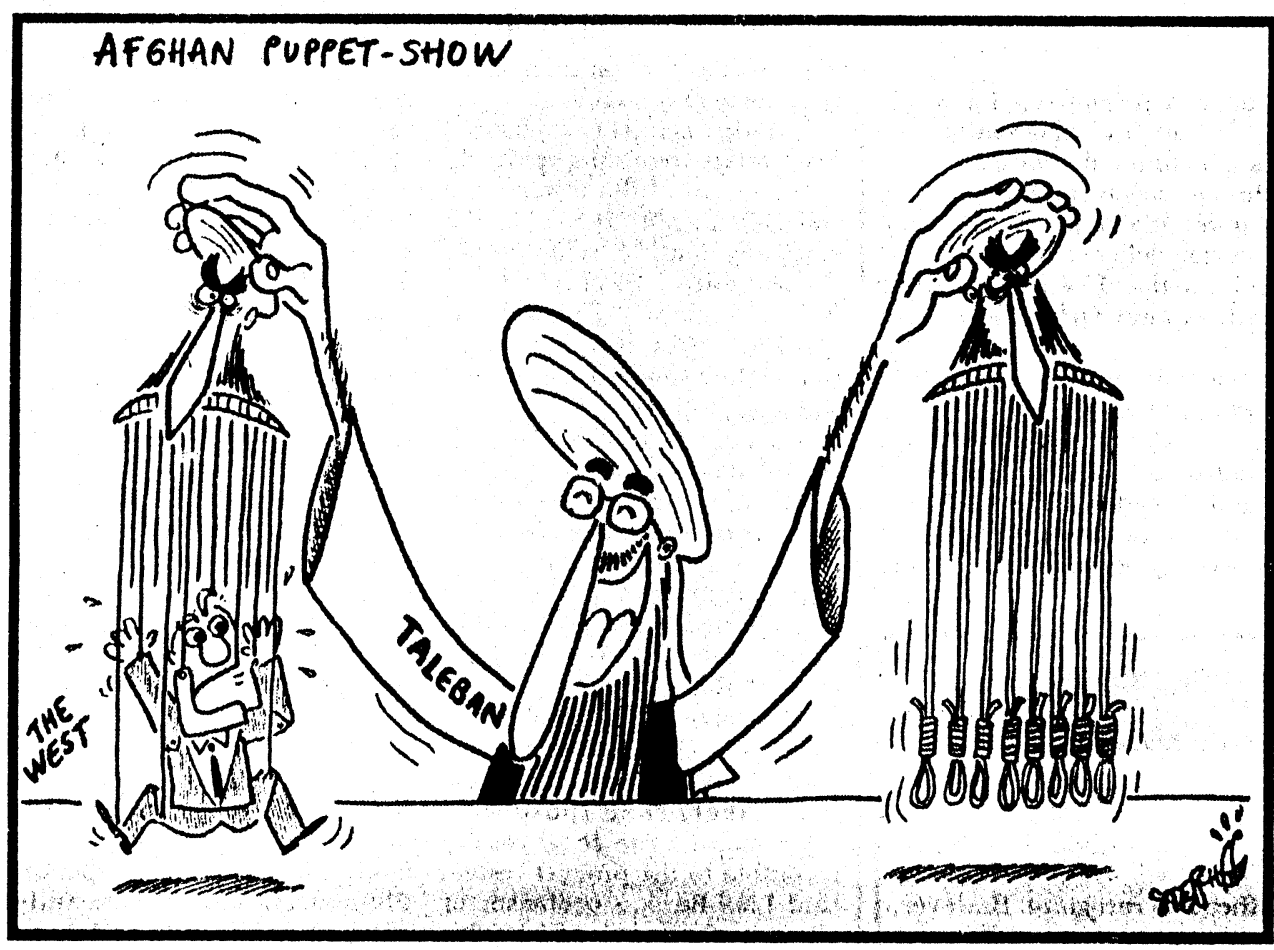

The News International, Thursday, September 13, 2001

$$
\begin{aligned}
& \text { UN envoy voices } \\
& \text { fears } \\
& \text { of US }
\end{aligned}
$$




\section{Will US again rain cruise missiles on Afghanistan?}

\section{Comment \\ Rahimullah Yusutzal}

PESHAWAR: Would the US again rain Tomahawk cruise missiles on Afghanistan as part of its likely retaliation for the daring attacks on some of the symbols of its power in Washington and New York? Or would it infiltrate commandoes into Afghanistan to pluck or assassinate Osama bin Laden? How about sending jet fighters to bomb bin Laden's hideouts and Taliban installations? These could be some of the options under consideration by American authorities as they prepare for revenge.

With each passing day, the US government seems to have closed in on bin Laden as the prime suspect in the terrorist strikes against the Pentagon and the World Trade Centre. Therefore, the next logical thing for the US would be to locate bin Laden in Afghanistan and try to get him. Besides punishing bin Laden, the US' has also vowed to strike at countries or groups that harbour terrorists. This clearly singles out the Taliban for hosting bin Laden and refusing to expel him as demanded by the UN Security Council.

The question is as to when the US would be able to put its act iogether and strike at Taliban-ruled Afghanistan. If President George W Bush listens to the mood of the American people and to most of the media, he has to go for "a swift and decisive" reaction to avenge his country's losses. But his own choice of words in the speech he made on Wednesday was rather non-hurried and restrained. He said the US would be "patient" and would rally the world to its side while waging the fight against terrorism. This could be interpreted as an effort by the president to restrain his people and assure the world that the new administration would not rush into judgement. Or is it a ploy to keep the world guessing until the US has had its revenge?

The shape the US retaliation would take is a more important question agitating the minds of all thinking people. In August 1998, the US fired about 80 cruise missiles from a ship in the Arabian Sea and some 60 of them hit their target, ie bin Laden's training camps, in Khost, eastern Afghanistan. The strike came only 12 days after the bombings of the US embassies in Kenya and Tanzania and was widely expected. The Bush administration could go for another cruise missile attack, certainly more intense and focused than "the last time." 'Or' If could experiment with some new weapons while pursuing its bid to get even with bin Laden.

Infiltration of American commandoes into Afghanistan has been speculated for quite some time as an option actively under consideration. Pakistani newspapers have often reported the sightings of American commandoes in Peshawar, Islamabad, Cherat and elsewhere but have never followed-up their movements. There was also a report how the Clinton and Nawaz Sharif governments agreed to stage joint exercises for their commandoes here before launching an op- eration to snatch bin Laden from his hideouts in Afghanistan. Sending the American commandoes into Afghanistan would be the most risky option and, therefore, less likely to be implemented. The memory of the botched-up US operation to rescue the staff of the American embassy taken hostage by Iranian students in Tehran apparently continues to haunt the Americans to this day. The US won't like to fail again, hence the need to comprehensively discuss whether America commandoes on Afghanistan's soil would be able to achieve their objective of capturing or assassinating bin Laden.

The option of putting jet fighters into service and flying bombing sorties in places such as Kabul and Kandahar would be found tempting by some of the American decision-makers. It would entail little risk on account of the weak Taliban anti-aircraft defence system and their ageing fleet of aircraft. 'But the "question' is' Whether the jets would be áble to cause maximum damage and destroy the infrastructure of bin Laden and Taliban bases.

The US may not use any of these options and instead employ something new and more effective. But one thing is clear: it would desperately aim at striking so hard at the Taliban that they may become weak and incapable of staying in power. That would also resolve the bin Laden problem once for all because no Afghan group other than the Taliban would have the guts and the resolve to protect the Saudiborn Islamic militant. 


\section{Osama's home in exile, seat of Pashtun power}

KABUL: In Afghanistan, Kandahar sits as a remote desert town, home of Osama bin Laden, a war room for the Taliban.

With a Pashtun population of about 200,000 people, it also serves as a vital link with the Taliban's chief supporter Pakistan and an important trade route with the sub-continent, Middle East and Central Asig':

And as Afghanistan's most celebrated "guest", Saudi dissident and reported millionaire bin Laden lives there as a close confidante of the Taliban chief, Mulla Mohammad Omar.

Omar and bin Laden both own houses in Kandahar - two-story concrete villas - towards the western end, on the city's only tracked road, which stretches about two kilometres across town.

Rumours about their friendship abound. They travel freely around town, are partial to evening walks and drive Toyota pick-up trucks. Security is tight, but unlike Kabul, not overwhelming.

Nestled within a mountainous buffer near the border with Pakistan, the city is two-day drive south of here and a safe distance from the bloody fighting that has dominated life in Kabul for more than a decade.

But Kandahar is dirt-poor. It was never a part of the fabled Sulk Road riches, which traversed this country for 1,000 years. Its buildings are shabby and crowded.

On August 24 1999, a massive truck bomb was detonated in an assassination attempt on Omar outside his house. Timed to coincide with an evening stroll, it warped the foundations of buildings at the extreme east and west ends of town.

The city and region is also bereft of natural resources. Gem stones, copper, oil, gas and arable land are all located hundreds of kilometres away in the north and central provinces.

"Kandahar is unique," one west. ern analyst told AFP "It needs the control of the entire country to survive and it needs outside support, whethe it's from bin whonto achieve this." It has two near by airports which are heavily a ined, and hold radar-guided surfaco to alr do fence capabilities.

In late 1999, the closest airport witnessed dramatic events when a freedom fighter hijacked an Air India passenger jet in Nepal and flew to Kandahar where the Taliban acted as mediators. The fighter escaped. A second airport, closer to the border, has been touted as bin Laden's primary base from where he travels in a fleet of helicopters with Egyptian and Arab bodyaround the country.

Outside bases include Sherbaghan in the west, Gharni in central Afghanistan and Hadda Farm outside of Jalalabad in the country's east.

More recently, bin Laden has been reportedly sighted in Mulla Omar's office in Kandahar and provinces north of the capital Kabul, where a series of battles has been fought in recent weels along the frontlines. Kabul is traditionally Afghanistan's ethnic melting pot mixing Pashtuns from the south with Tajiks, Turks, and Hazaras from the northern ard central provinces.

Increasing numbers of suspected Arab mercenaries have also been sighted around the capital in recent months, the raw recruits to the Taliban and bin Laden's vision of jihad, or holy war. Pashtuns - the largest minority - have virtually always ruled amid an Afghan maxim of whoever controls Kabul controls Afghanistan.-AFP guards to three other airstrips

\section{Taliban conveyed message from world community}

\section{Umor Farooq}

ISLAMABAD: Senior Pakistani diplomats on Wednesday conveyed a message from international community to the Taliban leidership regarding Osama bin Laden, who is emerging a prime suspect in terrorist attacks on US cities.

The message was delivered to the Taliban leadership in Kandahar after a senior US official held a telephonic conversation with a Pakistani official in Islamabad.

The official told The News that the message to Taliban has been delivered. However, he refused to divulge the exact content of the message. It is believed the message relates to the early extradition of Osama bin Laden. Taliban had refused to hand over Osama to US authorities in the past.

The United States has not so far officially accused any one of attacks on New York and Washington D.C.

The US Administration is now asking Pakistan to help in the extradition of Osama bin Laden. In the past Pakistan has been saying that Osama bin Laden is an issue betwieen Afghanistan and United states and the two parties should settle the matter between themselves through negotiations.

Sources said a senior US official is likely to meet President Pervez Musharraf on Thursday. President Musharraf remained engaged in a high level meeting in Rawalpindi till late on Wednesday night to discuss the emerging situation. The meeting was participated by senior military officials as well as Foreign Minister and foreign Secretary. 


\section{$\mathrm{UN}$, aid agencies pull out of Afghanistan}

\section{Abdullah Jan \& Naveed Ahmed}

PESHAWAR: Foreign aid workers, the UN and diplomats began pulling out of Afghanistan Wednesday as fears mounted the Tuesday's horrific terrorist attacks on US installations were carried out by Saudi dissident Osama bin Laden, sheltered by Taliban.

United Nations (UN) and International Committee for Red Cross (ICRC) were evacuating their international staff from Afghanistan. "They have started flying out of Afghanistan," said a source in the world body, adding that the UN had 80 international staffers in different towns of Afghanistan.

"Messages have been aired to all to leave immediately," said an official of a western NGO in Pe. shawar, referring to pull out of relief agencies from Afghanistan. He added decision was taken for the

security of our staffers with western nationalities, especially Americans and British.

Sources at the PakistanAfghanistan border at Torkhum confirmed that about a dozen foreigners crossed over into Pakistan on Wednesday. "At least 12 western NGO workers have reached Peshawar," said a government official, asking for anonymity.

Executives of different NGOs working in Afghanistan who met in a hurriedly called meeting at the offices of Agency Coordinating Body for Afghan Relief (ACBAR), a representative body of NGOs working in Afghanistan in Peshawar Wednesday morning, identified 41 expatriate aid workers for return from Afghanistan. They included 23 in the Afghan capital Kabul and 18 in the northern Mazar-e-Sharif city. Other sources said western NGO officials are also present in many
other parts of Afghanistan, with other parts of Afghanistan, with Jalalabad, Kandahar, Heart, and Faiz-
absid being on top of the list.

"We held threadbare discussion over the evacuation of expatriate staff from Afghanistan and agreed to go ahead for their removal from Afghinistan, especially American and British nationals," disclosed a privy to the meeting, attended by about a dozen representatives of dif-
ferent NGOs.

Francious Cautin Un Commission chief executive in Peshawar Jean add workers present inside Afghanistan and here to identify western their pull out.: "We tallied our nhanistan and make arrangements for list of our people there, ${ }^{n}$ said an official are trying to prepare a final sion' in Peshawar:

An ACBAR publication says a total of 331 permanenthy workers from western countries ar of 331 permanently enrolled aid AfGianistan. "Many others, however stationed in different parts of while permanent ones are however, also visit the country frequently, (1) transferred or gone on leave," said an ture.

know as to how travelling in and out of Afghanistan, so we don't ficial in a Dutch NGO in present there right now," said a Pakistani of said more than 150 in Peshawar, with a request for anonymity. He presently involved in res from different countries of the world are

The ACBAR publication puts the projects inside Afghanistan.

than a dozen western countron puts the total number of NGOs from more cluding five relief organization working inside Afghanistan at 70, inStates.

"I talked to our people in Mazar-e-Sharif in the morning them to move out," said a senior official of another western NGO, with
its country office in Peshawar.

Authorities at the Pakdstan-Afghanistan border at Torkhum also confirmed the arrival of a few American nationals from Afghanistan. The would reach Torkhum by late Wednese leaving Afghanistan by road northern parts of the country Wednesday evening. Those stationed in istan, he added.

The United Nations agencies in Afghanistan Wednesday partially suspended operations and are temporarily relocating its 80 member international staff in Pakistan.

The UN international staff is currently present in six locations of the country including Jalalabad, Mazar, Kandahar, Heart and Faizabad. The relocation exercise will complete today (Thursday). The UN Office for Coordination of Humanitarian Affairs (UNOCHA) acknowledged Taliban cooperation in issuing necessary flight clearances.

The UNOCHA spokesperson told The News "the operations have not been fully suspended in Afghanistan; some of the agencies would continue working there." Aasked to name the agencies that would continue work in Afghanistan, she said: "At the moment, I do not have any
more details about it."

The pullout came amid fears of possible US retaliatory strikes after Tuesday's terrorist attacks on it's important buildings. The rapid UN action resulted due to its past experience of the US surprise missile strikes on Afghanistan after the destruction of its two embassies in
Africa in 1998.

Reuters adds: UN sources in Islamabad said two special UN planes carrying staff and some aid workers arrived in Islamabad from Kabul 
The News International, Thursday, September 13, 2001

and Mazar-i-Sharif and two more were due later in the day.

Australian, US and German diplomats, who were trying to help eight foreign aid workers detained in Afghanistan on charges of preaching Christianity. are also being evacuated from Kabul after the US terror attacks, Australia said on Wednesday. Aid agency sources in Islamabad and Kahul said foreign aid workers in war-torn Aghanistan were leaving (II) apecial IIN fliphil in the iniddles of the day. Authorities in Afgharilstan were conperating in issuing necessary flight clearances for staff evacuation. "United Nations humanitarian agencies hope that activities can continue as normal so that critical pre-winter relief work can be completed," the UN statement said. Separately, a spokeswoman for the Australian Foreign Ministry said relatives of eight foreign aid workers from German-based Christian relief agency Shelter Now International were being flown out along with the diplomats trying to help them. Taliban authorities in Kabul on Wednesday beefed up security at government offices, thoroughly checking vehicles entering government compounds, witnesses said. The checks were being conducted hours after the attacks in the United States and an overnight rocket attack on Kabul airport by anti-Taliban forces based north of the Afghan
capital.

\section{Tajik airspace breached from Afghan side}

DUSHANBE: Unidentified aircraft entered Tajikistan's airspace from Afghanistan three times late or Tuesday and on Werincsday, : spokesman for liusstan guards ice sponsible for defending the bor. der wald.

On Tuesday at 170;, (1205 GMT) a propeller plane crossed the border at a height of $3000 \mathrm{me}$ tres and returned to Afghanistan after just five minutes in Tajik airspace, he told Reuters.

On Wednesday another plane. entered Tajik airspace from Afghanistan at 0235 (2135 GMT on Tuesday), followed by anothe similar incident an hour late There has been no comment yet from Tajik authorities. Former Soviet Tajikistan lies to the north of Afghanistan, bordering a region still under the control of the Northern Alliance, the main opposition to Taliban militia. Reuters

\section{Telephone system}

ISLAMABAD: The Taliban authorities in Afghanistan have restored telephone system of the Sar-e-Pul province and established a satellite station in the province. - NNI

\section{Foreign journalists seek Afghan visa}

\section{Special correspondent}

ISLAMABAD: A number of members of the international print and electronic media have sought Afghan visa to reach there as soon as possible, but the Af'ghan embassy In Islamabad is not in a hurry to oblige them.

The embassy has sent their visa requests to Kabul for official clearance that will take considerable time.

"Several mediamen have reached Islamabad sensing an early American attack on Afghanistan in the wake of stunning terrorist acts in New York and Washington.

The mediapersons met Afghan ambassador Mulla Abdul Salam Zaeef on Wednesday and requested early grant of Afghan visa. The ambassador told them that visa could not be immediately issued and his foreign ministry would take decisions on such applications that could take 15 to 20 days or even more.

\section{Masud's nerves system badly affected: Rabbani}

KABUL: The deposed Afghan president Professor Burhanuddin Rabbani has said that his military strongman, Commander Ahmed Shah Masud is being shifted to a
European country for treatment as the powerful bomb blast has badly affected his nerves system.

"We have decided to immediately send Masood abroad for treatment. There is no danger to his life. Masud's leges are critically injured and there are also burn signs on his face. The explosion has badly affected his nerves system." Rabbani told the BBC.

Asked has he himself talked to Commander Masud, Rabbani said he himself talked to him but doctor was stressing that he should not talk for long.

Asked is Masud being sent abroad for his critical condition, Rabbani said that he has sustained wounds but these are not serious to pose any threat. He said that they want to provide full treatment to him. "Here the doctors made all out efforts which have produced result with the grade of Allah almighty but we want him to be treated in a well equipped hospital abroad possibly Europe to ensure his good health form every angle." Rabbani said. -Sana

\section{Kabul not afraid of attack: envoy}

Tariq Butt

ISLAMABAD: Afghan ambassador in Islamabad Mulla Abdul Salam Zaeef said on Wednesday that Afghanistan does not rule out US attack on it.

He told newsmen that any use of force by the United States against Afghanistan would be highly unjustificd. "We aren't afraid of any such attack."

Zaeef reiterated the Afghan Taliban's stand to hand over Saudi dissident Osama bin Laden to America and said if the United States has any evidence against Osama, Washington should give it to Kabul and after that "we will decide whether or not to deliver him to the US".

The Taliban ambassador said that Osama has no facility of communication including telephone and Internet at his disposal. 


\title{
The Frontier Post
}

\author{
Thursday, September 13, 2001
}

His satellite phone is in the raliban's possession and his activities are in the Taliban's full control so he cannot talk to anybody, Zaeef said.

"Bin Laden is an innocent person," the ambassador said adding that the incidents of New York and Washington were very comprehensive and reflected remarkable skill and planning.

He said that these were impossible for an individual to execute and they seemed to be the job of professionals.

To a question about the withdrawal of the UN staff from Afghanistan, the ambassador said that it was because of their fear not ours that they were pulling out.

Zaeef said that neither Afghanistan nor Bin Laden has anything to do with the attacks on the 118 eltien or any olloer terroriat activity.

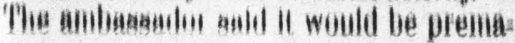

ture to blame anyone of the attacks on New York and Washington as the probe has not so far been completed. He said that the Taliban government has condemned the attacks and sympathize with the victims.

He said the comments on American TV channels involving Bin Laden were of no importance. Zaeef said that the attack on Kabul in the wee hours of Wednesday was sponsored by the Northern Alliance and the United States was not involved in them.

AFP adds from Kabul: Taliban spokesman Abdul Hai Mutmaen told AFP by telephone from southern Kandahar headquarters that any retaliatory attacks on Afghanistan and Osama bin Laden for the terror strikes in the United States would fail.

"If they want to target particular persons, they won't be able to find them,".he said. "If they want to target a military or economic installation, we don't have any of such installations here in Afghanistan which is worth the

price of one cruise missile. If they want to eliminate a whole nation, that's impossible and that will create further hatred for the US."

Mutmaen repeated the Taliban's position that bin Laden was not responsible for Tuesday's attacks, or any other terrorist strikes. "The US had not been able to provide evidences in the past and it won't be able to do that in future because Osama is not that strong to carry out such an operation," he said.

He said it would be a mistake for the US to target Afghanistan because its previous strikes were fruitless and there was no installation here that could be damaged by missiles.

"The result the US achieved from its strike was only the murder of 15 to 16 ordinary people but it used almost 70 cruise missiles, ${ }^{n}$ the spokesman said. He also dismissed security fears that led to the UN to evacuate international staff from Afghanistan on Wednesday. "That is up to the UN if it evacuates but there is full security in Kabul."

\section{Afghan unity}

-IGNS are ominous that Afghanistan could be the target of a US offensive, directly or indirectly, in retaliation for the terrorist hits, as its media and Congressmen, officials and experts are repeatedly pointing.accusing fingers at Osama $\mathrm{Bin}$ Laden. Whether they have found credible proof as to the 'finger prints' of Mr. Laden on these acts is still not clear, but what is clear is that Afghanistan could well be soon coming under a stringent US response to the terrorism perpetrated on its soil. Though the Taliban were quick to issue a denial of their involvement and also that of Mr Laden's, the US reaction to their categorical denial remains that of 'disbelief'.

Such is the fear of an impending aggression against Afghanistan that the rockets fired into its capital early Wednesday were immediately perceived as the beginning of a US operation. Naturally, this fear is firmly grounded in the previous misaile allacks latinghed against the hicleout of Osama-s Bih Ladeh in Afghanistah in 1998. Whether the suspleions beirig harboured against him would finally be translated into yet another attack on Afghanistan, only time will tell.' But this is a moment that calls for in-depth introspection by all those who are engaged in a totally useless fratricidal war in Afghanistan.

With their country facing the spectre of attack, they should display a high level of maturity and pragmatism and immediately halt their military activities against each other. In their true tradition, they should sit together to resolve all their points of conflict to forge internal peace and coherence in the wake of the external developments threatening their very existence. Leaving aside petty objectives, they should instead think about their people, who have already seen enough bloodletting and killing. Their people need a break from the ongoing orgy of violence to recoup their energies and rebuild their country and their lives. Caught as they are in the whirlpool of hardships and miseries caused by the civil war and UN curbs, drought and resultant famine, they need a breather. Left in the lurch by a. world that had been their biggest supporter in the war against the Soviet forces, they now need to pool all indigenous resources to start a new life. This is only possible if they could live in peace and pursue the task of national rehabilitation unhindered. It would thus be a catastrophe and a setback if they were subjected to unwarranted aggression at this junctute. But as in the case of Iraq, where destruction and Hunger have been brought upon millions of civilians because of the policies of their rulers, much would depend on the leaders of Afghanistan to protect them from a similar horrendous situation.

The warring groups in Afghanistan, particularly the Taliban and the Northern Alliance, thus have a monumental opportunity in hand to get united and work out a collective strategy to counter the threat emanating from the. US. This is a moment that could make or break their country. They should realise that Afghanistan may be standing at the edge of a precipice. One wrong step could bring even greater sorrolv and suffering.

Notwithstanding the latest attack on Ahmad Shah Masood that has added a dangerous twist to events in the country, the two main rivals should try to negotiate internal peace. For this, it is important for them to get out of the influence of outside actors. Instead of banking on external support, they should develop a nuanced approach to deal with their internal and external crises. Only through a broad based government could they face the fresh challenge. They should think along these
lines before it is too late. 


\section{The Frontier Post}

Thursday, September 13, 2001

\section{Kabul rocked by missiles attack} Taliban militia seals borders; United Nations moves staff out of Afghanistan

\section{Fákhar-ur- Rehman}

ISLAMABAD: As reports continued to pour in about possible US attack on Afghanistan following shocking acts of terrorism in New York, Washington and Pentagon suspected to have been master minded by Osama Bin Ladin, the Afghan capital was rocked in wee hours of Wednesday morning by missile attack from the anti Taliban forces.

Sources from Afghanistan told The Frontier Post that a gun ship helicopter of Northern Alliance fired missiles on military installations in Afghan capital and Kabul Airport. One civilian plane and a small aircraft were destroyed during the attack as huge $f^{\prime}$. umes of fire were seen with bangs of blasts with no reports of casualty. Attack was apparently thought to have been carried out by the United States but was immediately denied by White House spokesman . Reportedly, business community have started moving out of Afghanistan to neighboring Pakistan and Iran

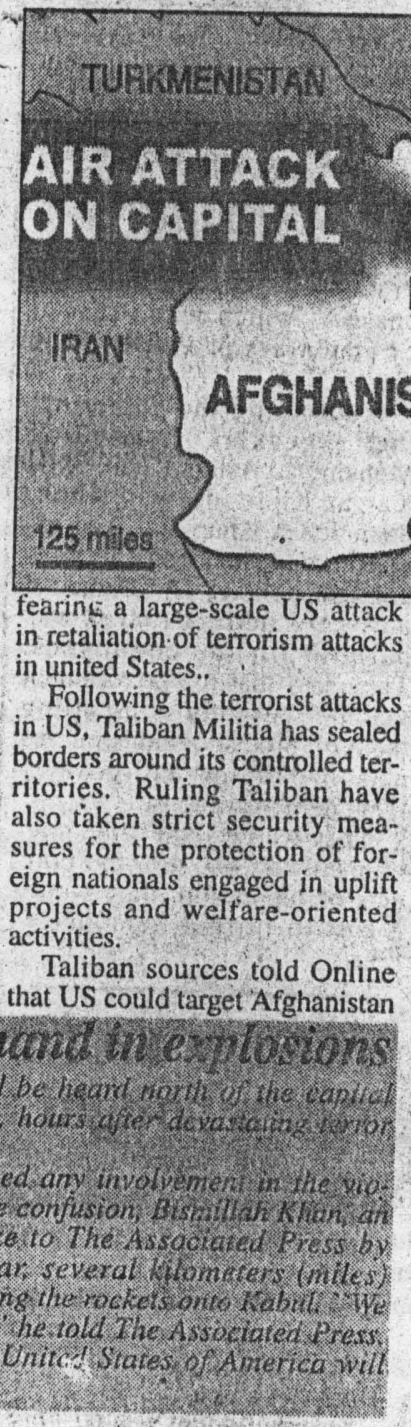

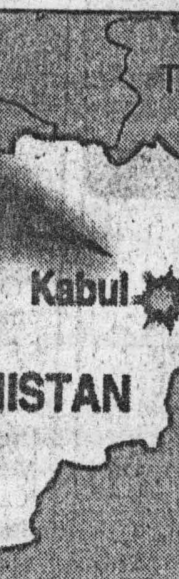

after terrorist attacks. "We are all set to face any attack while. we have sealed borders adjoining the areas under out control to keep an eye on movement of the suspected persons and defend the country against aggression", sources added.

Meanwhile, the United Nations has begun to evacuate their staff from Afghanistan. A UN spokeswoman said Wednesday it is a temporary move "due to circumstalices prevailing internationally".

She declined to say whether the move is because of speculation about US reprisals on the country, which hosts Osama bin Laden, the Saudi dissident. The relocation is expected to be completed by Thursday

Up to 80 international UN employees are in six Afghan cities-Kabul, Jalalabad, Mazar Sharif, Kandahar, Herat and Faizabad. 


\section{The Frontier Post}

\section{-Taliban seek evidence against Osama}

\author{
F.P. Report
}

ISLAMABAD : With Americans pooling up their resources for a large-scale attack on the hide outs of Saud dissident Osama Bin Laden inside Afghanistan in response to what it has described Tuesday's devastating terrorism incident as an act of war. the Taliban authorities said it was premature to discuss extradition of Bin Laden before any conclusive evidence against him.

The Taliban envoy to Pakistan Maulvi Abdus Saalm Zaeef tore the Journalists on Wednesday, handing over of Osama Bin Laden (to United States) is a second phase, first phase is the presentation of evidence against him which we will study first.

FBI is reported have said that it has evidence against followers of Osama Bin LAden who are believed to hav carried out terrorist attack against Americans on Tuesday.

He said Osama Bin Laden could not operate in such a manner as he had been deprived all facilities of communications.

Telephone, internet and satellite phone facilities have been taken away from him, there is no evidence against him and he has not been accused officially he remarked in reply to a question.

He sai there would be no justification by the United States for carrying out any attack against Afghanistan. People do not fear any attack, there is no reason for attack", he stressed.

\section{No radical change in Afghanistan} UNITED NATIONS (Agencies): Even if reports about Ahmad Shah Masood's death in Afghanistan are confirmed, no substantive changes will take place in that country overnight, Tajikistan's permanent representative to the United Nations Rashid Alimov

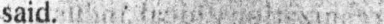

"World experience shows that no act of terror can exert a substantive impact on changes in the situation in one or another country," said he,

According to Alimov, "the death of the leader of the Northern Alliance will by no means affect the alliance of military-political forces" in Afghanistan because "it is impossible to resolve the Afghan crisis by force, even the use of acts of terror:

Undoubtedly, Ahmad Shah Masood "is a very serious, very symbolic figure" for all the Afghan forces that resist the Taliban rule, the ambassador said. But even in the event of the demise of the Northern Alliance leader, "some confusion in the ranks of his supporters" can be expected to occur only in phase one ${ }^{1 .}$

"In a longer-term perspective, the event will in no way affect the attainment of the objectives that the Taliban forces have set for themselves, said he.

\section{UN staff in \\ Afghanistan being relocated}

ISLAMABAD (SANA)-Due to circumstances prevailing internationally, the United Nations system in Afghanistan is temporarily relocating international United Nations staff working in Afghanistan. United Nations international staff are currently present in Kabul, Jalalabad, Mazar, Kandahar, Herat, and Faizabad.

Authorities in Afghanistan have co-operated in issuing the necessary flight clearances, said a press release issued by Office of the United Nations Coordinator for Afghanistan here on Wednesday.

The relocation of up to 80 international staff began on 12 September and is expected to be completed on 13 September. United Nations humanitarian agencies hope that activities can continue as normal so that critical pre-winter relief work can be completed.

\section{EU official postpones visit to Pakistan, Afghanistain}

\section{By Our Staff Reporter}

- ISLAMABAD-Poul Nielson, the European Union's development and humanitarian aid commissioner, Wednesday postponed his scheduled visit to Pakistan and Afghanistan due to "uncertainty linked to the security situation," an EU statement said.

Nielson was scheduled to visit Afghanistan and Afghan refugee camps in Pakistan during his stay in two countries. He was also scheduled to meet senior officials of Pakistan, Afghanistan and opposition Northern Alliance.

"I am shocked and outraged by these attacks," Nielson said in a statement, "I am very disappointed that I couldn't get first-hand experience in the important work of our non-governmental organizations in helping the Afghan people cope with the effects of war and drought." 


\section{Top intelligence services link attacks to Osama}

BERLIN (AFP) - German, British, French and Israeli intelligence services have identified strong links between the US terrorist attacks and Saudi-born extremist Osama bin Laden, German Chancellor Gerhard Schroeder's chiefof-staff said Wednesday.

The intelligence services determined that 'the type of motivation, the choice of targets, the military approach, the apparent motive, the professional preparation, the extent of the financial resources involved and the repeat attacks indicate that the culprits can be found in the entourage of Osama bin Laden,' said the head of the chancellor's office, Frank-Walter Steinmeier.

Steinmeier told a news conference that "none of the secret services were completely sure' that Osama's supporters were behind Tuesday's terrorist strikes.

'During our last exchange of information with US intelligence services before (the Group of Eight summit in) Genoa, there were no indications of this type of attack threatening the United States,'

\section{Steinmeier said.}

He said, however, that 'even in the case of a threat', attacks had been considered more likely against a US battleship in the Persian Gulf, for example, and not on civilian targets on American soil.

Osama communications intercepted: US intelligence intercepted communications between people associated with Osama bin Laden, who were heard discussing terrorist attacks on major buildings in the United States, a US senator said. 'I do have some information,' Republican Senator Orrin Hatch said Tuesday in reference to an FBI briefing.

'They've come to the conclusion that this looks like it may be the signature of Osama bin Laden, that he may be the one behind this.'

'They have an intercept of some information that included people associated with Osama who acknowledged a couple of targets were hit,' he added.

In the message intercepted by US intelligence-gathering satellites, individuals close to Osama were discussing the attacks on the
World Trade Center and the Pentagon, according to Hatch, who gave no further details.

Earlier, a US official, speaking on condition of anonymity, gave : similar assessment of the situation.

'Preliminary indications suggest that individuals associated with Osama or his al-Qaeda network may be involved in these attacks,' the official said.

Osama not behind attacks: The Arab League's ambassador in Russia said in Moscow on Wednesday that Osama bin Laden could not be held responsible for Tuesday's deadly attacks in the United States. The blasts are 'way beyond the means' of the Saudi Islamist multi-millionaire, said al Barami, as quoted by the Interfax news agency. Those involved in Tuesday's attacks 'must bear full responsibility for what happened in the United States,' al Barami said.

He added that the attacks are not part of a war between Christian and Muslim civilizations.

Such a conclusion would be 'unfounded, subjective and dangerous,' he said.

\section{Gilani slates attacks on US}

\section{From Our Correspondent}

PESHAWAR - Moderate Afghan leader and chief of the $\mathrm{Na}$ tional Islamic Front of Afghanistan Pir Syed Ahmad Gillani has expressed grief and sorrow over the tragic loss of lives and property as a result of terrorist attacks in United States and termed it an inhuman and immoral act.

Through a message addressed to United States President George W Bush on Wednesday. Pir Syed Ahmad (iillani states:" ()n behalf of the heroic people of Aluhanistan, the National Islant C Front of
Afghanistan and on my own behalf, I would like to express our profound grief and sorrow over the tragic loss of lives of innocent people as a result of barbaric terrorist acts both in New York and Washington."

He' further said "We would like to assure you and the people of United States of Americal that we are with you at this moment of extreme grief and offer our assistance in combating these cowardly lemorist acts and those behind it. and shall consider it as our war (oo." 


\section{$K_{\text {HYBER }} M_{\text {AIL }}$}

September 13, 2001

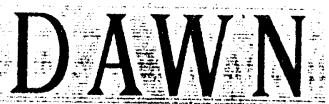

Thursday, September 13, 2001

\section{Taliban militia seals borders}

ISLAMABAD (Online): Following the terrorist attacks in US, Taliban Militia has sealed borders around its controlled territories.

Ruling Taliban have also taken strict security measures for the protection of foreign nationals engaged in uplift projects and welfareoriented activities

Taliban sources told Online that US could target Afghanistan after terrorist attacks "We are all set to fáce any attack while we have sealed borders adjoining the areas under out control to kecp an eye on movement of the suspected persons and defend the country against aggression", sources added.

\section{Russia, India, Iran to discuss}

\section{Afghanistan}

DUSHANBE, Sept 12: Officials from Russia, India, Iran and other states hostile to Afghanistan's ruling Taliban will meet in 'Tajikistan's capital Dushanbe this week to discuss a conflict now catapulted into world headlines.

Worldwide suspicion for 'Tuesday's deadly attacks on New York and Washington has focused on exiled Saudi-born militant Osama bin Laden, an arch-foe of the United States who is sheltered by the
Taliban.

A diplomatic source in Dushanbe said the meetings would be attended by a representative of the antiTaliban northern alliance, as well as Russia, India, Iran and ex-Soviet republics Tajikistan and Uzbekistan It could begin on Thursday, he said.

The meeting was planned before the attacks on the United States, and the source said the main issue would be the fate of the anti-Taliban alliance after a weekend attempt to assassinate its legendary military leader Ahmad Shah Masood.

Northern alliance figures have denied reports that Masood was killed in the attack by suicide bombers posing as reporters.

The northern alliance includes the ousted government recognised by most of the international community although it controls only a tiny portion of Afghan territory.

The alliance, openly backed by Russia, could play a key role if the United States launches an all-out fight against the Taliban. But the alliance has so far relied strongly on the leadership of Masood during years of opposing the Taliban.

Northern alliance officials have promised to show reporters videotape proving Masood survived Sunday's at tack, in which a video camera packed with explosives detonated while he gave an interview.

Moscow fought in Afghanistan for a decade during the 1980s and has taken responsibility for defending exSoviet Central Asian states from what it says are Taliban efforts to export Islamic radicalism.

India and mainly Shi'ite Muslim Iran share Russia's fear of the extreme form of Sunni Islam espoused by the Taliban.

Pakistan is the only. country bor. dering on Afghanistan that recognises the Taliban as the country's legiti.

\section{mate rulers.}

DUSHANBE BEEFS UP BORDER: Moscow and Dushanbe stepped up security measures on the TajikAfghan border Wednesday after the deadly terrorist attacks in the United States and an assassination attempt on Afghan opposition commander Ahmad Shah Masood, officials said.

Security officials in Dushanbe said they feared neighbouring Afghanistan, mostly under the control of the radical Islamic Taliban militia, might use these events to try and destabilize Tajikistan, which it considers a shelter for Afghan opposition forces.

"If the Taliban tries to take advantage of the situation, we will see a sharp increase in illegal border crossings and we are presently getting ready for this," said a Russian border guard spokesman, Pyotr Gordyenko.

Russian soldiers patroi the 1,200 kilometre border under an agreement between Russia and Tajikistan, a former Soviet republic.

Gordyenko said border guards increased identity checks and placed their troops on higher alert.

Afghanistan, mostly under control of the Taliban militia, gives shelter to the Saudi multi-millionaire Osama bin Laden, who is suspected of having masterminded Tuesday's suicide aeroplane attacks on the World Trade Center in New York and the Pentagon outside Washington

Bin I aden has denied his involvement in the attacks, which could provoke US retaliatory strikes.

"Several people have recently 
atlempted to enter lajikistan illegalIy with laaliban passports and we have uncovered a large weapons cache near the (Tajik-Af han) border," Gordyenko said.

Tajikistan also put its airforce on alert, said the head of the country's anti-aircraft defence, Akbar Kayumov.

He said several Afghan helicopters had recently violatted 'Tajikistan's airspace.

Tajik authorities are particularly preoccupied since they estimate thousands of unregistered weapons are loose in the country, officials said.

Sunday, anti-l'aliban opposition leader Masood was victim of an assas sination allempt.

American and Russian sources said he had been killed, while Afghan

opposition fiercely denies the claims.

lajikistan has suffered from the rise of radical Islamists.

From 1992 to 1997 , the country was torn by a bloody civil war between the Islamic opposition and the former communist government.

After a peace agreement in June 1997 , part of the Islamic armed opposition joined a coalition government.

IIowever, violent Islamism has not disappeared and is now represented by the Hizbi Takhrir movement.

In recent years, Tajikistan has also been rocked by a series of terrorist attacks targeting politicians and govermment officials.

The latest of these attacks killed Culture Minister Abdulrakhim Rakhimov.-Reuters/AFP

\section{Masud in extremely critical condition: Qanooni}

KABUL: Anti-Taliban military commander Ahmad Shah Masud's health is "very critical" and getting worse following an assassination attempt this week, a senior opposition official told AFP Thursday.

"Unfortunately we have some negative news. The state of $\mathrm{Ma}$ sood's health has become very critical, ${ }^{n}$ close Masud aide Younis Qanooni said amid conflicting reports over the veteran guerrilla fighter's condition.

"He was supposed to become conscious 12 to 20 hours ago but since last night he is still in a coma and his health status is becoming worse and worse.

"He has become conscious only once since he was injured and that was when Rabbani visited him. The doctors have said it is impossible to move him."

Qanooni served as deputy defence minister during former president Burhanuddin Rabbani's government before its ouster from Kabul by the Taliban militia in 1996.

He said Masud was still in hospital in Khwaja Bahauddin, his base in Afghanistan's northeastern Takhar province where the suicide bombing assassination attempt took place on Sunday.

But Qanooni's statement contradicted an earlier claim by the opposition commander's brother Ahmad Wali that he had emerged from the coma and was steadily recovering.

"It has been delightfully noted that Ahmad Shah Masud, who was in a state of virtual coma after the suicide attack... has regained his body movements and is able to communicate slowly," Wali said in a signed statement from London.

Earlier several opposition officials denied persistent reports that the attack on Masud was fatal.

Wali, who is charge d'affaires of the government-in-exile's mission in London, condemned the "terrorists' cowardly tactics".

"Such inhumane and desperate attempts would not the least help the terrorists in realizing their devil goal of crushing the spirit of resis. tance nurtured by the Afghans against the shameless foreign aggression on their country." Masud loyalists entrenched in the northeastern mountains are locked in fighting with the Taliban militia ruling most of Afghanistan. - AFT

\section{More western aid workers quit Kabul Bureau Report}

PESHAWAR: Another tens of western aid workers made out of Afghanistan Thursday, reaching Peshawar to avoid any untoward incident in wake of possible US attack on the war-ravaged country, sources said here.

Authorities at the PakistanAfghanistan border said about two-dozen westerners crossed over into Pakistan. "They were of different nationalities and organizations," said a border guard at Torkhum, requesting not to be named.

Several other were flown out of Kabul by ICRC, which resumed its. aerial operations on Thursday. ICRC had suspended all its flights on Wednesday due to closure of Khawaja Rawash Airport in Afghan capital.

Foreign aid organizations have pulled out their workers from inside Afghanistan after the air attacks in USA. It is believed that the pulyot is in wake of anyiref taliátiont from Afghans if Imerico goes for any action against the Saudi billionaire Osama Ben Ladin, in case he found involved in the WTC and Pentagon attacks

Sources in western NGOs in Peshawar said the expatriates who reached Peshawar included people from Australia, Germany, Deutschland, France, and British etc. No American national reached Peshawar on Thursday.

About 50 western aid workers are believed to be present in at least six towns of Afghanistan, where NGO's from more than a dozen western countries are undertaking relief operations. 


\section{Six-plus-Two technical meeting begins \\ 'Drug trafficking from Afghanistan reduced'}

\section{Naveed Ahmad}

ISLAMABAI): The Six-plus-Two technical meeting began here Thursday with i)('us on ways "to coordinate cfforts to curb drug trafficking originating from Afghanistan"

The heads of drug law enforcement agenries from China, Iran, Tajikistan, Irluekistan, Turkmenistan, Pakistan, the United States and Russia along with United Nation I)rug Control Programme (UNI)(P) are participating in the two-lay conference.

Talking to The News, UNDCP Representative for Country Offices for Afghanistan \& Paikistan Bernard Frahi said, "This is not a political meeting it is a tech ical

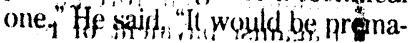

ture to say something about the likely course adopted to curb drug trafficking from Afghanistan."

He acknowledged the fact that there was less drug trafficking from Afghanistan after a total ban on poppy cultivation.

Frahi, however, said the recent six-plus-two technical meeting address the issue of total eradication of drug trafficking from the region.

The meeting is meant to provide a discussion forum of officials with policy responsibilities for measures to explore concrete steps for regional cooperation to enhance the effective interdiction of narcotics being trafficked from Afghanistan and to prevent the smuggling and diversion of precursor chemicals that are needediparticularly for the production of

\section{Security beefed up along Pak-Afghan border.}

\footnotetext{
-. Our correspondent

JAMRUD: Following Tuesday's terrorist attacks in the United States, the government of Pakistan has beefed up security arrangements along the Pak-Afghan border.

Political administration sources said militia forces have been deployed at unfrequented routes to stop illegal entry of Afghans into Pakistan. As a result of this vigil, the militia forces have arrested 35 Afghan refugees including six women ai the Ali
}

heroin.

During Thursday's session, common problems and ways to address them through mutual supportive regional actions including setting up structure for information sharing and strengthening law enforcement cooperation were subject of a detailed brainstorming.

With the joint efforts of UNDCP, other donors, the Pakistan's government has addressed the extremely complex problems of drug production and trafficking with great success.

To quote one of the ways UNDCP is trying to help countries check the drug trafticking, four years long project 'Support to drug law enforcement programmes in the Southwest, Sotutrand Centra Asialilastin ftitt Becember 2001.

\section{Afghan pilot says he trained 14 activists to fly}

DUBAl: A former pilot with Afghanistan's national carrier was on Thursday quoted as saying that he had helped train 14 Islamic militants, some holding European passports, to fly civilian aircraft.

The London-based Asharq alAwsat newspaper quoted the pilot as saying from an undisclosed location in Afghanistan that the trainees had left the war-torn country nearly one year ago to undisclosed locations after they completed their training. The newspaper did not say if the trainees were among the hijackers who slammed commercial aircraft into the Pentagon in Washington and the World 'Trade Center in New York on Tuesday.

"A group of 14 radical Islamist men received special training on flying civilian aircraft, including Boeings, of which Afghanistan's Ariana airlines owns three," the Arabic-language newspaper said. - Reuters 
The Statesman

Friday, September 14, 2001

\section{PTV, radio \\ teams asked to reach Kabul}

\section{Statesman Report}

PESHAWAR: The central government has directed authorities of Pakistan Television (PTV) and Radio Pakistan to immediately send teams to Afitianistan for expected majer developments in the war-torn country.

"For the purpose, we have applied for visas and we may leave today (Friday)," said a PTV Peshawar station official.

Confirming the news, an official of Radio Pakistan here said: "We might be sent to Afghanistan so as to cover the possible American attacks."

Most of the political and diplomatic circles here expect military attacks from the US on Afghanistan, which might give birth to political, social and economic changes in this volatile region of the world.

Foreign media persons have already reached Peshawar, who are currently busy preparing stories and videos on Madaris and religious parties.

The NGO's, working in Afghanistan, have also pulled out their staff owing to fears of possible American attacks.

Employees of Medicines San Frontiers also reached Peshawar Tuesday, whereas UNHCR workers are awaiting directions from the international body. However, they are presently busy screening Afghan refugees.

The Pakistan Air Force has been put on high alert and official visits of all high officials of the force have been cancelled.

The overall situation in th? region is intensely strained and rumours are sailing about the future happenings.

\section{The Frontier Post}

\section{Friday, September 14, 2001}

\section{Osama not under house arrest}

ISLAMABAD: Taliban on Thursday denied a report that Saudi fugitive Osama bin Laden had been placed under house arrest, the Afgharı Islamic Press news service said. "This morning Taliban sources in Kabul told AIP these news stories that Osama or any of his associates have been arrested are false." - Reuters

\section{Masood's health precarious, says Qanooni}

KABUL (Agencies): AntiTaliban military commander Ahmad Shah Masood's health is "very critical" and getting worse following an assassination attempt this week, a senio opposition official said on Thursday.

"Unfortunately we' have some negative news. The state of Masood's health has become very critical," close Masood aide Younis Qanooni said:

"He was supposed to become conscious 12 to 20 hours ago but since last night he is still in a coma and his health status is becoming worse and worse."

Meanwhile, Gulbuddin Hekmatyar says the reports that Afghan opposition chief Ahmad Shah Masood is still alive following a suicide bomb attack are false.

"Masood is indeed dead but his associates and comrades are giving false accounts of his physical state in order to keep. up the spirits of the Northern Alliance fighters," Hekmatyar told the English-language daily. Iran News.

But he gave no firm evidence apart from saying it was impossible for Masood to have survived Sunday's blast, believed to have been caused by a booby-trapped camera carried by two Arab suicide bombers posing as journalists at his base in northeastern Afghanistan.

\section{PPP asks mly to distance itself from Taliban \\ F.P. Report}

ISLAMABAD; pakistan People's Party has advised gov. ernment to distance itself from the Taliban regime as the focus for the terror attacks on America has turned to Afghanistan and the Saudi fugitive Osama bin Laden. $y^{2}$ e

A party spokesperson kaic here that the bomb attack on Afghan leader Ahmad Shah Masood two days before the terror attacks on America was "more than a coincidence"

"Those who perpetuated the attack knew that retaliation would come. Ahmad. Shah Masood was the rallying point for an international response. The deadly suicidal attack on him could be more than a coincidence", he added.

PPP said that with the inter national focus on Islamabad it was important for the military to bury partisan political divalies and immediately withdraw the politically motivated cases and create a government of national consensus".

Spokesperson further maintained that if internationat retaliation focused on Afghanistan, "Pakistan could be a pivotal player", However, he pointed out that "militant outfits swithin the country could react unless the military regime broadened the political base".

Islamabad and the Taliban both have condemned the attacks on America. However their condemnations could be put to test as NATO invokes article $S$ and the world community gets ready for a response to the terror attacks on America. 


\section{The Frontier Post Friday, September: 14, 2001}

\section{Western diplomats \\ leave \\ Afghan capital}

Hamid Nawaz

PESHAWAR: Western diplomats assisting eight foreign aid workers detained for preaching Christianity left Afghan capital on Thursday after appointing an Islamic scholar as defence counsel reports said.

According to report the Afghan Supreme Court had indicated that the counsel should be allowed "regular access" to the detainees.

Osama bin Laden is a key suspect in Tuesday's 'attacks on the World Trade Center in New York and the Pentagon in Washington and the prospect of U.S. retaliation has raised tensions in Kabul.
Washington denied involvement :'hen Kabul's airport was rocked by blasts on Tuesday. An Afghan opposition group said it was responsible.

The Taliban detained 24 workers of the Christian relief agency to Shelter. Now International four Germans, two Americans two Australjans and 16 Afghanis -five weeks ago, accusing them of trying to convert Muslims to Christianity.

Sources informed that the diplomats from Australia, the Uniter States and Germany, who had been in Kabul to help the detained foreigners, would evacuate to Pakistan in a United Nations aircraft.

Sources further revealed that diplomats will be able to return to Afghanistan," but no date was set. It is worth mentioning here that Pakistanbased diplomats last visited the detained workers on September 11. The trial of the eight foreign aid workers will be held before a council of qualified Islamic scholars. The Afghanis will be tried separately.

The foreign detainees, who at a court appearance appeared healthy, have been identified as Germans Georg Taubmann, Katrin Jelinek, Margrit Stebner and Silke Durrkopf, Australians Peter Bunch and Diana Thomas, and Americans Dayna Curry and Heather Mercer.

\section{NZ-Afghans keeping low profile}

SYDNEY (Agencies): Members of Auckland's Afghan community, wary of a backlash, are aiming to keep a low profile following the bad press embroiling their country:

The international saga of the Afghan refugecs, suspicion that a terrorist harboured by their country was involved in the attack on the World Trade Center, and an attack on Kabul airport by the anti-Taleban opposition - initially seen as American retáliation - have made them watchful.

The Federation of Islamic Associations has sent a message advising members to keep a low profile and avoid trouble, especially if their traditional beards and turbans made them targets for anti-Muslim sentiment, says communications officer Abdullah Drury.

Good advice, especially if you are a taxi driver, as are two members of the Tajek family of Mt Roskill/ Hamayun and Khalil.

But the Afghans, all of who came to New Zealand as refugees, have found their adopted home a tolerant society, says Nader Tajek, a university physics student.

"It there was anything [that happened]," says Siraj Salarzi, "we could only put it down to a lack of understanding. We condemn every act of this sort of evil." Dawood Tajek said the
Afghan people had no say in Osama bin Laden's sanctuary there.

"He kills Afghun people," he said, tears starting to shine at the corners of his eyes.

But they were concerned that New Zealanders might react negatively -so Mr Salarzi offered a snapshot of the Afghan personality.

"They're frank, and they do not hide their feelings. They would express their feelings. They're tolerant, and that would be the same in Afghanistan.

"They wouldn't stab someone in the back. They would," he added with a winning grin, "do it right in front of them.

\section{Taliban deny Osama under arrest}

\section{F P Report}

PESHAWAR: Afghanistan 's ruling Taliban on Thursday denied a report that Osama bin Laden had been placed under house arrest, Taliban sources said..

Taliban sources in Kabul said that these news stories that Osama or any of his assoclates have been arrested are false and fabricated.

An Arabic online newspaper Ilaf, quoting "A Arab sources," said the " Taliban have arrested Osama bin Laden before placing him under surveillance with sevcral of his assistants," including the head of the Egyptian.

The ruling Taliban have always refused demands that he be turned over to U.S. authorities to face trial for previous alleged attacks on the United States.

"The Taliban are of the opinion that Osama or his group are not involved in this enormous act (attacking the United"States) as there are complete restrictions on communications and such acts cannot be done without communications," report said. 


\section{The Frontier Post Fridays September 14, 2001,}

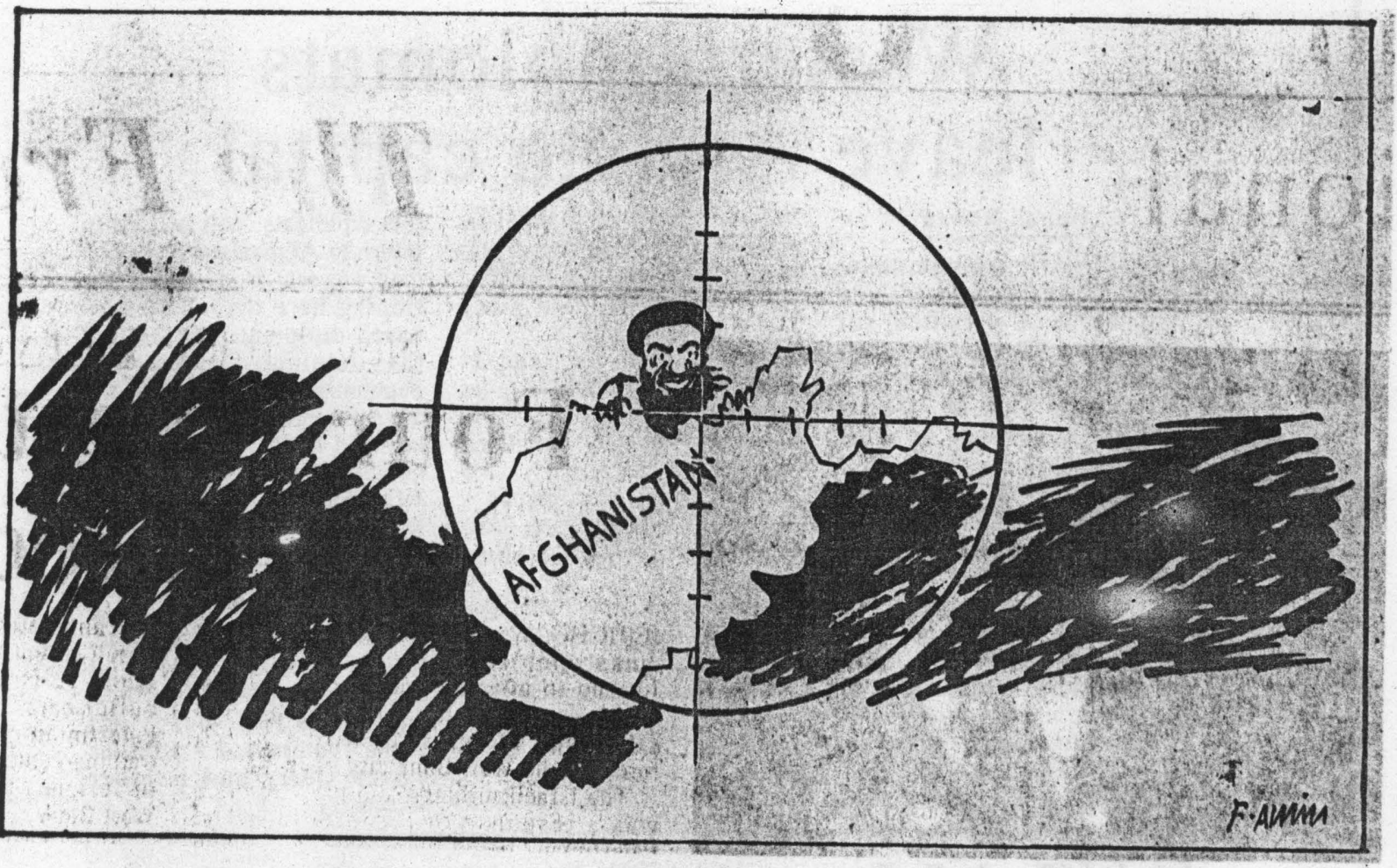

Food supply to Afghanistan expedited

\section{F.P. Report}

PESHAWAR: In wake of possible autacks on Afghamistan by the US, food supply to that country has been expedited, while most of the local traders expressed concern over low transaction of trade.

The Frontier Post learnt on Thursday that several conveys of trucks carrying food items including sugar, wheat, flour and other necessary items entered into Afghanistan to come up with the food requirements during possible attacks over Afghanistan. It was also obserizd that government of Pakistan showed some relaxation while clearing their traveling documents for their entry into Afghanistan.

A Peshawar-based spokes- person of the World Food Programme told The Frontier Post that a special canvey of tfucks, earfying food items was sent to Afghanistan on Thursday.

The spokesperson added that they had not received any directixes from Islamabad to suspend their supply operations to Afghanistan. While the drivers and cleaners of these trucks said that due to possible attack on Afghanistan they were feeling fear, while entering into that country.

One of them said that if his economic conditions were not so bad he would never think of going to Afghanistan such a tense and critical situation. Another one said that in case of attack what would be the fate of them and all those
Afghans living inside Afghanistan.

It merits to mention here that Afghanistan is highly depended on Pakistan and other donor agencies for food items including wheat, sugar, maiz etc. Whenever food supply to Afghanistan was disconnected it created alarming results inside Afghanistan.

Meanwhile traders at Peshawar, were contacted regarding economic situation in perspective of Tuesday terrorists attacks in Washington and New York, they said that most of the Peshawaritis feeling fear that there was a possibility that: Peshawar may also come in the range of possible missile attacks due to which they had stopped all recreation and other activities. 
The Nation

FRIDAY, SEPTEMBER 14, 2001

\section{Action against Osama}

TIIE callous terrorist act in the USA was bound to be condemned by the world at large. Messages of condolence and sympathy have been sent to the US administration by states with different political orientations. Even countries strongly opposed to certain US policies, like China, Iran, Libya and Syria have expressed horror. President Arafat has called the attacks a crime against humanity. The Security Council has called on all states to help bring the perpetrators to justice.

Onc van appreciate the anger and frustration of the US administration. The terrorists targeted the symbols of its military might and linancial clout. The terrorists outmanoeuvred the CIA and FBI and struck with precision where Washington had least expected and in a way it was ill prepared to deal with. The great loss of human life and property combined with the humiliation of being challenged inside its own fortress, and that too by a small band of terrorists, might force Washington to over-react. The Tuesday attacks have been characterized by President Bush as an act of war, the armed forces put on the highest state of peacetime alert. The administration is frantically trying to determine the identity of the terrorists. The action being meditated is supposed to be massive and indiscriminate and could cause casualties and destruction of great magnitude. It is therefore extremely important to ensure beyond shadow of doubt the true identity of the perpetrators. If the US action is seen to be targeting people as innocent as the American victims, it might lose the US the widespread sympathy. A responsible state must not act like a band of terrorists. NATO has expressed full solidarity with the US and has gone to the extreme of invoking Article 5 of its Treaty which states that an armed attack on one or more of the Allies shall be considered an attack on all.

After a meeting at Joint Staff Headquarters on Wednesday, General Musharraf again stressed the need for concerted international effort to light terrorism. Secretary of State Colin Powell wants Pakistan's fullest cooperation and support to tackle the terrorism issue and help secure the extradition of Osama bin Laden. Pakistani diplomats have shuttled between Islamabad, Kabul and Kandhar during the last two days to help resolve the issue. Osama may or may not have been involved in the recent attack, but the way the US media and security officials had been pointing the finger at him before any enquiry had yielded evidence has created suspicions which need to be allayed before the initiation of action by the US against him. The US should also take stock of the public reaction in the Muslim world, which is much more ambivalent than the straightforward condemnation by governments. It is clear the US must either review the policies provoking such animus, or work out how it is bemg misunderstood. IS policymakers may nol feel that Pakistani public opinion matlers more than American. but if it hopes to obtain full Pakistani cooperation, and if it contemplates acting in this area. it would be better if it could muster more support for any action than it presently hass. 
Friday, September 14, 2001

International Herald Tribune

\section{A Plea by Afghanistan: Don't Add to Misery}

Barry Bearak New York Times Service

KABUL Ifthere are Americans clamoring to bomb Afghanistan back to the Stone Age, they ought to know that this nation does not have far to go.

This is a post-apocalyptic place of felled cities, parched land and downtrodden people.

The fragility of this country was part of the message the Taleban government conveyed in a plea for restraint issued late Wednesday night.

It said, "We appeal to the United States not to put Afghanistan into more misery, because our people have suffered so much."

Whatever Afghanistan's current cataclysm, its next one seems to require little time to overtake it. Wars fought by sundry protagonists have gone on now for 22 consecutive years, a remorseless drought for four.

Since 1996, most of the country has been ruled by Taleban mullahs whose vision of the world's purest Islamic state has at least as much to do with controlling social behavior as vouchsafing social welfare.

Osama bin Laden has found a home here, angering much of the world. In 1998, America fired a volley of more than 70 cruise missiles at what it alleged were guerrilla training camps operated by Mr. bin Laden. Now, there seems to be the prospect of another U.S. attack, with Afghan hospitality to the same man as the cause.

As fear of a U.S. attack mounted, the Taleban's senior spokesman in Kandahar, Abdul Hai Mutmain, called the few foreign reporters here to issue the plea for restraint.

"These days, Osama bin Laden's name has become very popular, and to an extent it has become a symbol," he said. "These days, even to the common,people, Osama bin Laden's name is associated with all controversial acts. Osama bin Laden does not have such capabilities. We still hope that sanity prevails in the United States. We are confident that if a fair investigation is carried out by American authorities, the Taleban will not be found guilty of involvement in such covardly acts."

The plea continued, "There is no factory in Afghanistan that is worth the price of a 
single missile fired at us. It will simply increase the mistrust between the people in the region and the United States."

Whatever else there is to say about this entreaty, one part that is indisputably true is that this land-locked, ruggedly beautiful nation is in absolute misery.

Here in Kabul, the capital, roaming groups of widows beg in the streets, their palms seemingly frozen in a supplicant pose. Withered men pull overloaded carts, their labor less costly than the price of a donkey.

Children play in vast ruins, their limbs sometimes wrenched away by left-over land mines. Life expectancy, according to the statistics office, has fallen to the age of 42 for men and 40 for women.

The prolonged drought has sent nearly 1 million Afghans - about 5 percent of the population - on a desperate flight from hunger. Some have gone to Afghan cities, others across the border. More than 1 million are "at risk of starvation," according to the United Nations.

Famine is the catastrophe Afghans are used to hearing about. Few yet know of the threat of a U.S. reprisal. The Taleban long ago banned television, and the lack of electricity keeps most people from listening to radio.

But however much the Taleban hierarchy was beginning to fret, streets and bazaars were a picture of normality. Word has spread slowly about the terrorist attacks in - New York and Washington. And even when Afghans heard the news, there were no . accompanying video images to sear the horror into their memories. Personal conversations carried only the dull stimuli of abstract words: hijacked planes and collapsed buildings.

Khair Khana, selling fertilizer in a market, knew just a bit about the attack. He thought a plane had crashed into the White House.

And he considered the perpetrators, whoever they were, to be "enemies of God," though he also felt "Americans should look into their hearts and minds about why someone would kill themselves and others" in such a way.

He had not thought much about U.S. retaliation against Afghanistan. When he did consider it, standing in a ramshackle collection of stalls, he shrugged and said, "Americans are powerful and can do anything they like without us stopping them."

Nearby, a tailor, Abdul Malik, saw God's justice in America's pain because, as he understood it, the United States had armed the Afghan resistance to fight against the Taleban. "So they at least now know how it feels in their own country," he said.

As for Mr. bin Laden, the tailor considered judging him to be God's affair. "If Osama is Islam's enemy, he should be got rid of," he said. "But if he is a good 
Muslim and wants Islam to prosper - and if America wants him dead - then we hope he destroys America."

TIMES

Thursday, Sep. 13, 2001

How to Beat Bin Laden

How Osama Bin Laden operates - and what it will take to defeat him

BY TONY KARON

Washington may never have declared war on Osama Bin Laden, but he has been at war with America for the better part of a decade. Now, with the Saudi terroristfinancier a prime suspect in the World Trade Center attack, President Bush has vowed that the U.S. will devote all necessary resources to beating Bin Laden. Easier said than done; and if Bin Laden is in fact re-sponsible, the most important thing is to know who he is, how he operates - and why he has so much support. .

Understanding the enemy This will be a protracted, complex and unconventional war in which many of the tactics of war as we know it are superfluous. The "Powelk Doctrine," the theory that wars are best won by deploying "overwhelming force," doesn't apply here, for the simple reason that the enemy has hardly any visible military assets or civilian economic infrastructure, and may not even be ultimately dependent on his current territorial home base. And if the experience of nations more seasoned than America in counter-terrorism (such as Israel and France) is any indicator, it's a war that could eventually require alliances and tactics unthinkable in the broad light of day.

Osama Bin Laden is a man, not a state. And he wields very little by way of conventional military power - estimates of the number of men under arms in his Afghanistan canıs at any one point seldom range above 2,000 . But those men are extremely well-trained, well-funded and have shown a fanatical willingness to die in order to inflict pain on their enemies. Technology and globalization has made their reach almost boundless, and they are linked to a vast network of terrorist groups throughout the Muslim world from western China and the Philippines all the way across to Algeria.

Bin Laden's is hardly the first terrorist group to operate well beyond home base, but it is the first truly global terror operation. And where Cold War-era terrorist groups invariably relied on the support of "rogue" states, Bin Laden's is independent: It is able to finance itself and provide sophisticated training to its own men - and build its operational alliances by providing such training to like-minded groups. And it has already once demonstrated an ability to relocate its headquarters from one country to another. 


\section{Targeting America}

The foundations of Bin Laden's network were laid during the Afghan war, during which the wealthy Saudi heir had been the prime organizer of volunteers for the 'jihad' against the Soviet invasion. That made him a key player in an effort backed by the CIA and the intelligence agencies of Egypt and Saudi Arabia to funnel aid, equipment, training and volunteers to the Afghan mujahedeen. Many of the "Arab Afghans," as the volunteers became known, had been radical Islamist dissidents in their home countries, and their pro-Western governments were only too happy to ship them off to fight the Russians. But the 'jihad' experience forged unprecedented bonds among the world's radical Islamists, turning them in spirit and in direct combat experience into a single army of 'holy' warriors.

Bin Laden emerged from the Afghan experience determined to overthrow Saudi Arabia's pro-Western rulers and institute a radical brand of Islamic rule. And when those rulers invited U.S. troops onto Saudi soil to defend them against Saddam Hussein, Bin Laden began to call for a global 'jihad' against the U.S. because of its support for Israel and for moderate Arab re-gimes.

He set up camps in Afghanistan and the Sudan - two states that the end of the Cold War left in conditions of near collapse - to keep his "Arab Afghans" together. And he combined his own personal fortune with funds raised throughout the Arab world to maintain his "Al Qaida" ("The Base") organization, which began sending fighters to Bosnia, Chechnya and to Muslim insurgencies all over East Asia. Bin Laden also extended his reach by turning his camps into a terrorism college providing highly specialized training to Islamist fighters from all over the world.

Bin Laden began attacking the U.S. in 1993, claiming responsibility in retro-spect for the ambush that killed some 17 U.S. soldiers in Mogadishu that year. Although he had no direct role in the first World Trade Center bomb-ing, he later sheltered its perpetrator, Ramzi Yousef, after the attack.

The U.S. hits back

The U.S. military finally put Bin Laden in its sights following the 1998 East African embassy bombings. President Clinton ordered cruise missile strikes on camps associated with Bin Laden in Afghanistan and on a factory linked with him (possibly erroneously) in the Sudan. But those strikes did little to impair Bin Laden's operational ability, and the U.S. reverted to containing his operations through cooperation with Arab intelligence agencies to foil planned attacks and round up and prosecute the perpetrators of the embassy bombings. Washington also sought to use Pakistan's close relationship with the Taliban to press Bin Laden's hosts into extraditing him, to no avail.

The Bush administration has promised a full-blown war against Bin Laden following 'Tuesday's attacks, but the key to winning that war and climinating the terrorist threat may lie in the extent to which the terrorists can be iso-lated. 
Isolating Bin Laden

Without the layers of support he has mustered in the Islamic world, Bin Laden would be nothing more than a crazy killer who could be hunted down and brought to trial or simply eliminated. Instead, his relatively tiny organization has menaced the world's largest military power largely because of its ability to capitalize on growing anti-Am.rican sentiment in the Arab world.

Reports of funds interdicted en route to Bin Laden in recent years suggest that he continues to enjoy the support of some'wealthy Arab businessmen, who either directly support his beliefs or else are inclined to hedge their bets on the outcome of his battle with the U.S.

Anti-American anger on the Arab streets - fueled by the ongoing campaign against Iraq and by Isracli military actions against the Palestinian uprising - provides Bin Laden with a growing pool of potential recruits, often highly educated and skilled young men who are willing to die for his cause. And the passions on the street also make it more difficult for even pro-U.S. governments in the Arab world to be seen to be working too closely with Washington. The performance of Yemen's security services in the U.S.S. Colc bombing investigation, for example, has been less than stellar.

Isolating Bin Laden may require ongoing efforts to repair and maintain Washington's relations with its Arab allies, whose security services remain the front line of the battle against Bin Laden.

\section{Building a coalition}

While NATO's support improves the U.S. striking power and widens political and diplomatic consent for any counterstrike, the crucial allies in the battle against Bin Laden remain the governments and security services of the Islamic world because it is intelligence, rather than air power or armor, that wins the war on terrorism.

Despite the ability of U.S. satellites to intercept cell-phone and email messages, human intelligence remains the most effective way of staying forewarned of Bin Laden's plans and movements. That's not going to easy. There are distinct limits on the ability of U.S. agents to directly infiltrate Bin Laden's networks, which are often based on family and other kinship ties. Such operations would require agents able to blend in ethnically and spend years away from their American lives in the extremely harsh conditions of Bin Laden's mountain camps. Plainly, the U.S. needs the active support of allied security services closer to the action. And the need to maintain such alliances also affects the range of options for responding to the latest outrage.

Why not simply bomb Kabul? 
Although the U.S. will very likely seek to punish the Taliban for hosting Bin Laden in Afghanistan, Afghanistan long ago ceased to function as a state. The Taliban are simply its dominant militia, and to the people of Kabul, they are outside occupiers.

While determined to hit hard against both the perpetrators and their protectors, U.S. officials will also be mindful of the danger of taking actions - particularly any that cause suffering among innocents - that widens the anti-American sentiment in the Muslim world on which Bin Laden feeds.

Invasion?

Others have asked why the U.S. doesn't simply round up a Gulf War-style posse to invade Afghanistan, overthrowing the Taliban and putting an end to the country being used as a safe haven for terrorists. But that would require tens of thousands of allied troops deployed in an open-ended commitment to remain a heavy troop presence in an extremely unfriendly environment. If the decision is made to take down the Taliban, that may be more likely to be attempted in concert with its regional enemies - including Russia and possibly even Iran - in support of the Northern Alliance opposition forces.

The Pakistan dilemma

The trickiest aspect of the Bin Laden equation may be Pakistan. Despite being a close ally of the U.S. during the Cold War, Afghanistan's nuclear-armed neighbor is also hotbed of anti-American Islamic radicalism. Pakistan has reportedly promised full support for a U.S. retaliation against Bin Laden, including allowing Pakistani airspace to be used by U.S. planes to strike Afghanistan. But President Bush's comment that Washington would have to wait and see what that means suggests the U.S. is not sure of the extent of Pakistan's commitment to the battle against Bin Laden. But Pakistani intelligence agents are probably closer than any other to Bin Laden's operations on the ground, and their cooperation - as unsatisfactory as the results may have been in the past - may be a critical element of the war against terrorism.

A war not won in a day

"Let's not think that one single counter-attack will rid the world of terrorism of the kind we saw yesterday," said Secretary of State Colin Powell on Wednesday. Indeed, it is to be anticipated that the Bush administration will develop a layered response of short-term and long-term actions to bring to bear military, economic and political pressure to isolate and ncutralize not only Bin Laden himiself, but the movement that would almost certainly seek to continue even if he were eliminated. And that's a war in which the U.S. needs its allies more than ever. 
Independent.co.uk

14 September 2001

\section{Secretary of State names bin Laden as main focus}

The Prime Suspect

By Rupert Cornwell in Washington

Now it is official. Colin Powell, the Secretary of State, became the first senior member of the Bush administration publicly to identify the elusive Saudi-born Osama bin Laden as a prime suspect behind the terror onslaught against America.

Asked why the US was turning up the diplomatic heat on Pakistan in particular, General Powell told a news conference that Washington had not yet identified the organisation responsible for the attacks, but he added: "When you look at the list of candidates, one resides in that region." Asked if he was referring to $\mathrm{Mr}$ bin Laden, General Powell replied: "Yes". Finding him may be another matter, though, even for the ultra-sophisticated technology of the US.

Word from the region last night was that America's most wanted terrorist target, already suspected of being behind the two 1998 US embassy bombings in Africa and last year's attack on the USS Cole, changed his hiding place within minutes of the destruction of the World Trade Centre.

Mr bin Laden was last seen in public in February, attending the wedding of his son in the southern Afghan city of Kandahar, the headquarters of the Taliban militia. Arab nationals are reportedly leaving Kandahar, probably because they expect the city to be a focus of American retaliation.

But Mr bin laden has probably moved on. He rarely stays in one place for more than a few days, moving around the country in small convoys surrounded by bodyguards, and taking full advantage of the network of caves that honeycomb the mountains of eastern Afghanistan for shelter.

One of them, in Paktia province, is said to be a warren of caves built with the help of American money in the 1980 s when Washington backed the Afghan insurgents against the Soviet invaders.

Though the Taliban has condemned the New York and Washington suicide attacks, it says it will not hand over Mr bin Laden without solid proof that he was the organiser. Its Foreign Minister, Wakil Ahmed Muttawakil, said yesterday that Mr bin Laden had been deprived of communications equipment. He denied, however, that he had been placed under house arrest. 
Taliban radio claimed that America was picking on Mr bin Laden simply because he was well known. "Does Osama have the planes to train pilots?" it asked. "Where did they get their training? Who trained them? From which country are they? In Afghanistan this kind of training is not possible." The American authorities now believe they are close to answering all those questions. In the meantime, Washington is turning the screws on Pakistan, one of only three countries that recognise the Taliban and supports the Islamic regime.

Mr Powell held what he termed a "good conversation" with General Pervez Musharraf, the Pakistani President. But the diplomatic nicieties conceal some very tough talking. Pakistan, a valued US ally during the Cold War, is being told either to co-operate in bringing Mr bin Laden to justice, or risk further isolation and the end of any prospect of a resumption of aid.

Earlier, Richard Armitage, the deputy Secretary of State, summoned Pakistan's ambassador to the State Department to read her the diplomatic equivalent of the riot act. "Our message basically was, 'Are you with us or against us?"' a US official said last night. Publicly, General Musharraf has aligned Pakistan squarely with the US, but Washington is yet to be convinced this will translate into deeds.

The Taliban government, meanwhile, is warning that any missile attack would be pointless After the 1998 embassy bombings, US warships and aircraft launched 70 cruise missiles against reputed bin Laden training camps in Afghanistan, with no success.

"Killing our leaders will not help our people. There is no factory in Afghanistan that is worth the price of a single missile fired at us. It will simply increase mistrust between the people in the region and the United States."

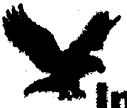

14 September 2001

\section{Afghanistan's neighbours unite against Taliban}

Central Asia

By Patrick Cockburn in Moscow

Senior diplomats from Russia, India, Iran and other countries hostile to the Taliban in Afghanistan held an emergency meeting in Dushanbe, capital of Tajikistan.

They planned to discuss the role of the anti-Taliban alliance of Afghanistan's neighbours as the United States prepared to retaliate for the attacks in New York and Washington. 
In the past the anti-Taliban group has supported the Northern Alliance, the sole remaining opposition to the Taliban in Afghanistan. But Ahmed Shah Masood, the Northern Alliance's charismatic leader, was killed or badly wounded by a bomb last Sunday, just as his retreating forces might have been revived by foreign aid. The Taliban is not short of enemies, but Masood, who built his military prestige during the Soviet intervention in Afghanistan, was its only opponent with an army in the field.

"I think the alliance will almost certainly disintegrate," said Robert Templer of the International Crisis Group's Asia programme. "Masood really did fight battles and didn't just bribe his opponents to go away. It won't be much of a military force without him."

Outside Afghanistan, notably in Russiá and Iran, Masood was the only opposition leader with any credibility. The new military commander of the Northern Alliance, which consists mainly of ethnic Tajiks, is General Mohammed Fahimkhan, who does not have the prestige of Masood. Mr Templer said the Northern Alliance does not have wide popular support.

At first glance the Taliban faces a formidable array of enemies who are willing to help the US pursue those responsible for the attacks. But the meeting in Dushanbe brought together a disparate group of powersthat have little in common apart from dislike of the Taliban.

Russia still has a division of troops in Tajikistan, which shares a long common border with Afghanistan. President Vladimir Putin has long spoken of joining the US in tracking down "international terrorism", which he blames for the war in Chechnya. The Kremlin has also offered help to central Asian states such as Uzbekistan and Kyrgyzstan which are fighting guerrillas.

The Iranians regard the Sunni Muslim Taliban with extreme antipathy because of its oppression of the Shia minority, known as the Hazara, and the murder of Iranian diplomats.

Uzbekistan fears guerrillas from the Islamic Movement of Uzbekistan, which has raided its territory. Tajikistan is the main conduit for heroin from Afghanistan and also fears the export of Islamic revolution. India does not want Islamic rebels trained in Afghanistan to cross into Indian Kashmir.

The position of some states in the region is ambivalent. China has good relations with Pakistan and recently signed an economic agreement with the Taliban. But it also fears the spread of Islamic revolutionary ideas to Xinjiang, its largely Muslim province.

Russia has been leading the charge in opposing "Islamic fundamentalism and terrorism". Immediatel alter the attacks in the US, Mr Putin said: "What 
happened today underlines one more time the importance of the Russian proposal to unite international forces in the fight against terrorism. That is the plague of the 21 st century. Russia directly knows what terrorism is and for that reason we understand the feelings of the American people."

American calls for international solidarity against "terrorism" fit in well with Russian policy on "terrorism" in Chechnya. But central Asian states worry about becoming too dependent on Russian military support to combat what at this stage are minor guerrilla incursions.

Mr Templer says that despite declarations of solidarity, the states that ostensibly stand shoulder to shoulder against terrorism and fundamentalism regard each other with deep suspicion. A decision to set up a joint research institute into terrorism in Bishkek, the capital of Kyrgyzstan, foundered because nobody would pay for it.

The key to any move against Osama bin Laden, other radical Islamic groups in Afghanistan or the Taliban is likely to be Pakistan. The Taliban is, after all, largely the creation of the Pakistani intelligence service. Only the Pakistanis have the knowledge and the manpower to eradicate radical groups in Afghanistan, unless the US intends to use ground troops.

The US does not need Russian material support. But the daily Vremya Novostei said that in talks in the past few days between the Kremlin and the White House it looked as if there was a political agreement reached similar to that in 1991 before the military operation against Saddam Hussein. "The Americans do not need our assistance, but a guarantee not to interfere," it stated.

Moscow will find it easy enough to act in concert with the US over Afghanistan. But it would be much more worried if US actions were directed against any of seven states - Iran, Iraq, Sy ria, Libya, Cuba, North Korea and Sudan - with whom it has had close relations.

In one respect the situation resembles that after the Iraqi invasion of Kuwait. Even more than then, nobody wants to make an enemy of Washington.

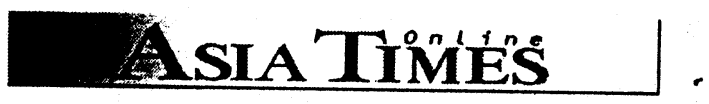

September 13, 2001

THE ROVING EYE

All no longer quiet on the Afghan front

By Pepe Escobar

THE SHAMALI PLAINS - General Baba Jan, one of Ahmad Shah Masoud's 
trusted commanders, is a jovial fellow in his late $40 \mathrm{~s}$. He points to the hills facing Bagram Airport, about 60 kilometers north of Kabul. Eight Taliban tanks are facing us on a 120-degree angle. But they are more than 5 kilometers away. The general comments: "I ou know what's behind tl.ose hills? Taliban training camps. They may now hold something like 50 or 60 fighters, including Uzbeks, Kashmiris and Chechens. And their logistical support comes from Osáma bin Laden."

This is the calm before the storm. This was just three weeks ago. At the time, no one could imagine that two Arab suicide bombers disguised as journalists in northern Afghanistan would try to assassinate the commander of the Northern Alliance forces fighting the Taliban, Masoud himself. And no one could possibly imagine that only two days later, a bunch of so-called Arab-Afghans - professionals of jihad affiliated with the Muslim Brotherhood (the main Arab Islamist movement, founded in Egypt in the late 1920s) - would perpetrate the deadliest terrorist attack in history, on the heart of economic and military American power.

Getting to Bagram is in itself an eerie experience - especially coming from the spectacular mountainscape of the northern Panjshir Valley. We suddenly drift into the Shamali Plains, badly affected by drought and once the scene of endless battles between the Soviets and the mujaheddin, later between the Taliban and the Northern Alliance. As we drive toward Bagram, we are within shooting distance of Taliban tanks. It's almost surreal to imagine that if the deserted paved road was not cut, we could be in Kabul in less than half an hour. But this has been a frontline for at least five and a half years.

At the top of Bagram Airport's derelict control tower, General Baba Jan says the Taliban fire almost every day. There is an enormous hole in the tower, caused by a rocket. There is a constant war of attrition between two checkpoints, separated by only $\mathbf{5 0 0}$ meters, with a village in the middle. All the inhabitants fled the fighting. Some can be found in refugee camps in Pansjhir Valley. But a lot can also be found in the Jalozai camp near Peshawar, in Pakistan - living in infinitely more miserable conditions. It is almost certain these latter refugees eventually will be deported back to Afghanistan.

On the other side of the airport there are an additional three or four Taliban checkpoints, according to the general. Their shots cannot reach Bagram, because their range is a maximum 3 kilometers. Children living in the region come to Bagram by bicycle to see their fathers fighting. The mujaheddin proudly exhibit their war wounds and trade jokes. They burst into laughter every time the Taliban fire a shot way off target. All of the enemy's communication - in Pashto - is monitored by radio. Some of the mujaheddin, like Mungal, are only 14 years old. Mungal is a volunteer in Masoud's army. His whole family died in the war. His best friend is a rocket launcher.

There's a lot of talk in the area about the situation in Kabul - only that virtual halfan-hour drive away. The Kabulis now refer to the Taliban as "dirty souls" - in a free translation from Dari, their Persianized language. The mujaheddin comment 
there are now lots of hardcore Arabs from the Wahhabi sect working in the Taliban ministries, menacing non-governmental organization officials with a systematic
campain of slittiıg throats.

The Taliban intelligence services, according to locals who have been to Kabul recently, now ressemble those in power during the hated dictator Najibullah's regime: "It's a well structured organization, with 12 branches. At the Ministry of the Interior, they are totally Pakistani," says a mujaheddin. "There's no more security," says another, "Kabul is full of robbers in the middle of the night. Nobody can complain, because that would be un-Islamic. The population is fed up. But sooner or later the youth will resist."

During the jihad against the Soviets in the 1980s, 300 to 350 planes could take off on any given day from Bagram. When the mujaheddin were in charge of Kabul, from '92 to '96, the airport was also controlled by Masoud's forces. But since the Taliban took Kabul in '96, the strategic airport has already been captured four times. The first two times, the Taliban maintained their position for 6 months, and then for one month. The general quickly adds that "last time, two years ago, they could not hold it for more than three days." Some of the Taliban attacks are highly coordinated with jets, tanks, helicopters and infantry: "We can be attacked anytime."

But this very week, it was the Northern Alliance's turn to attack - in retaliation for the Arab-Afghan assassination attempt on Masoud. Commander Bismillah Khan, also posted in the Shamali Plains, attacked the vicinity of Kabul with two helicopter gunships and medium-range Russian missiles, destroying two Taliban planes at Kabul Airport and hitting an ammunition dump. The world thought at first this was the beginning of the American-sponsored Great Incineration of the Taliban regime.

General Baba Jan has no doubts about Pakistani interference in the ongoing Afghan tragedy. On the close rrlationship between Pakistan's intelligence services and the Taliban, he prefers to quote an Afghan proverb: "If you start feeding a dog, one day he will want to bite your leg." Like all of Masoud's commanders, he describes an intimate relationship between the Pakistani Inter-Service Intelligence (ISI), the Taliban and Osama bin Laden. These are exactly the same actors who are being singled out by Masoud's Northern Alliance as the perpetrators of the American tragedy.

The Taliban-ISI-Osama connection may not make as much sense as the OsamaArab-Afghan-Muslim Brotherhood connection, but it's far from being far-fetched. The extremely cosy relationship between Afghans and an array of Middle Eastern groups started to be forged in the ' 80 s, during the jihad against the Soviets. America simply cannot forget that an alliance including the CIA, Saudi intelligence and the ISI ultimately established an international network to support the mujaheddin - and, the whole thing was coordinated by the Muslim Brotherhood. This is how a lot of Arabs of the radical Islamic kind came to fight in Afghanistan.

The hub of this informal network was Peshawar, the tribal area capital in Pakistan. 
It was directed by a Palestinian-Jordanian affiliated with the Muslim Brotherhood, Abdullah Azzam; and by none other than Osama bin Laden himself. Bin Laden even directed a foundation in charge of recruiting and financing the jihadis. This was how the Middl: Eastern religious and political debate started to infiltrate the Afghan mujaheddin mind.

It was a deadly cocktail: a mix of so-called "salafism" (an Islam theoretically close to an ancestral view) and the ultra-conservative Saudi Wahhabi brand. Sooner or later these Arab-Afghans started to oppose the natural, easygoing Sufi way of the Afghans. They openly declared themselves in favor of the destruction of shrines this would climax, under the Taliban, in the orgy of destruction of the Bamiyan Buddhas. And to top it all, they did not understand the jihad as a struggle against communism, but against any kafirs (infidels), especially those belonging to Christianity and Western civilization. This - the triumph of what we could call the "Saudi model" - is the root of the neo-fundamentalism of the Taliban. A tragic development when seen in retrospect, because these so-called Arab-Afghans started to come to Afghanistan with the encouragement of the Americans themselves.

There's no better way to meet the Taliban and Osama's deadly Arab-Afghans than to visit the prison in the Panjshir Valley where the Northern Alliance keeps its prisoners of war. It is an inevitably spectacular location on a plateau on the base of a hill, surrounded by rock face, on a bend of the Panjshir River. According to Commander Mushtar, in charge of prisons since 1975, Masoud's forces hold 342 POWs, plus 22 foreigners. Not all of them were captured in battle: 95 were captured with various "documents", and are accused of spying for the Taliban.

It is quite an experience to enjoy the midday Panjshiri sun surrounded by a bunch of professional killers. At any time they could run amok and transform their visitors in hostages. But they would have nowhere to run, faced with rock face or river. They have permission to go to the river five times a day to perform their prayers and ablutions. Mushtar says the occasional escape plan is inevitably thwarted.

Their treatment, the same for Muslims and non-Muslims, is quite extraordinary even compared to the best Western prisons - one more confirmation of the legendary graciousness of Panjshiri natives. Mushtar says the emphasis is on "respect for humanity". The food is the same for everybody - administration personnel included. This is in stark contrast to the dreaded Taliban prisons, which Mushtar describes as "very difficult on our prisoners: it's everybody in only one room, with no permission to get out, and they only eat a piece of bread 3 times a day".

The foreigners - part of Osama's international jihad army - include a handful of Pakistanis like Muhamad Assam, from Karachi. Another prison in Takhar province even boasts a kind of tourist attraction: Chahab, an English Taliban inmate - in fact a Pakistani Muslim with an English passport. There is a suspicious Uighur from Xinjiang, western China, who says he only wants to go back to farming. And there is Ali, a most improbable character from Iraq. Ali maintains he is a member of the 
Iraqi opposition, an enemy of Saddam Hussein. He was supposedly trying to go to Tajikistan via Afghanistan, so that later he could get to Russia. It's a bit of a long way round for someone who could easily cross the Iraqi-Jordanian border.

Mushtar promptly dismisses Ali's version: "Everybody here claims their innocence. But most of them, when they are caught, had already spent six months being trained by the Taliban." Ali's documents apparently are fake: "He had a recommendation from the ICRC (the International Committee of the Red Cross). We phoned them and they said they had never heard of him."

Most of the prisoners predictably say they just want to go back to tending their sheep when the war is eventually over. Some say they want to keep on fighting for the Taliban and Islam. And some, unlike Ali, definitely don't bother to pose as a victim. They are the genuine jihadi article. Asked what would be the first thing he would do after leaving jail, an ex-major of the Pakistani army didn't even blink: "I will kill you."

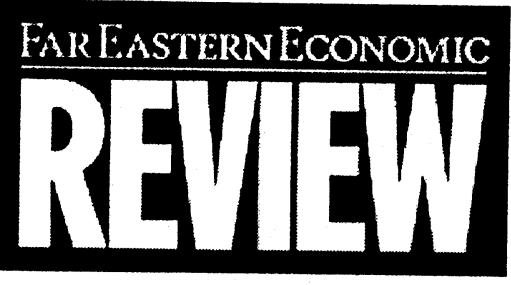

Issue cover-dated September 20, 2001

\section{AFGHANISTAN}

\section{Hitting Kabul}

The U.S. is angry and rady to retaliate against terrorists. All eyes now turn to Afghanistan

\section{By Ahmed Rashid/LAHORE}

UNITED STATES PRESIDENT George W. Bush's vow to bring to justice those responsible for Tuesday's carnage featured a chilling escalation of purpose: "We will make no distinction between the terrorists who committed these acts and those who harbour them."

As he spoke, many people already believed that Washington would lay the blame squarely on Saudi terrorist Osama bin Laden, based in Taliban-controlled Afghanistan. A number of current and former U.S. officials made bin Laden the prime suspect. A minority doubted that bin Laden was capable of orchestrating such a coordinated offensive. But though he has been lying low for the past year, 
there was never a doubt that bin Laden would strike at U.S. targets.

The ability of his Al'Qaeda organization to strike terror around the world is heavily dependent on the base it has built in Afghanistan and the support it draws from the Taliban and Pakistan's extremist Islamic groups. With the prospect of a massive and sustained U.S. military attack on Afghanistan, Western diplomats in Islamabad began making evacuation plans for their families. The United Nations began pulling out aid workers from Afghanistan the day after the U.S. bombings.

"It's the worst nightmare of the West, that bin Laden gets stronger, not weaker, in Afghanistan and virtually comes to rule the place," says a diplomat in Islamabad. "From there he can plan and organize strikes around the world."

Bin Laden has dozens if not hundreds of agents at the ready in the U.S. and Europe, many of whom are educated Arab militants who receive sophisticated training in bomb-making and communications in Afghanistan. In recent months, police in Europe arrested 20 residents suspected of planning to bomb the European parliament in Strasbourg.

But it is Afghanistan where bin Laden has the means, the freedom and space to build up his network. Al'Qaeda now has some 3,000 members from 12 different countries in Afghanistan who fight for the Taliban in the 055 Arab Brigade, which bin Laden finances and commands.

The U.S. attacks were preceded by several days by the attempted assassination of the anti-Taliban leader Ahmad Shah Masud, head of the opposition National Alliance, now known as the United Front. On September 9, two suicide bombers disguised as journalists set off an explosion during an interview with Masud at his base in northern Afghanistan. U.S. officials say Masud was killed; as the REVIEW went to press, the United Front said he was still alive.

Abdullah Abdullah, the United Front's foreign minister, accused the Taliban, bin Laden and Pakistan of carrying out the attack on Masud--a charge the Taliban and Pakistan have denied.

"The operation against Masud was classic bin Laden: meticulously planned . . . with great technical ability in being able to conceal a bomb in a video-camera and carry it across the who!e of Afghanistan before blowing it up," says a Western intelligence official in Central Asia.

Masud is or was the only holdout against total Taliban control of Afghanistan. With Masud incapacitated or dead, the fractious United Front would find it hard to hold together. However, hours after the attacks on New York and the Pentagon, the United Front launched a rocket attack on Kabul airport.

If bin Laden did have a role in the attack on Masud, he has won the eternal gratitude of Taliban leader Mullah Mohammed Omar, and immeasurably 
strengthened his power and influence with the Taliban, who may have had little choice but to allow bin Laden to carry out his U.S. strikes.

After the attack on Masud, Russia called for an emergency meeting of Indian, Iranian and Central Asian leaders in Tajikistan. They are likely to suggest more military aid for the United Front. They are also likely to discuss U.S. requests for airbases in Central Asia to be used to bomb bin Laden's bases in Afghanistan-which Washington first raised last October after the U.S. destroyer Cole was attacked in Yemen.

After the October incident, U.S. officials warned the Taliban that they would be held responsible for any acts of terrorism carried out by bin Laden. But the Bush administration has been delaying its promised new Afghanistan policy. Now the U.S. is suffering the consequences of that delay, with Afghanistan at the centre of global terrorism.

\section{The T30stond biblob}

9/13/2001

\section{THE TALIBAN LINK}

\section{Afghanistan host to unwelcome guest}

By Elizabeth Neuffer, Globe Staff

Afghanistan is a country on the brink of famine, ravaged by decades of war and ongoing infighting. It is also, regional experts say, a likely safe harbor for accused terrorist Osama bin Laden, even though its people grant him little popular support.

It is the country's Islamic fundamentalist ruling party, the Taliban - which has control over roughly 90 percent of Afghanistan - that has a strong sense of allegiance to bin Laden. That is largely because he has helped finance their military takeover of the ravaged land, beginning with their recapture of the capital city of Kabul in 1996.

Bound by that sense of debt, shared Islamic beliefs, and a culture that dictates hospitality be offered to fugitives, the Taliban welcomes the Saudi Arabian-born terrorist as an honored guest despite his status as an international pariah.

Rumors, in fact, abound that the Taliban's spiritual leader, Mullah Omar, is married to bin Laden's daughter. And the Taliban's ties to the leader are expected to grow all the stronger after this week's reported assassination attempt on their 
chief opposition leader, Ahmad Shah Masood, thought to have been bin Laden's handiwork.

But to most of Afghanistan's 25 million people, bin Laden is simply another of the now-unpopular radical Islamic fighters that over the decades have made their country their home.

"Most Afghans now wish Osama and the Taliban would evaporate and something rational would take their place," said Barnett Rubin, an expert on Afghanistan at New York University. "The overall Afghan view is that they are sick of the whole situation - there are millions of displaced people, a major drought, they don't have employment, and they are under the thumb of an insane government."

Bin Laden continues to be considered the chief suspect in this week's terrorist attacks on the World Trade Center and the Pentagon, although he has denied any responsibility. Yesterday, Abdul Saleem Zaeef, the Taliban's ambassador to Pakistan, denied that the well-coordinated attacks were bin Laden's doing.

The United States alreary wants to try him on charges of masterminding the bombings of two US embassies in Africa in 1998 in which 224 people died. The United States fired a missile at Afghanistan in retaliation for those attacks.

Regardless, the Taliban has refused to hand him over, saying the United States must provide evidence first.

Ironically, it was partly American doing that brought bin Laden to Afghanistan. He was recruited in the 1980's to aid the country's front-line fight during the Cold War as its mujahadeen battled the Soviet Union.

Since then, the country has continued to be a battleground, as regional neighbors and superpowers have used the country's warring factions for their own purposes.

Currently, as many as 3,000 Arab extremist fighters - Algerians, Egyptians and others - have made the country their base.

"The people of Afghanistan," said Andrew Cox, the UN's humanitarian affairs office for Central Asia, "are pawns of forces and people outside of their control."

Now, the Bush administration faces the difficult dilemma of how to bring bin Laden to justice - without further radicalizing the ruling Taliban party or wreaking havoc upon a civilian population already beaten down by 20 years of war.

The administration has vowed to take strong and swift action not only against whatever terrorist is responsible for this week's attacks on New York and Washington, bui also against the country that has granted him refuge. Yesterday, the United Nations' many relief agencies withdrew their staff from Afghanistan in case of retaliation. 
Diplomatic leverage, however, is limited. The Taliban government, already under international sanctions, is nearly isolated, recognized by only three countries: Pakistan, Saudi Arabia, and the United Arab Emirates.

Pakistan's military government, fearful of the dominance of its regional neighbor, India, maintains strong diplomatic relations with the Taliban government, even as it has grown increasingly extremist. Experts say Pakistan supplies the Taliban with military advisers, logistics support and possibly weapons.

Yet the Taliban has been known to ignore even Pakistan's pleas. Earlier this year, Pakistan was among those countries that called, in vain, for the Taliban to halt destruction of its ancient, towering statues of Buddha.

US military strikes on Afghanistan, humanitarian experts warn, would only further harm an already-desperate civilian population.

"Our staff have reported families who sell the children into servitude, just to have something to eat," said Sigurd Hanson of the International Rescue Committee.

UN statistics indicate that one in four people in Afghanistan faces starvation or bitter poverty.

An estimated 850,000 people have abandoned their homes this year, fleeing drought, fighting, and human rights abuses.

Afghanistan has one of the highest infant and maternal mortality rates in Asia, and one of the world's lowest literacy rates. Yet it also has the highest per capita number of small arms, according to UN and other estimates. It has no functioning education or legal system, other than the Taliban's imposition of Islamic law.

After decades of war, Afghanistan's infrastructure is in ruins. Said Rupert Colville, a spokesman for the United Nations High Commissioner for Refugees in Geneva, "There are parts of Kabul that look like the World Trade Center."

\section{USA TODAY}

\section{Taliban may be the first target of U.S.} retaliation for terror wave Afghan leaders' likely choice: Hand over bin Laden or prepare for attack

By Bill Nichols 
WASHINGTON -- When President Bush spoke to the nation Tuesday in the wake of the day's terrorist onslaught, one sentence stood out. "We will make no distinction," Bush said, "between the terrorists who committed these acts and those who harbor them."

Bush didn't single out a country by name. But the nation most likely to be affected by his threat appears to be Afghanistan -- a place many Americans have little knowledge of. In the days to come, that is likely to change.

The Taliban, the fundamentalist Islamic militia that governs Afghanistan, is harboring fugitive terrorist Osama bin Laden, seen as the chief suspect in the attacks.

Afghanistan already has been hit by one U.S. response to terrorist acts tied to bin Laden -- the 1998 bombings at U.S. embassies in Kenya and Tanzania that killed 224 people. President Clinton launched a missile strike to destroy a site believed to be a major bin Laden training camp in Afghanistan, but bin Laden was not there.

Taliban officials have condemned the attacks on the World Trade Center and the Pentagon and insist bin Laden could not have been involved. They claim to keep bin Laden on a tight leash by denying him communications access and restricting his movements.

In fact, the Taliban has tried to separate itself from bin Laden, saying it does not support terrorism. But analysts say the militia's basic views mirror those of bin Laden and his terrorist cell: that Western democracy, and the United States in particular, is a threat to the purity of Islam.

Bin Laden hates the United States "because of our values," Heritage Foundation terrorism analyst Jim Phillips says. "His terrorism is not meant to affect our policies as much as shake our confidence in ourselves, shake the confidence others have in us and help pave the way for a radicalization of the entire Muslim world."

U.S. officials, though not yet certain of bin Laden's complicity in the attacks, say they still believe that he can act freely within Afghanistan and that the Taliban could deliver him if it wanted to. Diplomatic analysts foresee a scenario where the Taliban could be asked to hand over bin Laden or face a massive U.S. attack.

Would they do it? "They've been in bed with him too long to kick him out now," Phillips says. "They cannot afford to throw over bin Laden." The Taliban has become an increasing problem for Western powers since it captured the Afghan capital of Kabul in 1996 and gained control of the country.

Only three nations -- Pakistan, Saudi Arabia and the United Arab Emirates -recognize the Taliban and its leader, Mullah Mohammed Omar, as the legitimate 
government of Afghanistan.

Both the United States and the United Nations have imposed economic sanctions on the Taliban and ban arms sales to the militia because of terrorist connections.

Practitioners of fundamentalist Islam, Taliban leaders moved into a power vacuum left in the wake of a civil war during the 1970s and 1980s between Soviet-backed forces and U.S.-backed rebels.

But it is not just the Taliban's decision to harbor bin Laden that has isolated it from the world. A series of edicts to the Afghan people, based on what Taliban officials see as a strict reading of Islamic law, has drawn international ire.

* All non-Muslims in Afghanistan must wear identification tags.

* Taliban forces destroyed two 2,000-year-old statues of Buddha that survived even the 13th-century onslaught of Genghis Khan.

* Women have been forbidden from working, even for United Nations relief agencies, and must be covered from head to toe when outside their homes. Women also face health care restrictions.

* Banned activities include watching television, dancing, photography and kite flying.

* Eight foreign aid workers, including two Americans, currently are on trial in Kabul on charges of preaching Christianity.

The religious views of the Taliban are an extremist interpretation of Islam that is rejected by the great majority of Muslims. Says Shireen Hunter, director of the Islam program at the Center for Strategic and International Studies:

"It is the expansion ... of a more simplistic and literalist version."

In recent years, hin Laden and the Taliban have appeared to grow closer. U.S. intelligence officials say bin Laden is a major financial donor to the Taliban. Mullah Omar also is rumored to have married a daughter of bin Laden, potentially putting him in the position of having to hand over his father-in-law to the United States.

Opposition to the Taliban does exist, particularly in the north of Afghanistan.

But an assassination attempt earlier this week against rebel commander Ahmad Shah Masood, which some U.S. officials also say has bin Laden's fingerprints on it, could devastate that movement.

Masood is believed to be dead, although some of his aides insist he survived the attack. 
If bin Laden is found to be responsible for the U.S. attacks, analysts say a threat to fund and arm the opposition is one way to try to force the Taliban to give him up.

It is not just the Taliban that will come under intense pressure should bin Laden be found to be the force behind the attacks.

Nearly $40 \%$ of the Taliban's fighters are from Pakistan, and Pakistan's intelligence service is believed to be a longtime patron. Administration officials say they are already warning Pakistan that help will be demanded if bin Laden is the culprit.

"Pakistan ... is going to have to make a very difficult choice, very soon, for we are counting," Senate Foreign Relations Chairman Joseph Biden, D-Del., said.

"We are counting and we are looking. Words will not be sufficient. Actions will be demanded."

\section{THE CHRISTIAN SCINCE MONITOR}

September 13, 2001

\section{Retaliation is trickier than Afghan terrain}

People staying in Osama bin Laden's complex have been moving out to undisclosed locations, according to reports.

By Cameron W. Barr and Scott Peterson | Staff writers of The Christian Science Monitor

\section{JERUSALEM AND MOSCOW}

A thousand years ago, a small Islamic sect called the Assassins used suicide attacks to terrorize Arab leaders and European crusaders for more than two centuries. The Assassins defied their enemies until a massive Mongol army wiped out their castle stronghold in the mountains of northern Persia.

The elusive Saudi millionaire Osama bin Laden, who is in some ways a modern-day Assassin, is being increasingly identified as the architect of Tuesday's attacks on the US. Like the ancient sect, he vows to evict foreigners from the Middle East and favors mountain hideaways. Without specifically referring to Mr. bin Laden, Secretary of State Colin Powell promised Wednesday to launch a "multifaceted attack on many dimensions ... to bring this scourge [of terrorism] under control." 
But analysts say that an American duplication of the Mongols' success will not be easy. If bin Laden is, indeed, the source of the attacks, US retribution is likely to be geographically complex and replete with risks that could lead to a wider war.

The main problem is that bin Laden is the head not of a country, or even a fortress, but of a network of hard-to-find militants and cells in the Middle East, Europe, Asia, and North America. The only nation that can be convincingly said to support him is Afghanistan, the war-torn, destitute country where he has lived since 1996.

"If [the attacks on the US] are linked directly to Osama bin Laden, the Afghans will be given an ultimatum to deliver him," says Mustafa Hamarneh, director of the Center for Strategic Studies in Jordan. "If they don't, the Americans and their allies will consider military action."

Afghanistan's leadership - the hardline Islamic Taliban militia - has already appealed to the US not "to put Afghanistan into more misery because our people have suffered so much," in the words of one spokesman.

NATO has already invoked a treaty provision that would allow it to assist the US and President Bush, and other officials have indicated they intend to assemble a broad coalition to face America's nearly invisible enemy. "I think it will be a replay of the Gulf war," Mr. Hamarneh adds, "except that it will be easier for the US ... to get Arab and Muslim countries on board against bin Laden and the Taliban" than it was to orchestrate regional support against Iraq.

But if the diplomacy is simpler, the logistics are not. "There's a danger in everything," says John Cooley, a journalist and the author of the book "Unholy Wars: Afghanistan, America and International Terrorism." "Suppose this is a composite job, with experts recruited from other organizations coming from all different countries. How do you retaliate?"

Arrests and investigations in recent years have demonstrated that bin Laden's organization includes Algerians, Egyptians, Jordanians, Palestinians, Saudis, and Yemenis. Some of their nations are among the closest friends of the US in the Middle East. One of the suspects identified in Tuesday's attack is a Saudi national who was trained ..S an airline pilot, and two hijackers were brothers who held passports from the United Arab Emirates. Analysts say there could have been as many as 50 people involved in the planning.

The Afghans, stricken by decades of conflict and impoverished by years of drought, would have little to lose in defying the West. Bin Laden, on the other hand, is said to provide financial and other resources to the Taliban, an ostracized group whose rule is only recognized by three nations.

Invading or occupying the country would prove difficult - Afghanistan is a rugged land whose fighters have defeated the imperial ambitions of several invading armies, 
including the Soviet Union in the 1980s. Any large military operation against Afghanistan would require the help of neighboring Pakistan, whose military intelligence service helped to create and train the Taliban. This critical connection is one reason why US diplomats have been working overtime, huddling with Pakistani officials yesterday and the day before to gain firm commitments of support.

"The Taliban are not exactly in one place. They are spread [out] in Kabul and Kandahar," Mr. Cooley says. "It would be a very messy operation, tracking them all down - let alone bin Laden's gang."

"It's like a bunch of grapes. Pick one grape, and the bunch remains," says the Western intelligence officer. "Each is a segment unto itself, but they're talking with each other. They're training together. They're working together for the same causes. Yet there's a protection in being separate."

Bin Laden is known to live with as many as 300 others in a sprawling housing complex in the southern Kandahar province. According to the Associated Press, several reports b'gan to appear Wednesday that Arabs were moving out of the complex. Meanwhile, several Arab families in Kabul have been seen loading their belongings into vehicles and leaving.

There is little sympathy from bin Laden himself. An aide, who spoke by satellite telephone to Abu Dhabi television in Pakistan, quoted him as saying he had nothing to do with the attacks, which he said were "punishment from Allah."

For the moment, it seems that Afghanistan is No. One on the target list, simply by default. "It's very difficult to put your finger on a precise place where they can strike," says Esther Webmen, an Israeli historian who has recently studied bin Laden's organization, referring to those interested in retaliating for the attacks on the US. She adds: "Except Afghanistan."

Some American and Israeli analysts have speculated that Iraq may have assisted bin Laden, but the connection is unproven. "If they decide to go after Saddam Hussein as well, then we could have a big regional war on our hands," says Cooley.

The Russians have been supporting anti-Taliban Afghan guerrillas in the north for years, and new US support of this Northern Alliance with cash or other assistance could be part of the equation.

Any such support might recall Washington's covert backing of the Islamic mujahideen in Afghanistan. Backing of the Afghan fighters - bin Laden prominent among them - has resulted in years of instability there and in other countries. Despite the proven risks of intervention, a military strike - $\hat{E}$ and even US forces on the ground in Afghanistan - $\hat{E}$ might receive only slight condemnation across the Islamic world, says Bashrahed Bashraheel, foreign editor of the Al-Ayyam newspaper in the port city of Aden, Yemen, where suicide bombers killed 17 American service personnel last (October on an attack on the USS Cole. 
"Everybody here thinks that the Taliban has been harboring and protecting these
guys for a long time, and that sooner or later the Taliban would be held
responsible," sats Mr. Bashraheel.

Jordan, Algeria and Yemen itself are all believed by Western intelligence sources to have bin Laden cells. But if no other nation is targeted, the view across the Arab Taliban are so extreme."

"The idea of a worldwide coalition against terrorism is much better and more effective than one huge military strike, because these people are spread all around the world," adds Bashraheel. "Cutting off its head is not effective - it has to be a
large, group effort by all countries to stop it."

International Herald Tribune

Friday, September 14, 2001

\section{Afghans Brace for a U.S. Attack}

Kamran Khan and Molly Moore Washington Post Service ISLAMABAD, Pakistan Afghanistan's ruling Taleban movement, which has provided a safe haven for Osama bin Laden, the accused sponsor of terrorism, is bracing for an imminent U.S. attack, sending its top leader into hiding and repositioning its military equipment throughout the country, according to reports by Pakistani intelligence sources.The radical Islamic movement's leader, Mullah Mohammed Omar, has left his headquarters in the southern Afghan city of Kandahar and is in hiding, according to Pakistani military intelligence officials. In addition, the Taleban has begun frantically moving artillery batteries, aircraft and other weaponry in anticipation of a U.S. strike, the sources said."We have definite reports that the Taleban are now preparing to meet a major U.S. military onslaught," said a senior security official in a telephone interview from the Pakistan city of Quetta, near Afghanistan's southern border." There is a warlike situation inside the Taleban military installations inside Afghanistan."The Taleban has denied that Mr. bin Laden, one of its staunchest supporters, was behind the terrorist-plane crashes that destroyed the World Trade Center in New York and damaged the Pentagon in Washington.But U.S. officials say they have evidence linking Mr. bii, Latden, accused of directing other terrorist assaults against U.S. targets, to the Tuesday at::acks. Intelligence officials here in the Pakistani capital said that although they believed Mr. bin Laden was in Afghanistan, they did not know exactly where he was. Most likely, they said, he is moving between hideouts even more often than he customarily does. The United States launched cruise missiles in 1998 against sites in Afghanistan where Mr. bin Laden was suspected of training 
terrorists. The strikes were carried out about two weeks after bombs exploded at two U.S. embassies in East Africa.Mr. bin Laden escaped the cruise missile attack, but about wo dozen Pakistanis at the sites were killed. Pakistan military authorities said they were not informed of the U.S. military strike until it was under way. Sources here said that U.S. officials had been pressing Pakistan for months to play a greater role in efforts to dislodge Mr. bin Laden from Afghanistan, a request Pakistan has resolutely resisted.State Department, intelligence and military officials have asked Pakistan to support military efforts against Mr. bin Laden, including secret deployment of U.S. special forees in northern Pakistan that would conduct operations inside Afghanistan in an effort to capture him, senior Pakistani officials said.Although Pakistan was a major staging ground in the 1980s for covert U.S. operations and support for Islamic rebels fighting against Soviet forces in Afghanistan, relations between the onetime allies have soured since the end of Cold War.U.S. officials in Washington have emphasized that relations are further complicated by the fact that Pakistan now possesses nuclear weapons, making American diplomats and other policymakers wary of taking any steps that would destabilize the country's leadership. Pakistani authorities said that even though they turned down the U.S. request for special-forces staging sites on their territory, the Central Asiann nation of Tajikistan, on Afghanistan's northern border, had granted the United States authority to allow special forces troops to operate at a site on the border.Mr. bin Laden, a wealthy Saudi dissident, has lived in Afghanistan for several years under the Taleban's protection.The issue of a joint U.S.-\$ Pakistani effort to force the Taleban to turn over Mr. bin Laden has been discussed regularly for more than a year in visits to Pakistan by the director of central intelligence, George Tenet, and General Tommy Franks, commander of the U.S. Central Command, according to Pakistani officials. The chief of Pakistan's Inter-Services Intelligence, the country's equivalent of the CIA, was in Washington Tuesday when the terrorist attacks in New York and Washington occurred. A Pakistani official here said Licutenant General Mahmood Ahmed had gone to the United States specifically "to soothe U.S. concerns about Osama bin Laden and his possible ties with militant religious organizations in Pakistan." General Ahmed was stranded in Washington bv the nationwide air-traffic shutdown, and he met Wednesday with Deputy Secretary of State Richard Armitage in a more highly charged atmosphere created by the teloorist attacks.U.S. and Pakistani officials also met here throughout the day, wrangling over the potential consequences of U.S. efforts to apprehend or attack Mr. bin Laden, according to Pakistani officials. In an effort to demonstrate its compliance with UN sanctions against the Taleban, Pakistan's military government has frozen all accounts of the Afghanistan government in the State Bank of Pakistan, as weli as accounts being used by religious organizations in Pakistan to help finance the Taleban.

Envoys Quit Kabul

Western diplomats representing eight foreigners detained on charges of preaching Christianity left Afghanistan on Thursday as the United Nations pulled out its last remaining international staff, Reuters reported from Kabul. 
The plight of the eight foreigners, all of whom worked for the aid organization Shelter Now International, has been dramatically complicated by the attacks in the United States on Tuesday.

The mother of one of those detained, lleather Mereer, wept openly as she prepared to leave.She had been given permission to visit her daughter at least once.

\title{
FINANCIAL TIMES
}

September 132001

\section{Fresh setback for the Taliban regime}

By Farhan Bokhari

\begin{abstract}
Afghanistan's Taliban rulers on Thursday suffered another setback to their weakening position in the wake of terrorist attacks in the US, as states surrounding the war-torn country met in the central Asian republic of Tajikistan to intensify their support for the main anti-Taliban alliance.
\end{abstract}

Diplomats from Iran, Russia, Tajikistan and India discussed fresh assistance to the Northern Alliance, the main rival to the Taliban. A suicide bomb attack on the alliance's charismatic leader, Ahmad Shah Masood, on Sunday was seen as a significant victory for the Taliban, although his death is still unconfirmed.

But the states at Thursday's gathering discussed new supplies to the alliance at a time when the Taliban is preparing for possible US military retaliation after this week's bombings. Osama bin Laden, the Saudi militant, was named by Colin Powell, US secretary of state, last night as the prime suspect.

"The countries surrounding Afghanistan, opposed to the Taliban, see an opportunity to push for their fall. The expected US military action helps these countries because the Taliban would become weaker," said a western diplomat in Islamabad, the Pakistani capital.

Central Asia's former Soviet republics fear the Taliban because of its commitmentto push Islamic insurgents, including those trained under Mr bin Laden's organisation, into relatively liberal central Asia. Some of the Islamic activists trained in Afghanistan are thought to have travelled as far as Chechnya to support the Chechen separatists, intelligence sourees say.

The Vorthern slliance appears io be banking on the possibility of being recognised as Afghanistan's alternative leadership in the event of the Taliban eventually falling from power, western diplomats say. 
But Afghan ainalysts warn that the alliance's ability to hold a country where ethnicity has historically played a major role in politics, is still untested.

By contrast, the Taliban, mostly members of the main Pushtoon tribes, takes pride for eradicating widespread lawlessness, even though their extreme practices such as a ban on women working in most professions have made them deeply unpopular inside and outside Afghanistan.

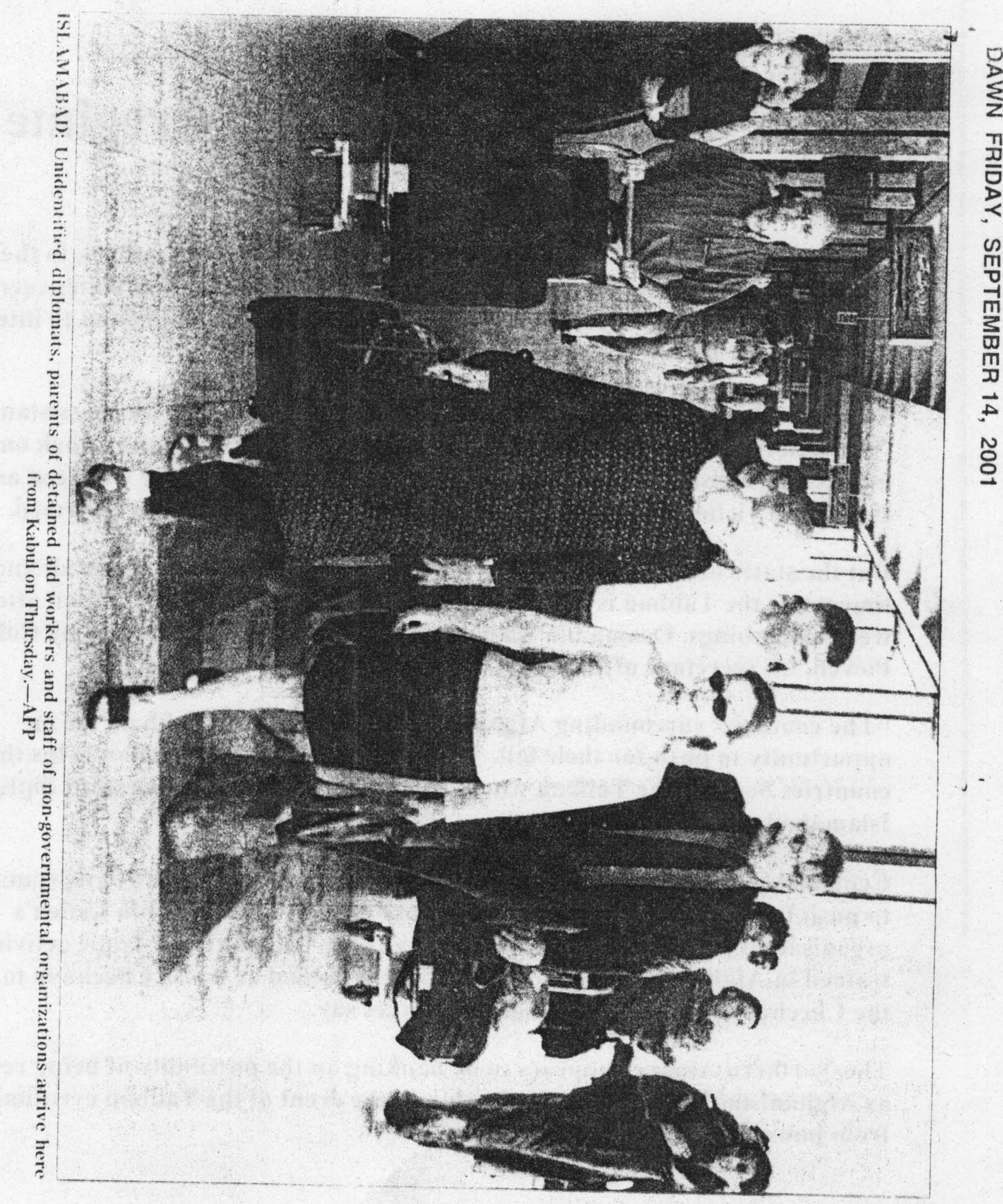




\section{Fridag fimes}

September 14-20, 2001

\section{The Taliban will never surrender Hamid Mir} argues that Washington is anti-Taliban because the Taliban
have refused to do its bidding

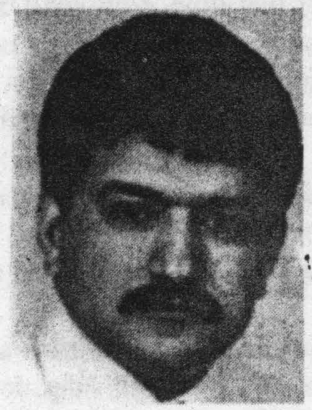

Six years ago, Nusrat Javeed of The News and I were invited to dinner in a Chinese restaurant by the then Interior Minister Maj ( ien (Retd) Naseerullah Khan Babar. "Why are you writing against the Taliban?"

te asked us. "Because the Americans are supporting them," I replied.

Babar gave us a long lecture about the Taliban but we were not ready to buy his theory. Finally, he picked up his famous stick in his right hand and said, "OK, you go to Kandahar independently, talk to them, come back and then see me."

A few weeks later, I was in Kandhar and had a meeting with Mullah Muhammad Umar Majahid. I asked him: "Why is Robin Raphael (then the US Assistant Secretary of State for South Asia) supporting you?" In response, Umar inquired "who is he?"

The Taliban were clearly not aware of who was supporting them and who was opposed to them outside Afghanistan. They knew only Pakistan. After coming back from Kandhar, I met Babar and told him that the Americans had a three-point agenda for the Taliban. One, they would like to use the Taleban against Iran. Two, they would like to pressurise them to arrange shelter and training camps to the rebels of Sinkiang in Afghanistan. And three, the Americans wanted to construct a gas pipeline from Turkmenistan to Pakistan through Afghanistan. But I told Babar that the Americans will not be able to achieve even a single objective because the Taliban will not take dictation from them. This time, Babar was not ready to believe me.

In October 1995, the California-based Unocal oil company signed a protocol with the Turkmenistan government to explore the prospects of constructing an oil pipeline to Pakistan through Afghan territory. When the Taliban captured
Kabul, the vice-president of Unocal, Christopher Taggart, confidently stated that "we regard it as very positive". He added that if the US followed Pakistan's example of cementing ties with the Taliban, this would open opportunities for them. Robert Oakley, former US Ambassador in Pakistan, was in due course hired by Unocal for lobbing its cause and was busy shuttling between Washington and Islamabad.

Benazir Bhutto was thrown out of power on November 6, 1996. I remember that a few days after her sacking, she told me that the American Ambassador in Islamabad, Thomas W. Simons, was not happy with her because the Taliban had refused to oblige Unocal. On November 16, 1996, the US assistant secretary of state Robin Raphel argued at a UN conference on Afghanistan in New York that the Taliban were a completely indigenous movement. Raphel said that the Taliban's policies may reflect extremism but the best way to moderate them was to engage them. She later went to Kandahar and had a meeting with top Taliban officials, but the policy of engagement failed because the Taliban signed a memorandum of understanding with Bridas, an Argentinian oil company, to develop the proposed gas pipeline.

Much later, when the US\$ 8 billion pipeline project had become a non-starter, they flared up and created an issue out of Osama Bin Ladin. They now demanded his extradition but the Taliban refused. This refusal lent credence to the Taliban because common Pakistans now realised that the Taliban were an independent force.

I have met Mullah Umar many times. He is convinced that the Americans are not interested in Osama Bin Ladin, that their real objective is to install a government of their own choice in Kabul which will take control of all the road links to Central Asia. The Americans clearly want to create problems not only for Pakistan and China but also for Iran. Some time back, Osama bin Laden revealed to me that once, 
when he decided to leave Afghanistan, he went to see Mullah Umar and informed him about his decision. But the Taliban militia leader refused to discharge him by saying "Don't give us a bad name."

There are some people who criticise Islamabad's Afghan policy. But is it not a reality that Pakistan is Afghanistan's only regional neighbour that has continued a dialogue with all sides of the Afghan political divide? Irrespective of the Northern Alliance's public stance, its leadership has actively sought Pakistan's intervention to initiate an intra-Afghan dialogue. Nobody can deny the fact that the Islamabad accord wals signed by all the Afghan parties in 1993 and remains testimony to Islamabad's commitment to a genuine home-grown peace process in Pakistan. It was under this accord that Sibghallullah Mujadidi became the President of Afghanistan in Kabul for six months. In fact, when he showed some hesitation in vacating the Presidentship for Burhanuddin Rabbani, it was Pakistan that forced him to step down. Yet, when Rabbani's term was up, in violation of the accord, he refused to step down with the encouragement of Washington and Moscow. Therefore when Pakistan's embassy in Kabul was attacked and Rabbani refused to implement the Islamabad accord, Pakistan was forced to support the Taliban.

There is pressure on Pakistan to withdraw its support for the Taliban. Some people argue that if Pakistan expects the US to support its Kashmir stance, it should not snub the US in terms of its requirements in Afghanistan. But the question is: what can the US do for Pakistan in Kashmir? Nothing. Suppose Pakistan were to withdraw its support for the Taliban, in how many weeks or months would India vacate Kashmir?

The day the Taliban are dislodged from Kabul, American, Indian and Isracli fighter planes will occupy all the bases close to Pakjstan's northern and western borders. They will start their covert operations not only against Pakistan but also against China and Iran. The Americams tried their best to convince the Talihan lo start a dihad in Sinkiang through a Saudi $N(i()$ called Rabta Alm-e-Islami, but the Taliban refused. Indeed, if Inday the Taliban were to agree to be used against China, all of their problems would be solved. But they are not opportunists. They have many faults and follies but they have become a defence line for Pakistan and China.

The claim is also wrong that Pakistan is suffering because of the Taliban. Pakistan faced sanctions in 1990 from the US but there were no Taliban at that time. Now the US is forcing Pakistan to implement the UN's onesded sanctions against Afghanistan, just to create misunderstandings between the Taliban and Pakistan. The UN wants to send monitors to implement its sanctions. And it wants Pakistan to facilitate the monitors and arrange security for them. But the UN should go and see the Pak-Afghan border which cannot be sealed. The monitors must go to the tribal areas and see that people from both sides don't accept the Durand line demarcated by the British government. They must listen to ordinary Pakistanis who support the Taliban because they think that the real crime of the Taliban is that they have refused to become puppets like Ahmed Shah Masood and Burhanuddin Rabbani. Both are responsible for bomb blasts in Afghanistan. Now Masood says that there has been a murder attempt on him in Northern Afghanistan by suicide bombers. This is a message for all the countries supporting the terrorism of the Northern Alliance to come to Masood's rescue.

The Taliban have proved that they are not weak, that they can get anywhere they want. They have brought peace to $95 \%$ of Afghanistan after 15 years but so-called civil society is not ready to recognize their contribution. There is women's police in Kabul, girls' schools are opening up in Kandahar, even a nursing school is working in Heart but western funded NGOs are not ready to speak the truth.

No matter what the pressure, the Afghans, a proud nation, are not ready to compromise. If the Americans want Osama to try and convict him then it is through negotiations with Kabul that a satistactory solution can be reached. Otherwise, they maty try again to hrowbeat the Talcban. But the Taliban will never surrender. 


\section{Fridag fimes September 14-20, 2001}

\section{Afghanistan}
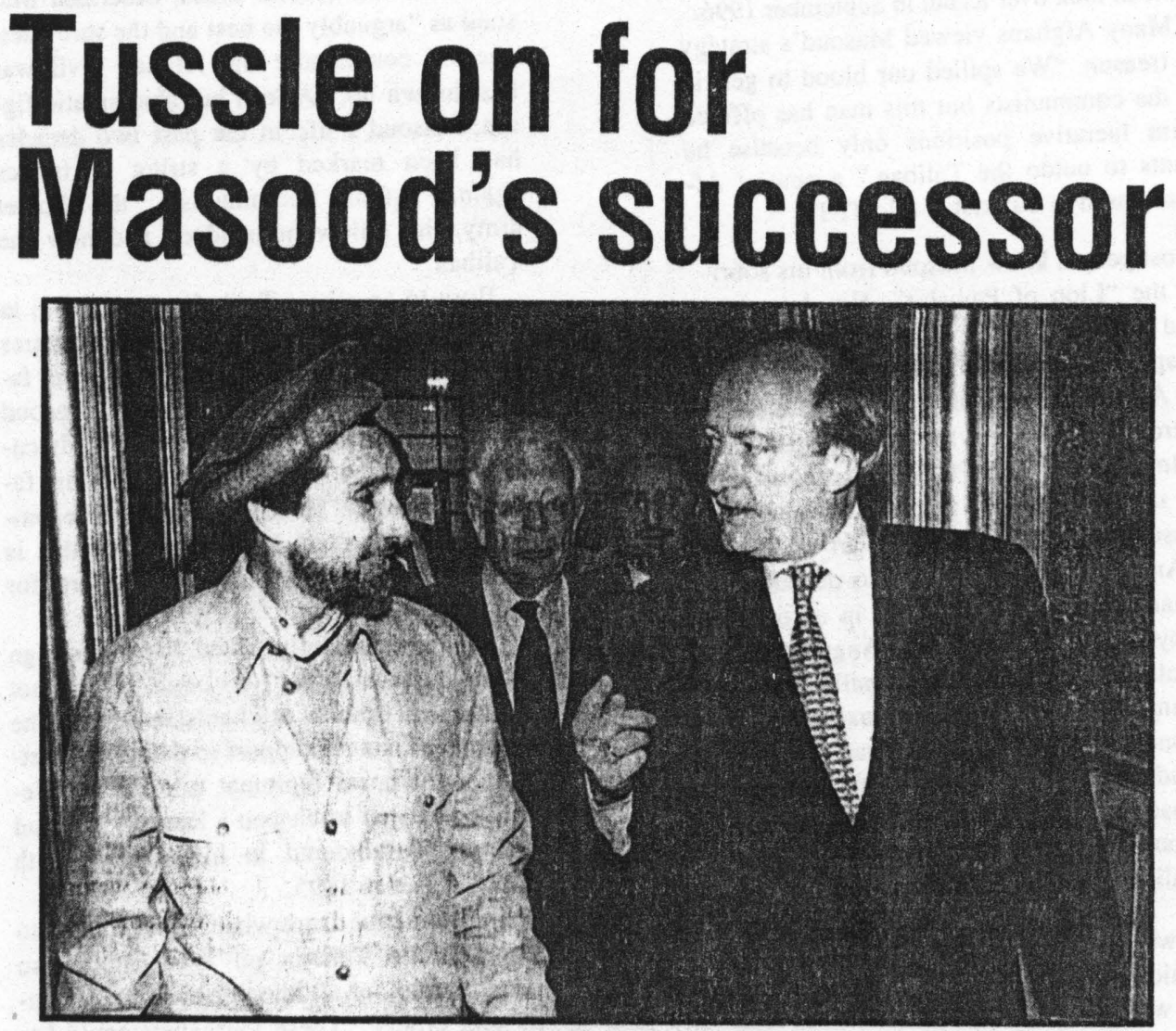

Paris (file photo): French Foreign Minister Hubert Vedrine greets Ahmed Shah Masoud

\section{Imtiaz Gul reports from Kabul}

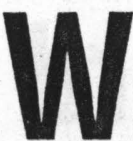
hile mystery still shrouds the fate of the Northern Alliance's commander Ahmed Shah Masoud, injured a few days ago in a bomb explosion, reports indicate he will never be battle-worthy again even if he survives.

Russian and Pakistani souices in fact indicate Masoud might already have expired. Itar-Tass, the Russian news agency reported Monday that Masoud had expired. The Alliance sources, however, deny the report and say he is being treated in a hospital in Tajikistan.

Whatever be the case, the search is on for his replacement. The Jamiat-e-Islami chief and former Afghanistan president Burhanuddin Rabbani is likely to retain his place as the spiritual head since he is considered too soft to lead the troops in the bittlefield. While some analysts point to Wali Shah Masoud, Ahmed Shah's brother, as the likely successor, sources in the Alliance told TFT that he is too "educated" for the job.

However, it seems the tussle is on among some of Masoud's generals. Insiders say the tug of war might not only weaken the Alliance but may even split it into many factions. The Alliance was never without internal differences but Masoud had kept it together because of his charismatic personality.

The fighting had become difficult even for Masoud despite his resources. When his troops lost big chunks of territory in the Takhar province a year ago, he opted to retreat to Khawaja Bahauddin in the Badakhshan province while using an obscure corner of Dushanbe, the capital of Tajikistan, for

his diplomatic overtures.

Over the past two years, Masoud had allowed former communist generals like Asif Dilawar, Salch Mohammad and Aman Brakzai to move into his closer circle, with the notorious Dilawar being made the chief of the armed forces' organisation committee. The Uzbek warlord Dostum, another former communist general, has also been Masoud's close friend while Gulbuddin Hikmetyar, an avowed enemy of Masoud since their univer- 
sity days, also joined up with him after the Taliban took over Kabul in September 1996.

Many Afghans viewed Masoud's strategy as treason. "We spilled our blood to get rid of the communists but this man has offered them lucrative positions only because he wants to outdo the Taliban," a neutral Afghan based in Tajikistan told TFT.

Most people know Masoud from his sobriquet the "Lion of Panjshir". His detractors called him the Darling of the West. But the best appreciation of his combative skill came from Alexander Rutzkoi, a veteran of the Soviet troops that fought the Muslim guerillas for almost a decade. "He is a master strategist," said Rutzkoi.

Masoud definitely knew the art of survival. And he survived some two decades of war and continuing civil strife in a country torn by ethnic hatreds. Larly August, when the Taliban appeared set to finally overrun the Panjshir Valley, his impregnable stronghold and birthplace in the Parwan province, Masoud staged one of the most surprising comebacks. In a blitzkrieg counter-offensive he retook almost all the areas he had lost to the Taliban, including the Bagram airbase.

Also, while the rise of the Taliban militia in the mid-1990s gradually demolished the myths woven around most of the seven lead. ing Mujahideen commanders, including Gulbuddin Hekmetyar, Masoud until now stood out as the best fighter among the old mujahideen leadership.

Sandy Gall, a British TV correspondent who met him several times, described Masoud as "arguably the best and the shrewdest guerilla commander the Afghan civil war has thrown up." A lean but charismatic figure, Masoud's life in the past two decades had been marked by a string of battles against Afghan communists, the Soviet army, the fellow mujahideen and now the Taliban.

Born to an ethnic Tajik family in 1948 in the Panjshir Valley, some 100 kilometres northeast of Kabul, and inspired by his father, a colonel in the Afghan army, Masoud fancied a military career but had to study engineering at the Kabul University at his father's insistence. He also dreamed of becoming the overlord of Afghanistan and that is why never liked Pakistan's support for Hikmetyar.

"Once he blatantly asked former foreign minister Sardar Assef why could a Tajik not become the ruler of Afghanistan and that he needed Pakistan's support to defeat Hikmetyar," a Pakistani diplomat told TFT in Peshawar. "I will teach you a lesson," Masoud reportedly thundered in his meeting with Sardar Assef in 1995.

Taking a clue from what has happened to Masoud, the Taliban on Wednesday also banned visas for all intending journalists until next orders. "These journalists could become guides for the Americans to target the Taliban leaders or Osama bin Laden as well," said an Afghan diplomat in Islamabad while explaining the ban.

\section{Taliban judge takes hard line on SNI prisoners}

\section{Imtiaz Gul}

\section{says the UN sanctions will continue to drive the Taliban to greater militancy}

Kabul - As the trial of the 24 Shelter Now International aid workers accused of trying to convert Afghans to (hristianity proceeds in Kabul, the question on everyone's mind is whether the prisoners will be put to death if the charge is proved against them.

Most media reports suggest the answer to this critical question is in the alfirmative. And these reports quote the Taliban decree 14 issued by Mulla Mohammad Omar, the militia's supreme leader who rules over 90 percent of the country from his southern stronghold in Kandahar.

The decree stipulates death for "Afghans who have converted, or found guilty of proselytizing", but prescribes a brief detention (up to 10 days) and eventual expulsion for the foreigners. However. the decree is "silent on the penalty for forcigners if caught red-handed", a distinction the Taliban foreign minister Wakil Ahmed Muttawakil made when pressed by the media on the subject during his press confer- 
ence in Kabul on September 6.

"It is unprecedented and that is why we have referred the case with all the evidence to the Supreme Court," Muttawakil said.

Two days later, Chief Justice Noor Mohammad Saqib almost defined the yardstick he intends to apply while determining the punishments for the four Germans, two Americans and two Australians. "Let me give you an example. In an artillery unit it is not the gunner alone who is responsible for firing, he obviously gets orders from somebody. Then there are others who arrange the ammunition for the guns on the orders. Thus you have to see as to who carries greater responsibility," the softspoken Sayib told reporters minules after the eight foreigners were whisked alway by armed security guards after thei firsi appearance at the court.

This explanation by Sacjib also put at rest the inferences almost all journalists had been drawing from his previous statements, which did not rule out death sentence. "I have been telling you and others that the punishment would be determined only after scrutinising the materials seized from the SNI offices and the investigations," the judge told reporters milling in his crowded chamber. The chamber also serves as the courtroom decorated with antique swords and Quranic verses in Herati embroidery.

Most of Saqib's colleagues - religious scholars and judges - sit in a semi-circle to the right and left of the chief justice. They have all been fuming over what they call a "very serious crime committed by the SNI," a fact manifested also in Saqib's scathing condemnation of the organisation in the Friday prayers sermon in Kabul's central Pule-Khishti mosque.

"These people first offered bread to the poor and then asked them to turn to a religion which was cancelled out by the advent of Islam," Saqib thundered in his sermon. Yet, he assured the accused on their first appearance in the court Saturday that they would get a fair trial.

"We will convince not only you but the whole world of our justice in this case because it is very important lor Afghanistan as well as the whole world," Sayjib said. He underlined the "crusade" the Taliban authorities have launched to purge Afghanistan of evil forces. Non-governmental organisations (NCOS), particularly church organisations like the Interna-

tional Assistance Mission (IAM) and SERVE, were also expelled from Afghanistan last week for promoting Christianity.

In addition to the display of what the Tali- ban claimed were Christian materials recovered from the IAM offices, the authorities also arrested as many as 35 Afghan workers of the organisation, which had been running eye and health clinics in Afghanistan since the mid 1960s.

The same day Foreign Minister Muttawakil announced strict enforcement of the existing rules and regulations governing the work of all NGOs, including the UN, and said that they would have to strictly abide by the laws. "It is a definite pattern which is likely to continue," said a western diplomat. "We think the Taliban authorities want to stay on top of the news as ? part of their drive for recognition until the UN General Assembly meets in October," he told TFT.

"Working conditions for the NGOs have become harder in the past six months or so, particularly for those being funded by the Church," admitted Dr. Willy Kaemmer, who has been working at Kabul's Indira Gandhi Hospital for Children for more than a year. $\mathrm{He}$ also conceded that the SNI case created a lot of mistrust and suspicion among all and sundry in Afghanistan and added to the pressures other NGOs and the UN are already faced with.

Looking at the trial, it seems that more than six months after the brutal demolition of the ancient Buddha statues, the Taliban hard-liners have yet another issue at hand to edge out the moderates. Within three days of the commencement of the trial, it became abundantly evident that the two under-currents within the Taliban hierarchy continue to be at odds for control of power.

"Whatever you heard in this regard earlier didn't come from us. We will decide the course of the trial, whether to allow the media or the diplomats to see the trial and whether the accused needed legal assistance," Chief Justice Noor Mohammad Saqib told reporters.

The prisoners, charged with preaching Christianity, were arrested in the first week of August and the organisation's offices sealed across the country. This action was followed by the expulsion of International Assistance Mission (IAM) and SER.VE on similar counts.

Just a couple of days before the commencement of the proceedings on September 4, foreign minister Wakil Ahmed Muttawakil had raised hopes of an open trial which would be open 10 diplomats, parents of some of the workers and the media. But he was publicly rebuked by Chicf Justice Saqib, who told reporters after several hours of consultations on the first day that the court will eventually decide whether the trial would be opien.

The Supreme Court comprises four benches 
- each with a chairman and four judges - qazis, but it is still not clear how big a bench would conduct lle trial. "Since it is an important case, not only for Afghanistan but also the entire Muslim world, we will try to have at many religious scholars on the bench as possible," the chief justice said.

Muttawakil in his press conference in Kabul on September 6 also sounded cautious and responded to guestions on the course and nature of the SNI-trial by saying: "I wouldn't interfere in the affairs of the judiciary." Clearly chastened, he tried to stay out of any further controversy.

"The moderates don't have anything in hand to persuade the militants of the virtue of dialogue and engagement. That is why even a person like Muttawakil has to speak the language of the hard-liners," said an observer in reference to Muttawakil's press conference.

"We have done our bit on narcotics, and aviation (by making the air travel safer through a new ATC system) but the world hasn't reciprocated yet, that is why we will also now do what suits us," the foreign minister said at the press conference. It seems the UN sanctions will continue to drive the Taliban to greater militancy.

\section{US should strike Pakistan: Afghan opposition}

MOSCOW: Washington should strike Pakistan in retaliation for Tuesday's dendly attacks in the United States rather than Afghanistan, a senior Afghan antiTaliban diplomat in Moscow said Friday.

"If the United States really wants to obtain results, they should strike Pakistan", said Ghulam Sakhi Ghairat, First Secretary of the Afghan embassy in Moscow.

The embassy represents the Northern Alliance of Ahmad Shah Masood and ousted President Burhanuddin Rabbani fighting the Taliban. Although Afghanistan gives shelter to Osama bin Laden, whom the United States considers the prime suspect for the deadly attacks, the Saudi-born millionaire "has already evacuated his bases (there) anyway," (Ghairat said. AFP

\section{ICRC to pull out more staff of Afghanistan}

GENEVA: More International Committee of the Red Cross (ICRC) staff are to be withdrawn from Afghanistan over the weekend following the departure of 40 staff on Thursday, a spokeswoman said on Friday.

About 14 more people are expected to be flown out to neighbouring Pakistan on Saturday at the earliest, Macarena Aguilar, a spokeswoman for the International Committee of the Red Cross, said.

Friday. is a holiday in Afghanistan and there are no flights out of Kabul. "These are people that had to leave the regions at the end of their work and were being taken to Kabul in any case, there's nothing special about it," Aguilar added. But Agullar emphasised that the remaining 16 expatriate ICRC staff in the field were constantly reassessing security. "The situation is changing all the time, they might decide during the weekend that more people will go to Pakistan," she added.

Four expatriate ICRC workers are in Kaioul, and two expatriate staff will stay in each of the six other main cities in Afghanistan where the ICRC is based. About 1000 Afghans employed by the ICRC would be able to continue with essential operations, she indicated. All 75 of the UN's international staff arrived in Islamabad, Pakistan on Thursday evening after the UN ordered a temporary evacuation of most aid workers in Afghanistan in the wake of the attacks in the US. - AFP

\section{Regional diplomats discuss Masud's health condition}

DUSHANBE: Diplomats and secret service agents. from India, Iran, Russia, Tajilistan and Uzbekistan have held talks in the Tajik capital to assess contradictory reports over the condition of Afghan oppositton Commander Ahmad Shah Mosoud, oflicials said on Friday.

Thitr securtity officials said: "No official document was adopted following the meeting on Thursday, but that all involved agreed to further support the opposition Northern AL- liance formerty headed by Masoud". Masud, 49, was reported in "very critical" condition on Thursday. Hę was the target of an assassination plot carried out by two Arabs posing as journalists who detonated a bomb during an interview on Sunday. However, Masud's aides denied that a permanent successor has been named to head the Northern Alliance which controls only a sliver of land in northern portions of Afghanistan, - AFP 


\section{UN warns of massive displacement in Afghanistan}

\begin{abstract}
JALOZAI: Some 1.5 million Afghans could be forced to leave their homes in search of food following the pullout of aid workers amid fears of possible US retaliatory strikes, the United Nations warned Friday.
\end{abstract}

"The World Food Programme for Afghanistan is currently helping feed three million people in Afghanistan's rural areas alone. If this support cannot be continued, massive displacement cannot be ruled out," it said in a statement.

"At least half may be forced to leave their homes to avert starvation, seeking survival either within or outside Afghanistan's borders."

All the UN's international staff was evacuated from Afghanistan on Thursday because of concerns about possible military retaliation by the US fol Tuesday's terrorist attacks in New York and Washington.

Several hundred staff at other international aid organisations has

\section{Afghan warlord Masud is dead}

\section{Monitoring Report}

ISLAMABAD: Ahmed Shah Masud, the Afghan Opposition National Alliance leader and 'Lion of Panjsheer Valley', has died, the French Foreign Minister was quoted by a US Radio, based in Delaware.

The French Minister gave an interview to a news agency in which the death of Masud was confirmed. He was seriously injured in a bomb blast few days back when two attackers, posing as TV journalists came to interview him and their TV camera exploded in his face.

The US Radio said his death was a severe blow to United States and the western countries that were planning to launch an attack on Afghanistan following the New York/Washington bombings. also left the country. Fears of an impending US attack have grown after US officials said they suspected Osama bin Laden, a Saudi dissident based in Afghanistan, of involvement in the attacks, which have left more than 5,000 people dead. The UN estimates that one in four Afghans - some six million people is at risk of death because of armed conflict, drought or chronic poverty. The war between the ruling Taliban and opposition forces is raging in 17 out of 32 provinces and the country has 900,000 internally displaced people.

There are more than three million Afghan refugees in Iran and Pakistan alone, most of whom were displaced during the Russian occupation of Afghanistan between 1979 and 1989.

Another 180,000 have passed through this makeshift camp near the northwestern Pakistani city of Peshawar over the past 12 months, mainly due to the war and three

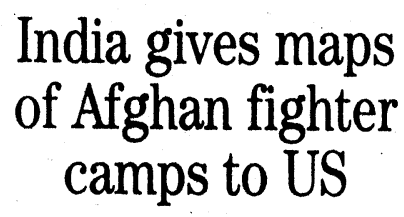

NEW DELHI: India handed over information on fighter training camps inside Afghanistan to the United States on Friday, a television news network said.

"Today India gave the United States intelligence detailed maps and information of terrorist training camps inside Afghanistan," Star News said.

The network said details were provided about Asababad, Sarkanar, Ghazni, Jalalabad, Khost, Paktya and Kandahar camps.

The United States has pointed to Saudi-born Osama bin Laden, sheltered by Afghanistan's ruling Taliban movement, as the prime years of drought.

"I don't know where in America or when the attack took place," said Hukam Khan, who has been living beneath a plastic tent here for eight months.

Khan said he had a farm with a big orchard on the outskirts of Kabul until he "lost everything to the warn.

"My country is already destroyed and it will be in further ruin if there is an attack from any country. I have not seen Osama, I have only heard about him.

Why the Taliban is holding him, I dont know."

In a report last month, UN Secretary General Kofi Annan called on the world community to draw up plans for the reconstruction of Afghanistan as part of a new ap. proach to the country's problems. The goal of the new approach would be to create positive incentives for the warring parties to agree to a political settlement.-AFP

suspect in Tuesday's terror attacks in New York and Washington.

The Press Trust of India (PTI) said India has expressed willingness to cooperate with the US on exchanging information on international terrorism.

"There is no question of holding back. We will be willing to cooperate," PTI quoted Home (interior) Minister L. K. Advani as saying after meeting new US Ambassador Robert Blackwill.

India's Cabinet Committee on Security decided on Thursday to allow US military forces to use its facilities if they needed them to launch operations in retaliation for the attacks. - Reuters 


\section{US may take over Afghanistan}

\section{Our correspondent}

WASHINGTON: As the United States prepares for retaliatory attack, there is a possibili $y$ that the coalition forces being tailored may just take over Afghanistan and install a new government under international supervision after overthrowing the Taliban.

The initial information about the strategic planning that is being mulled over indicates that the taking over of Kabul is being considered seriously.

The New York Times confirmed that "the planning and the language used by administration officials was read by military analysts as a sign that Secretary Powell, a former chairman of the Joint Chiefs of Staff, is preparing the way for a military force that could ultimately be used to occupy Kabul and overthrow the ruling Taliban."

Mainstream TV networks continued to discuss the strategic options once the US decides to attack Afghanistan. The major concern was how to go about it. A defence expert on CBS observed that "a comprehensive long-term strategic plan" was the only way that the world could resolve the problem of Osama and terrorism emanating from Afghanistan.

Another report in The Times reported about the Bush administration's efforts to galvanize an international coalition with.."its diplomatic and military stratey focused on trying to use Russia and Pakistan in an encircling movement on the north and south of Afghanistan.

Deputy Secretary of Defence Paul D. Wolfowitz added credence to this theory when he said that, "it's not just simply a matter of capturing people and holding them accountable but removing the sanctuaries, removing the support systems, ending states who sponsor terrorism".

Some interpreded the statement. as a veiled threat for Pakistan as well. Mr. Wolfowitz further said the United States and its allies would wage "a campaign, not a single action" to dismantle the terrorist group or groups responsible for this week's atlacks, and lo bring down the gevermments that sup. port them.

TV networks continued to discuss Russian views in joining the possible military operation in Afghanistan. ABC noted that Rus-

sia still has bases in Tajikistan and Uzbekistan and could also offer important intelligence to the United States for a military assault on Osama.

The New York Times also noted the irony of the situation where Russia and the United States appeared to be looking for ways to work together in Afghanistan. Reports suggest that deputy secretary of state, Richard L. Armitage, is taking a high level team to Russia to gauge what Moscow has to say on such a proposition.

Accompanied by a team of Pentagon and National Security Council officials, Armitage is scheduled to meet Russian first deputy foreign minister, Vyacheslav Trubnikov, in Moscow this week.

State Department said Armitage will be asking the Russians for their detailed knowledge of Afghanistan as well as for access to the Russian military facilities in Tajikistan and Uzbekistan. In addition t9, Russian aipbases in those two Central Asian nations a crack Russian division, the 201 st Motorized, operates on the border of Tajikistan and Afghanistan, officials said.

"I'm sure they will be helpful on many things," Secretary Powell said of the Russians on Thursday. "They do have a great deal of experience in Afghanistan, and we will draw on all of that experience."

However, not much was being discussed about China's view on this aggressive policy in their backyard. The issue also raises several questions for Pakistan. Whether a possible UN sponsored government in Afghanistan would bring stability in the region and may finally open doors for Central Asia.

The US side gave indications that the US might just do it alone. Powell said on Thursday that despite the current efforts to fashion an international alliance to conduct. the battle he envisions, the United States reserves the right to act alone to protect its citizens and its interests. "We will not be constrained by the fact that we are working with others as well, ${ }^{n}$ Secretary Powell said.

US military observers were heard saying on TV networks that the old idea of firing cruise missiles was being abandoned. There was no risk to American personnel; unfortunately for the Pentagon, there was little risk to the terrorist leadership either, said yet another report in The New York Times.

"Forget about the cruise-missiles," a French military expert was quoted as saying by The Times. "The only thing that is worth thinking about now is how to dismantle and eradicate the organization that brought the terrorism about. You can use air power in support of joint military operations. But the coalition that takes on the terrorists has to actually send in people with guns and that peans taking

Experts say conventional bombing of military headquarters and forces may not work this time. The use of ground troops supported by air power seems like must. But what worries the Americans are the high number of casualties in ground wars.

"Forget about avoiding casualties, "British expert John Keegan was quoted as saying. "Air power can play its part, but this is not a conventional enemy." The report said that with the political stakes so high, the United States may be obliged to seek unconventional partners. Afghanistan is remote from NATO's bases.

"Access to bases or airfields in Russia, once unthinkuble, or Pakistan, problematic because of its relations with the Taliban, could be important if the United States decided to take the fight to the terrorist cells in Afghanistan, said the report. 


\section{The Statesman Saturday, September 15, 2001}

\section{Afghan group offers support to US}

ISLAMABAD: National Islamic Front of Afghanistan (NIFA), a group of moderate Afghans, has offered fullest support to the United States at this crucial stage.

NIFA which remained in the forefront at the time of waging Jihad against former Sovict Union, stressed that Muslim Ummah should extend due cooperation to the US in rescue operations.

NIFA has condemned terrorist attacks in the United States. In a statement issued here, NIFA stressed that terrorists should be resisted through unified efforts world over.

NIFA expressed grief and sorrow over losses in attacks on the World Trade Centre and Pentagon. - PPI

\section{Gen Fahim hurt} in attack: Taliban

Statesman Report

QUETTA: The newlyappointed chief commander of Northern Alliance forces, General Fahim, has been injured in the ongoing fighting, Taliban officials here claimed on Friday. However, the news could not be confirmed from independent sources. Taliban said they heard the opposition forces communication by intercepting it. They had been making forceful push to take the northern areas from the Northern Alliance, the officials added. Gen Fahim had replaced Ahmed Shah Masood after he sustained critical injuries in a suicide bomb attack in Takhar province.

\section{Tajikistan may not offer US airspace}

ALMATY: Tajikistan said Friday it was not yet pre pared to guarantee the United States air space for launching retaliatory strikes against suspected terrorist bases in Afghanistan. "The question of bombardments is one thing, but its consequences are another." - AP
Taliban add to Pakistan's dilemma:

Nadeem Malik

The Taliban government on 1 Friday warned Pakistan nó to give any assistance to the United States in attackin Afghanistan or Osama bin Laden, saying that to do so would incur the enmity of Afghans, "which is more dangerous than any other thing".

Washington has asked Islamabad - one of only three countries that recognises the Taliban government in Afghanistan - to join its fighit against global terrorism, and Pakistan's military ruler General Pervez Musharraf has promiset full cooperation; although the exact terms have yet to be announced.

A Taliban government spokesman in Kabul alsO warned of revenge "by other means" if the US attacked its country in retaliation for Tuesday's terror strikes on New York and Washington.

There are also credible threats of widespread civil unrest, unleashed by armed relis gious groups in Pakistan, if the government is seen to be too accommodating to the US.

Senior official sources claim that Pakistan has offered the US the right to use its airspace against any group operating inside the Afghan border, without touching anyone in Pakistan's border city of Peshawar or adjoining tribal areas where religious fervo against the Islamabad adminis tration runs high.

Interior Minister Moeenuddin Haider says Pakistan's policy is to cooperate in efforts against terrorism. However, he demanded joint efforts under the United Nations charter, and he also indicated that Pakistan had taken extraordinary security measures, such as tightened checks at the Pakistan-Afghan border. Islamabad airport was alsö unexpectedly closed for six hours on early Friday morning for unspecified reasons. Some suggest it might have been to allow the movement of troops, possibly US.

The US is believed to have discussed with Pakistan the specifics of ground and air attacks inside Afghanistan, and action aganst Arab groups opet ating elsewhere. The capita is as with rumors that the American's are demanding the closure of all borders with Afghanistan so that no one escapes before possible US air strikes and commando raids.

Wendy Chamberlin, the US Ambassador to Islamabad, met Musharraf on Thursday, saying that it was a meeting of minds. "The president assured me several times in the meeting that he was with us," she said.

Pakistan already has a histo'ry of supporting US causes by acting as a frontline state against the Soviet Union during the Cold War era and its occupation of Afghanistan.

However, the US abandoned Pakistan at a crucial juncture, leaving it alone to face the present-day Afghanistan. Political analysts believe that any cooperation with the US particularly in the context of Afghanistan, should be under a comprehensive action plan and roadmap of future strategic relations. However, Pakistan canno go all out to support the US without consulting its time tested friends, such as Saudi Arabil and China. And its economit woes require that the goveri ment stay engaged with the Americans to ensure substantial support from International Financial Institutions. 


\title{
The Statesman
}

\author{
Saturday, September 15, 2001
}

\section{latest terc}

Osama not involved in

PESHAWAR:

Mohammad Omar Mullah leader of the Taliban, supreme Osama bin Laden cot'd not be held responsible for the massive terrorist attacks on the United States.

In comments which made it clear that Afghanistan's ruling Taliban has no intention of bowing to pressure to hand over bin Laden, Mulla Omar said the Osama could not have masterminded an operation of the sophistication and complexity of Tuesday's killer attacks on New York and Washington.

Mulla Omar said in a statement issued from Qandahar.

Report quoted Taliban leader said that only trained pilots could have carried out the attacks and that bin Laden did not have any under his command.

"The incidents which took place in America are testimony to Osama bin Laden's innocence because where are Osama's pilots and where were they trained?" Omar argued.

"Blaming Osama without any rhyme or reason is a separate thing and a move by the (Western) intelligence agencies to escape their own failure."

It is worth mentioning here that Mulla Omar's comments followed similar remarks by the Taliban's foreion minister, Maulvi Wakil Ahmed
Mutawakel, who siad that reports of emerging evidence linking Osama bin Laden to the attacks were not credible.

Meanwhile, another report quoted Qudratullah Jamal, the Taliban information minister.

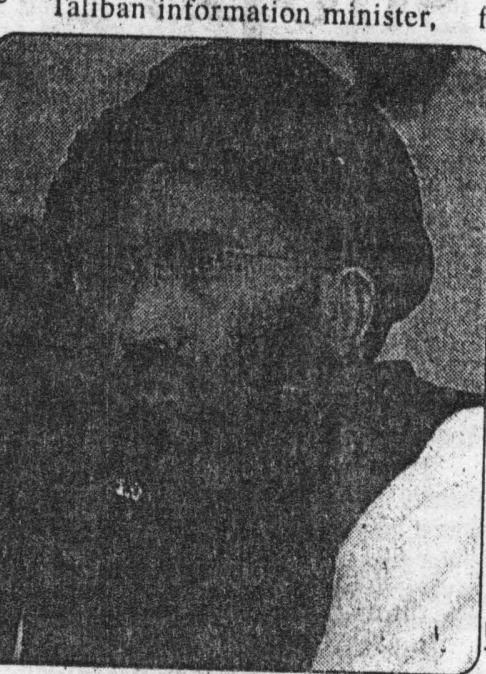

dismissed reports that Osama bin Ladin had been detained in Kandahar, the Taliban headquarters, saying his status had not changed in two years.

"He has been under surveillance for the past two years. Osama has been deprived from any communicationn means since then and the case is the same now too," Taliban minister said.

"He is now in an unknown location and, as before, has no means of contact with the outside world."
Meanwhile, reports from ISlamabad said Taliban leader Mullah Mohammed Omar, said that to surrender Osama bin Laden to the United States would betray Islam -impossible for a movement whose very existence is rooted in its image with Islamic purists.

In a statement read Friday by Taliban offirials in Pakistan, Omar said investigators were trying to link bin Laden to the attacks "unjustifiably and without any reason."

Abdul Salam Zaeef, the Afghan ambassador to Pakistan, told reporters that handing over bin Laden would be a "long process," and U.S. authorities would have to provide evidence against him.

"So far the Americans have not contacted us on providing any evidence. Our position is very cleàr," he said. We have condemned the attacks."

The Afghan Ambassador said under these circumstances, it is not possible for Laden to carry out such coordinated, well. designed and well-planned act of terrorism.

To a question he said handing over Osama Bin Laden to the United States for trila is the second phase. He said in the first phase, evidence against him should be produced. He said the Taliban government would be ready to talk in the light of the evidence, once it is produced. 


\section{The Statesman}

Saturday, September 15, 2001

\section{Asylum seekers may be terrorists: Australia}

SYDNEY

(Agencies):

Australian government lawyers told a court Thursday any ruling that would restrict its authority to keep out suspected asylum seekers could leave it vulnerable to disasters such as the World Trade Center attack in New York.

Solicitor-General David Bennett told the full. bench of the Federal Court in Melbourne the government needed to use its executive powers to refuse entry to "friendly aliens".

The government was appealing Federal Court Justice Tony North's ruling that 430 asylum seekers, who were stranded on Norwegian freighter the Tampa for more than a week after Australia refused to accept them, should be allowed to land here by Friday.

Bennett told the court the executive needed powers to keep out "friendly aliens" who the government believed represented a threat, even if there was no proof. "The pecple who did what happ ned in

\section{Russia doubts anti-terrorist strike}

YEREVAN (AgenciesP): Russian Defense Minister Sergei Ivanov on Friday tried to squelch speculation that a U.S.led anti-terrorist operation could be launthed against Afghanistan from formerly Soviet Central Asia.

"I don't see any basis for even the hypothetical possibility of NATO military operations on the territory of Central Asian nations that belong to the Commonwealth of Independent
New York yesterday were friendly aliens," he said. Bennett denied the asylum seekers had been detained on the Tampa but had merely suffered "a loss of freedom".

He said the asylum seekers brought the situation down on themselves. "We didn't, put them on the ship," Bennett said. "We didn't put the ship where it was. "They say they have right to come to Australia, We say they do not."

The mainly Afghan boat people are now on board an Australian troop carrier. HMAS Manoora, heading for Nauru, from where some of their number will eventually be transferred to New Zealand. Their claims for legal refugee status will be assessed by the two South Pacific nations, who have offered to process and house them in order to defuse the diplomatic row that followed the refusals of Australia, Norway and Indonesia to accept them. The Manoora will continue to steam towards Nauru pending the outcome of Thursday's appeal hearing.

States," "vanoy told reporters in the Armenian capital Yerevan.

Russia has about 25,000 troops stationed in Tajikistan, which borders on Afghanistan and is one of the few countries from which an offensive could be launched. Impoverished Tajikistan is still trying to recover from a five-year civil war between mostly Istamic opposition forces and the hard-line secular government, and it is frequently wracked by violence.
Noose around Afghans tightened in capital

ISLAMABAD (Online): Law enforcing agencies have beefed up security around foreign banks and offices of multinational concerns while a hunt has been launched in Afghan colonies to tighten noose around suspicious elements amidst threats of a possible strike on US installations in Pakistan.

The control of diplomatic enclave especially the American embassy has been handed over to military contingents while the intelligence agencies are maintaining strict 'vigil on the entire area. of

Strict chocking is carried out at all entry and exit points of the federal capital while helicopters of Army Aviation could be seen patrolling at regular intervals.

Taliban ask US for solid proof F P Report

PESHAWAR: The Islamic Emirate of Afghanistan (IEA) has honestly asked America to give clear and substantial evidence for what it considers Osama to be responsible for," $B B C$ monitoring quoted the Taliban's Radio Voice of Shariat as saying.

"And the IEA wilt hand him over to one of the Islamic courts of the world in order to be tried," it added.

The Taliban says bin Laden, who has a $\$ 5$ million U.S. reward on his head for suspected involvement in the deadly 1998 bombings of two U.S. embassies in Africa, told them he had no role in Tuesday's terror attacks. 


\section{KHYBER $M_{\text {AIL September 15, 2001 }}$}

\section{Taliban seek Pak support}

\section{against US attacks}

ISL $\triangle M A B \wedge I)(() n l i n e):$ The laliban firday urged Pakistan not to "allow its soil to be used for an allack on Alghanistan" by US armed forees and denied press reports that the laliban leader Maulana Mohammad Onar had gone into hiding.

"We don't know what the U.S. is planning about (an) allack on Alghanistan, but we have reports that there is something cooking against our country," the Taliban's Ambassador to Pakistan, Abdul Salam Lacel, told a press conference here.

He said if the US takes such an action, the brave people of $A$ ighanistan are fully capable of countering such altacks and it would be a grave mistake on the part of the United States.

He said the Taliban was in constant touch with the

Pakistan government. He expressed the hope that Islamabad, being an old friend and supporter would not allow the US to launch any strikes from Pakistani territory. Asked if the Taliban expected U.S. retaliatory strikes, Zaeef replied: "We cannot rule it out either."

"We welcome (U.S. President George W.) Bush's comments that the investigation will contimue umtl ther: is proof of who is respunsible," he said. "Unreasoned and emotional measures should not be taken."

Ruling out any speculations of handing over bin laden the Taliban envoy made it clear that Osama was a distinguished and honourable guest of Afghanistan and the Afghan people know how to protect their guests.
"We're ready to negotiate the fate of bin Laden with the U.S. provided Washington comes out with enough ovidence of his involvement in terrorist activitios," Zaeef said.

He explained that the question of extraditing bin laden to the U.S. could be considered only if evidence against the Saudi renegade was produced.

"We will be willing to talk to the U.S. in the light of evidence Washington may come out with," Zaeef said, insisting that bin Laden was not involved in Tuesday's horrendous attacks adding that any false or propagated evi. dence against bin Laden would not be tolerated at any cost.

Zaeef claimed bin Laden's hand in the U.S. attacks was impossible because he did not have the apparatus to communicate with anyone in or outside Afghanistan.

"All means of communications have been taken away from him and he is not allowed to meet anybody.
Ulema warn against letting US to use Pak soil for attacks

By Abrar Saeed

RAWALPINDI - Ulema belonging to various sects in their Jumma congregations here warned the government not to let America use its soil and airspace against the neighbouring Islamic state of Afghanistan and vowed to resist any such move.

Amir of Jamiat-i-Ahle Sunnat Wal Jamat Maulana Ashraf Ali, Naib Amir of Jamat Maulana Qazi Abdur Rasheed, Qari Atiqur Rehman, Maulana Abdul Ghaffar Tohaidi, Qari Abdul Malik, Maulana Zahoor, Ahmad Alvi, Maulana Mohammad Nazir Farooqi and Qari Ehsanullah in their Jumma sermons said that the Americans nowi wanted to use the fecent terrorist âttacks in Washington and New York against Afghanistan and Usama bin Laden.

They warned the military gov: ernment of Pakistan not to be part of this conspiracy against the Afghanistan and Usamabin Laden. They said that people of Pakistan would not let the government use the Pakistani soil and airspace against the brother Islamic state of Afghanistan and would make things difficult,for the government if any such step was taken.

They said that the United States should put their own house in order and review their policies which had invited such terrorist attacks. 


\section{Bombing can't make \\ things worse for Afghans}

KABUL (AFP) - Growing signs that the United States is gearing up for a military attack on Afghanistan were greeted with weary resignation by the residents of Kabul on Friday.

After more than two decades of war, even the prospect of an onslaught by the world's most powerful military machine left many of the shattered capital's inhabitants unfazed.

'I am not worried at all, now we are used to it,' said Faiz, a 33-yearold butcher in the Shari-Nau market district of the Afghan capital. 'Since I was 12 all I have known is fighting and more fighting.

'So once again innocent people will be killed and nobody will care about it,' he added with a shrug.

Nasir Ahmad, another mutton seller in the Shari-Nau, said it was

inconceivable for Afghans $t$ col. template handing over Osama bin Laden - even if the price was suffering US airstrikes.

'If a guest comes to our home and some else wants to kill him, he should first kill us and then our guest - even if the guest is an infidel, not a Muslim like Osama.'

Mirza Jan, who was selling fruit in the market, admitted to being fearful of the possible US attack. 'That will add to our pains,' he said. 'We have already suffered enough.' Jan said he did not see why ordinary Afghans should not have to pay for the Taliban's decision to offer bin Laden shelter, especially given the role of America in helping to create the Taliban in the first place.

'I have not told Osama to come to Afghanistan. I have not chosen

the Taliban to reign over us. If they do something wrong, why should I pay for that? 'Both Osama and the Taliban were imposed on us by America,' he said.

The likelihood of a US attack was widely seen as having increased after Washington on Thursday named bin Laden as a suspect in the investigation into this week's massive terrorist attacks on New York and Washington.
'Now they (the US) are indicating in clear words that they are going to strike,' Abdul Hai Mutmaen, a spokesman for the Islamic militia's supreme leader Mullah Mohammad Omar told AFP.

He said he expected the attack to be far more extensive than the limited cruise missile strikes launched by the US in 1998 over

bin Laden's alleged involvement in the bombing of American embassies in Africa.

'It will be at a very' high level. Last time they only attempted to strike a (bin Laden) camp. This time they want to eliminate the whole system and government.

'They have been looking for a pretext and now they have found one.'

Suta Shah 64 an old man selling potatoes, onions and tomatoes from a wheelbarrow said God would punish the US if it did attack Afghanistan.

'We have our owner, we have our Lord. If they attack us the Almighty will punish them. They should be careful.'

'Why does America want to attack us - what have we done wrong to them?'

\section{Afghans throng border for entry into Pakistan From Shamim Shahid}

PESHAWAR - In view of the anticipated air raids by the United States on Afghanistan in retaliation for the terrorist attacks on World Trade Center and Pentagon, thousands of Afghans on Friday thronged the Pak-Afghan border at Torkham to enter Pakistan.

"It was the biggest ever gathering of Afghans on western side of the border in the recent past," a Pakistani officer remarked. However, in the light of the decision of the NWFP Governor's in January 2000 , those lacking valid travelling documents were denied entry. Apart from the Afghan nationals, the foreigners continued to flee from Afghanistan on third consecutive day (Friday) whereas 20 foreigners entered into Pakistan at Torkham. They included 16 men and four women belonging to Germany, Spain, Australia, Japan, Ireland, Norway, France, United Kingdom and other countries.

But like in Afghanistan these foreigners also feel unsafe in Pakistan. In this respect, the UNH-
$C R$ has stopped the screening process of Afghan refugees at Jalozai. Similarly, most of the diplomats, particularly from the United States have already been confined to their homes and hotels.

Surprisingly, on the one hand the foreigners are fleeing from the Afghanistan but on the other Peshawar has been jampacked with

scores of foreign journalists. During a visit to local Pearl Continental, Green Hotel, Hotel Grand and a number of rest houses, this correspondent saw a large number of foreign journalists waiting for hot news.

Reports from Torkham reveal that thousands of Afghans, fearing US raids on Afghanistan thronged the Pak-Afghan border to enter Pakistan. These Afghans, mostly women and children, want to join their near and dear ones residing in Peshawar and its suburban areas. But they were denied entry for lacking valid documents. However, some of them got entry by greasing the palm of the law-en- 
forcing personnel at Torkham border.

Due to an unprecedented rush of Afghan nationals at Torkham the authorities concerned deputed additional contingents of Frontier Copps and Khasadar Force to control any untoward incident. An officer said that around $300 \mathrm{Afghan}$ nationals possessing legal travelling documents were allowed entry.

In Peshawar, rumors of possible US strikes against Afghanistan continued doing the rounds, creating unrest among the locals. Since Friday morning there was rumor of landing of US commandos in Peshawar. A large number of people also ranged up the offices of newspapers in this regard.

\title{
UN slashes budget for Afghan mines
}

\author{
Bureau Report
}

PESHAWAR, Sept 14: The United Nations Office for Coordination of Humanitarian Assistance has reduced by 25 per cent its budget for mine action programme in Afghanistan.

The Afghan campaign to ban landmines, in its report, on Tuesday said the budgetary cut would badly affect the mine clearing operation in Afghanistan, which is still one of the heavily mined countries in the world.

Mines planted by the invad. ing Soviet troops and later by the Mujahideen groups are taking a heavy toll on the Afghan people, killing and maiming scores of them, it added.

The mine action programme has cleared $224 \mathrm{sq}-\mathrm{km}$ of mined areas in Afghanistan from 1990 to December 2000, destroying 215,908 anti-personnel mines, 9,897 anti-tank mines and 1.30 million unexploded ordnance. The mine clearance operations cost $\$ 172.8$ million.

The report said the budgetary cut would adversely affect the ongoing operations as areas measuring about 732 sq-km still needed to be cleared.

"Obviously, due to the ongoing war, the Afghan authority is not in a position to pay for such an exercise," it said.

The report expressed concern over the reduction in the budget and appealed to all donor countries to continue their humanitarian financial assistance to the mine action programme.

\section{THE PAKISTAN TIMES}

Saturday, September 15, 2001

\section{Panjshir valley \\ an Afghan Shangri-La}

KABUL: Panjshir Valley, the Afghan Shangri-La is a natural fortress. The lush green valley was surrounded by sheer rock face. There are no crowds, no Big Macs, no symbols of corporate. greed.

The Panjshir offers magnificent hospitality, pure mountain air, pristine rivers and immaculate landscapes filled with artsy intrusions " "Still life with tank" is the great Afghan contribution to modern art). But bring your own Bordeaux and Bric: the menu is a little too biased toward mutton kebab, reports Asia Times.

In the unlikely event that Afghanistan's civil war between the Islamic Emirate (the Taliban) and the Islamic: State of Afghanistan (opposition) comes to an end, the best market positioning for the Panjshir Valley would be as the epitome of the Asian Shangri-La To top it all, the Panjshir (five lions) boasts a resident lion, unrivalled both in charisma and righteous freedom struggle credentials; Ahmad Shah Masud - injured in a suicide bombing, victor over the Soviet Red Army, bete noire of the Taliban and vice president of the Islamic State of Afghanistan.

As the heart of the Afghan resistance against the Taliban, visitors to the Panjshir expect to confront countless intimations of war - from the rumble of military helicopters to the conceptual art of accumulated destroyed tanks and armoured carricrs. Mujahiddin or not, almost anyone carries a kalashnikov. But there is also a semblance of "normal" life, at least by Afghan standards. The chaikhanas (tea shops) are lively, the bazaars are stocked with products from Iran, Pakistan and most of all China. Kids, who don't appear to be undernourished, swim in the Panjshir River. Peasants harvest wheat. And unlike Taliban-controlled areas, girls actually go to school.

Almost every family exhibits a photo of a benevolent "Saint"

Masud in their visitors' room, but underneath there are always the inevitable few photos of dead relatives, killed during the years of war. Camps for what are officially called internally-displaced persons (IDP) are scattered all over the valley, mostly people who have fled from the fighting in the torrid Shamali plains in the central regions of the country.

Make no mistake, though, this Shangri-La is no bed of roses. The chief doctor at Rokhah vil- 


\title{
THE PAKISTAN TIMES
}

\author{
Saturday, September 15, 2001
}

lage hospital is adamant, "Our main problem is no food. And at least 20 children froze to death last winter alone. There is no protection for them in those flimsy tents".

At the Doctors Without Borders/Medecins Sans Frontieres (MSF) office in Rokhah, a nurse from southern France is extremely gloomy when referring to the living conditions of most families. According to the MSF,

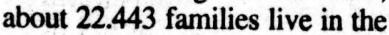
valley - plus 2,900 IDP families,

averaging eight or nine people. At their office in Rokhah, the doctors have between 50 and 60 consultations a day, and about 200 in the larger Gulbahar village. According to the nurse, the main problems are malnutrition and diarhoea.

But as far as the "international community" relates to war zones, the Panjshir couldn't be sexier. It is the domain of a superstar Masud. It is the symbol of the resistance against the bad guys - the Taliban. No wonder it is now the definitive political fashion accessory on a trip to Afghanistan compared to the hardcore conditions in provinces such as Badakhshan and Takhar.

Such a glamorous destination could not but host a perpetual travelling motley crew. The cast of characters assembled on a recent week this summer was more than representative.

There was a creepy Italian photographer with a dubious agenda (he was later expelled

from the Islamic State, without even knowing it, alongside his posh English girlfriend of the "let's-get-some-thrills-in-exoticplaces" kind). There was a French photographer-filmmaker, shooting a Masud documentary and dreaming about being the only one at the supposedly imminent recapture of the strategic city of Taloqan in the northeast.

There was an editorial writer from a Parisian fashion magazine who arrived with 20 kilograms of beauty products: certainly Hermes and Lancome are an absolute must for IDPs eating grass.

There was a politician from Geneva whose main aim was to use sexy Masud as bait for her ambitious mayoral campaign back in Switzerland.

And there was the most complex character of all - Chekheba, an Afghan-Parisian hybrid, daughter of one of the oldest and most prominent families in Kabul. Het agenda, apparently, was to use her impeccable

Afghan connections to bring influential Europeans to the Panjshir and so reinforce the perception that Western Europe supports a progressive Afghanistan. She is the president of Association Afghanistan Libre, a Paris-based NGO.

There was the matter of the building of a school for girls (there are only two schools in the valley). In theory, the politician from Geneva donated $\$ 20,000$ for that purpose, but in fact a Swiss government body pledged the money. There is no school, yet but that did not prevent a splendid Afghan photo opportunity to be later exploited to seduce Swiss voters.

The minister of foreign relations provided himself the land for the school building. It is adjacent to his house. There was ab solutely no guarantee from any. one that the money would serve for the sthted purpose - the building of the school. And it was clear there would be no follow-up from

any of the parties involved. Asked about the teaching methods to be employed at the new school, the Afghan-Parisian was definitely puzzled. I ncrot w

In the end, the Western European groupies all got what they wanted - their 15 minutes with the Super Warrior. With impeccable flak jacket, trademark Chitral hat from the Pakistan region of the Hindu Kush, and 700 shoes, Masoud can be as dazzling as U2's Bono Vox. The women were on the verge of throwing him their knickers. And after a few more photo ops, everybody happily boarded a chopper back to Dushanbe, Tajikistan, and then Western Europe.

A cynic would say Masud is using European NGOs and politicians as his luxury shield. But a realist would say that the effect of a local product - a small red and yellow melon - could maybe offer the best metaphor for the Panjshir Valley: you can smell it, but you can't eat it. -NNI

\section{NZ govt slams lawmaker over Afghan refugee query}

WELLINGTON: The New Zealand's government on Thursday rebuked a lawmaker who queried a move to accept Afghan asylum-seekers in the wake of the unprecedented terror attacks in the United States this week.

"It is reprehensible to link the terrorist attacks in the US to refugees in New Zealand, let alone the Muslim community," Deputy Prime Minister Jim Anderton said in a statement.

His remarks were in reply to a question from nationalist opposition MP Winston Peters about the government's decision to accept 145 people, mainly Afghans, rescued off the coast of Australia's Christmas Island.

"Having regard to the recent terrorist attacks on the United States, is the government still offering to take 145 Afghan asylum-seekers; if so, why?" Peters asked in parliament.

"What guarantees does (the government) have that there's going to be proper security surveillance of these people?" he said.

Anderton said it was unacceptable to link all Muslims with the crashing of hijacked airliners into New York's World Trade Centre and the Pentagon earlier this week.

Anderton said he had heard reports on Thursday of people in New Zealand being spat at because they were thought to be Muslim

"Even if fighters are ultimately shown to be responsible for the terrorist activity, refugees to New Zealand are, by definition, trying to get away from persecution from extremist regimes and they can hardly be blamed for that," Anderton added.

Peters said his question was about security, not race, as Chinese Triad gang members pad in the past slipped into New Zealand as immigrants. -Reuters 


\section{Pakistan freezes Afghan nationals' accounts}

\section{Hasan Khan}

PESHAWAR: Pakistan Saturday froze the bank accounts of some 300 important Afghan nationals including present and former ministers and war commanders sources said here.

High-ranking sources in the banking sector confided to The News the Sate Bank of Pakistan issued a circular on Saturday to the banks to freeze the accounts of some 300 important Afghan nationals till further orders.

The SBP, sources disclosed, had provided a list of names, which include some ministers of the Taliban establishment and former ministers and war commanders to all the branches of the scheduled banks. The decision, the source said, is seemed to be taken in the backdrop of US charter of demands presented to the Pakistani government to stop all sorts of moral and material support to the Taliban regime.

The sources said the freezing of bank accounts of the Afghan nationals, particularly those in the high positions, was the first step in that direction taken by the Musharraf administration.

Most of the names, said the sources, in the list provided by the SBP to the scheduled banks are the leaders of the Taliban administration. However, when the Chief Manager Omar Khitab of the Sate Bank of Pakistan, Peshawar, was contacted at his home on telephone he expressed ignorance about any such decision.

"It might have been decided in late hours," Khitab said adding that in office hours he had not receive any such order from the head office. "Till now I have no information about any order," he concluded.

\section{Plan to install Zahir Shah in Afghanistan}

Muerat Javeed

ISLAMABAD: The United States of America has "virtually bought" the idea that "within minutes of taking over Kabul," the former king of Afghanistan, Zahir Shah, should be installed as the legitimate ruler of that country.

Highly reliable sources from the diplomatic community of Islamabad also revealed to "The News" that the plan to restore Zahir Shah was originally drawn by NATO-related security experts from a European country. They already have been working on restoring the former king through the so-called "Rome Process" for several months.

The person and aides of the former king, who is living in Italy since dethroned by his cousin in 1974 , were actively consulted during preparations of the said plan.

Despite the plethora of often conflicting and confusing news as to how the USA would begin fighting "the global war of this century against terrorism," most diplomats in Islamabad do not expect the repeat of attempts to cripple Osama Bin Laden through aerial attacks only, as Clinton tried doing in 1998.

"Washington has to commit its ground forces this time around," said a European diplomat.

As if to substantiate the perception of his colleague, another diplomat recalled that an oil tanker, carrying 235,000 barrels of diesel fuel was already approaching "Diego Garcia, the British developed military base in the Indian Ocean. A good number of B-52 bombers are also sta. tioned there with the capacity of firing the cruise missiles.

But the same diplomat would give more importance to the mobility of another oil tanker to Moron air base in the south of Spain. KC-10 tanker aircraft which can do the refueling of the US fighters in the air are stationed on this base.

The diplomat believed that with the word go, troops of 82nd air- borne division, stationed at Fort Bragg, North Carolina and the Kentucky based 101st would begin flying off to the assigned destinations. They can also be joined by soldiers of 1st Infantry, already on exercise in Kuwait these days. As many as 500 Abrams tanks are also available to them. Many diplomats this correspondent talked to insisted that with the availability of such a massive number of highly trained troops, the USA did not need the support of soldiers from any other country to take control of Kabul.

Speculations were rife that Russians were willing to do "the soldiering for Americans - in Afghanistan," if provided with the lethal air cover. But not less than the person of Russia's chief of staff categorically refuted the said possibility Friday evening.

Even a historic. ally like Britain didn't expect the Americans to ask. r. the supportifitheirground troops for combat operations in Afghanistan.

"For various reasons," said a diplomat, "the Americans have to appear fighting it solo on the ground, at least during the opening moves of the global war against terrorism."

Since Vietnam, Washington was always shy to commit the ground forces, especially when it would come to defend "foreign countries." The possibility of the US soldiers coming back in "body bags" would make the American presidents shiver. It was to avoid the potential backlash of body bags again that Bush the senior did not pursue the Gulf War to its logical end, i.e., the toppling of Saddam Hussain and installation of an alternative power structure in Iraq.

But thousands of deaths of average Americans under the debris of World Trade Center have radically altered the context. The American soldiers have to appear avenging the death of their citizens now.

Russia, India and Israel are almost loud and indecent in expressing their hasty willingness to join the USA in fighting "the global war against terrorism." But Washington fully realizes that they want to join for their very own reasons.

The USA also appreciates the limits of Tajikistan and Uzbekistan, 
The News on Sunday

September 16, 2001

where Islamic radicalism is becoming a serious political threat.

The US public opinion wants to see Afghanistan "wiped off the world map" since September 11, no doubt. But as a superpower with global interests, United States of America can't afford reacting in arrogant haste.

A senior European diplomat told The News that while moving into Afghanistan, Washington will do everything to convey it to the mass of Muslim people that it had nothing against them per se. "It will also want to appear as if prudently caring for the people of Afghanistan while taking its revenge," he said.

After an intense study of the country profile of Afghanistan, many strategic planners of the USA and NATO are reportedly convinced that Taliban relish the public support no more. They were initially welcomed for providing security and peace. But they terribly failed to lead the economic and social regeneration of their country. Clueless about the means of doing that, the Taliban leadership kept behaving like

\section{Opposition takes stock after Masud demise}

DUSHANBE: Leaders of the Afghan Northern Alliance held talks at a secret location in northeasterhntafghanistan Saturday after the death, of their charismatic "military commander Ahmad Shah Masud, diplomatic sources said.

Field commanders, political leaders and diplomats were expected to attend the gathering, called to take stock of the situation in the light not only of Masud's death, confirmed after the "enfant terrible" of the world.

The smashing of Buddha's statues in Bamiyan, the distinct dress code for non-Muslims and trial of some aid workers reflected a frustrated mindset.

"As a recognized patriarch," said a diplomat, "Zahir Shah can surface as the true savior in such a dismal state, once the.American forces are there to ensure' his protection."

Zahir Shah, we are told, is also required "so that Afghanistan remains a united and viable country after the US attack. ${ }^{n}$

In the absence of a credible alternative to the Taliban government, Afghanistan would be there for grabs once the Americans devastate it. Iran can stretch its control up to Heart; Tajikistan may gobble the Tajik areas and Uzbekistan goes for Mazar-e-Sharif etc.

It will be the Pushtun majority which will get desperate without any takers.

And, that ensures total chaos, especially for Pakistan which has the Pushtun dominated areas in the NWFP and Balochistan.

"It's in everybody's interest, therefore, that Afghanistan remains united, even after Taliban," said a Middle Eastern diplomat.

"Propped up by the Americans," said the same diplomat, "Zahir Shah can always tell his people that he came back to liberate them from the miseries, perpetrated on them first by the mis- guided communists and later the inexperienced Taliban, who virtually became the hostages of Afghan-Arabs like Osama bin Laden. It's about time that nonAfghans are sorted and sent out so the Afghan people could concentrate on rebuilding their country."

Our sources claimed that some NATO experts were convinced that the return of Zahir Shah would generate "tremendous hope" amongst the mass of Afghan people.

"Under the security blanket of the US forces, they could think of rebuilding their country as Germany and Japan did after the devastation of World War-II," said a European diplomat.

The combined presence of Zahir Shah and the American troops in Afghanistan will also attract the waves of expatriate Afghans of the elite community.

"With a Marshall Plan type arrangement for the rebuilding of Afghanistan, the exiled bureaucrats, diplomats, academicians, scientists and entrepreneurs can resurrect their country in no time," the diplomat believed.

This in the long term, he continued, "will project the USA as a real friend of Afghanistan, rather a reckless and arrogant enemy. And the whole Muslim world will also get some positive message about the sole superpower of these days." the meeting opened, but also ahead of possible US military reprisals for outrages attributed to Osama bin Laden, the Saudiborn businessman who is being sheltered by the Kabul authorities.

Western reporters were being flown from Dushanbe to the meeting in the Panjshir Valley, Masud's traditional stronghold and support base.

The various leaders are expected to issue a statement summarising their view of the current

\section{situation.}

Deposed uAfghan president Burhanuddin Rabbani was to attend the meeting along with foreign minister Doctor Abdullo and Masud's deputy, General Mohammad Fahim, who last Tuesday was named "temporarily" to replace Masud as the apposition
commander.

The meeting was likely to be a sombre affair following the announcement by a Rabbani spokesman that Masud had 


\section{The News on Sunday}

September 16, 2001

succumbed early Saturday to wounds sustained after two Algerians posing as journalists detonated a bomb during an interview at his base last Sunday.

Despite persistent reports from both Russian and US intelligence sources that Masud had died soon after the attack, Afghan opposition spokesmen maintained for as long as possible that he was clinging to life.

The 49-year-old military strategist was regarded as the lynchpin of the fragile opposition alliance, made up largely of minority ethnic groups.

His troops hold the strategic Panjshir valley north of $l$ abul, his native region, as well as rugged mountainous country in the far northeast where they are the last obstacle to the Taliban claiming control of all of Afghanistan.

Western capitals and Russia fear that the Alliance, which currently controls.less than five percent of Afghanistan could fall apart withoutwkasud to provide inspirational leadership to bridge its sectarian divisions.

Moscow in particular is worried at the potential threat posed by a complete Taliban takeover of Afghanistan to the former Soviet republics, already unsettled by growing Islamic militancy, along its southern flank.

However Alliance leaders are also concerned at the possible consequences if the United States launches military reprisals against Afghanistan for sheltering bin Laden, regarded as the prime suspect for the terror attacks in New York and Washington Tuesday in which more than 5,000 people are believed to have died.

The opposition envoy to Iran, Mohammad Kheirkhah, said he hoped no such atlacks would take place, but if they did, they should "spare the people."

Russia and Afghanistan's immediate neighbours are also concerned US military action could trigger a massive outflow of refugees. -AFP

\section{Western countries mourn death of Masud}

BRUSSELS: European Parliament President Nicole Fontaine said Saturday she was "profoundly saddened and dismayed" by the death of Afghan opposition commander Ahmad Shah Masud, who died of wounds suffered in a suicide bomb attack last Sunday.

"I feel the greatest concern for the future of Afghanistan," Fontaine said in a communique issued by her spokesman.

"His death creates an immense void," she said. "With his passing goes the most emblematic figure of the Afghan people's resistance to all oppression.

"He continued to bring hope of freedom to the Afghan people in the face of the destructive lunacy of the powers in place in Kabul."

Fontaine recalled that Masud, at her invitation, had come to the European Parliament last spring and asked, "not for aid to make war, but to make peace. But peace in freedom, and not in subservience."

After Masud's visit to parliament, and visits by three Afghan women who spoke with parliamentarians and the press, Fontaine said, "I called on EU governments to put pressure on the countries that support the Taliban.

She cautioned against any retaliatory action against Afghanistan, where the prime suspect in terrorist attacks against the US is believed hiding that might harm the Afghan people.

She said those who committed the "heinous" terrorist acts against the US, and their backers, "wherever they are in the world, must be tracked down, neutralized and brought to justice."

France's parliamentary Speaker Raymond Forni Saturday hailed the "courage and tenacity" of Afghan opposition commander Ahmad Shah Masud.

"Today, with much emotion, I salute the political courage and the tenacity of this fighter, who was so concerned with the well-being of his people," Forni said in a statement.
Russia expressed condolences to the Afghan opposition Northern Alliance Saturday for the death of its military commander Ahmad Shah Masud and stressed it would continue to cooperate with the alliance.

Defence Minister Sergei Ivanov sent a message of condolence to Masud's successor, General Mahammed Fahim, the Interfax neiws agency r.mitad.

Referring to the deposed Afghan administration, which Moscow continues to recognise, Ivanov said he conveyed his sympathies "to the military-political administration of the Islamic State of Afghanistan and the relatives and co-workers of Ahmad Shah Masud due to his death as a result of a terrorist act." - AFP

\section{Taliban close Chaman border}

PISHIN: The Taliban administration has closed the Pak-Afghan border at Chaman as part of its defence arrangements against a possible US attack.

Hundreds of Pakistani traders and trucks and vehicles have been stranded at Spinboldak in Afghanistan after the closure of the border. Some drivers have left their trucks inside Afghanistan and crossed the border on foot from some other place.

A driver Khan Muhammad said the Taliban authorities told them that they would help them cross the border after easing of the situation. However, he said they could not wait for long so they parked their vehicles at Spinboldak and came back to Pakistan. - SANA 
The News on Sunday

September 16, 2001
The Frontier Post

Sunday, September 16, 2001

\section{Switzerland freezes Afghan bank accounts}

BERN: Switzerland froze several bank accounts held by Afghan banks last year, as part of a United Nations embargo on the Taliban regime, an Economics Ministry spokesman said Saturday.

+ At least six bánk accounts were frozen last year, spokesman Alan Kocher said in an interview with the German language daily Tages Anzeiger.

The largest account held close to 300,000 Swiss francs (about 200,000 euros, 185,000 dollars), Kocher said, but he did not provide the names of the banks.

The ministry holds a list comprising 170 Afghan companies and individuals, including members of the Taleban regime and people associated with bin Laden's Al Qaeda network, who hold money in Switzerland through Afghan banks.

The measures taken by the Swiss government were taken months ago, Kocher said, and as yet have nothing to do with an investigation into Tuesday's terrorist attacks on New York and Washington, which US authorities believe were masterminded by Osama bin Laden, the Saudi billionaire who resides in Afghanistan.

Tages Anzeiger reported that new accounts were ilocked this week and expected to be frozen, following the attacks, but Kocher refused to comment.- AFP

\section{Pak diplomats

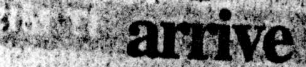 backirom

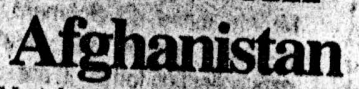

ISLAMABAD (PPI): Pakistan's Ambassador to Afghanistan Arif Ayub has arrived here as Islamabad has called back its senior diplomats based in Kabul keeping in view the security aspect in the backdrop of the situation arising out of terrorist attacks in US

Informed sources said senior diplomatic staff has been called back from Afghanistan. The diplomatic staff will arrive here boarding a special plane.

The sources said Pakistan's Ambassador to Afghanistan Arif Ayub has reached Islamabad and has presented a report to the high officials of the Foreign office about the situation prevailing in
Afghanistan.

Osama free to

leave: Taliban

DUBAI (Online): Saudi dissident Osama bin Laden, a prime suspect in the terror attacks on the United States, is tree to leave Atghanistan but would not be forced out, according to Taliban charge d'affairs in the United Arab Emirates. "If the man wanted to leave of his own will. we will not stop him. But if he wanted to stay in Afghanistan, we cannot make him leave," the Taliban diplomat, Aziz alRahman, told Abu Dhab television in an interview aired early on Saturday. Asked if there was any chance that the Taliban would consider handing over bin Laden to the United States to spare Afghanistan the prospect of military action, he said: "Basically, this is not a consideration... We have no agreement with any country to extradite criminals or suspects to hand him over."

\section{Bush calls Laden 'a prime suspect' \\ WASHINGTON (NNI): The}

United States President Bush called Osama bin Laden "a prime suspect" in Tuesday's terror attacks in Washington and New York and said America was prepared to do "whatever it takes" to root out those responsible.

"They will try to hide, they will try to avoid the United States and our allies and we won't let them," he said from Camp David. where he is meeting with his national security advisers. "We will smoke them out and get them running," CNN quoted Bush as saying. Speaking five days after hijacked jets ripped through the Pentagon in Washington and the glass and steel facades of the World Trade Center's twin towers in New York.

\section{Taliban rules out to deal with US}

ABU-DHABI: Head of the Taliban diplomatic mission Aziz ur Rahman has turned down the possibility of making a deal with the United States on extradition of Osama bin Laden so as to avoid acts of vengeance planned by the Pentagon and NATO. The deal is impossible because it has no legitimate grounds - no proof of Osama bin Laden's guilt has been provided yet, he said.

\section{Rakhmanov discusses Afghan with Omar}

ISLAMABAD (SANA); the President of Tajikistan, Imamoli Rakhmanov has held talks with the Indian Deputy Foreign Minister Omar Abdullah in Dushambe discussing the situation in Afghanistan. Both are supporting the anti-Taliban alliance reports VOA. The talks between the two sides concentrated on Afghanistan with particular reference to possible. US attack. 


\section{The Frontier Post sunday, September 16, 2001}

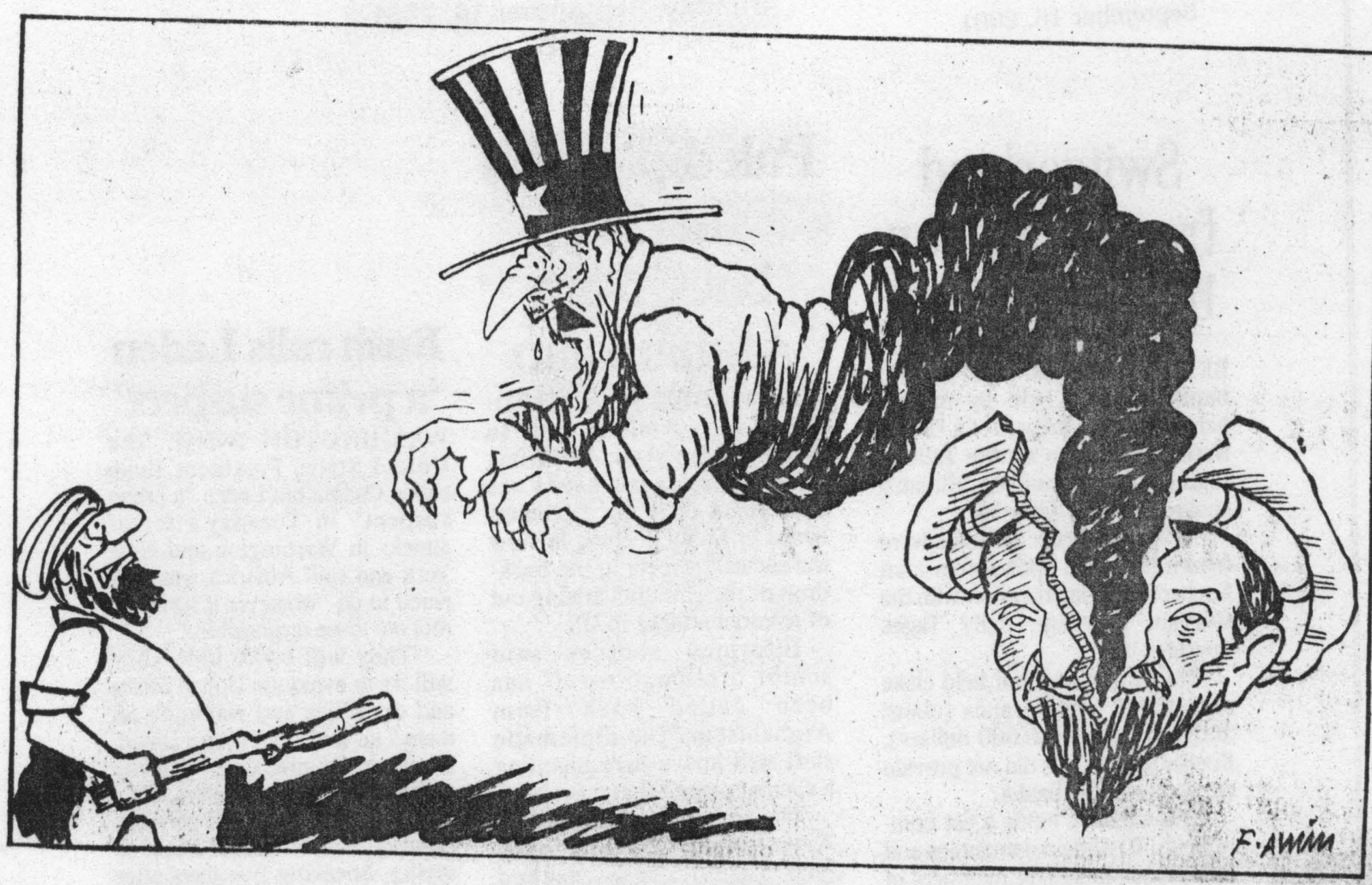

Pakistan still mulling US request for help

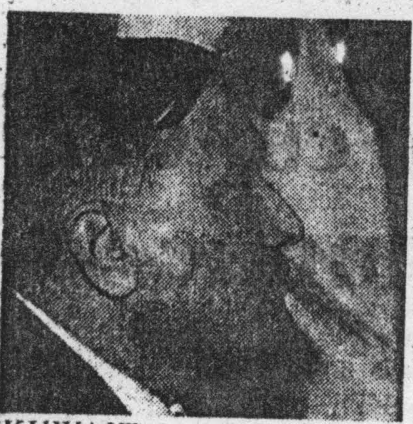

KUWAIT (Agencies): The Interior Minister of Pakistan, Moinuddin Haider said on Saturday his country wanted to help. in an American-led war on terrorism but was still considering a response to measures requested of it by the United States.

Certainly we would like to assist -. deliberations are going on in Pakistan...on how this cooperation could be extended, he told reporters as he arrived in Kuwait for a three-day official visit.

He said Pakistan had received requests from the
United States and was considering them, adding "it is state policy that we are against all type of terrorism. We have been copoperating before and will continue to cooperate."

Washington is seeking a global alliance against the perpetrators of Tuesday's attacks in New York and Washington that killed an estimated 5,000 people.

Pakistan is one of only three countries to recognise the Taliban movement, which has given a safe haven to Osama Bin Laden.

President General Pervez Musharraf is under intense US pressure to help in the hunt for those behind the attacks but. knows a large part of his population is opposed to helping any attack on Afghanistan.

The Taliban warned on Saturday they might attack any neighbour, which gave assistance to any US strikes on Afghanistan.

The US requirements were laid out during a call on
Thursday between US Secretary of State Colin Powell and Musharraf, the interior minister added. Powell said on Friday that Washington would now judge countries by their willingness to help.

"We will see what the United States has asked us and then we shall evaluate it," said Interior Minister. "It could be air space, it could be beyond that."

Moinuddin Haider stressed the world should have direct dialogue with the Taliban rather than isolating them.

Afghanistan is a sovereign country and they have their own leadership...If they are doing something wrong, which the world does not like, extremist policy or whatever, then the world should talk to them directly, (and) should not look at Pakistan.

"We are not responsible for any (Taliban) act recognition does not mean we become responsible," he added. 


\section{The Statesman sunday, Spperember 16, 2001}

\section{UAE reviewing ties with Kabul}

ABU DHABI: The United Arab Emirates, one of only three countries to have diplomatic relations with the Taliban, is "reviewing" ties with Kabul following the terror attacks on the United States, an ofricial said Saturday "The UAE is reviewing relations with Afghanistan after the latest developments," he said. - AFP

\section{Kabul orders out foreigners}

KABUL: Afghanistan Saturday ordered all foreigners to leave the country amid fears of a retaliatory US military strike, officials said.

A statement issued by the foreign ministry said the United States intended to use the presence of Osama bin Li.jen on its territory as a pretext for an attack on the country.

"In view of the current situation all foreign nationals are therefore asked to leave Afghanistan temporarily," the statement said.

It reiterated the Taliban's view that US suspicions that Osama was involved in terrorist attacks on New York and Washington were baseless.

Meanwhile, Pakistan has pulled back its senior diplomatic staff from Kabul, including its ambassador Arif Ayub, in the wake of extraordinary situation emerging after strikes on the World Trade Centre and Pentagon.

Reliable sources said that in view of their security, senior officials of Pakistan High Commissioner at Kabul have been withdrawn while the rest of staffers are asked to get ready for departure through a special plane at any time.

Soon after his arrival in Islamabad, Arif Ayub apprised the Foreign Office about the latest developments and Taliban's policy to thwart any aggression by the United States.

A senior Foreign Office official when contacted to comment on the situation said that the decision was taken to ensure safety of the staff, which is our primary concern. - Agencies

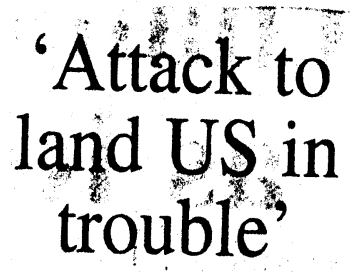

\section{From Suhail Kakakhel \\ NOWSHERA: Represen-} tatives of international media are converging on Akora Khattak to have first-hand knowledge of the future line of action of Defence Council of Afghanistan (DCA) following the recent terrorist attacks on US.

Journalists belonging to international media are desperately seeking appointment with known religious leader and chief of Defence Council Afghanistan, Maulana Samiul Haq here to discuss with him the present scenario and to know about his arganisation's future mode of action if the US attacks Afghanistan

Well-placed sources told The Statesman that Maulana Samiul Haq, considered as a spokesman for Taliban, has made it clear to the visiting pressmen and delegations that any attack on Afghanistan could bring more miseries to the Americans.

Sources said, Maulana Samiul Haq has told foreign mediamen that since Muslim states and Osama had already condemned the terrorist attacks on the World Tradecentre and Pentagon, therefoge there is no

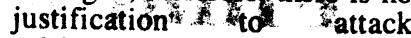
Afghanistan without any solid and credible evidence.

Maulana has reportedly told the visiting journalists that America considered Muslim states as her enemies and this is a stereotyped attitude of the US leadership.

He said that Islam is the religion of peace and stands against any sort of terrorism and it is not the enemy of the US, therefore, America should try to recognise her real enemy as any action hastily taken could only bring more agonies to the US.

He said that the Bush administration was exploiting the New York and Washington attacks and it wanted to nab Osama to please American people. He added that Osama bin Laden was innocent and he is not involved in any kind of terrorist activities.

He went on to say that the US supported Afghan Jehad when its leadership wanted to destroy the USSR; but now to its leadership these Afghans are terrorists.

"Osama bin Laden was not a terrorists when he had been fighting against Russians for 12 years, but now the US administration is projecting him as a terrorist" when he supports interests of the Muslim world.

The sources said Maulana Samiul Haq asked the President Musharraf not involve Pakistani forces in the matter as, it might yield bitter results.

Most Taliban ministers have studied in Darul Ulum-i-Haqnia of Maulana Samiul Haq that's why the Maulana command an unprecedented respect among the Taliban. 


\section{Khyber $M_{\text {AlL September 16, } 2001}$}

\section{Osama free to leave, but would not be forced out: Taliban}

KMI Af han Desk

PESHAWAR : Saudi dissi-

dent Osama bin Laden, a prime suspect in the terror attacks on the United States, is free to leave Afghanistan but would not be forced out, according to Taliban charge d'affaires in the United Arab Emirates.

If the man wanted to leave of his own will, we will not stop him. But if he wanted to stay in Afghanistan, we cannot make him leave," the Taliban diplomat, Aziz alRahman, told Abu Dhabi television in an interview aired early on Saturday.

Asked if there was any chance that the Taliban would consider handing over bin Laden to the United States to spare Afghanistan the prospect of military action, he said: "Basically, this is not a consideration... We have no agreement with any country to extradite criminals or suspects to hand him over."

Aziz al-Rahman sharing the grief of the US people repeated the position of Taliban movement that bin Laden would be handed over to an Islamic court if Washington could prove his invo:vement the attacks adding that the movement and the people of Afghanistan were innocent of any wrongdoing in the US attacks.

\section{Religious group vows to back Taliban}

KMI Report

PESHAWAR: America will not retaliate on Taliban and if it do so we will consider it an offence against the whole muslim world, said Muhammad Noor ul Haq Qadri, the vice president of Tanzeem-ahlesunnah-Waljumat, in a press release while commenting on the threats given by America against

Taliban government. He said that the explosion in U.S.A were not conducted $t y$ the muslims but these were

the Jews who implemented that evil task and they do so to defame the muslim unity. Unfortunately when there come any human violation, the American and the Jews declare it as the terrorism by Usama-bin-Ladin and other muslims but this shows their evil desighnes

Because Islam is a religion of peace, tranquility and brotherhood, he opined.

M.Noor-ul-haq Qadri said that we will support Afghanistan to the full extent and will not leave it alone in this crucial situation. If the govt provide the track for Amicracans it will be responsible for that, he added.

USA want to defame Pakistan and it is time to think thoroughly and the whole Muslim world need to unite, other wise we will fall ourselves in to the abyss of darkness, he added. We will call a meeting regarding national and international circumstances very soon, he declared.

\section{Afghanistan has} always been invaders' graveyards:Report

KMI Afghan Desk

PESHAWAR: Afghanistan has been the graveyard of invading armies. No country has proved so difficult to conquer, so deadly in its terrain and so vengeful in its retribution, reports The Time

The Moguls, Mongols, British and Russians have all tried to subdue the warrior tribes, and all have perished. Perhaps only Alexander the Great had any success in maintaining a brief hold over the country - and that was more than 2,000 years ago. Because of its high mountains, impassable ranges and bitter climate, Afghanistan has formed a natf.ural buffer in the centre of $\therefore$ sia. For this very reason it has also been bitterly fought over by outside imperial powers. For whoever controlled the buffer would control access to the other side, it was believed.

But whoever attempted to do so soon learnt the folly of such a strategy. Darius the Great expanded the Persian empire into Afghanistan in $500 \mathrm{BC}$, taking in most of the country including the ancient cities of Herat, Merv, Kabul and Jalabad. But the Persian empire was plagued by constant bitter and bloody tribal revolts from Afghans living in Arachosia (modern Kandahar and Quetta).

Alexander the Great reached :)rthern Afghanistan in $329 \mathrm{BC}$, but stayed only three 
years. The Persians returned 800 years later, but were no more able to assert control over the tribes than Darius had been. Even after Islam reached the Afghan mountains, the tribes were not amenable to outside rule. Tamerlane tried to impose his authority in AD137()-1404 but was unable to quell the countryside.

". The Persian returned, time and again, but always without decisive or lasting victory. In 1834 the Sikhs, moving up from the south in one of the few invasions from India, cap. tured Peshawar. But they were soon defeated and their general was killed. The most famous ijuel for Afghanistan took nlace throughout the 19th century, fought largely by tine British attempting to consolidate their hold in India and the Russiuns pushing south the boundaries of their Central Asia empire.

\section{The Nation \\ SUNDAY, SEPTEMBER 16, 2001}

\section{Masud's death}

IT has finally been confirmed that Ahmad Shah Masud, the charismatic commander of the Northen Alliance, has died as a result of serious injuries caused by a suicidal attack. The Afghan opposition had earlier denied the report, and to convey that their morale remained as high as ever, it had subjected Kabul to early morning rocket attacks the same day. The death of the Lion of Panjshir, as he was hailed during the war against Afghanistan, is a landmark, and may even mark the end of an era.

However, the civil war in Afghanistan is in fact not being fought around personalities, though this does not imply that individual leaders are necessarily unimportant. During the last few years, the country has gradually been divided on ethnic and communal grounds. On the one side are the Taliban, who are dominantly Pakhtuns, the largest ethnic group in the country. They comprise a relatively homogenous group. The opposition on the other hand is a coalition of Tajiks, Uzbeks and Hazaras who speak a variety of languages, with Persian serving as a lingua franca among them. The division has a communal basis also, for the Taliban are Sunni Muslims while a significant chunk of the opposition consists of Shias. Ethnicity and communal character have combined to define the relations of the two sides with the neighbouring countries. The Taliban have for instance closer links with the Pakhtun community living inside Pakistan. The opposition on the other hand has close relations with Iran and Central Asian republics which have continued to supply its military needs in the civil war. Though the Taliban currently occupy 90 percent of Afghanistan, they face tough resistance from the other side on account of the fault lines that divide them. Unless the two sides join hands, thus restoring the ethinic balance that had existed between the communities before the civil war, there is little hope of peace returning to Afghanistan. A gradual development is the limitation of the only effective opposition, that led by Masud, to Tajiks. This has solidified the stalemate, for Masud's forces now have ethnic cohesion. However, that may now change.

While the fratricidal civil war continues to rage and cause untold sufferings to both, the Afghan nation has been overtaken by new developments. After having achieved its aim of bleeding the Soviet Union in Afghanistan, the US had turned its back on the war-ravaged country. The fanatical forces it had collected from all over the Muslim world in the name of jihad have over time become autonomous. What is required is to engage with them to neutralize them. Now that it seems a war is about to be imposed on Afghanistan, a whole nation which was earlier used as a pawn by one superpower against another and devastated in the process, will again be exposed to a similar trauma. 


\section{The Nation}

SUNDAY, SEPTEMBER 16, 2001

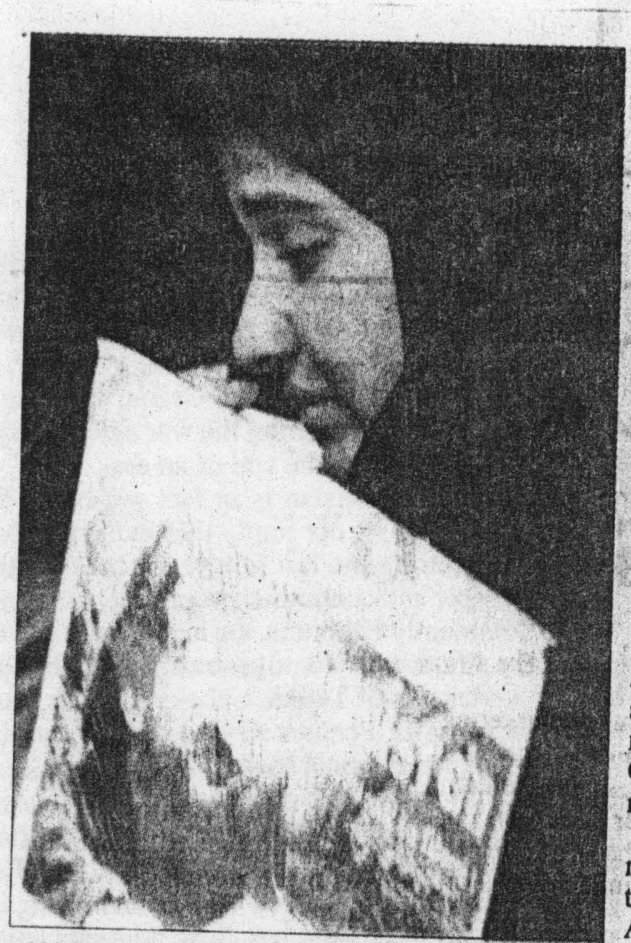

\section{Rabbaniblames Taliban,Pakistan for leader's death}

KABUL (AFP) - Afghan opposition commander Ahmad Shah Masood died Saturday after a suicide bombing plotted by Pakistan, the Taliban and Osama bin Laden, ousted President Burhanuddin Rabbani said. In the first official confirmation of the veteran commander's death, Rabbani described him as a "national hero" who had martyred himself for "jihad and resistance".

A spokesman for Rabbani said Masood had died at 10:00 am (0530 GMT) Saturday in a hospital in northern Afghanistan, after losing his last battle against injuries sustained in Sunday's suicide bombing. "Masood was martyred in a conspiracy involving Pakistan, group of Osama bin Laden and the Taliban," Rabbani said in a message.

"He was a national hero of the Afghan jihad and resistance. He was a symbol of resistance and jihad for the past 30 years (and a) thorn in the eyes of Afghanistan's enemies."

HAMBURG: A woman, holding a placard carrying a picture of Ahmad Shah Masood, weeps during a demonstration against violence.-AFP

Rabbani and other opposition alliance leaders attended the service along with thousands of mujahideen fighters, it said. The report could not be immediately
confirmed.

\section{Any US attack on Kabul should 'spare' the people}

TEHRAN (AFP) - The Afghan opposition's envoy to Iran. Mohammad Kheirkhah, said Saturday he hoped the United States would not attack his country in retaliation for the September 11 terrorist attacks on New York and Washington, and that any attack should "spare the people."

The Taliban, the fundamentalist militia that controls most of Afghanistan, is harboring Saudi Islamic fundamentalist militant Osama bin Laden, who is the key suspect in those attacks.

"I hope that my country is not the target of an American attack," Kheirkhah told AFP.
"But if, in the context of the anti-terrorist battle, the Americans want to do something, let them act only against terrorists, while sparing the people," he said.

"Any action against terrorists should target the Taliban, Osama bin Laden and their Pakistani protectors," he added. "If the action is a blind act, and innocent people suffer, then of course we are against it."

According to the Kheirkhah, the attacks in New York and Washington took place because of the "negligence of the world via-a-vis terrorism.

"One should destroy the roots of terrorism," he said.

Questioned on the reported death of Ahmad Shah Masood, the Afghan opposition commander, Kheirkhah affirmed that it would not "weaken resistance" against the Taliban.

"Our fight does not depend on a single person. This drama will revive the anger of our people who will come out of this strengthened," he said.

Kheirkhah said there is great concern in Afghanistan and that many people want to flee the country and seek refuge in Iran or Pakistan, but that the Taliban are preventing them from doing 


\section{Afghanistan: not much left to blow up \\ By Luke Harding and Rory McCarthy}

ISLAMABAD: American strategists face a dilemma as they contemplate a missile strike against Afghanistan: what, exactly, to destroy when so much has already been destroyed.

Between 1992 and 1996, as civil war raged, rival Mujahideen factions shelled Kabul relentlessly. Innumerable rockets fell from the high brown mountains that encircle the city killing some 50,000 people. Most buildings of importance were pulverized and much of the city is still a ruin.

Nevertheless, US military planners will be working to identify key buildings and military installations used by the Taliban's regime. The Taliban now appear to be as much a target as Osama bin Laden, the man they refuse to give

up. Some important Taliban buildings are set a little distance away from the civilian population. The foreign ministry, which looks rather like a Swiss town hall, is surrounded by pine trees and stands in its own pleasant gar.
dens.

Kabul's former royal palace nearby also offers a discrete target. Senior Taliban officials hold cabinet meetings here every Wednesday afternoon. But many of the Taliban's major ministries . are in the heart of Kabul itself.

The modern culture ministry adjoins a busy bazaar. The interior ministry - damaged by an unexplained bomb last Saturday - is in the middle of a commercial district. And the modern education ministry is next to a row of shops, surrounded by pedestrians, cyclists and yel.
low Toyota taxis.

Inevitably any missile strikes here would run the risk of heavy civilian casualties. Kabul airport, to the north-east of the city, is a more uncomplicated strate gic target.

Soon after the attacks in New York and Washington, Afghanistan's antiTaliban opposition blasted the airport with a helicopter gunship.

Further strikes would damage an airport building already riddled with bullet holes. The carcasses of wrecked planes already litter the side of the shrapnelscarred runway. Not, though, that the Taliban have much of an airforce: they are estimated to have only three Mic; jets, left by the retreating Soviet army.

All can expect to be the targets of US retaliation. So too can the house in central Kandahar belonging to Mullah Mohammad Omar, the Taliban's reclusive spiritual leader. Mullah Omar's previous house was badly damaged by a mysterious bomb left in a truck, which killed at least 10 people

The difficulty America faces is that the Taliban leadership knows full well what is coming. "Last time they only attempted to strike the camp. This time they want to eliminate the whole system and government," Abdul Hai Mutmaen, the Taliban's spokesman, said on Friday.

The irony is that there is not much left in Afghanistan that has not already been blown up.-Dawn/The Guardian News
Service.

\section{Supporters of Osama leave Kabul}

\author{
By M. Ismail Khan
}

PESHAWAR, Sept 15: Tension grips Kabul, amid reports that Pakistani and Arab supporters of the Taliban and Saudi dissident Osama bin Laden have evacuated Kabul, anticipating retaliatory strikes by the United States.

A senior Pakistani diplomat in Kabul said they might pull out any time.

Sources from the beleaguered Afghan capital told Dawn by phone that Pakistanis, associated with Harakatul Mujahideen and Lashkar-i-Toiba and Arab supporters of Osama bin Laden's Al Qaida, had abandoned Kabul and had moved to safer locations in Logar, Baghlan and other areas in northern Afghanistan. "The 'guests' have gone. You cannot see them anymore," the sources remarked.

They said that important Taliban leaders had also left Kabul on 'one pretext or the other.' Taliban foreign minister, Wakil Ahmad Mutawwakil, the last remaining leader, also left for Kandahar on Saturday.

By the same measure, these sources said that the people in the relatively affluent district of Wazir Akbar Khan, north of the capital, were also moving to safer places. "There is fear that the front lines, to the north of the capital with the opposition. Northern Alliance, may collapse in the event of a US strike," the sources said.

They said that tension prevailed in Kabul and people were stockpiling food, fearing strikes by the US. The sources said the demand for edibles had pushed the prices up; sugar, which was available for 25,000 afghanis per $\mathrm{kg}$, was now being sold at 28,000 afghanis. 


\section{The Independent UK \\ By Peter Popham in Islamabad \\ 17 September 2001 \\ Taliban is a 'monster hatched by the US'}

If the United States follows through with the rhetoric and commits ground troops to Afghanistan, one day soon, American troops will come face to face with the Taliban - the monster they helped to create. This may, as we are told, be a war between civilisation and fanaticism. But in a quiet corner of the brains of those busy committing the United States to another world war, one hopes there will be a recognition of the fact that the Taliban is, in an important sense, the creation of America's foreign policy.

Without America's hubristic determination to rule the world without having to pay the price that all prior empires paid in human life, this enemy would not have sprung up to challenge it now.

The story goes back 22 years, to 1979. America had decided, post-Vietnam war, that American deaths were an unacceptable price to pay for victory (let alone defeat) in far away countries of which they knew little. But in 1979, this was still a bipolar world. The Soviet Union was already ailing, in far worse shape than anyone imagined, but around the world,the proxy struggles between the superpowers went on; in the Middle East, in Angola, Ethiopia, South Yemen.

In Afghanistan, a Counmunist government was in power, propped up by the Soviets. But Moscow's trusted puppet, Muhammad Daoud, cousin of the ousted King Zahir Shah and sometimes called the "Red Prince", had gone, murdered with most of his family in a military c sup. Moscow was much less sure about Daoud's replacement, President Nur Muhammad Taraki. Because Afghanistan was at best a very rum sort of Communist state. In Kabul, the apparatchiks wore suits and their wives wore skirts and heels and even went to work. But the secular, atheistical fabric of the state was flimsy and fragile. A little way out in the rugged countryside, it remained rigidly tribal; women wore the burqa, Islamic piety was universal, and the Soviet Union was Satan.

Nudged and funded by the CIA, Iran and Pakistan, the tribal leaders began to cause their overlords some trouble. 
Moscow under Leosid Brezhnev, fat and an: enough was enough and sent in the army. The Sovict invasion and occupated Afghanistan was under way.

It was a rash adventure from the start, and the anti-Soviet hawk in President Jimmy Carter's cabinet, his National Security Adviser, Zbigniew Brzezinski, persuaded Mr Carter that it offered the perfect opportunity to give the Soviets far more trouble than they had bargained for. Building on a modest programme of assistance that had started six months before the Soviet invasion, Mr Brzezinski got the President to sign a secret directive to send covert aid to the Mujahedeen, the tribal Islamic warriors who were then in the earliest stages of giving the Soviets hell.

The Afghan civil war was under way, and America was in it from the start - or even before the start, if Mr Brzezinski is to be believed. "We didn't push the Russians tointervene," he told an interviewer in 1998, "but we consciously increased the probability that they would do so. This secret operation was an excellent idea. Its effect was to draw the Russians into the Afghan trap. You want me to regret that?" The long-term effect of the American intervention from the cold-warrior $\mathrm{Mr}$ Brzezinski's perspective was 10 years later to bring the Soviet Union to its knees. But there were other effects, too.

To keep the war going, the CIA, in cahoots with Saudi Arabia and Pakistan's military intelligence agency ISI (Inter-Services Intelligence Directorate), funnelled millions and millions of dollars to the Mujahedeen. It was the remotest and the safest form of warfare: the US (and Saudi Arabia) provided funds, and America also a very limited amount of training. They also provided the Stinger missiles that ultimately changed the face of the war.

Pakistan's ISI did everything else: training, equipping, motivating, advising. And they did the job with panache: Pakistan's military ruler at the time, General Zia ul Haq, who himself held strong fundamentalist leanings, threw himself into the task with a passion. But during that process of supply and training, as veteran journalist John Cooley puts it, the US indirectly "hatched a monster of Islamist extremism, the Taliban movement".

By 1989, the Mujahedeen had put the Soviets to flight. But then they themselves, representing the whole ethnic spectrum of the country, from Pashtuns in the south and east to Tajiks and Uzbeks in the north and mongoloid Hazaras in the middle, just carricd on fighting for supremacy.

The long civil war had also produced millions of refugees, more than three million of whom ended up in Pakistan. And it was in their squalid camps that Pakistan alighted accidentally on the civil war's appalling resolution.

A militia sprung up from the thousands of Islamic seminaries or madrassas that opened in Pakistan during the civil war to give a rigid Islamic education to the 
young refugees; a militia composed of youths who had been born or at least rased in exile, who knew nothing and cared less about the rich heritage of traditional, tribal Afghanistan, or about the patterns of give and take that held together this mosaic-like country.

They were deracinated, ruthless, they had nothing at all to lose. All they had, all they held to tightly, was a fiery belief in the most reductive, regressive form of Islam ever practised anywhere. And America, now bent, perhaps, on destroying them, was in there at the creation

\title{
THE WASHINGTON TIMES September 17, 2001
}

\section{US aim: isolate Taliban, prepare Pakistan}

\author{
By PAMELA HESS and ELI J. LAKE \\ UNITED PRESS INTERNATIONAL
}

WASHINGTON, Sept. 17 (UPI) -- The United States Monday ramped up its diplomatic offensive against the radical Muslim regime in Afghanistan believed to be harboring the men behind last week's terror attacks -- preparing to send officials to Pakistan to lay the groundwork for possible U.S. military action.

"With respect an inter-agency team going to Pakistan, we are making a determinatio sow," U.S. Secretary of State Colin Powell said Monday. "It'll take a day or two (in decide) what we might want to ask the Pakistanis for. And when that has been deters:ined, then we will form a team appropriate to that task." A spokesman for the Pakistani embassy in Washington said that the team, when it arrived, would also be able to speak directly to Taliban leaders, if necessary. Pakistan Monday sent a delegation to Taliban headinartens to arge hem to hand over Osama bin Laden, named by U.S. officials the puinc suspect ha bat hunt for the man behind the suicide hijackings that left re than 5,000 feared dad. But it secmed unlikely the mission would bear fruit, despite telling the Talibaia bay had three days to act or face U.S. military action.

A Pentagon official said Pakistan established that deadline on its own and the U.S. military has not promised any attack within that time frame.

Pakistan has been the main ally and supporter of the Taliban regime, which controls 90 pereent of the landlocked mountainous and war-battered temitory of Afghanistan.

U.S. diplomats are also pressing the Taliban's other neighbors and allics to cut off contact with them, officials said.

A Pentagon official said the inter-agency team is likely to include one person from the Office of the Secretary of Defense, a general-level officer from lls. Contral 
Command, and possibly an official from the Joint Staff.

When the United States launched a volley of 65 cruise missiles at presumed terrorist training camps in Afghanistan through Pakistani airspace in 1998, it dispatched then-Vice Chairman of the Joint Chiefs of Staff Gen. Joseph Ralston to inform Pakistan so the country would not think it was under attack from India, its longtime
enemy.

The United States has asked -- and Pakistan has agreed -- to seal its border with Afghanistan, allow U.S. jets to use its air space, cut off fuel shipments to the Taliban and share intelligence information.

United Press International reported Súnday that the United States had already sent some senior officials to Islamabad to coordinate talks between Pakistan and the

Pakistani officials told United Press International over the weekend that -- in return for Pakistan's aid -- the United States had agreed to lift the sanctions imposed after its nuclear tests in 1998 and to help the country get its \$37 billion international debt re-scheduled or written off.

But a senior State Department official Monday denied that there was any direct quid pro quo, while acknowledging that Pakistan's cooperation might bear fruit for them.

"The discussions with Pakistan were made without conditions, without any demands on their part and without any quid pro quo. Although clearly we've made this the most important issue in our relationship and positive movement on this issue, if they support us on this, we'll support them on other things," the official said.

That support is likely to prove invaluable to Pakistan's embattled military ruler, Gen. Pervez Musharraf, who told an extraordinary meeting of the country's religious and political leaders that he only agreed to cooperate with the American war on terrorism -- in his own words -- "as a matter of national survival." In UPI's first-hand account of the late-night meeting, Musharraf said he only agreed to cooperate with Bush under duress, to save Pakistan's nuclear weapons. Pakistan is the only Islamic state to have successfully tested a nuclear bomb.

"If I had not committed, Russia, India and Israel would do us great harm," Musharraf told the initially hostile leaders, who warned him of civil war and divisions within the Pakistani armed forces if he cooperated with the Americans. "To safeguard our nuclear program, we must back the United States without reservations," he went on. "If we don't support the United States, we ourselves won't survive -- nor will Islam.

"It is my responsibility to safeguard our national security. I did not compromise with the United States. It was a matter of Pakistan's survival," Musharraf said, according to notes of the meeting taken by Ajmal Khattak, president of the National Alliance Party, who shared them with UPI's Arnaud de Borchgrave.

Those at the meeting reluctantly and provisionally agreed to accept Musharraf's decision, but only after the Islamic religious leader Sami ul-Haq told Musharraf: "America is not the power of God. God himself is. We don't need anyone else's help."

Musharraf replied: "If we are not prepared to help, India is. So if you want to commit suicide, I am not." 
A senior State Department official told reporters Monday that the United States was also secking assurances from other countries on sharing intelligence; shutting down terrorist financial networks; sealing off border access; and shutting down the offices and investigating the activities of terrorist organizations.

In some cases this has already paid off. The official said that U.S. officials have received "indications" from the United Arab Emirates that it will soon close the Taliban's office in that country.

"The UAE has given us indications that they will close down the Taliban office there, but we'll just have to wait and see," this official said. "Seeing is believing."

The official also said U.S. officials have been in touch with a number of Central Asian states north of Afghanistan, including Tajikistan, Turkmenistan and Uzbekistan. The Russian military has access to these former Soviet republics but diplomatic officials said no Russian forces are inside these countries.

Deputy Secretary of State Richard Armitage will meet with Russian foreign ministry officials in Moscow this weck, while that country's Foreign Minister Igor Ivanov is scheduled to be in Washington for talks with Secretary of State Colin
Powell.

Powell on Monday spoke with Yemen's President Ali Abdullah Saleh. In a news conference Monday he praised the president's prior cooperation on the U.S. investigation into last October's sinking of the USS Cole.

On Tuesday, Powell will meet with the current president of the U.N. General Assembly, South Korean Foreign Minister Han Seung-soo. On Thursday, the Secretary is scheduled to meet with European Union Commissioner Chris Patton, EU High Representative Javier Solana and the current president of that body, Belgian Foreign Minister Luis Michel. He will also meet with Saudi Foreign
Minister Prince Saud el-Faisal.

The State Department has also been courting some states it regards officially as sponsors of terrorism such as Syria. On Friday Powell spoke with his Syrian counterpart.

"If they are willing io take steps against the perpetrators of this act, it will be useful to have them with us," one official said.

This source was considerably more skeptical when asked about Iran, a country the State Department considers the world's leading sponsor of terrorism. This official said there has been no contact with Iran since Tuesday's attacks and there was no coordination with Washington on Iran's decision Sunday to seal its western border with Taliban-controlled Afghanistan.

"Iran has a long way to go to show a shred of credibility," this official said, adding the State Department was giving hoth Iran and Syria a chance to "join the world." 


\section{Uzbekistan ready to host US for Afghan strikes}

TASHKENT: Uzbekistan may consider lending its military bases to U.S. forces for staging strikes against terrorist targets in neighboring Afghanistan, the Foreign
Ministry said Monday.

"Uzbekistan is ready to discuss any form of cooperation in the struggle against international terrorism in our region, including the deployment of U.S. forces," Foreign Ministry spokesman Bakhodyr Umarov said.

But Umarov said it was too early to discuss specifics, since the United States had not yet asked Uzbekistan for permission to deploy forces to the Central Asian nation.

Earlier, Foreign Minister Abdulaziz Kamilov told the Washington Post that the former Soviet republic was ready to consider all "possible forms of cooperation," including the presence of U.S. troops in Uzbekistan.

The comments by Kamilov and Umarov represented the only standing offer from a former Soviet republi : to help the United States in launching military strikes against Osama bin Laden, the suspected mastermind of Sept. 11 attacks.

Uzbekistan's neighbors in volatile Central Asia have condemned the attacks, but stopped short of offering their bases or airspace to the U.S. military. The leaders of Tajikistan, Kazakstan and Kyrgyzstan have voiced fears that U.S. strikes on Afghanistan could rock the unstable Muslim region and prompt a massive refugee exodus.

"Uzbekistan's move may bring the conflict zone closer to us," Col. Mirbek Koilubayev, a Kyrgyz Defense Ministry spokesman, said Monday.

Tajikistan, which borders Afghanistan, had initially said it might consider offering its bases to the U.S. military, but only on condition Russia approves the move. Moscow quickly made clear it would not welcome the use of Central Asia as a launching pad for the attacks, and Tajikistan then said the offer was off.

Russian President Vladimir Putin on Monday discussed regional security in telephone conversations with the presidents of all five ex-Soviet states in Central Asia. The secretary of Putin's Security Council, Vladimir Rushailo, left Monday for
a tour of Central Asia.

Unlike Tajikistan, which has about 25,000 Russian troops and depends on Russian subsidies, Uzbekistan has carried a more independent course, often bristling at Moscow's attempts to strengthen its military presence in Central Asia. 
The Uzbek government has long struggled with Islamic militants who it says aim to carve out an Islamic state in the Ferghana Valley. Uzbekistan says the extremists have links with Afghanistan's ruling Taliban militia.

In the past, the United States has provided aid to help Uzbekistan guard its porous border with Afghanistan, and has declared the Islamic Movement of Uzbekistan a terrorist group. But Washington has also accused Karimov's government of human rights violations in its campaign against the extremism.

During the Soviet war in Afghanistan, Moscow used Uzbekistan as its main supply and logistics base. Uzbekistan has two large Soviet-built air bases which are capable of hosting all types of military aircraft. One, Sherabad, is located just 32 kilometers (20 miles) away from Afghanistan's northern border. Another, Cherchik, is near the capital, Tashkent.( AP )

\section{US has not asked for Laden: Taliban}

TEHRAN: The United States has made no demand, direct or indirect, to Afghanistan's Taliban rulers to hand over Osama Bin Laden, prime suspect in last week's attacks in New Y rk and Washíngton, a Taliban envoy was quoted saying on
Monday.

The Taliban's ambassador to Pakistan, Abdul Salam Zaeef, added in an interview with the Iranian newspaper Entekhab that Bin Laden would only be extradited if his guilt were proved by an Islamic court.

"There has been no contact with the Americans and we have received no indirect message" relating to Bin Laden, the Saudi multi-millionaire who is accused by the United States of mounting the September 11 attacks which killed an estimated 5,000 people, Zaeef said. He added: "We think that any accusation by the United States must be proved
judicially."

"If it is proved before a court convened under sharia (Islamic law) that he did this, we are prepared to hand him over to international authorities," Zaeef said.

He called on Iran, which backs the former Afghan government toppled by the Taliban in 1996, to "stand by the Muslim people of Afghanistan" and warned Pakistan its cooperation with the United States would have many effects. 
Pakistan on Monday launched a last-ditch effort to persuade the Taliban to hand over Bin Laden and avert a US military attack that would have grave consequences
for the entire region.

A delegation led by the head of Pakistan's influential intelligence service, a longstanding ally and backer of the Taliban, began the make-or-break talks with the Afghan militia's leaders by meeting foreign minister Wakil Ahmed Mutawakel in : the southern Afghan city of Kandahar.

In case of a US attack, "we will fight to the death," Zaeef said.

"We will defend ourselves seriously, as we did against the Russians," he added, referring to the unsuccessful Russian campaign in Afghanistan launched in 1979. Zaeef said the US aim was not to wipe out Bin Laden but to establish a military
presence in central Asia.

Meanwhile an Iranian-based leader of the Afghan opposition to the Taliban, Mohamad Fayaz, told the daily Iran News that if Bin Laden was proved to be responsible for last week's attacks, US retaliation was justified.

"However the question is how much and to what extent will the innocent Afghani population suffer from a retaliatory strike by the US military," he said.

Iran Daily for its part quoted leading members of the Iranian parliament's national fecurity and foreign policy committee expressing alarm over the fallout for Iran from any US attack on Afghanistan.

Such an attack "can affect our national and security interests due to our borders with that country," Mohammad Kyanoushrad said. "Foreign ministry officials should adopt appropriate measures."

Colleague Hassan Qasqavi said: "Any US attack against Afghanistan would entail negative results for Iran" and not be beneficial to Washington in the long run.

"Attacking Afghanistan, a war-trodden country with a poor economy, cannot have an impact on the fight against terrorism," he added.( AFP) 


\section{HERALD TRIBUNE}

Tuesday, September 18, 2001

\section{Afghanistan Maps? A Hot Item}

WASHINGTON: One of the hottest items in this capital now is a map of Afghanistan. Afghanistan, of course, is the Central Asian country believed to be harboring Osama bin Laden, the U.S. government's declared prime suspect in last week's attacks. Map store owners said on Monday that their stock of maps of Afghanistan sold out within days of Tuesday's attacks.

Most of the buyers came from U.S. government departments, security agencies and news organizations, presumably in need of maps in case of the United States attacks Afghanistan.

"We had about 20 maps of the Afghanistan area, and all of those sold out very quickly after the attack," said Seth Lavisfiere, manager of ADC Map and Travel Center near the White House. "We have had dozens and dozens of inquiries."

Mr. Lavisfiere said that with demand so high he had tried without success to track down more maps.

"We have about 100 su'pliers, and no one seems to have anything at the moment,"
he said.

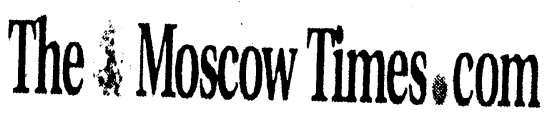

Tuesday, Sep. 18, 2001

\section{Bush Wants bin Laden Dead or Alive}

WASHINGTON/NEW YORK -- U.S. President George W. Bush said Monday that the United States wanted Osama bin Laden "dead or alive" for last week's attacks, but Afghanistan's Islamic rulers refused to give him up.

Speaking to reporters during a visit to the Pentagon, Bush put Afghanistan's radieal Islamic Taliban government, which offers Saudi-born bin Laden its protection, on notice that it would also be held accountable for last Tuesday's attacks.

Asked if he wanted to see the death of bin Laden, Bush said: "I want justice. And there's an old poster out West that says, dWanted: Dead or Alive.""

"We are going to find those evildocrs, those barbaric people who attaclicd our country, and we're going to hold them accountable, and we're going to hold the 
people who house them accountable, the people who think they can provide them safe havens will be held accountable, the people who feed them will be held accountable, and the Taliban must take my statement seriously," Bush said.

In Afghanistan, Taliban rulers refused to hand over bin Laden to a Pakistani delegation, saying a council of senior Islamic clerics would decide bin Laden's fate
Tuesday.

"The Shura meeting of clerics in Kabul tomorrow will fully discuss and make a decision on the latest situation arising out of a possible attack by the United States and Osama bin Laden," Taliban spokesman Abdul Hai Mutamaen told the Afghan
Islamic Press. "The decision and edict of the clerics ... is important and compulsory and the
government will implement it fully," he said. Taliban leaders, meanwhile, moved weapons, including Russian Skud missiles, near
the border with Pakistan.

On vacation in the Black Sea resort of Sochi, President Vladimir Putin called up the presidents of Uzbekistan, Tajikistan, Kazakhstan, Kyrgyzstan and Turkmenistan in volatile Central Asia, as well as the presidents of Ukraine and Azerbaijan to discuss jointly fighting international terrorism, the presidential press service said.

Putin and the other presidents "discussed the situation developing in the Central Asian region and in the world as a whole as a consequence of the terrorist attacks on
the United States," the press service said.

Azeri President Heidar Aliyev's press service said Putin proposed relocating next week's summit of prime ministers from the Commonwealth of Independent States from Turkmenistan's capital Ashgabat to Moscow because of the attacks.

Security Council chief Vladimir Rushailo flew to Central Asia on Monday for talks on possible U.S. retaliatory strikes on Afghanistan.

Interior Minister Boris Gryzlov, during a visit to Finland, said Russia was prepared to supply the United States with intelligence on where certain terrorist bases are located and "the whereabouts of certain people." He did not elaborate.

In New York, rescue workers labored for a seventh day over the ruins of the towers in the heart of New York's financial district.

The body of a male air crew member was found bound hand and foot, a police source said. Earlier, the body of a flight attendant was found with her hands bound.

Away from the site, thousands of posters of those missing covered bus shelters, telephone booths and subway walls. One had a telephone number and a photograph 
of a smiling toddler playing with her father. It read: "Have you seen iny Daddy?
Jason Jacobs."

The latest toll of missing people in New York is 4,957, with 190 more confirmed
dead. Another 188 died at the Pentagon and 45 in the crash of a hijacked plane in
Pennsylvania.

The FBI has 4,000 agents tracking 40,000 leads. U.S. officials said two more "material witnesses" had been taken into custody,
joining two others already detained.

A further 25 people were taken into custody on alleged immigration violations and were being questioned. The FBI was seeking more than 100 others for questioning.

Back in Washington, Bush planned a meeting with his top economic advisers later Monday to discuss the U.S. economy. In particular, he wante $\mathrm{d}$ to discuss the airline industry, which has been battered
since the attacks.

In another complication generated by the attacks, Bush was to visit an Islamic center to try to put an end to rising anti-Moslem sentiment in the United States generated by suspicions that radical Moslems carried out the attacks.

Bush urged Americans to get back to their daily routines as he shook hands and offered words of encouragement to employees showing up for their morning coffee at a cafeteria in the Old Executive Office Building next door to the White House.

Despite the grim circumstances Bush was jovial with the employees, telling one, "Have a cup of coffee on me," and posing for a picture with a woman and her ham
sandwich.

"I'm here to remind people the best way to fight terrorism is to not let terrorism intimidate America," Bush said.

n-After Tuesday's attacks, Bush gave the military orders to intercept and shoot down any commercial airliners that refused instructions to turn away from Washington, Cheney said Sunday.

"I wholeheartedly concurred in the decision he made, that if the plane would not divert, if they wouldn't pay any attention to instructions to move away from the city, as a last resort our pilots were authorized to take them out," Cheney said on NBC's "Meet the Press."

Bush acknowledged later that he gave the order. (Reuters, AP) 


\section{The Moscow Timesscom}

Tuesday, Sep. 18, 2001

\section{Journalists Ready for New World Order.}

By Alexei Pankin

On Monday, Sept. 10, the daily Vremya Novostei came out with the following headline: "The valley which the Taliban will never reach." The report was from Ahmad Shah Massood's hideout. The same day it emerged that suicide terrorists had assassinated Massood in his Panjsher stronghold.

The author, Arkady Dubnov, had prepared his report honestly and professionally. His only error was assuming that convention and tradition would be observed. (As Dubnov said the next day, those who visited General Massood were not searched, "For fear of insulting the guests.")

Massood's assassination quite literally shattered centuries-old, Afghan traditions of hospitality. The attack on America shattered the way Americans and the entire world see themselves. At such moments it is hard for the public to exercise restraint and resist the temptation to embark on a witch hunt at home and to demand the immediate punishment of enemies abroad. Too often the media tend to see themselves as vox populi and therefore as superior to the law courts. It is very important particularly at moments when nothing is clear and emotions have reached boiling point to recall how vulnerable and imperfect our profession is and to stick to the principle of not making things worse.

From the moment that Soviet miners went on strike in the summer of 1989 , the prevalent approach of the domestic press has been to stir things up.

Last week it seems to me, a completely different set of mechanisms kicked in. I personally watched or discussed with trustworthy experts virtually all news and analysis programs broadcast by the leading television stations. Furthermore, I read a broad selection of newspapers, ranging from the tabloidy Komsomolskaya Pravda and Moskovsky Komsomolets to the respectable Izvestiya and Kommersant, and up to the high-brow Nezavisimaya Gazeta and Vremya Novostei. And my conclusion? I concluded that the media were trying to stabilize the situation. 
What could the immediate, negative side-effects of the American tragedy be for Russia? Increased Caucasus- or Islamophobia. Yes, the word on the street would indicate that such sentiment has increased, but I do not believe that the press is to blame here. The subject of the guilty has been treated with considerable tact.

There could have been a surge in the number of citizens panicking about their safety. And indeed, the subject of our vulnerability to terrorism did not escape the attention of our media -- however, coverage lacked the usual hysterics, global generalizations and apocalyptic predictions. I noticed only one isolated case of irresponsibility; when MK ran the headline: "In two weeks' time they will poison the water, according to our security services." The article considers where Americans should potentially expect the next strike.

Then there was the panic over the dollar. It flared up but was at once extinguished by -- among others -- convincing articles appearing in papers across the political spectrum, which argued that the dollar was under no threat. The only piece of provocation was a front-page article in Saturday's Kommersant titled: "The dollar didn't hold," and ending with the words: "In the space of a few days the dollar turned from being the most stable currency in the world to one of the most unpredictable and, therefore, most risky."

And so I am proud to conclude that in this tragic week Russian journalists and editors didn't just announce that we are now living in a different world. They also proved themselves worthy of it.

Alexei Pankin is the editor of Sreda, a magazine for media professionals (www.internews.ru/sreda)

WASHINGTON POST

September 18, 2001

\section{Taliban Asks Clerics to Rule On Surrender Of Bin Laden}

By Molly Moore and Pamela Constable

Washington Post Foreign Service

ISLAMABAD, Pakistan, Sept. 17 -- Pakistani officials sent to Afghanistan to seek the surrender of Osama bin Laden extended their visit today after Afghanistan's ruling Taliban militia said a council of Islamic clerics would decide whether to hand 
over the suspected terrorist.

The official Taliban radio said the Islamic movement's leader, Mohammad Omar, had decided that the fate of bin Laden should be decided by the group of senior clerics, who will meet Tuesday in the Afghan capital, Kabul. The Pakistanis, who met with Omar today in the southern Afghan city of Kandahar, traveled to Kabul to await the decision. Bin Laden has been identified as the prime suspect behind last week's terror attacks in New York and Washington.

The Pakistani delegation headed by Lt. Gen. Mahmood Ahmed, who met last week with high-level U.S. officials, spent more than three hours with Taliban leaders, according to Taliban spokesman Abdul Hai Mutmaen. The Pakistanis reportedly told the Taliban that giving up bin Laden, whom it has harbored for the last five years, could spare Afghanistan from military attack by the United States.

"Time is short, patience has run out," Pakistani Foreign Minister Abdus Sattar said the delegation told the Taliban. "There is no room for negotiations. It's time for
action."

In recent years, bin Laden has become increasingly influential within the Taliban, providing the radical Islamic group with funding and weapons for its effort to seize the last pockets of Afghanistan it does not control. One Pakistani official here said it would be "a miracle" if the Taliban surrendered a man who has become not only its benefactor but a hero in parts of the Muslim world.

Taliban officials have said repeatedly they will protect bin Laden unless presented with proof of his involvement in the attacks. They have warned they will attack any country that supports a U.S. assault, including Pakistan.

In Pakistan and other countries bordering Afghanistan, tensions were rising in
anticipation of a U.S. military strike.

Pakistani Muslim groups denounced U.S. efforts to capture bin Laden and promised violence if Afghanistan is attacked. Russia met with representatives of other former Soviet republics in Central Asia to coordinate their responses to the U.S. appeal for assistance. And weapons and combatants from Afghanistan and Pakistan were converging on the border in increasing numbers.

Pakistan's agreement to assist the United States has provoked increasing outcry inside Pakistan, where bin Laden's appeal runs strong.

In the city of Lahore, leaders of a coalition of 35 Islamic groups warned today that the United States would be taking on "the entire Muslim world" if it attacks Afghanistan. The Afghan and Pakistań Defense Council, which represents a broad spectrum Sunni Muslim factions, said it would declare a "holy war" to defend Afghan and Pakistani sovereignty if such an attack comes. 
"I wish from my heart that President Bush does not do a wrong thing" by attacking Afghanistan, said Sami ul-Haq, the coalition's chairman and leader of a pro-Taliban religious party. "There are 1.3 billion Muslims in the world. Will America take on all of them to go after just one Arab?"

Speakers at the Lahore meeting condemned the terrorist attacks on the Pentagon and the World Trade Center. But they denied that Muslims were responsible and blamed the attacks on Israeli and Jewish interests, which they asserted seek to provoke a cataclysmic confrontation between the West and the Muslim world, and to distract attention from what they called Isracl's mistreatment of Palestinians in the occupied territories.

"This is an attempt to accelerate the clash of civilizations," said Qazi Hussain Ahmed, leader of Jamaat-e-Islami, a mainstream religious party that claims nearly 5 million followers across Pakistan. "Islam is spreading fast in the West, and this is an attempt to stop it. The only ones who benefit from this attack are not Muslims but Zionists. We must not fall into this trap." He called on all Islamic groups at the meeting to form a "wall of steel" to defend Pakistan's interests.

Religious fervor also was evident in towns and villages across northern Pakistan's Baluchistan and North-West Frontier provinces, according to military intelligence reports described today by a senior military official. Armed tribal groups sympathetic to the Taliban are mobilizing in the two large provinces, which share a border with Afghanistan, according to the military reports.

The border region, where many Pakistanis share the ethnic Pashtun culture and severe interpretation of Islam with the Taliban, has some of the largest arms bazaars in the world. Local tribal chiefs closely associated with the Taliban are ordering their supporters to arm themselves and prepare to assist the Taliban against foreign attacks, according to a senior military official.

Throughout Central Asia, countries were tightening border security. Pakistan has closed its most critical border crossing with Afghanistan, at Torkham near the Khyber Pass, in an effort to shut off the flow of Afghan refugees.

A Pakistani officer told the Reuters news agency that the Taliban had massed up to 25,000 fighters armed with Scud missiles in positions near the border. "We fear they may attack us, but we will defend the motherland," Capt. Abid Bahtti, of the paramilitary Khyber Rifles, told reporters at a checkpoint in the Khyber Pass.

Along Afghanistan's northern border, where the former Soviet republics of Central Asia also are bracing for possible hostilities, Russia held high-level talks aimed at influencing what kind of cooperation -- if any -- those nations will offer to the United States.

Russian President Vladimir Putin consulted by phone with five Central Asian leaders and then dispatched his top security adviser, Vladimir Rushailo, to the 
region for talks on how to coordinate their response to the threat of war in the
region.

Two countries -- Uzbekistan and Georgia -- have signaled willingness to help the United States launch strikes, while Tajikistan and Turkmenistan have been more circumspect, warning of a possible refugee crisis and other negative consequences of an attack and suggesting they are not willing to serve as a staging ground for U.S.
forces.

Russia's position remains unclear. U.S. Undersecretary of State John R. Bolton told reporters in Moscow after meeting with Russian Foreign Minister Igor Ivanov that he had discussed possible help from Central Asia with his counterparts. "I don't : think they've ruled anything in or anything out," he said.

Over the weekend, Russian Defense Minister Sergei Ivanov strongly discouraged any attempts by the United States to use Central Asia as a launching pad for an assault on Afghanistan. Russia remains a major player in the region, particularly in Tajikistan, a major ally of the Afghan opposition fighting Taliban rule. Russia has 10,000 troops guarding Tajikistan's volatile border with Afghanistan.

Constable reported from Lahore. Special correspondent Kamran Khan in Islamabad and correspondent Susan B. Glasser in Moscow contributed to this report.

\title{
Herald \\ Tuesday, September 18, 2001 \\ Troops mass on Afghan border
}

\author{
By Christopher Kremmer, \\ Gay Alcorn and Mark Riley, \\ Herald Correspondents
}

Afghan and Pakistani troops were reported to be massing on the border between the countries as the United States issued an ultimatum to the ruling Taliban in Afghanistan to give up Osama bin Laden and prepared for a dirty war against terrorists.

The Taliban deployed between 20,000 and 25,000 troops just across the border from the Khyber Pass into Pakistan, a Pakistani army officer reported late yesterday.

At the same time, reinforcements of Pakistani troops had fanned out along the 1,400 kilometre western border with Afghanistan, Captain Ahmed Bahtti said.

"We are also forming our forces, but there has been no firing," he said at a military base in the Khyber Pass, about 200 kilometres west of the capital, Islamabad. 
The United States will review its intelligence operations to allow presidents to order assassinations and the recruitment of criminals as spies in the hunt for those behind the terrorist attacks on New York and Washington.

As the country prepares for massive military strikes against the Taliban militia, the Vice-President, Mr Dick Cheney, said it had to "work the dark side" of intelligence if it was to win its declared war on terrorism.

"It is a mean, nasty, dangerous, dirty business out there and we have to operate in that arena," he said. "We also have to work the dark side. We have to spend time in the shadow."

In other developments:

Pakistani officials were preparing for crisis talks with the Taliban militia's supreme leader, Mullah Mohammed Omar, in a desperate bid to avert war between Afghanistan and the US.

The US demanded that the Taliban hand over bin Laden, the prime suspect in the attacks, within the next few days or face military attack.

Rescuers at the Wo. Id Trade Centre shifted their focus to recovering bodies as a fourth consecutive day passed with no survivors found. The number of dead or missing there reached 4,957, while the death toll in the Pentagon attack stood at 188.

Australian investors, spooked by fears of a plunge in New York, yesterday wiped more than $\$ 30$ billion off the value of Australian stocks. The All Ordinaries index closed at its lowest in 18 months.

At one stage the insurance company QBE lost about 40 per cent of its market value after it admitted that its exposure to the New York attacks was higher than first anticipated.

In the US, Mr Cheney made clear that the planned assault on terrorism would be far broader than military strikes and the Secretary of State, Mr Colin Powell, said the Administration was "examining everything" related to intelligence, including removing the ban on assassinations.

Mr Cheney said the CIA needed to recruit "very unsavoury characters" if it was to infiltrate terrorist groups. 
The intelligence community has come under intense scrutiny after its failure to detect that terrorists planned to hijack commercial planes and crash them into
major landmarks last week.

Mr Cheney said he had "no doubt" that bin Laden was behind the attacks but warned that other groups, including the Egyptian Jihad, may have been involved.

Opinion polls show that Americans support the assassination of bin Laden, and when Mr Cheney was asked if he would like the suspect's head "on a platter", he replied: "I would take it today."

However, many lawyers say state-backed killings would breach international law and send a signal that the US is abandoning its stance as a beacon for democracy
and legal process.

The country was on a full war footing yesterday, with Mr Bush preparing Americans for a long "crusade" against terrorism and warning them of possible
future attacks on US soil.

"We will rid the world of the evil-doers," he said. "They have roused a mighty giant and make no mistake about it, were determined."

US sources say that if the Taliban turns over bin Laden and shuts his network of training camps in Afghanistan, it will be allowed to stay in power. But US officials said the chances of the Taliban agreeing were "very poor".

The head of Pakistan intelligence, Lieutenant-General Mehmud Ahmed, arrived in the southern Afghan town of Kandahar early yesterday and met senior Taliban officials. He was expected to call on Mullah Omar to appeal for the handing-over of bin Laden.

Lieutenant-General Mehmud was reportedly accompanied by Islamic scholars to bolster efforts to persuade the Taliban that surrendering bin Laden would not transgress religious principles.

Unconfirmed reports said he was also carrying evidence, provided by Washington, of bin Laden's involvement in the attacks.

The former Pakistan interior minister and retired general Naseerullah Babar, who is widely credited with creating the Taliban movement, said he believed Mullah Omar could be persuaded to see reason.

But a former Pakistan foreign secretary, Mr Niaz Naik, said he feared the mission to Kandahar would fail. "I don't think we will succeed because we are dealing with people who live in prehistoric times, who are very committed to their views and don't see modern logic or reason," he said. 
The Taliban has justified providing refuge to bin Laden by saying there is no hard evidence against him, and that in Afghan culture guests must be protected.

It has said in recent days that bin Laden is under tight Taliban control and could not have had a role in the attacks. But observers cite strong evidence that the multimillionaire has become one of the movement's main financial backers.

Mullah Omar, a former mujahideen rebel who fought against communist-backed forces during Afghanistan's civil war, has summoned religious leaders to Kandahar to consider declaring jihad, or holy war, against the US if attacked.

\section{The GuardianWeekly}

September 6-12 2001

\section{Australia plays politics with asylum seekers}

\begin{abstract}
Analysis Patrick Barkham in Sydney

When John Howard's Sunday evening was disturbed by the vexing question of what to do with 433 refugees heading for Christmas Island on a Norwegian freighter, the Australian prime minister made a decision whose consequences he could not have fully calculated at the time.

More than a week later, it seems that Mr Howard's refusal to let the Tampa dock at Australia's remote territorial outpost of Christmas Island has done more to boost a prime minister's pre-election popularity than
\end{abstract}

any ship since the Belgrano, the Argentine cruiser sunk by the British during the Falklands war, which helped Margaret Thatcher win the 1983 election in Britain.

Mr Howard must call a federal election before the end of December.

"I did it because I thought it was right," the prime minister insisted this week. His hard-line stance was also popular. According to polls on Tuesday, Mr Howard's approval rating has jumped 11 points to $57 \%$, while $74 \%$ of voters backed his han. dling of a tense week in which the shipwrecked Afghans were forced to huddle in empty containers on the ship's deck while Australia, Indonesia and Norway squabbled over who should take them.

Watching pictures of SAS troops storm the Tampa to ensure its Norwegian captain did not dock his human cargo, most of Australia went into war mode. It helped that there was almost no sympathy-inducing footage of the exhausted Afghans.

A spirit of national unity prevailed. The press predominantly accepted government claims that the refugees had no legal right to come to Australia and praised Mr Howard for displaying firm leadership. Desperate not to be seen as soft on "illegals" - as asylum seekers are widely called in Australia - the opposition Labor party followed

the government's lead, only daring to oppose it when Mr Howard proposed draconian emergency legislation to head off the threat of legal action against his administration.

Domestic opinion remained implacably on Mr Howard's side after the SAS's successful transfer of the asylum seekers to the troopship HMAS Manoora on Monday for a seven-day journey to Port Moresby in Papua New Guinea.

Australians were momentarily shaken when the government accepted New Zealand's offer to take 150 of the refugees and the moral high ground - which its prime minister, Helen Clark, was careful not to exploit. But few Australians questioned the bizarre spectacle of the largest nation in the South Pacific relying on the charity of the smallest republic in the world, Nauru, which offered the remaining 283 asylumseekers temporary sanctuary on what is little more than an exhausted, toxic phosphate mine $20 \mathrm{sq} \mathrm{km}$ in area.

An ongoing court challenge in Melboure could still derail the Howard government's face-saving scheme to avoid processing the asylum seekers on Australian soil. But the plan's prohibitive cost - A $\$ 3 \mathrm{~m}$ (US $\$ 1.5 \mathrm{~m}$ ) a day, rising to $\mathrm{A} \$ 70 \mathrm{~m}$ at a conservative estimate - has failed to dent $\mathrm{Mr}$ Howard's new-found popularity.

In the short term the dramatic stand-off in the Indian Ocean erased from the headlines embarrassing allegations of tax fraud in party branches of the Coalition, which comprises Mr Howard's Liberal party and the National party. In the medium term it bodes well for the federal election prospects of the Coalition after a disastrous 2001 in which it has lost three state elections.

Analysts point out that immigration is unlikely to be the major vote winner unless Mr Howard goes for a transparently opportunistic early ballot. Most Australians will vote on the state of the economy and public services, particularly health and education.

But the polls suggest that $\mathrm{Mr}$ Howard has now done enough to win 


\section{The Guardian Weekly}

September 6-12 2001

Khalecj Times, Sunday,

September 9, 2001

over the crucial block of disaffected regional voters who before the Tampa crisis might have plumped for Pauline Hanson's anti-immigrant One Nation party.

One poll this week found that $98 \%$ of One Nation voters supported $\mathrm{Mr}$ Howard's stance. Another found the Coalition's support soared five percentage points in a week to $45 \%$, while Labor remained unchanged on $3.9 \%$, apparently confirming that the government is stealing support from the smaller parties.

It all adds up to a domestic triumph for Mr Howard. Perhaps, but the long-term implications of his handling of the stand-off at Christmas Island do not look so rosy.

Australia has further alienated its most important neighbour. The fact that Mr Howard has taken responsibility for the asylum seekers in a roundabout and costly way demonstrates his impotence over Indoncsia. Australia's claim that its neighbour was responsible for the refugees was quietly rebuffed by Indonesia, which lay low as international pressure was applied to Australia. The Indonesian president, Megawati Sukarnoputri, refused to return Mr Howard's desperate telephone calls last week.

The numbers of refugees arriving in Australia to seek asylum actually fell in the 12 months to July compared with the previous year. But the government has talked up the problem, and the public now expects a solution.

Despite his rhetoric of deterrence, Mr Howard knows that his posturing over the 4.33 asylum seekers - many of whom will settle in Australia as refugees after a three-month assessment on Nauru - will do little to stop desperate people fleeing Afghanistan and Iraq and heading for Australia via Indonesia.

Any long-term plan to stop the people smugglers must entail enhanced co-operation with Indonesia. But Mr Howard's tailoring of the Christmas Island crisis to suit his domestic needs appears to have precluded any easy diplomatic solution.

\section{Taliban shut down more aid agencies}

\section{Rory McCarthy in Islamabad}

Afghanistan's Taliban regime extended its crackdown on Western aid agencies in Kabul last week by closing two Christian organisations, a month after it arrested 24 aid workers eight of them foreign - and accused them of proselytising.

Security officials closed the offices of the International Assistance Mission, a large American aid organisation that has worked in Afghanistan for 36 years, and Serve, a smaller aid group. The foreign staff of both agencies left Kabul after being warned that their offices would be closed.

A third Christian group, Pactec, which provides low-cost flights for aid workers between Afghan cities and Peshawar in northern Pakistan, also withdrew its six foreign staff from Afghanistan.

Aid workers in the capital, who provide education, healthcare and food for a population badly affected by 20 years of war and now a worsening drought, are afraid that more agencies will be closed as some elements in the Taliban regime press for all Western groups to be forced out of the country.

The ministry for the promotion of virtue and prevention of vice is still holding eight men and women from Australia, Germany and the United States and 16 Afghans, staff and employees of Shelter Now International (SNI), a German-based Christian aid agency. The aid workers were arrested last month and are to be tried under Islamic sharia law for spreading Christianity. While the foreigners are likely to be deported, the Afghans face the death penalty if they are found to have converted from Islam. The head of the religious police said last month that other agencies as well as SNI were involved in "religious activities" and were being investigated.

\section{Four security officers held for killing Afghan refugee}

CALAIS - Four people have been detained in connection with the shooting of a teenage Afghan refugee earlier this week near the Channel Tunnel in France, a legal sources said yesterday.

The four, detained on Friday, are security officers belonging to a private firm which works for the French rail company SNCF near the Coquelles terminal, near $\mathrm{Cal}$ ais, the source said.

They were being questioned yesterday by the public prosecutor in Boulogne-Sur-Mer.

The shooting, which followed the death of another refugee in a road accident a day earlier, fed growing tensions at the overcrowded Sangatte refugee camp nearby, as local officials demanded help from Paris and London to stem the influx of asylum seekers.

Police said on Friday they had ruled out the possibility that the Afghan teenager had been shot by one of its officers, after examining the fatal bullet.

Eurotunnel has also denied that . one of its security guards fired the shot, saying its staff was not allowed to carry weapons.

On Wednesday between 150 and 200 illegal immigrants from the refugee centre in Sangatte demonstrated against the attack.

French officials are drawing up plans to convert a psychiatric hospital in northern France into an overflow camp to take the pressure off the saturated Sangatte centre. - AFP 


\section{over role of Masood}

KABUL - Leaders of Afghanistan's opposition alliance were to meet yesterday following an assassination attempt on military chief Ahmad Shah Masood, officials said.

Ousted president Burhanuddin Rabbani had called a gathering of the opposition Supreme Shura, or council of elders, amid unconfirmed reports that Masood had died after suicide bombers attacked his office, they said.

Resistance leaders have insisted that Masood was recovering in hospital with serious injuries to his leg, hands and face after Sunday's bomb attack.

However, diplomatic sources in several countries have said the bombing was fatal.

Opposition spokesman Mohammad Habeel said that Rabbani had appointed Masood's confidant and former intelligence chief, General Fahim, to lead the anti-Taleban resistance until the commander recovered.

"Masood himself instructed that Fahim would substitute for him," Habeel said late on Tuesday, adding the decision was made before Masood was shifted to hospital in the wake of Sunday's bombing in northern Takhar province.

Opposition foreign affairs spokesman Abdullah confirmed that he would attend Wednesday's meeting in northern Afghanistan.

Speaking from neighbouring Tajikistan, Abdullah would not reveal Masood's whereabouts, but he said two other senior resistance officials injured in Sunday's attack were in hospital in the Tajik capital Dushanbe.

"Professor Rabbani is in frequent contact with all members of the Shura. I am leaving for Afghanistan tomorrow. We will see what will happens," he said.

The opposition alliance includes former governor of western Herat province Ismail Khan, ethnic Uzbek warlord Abdul Rashid Doslam and ethnic Hazara faction leader Karim Khalili. - AFP

\section{ANP calls for ban on jihadi parties}

From our correspondent

LAHORE - Awami National Party's senior vice-president Ehsan Wyne has called for a ban on all jihadi organisations, saying his party believes that a jihad can be launched only by a government, and not by an individual, a group or groups

Talking to reporters here, he said his party's central working committee was of the opinion that if any organisation was allowed to launch a jihad, eventually the country would have to face anarchy and consequences of which could be very serious.

Mr Wyne said the ANP also believed that the government should immediately impose a ban on the jihadi like it did on some sectarian organisations.

He said his party was opposed to the proposed deployment in Pakistan of UN observers for Afghanistan because it would mean a direct interference in internal affairs of a sovereign country.

The task entrusted to the UN observers should be carried out by the government of Pakistan, he said. The people of Afghanistan, the ANP leader said, should be allowed to settle their matters on their own, without any foreign interference.

He said it was strange that the United Nations did not decide to deploy observers along the Afghanistan-Iran border.

He also said that the military government had failed to discharge its obligations and should step down without any delay.

The ANP leader welcomed the forthcoming talks between President Pervez. Musharraf and Indian Prime Minister Atal Behari Vajpayee in New York and said his party had been stressing the need for talks between the two countries since partition.

It augurs well for peace in the region that the two countries were prepared to settle their differences across the table.

He said his party had expressed its reservations on General Musharraf's roadmap for restoration of democracy. However, it had decided to take part in general elections to be held next year.

Khaleej Times, Friday, September 14, 2001

\section{Taleban back Bin Laden}

KABUL - Afghanistan's ruling Taleban yesterday closed ranks behind Osama bin Laden, making it clear they had no intention of handing over the Saudi dissident despite the looming threat of a US military attack on their country.

Mullah Mohammad Omar, the reclusive supreme leader of the militia, said in a statement that only trained pilots could have carried out the attacks but that Bin Laden did not have any under his command. "The incidents which took place in America are testimony to Osama bin Laden's innocence because where are Osama's pilots and where were they trained?" Omar said in the statement, which was read out on the Taleban mouthpiece Radio Sharia.

"Blaming Osama without any rhyme or reason is a separate thing and a move by the (Western) intelligence agencies to escape their own failure." Taleban Foreign Minister Wakil Ahmed Muttawakel had earlier said that claims Western intelligence services had evidence of Bin Laden's involvement in plotting the attacks on New York and Washington were not credible.

"The intelligence services have to say something because they are responsible to the people of the US and the Congress," Mr Muttawakel said. "So in order to mask their failure they will accuse anyone." The minister appealed to US President George W. Bush not to be rushed into military action against Afghanistan. "We welcome Bush's comments that the investigation will continue until there is proof of who is responsible," he said - AFP 


\section{Stern message to Taleban}

WASHINGTON - The United States gave its clearest signal yet yesterdily that it intends to hold Afghanistan's ruling Talcban accountable in its response to this weck's terrorist allacks on New York and Washington because of its support for Saudi dissident Osama bin Laden.

IS diplomats across the Middle East and around the world are telling other governments that their actions in trelping or hindering the US effort to hunt down and punish the plotter: in Tuesday's attacks $\checkmark$ il! 'we a "ber.'tumark" for their future relations with Washington. Secretary of State Colin Powell said. In a brief exchange with reporters, Mr Powell issued a terse "message" for the Taleban, which has sheltered Bin Laden since 1096.

"The message is, to the extent that you are providing havens, support, encouragement, and other resources to organisations such as ... Mr Osama bin Laden, killing innocent people ... you need to understand you cannot separate your activities from the activity of these perpetrators." Mr Powell said.

"And I would give this message to any other regime and any other country that might be doing similar things." Mr Powell said.
Mr Powell stressed that President George W. Bush and his administration have not yet identified Bin Laden as the mastermind of Tuesday's suicide hijackings that destroyed the World Trade Center and badly damaged the Pentagon. "But the evidence is mounting which will allow us to determine in the near future who it is," he added.

Meanwhile, Afghans fled their capital Kabul, fearful of US retaliation. But Taleban leader Mullah Mohamamd Omar appeared to try to stem the exodus by issuing a message to Afghans to face up to any US assault. - DPA, Reuters

\section{Khaleej Times, Sunday, September 16, 2001}

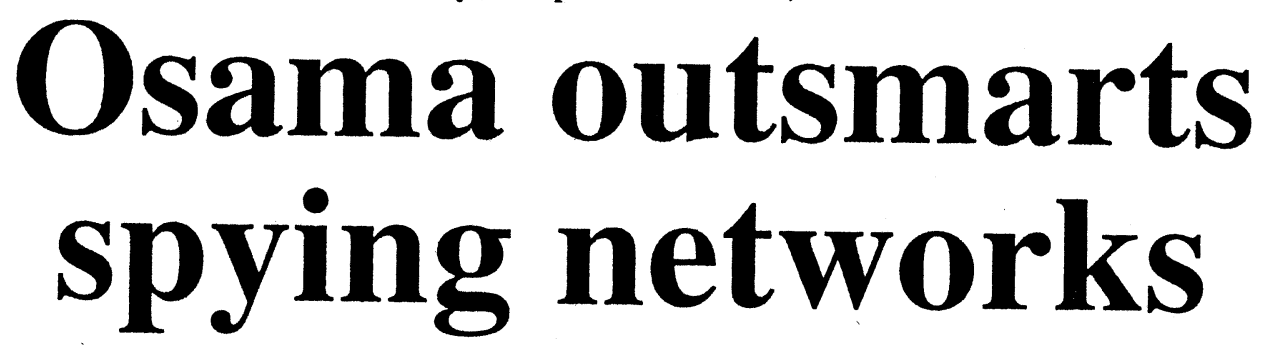

WASHINGTON - Osama bin Laden has survived despite spending much of his life opposing the great powers of the world.

And while Bin Laden, the West's chief suspect for Tuesday's slaughter, likely remains confined to a network of camps and caves in eastern Afghanistan, tracking him consistently has proved ex:traordinarily difficult for US intelligence agencies.

It is so difficult that the administration of former President Bill Clinton prepared to strike Bin Laden last December when officials believed they had solid information of his whereabouts. After an internal debate, they pulled back in part over concerns that the information was out of date further driving home that realtime intelligence on the man is hard to come by.

It isn't for lack of trying. The full assets of the intelligence community - from CIA spies, to National Security Agency wire and computer taps, to the military's satellites - are used to track Bin Laden's activities. The United States and its allies also share information.

Intelligence officials, however, avoid discussing how successful those efforts are for fear of giving away US capabilities.

It's clear Bin Laden knows US spy methods and takes steps to avoid them. He moves fast and goes into hiding. He stops using communications channels he learns are monitored such as his satcellite phone.

"The fact that we seem to have so little information about his recent activities suggests that they ve made some important innovation in communications and is something we re going to have get up to speed on fist," said Daniel Benjamin, a former National Security Council staffer and terrorism expert now with the Centre for Strategic and International Studies. "It is quite possible that they're doing most of their communications by face-to-face conversation."

That calls for human intelligence - US agents able to observe those conversations directly. So far. finding those has proved almost impossible for the ClA. Just as the United States does with its most serious secrets. Bin Laden keeps sensitive information close, sharing it with few people.

Despite his efforts, the CIA, working with its foreign counterparts, has managed some victories, thwarting attacks by $\mathrm{Bin}$ Laden's network in Jordan. Egypt, Kenya and the Balkans in recent years.

Among other countries, Pakistan is believed to have the best intelligence on the militants operating in eastern Afghanistan. Patkistani intelligence sources said Bin Laden changed locations immediately after the attacks on New York' World Trade Center and the Pentagon.

So far, investigators have tied the altacks to known associates of Bin Laden and his organisation, Al-Qaeda, or "The Base."

A telephone call. lapped by US intelligence officers, between two of those associates was an early clue. More links have accumulated since, said a US official, speaking on condition of anonymity.

As they learn the names of those involved in the attacks, investigators can check them against a huge matrix of suspected terrorists maintained by intelligence agencies.

The list contains terrorists' associates and affiliations, allowing investigators to tratec a chain of relationships to Bin Laden or at radical group. - AP 


\section{Pakistan may have to choose between US and Taleban}

ISLAMABAD - The fall-out from this week's attateks on the Inited States has left Pakistan at a crossroads where it will be forced 16) choose between Washington and the Talcban on its doorstep.

With the United States vowing to build an international coalition against terrorism. Islamabad is under intense pressure to use its influence to press the Taleban to hand over Osama bin Laden.

President Perez Musharraf pledged yesterday to cooperate with US efforts to find those responsible for the worst terrorist atrocity in history.

"It is a defining moment for $\mathrm{Pa}$ kistan." a Western diplomat based here told AFP. "It is their last chance to prove that they are not on the fringes of extremism."

While Pakistan has traditionally allied itself closely to the United States and the West, it has always been reluctant to translate that into "definitive action against terrorism". the diplomat added.

The ambivalence. observers say, partly reflects deep-rooted schisms in the political and cultural psyche which allow a profound antiAmericanism to exist alongside admiration for the dynamism and values of the United States.

According to Basit Hamid, the 53 -year-old president of California-based Elixir Technologies, there is a "sort of schizophrenia" that was reflected in many Pakistanis" response to this week's attacks.

On the one hand there was a degree of admiration for the ingenuity of the terrorists and the fact that the United States hatd been "laught a lesson" over its treatment of tray and its backing for
Isratel.

But at the same time, most people also immediately recognised thatt the country's ambivalence toward extremism would have to change.

"It is a wake-up call for both the United States and Pakistan," said Mr Basit.

Saced. a 25-year-old from Karachi who wats on the plane carrying dozens of Western journalists into Islamabad, echoes this theme.

"Take the passengers of this plane. Ask who wants a visa for the US and 90 per cent will stick their hand up.

"But at the same time, in their hearts they dislike, they hate America."

The sense of Pakistan being at a turning point has also been reflected in commentaries in the country's Press.

An editorial in The Ne'ws daily warned yesterday that Pakistan woukd have to pay a heavy price if it "did not now amend its Afghanistan policy drastically".

But according to writer Ahmed Rashid, Gen. Musharraf cannot afford to be seen as siding too openly with the US.

A better option would be for the president to concentrate his efforts on persuading the Taleban to hand over bin Laden, if he is shown to be behind the attacks.

"That way it can be projected as a Taliban decision and Pakistan can avoid a backlash at home. I think this is the best way out for Pakistan." - AFP
Khaleej Times, Saturday, September 15, 2001

\section{Stay of Afghan nationals extended}

NEW DELHI - The Indian government yesterday announced concessions, including extended stay permits, for Afghan nationals in view of the "continued disturbing conditions" in Afghanistan.

The United News of India (UNI) reported that in a letter the union government has directed all state governments to extend the stay concessions of Afghan nationals by a year.

Since 1999, renewal of residential permits for Afghans had been reduced drastically. Also, according to UNHCR officials, there had been no renewals for the last few months. However, Afghan nationals with stay permits until June 30 2001 will now be allowed to stay in India till June 2002. Those who have not obtained these permits are also likely to get an extension.

Provision has also been made to waive any fine for over-stay or renewal of residential permits. A committee will be set up to decide cases of Afghans who do not have travel documents but want registration and identification certificates.

Also, Afghan nationals registered with regional foreign registeration offices in India will be allowed to travel in most of the country without any restrictions. However, Afghans looking to settle in a third country will first have to register themselves, before their cases are considered. - DPA 


\section{The GuardianWeekly}

September 13-19 2001

\section{Afghan rebel leader blown up}

\section{Assassins may have succeeded in killing Masood}

\section{Luke Harding}

Ahmed Shah Masood, the veteran leader of Afghanistan's anti-Taliban opposition, was in a serious condition in hospital after an attempt to blow him up by two Algerian suicide bombers, according to close aides.

The commander of resistance forces in the north was reported to have a head injury and shrapnel injuries to his leg and hands after the attack, which took place last Sunday afternoon at his base in northern Afghanistan.

"The doctor says it will be 10 or 12 hours before we know. His condition is stabilising, but he is still unconscious," Ahmed Wali, Mr Masood's brother and the Afghan opposition's ambassador to Britain, confirmed on Monday. Doctors performed emergency surgery on Mr Masood in a hospital in neighbouring Tajikistan, Mr Wali added.

A leading diplomat at the Afghan embassy in France said Mr Masood was conscious and his condition had stabilised. A chargé d'affaires, Mehrabodin Masstan, suggested that the bombing could be the wor of Osama bin Laden, accused by ine United States of blowing up its two embassies in east Africa in August 1998.

But despite assertions that $\mathrm{Mr}$ Masood survived the assassination attempt, a US official told Reuters news agency: "We believe he's dead".

Afghan opposition sources had denied an earlier report by the Russian news agency Itar-Tass that $\mathrm{Mr}$

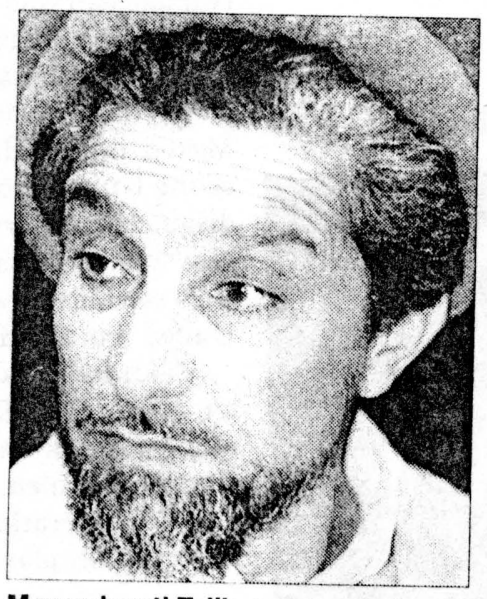

Masood: anti-Taliban commander

Masood had been killed in the blast - the latest in a long line of assassination attempts on the rebel leader.

According to Bismillah Khan, $\mathrm{Mr}$ Masood's spokesman, the commander was at his base in Khodja Bahauddin, in the northern Takhar province, when two Algerians posing as television journalists appeared to detonate a bomb concealed in their camera.

Mr Masood's close aide, Azim Suhail, was killed and another aide was seriously injured. One of the bombers, who had come from Kabul, died in the explosion and Mr Masood's guards shot dead the second Algerian as he tried to escape, it was claimed.

The suicide bombers had arrived in opposition territory from Kabul, the Taliban-controlled capital of Afghanistan. They were met by opposition fighters at Shomali, $50 \mathrm{~km}$ north of Kabul, and were then taken to meet Mr Masood.

After the blast, Mr Masood was flown to the Tajik capital, Dushanbe, for emergency treatment.
The Taliban denied claims that they were responsible. "We are not involved in the incident. If we were, we would have said that proudly because he is our enemy," the Taliban's chief spokesman, Abdul Hai Mutmaen, said.

Meanwhile Afghanistan's hardline Taliban rulers last week finally paraded in court the eight foreign aid workers arrested five weeks earlier on charges of preaching Christianity. The four Germans, two Americans and two Australians had had virtually no contact with the outside world since the offices of their relief agency, Shelter Now International, were closed.

"We have never been informed of the charges against us or why we have been detained. What have we done?" George Taubman, Shelter Now's German director, said in court. "We have never converted anybody. We are shocked with the accusations."

Their trial had in fact begun days earlier when the Taliban's chief justice, Mullah Noor Mohammed Saqib, and senior Islamic scholars met for the first time behind closed doors. The aid workers discovered that their trial had started without them three days later.

Mullah Saqib told the aid workers that they were entitled to be represented by a lawyer if they wanted one, either Afghan or non-Afghan, Muslim or non-Muslim. This might prove some consolation to the relatives of the aid workers, who have been camped in Kabul for nearly two weeks, and for foreign diplomats, repeatedly frustrated in their attempts to reach the detainees. Both groups were allowed into court.

The 16 Afghan aid workers who were also detained last month face trial at a later date. 


\section{Hitting Kabul}

The U.S. is angry and ready to retaliate against terrorists. All eyes now turn to Afghanistan

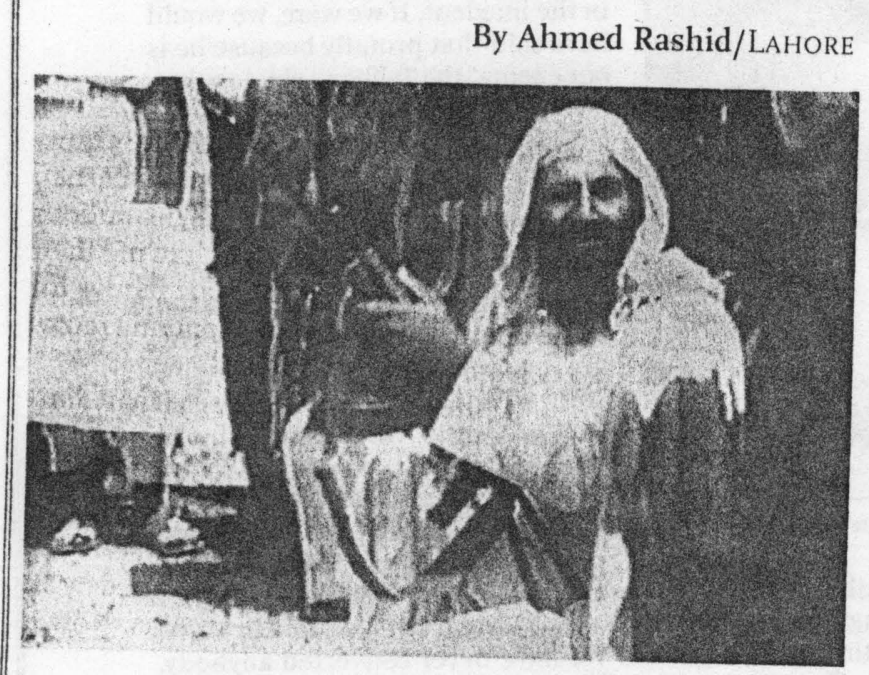

UNITED STATES PRESIDENT George W. Bush's vow to bring to justice those responsible for Tuesday's carnage featured a chilling escalation of purpose: "We will make no distinction between the terrorists who committed these acts and those who harbour them."

As he spoke, many people already believed that Washing. ton would lay the blame squarely on Saudi terrorist Osama bin Laden, based in Taliban-controlled Afghanistan. A number of current and former U.S. officials made bin Laden the prime suspect. A minority doubted that bin Laden was capable of orchestrating such a coordinated offensive. But though he has been lying low for the past year, there was never a doubt that bin Laden would strike at U.S. targets.

The ability of his Al'Qaeda organization to strike terror around the world is heavily dependent on the base it has built in Afghanistan and the support it draws from the Taliban and Pakistan's extremist Islamic groups. With the prospect of a massive and sustained U.S. military attack on Afghanistan, Western diplomats in Islamabad began making evacuation plans for their families. The United Nations began pulling out aid workers from Afghanistan the day after the U.S. bombings.

"It's the worst nightmare of the West, that bin Laden gets stronger, not weaker, in Afghanistan and virtually comes to rule the place," says a diplomat in Islamabad. "From there he can plan and organize strikes around the world."

Bin Laden has dozens if not hundreds of agents at the ready in the U.S. and Europe, many of whom are educated Arab

militants who receive sophisticated training in bomb-making and communications in Afghanistan. In recent months, police in Europe arrested 20 residents suspected of planning to bomb the European parliament in Strasbourg.

But it is Afghanistan where bin Laden has the means, the freedom and space to build up his network. Al'Qaeda now has some 3,000 members from I2 different countries in Afghanistan who fight for the Taliban in the 055 Arab Brigade, which bin Laden finances and commands.

The U.S. attacks were preceded by several days by the attempted assassination of the anti-Taliban leader Ahmad Shah Masud, head of the opposition National Alliance, now known as the United Front. On September 9, two suicide bombers disguised as journalists set off an explosion during an interview with Masud at his base in northern Afghanistan. U.S. officials say Masud was killed; as the REVIEW went to press, the United Front said he was still alive.

Abdullah Abdullah, the United Front's foreign minister, accused the Taliban, bin Laden and Pakistan of carrying out the attack on Masud-a charge the Taliban and Pakistan have denied.

"The operation against Masud was classic bin Laden: meticulously planned... with great technical ability in being

POWER SHIFT: bin Laden (left) is suspected in attacks in the U.S. and on the life of Masud (below)

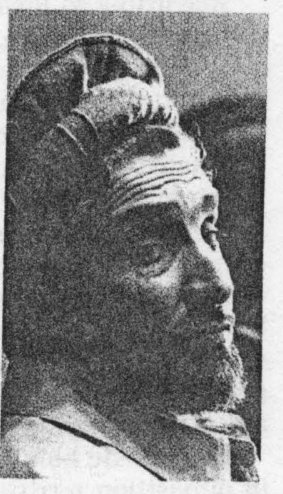
able to conceal a bomb in a videocamera and carry it across the whole of Afghanistan before blowing it up,' says a Western intelligence official in Central Asia.

Masud is or was the only holdout against total Taliban control of Afghanistan. With Masud incapacitated or dead, the fractious United Front would find it hard to hold together. However, hours after the attacks on New York and the Pentagon, the United Front launched a rocket attack on Kabul airport.

If bin Laden did have a role in the attack on Masud, he has won the eternal gratitude of Taliban leader Mullah Mohammed Omar, and immeasurably strengthened his power and influence with the Taliban, who may have had little choice but to allow bin Laden to carry out his U.S. strikes.

After the attack on Masud, Russia called for an emergency meeting of Indian, Iranian and Central Asian leaders in Tajikistan. They are likely to suggest more military aid for the United Front. They are also likely to discuss U.S. requests for airbases in Central Asia to be used to bomb bin Laden's bases in Afghanistan - which Washington first raised last October after the U.S. destroyer Cole was attacked in Yemen.

After the October incident, U.S. officials warned the Taliban that they would be held responsible for any acts of terrorism carried out by bin Laden. But the Bush administration has been delaying its promised new Afghanistan policy. Now the U.S. is suffering the consequences of that delay, with Afghanistan at the centre of global terrorism. = 
The Economist September 15th 2001

The perpetrators

\section{Who did it?}

The prime suspect is Osama bin Laden. Proving his guilt will be another matter

FARLY on in the assault, George Bush talked about an "apparent" terrorist attack. Although suspicion immediately fell on the FBI's most wanted man, Osama bin Laden, Mr Bush's caution is reasonable. The last time America witnessed an outrage on a remotely similar scale, in Oklahoma City in 1995, officials were quick to blame Muslim fanatics, only to discover that an American had done it.

That seems unlikely this time around. Americans are not prone to suicide attacks. The right-wing militia movement that spawned Timothy McVeigh, the Oklahoma bomber, is a shadow of its former self. The group to which McVeigh himself once belonged no longer has enough members with military experience to conduct proper training exercises. The likelihood of one of its counterparts marshalling the expertise to hijack and fly four commercial airliners is small. And the militia movement is now closely watched.

On the other hand, American intelligence about the Middle East has suffered lately, thanks to Arab anger at the plight of Iraqis under sanctions and Palestinians under Israeli occupation. Since the Palestinian intifada began last year, the State Department has worried that an outraged Arab might imitate the suicide bombings now common in Israel. It has issued several warnings about the threat of terrorist reprisals, including one on September 7 th suggesting that militants might target Americans in Japan or South Korea. That implies that America had indeed expected an attack, but had disastrously bad intelligence about its nature.

Investigators have already turned up evidence pointing to Arab involvement. The Boston Herald has claimed that several men from the United Arab Emirates, including a trained pilot, had boarded one of the hijacked flights. Flight-training manuals in Arabic were reportedly found in a

car parked outside Boston airport, where two of the planes were hijacked. Two suspects flew down to Boston from Portland, Maine-close to the Canadian border. There were also reports of triumphant telephone calls after the attack from Mr bin Laden's followers. On Wednesday, arrests apparently connected to the investigation were made in Boston and Florida.

But even if, as seems likely, the authorities soon establish that the perpetrators were Muslim militants, they will find it harder to work out who sent them. Latterday Islamic terrorists operate more through a loose fraternity than through rigidly hierarchical organisations. Past arrests of suspected militants in Canada, Germany, Britain, France and Jordan, as well as the United States, leave a picture of like-minded individuals providing one another with frequent support, occasionally coalescing into groups for specific attacks.

Many of these comrades, including $\mathrm{Mr}$ bin Laden, made one another's acquaintance while fighting in Afghanistan. It may be possible to show that Mr bin Laden knew the perpetrators, but the paper trail is unlikely to reveal more than that. According to a Pakistani newspaper, he has already denied direct involvement.

Nonetheless, there are several reasons to suspect $\mathrm{Mr}$ bin Laden. First, he is one of the few terrorists capable of orchestrating such a daring and complicated series of attacks. He was blamed for the audacious assault on the USS Cole in Yemen last year, when suicidal militants steered a dinghy full of explosives into the American warship in Aden harbour. Mr bin Laden specialises in multiple attacks. Members of his organisation, al-Qaeda, carried out simultaneous attacks on the American embassies in Kenya and Tanzania in 1998, according to testimony given in a trial this year by

some of those convicted for the bombings. Again, however, prosecutors could not prove that $\mathrm{Mr}$ bin Laden ordered the attacks. America also fingered him for another (foiled) plot, to bomb a string of airports and aircraft on the eve of the millennium.

Next, Mr bin Laden recently released a long video, during which he repeated his usual fulminations against America. An Arab journalist in London says he had heard talk of an "unprecedented" action against the United States. That fits $\mathrm{Mr}$ bin Laden's habit of circulating virtual advertisements of forthcoming attacks.

Above all, the World Trade Centre has particular resonance for $\mathrm{Mr}$ bin Laden. It was there that the first big terrorist attack 
on American soil was mounted, in 1993. when a group of Egyptian, Pakistani and Palestinian terrorists planted a car bomb in the basement car park of one of the nowtoppled twin towers. American investigators have long suspected that Mr bin Laden was involved.

A doubt is raised, however, by recent testimony in the trial of the East African bombers. Mr bin Laden's former associates suggested that he was running short of funds. They also described endless bickering and confusion among his men. His former accountant, America's star witness, stormed out of al-Qaeda after being refused a loan. If he was behind yesterday's horrors, $\mathrm{Mr}$ bin Laden had clearly found some more dedicated employees.

Afghanistan

\section{A bitter harvest}

LAHORE

\section{The sufferings of Afghanistan come to New York}

TN ITS understandable rage for justice,

1 America may be tempted to overlook one uncomfortable fact. Its own policies in Afghanistan a decade and more ago helped to create both Osama bin Laden and the fundamentalist Taliban regime that shelters him.

The notion of jihad, or holy war, had almost ceased to exist in the Muslim world after the tenth century until it was revived, with American encouragement, to fire an international pan-Islamic movement after the Soviet invasion of Afghanistan in 1979. For the next ten years, the CIA and Saudi intelligence together pumped in billions of dollars' worth of arms and ammunition through Pakistan's Inter-Services Intelligence agency (ISI) to the many mujahideen groups fighting in Afghanistan.

The policy worked: the Soviet Union suffered such terrible loses in Afghanistan that it withdrew its forces in 1989 , and the humiliation of that defeat, following on from the crippling cost of the campaign, helped to undermine the Soviet system itself. But there was a terrible legacy: Afghanistan was left awash with weapons, warlords and extreme religious zealotry.

For the past ten years that deadly brew has spread its ill-effects widely. Pakistan has suffered terrible destabilisation. But the afghanis, the name given to the young Muslim men who fought the infidel in Afghanistan, have carried their jihad far beyond: to the corrupt kingdoms of the Gulf, to the repressive states of the southern Mediterranean, and now, perhaps, to New York and Washington, DC.

Chief among the afghanis was Mr bin
Laden, a scion of one of Saudi Arabia's richest business families. Recruited by the Saudi intelligence chief, Prince Turki al Faisal, to help raise funds for the jihad, he became central to the recruitment and training of mujahideen from across the Muslim world. Mr bin Laden fought against the Russians on the side of the IsI's favourite Afghan, Gulbuddin Hikmatyar, whose Hezb-e-Islami party became the largest recipient of CIA money.

After the Russians withdrew from Afghanistan in 1989, the Americans quickly lost interest in the country and a struggle for power erupted among the mujahideen. But since no group was strong enough to capture and hold Kabul, the capital, Afghanistan slumped into anarchy. In 1995-96, a movement of Pathan students-Taliban-from religious schools in the border regions of Afghanistan and Pakistan swept the country, promising a restoration of order. They enjoyed Pakistani backing, and almost certainly the approval of the Americans.

Meanwhile, $\mathrm{Mr}$ bin Laden had become a self-avowed enemy of America, appalled at the presence of American troops on holy Saudi soil during the Gulf war. Exiled to Sudan, he was soon forced to leave. He secretly returned to Afghanistan, becoming a guest of the Taliban, whose interpretation of Islam and hostility to the West he shares. After attacks on two American embassies in 1998, America tried to persuade the Taliban to surrender him. When the regime refused, the Americans retaliated by raining cruise missiles on guerrilla camps in Afghanistan. The Taliban have steadfastly refused to hand $\mathrm{Mr}$ bin Laden over. As their guest he remains. 
The Eonomist Sepreniber it theor

Afghanistan

\section{The Lion clawed}

DELHI

The Taliban's deadliest enemy is struck

T IS scarcely surprising that mystery has surrounded the health and whereabouts this week of Ahmad Shah Masoud, the veteran Afghan warlord known as the Lion of the Panjshir, after he was the target of a suicide bomb attack last Sunday. Ever since he hit the international headlines in the early 1980 s as a leader of the mujahideen resistance to the Soviet occupation of Afghanistan, Mr Masoud has been renowned for suddenly appearing and disappearing without warning in the Panjshir valley, his base in northern Afghanistan, or some other part of his territory. Even his closest aides rarely know where he is till he climbs out of one of his battered old handme-down Russian helicopters or a rather smarter Pajero jeep.

That technique has helped him survive

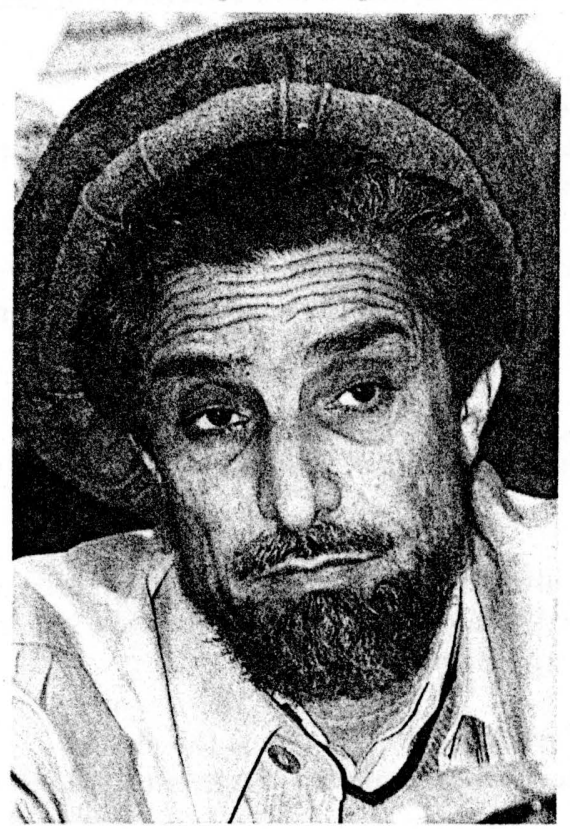

both the Soviet occupation and the fiveyear-old guerrilla war against the Taliban, which he has led for Afghanistan's Northern Alliance since the Taliban took control of Kabul, the Afghan capital. But on September 9 th the technique failed when a bomb exploded in a video camera carried by one of two men, believed to be Algerians or Moroccans, posing as journalists.

At midweek it still appeared possible that Mr Masoud might have survived the attack and be recovering either in Afghanistan or in neighbouring Tajikistan, which supports him logistically. However, a close aide, Assem Suhail, was dead and the proMasoud Afghan ambassador to Delhi, Masoud Khalili, had been injured. The attack took place at Khawja Bahauddin, a sprawling town where Mr Masoud has a helicopter base and a rest house, near both the Tajikistan border and one of the front lines with the Taliban.

In what was probably his last television interview before the attack, Mr Masoud virtually admitted last month that he had no hope of driving the Taliban out of Kabul and gaining control of the country. "The problem of Afghanistan does not have a military solution, but our achieving a military balance and equilibrium is essential," he said. He claims to control up to $30 \%$ of Afghanistan, but in fact probably has only $10-20 \%$, with the Taliban holding the rest. His strategy is to harass the Taliban sufficiently for Pakistan to tire of providing it with financial and military equipment and know-how. Then he hopes that other foreign governments will put pressure on Pakistan to withdraw its support and help pull the Taliban into negotiations. Without Pakistan, said Mr Masoud, "the Taliban

cannot last for six months."

He believes that the Taliban are no longer seeking the Northern Alliance's "total surrender" and are willing to do a deal that gives him his fief of Badakhshan, which includes the Panjshir. But that is not enough for a man who, as a moderate Muslim, wants to free his country of the Taliban's extreme form of Islam-and of Osama bin Laden, the Saudi terrorist who heads most lists of the suspects responsible for the devastation in the United States this week. This has given rise to the theory that Mr bin Laden may have been behind the bomb attack on Mr Masoud, in an attempt to secure his position in Afghanistan by ridding the Taliban of the man their leaders most fear.

Without the Lion, there would be little chance of removing the Taliban from power. He is the defence minister of the Badakhshan-based United Front government of Afghanistan, headed by President Burhanuddin Rabbani, that is still formally recognised by all countries apart from Pakistan, Saudi Arabia and the United Arab Emirates. But he is much more important as the leader of the anti-Taliban forces, which he holds together with his personality and presence, and with his record as Afghanistan's most experienced and respected guerrilla leader. If he were to die, the resistance would probably crumble as quickly as he claims the Taliban would fall if Pakistan withdrew its support. 


\section{Hand over Laden: Security Council}

NITED NATIONS: The UN Security Council said on Tuesday it had one message for Afghanistan's Taliban rulers: hand over suspected terrorist Osama bin Laden and close all terrorist training camps "immediately and unconditionally."

The council issued a short statement after a briefing by Undersecretary-General for Political Affairs Kieran Prendergast on the political, military and humanitarian situation in Afghanistan, "including the dire consequences of Taliban rule for the Afghan people."

"There is one and only one message the Security Council has for the Taliban: implement United Nations Security Council resolutions... immediately and unconditionally," said the statement, read by France's UN Ambassador Jean-David Levitte, the current council president.

The council singled out a resolution adopted last December which demanded that the Taliban turn over bin Laden to the United States for trial in the twin US embassy bombings in Kenya and Tanzania in August 1998 - or to a third country "where he will be arrested and effectively brought to justice."

The resolution also demanded that the Taliban stop providing sanctuary and training for international terrorists, take measures to ensure that its territory is not used to prepare terrorist acts against other states or their citizens and act swiftly to close all terrorist training camps.

Pakistan sent a high-level delegation on Monday to tell the Taliban to either hand over bin Laden or face a punishing assault from the United States, which has named the Saudi-born millionaire as the prime suspect in last week's terrorist attacks in New York and Washington.

The Taliban's supreme leader, Mullah Mohammed Omar, turned the decision over to a grand Islamic council, or ulema, which was gathering in the Afghan capital of Kabul and was expected to discuss the ultimatum Wednesday.

The Security Council froze Taliban assets and imposed an international flight ban on Afghanistan's Ariana airlines in November 1999 to pressure the hard-line Islamic militia to turn over bin Laden. It added an arms embargo on the Taliban in January to step up the pressure.

Earlier Tuesday, Afghanistan's U.N. Ambassador Ravan Farhadi, who represents the ousted government of Burhanuddin Rabbani, offered 15,000 fighters for any operation against bin Laden or the Taliban.

The United States has not asked for assistance from the anti-Taliban forces, which control about 5 percent of the country in the north.

"We have 15,000 people ready to fight. They are trained to fight the Taliban," Farhadi told a news conference.

He alleged that Pakistan's military intelligence knew where bin Laden was hiding since it had trained and worked with the Taliban. Farhadi called for a Security Council meeting to discuss Afghanistan. 


\title{
The Moscow Times
}

Wednesday, Sep. 19, 2001

\section{World Awaits Taliban Decision}

\author{
By Peter Millership and Michael Arkus \\ Reuters WASHINGTON/NEW YORK -- A week after the terrorist attacks in the United States, \\ Afghanistan gave mixed signals Tuesday over whether it would give up Osama bin Laden.
}

Some reports said Afghanistan's ruling Taliban may be prepared to hand over the Saudi-born exile under certain conditions, including trial in a neutral Islamic country.

Many Americans, led by President George W. Bush, observed a moment of silence shortly before 9 a.m., a week to the hour after the first plane slammed into the World Trade Center. "May God continue to bless America," he said quietly as he stood by Vice President Dick Cheney on the White House south lawn.

Stocks clawed higher in early trading following a see-saw opening as investors regained some confidence and prowled for bargains. The Dow Jones Industrial Average gained 0.35 percent, after a 7.5 percent drop Monday.

Commerce Secretary Donald Evans said Bush was considering direct financial aid to help U.S. airlines reeling from cancellations and layoffs.

After airline shares suffered the heaviest selling on Monday, industry airline executives met with Transportation Secretary Norman Mineta on Tuesday to review a request for $\$ 24$ billion in government aid.

While Bush sought to build a strong international coalition for a possible attack on Afghanistan, some world leaders who condemned the terrorist attacks sounded alarm bells at the prospect of U.S. military strikes.

China said any U.S. military action should avoid harming innocent people and should respect international law.

Germany voiced caution. "We need to react with a cool head," Foreign Minister Joschka Fischer said.

But with Washington warning the world it was time to pick sides, Britain and Italy said they would contribute their military forces if asked to.

Reports in Pakistani newspapers raised the possibility that the Taliban could be ready for negotiations. The Taliban may be prepared to hand over bin Laden, who has denied any hand in the attacks, under certain conditions, according to reports in the Nation and Jang newspapers. The reports could not be independently confirmed.

Conditions included the trial of bin Laden in a neutral Islamic country, lifting of UN sanctions against the Taliban, economic assistance and suspension of foreign aid and military supplies to the Afghan opposition, the reports said. 
But a senior Afghan cleric also said the Taliban would launch a jihad, or holy war, against the United States if it attacks. Officials of the Islamic movement quickly said the final decision was with a council of cleries, due to convene this week. That council on Tuesday postponed for 24 hours a discussion on the fate of bin Laden.

The FBI is following up 47,000 leads. U.S. authorities have arrested at least four witnesses with key information about the attacks or who posed a flight risk. They have also detained 49 other people for inmigration violations.

\section{Hindostan Times}

Wednesday, September 19, 2001

\section{Najibls family moved to secret place}

\section{Chetan Chauhan}

(New Delhi, September 18)

In an unprecedented security cover for foreign nationals, the exiled family of late Afghanistan President Najibullah has been moved to an undisclosed destination from their New Delhi house. The security agencies see an increased threat perception to the family in the wake of a possible war in Afghanistan.

It was believed that the family could be targeted by Islamic fundamentalists.

In 1996 after the Taliban takeover of Afghanistan, Najibullah was taken out of the United Nations office in Kabul on and was hanged to death in public. His family -- wife, three daughters and motherin-law -- were allowed entry by the Indian government in 1992 when civil war broke out in Afghanistan.

A senior police officer said Dr Najib's family was shifted from their house in Asiad village to $\mathrm{K}$ Kamraj Marg in New Delhi district after the IC.-814 hijacking.

Now again, the officer said, the family was asked to temporarily move to a new place as their residence had become an 'open secret' with their interview coming in newspapers. "They are on the hit list of the militant groups that opposed Russia-backed Najibullah government," the officer said.

"As they have $Z$ plus security cover, their movements are kept secret. Madam (Najibullah's wife) told us that she will be back in a few days. The entire family left together with their belongings," said a domestic help. 


\section{Hindostan Times}

Wednesday, September 19, 2001

\section{Material evidence on Pakls Taliban links}

HT Political Bureau

(New Delhi, September 18)

India has shown the United States evidence of Pakistan's close ties with the Taliban. Intelligence provided by India shows that Islamabad's clain that it has no leverage with the Taliban is untenable. information. The to Pakistan after Black Tuesday, may have been influenced by this established by thindustan Times has documents that India has given the US to fulfil commitments collaboration show Joint Working Group on Counter-Terrorism. The details of Islamabad's

The regime headed by Mullah Omar in Afghanistan has got all that it has demanded from Pakistan President Musharraf's regime $S$ food, oil, medical aid, military supplies and even ISI expertise for carrying out important missions and manning sensitive outposts.

Maulana Masood Azhar, the militant freed in the IC-814 hijack deal, last month thanked Pakistan at a meeting of the so-called Afghan Defence Council in Islamabad to protest against the UN's decision
to deploy sanction monitors in Pakistan.

"If you gentlemen decide that the monitors should not come, then they will not come," Azhar said,
underlining the close ties between Kabul and Islamabad.

This is what India has told the US. The ISI uses abandoned factories and closed cotton mills in the NWFP's Mansehra, Lakki, Nowshera and Charsadda areas as staging posts to send military
hardware and aviation fuel to Afghanistan.

It has opened offices in Kandahar and Kabul under a Major and a Brigadier respectively. They are responsible for co-ordination between the Pakistan Army, the ISI and the Taliban. Another office at Mazar-e-Sharif handles co-ordination with Uzbekistan-based terrorists.

What India has told the US * India says it has material evidence that Pak is flouting UN resolution banning military aid to
Taliban

* Under garb of relief, arms and ammunition sent to Afghanistan

* Pak using abandoned factories in border towns as staging posts

* Equipment trucked to Mardan, Bannu etc by night. Baluchistan route to Kandahar also used

* Peshwar-Jalalabad highway is avoided; obscure feeder roads are used instead

* ISI has two new offices in Kandahar and Kaful

* ISI opens office in Mazar-e-Sharif for expanding Uzbekistan ops

* In April, Taliban Deputy Minister Ahsan Akhund allowed to attend Deoband confence in Peshawar 


\section{The Economic Times}

Wednesday Sep 192001

\section{Govt for vigil against ISI agents}

Our Political Bureau

NEW DELIII

THE UNION cabinet on Tuesday stressed the need for stepped up vigil against possible subversion by ISI "sleepers"'.

Although the security agencies have busted nearly 110 ISI modules spread across several states over the recent years, there exist an equal or even greater number of these cells which are dormant but can be activated as part of the Pakistan agency's gameplan to perpetrate terror.

The Cabinet felt that the ISI, under pressure from the fundamentalists in Pakistan who are opposing President Pervez Musharraf's offer of unstinted cooperation to the US in its fight against the Taliban, may act out of desperation and strike some vulnerable targets in the country including
dams.

The dams, mostly located in the interiors, often lack security which makes them easy targets of subversion. The assessment of the intelligence agencies is that the "activated" ISI "sleepers" may train their guns on these low-security installations with the aim of causing maximum economic damage to India.

It is in this background that the Cabinet today discussed the need for a comprehensive anti-terrorism legislation. The proposal to enact Tada-II, albeit with safeguards against human rights violations, had to be set aside following opposition from a majority of states who were not satisfied with the "safeguards" proposed in the draft anti-terrorism bill prepared by the Law Commission. Earlier, the NHRC too had rejected the need for a Central anti-terrorism law.

The government, which has asked the law panel to rework the draft to take care of the NHRC'S objections, has in the meanwhile suggested to the states to introduce their own state laws to deal with organised crime and terrorism on the lines of the Maharashtra Control of Organised Crime Act.

Andhra Pradesh and Gujarat have already taken the lead in this regard and nearly all state DGPs, at a recent conference of DGPs/IGPs, supported the need for an anti-terrorism law be it at the Central or state level.

\section{The Economic Times}

Wednesday Sep 192001

\section{China disappoints Musharraf this time}

\section{Our Political Bureau}

\section{NEW DELHI}

IN the midst of reports that Pakistan president General Pervez Musharraf would be travelling to China to confer with Islamabad's traditional allies about the brewing crisis, foreign minister Abdul Sattar today put the brakes on such speculation saying Gen Musharraf was yet to schedule his visit. 
security decisions. This was the norm during Chagai as well as during Kargil. However, authoritative sources say that it was Beijing this time that was reluctant to entertain Gen Musharraf.

While this should not be taken to mean that China was about to dump its all-weather ally, Pakistan, Beijing's decision probably had a lot to do with the fact that five Pakistani nationals were arrested in Macau yesterday for planning strikes against US targets in Taiwan, Hongkong and China.

It was also reflective of Beijing's discomfort with Pakistan allowing a US-led military presence in the region, a prospect Beijing views with strong disfavour.

China has been traditionally against US presence in its backyard which has been used to explain its discomfort with the Pakistan demand for US presence in Kashmir. With the present US administration when China's position as the "strategic competitor" has been sharpened, it is even less likely to countenance US presence.

China will not oppose a UN security Council resolution on multilateral action against terrorists in Pakistan and Afghanistan if it comes to vote, even if they don't wholeheartedly endorse it.

China has been quietly building its relations with the Taliban over the past couple of years with the quid pro quo that they would lay off the Xinjiang province where China is battling a Muslim separatist problem by the Uighurs.

Part of its quiet diplomacy is also intended to increase Beijing's footprint into Central Asia.

It is unlikely that Gen Musharraf would be overly unhappy at Beijing's reluctance. Right now, with the current crisis breaking over his head, being away from Islamabad is probably not in his interest.

His decision to ally with the US against the Taliban has had the inevitable repercussions within his own establishments, which necessitated him not only holding meeting ater meeting with all sections of the government but looking at ways to stem the implosion within Pakistan.

His meeting with the military commanders over the weekend dragged on for over seven hours and saw strong dissent by three top military chiefs. Some commentators have even speculated on the fact that Gen Aziz may well lead another coup against Musharraf.

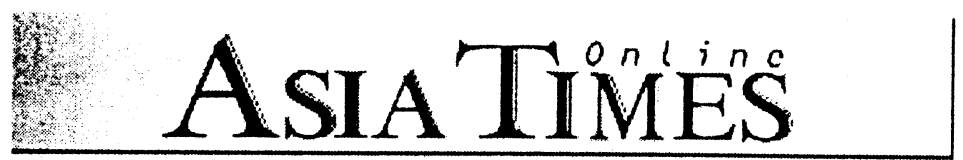

September 19, 2001

\section{Stinger in the tail of US policy}

By Ranjit Devaj

NEW DELHI - One worry for United States forces considering any aerial assault on the bases of Osama bin Laden is the arsenal of deadly Stinger missiles provided by Washington during the Afghan war in the 1980 s.

The shoulder-fired anti-aircraft missiles are part of a stockpile of infantry weaponry worth more than USS8 billion that has been a source of worry to Indian troops fighting jiladis (warriors) in the disputed temitory of Kashmir. 
According to security officials, the US Central Intelligence Agency (CIA) made desperate efforts following the end of the Afghan war with the pullout of the Soviet army in 1989 to buy back at least some of the 1,000 Stingers it had supplied to anti-Soviet forces in Afghanistan. But they met with limited success, they say.

The Stingers and other weaponry and the Mujahideen who fought the Soviet occupation, now transformed into the Taliban that rules most of Afghanistan, are turning out to be the fateful seeds of
policy that Washington sowed in the region, along with support from Pakistan's Inter-Service Intelligence (ISI).

Experts say that when the Russians invaded Afghanistan in 1979, the CIA pumped in \$2.1 billion over a 10-year period to create an anti-Soviet resistance that included 200,000 fighters garnered from 20 Muslim countries. Bin Laden was one of those who joined the Afghan jihad (holy war).

India's leading defense specialist, K Subrahmanyam, says that the Saudi fugitive bin Laden, based in Afghanistan and identified by the United States as a prime suspect in the September 11 terror attack, had himself warned his American benefactors that once the Soviets were ejected, it would be the turn of the other superpower to feel the heat of jihad.

But no one took bin Laden seriously, and with the Cold War over, Washington shut its eyes to the Afghan Mujahideen and the ISI and allowed them to spend their energies on Kashmir, a dispute simmering between Pakistan and India for more than 50 years, analysts say.

Pakistan itself began to suffer a backlash, with the Taliban extending and exerting influence among the influential clergy and various Kashmiri militant groups based within the country.

This despite the fact that the Taliban owes to the ISI its huge military sucess in confining the United Nations-recognized opposition, the Northern Alliance, to about 5 percent of Afghanistan in the far
north of the country.

By the mid-90s, the Americans were showing alarm that Taliban-ISI activities had found a new source of funding in growing, processing and trafficking heroin, according to the South Asia Analysis Group, an independent New Delhi-based think tank.

In July this year Brigadier Imtiaz, who led the heroin operations for the ISI, was convicted and jailed for eight years for holding unaccountable bank assets worth $\$ 40$ million, apart from owning vast
properties.

Writing in the Pakistani daily The News, the analyst $\mathrm{H}$ K Burqi blames all the major ills that Islamabad now faces on the "swashbuckling years of the Afghan jihad."

"The heroin, the Kalashnikovs, the Afghan refugees, the sectarian lashkars [jihadists|, the allconsuming corruption, nationwide outbreaks of violent crime, they were all bequeathed by the $\mathrm{Zia}$ regime. The dictator $\mid \mathrm{Zia}$ ul-Haq| knew all about it. He wanted to keep the officer corps happy and loyal," Burqi writes.

Evidently, Islamabad has had to pay a heavy price for acting as a frontline state for US interests during the Afghan war and at the end of it, trying to convert military gains into "strategic depth" for itself in the region by continuing the ISI-Taliban relationship.

Other people in the region have had to pay a price as well. The Kashmiris for one are now suing for peace at any cost and have been reduced to resisting attempts to "Talibanize" the valley by militants - mainly, recent news reports say, requiring women to wear the burga (veil) on pain of having their faces disfigured or legs shot at. 
During the July summit with Indian leaders at Agra, Pakistan's military ruler President General Pervez Musharraf, when reminded of the heavy civilian casualties in Kashmir through a decade of armed militancy, remarked that this was normal to all freedom struggles.

But ordinary Afghans have had to flee in droves to Pakistan and other neighboring countries such as Iran and India and have even turned up recently in places as far afield as Australia, simply because they are unable to live in their own blighted homeland, where, according to UN figures, four million people are starving because of US-led sanctions.

With the US now ordering an embargo on oil and food supplies over the Pakistan border and planning to launch aerial assaults, even more of the long-suffering Afghan population is pouring over the Afghan borders.

Musharraf has now been asked by Washington to help dismantle the very structure it was encouraged to set up in Kabul on the suspicion that the Taliban's Arab guest, bin Laden, was behind last week's terrorist attacks.

The general has naturally balked at the prospect, but cannot play the same game of asking for "convincing evidence" to show that bin Laden was actually involved, as Pakistan did after the earlier

This time, Washington is clearly in no mood for protracted debates or legal niceties, such as waiting for a UN mandate for an attack on Afghanistan.

Musharraf has his own problems from jihadists operating in his country. So far he has been able to ignore their activities, including sectarian murder under justification of providing support for armed militancy in Kashmir, the liberation of which territory from Indian rule is a hugely popular issue in
Pakistan.

In addition to that, he has been under international pressure to restore democracy in the wake of his 1999 scizure of power through a coup.

"General Musharraf has sought American indulgence of his deviation from democracy on the grounds that he plans to act against Islamic extremists," writes Husain Haqqani, a Pakistani commentator and former information minister, in an article published in the Indian Express newspaper.

But last week's suicide attacks on New York and Washington have left Musharraf with little room for prevarication. The elimination of terrorism is now on top of Washington's agenda - making the Kashmir issue, restoration of democracy in Pakistan and even nuclear proliferation in South Asia secondary issues. 


\section{Omar calls ulema to discuss jihad}

\section{Residents flee from Afghan capital}

ISLAMABAD: Frightened residents of Kabul fled their homes and Taliban leader Mullah Mohammad Omar summoned religious scholars to the capital to discuss waging a jihad, or holy war, against the United States.

In a statement printed in the Taliban-controlled Shariat daily newspaper, Omar said the ulema, or senior scholars, would be called on to issue a fatwa, or learned opinion, possibly calling for holy war in the event of a US attack.

Some 700 to 1,000 elders and Islamic scholars from each of Afghanistan's 32 provinces are expected to attend the meeting, due to take place Tuesday.

Culture and Information Minister Qudratullah Jamal said jihad was inevitable if Afghanistan was attacked in retaliation for last week's terrorist atrocities in New York and Washington which left some 5,000 people dead.

Afghans who can afford to leave Kabul were packing their bags and taking their families to the countryside Sunday amid

growing fears of a US military strike on Afghanistan, where bin Laden, the chief suspect behind

the attacks in the United States, lives as a "guest" of the Taliban.

With the expulsion of the last remaining foreigners from the International Committee of the Red Cross, eight aid workers held in custody for allegedly preaching Christianity were among the only remaining Westeners in Afghanistan.

A source close to the Pakistani government said consultations between the United States and Islamabad were continuing on what assistance Pakistan could provide in a "war against terrorism."

They said a number of areas of potential cooperation had been identified including sharing intelligence information on the move-

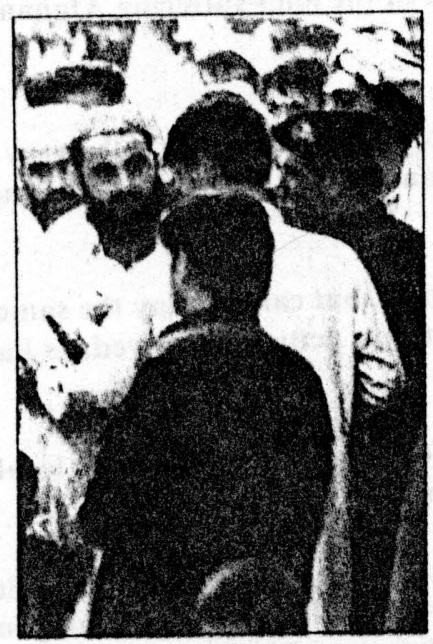

Border guards check documents of Afghans arriving at the Pakistan-Afghan border at Torkham. -Reuters

ments of bin Laden, a closure of the Afghan-Pakistani border and possible use of Pakistani airspace by US forces.

The source stressed that no specific US request had been

made so far by the United States for the use of Pakistani territory to launch ground operations into Afghanistan.

On Sunday, Pakistan's main secular and religious leaders met in the eastern city of Lahore and heard a warning of "grave consequences" from the country's main Islamic fundamentalist party chief. Hussain Ahmed told the emergency gathering of some 30 religious and secular parties an attack on Afghanistan would be disastrous. "We advise Pakistani rulers and the United States to keep away from a path that had in the past led to the defeat and destruction of the Soviet Union."

He warned the government of "grave consequences if it allowed
Jamaat-i-Islami leader Qazi the use of its territory in any way by the United States to launch attacks on Afghanistan." The statement was the strongest sign yet Musharraf will face potentially vi-

olent opposition from domestic Islamist groups which have close ties to the Taliban.

The Taliban have also warned they would retaliate against neighbouring states who assist the United States. The announcement that a Pakistani delegation would visit Kabul on Monday came shortly after bin Laden issued his first direct denial of any involvement in the US attacks.

"The US is pointing the finger at me but I categorically state that I have not done this," bin Laden said in a statement faxed to the Afghan Islamic Press (AIP), a Pakistan-based private news agency with close contacts to the Taliban.

The Taliban have refused repeated US demands to extradite bin Laden for trial in connection with a string of terrorist attacks on US interests, including the 1998 bombing of two embassies in Africa in which more than 200 people died.-AFP 


\section{Economic blockade of Kabul underway as ISI chief heads for Kandahar}

\section{Ikram Hoti and Shakil Shaikh}

ISLAMABAD: Pakistan practically started blocking shipment of goods to Afghanistan on Sunday by suspending the transit trade to that land-locked country, as chief of the ISI Lt Gen Mahmood headed for crisis talks with the Taliban leadership to secure custody of Osama bin Laden.

Pakistan decided to make a last ditch effort to persuade the Taliban leadership not to sacrifice 25 million people for the sake of one person, officials said, as a major policy shift against the Taliban government started taking effect following the Tuesday bombings in US.

The decision to send a delegation of ISI to Kandahar to meet Mulla Omar and other leaders was also conveyed to US authorities and sources said a three-day deadline would be given for handing over Osama to Pakistan, or any third country acceptable to the US. After that deadline, the US may start what is feared to be one of the heaviest carpet bombing in decades.

Pakistani authorities were said to have conveyed their agreement to the US that they would not take part in any joint operations with US troops outside Pakistan, as Foreign Minister Sattar stated on Saturday. Beyond that Pakistan

may consider providing all help to US personnel, should they want to come to Pakistan and prepare for the anti-Osama operation.

"The clearance and transportation of all food, other consumer goods and equipment from abroad by Afghan traders and the government under transit through Pak sea and land routes, has been suspended with immediate effect," a CBR official told The News. He added that from Monday onward, the shipment would remain suspended "until further order". He did not explain whether a formal order has been received "from above" in this connection to the clearing authorities at the Karachi

port and the dry port authorities in Peshawar and Balochistan area.

He only said, "the clearance has been suspended". When contacted, a government official involved in Afghan shipments via Karachi said, "I am in no position to clarify what is going on. I can only say transportation up-country and beyond to the Afghan destinations is practically impossible".

He did not specify who and where the Transit Trade Agreement (TTA) goods transporting lines would be blocked and by witch authorities, but was content to indicate, "The entire country (Afghanistan) is presumably under a blockade. How can such a trans-

\section{portation take place?"}

An Afghan source told The News that more than 100 million dollar worth of investment on the orders already placed for TTA transaction is in the pipeline, while goods of about the same value presently remain stored at the Karachi port and other regional warehouses. This investment is going to remain blocked for a period no authority could specify.

More than a million dollars worth of food and other items of intermediary nature plus plug-on machinery etc including electronic goods and lighting equipment is shipped up-country every month, from Karachi and en route the Ira-

nian-Pak adjacent territories to Afghanistan under the TTA.

The agreement for duty-free clearance between Afghanistan and Pakistan was signed in mid$60 \mathrm{~s}$, and has remained operative notwithstanding even the 1971 Pak-India war and the turmoil of two decades of $1970 \mathrm{~s}$ and $80 \mathrm{~s}$ Afghanistan has been through.

Islamabad has, in the past, been reluctant to suspend or do away with the clearances under agreement despite the local business community's long standing and oft repeated complaint that the shipments allowed duty-free for Afghanistan flood back Pakistani markets giving rise to the

smuggling of goods and rendering the local industry uncompetitive.

The government of Pakistan cut back on the list of shippable items under the agreement to satisfy the most orchestrated grievance of the local industry, it never did away with the implementation of the agreement "on strategic grounds", one senior tax official told The News.

The source further said that the blockade would also render access of the Afghan population in the urban and semi-urban population impossible to the imported goods for a long period, until and unless a TTA goods clearance by Pakistani authorities resumes. 


\section{Ahmad Shah Masud} buried in Panjshir Valley amid tears

PANJSHIR VALLEY: Assassinated Afghan opposition commander Ahmad Shah Masud, the "Lion of Panjshir," was buried on Sunday at a funeral attended by thousands of emotional villagers in the Panjshir Valley.

Supporters lined the dusty tracks of Afghanistan's Bozarak district to bid farewell to Masud, the leader of the last pocket of anti-Taliban forces in Afghanistan.

Masud's coffin arrived at his beloved Panjshir Valley by helicopter from northeastern Takhar province, where the veteran guerrilla died Saturday of injuries sustained in a suicide bombing the previous Sunday.

Draped in the green, white and black flag of the ousted Afghan government, the coffin's arrival sparked chaotic scenes as hundreds of men shouting "Allah Akbar" (God is Great) rushed forward to touch it or throw flowers.

Opposition leaders including Masud's replacement, General Fahim, and ousted president Burhanuddin Rabbani were present, along with Masud's 13-yearold son Ahmad, who vowed to pick up the fight against the Taliban militia.

"I just want to follow the path of my father and achieve independence form my country," the boy told the crowd with a clear, steady voice as everyone around him burst into tears.

"It was one of my father's aims to be a martyr and he achieved that aim, but it was not the right time." Masud's death has left a gaping hole in the anti-Taliban alliance, which clings to the Panjshir, northeastern Badakhshan province and pockets of territory in the north and west.

The 48-year-old ethnic Tajik defended the Panjshir against the Soviet army throughout the 1979 . 89 occupation and has never let it fall to the radical Islamic militia which captured Kabul in 1996.

Almost every house and car in the district was bedecked with black flags, photos of Masud wearing his trademark woolen hat, and banners hailing "Masud the Hero".

"You are the heart of every Afghan. You have broken our hearts with your death," said the inscription beneath the photos.

As the coffin was displayed in

view of Masud's modest one-story house, Rabbani launched a broadside against the Taliban and their main allies, Pakistan and Saudiborn dissident Osama bin Laden.

Notable absentees from the funeral service were opposition alliance members Abdul Rashid Dostam, a strongman from the Uzbek ethnic minority based in northern Balkh province, and Ismail Khan, the former governor of western Herat province.

In the blazing morning sunshine, a mullah (cleric) led a prayer with a loudspeaker from the back of a military jeep as women and girls watched from nearby hills.

The coffin was then loaded onto a cannon trailer and slowly towed behind an armoured personnel carrier some four kilometres to Saricha village in the heart of the Panjshir.

People lined the road and jos-

tled to get close to the coffin as it: meandered through the rural countryside, between fields sown with wheat and vegetables, to a hill where it was lowered into the ground.

Messages of condolences have come from the European Parlizment, where Masud met European leaders in a rare diplomatic forisy outside Afghanistan earlier this year, as well as Russia and Britain. - AFP

Masud's killers were Moroccan,
say Tajik officials

DUSHANBE: Tajik officials said Sunday they had ider tified as Moroccans the men who posed as journalists in a successful ploy to assassinate Afghan opposition commander Ahmad Shah Masud on September 9.

The men, named as Kacem Bokuli and Karim Sujani, had been resident in Belgium, foreign ministry spokesman Igor Satarov said.

They had posed as television journalists, concealing explosives in a video camera, which blew up and fatally wounded Masud, he said. Initial reports had said the two men were Algerian.

Mohammad Saleh Registani, an Afghan diplomat in Moscow representing the anti-Taliban opposition and currently visiting Dushanbe, said the men had travelled from Pakistan to the opposition Northern Alliance headquarters in northeastern Afghanistan, transiting through Taliban-controlled territory. Both men were killed, one in the explosion that killed Masud and the other by Masud's bodyguards.- AFP 
The News International, Monday, September 17, 2001

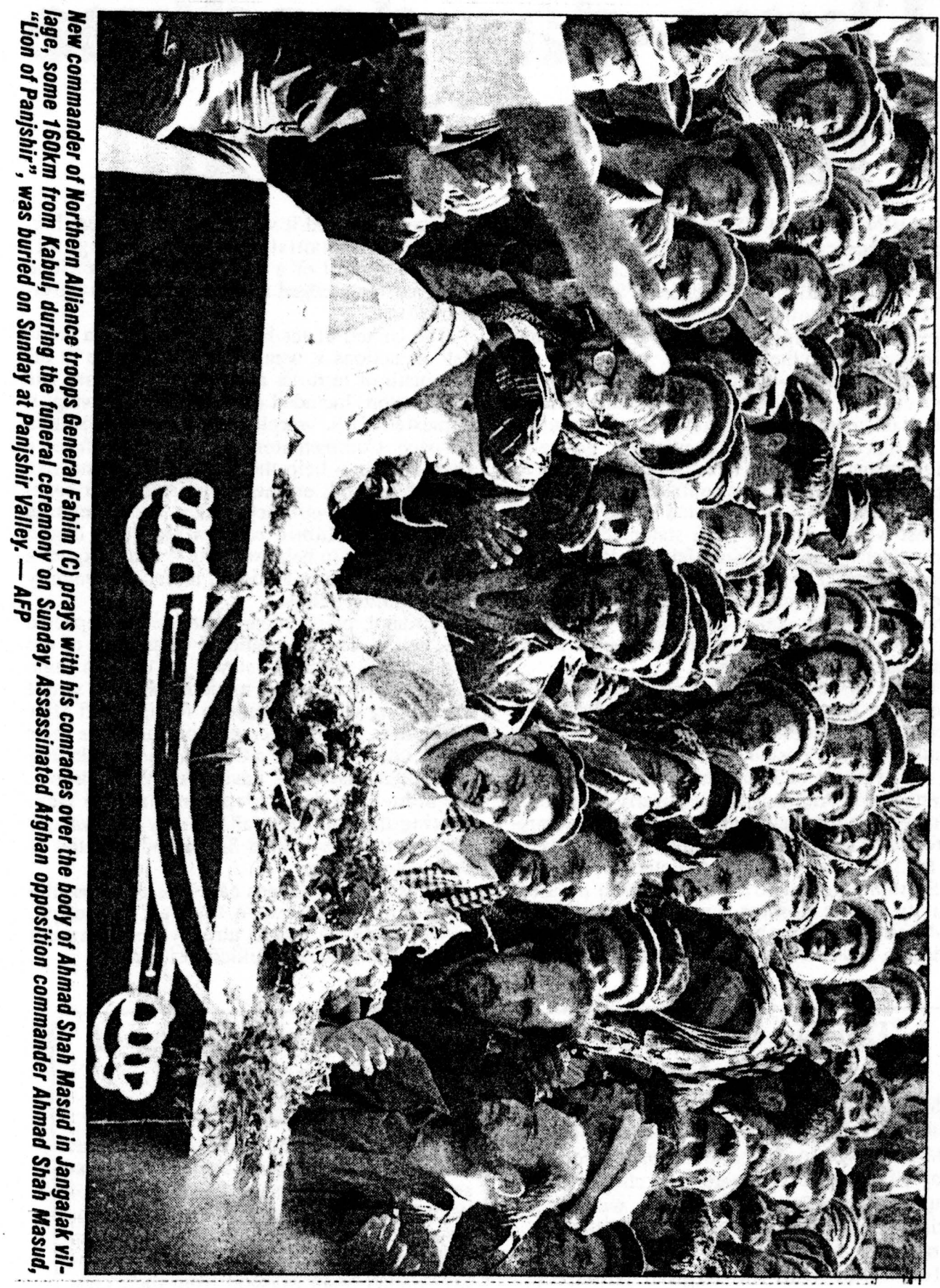




\section{The Frontier Post Monday, spptember 17, 2001}

\section{Demand for extradition of Osama Three-day deadline \\ likely

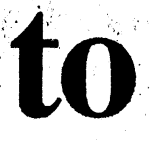 \\ Taliban}

WASHINGTON (NNI): Pakistan is to give the Taliban rulers of Afghanistan three days to hand over Saudi millionaire Osama bin Laden or face U.S. military action, CNN reported Sunday.

The ultimatum comes as Pakistan makes eleventh-hour diplomatic efforts to prevent a military strike in the region.

It follows a late-night telephonic conversation between U.S. President George W. Bush and his Pakistani counterpart General Pervez Musharraf.

A Pakistan emissary will be going to Afghanistan within the next 24 hours to push for a peaceful solution to the confrontation.

Bin Laden on Sunday denied any involvement in last week's attacks, via a statement faxed to the Pakistan-based Afghan Islamic Press (AIP) news agency. The spiritual leader of the Taliban movement, Mullah Mohammad Omar, called Islamic clerics to gather in Kabul on Sunday for an urgent meeting. Meetings were also taking place late Sunday in Pakistan.

CNN has been told by sources close to Musharraf that Pakistan has insisted that in any arrangement involved its airspace only US forces would not use Pakistan soil, and that there would be involvement of India and Israel in any such arrangement. Afghanistan was nearly isolated on Sunday as almost all remaining Westerners prepared to evacuate ahead of expected U.S. attacks on bin Laden and his Taliban protectors.

Surrounding countries buzzed with political. activity, border clasures, support and opposition to American military action, warnings of cultural conflicts, and at least one anti-American protest.

\section{Taliban to protect Osama bin Laden}

ISLAMABAD (Online): The Taliban on Sunday refusing to back down on their stance vowed to protect their guest under any circumstances. "There is no change in our policy on Osama Bin Laden, we still stick to our previous stand," the Taliban Foreign Minister, Wakil Ahmad Mutawakel, told the Afghan Islamic Press.
Iran announced it was sealing its eastern border with Afghanistan, opposition fighters retained control of a narrow northern corridor, and Pakistan pledged to support U.S. enti-terrorism efforts.

The United States has given Pakistan a "wish list" of actions it wants Pakistan to take in the aftermath of terrorist attacks on New York and Washington. Included on that list is allowing, if requested, U.S. warplanes access to Pakistani airspace. Commentators say Musharraf faces a stark choice - help the United States and risk internal turmoil, or back away and suffer sanctions, possible military strikes and economic meltdown. Islamic extremists have urged Musharraf not to help, warning it could trigger a violent backlash in Pakistan, an Islamic country of 140 million people.

In Kabul, preparations continue for expected U.S. action. The International Committee of the Red Cross -- which has stayed put through some of the worst conflicts in modern history - said it was pulling out its remaining foreign staff after the Taliban said they could not guarantee their safety. Other Western aid agencies -- including the United Nations -- have already withdrawn. Frightened Afghans also continued to flee, ignoring the Taliban's calls to stay and wage a jihad against the United States; and its allies if Washington attacks.

Thousands of Afghans have poured across the border into Pakistan in the past few days, swelling refugee camps already near bursting point with around two million residents.

NA to take revenge of Masood death

$$
\text { E.P. Report }
$$

PESHAWR: Ousted Afghan President, Professor Burhanudeen iR bbani, in a message to the nation, said that the death of: Ahmad Shah Masoid was a great loss for: Afghan nation especially for Northern Alliance will take revenge of late comman-. der Ahmad Shah Masood from their enemies. 


\title{
The Frontier Post
}

\author{
Monday, September 17, 2001
}

\section{Taliban rush their families to Kandahar}

ISLAMABAD R Reports from say that Taliban leaders and their families are moving to the surrounding areas of Kandahar as they feel secured there. There are also taking soine of their foreign guests like A rabs and Pakistanis along with them.

It would be difficult to trace and attack them if they remain scattered in villages and towns People in capital Kabul say that additional forces have artived there and while common people have preferred to leave areas close to military based ?

Afghans fiving in Kabul city have stated feeling themselves insecure now as they think that these areas might be the open targets 6 of afthcks by Americans. Since there is no television in Afghanistan, the people would not have seen the horrible pictures and scenes of destruction in the United States but they can listen to foreign radio stations. They have heared that the reports that for: eign workers of aid agencies have left Afghanistan.

Some Afghans are trying to cross into Pakistan but Pakistan's border is also closed for them. Anyhow, most of the people who are used to day/to day dangers and have no travel expenditures would remain in their areas. 4.4 .84

\section{'Get Osama' operation}

$\mathrm{T}$ HE details of the US's 'Get Osama' operation have yet to be"
revealed. Nor is it clear how Pakistan revealed. Nor is it clear how Pakistan intends to dispose of the 1 demands that are being placed on it by the US to qsist in this campaign. In the absence so far of a detailed plan of action by the US, three demands seem to be at the top of Washington's wish list. First, sharing of intelligence and information on Osama ben Laden's whereabouts and movements. Second, the use of Pakistani airspace. Third,
logistical support for the operation.

The military government's response to these demands appears to be that the sharing of intelligence and information does not pose any insurmountable obstacles. The use of its airspace too seems acceptable, although it has been argued in certain quarters that Pakistan has little choice, short of trying to resist intrusions into its airspace; an approach too risky when the intruder happens to be the only superpower in the world, and one deternined to have its way. Logistical support implies the possible use of Pakistan's naval facilities to allow US warships to unload materiel and men for forward transportation to the operational front lines. That front line would require forward staging posts, fuel and other materiel dumps, etc. This poses certain risks for Pakistan, given the Taliban's explicit threat to attack any neighbouring country that lends itself to an attack on Afghanistan.

The military government appears anxious to distance itself from any appearance of collusion with a unilateral US military action. That' is why Foreign Minister Abdul Sattar has strongly emphasised that Pakistan would be bound by any UN Security Council resolutions on the subject. What the military government has dug its heels in on is any participation by Pakistani forces in operations beyond its borders, whether as part of a 'go it alone' offensive by Washington, or as a member of an international coalition that decides to launch an offensive against Taliban-ruled Afghanistan.

Pakistan can hardly ignore the dictates of geography and history. It has to live as Afghanistan's neighbour, no matter who rules in Kabul. Its ties of history, culture and religion with its neighbour cannot be ignored either. Public sentiment in Pakistan too is not well disposed towards whatever punishment the US is planning to inflict on Afghanistan. As it is, the mere acceptance by Islamabad of the three US demands mentioned above, may be enough to bring down the wrath of the Taliban and their local supporters on its head. The backlash to US military action, if and when it comes, will have to be borne by Pakistan:

Irrespective of the fact that the military govermment has restricted rrom for manouevre in terms of the pressure being exerted by Washington to stand by it in its hour of need, Pakistan has to consider what is in its best interest. The US has determined that it is Osama ben Laden who is responsible for the outrage on US soil, although no evidence for that determination has been presented. The Taliban are in harm's way because of their giving sanctuary to Osama.

It is a sad day when the Taliban, for whose victory and consolidation of rule the state and people of Pakistan have given so many sacrifices and suffered immeasurably, use the language of threats. The fact, however, is that perceptive observers have held for years that one day the support for the Taliban would cost Pakistan dear. Some indeed have argued in recent days that it is time Islamabad reviewed its policy of unstinting support for the Taliban, since this policy would now yield diminishing returns and may even prove harmful for Pakistan'sinter-

Pakistan has to play its cards coolly, and not be rushed into any precipitate commitment to Washington which could prove highly damaging in the long run. There are definite losses that Pakistan could suffer and some gains if it uses adroitly the opportunities that have presented themselves. First and foremost, Pakistan's security environment is under definite threat from these recent developments. To refuse the US demand outright may invite more. trouble than we can afford. However, the country's security assets, including its nuclear deterrent, need to be safeguarded against any attempt to encroach on our defence preparedness, no matter from which direction such a threat emanates. The 


\section{The Frontier Post}

\author{
Monday, September 17, 2001
}

Kashmiri freedom struggle has to be insulated and distinguished from being described by the blanket tern 'terrorism', a redefinition India is exerting itself to convince the US of, trying to take advantage of the
mood in Washington.

Pakistan's interests also dictate that it must have a say in the American operation to be launched against Afghanistan, especially if it offers intelligence, airspace and logistical support as demanded by the US. Pakistan's preference would naturally be for a limited operation that is specifically targeted against Osama ben Laden rather than the long suffering Atghan people as a whole. Islamabad would also want to be part of any consultation on a change of government in Kabul, to ensure that a friendly, or at the very least neutral regime emerges post:-
operation.

What Pakistan could hope for is that its economic travails would be addressed by a grateful US administration and help the country to emerge from the long dark tunnel of the debt trap and towards prosper-: ity for its people. This is the minimum price to be demanded from the US as a quid pro quo for what seems an inescapable nutcracker in which Islamabad finds itself squeezed.

\section{- Armed security forces deployed} Iran sealing Afghan border

TEHRAN (Agencies): Iran would seal its border with Afghanistan to prevent a possible influx of refugees as the prospects of a American strike against the Kabul government increased, the official news agency reported.

Iran has called on the security forces...to seal off the 900 $\mathrm{km}$ joint border to encounter the consequences of probable US retaliatory strikes against Afghanistan, the agency quoted the interior ministry as saying.

The ministry said that Iran has deployed military and police forces along with the border to prevent the influx of would-be Afghan refugees into Iran in the aftermath of the probable US attacks.

But the ministry urged provincial officials to continue to provide aid in cooperation with local and international relief agencies to Afghans inside Afghanistan, Millions of Afghan refugees fled to Iran during war and civil strife over the part couple of decades. Some $1.5 \mathrm{mil}$ lion Afghan refugees currently live in Iran.

The possibility of the American military action

\section{The Statesman}

Monday, September 17, 2001

\section{Afghans to be confined to camps}

\section{By Azizullah Khan Marwat}

PESHAWAR: To cope with the emerging scenario in Pakistan, the NWFP government has decided to stop the influx of Afghans and to confine all refugees to their camps.

NWFP Governor Iftikhar Hussain Shah while presiding over a high- level meeting here directed the authorities to be vigilant and take strict measures to ensure law and order.

The governor also ordered the authorities to check the fresh influx of the refugees into Pakistan.

Sources said that the meeting pondered over the situation arising out after Pakistan assured support to the America for a possible attack on Osama and the reaction of the neighbouring country.

The governor said that it was not possible to close the $1300 \mathrm{~km}$ long porous PakAfghan border but extra-forces would be deployed to keep vigilant eye on the border and stop the fresh influx of the refugees from frequented and unfrequented routes.

The NWFP governor also ordered to establish an operation room in the Home Ddepartment to monitor security measures. He asked the lawenforcement agencies to be on a state of high alert and stressed the need to have a close co-ordination between them.

He said that all the lawenforcement agencies would be equipped with all facilities and ordered the administration to arrange transport and other facilities immediately.

The governor ordered to maintain law and order in the tribal areas and constituted two team headed by chief secretary and secretary home. 


\section{The Statesman Monday, September 17,2001}

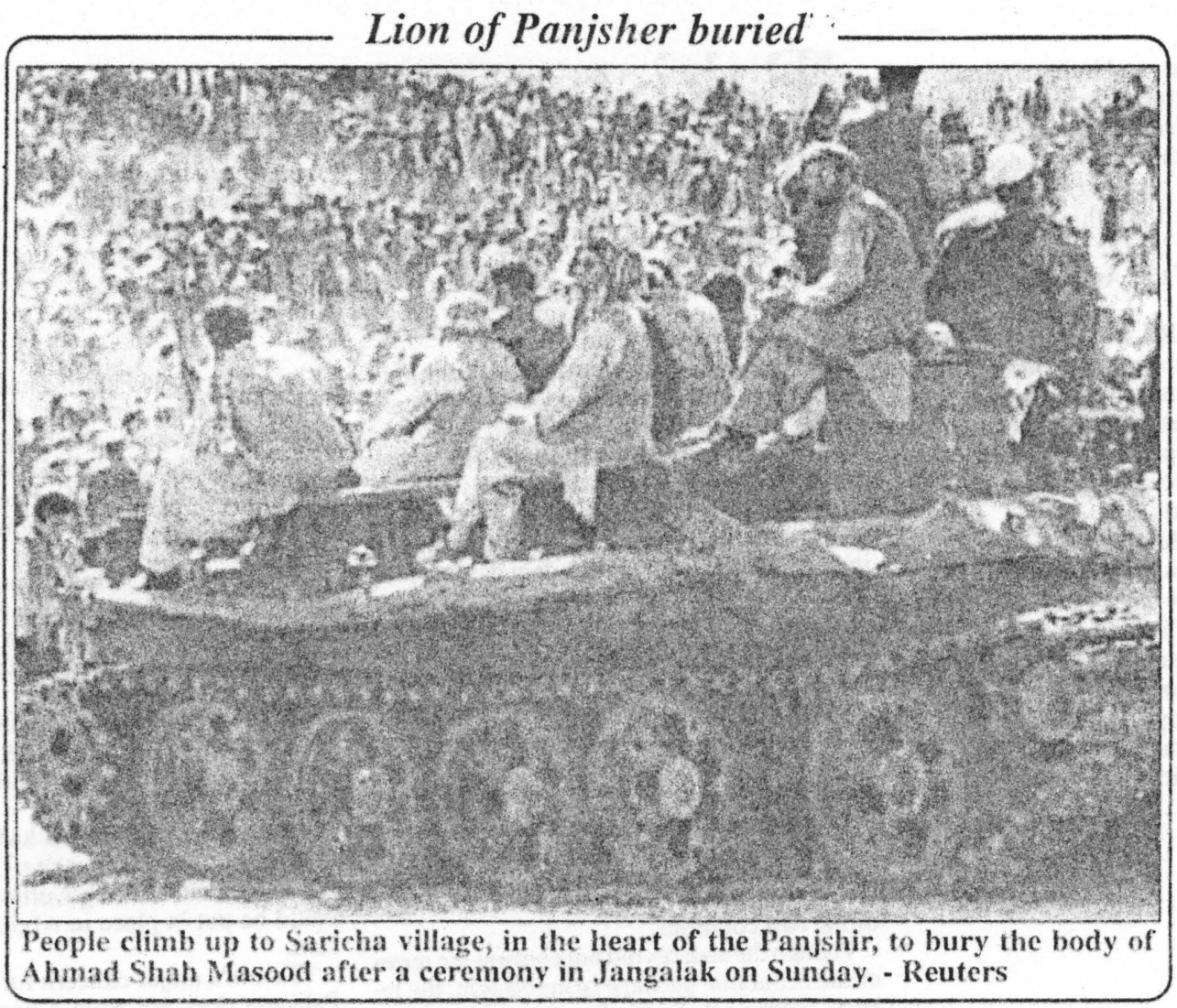

The Nation MONDAY, SEPTEMBER 17, 2001

\section{Assault on Afghans not to lessen US grief, says RAWA}

ISLAMABAD (NN1) - While clear to all that Osama bin Laden expressing its deep sorrow and has the blue-eyed boy of CIA. solidarity with the people of Un- But what is more painful is that tied States, the Revolutionary As- American politicians have not sociation of Women of Afghani- drawn a lesson from their polistan (RAWA) Sunday said at- cies in Afghanistan and are still tacking Afghanistan and kill- supporting this or that fundamening its most ruined and desti- talist band or leader.

tute people will not in any way decrease the grief of the American people.

"We sincerely hope that the great American people could differentiate between the people of Afghanistan and a handful of fundamentalist terrorists, Ou hearts go out to the people of the US," a statement issued by the RAWA said here.

The statement said that it is have committed every possible type of heinous crimes against the people of Afghanistan.

"If it is established that the suspects of the terrorist attacks are outside the US, our constant claim that fundamentalist terrorists would devour their creators, is proved once more," it said.

The US government should consider the root cause of this terrible event, which has not been the first and will not be the last one too. The US should stop supporting Afghan terrorists and their supporters once and for all.

Now that the Taliban and Osama are the prime suspects by the SU officials after the criminal attacks, will the US subject Afghanistan to a military attack similar to the one in 1998 and kill thousands of innocent Afghans for the crimes committed by the Taliban and Osama? Does the US think that through such attacks, with thousands of deprived, poor and innocent people of Afghanistan as its victims, will be able to wipe out the root cause of terrorism, or will it spread terrorism even to a larger scale," it 


\section{The Nation}

MONDAY, SEPTEMBER 17, 2001

asked.

$A$ vast and indiscriminate military attacks on a country that has been facing permanent disasters for more than two decades will not be a matter of pride.

"We don't think such an attack would be the expression of the will of the American people," it said.

The RAWA said that the US government and people should know that there is a vast difference between the poor and devastated people of Afghanistan and the terrorist Jihadi and Taliban criminals.

"W'hile we once again announce our solidarity and deep sorrow with the people of the US, we also believe that attacking Afghanistan and killing its most ruined and destitute people will not in any way decrease the grief of the American people," the statement said.

\section{Pakistan asks US for debt relief, security}

\author{
By Rana Qaisar
}

ISLAMABAD - Pakistan has asked the US for protection of its national security and continuity of economic assistance in return for Gooperation against terrorism and allowing the use of its airspace and naval bases besides sharing intelligence.

"Pakistan has given its demands to the US including relief from foreign debt burden, protection to its national security, and resolution of the Kashmir issue," informed sources told The Nation.

The government is also demanding an assurance that in the likelihood of any action against the Taliban by the coalition forces would not pose any threat to its nuclear installations.

The sources, who did not disclose the nature of economic relief, said it would soon be worked out in a meeting between the officials of the two countries.

Though the sources did not confirm the terms of the economic package being sought, the reports pouring in from abroad suggested that the Pakistan government had asked the US that its foreign debt be written off.

Pakistan's current foreign debt burden is US\$ 37 billion that has piled up over the years. This foreign debt is a major problem as it is crippling Pakistan's economy.

"One of our main concerns is national security in case of the US attack on Afghanistan if the Taliban government does not agree to the extradition of bin Laden," the sources said.

A delegation of top officials will leave here today for Afghanistan to take up the current situation and the issue of Osama bin Laden with

the Taliban government to avoid a major conflict in the region.

The sources said the US had assured Pakistan of the continuity of ongoing funding by the international financial institutions.

"This assurance also includes enhancement of the scope of these fundings."

The sources said the US assistance and help for the resolution of the Kashmir dispute between Pakistan and India was also on the list given to the Bush administration.

"If Pakistan's demand are met, there is no hurdle in the way to extend all-out cooperation to the US against terrorism," the sources said.

They said if the modalities were finalized, financial assistance to Pakistan for getting rid of its loans would immediately come.
The sources said Pakistan had told the US in clear terms that the resistance within the country against cooperation for a 'possible' attack on Afghanistan could be handled if its economic situation radically improved.

"But Pakistan, while allowing the US to use its airspace and naval bases, will not allow the foreign forces to use its strategically important bases," they said.

However, they said the final decision to this effect depended on the US response to the conditions put forth by Pakistan.

The sources said the US had indicated that besides getting Osama bin Laden, a new government could be put in place in Afghanistan.

"This is a major concern for us. Pakistan does not want a hostile government on its western border," they said.

They said Pakistan would ensure that in case the US installs a new government in Afghanistan, it should not be having any tilt towards India.

\section{Pakistan's assistance to spark civil war: Imran \\ LONDON (Agencies):} Chief of Pakistan Tehreek-eInsal Imran Khan has cautioned that Pakistan government's coalition with United States in retaliation against Alghanistan could lead to Civil War in the country. While talking to $\mathrm{BBC}$ in Sunday 'Tehreek-e-Insat chief said that the Government's assurance of full cooperation to United States in routing out terrorism was ambiguous as it was not clear in what form the country was willing to render assistance. 


\section{$K_{H Y B E R} M_{A I L}$ Monday, September 17, 2001 China denies links}

\section{with Taliban}

BEIJING (Agencies): China has termed as "false" US media reports alleging that Heijing has had business and technical links with the ruling Taliban in Afghanistan, which is sheltering Saudi millionaire, Osama Bin Laden.

"Reports in some US newspapers of connection. between China and the ruling Taliban, regime in Afghanistan are false," PTI quoted Chinese Foreign Ministry Spokesman Zhu Bangzao as saying on Saturdas:

Zhu was clarifying reports in The Washington Post and The Wall Sireet Journal

\section{Osama being protected by 13,000 guards, claims opposition}

FRANKFURT (Agencies) Usama bin laden, America's proclaimed enemy no 1 , is "still in Aghamistan" and is protectcal by a 13,000 mstrong private arm!, aceording to a senior Niphan upposition leider. "Bin 1 aten has bodyguards represonting a small anny, probably some 13,000 men," Abed Rajib, a spolesman for Burhanuddin Rabbani. presidum of the Northem Alliance, wh the Sundas edrion of the frankfurter Allgemeine levilung

Rajib said Rabbani was currently in northern Afghanistan, where he attended the funeral of Afghan opposition leader Ahmad Shah Masood who died yesterdat of injuries sustained a week ago in a terorist atlack which claimed China has very close ties with the Taliban with Beijing sending its diplomats to Kabul on a regular hasis, and offering consultation service on matters such as dam construction.

The reports also said at least one Chinese company, Huawei Technologies, is assisting the Taliban to build a te!ephone network. A Pakistani newspaper said that China has signed an agreement with the Taliban on providing economic and technical assistance.

Seeking to distance itself from the Taliban, Zhu said the repurts were "at serious

\section{Taliban to protect bin Laden under any circumstances: Mutawakil \\ Bureau Report \\ . ISLAMABAD}

Alghanistan's ruling Taliban on Sunday refusing to back down on their stance vowed to protect their guest under any circumstances. "There is no change in our policy on Osama Bin Laden, we still stick to our previous stand," the Islamic mililia's foreign minister, Wakil Ahmad Mutawakel, told the Aighan islamic Press.

"We will use all available means and resources for the defence of our cointry. variance with the facts." He pointed out that due to safety consideration, China shut down its embassy to Afghanistan in February 1993 after civil war broke out in Afghanistan.

"China has never sent resident personnel there since then," "Zhu said, describing the report of the regular dispatch of diplomats as "groundless."

He also described the reports on China's involve. inent in the construction of dam and telephone network, as well as the memorandum signed with the Taliban as "ahsurd."

\section{Last aid worker says good bye to Kabul}

KABUL, (Agencies): The last of the international aid workers in Atghanistan left the beleaguered capital on Sunday atter being told by the ruling Taliban to leave because they could not guarantee their sutety should the US launch a retaliatory strike. The International Red Cross, which rarely withdralls from a war-lorn nation, pulled the last is international staff employees that were still in Atghanistan. 


\section{Red Cross pledges to continue Afghan relief effort}

BELJNG: The International Committee of the Red Cross will continue relief efforts in Afghanistan despite evacuating foreign staff because of fear of US retaliation for last week's terror attacks, an official said on Monday.

"We have a thousand local collaborators - Afghan collaborators working with them. Of course those people remain," said Harald Schmid de Gruneck, East Asian head of the International Committee of the Red Cross (ICRC).

"They go on making the basic activities which we have been performing in the last years." The ICRC was moving all of its 70 or so expatriate workers to Peshawar, just over the border in Pakistan, after Afghanistan's ruling Taliban said it could not guarantee the security of foreigners, said de Gruneck.

The Taliban told all foreigners to leave the country in view of a possible US attack.
Some 40 ICRC workers were evacuated last week from the country sheltering Saudi-born militant Osama bin Laden.

Bin Laden is Washington's top suspect, along with a web of dissident groups, in the attacks on the New York's World Trade Centre and the Pentagon in Washington.

The United States has threatened retribution against those responsible for the attacks and those who harbour them.

The departure of foreign aid workers is a severe blow to relief efforts in Afghanistan, where six million people, or a quarter of the country's population, are vulnerable to food shortages, according to the United Nations.

But more than 1,000 Afghan workers at eight Red Cross offices scattered around the country would go on distributing food and medical equipment and helping victims of landmines, said de Gruneck.
The ICRC hoped the evacuation would be temporary and it would reassess the security situation on a daily basis in the hope of sending ad hoc missions from Pakistan to Afghanistan, de Gruneck said.

"The needs of the population are immense," he said.

The ICRC has lost dozens of members of staff in conflicts in Eastern Europe, the Middle East, and Africa over the last two decades.

The organisation routinely considers pulling out of countries where the parties to a conflict do not guarantee their security, said de Gruneck.

It can.take years for it to return to a country, as was the case in Cambodia after the fall of Phnom Penh to the Khmer Rouge in 1975 , when the ICRC was ordered to leave. "While we hoped at the time to come back, we did not come back for "many, maniy, many years," said de Gruneck.- Reuters

\section{Khamenei opposes \\ US attack}

TEHRAN: Iran's supreme leader Ayatollah Ali Khamenei condemned Monday possible US retaliation against neighbouring Afghanistan for last week's attacks in New York and Washington, state radio said.

The Islamic Republic of Iran condemns any eventual military action in Afghanistan which would lead fo a new human catastrophe," khamenei was quoted as saying in a meeting with clerics.

"If the Us wants to increase its power through its presence in Pakistan and sending troops into Afghanistan, the problems will increase on a daily basis," he added.

"The innocent people of
Afghanistan have suffered for 25 years. Are these Muslim people once more to be crushed under the yoke of war because some people are alleged to have taken part in the attacks in the United States, although these accusations have not been proved?"

Speaking of the main suspect, the Saudi-born millionaire now living in Afghanistan, Khamenei asked, and iCan the fact that some Muslims, willingly or unwillingly, might have joined this terrorist group of Osama bin Laden, be an excuse to oppress Muslims and attack the people of Afghanistan?"

Referring to Iran's arch-foe Israel and its conflict with the Pales- tinians, Khamenei said, "Should one condemn all.Jews because the Zionists are committing the most heinous crimes in occupied Palestine?"

And, he added, "We are convinced that the Zionists are the principal instigators of the current wave of anti-Muslim propaganda."

Khamenei stressed, "Islam condemns all mass murder, any killing of defenceless human beings, Muslims, Christians or others, wherever they are and whatever the methods or weapons used, whether atomic bombs, long-range missiles, biological and chemical weapons, airliners or warplanes." $-\mathrm{AFP}$ 


\section{Pakistan's Taliban}

policy must change

\section{Dr Samina Yasmeen}

$\mathrm{M}$ oments bring their own truths and understandings. They also bring their own questions that must be answered. The horrific terrorist attacks on New York and Washington brought us in touch with such moments last week. As we were sitting in the comfort of our homes, living our everyday lives, we witnessed disasters unfold in two cities. The twin towers of the World Trade Centre disappeared as we watched them on television. Who committed such a crime against humanity? How do we deal with it? Do we need to establish a coalition of countries to counter such future acts of terrorism? What is the role of Islamic militant movements in such acts of terrorism?

Answers to these and other questions need to be found. But equally important are the lessons we must learn from these moments. A number of alleged perpetrators have been identified by the US agencies, and they are all linked to Osama bin Laden in Afghanistan.

The Afghan Government questions these conclusions and Osama bin Laden denies any involvement in the attacks. Whatever the merits of these denials, one fact cannot be denied. Osama bin Laden was the creation of the United States. The same can be said about the militant Jihadis in Pakistan who were encouraged and ectucated to participate in Jihad. The ultimate goal of defeating and rolling the Soviets back was so attractive and essential that an international coalition was established which supported these groups. 'They received training and state of the art weapons. Such was the case even when the $M u$ jahideen were not totally trained to use these weapons. Remember the case of stinger missiles which were not always effectively used? And so available were these weapons that when some were sold to third parties, they did not attract the attention of the coalition members.

All of this changed with the Soviet withdrawal from Afghanistan. As the United States diverted its attention to other areas, these Jihadis also redefined the reasons for their existence. Their mission statements changed. Instead of the Soviet Marxist Russiz, capitalist Christian America becarne their main enemy. The aim of rolling the Soviets back was also replaced with the stated aim of making no distinction between military personnel and civilians in a Jhad against America. Such characterisations of the 'other' ignored the fact that in a globalised world of today, America could not be simply equated with being 'White'. They also ignored that with international migration, a number of Muslims have chosen to make Anierica and other western countries their home. So, with a twist of fate, the jihad against the infidels became a jihud against both innocent Muslims and notMuslims living in America.

Who is responsible for this metamor. phosis of thoughts and identification of the enemy? There is little questioning that the disillusionment with America's policies towards Muslim states has a role to play in this process. Equally significant are the linkages between the US Gove. $n$ ment and

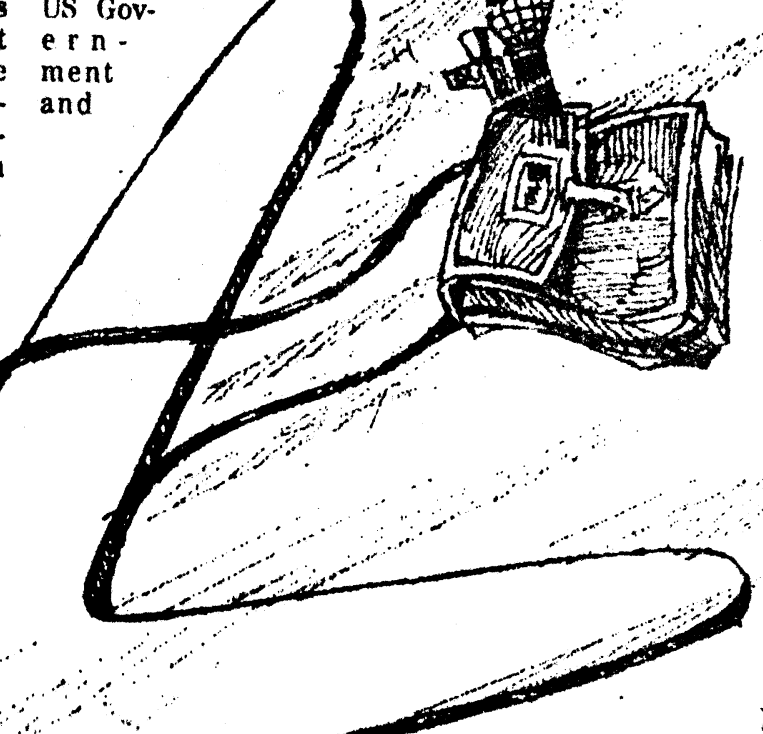

allie, can turn ag:inst us Instrad of bxeing a souree of support, they can start posing a threat to our oun servity. The Is Govermment has experienced this lesson painfully. It may still nced to learn it so that its future poticies take into accoumt the unintended consequerices of its policies.

The Pakistan Government also needs to gain a sintat anderstanding from the moments that have entered our consciousmess. For the last ane derade, some of its members have engaged in a policy of acquiring strategic deyth by establishing a pro-Pakistan regime in Afghanistan. We have also supported the freedom struggle in Kashmir. The policy has been motivated by a sense of principles as well as a notion of strategic gains that may be possible by keeping India bogged down in the princely state. The transnational connections that have emerged in the process include linkanges between fihadi groups in lakt.stan, Afghanistan and the lidian part of hashmir. Not all of these groups have been under Pakistan's control. But a blind cye has been turned to their operations due to the interest of those subs(ribing to the iffa of Islamic connections and Jilical.

Now, as the after shocks of the terrorist attacks are being felt., and as the Afshtian Government be? gins to issue thialy veiled warnings of the implications of Pakistan joining hands with the US, we need to reassess on policies towards both Afghan and kanmiri $J i$ hadis. It has alrealy reached a stage where a reassessment would attrat negative reacrions from bath these quates. But continuing it uncritically or at honger period may cost us even more. Anl when it happens, we will not be in the same prosition as the Iniled States. W: would ant be able to muster an internatumal coalition against terrotism. Our experience in the past has already tanght us that. Yo we. nevd some morr moments which bring these lesions and !nderstandings to is:" an unacceptable situation.

There is, however, another under standing that needs to be secured from the moments we have all experienced. Exporting terrorism or strugste can sometimes backfire. For whatever reason, our
The writer is Senior Politiral Science Lecturer in Universily of Western Australia

syasmeen (a cyilene,uka.rdu.a॥ 
The News International, Tuesday . September 18, 2001

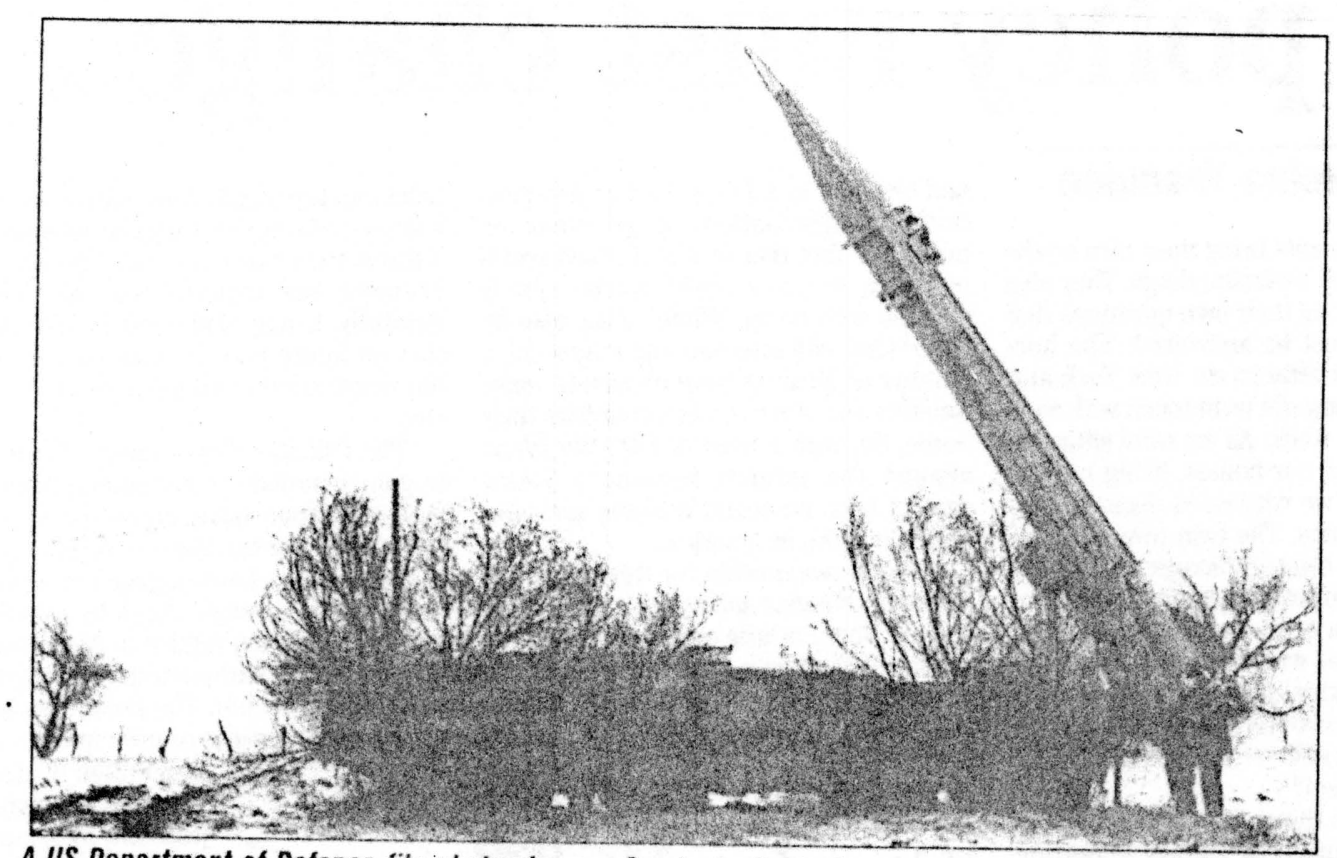

A US Department of Defence file photo shows a Scud missile during the 'Exercise Roving Sands ' 97 ' at Roswell, New Mexico on April 26, 1997. Afghanistan's Taliban rulers have moved a large arsenal of said on Monday. Reuters

\section{Pakistan forces alert as Taliban deploy troops, Scuds}

\section{Afghanistan's airspace closed; Kabul rulers take measures to hide Osama; deploy up to 25,000 troops near Pakistan border}

DUSHANBE: Taliban have closed the Afghanistan's airspace and placed air defences on alert in view of possible strikes by the United States, a senior military source in neighbouring Tajikistan said on Monday.

The Tajik official, who declined to be named, said the Taliban were also taking measures to hide Saudiborn Islamist Osama bin Laden, suspected by US officials of masterminding last week's attacks in New York and Washington.

"The Taliban declare they will shoot down aircraft of any country trying to cross into Afghan airspace," he said. "They are now trying to camouflage military targets on their territory."

"The Taliban are also taking measures to boost the security of Bin Laden hiding in Afghanistan," the official said. He declined to disclose the source of his information.
Tajik Foreign Ministry spokesman Igor Satarov said on Thesday that Tajikistan was "ready to cooperate with the United States in fighting terrorism," but had so far not received any official request from Washington.

Neighbouring Uzbekistan has said it might discuss with the US using its bases and airspace to attack extremist groups in Afghanistan, but that it was premature to say the country had made a final decision to aid Washington in a possible strike. - Reuters

AP adds from Islamabad: Taliban shut down its airspace two weeks after threatening to close it if the United Nations did not lift sanctions against its beleaguered airline, said an international diplomat.

There are an estimated 110 flights crossing the Afghan airspace.

However there are no flights currently landing in Afghanistan. The United Nations and the International Red Cross stopped flights to Afghanistan within two days of the nightmare terrorist assault on New York and Washington.

Our correspondent Abdullah Jan adds from Peshawar: Unusual movements of Pakistan army troops and personnel of different security agencies were observed in different parts of Khyber Agency, especially near the Pak-Afghan border at Torkhum.

Many army jawans were witnessed around the otherwise deserted Shagai Fort and Ali Masjid Fort in the tribal agency. Many of the regulars were performing drills 
The News International, Tuesday, September 18, 2001

in an open ground beside the British time fort, while some were seen attending a class in the same vicinity.

More than another two-dozen fully dressed khakis were witnessed undertaking an exercise near Ali Masjid Fort, about 25 kilometers from leshawar.

Pakistan army is reported to have taken positions along the Pak. Afghanistan border both in NWFP and Batochistan, whale heavy weapons have also been fixed over the peaks in Khyber Agency.

The preparations are undertaken in wake of threat from the Taliban government in Afghanistan to retaliate to the neighbouring countries if they provided land or air spaces to America to attack Afghanistan.

A number of sleuths of severa

\section{Woman doctor}

\section{mourns death of Masud}

CHANGRAN: It's hard to imagine a plare on earth nure unilike Paris than the hardscrabble mountains of aorthern Aghatustan, but Nilab Movarez now calls both of them home.

A former profescor of surgery at Kabut liniersity, she left in 1989 for Paris, and still practises there.

In most of Afghanistan Mobarez wothld be unwelcome.

Ninety-five percent of lier native country is ruled by the Tal. iban militia. for whom a womam who hide's neither her face, nor her views, nor her professional skills, is anathema.

lsut in lume she rewumed to the Panjher valley in the country's norla, invited by Almat shah Hastud, the mituaty combiander of the opposition allian e that has krpt this tiny and remote section of the country at of Talibat control. She now divides her tinte between l'aris and Jatrisher.

Now Mobarez. like many in the region, fears for the lature.

"l hope his coticantess will say together," she lobl linuters late on Somday, a few hours after the fir. meral

"Everybody know that the chanisma of sasud was exceptimal.

Everything now depends on low his collengles behave." For federal and provincial government security agencies were also seen active at Torkhum border, 50 kilo meters noith of Peshawar. The secret agency personnel were questioning almost every foreigner risiting the area.

More than two-dozen foreign journadists visiting Torkhum border hiad to fare an embarrassing situation when agencies personnel and border gutards refused them pernission to approach the border gate.

A tribesman living in a village near Shagai fort said to have seen army troops dragging a big camon to a hiltop. "It was really big and they were dragging it with ropes," recalled the tribesman, who believed that many such batteries might have been taken up to the hilltops.

her, Masud's control over at least a sinall part of Afghanistan mean sle and others like her could address women's issues in a way that is all but impossible elsewhere.

"In Taliban-controlled areas, women don't go to school, they don't work, they don't have access to medical care from male doctors, all these fundamental laws are violated." By contrast, she says, in the Panjsher vailey there ate 59 schools, of which 29 are for girls. And in an area where women still halve some rights, she is welcomed.

specialising in childcure, it now hats six stalf, allhough she wants to boost this 101 is and says there are plans to open more.

"He reecived me here in June and asked all his collcagtues to help we and my organisation, Bactriane. He said the valley has lots of gynaeroligical and paediatric probleris, and encouraged me to open another thee clinies." Masud's death is a biter blow not just to the Northern Allance as a military organisation, but to the: kind of small-scale projects being run by Mobarez, which have no equivalent in Taliban-controlled territory.

But she says there are signs of hope that the Alhatce will not fall appat after his deah. - Reuters

\section{Louvre Museum puts off programme on Afghan art}

PARIS: Paris' Louvte Muse'um on Monday announced that it had postponed a series of events schedviled this week on Afghanistan's artistic heritage ont of security concerns linked to the terrorist atlacks in the linited States.

"We determined that, given the current context, it would be unreasonable to proceed with the programme," said (Bristophe Monin, thr inuseum's spokesman.

He said the museum on Monday had plammed to show several fiims on Afghan art, including footage of the ancient Bamiyan Budrlla statues destroyed in March by Aighanistan's ruling Taliban militia.

On Wednesday some 200 people were expected to attend a conference by a panel of seven experis on Afghan art. "We were afraid that the conference might attract the wrong kind of people and questions linked to the terrorist attacks would be asked," Monin siaid. - $\mathrm{AlN}^{\prime}$

\section{Russia calls for anti-terrorist curbs against Taliban}

MOSCOW: Russia ralled upon the United Nations Monday to introduce anti-terrotist same. tions against Afgharistan's ruling Taliban movement.

"Recent events have demonstrated the need for the UN St: curity Council to introdure antiterrorist sanctions aggainst the Taliban," the foreign ministry said in a statement. referring to last week's suicids attacks on Now lirk and Washington in which more than $5,(4) 0$ pecople may have died.

"Russia is prepared, along with the international conmmnity, to join an anti-terrorist front under IN auspices," the statement added.

Iis President George W Bush has calded for the creation of an international condition ti, oppose terrorism, in line with a similar earlier proposial by his Russian counterpant Vlidituti? Putin. - ANP 


\section{Afghan shura decides on Osama fate today Remote possibility of Taliban taking U-turn: Mutmain
sees positive outcome of talks on 60 pc of issues}

\section{Rahimullah Yusufzai}

PESHAWAR: After crucial but inconclusive talks between a Pakistani delegation and Taliban lead('rs in Kandahar on Monday, all attention has now been shifted to Kabul where a shura (council) of Afghan religious scholars has ben approached by the Taliban supreme leader Mulla Mohammad Omar to decide the fate of Saudi dissident Osama bin Laden.

Informed sources in Kandahar said the members of the Pakistani delegation have also gone to kibul to wait for the council's decisions. They may return to Islamabad this evening once the decisions of the council are known and endorsed hy Mulla Omar.

The council was originally convened to issue a fatwa (decree) on declaring Jihad in case the US attacked Afghanistan. Now it has been entrusted with the added responsibility to discuss afresh the bin Laden issue and take a decision in light of lslamic teachings.

In the past also, Mulla Omar

has sought the opinion and advice of the council of lilema (religious scholars) on issues of national importance. The council was con-

sulted while taking a decision to destroy the giant Buddha statues carved into a mountainside in Afghanistan's central Bamiyan province. But the number of Ulema who deliberated the issue of "statues was small compared to the huge gathering expected in Kabul today. A bigger number of lema have been invited to the Kabul meeting due to lle fact that the issues of a likely Is attack and bin Laden's fate are murch more important and could have grave implications for the country.

It would be pertinent to mention that Mulla Omar limself was declared the supreme leader of Afghanistan and given the title of Amirul Momineen (Commander of the Faithful) by a similar council of Ulema in Kandahar some years ago. That gathering was particularly huge as religious scholars from all over Afghanistan and from the Afghan refugec camps in lakistan had flocked to Kandahar at a time when the laliban were

enjoying popularity and were being hailed as the saviours of the country.

By approaching the council of Ulema, Mulla Omar has tried to absolve himself of responsibility and sought to involve the country's top Ulema in decision-making. Describing himself as a Talib (student) rather than Mulla (teacher), he once said in an interview that he couldn't complete his religious education due to the Soviet invasion of Afghanistan and was, therefore, keen to consult those (ie Ulema) who knew more about Islam than him. Mulla Omar has normally endorsed and implemented all decisions by the council of Ulema.

But it is apparent that many of the Ulema are often Taliban leaders or activists and are thus able to guide and influence the council's decisions. It won't be difficult for the Taliban authorities to seek a favourable opinion from the council either way, whether they want to deliver bin Laden or keep hosting him in Afghanistan. Sources said the fact that the Taliban leadership has decided to have a fresh look at the bin Laden question shows that they would be willing to take into ac. count any new evidence implicating him in acts of terrorism against the US. Still it won't be easy for the Taliban and their council of Ulema to negate their earlier policy on bin Laden and agree to his extradition.
Therefore, the chances of a Taliban decision to abandon bin Laden in the hope of avoiding a

US attack appears unlikely. There is only a remote possibility for such an about-turn by the Taliban, who are normally not known to buckle under pressure.

Meanwhile, the Pakistani delegation headed for Kabul on Monday afternoon after holding talks with Mulla Omar and other Taliban leaders in Kandahar. A Taliban spokesman Abdul Hye Mutmain was being quoted as saying that there was a possibility of a positive outcome on 60 per cent of the issues discussed in the Kandahar meeting. He felt the remaining 40 per cent of the issues could be settled in further talks. But he declined to provide specific details about the proposals brought by the Pakistanis and the response of Mulla Omar.

The Pakistani delegation includes additional foreign secretary Aziz Ahmad Khan, ISI chief Lt Gen Mahmood Khan and his deputy Maj Gen Faiz Jillani.

Umer Farooq adds: While trying to convince the Taliban authorities about the grave situation faced by Arghanistan, Pakistan has made it clear that it will work with the international community in combating terrorism.

In the three-hour session with the Taliban leadership in Kandahar the Pakistani delegation informed them about emerging dangerous scenario that posed grave threat to the people of Afghanistan.

The decision to send a high level delegation to Afghanistan was taken in a high-level meeting presided over by President General Pervez Musharraf on Sunday. 
The News luternational, Tuesday, September 18,2001

Pakistan has already announced that it would continue its policy of support to the peo. ple and state of Afghanistan. However at the same time Pak. istan said that it stands with the international community in the fight against terrorism.

The delegation delivered a special message from the president General Pervez Musharraf for the leader of the Afghan gov. crmment, Mullah I:mar.

There are reports that a contingent of US special forces has arrived in Pakistan and has started preparation for possible air strikes against Osama bin laden's hidrout inside Afglianistan.

However, there are analysts who believe that extradition of Osana bin Laden would not satisfy Lnited States administration as there are reports of plans to replace the Taliban government with more moderate regime in Afghanistan.

The initial reports that the talks between Pakistan delegation and Taliban authorities have failed were followed by reports that the two sides have made progress on some of the issues.

A statement of the foreign minister on delegation's visit to Afghanistan said that President General Pervez Musharraf had made it clear Pakistan would work with the international community in combating terrorism.

Observers see Pakistan dele. gation's visit to Afghanistan as the last ditch attempt to avert a military crisis that poses a severe threat to the security of people of Afghanistan.

\section{Time running out for Taliban: Sattar}

ISLAMABAD): Pakistan said on Monday that time was rumning out for Afghanistati's Taliban fovermment to hand wer terror suspert Osama hin Laden and avoid retribution from the Enited states.

"Time is of the essence," For. cign Minister Abdul Stuttar sial in an interview with Reuters. "There is no ultimatum, lut time is detinitely running out." Ite was speaking after a delegation of Pakistani officials met the Taliban leadership in the southern
Afghan city of Kandahar on Monday to warn them of the danger they face after last week's terror attacks in the United States. Taliban officials said the meeting was "positive", but no further details were available.

The Pakistan team extended its stay and flew to Kabul and was due to return home on Tuesday. Washington says bin Laden - who lives in Afghanistan as a "guest" of the Taliban - is the prime suspect behind the attacks, and has vowed to punish him and anyone who protects him.

"The object of the visit is an 11 th-hour attempt to convey to the leadership that there is no time for negotiation in order to avert a crisis," Sattar said. "The US feels very deeply hurt. It doesn't have the patience for ar. guments or negotiation. It is time for action, decisions." He said that unless the Taliban reacted swiftly, they may well bring about their own demise. "That is a real possibility," he said. "It is difficult to entirely appreciate the nature of the government in Afghanistan, but given current circumstances it is realistic to conclude."

The Pakistan delegation is headed by intelligence chief General Mahmood Ahmed, who was in Washington on September 11 during the terror attack and stranded in the United States in the airline chaos that followed.

Asked if Mahmood Ahmed had delivered a message or ultimatum to the Taliban from the United States or Pakistan, Sattar said. "No, but I am sure he would have given them a summary of what he heard from high-level US officials and give them his own assessment of the critical nature of the current situation." But Sattar said that handing over bin Laden would probably not be enough to appease the United States. "They have been aware for a long time of American and others' concern about what is happening and they now have a last opportunity to take action, their own action, to do something."

Were the Taliban aware of the gravity of their situation? "Try to picture the environment in which the government makes deci- sions," Sattar said of the Taliban, who are led by Mullah Mohammad Omar, a reclusive, one-eyed cleric who has never been filmed or photographed and is believed to have met only two non-Mus-

lims in his life. "Their sources of external information are possibly television and probably radio... my fear is perhaps the government and leadership are not fully aware of the storm that broke loose on September 11."

Pakistan is one of only three countries to recugnise the Taliban government and was a key backer of the purist Islamic movement as it swept to power in the mid-1990s, taking most of the country and ending two decades of civil war. But that relationship appears to be changing as Pakistan President Perve' Musharraf has promised full cooperation with US efforts to end global terrorism and because of anger at the blunt warning delivered in Islamabad by the Taliban ambassador, who threatened revenge if Pakistan helped Washington. "That was not welcome," Sattar said.

The foreign minister said Pakistan had not been informed of any timetable for US action against bin Laden or the Taliban, but was not expecting one until Washington concluded a full investigation. "We have seen no evidence yet and we are not asking for any," Sattar said. There is an environment of trust and confidence between us." - Reuters 


\section{Taliban relieved of 'fox-minded' rival}

\section{Sami Yusufzal}

PESHAWAR: The Taliban movement in Afghanistan feels relieved of a formidable and "foxminded" rival Ahmad Shah Masud at a crucial moment when the United States is preparing for attack on the Islamic Emirates of Afghanistan.

The most controversial Jihadi commander Masud, who was equally loved and hated, is no more but he left a mark on the history of the country and will be remembered as one of the best Afghan guerrilla commanders. With his death the Americans lost a natural ally against the Taliban.

Masud was born in Kabul in 1954. His father Dost Muhammad Khan was a major in the Royal Afghan Army. His family migrated from Tajikistan to Panjsher valley in Afghanistan.

After passing his intermediate examination in 1971, Masud joined the Engineering Department of Kabul University. At that time Kabul University was centre of political activities. Students wing of the Communist Party and Akhwanul Muslimin, a group of religious elements, were active in the university. Masud joined Akhwan of which Gulbaddin Hikmatyar was an important office-bearer. He never liked Hikmatyar and was considered a rival of the ultra orthodox student leader.

When the government of Muhammad Daud Khan started persecution of Akhwan leaders, Masud fled to Pakistan and met the then governor of NWFP Naseerullah Babar, who recommended him for commando training to the Special Service Group of the Pakistan Army. Babar wanted to counter the Pukhtunistan campaign of Daud by supporting Afghan opposition leaders.

After Soviet invasion of Afghanistan in 1978, Masud emerged as a guerrilla commander in his native Panjsher valley and conducted very successful raids on convoys of the invading force. His well-planned attacks against the Soviets won him the laurels of many at home and abroad. He was well versed in Pushtu, Persian, English and French. His knowledge of French made him the darling of print and electronic media in
France. The French media dubbed him as the Lion of Panjsher.

In 1982, the Soviet General Grumov had to bribe him for safe passage of his troops to Kabul. He struck a secret deal with Russians and allowed the troops to reach Kabul un-intercepted on the Salang highway.

In 1992, Masud made a secret deal with the Afghan chief of army staff General Asif Dilawar for control of Kabul but Hikmatyar thwarted his design. The trio of Hikmatyar, Masud and Dostam fought fetched battles in Kabul. Hikmatyar later withdrew his forces to Charasiab after Masud was made the defence minister in the Rabbani-led government with Hikmatyar as its prime minister but still they remained at odds against each other, courtesy to the involvement of former Communist generals in their ranks.

In 1994, the Taliban emerged on the Afghan political scene and after sweeping other areas of the country they took over Kabul in 1996 and pushed Masud into his native Panjsher valley. The Taliban captured 95 percent of the country but

\section{The Frontier Post Tuesday, September 18, 2001}

US planes flying between Oman, Gwadar: BBC

ISL.AMABAD (PPI): Twenty US plancs have heen seen flying between Omnan Gwadar reports BBC.

Reports said Pakistan Navy has been placed on alert adding that some foreign war and surveillance aircralt were seen flying hetween Oman and Gwadar. The aircraft have been asked to remain out of the Pakistan territory and for the time being, no aircraft has violated the Pakistan temitory.

Reports further said that the Pak Navy has increased vigi-

- lance in the sea territory. The surveillance was ordered following reports that at least 20 US war planes were present in the scit near Oman while the aircraft of France and Britain have also entered the region.

\section{US likely to use deadly arms against Afghanistan \\ Naveed Miraj}

ISLAMABAD: Americans are likely to use the deadly "Nuclear Fuel Bomb" in its retaliatory assault agains Osama bin Laden and Taliban who are judged by the investigating authorities of the aggrieved party as the 'actual designers and executors' of the "Black Tuesday" destruction, The Frontier Post has learnt.

An official sources in -Foreign Office while sharing the details of America's 'smoke out and hunt down' mission said, the bereaved nation will hit back with full force by putting in service every weapon of mass destruction from its armory and will not even hesitate from using nuclear weapons.

Pakistan, source conceded, is under immense pressure and is consulting all the vocal sections of the country including the media, political and reli-

gious leadership in a bid to evolve an up-to-date strategy to cope with the situation with- 


\title{
The Statesman
}

\author{
Tuesday, September 18, 2001
}

in the curriculum of its prosperity and sovereignty above all.

Archival India's courteous offer to the ferocious American is another ground reality that Pakistan has to take care of besides other intriguing things on the roster.

Pakistani is also kecping in view from the comer of its eye what it can extort out of a 'friend' who is presently secking 'unstinted conperation' from it against neighboring Afghanistan?

Rulers here deem it an exact instance where the Americans, who seems to have developed a habit of standing at the receiving end in its relations with Pakistan, should at least lift its economic and military sanctions against Islamabad in recognition of its loyal services. Rescheduling of loans is another card at bargain.

Sources further maintained that Pakistan eventually would not mind the utilization of its air space and intelligence information by the Americans if they come for it as inevitable against Afghans in the present scenario but they ruled the possibility of rendering ground lacility for US troops specifically.

\section{Zaeef insists charges concocted}

ISLAMABAD: Taliban envoy Mullah Abdul Salam Zaeef has said that his country was capable of defending its territory and aggressor would be given a befitting response. Addressing a press conference here on Monday, the envoy warned that if any country provided military assistance to the US, the Taliban would wage a war against that country as well. lie said Afghanistan would never hand over Osama to the US under any circum. stances, adding that all allegations against their guest were baseless and concocted. - Agencies
Kabul closes air space for transit flights

KABUL: In order to prevent unexpected events from the probable attack of the US on Afghanistan the country air space closed to transit flights.

The ministry of civil aviation and tourism of the IEA recalled this decision as a temporary step taken for security measure, repurts BIA.

Mullah Akhter Muhammad Mansoor, IEA civil aviation and tourism minister, recalled this decision as a temporary gesture taken for avoiding unexpected events of the USA allack and adds that they have asked all airliners companies not to use Afghan air space.

It is mentionable that more than 35air line companies including the United Nations, ICRC and Paktic were using Afghanistan air space for transit flights.

Taliban Afghanistan shut down its airspace two weeks after threatening to close it if the United Nations did not lift sanctions against its beleaguered airline. said an international diplomat.

An estimated 110 flights cross the Afghan airspace. However, there are no flights currently landing in Afghanistan. The United Nations and the International Red Cross stopped nlights to Afghanistan within two days of the terrorist attacks on New York and Washington.

Afghanistan's Taliban have been twice sanctioned by the United Nations for refusing to hand over suspected Osama bin Laden. - Agencies

\section{Afghan govt must weigh consequences}

KUWAIT: Interior Minister Moinuddin Haider said on Monday Taliban should consider the consequences of not cooperating with the US in its efforts to hunt Afghan-based terror sus- pect Osama bin Laden.

The minister said at the end of a visit to Kuwait that Afghans would face problems if the Taliban did not draw the logical conclusions in talks with a Pakistani team.

"The delegation is motivating and advising (Taliban leader Mullah Omar and the Taliban leadership that they should consider the pros and cons of not c(w)perating with America and others on matters of terrorism because if Afghamistan does not do the logical, balanced antitude in this regard it will be a probiem for Afghanistan and its people," Haider toid reporters.

He added: "We will cooperate on issues of terrorism including our intelligence exchange (with America) and have bien asking Taliban, myself personally, for quite some time (about the Taliban's training of nonAfghans) and we do not wait that they be carrying oul any training of any country, especially of Pakistanis." - Reuters

\section{JUI warns govt against attack on Taliban}

\section{Statesman Repor}

WANA: Sabirullah Sahir nazim of Jamiat Ulema-e-lslum (JUI), Wana, has warned the United States against attacks on Afghanistan and said that anly such move would be strongly resisted by the tribesmen.

In a press statement, the JUI leader strongly castigated the United States for its alleged antiIslamic policies and designs. He added that US forces winted to subduc the Taliban by the use of sheer force however, they would fail to do so.

He said cvery tribesman was ready to protect Afghanistan against foreign aggression and "we would not allow any foreigner on our soil." He vowed in stand by the Taliban against USA.

He also demanded of the military government to desist from assisting US ficreces in pesssible attacks on Afghanistan. He said any such move would be detrimental for the country's solidarity and integrity. 


\section{The Statesman Tuesday, Seplember 18, 2001}

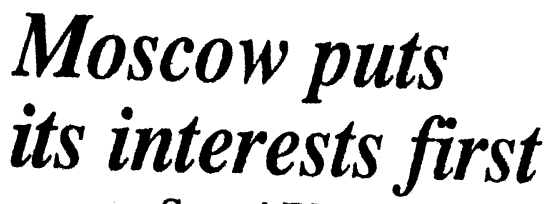

Sergei Blagov

The Kremlin has repeatedly expressed symthe United the wake of the deadly attack on the United States. However, Moscow has wamed against disproportionate use of force to punish the perpetrators of acts of terror. Furthermore, Russia and its Central Asian allies appear reluctant to become directly involved in armed conflict.

Notably, Russian Defence Minister Scryei Ivanov has already ruled out the possibility of the deployment of North Allantic Treaty Organisation (NATO) forces in fonner Soviet states in Central Asia. Further, he warned that an indiscriminate military assault, such as carpet bombing, would do little to punish the perpetrators of terrorist attacks.

While visiting the Armenian capital of Yerevan on September 14, Ivanov said that he did not "see any basis for even the hypothetical possibility of NATO military operations on the territory" of former Soviet Central Asia.

Moreover, Dmitry Rogozin, head of the intemational affairs committee of the Russian State Duma, the lower house of parliament, wamed against the use of nuclear weapons. "It would amount to madness to employ nuclear weapons," he was quoted as saying by the Russian RIA new's agency.

During his trip to Armenia from Septemher 14 to 16. President Vladimir Putin stated that "terrorism has become the main threat of the 21 st century. The old security system was unable to forestall such attacks," Putin told a news conference. "A new concept of security is needed."

Putin compared the terrorist attacks to Nazi war crimes. "I also feel inyself responsible for these tragic events," Putin admitted in a speech at Yerevan University. "We talked a lot about the terrorist threat, but probably not enough,"

Putin and his Armenian counterpart Robert Kocharyan signed a joint statement which sug. gested "a worldwide joint struggle agains international terrorism". They also said that bilateral military cooperation was not directed against any third countrics.

Moreover, Ivanov told journalists in Moscow that Russia had put its 201st Division in Tajikistan on "full military alcrt due to ongoing developments in the region". About 25,000 Russian troops are stationed in Tajikistan, which borders Afghanistan and is one of the few countries from which an offensive into that country; could be launched. Moscow used Tajikistan in 1979 to launch an ill-fated 10-year occupation of Afghanistan.

Tajikistan was badly torn apart during the 1992-1996 civil war between mostly Islanic opposition forces and the hard-line proRussian government. The Russian military presence remains a major factor in the relative stability of Taijkistan.
On September 14, Tajik Prime Minister Akil Akilov announced in Alinaty that his govemment would be willing to consider a US request to provide air corridors for strikes on Afghanistan, following consultations with Moscow. However, Tajikistun backtracked somewhat on its stated support for US retaliation. The country's foreign ministry dismissed media repons thtit:al USidied operation could be launched against Afghanistan from Tajik teritory. A spokesman said that "these numors were groundless".

At the weekend, the leaders of a body called the Shanghai Cooperation Organisation (SCO - formerly the Shanghai Five) issued a joint declaration in Almaty condemning the attacks in the United States. "We are prepared to cooperate closely with all states and international organisations to take effective measures for a steadfast fight to cradicate the global threat stemming from terrorism," the declaration
said.

In Almaty, Russian Prime Minister Mikhail Kasyanov said that he was not aware of any US-Russian talks on staging strikes on Afghanistan from Central Asia, which Moscow views as its own backyard. Turkmenistan President Saparmurad Niyazov, who has tended to remain ncutral in Central Asia's numerous conflicts, reportedly supported any US action against terrorism.

Despite growing volatility in the region, the SCO premiers also signed a memorandum on regional economic cooperation, designed to further increase multilateral trade and investment.

In 1997, Russia and China signed a treaty along with the former Soviet states of Kazakhstan, Tajikistan. and Kyrgyzstan on the significant reduction of border troop numbers. These nations that now share the former Sovict-Chinese border hecame known as the Shanghai Five. The group's transformation into the SCO took place at its fifth annual summit in China from June $14-15$ with the inclusion of Uzbekistan.

Last June, the six leaders also signed the "Shanghai Convention to Combat Terrorism, Separatism and Extremism". which is supposed to be a basis for the subsequent establishment of a joint anti-terrorism center in Bishkek, the capital of Kyrgyzstan.

On the other hand. Almaty has also hosted a meeting of the so-called Eurasian Economic Commonwealth, grouping Russia, Kazakhstan, Kyrgyzstan, Belarus and Tajikistan. Although the SCO and the Cornmonwealth overlap to some extent, Kasyanov argues that the two bodies will not duplicate agendas. The SCO is supposed to prioritise security cooperation, while the Commonwealth will deal with economic ties, Kasyanov says.

However, on September 14, Russian representative Grigory Rapota was nominated to become the Commonwealth's general secretary. He previously headed Russia's forcign intelligence and Russia's statc-owned arms exporting monopoly, Rosvooruzhenye. Rapota's nomination may suggest that Moscow could use the growing volatility 
around Afghanistm to increass its intluence in Cintral Asta.

Fomer Russian premier Sergei Sicpashin has said thal Moscow mieht use its influence over the Northern Alliance in Afghanistan. which is fighting the Tathan government in that country. Stepdshin reveated that he secretly visited Afyhanistan for talks with the Northern Alliance's leaders in 1996. when he served as head of Kussia's main security service.

Moreover, on September 16 the official
Russian RTR tclevision focitured an cxclusive intervicw with someone naned ats Dr. Abdullo. foreign ininister of the Northern Alliance. Abdullo reportedly said that the alliance's $15,000-$ strong anny was ready to suppont any US invasion.

Therefore, it can be argued that Russia has learned from its unsuciessful decade-long war in Afghanistan, and is unwilling to engage its own forces outside former Sovict borders to punish Alghan-based terrorists.

\section{The Nation TUESDAY. SEPTEMBER 18, 2001}

\section{US security agents}

ISLAMABAD (AFP) - The United States has already deployed up to 50 agents, including some from the special forces, in Pakistan. Western and Pahistani sources told AFP Monday.

The inajority of the agents arrived overnight Thursday and early Friday when Islamabad airport was closed mysteriously for five hours, the sources sitid.

The Americans are involved in advance liaison work and the selection of Pakistani officers to uork with them in preparation for possible military operations in or against Afghanistitn.

They are also carrying out research, motably on the feasibil. ity of getting troops into Afghanistan.

Some of the Americans have gone to Qhetta and Peshawar. Buth cites are close to the border with Afghanistan.

US Secretary of Stite Colin Puwell said Sunday a team of of ficials would be arriving in Pakitain this weeh to follow up on Islamabad s offer to help with antitcrorism measurce.

IS has tirepower ready for strike in Isia

With more than gionom US urop: in Asial a smate eic arbatse and at least one carrier hattle group in the lndian Ocain. LS Prevident Gorge W. Bush has plenty of firepower is latuch an anti-ternorist strike in the region.

(ivemments have also offered

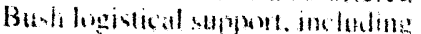
the ase of ofher now-ls bases bin concentrating that pouser ofl at tatget like Afghanisum will will bo a natjor lest, defence enpents said.
Americas hey military role in Asta ower the paiv five che cades has given it the hasis for a strike force in the region.

SOlTH KOREA: The Inited States has 37.640 boreps south of the beaty forstied de-militarised zone dividing the koraan peninsula. The United States fought with the Sonth ayainst the communist North in the 195(1)-53 korean War.

JAPLN: The United States has kept troops in bapan sikce the end of World War II. Thete are currently $54.0(0)$ military personncl with more llawn hall in the island of Okinawa.

- DIEgO g.arCIA: Closer to Afghanistan, which has been bracing for reprisals for the September 11 attacks in New Yosh and Washington. is the Dicgo Garcia air base in the Irutan sean.

The small island has 1.5 B -52 hombers, which can carry up to 20 cruise missiles each, and $[-117$ sealt; fighters.

The USS Carl Vinson, an aircaft carrier, is aloo leading a battlo gromp in the Indian Ocean west of lndia closer to :he Ciulf. while the USS Enterprise is kadding a similar 12 ship group in the Aribian Sea near Pakistan.

Mediat reports say the US navy hat tondered for wo tankers to lake extra marine fied from ku. wait to Diego (Batcia. Despite being on a tup alert with all leave cancelled. activity at other US bases in A sia has also drawn attention.

The guided missile cruiser liss Vimenones and the USS cimtis Willour. a guided mikile destroyer. laft Yokosuka base near Tokyo an Monday, Us Nary spokesman lientenant Chuck Bell wh AlP.
The guided misile cruiser Cowpens left Yokosuka on Saltuday and Japanese media reports said the aircraft carrier USS Kitty Hawk could leave this week.

Bell confirmed the departure of the three vessels but alded: linder the circumstances we cant comment on the specilics of any mission. President Bush has also had an outpouring of olfiers from help from Asian allies.

President Gloriat Arroyo of the Philippines said her country would make available two former US military bases, Clath and subic.

for an anti-terror operation.

South Korea's Presiden Kim Dae-Jung also offered military support on Monday in a messige sent to Bush.

Japan's Prime Minister Junichiro Koizumi has also pronised Bush that Japan will closely cooperate with Washington's efforts. India's Prime Minister Atal Behar Vajpayee promised Bush fullest cooperation' on Sunday.

A European defence attache in Seoul added: "They could send some for smaller operations against camps run bx these radical groups but this will not be the focus of the campitim. 


\section{The Nation}

TUESDAY, SEPTEMBER 18, 2001

\section{US wants to protect Gulf, surround China:" Gen. Gul}

PARIS (AFP) - The former head of Pakistan's secret intelligence service on Monday warned that any attempt by the United States to launch attacks on Afghanistan from Pakistani territory could destabilise the region.

Pakistan would be completely destabilised ... and India in its turn, General Hameed Gul said in an interview with the French daily $l e$ Figaro, warning of popular unrest if Pakistan permitted US troops on its soil.

The Pakistani people would never accept an American presence on their soil. They would revolt. he warned, predicting massive civil unrest in the tragile, nuclear-armed military dictatorship.

The government would have to rely on the army to control the insurrection. But the soldiers would refuse to turn on the people, they would not fight against the Pakistani nation, he said.

The general said that Washington was using the excuse of the terrorist attacks, which left more than 5,O(x) dead, to establish a military presence in Pakistan and Afghanistan in order to protect the Gulf and surround China. It's a long term strat.egy that goes far heyond the will to punish those behind the attacks, he said. I know the Americans well. I worked with them in intelligence. All they want to know is if Pakistan is on their side or with China.

The general was head of Pakistan's Inter-Service Intelligence (ISI) until six years ago and led the agency at a time when it worked closely with the US Central Intelligence Agency (ClA) to support Afghan fighters against the Soviet Union.

\section{China seals borders with Afghanistan, Pakistan}

BEIJING (AFP) - China has closed its borders with Afghanistan, Pakistan and two central Asian nations, locial officials told AFP Monday amid increasing fears of impending US military strikes.

An official with the para-military People's Armed Police in the Taxkorgan Tajik autonomous county in westernmost Xinjiang region said the border with Afghanistan had been sealed off since the weekend and remained shut.

The head official of the county who gave his surname as Zhang. said the borders with the two countries as well as those with the firmer Soviet republics of Kyrgyzstan and Tajikistan further north, had been closed since Friday.

However, a customs official at the Kunjirap Daban border station on the Chinese-Pakistani frontier said the frontier had been closed Saturday and Sunday but had reopened Monday.

A Pakistani diplomat in Beijingsaid he had not heard any reports ahout border closures.

The apparent decision to seal its western frontiers with the four nations comes amid speculation the United States is planning military strikes to retaliate for last week's terrorist attacks in New York and Washington.

Iran announced Saturday it was closing its 900-kilometre border with Afghanistan to block an influx of refingees

\section{Pak-Afghan defence council calls for Muslim unity}

LAHORE (NNI) - Defence of Pakistan and Afghanistan Council has taken a tough stand over the US ambitions to attack Afghanistiln, terming any such move as a warr against the Muslim Ummah.

It was announced at a meeting of the council held here on Monday, which was attended by over lifty prominent leaders, including Chairman of the Council, Maulana Sami-ul-Haq, Qazi Hussain Ahmad, Maulana Fazal-ur-Rehman, Maulana Azam Tariq. Hafiz Muhammad Saeed, Aafaq Ahmad, Dr. Israr Ahmad , General (Retd) Hamid Gul, Maulana Abdul Malik and others.

The Council chalked out a comprehensive programme to hold countrywide protest rallies to motivate the general public and apprise it of the emerging situation.

The council decided to hold a meeting with the foreign diplomats within the next few days to apprise them of the public sentiments about the latest developments and stressing upon them to prevail upon the US to refrain from attacking Afghanistan to avoid a human catastrophe.

It also decided to send a delegation consisting Maulana Sami-ulHay and Lt. General (Retd) Hameed Gul to launch a reconciliatory move to bring together all the Afghan factions at this hour of trial.

The Council noted with concern that the US President was hell bent to launch strikes against Afghanistan and Osama bin Laden even after having intelligence reports about the possible involvement of Israeli Agency, MAUSAD in the terror attacks on America. 
THE PAKISTAN TIMES

Tüesday, September 18, 2001

The NewS International, Wednesday, September 19, 2001

\section{Mass exodus from Afghan cities witnessed}

GENEVA: Tens of thousands of Alghans are leaving Alghanistan's major cities, in cluding Kabul. to setk refuge in the countryside, the UN's refuge agency said on Monday.

"Kandahar is hall empty. people are fleeing Kabul and Jalalabad for the countryside." Kris Janowski, a spokesman for the Geneva-hased UN High Commissioner for Refuges (UNHCR) said.

"Some are trying to reach the country's borders, we don't know how many exactly," Jainowskl'sidded!"

Kandahar's population was estimated at 100,000 , according to UNHCR.

The agency said that it hat reinforced its staff in Iran and Pakistan, ahead of an expected arrival of more refugees from Afghanistan.

Iran and Pakistan. which al. ready shelter millions of $A$ fghan refugees, have closed their borders to new arrivals.

Janowski noted that it would be hard for either couniry to maintain surveillance over the whole length of their frontiers with Afghanistan.

UNHCR said it had "a couple of dozen" local staft inside Afghanistan to help the displaced. following the evacuation of all the agency s international staff along with other aid agencies.

In Geneva, the International Conmittee of the Red Cross (ICRC) said the last remaining international staff evacuated from Afghanistan on Sunday had already started to see people kaving cities.

The ICRC said it was still evaluating if it would be possible for its international staff to cnter Afghanistan on shon visits to back up about 1.000 local Afghan employees still in the country.

"The idea is to see how much we could get into Afghanistan even during the day," ICRC spokeswoman Macaiena Aguilar said.

She indicated that the Red Cross was even considering Mights to cities deep into Afghan. territory, not only around border. areas, to cheek on the humani. tarian situation. - AFP

Reuters adds: Ofticials of ruling Taliban movement have stirned to flee the cippital. Kabul. amid growing expectatious the United States is preparing a punishing attack on the purist Islamic movement, witnesses said on Monday.

The flecing Taliban officials appeared mainly to be junior commanders and oflicials, witntsses said.

\section{'19 Osama aides entered Japan before attacks'}

TOKYO: Nineteen suspected followers of Saudi lsianist Osama bin Laden may have entered Japan shortly before last week's terror attacks in the United States, with some of them coming from the Taliban headquarters in Afghanistan, a news report said.

The suspected men are believed to have entered Japan in two groups early this month, with an unspecified number orig. inating in Kandahar, Japan's Kyodo News agency reported.

A spokesman for Japan's National Police Agency said police have beefed up security at US-related facilities in Japan since September 12, one day after the US attacks in New York and Washington. But the police spokesman, said police could not disclose whether any foreign intelligence agency had informed Japan about the suspected Bin Laden followers. He spoke on condition of anonymity.

Kyodo, quoting Japanese public security sources it did not identify, said the suspected entry into Japan was known Monday through information provided by US intelligence authorities.

On Monday, Kyodo quoted public security sources as saying that a dozen suspected folluwers of bin Laden were believed to have entered Japan prior to the attacks in the United States.

According to the latest information, Kyodo said the number totalled 19 in two groups - one comprising 13 and the other 6 .

The group of 13, was led by an identified Tunisian man, Kyodo said. The group of six includes nationalities such as Iraq and Saudi Arabia, it said.-AP 
The News International, Wednesday, Septentiver 19, 2001

\section{Opposition hopes for US help against Taliban}

BAGRAM: Only 40 kilometres north of Kabul, General Babajan's forces are the closest the beleaguered opposition are to striking the ruling Taliban regime.

And as Washington prepares for punitive strikes against the Taliban and their "guest," Saudi-born Osama bin Laden, blamed for last week's bloody terrorist attacks in the United States, Babajan can scent his opportunity.

Stunned by the assassination of his military leader, Ahmad Shah Masud, two days before the suicide plane attacks in New York and Washington, Babajan and the antiTaliban forces now have cause for hope. If the United States wants to wipe out the terrorist training camps allegedly rum by bin Laden in Afglanistan and prevent the Taliban from harbouring such again, then it will offer them large-scale military support, the opposition reasons.

"I an really hopeful that the beginning of the end of terrorism and the Taliban will be launched from here and we will revenge the blood of Masud and the blood of America," Babajan said at his frontline base.

"We can serve America's best interests, from intelligence to military operations," he added, looking out towards Taliban positions from the top of a gutted control tower at Bagram airbase.

So far, the United States has given no sign it is willing to become directly engaged in the struggle waged by Masud's Northern Al liance against the Taliban militia.

Nevertheless, Babajan said with satisfaction that his enemy was nervous as he watched them three kilometres away ferry supplies and reinforce their positions.

The possibility of US military help has come at a critical time for the opposition, even before Masud was killed by two Arabs posing as journalists. Despite help from Russia, India and Iran, the opposition meanwhile has seen its share of Afghanistan stirink.

It now clings to Masud's native Panjshir Valley, northeastern Badakhshan province and pockets of territory in the north and west. A motley alliance of warlords from the Uzbek, Hazara and Masud's Tajik ethnic minorities, the loose coalition was only kept together by the strong leadership of the veteran 49-year-old guerrilla commander, and his death provoked fears it could split apart.

"His voice gave morale to everyone, kept them strong," said Babajan dejectedly.

"I would prefer to lose 10,000 troops than have Masud die." Little is known about Masud's replacement, General Fahim, who has yet to be confirmed in his post.

Also from the Panjshir, Fahim commanded the front lines in the northeastern Takhar province, but "was always very reserved," according to a Masud confidante.

"Masud stood head and shoulders above everyone else, but all the other commanders are on the same level. The alliance needs someone who can command respect," he added, speaking on condition of anonymity. - AFP

\section{Afghanistan in chaos in face of looming US attack}

KABUL: Tens of thousands of Afghans were trying to flee cities for the safety of the (m)untryside Tuesday as fears of a US military strike turned to panic and aid workers warned of a humanitarian disaster, United Nations officials said.

The exodus continued from the ruling Taliban militia's southern nerve-centre Kandahar, where alleged suspected Osama bin Laden has a home, with more than half the population of some 200,000 people reportedly evacuating.

In the northeast, an area ravaged by conflict last year, the Taliban launched a heavy offensive against opposition lines in a bid to capitalise on the death of resistance leader Almmad Shah Masud last week.

Fighting raged throughout the morning in northeastern Takhar province, but opposition sources the militia's advance had been checked in some of the heaviest battles so far this year.

Thousands of people were arriving at checkpoints and crossings along the Pakistani border, while others were being turned back by Taliban roadblocks as desperate families streamed out of areas known as bin Laden's hideouts.

Shopkeepers in the capital Kabul began taking precautions against looting, and residents expressed growing fears of a breakdown in law and order should the Taliban crack under the threat of US military might.

Afghan aid workers, left behind to manage the massive international relief effort following the pullout of foreign staff last week, were being told to stay home, leaving thousands of Afghanistan's poorest without their only lifeline to humanitarian assistance.

Most people have been fleeing from Kandahar as well as Jalal. abad, where bin Laden, the key suspect believed to have plotted last week's devastating attacks on the World Trade Centre and the Pentagon, is believed to have a communications base in a nearby cave system.

The UN last week warned that some 1.5 million Afghans could be forced to leave their homes in search of food following the pullout of aid workers last week.

Aid workers predict the numbers of displaced people seeking assistance in neighbouring countries - all of which have closed their borders to Afghan refugees will rise dramatically over the next two weeks.

The World Food Programme had been helping feed three million people in Afghanistan's rural areas alone before its foreign staff pulled out due to security concerns last week. - AFP 


\section{India amends immigration rules for Afghan refugees}

NEW DELIIL: India on Thesday laid out new' stringent conditions foi refugees from Afghanistan, putting them umler the security micrsscope here in the wake of last week's terrot attarks is the l'nitiret sitates.

The home ministry, in-charge of India's internal security, said Afghan nationals who so far tanjoyed virtua! immunity from local immigration laws, will have to register themselves to continue living as refuges in the country.

"This follows an inmediate revision of policy relating to the stay of Afghan Hationals in India,' the home ininistry an. nounced.
All Afghans, possessing valid or expired documents, will now have to register themselves and the cases of liwse who ar not in possession of any decurintut will be examitted by a newly-consti tuted home ministry panal, a ministry spokesman added.

The ministry also put the state-run Bureau of Inmigration directly unite: its wings ats part of a thassive security exercise to put Afghan nationals under close ob. servation.

An estimaied 80,000 Afghans including hundreds holding papers from the linited Nations High Commissioner for Kufugees, tive in India along with peopls of lidian origin who have: fled the war-torn country.

A najority of the refugees are former bureaucrats, politicians and supporters of a Soviet-in. stalled regime which was toppled by the Mujahideen in early 1990 s.

Aniong the refugees are several state guests such as the widow of deposed Afghan president, Najibullati, who was murdered by the Taliban militia after they took over miost oi the coun. try in 1996.

India extends diplomatic ac. credition to the ousted government of deposed Atghan prosi. ient Burhanuddin Rabbani and permits its mission in New Delhi to function as einbassy. - . AFP

\section{Taliban launch massive attack in northern area}

KABUL: The Taliban lambled a najor offersive in the north of the comery on the stay, in what their morthers opponents described as the militia's hean in st melaught in montis.

Opmosition spokesmaut Mohammad Habed sain the attack on Kulagian, situatent 50 kilometres east of Tolengan in Ththar province

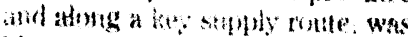
himted by a strong rounter attack.

"They launched their most sevare anil strongest offensive last night with a lesite to capture Kalafgan," Hatuel told AFP by

\section{satellite telephone.}

"They were able to capture some hilltops and advance, but later in our counter attack they were forced to withdraw," he said, adcling that fighting was still raging in the mountainous northern province.

The spokesman said the fighting was concentrated around the towns of Dashti-Rubat, Kalafgan Junction and Lata Band - positions the ofposition must hold if they are to maintain their supply of arms and fucl to frontline positions north of Kabul.
No independent confirmation of the fighting was inmediately available.

Habeel said Thliban forces were secking to exploit the death of upposition strongman Ahunad Shah Masud, a charismatic commander who was widely seen as the role hurdle to the militiat's total control of the country. Forces loyal to Miasud, who has been replaced by General Fahim, now only cling to Masud's native Parjshir Valley, mortheastern Badaktshikan province and pockets of territory in the north and west. - AFP

\section{No ill will towards Afghan people: Powell}

WASHINGTON: Seretary of state Colin l'owall tisld the pero. ple of Afghanistan on Monday "we mean mo ill." Bet he said the US campagn agairst Osama bin laden mighe include military action.
With the IS drive for worldwide stuport against hin Latens terrorism netwonk gaining genuml. Jowell satid, "All roads basd to the leader of that organization ... and his lowtion is Aghanistan." Powell's re. marks at a news conference appeared to be all attempl to pre. pare Arab and other nations for Us military retaliation in !at week's terrorist attacks in Now Yort: and Wastington, while assuring civilians the lis arght- 
The News International, Wednesday, September 19, 2001

ment was with terrorists and not with them.

"We mean no ill to the people of Afghan," Powell said. "They are a suffering people. They are a poror people. And for that reason alone they should not allow these invaders to put their society at risk." While an Islamic court in Afghanistan considers a US demand for bin Laden's expulsion, delivered by Pakistan, Powell said the United States intended to reinforce it with "some communication in

the future." He declined to provide any details.

Powell has taken charge of a tiplomatic drive to line up support or a wide range of actions, includng political, economic and military measures. "I am pleased that the coalition is coming together," he said. "I think everybody recognizes that this challenge is one that went far beyond America, far beyond New York City and far beyond Washington."

Powell gave his positive account after talking by telephone to President Ali Abdullah Saleh of Yemen, who he said was very helpful. The Arab leader said Syrian President Bashar Assad, who was visiting Yemen, would join him in a statement condemning the terrorist attacks "and committing themselves to work with us in the days and weeks ahead, ${ }^{n}$ Powell said.

In Cairo, striking a cautionary note, Egyptian Foreign Minister Ahmed Maher said the response to the terrorist attacks should not be

hasty and be "within international legitimacy and the international system."

The nations in the coalition will play various roles, Powell said. The campaign will have many parts to it, he said - "legal, political, diplomatic, law enforcement, intelligence collection and military, as appropriate." President Bush, putting heat on bin Laden's supporters, said at the Pentagon that "the people who house him, encourage, provide fond, comfort or money are on notice. "The Taliban must take my statement seriously," Bush said of the Muslim fundamentalist movement that controls most of Afghanistan.

President George W. Bush planned to meet on Tuesday with President Jacques Chirac of
France. Chirac's spokesman he would emphasize France's commitment to fighting terrorism.

State Department spokesman Richard Boucher said the victims in the terrorism attacks came from 62 countries.

Powell conferred, meanwhile,

by telephone with U.N. SecretaryGeneral Kofi Annan. The foreign minister of Saudi Arabia, Saud al. Faisal, is due to fly to Washington on Wednesday for talks. "I expect he will be carrying a message of support and commitment," Powell said.

Powell said he hoped Saudi Arabia would be explicit in its support for the United States. German Foreign Minister Joschka Fischer is also due in Washington for talks on Wednesday and British Prime Minister Tony Blair is coming Thursday $-A P$

Reuters adds: US President George W. Bush will meet Qatar's Emir Sheikh Hamad bin Khalifa alThani on Oct. 4 for talks that will include promoting peace and stability in the Middle East, the White House said on Monday. The White House said in a statement that Bush's meeting with the leader of Qatar, who has condemned last week's attacks on New York and Washington and pledged solidarity with the United States, would take place in Washington.

\section{WFP has three weeks food stock in Afghanistan Naveed Ahmad}

ISLAMABAD: The World Food Programme (WFP) Tuesday said that the agency has enough food stocks inside Afghanistan to last normal operations for two to three weeks.

Currently, WFP has stopped food shipments into the country partly due to the lack of commercial trucks in various parts of the country to move our food. WFP's local staff members continue normal operations in Afghanistan as much as possible especially in essential projects such as feeding the displaced people in camps in Herat.

WFP is concerned about possi- ble massive movement of people towards neighbouring countries. Reportedly, thousands have already left Kabul and Kandahar and more would follow if conditions deteriorate.

WFP Spokesman Khaled Masour said, "WFT, however, is finalising contingency plans to help the people who may cross the borders into Pakistan, Iran or Tajikistan. For planning purposes, WFP hopes to be ready to help as many as 1.5 million people." He said, "We believe that millions of people will face serious food shortages within Afghanistan if we cannot deliver relief assistance for security reasons."

Before the current crisis, WFP was expanding its operations to help 5 million people this fall and winter because of the drought and the economic collapse of the country after 22 years of war.

"We will do our best to support all those who could become fully dependent on food aid but our access to Afghanistan and ability to bring food into the country are already curtailed and could be further reduced, "he explained.

\section{Annan grieved over Masud demise}

NEW YORK: UN Secretary General Kofi Annan was "saddened" by the murder of the Afghan opposition leader Ahmed Shah Masud, UN spokesman Fred Eckhard said Monday.

"The Secretary-General is saddened at the assassination of Commander Ahmad Shah Masud," Eckhard said.

Masud "had long established himself as an outstanding military strategist who made a crucial contribution to the preservation of the sovereignty of his country," he added. "This act of terrorism has eliminated a key Afghan leader" who was prepared to find a political solution to the Afghan conflict, Eckhard said.

"Both the method and the apparent involvement of non-Afghans elements in this crime further complicate the efforts of the international community to end the conflict," added the spokesman. - AFP 
The News International, Wednesday, September 19, 2001

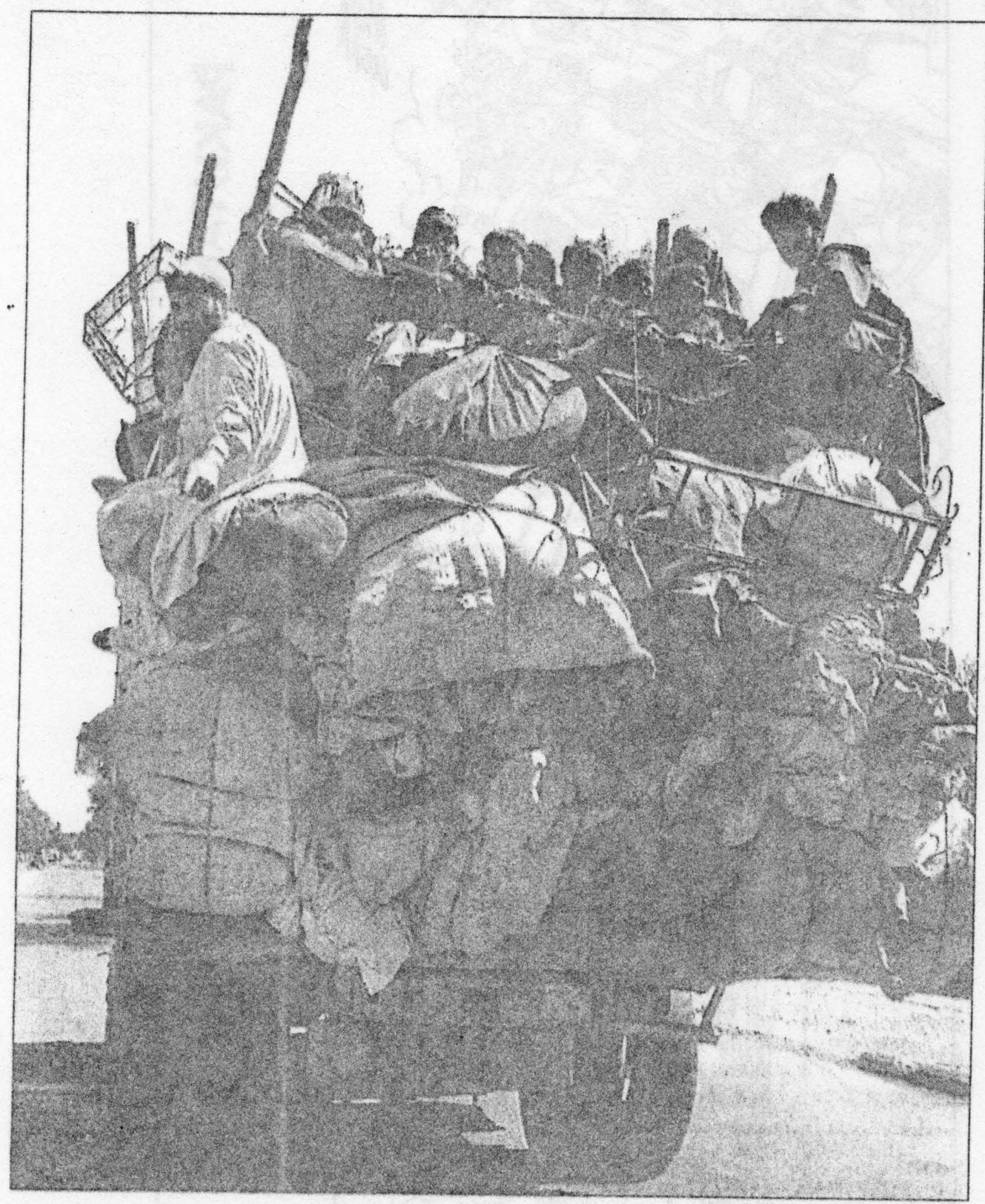
A group of Afghans with their belongings loaded onto a truck escapes Kabul on Tuesday, due to fears of
possible US attack. - Reuters 
The News International, Wednesday, September 19, 2001

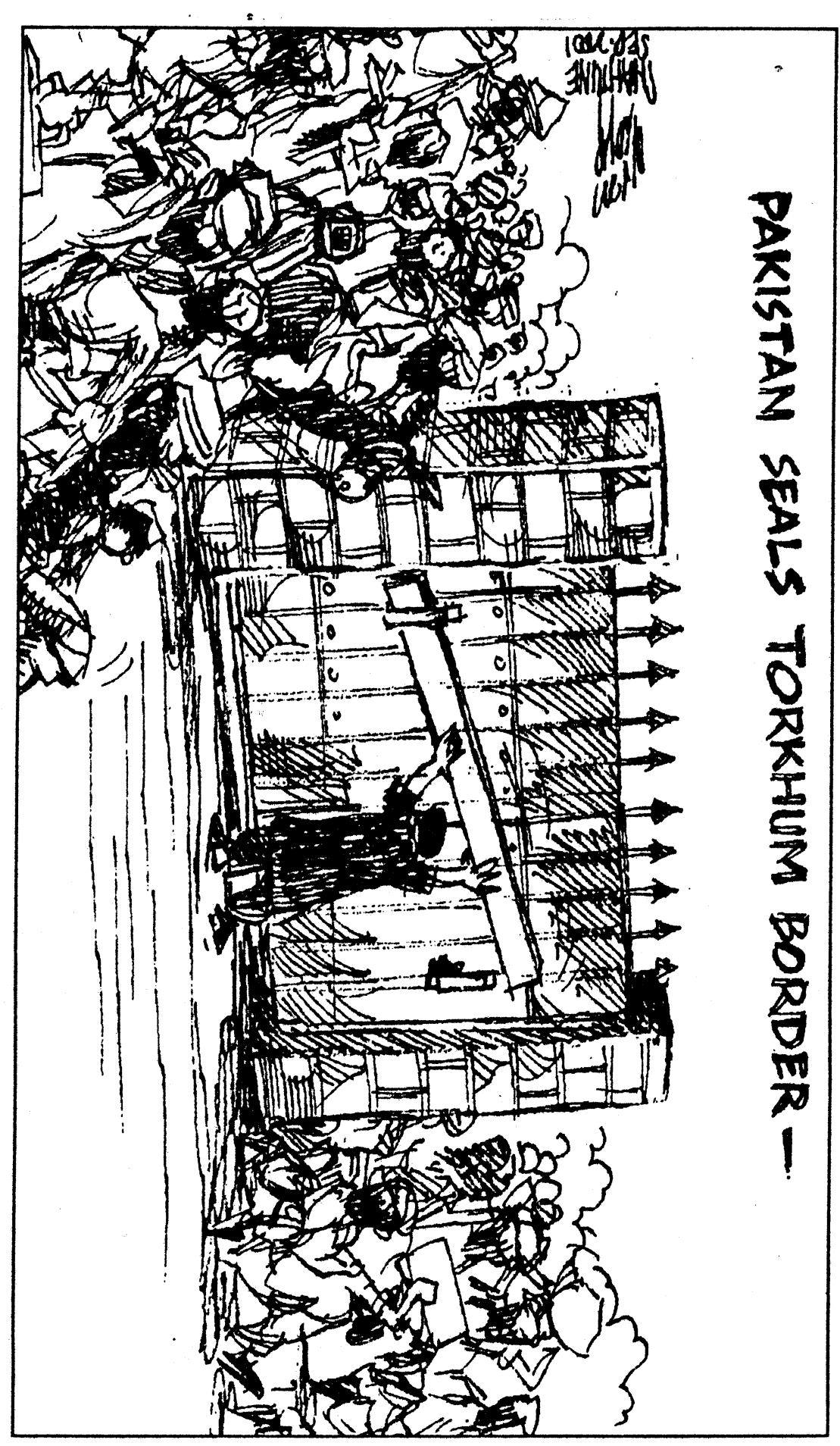




\section{'Journey to Jalalabad' \\ launched at British High Commissioner's residence}

\begin{abstract}
Shahina Maqbool
ISLAMABAD: I firmly believe that one day, the Afghans will rise again to be a good suciety. Things will be positive. All I can do is to pray that the West will sit and think before it does anything.

It was in these words that writer and photographer Maureen Lines expressed her fears on Afghanistan's destiny in the wake of the shocking events of September 11. She was addressing a select gathering of friends, who had assembled at the residence of British High Commissioner Hilary Synnott to attend the launching ceremony of her book 'Journey to Jalalabad' here on Tuesday.

"If the past is anything to go by, then all the goodness $I$ saw and experienced in that wild beautiful land will not die," Maureen writes in the book's foreword.

And she echoed similar sentiments in her
\end{abstract} short speech on an evening when she had planned to say so much, only if everything was normal. "I had all sorts of things in mind to say tonight but the events of last Tuesday have totally changed my perception," Maureen said in an emotionally charged voice. Nevertheless, she couldn't help but fondly recollect memories of the "many, many years" which she spent with friends in New York, lower Manhattan.

Maureen offered special thanks to Nancy Hatch Dupree, an expert on Afghanistan, for writing the preface of what she described as a "personal but positive book." Written in the setting of Nuristan, one of Afghanistan's most unique corners, the book also includes details of a fleeting excursion by the writer into the war-torn outskirts of Afghanistan and its equally devastated capital, Kabul.

Dupree has described Maureen's intellectual curiosity about the people of Nuristan with whom she had developed a passionate altiance - as being one of the major factors that drove her to the journey she has described in the book.
She goes on to describe Maureen as a person who "adores the mountains, delights in exploring the unknown, and is absorbed by meaningful interactions. She thrills to moments of danger. She finds peace and joy in nature's abundant beauties."

Earlier, in his welcome address, Hilary Synnott also spoke about the US tragedy. "We are all horrified by the events of September 11, which will have a profound effect on Afghanistan. Today, we are faced with a situation where there is an international effort to deal with an international problem. Tuesday's events were symbolically against the World Trade Centre but have affected many countries. The action to follow will be directed at the international phenomenon of terrorism, which knows no boundaries. We have terrorism in the UK ton. However, we must see that the current situation does not lead to polarisation of civilisations and religions," he suggested.

Commenting on the book, the British High Commissioner said, "The writer provides a fascinating insight into the people, terrain and mentality of the people of Afghanistan, whose sufferings are set to increase in the days to come."

Throughout the ceremony, the atmosphere was laden with fears of the unforeseen events in Afghanistan's context. However, the tension was temporarily : diffused with the screening of a promo from a beautiful documentary titled 'Beyond Frontiers.' A Serendip Production on which the company's husband and wife team, Huma and Farooq Beg, are working together with Maureen, the documentary captures glimpses from the life of the Kalash people.

The promo was a comprehensive comment on an unwritten language, an ancient cuiture, and a forgotten way of life. Today, 20 years of friendship and affection bind the people of Kalash and Maureen Lines, who first visited the Valley in 1980. "But in 1981, 
she had found a second home and a second family - a family of 3,000 ," the commentary told viewers.

Speaking on the occasion, Farooq Beg termed the documentary as "a window into the world of the Kalash people who are just 3,000 in number and are facing extinction. While the world in increasing, the Kalash are shrinking. This is a culture that is dying. We aim to help the Kalash people by working closely with Maureen. We will set up trusts and projects for them, and will help to help themselves."

Maureen, who is one of the most vital characters in the documentary, tells viewers how the Kalash people initially felt threatened by her. "People wanted to get me out. You know, I tread on people's feet," she said, and went on to add: "The need of the day is to give these people a chance to work out their own destiny with a little assistance; to guide them, to help them."

The Kalash people are a small community for whom at least one woman has given up her home and her life in the west. "The documentary will be the story of Maureen Lines and a small community struggling for survival in the days of an uncompromising 21 st century," Beg said while talking to "The News.'

Maureen first visited Pakistan in 1980 and since 1986 has worked voluntarily among the Kalash people. Her sojourn in Chitral afforded her a unique view of the Mujahideen. She is the author of 'Beyond the North West Frontier,' a culmination of many months of travel into the remote lands of the Hindukush and the Karakorums; and a 58-page booklet titled "ihe Kalash People of North Western Pakistan,' an informative companion for prospective travelers.

In her 336-page book on Jalalabad, Maureen has specially thanked the Daulet, the Jamiat-e-Islami, and the Hezb-i-Islami for the way their people looked after her while in Afghanistan.

\section{Putin, Jiang discuss Afghan situation}

MOSCOW: Russian President Vladimir Putin on Tuesday held telephone talks with his Chinese counterpart Jiang Zemin focusing on the situation around Afghanistan and a possible US reprisal attack, the Kremlin said.

A Kremlin statement quoted by Interfax said that the two leaders reaffirmed their commitment to the fight against terrorism "in all its forms."

Putin and Jiang also agreed to pursue bilateral cooperation in the field, the Kremlin said, without providing further details.

A Chinese foreign ministry official earlier Tuesday said that a US attack on suspected terrorist bases in Afghanistan must be based on "concrete evidence," making certain that civilians were unharmed.

Putin has also given his conditional support to Washington, although Moscow officials have stressed that Russia had no in tention of joining a possible reprisal strike. - AFP

\section{Camps to be set up for fresh refugees}

\section{Tariq Butt}

ISLAMABAD: The Balochistan and NWFP governments will designate on Wednesday the places where the new Afghan refugees will be kept, an official told The News.

The provincial governments and the Commissionerate for Afghan refugees will sit together to select the places for new Afghan arrivals, the official said.

The new refugees will not be shifted to the existing camps as they are already overcrowded.
"We do not want them to be mixed up with the present lot. We want to maintain a separate count of the new arrivals, " the official said.

Already, more than 2.5 million Afghans are living in Pakistan for the past several years and a large number of have settled here permanently. They

came here during the Afghan war.

The official said the Afghan Support Group has urged the Pakistan government to let the Afghans, who want to leave Afghanistan, come into Pakistan to avoid becoming victim of the impending US attack.

However, the Pakistan government has pleaded that it would not open the border, as it has no capacity of any kind to accommodate more Afghan refugees. The government is of the view that it is meeting the requirements of the present retugees with tremendous difficulty with the international aid having declined unprecedented.

The official said that the Pakistan government has urged the Afghan Support Group to provide the humanitarian assistance to the Afghans inside Afghanistan.

Hundreds of thousands of Afghans are packing up to sneak into Pakistan through different nor$\mathrm{mal}$ and uninhibited routes fearing massive American retaliation.

The official said that the new arrivals could touch the figure of two million in the next few weeks after the start of the American military campaign against Afghanistan. 


\title{
The Frontier Post
}

\author{
Wednesday, September 19, 2001
}

\section{US should provide evidence against Osama, says Moin}

ABU DHABI (Online): Interior Minister Moinuddin Haider has said it is necessary that the US give material evidence that Osama birr Laden was involved in last week's attacks in New York and Washington.

The Qatari news agency quoted Haider as telling Al Rac Al Am newspaper; "It is the demand of the whole world, Muslim or otherwise."

"If the U.S. wants Pakistan to cooperate in its campaign against terrorism, we want them to share with us the incriminating evidence they have in order to convince us bin Laden has links to these attacks. Only then we shall be able to be part of the intermational support for the campaign against terrorism", he added.

Asked if Pakjstan has passed this demand on to the U.S., he said "no" justifying that the U.S. authorities have not yet completed its findings and it is premature to ask them that now.

Haider said: "The U.S. would provide evidence like it did in the case of the truck bomb blast of the U.S. embassy in Kenya, when the prime suspect was arrested in Karachi."

At the time, Haider said he was the governor of Sindh province and the suspect was handed over to the Americans.

On reports that a Pakistani delegation visiting Afghanistan gave the Taliban a three-day waming to deliver bin laden, he said: "I do not believe hin Laden is wanted by Pakistan, but by America and we do not give wamings to anyone."

He said he is unsure whether the military option would achieve, as it was tested before.
He said any land operation would not be an easy in Afghanistan and would not achicve the expected objective and neither will the use of fighter planes.

"Wc have often told the Americans that Afghanistan is a sovereign state which we recognise, but that does not mean we are responsible for their mistakes and if you want bin Laden engage in direct dialogue with Afghanistan. We can assist you," he was quoted as saying.

A high-level Kuwaiti security delegation will, meanwhilc, head for Pakistan in two weeks time to discuss bilateral security issues, Deputy Prime Minister and Interior Minister Sheikh Mohammad Al Khalid A) Sabah said. While seeing oft Interior Minister.

\section{UN ready to lead crusade against terrorism, says Annan}

UNITED NATIONS (APP);

The United Nations is prepared to lead a worldwide fight against terrorism following altacks on the United States in which more than 5.000 are feared killed, Secretary General Koti Annan said. Several governments have called on stronger UN action against terrorism as it hecomes likely the United States will take military action against those it considers responsible for the devastating attacks on New York's World Trade Center and the Pentagon.

"Every country is worricd about terrorism and everyone has suffered from terrorisin, and they would want to join this fight," Annan said in an interview on Cable News Network.

The United Nations Security Council on September 12 said the attacks were a threat to international peace and security, and called on UN member states "to work together urgentIy to bring to justice the perpetrators, organizer's and sponsors of these terrorist acts."

"I think the crucial work is being done now," Annan said, speaking after a meeting with US Secretary of State Colin Powell about the investigation and the US efforts to create a coalition against terrorism. Annan, however, warned that any action not further inflame tensions in the Middle East.

"We have to make sure that we don't get into a division between the west and Muslims." Annan said.

His concerns wete echoed by the UN high commissioner for refugees. Ruud Lubbers, who said be would travel to
Washington to plead with US leaders to recognize the humanitarian consequences of any military action against Afghanistan..

"It is important to be aware of the plight of the Afghan people and of the humanitarian consequences," said Lubbers, expected to meet later in the day with US officials.

Meanwhile, a UN spokesman said the ministerial session of the UN General Assembly scheduled to start September 24 is likely to be postponed because of last week's attacks.

"The most likely scenario is a postponement for a certain period of time," said General Assembly spokesman Jan Fischer.

A formal decision is expected Wednesday. 


\section{The Frontier Post wednesday, September 19, 2001}

\section{Shoora to decide \\ Osama's fate today \\ ISLAMABAD: Led by ISI chief Lt. Gen. Mehmood Ahmad, Pakistan's high level delegation that went to Afghanistan as the last ditch effort to avoid military conflict in region returned home Tuesday evening. \\ The delegation went to Kandhar and Kabul. \\ The delegation also comprised senior officers of the foreign office. Unconfirmed reports said that PPP leader and former interior minister Gen. (Retd) Nasirullah Khan Babar also included in the delega- tion. Babar cabinet minister of former Premier Ms. Benazir Bhutto is being considered as "mentor" of Taliban. \\ The delegation first held talks with the Foreign Minister Maulvi. Ahmad Mutwakli and later on held about three hours discussion with the Taliban leader Mullah Muhammad Omar in Kandahar on. Monday. However, nothing has become known officially about that contact. Pakistani delegation also visited Kabul for further discussions with the Deputy Chairman of the Council of Ministers Mullah Hassan Akhund. It is not yet clear whether Taliban have agreed to send Osama bin Laden to any other country. \\ Meanwhile, the visiting high-level delegation of Pakistan held talks with Vice Chairman of the Council of Ministers, Mullah Mohammad Hassan Akhund, said a spokesman for the Taliban govern- ment of Afghanistan on Tuesday. \\ The spokesman for Taliban government said that final decisions on all the issues would be taken tive body 1 which will meet on Wednesday. \\ Earlier, the Shoora's meeting which was to be held on Tuesday has been postponed until Wednesday as a majority of the Ulema belonging to other provinces could not reach capital Kabul, Tribal and national leaders of the provinces are also meeting in their respective provinces to discuss the prevailing situation. \\ Meanwhile, Afghans fleeing of Kabul and Kandahar continued despite difficulties in obtain- ing transport on Tuesday, said an official of United Nations High Commission for Refugees here. Over the past days, tens of thousands of people have. been on the move, mainly traveling from cities into rural areas of the mountainous country. There are also reports from Kabul that some food commodi- ties are becoming even more scarce than usual as residents purchase available remaining stocks. \\ The number of Afghans leaving. Kabul and Jalalabad is reportedly decreasing. UNHCR staff report that new Taliban checkpoints have sprung up along the road from Jalalabad to the Torkham bor- der crossing. Taliban guards are reportedly allow- ing only Afghans bearing passports to cross into Pakistan, which severely limits the movements of people into Pakistan. \\ In Afghanistan's western city of Herat, the atmo- sphere is tense and residents are reportedly con- fused about developments in the country because of the general lack of information. People are so impoverished that even radios and batteries are in short supply and television is banned.}

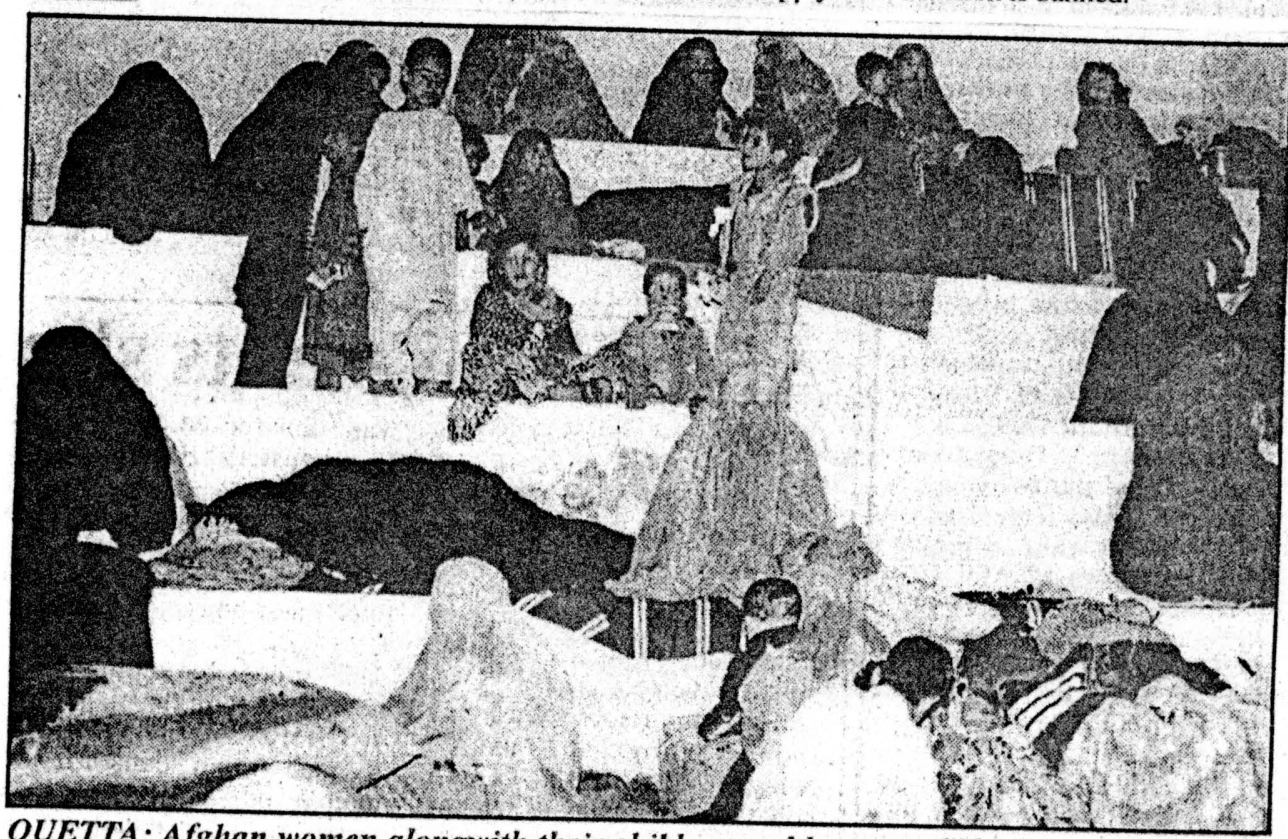




\section{The Frontier Post wodnosday, September 19, 2001 \\ British Special Forces gear up for attack on Bin Laden}

\begin{abstract}
Shahid Abmed Qureshi
LONDON: The SAS is expected to play a leading role in any future ground action in Afghanistan because of its unique experience training with Pakistani forces in the mountains bordering the country harbouring Osama bin Laden.

A special unit of the SAS called the Revolutionary World Warfare (RWW) wing has been engaged in mountain training in Pakistan for at least five years. It has built up the sort of expertise that will be crucial in any US-led ground attack to capture or eliminate bin Laden, named as the chief suspect in the New York and Washington attacks, in the harsh terrain of southern Afghanistan, where
\end{abstract}

he runs his terrorist training camps.

It has also trained at altitudes of up to $18,000 \mathrm{ft}$ and developed excellent working relations with Pakistani special forces. That may also help towards encouraging Islamabad to offer bases to America for a future ground. campaign in Afghanistan.

The RWW unit was first into Kosovo at the end of Nato's bombing campaign against Yugoslavia in 1999 and is likely to be among the first to enter Afghanistan if President Bush goes ahead with some form of ground attack.

There is already a large SAS force in Oman, preparing to take part in Exercise Saif Sareea with Omani troops. The

whole of A Squadron of the SAS has been sent to Oman for the exercise. Acclimatisation training has already begun and the presence of 20,000 British tri-Service military personnel in the Gulf is helping planners in Britain in their work.

The US Administration has made clear that any military. action to counter the threat from bin Laden's al-Qaeda terrorist organisation will include ground troops and could involve attacks on more than just Afghanistan, if other countries are seen to be harbouring the Saudi, dissident's agents.
Iraq is not at present on the list. Richard Cheney, the US VicePresident, and Colin Powell, the Secretary of State, said yesterday that there was as yet no

evidence linking the terrorist attacks on the World Trade Centre and the Pentagon to Baghdad.

As a further sign of Britain's expected participation in any military operation, the Joint Force Headquarters, which runs. British tri-Seryice missions, has been ordered not to go to Oman to take charge of Exercise Saif Sareea.

In another move, Lieutenant-General Sir Anthony Pigott, Assistant Chief of the Defence Staff (Operations), leaves for Washington today to consult the Pentagon over what Britain can offer for a future military operation.

In the Gulf, the American aircraft carrier USS Enterprise

will be joined this week by a second carrier battle group. headed by the aircraft carrier USS Vinson, providing President Bush with formidable firepower, including many Tomahawk cruise missiles.

Although Donald Rumsfeld, the US Defence Secretary, has made clear that America is not planning to limit a future attack to using Tomahawks or other precision-guided missiles, any sudden intelligence of bin Laden's whereabouts could lead to a decision for an instant missile attack. A ground-launched operation is likely to take weeks to prepare and will need bases close to Afghanistan. Tajikistan, which borders Afghanistan, cast

doubt on whether Mr Bush could rely on its bases for launching a military attack

$\mathrm{Mr}$ Rumsfeld said that American special forces would be in the forefront of any military operation. They include the US Army's Green Berets, who were modeled on the SAS. When the US struck back at the terrorist networks behind last week's attacks, "a lot of it will be special operations", Mr Rumsfeld said.

The US has 40,000 special forces personnel, who come under the Special Operations Command. Other units likely to be used are the Rangers, who had a disastrous campaign in Somalia when 18 were killed while trying to capture a Somali wariord.

\section{Impoverished Kandahar}

KABUL (Agencies): The dusty, poverty-stricken southern Afghan city of Kandahar, home of the ruling Taliban and a likely US target after last week's devastating terror attacks, has been at the crossroads of bitter conflict for generations.

"1 start worrying about Afghans who are affected by 20 years of civil war, three years severe drought resulting in large number of IDPs (internally displaced people), food insecurity and poverty, in case the activities of the assisting communities suspend in Afghanistan," one Afghan who works for an aid group said in an appeal sent to his organisation in Islamabad.

"It is the most unclean in terms of sanitation, possibly the dirtiest city in Afghanistan, the least educated," said one United Nations aid worker who was evacuated from Afghanistan last week.

Aid workers said there is still a certain economic vibrancy to the city, the main market centre for southern Afghanistan. 


\section{The Frontier Post}

Wednesday, September 19, 2001

\section{Russia consults former Soviets, republics}

MOSCOW (APP): The

Russian government embarked on consultations with the leaders of former Soviet republics amid uncertainty as to the policy it would adopt over US plans to launch reprisals against the Afghanistan.

President Vladimir Putin held telephone talks with Turkmenistan President Saparmurád Niyazov, whose country borders with Afghanistan, and sent the head of Russia's Security Council to the central Asian region to meet local leaders.

Moscow has signalled its assent to whatever action A merica might seek to take over the terror attacks in which more than 5,000 people died, including 117 Russians according to the Russian embassy in Washington.

However, it has displayed reluctance to take on an active role, ruling out taking part in a military operation against Afghanistan and announcing that it would not allow NATO troops to be based in the Commonwealth of Independent States.

As Russian media expressed concern at Moscow's hesitations over greater involvement in the coalition that is forming around possible strikes on Afghanistan, analysts noted that Russia faced a major policy dilemma in view of its close ties with some of the US-designated rogue states.

However a firmer commitment to the US anti-terrorist crusade would create a clash of interesf in Russia's relations with countries such as Iran, which Washington has placed on its list of rogue states but which Russia regards as a leading client for its weapons industry.

\section{Taliban's credibility} at stake on bin Laden

enior Pakistani officials failed yesterday in attempts to persuade Afghan leaders to hand terrorism suspect Osama bin Laden to the US in the wake of last Tuesday's attack on America. Taliban officials described the meeting as "positive", saying that the Pakistani delegation had not presented an ultimatum or a warning but had simply advised the Afghans to co-operate with the US in order to avert armed retaliation. Despite America's assertion last night that "all roads lead to bin Laden" as the prime suspect in their investigation, the Taliban leaders' credibility is at stake if they surrender their guest to the US. Before they could contemplate that step, they would need proof of bin Laden's involvement. If such proof exists, it has not been made public.

The gravity of the situation has been underlined by measures such as the closing of the AfghanistanPakistan and Afghanistan-Iran borders, the placing of Russian troops in Tajikistan on high alert and the Taliban's own plea to the Organisation of the Istamic Conference for help if there is a US strike. The plea was made even though the OIC does not recognise the Taliban regime. Pakistan seems likely to continue its efforts to persuade to the Taliban to comply with US wishes over the next few days, though the chances of success are slim and the risk of a US attack is very great. One factor that the Taliban may hope will save them is that US planners would find it very difficult to find a safe and effective way to take them on.

Washington discovered in its earlier attack that cruise missiles have little effect on a country that is already devastated by decades of war. The alternative or additional - strategy would be to send in troops. However, Afghanistan is still strewn with landmines from the time of the Soviet occupation, which would add to the extreme difficulty of undertaking any ground operations. Even so, the current mood in America would seem to support any effort to exact revenge for the attacks, no matter how hazardous. That mood might change if there were significant US casualties but by then Afghanistan could have suffered severely and there could be serious repercussions throughout the Muslim world. Already, Pakistani Islamists are rallying in support of the ir Afghan brethren, despite Islamabad's decision to support any Security Council approved anti-terrorism action. The Afghans who are fleeing their already ruined cities understand how serious the situation is and that they may be made to suffer for other people's actions. They may be being more realistic than their government. 


\section{The Statesman}

Wednesday, September 19, 2001

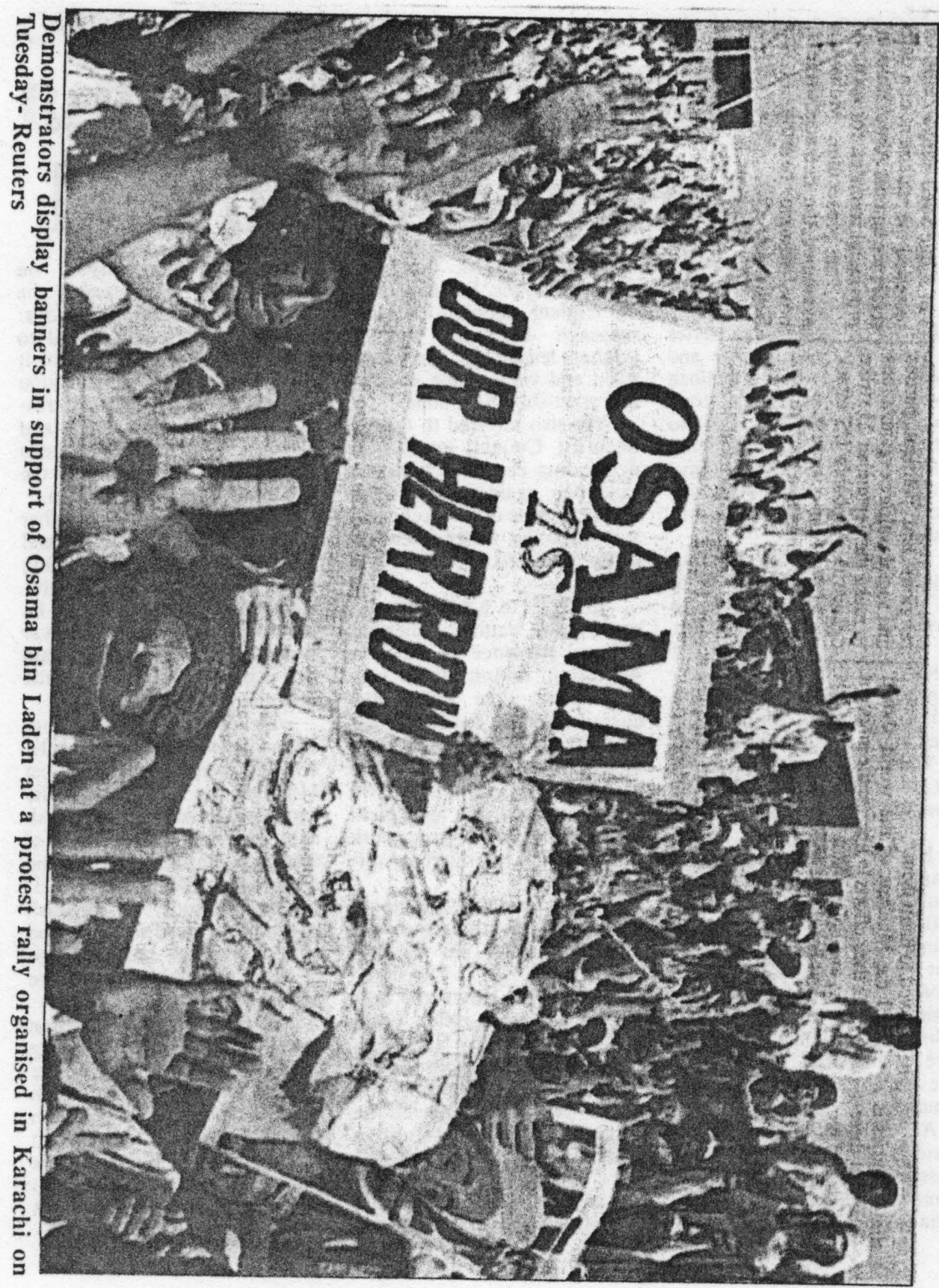




\title{
The Statesman
}

\author{
Wednesday, September 19, 2001
}

\section{War against terrorism, not against Kabul: FO No option except Osama surrender, Taliban told}

From Sikander Hayat

ISLAMABAD: A visiting Pakistani delegation, in a scries of meetings at Kandahar and Kabul, has conveyed to Taliban leaders in most certain terms that they were left with no option but to meet the 'demand of the international community, a diplomatic euphemism for extradition of Osama bin Laden.

"Pakistan is not holding negotiations with the Taliban, but impressing upon them the gravity of the situation and what the international community expected of the Afghan leadership," Foreign Office Spokesman Riaz Muhammad Khan told a media briefing here on Tuesday. He also indicated that a decision from the Afghan government had to come 'quickly.'

However, Riaz Muhammad Khan stressed Afghanistan should understand it was war against terrorism and not against it or its people. "It is fight against terrorism and its perpetrators." The spokesman continued food for the internally displaced Afghans would go there. "Pakistan does not believe that the Afghans should be punished."

Asked about the nature of President Pervez Musharrafs message delivered to Taliban's supreme leader Mullah Muhammad Omar, the spokesman replied, "there were no negotiations. But as a friend of Afghan people, Pakistan's message conveyed to the Afghan leadership our assessment and view of the situation and what should be done."

He also referred to the UN Security Council resolutions demanding certain actions and sanctions against the Taliban regime in case of their refusal to surrender the alleged terrorist being sheltered by the Afghan rulers.

In reply to a question, the spokesman denied American military presence in Pakistan 'at present,' noting certain 'contingencies' were being discussed between the two sides. He also refuted the report that Pakistan had proposed some no-fly zones although "we have conveyed our agreement in principle in the framework of combating international terrorism."

He told another questioner "hundreds of thousands of Afghan refugees are trekking their way to Pakistan." Islamabad had closed the border but a refugee influx could not be realistically stemmed, given the mountainous nature of the terrain straddling the porous frontier. He rejected the suggestion that non-Taliban Afghans were being refused entry, saying, "we don't care who is Taliban and who is not."

Giving an overview of the
Pakistani perspective on Afghanistan, he observed the issue had three dimensions: "First, Pakistan is opposed to international terrorism; two, it is obligated to implementation of the UN Security Council resolutions including 1333 and 1368; and three, it would keep in mind as to what is in the interest of the Afghan nation."

Not only the US but other members of the international community were also making an effort to ensure 'cultural crusades' were not revived, he remarked, reiterating the war was basically against terrorism and Pakistan was part of the international coalition.

To the query what the government was doing against the ongoing hate campaign against Muslims in the US, the spokesman said the Bush administration was mindful of the development and as such the American president had himself visited a mosque. "There Bush talked of the need for unity and amity between various segments of the society and we are appreciative of this move."

He claimed the Pakistan government had taken a strong note of recent remarks of the Afghan ambassador, in which he threatened Islamabad with reprisals in case it took part in American moves against his country. The issue was also raised with Mullah Omar at Kandahar, he concluded. 


\section{US must not hurt Afghans,
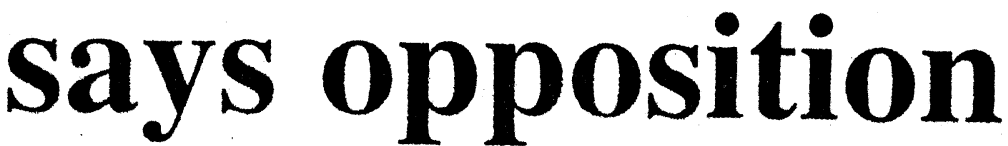

TEHRAN (AFP) - A senior official of Afghanistan's opposition appealed to the United States on Tuesday to spare the Afghan people from Washingtou's wrath over the terror attacks in New York and Washington.

'We are hoping for the roots of terrorism to be burnt out in Afghanistan,' said Abdullah Abdullah, foreign minister of the government of President Burhanuddin Rabbani, which was ousted from Kabul in September 1996.

'But we do not want the Afghan people, who have endured two decades of devastating war, to be hur.' he told Iranian state radio in an interview from opposition-held territory in northern Afghanistan.

Abdullah on Sunday appealed to the United States to support its struggle with the Islamic 'faliban which controls most of Afghanistan and warned that air strikes alone would not achieve Washington's goals.

The United States has blamed the September 11 suicide plane attacks which killed around $5,(0) 0$ people on Saudi-horn terrorist suspect Osama bin Laden, who is sheltered by the Taliban.

'If the idea is to fight terrorists inside Afghanistan, the people who have been fighting them for years should be taken more seriously.' said Abdullah, whose opposition Nonlern Alliance is supported by Iran.

If our efforts are combined then

an operation against them will he much more effective.

\section{Afghans have food aid for only 3 weeks}

Some 3.8 million Afghans, who are tot:ally deprendent on outside aid, have only enough food stock. for two to three weeks, the UN's World Food Programme (W/F) said on Tuesday.

WFI' spokeswoman Christiane Berthiaume said food deliveries inside Arghanistan had virtually ground to a halt with the declining security situation.

'We have enough food stocks inside Afghanistan to last normal operations for two to three weeks. We have stopped forl shipments into the country dac to the lack of

commercial trucks in various parts of the country to move lond, Berthiaume said.

She also cited fuel shortages and a lack of truck drivers willing to take the risk of driving around Afghanistan.

International aid workers vere evacuated from the country last weck because of security fears.

About 370 Afghans working for WFP were trying to ensure food distribution amongst 200,000 displaced people, mainly near the city of Herat, according to Berthiaume.

We, together with other agencies, believe that millions of people will suffer serious food shortages if we cannot deliver relief assistance for security

reasons,' Berthiaume added.

Only days before the terrorist attacks in the United States, WFP appealed to international donors for 150 million dollars and raised its estimate of the number of people facing hunger in the war- and drought-ravaged country to 5.5 tivillion.

Berthiaume estimated that out of a population close to 20 million. about 12 million were affected by drought.

WFP is preparing contingency plans to help about 1.5 million people on the borders of Afghanistan.

\section{America's eyes in the} sky turn to Afghanistan

America's constellation of spy satellites will play a key role in any strike on suspected lerrorist mastermind Osama bin Laden. but nothing will beal having an agent on the ground fordivining his plans and moventents, experts say.

The cream of us electronic surveillance from space is halt a dozen satellites. laun hed from the 1990 s, which have astonishing capacities to photograph and eavesdrop while in orbit.

Two of them are advanced KH (Key Hole) satellites. whose sliell and solar pancls are the same as that of the Hubble space telescope, but fitted with different optical and infra-red sensors than their cosmos-gazing counterpart, said David Baker, editor of Jane's

Space Directory, a specialist British publication.

By repute, this series - each of which costs 1.5 billion dollars has the power to identify an ohject 1.5-20 centimetres (six to 8.5 inches) across.

But according to an estimate by the private Federation of American Scientists (I:AS), the true resolution is as good as 10 centimetres (four inches).

In other werds, an object as small as a tennis ball could be spotted from several hundred kilometers (niles) away.

Other top US performers are three satellites in the Lacrosse series, which use radar to provide imaging, meaning that they can get pictures even il there is ctoud

over the target, according to a French parliamentary report issued in July.

The latest addition is a $8 \mathrm{X}$, launched in May 1990 in the first of a likely series of 24 multifunction satellites that will eventually girdle the globe, passing over any given spot of the planet every 15 minutes, the report said. 


\section{The tension builds}

THE postponement of the meeting of Ulema, summoned to issue fatwas for the Taliban on the interlinked questions of the fate of Osama bin Laden, and the righteousness of jehad against the USA and its allies, can be viewed as allowing a breathing space for all concerned. The Taliban have gained more time to consider their position, which is as grave as it could ever be; Pakistan to attempt to persuade them to comply with existing US sanctions and to hand over Osama bin Laden; the USA to consider the possibility of obtaining bin Laden without having to carry out a major military operation, but without necessarily obtaining immediate custody of its prime suspect for the September 11 attacks. The Taliban have initially offered the same conditions for surrendering bin Laden as they have floated in the past, but this time it is apparently a firm offer: surrender of Osama to a neutral country, removal of sanctions, recognition of the regime, and economic aid for reconstruction of the devastated country. The key demand is the first, of surrender. to a neutral country, for all the rest would follow almost automatically.

The problem lies in the strong possibility that this will not be acceptable to the USA, where the Bush Administration is at the moment seeking to placate its outraged public opinion, manifested in attacks on Muslims (and even Sikhs) out in the American heartland, and which feels it essential to appear strong and able to respond. This explains the difference in the perceptions of the Afghan and Pakistani Foreign Ministers. While Mulla Mutawakkil feels there are 60 per cent chances of success, Mr Sattar believes that only a miracle can save the situation. The Pakistani team in Kabul is trying its best to impress upon the Taliban leadership that the USA is bent upon at least a token revenge, which means Osama's surrender, whether voluntary or by the Taliban, to the USA. The Taliban, on the other hand, are trying to negotiate a facesaving way out of the situation.

Is the USA interested only in getting Osama bin Laden, or does it also wish to bring down the Taliban regime? It is possible that the latter may only be secondary to the primary goal of nabbing Osama, in which case the USA will be willing to accept a compromise of some sort. It is also in Pakistan's interest to work for some compromise, because if the Taliban are perceived by Pakistani public opinion as having made a reasonable offer, any US action against Afghanistan afterwards, particularly if it involves the use of Pakistani soil, could well create serious problems for the government. This is a factor that the USA should also consider in responding to the Taliban demands. The Taliban are preparing for any eventuality, and have moved 25,000 troops up to the Pakistan border. It is essential at this juncture that all parties, the Pakistan and US governments, the Taliban and even Osama himself, should accept the need for a solution that allows the USA to demonstrate a firm response to the horrific attacks, while preserving innocent Afghans from destruction. Killing lots of Afghans will not bring back the victims of the World Trade Center outrage.

\section{Pak mufti calls for Jehad if Kabul attacked}

KARACHI (AFP) - A top Pakistani Muslim cleric, Mufti Nizamuddin Shamzai, called for Jehad Tuesday to defend Afghanistan if the United States launches attacks against the Taliban and their ally Osama bin Laden.

If non-Muslim forces attack Afghanistan, it would be the religious duty of every Muslim to fight Jehad side by side with their Afghan brothers, Shamzai said in a fatwa faxed to AFP.

Shamzai is the head mufti at Jamiat-ul-Uloom-ul-Islamia, Binori Town, the biggest Sunni seminary in Pakistan, where thousands of students from various countries receive Islamic education.

In a direct warning to Pakistan, he said Muslim countries that supported an attack against Afghanistan by non-Muslim forces would lose their authority under Islam.

Those rulers who extend their support to non-Muslims in an attempt to eliminate the Afghan regime will be treated as traitors of the Islamic nation, Shamzai said.

He condemned last week's terrorist attacks in the United States, but said it was wrong to punish the people of Afghanistan without convincing evidence. 


\title{
THE PAKISTAN TIMES
}

\author{
Wednesday, September 19, 2001
}

\section{America's eyes in the sky turn to Afghanistan}

PARIS: America's constellation of spy satellites will play a key role in any stlite on suspected larrorist mastermind Osama bin Laden, but nothing will beat having an agent on the ground for divining his plans and movements, experts say.

The cream of US clectronic surveillance from space is half a dozen salcllites, launched from the IOOOs, which have astonishing capacitics to photograpis and cavesdrop while in orbit.

Two of them are advanced KII (Key Hole) satellites, whose shell and solar panels are the same as that of the Hubble space telescope, but fitted with different optical and infra-red sensors than their cosmos-gazing counterpart, said David Baker, editor of Jane's Space Directory, a specialist British publication.

By repute, this series - each of which costs 1.5 billion dollars - - has the power to identify an object $15-20$ centimetres across. But according to an estimate by the private Federition of American Scientists (FAS), the true resolution is as good as 10 centimetres. In other words, an object as small as a tennis ball could be spotted from several hundred kilometres away.

Other top US performers are three satellites in the Lacrosse series, which usc radar to provide imaging, meaning that they can get pictures even if there is cloud over the target. according to a French parliamentary report issucd in July.

The latest addition is a XX. launched in May 1999 in the first of a likely series of 24 multi-function satellites that will eventually girdle the globe, passing over any given spot of the planet every 15 minutes, the report said.

Reconnaissance satellites are operated by the - National Reconnaissance Office (NR()), an agency that was formed in 1961 and whose existence was only oflicially acknowledged nine years ago. It has a hudget of 30 billion dollars a year, Baker said in a phone interview from London. Other capacity at the NRO's disposal lies ahoard ageing reconnaissance satellites that are at the end of, or beyond, their scheduled life expectancy, and imaging ability bernhed aboard civilian satellites. Added to these are the United States' clectronic eavesdroppers, "big cars" in space that suck up mobile phone and e-mail communications, hoping to pin down the location of a suspect or livine his plans, perhaps by identifying key words in messages.

They cannot be used to monitor landline telephones - nor, of course, conversations and ordinary mail. "The problem with satellites epitomises the problem that the West has got itself into," Baher said. Last week's terror attacks on the Pentagon and the World Trade Center showed the "total, total failure" of dependence on technology rather than human resources, he said, adding that the scrapping of the SR-71 Blackbird spy plane left the United States without a manned reconnaissance ability in the air.

Satellites carry propellant onboard that can be used to push them into a different spying orbit. This is an operation that is called "retasking" and is usually only done only at times of great crisis, because propellant is limited, and once it is used up the satellite's orbit cannot be shifted.

Two KH satellites, as well as two electronic eavesdropping satellites, have been retasked over Afghanistan as part of the search for bin Laden, the $B B C$ reported Tuesday.

Although big advances have been made in the technology of satellites themselves, perhaps the greatest progress has been made on the ground, in processing the the digital data sent back.

Powerful computers are able to turn satellite pictures into a 3-D image of terrain and streets, and even give military planners an idea of the view from a terrorist's window.

This is a boon for pilots flying low-altitude missions through rugged mountains or a snatch squad that has to carry out a covert raid on a building and make a quick getaway. Increasingly, the powerful of satellites has been entering the commercial domain, posing a dilemma to military chiefs.

There are several civilian companies now selling high-resolution one-metre images that, only a decade or so ago, were only available through a spymaster's lens. "The genic is out of the bottle." Baker said, adding that Iraq used pictures of Kuwait City it bought from SPOT Image, a French company, as part of its military plans for invading Kuwait in August 1991. - By special arrangement 


\section{THE PAKISTAN TIMES Wednesday September 19, 2001}

\section{Taliban stand by Osama, refuse to budge before US \\ Ask their people to get ready for holy war; Shura session postponed till today}

KABUL: Afghanistan's ruling Taliban Tuesday told their people to be ready for a holy war as Islamic scholars gathering to decide Osama bin Laden's fate made it clear they would not hand over the man wanted "dead or alive" by the United States.

The Islamic regime's army also unleashed a fierce offensive against their last opponents within the country in a bid to pre-empt US moves to strengthen them. The display of defiance from the Taliban came as their supporters in Pakistan mounted the biggest anti-American demonstration yet, heightening fears that any US attack on Afghanistan will have devastating implications for the sta-

\section{bility of its neighbour.}

"Of course if there is an invasion of an Islamic country, there will be jihad against the invaders," a senior Taliban official told AFP as hundreds of Islamic clerics, or ulema, streamed into Kabul.

"After the invasion jihad will be the only alternative and that is the obligation of Muslims." The ulema are expected Wednesday to begin a meeting which will consider whether to extradite bin Laden. who is suspected of orchestrating last week's terror attacks on New York and Washington and has been indicted in New York for the 1998 bombing of two US embassies in Africa.

The Taliban have previously hinted they might give bin Laden up for trial in a neutral, preferrably Muslim, country. But the clerics arriving on Tuesday were in no mood for compromise.

"Even if the whole of Afghanistan is devastated we won't hand him over until there is a solid proof against him," Mullah Mohammad Hassan, a representative of Paktika - province told AFP.

Another scholar, Maulawi Mhdul 7.ahir frum the Bagram district of Kabul, added: "We are ready for to defend ourselves if the Americans attack us. "We have already defeated and taught a lesson to their

British grandfathers and their Russian brothers," he said.

In their biggest offensive in months, Taliban forces launched an attack in the northeastern province of Takhar in a bid to cut their opponents' key supply lines from neighbouring Tajikistan. Fierce fighting was still raging Tuesday, an opposition spokesman told AFP. The onslaught represents an attempt by the Taliban army to exploit last week's death of the opposition's charismatic commander Ahmad Shah Masood and cut their supply lines before the mountainous region's harsh winter sets in.

If they succeed, the opposition forces could be eliminated before they have time to reap the benefit of an anticipated surge in support from the
United States in the wake of last week's terror attacks. Ordinary Afghans were fleeing the main cities in fear of a US strike, with thousands massing near the Pakistani border.

Those who stayed behind were becoming increasingly anxious over possible civil unrest or conflict between rival factions of the ruling Islamic militia. In neighbouring Pakistan, a crucial US partner for any attack on Afghanistan, hundreds of police and paramilitaries had to be deployed in the teeming port of

Karachi to prevent more than 5,000 radical Islamic students marching on the US consulate.

It was the largest anti-US demonstration in the current crisis and also the biggest since military ruler Pervez Musharraf seized power two years ago. Troops remained on alert but there was no movement out of barracks pending the outcome of the talks in Kabul, which Pakistan is desperately hoping will produce some sort of compromise. Pakistani radicals have vowed to join any Afghan jihad and warned the government that helping the US in any attack will mean civil war.

Pakistan President Musharraf has promised his "unstinting cooperation" with any US action. But political leaders have warned him that this must stop short of letting Pakistan be used as the launching pad for an attack. "If the govern- 
THE PAKISTAN TIMES

Wednesday, September 19, 2001 ment agrees to let American ground troops into Pakistan there will be a hell of a reaction," a former senior army officer, retired Licutenant-Gencral K.M. Azhar, told AFP.

The meeting of the ulema in Kabul had been due to start Tuesday but was delayed because many scholars had not been able to get to the city in time. The unexpected decision to seek a ruling from the schol. ars was announced by Taliban leader Mullah Mohanmad Omar after a high-level Pak-

istani delegation visited him Monday in the southeastern city of Kandahar, where bin Laden is also based.

The ulema includes many non-Taliban scholars who could be prepared to countenance some surt of deal - although any decision, or fatwa, will have to be approved by Omar, who is married to bin Laden's eldest daughter. A team led by the head of Pakistan's intelligence services, the Taliban's main backers, gave Omar a blunt warning Monday that the country could be bombed back to the stone age if bin Laden is not handed over. US President George W. Bush has warned that Americans will not rest until they secure justice.

"There's an old poster out west that says, as I recall, 'Wanted dead or alive"." he said during a visit to the Pentagon, a target in last week's suicide attacks along with the World Trade Center in New York. The Taliban consider bin Laden an honored "gucst" and have repeatedly rejected his extradition in the past. despite UN sanctions following the twin US embassy bombings in East Africa in 1998 which he is accused of masterminding.

The last Afghan jihad was issued against the Soviet Union afler its 1979 invasion of the country and resulted, a decade later, in the Red Amy heating a humiliating retreat.- AFP

\section{Osama accused of Masud's death}

WASHINGTON: The assassination of Afghan opposition leader Ahnad Shah Masud was likely to be carried out by associates of Osama bin Laden. US officials said on Monday.

Although Masud was a charismatic leader, it is premature to assume his death will mean defeat of his anti-taliban Northern Alliance, especially given the new situation created by what Washington considers terror attacks, they said.

"I think it (the Masud assassination) was a favour done by bin Laden for the Taliban," one official told Reuters. Another official said the assassination "bears all the hallmarks" of a bin Laden operation. "It's hard to imagine who else would do it," he said.--Reuters

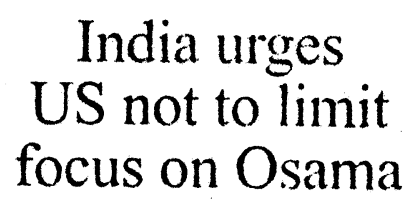

NEW DELHI: India called on Tuesday for the United States and other countrics to tackle terrorism at its roots rather than focus on Osama bin Laden.

"Fighting against one Bin Laden here or there hardly matters," Parliamentary Afrairs Minister Pramod Mahajan told Star News television.

"... the US and all other countries should fight against terrorism as a systicm and not only the symptoin because that will not eradicate terrorism from the globe totally."-.. Reuters

\section{Benazir condoles Ahmed Shah Masud's death}

ISLAMABAD: Former prime minister Benazir Bhutto has condoled the death of Afghan leader Ahmed Shah Masud who was killed in a bomb blast recently.

Benazir Bhutto, in a letter to Ahmed Wali Masud, the brother of deceused Afghan learler, wrote that Ahmad Shah Masud was a great and far sighted freedom fighter who embraced death whilst loyal to his principles.

She underlined that he stood by his people to his last breath. Described as the lion of Panjshir, he fonght tenaciously for the independence of Afghanistan. He was the rallying point for the Afghan resistarce. His martyrdom appears more than a coincidence, she observed. "The Pakistan Peroples Party and I mourn passing away of our brother Ahmad Shah Masud. May allih bless his soul and give all of you in the fanily the patience to bear the loss", she concluded. - NNI

\section{or \\ Danish Red Cross ready to return to Afghanistan}

COPENHAGEN: The Danish Red Cross said it is ready to return to Afghanistan if the United States attacks the country in retaliation for last week's suicide air strikes.

"We are ready as much as we can be to help people in need," the head of the Danish Red Cross, Joergen Poulsen, told the Ritzau news agency. "But we must einphasis that Afghanistan is already in a catasirophic situation, with drought, earthquakes and war for more than 30 years, and six million people who have fled the country."

The International Committee of the Red Cross withdrew its last 2: employees from Afghanistan on Sunday, including Diunes. However Andsen said he believerd the pullout was tenporary, and said that Danish employees could return to the country within 24 hours if pernitted. "We also have a mobile logistical unit that is ready to operate in Afglanistion," he sidd. - AFP 


\section{Sattar, Kharazi for action against terrorism under UN}

TEHRAN: Iran and Pakistan "agree" that any global action against terrorism needs to be done within the framework of the United Nations, Iranian radio reported Wednesday.

During a telephome conversation, Iranian Foreign Minister Kamal Kharazi and his Pakistani counterpart, Abdul Sattar, agreed that there is a "global framework to light against against terrorism" and that "international actions, under the aegis of the United Nations, were effective," the radio said.

During the conversation, Kharazi said he was "eoncerned" about the "attempt to tarnish the image of Muslims in the world" and that "precipitous decisions would not succeed in uprooting terrorism."

Iran has criticized US preparations for a possible military operation in Afghanistan, which is harbouring Osama bin Laden, the Saudi-born Islamic militant who is, the key suspect in the September 11 terrorist attacks on the United States.

Pakistan, meanwhile, has been asked by the United States to allow use of its airspace in the event of an attack against neighbouring Afghanistan - AFT

Reuters adds: Iran's Foreign Minister Kamal kharrazi told his Pakistani counterpart on Wednesday that he wanted those behind the attacks in the United States "tracked down and severely punished", Iran's IRNA news agency reported.
"The terrorists must be tracked down and severely punished," Kharrazi told Pakistan's Foreign Minister Abdul Sattar in a telephone conversation, referring to the deadly attacks in New York and Washington last week.

Iranian leaders have strongly condemned the attacks and offered deep sympathy to the United States in ways unprecedented since the 1979 lstamic revolution, which led to a break in their diplomatic ties.

US Secretary of State Colin Powell said Tehran's response was "worth exploring".

But Kharrazi cautioned against any "over-hasty decision which will bring about no tangible and effective results" in fighting terrorism.

Iran has been involved in a furry of diplomatic activity to try to avert a new war in neighbouring Afghanistan, which harbours Saudi-born Osama bin Laden, Washington's prime suspect in the attacks.

"Iran is worried about the outbreak of a human catastrophe in Afghanistan," Kharrazi said.

Iran's state radio said earlier that President Mohammad Khatami had written to British Prime Minister Tony Blair urging caution in response to the attacks.

The letter was an answer to a message from Blair in which the British premier called on Khatami and other Islamic leaders to cooperate against terrorism and prevent a clash of cultures and religions.

"President Mohammad Khatami said terrorism is a threat to the whole of humanity and it is necessary for the international commu. nity to be cautious in dealing with the roots and foundations of terrorism and its consequences," the radio said.

Khatami agreed, "III-willed people must not be allowed to create a clash or conflict between differen religions and cultures," it said, adding that the president had warned "hasty, unreasoned and violent reaction will only help terrorists reach their ends".

Newspapers have said Britain was acting as an intermediary between Iran and London's top strategic ally the United States, which has never restored diplomatic ties with Tehran broken after radical students seized the U.S. embassy in Tehran in 1979.

Canada's National Post said on Tuesday senior Iranian officials had sent a message to Washington through Canada saying Tehran would not oppose targeted military strikes against those believed responsible for the attacks.

But an Iranian foreign ministry spokesman denied the report.

Iran, with some two million Afghan refugees already on its soil and heavily armed drug-sinugglers along its border, has ordered its forces to seal the $900-\mathrm{km}$ (560mile) frontier with Afghanistan in preparation for possible US action.

"In order to get rid of the scourge of terrorism today, more than ever we need perseverance and patience. We should not rush to take revenge," Khatami said. 


\section{Text of President}

\section{Pervez Musharraf's address}

ISLAMABAD: Following is the text of President Pervez Musharraf's speech to the nation.

The situation facing the nation today and the international crisis have impelled me to take the nation into confidence. First of all, I would like to express heartfelt sympathies to the Inited States for the thousiands of valuable lives lost due to terrorism.

We are all the more grieved because in this incident people from about 45 countries from all over the world lost their lives. People of all ages and people from all religions lost their lives. Many Pakistanis also lost their lives. These people had gone to the US to improve their life. These people were highly capable Pakistanis who had gone to improve their lives. On this loss of life, lexpress my sympathies with their families.

And I pray to Allah to rest their souls in peace.

This act of terrorism has raised a wave of deep grief, anger and retaliation in the United States. Their first target from day one is Osama bin Laden and his movement Al-Qaida about which they say that it is their first target.

The second target are Talibans and that is because Taliban have given refuge to him and his network. 'This is their demand for many years. They have been demanding his extradition and presentation before the International Court. Taliban have been rejecting this. This have made Taliban their target.

The third target is a long war against terrorism at the international level.

The thing to ponder is that in these three targets nobody is talking about war against Islam or the people of Afghanistan.

Pakistan is being asked to support this campaign. What is this support? Generally speaking, there are three important things in which America is asking for our help. First, is intelligence and information exchange, second sup- port is the use of our airspace and the third is that they are asking for logistic support from us.

I would like to tell you now that right now, they do not have any operational plans. Therefore, we do not have any details on this count. But we know that whatever are the United States intentions they have the support of the UN Security Council and the General Assembly in the form of a resolution.

This is a resolution for war against terrorisin and this is a resolution for punishing those people who support terrorism. Islamic countries have supported this resulution. This situation prevailed in the outside world

Now I would like to inform you about the internal situation.

Pakistan is facing a very critical situation and $I$ believe that after 1971 this is the most critical period.

The decision we take today can have far-reaching and wide-ranging consequences. The crises are too strong and too widespread. If we take wrong decisions in this crisis, it can lead to worst consequences. On the other hand, if we take right decisions, its results will be very good. The negative consequences can endanger Pakistan's integrity and solidarity. Our critical concerns, our important concerns can come under threat. When I say critical concerns, I mean our strategic assets and the cause of Kashmir. If these come under threat it would be a worse situation for us.

Politically, we can re-cmerge as a responsible and dignified nation and all our difficulties can be minimized. I have considered all these factors and held consultations with those who hold different opinions. I met the Corps Commanders, National Security Council and the Federal Cabinet. I interacted with the media. I invited the religious scholars and held discussions with them. I met politicians. I also invited intellectuals. I will be meeting with the tribal chiefs and Kashmiri leaders tomorrow. This is the same process of consultation that I held earlier. I noted that there was difference of opinion but an overwhelming majority favours patience and wisdom. Some of them, I think about ten percent favoured sentimental approach.

Let us now take a look at the designs of our neighbouring country. They offered all their military facilities to the United States. They have offered without hesitation, all their facilities, all their bases and full logistic support. They want to enter into any alliance with the United States and get Pakistan declared a terrorist state. They want to harm our strategic assets and the Kashmir cause. Not only this, recently certain countries met in Dushanbe. India was one of them. Indian representative was there. What do the Indians want? They do not have common border with Afghanistan anywhere. It is totally iso. lated from Afghanistan. It my view; it is not surprising that the Indians want to ensure that if and when the government in Afghanistan changes, it shall be an anti-Pakistan government.

It is very important that while the entire world is talking about this horrible terrorist attack, our neighbouring country instead of talking peace and cooperation, was trying hard to harm Pakistan and defame Islam.

If you watch their television, you will find them dishing out propaganda against Pakistan, day in and day out. I would like to tell India "Lay Off"!

Pakistan's armed forces and every Pakistani citizen is ready to offer any sacrifice in order to defend Pakistan and secure its strategic assets. Make no mistake and entertain no misunderstanding. At this very moment, our air Force is at high alert. And they are ready for "Do or die" missions.

My countrymen!

In such a situation, a wrong decision can lead to unbearable losses. What are our critical concerns and priorities? These are four:

1 First of all is the security of the country and external threat. vival.

2 Second is our economy and its re-

3 Third are our strategic nuclear 
and missile assets

4 And Kashmir cause.

These four are our critical concerns. Any wrong judgement on our part can damage all our interests.

While taking a decision, we have to keep in mind all these factors.

The decision should reflect supremacy of righteousness and it should be in conformity with Islam. Whatever we are doing by now, it is according to Islam and it upholds the principle of righteousness.

I would like to say that decisions about the national interests should be made with wisdom and rational judgement.

At this moment, it is not the question of bravery or cowardice. We are all very brave. My own response in such situations is usually aggressive. But bravery without national judgement tantamounts to stupidity. There is clash between bravery and sound judgement.

Allah Almighty says in the Holy Quran, "The one bestowed with sagacity is the one who get a big favour from Allah".

We have to take recourse to sanity. We have to save our nation from damage. We have to build our national respect. "Pakistan comes first, everything "lse comes later."

Some scholars and religious leaders are inclined towards taking emotionat decisions. I would like to remained them the events of the first six years of the history of Islam. The Islamic calendar started from migration. The significance of migration is manifested from the fact that the holy Prophet (PBUH) went from Makkah to Madina. He (PBUH) migrated to safeguard Islam.

What was migration? God forbid, was it an act of cowardice?

The Holy Prophet (PBUH) signed the charter of Madinah (Meesaq-e-Madinah) with his Jewish adversaries. It was an act of sagacity. This treaty remained effective for six years. Three battles were fought with non-believers of Makkiah during this period, like the battle of Badr, Uhad and Khandaq. The

Muslims emerged victorious is these battles with the non-believers of Makkah because the Jews had signed a treaty with the Muslims.

After six years, the Jews were visibly disturbed with the progress of Islam, which was getting stronger and stronger. They conspired to forge discrete relationship with the non-believers of Makkah. Realising the growing ties between the two adversaries of Islam, the Holy Prophet (PBUH) signed the treaty. of Hudaibiya with the Makkhans who had been imposing wars on Islam.
I would like to draw your attention to one significant point of this pact. The last portion of the pact was required to be signed by the Holy Prophet (PBUH) as Muhammad Rosool Allah. The non-believers contested that they did not recognise Muhammad (PBUH) as the Prophet of Allah. They demanded to erase these words from the text of the treaty. The Holy Prophet (PBUH) agreed but Hazrat Umar (RA) protested against it. He got emotional and asked the Holy Prophet (PBUH) if he was not the messenger of God (God forbid) and whether the Muslims were not on the right path while signing the treaty. The Holy Prophet (PBUH) advised Hazrat Umar (RA) not to be led by emotions as the dictates of national thinking demanded signing of the treaty at that time.

He (PBUH) said this was advantageous to Islam and as years would pass by, you would come to know of its benefits. This is exactly what happened. Six months later Jews attacked and in the battle of Khyber Muslims, by the grace of Allah, again became victorious and Jews were defeated.

It should be remembered that this became possible because Makkhans could not attack because of the no-war pact.

On 8th Hijra by the grace of Allah the conquest of Makkah took place. What is the lesson for us in this? The lesson is that when there is a crisis situation, the path of wisdom is better

\section{than the path of emotions.}

Therefore, we have to take a strategic decision. There is no question of weakness of faith or cowardice. For Pakistan, life can be sacrificed and I am sure every Pakistani will give his life for Pakistan. I have fought two wars. I have seen dangers: I faced them and by the grace of Allah never committed a cowardly act. But at this time one should not unnecessarily bring harm to oneself.

We cannot make the future of a hundred and forty million people bleak. Even otherwise it is said in Shariah that if there are two difficulties at a time and a selection has to be made it is better to chose the lesser one. Some of our friends seem to be much worried about Afghanistan. I must tell them that I and my government are much more worried about Afghanistan and Taliban.

I have done everything for Afghanistan and Taliban when the entire world is against them. I have met about twenty to twenty five world leaders and talked to each of them in favour of the Taliban. I have told them that sanctions should not be imposed on Afghanistan and that we should engage them. I have been repeating this stance before all leaders but I am sorry to say that none of our friends accepted this.

Even in this situation, we are trying our best to cooperate with them. I sent Director General ISI with my personal letter to Mullah Umar. He returned after spending two days there. I have informed Mullah Umar about the gravity of the situation. We are trying our best to come out of this critical situation without any damage to Afghanistan and Taliban. This is my earnest endeavour and with the blessings of Allah I will continue to seek such a way out.

We are telling the Americans too that they should be patient. Whatever their plans, they should be cautious and balanced. We are asking them to come up whatever evidence they have against Osama bin Laden. What I would like to know is how do we save Afghanistan

and Taliban. And how do we ensure that they suffer minimum looses. I am sure that you will favour that we can bring some improvement by working with the nations of the world.

My countrymen,

At this juncture, I am worried about Pakistan only. I am the Supreme Commander of Pakistan and I give top priority to the defence of Pakistan. Defence of any other country comes later

We want to take decisions in the in. terest of Pakistan. I know that the majority of the people favour our decisions. I also know that some elements are trying to take unfair advantage of the situation and promote their personal agenda and advance the interests of their parties.

They are poised to create dis. sentions and damage the country: There is no reason why this minority: should be allowed to hold the same majority as a hostage.

I appeal to all Pakistanis to display" unity and solidarity and foil the nefari-. ous designs of such elements who in -: tend to harm the interests of the coun:try. At this critical juncture, we have to" frustrate the evil designs of our enemies and safeguard national interests.' Pakistan is considered a fortress of Islam. God forbid, if this fortress is harmed in any way it would cause dam age to the cause of Islam.

Mr dear counrtymen,

Have trust in me the way you re' posed trust in me before going to Agra.' I did not disappoint the nation there. We have not compromised on nationat honour and integrity and I shall not dis." appoint you on this occasion either. This is my firm pledge to you.

In the end before I take your leave, $F$ 
would like to end with the prayer of Hazrat Musa (AS) as given in Sura-eTaha: "May Allah open my chest, makè my task easier, untie the knot of my tongue so that they may comprehend my intent".

May Allah be with us in our endeap" ours.

Pakistan Paindabad

\section{Masud killers hold Belgium passports}

BRUSSELS: The suspected killers of Afghan opposition commander Ahmad Shah Masud held stolen Belgian passports, but they are not known in Belgium, the Belgian foreign ministry said Monday.

Tajikistan's foreign ministry said that Kacem Bokuli and Karim Sujani, suspected of killing Masud on September 9, were Moroccans who had been resident in Belgium.

Belgian foreign ministry spokesman Michel Malherbe confirmed that the passports the men were carrying had been stolen in 1999 break-ins at the Belgian embassy in The Hague and the Belgian consulate in Strasbourg, France.

But he added that the names of Bokuli and Sujani were "un. known in Belgium," where stateissued identity cards and household registration is - as in most other. European countries. mandatory.

Masud's death is seen as a major setback for the Northern Alliance, a fractious ethnic coalition that controls around five percent of Afghan territory and is fighting Afghanistan' $s$ ruling Taliban movement. -AFP

\section{Zahir Shah urges Afghans to oppose terrorism}

ROME: The 87-year-old ex' king of Afghanistan called on $\because$ his people Wednesday to "rescue themselves" by renouncing terrorism.

The United States is pressing Afghanistan to hand over Osama bin Laden, the prime suspect in the terror atlacks last week in New York and - Washington, and warned it could face military retaliation if it refuses.

"My concerns and anxieties for the future of Afghanistan have increased in these precarious moments," former King Mohanmed Zahir Shah said in a statement.

"I appeal to the Nghan people and to their sense of honour and patriotism to rescue ourselves from this dangerous situation," he said.

He urged his country to "acknowledge with regret that the presence of foreign, imposed terrorists has causes unrest and danger" for Afghanistan. Bin Laden is a Saudi millionaire and an exile from his own country.

And aide said Zahir's message was recorded and broadcast inside Afghanistan, but provided no details. An English translation was provided to the Associated Press in Rome, where Zahir has lived since his 1973 overthrow.

His 40-year reign ended with a coup by his nephew, which opened Afghanistan to three decarles of conflict that have left it devastated.

The former king lives surrounded by a small court of aides and advisers and is rarely seen in public.

llis last appearance was in January at an assombly of Afghan exiles - loyalists in robes, turbans and fezzes and in European-cut suits dreaming of someday convening of a tra. ditional Girand Assembly of

- Afghan leaders in Kabul, the

\section{US 'very pleased' with Pak cooperation}

WASHINGTON: The Inited States is "very pleased" with Pakistan's cooperation in fighting terrorism, the White House said Wednesday. following President Pervez Musharraf's crucial address to his nation.

"The president has noted the speech of President Musharraf today in Pakistan," said White Housc spokesmin Ari Fleischer

"The Inited States is very pleased with the (o(s)peration of Pakistan and President Musharraf's speech is an indi(eation of the strongs relationship between He Heited Stites and Pakislatu to conmler lerrorism," her said.

Pakistan has been under intense pressure to sign up for a US campaign against terrorism and to pressure Afghanistan's Taliban to hand over (Osama bin Laden - the IIS government's top suspect in last week's terror attacks on New York and the Pentagon last week.

Musharraf urged Washington in his address to show "balance and reason", but confirmed US officials had requested the use of Pakistani airspace to hit the Taliban and bin Laden. "Bin Laden was a suspect from day one; his movement al. Qaeda ("The Base") is Anerica's main target," he said. Their second target is the Taliban, who they believe are harbouring the terrorist and his network," he said.-AFP 


\section{Omar wants talks with Washington}

\section{Seeks evidence against 0sama; strong pro-Laden sentiments in shura meeting; Taliban getting ready to face attack}

\section{Rahimullah Yusufzai}

PESHAWAR: Most speakers on the first day of the Ulema Council meeting in Kabul on Wednesday opposed handing over of Osama bin Laden to any country until the US provides solid evidence about his involvement in acts of terrorism.

The council, which met in the former palace, Arg, is expected to continue its deliberations today. It was convened by Taliban supreme leader Mulla Mohammad Omar to advice him on handling the bin Liden affair. The council was also asked to consider declaration of jehad in case the IIS atlaicks Afghanistan.

Taliban officials in Kabul told The News that Ulema invited to the council's meeting were still arriving from all parts of Afghanistan. They said the council's meeting could be prolonged to enable senior clerics to make speeches and discuss proposals on tackling the crisis arising from the US demand that bin Laden be extradited.

Mulla Omar's message to the council was said to have set the

tone for the meeting. He made three important points in his message, sent from Kandahar. He argued that the Taliban had never refused talks with the US on the bin Laden issue in the past and had held several rounds of negotiations to find a peaceful solution to the problem. He said the Taliban were willing for further talks on the matter.

Mulla Omar also urged the US to be patient instead of rushing to judgement with regard to the identity of those who attacked the Pentagon and the World Trade Centre. He called for thorough investigations before responsibility could be fixed.
The Taliban leader also reiterated his stand that bin Laden won't be extradited unless enough evidence about his involvement in terrorist activities was presented. He felt it wasn't possible for bin Laden to organize such a sophisticated attack in the US while operating from a poor country like Afghanistan.

Taliban officials said some of the Ulema echoed the same sentiments in their speeches. One of them was said to have referred to bin Laden as "a stateless person," just as Mulla Omar had done in his address to the nation on Radio Shariat a few days ago, and asked how the Afghan people could abandon a fellow Muslim who had sought refuge with them.

The speakers also recalled how bin Laden had risked his life to participate in the jehad against the Soviet occupation troops in Afghanistan and assisted the Afghan mujahideen, widows and orphans.

Though the Taliban authorities disallowed the press from attending the council meeting, sources in Kabul said the mood at the venue was overwhelmingly

pro-bin Laden. They said the participants wanted credible proof that bin Laden had sponsored international terrorism before the Taliban could commit themselves to hand him over to a third country for trial.

The council would forward its recommendations to Mulla Omar, who normally endorses all decisions taken by the Ulema in light of Shariah. It would then become government policy and made public as a Fatwa, or religious decree.

The final Taliban decision on bin Laden's fate would also be conveyed to the Pakistan government, which a few days ago sent a delegation to Afghanistan in a last-ditch effort to convince the Taliban leadership to give up the Saudi-born Islamist to avoid a US attack.

Agencies add: "We appeal to the U.S. government to exercise complete patience, " the Pakistanbased AIP news agency quoted Mullah Mohammad Omar as saying in a speech read out to a meeting of hundreds of clerics gathered in the presidential palace in Kabul. "We want America to gather complete information and find the culprits," he said, adding evidence could be given to the Afghan Supreme Court or to clerics of three Islamic countries. "We assure the whole world that neither Osama nor anyone else can use Afghan territory against anyone, ${ }^{n}$ he added.

"The enemies of this country look on the Islamic system as a thorn in their eye and they seek different excuses to finish it off. Osama bin Laden is one of these," Omar told the clerics.

"We have not tried to create problems with America. We have held negotiations with former American governments and we are ready to hold negotiations even now," he said. "We have

conveyed to America that we have snapped all Osama's communication links and he cannot talk to anyone in the outside world. We have also told America that the Islamic government of Afghanistan denies any involvement in the recent incident. "We have denied this but the tragedy is America is not listening to us. Americans are threatening us."

"Anyone who is responsible for this act, Osama or not, we will not side with him," said Afghanistan's interior minister.

Taliban troops appear to be readying for a US military onslaught in retaliation for their harbouring of alleged terrorist mastermind Osama bin Laden, fleeing refugees told AFP Wednesday.

"The Taliban are very nervous and expect something to happen. I've seen a lot of soldiers moving around along the Kabul road," said one refugee from Kabul as he arrived in this northwestern Pakistani frontier city. "But they don't look frightened, in fact a lot of them seem to be quite excited 
by the whole thing. They're just ready for a big war," said the refugee, who bused into $\mathrm{Pe}$ shawar after walking around the tightening Pakistani border post at Torkham at the foot of the Khyber Pass.

Major troop movements were. reported to be especially intense around the eastern Afghan city of Jalalabad, explained the refugee, who only identified himself as 41 . year-old Mohammad.

"There are alot of Talib there, along with anti-aircraft guns and some tanks," he said, but he insisted he did not spot any Arab fighters. "I was very scared but we got through without any problems." "We just wanted to get out as quickly as possible. There is nothing for us here, we have no money, but why wait around for another war?" he said.

\section{US fighter planes coming to Pakistan Monitoring Desk}

ISLAMABAD: Over 100 IIS fighter planes are leaving for Pakistan to laumich operations against terrorist bases in Afghanistan, CNN refortted on Thursday morning.

The TV stations did not give any detail but repents said IS had decided to launch specific: assaults on targets idrntificd by intelligence provided to the is machine.

An "operation lnfinite Jus. ticen has been launehid CNN said.

\section{US wants action}

\section{not words}

IVASHINGTON: The Iniled states on Wednesday told Afghanistan's ruling Taliban it Watts action, tont hegotiations after the Tabiban reporterlly offired to hedif talks uver Osama hin taden, the prime susplect in the altarks on Now York and Washington.

"The president's messigge to the Taliban is very simple - it's time for action not negotiations," White Inouse spokesman Ari Fleischer said. Ho was responding (o comments by taliban leader Mullah Mohammed Omar, who reportedly said he

was ready to hold talks with the United States about bin Laden.

. Asked to explain his conments further, Fleischer would only say President George: W. Bush wanted the Tuliban to "take the actions necessary to no longer harbour terrorists - whatever form that tatces."

.US President Genrge W. Bush on Wednesslay worked to broaden support for his global anti-terrorism campaign, pledging to welcome countries than carnot openly support retaliation for last week's terror attacks.

$\because$ "Hetp us round-up these people. You can play a constructive role." Bush urged reluctant nations during a joint Oval Oftice appearance with Indonesian President Megawati Sukarnoputri, leader of the world's most populous Muslim country. Some countries will be able to offer limited ur secret support for any IS-led military action in response to last week's strikes on the World Trade Center and the l'entagon, which left some 5,800 people dead or missing, siid Bush.

"Some nations will be comfortable supporting overt activities, sọme nations will be comfortable sulporting! covert activitics, some notionis will only be comfortable in providing information, others will be helpuit and only feel comfortable helping on financial matters. I understand that," he said.

"We'll do what we need to do to achicue the first objective of a long campaign, and the first oljective is to bring people to justice who ... committed this particular set of atrocities," he said. He also vowed to "hold those who harbor them accountable" and called on the Islamic militia that rules Afgitanistan, where bin Laden resides, to turn hum over. "I would strongly urge any nation in the world to reject terrorism, expel turrorists. I would strongly urge the Taliban to turn over the al-Queda organizers who

hide in their country," he said.

Bush also said he expected actions against non-governmental organizations that support terrorists.

Russia "wants to be helpful" in a US-led anti-terrorism campaign and has not asked for anything in return for its assistance, Secretary of State Colin Powell said Wednesday.

"They were very forthcoming," Powell said after meeting lussian Poreign Minister Igor Ivanov to ask for Moscow's help in retaliating for the September 11 atlacks in New York and Washington and in a larger struggle against terrorism in general. "They want to be helptul and they didn't put any specific requests or bills or links on the table," he told reporters before heading to the White House to sit in on a meeting between Ivanov and President Gerrge W. Bush.

Ivanov said he and P(s)well had agreed that the Inited States and Russia should work toggther to combat terrorism and that Moscow believed the battle might require military action.

The US Federal Bureau of Investigation has searcherl an apartment complex, which is home to relatives of Osama bin Laden, the Saudi-born exile named the rtain suspect in last week's terrorist attack, the Boston Herals reported Wednesday.

Word of the probe into bin Laden's relatives follows the arrest 
Friday of an unidentified man at New York's John F. Kennedy Airport, who reportedly knew one of Osama bin Laden's brothers, said the report, citing informed sources. FBI agents arrived at the Flagship Wharf condominium complex hours after the attacks and conducted a series of interviews with unit owners, according to the paper.

Hope faded by the hour Wednesday that survivors would still be found amid the rubble of the devastating terror assault in the United States, as more than 5,800

people were feared dead.

A US aircraft carrier battle group set out Wednesday from Norfolk, Virginia for the Mediterranean and "points east" as the US military began repositioning forces worldwide for its campaign against terrorism, Pentagon officials said.

The USS Theodore Roosevelt and its wing of fighter jets leads a naval task force that includes amphibious assault ships with some 2,000 combat Marines capable of conducting special operations, navy officials said. Guided missile cruisers, destroyers, frigates and submarines are in the 13-ship force. Two other carrier battle groups already are in the Indian Ocean, they said.

"You will see a repositioning of US forces worldwide to support the president's call for a campaign against terrorism," said a official, who spoke on condition of anonymity.

Attorney General John Ashcroft said Wednesday the terrorists behind the attacks on the United States likely received support from foreign governments and that it was too early to tell if surprise arrests in Michigan were a major break in the case.

Emerging from a visit at the Pentagon that was badly damaged by last week's attacks, the attorney general raised the possible involvement of foreign states. "It is pretty clear that the networks that conduct these kind of events are harboured, supported, sustained and protected by a variety of foreign governments," he said.

"It is time for those governments to understand with crystal clarity that the United States of America will not tolerate that kind of support for networks that would inflict this kind of damage on the American people."
Ashcroft said authorities were still reviewing the first criminal charges in the investigation, involving three men near Detroit who had false documents and air-

port diagrams. He said it was too early to tell if the arrests were a break in the 8-day-old investigation.

The arrests occurred after FBI agents raided a residence looking for one of the nearly 200 witnesses being sought in the investigation. Instead, they found the three men and a cache of documents. The trio was charged Tuesday in Detroit with fraud and misuse of visas, passports and other immigration documents. Authorities continued to follow a money trail leading to the terrorist network.

Federal banking regulators on Wednesday distributed a list of 21 possible suspects to all U.S. banks, asking them to research any accounts or financial transactions in the suspects' names and report them immediately to the FBI. The list included most of the 19 men identified as hijackers and a few other names of men the FBI is seeking. And agents contacted Muslim leaders in the Washington asking for help.

Stanley Cohen, an attorney, said at least three clients who are Muslim leaders in Washington received contacts from the FBI "asking for help gathering intelligence on the Muslim community." Cohen said his three clients declined. On Tuesday, Ashcroft expanded the terrorism investigation to include U.S. attorneys in every city, vowing to wage a "concerted national assault." Aided by a federal grand jury in New York, the investigation has detained 75 people for questioning and has four people under arrest as material witnesses. The government also announced a new policy giving investigators wide latitude in detaining the non-citizens whom it takes into custody on possible immigration violations in the terrorist probe.

Officials would be allowed 48 hours, or longer in emergencies, to decide whether to charge an alien with status violations, up from 24 hours. - Agencies

\section{Taliban issue visa to aid workers' counsel}

\section{Naveed Ahmad}

ISLAMABAD: The Taliban authorities Wednesday granted one-month visa to Atif Ali Khan, counsel for eight aid workers of Shelter Now International, who were held on charges of preaching Christianity in Afghanistan.

Speaking to The News on telephone from Peshawar, Atif said: "The Taliban have been very cooperative lately. The Foreign Ministry had asked their consulate in Peshawar to issue me a visa."

The Taliban have also issued visa to his associate, Arshad Ali. The relatives of the detainees and officials of the embassies concerned have chosen Atif Ali Khan to defend the case with the consent of the Taliban's Supreme Court.

Atif, a Pakistani national, earned his LlM degree from American University in Washington DC after graduating in Islamic law from International Islamic University, Islamabad. He has also worked with the Organisation of Islamic Conference and United Nations.

Atif said, "Mr Afgani, the chief of protocol at the Taliban Foreign Office, has been very forthcoming." To a question, he said the Taliban have assured him full cooperation, including access to the detainees and the court officials in Kabul.

The aid workers - 24 members of German-based Christian relief organisation Shelter Now Interna-

tional, with 16 Afghans, four Germans, two Australians, and two Americans - were arrested by the Taliban in the first week of August.

The Taliban first refused but later allowed three senior diplomats - American counsel David Donahue, Australian consul Alistair Adams, and German counsel Helmut Landes - to meet the arrested workers of their respective countries. The relatives of the aid workers as well as the ICRC officials were also allowed access to the eight workers.

Meanwhile, the United States embassy Tuesday failed in its efforts to facilitate Atif's visit to Kabul through an ICRC plane for a possible meeting with the arrested aid workers before the outbreak of a likely war. The flight, which was planned to return to 
Peshawar the same evening, could * not take off as Taliban refused to allow the aircraft enter Afghan airspace. About any kind of contact" with aid workers, Atif said, "although we have been assured full access to: the detainees whenever we are in Kabul, I have had no communication. with them due to the lack of such fa cilities there." The Taliban have : moved the arrested aid workers to : some other place for their protection. He, however, hoped, "I feel we have a't" good chance and Islam advocates compassion." United States, Germany and Australia are making desperate ef: I forts for the release of their respective' citizens from the Taliban authorities: Taliban's ministry of vice and virtue prohibits any non-Muslim to preach his religion inside Afghanistan.

\section{3 lakh refugees reach Quetta in a week}

\section{Nusrat Javeed}

QLETTA: Three hours drive from the Afghan border, the capital city of Balochistan, Quetta, is virtually on the edge. Its streets take it for granted that the United States would begin its punitive strikes against Taliban from their spiritual capital, Kandahar. And, they are coming soon; may be by the coming weekend.

As if to heighten their fears, Afghans have been trickling down to this city in droves since September 13. Eyewitnesses claim that on average not less than ten thousand persons began (rossing over to Pakistan the moment Washington expressed the intent of fighting the "global war agrainst terrorism.

Most came through the regular route at (haman. But many also sneaked in the dark and via the sparsely manned posts at a very porous border. Though authorities concede coming of forty thousand-plus persons in four days, the streets insist that not less than 300,000 , persons have already reached here in the past one wiek.'

It was a train-load from Chaman to Quetta on September 16. the streets claim, which took the authorities by surprise. By then. Taliban had also declared that they would retaliate against all those 'Muslim neighbours' who would cooperate with the USA in 'war against terrorism.'

Security officials had to fear that some diehard supporters of bin Laden or Taliban must have been crossing over to Pakistan with the crowd of hapless looking refugees. They could always act to avenge the US attack on Afglianistan' and 'punish Pakistan for supporting it."

The law enforcing personnel spread in town for at random check of suspicious looking strangers. More than a thousand were nabbed and taken to a local stadium. The assembled persons are now moved to a camp, well outside the limits of Quetta.

Since Tuesday morning, the border at ('haman has been literally sealed with heavy positioning of regular and paramilitary troops. At various points, barbed wire fencing is also erected.

Talking to The News on phone from a point very close to the border, a transporter claimed: 'senior military officials visited areas around Chaman to firmly tell the police and district authorities to deny entry to Afghans. Some regular and known transporters were also summoned for meetings and categorically told that only the trucks with rations would be allowed to leave for Afghanistan.'

Another transporter claimed

that 'everybody, even with regular identity cards and other valid documents for transportation and travel to Afghanistan, is stopped by Pak authorities at a post half a kilometer from the border.' But even from that point, he could notice a crowd of 'five to six thousand persons, desperately wanting to enter Pakistan for security on Wednesday.'

Some political activists from areas close to Chaman insist that the sealing of regular entry points may not prove to be very helpful in the end. 'For the past two days, desperate farnilies prefer to sneak in after the dark from irregular entry points,' they reported. Even if caught crossing, the locally raised militia will not deny entry to women with small children.

'Our culture does not permit getting into arguments with a woman seeking shelter in despera.

tion,' said a political activist. Some sources also claimed that these are not the average Afghans only, from Kandahar and the adjacent areas, who are running for life. 'Even some known Taliban commanders were fleeing.' A regular truck driver to and from Kandahar told The News that 'notwithstanding the boastful thunder of Mullah Omar, many people around him fully realize that fighting the USA is no joke.' He insisted that 'with my own eyes, I saw a known Taliban commander of Kabul who tried to reach Pakistan with his family through Chaman.' When caught, the said commander reportedly claimed that he was only trying to send his family across. And, why shouldn't he do it, 'when the interior minister of the Taliban government also planned sending his family to safety in Pakistan.'

Another transporter, who came

from Chaman to Quetta on Wednesday afternoon also claimed to have 'seen Hafiz Majeed.' The transporter said that Majeed was a well-known Taliban commander of Kandahar and 'he is now stranded at Spin

Bodlak,' a point close to Chaman.

The stories, one is hearing in Quetta since landing Wednesday afternoon conveys the strong impression that at least in and around Kandahar, the panic had been set among the average Afghans. But just not understandable is the fact as to why the national and international media is not reporting it.

It's about time to make the world realize that Pakistan can simply not block the waves of desperate Afghans in case the full blown attack on Kandahar by the USA. The international community must establish 'safe corridors' for utterty helpless and innocent residents of Afghanistan now, who have been 
The News International, Thursday, September 20, 2001

enduring the incessant brutalities since 1979. Pakistan needs to prepare itself for handling the brewing crisis. Already, the coming of more than a million refugees during the Soviet occupation of Afghanistan. has made the living in cities like. Quetta unbearable. Its available re" sources are just not enough to cater." for the basic needs of the residents.:

Also important is the political: fallout. The non-stop coming of the : Afghan refugees for more than two: decades have dangerously upset: the ethnic balance of this volatile: province. The historic Baloch-Pushtun bonhomie is no more. Ethnic: divide between them is rather expressed in volatile political divi-" sions and competition. It also is leading to a strong resurgence of: Baloch nationalism, which the state : of Pakistan had managed after : much efforts throughout 1970 s and early eighties.

\section{POWs praise martyrs}

\section{who carried out attack on NY}

PANJSHIR: Jailed for years since being captured fighting anti-Taliban forces in Afghanistan, volunteers have lost none of their defiance.

Pakistani Khaled Salakhudin, 27, who has spent half a decade in this remote prison in the Panjshir Valley, praised the "martyrs" who carried out the terrorist attacks last week on New York and Washington. "We cannot fight the United States face to face because we don't have the military resources. We have just one way, as terrorists, "he said, staring fixedly through his thick glasses.

The bearded young said he would have been proud to carry out the suicide plane attacks on the World Trade Center and the Pentagon, betraying no remorse for the estimated 6,000 victims.
"Those who died were specialists and professionals working with the American government. If I was ordered to go the United States to carry out such a thing, I would do it. I am not afraid of death, I want to be a martyr," he said.

Isolated in this one-storey opposition prison compound, surrounded by arid mountain landscape and far on foot from the nearest village, the 333 inmates cannot hope to escape. But the prisoners, who include 21 foreigners including Pakistanis, Chinese Uighurs and Burmese, still know what is going on in the outside world.

Salakhudin shrugged off the threat of US retaliation against Taliban-ruled Afghanistan for the termorist strikes, blamed on Saudi-born extremist Osama bin Laden. And he vowed to wage a jihad against the United States and other "infidel" countries from Western Europe to Russia and India.

"We want to make Afghanistan an Islamic state and then move into all other countries, from Central Asia to the rest of the world," Salakhudin said in a determined voice. Above, the sky thundered with the roar of Taliban warplanes which made the windows of the jail rattle furiously as they dropped bombs on a mountainside just behind.

The strategic Panjshir Valley, north of Kabul, is part of just 10 per cent of Afghan territory controlled by the opposition, which was driven out of the capital in 1996. - AFP 


\section{The Frontier Post}

Thursday, September 20, 2001

\section{Norther Alliance hails \\ former Afghan King's role}

\section{F.P. Report}

PESHAWAR: The President of ousted Afghan government, Professor Burhanuddin Rabbani welcomed any positive role for former Afghan King Muhammad Zahir Shah to end the Afghan crisis.

Abdul Sattar Murad, the ousted government envoy said in a statement that the majority of Afghan people would be pleased to see the deposed king playing a constractive role in the country.

Afghanistan, said in a statement, under conflict of 20 years, former king could help unite the country and the Afghan people, Afghan people, due to war, have become refugees in neigbouring countries.

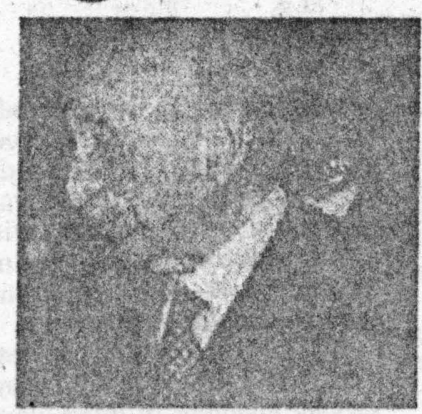

The Northern Alliance welcomes any solution to the Afghan conflict as long as it guarantees the return of peace, sovereignty and independence to the country.

Afghanistan is under threat of a military attack following the devastating terrorist assaults in the New York and the Washinton, which the US suspects were carried out by a network linked to Osama bin Laden, who is protected by the Taliban.

The ousted government envoy said the former king could assume any role that could help for permanent peace in the country. The Northern Alliance was willing to work for the setting up of a broadbased government.

Taliban opposition thinks that former King can play an active as well as important role for the country's etterment.

The former King Zahir Shah earlier. this year met with Afghan leaders in Rome for end the war and also sent representatives to the US and other countries for the same purpose.

\section{Alliance seeking involvement in war against Taliban}

KABUL (Online): The Afghan Ambassador to the United Nations indicated that the Islamic State of Afghanistan might not support a United States strike against the Taliban regime, if such a military oftensive did not involve the Rabbani government.

Afghan Ambassador A G Ravan Farhadi said while President Rabbani fully supports a collective response to the terrorist acts in New York, Washington needs to take the legitimate government of Afghanistan into confidence.

"We have 15,000 people on the ground ready to fight the Taliban," he said.

"So, this group needs to be involved," he said, adding that the Afghans know the terrain and they know the psychology of the people living there. He claimed that the notthern alliance controls many parts of the country.
"Our hold spreads to almost 25 percent of the geographical areas," he said.

However, Faradi would not clearly say if Kabul would oppose the US, in case it chose to carry out joint operations with Pakistan to nab Osama bin Laden, the prime suspect in the September 11 terror attacks. "This has to be discussed," he said.

The Afghan ambassador was clearly wary of the possible role of Pakistan, alleging that Inter Services Intelligence has been supporting and helping the Taliban and Laden.

He alleged that Pakistan has an ulterior motive in agreeing to co-operate with Washington at this stage, which, he claimed, was to get political and financial bargains from the US.

"They are saying that they would hand over bin Laden to a Islamic country, but there is no Islamic country that would agree to take bin Laden," he said. "This is just for buying time," he added.

Faradi also asked the international community to consider all aspects of terrorism in the Taliban occupied parts of Afghanistan, which 'the ISI has transformed into a hub for terrorist activities'.

H. also said, "The international community should put effective and bold pressure on Pakistan, Taliban's main backer, to immediately cease their aggression in Afghanistan and withdraw their armed personnel from Afghanistan."

Faradi also sought to draw the attention of the Security Council to the critical and dangerous situation in Afghanistan and the region.

"The International community must help us to set up a multi-ethnic, broad-based and fully representative government," he said. 


\title{
The Frontier Post
}

\author{
Thursday, September 20, 2007
}

\section{Taliban to make decisions today}

destabilise the Taliban," he said in his message. As the meeting, which was closed to the media and the public, got under way, dozens of soldiers armed with rocket-launchers and Kalashnikovs stood guard outside presidential palace.

More that 1000 Ulema from across the Afghanistan, some driving hundreds of miles along dirt roads, traveled to the capital to help the Taliban leadership make its decision.

A high-ranking Pakistani delegation met with Taliban leaders earlier this week to discuss the US demand for extradition and the Shoora meeting will decide the fate of Osama.

The United States blames bin Laden, who lives as a guest of the Taliban, as the prime suspect in last week's attacks on New York and Washington, and has vowed to punish him and his protectors. effort to harm the Taliban.

"Osama is just an excuse. And, in fact, America wants to

\section{US, NA join hands against Taliban}

KABUL (Online): Contacts between US and the Afghianistan's anti-Taliban Northern Alliance have increased to "frantic" levels, senior Alliance officials said.

The officials say over the past 24 hours, contacts with the U.S. have amplified dramatically, with the U.S. asking for information on possible targets including airports, weapons depots, military headquarters, training camps, troop positions and movements. One senior official told that the U.S. has asked the Northern Alliance -- which controls about 5 percent of Afghanistan -- to work harder, telling them that the U.S. needs more information and it needs it now.

The official, who did not wish to be named, said he believes it is only a matter of days before the U.S. launches a military offensive in Afghanistan. He added that so far, requests have only been for information although the Alliance has told the U.S. it is willing to play a large role in any military operation in Afghanistan.

\section{Taliban urged to implement UN resolutions F.P. Report}

ISLAMABAD: United Nations Security Council delivered a terse and direct message to the Taliban after holding a closed session on the political, military and humanitarian situation in Afghanistan on September 18.

"There is one and only one message the Security Council has for the Taliban: implement United Nations Security Council resolution, in particular UNSCR 1333, immediately and unconditionally," said Council President Jean David Levitte of France.

According to news release of US Embassy here Wednesday the UN Security Council resolution (UNSCR) 1333 was passed by the Security Council on December 19,2000 . It is the latest in a series of resolutions passed by the Council condemning the Taliban for sheitering and training terrorists and planning terrorist acts. It insists that the Taliban comply with the Security Council's 1999 demand that it "turn over Osaka bin Laden to appropriate authoritics in a country where he has been indicted. . or to appropriate authorities in a country where he will be arrested and effectively brought to justice. The Council also. demanded that the Taliban "act swiftly ". to close all camps where terrorists are trained within the territory under its control and confirm such closure through the United Nations.

The Council also impose a series of economic and military sanctions including closing all Taliban offices and offices of the Ariana Airlines, freezing the assets of Bin Laden and banning all flights to Afghanistan except for humanitarian purposes. 


\section{The Frontier Post}

:Thursday, September 20, 2001

\section{Indonesia fears terrorists may slip with illegal immigrants}

JAKARTA (APP): Indonesia's immigration chief warned in report Wednesday that trained terrorists could be among illegal immigrants from the Middle East who are flooding into Indonesia en route to Australia and New Zealand.

Immigration director Muhanmad Indra said tougher controls were needed to curb the thousands of mainly Afghans, Iraqis, Iranians and Pakistanis arriving in Indonesia.

"We cannot ignore the possibility that these Afghans are members of the Taliban forces or trained personnel of terrorist groups," he said.

"If we fail to handle the illegal immigrant issue properly ... the effect may be fatal io Indonesia since we could be considered a safe transit zone for terrorist groups."

He anticipated a fresh flood of illegal immigrants from Afghanistan if the US attacks that country in an attempt to capture Osama bin Laden. Most Afghans will likely run to other countries, mainly Australia, via our country, he said.

Muhammad Indra appealed to. neighbouring countries to help Indonesia build tighter quarantine and detention facilities, because so many illegal immigrants escaped from the detention centers or guest houses in which they were held.

\section{Pak must choose between US and Taliban: envoy Moscow (Online):} Washingtor. in its decisive tone, has asked Islamabad to choose between siding with Afghanistan's ruling militia and supporting U.S.-led strikes there.

The U.S. has been asking Pakistan to ensure it gets Saudi renegade Osama bin Laden -- a man President George W. Bush wants "dead or alive" for his alleged role in terrorist strikes last week. He currently lives in Afghanistan.

U.S. Ambassador Alexander Vershbow in an interview to the state-controlled RTR TV channel bas said it is time for Pakistan to take a clear stand on whether to side with the U.S. plan to launch military action against Afghanistan or the ruling Taliban militia in Kabul.

Earlier, Pakistan, left with limited choices, had declared support to U.S. military action against Kabul.

The U.S. envoy's comment came on the heels of Pakistan's representative here saying his country's delegation had gone to Kandahar to discuss the seriousness of the emerging crisis arising out of terrorist attacks on U.S. cities and not to convince the Taliban to hand over bin Laden to the US.

\section{Taliban orders CNN to leave Afghanistan F.P. Report}

ISLAMABAD. Taliban militia Wednesday ordered the crew members of the well-known news channel, Cable News Network (CNN) to leave Afghanistan with immediate effect, informed sources privy 0 the situation.

American based news channel that was reporting round. the-clock from the Taliban territory since the announcement by the Americans to go after Saudi dissident Osama Bin Ladin declaring him as the prime suspect of mass destruction in Washington and New York on September 11.

The exact reasons were not accounted by the Taliban who are fearing a foreign invasion shorlly after their refusal to extradite their 'state guest' Osama to America against the allegation of terrorism but sources say they were annoyed with the way the American channel was portraying things around them. 


\section{$K_{\text {HYBER }} M_{\text {AIL }}$}

Thursday, September 20, 2001

\section{Taliban have enough}

\section{weapons to fight for a decade: Moin}

DUBAI (Agencies): Interior Minister Moinuddin Haider has said that Taliban has enough weapons to fight for a decade emphasising that Pakistan has no leverage with the Taliban and the US should deal with them directly.

He said, while talking to Khaleej Times, Islamabad had no influence on the Taliban contrary to popular perception in the West and in fact, the two differed on many international issues.

"We told them not to train any Pakistan national in their camps...even then, (during the Buddha statue episode) we tried to knock some sense into the mindset

but we could not succeed," he said.

He also denied the West's common perception that Pakistan was in any way involved in arming and financially supporting the Taliban, "As far as weapons are concerned, this is my strong belief that they (the Taliban) have enough weapons to fight for 10 years. The booty from the Soviet leftovers is that strong."

\section{The Nation}

SEPTEMBER 20, 2001

\section{....Attacks against Afghanistan pre-planned: Niaz}

ISLAMABAD (NNI): A Former Foreign Secretary of has claimed that the United - States was planning to take punitive action against Osama bin Laden and the Taliban before last week's attacks on New York and Washington.

He told $B B C$ that the senior American diplomats had talked of such an action during his meeting with them in Berlin a couple of months ago. "We usually meet in Berlin.

This was the third session which was held from the 17 th to the 2nd of July and in that meeting I think the American participants, there was American Ambassador Simon, Former Ambassador over here Karl Inderfurth, former senior oflicials and they had indicated to us that in case the Taliban.

\section{Stern US warning to Kabul}

WASHINGTON (AFP) - The White House sternly warned Afghanistan's ruling Taliban militia Wednesday, saying 'it is now time to act, not to negotiate' over handing over Osama bin Laden.

Afghanistan must 'take the action necessary to no longer harbour terrorists,' said Ári Fleischer, spokesman for US President George W. Bush.

The warning came as Afghanistan's Taliban signalled in Kabul it would sooner face a massive military onslaught than surrender Osama.

US Defence Secretary Donald Rumsfeld emphasised that the US campaign against terrorism will not be confined to Osama and his al-Qaeda network.

'It is a problem of a number of networks of terrorists that have been active across the globe, and it is something that strikes at the very heart of what Americans are, which is a tree people,' he said on CNN.

\section{Mujahideen to get second chance: Taliban minister}

KABUL (AFP) - Islamic fighters who missed the war of liberation against the Soviet Union will get a second chance against the United States, an Afghan Taliban minister has said.

Said Jalaluddin Haqani, the borders minister in the fundamentalist Islamic regime and veteran of the war against the 1979-89 Soviet occupation of Afghanistan, warned Washington faced the same fate as Moscow. 'By means of Jehad (holy war) we were able to liberate our country and now we know about its benefits,' Jalaluddin said late Tuesday in remarks broadcast over Taliban-run Radio Shariat.

'I think this could be a very good chance for those Afghans tho missed the opportunity of Jehad against the Soviets. 'I urge all those Afghans who are inside the country or abroad to participate in Jehad if the US attacks Afghanistan.' Afghanistan is the base of Saudi extremist Osama bin Laden, the chief suspect for the devastating September 11 attacks against New York and Washington which killed thousands of people. But the Taliban minister said the United States should look to its own lax security before casting blame for the strikes against the World Trade Center and the Pentagon.

'The US is in charge of its own security, nobody else. When it fails to ensure its own security, it blames Muslims and Osama for that. 'All of these are pretexts and anti-Jslamic policies,' Jalaluddin said, adding: 'Allah is always pleased with mujahideen (Islamic fighters).' Bin Laden is believed to have been instrumental in organising Muslim volunteers from around the world to fight against the Soviet Union, which eventually pulled out of Afghanistan with heavy losses. 


\section{Chamberlin \\ assures aid to Afghan refugees}

\section{By Cilocia Zaidi}

ISL AMABAD - US Ambassador to Pakistan Wendy Chamberlin called on Federal Minister of KANA and SAFRON Abbas Sarfara: Khan here on Wednesday and discussed various matters re. lating to A tighan refugees and their ansistance.

The minister informed the ambassador that the policy of the Pathistan govermment on movement accross Path-Afghan border is still the same. He satid that Pathistan is already shouldering the burden of ahou 3 million Afghan retigees derpite severe economic constraints.

The minister said, however the government is preparing contingency plans to meet any challenge. The government, he said, is evallating the situation carefully and all possibilities atre being considered in case of emergency in $\mathrm{Af}$. ghanistan. The plan would be ready within next couple of days. Sarfaraz added.

The minister also appreciated the assistance and cooperation provided by the United States to the religees on humanitarian grounds, and hoped that assistance would continue for the refugees in the coming days.

The is ambassador, while talking (1) the minister, satid that the linited States is the single largest country, providing find and linancial assistance to Afghanistan and Aghan refugees since long. She assured that the United States would extend an uninterrupted humanitarian assistance to the refugees. Wendy Chamberlin also said that the United States is not against the Afghan people. but it i) a light against terrorism. The l's would make all out efforts to resolve the problems of the Afghan refugees in this respect, she added.

\section{Kashmiris watching Afghan situation}

SRINAGAR (NNI) - The recent attacks in America and their fallout on Pakistan and Afghimistan is bound to alfect the security sitvation in Hold Kashmir.

'The attacks came as a surprise for the common people here. The Mujahideen, security forces, and the state government were equal. ly puzzled, reports Kóshmir Times.

The All Parties Hurriyat Conference lost no time in describing the incidents as worst kind of terrorism. It strongly condermned the innocent killings and expressed sympathics with the bereared families.

Most people believed that killing of people in USA was the outcome of the wrong and anti-Muslim foreign policy of that country. According to them America is directly involved whatever is happening in Palestine, Iray and other Muslim areas.

The large scale killings in Kashmir have made a number of people insensitive towards stu h incidents in other parts of the world." We have been witnessing the killings for last 11 years. We have lost over $70 .(K K)$ thousand people and the killings continue unabaled. No serious affort was made to solve the Kashmir issue. The entire world including the USA and Is-

lamic block seemed least hothered about the plight of Kastmiri people", said Irshad Ahmad a businessmath.

The security authorities were really concerned when the news about the attacks in America reached here. They belicesed that the incidents would boost up the morale of the Mujahideen in Kashmir also and they might strike on a large scale.

However, the security officials heaved a sigh of relief as Pakistan started sticcumbing to US pressure and agreed to help America in launching an attack on Osama Bin Laden and Taliban in Afghanistan.

Pakistan's request to USA to help in solving the Kashmir issuc could not generatic much enthusi- asm here. "In past America assured a number of times to help in finding a solution of the issue. But the assurances were never given a practical shape", said Mohammad Alam. America looks like a shattered country atter the recent attacks. Its image as the most powerful country stands tarnished. When it miscrably failed to protect its own citizens, how can it suggest a solution against the wishes of government of India, said Ali Mohammad a linit seller.

\section{US battleships not heading for Pakistan}

\section{By Our Staff Reporter}

ISLAMABAD - Pakistan Wednesday said the Us battle. ships were not heading for Pakistan as it was toc early to go into such specifics in the absence of an 'operational plan.'

"There is no government to government contact," Rashid Qureshi, the Director General Inter Services Public Relations, told The Nation when asked to comment on the reports that US had moved its battleships in the Culf and Arubian Sea.

"So far they are not coming in here," Qureshi said. He said the movement of these battleships was not towards Pakistan but the US might be gathering its coalition forces as it did before the Gulf War.

The US has its military bases in Saudi Arabia and Kuwait. Media reports, quoting IS Defence Secretary Colin Powell, said the US had moved at least three of its battleships to unknown destination to initiate its fight against terrorism.

Following the bombing in New York and Washington, the US has given an ultimatum to Talbain governnent of Afghanistan to hand over Os. uma bin Laden, who is teh prime suspect in these terrorist activities. Taliban are refusing to turn over Osamn unless credible evidence is produced. 


\section{THE PAKISTAN TIMES}

Thursday, September 20, 2001

\section{US and Russia engage in Central Asia tug of war}

TASHKENT: A tussle for influence was raging in Central Asian republics neighboring Afghanistan on Wednesday as regional regimes chose between keeping in line with their old mentor Moscow or assisting US punitive strikes on Afghanistan.

The three former Soviet republics of Uzbekistan, Tajikistan and Turkmenistan are emerging as potential frontline states in any US attempt to retaliate against the prime suspect in last week's attacks, Osama bin Laden, who is hiding in southern Afghanistan.

Resolutely opposed to granting US access to former Soviet bases in the energy-resource rich region, Moscow this week sent a top security envoy and the army chief-ofstaff on a diplomatic tour aimed at keeping the three republics dubbed by Russia as the "nearabroad" - in line. The United States has alsp stepped up contacts with the isolated states. Most regional powers here appear to feel they have something to gain from a US anti-terrorist assault in a region that has been the subject of Islamic guerrilla attacks in August 1999 and 2000.

But the mainly Muslim and mostly secular former Soviet republics are also wary of possible retaliation by the Taliban, or from Islamic rebels inside their own states.

"If they allow bases to be used by the US, they may turn from a presently small target to a big target and they will want to know that they have the backing of a big country," said Christopher Langton, an analyst with the International Institute for Stralegic Studies.

Russia, itself ruling out participation in any reprisal attack, is expressing deep concern about future stability in Central Asia, where it is competing with Western companies over control of oil and gas fields and pipelines. "The situation in Central Asia was never easy, in terms the fight against international terrorism ... and the events of September 11 naturally concerns the president of Russia," said Russian Security Council chief Vladimir Rushailo.

Central Asian leaders further fear that US strikes on Afghanistan could release a massive flow of refugees, bringing Islamic rebels, weapons and drugs with them. Of the three republics only Uzbekistan, which shares a 170-kilometre border with Afghanistan, has indicated that it might open up its territory for use by the United States, if requested.

With the largest military presence in Central Asia, analysts suggest Uzbekistan may be powerful enough to repel Moscow's pressure and side with the United States. Relying on a 7,000-strong Russian peacekeeping force and another 11,000 Russian troops protecting its border with Afghanistan. Tajikistan has appeared to reject the idea of assisting the United States. - By special arrangement
Rally to support Afghan women's Olympic participation in doubt

PARIS: A decision on whether a rally to encourage Afghan participation in the 2004 Olympics Games will go ahcad in Paris on October 7 will be made shortly, French sports minister MarieGeorge Buffet said Wednesday.

Buffet said that at present the event was going ahead is planned but that because of the intemational situation a decision would be made after consultation with Interior Minister Daniel Vaillant.

"There have been many calls for solidarity with Afghan women. An initiative is needed. But I will follow the situation to ensure that this is not hijacked by issues other than that for which it was initially intended," said Buffet.

"October 7 is a stage in this process not a culmination," said Buffet.

Algeria's Hassiba Boulmerka, who won a 1,500-metre gold medal at the 1992 Barcelona Games, sent a message of support and said that she hoped to be present on October 7.

After her Olympic victory, Boulmerka received threats from Islamic fundamentalists for baring her legs.

The Afghanistan National Olympic Committee was suspended by the International Olympic Committee (IOC) in 1999 because it was judged not to be in control of sport in the country.-AFP 


\section{Former president for UNSC meeting}

INITED NATIONS: Forner president of Afghanistan Burhanuddin Rabbani called for all urgent United Nations Serurity Council (bSC) meeting to disenss what he said was a Pakistani military presence in Afghanistan.

"We earnestly propose the conveuing of a special meeting of the Security Councli to address the presence of foreign military and armed personnel in Afghinistan," Rabbani wrote in a letter to UN Secretary General Kofi Annan and the president of the council.

Rabbani's government, ousted in 1996 by findamentalist Tadiban militias, still tises the Afghani mission to the United Nations, thougt its Nurthern Alliance resistance forces control less than 10 per cent of the country.
"A resolution specifically asking Pakistan to withdraw its armed nationals ... needs to be adopted," Rabbani said in the letter. He said the resolution also should call on Pakistan to stop supporting Islamic extremist groups in Afghanistan.

Af ghan opposition forces claim that Prakistan has in the past sent several thousand people to fight alongside the Tatiban in the war ravaged country.

Pakistan, the main backer of the Taliban, has promised to fully support the United States in its quest to obtain the extradition of Osama bin Laden, named as the primary suspect in the September 11 terrorist attacks on Washing. ton and New York that killed close to 6,000 people. - AFP

\section{Aid workers fate raises concern as war looms}

TEXAS: With the threat of IS military strikes looming in Afghanistan in retaliation for the terror strikes on New York and Washington, friends and family menibers of two Anerican women teing held there are expressing growing fears about the plight of their loved ones.

He:ather Mercer. 24, and Dayna Curry, 29, were arrested six weeks ago along with six other westerners and 16 Afghars on charges: of spreading Christianty in the devoutly Istamic comitry:

The two wonnen were members of the Antioch Commenity Church in Waco. Pastor Jimmy Sribert, ufo is organizing praver vigils and finaticial aid drives to holp the women, said he fears they will become "human shields" in the event of a US attack in retaliation for the September 11 kamikaze strikes. "Our prayer is that, no they wont be," Seibert sait. "But I thuik it's a valid concern for all of us."

In a telephone intervew from Islamalad, Nancy Cassoll, Curry's mother, sud the fanily stayed quiet before last week's terror attacks because they feared it might jeopardize the nomen's case as they face trial before Muslim clerics in Afghanistan. Now she fears the women are being forgotten. "That's why we've gone $u$, the press a bitule more now, so they won't be forgot. ten," Cassell said. "Our problem becomes very smull in the midst of what is happening in the United States." "It's almost like it's going to take a miracle to get them out of thert," she added.

Afghanistan's ruling Taliban Wednesday signaled it was prepared to face a US attack rather than hasul over Saudi-born militant Osama bin Laden, whom Washington regards as thie prime suspect in the terror strikes. As more than 600 clerics from all over Afghanistan began considering bin Laden's fate, the Islamic militia's supreme leader Mullah Motkammad Omar said bin Laden would not be extradited without clear evidence and dismissed US allegations against the Saudi-born militant as a pretext 6 wage war on Islam.

Curry had been in Afghauistan for nearly $(w)$ years, and Mercer joined her last March. Both had been sent as aid workers for the Cerman-based Shelter Now International group. Also being held are two Alstradians, Diana Thomas and Peter Bunch, and four Germans. AF?'

\section{Iran in diplomatic drive to avoid Afghan war}

TEHRAN: Iran has launched a diplomatic drive to try to head off US military strikes against neighbouring Afghanistan fearing they would lead to humanitarian catastrophe and a hardening of Islamic opinion against the West.

Foreign Minister Kamal Kharrazi telephoned European Union foreign policy chief Javier Solana and the foreign ministers of Italy, Pakistan, India and current EU presidency holders Belgium to press the point, the IRNA news agency said on Thursday.

"Any retaliatory action against Afghanistan would lead to the massacre of more innocent people and leave many homeless," the official agency quoted Kharrazi as telling his Italian counter. part Rertato Ruggiero.

Iranian President Mohammad Khatami reacted quickly to condenin last week's suicide attacks in New York and Washing. ton, a response the United States described as "worth exploring".

"The terrorists must be tracked down and severely punished," Kharrazi told Pakistan's Foreign Minister Abdul Sattar. But Iran has also called for caution in responding to last week's deadly attacks.

The United States has accused Afghanistan's ruling Tal. iban of harbouring Saudi-born Osama bin Laden, who the White Ilouse says is the prime suspect in the attacks. With some two million Afghan refugees already inside the country, Iran has ordered troops to seal its $900 \cdot \mathrm{km}$ eastern border with Afghanistan.

Though vehemently opposed to what it regards as the primitive interpretation of Islam put forward by the Sunni Taliban, Shi'ite Iran would be loath to see fellow Mustims suffer at the hands of a Western power.

"Military action that can result in a human tragedy will leave a negative impaci on pub. lic opinion and the Islamic countries," Kharrazi told Ruggiero. He gave similar messages to the other ministers he contacted. - Reuters 


\section{Law, order become worse in Kabul}

KABUL: Amid signs the United States may be preparing to strike Afghanistan, law and order began to break down in Kabul with residents on Thursday reporting armed daylight robberies, looting and shooting.

The slide towards lawlessness came as a council of Afghanistan's leading clerics met for a second day to decide the fate of the world's most wanted man, Osama bin Laden, after a warning from their leader that the United States was bent on the Taliban's destruction.

"There is a sharp rise in thefts," said one resident who was robbed in his home at gunpoint. Crime in Kabul, a city once known for its streets lined with roses but pounded almost to rubble by factional fighting in the $1990 \mathrm{~s}$, is home to the poorest of Afghanistan's 20 million people.

The capture of the capital by the hardline Taliban in 1996 marked the return of law and order as the purist movement imposed its Islamic system of government.

Many of the new attacks were carried out by looters posing as members of the Taliban's feared religious police. "Mainly men carrying arms are entering people's homes under the guise of checking to see if they have arms or are watching a movie or listening to music," said one resident who declined to be identified.

"The owner of the house lets them in because he has nothing to hide. Then he and the rest of the male family members are rounded up and women are forced to hand them over cash or jewellery," he said.

The Taliban religious police keeps a tight leash on public behaviour strictly enforcing rules that require men not to trim their beards and to wear tra. ditional loose Islamic dress, ban movies and music and forcing women always to wear burqa that covers them from head to toe.

Another resident said his neighbour's house was looted by six armed men on Tuesday. "At around nopn, a car with at least six armed men parked outside our neighbour's house, but we thought they were probably relatives," the resident said.

"There was a big shout after the robbers' car disappeared and my neighbour said they took all their valuables. We could not have helped them even if we knew that the men were thieves because they were armed," he said.

There was no immediate comment from the Taliban, whose shura, or council, was meeting in Kabul to decide the fate of Osama bin Laden and how to respond to the threat posed by the United States attacks.

"I have lost everything. We don't know what sort of security the Taliban are saying they have brought to the city and what will happen if there is a strike," said one frightened man.

The Taliban, in their drive to conquer a country ravaged by more than two decades of war, have disarmed the population and banned guns except those held by their own security personnel.

In one attempted robber, Tal. iban security guards opened fire on a gang of thieves as they tried to enter one house, forcing them to flee, a witness said.

Residents said law and order appeared to be deteriorating rapidly in the city from which thousands have fled fearing the US strikes.

The US has vowed to hunt down bin Laden - who lives as a "guest" of the Taliban - and to punish his protectors. The Saudi-born dissident is the chief suspect in last week's suicide attacks on Washington and New York that killed nearly 6,000 people. Reuters

\section{Tajik president inspects border with Afghanistan}

DUSHANBE, Tajikistan: The chief of Russia's Security Council and the president of Tajikistan new to the impoverished former Soviet republic's frontier with Afghanistan on Thursday to assess the combat-readiness of Russian border guards there following the terrorist attacks in the United States.

As discussion of US retaliation for the attacks focuses on Afghanistan - where the main suspect in the attacks, Osama bin Laden, has sheltered neighboring Tajlkistan is bracing for tens of thousands of refugees to rush the border.

Vladimir Rushailo, the secretary of the Kremlin's Security Council, and Tajik President Emomali Rakhmonov flew to the border with Col Gen Nikolai Reznichenko, the chief of staff of the Russian border service.

A 25,000-strong Russian force patrols Tajikistan's border because after years of civil war, the impoverished former So. viet republic is too weak to guard it.

Just beyond the burder, fighting between Afghanistan's ruling Taliban militia and the northernbased opposition alliance, has intensified in the past two days.

Russian President Vladimir Putin dispatched Rushailo on a tour of Central Asian nations on Wednesday. Several of them could serve as a convenient launch-pad for strikes against Afghanistan, though Moscow has indicated it would not welcome such a move.

On Wednesday, Rushailo met with Rakhmonov. He said they discussed details of possible cooperation "in case the situation becomes tense." Gen Anatoly Kvashnin, the head of Russia's General Staff, was also in Tajikistan, reviewing the combatreadiness of the 201 st Motorized Rifle Division, which is based there. - AP 


\section{Shura asks Osama to leave voluntarily \\ Says jihad must if Afghanistan attacked; expresses sorrow over deaths in US; urges UN, OIC to probe incident}

\section{Rahimullah Yusufzal}

PESHAWAR: In a calculated move, Afghanistan's Ulema Council on Thursday recommended to the ruling Taliban to ask Osama bin Laden to leave the country voluntarily.

After its two-day deliberations in Kabul, the council also resolved that jehad should be declared in case the US attacks Afghanistan.

The much-awaited decisions of the council, attended by clerics from all over Afghanistan, were announced at a press conference in the Afghan capital. Some of the decisions were referred to as a Fatwa, or religious decree.

The council was convened by Taliban supreme leader Mulla Mohammad Omar to offer him advice on how to tackle the bin Laden issue. It was also required to guide the Taliban-led government whether declaration of jehad would be justified in case the US launches an attack on Afghanistan.

Afghanistan's official Bakhtar News Ageney reported that the Gouneil didn't specify any deadline by which bid Laden was required to get out of the country. The council felt bin Laden should find another sanctuary for himself in a bid to find a solution to the present crisis and avoid similar situations in future.

Concerning the threatened US attack on Afghanistan, the council guoted a number of verses from the Holy Quran to highlight the significance of jehad. It resolved that it was incumbent on every Muslim to take part in the jehad once an Islamic territory has been pittacked.

One of the council's resolutions expressed sorrow over the pttacks in Washington and New

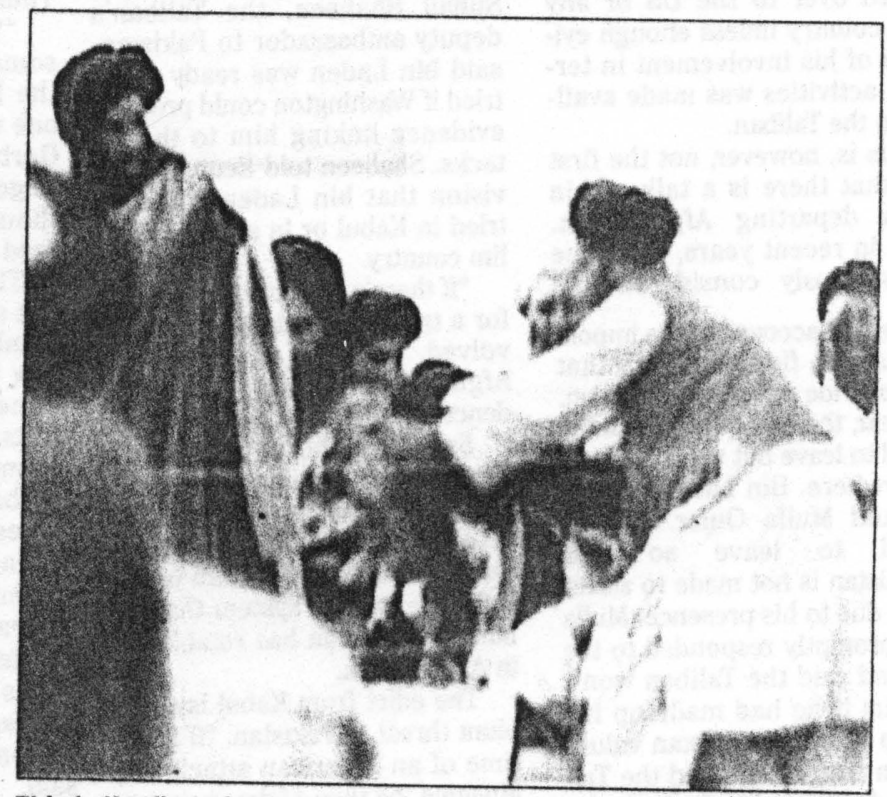

This is the first picture of Mulla Mohammad Omar (extreme left), Taliban leader. The picture was taken secretly by BBC2's Newsnight five years ago in Kandahar.-AFP (Related photos on Page 11)

York and sympathized with the affectees. It called for patience on the part of the US until the investigations were complete and those who sponsored the attacks were exposed. Instead of rushing to judgement, the council hoped the culprits rather than innocent people would be punished.

Through another resolution, the council asked the United $\mathrm{Na}$ tions (UN) and the Organization of Islamic Conference (OIC) to conduct independent investigaitions into the acts of terrorism feommitted in the US to find out the real culprits so that innocent people aren't made to suffer.

The council's fifth resolution asked the UN and the OIC to take notice of the term "crusades" used by US President George W Bush in one of his statements and felt it had provoked the Muslims and threatened world peace.

The council noted that the Ulema had always offered sacrifices for the glory of Islam and the homeland and that is why they were approached by the Taliban to deliver Fatwa and give decisions on certain issues arising out of the US threat to attack Afghanistan.

The council's recommendations were expected to be ratified by Mulla Omar and made the official Taliban policy. They may also be conveyed to the Pakistan government, which a few days ago dispatched senior officials of its foreign ministry and Inter-Services Intelligence (ISI) to Afghanistan to persuade Mulla Omar to give up bin Laden to avoid a US attack. Islamabad was supposed to pass on the information to the US government, which 
The News International, Friday, September 21, 2001

has already rejected the Ulema Council's decision and reiterated its demand that bin Laden be ex. pelled from Afghanistan.

The council made no mention of the lack of evidence regarding bin Laden's involvement in acts of terrorism. This point was highlighted in a message sent by Mulla Omar, who is based in Kandahar, to the council and was repeatedly stressed by most Ulema who spoke during the proceedings. Mulla Omar in his message made it clear that bin Laden won't be handed over to the US or any other country unless enough evidence of his involvement in terrorist activities was made avajlable to the Taliban.

This is, however, not the first time that there is a talk of bin Laden departing Afghanistan. Twice in recent years, the issue was seriously considered and

dropped on account of the impossible task to find a country that could provide refuge to bin Laden. Last year, the Saudirborn Islamist offered to leave but was unable to go anywhere. Bin Laden reportedly told Mulla Omar that he wanted to leave so that Afghanistan is not made to suffer further due to his presence. Mulla Omar promptly responded to the offer and said the Taliban won't stop him if he had made up his mind to leave Afghanistan voluntarily. In fact, he ordered the Taliban to facilitate bin Laden's departure. On that occasion, Mulla Omar made it clear that the Taliban would continue to treat bin Laden as a guest and protect him if he was unable to find another sanctuary.

For a while last year, Chechnya was listed as a likely bin Laden destination once he left Afghanistan. But Russia's second invasion of Chechnya in August 2000 to avenge a previous military defeat at the hands of Chechen guerrillas made it almost impossible for bin Laden to safely travel to the rebel republic. The option of bin Laden disguising himself to reach Chechnya was also considered and found unsafe. The Chechen guerrillas led by Shamil Basayev and Khattab, who is of Jordanian origin, had earlier invited bin Laden to come to Chechnya and be their guest.
As in the past, it appears that the Taliban move to ask bin Laden to leave Afghanistan voluntarily won't materialize because no country or government would be able to provide him refuge.

Meanwhile, Taliban officials in different parts of Afghanistan have been claiming that bin Laden was untraceable since the past two days. They said even the Tal-

iban leadership was unaware of his whereabouts.

Reuters adds: In Islamabad, Suhail Shaheen, the Taliban's deputy ambassador to Pakistan, said bin Laden was ready to be tried if Washington could produce evidence linking him to the attacks. Shaheen told Reuters Television that bin Laden could be tried in Kabul or in another Mus. lim country.

"If there's evidence, he is ready for a trial." "He said 'I am not involved, I am a guest (in Afghanistan). If they have evidence, I am ready"," Shaheen said. Speaking shortly before the edict was issued, Shaheen charged that Washington was not providing proof implicating bin Laden because its real aim was to fight the Islamic system that the hard-line Taliban has established in Afghanistan.

The edict from Kabul issued a blunt threat to Pakistan. "If in the time of an American attack, any Muslims, be they Afghans or nonAfghans; cooperate with the infidels, accomplices or spy, that person also is punishable to death like the foreign invaders," it said, adding such enemies also faced holy war.

"What's the use of sending a $\$ 2$ million missile into a $\$ 10$ tent to hit a camel in the butt?" Bush said in private talks with members of Congress last week, according to aides.

Some of Washington's allies have sounded notes of caution. - Saudi Foreign Minister Saud al- Faisal, representing a nation which could prove crucial to any U.S. drive for Arab support, said the focus should be on justice. "We can't fight terrorism by being vengeful," the minister said in Washington.

\section{Mikhail Gorbachev warns against rash Afghanistan moves}

BERLIN: Former Soviet leader Mikhail Gorbachev, who ended Moscow's nine-year military intervention in Afghanistan, called for caution in response to the attacks on the World Trade Centre in an interview published on Thursday.

"When' one finds out that some terrorists studied in the Harburg area of Hamburg one would not bomb Hamburg," Gorbachev told the Frankfurter Allgemeine newspaper. "We shouldn't lose our heads. We need a dialogue with Islam." ."

The United States suspects that three students at Germany's Hamburg Technical University flew three of the four hijacked planes used in last week's attacks.

Former Soviet leader Mikhail Gorbachev withdrew' Soviet forces from Afghanistation 1988, ending a conflict that started at the end of 1979 and resulted in at least 13,000 Soviet Unions deaths.

"This war was not only a trauma for us, it taught us an important lesson," the last Soviet leader said.

"How can one wage a conventional war in this mountainous country? By again introducing tanks and bombing cities? By sending in soldiers to bring areas under control? I cannot imagine this." - Reuters 


\section{Washington rejects Afghan ulema decision}

WASHNGTON: The United States rejected on Thursday a recommendation by Afghan clerics that Osama bin Laden be allowed to leave Afghanistan, saying the prime suspect in last week's attacks must be turned over to authorities.

The White House laid out its stance as President George W. Bush consulted top officials from key US allies Saudi Arabia and Britain and prepared to make a national spesech on Thursiay night to make his case for a long campaign against terrorism.

Separately, an Afghan official said the country's ruling Taliban movement, which has kept bin Laden as its "guest" for yeurs, was likely to accept their ruling and asked for new talks with the United States on the issue.

"It does not meet America's requirements," White House spokesman Ari Fleischer bluntly fold reporters. "This is about much more than one man being

allowed to leave voluntarily, presumably, from one safe hartour to another safe harbour. "It is time for action, not words," he added, echoing previous ts statements. "The president has demanded that key figures of the al Qaeda terrorist organization, meluding Osama bin Laden, be turned over to re. sponsille authorities and that the Taliban close terrorist camps in Afghanistan, and the United States stands behind those demands."

A US official who asked not to be named dismissed the Taliban's response, saying: "The Taliban have to understand how serious this is and their responsibilities to the free world."

Bush was scheduled to give an address to a joint session of Congress on Thursday night to urge Americans to be vigilant and patient as the United States prepares to strike the first blow in a war on terrorism.
Working to form a global coalition against the threat, the US president was also due to meet British Prime Minister Tony Blair on Thursday as well as the Saudi foreign minister, Prince Saud alFaisal. Blair has pledged Britain will stand "shoulder to shoulder" with the United States, while Suudi Arabia has offered support and cooperation with its key ally but has not given details.

After meeting Bush in the Oval Office, Prince Saud told reporters that his country would do "everything that is within our capacity to fight this scourge of terrorism." "We're still hopeful that Taliban will accept the wis. dom of handing over criminals to face justice," he said.

"A lot of our citizens have got a lot of questions about what has taken place on Sept. 11 and subsequent to that, and I owe it to the country to give an explana. tion," Bush told reporters on Wednesday.

Fleischer said Bush's 9 p.m. EDT (0100 GMT Friday) speech would last no less than half an hour, assuming some applause from the lawmakers, and he would not announce military action. "The president will talk about how this is a hattle that is between freedom and fear, and that freedom will prevail," Fleischer said, adding that Bush would try to prepare the nation for a long campaign. "He is not going to be pinpointing military actions or discussing military options," he added. "The president will also sound a note of patience to the American people."

In one sign of Washington's continuing security concerns since the coordinated attacks by knife-wielding hijackers who commandeered four civilian aircraft, Vice President Dick Cheney will not attend the speech in Congress. In addition, a "designated survivor" from the Cabinet will be kept at a secure loca- tion.

Hope that survivors would yet be pulled from the remains of New York's World Trade Center was all but extinguished Thursday, more than a week after the last survivor was dragged from the rubble.

New York Mayor Rudolph Giuliani has warned that the chances of finding survivors are "very, very small," as the feared death toll from the carnage crept up to neariy 6,000. For some of those fearing the worst for loved ones reported missing after the September 11 attacks there was relief, as one by one, more and more dazed and decply shocked people telephoned triends and family to say they were safe. But for thousands of others, the chance that bodies of relatives would ever be recovered looked dim as emergency workers at the site where the WTC once stood had still recovered only 233 victims after more than a week of non-stop efforts.

President George W. Bush was to call for patience Thursday from Americans burning to avenge last week's terror strikes on New York and Washington and seek to stee! them for a marathon global campaign against terrorism.

Officials said he would not seek a formal declaration of war in his $9 \mathrm{pm}$ (0100 GMT) televised speech to a joint session of Congress, even as US Army units were ordered overseas and other US forces repositioned ahead of expected retaliation.

"He's going to talk about the need for patience and that this is going to be a long, sustained campaign," but a discussion of military options "is not in the cards," said Bush spokesman Ari Fleischer.

A Middle Eastern man on the FBI list of people wanted for questioning in the terrorism investigation was captured outside Chicago, the FBI said Thursday.

Nabil Al-Maraht, 31, was ar- 
The News International, Friday, September 21, 2001

rested Wednesday night in suburban Justice by police and FBI agents, FBI spokeswoman Mary Muha said. She said he was being held on a warrant issued in

Boston in March for assault with a knife.

Federal agents had been looking for him since at least Monday. That day, they raided a Detroit house with Al-Marabh's name on the mailbox and arrested three men after discovering false visas, passports and other identification, as well as what appeared to be a diagram. of an airport flight line. The FBI list that Al-Marabh is on includes suspects, potential associates of the suspects, and potential witnesses related to the attacks, the FBI said.

While agents were in Detroit on Monday, Al-Marabh was in Three Oaks, in the southwestern corner of Michigan near the Indiana state line, getting a duplicate driver's license, state authorities said. The FBI said details of his capture were not immediately available.

Britain said on Thursday that proposals by Afghan clerics that Saudi-born dissident Osama bin Laden leave their country voluntarily would not satisfy an international campaign to crack down on militants.

A senior British Foreign Office source said a US-led coalition emerging from last week's devastating attacks in New York and Washington aimed to eliminate the ability of both bin Laden and his al-Qaeda organisation "to commit further atrocities of this kind".

"One person is very important in all this, but it's not about one person by any means," sajd the source, speaking a few hours before British Prime Minister Tony Blair met US President George W. Bush in Washington.

"It's about a large organisation...That has to be the test. It's not about one person's head on a plate," he added. -Agencies

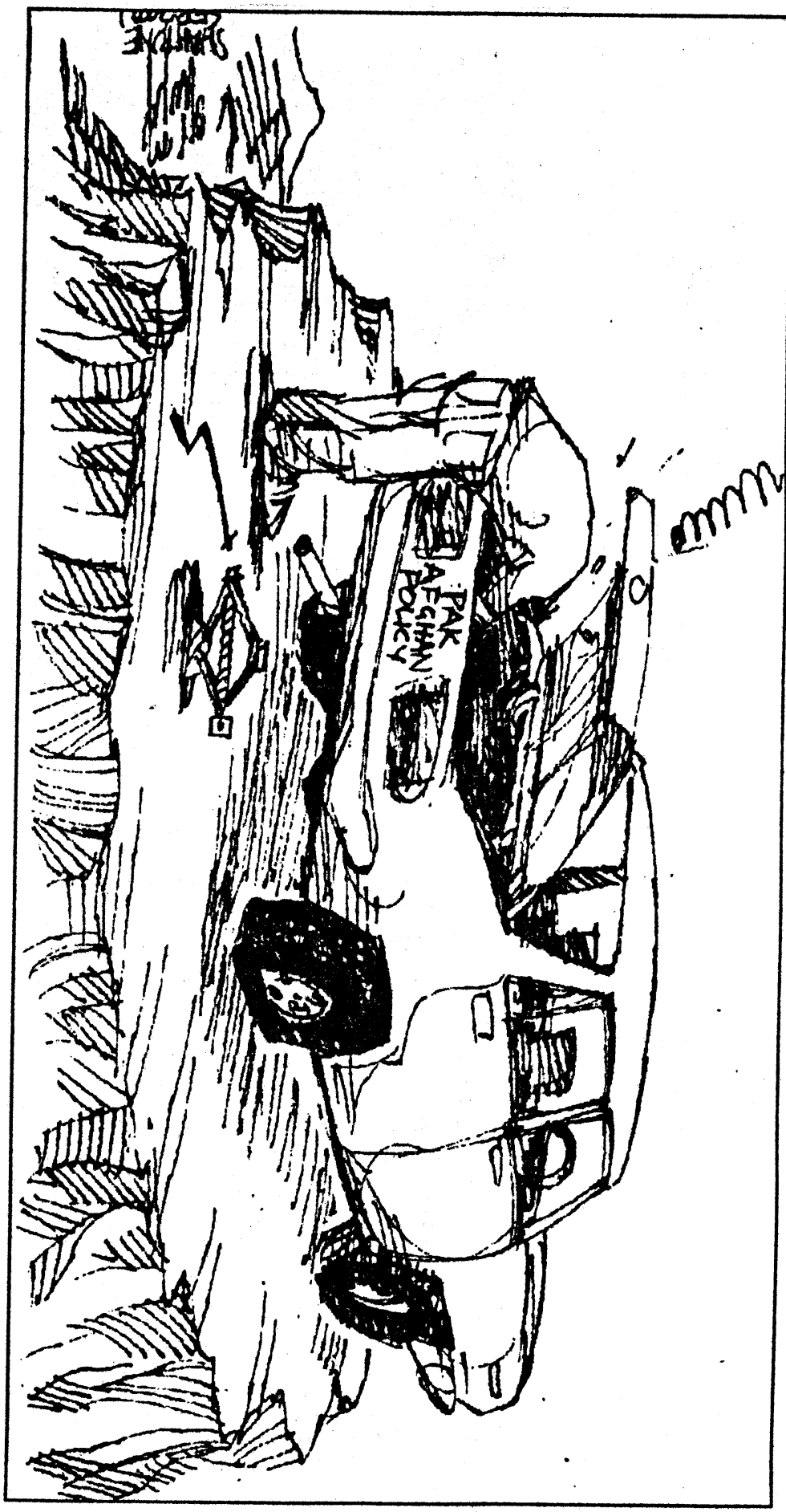




\section{Taliban approve war music as Afghans ready to face US threat}

\section{Quraysh Khattak}

PESHAWAR: The Taliban government in Afghanistan for the first time allowed the traditional war music "daff" (hand drum beating) as Afghans are flexing their muscles to defend their motherland against possible US attack while common people are varating cities and shifting to safer places.

Glulam Gul, a truck driver, in an interview with The News at Michini Post, some four kilomeins from Torkhain, said Thursday that Kabul, the capital of Afghanistan, was almost deserted and people were shifting to far-flung and safer places from Jalalabad.

He said there were Afghans at the Torkham Gate: Afghan authorities were not allowing people to come near border, he added. Pakistan government banned entry of Afghans on Monday and thousands of Afghans who wanted to flee the possible attacks were stranded on the other side of the border. The adventurous among them opted to cross the Durand Line through hundreds of unguarded points and continued pouring into Pakistan despite a strict security check at the border.

Gul, who drove a fruit truck from Kabul on Wednesday night and reached Michui Post Thursday afternoon, said the Taliban were deploying troops at strategic places throughout the country.

"Every where they (Taliban) have deployed canons and heavy guns," he said.

However, another trucker Waris Khan contradicted the re. ports and claimed that all was okay inside the war-ravaged country. He said every Afghan irrespective of age and health was ready to offer the sacrifice of his life for the defence of the country. "My sixty-five-year old grandfather is determined to join
Jihad (holy war)," he said. As a young and healthy Alghan how could I shirk from fighting, he added.

Elders at the Nasir Bagh Refugee Camp near Peshawar urged the Us not to attack their country. "Afghanistan is a barren country and there is no! a single civil or military installation worth the price of a cruise missile," Owais, a refugee opined. He said the country was alreaty in ruins and the lis would create a very serious threat to its own security if it engages itsell in Afghanistan.

Malik, 65, said the Americans should first prove Osama's involvement in terrorism and then talk of attacks on Afghanistan.

He said Afghans liar a systen of justice and Osama would be tried for his alleged crimes if evidence was hrought against him. Violence would nat solve the problem but would lead to serious consequences for the linited States, he added.

\section{Bin Laden has already left Afghanistan}

\section{Behroz Khan}

PESHAWAR: The most wanted man in the US, Osama bin Latden, has silently left Afghanistan for ail undisclosed destination. solurces said.

They said he has moved out of the Afghan territory at least 4 days before the religious shura of the clerics issued its recommendation for him to leave the country voluntarily.

Sources in Pakistan, known . for their close contacts with Tal. iban. as well as some officials of the students' militia confided to The News that Osama bin Laden has no longer been on the Afghan soil since Monday.

Taliban sources said that a reluctiant Mulla Omar accepted the request of Gama to leave
Afghanistan ahead of the shura in Kabul, which called on the Talihan government to persuade the Saudi dissident to take refuge outside Afghtanistan.

"Osama has left Afghanistan four days ago and is no longer in the country", a source closed to Taliban said during a chat with this correspondent. "I believe the news is not wrong. He must be out of the Afghan soil", endorsed a Taliban official, who asked not to be named.

"Osama bin Laden decided on his own to leave Afghanistan, given the threats of the US government to attack the country.

Taliban supreme lealer, Mulla Muhammad Omar had turned down an earlier request by Osama after the last. IIS cruise missiles attack on Khost in

\section{Afghanistan.}

Sources close to religious parties believe that Lebanon or the remote inountainous region of Chechnya could be the possible places, where Osama might have opted to make his new hidrout.

An Afghan national, known for his close links with Osama bin Laden because of his time tested loyalty told The News that "Shiekh", a reference to Osama, was in good health and surrounded by the Arab youngsters, who had given the pledge to Osama to sacrifice their lives in pursuit of his defence.

"These educated and committed Arabs know about biology, che ritistry and miclear sciences and are ready to make use of 
The News International, Friday, September $2 \dot{1}, 2001$

their knowledge to defend Muslims all over the world", he said in a written statement available with The News.

Another indication came from a former interior minister of Pak. istan in the PPP government, Naseerullah Babar, who said in Nowshera that Osama had left Afghanistan four days ago.

Talking to reporters on Thursday, he said the supreme commander of ruling Taliban, Mulla Mohammad Omar, had to give the required endorsement to the shura edict and that was why he took four days so that Osama could get some time to leave Afghanistan.

Several attempts by The News to obtain official confirmation from top Taliban leadership proved abortive, but informed sources among the Taliban ranks did not deny his departure along with his trusted lieutenants, mostly Arab volunteers and few Afghans as well.

"We do not know, which country Osama was heading for, but the reports carry weight that he is no longer in Afghanistan", said the Taliban sources. "I am sure Mulla Omar will endorse the resolution passed at the meeting of religious clerics in Kabul within days. That means Osama has already left", said the source in Pakistan.

The recommendations made through resolutions and the fatwa calling for jihad if Afghanistan is attacked in pursuit of Osama bin Laden will be presented to Mulla Omar for final approval.

\section{Talks with Taliban possible: Powell}

WASHINGTON: US Secretary of State Colin Powell said Thursday he would not rule out eventual talks with the Afghanistan's Taliban should they expel Osama bin Laden and act against other alleged terrorists in the country.

"We do not rule it out," Powell said when asked whether the United States was willing to consider speaking with Taliban officials who have thus far refused to expel Bin Laden, the US government's prime suspect in last week's terrorist attacks in New York and Washington.
"We don't see a basis to initiate a conversation but that may well be a possibility if they are prepared to do what is required," Powell told reporters after meeting here with top officials from the European Union.

What is required, Powell said, is for the Taliban to "túrn over Osama bin Laden, and not just Osama bin Laden, but all the other lieutenants and (terrorist)

infrastructure that exist in Afghanistan."

- He then reiterated that the batthe against terrorism would not end with the capture or death of Bin Laden and the destruction of his alQaeda network.

"This is not a campaign against one individual but also the network he is the leader of and when we have dealt with al-Qaeda, the network, Osama bin Laden, the indvidual, we will then broaden our campaign to go after other terrorist organizations and forms of terrorism around the world," Powell said.

Earlier Thursday, senior religious leaders from across Afghanistan urged the Taliban to voluntarily but officials in Washington have dismissed the move as meaningless. or ulema, expressed "anguish and sorrow" over last week's attacks but also resolved to conduct a jihad or holy war against Washington in the event of US military strikes.

'I saw the clerics' statement but we want action not just statements, " Powell said. "Voluntarily or involuntarily, we believe that Osama bin Laden has to be put under control and turned over to authorities who can bring him to justice, and it should be done rather quickly, he added. - AFP ask Bin Laden to leave the country

An edict issued by the clerics,

\section{Pakistan, Oman seek OIC meeting}

ISLAMABAD: Paldstan and Oman have agreed to seek convening a meeting of OIC countries for talks on the crisis created by terror strikes against the United States, officials said Thursday. The German foreign minister also lauded Pakistan's stand on the issue.

A foreign ministry statement said Foreign Minister Abdul Sattar and his Omani counterpart, Yousuf bin Alawi bin Abdullah, discussed the proposed meeting of the 56-nation Organisation of Islamic Conference (OIC) in a telephone conversation on Thursday.

It said the two ministers also shared the concern that identifiable lobbies are trying to exploit the irrational and barbaric acts of a suicidal group of terrorists to tarnish the image of Islam, it added, in a veiled reference to Pakistan's arch-rival India.

The statement further said Muslim countries need to project a correct understanding of their faith.

The US is trying to forge an international coalition for its war against terrorists and countries whrch harbot theit, a campalth that includes military, diplomatic, political and financial components.

Meanwhile, German Foreign Minister Joschka Fischer and Foreign Minister Abdul Sattar also had a telephonic conversation on the grave situation triggered by the terrorist attacks in the United States.

Fischer complimented Pakistan for courageous and farsighted policy, which was greatly appreciated by Germany and other partners in the coalition against terrorism.

The foreign minister agreed that the fight against terrorism required a long-term strategy to address its root causes. It called for an enduring commitment to solution of political, economic and social problems, and interna. tional cooperation for alleviation of poverty, ignorance and despair.-APP 


\section{Afghanistan to become new Vietnam: Hekmatyar}

TEHRAN: Exiled former Afghan Prime Minister Gulbuddin Hekmatyar warned on Thursday that

Afghanistan would become another Vietnam for the United States as Afghans would fight to repel foreign invaders.

"The United States has no right to commit aggression against the Afghan people," Hekmatyar told the agency from his apartment in a Tehran suburb.

"If it is looking to take revenge against somebody, it should take it somewhere else." Hekmatyar, leader of the Hizb-e. Islami and a former prime minister before the Taliban took control of most of Afghanistan, said. He added Afghans would repel any US attack.

"If invaded, the Afghan people will have no choice but to fight for every inch of their territory," said the 53-year-old Hekmatyar, an engineering graduate from Kabu University.

"The United States should

learn from its own experience in Vietnam and the Soviet occupation of Afghanistan that waging war against innocent civilians is not a proper option," he added.

Hekmatyar said Saudi-born Osama bin Laden, who is protected by Afghanistan's ruling Taliban, had denied involvement in the suicide attacks in Washing. ton and New York last week and that the United States did not have any evidence of his complicity.

"If they have any evidence let them bring it forward. Let the world see and know the evidence," Hekmatyar said.

He also criticised President George W Bush for speaking of a crusade and the first war of the 91 st century. "They can't just punish the whole of Afghanistan and so many innocent civilians because they suspect bin laden without having clear proof," Hekmatyar said.

-The Afghan people have not gone to war with the United States, the US wants to impose war on them." Afghan clerics on Thursday urged bin Laden, Washington's prime suspect in the suicide attacks, to leave their country and a Taliban official said bin Laden was ready to stand trial if evidence was produced.

The United States, which has ordered 100 extra warplanes to the Guif region in response to the attacks which left 6,000 dead and missing, had urged the Taliban to hand over bin Laden, who has lived as a "guest" of the Taliban, or face the consequences.

Hekmatyar criticised a number of Northern Alliance chiefs, who are fighting the Talibarr; for calling for coordination with the United States in attacking Talibañ strongholds.

The Alliance is loyal to President Burhanuddin Rabbani, who is officially recognised by the United Nations as head of state. - Reuters

\section{BBC extends service to Afghanistan}

LONDON: The British Broadcasting Corporation (BBC) said on Thursday it was expanding its services to Afghanistan and the surrounding region in response to the escalating tensions in the area following last week's attack on the United States.

Saudi-born Osama bin Laden, named by the United States as the prime suspect in the attacks that killed thousands in New York and Washington, is believed to be staying in Afghanistan.

"For the region, the BBC World Service is a vital lifeline. Audiences literally' depend on the $\mathrm{BBC}$ for impartial, accurate, trustworthy news and information," BBC World Service Director Mark Byford said in a statement.
"In Afghanistan, with no television and no national news. paper, the $B B C$ radio is a main form of communication."

The BBC World Service has also boosted shortwave transmission to the region and expanded output in Arabic, Pashto, Persian and Urdu, key languages in the region.Reuters

\section{Text of Afghan scholars' edict}

ISLAMABAD: Following is a translation of the text of an edict issued by an Afghan grand Shura, or council, of Islamic clerics in Kabul on Thursday. The text was translated by the Pakistan-based Afghan Islamic Press from the original Pashto into Urdu, and from Urdu into English by AFP.

"This meeting of ulema (scholars) expresses its anguish and sorrow over the attacks in the United States and hopes that America will not launch any attack against Afghanistan, and carry out full investigations. "The meeting demands that America and the OIC (Organisation of Islamic Conference) should probe the incident freely to bring out the truth se that innocent people are saved.

"The present crisis should be defused and steps should be taken to prevent a repeat of such misunderstandings in the future. "This Shura of Islamic scholars demands from the Islamic Emirate (Afghanistan's Taliban regime) that Osauna bin Laden should voluntarily leave Afghanistan for a place of his choice at an appropriate time. "The United Nations and the OIC should take notice of the statement of President Bush describing the contemplated military action as a crusade. This has hurt the feelings of Muslims around the world and created a dangerous situation for the world.

"If America does not show 
restraint even after the above decisions, a jihad will become incumbent in accordance with the principles of Shariat (Islamic law) and the entire Muslim community should support this." -AFP

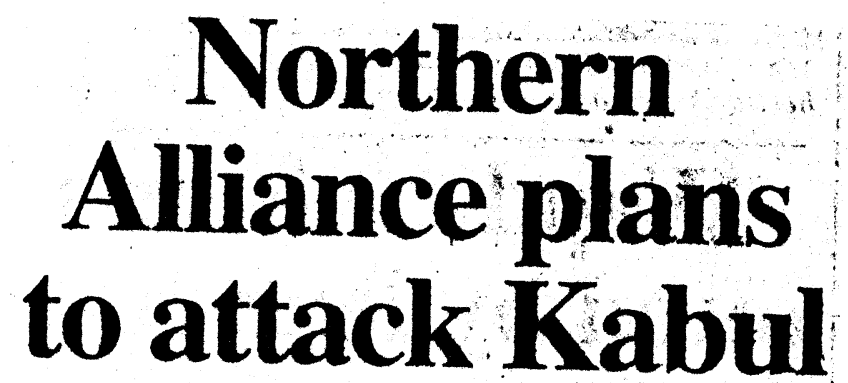

DUSHANBE (Agencies): Afghanistan's Northern Alliance said on Thursday the time was right yor it to launch an attack against the Kabul government of the Taliban, but it wanted to coordinate its action with the United States first.

The military official of Northern Alliance govemment, Soleh Muhammad Registani, which is recognized by the United Nations, told that the Taliban was worried about impending attacks from the United States.

The United States is preparing a global war on terrorisni atter the attacks in New. York and Washington and wants Csatha bin Laden. The Taliban are so concerned about a US attack. It's a good opportunity for us to attuck, he said.

Soleh Muhammad, speaking in the Afghan embassy in Tajikistan, said the Alliance was still hoping for support from the United States before attacking Taliban positions.

"We have to coordinate our attack with the United States. We don't have official contact with the United States, but we hope we will have contact with them. I think this will be possible and we're waiting for some contact from their side."

Meanwhile, the Northern Alliance of Afghanistan ambas- sador to the United Nations said that the Islamic State of Afghanistan (Afghan government in exile) is ready to coop. erate with the United States to find Osama bin Laden.

Addressing a press confer ence at UN headquarters, A.G Ravan Farhadi said, "our side is ready for cooperation. We have information how to deal with Mr. bin Laden."

"It means nothing to bomb Kabul or Kandahar. This is use. less. What we say (is) we have 15,000 people on our side ready to fight, ready to fight and...trained for fighting the Taliban. And they have done this job for five years," Farhadi said. "We know the land and we know the country and we know the people and we know where Mr. bin Laden can hide," Farhadi said.

"We know also the psychology of people and we know especially that in any Talibanheld territory there is a move: ment. There is an underground movement against the Taliban because the Afghan people are fed up with the Taliban....and fed up with bin Laden and his army," he claimed. "It is important. We have to be consulted and we will give our coopera. tion, we will give our views," he said. "If any cooperation is needed internationally we are ready."

\section{Iran launches diplomatic drive}

TEHRAN (Agencies): Iran has launched a diplomatic drive to try to head off US military strikes against neighbouring Afghanistan fearing they would lead to humanitarian catastrophe and a hardening of Islamic opinion against the West.

Iranian Foreign Minister, Kamal Kharrazi telephoned European Union foreign policy chief Javier Solana and the foreign ministers of ltaly, Pakistan, India and Belgium to press the point, the state-run news agency said on Thursday.

Any retaliatory action against Afghanistan would lead to the massacre of more innocent people and leave many homeless, the official agency quoted Kharrazi as telling his Italian counterpart Renato Ruggiero.

Iranian President Mohammad Khatami reacted quickly to condemn suicide attacks in New York and Washington, a response the United States described as worth exploring.

\section{Omar to inform Osama about Ulema verdit}

\section{F.P. Report}

ISLAMABAD: Mullah Omar will formally inform Osama about the decision of the Ulema about his tate shortly requesting him to leave Afghanistan, disclosed a Taliban official source here on Thursday.

However, the source has said the Taliban spiritual leader will ask him to leave Afghanistan voluntarily'at a proper time.

The Taliban Shoora has ruled in its edict that, "to defuse the prevailing tension. Osama bin Laden should be persuaded to leave Afghanistan voluntarily". 


\section{The Frentier Post Friday, September 21, 2001}

\section{Severe food shortage hits Afghanistan Hamid Nawaz}

PESHAWAR: Stoppage of food supply by World Food Programme and non-availability of private vehicles to transport food items to Afghanistan have created a shortage of edi. ble items in the war-torn country due to which the prices increased manifold.

The reports pouring in from Afghanistan confirmed that the stoppage of food supply through WHO to Afghanistan due to allege involvement of Osama Bin Ladin backed by Talibans in New York and Washington terrorist attacks and refusal of public transporters to continue supply of edible items to Afghanistan have created shortage of food in the entire Afghanistan.

Sources further informed that due to the acute shortage of food, the prices of wheat, rice, dry milk and cooking oil raised to celestial height and common man find it hard to feed his family once in a day. Most of the people are crying that what is their fault that the US-backed WFP stopped supply of food to Afghanistan. which threatened the lives of the entire Afghan population reports said.

Reports reaching Peshawar also confirmed that if supply of food was not restored to its previous momentum then there is possibility of a big human disaster as Afghans mostly dependent on food supply from Pakistan being initiated by WFP and some public transport companies.

It is worthy to be mentioned here that since terrorist attack in New York and Washington and allegations of Osama Bin Ladin's involvement in the attack the food supply to Afghanistan through WFP has been stopped since 12 th September, 2001 while supply through public transport continued for some days. But the much-talked US attack on Afghanistan created feelings of insecurity among the drivers and they too refused to continue food supply to Afghanistan.

There are also reports that fare of public trucks has also been increased alarmingly as prior to terrorist attacks the truck fare for Jalalabad was around Rs.7,000 and Rs.8,000 for Kabul and now it ranges around Rs. 18,000 and most of the Peshawar based driver told The Frontier Post "they can not risk their lives, for few thousands rupees and would not opt for going to Afghanistan".

Trans" border movement of trucks also informed that Afghanistan is mainly dependent on Pakistan for food sup. ply including wheat, dry milk, sugar, and cooking oil while grapes, water melon, onion is being supplied to Pakistan.

\section{Afghan refugees to be sent back}

ISLAMABAD (Online): No Afghan refugee would be allowed to stay in Pakistan in case of any hostile military action by Taliban against Pakistan, a top government official told Online Thursday.

"All the 3 million refugees will have to go. We can't provide' shelter to citizens of a hostile country", the official contended.

"The government wants data about all the Afghan refugees within the next few days so that if the Taliban make any hostile decision their gift (the refugees) can be sent back", the official added.

The official said, "We have already told the United Nations that we cannot afford the menace of refugees any more and we will soon convey, our message to disown the refugees residing in the country".

During the last 8 days alone over 50 thousand Afghan refugees have entered Pakistan illegally keeping in view the possible US military action against Afghanistan.

The border security forces despite hectic efforts have failed to control the intruders.

The government has however, not stopped entry of people having valid having visas.

Officially, around 3 million Afghans stay in Pakistan. The number according to independent sources is even higher. Less than half of the Afghan refugees have attained refugee status others stay in the country illegally. 


\section{The Statesman}

Friday, September 21, 2001

\section{Million Afghans face starvation: $\mathbf{U N}$}

ISLAMABAD: At least a million Afghans face starvation if the World Food Program cannot return evacuated staff to the country and resume its normal operations there, a spokesman said on Thursday.

The WFP still has three weeks' worth of supplies in warehouses in Afghan cities, but it could not distribute it to nural areas hard hit by a severe drought and the crisis due to the current situation in Afghanistan, Khaled Mansour told Reuters Television in an interview.

Although Afghanistan desperately needs fondstuffs, there was no reason for WFP to send in more aid if it could not get it to the millions most threatened by the famine, he said.

"We have pre-famine conditions," he said. "If for a long period of time we canno have access to Afghanistan then I'm afraid people may starve. About one million people would be most threatened."

Like all other United Nations agencics. the WFP had to evacuate its staff from Afghanistan hastily last week as the United States threatened to raid Afghanistan to punish it for harboring Osama bin Laden.

Mansour said the WFP was preparing contingency plans to help struggling Afghans but its hands were tied as long as it could not assure proper distribution.

"There is no point in sending food to warehouses in Kabul and Kandahar if you cannot take it to people who need it," he said.

The WFP had enough food stocks to feed up to 5.5 million Afghans, or 25 percent of the total population. But there was little hope of getting it to them.

"Afghanistan was already in a bad situation before the current crisis and it can only get worse," Mansour said. "Now with the current crisis, we are losing access to rural areas."

Food prices were rising in Afghanistan due to stock piling, adding more misery to a desperate situation, he added. - Reuters

Meanwhile, European Union (EU) justice and interior ministers discussed proposals Thursday for joint anti-terrorism efforts following last week's terrorist attacks on the United States.

The proposals, adopted by the European Commission, the EU exccutive body, a day earlier, would work to harmonise the EU police and judicial action with a common European arrest warrant.

Sources here said the ministers rejected a British proposal to - draw up a US-style list of "terrorist" organisations to be banned within the 15-nation bloc.

The ministers hoped that the EU executive proposals on a pan-European definition of terrorism and an EU arrest warrant would be formally approved no later than December 6-7. - AFP
US links talks to Osama

WASHINGTON: US Secretary of State Colin Powell said Thursday he would not rule out eventual talks with the Taliban should they expel Osama and act against other alleged terrorists in the country.

"We do not rule it out," Powell said when asked whether the United States was willing to cohsider speaking with Taliban officials who have thus far refused to expel Osama.

"We don't see a basis to initiate a conversation but that may well be a possibility if they are prepared to do what is required," Powell told reporters after meeting here with top offi. cials from the European Union.

What is required, Powell said, is for the Talian to "turn the other licutenants and (terrorist) infrastructure that exist in Afghanistan."

He then reiterated that the battle against terrorism would not end with the capture or death of Osama and the destruction of his al-Qaeda network.

This is not a campaign against one individual but also the network he is the leader of and when we have dealt with then broaden our campaign to go after other terrorist organisations and forms of terrorism around the world," Powell said. - AP 
$K_{\text {HYBER }} M_{A I L}$

September 21, 2001

USCR urges the United States to safeguard

\section{Afghan civilians}

W A S H I N G T O N (Agencies): The U.S. Committee for Refugees (USCR) has urged the U.S. government and the American people to distinguish between the Taliban and the Afghan people and called on the United States, Pakistan, and Iran to safeguard Afghan refugees and civilians.

"The U.S. must take every precaution to protect the lives of Afghan civilians and refugees, the majority of whom do not support the Taliban and have suffered tremendously under their authoritarian rule," said USCR senior policy analyst Hiram A. Ruiz, who has visited the region twice this year and reports extensively on Afghan refugees.

The possibility that the United States will take military action against Afghanistan is triggering fear and alarm among Afghan civilians. The recent withdrawal from Afghanistan of UN personnel and international relief groups that were distributing food aid to millions of Afghan civilians affected by intemal conflict and drought threatens to place countless civilians at even greater danger. Thousands of Afghans are already fleeing to Pakistan and Iran.

It said that the United States asked Pakistan to seal its border with Afghanistan for security reasons, an action that is trapping thousands of Afghan civilians - ordinary men, women, and children who cannot be held responsible for the actions of those who rule them - in a place of danger. USCR urged the United States and $P r^{\prime}$ istan to reverse that course of action.

\section{DAWN FRIDAY, SEPTEMBER 21, 2001}

\section{Ulema's} advice

\section{non-binding, says Muttaqi \\ By Our Correspondent}

KABUL, Sept 20: Taliban's Education Minister, Mulla Amir Muhammad Khan Muttaqi on Thursday clarified that the recommendation by a shura of ulema asking Osama bin Laden to leave Afghanistan was nonbinding and not an order.

Addressing a press conference here, Muttaqi said that the recommendation by the shura asking the Islamic Emirate to persuade bin Laden to leave the country was not an order. "It is a hope, $a$ wish that he be persuaded to go to some other country."

Answering a question, Muttaqi said that he was confident that Mulla Omar, in line with the recommendation of the shura, would urge bin Laden to leave Afghanistan. "He has always respected and implemented the fatwas of the ulema," he said.

He described as premature when asked about the Taliban reaction if bin Laden did not leave Afghanistan as desired. "This is premature," he remarked.

The education minister said that the Russia's military might was no less than that of the Americans' compared with the poorly-armed mujahideen who lacked centralised command nor had they any resources, yet they had been able to defeat the Red Army.

He said that the morale of the people was high. "We can fight out any aggressor," he claimed. "The Afghans have a lot of experience in war and fighting," he remarked.

Muttaqi said Jihad was binding on Muslims in the event of an attack by non-believers on any Islamic country.

"You don't think about how mighty your enemy is. Jihad is then binding on all Muslims," he said.

\section{'Afghan decision not a giant step'}

\section{By Our Staff Reporter}

ISLAMABAD, Sept 20: Pakistan's foreign minister Abdul Sattar on Thursday said that the Afghan Shura's (council of religious leaders) decision to ask Osma bin Ladin to leave Afghanistan voluntarily, was "significant but not a giant step".

He was talking to foreign arid local journalists at a reception hosted in their honour by the information secretary.

Explaining the significance of Afghan Shura's decision on Thursday, he felt that the Afghan tradition of protecting their guests was the reason for turning down a similar request from Pakistan.

To a question, whether there was any possibility of the Taliban's requesting Iran to accept and protect Osama bin Laden, he said that it was most unlikely.

The minister said that importance of Afghan Shura could be gauged from the fact that it is the same body which made Mulla Omer, ruler of Afghanistan. 
DAWN FRIDAY, SEPTEMBER 21, 2001

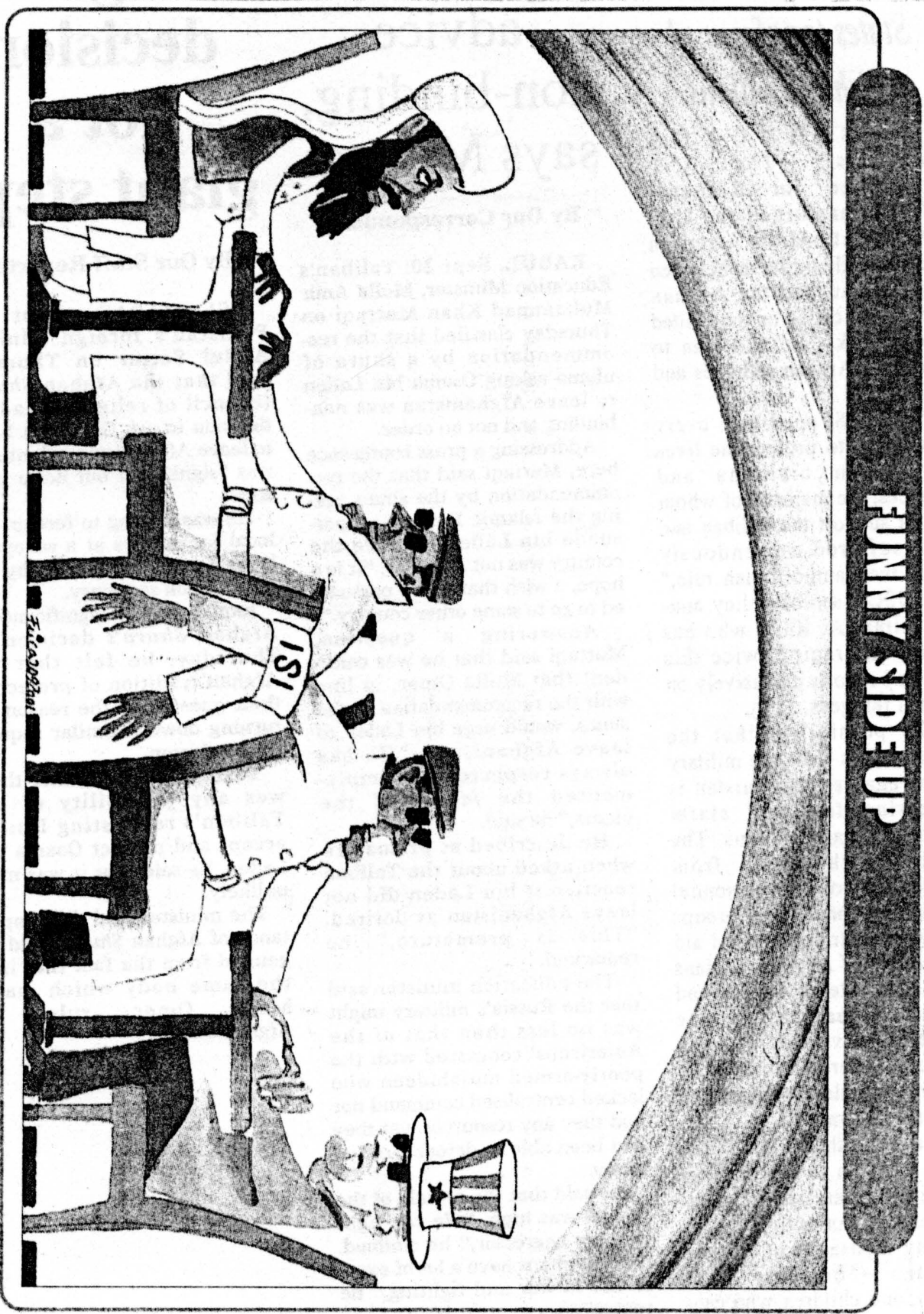




\section{Impending US attack on Afghanistan Residents shift families \\ as panic \\ grips Afghan cities}

Hasan Khan

PESHAWAR: Kabul, Kandahar and Jalalabad are gripped by panic as residents struggle hard to get out for safe havens in the wake of impending US attacks on Afghanistan, said Dur Muhammad, who succeeded in crossing the Pak-Afghan border somewhere in the mountains of Khyber Agency with three other families late Thursday.

"I saw many influential persons shifting families outside Kabul to the suburban areas," the apparently tired and desperate Dur Muhammad told The News at Charwazai village in Khyber Khas near Ali Masjid area.

Dur Muhammad along some 25 other refugees including children and women had just arrived at Chawarzai in Khyber following three days long and arduous journey from Kabul. They were waiting on the main Torkham Road for vehicles to come to Peshawar when this scribe found the opportunity to interview them.

While narrating ordeals of the journey, which he suffered along with two other families including three womert and some dozen children below 7, Dur Muhammad literally started crying. He said he left his house full of everything and opted for coming to Pakistan with a single box containing eight pairs of clothes and nothing else. "There is nothing dear to me than my life and my family," he said, and added, "I just want to live with peace and honour".

About the journey from Kabul to Pakistan with a family of eight including children and his wife Dur Muhammad (57), said he started his journey towards Pakistan on Monday evening (three days back). "You cannot imagine how we reached here," he said with a chocked voice.

Pointing finger to the high mountains, which they had crossed, he said: "We used donkeys in the mountains and also covered a long distance by foot in the hard and hazardous valley with these small children."

Most of the time we walked at night to avoid the Taliban militia's questioning deployed at various check posts, keeping vigil on those trying to cross the border into Pakistan, he added.

About the movement of Taliban militia, he said he had only heard about it. "I personally didn't observe any extraordinary movement of the militia on the way," he said but added, "I heard from the people that the Taliban have mobilised their militia towards the borders and other sensitive areas," Dur said.

"No I didn't see tanks, canons or other heavy weaponry installed on routes leading towards Pakistan," he said while responding to a query regarding any heavy deployment.

Wali Jan (40), accompanying Dur Muhammad, said he reached here with five small children and his wife. Wali was very cautious while talking about the situation inside Afghanistan and Taliban.

"It isn't something secret, ${ }^{\text {" he }}$ said to a query about the current situation inside Afghanistan while cutting short Dur Muhammad in the middle of his comments, who seemed to be a little bit critical of the policies pursued by the Taliban.

"Every person can imagine the pathetic condicon through which the poor Afghans are passing in the wake of impending US attacks," Wali said while trying to avoid any specific reference towards Taliban.

"It is the height of injustice to target the whole nation for the action of an individual (referring to Osama)," he said and urged Taliban to adopt such policies in the current situation that could best suite its people and the land.
"We don't want war anymore," he said, adding that the Afghans are tired and want peace and security. "It is our humble request to both the US and Pakistan not to impose another war on the poor and impoverished Afghans," he added.

"We suffered a lot during the last 25 years. The Afghans have been shattered both physically and psychologically now," he added.

About their expectations from the government of Pakistan after reaching here, Dur Muhammad, holding a five-year-old brightfaced daughter in his arms, said: "We expect a fair and better treatment from President Musharraf as our Muslim brother. "We need nothing but shelter and food," he said. "But still I am not sure what the future holds for us," he said.

When asked about any knowledge of the Pakistan government policy to send the new refugees back to Afghanistan, Dur Muhammad said: "Yes we heard about that but we have no other option due to security reasons and safety of our own lives and families." "Just for the safety of my life and family, I left behind a house full of everything and with all facilities," he said. "Pakistan is a Muslim state and we consider it as our own country, ${ }^{\text {h he }}$ confidently said and requested the President Gen Musharraf to let them live in Pakistan honourably till the settling down of the present uproar in Afghanistan.

A few kilometres back from Charwazai area, an official of the check post near Shagai Fort informed the The News that during the last few days they have arrested some four to five hundreds new Afghan refugees. "They came here through the Chora area," and were arrested at the check post and trucked in several vehicles to be ferried back into Afghanistan via Torkham. 


\section{Wants access to training camps in Afghanistan; demands not open to discussion; asks nations either you are with us or with terrorists}

\section{Amir Mateen}

WASHINGTON: President Bush declared on Thursday night a global war against terrorism, issuing an ultimatum to the Taliban to immediately turn over Osama bin Laden.

He was addressing a packed joint meeting of the US Congress

He vowed that "from this day forward, any nation that continues to harbor or support terrorism will be regarded by the United States as a hostile regime."

He demanded that Taliban close down every terrorist camp in the country or face military attack by the United States.

"These demands are not open to negotiation or discussion," he said.

"The Taliban must act and act immediately. They will hand over the terrorists, or they will share in their fate." Bush outlined his war plans, reaching far beyond Afghanistan and Osama bin Laden's organization, Al Qaeda.

He made it clear that American ground troops would be involved, and that a military strike could

come soon. "Be ready," he said to the US military.

But Bush, describing a titanic struggle between "the civilized world and radical Islam", was open-ended about the war's conclusion. He mentioned several times that the terrorists he was targeting practise a "fringe form of Islamic extremism," and that he was not labeling all Muslims as enemies.

"Our war on terror," he said, "will not end until every terrorist group of global reach has been found, stopped, and defeated."
"From this day forward, any nation that continues to harbor or support terrorism will be regarded by the United States as a hostile regime," Mr. Bush said in a blunt warning that could encompass countries far beyond Afghanistan.

The demands included an in: sistence that Americans be able to inspect every terrorist training camp in Afghanistan to ensure that they have been dismantled.

Amid applause and cheering, the US President declared that every nation must choose sides in the coming conflict against a ter-

rorist network that he said involved thousands of people in more than 60 countries.

Bush said such groups wanted to overthrow existing governments in Muslim countries, like Egypt, Saudi Arabia and Jordan.

He posed a stark choice to other nations. "Every nation, in every region, now has a decision to make," he said. "Either you are with us, or you are with the terrorists."

Mr. Bush said Washington would ask its allies from Latin America, Europe, Asia and the Islamic world for help, including help from their police and intelligence services and international banking systems.

Bush tried to separate the people of Afghanistan from Taliban, saying the Taliban leadership there has "brutalized" the population. He said that "you can be jailed for owning a television" in Afghanistan.

He noted that the United States was the largest source of relief aid to Afghanistan, but said clearly, and to applause, "We condemn the Taliban regime."

Bush asked the Americans to expect a long campaign that will be fought with the visible weapons of war and secret operations.

He implored them to be patient in what he described as a coming global struggle and made it clear that Americans should be prepared for casualties.

The war, he added, would not be like the swift battle against Iraq a decade ago. Nor would it be like the air war waged by Nato over Kosovo in 1999 without a single American combat death.

Bush spoke to a House chamber that included members of Congress, the cabinet, the supreme court and the uniformed military chiefs. In the gallery with Laura Bush, the first lady, sat New York's rescue workers as well as religious leaders and allies of America.

On either side of Mrs Bush sat Mayor Rudolph W Giuliani of New York and Prime Minister Tony Blair of Britain.

Mr Bush emphasized that his fight against terrorism would not simply be an air campaign. "We will direct every resource at our command, every means of diplomacy, every tool of intelligence, every instrument of law enforcement, every financial influence and every necessary weapon of war to the disruption and defeat of the global terror network, " he said.

The speech came as the US military was rapidly reviving its war machinery, dispatching ships and aircraft to the theatre of war. He did not give any indication of when the war would start-Wash- 
ington's most closely kept military secret, and perhaps a decision not yet made.

He declared: "The hour is coming when America will act." He told the US military: "You will make us proud." He did not further define for a worried American public what form it might take.

He did not say whether a "long campaign" meant one year or 10 . "We will rally the world to this cause, by our efforts and by our courage," the president said.

"We will not tire, we will not fal: ter, and we will not fail."

Bush also warned against racial prejudices, saying that no. one should be singled out for unfair treatment or unkind words because of their ethnic back:" ground or religious faith.

He said of the terrorist. groups: "Americans are asking: Why do they hate us?" and he was blunt in providing an answer:" "They hate what we see right". here in this chamber, a democratically elected government." Their leaders are self-appointed, They hate our freedoms, our free dom of religion, our freedom of: speech, our freedom to vote and assemble and disagree with each other."

The speech was delivered in an atmosphere of extraordinary security. Vice President Dick Ch: eney, who normally would have sat directly behind the president, was kept out of the Capitol building entirely, a pre:caution taken to leave the country with a leader should there have been an attack on the as. sembled high command of the United States.
US, allies, Iran meet with UN on Afghanistan: UN

GENEVA: Envoys from the United States, Germany, Iran and Italy, began a meeting here on Friday with the UN's chief envoy for Afghanistan to review the situation in Afghanistan, a UN spokeswoman said.

"There is an extraordinary meeting of the 'Geneva Initiative' on Afghanistan, they are private consultations headed by Francesc Vendrell," spokeswoman Marie Heuze said.

"We have no more information to give you, we have no more comment to make at this stage, it's a private meeting," she added. The meeting was expected to continue on Saturday.

The 'Geneva Initiative' was launched by Vendrell, a UN assistant secretary-general, and the four countries at a meeting on September 9 , two days before the attacks in the United States.

"These were regular consultations among some states and nonbelligerent Afghans who are outside Afghanistan," a UN source told AFP.

However, no Afghans were said to be taking part in the latest meeting, which was being held in a guarded room at the UN's European headquarters in Geneva.

"The situation in Afghanistan has been completely turned upside down since the initiative was launched, obviously," the source added, but declined to comment any further on the content or aim of the meeting.

Sources said the envoys from the United States, Germany, Iran and Italy were specialists on the region who had flown into Geneva.

Before the latest Afghan crisis, Vendrell was trying to secure the release of eight western aid workers - four Americans, two Germans and two Australians - who were arrested by the Taliban authorities in Afghanistan on charges of propagating christianity.-AFP

\section{Turkey urges US to strengthen Afghan opposition}

ANKARA: The United States should work to strengthen the opposition in Afghanistan to enable them to overthrow the hard line Taliban regime instead of carrying out a ground operation there, Turkish Prime Minister Bulent Ecevit said on Friday.

Ecevit also said that Turkey, the only Muslim country in NATO, was ready to offer military training to the Afghan opposition, in an interview with the CNN Turk news channel, the text of which was carried by Anatolia news agency.

"The deployment of ground troops from outside to Afghanistan turned out to be unsuccessful in the past," Ecevit said.-AFP

\section{Osama will not be allowed to pass through China}

BEIJING: The Chinese government said Friday it would not allow Osama bin Laden to pass through its territory should the terror suspect flees Afghanistan.

"We don't think that this kind of possibility exists, meaning he (bin Laden) will not be able to go to another country via China," a foreign ministry spokeswoman told AFP.

China shares a mountainous 70 kilometre border with Afghanistan, where bin Laden has been sheltered by the Taliban Islamic regime.-AFP 


\section{. Opposition steps up anti-Taliban operations}

\section{Rahimullah Yusufzal Jamiat-i-Islami commander Ustad}

PESHAWAR: Taking advantage of Ata and a Shia commander Rais the challenges confronting the rul- "Dostum to fight against Taliban. ing Taliban, the opposition Northern Alliance is trying to step up its military operations to wrest control of some of the areas under their occupation in Northern Afghanistan.

Uzbek warlord Rasheed Dostum, who reportedly returned to Afghanistan recently after enjoying Turkey's hospitality for a long period, claimed in a telephonic conversation with a member of Germany's parliament that up to 15,000 of his Uzbek troops were ready to march on Mazar-i-Sharif in. northern Afghanistan. German journalists told The News that the conversation between Dostum and Willy Wimmer, a parliamentarian belonging to the conservative $\mathrm{CDU}$ party, took place on Thursday. Dostum said his forces were only 50 kms from Mazar-i-Sharif and were capable of capturing the city from the Taliban.

The Taliban had captured Mazaris Sharif and several other cities and provinces from Dostum in the summer of 1998. Dostum, a former factory worker who raised a militia force that first fought for the communist regime in Kabul and later defected to the Afghan mujahideen, was the ruler of six provinces in northern Afghanistan till his defeat at the hands of the Taliban. Other Northern Alliance military commanders were also said to be gearing up for action against the beleaguered Taliban. Former
Though demoralized by the recent assassination of its military commander Ahmad Shah Masood in a bomb explosion, the Northern Alliance doesn't want to waste this opportunity to reclaim Kabul and other cities and towns that it lost to the Taliban in recent years. It has even offered to cooperate with the US to capture Osama bin Laden and overthrow the Taliban regime.

A Peshawar-based official of the Harkat-i-Islami; a component of the Northern Alliance, argued that Masood's death had prompted the commanders to actively participate in the anti-Taliban military cam. paign because they would now be given proper credit for their achievements. "Earlier, all credit would go to Masood. Many commanders stopped fighting because they neither got credit nor assistance from the foreign supporters of the Northern Alliance," he commented while requesting anonymity. Masood's successor General Faheem would also have to justify his selection by showing his prowess in the battlefield. Masood's loss has been a huge setback for the Northern Alliance, leaving Faheem with a difficult job to fill the leadership vacuum and keep the normally fractious coalition united and vibrant. He lacks Masood's stature to command respect from his group's rank and file and continue enjoying international assistance from countries in the anti-Taliban camp.
Meanwhile, other opposition commanders were also reported to have stepped up military activities in Badghis, Ghor, Samangan, Balkh, Takhar and Saripul provinces. Former Herat governor Ismail Khan's fighters have been involved in skirmishes with Taliban forces in Ghor and in Badghis bordering Turkmenistan. Plans were also reportedly been drawn up to harass the Taliban in frontlines in the Shomali area north of Kabul, in Kunar and Laghman provinces in eastern Afghanistan, and in areas bordering Iran.

It is not known if the Northern Alliance has received any fresh weapons' supply from abroad to engage the Taliban. There have been speculations that the US may decide to supply arms and other needed equipment to strengthen the Northern Alliance and enable it to take the fight to the Taliban. The Northern Alliance, lacking airpower and air defence system, may get assistance to overcome this deficiency. Russia, Iran, Tajikistan, India, Turkey and Uzbekistan, traditional backers of the groups that make up the Northern Alliance, could increase their assistance to them now that the Taliban are facing threats of a US attack and have been deprived of support by their only supporter, Pakistan.

The tide could turn against the Taliban once they start losing ground on the battlefront. In their internal battles, Afghan people have a habit of joining the side that is winning and deserting the one that is losing. 


\section{Afghan opposition warns US against occupation}

KHODJA BAHAUDDIN: Opposition commanders in Afghanistan on Friday welcomed US efforts to strike at terrorism and their chief foe, the Taliban but warned against attempts to encroach on their independence.

The opposition has been fighting the Taliban for years and has been squeezed to just five perrent of Afghan territory. The opposition alliance has been encouraged by US threats to strike Afghanistin.

"The northern alliance condemns international terrorism and is prepared for cooperation with the United States, but we will never give up our independence," General Abdul Ghafoor, the chief of the alliance's forces in this region, said Friday.
He spoke from a hill overlooking a river valley and Taliban-held mountaintops seven kilometres away. A gutted tank stood nearby, apparently hit by Taliban fire.

"If America decides to enslave us we are ready to fight against America," he said.

"We didn't have weapons when we fought Soviet troops, but we won. Now, that we have enough weapons, we aren't afraid of the Taliban and we will defeat them," he said.

Russia's ITAR-Tass news agency said Friday that troops under opposition commander Rashid Dostum are re-grouping around the city of Mazar-i-Sharif for a new attack on the Taliban, possibly aimed at capturing bin Laden.- AP

\section{Taliban not to hand over Osama}

\section{Zaeef says he has no information about bin Laden's whereabouts}

ISLAMABAD: Afghanistan's Taliban rulers refused Friday to hand over alleged terrorist mastermind Osama bin Laden and warned that US attempts to apprehend him by force could plunge the whole region into crisis.

The refusal by the hardline Afghan leadership, which has sheltered bin Laden for the last five years, was announced by the Taliban ambassador to Pakistan, Abdul Salam Zaeef. He spoke after U S President George W Bush warned Afghanistan must hand over bin Laden and his lieutenants "or they will share their fate."

However, there was no sign that Bush's warning was enough to convince Afghanistan's rulers to move against bin Laden, the prime suspect in the Sept. 11 terrorist attacks in New York and Washington.

"Our position on this is that if America has proof, we are realy for the trial of Osama bin Laden in light of the evidence," Zaeef said. Asked if the Taliban were ready to hand bin Laden over, he snapped "No" but his translator said, "No, not without evidence."

The envoy also said he had no information on bin Laden's current whereabouts.

Zaeef said he was sorry people

died in the suicide jet attacks on the World Trade Center and the Pentagon last week, but appealed to the United States not to endanger innocent people in a military retaliation.

Zaeef also called for an investigation by the United Nations, telling reporters President Bush's ultimatum poses great danger for Muslims.

"It has angered Muslims of the world and can plunge the whole region into a crisis," Zaeef said. "We are ready to cooperate if we are shown evidence. If American agencies are bent on putting the blame on bin Laden, then they won't be able to catch the real culprits."

The Taliban envoy added that his government was ready if necessary to defend the country against American attack.

"If they want to show their might, we are ready and we will never surrender before might and force," he said. "According to Islam, the blood of anyone who spies for the enemy or sympathizes with it in time of war must be shed.'

In the Afghan capital Kabul however, wary Afghans piled belongings on carts and trucks and left the Afghan capital for fear of U S air strikes.

Mohammed Hussein and his family of seven loaded their belongings into a pickup truck and headed south to join relatives in Logar province south of Kabul.

Out of 20 homes on our street most of the families have left," said Mohammed Hussein as he piled his wife and six children into a pickup truck to join relatives in a province south of Kabul. ing."

Anyone who can is leav.

On a main road leading north of Kabul, Azizullah pushed a cart piled high with pots and pans, a metal trunk and a few tattered carpets. His two daughters appeared pale and weak from dysentery. His 12-year-old boy, Hamidullah, pushed a smaller cart loaded with some mattresses and pillows.

His wife, he said, remained at home because she suffers from rheumatism and cannot walk.

"I don't know where to go," said Azizullah, who like many Afghans uses only one name. "I've been wandering the city trying to find a safe spot. But I have no money and I don't know what to do.

Our home is near a military base, and I don't want to stay there with my children."-AP 


\section{The Frontier Post}

Saturday, September 22, 2001

\section{US, allies ponder over makeup of new Afghan leadership}

LONDON: The United States and its anti-terror campaign allies are looking beyond a possible military strike against the Taliban, and are already discussing the makeup of a new Afghan leadership, officials say.

A spokesman for Britain's foreign office said the coalition was reviewing all the possible outcomes if the Taliban is overthrown. "Our objective has always been to see a broad based legitimate government in Afghanistan," the spokesman told Reuters on Friday. "We have always maintained contacts with all factions in the country."

Citing diplomatic cables from Washington, Britain's Guardian newspaper said the US was canvassing opinions on a "post-Taliban Afghanistan after the liberation of the country". Former king of Afghanistan Mohammad Zahir Shah, who was been living in exile in Rome since 1973, has appealed for an emergency assembly of representatives of all Afghan groups to elect a head of state and establish a transitional government.

Western intelligence agencies have blamed Saudi-born Osama bin Laden, a so-called "guest" of the Taliban in Afghanistan, for the attacks on the World Trade Center and the Pentagon on September 11 in which more than 6,000 people were killed. The United States has demanded the Taliban hand him over, and on Friday a blunt President George W. Bush said countries not in the anti-terror coalition would be deemed enemies.

Experts say Washington faces $\mathfrak{a t}$ nightmare choice - do nothing and open the door to a repeat of the suicide attacks on New York and Washington last week, or overthrow the regime shiflding bin Laden and risk destabilising the whole region.

"Take out the Taliban? It really is a matter that you are damned if you do and you are damned if you don't," Rahul Bedi, India correspondent of Jane's Defence
Weekly, told Reuters. "Defeating the Taliban militarily is not that hard a task, although small pockets would remain in the mountains. What you put in their place is the nightmare question," he said.

What the United States does not want is a repeat of the dismal failure of the US-led bid to oust Iraqi leader Saddam Hussein after liberating Kuwait - a failure that left him in power and the region in limbo. But to break the military back of the Taliban and force them to take to the hills would by definition leave a vacuum in pivotal part of central Asia. "There are really only two scenarios - bring back the old King Zahir Shah, who by all accounts is very reluctant, or bring the rebel Northern Alliance into Kabul," Jane's Bedi said.-Reuters

\section{Greek detains 197 Afghan immigrants}

ATHENS, Greece: The Greek coast guard detained 197 Afghan immigrants on Friday after they were found floating in a small boat off the Aegean Sea island of Ikaria, the Merchant Marine Ministry said.

The boat was spotted by a helicopter in the sea between the resort islands of Mykonos and Ikaria: The illegal Afghan immigrants including four women and two chil: dren - were found aboard a 27 . meter wooden boat by coast guard rescue and patrol vessels. A passenger ferry tugged the wooden boat to the island of Samos, the ministry said.

In another incident, on Tuesday about 300 illegal Iraqi Kurd and Afghan immigrants were detained in the open sea between Greece and Italy. The coast guard intercepts boats on near daily basis carrying people from the Middle East; Asia and Eastern Europe trying to sneak into European Union member Greece.

Greece said Thursday it will seek closer cooperation with neighboring Turkey to stem the flow of illegal immigrants. Officials said they fear a reported 1 million Afghan refugees may try to reach the European Union. - AP

\section{China not to allow transit to Osama}

BEIJING (Online): China on Friday said it would not allow Osama bin Laden, the suspected mastermind of last week's terrorist attack in US to pass in transit through China on the US seek to flee Afghanistan.

"We don't think that this kind of possibility exists, meaning he (bin Laden) will not be able to go to another country via China," a foreign ministry spokeswoman said.

The spokeswoman said the foreign ministry had not yet put together a formal response to the speech made by US President George W. Bush late on Thursday, calling on the Afghanistan's ruling Taliban regime to immediately turn over bin Laden and his AlQaida organization to the United States.

Chinese Foreign Minister Tang Jiaxuan is in Washington where he was scheduled to hold a meeting with his counterpart, Secretary of State Colin Powell. Tang had expressed deep sympathy for last week's onslaught which killed more than 6,300 people.

\section{AISO to defend Afghanistan}

PESHAWAR: Afghan Islamic Students Organisation (AISO) on Friday said that if US attack Afghanistan they would be the first holy war fighters to defend their country.

In a press statement said that the Afghan students had strongly condemned the terrorist attacks on World Trade Center and the Pentagon, and had always opposed terrorism in the world but it would never allow the United States to launches attack on Afghanistan.

AISO urged the world community and Organisation of Islamic Countries (OIC) to investigate the terrorist acts at New York and Washington. "If the miserable Afghan people were targeted by the US without any solid proof it would also be tantamount to terrorism against Afghan nation," the AISO statement added. 


\section{The Frontier Post}

Saturday, September 22, 2001

\section{US plans to instal puppet regime in Kabul}

Fakhar-ur- Rehman

ISLAMABAD: Amid reports pouring in from around the world about United States plans to deploy its troops in Uzbekistan and Tajikistan as part of its global coalition to combat terrorism, it has been learned that it would

- provide all logistic assistance to paratroops the Northern Alliance forces in Kabul while it would launch air strikes on Afghanistan

Informed Sources have told the Frontier Post that the strategy seems to be installation of a proUnited States regime in Kabul by first capturing it by the Northern Alliance troops and then install a puppet government under Prof.
Burhanuddin Rabbani which in return would ask the US troops to land in Afghanistan to fight out terrorism, thereby legitimizing US ințervention in that war torn country.

While the Taliban sources have ruled out such a possibility by saying that after the death of Commander Ahmed Shah Masood a division has already taken place in the ranks of Northern Alliance on the contention of supporting a possible US entry in to Afghanistan. " Fight among Afghans is different , we may fight years but when there is invasion by outsiders then we set aside our fight and joins a hands to kick out the invading forces, this had been our tradition", remarked a senior Taliban official.

Taliban sources however have also said that capturing a place is easier then to sustain its control and "US troops once entered would find it very difficult to get out".

This is the first time in history of Pakistan and Afghanistan bilateral relations that a proIslamabad government was established in Kabul. President Najibullah who was a pro-Ex Soviet Union, Afghan leader, had invited Soviet troops to Afghanistan and was hanged by the Taliban forces after falling of Kabul in to their hands.

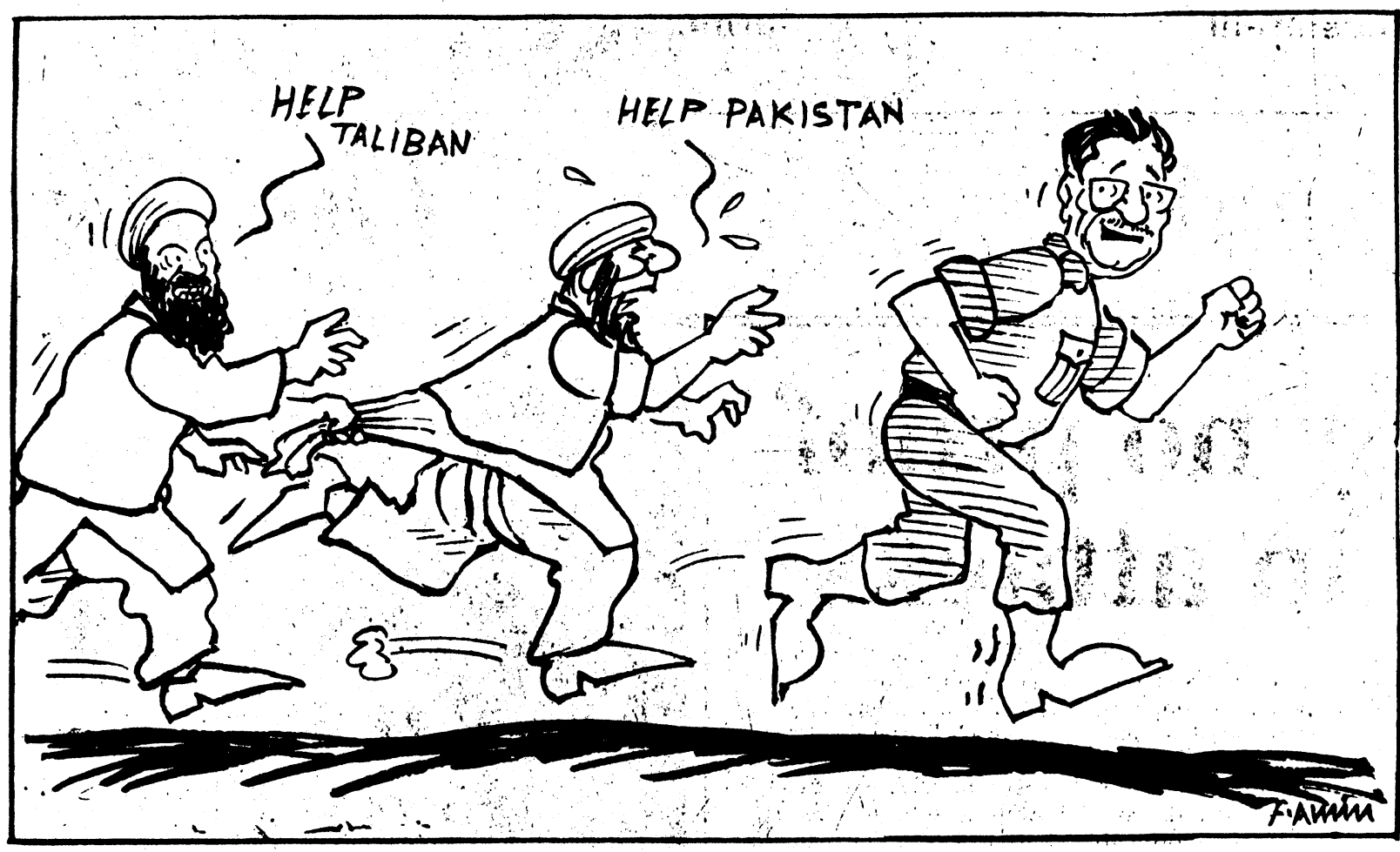




\section{The Frontier Post saturday, September 22, 2001}

\section{Attacks on Kabul not to end tension: RAWA}

\section{F.P. Report}

PESHAWAR:

The

Revolutionary Association of Women of Afghanistan (RAWA) on Friday, asked the world community to stop financial and political support to both the Taliban and Northern Alliance and added that the people of Afghanistan had nothing to do with Osama and his accomplices.

Addressing the press conference here at Peshawar Press Club, Saima Karim said that attacks on Afghanistan and killing its most ruined and destitute people would not in any way decrease the grief of the American people, adding that US should differentiate between the people of Afghanistan and a handful of fundamentalists.

She regretted that the world was shocked with the horrific attacks on the US and RAWA also condemn for this act of violence and terror, saying that the RAWA had already warned the US and its allies not to support the treacherous, criminal, anti-democratic and antiwomen rights elements.

She claimed that Osama was the blue-eyed colleague of CIA and now the Taliban and Osama were the prime suspects by the US officials after the attacks, saying that the US should consider the root cause of this terrible event.

" People of Afghanistan are not terrorists and also in a position to bear more terrorism as that Afghanistan is passing through terrible time and ruined by attacks from last twenty years," she added.

She stated that the government of Zahir. Shah would be a better one than Taliban if he was given a chance, adding that the world should differentiate between the poor and devastated people of Afghanistan.

\section{Exodus of refugees UNHCR urges free movement for Afghans}

\section{F.P. Bureau Report}

ISLAMABAD: United Nations High Commissioner for Refugees, Ruud Lubbers urges governments to keep their borders open to Afghans fleeing their country and calls for a concerled humanitarian response. UNHCR appeals for $\$ 6$ million in initial emergency funds to cover the immediate deployment of emergency personnel, the positioning of stocks and for contingency planning. Relicf agencies plan next week to issue a regional and comprehensive inter-agency appeal for a much larger sum.
UNHCR orders 20,000 tents and sends 20,000 kitchen sets to Pakistan in order to meet the needs of new arrivals in Quetta and to bolster emergency stocks. Three UNHCR emergency teams of specialist staff prepare to depart for Pakistan within 72 hours. Iranian authorities report that up to 1,000 Afghans have gathered in Zaranj, near the Iranian border town of Zabol, west of Kandahar. Some 500 Atghans reportedly cross from Pakistan into Iran at Mir Javeh, Iranian authorities report.

UNHCR Calls for Open Borders High Commissioner Ruud Lubbers again urged gov- ernments to keep their borders open to Alghans llecing their country, not least hecause of the deteriorating security situation there. Lubbers also called for a concerted humanitarian response to the serious plight of Afghan civilians who are directly affected by the current insecurity in Afghanistan.

"We believe that given the current situation inside Afghanistan, there is even more reason to encourage all countries, including countries bordering Afghanistan, not to close

their doors, "Lubbers said.

He said UNHCR was asking for "temporary protection" for Afghans tleeing their homeland, adding that his agency would then " work with all concerned to help people to return as soon as circumstances would allow and look into other possibilities to spread the burden."

The UN refugee agency, with support from its donors, will assist Afghanistan's neighbors with any movements of Afghans beyond their borders. As the international community works toward a global approach to combat terrorism, Lubbers said a "humanitarian coalition" was also necessary to address civilian needs.

Initial Appeal for $\$ 6$ million in Emergency Funds UNHCR appealed to donors on Thursday for $\$ 6$ million in initial emergency funds to cover the immediate deployment of emergency personnel, the positioning of stocks and for contingency planning activities for the entire region. Relief agencies plan to issue a regional and comprehensive inter-agency appeal for Afghanistan and the surrounding region next week, of which UNHCR's portion will be for a much larger sum.

UNHCR is ordering 20,000 tents from South Asian suppliers in order to boost emergency stocks in the region, while 20,000 kitchen sets are being diverted to Pakistan from UNHCR's regional stock in Dubai.

Pakistan UNHCR staff in Pakistan have prepared an initial emergency needs assessment to address the immediate survival needs of up to 100,000 Afghans. Some 15,000 have already arrived in the country. 


\section{$K_{\text {HYBER }} M_{\text {AIL }}$ saturday, September 22, 2001 Pushtoon population to join if war}

imposed on Afghanistan: Aslam Beg

Former Chief of Pakistan Army, Generalv (Retd) Aslain Beg says the Pushtoon population of Pakistan, from Balochistan to the NWFP, will join the Afghans if a war is imposed on them.

In an interview with $B B C$, he said that the Pushtoon in these two provinces have historic and traditional blood relationship with the Afghans. "They will not remain silent. So, the situation is not favourable for Afghanistan, Pakistan and the regional stability", he added.

Referring to the situation in the country, he said that protests have begun against not only government's decision but also against the expected US aggression and it will gain momentum. "Two elements will be part of this protest, the Jehadi group opposed to the US aggression and the Pakistani young generation, which is enraged. If you have gone through the
CIA report, the same people are here as well. They are unemployed and in rage and are against such kind of aggression. These are like the same 18 people, who decided to commit suicide and mounted attack on Washington and New York. These people were not linked to some terrorist or radical organization. These were educated youth, which, are in deep rage" Aslam Beg observed.

Referring to Pakistan decision to support the United States, he said "by exerting pressure, the United States made Pakistan accept in help in any action, Washington wants to take against Afghanistan. It (Pakistan) will allow use of its air space, provide logistic support and exchange information. It means that the US wants to replace Taliban with some new people, more moderate and responsive. Pakistan has averted the pressure and the dangers by accepting this. Otherwise,
Pakistan, particularly its nuclear and military installations would also be a target, in which India and Israel might also join," he said.

He said that the instant danger to Pakistan's security has been averted. However, the danger in Alghanistan is more serious. When the war begins in Afghanistan not only the people of that country would be involved. There is an intention of imposing an organized war on Afghanistan, which the United States has already expressed. But, what I am secing is that what has left in Alghanistan, which they want, to damage. The country is already destroyed, its infrastructure has been perished. The people are hungry, ill and are flecing their houses. But certainly their might is vested in the Mujahideen, the Taliban, who are fighting for last five years, who have the experience in war and they are ready to confront every danger.

\section{Pakistan averted pressure by accepting US demands: Hameed Gul}

ISLAMABAD (NNI): Former Chief of ISI and a leader of Council for Defence of Afghanistan L.t. General (retd) Hameed Gul is of the view that Pakistan's decision to support the United States against terrorism was made under duress.

In an interview with $\mathrm{BBC}$, he said "I believe that a clear threat has been given to this government that you have only two options, either yes or no. You are either our friend and if you don't accept our order, you are our opponent".

"Instead of facing the blackmail, the leadership decided to accept their demands. But, when you accept the first demand of a blackmailer, his demands become longer and longer. After this decision, the problem before the nation is that if the support is limited to. provision of intelligence support, share information, provide airspace and logistics, then it is o.k, but if they demand bases and try to involve Pakistan in the attack directly or indirectly, I believe it will be destructive for Pakistan. Secondly, no details of the loose term of logistics have been given" Hameed Gul remarked.

To a question of past support to Taliban through ISI, he said at that time, we had our own objectives. "There is some difference that when Soviets and invaded Afghanistan, there is no doubt that Americans supported Afghans. When General Ziaul Haq had decided to support Afghans, the United States was not there. Washington had joined it after a year. But at that time, this decision was taken by Pakistan itself to protect its interests. There is no doubt that later the whole West stood by us and used as a frontline state. Therefore, this decision cannot be linked to that decision," he added. 


\section{The Statesman saturday, September 22, 2001}

\section{Give the Afghan people hope}

Ahmed Rashid

\section{$\mathrm{T}$} This is a moment of despair for Afghans and their country - a 22 country that has been at war for 22 years. Tens of thousands are fleeing Kabul and Kandahar to escape expected U.S. bombing, while the humanitarian crisis has worsened with the pullout of all international relief agencies. Senior U.S. officials need, at the very least, to make it clear to the American people and the world that America is not at war with Afghanistan and Afghans.

This can in fact be a moment of hope, if the United States and its allies are prepared to remain engaged in Afghanistan and the region once the military action is over. But the U.S. record on this count is not good. The United States walked away from Afghanistan in 1989, after the withdrawal of Soviet troops from that country. Washington allowed two allies, Pakistan and Saudi Arabia, to run with their own proxies - first Gulbuddin Hekmatyar, who destroyed most of Kabul with rocket attacks in 1993, and then the Taliban. Iran, Russia, India, Turkey, Uzbekistan and Tajikistan backed other factions, thus ensuring that the civil war, fueled so heavily by out-
siders, would continue.

The United States has failed to give adequate political support to successive special representatives of the

U.N. secretary general who for the past decade have been trying to make peace in that blighted land. In 199496, the Clinton administration supported Pakistan and Saudi Arabia's military and financial aid to the Taliban. The mood changed in Washington only after Osama bin Laden arrived in Afghanistan in 1996 and Hillary Clinton and Madeleine Albright were deluged with appeals from American women's organizations concerning the Taliban's treatment of Afghan women.

U.S. policy shifted slightly - not it appears, because Washington had evolved a strategic vision for the region or because the Taliban were giving sanctuary to extremist groups from a dozen different countries, but because the Clinton administration was facing domestic criticism from such as Jay Leno. The Clinton administration's focus was never on making peace in Afghanistan but on apprehending bin Laden - as if that alone would resolve the problem of the international network and the 3,000 Arab fighters in Afghanistan who fight for the Taliban and have committed horrendous atrocities against

Since January the Bush administration has been promising a new Afghan policy that would not revolve around Osama bin Laden. But it was

repeatedly delayed as Afghanistan again slipped off the radar screen in the White House. Meanwhile, the U.S. media continue to be marked by a lack of introspection, debate and criticism of a decade of failure in U.S. policy on Afghanistan. To be sure, credit must

be given to many mid-level U.S. officials who understood this failure, but they were never able to convince their superiors that Afghanistan was important enough to care about.

The fear now is that U.S. military action could cause the region to unravel, with Pakistan and the Central Asian republics dissolving into chaos and economic meltdown, while public support increases for an fundamentalist takeover of these states. Such dangerous consequences can be averted if Washington remains engaged after the war and uses the international coalition it is now building to force the pace of a peace settlement inside Afghanistan and a new government of national unity.

The U.S.-led international alliance needs to give strong political backing to the United Nations' special representative, Francesc Vendrell, who has been trying to help the Afghans form a new government. The alliance also needs to pledge now, rather than later, a substantial sum for the reconstruction of Afghanistan. That would do much to strengthen the U.N. political efforts, strengthen the anti-Taliban Afghans who want an equitable peace settlement, demonstrate the U.S. long- term commitment to an Afghan peace and convince Afghanistan's neighbors that there will be economic benefits to them if they stop meddling.

Most important, the U.S. military campaign should not be left solely to the Pentagon. It must have a strong political component so that as the military campaign continues, anti-Taliban Afghan groups are encouraged to form an alliance under the leadership of the Loya Jirga, or tribal council, which is being put together by former King Zahir Shah. The U.S. military can provide air cover to these Afghan forces as they mop up Taliban and bin Laden forces. There will also be thousands of defections from Taliban ranks, and it is critical that they have somewhere and someone to defect to: Afghan forces on the ground, not American troops.

But once the military campaign is over, will the Bush administration have the stamina and interest to sustain Congress and the American people's support long enough to help construct and support a new government in Kabul? Or will the United States walk away once again, leaving Afghanistan in another civil war and the neighbors back in the business of propping up proxies?

The Bush administration needs to spell out its intentions now in order to give the Afghan people some hope.

The writer is the author of "Taliban: Militant Islam, Oil and Fundamentalism in Central Asia." The Washington Post 


\section{The Nation}

\section{War clouds over Kabul}

While addressing a joint session of the US Congress on Thursday, President Bush turned down the decision taken earlier by the Afghan amounted to an ultimatum, Bush duaded to leave Afghanistan. In what Osama and an ultimatum, Bush demanded that the Taliban hand over fate. His tone was strident leaders present in Afghanistan, or share their and there was no room for negotiation. standing ovation as mood currently prevailing in the US. Whiless indicates the vengeful or at least give prevailing in the US. While the US has still to collect, of at least give out, proof linking Osama prima facie to the terrorist act far pointed to hresident Bush insisted that all evidence gathered so far pointed to his organization. The way war preparations are afoot yet to be seen is whether the is poised for a military operation. What is Afghanistan or places in the targets are limited to vital installations in Osama and or places in the country supposed to be the hideouts of The fatwa comrades, or is of a much wider scope.

The fatwa issued by the Afghan clerics was a polite way of asking their guest to leave so that the country does not have to suffer on his account. While Taliban supporters might regard it as satisfactory, the Recision certainly falls short of what the Security Council required. Resolution.1333 passed by the Council on December 20 and reiterated by it a few days back, had expressly demanded that the Taliban turn over Osama to one of the three clearly specified parties; the appropriate authorities in a country where Osama has been indicted, the appropriate authorities in a country where he will be returned to the country of indictment, or to appropriate authorities in a country where he will be arrested and effectively brought to justice. While the Security Council members unanimously support the demand that the Taliban hand over Osama for trial, it is yet to be seen if all of them would endorse military strikes undertaken by the US. Some of the countries, including France, China and Russia want the UN to play an active role in coordinating a global effort to fight terrorism. While they do not rule out the use of military force in principle, they recognise that the menace of terrorism can best be addressed through long-term diplomatic and economic measures by the world community at large.

No Muslim country, including Pakistan, has so far agreed to give unstinted support to the US while it attacks Afghanistan. Muslim countries, particularly the Arabs, want the US to stop Israel from practising state terrorism on the Palestinian people and recognize their right to live in honour in an independent state, before they can join a USled coalition. If the Afghan adventure was to cause many casualties and if the US decided to simultaneously launch military strikes inside certain Middle East countries, the sympathy recently generated for it in the Muslim world could turn into hostility. The response to terrorism must therefore be measured. The aim should be to end the recurrence of such acts, not to satisfy the desire for revenge which characterizes societies still at a primitive stage of development.

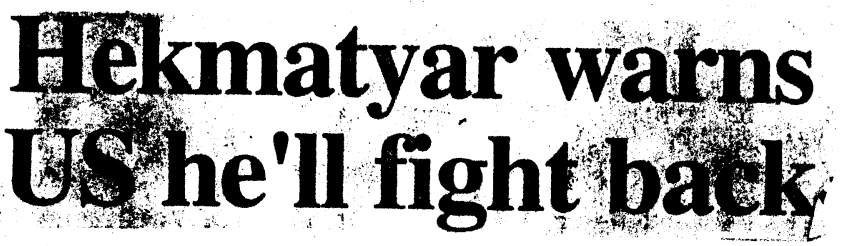

GENEVA (AFP) - Exiled Afghan warlord Gulbuddin Hekmatyar said Friday that he and his followers would take up arms if the

- United States takes military action against Afghanistan following last week's terrorist strikes. them what I'm telling you. Afghanis can never accept a foreign presence in their country," he said.

Hekmatyar, now head of the Hezb-e Eslami group, was prime minister of Afghanistan before the gove I nment of Burhanuddin Rabbani was ousted and replaced by the Taliban in 1996

"Our response will depend on the methods the Americans use in their attack. If they limit themselves to an aerial assault, we will prepare an adequate response. But if they send in ground troops, we'll do what we have to do,"

\section{Hekmatyar said.}

The US has begun deploying aircraft carriers, warplanes and ground troops to regions around Afghanistan, as US President George W. Bush said Thursday that "justice will be done" against prime suspect Osama bin Laden and his Afhgan-based al-Qaed organisation for their alleged role in planning the terrorist attacks of September 11, which may have killed nearly 7,000 people.

Hekmatyar said, however, that he "had no reason not to believe" bin Laden when he denied masterminding the attacks.

A veteran of the war in which Afghanistan drove out one of the world's superpowers in the Soviet Union's "Vietnam," Hekmatyar said he thought the "United States is less well-placed than the USSR was" to fight a war in Afhganistan.

"All regional equations will be changed," he predicted.

"This time, we will clearly see the stance of countries like Iran, China, Russia, :nd Pakistan," he continued.
"We have to defend our country," Hekmatyar told the Swiss daily Le Temps in Tehran, where he has been living in exile for five years.

"The Americans contacted me after the suicide attacks. I told 


\section{Turkey warns against ground troops in Afghanistan}

ANKARA (AFP) - The United States should work to strengthen the opposition in Afghanistan to enable them to overthrow the hardline Taliban regime instead of carrying out a possibly protracted ground operation there, Turkish Prime Minister Bulent Ecevit said on Friday.

$\mathrm{He}$ also said that Turkey, the only Muslim country in NATO, was ready to offer military training to the Afghan opposition, in an interview with the CNN Turk news channel.'Thedeployment of ground troops from outside to Afghanistan turned out to be unsuccessful in the past," Ecevit said.

"A classic military intervention could last for years. New methods, new strategies should be outlined, because the world cannot live with such an intervention for a very long period of time," he added.

"There are opposition groups in the north, but they have so far failed tounite. I think it would be better to envisage a military operation (against the Taliban) on the ground by the Afghans themselves by ensuring their unity," Ecevit said.

The prime minister added that the opposition forces were weak at present and called on the US to help them strengthen their ranks.

"The US has a great duty on this issue... Afghanistan cannot be left with such an archaic regime. This regime should change," he said.

"Turkey cannot send ground troops there, but can provide military training (to the opposition), of course, if they desire so," said the prime minister of this country, which has the second largest NATO army in number after the US.Ecevit expressedhopethat Turkey'ssouthem neighbor Iraq, an arch-foe of the US, would not become a target of the US-led anti-terrorism campaign.

"It will be very dangerous to extend the front and the targets," he warned, adding that the eventual strike in Afganistan should concentrate on "pinpoint targets."

\section{Fridan frimes}

September 21-27, 2001

\section{Options for Pakistan}

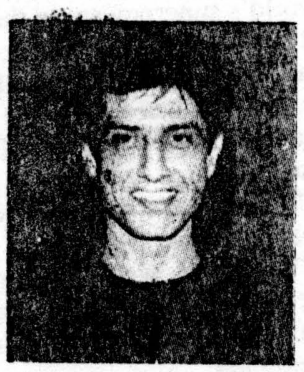

Ejaz Haider

says the

government's

decision does not

offer Pakistan

many choices but

the alternative

could be worse

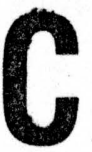

ome crunch time, the proponents of Pakistan's Taliban policy seem to be getting wise. They pushed it ostensibly for "strategic reasons"; they are now prepared to ditch the Taliban ostensibly for other "strategic reasons". Meanwhile, the obvious is being stated every day now - that Pakistan is between a rock and a hard place. But it always was, given its untenable Afghan policy. There was a time when it could calibrate that policy; it did not. Now, it is being coerced into doing that without the same leverage.

Within the given circumstances the government's decision to go along with the United States is correct. This is not because Washing- ton has a solid case against Osama bin Ladin or is intrinsically a higher moral authority but because, plainly speaking, it has the military power to pose a grave danger to $P_{:^{\prime}}$ istan. It is the logic of might.

Any talk of a quid pro quo may therefore be misplaced. Pakistan is in no position to bargain up-front. This is just one of the negative upshots of being so close to the wrong actors in Afghanistan. However, this issue is likely to have a long shelf life and if Islamabad plays its cards right some good may come out of this decision in the longer term.

Expectedly, religious parties have opposed the decision to accept US demands and promised to hot things up for the military government. They may not have the capacity to do so in any sustained manner in an open con- 
frontation, but what happened in New York and Washington could more easily happen in Pakistan. The state has been institutionalising obscurantism, both for reasons of strategy and misplaced ideology, and its fallout may come to haunt it in the future as it grapples with the new geo-strategic realities in the region and beyond.

What was wrong with Pakistan's little imperial game in Afghanistan. Nothing per se if it could have effectively controlled the actors and kept them away from posing a credible threat to bigger players in the league. It failed to do that and now finds itself in a bind. The attacks in the US, more than anything else, bring to light this fact. If Bin Ladin is indeed behind those attacks (for which there is no direct proof if open sources are to be believed) then it is clear that he was doing things that lslamabad did not know about. Whether the Taliban knew of Bin Ladin's capers is anybody's guess; that, in any case, does not matter now. What is, however, known to every Afghanistan watcher is the fact that the militia never cared about Pakistan's sensitivities even as the latter continued to take the flak for their ill-conceived policies. Pakistan never had an Afghan policy; it was passivity at its worst, masquerading as policy.

So, what is in store for Pakistan? First, it must realise that the issue, at least in the shortterm, does not relate to niceties of international law. It is about power projection and Washington has the wherewithal to project power. Whether it will solve the problem of terrorism or whether Bin Ladin indeed is culpable is a

\section{What was wrong with Pakistan's little imperial game in Afghanistan. Nothing per se if it could have effectively controlled the actors and kept them away from posing a credible threat to bigger players in the league. It failed to do that and now finds itself in a bind. The attacks in the US, more than anything else, bring to light this fact}

different debate. In the immediate context therefore Pakistan does not have many options but to play along. That it has done.

Secondly, Pakistan is attempting so far to keep the US focus on Bin Ladin rather than the Taliban. It sent a high-level delegation to Kabul and Kanadahar to impress upon the Taliban that they must give up Bin Ladin. The Taliban have agreed to put the issue to the assembly of Islamic scholars. At worst the militia would refuse to hand him over; at best, they may put conditions, as indeed some reports suggest they have, that the US should give credible evidence of Bin Ladin's involvement before he could be handed over to a neutral country to stand trial.

This may not be acceptable to Washington but any indiscriminate offensive against Afghanistan in the face of flexibility by the Taliban on the main issue will threaten to deprive the US of the moral high ground it occupies because of its civilian casualties. While the attacks have been universally condemned, even the European countries, as also China and Russia, have cautioned the US against acting in haste.

Thirdly, given any such opening, Pakistan would be slightly better placed to insist that the US involve the UN Security Council rather than just invoking article 5 of the NATO charter. There is already difference of opinion within the US on the likely diplomatic and operational approaches to the coming war. While Secretary Powell wants to put together a coalition and keep the campaign focused on Afghanistan, Defence Secretary Donald Rumsfeld is reportedly recommending hitting targets in Iraq and Lebanon also. International pressure on the US to show more discrimination, voiced by China and Russia, is likely to make it that much more difficult for Washington to be indiscriminate. However, the scenario works only on the assumption that the Taliban show flexibility on the issue.

Chances are that will not happen. The militia's intransigence is likely to lead to an offensive against Afghanistan. The US has already got the UNSC resolution 1368 condemning the attacks and calling "on all states to 
bring to justice the perpetrators, organizers and sponsors of these terrorist attacks". Potentially, it can arm-twist the UNSC into giving it a specific resolution under chapter VII. In the face of Taliban's inflexibility it would become that much more difficult for China or Russia to veto such a resolution.

The likely scenario for Pakistan would then be to watch the Americans destroy Taliban power in Afghanistan, most probably with the help of the anti-Taliban elements and install a "neutral" government in Kabul. It will be difficult for the US to flush out Bin Ladin first so they will go after the Taliban before getting hold of Bin Ladin. For that the US will have to commit more troops than some initial estimates suggest. In the event that Taliban supporters in Pakistan decide on fomenting trouble, Pakistan army will have to engage them with some dire consequences.

What does this translate into? Essentially, that Pakistan will have to review its national security policy even as events unfold. Since it failed to calibrate its policies and control the actors under its perceived influence, it will now have to face the same actors as adversaries. This is not a happy scenario but the alternative may be worse.

\section{Interview: Qazi Hussain Ahmed, Amir, Jama'at-i Islami By Wajahat Ali}

\section{"Pakistan should take the Taliban warning seriously..."}

Amir Jama'at-i Islami, Qazi Hussain Ahmed, has opposed Islamabad's decision to support Washington's war against Afghanistan. On September 18, Ahmed addressed a press conference at Mansoora, Jama'at's headquarters and criticised the government for kowtowing to the US. While he condemned the terrorist attacks in New York and Washington, he said that Washington was using the event as a pretext to bring its military presence in the region. Ahmed also pointed out that what has happened has only benefited Israel. TFT spoke with him exclusively to seek his views on the situation. Excerpts:

TFT: You have criticised the government for succumbing to the United States. Does Islamabad have a choice?

QHA: Pakistan should have tried to avoid the U.S. It could have done so by asking for evidence of the Afghan involvement in the terrorist attacks in New York and Washington. It should also have been upfront about its limitations. The popular sentiment in this country is

anti-American. The government should have conveyed it to the U.S. and asked the managers of that country how they expect any government in Pakistan to survive by going against the popular sentiment.

But they haven't done that. Instead, the U.S. handed them a list of demands, which they have accepted in a show of haste. That has not only undermined the sovereignty of this country but also proves the weakness of the military government.
TFT: The US secretary of state, Colin Powell, told a press briefing that the US fundamentally aims at destroying the Al Qaeda network. Do you think a U.S. military offensive against the Taliban will help it do so?

QHA: There are no communication networks in Afghanistan. It can take you months if you want to contact Osama Bin Laden today. If he is behind the terrorist altacks in America, as the U.S. makes us believe, then he must be based somewhere in that country. The U.S. belief that it can destroy Osama by striking at the Taliban is misplaced.

TFT: What will happen if the U.S. commits its ground troops to fighting against the Taliban?

QHA: Exactly what happened to the Sovict Union.

TF T: But the situation was different then.

QHA: Technology and the situation do not matter here. Nothing can change the minds of desperate people. What can technology accomplish 


\section{Fridaz Fimes}

against those bent on carrying out suicidal missions? There are thousands in Afghanistan capable of doing that. And I tell you the same goes for Pakistan as well.

TFT: If the U.S. invades Afghanistan, how long do you expect the war to continue?

QHA: It will be a never-ending war, which might have devastating consequences for the neighboring states.

TFT: What is your take on the Taliban's warning to the neighboring countries?

QHA: That warning should be taken seriously by Pakistan. They will not attack from outside. Their men are within this country.

TFT: So what options are open to the US in Afghanistan?

QHA: We have long maintained that the U.S. should engage the Taliban constructively. It can do so by participating in the reconstruction of that country and stabilizing the political process there. The U.S. must have a long-term policy for

\section{Afghanistan}

TFT: Is that possible after what happened in New York and Washington?

QHA: Certainly. In fact, more so. All it requires the U.S. to do is to change the public opinion there. It will have to tell its people that they are not gods. This can be done if the leadership in that country is truly visionary.

TFT: Is it possible that the Taliban hand over Bin Laden to a third country to revert the war in the making?

QHA: This question should be directed to the Taliban. We don't know the answer to this. What we do know, however, is the U.S. history of ditching its allies. They might go back from here. But we will have to continue living next to Afghanistan.

TFT: Could this war become a clash between the West and Islam?

QHA: We don't want to make it that. Our strug. gle is solely against those perpetrating injustices in the world.

\section{Northern Alliance} hopes to reap benefit of Taliban folly

\section{Iqbal Khattak}

says with the situation in Afghanistan about to undergo drastic change, the Taliban will not be able to take advantage of Masoud's death

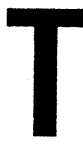

he anti-Taliban commander and Norther Alliance warlord, Ahmed Shah Masoud, was finally buried September 17 in his native Panjshir Valley, bringing the speculation about his death to an end. The Alliance will now be led by Masoud's brother, Wali Shah Masoud, while the Alliance forces are to be commanded by Gencral Fahim, known for being an extremist.

Masoud was assassinated by two Arabs posing as journalists who used the video camera as a bomb while interviewing him at his military base in Afghanistan's Takhar province. While some sources identify the two assassins as a Tunisian and an Algerian, other reports sily they were Mo- roccans. The two Arabs who carried "Belgian passports" had forwarded the request for an interview with Masoud through Abdul Rab Rasool Sayyaf, head of Ittehad-e-lslami, one of the component parties of Northern Alliance.

Some of Masoud's close aicles point a finger at Sayyaf. However, the Ittehad-e-Islami leader vehemently denied his complicity in the plot to kill Masoud in a recent interview with an Arab TV channel. Sayyaf said it was totally wrong to blame him.

An Ittehad source told TFT: "They [attackers] carried a letter from an unknown person to Sayyaf and requested him for help. Sayyuf told Masoud's aides that he did not know the Arab journalists but he knew the person who had sent them." Accord- 
ing to Sayyaf's sources, he (Sityyaf) even told Masoud's security advisers to ensure the bona fides of the two journalists and that they were clean. TFT has learnt that the two Arabs were kept and watched for 20 day's by Masoud's security personnel before they were cleared for the interview.

Apparently, Masoud's security personnel failed to identify the bomb that was hidden in the video camera operated by the assassins and which went off within minutes of the interview. Alliance sources comoborate this view. "Another reason could be that the assissins were walched for 20 days before being cleared. It seems that they were highly trained killers and made no move that could have aroused suspicion," says an insider.

Some sources allege that Sayyaf, a Wahhabi commander, might be acting at the behest of $\mathrm{Rj}$ yadh. "He was always very close to Riyadh but fell out with his mentors after the rise of the Taliban. Maybe, there is something for him in this," says an insider.

Masoud is the second Afghan leader to be killed by Arabs after Maulvi Jamil-ur-Rehman was shot dead by Abdullah Roomi, an Egyptian, at his home in Bajaur Agency in Pakistan's North West Frontier Province. The Matulvi's bodyguards killed the assassin on the spot.

Similarly, an unknown Arab attacker's bid was foiled when he attempted to stab the Rome-based exiled former Afghan king Zahir Shah in 1995, a year before the Talihan took over Kabul in September 1996. The attacker was arrested but no details of his motive have been released so far.

Former President Burhannuddin Rabbani, leader of Jamiat-e-Islami has accused Pakistan and the Taliban of getting Masoud assassinated. Northern Alliance sources say the Taliban estimated with some accuracy that Masoud's death could cause the Alliance to fall apat or at least become weakened.

However, the September 11 events in the US seem to have changed the hue of the game and now the Taliban are under threat of an attack by the US. The Nothem Alliance commander General Fahim has already announced that his 15,000-strong army is prepared to fight on the ground against the militia in case of a multi-national attack on the Taliban.

"From the anti-Alliance perspective it was good strategy to get rid of Masoud but now the situation has changed. It makes little difference now whether Masoud is dead or alive. The Taliban are on the brink of disaster themselves," an Afghan analyst told TFT.

Masoud never hid his hatred for Pakistan. But his death has brought General Fahim, former intelligence chief, to take charge of the Alliance's military command. Fahim, too, abhors Pakistan and more. He is an extremist. When the Pakistan Enbassy was attacked in Kabul during Rabbani's rule in 1995, Gencral Fahim was Kabul's chief of security and Islamabad was certain that the attack was his handiwork.

But for the changed situation, Masoud's death would indeed be a big shock for the Alliance, which lost several key commanders last year in various campaigns. However, the return of several key military allies, like Uzbek warlord General Dostum and former Herat govemor, Ismail Khan, had strengthened the Alliance this year and Masoud thought he stood a good chance to dislodge the Taliban militia. Now that he is dead, the Alliance sources say they are banking on Washington to deliver following a US allack on Afghanistan. There is also the likeliheod of more cooperation between Fahim and Dostum since the two are considered quite close.

A follower of radical Islamic politics as a young man, Masoud became one of the most successful mujahideen commanders in the fight against the Sovict invasion in 1979. He was appointed defence minister by Rabbani soon after he captured Kabul in 1992. But Masoud was never liked by Pakistan's Inter-Services Intelligence, which thought he was too independent. His Tajik roots also went against him since Pakistan was more interested in wooing the Pukhtun commanders. Masoud was also suspected for his links with the Soviet KGB.

After he captured Kabul, Pakistan-backed groups tried to dislodge him but failed. That crealted further bad blood between Masoud and Islamabad. However, after 1994, things came to a head when Pakistan found out that Masoud was planning terrorist strikes within Pakistan. His men bombed a departmental store in Peshawar, killing more than 200 people, besides hijacking a school bus. The hijackers were later killed and the children released by a team of army's Special Services Group.

Matters came to a head with the rise of the Taliban. The Taliban onslaught brought most of the former mujahideen commanders together under the umbrella of the Northern Alliance, a loose conglomeration of various partics whose troops were commanded by Masoud. Now, with Masoud dead and the Taliban at the brink of disaster, the Northern Alliance hopes to reap the benefit of any international campaign against the Taliban. 


\section{Fridag Fimes september 21-27, 2001}

\section{NWFP tense in face of likely US attack}

Iqbal Khattak says the situation could become explosive in the coming days

W ith US atlacks on Afghanistan imminent, the situation in Pakistan's North West frontier Province is becoming tense with pro-Taliban tribesmen calling for a jihad against the American troops and Pakistan army contingents bracing up for the events ahead.

"Anything can happen," an army officer told TFT at the Shagai Post in the Khyber Agency bordering Afghanistan. "We admit that we are not equipped well to resist the US army in conventional warfare but there is always the option to use guerilla tactics. Also, we have the spirit of sacrifice," Haji Jalil Jan, a provincial leader of the Deobandi Jamiat-e-Ulcma-e-Islam (F) told TFT. The JUI(F) and (S), both Deobandi outfits, are the biggest supporters of the Taliban most of whom have graduated from their seminaries spread throughout Pakistan.

"The Americans will face in Afghanistan what they had suffered in Victnam, this time at a higher scale," a JUI(F) leader told a meeting of the party's cadres.

A senior law-enforcement oflicial told TFT the government had decided to not disrupt the protestors if they kept within the legal limits. "We have already demonstrated this by allowing peaceful protest rallies and demonstrations. But certain parameters cannot be allowed to be crossed," he said.

However, a source close to one of the proTaliban elements told TFT that anti-US sentiments would be sparked in a manner that could shock the government. "If the government moves ahead with its decision to oblige the Americans we will retaliate with force," he warned.

He refused to give details of the plan but said that the reaction to the US attack on Afghanistan would be quite explosive.

Most political analysts agree that the situation could get bad since the US strikes would not only aim at eliminating Bin Laden but would also seek to remove the Taliban militia, which controls 95 percent of that country's territory. "Threat to the Taliban is a threat to their several close allies in Pakistan, mainly Islamic groups. They will be fighting a battle of survival," political analyst Afrasiab Khattak told TFT.

Experts agree that the situation poses grave in- ternal danger to Pakistan. The Taliban's move to take positions along the Afghanistan borders to threaten any neighbour that may provide air and ground facilities to the Americans is a clear signal of what could be in the offing.

A visit by TFT to Torkham revealed unusual mobilization and deployment of paramilitary forces of the Khyber Rifles in and around the border check-post. "The Taliban have positioned their anti-aircraft guns towards Pakistan," a senior officer of the Khyber Rifles told TFT. "We are trying to avoid a confrontation," he added.

So frightened were the Pakistani security personnel of the Taliban's reaction at Torkham that they kept asking the foreign media to not take pictures of the Taliban soldiers on the other side of the border.

TFT's tour of the Khyber Agency revealed rising anti-US feelings. "Tribesmen regard Afghanistan as their second mother country and then their is the bond of Islamic solidarity," a tribal chieftain in Landikotal told TFT.

Afghanistan's terrain, says a Pakistani military strategist, may cost the US dearly in terms of human losses. "The terrain in Afghanistan is very tricky. While Americans will have satellite information, physical reconnaissance is very important before landing troops," a Pakistan army officer said, adding: "That is where the Americans will rely on Pakistan."

Meanwhile, reports indicate that confused Afghans continue to leave major cities, mainly heading for rural areas in the country. Yusuf $\mathrm{Ha}-$ san, a spokesman for the UNHCR in Islamabad, told TFT that some 5,000 Afghans were reportedly massed at the Chaman border in Balochistan. "Population movement out of Afghanistan's principal cities of Kabul and Kandahar is continuing, with residents leaving mainly for surrounding rural areas.

However, transportation is now reportedly difficult to obtain. Over the past days, tens of thousands of people have been on the move, mainly traveling from cities into rural areas of the mountainous country to escape the American bombing.

In the western city of Herat, the atmosphere is tense and residents are in the dark about what is happening. 


\section{Fridga fimes September 21-27, 2001}

\section{American military} options in Afghanistan

\section{Rodney W. Jones}

says circumstances today provide Pakistan a better opportunity than has been available at any point in the last 12 years to turn this corner with the revival of support that would be inherent in positive cooperation with the United States, Europe and Japan

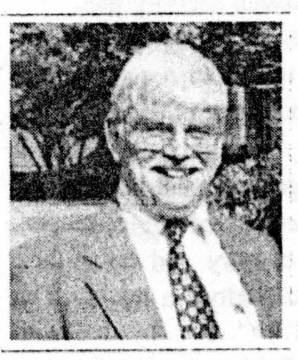

While Americans continue to grieve the lives lost in the September 11 suicide atlacks, the United States is also pulling itself together to launch, along with allies and friends, a war against international terrorism. The Americin public debate clearly shows that the US military response will be discriminating and focused on terrorists, their protectors, and those who knowingly assist them. It will

- not target whole societies or countries, and certainly not Arab or Muslim countries per se. It will not shy away, however, from using deliberate self-defense against those who have harbored or made excuses for terrorism.

Quick FBI tracing of passenger manifests identified names of the hijackers, revealing roots in the Middle East. Other information links some of them to Al Qaeda and Osama Bin Laden-who the Taliban gave sanctuary in Afghanistan. But informed Americans know that the attacks on Americans were not acts of the Muslim ummah. They know that authentic Islamic representatives around the world have denounced the slaughter of Americans as antithetical to Islam.

Informed Americans are also clear that engaging in a focused war against international terrorism is not war on Islam. Nor is it war between civilizations. Indeed, rooting out and neutralizing those who slaughter innocents is an essential basis of all civilization. Muslims who recognize the same distinctions will find a common cause against barbarism, fanaticism, and violence against humanity.

Any rational discussion of options for the use of force against terrorist networks in the Middle East in general, or Afghanistan in particular, depends on these distinctions and perspectives. Obviously, the most efficient use of force related to Afghanistan would depend operationally on Pakistan's cooperation and territory.

Fortunately, Pakistan has unequivocally denounced the acts of terrorism and chosen to cooperate with the US and other countries opposing the scourge, acting under United Nations imprimatur. Reportedly, Uzbekistan and India have also offered support to the US and UN operations against the terrorist networks in Afghanistan.

What do requirements for the use of force in land-locked Afghanistan look like? What would be the respective benefits of success? And what would be the downside consequences? Being once again in the front line, these issues matter profoundly to Pakistanis, as well as to Americans.

Near term and long term requirements may be somewhat different, and, against international terrorism, a long-term perspective is crucial. Osama Bin Laden's Al Qaeda is but one of a number of terrorist organisations and the September 11 events probably involve other networks. Magnified by media coverage, Bin Laden has become a symbol and inspiration for Middle East terrorists, but eliminating him and his immediate circle may only be the beginning.

Thus, the long-term requirements demand patience, intelligence penetration, interdiction, communications disruption, and new, non-military measures that dry up the financial resources available to long-distance terrorists. More broadly, 
diplomatic resolution of regional conflicts and political and economic programs will be needed that drain the swamps of despair and desperateness that breed recruits for terrorist organisations.

Pakistanis and the Taliban have correctly sensed that American rage may require a highly visible form of punitive retaliation and retribution-acting without delay, while memories are still fresh and uncluttered by vitriolic propaganda. This could occur in the near term and might take the form of bombing targets inside Afghanistan,

and conceivably ground assault as well. To prepare for such an eventuality, the US has already begun to move constellations of naval and naval air forces into the Arabian Sea.

These preparations are also vital in the short run as demonstrations of resolve. Terrorist leaders, unfortunately, do not fear their victims' resolve and may actually welcome the application of force. It enhances their visibility and plays to their political agendas of instigating instabilitysuch is their contonted mindset. But demonstrating resolve sends messages to those who run governments and social institutions, and who know that their authority could be shaken or their constituents could suffer collateral damage if major military intervention occurs. It may be understood as a message to cooperate or get out of the way. Cooperative tasks have a better chance of succeeding and in minimizing collateral damage. Fortunately from America's perspective, that seems to be the path most Pakistanis will support.

How much military force is ultimately deployed or used in attack will depend on the degree to which well-placed government leaders and political organisations use their influence to curtail or remove terrorist freedom of action and access to resources. The Taliban was nurtured in, and has been supported by Pakistan. Thus, Pakistani cooperation could be indispensable to the efficiency of any US or multinational operation against the terrorists whom the Taliban have given sanctuary in Afghanistan.

In this case, step one has been the Pakistan-led attempt to persuade the Taliban to extradite Osama and his associates, and to shut down terrorist training camps in Afghanistan. Pakistan's quick ac-

tion to close its borders with Afghanistan to the flow of trucks and key commodities, particularly gasoline, is a sign of its own resolve. Standing up to the Taliban threats takes courage, not because the Taliban could invade Pakistan-they are too poorly armed for that, but because their ethnic compatriots in Pakistan could rebel, inflict terrorism in Pakistan's crowded cities, or possibly even revive the old specter of Pushtun separatism in Pakistan's northwest frontier province.

There are signs that the Taliban are looking for an exit from confrontation as tens of thousands of Afghans vacate cities and towns and seek sanctuary in Pakistan. There is little doubt that Pakistan's efforts to get the Taliban to regurgitate Bin Laden and company carry some weight. But the Taliban leaders have also adopted extraordinarily intransigent positions, ultimately self-defeating and inhumane for most of the Afghan populace. Their conditions for extraditing Bin Laden to another Islamic state, for trial by Islamic law, are unlikely to be feasible. If they continue to stonewall, what then?

There are basically three forms of US (or multi-

national) military intervention that could occur, theoretically. In descending order of visibility but perhaps ascending order of effectiveness, these are: (1) long-distance air bombardment from the sea, or from bases in Central Asia or India; (2) mobile ground and conventional air force operations from vantage points in Pakistan and possibly also from Uzbekistan; and (3) covertly prepared commando operations, based on close cooperation with Pakistan's military services and intelligence institutions. Variations on these could be imagined, depending on potential cooperation with other powers, notably Russia. Each of these will cause the US negative political reverberations in Muslim countries, but the penalties probably will be least for operations that succeed quickly, or, if they must be sustained, that are least visible.

Long distance bombardment from the sea (or Diego Garcia) is feasible, though the distances are great, requiring in-air refueling, especially for naval aircraft. Kabul is about 700 miles from the Arabian Sea coast, for instance, and even Kandahar is nearly 500 miles from the sea. Such operations probably would be 
ineffective in extracting Bin Laden or suppressing the Taliban, and would only spread more misery in that sad, wartom country. There are few targets in Afghanistan that could be attacked and attacking then probably would not force Taliban accommodation. It might set back Taliban efforts to win military control over the whole country, and increase the chances that the northern ethnic and linguistic groups could recover and force an intemal political settlement.

If such operations were sustained for a long period of time, they would expend large quantities of consumables, fuel and ordnance. This approach would, however, depend less on Pakistan, other than for overflight rights and intelligence cooperation. It would mean fewer Americans at risk from domestic terrorism on Pakistan's soil.

Long-distance hombardment from air bases in Central Asia or India might be more efficientAmritsar is only 380 miles from Kabul, for instance, and in-air refueling would not be as crucial. Looking north, Termez to Kabul is a little more than 200 miles, and to Kandahar about 400 , better than India on air distance, but probably far more difficult to transport and concentrate supplies logistically for staging purposes. Needless to say, air bombardment from bases in India, especially with Indian participation, would be nervewracking for Pakistan, since it would mean overflying nuclear-sensitive areas.

Option two, mobile ground and conventional air forces operating from facilities in Pakistan, could provide much greater leverage, potentially, in getting Afghans to expel terrorist organisations. It would be technically possible, for example, to

occupy a bridgehead of territory around Kandahar in Afghanistan, using Karachi as the point of entry and bases near Quetta as a neirby staging point for paratroops and helicopters, reinforcing the first wave in Kandahar quickly by land as well as air. Kandahar is only about 125 air miles from Quetta, and connected by a paved road. American planners would be determined never to get caught in a
Dien Bien Phu-like situation (this could be a higher risk in mountain-ringed Jalalabad or even Kabul). But Kandahar is on a high, almost treeless plateau, with good visibility over long distances. Once US troops were ensconced at the airport with well-prepared perimeters and sensors, Taliban attackers would be relatively exposed to detection and counter-attack by light tanks and mortars, as well as helicopters. This tactic would hold, fortify, and thoroughly defend a very small section of Afghanistan, use attrition patiently to wear down the Taliban, and provide incentives for the ordinary population to turn against the Taliban. Combined with other support to the northern opposition, this approach would squeeze the Taliban politically, and probably convince them to offer up Osama Bin Laden.

This approach would not be casualty-free, and morale would be hard to sustain for troops in such primitive conditions for many months. The logistical train would have to deal with near desert conditions, perhaps bringing in drinking water over long distances. But this sort of operation would also be resistant to surprise or defeat, and relatively easy to extricate once the mission had been accomplished. Having major US forces stage through Pakistan would be possible only with strong government support, however, and carry significant risks of attack from domestic terrorists and public backlash. It would be easier to justify in the region, however, than heavy, long-distance bombing.

The third approach would require far more operational sophistication, special forces, and positive cooperation by Pakistan. Commando forces would be much smaller and far less visible within Pakistan. They would not seek to hold territory in Afghanistan. With good intelligence, however, they would strike quite precisely and strategically against hostile leadership and terrorist organisations.

It is quite obvious that Pakistan could pay a high price for hosting major US forces on its territory that operate against terrorist organisations in Afghanistan. Pakistani authorities have viewed the Taliban as a congenial means of imposing order in Afghanistan, snuffing out the fructiousness and chronic civil warfare. They have assumed that the Pushtun-dominated Taliban would be, if it achieved power in Afghanistan, the least threatening neighbor for Pakistan-disabled by its dependence on Pakistan from reviving the separatist issue.

Time has not worked otherwise in Pakistan's favor since the Soviet withdrawal ended the Afghan guerilla war in 1989. Weak political governments and endemic corruption have sapped the political system and retarded the economy. Islamic extremism has spread more easily within Pakistan during this period, partly because of the struggle over Kashmir and partly because secular educational 
and employment opportunities have not grown fast enough to keep pace with population increases. The Afghan refugee problem has also remained a special burden. Pakistan's road has been hard. American attention over the last ten years was limited, and US sanctions had an embittering effect. Experts who have stayed in touch with $\mathrm{Pa}$ kistan know it has had bitter pills to swallow.

There is no question that taking on terrorism that wears an Islamic mask poses political risks of ungovernability to Pakistan. One must ask, however, what the fundamental question for Pakistan's future is. Is it that Pakistan's stability is at risk from the consequences of an explicit war against terrorism? Or is it that Pakistan wil! only resume its economic modemization and restore its vision of a better future by taking its own stand against extremist forces in society and the neighboring region? Circumstances today provide a better opportunity than has been available at any point in the last 12 years to turn this corner with the revival of support that would be inherent in positive cooperation with the United States, Europe and Japan.

Dr Rodney W. Jones is President of Policy Architects International in Reston, VA. He is an expert on nuclear security issues who has lived in both India and Pakistan and published extensively on South Asia

The New York Times

Saturday September 22

\section{U.S. Puts Afghan Strike Ahead of Full Plan}

\section{By DAVID E. SANGER and ERIC SCHMITT}

A senior Bush administration official said that the "initial phase" of the assault on terrorism would be aimed at Osama bin Laden and his network in Afghanistan.

WASHINGTON, Sept. 21 A senior Bush administration official said today that the "initial phase" of the assault on terrorism would be aimed at Osama bin Laden and his network in Afghanistan, but that the scale and timing of the next, broader phase had yet to be worked out.

President Bush will sign an executive order identifying specific terrorists and terror groups, and freezing assets in the United States beyond those already covered by existing measures, another senior official said. That document, the official said, would provide a road map of the terrorist groups that could be targeted over the medium term.

At the president's meeting with his security team at Camp David last weekend and in subsequent meetings in the White House, the administration official said, there was "broad agreement" that the first assaults had to be narrowly focused on the terrorists believed responsible for the attacks on the World Trade Center and the Pentagon on Sept. 11.

But the official acknowledged that there was still debate about how to conduct the next phase of the assaults, which could involve attacks on states that sponsor terrorism, unless in coming weeks they accepted Mr. Bush's invitation to come over to his side of what he has painted as a global war against terror. 
"This is such a broad war on terrorism that you couldn't do everything at once," the official said.

The officials' description of Mr. Bush's immediate goals came as the Afghan leadership rejected his demand, made in a speech to Congress on Thursday night, immediately to turn over Mr. Bin Laden, his followers and any other terrorists in Afghanistan to the United States and to open their camps to American inspection.

A fourth aircraft carrier group the Kitty Hawk and its 40 attack aircraft and halfdozen accompanying warships left its base in Yokosuka, Japan, today, headed for an undisclosed location.

Two carriers are already in the Persian Gulf or Indian Ocean, and a third, the Theodore Roosevelt, left Norfolk, Va., this week for the Mediterranean Sea, and possibly points east.

At the Pentagon today, Defense Secretary Donald H. Rumsfeld signed a second deployment order, meaning that nearly 100 bomber and support airplanes are now being sent to the Persian Gulf. About 175 warplanes were already based in the gulf region, primarily to enforce the no- flight zone over southern Iraq.

More than 5,000 reservists have been called to active duty, largely for missions defending the United States, and military officials said today that planners were drafting call- ups that could far exceed the 35,000 reservists Mr. Rumsfeld has requested so far.

" "I think we'll blow right past that," said Lt. Gen. Paul E. Weaver, chief of the Air National Guard. "This is going to be an extraordinarily protracted effort."

Another senior administration official said that before Monday, Mr. Bush would sign an executive order identifying specific terrorists and terror groups, and freezing assets in the United States beyond what was already restricted by the Clinton administration.

Asked about Iraq, which Mr. Rumsfeld and his aides have reportedly pressed to include on the target list, the senior White House official strongly suggested that any decisions on military action against that country would be deferred.

"The president said last night we begin with bin Laden, but it doesn't end there," the official said.

States that sponsor terrorism are to have a chance "to turn over a new leaf," the official said. Iraq, the official added, is considered unlikely to do that.

The official was repeatedly asked if the United States now held evidence specifically linking Mr. bin Laden to the two attacks on Sept. 11. Each response focused on links to Al Qaeda, the loose network of terrorists that Mr. bin Laden leads, but made only tangential reference to $\mathrm{Mr}$. bin Laden himself. 
This is consistent with how other administration officials have dealt with the same question. On Thursday, the deputy secretary of state, Richard L. Armitage, told a closed mecting of NATO ambassadors in Brussels that Washington was not yet prepared to provide allied nations with information pinpointing the culprits behind
the attacks.

Asked at the White House today about the evidentiary trail to Mr. bin Laden, Ari Fleischer, Mr. Bush's spokesman, also talked only about Al Qaeda, but noted that both the organization and Mr. bin Laden were named in indictments for the bombing of American embassies in Kenya and Tanzania in 1998.

Mr. Fleischer suggested that there could be no equivalent of President John F. Kennedy's decision to release photographs of Soviet missiles moving into Cuba in 1962. "The challenge that the government always faces when you ask a question like that 'provide the proof' is the means of providing the proof provides valuable information to those who are the objects of any potential action," he said.

"They would like nothing better than to be able to hide where they are hiding and have the United States reveal what we know and how we know it, which will make it easier for them to hide and will make it easier for them to carry out further actions, if we report our sources and our methods or how we obtain information," Mr. Fleischer said. "We're just not going to do that."

Mr. Bush met with his national security advisers today to review war planning and the administration's efforts to rally international support around the war against terrorism. He plans to speak with his national security team again on Saturday by video conference from the presidential retreat at Camp David, Md., a National Security Council spokesman said.

The deployment order that Mr. Rumsfeld signed today sends additional bombers and support aircraft, as well as maintenance crews, air controllers and security personnel, to the gulf region and Diego Garcia, a British base on an island in the Indian Ocean from which B-52 and B-1 bombers will fly, a senior Pentagon official said.

As the military continued to step up its war footing, the White House said the Defense Department would get about half of the first $\$ 5$ billion installment of the $\$ 40$ billion emergency package Congress passed to respond to the attacks.

The Defense Department will get $\$ 2.55$ billion to upgrade intelligence and security in the aftermath of the stunning attacks, and to bring the military to full readiness. Money will also go toward repairing the damage done to the Pentagon by the hijacked airliner that smashed into it.

Mr. Rumsfeld aleo said he was invoking a rarely used Civil War-era law, the Feed and Forage Act, that allows the military to spend more than Congress has appropriated for clothing, fuel and medical supplies for the armed forces.

In addition, the Energy locpartment said today that it had suspended all shipments of nuclear materials and nuclear waste because of the terrorist attacks. 
"There is a temporary hold on our shipments," said Joseph Davis, a department spokesman. "We continue to evaluate it on a daily basis."

The department did not cite a specific threat, but there is concern that such shipments are vulnerable. The material, which moves by truck, includes fuel for research reactors and waste from the production of weapons.

\title{
Guardian! Initod
}

Saturday September 22,2001

\section{Threat of US strikes passed to Taliban weeks before NY attack}

\author{
Jonathan Steele, Ewen MacAskill, Richard Norton-Taylor and Ed Harriman
}

Osama bin Laden and the Taliban received threats of possible American military strikes against them two months before the terrorist assaults on New York and Washington, which were allegedly masterminded by the Saudi-born fundamentalist, a Guardian investigation has established.

The threats of war unless the Taliban surrendered Osama bin Laden were passed to the regime in Afghanistan by the Pakistani government, senior diplomatic sources revealed yesterday.

The Taliban refused to comply but the serious nature of what they were told raises the possibility that Bin Laden, far from launching the attacks on the World Trade Centre in New York and the Pentagon out of the blue 10 days ago, was launching a pre-emptive strike in response to what he saw as US threats.

The warning to the Taliban originated at a four-day meeting of senior Americans, Russians, Iranians and Pakistanis at a hotel in Berlin in mid-July. The conference, the third in a series dubbed "brainstorming on Afghanistan", was part of a classic diplomatic device known as "track two".

It was designed to offer a free and open-ended forum for governments to pass messages and sound out each other's thinking. Participants were experts with long diplomatic experience of the region who were no longer government officials but had close links with their governments.

"The Americans indicated to us that in case the Taliban does not behave and in case Pakistan also doesn't help us to influence the Taliban, then the United States would be left with no option but to take an overt action against Afghanistan," said Niaz Naik, a former foreign minister of Pakistan, who was at the meeting.

"I told the Pakistani government, who informed the Taliban via our foreign office and the Taliban ambassador here." 
The three Americans at the Berlin meeting were 'Tom Simons, a former US ambassador to Pakistan, Karl "Rick" Inderfurth, a former assistant secretary of state for south Asian affairs, and Lee Coldren, who headed the office of Pakistan, Afghan and Bangladesh affairs in the state department until 1997.

According to Mr Naik, the Americans raised the issue of an attack on Afghanistan at one of the full sessions of the conference, convened by Francese Vendrell, a Spanish diplomat who serves as the UN secretary general's special representative on Afghanistan. In the break afterwards, Mr Naik told the Guardian yesterday, he asked Mr Simons why the attack should be more successful than Bill Clinton's missile strikes on Afghanistan in 1998, which caused 20 deaths but missed Bin Laden.

"He said this time they were very sure. They had all the intelligence and would not miss him this time. It would be aerial action, maybe helicopter gunships, and not only overt, but from very close proximity to Afghanistan. The Russians were listening to the conversation but not participating."

Asked whether he could be sure that the Americans were passing ideas from the Bush administration rather than their own views, Mr Naik said yesterday: "What the Americans indicated to us was perhaps based on official instructions. They were very senior people. Even in 'track two' people are very careful about what they say and don't say."

In the room at the time were not only the Americans, Russians and Pakistanis but also a team from Iran headed by Saeed Rajai Khorassani, a former Iranian envoy to the UN. Three Pakistani generals, one still on active service, attended the conference. Giving further evidence of the fact that the Berlin meeting was designed to influence governments, the $U N$ invited official representatives of both the Taliban government in Kabul and the anti-Taliban Northern Alliance. Dr Abdullah Abdullah, the Northern Alliance's foreign minister, attended. The Taliban declined to send a representative.

The Pakistani government took the US talk of possible strikes seriously enough to pass it on to the Taliban. Pakistan is one of only three governments to recognise the Taliban.

Mr Coldren confirmed the broad outline of the American position at the Berlin meeting yesterday. "I think there was some discussion of the fact that the United States was so disgusted with the Taliban that they might be considering some military action." The three former US diplomats "based our discussion on hearsay from US officials", he said. It was not an agenda item at the meeting "but was mentioned just in passing".

Nikolai Kozyrev, Moscow's former special envoy on Afghanistan and one of the Russians in Berlin, would not confirm the contents of the US conversations, but said: "Maybe they had some discussions in the corridor. I don't exclude such a possibility." 
Mr Naik's recollection is that "we had the impression Russians were trying to tell the Americans that the threat of the use of force is sometimes more effective than force itself".

The Berlin conference was the third convened since November last year by $\mathrm{Mr}$ Vendrell. As a UN meeting, its official agenda was confined to trying to find a negotiated solution to the civil war in Afghanistan, ending terrorism and heroin trafficking, and discussing humanitarian aid.

Mr Simons denied having said anything about detailed operations. "I've known Niaz Naik and considered him a friend for years. He's an honourable diplomat. I

didn't say anything like that and didn't hear anyone else say anything like that. We were clear that fecling in Washington was strong, and that military action was one of the options down the road. But details, I don't know where they came from."

The US was reassessing its Afghan policy under the new Bush administration at the time of the July meeting, according to Mr Simons. "It was clear that the trend of US government policy was widening. People should worry, Taliban, Bin Laden ought to worry - but the drift of US policy was to get away from single issue, from concentrating on Bin Laden as under Clinton, and get broader."

Mr Inderfurth said: "There was no suggestion for military force to be used. What we discussed was the need for a comprehensive political settlement to bring an end to the war in Afghanistan, that has been going on for two decades, and has been doing so much damage."

The Foreign Office confirmed the significance of the Berlin discussions. "The meeting was a bringing together of Afghan factions and some interested states and we received reports from several participants, including the UN," it said.

Asked if he was surprised that the American participants were denying the details they mentioned in Berlin, Mr Naik said last night: "I'm a little surprised but maybe they feel they shouldn't have told us anything in advance now we have had these tragic events".

Russia's president Vladimir Putin said in an interview released yesterday that he had warned the Clinton administration about the dangers posed by Bin Laden. "Washington's reaction at the time really amazed me. They shrugged their shoulders and said matter-of-factly: 'We can't do anything because the Taliban does not want to turn him over'." 


\section{LOS ANGELES}

September 23, 2001

\section{Sand Trap}

Indiscriminate bombing of Afghanistan would play directly into Osama bin Laden's hands.

By ARTHUR SCHLESINGER JR., Arthur Schlesinger Jr.'s most recent book is "A Life in the 20th Century: Volume I, Innocent Beginnings."

NEW YORK -- In his powerful address before Congress last Thursday, President Bush correctly defined the threat of terrorism. And he correctly characterized the motivation of Osama bin Laden, the presumed evil genius of terrorism.

President Bush correctly called for American leadership in a global campaign against terrorism. But he laid down non-negotiable specifications for his "war" that friendly states will consider ill-judged and delivered in a tone they may regard as arrogant.

Our allies have had more experience with terrorism than we have had. They know how difficult it is to eradicate terrorism, even when the terrorists operate in their own countries. The Basque terrorists live in a relatively confined space in northwestern Spain, but Spanish governments have tried and failed for 25 years to stop their outrages. The Corsican terrorists live on an island, but they continue to defy all efforts by the French authorities to stamp them out. The British could not stop Irish Republican Army bombings in England; nor, now that the IRA has abandoned terrorism, can they stop bombings by the thugs who style themselves the "Real IRA." There is no knock-out blow against terrorism. Does our president really understand what he is getting us into? President Bush believes he knows how to deal with terrorists in a part of the world in which we have had meager historical experience and small operational knowledge. He should have asked himself what Bin Laden would wish us to do next. What American response would best serve the villain's purposes?

The answer surely is indiscriminate American air attacks on Afghanistan, killing large numbers of innocent people. Bombing is not likely to eliminate Bin Laden and his crowd, who have well-prepared hideouts. It would only demonstrate once again the impotence of the American superpower. ('ivilian casualties would confirm Bin Laden's thesis of an evil America, push even moderate Muslims toward hatred of the United States, produce a new generation of suicidal bombers for Al Qaeda, Bin Laden's terrorist network and incite radical Muslims to rise against moderate regimes. 
The only thing that would probably please Bin Laden more would be an invasion by American ground forces. Afghanistan is famous for its unconquerability. The s. British Empire and the Soviet Union failed in their efforts to dominate the country, and they at least knew the rocky terrain and had people who spoke the languages. American troops in Afghanistan would be even more baffled and beset than they were a third of a century ago in Vietnam.

There is, in addition, the land-mine problem. According to Robert Fisk, Middle Eastern correspondent for The Independent in London, Afghanistan contains onetenth--more than 10 million--of the world's unexploded land mines, laid by the Soviet Red Army in 27 of 29 provinces. Two dozen Afghans are blown up every day.

Moreover, by November freexing weather will arrive, and the Pentagon has no hope of dispatching troops and winning the war in the six weeks remaining before winter comes to Afghanistan. Nor could an invading American army count on serious assistance from the internal anti-Taliban resistance, their most effective leader, Ahmed Shah Masoud, having been assassinated shortly before the assault on America.

But President Bush is not confining his attentions to Afghanistan. He seems to be contemplating confronting much of the Arab world. "Either you are with us," he said, "or you are with the terrorists. From this day forward, any nation that continues to harbor or support terrorism will be regarded by the United States as a hostile regime." That sounds like the "ending states" and "regime change" talk of Paul D. Wolfowitz, the deputy secretary of Defense and the most high-flying of hawks.

Does this mean that, after Afghanistan, we will be taking on Iraq, Iran, Syria, Libya? And though the president correctly distinguishes between the moderate and the militant Muslim states, this hard line will make life considerably more difficult for the moderates in Egypt, Jordan and Pakistan.

Little is more vital in the months ahead than retaining the support of moderate Muslim states. President Bush has set an admirable example by visiting a mosque and condemning attacks on American Muslims. Islam has historically been a tolerant faith. Mohammedans ruled Spain for five centuries, during which Spain was culturally more advanced than the rest of Europe. Muslims coexisted cheerfully with Christians and Jews. Most moderate Arab states have fragile regimes threatened by radicals within. It is essential that we take no drastic actions that would please our own firc-eaters but would drive Arab states into the arms of the terrorists.

The Harvard political scientist Samuel P. Huntington wrote a provocative article in Foreign Affairs some years ago forecasting a "clash of civilizations" that would determine the future. The Bush administration has no greater challenge than disproving Huntington. If we let the international police action against terrorism 
degenerate into a civilizational war of the West versus Islam, we are heading toward catastrophe. The last thing we need is a counter-jihad to respond to the jihad invoked against us by the pals of Bin Laden.

Bin Laden has set a trap for the United States. Let us not walk into it. It is hard to think of a drastic action taken at once that would not rebound against us. The quest for a knock-out blow is an illusion. We must pray that the president's tough talk will work. But, as President John F. Kennedy said during the Cuban Missile Crisis, it is "one hell of a gamble."

If he wants to win the gamble, our president had better take more care with his language. As Calvin Coolidge put it, "One of the first things a president has to learn is that every word he says weighs a ton." When Bush spoke of wanting to capture Bin Laden "dead or alive," he no doubt pleased his domestic audience, but he sent a chill through the chancelleries of our allies already fearful of "cowboy diplomacy." When he spoke of organizing a "crusade," he angered Middle Easterners who still harbor ancient resentments of the Crusaders. His persistent use of the word "war"

recalls Harry $S$. Truman's preference in the Korean War for a more appropriate term--"police action." The terrorists are criminals; we should not bestow on them the dignity of a sovereign :tate. "Police action," not "war," is what we should be talking about today.

President Bush is everlastingly right in secking an international coalition, as his father did so effectively in the Persian Gulf War a decade ago. If the campaign against terrorism is to sueceed, he must continue along a resolutely multinational course and put together a united international front. We need collective action for several reasons--to confer legitimacy on our response, to divert blame from the United States and to gain counsel from countries that have had far more experience than we have had in dealing with the tortuous polities of the Middle East.

In the short run, the international coalition must pool intelligence in order to avert new terrorist attacks. Using commercial airplanes as missiles is probably finished; biological and chemical terrorism is very likely the next step. The coalition working through the United Nations must also set up global financial controls to stop the covert funding of terrorist operations and global arms controls to stop the arming of terrorists. It is in the interest of governments everywhere to join in the campaign against terrorism. Persons from 80 nations died in the World Trade Center.

At home, Congress must not abdicate its constitutional role and give the president a blank check. "In politics," as Samuel Laylor Coleridge said, "what begins in fear usually ends in folly."

We live in an age of violence and, with all the pressures of globalization, the United States cannot hope to remain immune. I have no doubt that most Americans will confront terrorism with resolution as a horrible hazard of modern life--a hazard that will take a little time before we with our friends and allies ean bring it to an end. 


\title{
LOS ANGELES TIMES
}

September 23, 2001

\section{Include Afghans in Fight Against Taliban}

\author{
By AIMLII) RASIIII)
}

\begin{abstract}
Ahmed Rashid, a correspondent for the Far Eastern Economic Review, is the author of "Taliban, Militant Islam, Oil and Fundamentalism in Central Asia."

LAHORE, Pakistan -- The total war being planned in the White House against Osama bin Laden and Afghanistan's Taliban will dramatically reshape the political contours of Central and South Asia. Instead of merely dealing with the threat of terrorism, the magnitude of the U.S. response to the attacks in New York and Washington could destabilize the region and create even more serious problems. The risks are huge, but so are the potential benefits. The outcome will depend more on Washington's political strategy than on its fire power.
\end{abstract}

For Pakistan, the potential rewards are great. Its military could de-link itself from Islamic fundamentalists and the growing culture of jihad, or holy war. It could rebuild its ties with the West, improve relations with India and ask that a major portion of its $\$ 38$ billion international debt be written off. But if the U.S. military offensive is drawn out and Washington lacks an overarching strategic vision for the region, Pakistan could unravel. Islamic militants would take to the streets, the already wobbly economy could fall and the army splinter into rival factions. The risk-reward equation is no less dramatic for Central Asian republics. A U.S. military success would rid these countries of the militant Islamic opposition movements that are based in Afghanistan. They could then concentrate on improving their economies and instituting democratic reforms. Or they could dissolve into even more authoritarian and repressive states if the U.S. fails.

As for Afghanistan, a U.S.-led alliance could help construct a new government that would bring peace after more than 20 years of war. Or it could re-create the warlordism that dominated the country in the 1990s and cleared the way for Taliban rule, setting in motion a new flood of Afghan refugees that would offer terrorists fresh recruits for their operations.

The key to suceess will be Washington's commitment to remain engaged in the region, in gencral, and in Afghanistan, in particular, once the shooting is over. As the threat of a U.S. attack mounts, Bin Laden and Taliban supreme leader Mullah Mohammed (Omar, along with the Arab and Afghan hard-liners around them, will be increasingly isolated. The Taliban, which is dominated by the Pushtun ethnic 
group from southern and eastern Afghanistan, are deeply factionalized. Its moderate leaders have already sent their families to Pakistan for safety reasons. They are also making contacts with anti-Taliban forces. Many of these leaders will desert if they see a credible anti-Taliban Pushtun alternative backed by U.S. forces.

The strongest opposition group on the ground at present is the United Front. But it is largely composed of Afghanistan's minority ethnic groups--Uzbeks, Tajiks, Turkmens and Hazaras--and its base of support is in northern Afghanistan, not the critical south. It is therefore critical that the U.S.-led alliance back a Pushtun uprising against the Taliban.

Commanders and supporters of Mohammed Zahir Shah, who was deposed as king in 1973 and now lives in Rome in exile, want to do just that by creating a national resistance composed of the United Front, other Afghan factions and representatives of Afghan civil societs. Since November 1999, Shah has been calling for a loya jirga, or grand tribal council, to be held in Afghanistan. Such a council is the only legitimate authority that can form a new government and attract broad support.

Many Taliban have privately supported the formation of a loya jirga, but they have been unwilling to confront their hard-line colleagues. But with U.S. military action imminent and the collapse of the Taliban regime near, these Taliban dissidents are now directly approaching potential members of such a council.

These Afghan forces must be given a role in U.S. military strategy. Afghanistan's mountains and deserts will prove difficult terrain for U.S. soldiers, especially since the Taliban-Arab forces are likely to break up into small, highly mobile guerrilla groups. There are few obvious targets in the country, and the continued presence of U.S. forces could spark a backlash by the fiercely nationalistic Afghans.

Accordingly, Washington would be wise not to use ground troops to invade or occupy even a small part of Afghan territory. U.S. special forces could operate out of an airbase inside Afghanistan for a limited time, but airstrikes against cities, or occupying them, would be hazardous and useless.

Enter the anti-Taliban forces under U.S. air cover. The Taliban need to know that there are Afghan fores on the ground to whom they can defect, not the Americans. And as the anti-Taliban forces take territory and cities, U.S. forces will need to provide humanitarian aid and air protection to the liberated populations.

By supporting the loya jirga peace process and encouraging all anti-Taliban Afghan factions to join it, the United States could help establish a post-Taliban government in Afghanistan that would enjoy the support of all the country's ethnic groups. But for that to happen, the U.S. would have to stay committed in the region and enter into dialogue with Afghanistan's neighbors, including Iran, with which the U.S. has no diplomatic relations. It should also pledge at least $\$ 1$ billion toward a Marshall Plan for Afghanistan. Managed by designated international agencies, money from this reconstruction fund would be disbursed when all the anti-Taliban factions agreed to form a national unity government and comply with U.N. resolutions 
calling for the surrender of all terrorists in Afghanistan.

In short, the United States has to construct a global alliance not just to make war against terrorists, but also to make peace after the terrorist networks are destroyed. Washington cannot do this alone, of course. It needs the support of the United Nations and, in particular, its special representative to Afghanistan. Previous U.N. efforts have been stymied by the obduracy of Afghani factions and by Afghanistan's neighbors, particularly Pakistan. But a major cause of failure has been the lack of support from the international community, particularly the U.S.

Americans, angry at the mounting casualties caused by the attacks on New York and Washington, want instant and overwhelming retaliation against the terrorists. They may also be angry at the enormous wave of anti-Americanism now sweeping through the Muslim world. That can only change if the American people insist that their government remain engaged in the region to build a real peace in Afghanistan, which would put the United States on the side of the people who now protest its very existence.

\section{LOS ANGELES}

\section{Sunday September 23, 2001 \\ Beyond bin Laden}

\section{The future of Afghanistan itself should lie at the root of Western political thinking}

Events of the past week have underlined both the importance and pitfalls that beset discussion of international affairs. All areas of political and social life involve controversy and commitment: this is as true of debates on the family, the role of the state in the economy, education and the causes of crime. But in no area of public discussion is there as high a dose of posturing, misinformation and irrationality as that of international issues.

There are, in broad terms, two conventional stances that arise in regard to international issues - complacency disguised as realism and irresponsibility posing as conscience. These poles have been evident in regard to the major cases of humanitarian intervention in the 1990s (Kuwait, Bosnia, Kosovo) and are present in much of the debate on the causes of globalisation and world inequality. They are present in very specific form in the question of what can be the future political system in Afghanistan.

For hard-headed realism, the international is a domain of power, mistrust and recurrence of conflict. This is the way the world, or God, or the market make it, and there is not much you can do. The most dangerous people are the do-gooders who make a mess of things by trying to make the world a better place: foreign aid, human rights, a lowering of the security guard, let alone education in global issues, 
are all doomed to failure.

Last week, in a typical realist calumny, one that allows legitimate international action only to states, President Bush cast responsibility for the terror attacks on, among others, NGOS (he had to spell out that this meant 'non-governmental organisations'). More ominous are the voices, now pushing a realist agenda, that were already under starter's orders on the morning of 11 September and are now in full canter: identity cards, immigration controls, National Missile Defence. In the field of cultural speculation, the great winner has been the theory, first espoused by Samuel Huntington in 1993, that says we are entering an epoch that will be dominated by 'the C'lash of Civilisations'.

The alternative view to realism has its own, equally simplistic, answers. This assumes that there is a straightforward, benign way of resolving the world's

problems and that there is one, identifiable and single, cause of what is wrong. Two centuries ago, the cause was monarchy and absolutism, then branded as the cause of poverty, ignorance and war; over the past two centuries, it has been capitalism and imperialism; now it is globalisation. More specifically, the USA is held responsible for the ills of the world - global inequality, neglect of human rights, militarism, cultural decay. It is not always clear what the 'America' so responsible is - this Bush administration, all US administrations, the whole of 'corporate' America, Hollywood or, in the implication of 11 September, the whole of the American people and, indeed, all wno choose to work with, or visit, or in anyway find themselves in the proximity of such people.

Both of these positions are, perhaps, caricatures, yet the themes they encompass are evident, and will be even more evident, in the crisis that has engulfed the world. There are, however, some core issues where, perhaps, an element of reason about international affairs may be sustainable.

First, history: much is made of the antecedents. Some involve the Crusades, others jihad, but the image of the Crusades means little to those outside the Mediterranean Arab world; jihad is quite an inappropriate term for the proper, Koranic, reason that the armies of Islam sought to convert those who conquered to Islam.

As for the Cold War, it has contributed its mite to this crisis and, in particular, to the destruction of Afghanistan but in a way that should give comfort to few. One can here suggest a 'two dustbins' theory' of Cold War legacy: if the Soviet system has left a mass of uncontrolled nuclear, chemical and biological weapons, and unresolved ethnic problems, the West has bequeathed a bevy of murderous gangs, from Unita in Angola to the Mujahideen in Afghanistan.

A second issue that is present is that of culture. It takes two to have a 'Clash of Civilisations' and there are those on both sides who are using the present conflict to promote it. Huntington's theory misses what is the most important cause of the events of recent days, and which will define the consequences in the Muslim world of what is to come, namely the enormous clash within the Muslim world between those who want to reform, and secularise, and those whose power is threatened, or 
who want to take power in the name of fundamentalism. This has been the basis of the conflicts going on these past decades in Pakistan, Iran, Egypt, Turkey and, most violently of all, Afghanistan.

Religious fundamentalists in all societies have one goal: it is not to convert other people to their beliefs, but to seize power-political, social and gendered - within their own societies. Their greatest foe is secularism.

The third and, arguably, most important and difficult issue underlying the erisis is that of the most effective and just way to combine the two instruments of international politics - force and diplomacy. Under international law, states are entitled to use force in self-defence. An clement of retribution is part of any legal system, domestic or international. The $U N$ is not some pacifist, supranational last resort, but a body which, in its charter and in the Security Council resolution 1368 of 12 September, has authorised military action by states in this case.

At the same time, any use of force, in the immediate future or in the longer conflict promised by both sides, has to be matched by diplomatic and political initiative. This can cover each of the separate issues that make up the greater west Asian crisis underlying these events, from Kashmir to Palestine, and on to Kosovo, but it must, above all, address the future of Afghanistan itself.

Ilere, the UN has, since 1993, been on record, and with the support of all the Permanent Members of the Security Council and all the neighbouring states, in calling for the setting up of a new government. The UN has insisted that this be broadly based, fully representative, multi-ethnic and opposed to terrorism. This is a goal which the current crisis requires and brings closer to view. It is also one which, it is generally agreed, the great majority of Afghans would support.

Freud once argued that the aim of psychoanalysis was to reduce extreme hysteria to everyday common misery. The function of reasoned argument, and an engaged scepticism, in international affairs is to do just that.

Fred Halliday is professor of international relations at the LSE and the author of The World at 2000 


\title{
GULF NEWS
}

September 24, 2001

\section{Ties with Afghan people unaffectedby diplomatic cut}

\author{
Abu Dhabi |WAM | 24-09-2001 \\ Print friendly format | Email to Friend
}

The UAE yesterday said that its decision to cut off diplomatic ties with the Taliban government of Afghanistan would have no negative impact on the fraternal ties between the two peoples of the UAE and Afghanistan.

An Interior Ministry statement said, "The decision of the UAE to sever diplomatic ties with the Taliban government of Afghan-istan will have no negative effects on the brotherly and historical relations between the two peoples of the UAE and Afghanistan.

"The decision will not also affect the Afghani community in the UAE whose contribution and service to the country are highly appreciated," it added, noting that the UAE was keen to provide them with security and comfortable life.

The statement expressed the government's satisfaction at the abidance of the citizens and residents alike by the country's laws and their keen and honest desire to maintain its stability and security.

"With the help of God and the cooperation and cohesion of all citizens and residents, the UAE shall remain an oasis of brotherhood and tolerance," the 


\section{GULF NEWS}

September 24, 2001

\section{President orders aid for Afghan refugees}

Abu Dhabi /WAM | 24-09-2001

Print friendly format | Email to Friend

President His Highness Sheikh Zayed bin Sultan Al Nahyan and Abu Dhabi Crown Prince and Deputy Supreme Commander of the UAE Armed Forces His Highness Sheikh Khalifa bin Zayed AI Nahyan have ordered emergency relief assistance to Afghan refugees.

Minister of State for Foreign Affairs and President of UAE Red Crescent Society (RCS) Sheikh Hamdan bin Zayed Al Nahyan has instructed the RCS to engage in the worldwide relief campaign spearheaded by the International Committee of the Red Cross and Red Crescent Societies' Feder-ation and to prepare as quickly as possible the first consignment of relief supplies which include foodstuff, medicines, water, tents and blankets.

"Millions of refugees from Afghanistan have moved to bordering areas of neighbouring countries and are facing difficult living conditions as many more are expected to arrive in the next few days and weeks," Sheikh Hamdan said.

"UN relief agencies and other bodies have warned of the danger of starvation in much of Afghanistan, while the government of Pakistan is already facing an enormous burden in trying to cope with the refugee problem," he added. 


\section{THE HITIMS}

\section{America aims to topple Taleban}

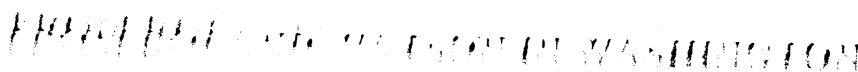

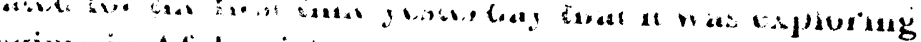
ways to topple the laleban regime in Afghanistan.

Condoleezza Rice, the Presidentls National Security Adviser, said that the Afghan people would be better off without the overy repressive and terribleö Taleban and that Washington was examining owhat means are at our disposal to do thatö.

Her admission marked a significant change of emphasis as Washington began to address publicly the military hurdles involved in fighting the Taleban.

Colin Powell, the Secretary of State, said that the Taleban army was dispersed and ill-equipped $S$ obut it is a force that one would have to take seriously because of their experience in the kind of warfare that is typical of Afghanistanö.

The White House insisted last week that overthrowing the Taleban was not a goal of any military action aimed at bringing to justice Osama bin Laden, Mr Bushls chief suspect for the suicide hijackings.

The Administration $\mathrm{S}$ which has offered a $\$ 25$ million (ú 17 million) reward as part its efforts to apprehend bin Laden and other leaders of the his al-Qaeda network $S$ yesterday dismissed claims by the Taleban that the Saudi-born millionaire had disappeared. Donald Rumsfeld, the US Defence Secretary, called the statement ôlaughableö and ônot credibleö.

General Powell said that government lawyers were checking whether killing bin Laden would contradict laws banning state-sponsored assassination.

He said that he hoped in the near future to be able to publish a document 0 that will describe quite clearly the evidence that we have linking him to this attackö.

He also stressed that the target of any American action would be bin Laden, not the 
people of Afghanistan, after Pakistan yesterday underlined its own concerns about potential civilian casualties.

President Bush took a significant step towards building his global coalition against terrorism by lifting American sanctions against India and Pakistan, imposed in 1998 after each country had carried out nuclear weapon tests. Mr Bush said retaining the sanctions was no longer in American interests. Both countries welcomed the move.

One setback for the US was the apparent reluctance of Saudi Arabia to allow the Americans to use the huge Prince Sultan air base, south of Riyadh, to command airstrike operations against Afghanistan.

Mr Rumsfeld also had to concede that the US had lost one of its unmanned Predator spy planes over Afghanistan. But he would not confirm Taleban claims that it had been shot down.

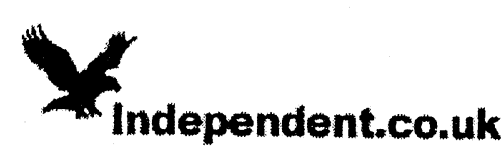

24 September 2001

\section{Deaths from hunger in a month, warn aid workers}

\section{War on Terrorism: Famine}

\section{By Raymond Whitaker in Islamabad}

Aid agencies helping to feed more than three million people in Afghanistan are warning that unless the World Food Programme, a UN agency, lifts its 12-day suspension on deliveries, people could start dying of hunger in less than a month.

The WFP put shipments on hold the day after the terrorist attacks on New York and Washington, saying it would not resume them until it could be sure that supplies were not being improperly diverted.

The agency's decision was savaged at an emergency meeting in the Pakistani capital over the weekend by representatives of the US and the European Union as well as all of the 30 non-governmental organisations present. But Khaled Adly, the agency's regional head, insisted that unless the WFP could monitor where the food was going, stocks would remain in warehouses in neighbouring countries.

One official said: "The WFP has never taken this line in any previous conflict. Its people on the ground have kept suppliés moving at considerable danger to themselves, even if some of it was being stolen ... We all said that now was the time 
to do what we can while we can."

Sources say the agency's figures show that some 400,000 people in north-western Afghanistan will run out of food in two weeks. Within three months, more than two million people will be starving if no more food gets through. Another official added: "That assessment was based on people staying put. The threat of attack has got half the population on the move, which puts more of them at risk.

"At this time of year we are normally moving supplies into Afghanistan as fast as possible, so as to get four months' worth in position by the end of October, when winter starts to make movement impossible ... If no more food gets in, you can expect people to start dying by mid-October."

John Wilder, Afghanistan country representative for the US branch of Save the Children, said he hoped the WFP would change its mind soon. His organisation still has 200 local staff within Afghanistan, who could dịstribute supplies.

Alex Renton, a spokesman for Oxfam, ssaid that since 11 September the agency had shipped 1,500 tons of grain to Herat, in western Afghanistan, where it had 40 local staff still able to distribute supplies.

Washington has been accused of putting pressure on the UN to hold back food, but recently the State Department said the US would continue to be the largest source of aid to the country. One aid worker said: "It would be politically disastrous for the Americans to be seen to be hurting ordinary Afghans."

\section{WASHINGTON POST}

Monday, September 24, 2001

\section{Islamic Fighters Head to Afghanistan for Jihad}

Hundreds Cross Border From Pakistan

\section{By Rajiv Chandrasekaran \\ Washington Post Foreign Service}

QUETTA, Pakistan, Sept. 23 -- As thousands of panicked Afghans continued fleeing toward the Pakistani border, Nisar Ahmed set off in the other direction today.

Toting his possessions in a single plastic bag, he went to the dusty bus terminal here and squeczed into a yellow van headed northwest, toward the southern Afghan city of Kandahar, which he left two months ago to attend a religious school in Pakistan.

Ahmed, 25, said he was dropping out of school and forsaking a relatively prosperous life in Pakistan to wage holy war. "I'm going back for a jihad against 
America," he said through a window as his van was pulling out of the station.

"They're going to attack, so we're going to fight."

Over the past week, hundreds of Afghan and Pakistani men are believed to have crossed into Afghanistan to volunteer for battle, answering a call from the country's. ruling Taliban militia to defend the nation if the United States mounts a military offensive against alleged terrorist Osama bin Laden.

Although there is no precise count of the number of people who have crossed into Afghanistan since the Sept. 11 terror attacks in New York and Washington, bus drivers report ferrying dozens of eager combatants from Quetta to the border crossing at Chaman, where the passengers catch other transportation for the bonejarring, three-hour ride to Kandahar. One driver said he has made several trips to Chaman with his 20-seat van filled with "people going for the jihad."

Many of those signing up for the fight recently trudged to Pakistan with their wives and children upon hearing from neighbors or on shortwave radios that the Taliban had rejected U.S. demands to hand over bin Laden. After depositing their families with friends or relatives in Pakistan, the men have been retracing their path back to Afghanistan.

Others, like Ahmed, have lived in Pakistan for months or years. But they too said they feel compelled to heed the call to arms. Yet others are hard-line Muslim Pakistanis who say they want to assist a neighbor in need.

"It is a religious duty for anyone who calls himself a Muslim to join the jihad," said Noor Mohammed, a top leader of a conservative Islamic political party in Pakistan. "If infidel forces unleash war on Muslims, the people in neighboring countries are duty-bound to help in the defense."

For the would-be warriors, getting to Afghanistan doesn't require much money or effort. The bus ride from Quetta to Chaman costs $\$ 1$. From there to Kandahar is an additional $\$ 1.50$. Once they're in Kandahar, they said, they simply seek out their erstwhile commanders, who will give them a gun and assign them to a military unit.

Many Pakistanis who live along the rugged border are members of the Pashtun ethnic group -- the largest in Afghanistan -- which has increased the obligation to fight. "We are the same race and the same religion," said Habib Ullah, 27, a farmer who was loitering in the bus terminal. "We share the same blood."

Pakistani officials said they have no evidence that aspiring fighters from other nations are traveling across the Pakistan-Afghanistan border. In the 1980s, Muslims from Saudi Arabia, Malaysia, Indonesia and other Islamic nations traveled to Afghanistan to join in trying to drive out Soviet forces that had invaded the country.

The new recruits likely will provide additional strength to the estimated 45,000 combatants in the Taliban militia, potentially complicating U.S. efforts to strike at bin Laden's camps, which are believed to be protected by Taliban troops. While some of the voluntecrs are greenhorns, others said they have years of experience 
battling Soviet fo.ces and an anti-Taliban force called the Northern Alliance.

"We have no fear," declared Ahmed, who said he had spent three years fighting the Northern Alliance. "We'll fight the Amerieans until our last drop of blood."

Diplomats and aid workers have criticized the Pakistani government for allowing aspiring fighters to cross into Afghanistan while preventing an estimated 15,000 Afghan refugees from entering Pakistan. "Ihey've closed the border in the wrong direction," said a diplomat in Islamabad, the Pakistani capital.

Pakistani officials said they do not want to close the Chaman crossing because Pakistani businessmen and laborers frecuently make day trips across the border. The officials insisted they have no way to identify potential fighters who enter Afghanistan.

While the fighters have the support of militant Muslim groups in Pakistan, which have staged noisy demonstrations to protest President Pervez Musharraf's decision to cooperate with U.S. efforts to crack down on terrorists in Afghanistan, many other Pakistanis dismissed the self-proclaimed holy warriors as misguided.

"Osama bin Laden helped to kill innocent people in America," said Mohammed Yusuf, 22, a political science student who arrived by bus in Quetta to watch his university's soceer team play. "These jihad fighters think they are going to save Afghanistan, but they're just going to defend a terrorist."

\section{WASHINGTON POST}

Monday, September 24, 2001

\section{Anti-Taliban Rebels Eager to Join U.S. Retaliation}

\section{By Peter Baker and Molly Moore}

Washington Post Foreign Service

JABAL SARAJ, Afghanistan, Sept. 23 -- The road through the Panjshir Valley that leads to this rebel outpost is littered with the detritus of past invaders.

Every 100 yards or so lies the rusted hulk of yet another demolished Soviet tank or armored personnel carrier -- some with weeds growing through them, some buried so deeply in the mud they have become part of the landscape, at least one upended in the shallow waters of the Panjshir River.

The parade of wreckage, now a generation old, offers a haunting reminder of what happens to foreign powers that send troops over Afghanistan's majestic mountains to try to conquer this ancient, defiant land. It also helps explain why Pentagon planners, as they map out strategy for President Bush's war on terrorism and weigh the option of introducing ground forces into Afghanistan, are considering the role 
that could be played by rebel forces already based here.

The rebels, known as the Northern Alliance, have been fighting the Taliban, the radical Islamic militia that controls most of Afghanistan, since the mid-1990s, and no one knows the territory better than they do. The rebel alliance is made up partly of elements of Afghanistan's former government, and they are eager to sign up for a U.S. war on the group that drove them out of Kabul in 1996.

"A unique opportunity is on the horizon," said Abdullah, a leader of the alliance who, like many Afghans, uses only one name. "If it is utilized for the will of the people of Afghanistan, I think there is a chance for establishment of peace and
stability."

It is not clear how useful the rebels could really be to the United States. Bush has targeted the Taliban because the group has sheltered Osama bin Laden, the leading suspect in the Sept. 11 attacks in New York and Washington. While the Northern Alliance has frustrated the Taliban's attempts to seize the entire country for five years, it holds just 5 to 10 percent of the territory -- and has yet to make significant inroads in recapturing the rest.

Yet the rebel alliance has clearly captured attention in Washington, where Bush talked last week about replacing the Taliban regime in Kabul. Congressional leaders have discussed funneling money, weapons, training and supplies to build up rebel forces, though officials in Washington and elsewhere are not proposing that the alliance be installed as Afghanistan's next government.

The object of Washington's interest is a sometimes fractious coalition of tribal, ethnic and religious groups united mainly by their mutual desire to rid Afghanistan of the ultra-strict Taliban. Sometimes called the United Front -- and still claiming to be the rightful government of the Islamic State of Afghanistan -- the Northern Alliance is a loose group of four factions whose commanders led guerrilla forces against the Soviet occupation of Afghanistan from 1979 to 1989, then turned on each other in the early 1990s.

As the extremist Taliban militia swept across the country, ousting or co-opting local warlords, opposing factions were shoved deeper into the mountains and valleys of the northeast. Eventually they joined forces, largely due to the charisma and tenacity of Ahmed Shah Massoud, the ethnic Tajik guerrilla leader whose exploits against the Soviet army earned him the name "Lion of Panjshir."

The rebels' antipathy toward the Taliban is shared by Central Asian neighbors such as Tajikistan and great powers such as Russia, the old enemy of Afghanistan's guerrillas. With financial, military and logistical backing from capitals such as Moscow and Tehran, Massoud held the fragile coalition together and waged particularly intense battles against the Taliban over the past two years. But suicide bombers posing as Arab journalists fatally wounded him during a sham interview on Sept. 9, two days before the World Trade Center and Pentagon attacks.

Massoud's death presents a challenge: Can the rebel alliance survive without his 
vision and force of personality? While the alliance's political leader, Berhanuddin Rabbani, another Tajik, still claims the title of Afghan president, Massoud was the real spiritual leader here. "They killed the symbol, not simply the person," said Suhrob Sharipov, an analyst at the Tajik government's Center for Strategic Research in Dushanbe.

Massoud has been replaced as military commander by his deputy, Gen. Mohammed Fahim, and rebel leaders said they have continued the strategy devised by Massoud before his death.

In the last three days, the rebels have gone on the offensive in northern Afghanistan, launching guerrilla attacks aimed at isolating Taliban forces in the strategic city of Mazar-e Sharif. Abdullah said the alliance hoped to make a breakthrough south of the city tonight.

The drive follows a quieter period that Abdullah described as a defensive phase, in which rebels sought to hold and consolidate their lines while limiting themselves to a few minor thrusts. Although Abdullah said the offensive phase now underway was planned before Massoud's death, it appears aimed at least in part at taking advantage of a moment when the Taliban is retrenching in anticipation of a U.S. attack.

"It's a good opportunity for us to attack, too," said Saleh Registani, the rebels' military representative in Dushanbe, the Tajik capital. "We're ready."

The alliance says it can field 15,000 trained troops, a polyglot blend of ethnic Uzbeks, Tajiks and Hazaras. The Taliban, by contrast, commands an estimated 45,000 , mostly from the Pashtun ethnic group, which accounts for 40 percent of the country's 25 million people. The Taliban also counts on a large contingent of foreigners.

Though Russia, Uzbekistan, Tajikistan, India and Iran have supplied political, financial and logistical assistance to the rebels, the level of that assistance has been limited by geography and regional politics. The alliance controls only one small airfield in the northern village of Faizabad, so moving supplies from Iran to rebelheld territory requires a circuitous route across five countries.

Iran, with a largely Shiite Muslim population, strongly opposes the extremist Sunni Muslims of the Taliban. For most of the past three years, Russia, Uzbekistan and Tajikistan have facilitated the shipment of howitzers, multiple rocket launchers, boots and blankets from Iran across Afghanistan's northern borders, according to a recent report by the New York-based Human Rights Watch. Witnesses have also reported seeing Russian planes airlifting supplies into Northern Alliance territory.

Here in the Panjshir Valley, Northern Alliance guerrilla fighters walk the streets with their machine guns, while tanks rumble through town leaving traffic jams in their wake. Along the road from Astana to Jabal Saraj, several bases for heavy weaponry are visible, including one with 15 tanks and armored personnel carriers and another with about 50. Gunfire and artillery can be heard in Jabal Saraj, which 
is just 40 miles north of Kabul and about 12 miles north of the front lines at Bagram.

Abdullah said Massoud had made capturing Kabul a top goal, but his successors have not. "Kabul is not the priority," he said. "We know politically it is a unique symbol," but it is not a prime military target -- a grudging nod to the reality that they probably could not muster the force to take the heavily defended capital.

The Panjshir Valley is where Massoud reigned for decades and has become a haven for anti-Taliban Afghans in recent years. Vegetation along the river meandering through the valley seems a haven, too, from the desert mountains that ring both sides.

In some ways, Panjshir is its own country, complete with immigration officers checking passports. But like the rest of Afghanistan, it is an impoverished, isolated place.

The stalls at bazaars offer slabs of beef slung on hooks, dozens of bugs sampling it before customers get a chance. Virtually no signs of Western influence are visible, not even the Coca-Cola ubiquitous in most of the rest of the world. What few exceptions there are seem all the more striking, such as the $T$-shirt on sale at one stand assuring that the wearer would be a "Sex Machine."

The costs of war, on the other hand, are distinctly visible throughout the valley. Along the road lie scores of random, crude graves of fighters who died in battle, usually marked by small green rebel flags, sometimes set off by a simple fence, more often by just rocks. A few tent cities populated by refugees sit just off the road as well, filling up even more lately, thanks to the influx of Afghans abandoning their homes before an anticipated U.S. attack.

In recent days, the rebels have sought additional assistance to invigorate their campaign in light of the expected U.S. intervention. Abdullah returned here today from Dushanbe, where he met with Gen. Anatoly Kvashnin, chief of the Russian general staff, as well as senior Tajik officials. While Abdullah did not describe the conversations in detail, he said he won pledges of continuing support from Russia.

Abdullah said he did not meet with U.S. envoys in Dushanbe, although he noted alliance representatives had been in touch with State Department officials in Washington in the two weeks since the terrorist attacks.

"Of course we are willing to fight against terrorism," he said. "Then the issue is how to coordinate our efforts with what is supposed to come from the United States of America. In that regard, we are open to ideas. Recently our contacts have increased with the United States. Not only us, I think the people of Afghanistan would support an effort to eradicate terrorism in Afghanistan."

Asked if the alliance would resist the United States using its territory for military strikes against the Taliban, he said: "We don't see any objections. It is not like inviting an army to Afghanistan to do the job for us. Rather, we're in a situation 
where part of Afghanistan is being occupied by terrorists."

Rebel commanders report that the Talíban has been redeploying in preparation for U.S. bombing, including moving ammunition depots. The regime has been pulling back its forces to concentrate on defending three cities, Kabul, Kandahar and Jalalabad.

As a result, U.S. military planners should not look to hit empty bases first but instead concentrate on Taliban airports, according to rebel officers. The alliance would recommend that U.S. missiles and warplanes take out airports in Shindand, Jeezakh, Herat, Mazar-e Sharif and Kunduz, said Registani, the military representative.

Although the Taliban has only about 13 aircraft, by rebel estimates -- old Soviet Su22 and MiG-21 jets -- getting rid of them would make a difference, Registani said. "These will be one of the first targets. There's no question there. If they destroy the Taliban air power," it would weaken the regime.

If anything, alliance officials appear a bit impatient for Washington to take action, pleading publicly for support. Gen. Abdurrashid Dostum, an ethnic Uzbek warlord who fought on both sides of almost every Afghan conflict of the last decade and is now on the side of the Northern Alliance, has appealed for U.S. assistance by satellite telephone from his northern command post.

"The terrain in Afghanistan devours people," Dostum, who resided in Turkey from 1997 until last spring, said in an interview with the daily Sabah newspaper. "The U.S. and NATO have to work with us. The U.S. should give us logistic support. We are ready to give them help in the region."

Delay only would invite more terrorist attacks, Abdullah said today. "Every other day will provide another opportunity for the people the United States is looking to punish," Abdullah said. But he added he was confident the result of possible U.S. action would be decisive. "In my opinion, Taliban is on the verge of collapse, though some of them may not know it."

Baker reported from Jabal Saraj, Moore from Islamabad, Pakistan

\title{
WASHINGTON POST
}

Monday, September 24, 2001

\section{Innocents in Afghanistan}

\author{
By Larry Thompson
}

The United States has a right to respond to the attacks against the World Trade 
Center and the Pentagon by striking networks of terrorists and states that support - them. But it must carefully consider the humanitarian consequences of any military action. This is especially important should the response target Afghanistan, which already, before any new hostilities, is the site of the greatest crisis of hunger and displacement in the world. Twenty-two years of war, three years of drought and the difficulties imposed by the repressive Taliban regime have caused nearly 4 million Afghans to flee to Iran and Pakistan. According to the United Nations, 5 million people still in the country are in danger of starvation. Hoping to escape a U.S. response to last week's devastation, 100,000 Afghans have fled Kabul and other cities, and the Taliban stronghold of Kandahar is now half-empty.

The humanitarian disaster in Afghanistan will become even worse if international aid to the Afghan people is suspended while the United States searches for Osama bin Laden and his associates. The Afghans do not deserve to be demonized. They have a reputation for ferocity, but a visitor can walk down the strects of most Afghan cities with little fear of being mugged or molested by Afghans. A popular Afghan sport is quail fighting -- but the quail don't fight to the death. An Afghan will invite a guest into his house for a cup of tea and share -- literally -- his last crust of bread.

Bin Laden is not an Afghan, and most Afghans are neither supporters nor opponents of the ruling Taliban regime. Ninety percent are farmers struggling to grow enough food to survive. The country people in the northern regions of Afghanistan are on famine rations: bitfer wild roots and grass mixed with wheat flour to make bread. Tens of thousands of people in the cities, including war widows, the elderly and orphans, are dependent upon international aid for their survival. Only food aid -- mostly U.S.-donated wheat -- stands between them and starvation. Yet most U.N. and nongovernmental relief agencies have pulled out of Afghanistan since the bombings. The World Food Program says it has only enough food in the country for two weeks of distribution by local personnel. The borders with Pakistan and Iran are mostly closed to the flow of people and goods.

Given the fragility of life in Afghanistan, any military operation there is bound to hurt the Afghan people. The U.S. experience in the Gulf War suggests the importance of anticipating and minimizing refugee flows and starvation. In the Gulf War, the United States did not plan for civilian displacement and, as a result, was caught by surprise when more than 2 million Kurds fled, some to neighboring Turkey and Iran, to escape Saddam Hussein, necessitating an urgent humanitarian response for which the world was largely unprepared.

The Bush administration's security team consists of seasoned officials with experience of the Gulf War and its humanitarian consequences. Military operations should be planned to minimize the danger to people already tottering on the edge of famine and to repair humanitarian damage as soon as possible

Considering that the war is with terrorists and not with the Afghan people, the United States also needs to find a way to resume relief operations in Afghanistan and get food aid flowing to people. Immediate consultations are needed with the 
U.N. secretary general to look for ways that relief workers can return safely to the country and resume operations. The United Nations must anticipate huge refugee and humanitarian problems and, as it did in Macedonia this summer, get the people and the resources into the region to deal with them.

The most appalling and universally condemned aspect of the terrorist attacks was the targeting of innocent civilians. The United States cannot afford to be accused of doing the same in its response. The United States requires the support of moderate Muslims around the world and this means maintaining the moral high ground. A humanitarian disaster in Afghanistan or elsewhere, if attributed to U.S. military operations, could leave the American people even more vulnerable to terrorism in the future. The United States wants to win the war against terrorism -- not sow the seeds of future problems.

The writer is with Refugees International, a Washington advocacy group. He has visited Afghanistan twice this year.

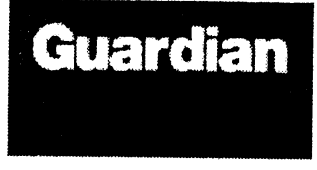

Monday September 24, 2001

\section{Trapped in the dark ages, a ragtag army welcomes the US bombs}

lan Traynor reports from northern Afghanistan on the rebel fighters who aw̃ait US military intervention in their battle to wrest control from the Taliban

Ian Traynor in Bagram, Afghanistan

In a country bombed and beaten long ago into a state of raw nervousness and medieval squalor, Abdurazek yesterday toyed with his Soviet vintage cannon 22 miles north of Kabul and looked for salvation in America.

In a dugout of reinforced mud and straw surrounded by dozens of spent shell casings, the 23-year-old farmer and fighter sat on the frontline of Afghanistan's civil war, his old gun trained on the enemy Taliban a few hundred yards away.

Around him bunched his retinue of grinning teenage fighters in trainers and long tunics, their Kalashnikovs at the ready. In front of him a vineyard and a cornfield and a deserted village of more baked mud. Beyond that the ficnatical fighters of the Taliban.

"There's shooting every night," he said. "We had a big gun battle four nights ago. They're always trying to take this post. We're always pushing them back."

But now Abdurazek, his young fighters, and the entire population of the opposition 
stronghold Panjshir valley north-east of Kabul think their fortunes have shifted for the first time in the seven years of the Taliban's incxorable takeover of more than $90 \%$ of this traumatised country.

The reason is the earth-shattering events thousands of miles away in New York and Washington. The fallout from the atrocities and America's declaration of war have focused global attention on Afghanistan. Afghans, in turn, are looking outward. The - Tair of expectation is palpable.

"America is our friend. We want America to bomb the Taliban. And then only Allah knows what will happen," said Abdurazek. "We will always fight the Taliban. They are very bad people."

Street urchins in the villages of the valley accost strangers with yelps of "America, America". Their parents stroll around with tinny radios glued to their ears listening to the $\mathrm{BBC}$, Voice of America or Iranian radio, desperately seekings clues to what may be about to befall them.

From a distance on the frontline the thud of sporadic mortar fire echoes across the hills that lie between the dugout and the Afghan capital. Soon the sound could be much louder, of US bombers splitting the night skies.

Colonel Malang, the deputy district commander of the United Front forces fighting the Taliban in the Bagram district, hopes he will soon be able to go home to his native city.

"I left Kabul six years ago. If the Americans help us, we're ready to go back soon. We're just waiting on our commander to order the attack on Kabul."

The colonel is one of thousands of Afghans who fled Kabul in 1996 when the Taliban took the capital and imposed their harsh codes of conduct and punitive penalties for dissidents.

"You know," he said, "we've had 22 years of fighting in Afghanistan. We're hoping America can help our army to destroy the terrorists. And it's not just me saying that. Everyone here thinks that.

"When the Taliban came at first, people helped them. But now we know they are very bad people, helped by the Arabs and Pakistan. At first we thought they were Muslim. But they are not Muslim. They kill people and destroy everything. And they protect terrorism in Afghanistan."

The key sources of trouble as perceived here, repeated by people over and over again, are not so much the Taliban as the outside powers, in this case Pakistan and "the Arabs" who are generally seen to control and fight for the Taliban.

"All the Americans need to do is seal the Pakistani border," said Zuwair, 27, a former Kabul medical student.

"It's not the Taliban that's the problem, it's the Pakistani troops. Afghanistan 
belongs to our people, not Pakistan, not the Arabs, not the Chechens. America was our enemy. Now it's not our friend. But it wants to get the terrorists.'

If the Americans do decide to put troops on the ground in Afghanistan, they will be landing on another planet. To arrive in Afghanistan is to travel back centuries to a world of relentless grime and crushing poverty where transport is by donkey or on foot, there is no light nor electricity, roads are few, and water is hauled in pails from unclean rivers. Isolated terracotta villages are carved out of the stunning duncoloured mountainsides.

The helicopter from Tajikistan to the north crosses the river Pyandzh and alights on a biblical seene of hundreds of people squatting in tents by the waterside beneath the raised town of Hoji Bahauddin, constructed entirely of khaki wattle hovels.

The tent people lead their camels to the water's edge, squat among the dust, build fires to cook a meagre pot of rice. There are 1,400 of them. They are all refugees from Taliban-seized villages on the frontline an hour away to the west, merely the latest of the $6 \mathrm{~m}$ refugees that have put Afghanistan at the top of that dismal international league over the past two decades.

Clutching her orange chadri across her face in the makeshift camp, Tutinisa, a 50year-old mother of five, said the Taliban had "destroyed everything, fired everything" in her village. "We were busy with their killing. They burned our children's books. And if we stay here we'll never last the winter. We'll end up eating one another." With three daughters, Tutinisa wanted none of the Taliban. "I want all my children to go to school."

But the refugees say they were among the fortunate ones, that the elderly or the sick were butchered.

We are taken to the sprawling Bagram air base north of Kabul, which offers one key to any US attempt to flush the Taliban out of the capital and install a new administration.

The air base is a demolition yard of wrecked aircraft, rusting equipment, roofless buildings, and shell-blasted barracks built by the Russians for their ill-fated attempt to occupy this battered country.

"It was fine when the Russians were here," laughs Hawani, a former cobbler now commanding the airport defence unit against the Taliban on the other side of the runways. "The Taliban are pricks. When the Russians were here, we could drink if we wanted to. Now under the Taliban, if you drink you get your head cut off."

Hawani's patch includes the vast runways a mere 20 miles from Kabul which are reasonably intact bar the odd Taliban rocket wedged into an apron or occasional shell crater.

This is a base, held by the Taliban until they were driven back two years ago, that could happily accommodate the biggest transport aircraft the US might need. But if the Americans are contemplating setting up base here, there is no evidence of any 
preparations for a new invasion. And before any US deployments were possible, the Taliban forces would need to be driven out of range and probably bombed off nearby hills from where they can currently target the air base.

Colonel Malang said he has 2,000 men locally who could supply the ground contingent to secure the base before setting their sights on Kabul. "We need Kabul now and we want to be in Kabul now."

But there is seant evidence of any imminent ground offensive by the opposition United Front forces in the Kabul area. The road down the valley to Kabul is a stony track skirting the fast waters of the river Panjshir be tween sheer mountains. There is little traffic. The Inited front has its dozens of tanks and artillery pieces dug into the hillsides or parked in clearings. But no troop movements or shipments of equipment are particularly visible.

The focus of military action is rather to the north, around the city of Mazar-i-Sharif and on the north-eastern frontline in the province of Takhar. Abdullah Abdullah, the "foreign minister" in the Northern Alliance opposition government, claimed yesterday that his forces had made big gains in the north in the past three days, though it was too early to talk of capturing Mazar-i-Sharif from the Taliban.

But in the valley and around Kabul, the years of fighting have ground to a weary stalemate. The country appears exhausted and burned-out after more than two decades of repelling foreign invaders and then turning viciously on one another.

But even if it is exhausted, Afghanistan may initially welcome the US only to turn on it later - if past experience is anything to by. Historically a graveyard for other empires' forces, Afghanistan has been invaded by sundry outsiders from Genghis Khan to the British to the Russians. They were able to destroy, but never subdue Afghanistan.

The vanity of such efforts is everywhere to be seen. The Panjshir valley is littered with the military debris of Russian imperial folly - dozens of rusting or carbonised tanks, armoured cars, military lorries blasted off the road or into the river by guerrillas who never surrendered the valley to the Russians and still have held on against the numerically superior Taliban. The Americans look like becoming the latest big power perhaps to get their fingers burned, although the Afghans say they want an outsider to bring peace rather than war for once.

"The Americans can support us and we will get rid of the Taliban ourselves, said Zuwait, the one-time medical student. But changing the government is up to us, not the Americans." 


\section{HA'ARETZ}

\section{Monday, September 24, 2001 \\ A convenient target}

By Zvi Bar'el

Let us assume that thousands of missiles fall on Afghanistan on Tuesday morning. Waves upon waves of attack planes will bombard this poor country, whose citizens want only to grow their hashish and opium in peace and live their lives according to the rules set for them by God's direct delegates. Let us assume that hundreds of clay houses and tents inhabited by the Afghan peasants will be ground to dust and their beasts of burden will be dispersed across the mighty Hindu Rush mountains.

How will this attack, which will definitely provide an impressive performance for the television networks, wipe out the "nests" of terrorism which can currently be found in the poverty-stricken neighborhoods of Egypt's southern cities, on Saudi Arabi's streets of resistence, in the red-bricked houses of Yemen's capital, Sanaa, where those responsible for the attack on the USS Cole are hiding out, and perhaps even in a couple of prestigious neighborhoods in Miami?

The world's willingness to go to war against Afghanistan in the name of America's demand that Osama bin Laden be extradited, is based on the trust that the world's leaders are willing to place in the American intelligence services. But these are the very same agencies that failed to prevent these attacks and did not know that a network of dozens, if not hundreds, of terrorists was at work under their very noses.

Attacking Afghanistan will be like painting a target around a convenient, predefined bull's eye. If the attack succeeds in assassinating bin Laden or at the very least, convincing Afghanistan to hand him over, this will be a big success for a military operation, but not for a war against terrorism. It may, for a time, be true that they managed to "cut off the snake's head" as the cliche goes, but what happens afterward? Moreover, what if this great attack does not destroy that target known as bin Laden.

The matter of targetted assassinations, as Israel, too, has learned, does not even provide the satisfartion of revenge. Regarding terrorism as a war against one man or one group against the entire world, or against an occupying force, is a mistake. Terrorism is a means, not an ideology, and in any case one cannot fight ideology by killing its flag bearers. They immediately become a martyr, or shahid or tortured saint, depending on their religion, and immediately, someone will name streets, squares or houses of prayer in their honor.

Mass destruction of the sort $\mathrm{Afghanistan}$ is about to experience if it does not hand over bin Laden "dead or alive," is even worse. Not just because of what will happen to Afghanistan, which is horrendous ir itself, but because the United States and the 
West will lose the moral grounds for its call to battle terrorism. There will after all be those who will comment, "What more does Ameriea want? They destroyed its Twin Towers and it in return destroyed a Muslim state." A nice profit and loss ratio for most. The road from here to the Muslim world identifying with Afghanistan will be a short one.

Indeed, this is the fundamental dilemma of those battling terrorism: How does one respond to an act of terrorism without being considered as fighting against an entire culture, from which one wild cell with a twisted ideology has come? How does one separate between a movement with principles, and its murderous interpreters? How much are the ideologies actually responsible for, and where does the line of interpreters begin and which of them must carry the blame?

Since we are already dealing with the question of the morals of war, it is worth mentioning that the Afghans, or at least their leaders born out of the Taleban movement, are not great Muslim sages. Far from it. Most Islamic arbiters have come out against their practices.

Moreover, most of the Western oil companies actually believed that they are the best bet for the state's security, for its peace and stability, and most importantly, for the safety of the gas and oil pipe that runs from Turkmenistan to Pakistan. The U.S. administration did not have a problem with the Afghan ruler Mullah Omar's policies toward women or antique religious artifacts. Now all the administration wants is the head of that murdering guest, and then the Afghans can go back to beheading citizens as they wish. The terrorist state does not hold that much interest, but it will be destroyed if it does not hand over the terrorist that so interests the States. 


\section{Taliban shoot}

\section{down US

\section{Washington refuses to confirm or deny militia claim}

\section{Behroz Khan}

PESHAWAR: The Taliban government in Kabul on Saturday claimed shooting down of an American spy plane in northern Afghanistan for violating the Afghan air space and issued a stern warning that others will meet the same fate.

Military analysts said if the shooting was confirmed it could herald the beginning of the much. awaited war between Afghanistan and the US, although on a disap. printing note for Washington.

"Our soldiers have shot down the spy plane in Sang-I-Siah arca of Samangan province at about 8:(0) am local time on Saturday. This was the third consecutive day that this plane violated our airspace", the Peshawar-based Consul General of Afghanistan, Maulavi Najibullah told The News.

The Taliban diplomat said that the pilotless spy plane was targoted with the Russian-made antiaircraft gun, locally known as Zikoyak, and the reports have been officially confirmed because our soldiers have visited the spot to collect the wreckage. It was a small sized plane.

American journalists in Peshawar believe the plane must be the small size drone, which is nor-

mally used for spying purposes. However, the US government has not issued any official statement so far to confirm or reject the Tal. iban claim.

The area, where the alleged spy plane has been shot down is close to Afghanistan's borders with Tajikistan and lizhekistan. Experts ruled out the possibility of using Pakistan air space and believed that the plane seemed to have entered Afghanistan from the north instead of south.

In a similar development, a Tal. iban jet fighter force-landed a helicopter of the Northern Alliance at Tashkurghan area in northern
Afghanistan, which the official news agency, Bakhtar reported was carrying arms and ammunition for the opposition.

Reports about the forced-landing of the helicopter, believed to be destined for the areas under the control of the Afghan opposition, could not be confirmed from the opposition sources.

Taliban pilots use the few fighter jets to target military bases of the opposition while the opposition makes use of its couple of gunship helicopters against the Taliban pusitions.

In a related development. Pakistan has alerted the hospital staff

at the P'ak-Afghan borders for emergency services and the staff have been directed to cancel their weekly off on Sunday, credible sources informed.

The orders to the hospitals in Kurram agency, including the agency headquarters hospital Parachinar and tehsil headquaiters hospitals in Alizai and Sadda, have been issued by the director gen. eral health on Saturday, the sources said.

"All the staff have been asked to remain on duty during the next two days as emergency arrangements have been made to tackle the situation, in case Afghanistan is attacked," the sources said.

No official confirmation of the emergency arrangements could be obtained from the authorities concerned.

Not only the agency hospitals have been put on high alert, emergency equipment and necessary medicines have beell shifted to the UNHCR hospital in Alizai area of the agency. The hospital is usually taking care of the refugees resid. ing in camps in the area, but the medicines and other equipment supplied to the hospital on Satur. day were mostly those dealing with war wounded and emergency situations, insiders informed.

Alizai and other parts of Kurram Agency share borders with Afghanistan's Khost province, which was hit by American cruise missiles on August 20, 1998 in pursuit of Osama bin Laden. The Jhawar training camps, allegedly run by Osama bin Laden's network, were the target of the attack, but failed to yield results.

Reports of similar arrangements from other tribal areas bordering Afghanistan have also been received.

Reuters adds: Afghanistan's ruling Taliban said their forces, armed with machine guns, shot down a pilotless aircraft over Samangan province in the north on Saturday, the Pakistani-based Afghan Islamic Press (AIP) said.

The Gulf-based television station Al-Jazeera said in a report in Dubai that it was a US aircraft.

"About two and a half hours ago, we shot down a spy plane in Samangan but we cannot say whose plane it was... there was no pilot in the aircraft," Taliban spokesman Mullah Abdul Hai Mutmaen was quoted as telling AIP

AFP adds: A US Defence Department spokesman refused Saturday to confirm or deny claims by Taliban militia that it had shot down an unmanned US spy plane in northern Afghanistan.

"We will not discuss operational issues and we are not going to respond to each and every statement that the Taliban make," said Pentagon spokesman Lieutenant Colonel Mike Milord, refusing further comment. 
The News on Sunday

September 23, 2001

\section{UAE severs ties with Taliban}

ABU DHABI: The United Arab Emirates (UAE) broke diplomatic ties with Afghanistanis ruling Islamic militia on Saturday for refusing to hand over Osama bin Laden, cutting one of the Talibanís last links to the outside world.

"The government of the United Arab Emirates has decided to break relations with the Taliban government in Afghanistan," a foreign ministry spokesman told the official WAM news agency.

"The decision comes into effect today," he said as the United States sent a second wave of warplanes to join those massing for a punitive strike on terrorist bases.

The UAE federation, one of only three countries to recognise the Taliban regime, said a week ago that it was reviewing the links following the September 11 jet. liner terror attacks on New York and Washington.

Saudi Arabia and Pakistan are the only other countries to have diplomatic relations with the Islamic hardliners who have sheltered prime suspect bin Laden.

"The Emirate authorities have made intense efforts to persuade the Taliban to give a favourable answer to the (UN) Security Council request to hand over bin Laden so that he can be given a fair trial by an international court on the charges linked to the terrorist attacks," the spokesman said.

"It is regrettable that the Taliban have not cooperated with the efforts of the Emirates and other countries" for the handover of bin Laden, he said.

"The United Arab Emirates considers that in such a situation it is not possible to maintain diplomatic relations with a government that refuses to yield to the will of the international community."

In Kabul, the Taliban said it had yet to be informed of the UAE decision. "We have not been informed so I cannot comment on that," Taliban Foreign Minister Wakil Ahmed Mutawakel told AFP by satellite telephone from Kandahar in southern Afghanistan.

The Taliban ambassador to Abu Dhabi returned home at the end of last year and was not replaced, leaving charge di affaires Hafiz Azizurahman to run the embassy.

Officials at the embassy were not aware of the news when AFP called.

Azizurahman was not available for comment.

Meanwhile the UAE gave Afghanistanís ruling Taliban militia just 24 hours to close their embassy and leave the country.

The quit order covered all Afghan employees at the embassy.

The UAE, where some 110,000 Afghans live, halted an air link between Dubai and Kabul in November last year as the UN sanctions came into force. -AFP

\section{Contingency plan for refugees in final stage}

Our correspondent

ISLAMABAD: Government of Pakistan and United Nations' frontline agencies are in the final stages of preparing a contingency plan to deal with any massive influx of Afghan refugees.

The details contingency plan will be made available to media in a press conference on Tuesday, Minister of Kashmir Affairs, Northern Areas and SAFRON, Abbas Sarfraz Khan, told The News Saturday.

He ruled out any possibility of an agreement on the issue. He, however, said there would be a clear understanding on settlement of new refugees as well their financing.

The resident representatives of the United Nations Development Programme, United Nations High Commission for Refugee (UNHCR), United Nations Children Fund, World Food Programme and World Health Organisation are participating in discussions with the government.

When contacted for any details, the UNHCR Senior Spokesman totally refused to speak on the issue saying, "I can't comment on this issue."

The minister said the task forces formed at national as well as provincial levels are taking up these issues. The home secretaries of Balochistan and North Western Frontier Province are also involved in this process.

About the establishment of camps, Abbas Sarfraz said, "As far Balochistan is concerned, we will set up all such camps along the Pakistan-Afghanistan border." $\mathrm{He}$, however, did not give the number of camps that could be set up as an aftermath of US attack.

While sources in UNHCR said the camps in NWFP would be set up in tribal areas of Khyber, North and South Waziristan, Kurram and other agencies.

About a week ago, the resident representative of UN agencies held a meeting with Minister for Kashmir Affairs, Northern Areas and SAFRON to discuss on growing humanitarian crisis in Afghanistan 


\section{US warplanes land in Tashkent}

TASHKENT: US warplanes have landed in the former Soviet republic of Uzbekistan as Russian President Vladimir Putin, after an extended silence, voiced readiness to cooperate with US plans to strike Afghanistan - but only after they are approved by the UN Security Council.

lobik military sources, speaking on condition of anonymity, told AFP on Saturday that the US jets were stationed just outside the lohek capital Tashkent and were equipped with surveillance devices, presumably aimed at Afghanistanis ruling Taliban militia just to the south.

The sources refused to disclose the number of aireraft or when they had arrived, although lizhek officials had previously denied that they were willing to cooperate with a US attack in reprisal for the Talibanis refusal to hand over suspected terrorist Osama bin Laden.

It has further emerged that heavily armed US attack helicopters are still stationed on a military base some 40 kilometres east of Tashkent, following joint N.ATO-lzbek military exercises in the region this month.

Its use of former Soviet bases has been busily debated in Moscow, which has pronounced itself ready to join a world anti-ter-

rorism campaign, but still worries that NATO forces will permanently root themselves in the lucrative Central Asian region should Russia agree to a joint attack.

In a sign that the two sides were starting to bridge their positions, Putin and US President George W. Bush held a 40-minute telephone consultation on the issue late Saturday Moscow time, although the kremlin refused to disclose any details of the talks.

Putin was further holding latenight consultations on the crisis with his most senior security officers in Sochi late Saturday, senior kremlin sources told AFP-AFP

\section{US allowed to use airspace: Sattar}

ISLAMABAD: Pakistan has agreed in principle to allow the US and other partners in the international coalition to use its airspace for over-flight for an operation against terrorism.

This was disclosed by Foreign Minister Abdul Sattar in an interview with $B o b$ Woodruff of $A B C$ News here. He said Pakistan is also ready to provide logistic support adding that specifics have to be discussed in the light of operation plan.

He said these specifics would be discussed during the forthcoming visit of US Assistant Secretary for South Asian Affairs Christina Rocca to Pakistan at the head of a high level delegation.

Asked if ground troops are going to be allowed, he said every proposal that comes from Washington is to be examined in the spirit of cooperation that Pakistan has assured to the United States.

He, however, said Pakistan has not been told that the US ground forces will be involved in an operation. He said he.believes that the US has not decided to place ground troops in Pakistan or Afghanistan for a long period.

He hoped that in the meeting, Pakistan would be taken into confidence with regard to precise nature of the operation and expectations from Islamabad.

Answering a question, Sattar warned against any attempt to foist a proxy government in Afghanistan. He said history is witness that attempts to plant in Kabul a regime preferred by outsiders have failed in the past.

The foreign minister said, therefore, it is necessary that the government in Afghanistan should be one that is respected by all segments of society in Afghanistan. He said a consensus government in Afghanistan that is responsive not only to the expectations of its own people, but to those of the international community would be good for Afghanistan.

He said Taliban leaders would not disappear from the scene. He said they are respected leaders in their society and for stability in
Afghanistan it is important that representatives acceptable to the Afghan people should form government.

He said the Government and the people have condemned the terrorist attacks in the United States, extended sympathy and assured that Pakistan will be partner in the fight against international terrorism. He hoped that the United States in cooperation with its allies would analyse the rootcauses of terrorism and.develop a long-term strategy to stamp out the menace of terrorism.

Answering a question about a possible US attack on Afghanistan, he said there is going to be strong action, but hoped that it should be carefully planned to spare the innocent people. He said the whole world has extended sympathy to the United States because thousands of innocent people died as a result of attack. "By the same taken, we can anticipate the reaction of the world opinion, if a large number of people die in the respose", he remarked.

He said non-compliance of UN resolutions by Taliban is not only unacceptable to the United States, but to the entire international community. He said there is resolve of the US administration and if Taliban does not comprehend this resolve, the consequences will be disastrous for people of Afghanistan.

He said he does not know if there is time to see whether Afghanistan complies with the demands of the world community. "Suppose this compliance is forthcoming, will the Taliban still be targeted", he posed a question. He said another question involves definition of Taliban. "Are we talking about the Afghan Government or hundreds of thousands of students who attended madaris", he questioned.

He said it should be seen as to who is the perpetrator of this horrible crime and who has violated the UN resolutions and not complied with the international community. - PPI 
The News on Sumlay

September 23, 2001

\section{Radio Pakistan}

\section{upgrades Dari service}

ISLAMABAD: Extermal Services of Pakistan Broaddeasting Services have upgraded its services for its listeners in Afghanistall and Afghan displaced people in Pakistan, a press release issued by PBC siays.

Radiu Pakislan has derirled to upurade its Aigham. P'ersiall. Mari and liazargi service so that its lis-

teners could be kept informed about the latest dovelopments in the area. Besides. it will holp to abreast the listencrs in Afghanistan about the correct policy and stejs being !ndertaken by the government for the well-being of the Afghan people. In addition to medium wave the service could be listened on short wave.

\section{Turmoil opens window for Zahir Shah's return}

KABUI: Expressions of popular support for the return of former king Mohanumad Zahir Shah are beginning to emerge in Afghanistan, as the threat of Us miltary strikes places the future of the tuling Taliban regime in doubt. Afghanistan's nonarchy was ousted by a Soviet-backed coup in 1973 , and king Zahir Shah, now in his late 80s, has lived in exile in Rome ever since.

But with the country in turmoil and the Taliban facing IS retribution for its refusal to hand over Osama bin baden - the main suspect in the terrorist attacks on New fort and Washington - some see the hing s return as the best hope for restoring a semblance of stability:

"Among all the players in Afyhan politics today, ling Zahir is the best.

People are more optimistic abcut him than anybody else," said Khan Haji, a 50-year-old trader in habul. "I have to saly he will not be able to solve all the problems, but at least he can establish an administration which might be pro-democratic," Haji said.

The former king is especially popular anong Aghans who call remember the peaceful and relatively prosperous decade of the 19(i)s. Having kept out of the bitter political and military wrangling of the past 28 years, he is also seen as a truly independent ligure.

But his age and lengthy absence from the country may have left hin as confused as many outsiders over the country's political scene, event though he would be assured the backing of the more moderate ethric P'ashiun factions, themseives pushed out by the Taliban.

Zahir Shah has also yet to state clearly whether he is ready to pick up the mantle of power in the country. Shopkeeper Sakhi Dad, 42 , said there was widespread concern that if the Taliban were toppled, the resulting power vacuum could irigger a damaging period of general lawlensiness. - AIY

\section{The Statesman}

\author{
Sundav. September 23.2001
}

\section{Turkey opens air space to United States}

ISTANBUL: Turkcy said on Saturday it had granled a US request to use Timkish airspace and airbases for (IS transport aircalt in any response to the September 11 atticks on New Yotk atid Washington.

Turkey also said it was increasing its support to antiPilliban forces in northern Afganistan.

"The prime minister said the Turkish goveniment had respondid positively to an Anterican request in use Turkish airspace and Turkish airbases for US tramsport airchali whemever necessatry." a statement issued by Prime Minister Bulent lecevit's offices said.

Il was the first pledge of specilic support fichn Tirkey, though it has already vowed full coingration with the $1 S$ as it builds up its forces.

licevit said latte on ritiday it was "natural" for the l!s to want (1) use 'Turkey' for hyovers and refuclling. - Reuters

\section{Taliban embassy}

\section{remains open} in Saudi Arabia

RIYADH: A Taliban official said Saturday there was "so far" no indication that Saudi Arabia would follow the UAE's lead and sever ties with the Talihan.

"The office (embassy) is still opren and we have not received any instructions (to) leave) so far," the Talihan's acting charge d'alfaires in Riyadh. Sayyed Motiullah Khalwati. wid Alit.

Riyadh downgraded ties with Kabul ho harge d'affaires level in 1998 in protest at the Talihan's refusal to hand over hin laden. 


\section{The Statesman Sunday, September 23, 2001}

Since then the Afghan embassy in Riyadh has confined its activities to administrative and consular matters, such as renewing passports of the approximately 200.000 Afghan residents of the kingdom.
In response to a request by Saudi authorities to keep the number of embassy staffers to a minimum, just two administrative employees work at the mission, in addition to the acting charge d'affaires. - Reuters
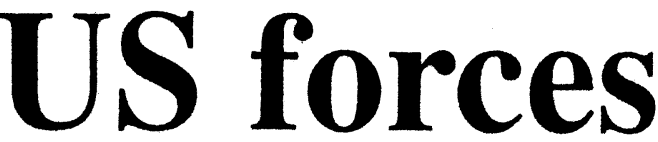

may

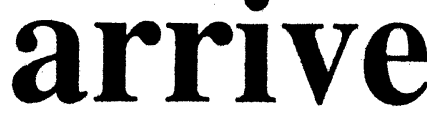

on

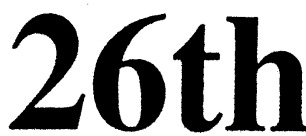

\section{Facility for B-52 bombers at Quetta air base sought}

From Our Correspondent

WASHINGTON: US forces have been readying positions in many states surrounding Afghanistan and they may get in Pakistan by Wednesday next.

Well-placed sources told The Statesman that some of these teams would work with Taliban opposition inside Afghanistan while others will operate from neighbouring countries and would at times move in for covert surveillance.

Enough US forces will be in Pakistan to launch a strike on Afghanistan by Wednesday, the sources said.

Talks between US and Pakistani military officials are focusing on what facilities American forces would like to use to back up possible operations in Afghanistan, senior Bush administration officials told the CNN.

Among the facilities the United States is seeking to use is the former B-52 bomber facility in Quetta, which is close to the border of [Kadahar] Afghanistan. The base was used for B-52 bombers during the Cold War, the network claimed According to some reports the US Air Force may also use the Badber air base, which was being used for U-2 flights during Cold War.

Meanwhile, US talks with aging start, with Uzbek officials sounding positive when asked whether the United States could base air and possibly ground units on its soil.

US officials claim they have been given overflight right by Tajikistan during military operations, but have not asked for any military facilities on the ground.

It has also been learnt that a second wave of US troops and warplanes deployed to staging points near Afghanistan on Saturday. About 40 aircraft have been tasked, a US ofticial said on condition of anonymity, including B-52 and B-1 bombers, U-2 reconnaissance planes and RC- 135 surveillance planes. "They will be moving shortly if they haven't started," he said.

US war machine gathers momentum. The United States is pursuing its biggest military mobilisation since the 1991 Gulf War.

US defence officials said about a dozen more aircraft, including refuelling planes, would soon move to the Persian Gulf and Indian Ocean -- within range of Afghanistan -- to join nearly 350 warplanes at land bases and on two aircraft carriers.

B-1 and B-52 heavy bombers as well as troops of the elite Army Special Operations
Command were also under orders to move to the region, although there was no immediate indication they had begun deploying.

The US assault ship, Essex, left Sasebo naval base in Japan on Saturday and was expected to head for the Indian Ocean. Kyodo news agency said. The carrier USS Kitly Hawk, which carrics about 70 aircraft, left its home port near Tokyo on Friday.

Meanwhile, Foreign Office spokesman Salturday denied Pakistani officials held any talks with the US officials on the use of Quetta air base by the American forces for the possible operation in Afghanistan.

"No such negotiations are going on" said FO spokesman Riaz Muhammad Khan at the regular media briefing when asked to comment on a US television network report that in the talks between US and Pakistani military officials American side is asking to use former B-52 bomber facility in Quetta. 


\section{The Statesman sunday Sepenterber 23,2001 Taliban bomb opp positions}

KABUL: The Taliban forces were pounding opposition held posts in Samangan province for the second struight day Saturday. the opposition satid.

"The Taliban have brought in reinforcements and latunched half-a-dozen offensives since Salturday' morning." said opporition alliance spokesman. Moharnmid A shraf Nadeem.

The Taliban push was part of a counter-altack launched Salurday after an oppesition offensive in Samangan succeeded in seizing several areas from the Islanist militia.

Nadeem said the Taliban pianes and heavy atillery had targeted opposition positions near the Dara-i-Souf valley. around 75 kilometers south of the provincial capital Aibak.

He gave no details of any opposition casualties.

\section{Stinger missiles}

\section{may be US nemesis}

WASHINGTON: Dozens of U'S-supplied Stinger missiles loft over in Afghanistan after ousting the Sovicts in the 1980s may ceturn to hatum us forces if they strike against the ruling Taliban, US experts said on Fridiy.

Stinger missiles gained mythical stature anong guerrilla groups afier the Mujahideen used them to shoot down Soviet helicopters and turned a losing war into victory.

The United States in 1986 hegan shipping hundreds of the shoulder-fired anti-aircraft missiles to the Aluiahideen who were locked in battle with Sovict forces trymg to control Afghanistan since 1979. The anns were pivobil in driving out Sovict forces hy 1989, experts said

The number of Stingers still in the hands of the Tiliban varied among analysts, with most estimutes hovering about 50 .

The Mujahideen used the Stingers to shoot down Soviet helicopters and forced Soviet aircraft to fly at higher levels and hecome less effective in strafing Mujahideen fighters shooting at them from mountain tops.

"It was a contributing factor for the larger developinent of ending the cold War. If certainly did the joo in halting the advances and eventually driving back the
The Taliban have stepned up ollenstves in northern Afghistan in the past weck, in emplo exploit the Ahmal Shat Masext.

Makn w was unlely seon as the sole faudl: wi the "Ththan's total controt of the country, and his death raised fears of the possible coilape of the fagile attiTaliban alliance.

An wher report from Istanbul sad an Afghan opposition leader was quisted on Saturday as inviting the lnited States to back his own long experence in fighting the Taliban with Westem logistical supput.

"I and my soldien have ixeen fighting the Taliban lior years. We are experienced. Thi Us should give us logistic support. We are ready to give lhem help in the region and with all hinds of lead-

Soviet forces," said Fred Ikle, who was an unicrsecretary of defence pushing to send Stingers to Afghanistan at that time.

Us expents said the Tulitan have many more, probably hundreds of Sovict-misuc surface-10air missiles that could be used against US forces.

After so many years, the Stingers may be in rough shape, some experts said.

"There are questions whether the Stingers are active, the sensors and batteries which are highly specialized need renewal and a lot of these probubly make them "lon-operational," said Anthony' Cordesman, a senion fellow at The Center for Strategic and International Studies. "The basic fail-safe 1 think is probably the shelf life." he added.

And even if they still work and are tumed on US forces, the Americans know the weapon. "lt's something that's known to our military so they know what to do," Ikle said.

V'incent Cannistraro, who was with the CIA and the White House National Security Council during the Soviet-Afghan war. said the Stingers "are practically wonthless now" because they had a "fricnd-or-foe recognition" chip that would allow firing only against a profile that matched Sovict aincraft. - Reuters ership," General Rashid Dosturn toid Turkey's Sulbah newspaper in a telephone interview from Aighanistan.

Afghan opposition officials saly that forces under Desumm. miliary leader of the country's lizbek minority. have recenily jorited in fighting against Taliban atuhorities in the north of the country.

Dostum wanned the United States against attempting any hind of ground action on Afghanistan in response to the Soptember 11 attacks on New York and Washington. "The terrain in Afghanistan devours people," he said. "The US and NATO have "o work with us."

Turkey has pledged to increase its equipment and train. ing suppon for forses of the Northem Alliance of antiTaliban forces. - AFP/Reuters

\section{Pakistan had no}

\section{links' with Osama,}

\section{ISI.AMABAD (APP):}

Minister for Science and Technology Dr Atta-urRehman has strongly dismissed the impression that Pakiotan had any links with Osama bion Laden. In a panel interview with the editorial board of daily "Die Welt" in Germany on Saturday the minister alsi contested the suggestion that Pakistan was in a position to intluence all decisions of the Taliban regime.

On the question of the possible Afghan response to the demand for handing over osama Bin laden, he said that lahistan has been trying to impress upon the Taliban the desirability of taking decision quickly. However, Pakistan could not dictate any thing to them. Concerning the imminent threat of military acticn against Afghanistan, lie said, General Musherraf has already said that Pakistan would support any action that is taken to eliminate the scourge of terrorism.

The decision of the Pakistan goverument to support the Us and the international cummunity in the light against terrorism was consistent with its policy nn Ierrorism, said Prof Atta. 
The Nation

SUNDAY, SEPTEMBER 23, 2001

\section{Masood's successor Fahim in Tajikistan}

DUSHANBE (AFP) - The new top military commander of the Afghan opposition. General Fahim, arrived in Tajikistan on Saturday for meetings with govt and military officials in this fomer Sovict republic bordering Afghanistan.

The military attache of the Afghan embassy in exile in Russia, Mukhamedsalekh Reghistani, described the trip as "a working visit, rather than an official visit."

As well as mecting Tajik military and government representatives. he said it was "also possible" that General Fahim would meet Russian army officers. he said.

Fahim was confirmed as the Afghan opposition's senior military commander on Septemiber 13. military successor to Ahmad Shah Masood, who died from injuries sustained in an assassination bid. Around $11,0(\%)$ Russian troops are stationed along Tajikistan's 1.200 -kilometre $(750)$ mile) border with Afghanistan.

Tajikistan and the other five countries bordering Alghanistan - China, Iran, Pakistan. Turkmenistan and W/behistan have officially closed their frontiers. some even before the crisis triggered by the September II terrorist attacks on the Uniked States. Pressure his mounted for them to reopen their horders to hordes of refugees flecing aheid of expected barge-scale US militury strikes.

Also arriving in Dushanbe on Saturday was the deputy chief of the anti-terrorist centre of the Commonwealthoflndependent States the former Soviet Union minus the three Baltic states), General Valery verchaguin.

\section{Taliban claim to have downed Opp helicopter}

ISLAMABAD (AFP) Afghanistan's Talihan militia said Saturday they had shot down an opposition helicopter in the northern province of Samangan.

Abdul Hanan Himat of the Taliban's Bahhter Information Agency (BIA) told AFP the helicopter had "apparently" been carrying sone leading figures in the Nothern Alliance hut could not provide any further information.

The Pakistan-bised Afghan Islamic Press (AIP) also reported that the helicopter had been shot down, yuoting Taliban sources. It said the helicopter had been carrying ammunition from the cpposition stronghold of the Panjshir valley to Darrae Soxf in Samangan province innorthem Af ghanistan. The AlP also reported that the Taliban forces had shot dow'n a spy plitne in the Sang Salid area of the same province.

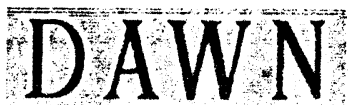

Sunday, September 23, 2001

Masood's killing linked to

\section{terror blitz}

WASHINCiTON, Sept 22: US intelligence officials said on Saturday they believed that Ahmed Shah Masood, chief of the Northern Alliance, was slain by Osauna bin Iaden's associates as part of a plot that ended with the Scpt 11 blity on the United States.

Macood, 48, was mortally wounded in his mountain camp in northern Afghanistan on Sept 9 by suicide lombers posing as cameramen.

The assassination probably was aimed at "disrupting the Northern Alliance at a time when they might be, among others, expected to be going after Bin Laden and Taliban forces", one intelli. gence official said.

Masood was a guerilla commander who received covert aid from the CIA while fighting Soviet troops in Afghanistan from 1979 an 1989 . He would have been a natural ally in any us military retaliation against Bin Laden.

Removing Masond - a leg. endary figure known to his followers as the "Lion of Panjsher" - could have been an attempt to protect Osama's flank somewhat by weakening a foe that Washington could turn to for help on the ground if US forces enter Afghanistan.

The United States has stepped up its contacts with Masnod's associates - who control only five percent of Afghan territory - since the Sept 11 tragedy.

"We are talking to various people within the US government," the alliance's US spokesman, Harum Amin, said in an intervicw on Fiday.

"Onr mectinus are very poductive and there secons to be a crescendn building." - Reutess 


\section{Osama men leave training camps}

\author{
By M. Ismail Khan
}

PESHAWAR, Sept 22: Thousands of Arab and other foreign countries followers of Osama bin Laden have abandoned training camps and dispersed in Afghanistan, highly competent sources Afghanistan told Date'n.

These sources which have a fairly comprehensive and latest information on the goings-on in Afghanistan said that Islamic groups who had been receiving guerilla training run by Laden's Al Qaeda had abandoned their camps spread across Afghanistan. "The camps are now empty and abandoned", the sources said.

The sources said that Laden's supporters that included Saudis, Figyptians, sudanese, a few Bosnians, Tunisians. Algerians, Morrocans, Yamanese, Chechens, Uighur Chinese, Uabeks and Tajiks had left caunps in the length and breadth of Alglianistan.

These sources said that the Taliban had initially allowed Osama bin Laden, the chief suspect in the Sept 11 terroris strikes in Washington and NeW York but later asked him to limit the number of the camps in the wake of the UNSC sanctions on Afghanistan in November last.

The New York Times reported quoting US Defence Secretary Doland $\mathrm{H}$. Ramsfeld as acknowledging the difficulty in identify ing bombing targets in Afghanistan. The paper also quoted President Bush telling senators: "What's the sense of sending $\$ 2$ million missiles to hit a \$10 tent that's half empty." The paper said that difiticulty in identifying t? in Atghanistan was leading Pentagon to develop a broader, more unconventional type of campaign, leaving the door open to ground troops, including commando units.

President Gen Musharraf told the nation in a televised address last week that Washington had requested Islamabad for intelligence sharing, logistic support and permission to use the Pakistani airspace. However, analysts here agree that there is very little the Inter Services Intelligence (ISI) could offer to its American counterpart - the C.IA- in providing information regarding whereabouts of Osarna bin Laden and his other close associates.

Laden, owns a satellite phone but avoids using it for fear of being traced to his location. $\mathrm{He}$ is known to have been making use of landline phones wherever available in the Taliban-controlled Afghanistan or spread the word around through contacts and couriers. "He iextremely catutious.

knows he is the prime target and takes all the security precaution required", the sources said.

According to these sources, Laden operated a network of these camps in Khushk-j-Nekhud on the Kandahar-Heart Road one camp the Saudi militant would frequently visit - Corps 8 in Kargha, Corps 7 in Rashkoor, Qalai Qazi, the former KHAl) IV premises in Pul-i-Charkhi in Kabul. These camps however, were later closed down on the instructions of the Taliban and the trainees were asked to move to Mazar-i-Sharif and Kunduz in northern Afghanistan, the sources said.

The training camp at Mazar-iSharif until recently, according to the sources, had radicals from the Islamic Movement of Uzbekistan.

\section{Unicef to spend $\$ 14 m$ in Afghanistan}

ISLAMABAD, Sept 22: The UNICEF's overall winter campaign for 7.5 million Afghan children and women in urgent need of humanitarian assistance is expected to cost $\$ 14$ million.

Addressing a press confer. ence here on Friday, Stephanie Bunker, spokesperson United Nation Office for the Coordination of Humanitarian Assistance to Afghanistan, said that UNICEF has more than $\$ 3$ million worth of relief supplies in the pipeline to help children in urgent need of humanitarian support in Afghanistan and neighbouring countries.

"Ihe supplies will be shipped over the next several days as the situation requires."

Additional emergency items valued at $\$ 750,000$ have been pre-positioned in parts of Afghanistan and Pakistan, she said, adding, these commit. ments were just the beginning of UNICEF's support for the

humanitarian relief effort which the staff has been planning for several months in anticipation of a difficult winter.

Stephanie Bunker said that 70 per cent of the population most at risk in Afghanistan comprises children and women in which nearly 20 per cent are children under five years of age.

She said that one out of four children die in Afghanistan before reaching the age of five years while 85,000 die annually due to diarrhoea.

Sixty per cent children have lost a family member in a conflict, she said.

The UNICFF spokesperson said that only 45 per cent children get immunisation while there is only one doctor for 50,000 persons in the coumtry.

Director UNICIF, Fic Falt said that preventive diplomacy was going on "but it is not UN policy to make such closed-door efforts public." 


\section{US must produce evidence against Osama: Pakistan}

ISLAMABAD: The United States must produce evidence about Osama bin Laden's involvement in the terrorist attacks in the US before the world.

"The US must come up with some evidence to prove that Osama bin Laden was involved or was behind these terrorist attacks in New York and Washington," Tariq Aziz, principal secretary to President Pervez Musharraf, said on Sunday. "The public in Pakistan and the world at large will only be satisfied if evidence is produced before the public, (before the) world community," he said.

He said that Pakistan wants to make sure no civilians get killed, a senior official said on Sunday.

"By cooperating with the United States, we can...ensure there are no civilian casualties," Tariq Aziz. His remarks underscored the dilemma facing Pakistan after it threw its weight behind the US "war of terror" to hunt down Osama bin Laden, , .
"We'll help them in moderating their actions, reducing the intensity of their actions," he told Reuters Television.

The Pakistan government was preparing for talks with a US team on how to proceed with any strikes against the bin Laden and the Taliban who swept to power five years ago and installed the hardline purist government to a land ravaged by war for more than 20 years.

"But as far as troops are concerned, no, they have not come yet so far and this is subject to negotiation," Aziz said. He said a three-member US team was due in Pakistan soon to discuss the plans of the US side and what Pakistan might allow the United States to do within its borders, Aziz said He declined to say when the team would arrive and said he was unaware yet of its composition.

"Pakistan welcomes the decision by the United States to lif sanctions imposed in 1990 and others imposed in 1998 following nuclear tests by India and Pakistan," Foreign Minister Abdul Sattar told Reuters.

Sattar noted, however, that Bush's order did not include sanctions relating to the 1999 coup that brought Musharraf to power. A government source said the "half measure" would disappoint many people in Pakistan.

"This is a first step but it is not enough," former information minister Mushahid Hussain said. "But it shows a change in American attitudes, a new kind of relationship is being built between the US and Pakistan."

Aziz described the US move as part of a process. "To exhibit confidence and trust between the two countries, it's better that we keep on negotiating and ultimately all the sanctions should be lifted. That would create confidencebuilding measures and promote trust...which is very necessary," he said. - Reuters

\section{Foreign TV networks airing baseless news: govt}

\section{Tariq Butt}

ISLAMABAD: Stampeding foreign journalists, converged in Pakistan, are, at times, falling prey to rumour mongering, gossiping and sensationalism, prompting a senior government spokesman to protest to at least four television networks.

A widely quoted TV network of the Middle East telecast the news that immediately after the launch of the US military campaign against Afghanistan to get Osama bin Laden and smash his network, curfew would be imposed in Pakistan from Karachi to Khyber.

The Pakistan government took a serious notice of it and made it clear that the news was totally baseless and figment of imagination of its sponsor.

Another TV network showed massive patrolling by the Pakistan army troops along Pakistan's borders that the spokesman described as ridiculous saying that patrolling is never done by a huge number of uniformed personnel.

When Information Secretary Syed Anwar Mehmood protested to the TV channel, the network took the plea that the report was given by an international video service presently working in Pakistan. He made it clear that border patrolling is always done by a small group of troops.

The secretary told the TV network that there has been no movement of Pakistani troops towards the border with any neighbouring country because there is no threat to Pakistan.

A Korean journalist got the news that emergency has been declared in Pakistan in view of the possible American attack on Afghanistan. The spokesman told him that the state of emergency was proclaimed in 1998 after Pakistan had detonated its nuclear devices.

The emergency was again pro- mulgated on October 14,1999, two days after the army had taken over. The journalist said that he got the news from a Pakistani colleague.

More than once, the government has strongly protested verbally as well as in writing to an American TV network, that is a household name in Pakistan, for showing a fabricated report on alleged camps for training terrorists to fight the Indian forces in the occupied Kashmir.

The TV channel president told the official spokesman that he shares the Pakistan government's concern on the issue. "We are ready to telecast anything provided by you on the subject to present Pakistan's point of view," the network chief said. It was stated in the report that the video was provided by the Indian army

"Does any terrorist training camp exist where the trainees wear military uniform as shown in the report?" the spokesman asked. 


\section{Hikmatyar's support to Taliban confirmed}

\section{Taliban release former Hizb governor}

ISLAMABAD: Former Afghan Prime Minister and chief of Hizbe-Islami Afghanistan Engineer Gulbuddin Hikmatyar is set to side with Taliban against the possible US attack on the war-devastated country, party and Taliban sources said here Sunday.

"Hikmatyar is planning to enter Afghanistan and to fight back along with Afghans if the United States commits any aggression," the sources told this agency.

The Hizb chief has been living in Iran since 1996 and has kept himself away from factional fighting.

Relations between Taliban and "Hizb-e-Islami have never been friendly, but his strong anti-US stance forced others to set aside differences with the Taliban rulers. In 1995, Taliban attacked Hizbe-Islami's military posts in Charasiab, southeast of Kabul.

"The two sides are in contact how to cooperate if the US launches attacks on Afghanistan," the sources added.

As goodwill gesture, the Taliban have released former Hizb-eIslami Governor of Baghlan province Bashir Baghlani, who has now returned to his home province.

The Hizb chief is the first Afghan opposition leader to announce support for the Taliban and ignored political differences.

Observers believe that Taliban and Hizb-e-Islami's coalition will, to some extent, enable the Afghans to show resistance to the US attacks.

After the April coup in 1978 in Afghanistan, Hizb-e-Islami became one of the main resistance force against the Soviet occupation of the country and the communist government. Hizb still has thousands of supporters in Afghanistan but they have not been siding with any faction in the civil war as per the party's policy.

The opposition Northern Alliance and the former Afghan monarch Zahir Shah have announced backing to any US attack on Afghanistan. The alliance has been calling for immediate bombing of Taliban controlled areas while Zahir Shah has called for revolt against the Taliban.-NNI

\section{UK elite troops clash with Taliban}

LONDON: Elite British troops, already in Afghanistan, have been involved in a minor clash with Taliban soldiers, the Sunday Times reported.

Special Air Service (SAS) troops in Afghanistan have been fired upon by Taliban soldiers in the first clash of the campaign against global terrorism.

Nobody was hurt, military sources said, adding that the gunfire had been "more symbolic than directed". They suggested that the small SAS team had "spooked" Taliban soldiers near Kabul, who had fired indiscriminately before fleeing.

However, the incident marks an escalation in what has so far been only an intelligence war. The Taliban are in a high state of alert for coalition forces waiting to enter their country.

It is rare for Ministry of De- fence insiders to confirm that their forces have been involved in skirmishes, but a source close to the SAS said there had been a clash late on Friday.

SAS troopers, together with members of MI6 and the CIA, are working with the anti-Taliban Northern Alliance in the search for Osama bin Laden, the Saudiborn millionaire believed to have masterminded the suicide hijacker attacks on America 12 days ago in which 6,818 are feared to have died.

They are seeking intelligence about bin Laden's whereabouts, the location of mines, routes he might take out of the country and the help of guides for later operations.

Unlike their American counterparts, SAS troopers specialise in long-term operations behind enemy lines, making them ideal for intelligence-gathering missions in Afghanistan. The soldiers involved in the clash with the Taliban were believed to be from a four-man unit that had crossed the border, possibly from Tajikistan.

The SAS men on the ground are communicating with commanders via $R A F$ Nimrods from the secretive 51 Squadron, using state-ofthe-art "squirt" radios to transmit large amounts of data in seconds, helping avoid either interception or

pin-pointing by the enemy.

American forces are also on the move. Advance units of two United States army divisions are on the Afghan border preparing for strikes against the Taliban regime.

Units of the 82nd Airborne and 101st Air Assault Divisions arrived at bases in Pakistan, near the border towns of Quetta and Peshawar, 
as a huge build- up of ships, aircraft and troops ordered to the re. gion by President George W Bush continued. A Pentagon official declared that the military was ready to respond "the second the president pushes the button".

The coalition operation inside Afghanistan coincided with intelligence reports that any further terrorist action would be radically different from the suicide hijackings that led to three passenger planes being crashed into the World Trade Center in New York and the Pentagon. "They've been there and done that, " said one US government adviser. "The real fear now is chemical."

It was revealed last night that crop-spraying planes had been grounded in America after police found evidence at a suspected terrorist hideout suggesting that

plans were being made to disperse biological or chemical agents. In Britain, the security services believe the main threat could be the release of poisons into the air or the contamination of water.

Proposals for emergency antiterrorist legislation were presented to Tony Blair yesterday amid pres. sure from opposition MPs and some ministers for an early recall of parliament. Ministers and MI5 officials are concerned that any crackdown on terrorist suspects could fall foul of human rights legislation. They are pressing for a new "judge-proof" law to be rushed through parliament.

David Blunkett, the home secretary, who has secured agreement for a European Union-wide arrest warrant and a faster extradition process, wants stronger powers to freeze or confiscate terrorist assets. American officials, who offered a $\$ 5 \mathrm{~m}$ reward and protection for anyone providing information about the terrorist attacks, said yesterday that the threat of further assaults would not divert them from hitting Bin Laden's Afghan allies hard. "They are about to see what the wrath of God feels like," said one intelligence source.

\section{Osama goes missing: Taliban}

\section{Waveed Ahmad and Behroz Khan}

ISLAMABAD/PESHAWAR: Amidst reports that Taliban supreme leader Mulla Muhammad Omar has approved the earlier decision of the religious scholars, Taliban Sunday stunned the world by saying Osama bin Laden has gone missing from his hideout inside Afghanistan. him."

They said "we are looking for

Taliban Ambassador Mulla Abdul Salam Zaeef Osama, Sunday told a press conference in Islamabad, that Taliban supreme leader found him missing when he wanted to convey to him his endors'ement of religious council's decision.

News of Mulla Omar's backing of the ulema council's suggestion got overshadowed with this anticlimax.

Zaeef said, "The Amir-ulMomeneen (Leader of the faithful)

has announced to abide by the Ulema Shoora's decisions which urge the leadership to convince Osama bin Laden to voluntarily leave Afghanistan and choose another destination for himself."

Zaeef said the Taliban came to know of this development on Saturday as they tried to approach him to put across the Amir's decision. Neither he spoke on whether where Osama might have left for nor how could he defy the security arrangement made for him given the sensitivity of the situation.

On shooting down of the unmanned spy plane, Zaeef said the wreckage had been shifted to Mazar-i-Sharif airbase.

The Taliban official skipped a comment as to which country it belonged to. According to him the computer system of the aircraft has been partially damaged.

Meanwhile, Taliban spokesman in Kandahar, Abdul Hai Mutmayan issued a statement saying that after approval and endorsement of Ulema Council's decision by. Mulla Omar, the search was on to find whereabouts of Osama to convey the decision to him.

"He is missing for the last several days and we find it difficult to convey the decision to Osama bin laden," Mutmayan was quoted as saying. The Taliban spokesman also said the ulema decision was a recommendation, which in no way convey the message that Osama was being forced to leave Afghanistan. However, the United States has rejected the Taliban stance and said it wolld not deter the Americans from taking action against the terrorists.

In a relative development, $\mathrm{Tal}$ iban authorities have collected all communication equipments from the UN staff and other aid agencies in Afghanistan due to security reasons while their vehicles have been parked inside the UN compounds elsewhere in the country, sources told The News.

Sources in Jalalabad, Kabul and

Kandahar informed that all wireless sets, satellite phones and other equipments have beêt taken over from them during the last three days. No reaction could be obtained from Taliban officials either to confirm or deny the reports coming out of Afghanistan.

A large number of vehicles used by the staff of the United Nations and foreign NGOs, the sources said, have been shifted to UN compounds, as war clouds hover on the Afghan horizon once again.

Credible sources informed The News that not only traders but common Afghans have started drawing their deposits from Pakistani banks due to fears that their accounts might be frozen in case new economic and other 
sanctions are imposed on Afghanistan.

Majority of Afghans having bank accounts in the tribal belt, sources said, have been drawing their amounts on emergency basis, which has affected the business of these institutions to a considerable extent during the last few days.

The closure of the Pak-Afghan border has also affected business activities in the border areas to a stand still during the last one week; and the bazaars give a deserted look, eyewitnesses said. No activities are witnessed either at Torkham, Angor Adda and to some extent in Miramshah bazaar as well. However, fleeing refugee families continue to pour in through the unfrequented routes as well as paying money to gangs of human smugglers to bring them to Pakistan.

Locals and refugees said that these smugglers charge from Rs 300 to Rs 1500 a person for crossing the border. But a large number of the unfortunate ones among them are stopped at the checkpoints and turned back, locals said.

In another development, unconfirmed reports suggest that another US spy plane was downed by Taliban in Aibak district of Samngan province in northern Afghanistan on Sunday evening.

Taliban officials could not be approached for confirmation. The development indicate that the arrival of the US small planes for spying purposes could not be possible without the support of Uzbekistan government, Afghan sources believe.

\section{Taliban lack}

\section{support in Kandahar}

\section{Nusrat Javeed}

CHAMAN: Cutting across the tribal and ideological divide, an overwhelming majority of Afghans stranded in the Pushtun areas of Balochistan which lie close to Kandahar province, very strongly believe that the United States of America can still get Osama bin Laden and his protectors among Taliban, 'without going for an allout and insane assault' on their country.

But for doing that they need to devise 'a political strategy which must give importance to Afghan traditions, culture and the current realities on the ground.' After crisscrossing into Pak-Afghan territories from the border town of Balochistan, Chaman, for two days, this correspondent also found out an anxious awaiting for Zahir Shah, the former king of Afghanistan living in Italy since toppled by his cousin, Daud Khan, in 1973.

Almost everyone imagines that he has a role to play. The most important, however, was the discovery that unlike the impression, drummed in Pak and global media, Taliban hardly enjoy any public support among the original inhabitants of Kandahar and villages around it.

Though welcomed during the formative months of their rise in

1994, Taliban are widely hated now, like all the preceding power groups the hapless Afghans have been incessantly enduring since the "communist revolution of 1978.

Stories after stories are narrated to highlight 'the tyrannical mindset' of some of their leading lights. Then is the insatiable greed of some Taliban-connected 'Mullahs' on both sides of the PakAfghan border. Names are named to show as to which minister, governor or commander of Taliban, and their Pakistan-based mentors, is connected to which broker and big time trader operating from Singapore and Dubai.

You have to give some weight

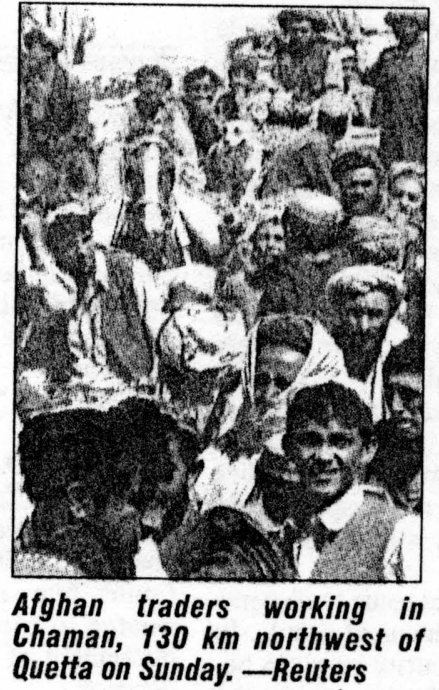

to these stories, after noticing a massive line oî huge containers despite the thick layer of dust, while standing at any last point on the Pakistani side of border with Afghanistan at Chaman. Loaded with luxury goods and branded consumer items, they are parked too close to no man's land.

Chaman is also crowded with donkey-driven carts. They are designed to carry the wheat and flour bags to Afghan side. Commuting back, they get the loads of 'goods in transit,' supposedly imported for Afghanistan. All residents of Chaman, this correspondent talked to, conceded in unison that theirs was a god forsaken town till only five years ago.

'The minarets of the main mosque were the highest points for human eyes,' many would recall. But those minarets are now hidden behind five or six-story 'shopping plazas.' Construction activity remains feverish in the narrow lanes of the bazaars of Chaman. And that is happening in spite of the widespread fears that the US will 'certainly pound' Kandahar, the spiritual capital of Taliban.

'The going price for a shop in bazaars of Chaman,' the residents proudly report, 'is higher than a shop of the same size in the famous markets of Lahore, Karachi 
or Islamabad.' For a standard boxtype shop in ever-rising plazas of Chaman, you need to commit six million Pak rupees. The price sounds outlandish if you try imagining the 'buying power' of around 600,000 residents of this city and helmets around. Most appear to be living in miserably poverty and water-less huts of cracking mud.

You set a shop in Chaman to cater for other kind of, whole sale, buyers based in affluent cities of Pakistan, one would safely presume. For the moment, let's talk of the way Taliban rule (?) Afghanistan, however. Since Taliban's taking over Afghanistan, their usual defenders in our mainstream media have been drumming a thing: 'If nothing else, Taliban have at least established a system of delivering justice without much hassle as per the pristine traditions of Islam.

These were not the 'Islamic scholars' like Dr. Israr Ahmad etc only, who claimed this. Many months ago, Dr. Javed Iqbal, a retired high court judge and son of Allama Iqbal, also visited Afghanistan with a delegation. Despite his 'liberal' education and pretensions, he also wrote articles for popular Pakistani newspapers to praise the quick delivery of justice' by Taliban.

But this correspondent found otherwise during the two-day stay in Chaman. Inayat, a trader, was willing to 'discuss everything about Taliban,' when I reached his shop in Sanatan Bazaar Saturday. But before settling for that he went to the local mosque to offer his Zuhar prayer.

'What justice are you talking about,' he wondered with a meaningful smile after coming back. Taliban judges decide after hearing two witnesses (adults and reputed to be 'good' Muslims). You only need to spend two thousand Pak rupees to 'hire' such witnesses in the poverty stricken Afghanistan of these days,' he dismissively declared in the end of a long discussion.

Realizing that I was finding it hard to swallow the cynical sounding claim, Inayat sent a shop assistant to fetch another trader. Akbar, the wholesale trader who came, used to give goods on credit to a Chaman-based Afghan refugee. This is done in this part of the world without any written documents, banks or collaterals.
Every deal is verbal and based on personal trust.

Anyway, around 300,000 Pak rupees got accumulated against the person Akbar was dealing with. He refused to do more business with him unless the owed money was returned. Instead of returning the outstanding amount in cash, the refugee went back to Kandahar. Akbar had to follow him. 'When nothing worked,' Akbar admitted after much hesitation, 'I went to a Kari (the judge).' But instead of getting to the real purpose of his visit, Akbar offered around 15,000 Pak rupees in 'all deference' to this Kazi cum Taliban commander.

The money rendered was not a bribe by any standard but comprised 'Zakat' (the Islamic tax Muslims pay voluntarily). Akbar gave it to 'the revered' Kazi 'to use

for any noble cause in his discretion.' Akbar waited for many weeks before approaching the same Kazi for another time with his 'complaint.' It was properly lodged and two witnesses were there to vow that Akbar was on the right. 'Justice,' of course, was 'instantly delivered.'

Akbar's could be ignored as an exceptional case. But at a sumptuous dinner, my host arranged for me at his Hujra (guest house) in a Killi (the muddy helmet of a clan) right at the Pak-Afghan border Friday night, also present was Malik Wazir Khan. He was introduced as a tribal elder and respected member of :Pushtun Jirga,' the traditional arbitration outfit.

Wazir Khan vehemently insisted that I must write down his name while quoting him. Any journalist dreams to have such a source. Only three weeks ago, Malik Wazir Khan reported to have traveled all the way to a village in Azurgan, a desolate Afghan province next to Kandahar. Despite a fragile person in late sixties, he had to make this backbreaking journey. For, two families of the village he was invited to were viciously getting at each others' throats. On both the feuding sides, 28 males had already been murdered.

Malik Wazir Khan spent eight days in that village to arbitrate the truce. Now, he was desperately awaited to get another bloody feud settled in another village of the same province. 'Why do they need an old and sick man like me, if Taliban have established the perfect system of delivering justice?' Malik

Wazir asked in exasperation after long narration of his story.

During the days, he spent in Kandahar on his travel to and back from Aruzgan, Malik Wazir also claimed to have met two important ministers of the Taliban government. "They desperately wanted to find means of getting rid of KHAR JAN (the outsiders) who were ruling Afghanistan these days in the name of Taliban,' he reported.

Another guest at the same dinner had sneaked into Pakistan from a village very close to Kandahar city only on September 16. 'In the name of Allah,' he swore, 'I can tell you that everyone in Kandahar and the villages around want Osama bin Laden to leave Afghanistan.' They don't consider him a 'great Mujahid of Islam,' he claimed.

Most guests agreed with him. 'Why does he (Osama) not go to Palestine to fight against the real enemies of Islam, the Jews,' they wondered. This correspondent couldn't help tossing a provoking question: 'Why the people of Kandahar and the villages around don't rise to demand the expulsion of Osama Bin Laden, if resentment against him is so widespread?' Instead of furnishing a reply they all put a question in return: 'Under whose leadership?'

The guests claimed that very systematically "Taliban have already eliminated, muted and forced to exile the potential voices of dissent. Without a credible rallying personality, no one will ever dare to speak up.' And, talking of the 'rallying symbol' would always prop the name of Zahir Shah. 
The News International, Monday, September 24, 2001

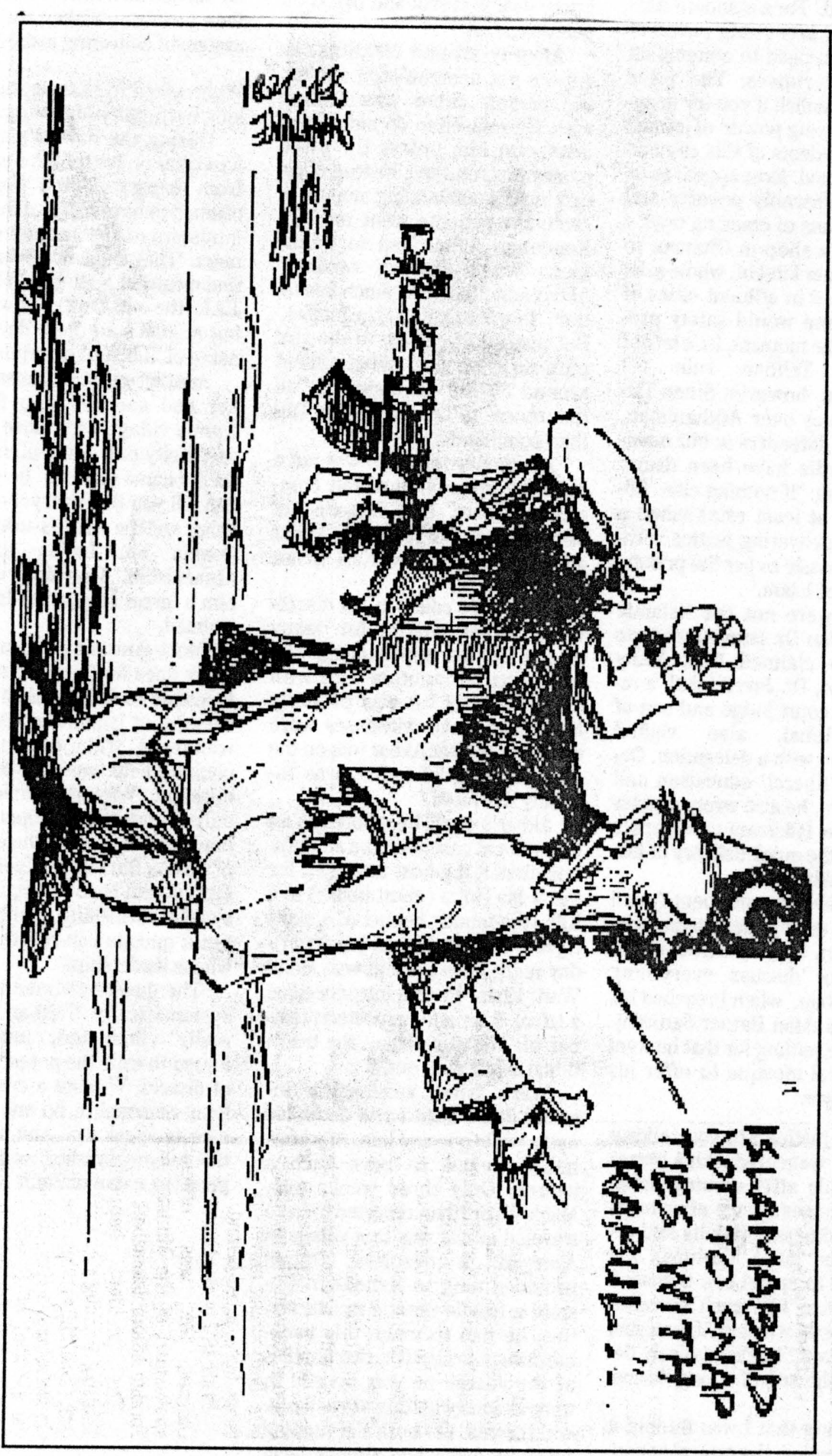




\section{US rejects Osama missing claim}

WASHINGTON: The United States rejected reports from Afghanistan on Sunday that Saudi exile Osama bin Laden was unaccounted for.

Defence Secretary Donald Rumsfeld said US officials did not believe the assertion from Afghanistan's ruling Taliban that bin Laden, head of the al Qaeda network, was now missing and may not even be in the country. "Of course not," Rumsfeld told the CBS "Face the Nation" programme.

"They know where he is." "They know their country. ... They have networks throughout the country, and it is just not believable that the Taliban do not know where the network can be located and found and either turned over or expelled," the defence secretary said.

Rumsfeld told reporters later that "some factions" of the Taliban were "pretending they don't where al Qaeda is located, which is laughable."

US President George W. Bush's national security adviser,

Condoleezza Rice, told the "Fox News Sunday" programme the United States would d. termine if bin Laden was, indeed, missing. "We're going to find out," she said.

With the threat of US military action looming, Rice reiterated demands the Taliban quickly turn bin Laden over to the United States in connection with the Sept. 11 suicide attacks. "We are not going to be deterred by comments that he may be missing. We don't simply believe it," she said. "The Taliban is not trustworthy in this regard," she added on CNN's "Late Edition."

Rice also had some threatening words for the hard-line Islamic movement ruling Afghanistan, calling it "a very repressive and terrible regime." "The Afghan people would be better off without it. We will see what means are at our disposal to do that," she said. "The Taliban is going to have to begin to understand it has a very tough choice to make." The United States is positioning military forces around the world to fight a war on terrorism that will involve more than Afghanistan, Defence Secretary
Donald Rumsfeld said on Sunday.

"What we've been doing since the day of the attack is getting our forces positioned in various places around the world, "Rumsfeld said on CBS television's "Face the Nation." "This is not an Afghan problem. This is a worldwide problem of terrorist networks," he said. Bin Laden's organization, al Qaeda, operates in at least 60 countries and is just one of many networks, Rumsfeld said.

"What we've been doing is getting our capabilities located, positioned, arranged around the world

so that at that point where the president decides that he has a set of things he would like done, that we will be in a position to carry those things out," Rumsfeld said.

Asked whether the United States had ruled out using nuclear weapons, Rumsfeld said that historically "the United States, to my knowledge, has never ruled out the use of nuclear weapons." But he did not suggest the country intended to use such weapons.

Sen. John McCain, an Arizona Republican, said nuclear weapons were not necessary, given the precision weapons available to fight the kind of threat that involves specific small groups of people at remote sites. "Nuclear weapons have a connotation associated with them that ... if you can't rule it out, you should certainly say that it is highly unlikely that this requirement would ever arise," McCain said on the same program.

Rumsfeld said he was never convinced that bin Laden's network had acted alone, but rather must have had outside help, possibly from other countries. "There's no way in the world that a network can function as effectively over such a long period of time, with such excellent finances and false passports and all of the intelligence information they had to have, without them being ... assisted and financed by states and by businesses and by nongovernmental organizations and by corporations," he said.

US officials have said there was no overwhelming evidence at this point that Iraq was linked to the attack, but others have said that angle should be investigated.
Asked whether the United States should go after Iraq, Rumsfeld would only say, "I think the president has a set of decisions and calculations he has to make."

\section{$\because$ McCain said Afghanistan was} the first priority, and then Washington should look at whether other countries were aiding extremists. "I think first you take care of the Afghanistan situation, and then you move on to other areas depending on what happens in those countries," he said.

Rumsfeld said the United States was receiving help from countries and individuals that in some instances were "surprising" and that would be key to the outcome. The United States had received "everything from Saudi Arabia that we have asked them to do," he said. "I've been in touch with Saudi leadership, and there is no question but that they are our friends and that they are determined to deal with this problem of terrorism just as we are," he said.

Rumsfeld confirmed that the US military had lost contact with an unmanned spy plane but told reporters the United States had no reason to credit assertions it had been shot down. "We have no reason to believe it was shot down," he told reporters after appearing on "Face the Nation."

Meanwhile, New York Mayor Rudolph Giuliani on Sunday acknowledged that the chance of finding any more survivors of the devastating attack on the city's twin World Trade Center towers was very slim. "If there is hope left, it is very, very slim," Giuliani told Fox News Sunday.

To date, 194 of the dead have been identified. The number of people reported missing after the September 11 double terrorist attack on the city remained at 6,333 , New York police said. By Saturday, nine more bodies were recovered from the rubble of the demolished towers, bringing the number of confirmed dead to 261 , officials said. -Agencies 


\section{UN monitors for Afghan curbs due in Pakistan}

\section{Aslam Khan}

ISLAMABAD: A group of officials appointed by United $\mathrm{Na}$ tions Secretary General Kofi Annan is arriving in Pakistan to monitor compliance with the UN sanctions imposed on Afghanistan earlier this year, sources said here Sunday.

"They will be here shortly to monitor compliance of the economic and military sanctions in requirement with the sanctions regime imposed by the UN," the sources told The News.

They informed that the monitoring team will be headed by Michael Chandler of the United Kingdom and comprise Ashraf Mohsen and Mohamed Mohsen of Egypt, Amod Gurung of Nepal, Phillipe Graver of France and Daniel Yorks of the United States.

When contacted, Director United Nations Information Centre Eric Falt confirmed that the UN monitors would be arriving but added that he was unaware of their exact schedule or where they would be based.

Kofi Annan appointed five experts to a Monitoring Group to monitor the Security Council sanctions against the Taliban government in Afghanistan.

"The move is in response to a decision by the UN Security Council to set up a Monitoring Group and in cooperation with countries neighbouring Afghanistan, including Pakistan, to tighten the sanctions against the Taliban," the sources said.

"The team will increase the capacity of Pakistan and the other states bordering Afghanistan to implement the UN sanctions against the Taliban," they added.

"Under the mandate given to them by the UN Security Council, the visiting team will set up a

- monitoring structure uith the aim of tightening military sanctions

and exerting more pressure on the Taliban to close terrorist training camps and hand over Osama bin Laden," the sources said.

The monitors would also be visiting Iran, Uzbekistan, Tajik- istan, Turkmenistan and China to monitor and verify their compliance with the sanctions regime.

It was in December 1999 that the UN imposed an air embargo and financial sanctions to force Afghanistan to hand over Osama bin Laden for trial.

In January 2001, the United Nations imposed further sanctions on the Taliban to force them to hand over Osama bin Laden, which they have continued to refuse to date.

\section{Taliban claim shooting down another plane}

MOSCOW: Afghanistan's Taliban regime claimed Sunday (1) have shot down another "unidentified plane" llying over Afghanistan, the Russian news agency ITAR-TASS reported. quoting the official Bakhtar agency in Kabul.

The plane was shot down some kilometres (miles) from the regional capital of Aibak. where Taliban forces claimed to have shot down a US spy plane on Saturday, the report added.

"We still do not know what country the plane is from," said Abdul Hanan Hinat, head of the Bakhtar agency, which is controlled by the Taliban.AFP

Reuters adds: Meanwhile according to a report from Damascus Syrian President Bashar al-Assad and his Iranian counterpart Mohammad Khatami on Sunday agreed that Islamic states should hold (on)sultations on last week's altacks on the United States.

\section{Zahir calls for formation of interim government}

ROME: The former Afghan monarch Muhammad Zahir Shah has appealed for an emergency assembly of representatives from all Afghan groups to elect a head of state and set up a transitional government.

The 86-year-old King, who has been living in exile in Rome since 1973 , made his ringing call in a statement here from his office. In his statement, Zahir Shah said his ultimate goal was the liberation of our homeland and people.

Despite the many sacrifices that the courageous nation of Afghanistan has endured for the noble cause of freedom and human dignity. "We must acknowledge with regret that the presence of the present administration in Kabul has caused unrest and danger for the stability of our country and peace in the region," he said.

Historically, our nation has acted in accordance with the guidance and tenets of Islam, embraced moderation and tolerance, opposed terrorism and terrorist behaviour, which is alien to Afghan traditions, former King said.
"I appeal to the Afghan people and to their sense of honour and patriotism to rescue us from this dangerous situation so that in the future we will have exonerated the Afghan nation before God Almighty and history," he said.

The King was forced into exile by a 1973 coup that marked the start of instability leading to a 1979 Soviet invasion and a civil war. Zahir Shah said he felt a na. tional duty to help Afghanistan by calling what he referred to as a Loya Jirga, an assembly made up of representatives from all tribal and ethnic groups.

A spokesman said that if the Loya Jirga could not be held in Afghanistan an emergency assembly could be held outside the country. The King said this would lead to an "Emergency Grand Assembly," in order to elect a head of state, and establish a transitional government. The spokesman said the king believed the United $\mathrm{Na}$ tions could play an important role in the eventual convening of the Loya Jirga.-SANA 


\section{Afghan opposition claims strategic gains}

KABUL: Opposition forces in Zaare in the course of last night northern Afghanistan claimed and this morningís fighting, but Sunday to have captured a strate- we recaptured all the areas we gic district from the Taliban mili- had lost."

tia, as the threat of US military strikes on the country loomed ever larger.

Abdul Rashid Dostum, one of the most powerful warlords in the anti-Taliban opposition, said his forces had ousted the Taliban from Zaare district, near Mazar-iSharif, capital of Balkh province.

"Zaare is very important because it is on the main highway linking the provinces of Balkh, Jozjan and Samangan," said Dostum, who was speaking to AFP from the frontline in Balkh, near the border with Uzbekistan.

But Taliban officials said they had recaptured the district after two days of heavy clashes.

"This afternoon we recaptured Zaare," a senior Taliban information ministry official told AFP.

"We had lost some part of support.

\section{The Frontier Post}

Dostum claims killing of Taliban soldiers

Monitoring Report

PESHAWAR: Northern Alliance commander Abdul Rasheed Dostum has claimed capturing a number of areas from the Taliban in Balkh province, BBC reported.

Independent sources have not confirmed the claim but General Dostum said that the fighting broke out in Sufaid Kotal-e-Chanchan stronghold of the Caliban last evening, it repoted.

He said that the Taliban had been holding this area for the last three years. Some 200 Taliban were arrested and 80 others killed during fighting.

He said that the fighting continued yesterday and all the areas of Sufaid Kotal were conquered. He claimed seizing heavy weapons including anti-aircraft guns.

Gerreral Dostum added that fierce fighting is still raging and the Northe* Alliance forces are matching towards Kishanda. He said that fighting is also going on in Faryab. The entire Lolash district has been seized,

He hoped that they would also capture Kishanda district to reach forty kilometers area of Mazar-e-Sharif.

\section{India, Russia \& Iran to engage in anti-Taliban manoeuvres}

NEW DELHI (Online): As the countdown begins for US retaliatory attacks on hide outs of Osama bin Laden in Afghanistan, regarded as the prime suspect of terror strikes in its cities, India; Russia and Iran are engaged in talks to jointly back the opposition Northern Alliance forces against the ruling Taliban regime in Afghanistan.

"The three countries are keen on jointly promoting the Northern Alliance, which is battling the Taliban," the Hindu newspaper said citing highly-placed Indian government sources. The paper said India, Russia and Iran "feel that a revived Northern Alliance, backed by a US-led coalition, should spearhead a military assault in Taliban strongholds in Kandahar, Kabul and Jalalabad." It added that these three countries feel that forming a strong alternative government in Afghanistan, would not only be central in rooting out international terrorism, but also protect their own interests.

Meanwhile, Ahead of imminent US retributive strikes at Afghanistan, chief of Russia's General Defence Staff, Army General Anatony Kvashnin held secret talks with a delegation of anti-Taliban Northern Alliance led by General Mohammad Fahim in the Tajik capital Dushanbe. The Afghan delegation also included Foreign Minister Abdullah of Rabbani-led Afghan government and other senior military officers: 


\section{The Frontier Post Monday, September 24, 2001}

\section{Iran setting up eight camps for Afghans}

TEHRAN (Agencies): Iran has set up eight camps to house some 200,000. Afghan refugees now stranded in its border who have fled their country in anticipation of American attack on Afghanistan, Iran's Home Ministry senior official said on Sunday.

Six camps have been set up along with the border in upper Khorasan province and two along with the border in Sistan-Baluchistan, all within Afghan territory and which can house some 200,000 Afghan refugees, Mohammad Reza Rostami said.

In the event the United States attacks Afghanistan, the Iran will settle the Afghan refugees in camps set up in a humanitarian gesture and in

\section{Iran, Saudi} Arabia oppose attack on Afghanistan

TEHRAN (NNI): Iranian Minister of Foreign Affairs Kamal Kharazi and his Saudi Arabian counterpart Prince Saud al-Faisal as-Saud, in a telephone conversation on Sunday, discussed developments since the devastating terrorist attacks (September 11) on the United States, the Iranian Foreign Ministry's Information and Press Department reported on Sunday.

The two sides condemned cooperation with international organizations, he said, pointing to the fact that the country's eastern borders have been sealed off.

He further noted that Iran alone cannot afford all the consequences of a possible US military attack on Afghanistan. He said that currentiy. some 2,800,000 Afghan refugees are already residing in Iran.

The state-run media, quoting the provincial immigrant affairs officer, also said that some 5,000 Afghan refugees, fleeing their country for fear of a US military strike, are stranded at the common border of Afghanistan and the Iranian province of SistanBaluchistan and are seeking to enter Iran.

the terrorist attacks and expressed their great concern over the possibility a human calamity could engulf the world, according IRNA news agency.

According to the same report, the two ministers stressed restraint by all countries of the world and the avoidance of taking any hasty decision that would risk more innocent human lives.

In the worst attack on American soil since Pearl Harbour, three hijacked planes slammed into the Pentagon and the twin towers of New York's World Trade Center on Tuesday (September 11) reducing the 110-storey towers to rubble and causing massive destruction to the Pentagon.
Moreover, the officer said that many of the refugees have already illegally entered the southeastern Iranian province through the help of human traffickers and have settled down in the cities of Zahedan and Zabol.

United Nations has announced that a humanitarian crisis at Afghanistan's borders with Iran and Pakistan has already started and that food supplies are good only for a week.

Meanwhile, Iranian Red Crescent personnel in Khorasan have been put on a state of full alertness in anticipation of American military strike against neighbouring Afghanistan, which harbors the prime suspect in the US attacks, Osama bin Laden. 


\section{The Statesman Monday, Seperember 24, 2001}

\section{Five groups linked to

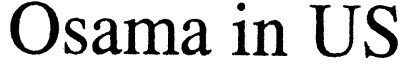

WASHINGTON: Four or five groups linked to Osama bin Laden have operated in the United States for the last several years, though investigators have not found any link between them and the hijackers responsible for the September 11 attacks, the Washington Post said on Sunday.

Citing unnamed government officials, the newspaper said the groups or cells are under government surveillance but no arrests have been made because the members entered the United States legally and have not been involved in criminal activity since they arrived the Post said.

US officials have alleged Osama bin Laden as the prime suspect in the attacks on the . World Trade Center and the Pentagon that left more than 6,800 people dead or missing The cells, according to the officials, are units of Al Qaeda, which US further alleged to have been working in many countries.

Government officials, who declined to identify the cities where the Al Qaeda cells are located, said they do not know why the groups are in the United States or whether they are planning attacks, the Post said.

"They are so good at compartmentalizing," an official told the newspaper.

The Post said the FBI was struggling with the question of why the groups have stayed in the United States. One official, the newspaper said, speculated that they were here to gather intelligence, to support or execute attacks or possibly to earn money.

Although investigators have not linked the groups to the hijackers, they have found links between the four groups of hijackers involved in the airborne assaults, the Post said.

The newspaper said the FBI had identified Mohammed Atta, who is believed to have piloted one of the jets that hit the WTC, as the main link between the four teams. - Agencies

\section{Dissident in Afghanistan: Mutmain}

\section{Statesman Report}

QUETTA: Taliban movement's supreme leader Mullah Mohammad Omar Sunday endorsed the Afghan Ulema Council's recommendation Osama bin Laden be asked to leave Afghanistan of his own volition.

"The recommendation has been endorsed by Amirul Momineen and we are now trying to get it through to Osama," Taliban's spokesman Mullah Abdul Haye Mutmain told The Statesman by telephone from Kandahar.

He denied reports the Saud dissident. Osama bin Laden, was missing in Afghanistan or had left the country. He said after the decision was submitted to him it would be up to him whether he decides to leave or not.

In Islamabad, Afghan Ambassador Mullah Abdul Salam Zaeef said, "the Amirul Momineen has announced to abide by the Shoora's recommendation urging the Taliban leadership to convince Osama bin Laden to voluntarily leave Afghanistan and choose another destination for himself."

Zaeef told NNI, "Taliban authorities have been searching Osama bin Laden to communicate to him the Ulema Council's decisions and Mullah Omar's endorsement, but they have not yet succeeded in tracing out bin Laden."

The Ambassador said the Taliban authorities tried to convey Mullah Omar's message on Saturday and Sunday but failed to find him.

To a question about the shooting down of the spy plane, Mullah Zaeef said the wreckage had been shifted to an airbase in Mazar-i-Sharif. He added one tyre of the plane had been burst while its computer system had been slightly damaged.

\section{Tajiks in Kabul fear Taliban as well as US}

EWABAD, Afghanistan: As the Taliban prepare for jehad against the United States should it launch retaliatory strikes, many of Kabul's oppositionassociated ethnic Tajik residents are leaving the city. Fearing a knock on the door and arrest as well as US bombs, 25-year-old Feruzidin decided in the middle of the night to flee the city, and by 4:00 am he and two brothers were on their way.

Relief was etched on his face as he igot: out of a mini-van 12. hours Iater ton Saturday, a few kilometres' into territory held by Afghan opposition forces northeast of Kabul. He said he would be in no hurry to return. "I will wait to see the situation," said the young man, who just had time to board up his photographic shop in Kabul and bundle together a few possessions.

Up to 500 refugees a day from the Afghan capital have been fleeing north for the past four or five days to their relatives in the Shamali plains and Panjsher Valley, nearly all from the ethnic Tajik minority.

Able to leave the city freely, if they have the money to pay for the $120-\mathrm{km}$ drive to the town of Gawa, they then have to trek on foot for two hours around the Ashuqan mountains to cross the frontline. - AFP 


\section{Benazir calls for Pak breaking off ties with Taliban}

From Our Correspondent

NEW YORK : [iormer premier Benazir Bhutto has asked the Pakistani military regime (1) snap diplomatic ties with the Islamic militia on the lines of the United Arab Fimirates. "UAli did the right thing in cutting olt rolations with Taliban. I would like my own government to do the same. In lact back in 1998, we called upon the g(overnment to severe ties with Taliban.

"laliban are a major problem. they are determined to go it alone," Bhutto said appearing in the CNN's programme 'l arry King Live'.

Bhullo saw the possibility of change in the leadership of the Taliban and empliasized on elforts to install a broadbased government in Alghanistan.

She said Taliban enjoyed support among those who fought Aighan war against the Soviet Union but have little following among the ordinary citizens.

However, she said, Mullah Omar is not going to cooperate as he is related to Osama
Bin Laden, suspected master terrorist, whose handover Americans are demanding for trial. There are other Afghans who would like to see peacetul resolution of the issue but it is very difficult until Tuliban are in power.

The Afghan 'Jehad', she said, had led to proliferation of weapons in Pakistan and rise of religious militants.

"We find professionals being shot down just because they are Shiias," So people in Pakistan are support the battle against terrorism," she added.

\section{Thousands of JUI fighters}

\section{march toward Afghan border}

QUETTA (Online): Secretary General of Jamiate-Ulema Islam (JUI) Maulana Abdul Ghafóór Haideri has said that thousands of fighters from JUI have begun marching to the Afghan border to fend off a possible U.S. invasion.

Addressing an emergency press conference here Sunday, he said that its Mujahideen would also be sent to surround air bases to try to prevent U.S. military firm using the facilities adding that millions of armed tribesmen are on war footings to foil American designs. "Our Mujahideen will cordon off all air bases in Pakistan where the U.S. army operates," Ghafoor said.

"The war against Afghanistan is not just against Afghanistan but it is against the world of Islam," he said. Deploring the colossal loss of human life as a result of terrorist attacks on World Trade Center and Pentagon; IIaideri said that these were a part of Jewish conspiracy to bring Muslims under American outrage.

JUI leader appealed to UNO, OIC, China and
Russia to play their active role in averting American aggression against Afghanistan that might escalate to a third world war. He asked US to avoid acting in haste, as the investigations into the terror strikes are yet to reach a conclusive stage.

The military regime he alleged has disgraced the nation before the entire Muslim world and warned General Musharraf that America has never been and would never be a loyal friend and has always betrayed us at difficult hour. 


\section{The Nation}

MONDAY, SEPTEMBER 24,2001

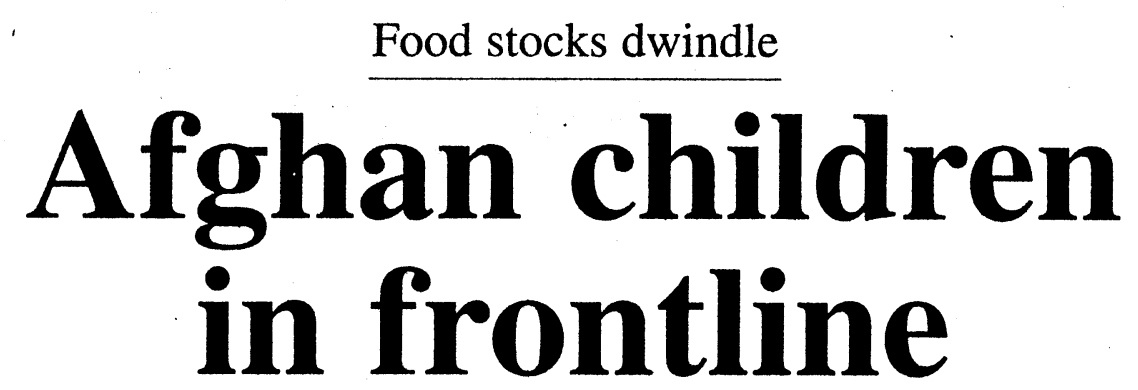

ISLAMABAD (AFP) - The United Nations Children's Fund (UNICEF) is hoping to begin emergency airlifts of supplies to people in Afghanistan but badly needed food is still being held up in Pakistan amid mounting fears of a humanitarian disaster, UN officials said Sunday.

Hundreds of thousands of people are on the move throughout theimpoverished country as US forces continue their build-up to possible attacks on the ruling Taliban militia and their ally, Osama.

Children are particularly vulnerable as the freezing Afghan winter approaches, threatening to catch them in the open, without shelter or adequate food.

'We know that children froze to death last year and we fear that they will be exposed in the next few months to the same conditions,' UNICEF spokesman Gordon Weiss told AFP in neighbouring Pakistan.

'The most pressing need is that we ensure that we get supplies into the country, but we don't know where these people are moving to - they don't know either.'

He said the first of six UNICEF emergency airlifts had been scheduled to leave late last week from Afghanistan's northern neighbour Turkmenistan, but it had been held up pending government approval.

'We only have shelter stocks for a few weeks, immunisation equipment, vaccines we have for the current campaign, but obviously they're going to run out. Unless we have access we face a real problem,' said UNICEF special representative for the region Nigel Fisher. 'Ourplanning estimate is that we may see as many as 900,000 (refugees) coming across this border into Pakistan. We're also estimating

\section{Gulf states seek joint stance}

JEDDAH (AFP) - Gulf monarchies, wary of attacks on Islamic states such as Afghanistan, held talks Sunday to coordinate their positions after assuring the United States of their support.

The foreign ministers of Bahrain, Kuwait, Oman, Qatar, Saudi Arabia and the United Arab Emirates went into a closed-door meeting here to draw up a 'common evaluation of the situation following the attacks on the United States,' a Gulf official said.

Saudi Foreign Minister Prince Saud al-Faisal was expected to brief his counterparts on his recent talks with US President George W. Bush, one diplomat said.

Prince Saud reiterated support for a campaign against terrorism but called for caution in order to avoid creating a huge gap between Western and Islamic nations.

The United States has launched a diplomatic drive to build a global anti-terrorism coalition in the wake of the September 11 suicide attacks in New York and Washington which left thousands dead. The Gulf monarchies, which are home to thousands of US troops and civilians, and are considered close allies of Washington, were quick to denounce the outrages and said they were prepared to help in the US anti-terror campaign.

The United Arab Emirates snapped diplomatic ties with Afghanistan's Taliban militia on Saturday for refusing to hand over Osama bin Laden, prime suspect in the World Trade Center and Pentagon outrages.

perhaps 300,000 into Iran, 150,000 to 200,000 into Turkmenistan.

Airlifts are coming in starting on Monday, not only here but also Iran and Turkmenistan. Basically we assume we have days and we have to act very quickly.' Afghanistan was already facing a humanitarian crisis before the September 11 terror attacks in New York and Washington raised the prospect of war with the United States.

Saudi-born dissident bin Laden has been accused of plotting the attacks on the World Trade Center and the Pentagon, in which more than 6,800 people are feared dead.

'Inside Afghanistan, the situation for children is among the worst in the world,' UN spokeswoman for Afghanistan Stephanie Bunker said.

'In Kabul alone there are 50,000 children working in the streets trying to help their impoverished families to survive. One in four children die before their fifth birthday.' Civil war and drought had driven some 900,000 people from their homes in the year to September, and the UN had warned of looming famine.

But with the pullout of international aid workers due to security concerns following the attacks in the United States, and the massive movements of people fearing US strikes, the situation has spiralled out of control.

Concerns have been compounded by a Taliban order for UN offices to stop communicating with the outside world, leaving the main coordinator's headquarters in Pakistan almost blind to the latest developments. The UN World Food Programme (WFP) has some 14,000 tonnes of stocks of food left inside the country, nowhere near enough to feed the hundreds of thousands of people who could face starvation within weeks. 


\section{The Nation MONDAY, SEPTEMBER 24, 2001}

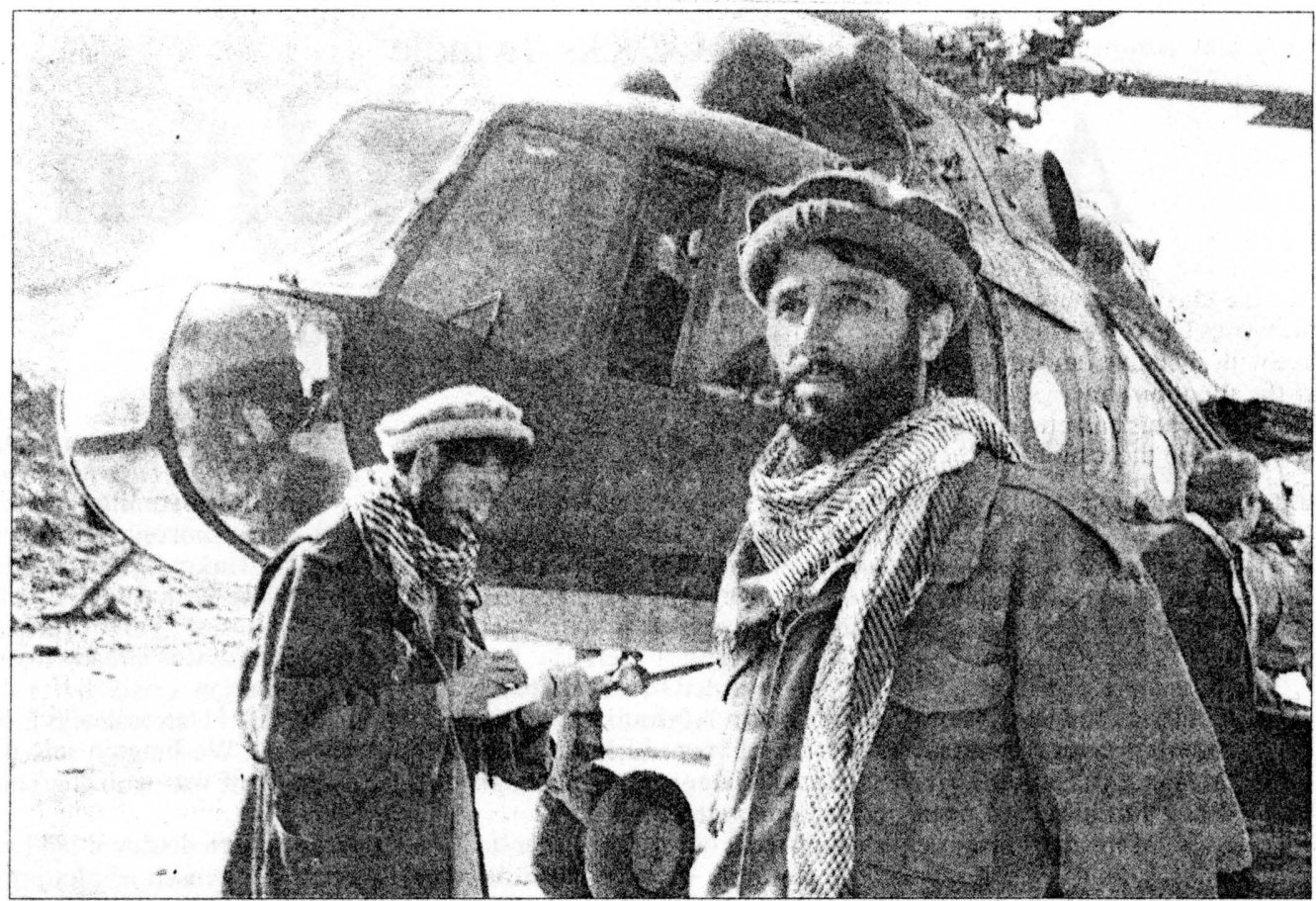

JANGALAK: Afghan Northern Alliance (anti-Taliban) soldiers stand next to a helicopter in the village of Jangalak, $160 \mathrm{~km}$ north from Kabul, in Panjshir Valley on Sunday.-AFP

DAWN MONDAY, SEPTEMBER 24, 2001

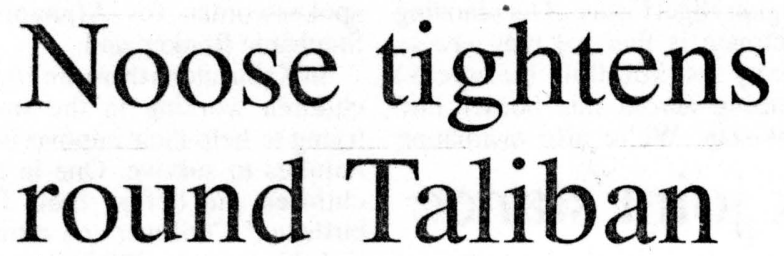

ISLAMABAD, Sept 23: A massive US-led strike force took up positions in countries surrounding Afghanistan on Sunday as Washington rewarded its key allies and speeded preparations for an attack on radical Islamic terrorists.

Reports from Kabul said that Taliban leaders had distributed thousands of Kalashnikov assault rifles to civilians in expectation of an attack, but the noose was tightening around them as a US-led coalition gathered strength.

Russian President Vladimir Putin gave his approval to US plans to launch attacks from bases in former Soviet Central Asian republics, US officials said.

Moscow's decision came as President Emomali Rakhmonov of Tajikistan said his country, which borders Afghanistan, would support the US effort and Uzbek officials said US planes and attack helicopters were already in Uzbekistan.

The choppers took part in a joint NATOUzbek military exercise earlier this month and were still at a military base some 40 kilometres east of Tashkent, the Uzbek sources said.

The Pentagon was maintaining a wall of absolute secrecy around the deployment of its troops and would not confirm or deny the reports.

On the western frontier of Afghanistan, Iran has not openly backed the idea of US attacks, but the country is a longtime opponent of the Taliban.

Indian officials said on Sunday that Iran would join India and Russia in supporting Afghan opposition in its civil war with the Taliban.

Intense fighting raged in northern Afghanistan as opposition forces under warlord Abdul Rashid Dostum claimed he had 
cut off a Taliban supply route leading to the town of Mazar-i-Sharif near the Uzbek and Tajik borders.

Dostum told AFP by telephone that his men had killed at least 60 Taliban fighters and secured a key highway. A Taliban official confirmed the opposition had advanced but said the fighting was ongoing.

Opposition forces have pledged to work with the United States in the event of an attack and military experts have suggested that the Mazar-i-Sharif airfield could be a key target for capture.

A massive array of US firepower has been deployed to the region.

Reports in the British press said that advance teams from US and British special forces had already arrived inside Afghanistan to consult with opposition forces and pinpoint bin Laden's position. -AFP

\section{Nazarbayev-Pope John Paul II meeting Kazakhstan ready to join coalition}

ASTANA (Kazakhstan), Sept 23: Kazakhstan's president said on Sunday his country, whose southern border is only $300 \mathrm{~km}$ from Afghanistan, was ready to join a coalition to fight terrorism.

"Kazakhstan has resolutely spoken out against terrorism and is ready, in a coalition of other states, to fight it jointly because we believe that a single state, however big, cannot defeat terrorism alone," he told Pope John Paul.

President Nursultan Nazarbayev made the comment during part of a meeting with the Pontiff.

He also thanked the Pope, on his first full day in Kazakhstan, for going ahead with the trip despite security concerns in the region since the attacks in New York and Washington.

Nazarbayev spoke a few hours after the Pope himself issued a dramatic appeal that the world not be allowed to slide into war.

Kazakhstan, a sprawling for mer Soviet Republic that gained independence in 1991, has many military air bases from the Soviet era. But it was not clear if the president was referring to eventual participation in a military operation, the use of bases or merely moral and political support for the United States.

POPE'S MESSAGE: Pope John Paul II said that religion could never be used as an excuse for war and urged all faiths to unite in a world without violence.

"We must not let what has happened lead to a deepening of division," the pope said in reference to the terrorist attacks in the United States after celebrating mass before thousands gathered in front of a blue Kazakh yurt.

"Religion must never be used as a reason for conflict," the pope said after the mass, pronounced in Russian before more than 2,000 Kazakhs.

"I wish to make an earnest call to everyone, Christians and followers of other religions, that we work together to build a world without violence," he

\section{Putin calls for}

\section{Afghan response}

MOSCOW, Sept 23: Russian President Vladimir Putin on Sunday called the leaders of the five Central Asian republics to coordinate a response to possible US strikes on Afghanistan, the Kremlin said in a statement.

It cited President Vladimir Putin's top foreign policy advisor Sergei Prikhodko as saying that Putin "continued his coordinated action related to the region and its surroundings."

No other details were dis closed.-AFI added, speaking slowly in a shaky voice. Later, the pope met Kazakh President Nursultan Nazarbayev, who is keen to earn greater international recognition for his oil-rich Central Asian state and who introduced the pontiff to his family.

John Paul's visit to this mainly Muslim former Soviet republic has taken on a new significance after terrorist strikes in the US.

UZBEKISTAN: Meanwhile, reports that US military planes delivered surveillance equipment to Tashkent have underscored Uzbekistan's potential in any possible US military action against Afghanistan.

Though the Uzbek government has not confirmed it, an official at the capital's civilian airport said two US C-130 cargo planes landed there on Friday for about an hour and a half. Military analysts say the arrival of US transport planes could signal that Karimov is courting the United States to bolster his own regional ambitions.

"During the Afghan war, Uzbekistan was the biggest supply and logistic base for Soviet troops fighting there," Russian military expert Alexander Golts said.

"There are a number of very big facilities which can be used for a military operation of any type. You can deploy a huge number of troops there, one or two divisions."-Reuters 


\section{Clinton says he ordered assassination
of Osama}

WASHINGTON, Sept 23: Former US president Bill Clinton has admitted that he ordered the capture and possible assassination of Osama bin Laden, who Washington believes masterminded this month's terror strikes here and in New York.

Clinton told reporters in New York that he gave the go-ahead for the clandestine operation following the 1998 bombings of the US embassies in Nairobi and Dar es Salaam - attacks for which bin Laden has since been indicted in the United States.

"We did everything we could," Clinton said.

"I authorized the arrest and, if necessary, the killing of Osama bin Laden, and we actually made contact with a group inside Afghanistan to do it.

"They were unsuccessful," he added.

Clinton said that his administration also began training commandos for a possible ground assault aimed at capturing or killing bin Laden, but that adequate intelligence and support from key international governments was lacking.

"We did everything we could, everything that I thought appropriate," he said.

Clinton's administration fingered bin Laden following the attacks on the US embassies in Africa and vowed vengeance against him.

The US launched stinging attacks on bin Laden's base in Afghanistan, where he is a "guest" of the Taliban regime, as well as on a target in Sudan, which turned out to be a pharmaceutical factory.

Despite Washington's longrunning attempts to take bin Laden, a millionaire Saudi dissident who has vowed to target the United States, he has eluded justice, staying out of sight, apparently in Afghanistan.

Clinton, who left office in January after eight years in power, said he felt President George W. Bush was handling the crisis provoked by the Sept 11 attacks on New York, Washington and Pennsylvania "in a strong way."

In the aftermath of the strikes, there have been calls in the US for a ban on the assassination of foreign leaders to be dropped.-AFP

\section{Alliance team visits Italy to discuss strategy with Zahir}

DUSHANBE: A delegation from Afghanistan's anti-Taliban alliance has left for Italy to consult with the exiled Afghan king and may ask him to lead their force, an official said Monday.

The group left Afghanistan's Panjshir region late Sunday for the capital of neighbouring Tajikistan, then flew through Uzbekistan to Rome, the military attache of the opposition alliance's embassy in Tajikistan, Muhamad Salekh Registani, told The Associated Press.

The team was to meet 86-yearold King Mohammad Zahir Shah, who has lived in Rome since he was overthrown in a 1973 coup by his nephew. The delegation was led by a deputy foreign minister in the opposition govern-
ment.

The goal of the talks was to consult with the monarch about the fight against the ruling Taliban and the U.S. anti-terrorism campaign in the region, the military attache said. - AP

\section{Taliban may run out of food soon}

\section{Rauf Klasra}

ISLAMABAD: Pakistan's wheat reserves may come under severe pressure in the near future if the inflow of Afghan refugees continues to grow in the coming weeks in the wake of possible US attacks on Afghanistan, Agriculture Ministry officials warned.

The officials said that usually Pakistan provides 0.6 million tons of wheat to Afghanistan in normal conditions every year. Last year due to local bumper crop, the government had tried to sell the wheat to Afghanistan through private parties and two sepa- rate deals of 2 million tons were also signed with the private parties.

But the Taliban regime, receiving wheat from illegal channels, had refused to allow them to sell the commodity there at the market rate. As a result, the deal could not materialize and the contracts were cancelled by the contractors themselves fearing financial losses.

So in real terms the Taliban have no wheat stock to meet

the demand of their population which is now coming to Pakistan in search of both safety and food.

Pakistan also has limited wheat stocks which are only sufficient to meet its own food requirements that have now risen up to 21 million tons including one million tons of strategic reserves for 2001 , against 19-20 million tons of last year, an agriculture ministry official confirmed.

Agriculture ministry officials say the government has little idea of how many Afghans would actually come to Pakistan seeking refuge and how much wheat it would require to meet their demands.

The government had drastically slashed the wheat procurement target this year by about 4.6 million tons as only 4 million tons of wheat 
was purchased by the official wheat procurement agencies against last year's total of 8.6 mil-

\section{lion tons.}

The officials said even agriculture ministry bosses had not raised any voice over drastic reduction in the wheat target just to save their own jobs and to please the finance ministry wizards who were insisting on the introduction of free market system in wheat trade, to meet international lending agencies' conditionalities and get some dollars.

So, the agriculture ministry officials said, this year the country had produced about 19 million tons of wheat against the actual needs of about 21 million tons. The situation was however under control as far as domestic food needs were concerned due to last year's carryover stock of 1.2 million tons, the agriculture ministry sources said.

But, officials said, sudden development on Afghanistan front had put the government under pressure " as the country could not afford to supply even a million ton of wheat

from its own existing stocks. The secretary office sources said that is why agriculture ministry which was absolutely unaware of serious implications of the US-Afghan crisis had now been directed to wake up and start doing some preliminary work on this issue.

The officials said keeping the fresh situation in view, Passco has already floated tenders in the national press for the purchase of about 200,000 tons of wheat from the private traders at the rate of $\$ 106$ per ton for its onward supply to Afghanistan to meet the emergency.

The officials said agriculture ministry has been asked to review the existing position of wheat stocks in the country and submit a report that in case of attack on Afghanistan by America, what would be the position of existing stock and how many days the country could afford to supply wheat to unwanted guests from across the border.

\section{Omar asks US to withdraw from Gulf}

\section{Says death of 0mar or 0sama not to solve problem; Taliban appeal to UN, OIC, American people to avoid war}

\section{Behroz Khan}

PESHAWAR: Taliban supreme leader Mulla Muhammad Omar has said the only way out to put an effective end to terrorism is to ask the United States to withdraw its forces from the Gulf states and demonstrate impartiality in the solution of the Palestinian problem.

"America will not come out of the ongoing crisis by Mulla Omar or Osama bin Laden. US forces should pull out from the Gulf and adopt impartial policy on the question of Palestine", Mulla Omar said in a statement issued from Kandahar on Monday.

The statement, which was readout to The News by Taliban spokesman, Abdul Hai Mutmayan, said that the United States was mistaken, if it believes that the elimination of Mulla Omar and Osama bin Laden would be of any help to find out solution to the crisis.

Mulla Omar said that American leadership was misinterpreting Islam for personal gains and asked for restrain and halting interference in the religious belief of the Muslims.

He said that the Americans want to hostage the holy religion and the ample proof of the same is the existing realities, as the United States plans to disrupt peace in Afghanistan by imposing a government of its own choice on the Afghan people.

He said that the US has fulfilled this agenda in the past by overthrowing governments in Muslims states and installing puppets to serve the interests of America.

"America has no choice other than overthrowing the government in Afghanistan or would be engaged in bloody war with the Afghans to harm them as well as itself without gaining ground on this front," Mulla Omar said.
The Taliban chief asked the people of America to rise against its government and force the rulers to change their policies towards the Muslims. "America dictates the Muslim world by threatening either to use atom bombs against them or block their sources of livelihood, in case of defiance," Mulla Omar said.

"If the US did not listen to reason and failed to withdraw its forces from Gulf, the entire responsibility of terrorist acts in future would rest with the American leadership," he warned.

The official Afghan news agency, Baktar reported that thousands of pro-Taliban Afghans staged a protest demonstration against the expected attacks of the United States in Kabul and vowed to fight for the defence of Afghanistan.

The vehicular procession, which started from Shakardara, north of Kabul and reached the capital also marched through the city roads and pelted stones on the deserted embassy building of the United States, the reports said.

The protesters also announced support to Taliban government and chanted slogans in favour of Mulla Muhammad Omar, Osama bin Laden and backed the edict passed by religious clerics in Kabul last week declaring jihad in case Afghanistan was attacked.

While the Afghan defence min-

ister, Mulla Ubidullah Akhund, in a statement issued from Kabul said that not only the government forces but, hundreds of thousands of former mujahideen have enrolled their names in aid of the Islamic Emirate in case the country was attacked.

"Apart from the regular Afghan army, more than $3,00,000$ experienced and skilled former mujahideen have enrolled their names with the government so far. They have already been given assignments and have been moved to de- 
fend their country against foreign invaders," the minister claimed and added that more and more mujahideen were reporting at the offices elsewhere in the country to enroll their names for jihad.

Agencies add: "We have instructed the whole mujahid nation to prepare themselves for jihad and wage holy war at any time they think is necessary," Obaidullah said.

Taliban appealed to the United Nations, Islamic countries and the: people of the United States to put pressure on Washingt on to pull back from a threatened military attack.

In a letter to UN Secretary General Kofi Annan, Taliban Foreign Minister Wakil Ahmed Mutawakel called on the world body to intervene in the crisis. "Your excellency is requested to use your authority and influence and not let big countries impose their evil interests on small and poor countries, especially on the Islamic Emirate of Afghanistan," the Taliban minister wrote.

He reiterated the Taliban's position that Osama bin Laden could

not have been involved in the September 11 attacks on New York and Washington because he did not have the means to communicate with the outside world.

"On the one hand, the United States itself describes Osama as a suspect but on the other it intends to attack our country which is against the principles of the UN and the declaration of Human Rights. "According to Islamic Sharia and all international laws a suspected person is treated as innocent until the court has pronounced its verdict."

Mutawakel attacked the world for not condemning a US spy plane's incursion into Afghanistan airspace. "Recently a US spy plane was shot down by the forces of the Islamic Emirate. Is the sending of such aircraft to the territory of an independent country not a terrorist attack?" Mutawakel asked. "Why the world is silent on that? There is no difference between the incidents which happened in the US and the sending of planes to our territory. They are both considered as terrorist attacks."

Mutawakel has sent a similar letter to the head of the Organisation of the Islamic Conference.
In an earlier statement, the foreign minister appealed to the United States people to put pressure on their government for restraint. The statement said Afghanistan deeply appreciated the aid it received from the United States during its resistance to the 1979-89 Soviet occupation.

"The help and assistance of the American people during jihad (holy war against the USSR) was appreciated. "But unfortunately the US government has been threatening the people and territory of Afghanistan for some unknown reason and different pretexts. "It has even sometimes talked of a crusade against the religion of this country which is very horrible."

More than 1,000 Afghan Taliban, or Islamic students, staged an angry demonstration outside the former US embassy building here Monday, vowing a fight to the death in defence of their country.

After a noisy procession through the streets of the capital, the militants gathered outside the abandoned embassy and kicked and stoned the building. They then attached an effigy of US President George W. Bush to the gates and set it alight.

The young men earlier chanted anti-US slogans and "Allah-oAkbar" (God is great) as they drove around central Kabul in trucks and buses. They chanted: "Death to the USA. We are ready for jihad. Long live the mujahedin," in an apparent attempt by the ruling Islamic militia to rally public resolve ahead of possible US-led military strikes.

Naveed Ahmad adds: In their last bid to avert a likely attack, Taliban Monday wanted American people to stop their government from any such aggressive act.

Speaking at a press conference, Taliban's Ambassador to Pakistan Mulla Abdul Salaam Zaeef said, "Afghans have no quarrel with ordinary people in the United States."

He recalled the unprecedented assistance provided by 'sympathetic people of the United States' during the Afghan's war against Soviet Union.

Zaeef said, "We still appreciate that assistance." He regretted that the American government was threatening the people of Afghanistan of war.

"We are urging the people of United States to inform their government of the serious consequences and to save the people of both the countries from these," he said.

The ambassador said, "Afghanistan would appreciate if America takes the issue prudently and resolve the crises with dialogue rather pursuing war. Otherwise, if it attacks Afghanistan, we will fight tooth and nail".

He also called upon all the Muslim countries for playing their role in stopping possible US attack on Afghanistan.

Mulla Abdul Salam Zaeef also called upon the United Nations to take notice of violations of Afghan airspace by the United States.

He also referred to shooting down another spy plane violating Afghan airspace.

Zaeef welcomed Colin Powell's statement about provision of proofs of Osama bin Laden's involvement in the September 11 tragic incidents.

He again confirmed that Osama was still missing and said he had no idea of his whereabouts. He, however, did not rule the possibility of his presence in Afghanistan.

Zaeef said the Afghans have acclimatized themselves of war-like situation during past two decade and "are living a normal life". However, the authorities are working to remove any difficulties.

About preparedness for war, he said, "We are taking all the step as per our capabilities to fight a war." 


\section{N Alliance inflicts heavy losses on Taliban}

\begin{abstract}
DUSHANBE: Anti-Taliban forces headed by General Rashid Dostam, military head of Afghanistan's Uzbek minority, killed 80 fighters of the ruling militia Monday while pushing towards a strategic northern Afghan town, his aides said Monday.
\end{abstract}

A. spokesman for Dostam based in the Tajik capital told AFP that another 200 Taliban fighters had been taken prisoner in fighting around the city of Mazar-iSharif, which has been controlled by the Taliban since 1997 .

The Northern Alliance official said that only five anti-Taliban fighters had been killed in the fighting. Dostam is a leading opponent of the ruling Taliban regime in Afghanistan which has been sheltering Osama bin Laden, seen by Washington as the primary suspect behind the September 11 terrorist attacks in the United States.
Taliban confirmed Monday that opposition forces had captured the town of Zaare near the strategic northern city of Mazar-iSharif, the Afghan Islamic Press (AIP) reported.

Taliban spokesman Abdul Hai Mutmaen told AIP that Zaare had fallen to the opposition in heavy fighting, but added that much of the surrounding district remained under Taliban control. He also denied opposition claims to have taken over the nearby district of Keshanda, saying an assault on the area had been repulsed.

The AIP report on Monday quoted unidentified Taliban sources as saying the opposition forces had also launched three successive assaults on Sange Bordo, 90 kilometers northeast of Kabul in Kapisa province. The attacks were beaten back by the Taliban militia, the sources said. AFP

\section{Numbers surge at Pak- India border crossing}

CHANDIGARH: The number of people entering India from Pakistan at the lone road border crossing between the two countries has surged amid expectations of a US strike against Afghanistan, customs officials said on Monday.

Some 60 people were crossing the border daily from Pakistan at Wagah in the north Indian state of Punjab, up from about two-dozen normally, the officials said.

Indian newspapers have reported the city of Amritsar, 20 $\mathrm{km}$ from the border crossing, could receive as many as 5,000 Westerners, mainly women and children, if the United States, with the support of Pakistan, attacks Afghanistan.

Western nations have been looking at Amritsar as a possible safe haven for their Pakistanbased nationals, and representa- tives of more than half a dozen countries have visited the border city from New Delhi to work out contingency plans for an overland evacuation from Pakistan to India.

"Up to Sunday evening, 231 foreign nationals including the family of a Polish diplomat had crossed into India over the past few days," Customs Commissioner Vineet Ohri said.

Some 70 foreign nationals from countries such as Canada, United States, Austria, South Korea, Germany, France and Poland were staying in guesthouses in Amritsar, $250 \mathrm{~km}$, local officials said.

India has decided to keep its border with Pakistan open night and day. Normally the Wagah border gates clang shut at dusk in a display of thinly veiled hostility by guards of the two nuclear-powered rivals.- - Reuters

\section{India wants talk on post-Taliban Afghanistan}

NEW DELHI: Indian Prime Minis ter Atal Behari Vajpayee told his British counterpart on Monday it was time for the international com: munity to start discussing the postTaliban structure of Afghanistan; an official said.

Vajpayee talked about a possible new political structure with Tony Blair during a 10-minute telephone conversation, a spokesman for the Indian premier's office told Reuters.

"The time has come for the international community to address the post-Taliban structure in Afghanistan, which our prime minister said should be representative in nature," the spokesman said.

Last week, Pakistan's military ruler, General Parvez Musharraf said in a televised address to the nation that India had joined Afghanistan's anti-Taliban neighbours in a meeting this month in the Tajik capital Dushanbe to discuss strategy in Afghanistan.

India has said it may offer refueling facilities for the US air force in the event of a strike on Afghanistan in what Washington calls its war on terrorism. The spokesman said the two prime ministers also agreed that the international community should seriously think about the humanitarian crisis in Afghanistan.-Reuters

\section{Family of Indian diplomat leaves Pakistan}

AMRITSAR: Amidst the reported drive by several countries to move their nationals to safer places in the wake of impending US action in Afghanistan, four members of the family of first secretary of Indian embassy in Pakistan Sunday crossed over into India from the Indo-Pak joint border check-post at Wagah, $25 \mathrm{~km}$ from here.

The members, who crossed over at $3.45 \mathrm{pm}$, included the diplomat's wife, mother and two children, BSF sources said. Sana 
The News International, Tuesday, September 25, 2001

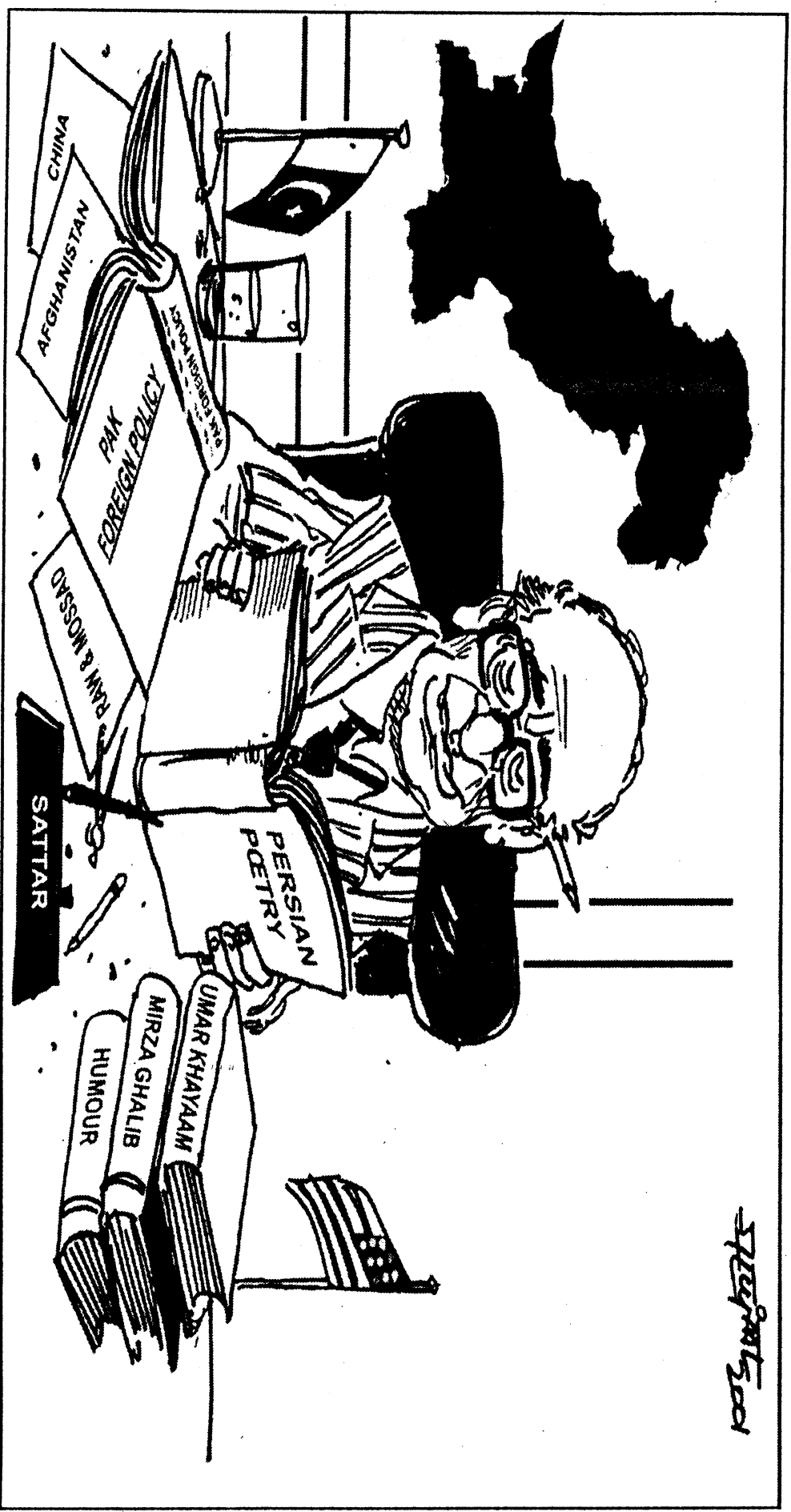




\section{Pakistan's 'strategic}

\section{nightmare'}

\section{Kamran Khan}

KARACHI: Pakistan appeared to be slipping into what a senior Pakistani official called "a strategic quagmire" as it emerged Monday that the United States was supporting anti-Pakistan and anti-Taliban Northern Alliance in their current military push to capture Kabul-only 45 miles north to Alliance's military base in Panjshir valley.

Sources associated with senior officials participating in Pak-US negotiations in Islamabad and Rawalpindi disclosed that Pakistan was using every argument available to impress upon the US government that any US-sponsored military assistance that facilitate Northern Alliance's takeover of Kabul would spell a disaster for the US military operation.

Uneasiness in Pakistani security circles over United States visible desperation to " hook-up" with Northern Alliance became more visible when the US made key moves to include Northern Alliance as an important partner in its military campaign against terrorist bases in Afghanistan.

"These folks, they know the lay of the land," Defence Secretary Donald H Rumsfeld said on Friday, referring to the Northern Alliance. "They know, in some cases, some targets that are useful; they have ideas about how to deal with the Taliban. I think that one has to say 'that they can be useful in a variety of ways."

Officials said that the current situation represents a quagmire for Pakistani officials because in order to dissuade the Bush administration from extending maximum military assistance to the Northern Alliance, Pakistan will have to present a feasible alternative to Taliban and Mulla Omar.

"This is the area where the US want meaningful cooperation from the Inter-Services Intelligence (ISI) so that Washington and Islamabad could work together to create a viable substitute for Taliban leadership," a well informed Pakistani se-

\section{curity official disclosed.}

US also wants Pakistani intelligence input on likely hideouts of Osama bin Laden and other terrorist groups operating from Afghanistan.

The Northern Alliance, also called the United Front, is the main anti-Taliban group. It is dominated by Tajiks, Uzbeks, and Afghan Shias. Pakistan army reckons that Northern Alliance may have 8,000 to 10,000 guerrillas. Their military strength was so limited that in normal circumstances they would never have thought of uprooting Taliban from Kabul.

Since a declaration of war by President Bush, Pakistan had been trying to convince US administration that any military campaign against terrorist networks that may also involve the participation and deployment of US ground troops in Afghanistan may turn the Taliban homeland into another Vietnam for the US forces.

"We are worried that a shortsightedness of some military planners in the US would trigger an unending civil war in Afghanistan which meant a strategic nightmare for Pakistan," noted a senior Pakistani official.

Pakistan, wary of Northern $\mathrm{Al}$ liance's deep ties with the Research and Analysis Wing (RAW)-the Indian secret service, is believed to be working hard to pull the US from getting very close to the Northern Alliance by arguing that an alliance of non-Pashtun forces would not only provide new vigour to the ranks and files of $\mathrm{Tal}$ iban militia, it will also unite the Pashtuns of entire South Asia against US-led forces.

Security sources said that Pakistani intelligence agencies have definite information that the RAW was not only making heavy financial contribution to sustain the Northern Alliance, Indian military officials are known to have served the deceased Ahmed Shah Masoud, new Northern Alliance military commander Gen Mohammad Fahim Khan, and Ismail Khan as their full-time military consultants.

These agencies also have reported extensively on the deep ties between Professor Burhanuddin Rabbani, political head of Northern Alliance, and the Indian secret services. Pakistan had made its position on Northern Alliance abundantly clear last week when during his address to the nation President Gen Pervez Musharraf spoke of recent diplomatic activities in Tajikistan capital of Dushanbe where India had participated in ministerial level negotiations with the Central Asian Republics, bordering Afghanistan and Iran.

The talks, Pakistani officials said, were aimed at raising the sinking morale of Northern Alliance forces by pumping more money and weapons, Gen Musharraf informed the nation in his address.

"Indians want to ensure, if and when there is a change of government in Afghanistan, it should be an anti-Pakistan government".

In the follow-up of the ministerial meeting in Dushanbe, reportedly dominated by the Indian state minister for external affairs Omar Abdullah, Ahmed Shah Masoud's successor Gen Fahim and Dr. Abdullah, a prominent political figure from Northern Alliance, reached Dushanbe on Saturday last for a meeting with the head of the Russian general staff, Gen Anatoly

Kvashnin and the Indian envoy in Dushanbe.

Since long military strategists in Pakistan have maintained that a friendly government in 
The News International, Tuesday, September 25, 2001

Afghanistan and Iran provides Pakistan army a much-desired strategic depth that is lacking because of country's geography. Because of the friendly nature of borders in Pakistan's west and southwest the armed forces designated for these territories are routinely available for other tasks. "Pakistan's military strategy cannot afford a hostile government in Afghanistan that will force us to make crucial realignments in troops deployment," said (Retd) Lt Gen Salahuddin Tirmizi, a former corps commander and commandant military National Defence College.

"Even a semblance of Northern Alliance's dominance over Afghanistan would make us uncomfortable," said the general who thought, "General Musharraf had handled the crisis very well." Gen Tirmizi thought that the US plan to prop up Northern Alliance as an alternative to Taliban "desn't make any sense." He observed: "Even the hints that the US is providing military assistance to the Northern Alliance would eliminate hopes for fragmentation in Taliban leadership."

Informed sources said that in order to achieve a best possible deal in the present circumstances, Pakistan would like maximum participation in the diplomatic, militäry and security developments that are taking place under US supervision.

Sources said that seeing an imminent downfall of the Taliban leadership in wake of a sustained military campaign Pakistan would

like to see its friends in Afghanistan dominating a broadbased set-up as envisioned by United Nations. "In the present diplomatic environment, Pakistan can encourage a broadbased arrangement comprising educated Afghan expatriates, moderate elements from Northern Alliance and Taliban followed by a grand Loyi Jirga that may agree to a globally accepted new administration in Kabul," said (Retd) General Khalid Mahmud Arif, former Vice Chief of Army Staff, who had watched the Afghan war as Gen Ziaul Haq's chief-of-staff.

Gen Arif said that since Taliban were controlling about 90 per.cent of territory inside Afghanistan, their inclusion in the new government that may emerge from the US-led military action is vital to the restoration of normalcy.

As Northern Alliance gears to launch a decisive action against Taliban with an apparent support of US army and Central Asian Republics of Uzbekistan, Tajikistn, Kazakstan, senior security officials in Pakistan received reports that the Islamic Movement of Uzbekistan (IMU), headed by Jummaboy Hajiyev Namangan-one of the most trusted ally of both Osama bin Laden and Mulla Omar, was preparing to launch disruptive strikes both in Tajikistan and Uzbekistan

The IMU was designated a terrorist organisation by the US State Department in 1997. Its chief Jummaboy Hajiyev Namangan, is considered, one of the most potent guerrilla Muslim fighter in the Muslim states of Central Asia. He is considered a potent threat to the US forces that are now landing in Uzbekistan.

\section{Taliban seal UN,}

\section{WFP \\ offices, \\ seize 14,000}

tonns of food

\section{Naveed Ahmad}

ISLAMABAD: The Taliban officials entered the United Nations offices including the World Food Programme office in Kabul and Kandahar,seized 14000 tonns of food and locked and sealed all the communication equipments, told spokesperson of United Nations Office for Cooperation on Humanitarian Assistance (UNOCHA) Stephanie Bunker at a press briefing here Monday.

Normally, the UN Pakistan offices maintain 24-hour contact with their operation inside Afghanistan using an array of means of communication tools.

She feared that any attempt to communicate with the outside world could put their staff at the risk of lives.

The United Nations is helplessly waiting for Taliban response to their request for permission of one high frequency radio in each of their office at every location, she said.

UN Coordinator for Afghanistan Mike Sackket has also advised the national staff to comply with the directive and not put their lives at risk.

Sackket has requested the Taliban authorities to allow one high

frequency radio to operate in each office in every location so that some form of communication could be possible.

UNOCHA spokesperson said, "We are waiting for the response."

Stephanie also feared that UN humanitarian activities might have to stop in areas where communication is not possible.

She said mostly UN activities have been disrupted or seized. "However, our activities are going on namely in Heart to provide shelter to the displaced persons".

In another stunning development, local Taliban officials have taken over UN offices along with of two NGOs working under the umbrella of UN Mine Action Programme in Kandhar.

Stephanie said this renders 4,800 de-mining staff totally ineffective. Afghanistan has mined areas spread over 724 square kilometres. 
The NewS International, Tuesday, September 25, 2001

"Afghanistan has most serious landmine and specially bomb problem in the world. With heavy mass movements all over the country, people are getting more exposed to high risk from landmines and unexploded bombs", she explained.

Stephanie shared with the press that there are 40 to 100 landmineand bomb-related injuries every

week. Only 40 per cent of the injured can get to any medical assistance.

She told people are moving to Kabul and Heart, which are heavily mined areas. Since official crossing points leading out of Afghanistan are very difficult to get through, people are trying to sneak into Pakistan through areas, which are completely mined, she observed.

Stephanie told the newsmen that despite the worst working conditions, three-day polio vaccination campaign has started under $\mathrm{Na}$ tional Immunisation Days all over Afghanistan by UNICEF and WHO along with many other partners.

About 5 million children would be administered polio drops. The programme involves 400 district coordinators, 2,400 supervisors, 3,400 social mobilisers and 34,000 volunteers.

AP adds: The Taliban militia began raiding $U N$ offices in cities such as Kabul, the capital, and Kandahar, where Taliban leadership is based, over the weekend and sealing their satellite telephones, walkie-talkies, computers and vehicles to bar them from further use, said Stephanie Bunker.

"They warned our staff that if they use these things they will face execution," said Gordon Weiss, the

spokesman for UNICEF in Islamabad.

Meanwhile a survey conducted by World Food Programme revealed that over 30,000 people in the northern provinces of Afghanistan will not have enough food to survive by the end of September.

Carried out in July-August this year, the food survey results show that some 1.6 million people will run out of food by the December in some other provinces of the country.

The epic center of the crisis lies in the northwestern district because of three-year drought.

WFP spokesman Khaled Mansour said Monday that WFP's food supplies were now limited to some 1 million people after tragic happenings of September 11 whereas prior to that over 4 million Afghans were getting food form the UN body.

Khaled said, "We are operating under extremely difficult circumstances due to lack of commercial trucks and absence of many aid workers. However, since September 11, WFP has distributed 2500 tonnes of food to the people."

He said that WFP has reasonably good stocks around Afghanistan.

\section{Osama staying near Pak border: Russia}

MOSCOW: Osama bin Laden, the Saudi dissident believed to have masterminded terror attacks in the United States, is in east Afghanistan close to the border with Pakistan, the ITARTASS news agency said Monday, citing unnamed intelligence sources.

Bin Laden is located near the
Afghan city of Jalalabad, 120 kilometres east of Kabul, and has several fortified and camouflaged bases in the region, ITARTASS quoted "security experts" as saying.

On Sunday Afghanistanís ruling Taliban said bin Laden, whom the United States has accused of organising the September 11 attacks on New York and Washington.

Washington is believed to be considering strikes against targets in Afghanistan following the Talibanís failure to meet a demand that they hand bin Laden over to "responsible authorities."

Meanwhile ousted Afghan president Burhanuddin Rabbani has sent a delegation to Italy to negotiate with the former Afghan king Mohammed Zaher Shah, a spokesman for the Afghan government in exile told AFP in the Tajikistan capital Dushanbe.

"The objective is to discuss whether a provisional government could be set up in Afghanistan, Mahajuddin Mehdi, the deputy Afghan ambassador in Dushanbe, said. - AFP

\section{US stops VOA from airing 0mar interview}

WASHINGTON: The Voice, of America decided against running a story on this month's terrorists attacks featuring an interview with the leader of Afghanistan's ruling Taliban militia after State Department complaints, US officials said Monday.

"It was felt that it was not appropriate," a senior State Department official said of the VOA report on reaction in Afghanistan to President George W. Bush's speech September 20 speech to Congress outlining the US response to the attacks in New York and Washington the week earlier.

"Everybody thought it was inappropriate and we told VOA that," the official said, noting that the Taliban has refused to turn over the US government's prime suspect in the strikes, Saudi militant Osama bin Laden, and faces possible US military retaliation for not doing so.

The VOA piece included portions of an interview with Taliban leader Mulla Mohammad Omar and was to have run on Friday but was removed from the broadcaster's play list after Deputy Secretary of State Richard Armitage intervened, officials said.

VOA, which broadcasts on short-wave and other radio frequencies around the world in nu-

merous languages, is funded by the US government but maintains editorial independence.

The Washington Post quoted unnamed VOA employees as say- 


\section{The Frontier Post Tuesday, September 25, 2001}

ing they were shocked by the pressure that they said amounted to a "gag order," censorship and violation of the broadcaster's charter.

One senior State Department official rejected that charge, saying VOA had kept in mind that its operations were paid for by US taxpayers. "Interviewing Mullah Omar seemed a bit much in view of the fact that the US taxpayers are paying for this," the official said. "There can be a tendency to lose sight of that goals. "These are government funded programmes that are supposed to adhere to the strongest values of independent journalism but at the same time, they must be responsible," he said. "This wasn't and there comes a point when you have to make your views known."

The four-minute piece was to have included sound bites from a 12-minute interview with Omar by a VOA journalist in Washington conducted in the Pashtu language. In it, the Post reported that Omar reiterated the Taliban's refusal to give up bin Laden and its belief that the United States

has "taken Islam hostage." "America has created the evil that is attacking it," Omar said, according to a transcript of the interview obtained by the Post. "The evil will not disappear even if I die and Osama dies and others die. . . . The US should step back and review its policy. It should stop trying to impose its empire on the rest of the world, especially on Islamic countries."

The Post said the State Department learned on Friday that VOA had been offered an interview with Omar and had objected; but that by the time the opposition was voiced it had already been completed.

State Department officials confirmed those details and said even before Friday they had been troubled that some of VOA's foreign language broadcasts, particularly the Pashtu and Dari services which air in Afghanistan, were not meeting standards of impartial journalism.

"We have been a bit concerned about some VOA services, like the Pashtu and Dari, which have been displaying some extremely poor journalism," one official said. "We felt they were becoming mouthpieces for particular advocates of certain causes," he said without elaborating. -AFP

\section{NA concludes talks . with Russian officials}

Monitoring Report countries of Afghanistan on DUSHANBE: The leader of what path the United States the Northern Alliance in should adopt.

Afghanistan have concluded He said that only Pakistan Afghanistan have concluded has completely created such a their meetings with the situation. He was referting to officials in the capital city of the large-scale reports that a officials in the capital city of Tajekistan

The talks, Alliance spokesperson said, were positive but did not elaborate. He admitted that the military leader of the Northern Alliance, General Fahim also attended the talks; reports BBC.

Spokesperson said the meeting was aimed at discussing the problems. He termed the outcome of the talks as very good. Asked did General Fahim and his delegation hold talks with the Russian Army chief, he said that they were having meetings with a num. ber of people. He said that his group has not negotiated with the US envoy in Dushanbe.

However, the delegation is in touch with US State Department. Not only Pakistan rather talks should be held with all the neighbouring number of Pakistani elements have helped in the emergence of the Taliban. He said that how a country, which has made such a huge investment in a project for years can extend full cooperation in the destruction of the entire investment.

General Fahim did not appear in the press conference. He would very soon return to Afghanistan along with Foreign Minister of the ousted government. It is important for the Northern Alliance to continue skirmishes in northern areas of Afghanistan and remain in touch with the United States and neighbours of Afghanistan within next few days, it said. :

He stressed that every step should be taken very cautiously and carefully so that the life of the civilians may not be endangered.

\section{Taliban, NA call on Iran to take in refugees}

TEHRAN

(APP) Afghanistan's ruling Taliban militia and opposition forces on Monday called separately on Iran to open its borders to refugees fearing probable US retaliatory strikes, the state IRNA nows agency reported "Taliban officials have called on Iran to leave the borders open to new Afghan refugees," an informed Afghan source told IRNA.

"In case of US attacks against Afghanistan, and in light of continuing wars and the ongoing drought, another human tragedy is facing this country," the Taliban said, according to IRNA's source.

Meanwhile the head of the Afghanistan Mujahedin office in Iran's northeastern city of Mashhad, Touryaleh Qiassi, also called on. Iran to open its borders to Afghan refugees in case of US military strikes.

"Considering the latest developments in Afghanistan and probable US attacks, most of the people are readying to move towards the mountains and the borders of neighbouring countries," Qiassi said.

He was speaking during a ceremony held in remembrance of Ahmad Shah Masood, the Afghan opposition's senior military commander who recently died from injuries sustained in an assassination bid, IRNA reported.

Iran, already home to some two million Afghan refugees, last week began sealing off its border. It has also set up refugee camps in Afghan territory to handle the expected exodus. 


\section{The Frontier Post}

Tuesday, September 25, 2001

\section{NA moves carefully to exploit US strikes}

JABAL SERAJ (APP): Torn apart by civil war in 1994-96 when they last controlled Kabul, the Afghan opposition is anxious not to misuse the unprecedented opportunity to topple the Taliban administration with US help.

General Bismullah Khan, one of the most influential figures since the assassination of Ahmad Shah Masood, denied any plans to attack Kabul, despite enthusiastic claims by frontline commanders. Interviewed at his main base 40 . kilometres from the frontline north of Kabul, General Khan made it clear that US retaliatory strikes against the Taliban and Osama bin Laden must be swift.

But in the clearest indication to date of the opposition Northern Alliance's strategy, he said the only lasting solution would be a political consensus among Afghanistan's patchwork of ethnic groups. "We have no plans to march onto Kabul, although we can easily capture it. Going to Kabul will not solve any problems," the general told journalists.

"We want a stable government, all ethnic groups should appoint one," he added, explaining that a meeting of Afghanistan's traditional tribal council, the Loya Jirga, could be convened for such a purpose. Publicly defiant, the Talibat. has threatened to launch a jihad against the United States, but reports of forced reçruitment amid a mass exodus of people from the cities indicate some panic within.

The Alliance controls some 10 per cent of Afghanistan, including the strategic Panjsher Valley northeast of Kabul and part of northeastern Afghanistan. The opposition, which has just launched an offensive in the northern Balkh province, hopes that Washington will provide it with logistical support and military supplies and that $U S$ air and missile strikes will cripple the Taliban.

\section{First Afghan asylum seekers due in NZ}

WELLINGTON (Agencies):

The first of 141 mainly Afghan asylum seekers being held on the tiny Pacific island of Nauru are expected to arrive in Auckland today (late on Tuesday), New Zealand officials said on Monday.

Two chartered commercial aircraft will bring the boat people to New Zealand. The second flight is due to arrive late on Wednesday, the New Zealand Immigration Service said in a statement.

The asylum scekers, part of a group of more than 400 people rescued from a sinking Indonesian ferry' by a Norwegian freighter in the Indian Ocean on August 26, were refused entry into Australia after being taken to Australia's Christmas Island.

An Australian naval ship transferred the boatpeople to Nauru last week after Australia offered a US\$10 million deal for the 21 square-km Pacific island nation to accept them for processing.

Among the people bound for New Zealand are 21 family groups comprising. 105 people and 36 unaccompanied minors, the New Zealand Immigration Service said.

They will be held at a Refugee Resettlement Centre. at Mangere, near Auckland, while their refugee status is determined -- a process that can take up to four years.

"Of the 1,700 asylum seekers who arrived in New Zealand in the year to June, 311 applications for asylum were approved.

\section{Eastern Shoora organises militia to invade Kabul}

KABUL (Online): Eastern Shoora (governing body of eastern provinces), a faction of Northern Alliance has organized a large militia with about 15 thousands soldiers in connection with its preparations to attack Kabul.

According to Afghanistan based news agency, Eastern Shoora is likely to strike Kabul during the possible US attack and they have finalised their preparations in this regard.

The recently organised militia to occupy Kabul included the eight thousand regular soldiers while the others are from reserved, it said.

Ariana reported, the militia containing 8000 regular while remaining reserved soldiers, accompanied by Scud Missiles and tanks would advance towards the Kabul from three sides, as the US would launch attack on Afghanistan.

A close companion commander of Haji Qadeer, head of Shoora, has disclosed that the preparations were started alter assurances of support from US, which has planned to invade Taliban's heart Kabul via eastern provinces of Gunned and Laghman.

\section{Taliban warn Uzbekistan}

ISLAMABAD (NNI): Afghanistan ruling Taliban Monday sounded warning Uzbekistan that it will be responsible of any dire consequences if it allows air space for the US attack on Afghanistan. Afghan Foreign Minister Maulvi Wakil Ahmed Mutawakkil in a letter to Foreign Minister of Uzbekistan, has accused Uzbekistan of allowing air space for an American spy plane which was shot down in Samangan province three days ago. "Sovict troops had invaded Afghanistan through Uzbeikistan. We want to make it clear that Uzbekistan will take responsibility if it allows its territory for American attack," Mutwakkil warned. 


\section{John Simpson traveled disguised as a woman: $B B C$}

ISI. AMABAD (NNI): A $B B C$ correspondent, who visiled Taliban-controlled Aighanistan says there secms to be an ecric emptiness in Nangarhar Provines which adjoins Pakistan and takes in Jalalabad.

People, it seemed, had either fled their homes in anticipation of an American attack or they were keeping their heads down.

"The Taliban, by contrast, were increasing their presence along large stretches of the border. Perhaps they think the threat to them will come by land via Pakistan. We saw new posts which had been set up, one of them containing as many as 80 Taliban fighters" John Simpson of BBC World Affairs reported.

"Yet the talk in
Afghanistan now is of gradual defection from the Taliban, as the militias and smaller contingents which joined them back in 1996 when they were plainly winning begin to have second thoughts now" he claimed.

He said we got into Afghanistan with the help of some of the cross-border smugglers who operate the full length of the border with Pakistan.

The smugglers insisted that the cameraman and I should wear burqas - the traditional full-length garment of Pathan women - which covers the entire figure and face and is compulsory for all women living in Talibancontrolled Afghanistan.

"Merely putting on the burqa, I found, has an extraordinary effect. It seems to make you disappear. At roadblocks, guards may look closely at the men in a car. But they simply ignore the women who are mostly immune from being searched, though in one or two places, it is said, women searchers have been recruited now.

In our case, the tactic worked superbly. Our minders were heavily armed both because there is always a certain amount of lawlessness in the border areas and because they wanted to protect us from the Taliban if they tried to capture us.

The Taliban are now reported to have orders to arrest any journalist they find, but they did not find us. Maybe the burqas, those cloaks of invisibility, did the trick" he reported.

Los Angeles Times

Tuesday, September 25, 2001

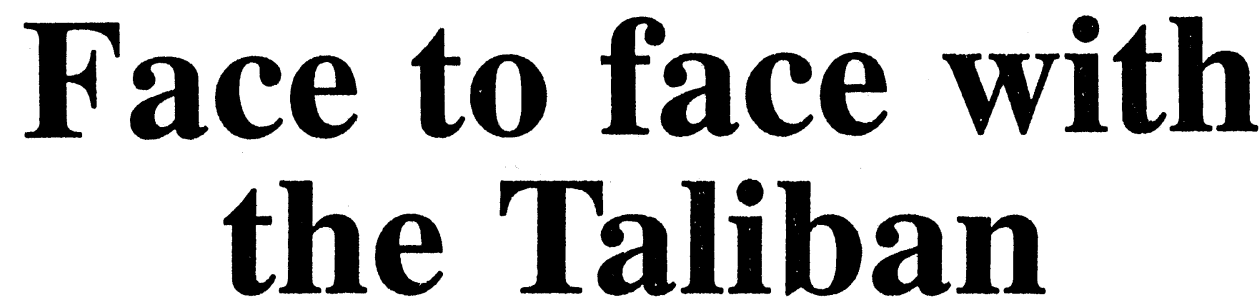

Karl F. Inderfurth

\begin{abstract}
A fter the terrorist attacks on the World Trade Center and the Pentagon, President Bush said we will make no distinction between the terrorists who committed these acts and those who harbor them. The Taliban of Afghanistan should not have been surprised by this statement. They were similarly warned by the U.S. government more than two years ago.

The meeting took place Feb. 3, 1999, at the U.S. ambassador's residence in Islamabad. As the assistant secretary of State for South Asian Affairs, I was instructed to deliver a message about
\end{abstract}

Osama bin Laden and terrorism to a highranking official of the Taliban movement. I was accompanied by the State Department's coordinator for counter-terrorism, Michael Sheehan. Mullah Abdul Jalil, a close associate of the Taliban's supreme leader, Mullah Mohammed Omar, and a possible liaison with Bin Laden, traveled to Pakistan to meset with

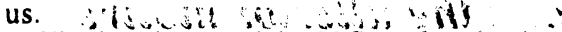

The bombings of the U.S. cmbassies in Kenya án Tantania nearly slx months carlier had made it horrifyingly clear that Afghanistan-based terrorism was a direct threat to the United States. We were out- 
raged that after all the support the United States had given the Afghan resistance during its struggle against the Soviet Union, the terrorists tied to the bombings, including Bin Laden, were trained and based in Afghanistan. The U.S. government had repeatedly demanded that the

Taliban stop giving

safe haven to terror-

ists. It had also appealed to nations, like Pakistan, that have influence in Kabul. But the situation did not change.

The message I delivered at the February meeting went further than any previous one issued by the U.S.

government. Arriving

late in the evening

from Kandahar,

Afghanistan, Mullah

Jalil was accompa-

nied by the Taliban's

representative in

Islamabad. Along

with Shechan, I

stressed that the

Taliban needed to

expel Bin Laden to a

location where he

could be brought to

justice. I emphasized

that it was yitally.

Itmpotsons forit the

Taliban to act:

becaist the American

government believed

that Bin Laden was

still plotting acts of

terrorism against the U.S. - and that we would hold the Taliban responsible for his actions. The message could not have been clearer.

Speaking softly through his interpreter, and frequently stroking his beard, Mullah Jalil responded. He began with a prayer,

$$
\text { then proceeded to }
$$

Taliban's actions conformed to their interpretation of Sharia, or Islamic law. He said Bin Laden was an honored guest of the Taliban for the role he had played in the jihad, or holy war, during the Soviet Union's occupation of Afghanistan. Mullah Jalil acknowledged that Bin Laden was increasingly a burden on Afghanistan, but the Afghani tradition of hospitality did not permit them to force Bin Laden to leave. Mullah Jalil assured us, however, that Bin Laden was under the Taliban's control and that he could not possibly be operating a worldwide terrorist inetwork as we tiade suggested. Fintlly, he' demanded : that 'we! show him the evidence against Bin Laden and that then the Taliban would act according to Islamic law. Sheehan did, citing chapter and verse from the indictment of Bin Laden for his role in the East Africa embassy bombings.

Later efforts were made to provide the Taliban with more information about the U.S. case against Bin Laden, but they

Today, the Taliban are I facing another hour of truth. Let us hope they will change their mind promptly and turn over Bin Laden to appropriate authorities in a country where he can be brought to justice and close down the terrorist training facilities in Afghanistan. If they do not, the United States will respond.

never responded. The nearly three-hour session with Mullah Jalil produced no meeting of the minds. Subsequently, the United Nations Security Council tried to persuade the Taliban to turn over Bin Laden. Two resolutions were adopted, in October 1999 and December 2000, and sanctions were imposed on the Taliban to accomplish that purpose. Again, the Taliban defied these calls by the international community.

Meanwhile, the Taliban, and some of their supporters, tried to misrepresent our campaign against Bin Laden and terrorism as an attack against Islam. Nothing could be farther from the truth. The United States does not oppose Islam. The United States respects Islam. But we oppose those who commit or condone criminal acts, especially those who commit and inflict grievous injury against civilians in the name of any ideology, religion or cause.

Today the Taliban and their leader, Mullan Offat dfe facting another ihour of

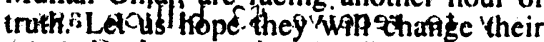
mind promptly and turn over Bin Laden to appropriate authorities in a country where he can be brought to justice and close down the terrorist training facilities in Afghanistan. If they do not, the United States will respond. The Taliban have been warned.

Karl $F$. Inderfurth served as the assis. tant secretary of State for South Asian Affairs from 1997 to 2001 
The Economist September 22nd 2001

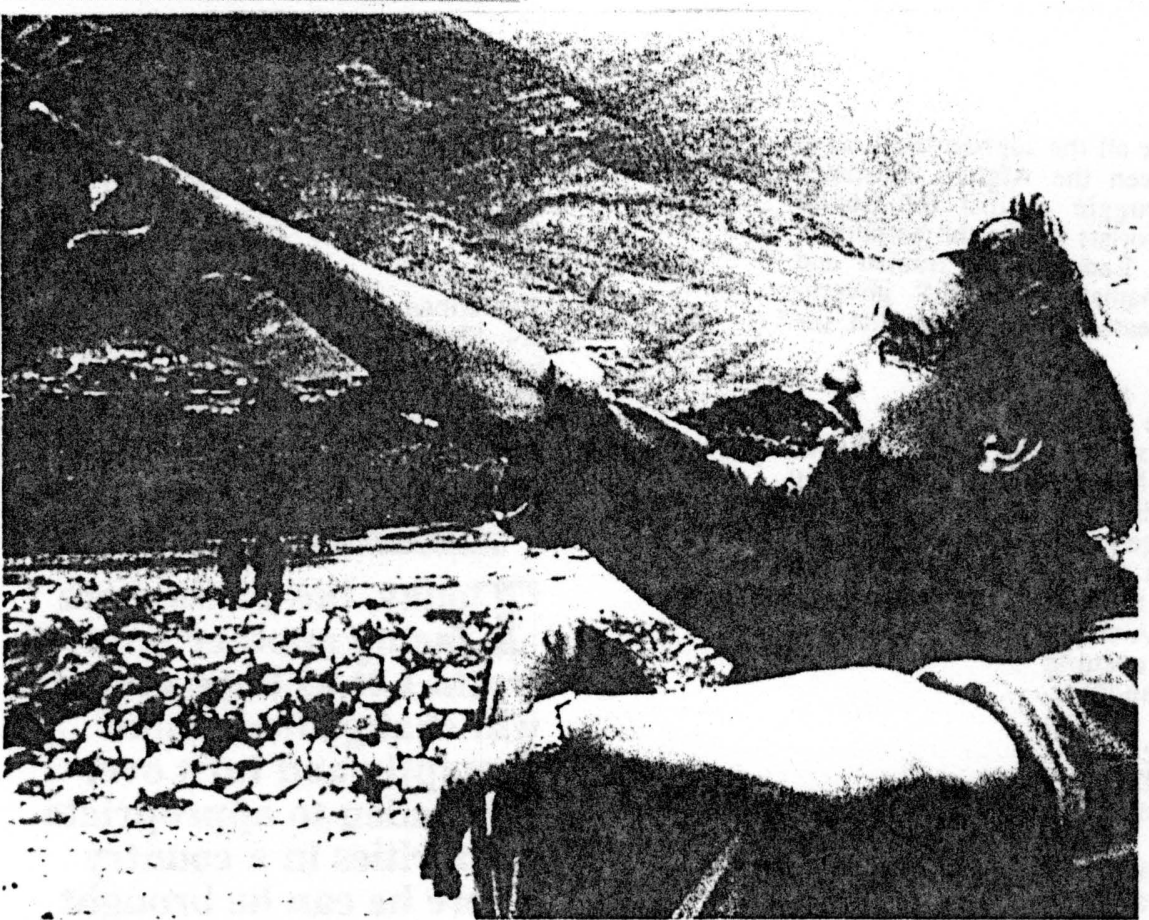

\section{Ahmad Shah Masoud}

\section{Ahmad Shah Masoud, a hero of Afghanistan, died on September 15th, aged 49}

FOR writers, broadcasters and assorted $\mathrm{F}$ adventurers seeking to understand Afghanistan, the headquarters of Ahmad Shah Masoud would often be their first call. Unlike leaders of the Taliban, whose belief in public relations was minimal and who anyway regarded westerners as inherently hostile, Mr Masoud was welcoming. He was patient with his visitors' questions, however naive, and willingly posed for photographs. He was a careful dresser: what looked like designer boots shined like a guardsman's. Now, would the visitors care to see the front line?

A writer in Adventure, an American magazine, repaid his host with an article that began:

The fighters were down by the river, getting ready to cross over, and we drove out there in the late afternoon to see them off...Across the floodplain, low, grassy hills turned purple as the sun sank behind them, and those were the hills these men were going to attack. They were fighting for Ahmad Shah Masoud-genius guerrilla leader, last hope of the shattered Afghan government...We wished Masoud's men well...The stars had come out, and the only sound was of dogs baying in the distance. Then the whole front line...rumbled to life.

Whether Mr Masoud enjoyed the article it is difficult to say. He preferred the ro- mantic writing of Victor Hugo to that of the Hemingway school. But he would have been grateful for the publicity. In the past few months Mr Masoud's forces, confined to a pocket of territory in the northeast of Afghanistan, have been short of money and arms, facing Taliban fighters convinced they could complete their conquest of the country. Mr Masoud had to show his supporters abroad that his cause was not lost. This year, he visited Russia, India and Europe to shore up his support. His speech to the European Parliament in April, at the invitation of its French president Nicole Fontaine, was a diplomatic success. Charm could be a potent weapon.

\section{Enter the Russians}

The French particularly admired $\mathrm{Mr} \mathrm{Ma-}$ soud. He had learnt their language at a lycée in Kabul, in the distant days of nostalgic memory when Afghanistan was a monarchy. He liked to say that De Gaulle was one. of his heroes, but as a politician rather than a soldier. Although his father was a colonel, Mr Masoud chose to study engineering. When the fighting was over, he would say, he would use his engineering skills to help rebuild the country.

The king was deposed in 1973. During the next quarter century Afghanistan became a battlefield, partly tribal, partly in- 
ternational. For ten years, from 1979 to 1988, the United States fought a proxy war with the Soviet Union, supplying the Afghan resistance with arms to fight the Soviet occupiers. It was at this time that $\mathrm{Mr}$ Masoud first became famous as a guerrilla leader. In the search for heroes in what was in fact a brutal and unglamorous campaign, he was a natural: the scholar who had put aside his studies and picked up a rifle to defend his homeland.

Some writers have credited Mr Masoud with driving the Sovie ghanistan when the reality was more prosaic: the Russians withdrew because of growing civilian opposition at home, rather as the Americans were undermined in Vietnam. All the same, Mr Masoud proved to be a resourceful leader, especially in defence. The Russians could never penetrate the redoubt he created in the Panjshir valley. The outside world liked to call him "the lion of Panjshir" although to his men he was simply arrir (the commander) or saab, an Urdu word from which sahib is derived.

In recent years Mr Masoud again retreated to the Panjshir with the advance of the Taliban. Like many Afghans, he at first welcomed the Taliban. Their fierce interpretation of Islam was not to his taste: $\mathrm{Mr}$ Masoud had been brought up with western ideas of personal freedom. But the Taliban had brought order to the lawless territories they occupied and seemed to offer the prospect of compromise in government. That illusion disappeared in 1996 when they laid siege to Kabul, the capital. They promised to "liberate" Kabul's people from their corrupt government.

Mr Masoud was defence minister in that government, headed by Burhanuddin Rabbani, which, theoretically, is still in existence in exile. The Rabbani circle was indeed probably corrupt, and Mr Masoud was blamed for much of the destruction of Kabul and the deaths of thousands of civilians opposed to the government. Nevertheless, for many Afghans he remained a popular figure. With his troops and what materials (including 2,000 books) he could transport, Mr Masoud made a fighting retreat to the Panjshir. He was murdered, apparently, by two men posing as western cameramen. The camera that he thought would convey his message to the world blew up in his face. According to some reports, the murder was arranged by Osama bin Laden as a gift to the Taliban.

Others will seek the leadership of the Panjshir, which is said to be defended by 12,000 fighters. One candidate being mentioned is Abdul Rashid Dostam, who controlled a slice of territory until it was taken by the Taliban. But he is a former communist, knows no French, lacks charm and, in the interviews he has given, no one has remarked on his boots.
The Economist September $22 n d 2001$

Iran and the United States

$$
\begin{aligned}
& \text { The enemy of my } \\
& \text { enemy }
\end{aligned}
$$

TEHRAN

A shared distaste for the Taliban

$\mathbf{R}^{\mathrm{ACK}}$ in 1991 Iran stood and watched as America, a distant foe, defeated Iraq, a neighbour, in the Gulf war. A decade on, as America squares up to another neighbour, the Taliban of Afghanistan, it is a bit different: Iran's leaders are far from being of one mind. President Muhammad Khatami and his reformist supporters would like to use the episode to get closer to America, while the establishment around Ayatollah Khamenei, the supreme leader, is determined to stop them. Both sides, however, are united in their desire to have a say in Afghanistan's political future, and both are anxious to prevent an influx of Afghan refugees: Iran already plays host to about $2 \mathrm{~m}$ of them.

At first, reformists and conservatives reacted to the attacks on American civilians with unexpected cohesion. The president's prompt message of condolence did not come as a surprise. More noteworthy was the sympathy offered by the same hardline clerics whose Friday sermons are so often accompanied by chants of "Death to America!" According to Colin Powell, the American secretary of state, such "signals" were "worth exploring". Meanwhile, Mr Khatami reassured Kofi Annan, the UN secretary-general, that terrorism was a "shared problem".

The back-slapping was too anomalous to last. Earlier this year America's State Department designated Iran the world's

"most active state-sponsor of terrorism in 2000". In June a United States federal jury found that Iran had "directed" the murder, in 1996, of 19 American marines in Saudi Arabia. For their part, Iranians of all hues accuse America of supporting a terrorist state, Israel.

On September 16th a State Department official said that Iran's help in a campaign against terrorism would be welcomed only if it withdrew support from $\mathrm{Hiz}$ bullah-hardly a realistic demand, not least because few countries, apart from America and Israel, consider Hizbullah to be a terrorist organisation. The next day $\mathrm{Mr}$ Khamenei waded in to bolster anti-Americanism in Iran. He attributed the attacks to America's policy in the Middle East and claimed to have detected "signs of Zionist direction and planning" in the mayhem.

In spite of all this, it is still possible that Switzerland's ambassador in Tehran, who 
The Economist September 22nd 2001

looks after America's interests there, will bear encouraging messages when he meets officials in Washington in the next few days. Afghanistan is the only subject on which Iran and America cooperate diplomatically. The Iranians' dislike for the Taliban is only a few notches short of that felt in America. It is an open secret that Iran supplies arms and training to the Northern Alliance, a loose anti-Taliban coalition. As a Shia Muslim theocracy, Iran projects itself as the protector of Afghanistan's Shia minority, who have been cruelly oppressed by the Sunni Taliban.

The ceasefire called by Yasser Arafat this week may have increased, slightly, the chances of co-operation between the United States and Iran-but not if America expects Iran to abandon long-held positions about the Palestinians, or appears to disregard its fears of a fresh flood of refugees. There would be strict limits to such co-operation. But deploying an extra division or two on the Afghan border to coincide with an American attack would prove an unwelcome distraction for the Taliban.

So, indeed, would allowing Afghan opposition groups based in Iran to raise, as they have requested, an irregular army made up of refugees to march across the border. According to Yousef Vaezi, the Tehran representative of the Unity Party, a component of the Northern Alliance, a force like this might attract as many as 100,000 volunteers. Such a scheme would please Iran's interior ministry, which has been trying for years to find ways to persuade Afghan refugees to go home.

\section{Pakistan and the United States}

\section{Caught in the middle} AHESE are nervous days in Pakistan. "If
America attacks Afghanistan, people
will come on to the streets and a civil war
will start," predicts Muhammad Rashid
Khan, who sells digital video disks in Ra-
walpindi's Hathe Bazaar. Whether or not
Mr Khan is right, an American-led war on
terrorism could transform Pakistan, as well
as the dynamics of its nuclear-tipped con-
frontation with India.

The country's self-appointed president, Pervez Musharraf, has little choice but to go along with American plans to punish Afghanistan unless it extradites the accused terrorist, Osama bin Laden. He fears that Pakistan's aid-dependent economy, its ability to stand up to India, even its nuclear installations, could be put at risk by American wrath. "Bad results", he told Pakistanis in a televised speech on
September 19th, "could put in danger our territorial integrity and our solidarity."

On the more positive side, though, there may be much for a compliant Pakistan to gain, including perhaps a partial write-off of its $\$ 37$ billion external debt and an adjustment to the recent American tilt towards India. It could even be, the wily

General Musharraf may be dreaming, a reprise of cold-war days, when an indulgent United States backed up Pakistan for the sake of defeating a common enemy in Afghanistan. If the Taliban fall, Pakistan is expecting a large say in whatever order succeeds them.

Could be, but with dangerous differences, as General Musharraf well knows. The prospective enemy this time is not a godless Soviet-backed regime but an emphatically Islamic one that Pakistan itself has carefully nurtured as a way of furthering twin policies: clout in Central Asia and pressure on India to settle the dispute over Kashmir, a Muslim-majority state divided between the two countries. Barring an unlikely agreement by Afghanistan's Taliban government to hand over Mr bin Laden and his associates, Pakistan has offered intelligence, air space and perhaps, if the president is feeling brave enough, it may provide ground facilities such as airports for an attack on the terrorists and the government that harbours them.

The Taliban have vowed to wage war against any country that joins the attack and are said to have placed anti-aircraft

guns along the border with Pakistan. This, though, looks the least of Pakistan's worries. The Afghan army is little threat to one as big and well-equipped as Pakistan's.

\section{Facing blowback}

The greater fear is what people in the region call "blowback". The war to liberate Afghanistan from the Soviet Union in the 1980 s flushed refugees by the million and armed zealots in their tens of thousands into Pakistan. It now faces another such influx (thousands of refugees have already come, and many more are at the border), perhaps with more explosive consequences. The target regime shares Pakistan's religion and the Pathan ethnicity of $15 \%$ of its population. So far religious groups have taken the lead in protesting at the prospect of American action. At one rally in Islamabad on September 17th, demonstrators wrapped in white shrouds to signify their willingness to die for Islam heard speakers proclaim that "friends of the us are traitors to Pakistan".

Such carefully-policed gatherings of hundreds help the government, up to a 
point, by dramatising the risks it runs on behalf of the anti-terror coalition. But if many Afghans were to die in an Americanled reprisal, the protests could turn into riots as thousands of ordinary Pakistanis joined the cause, egged on, no doubt, by the various mafias that profit from their dealings with the Taliban. General Mush arraf's government, many speculate, might not survive. And the more help he offers the Americans, the greater the out

rage he will have to contain. The general tried to pre-empt some of that outrage in his television speech by justifying the alliance as a blow against a bigger enemy, India. The Prophet Muhanmad, he said, would have chosen the same course.

Pakistan could emerge from a showdown with the religious right as a more liberal society and, perhaps, a more authoritarian polity at the same time. Since taking power in October 1999, General Musharraf has tried to tame the groups that preach Islam in its least tolerant form and sometimes kill members of sects that disagree with them. But he has been hesitant in pursuing such policies as the disarming of extremists. "Now the state may have to have a direct confrontation," says Shireen Mazari, director of Pakistan's Institute of Strategic Studies. One casualty of a tougher line could be the "road map" to democracy, which ordains the holding of elections by next October. In the circumstances, the United States might not object too loudly.

\section{The Kashmir connection}

Could General Musharraf engineer a coup of a different sort in relations with India? At first sight, the crisis plays into his hands. Pakistan has long tried to draw attention to Kashmir, portraying the dispute, correctly, as a "nuclear flashpoint". Now that the strikes against America have highlighted Muslim discontent, this ought to be easier. Part of its reward for joining the anti-terror coalition, Pakistan hopes, will be American help in forcing India to negotiate seriously over Kashmir.

This could be optimistic. India, too, will be a coalition member, though presumably a less valuable one since it has no border with Afghanistan. More worrying for Pakistan, the outrages in America pile additional discredit on its political and probable military support for the mujahideen who cross into India's side of Kashmir from bases in the Pakistani portion. Their targets are not just Indian soldiers; they are the likeliest suspects in frequent massacres of non-Muslim civilians.

Many of these groups train their fighters in Afghanistan. General Musharraf insists that their activities are not terrorist,
The Economist September 22nd 2001

.

but the distinction may collapse in American attacks on mujahideen installations in Afghanistan. The Indians will point to the camps in Pakistani-controlled Kashmir. Unless they are closed, those Indians who advocate "hot pursuit" of militants across the de facto border will no doubt press their case more strongly than ever.

There is thus a danger that the American-led war on terror will merely entrench south Asians in their earlier positions. But there is still a chance of a better outcome, if the fanatics are defeated and the moderate majority is shocked into compromise. This could be a defining moment indeed.

\section{Afghanistan \\ Honoured guest}

\section{The Taliban show no signs of surrending bin Laden}

$\mathrm{B}$ Y THURSDAY, it looked unlikely that the Taliban would be ready to hand over Osama bin Laden, whom they have sheltered since they took power in Afghanistan in 1996. The offer by Mullah Muhammad Omar, their reclusive one-eyed leader, for Mr bin laden's case to be decided by a panel of clerics from any three Islamic countries has been made beforeand rejected by the Americans in no uncertain terms. An Islamic conclave advised the Taliban government to persuade him to leave voluntarily. But this stops well short of America's demands-and is not likely to be taken too seriously by the Afghan leadership.

This may on the face of it seem to be a baffling miscalculation by the Taliban of their own best interests. Not only is the downside-American military action against their country-dreadful to contemplate, but the benefits that would flow from handing over the wanted man would be impressive too. They might include the lifting of crippling sanctions, the possibility of investment (American oil companies have been keen to run pipelines from the Caspian to the Arabian Sea through Afghanistan) and a sharp increase in much-needed aid. Until a year or so ago, the Taliban were eagerly seeking diplomatic recognition and better relations with the West. To help get them, they destroyed their country's opium crop, slashing global production of heroin in half.

Their bid for diplomatic respectability came to nothing, for a simple reason. 
America made it clear that the price was the handover of $\mathrm{Mr}$ bin Laden, whom it wanted at that time for the deadly attacks un two American embassies in Africa in 1998. When the raliban refused to surrender him, America pushed for, and got, last December, the imposition of tough UN sanctions on Afghanistan. The Taliban's relations with the outside world have been much more hostile since then.

Mr bin Laden, in other words, is appar. ently non-negotiable. And the reason is that he and the Arab soldiers he commands are a powerful force inside Af ghanistan in their own right, his money and men constituting an important element in the Taliban's ability to squeeze their enemies, the Northern Alliance, into an ever-smaller wedge of territory in the north-east. A graphic example was provided two weeks ago when two Arab journalists blew up Ahmad Shah Masoud, the commander of the Northern Alliance's forces, along with themselves. It seems probable that this assassination was carried out by $\mathrm{Mr}$ bin Laden's men. So powerful have the Arab fighters in Afghanistan become that ordinary Afghans have been heard to complain that it is they, not the Taliban, who really control the country.

Discontent, however, is something that the American-led coalition may be able to work with. The Taliban are mainly Pashtuspeakers from the country's south and east. The ethnic Uzbeks, Tajiks and Hazaras of the north and west resent their hegemony. For everyone, the Taliban's social strictures have become more onerous, while the initial delight at their resturation of law and order is fading. Several protests broke out over the summer. They followed the series of bombs that have exploded outside Taliban offices over the past few years; one destroyed Mullah Omar's home in Kandahar. But translating all this into the overthrow of the Taliban will be an uphill struggle.

\title{
Allies in search of a strategy
}

\author{
The Economist September 22nd 2001
}

LONDON ANO WASHINGTON, DC

First, build the coalition. Then, think what to do

TWO days after the destruction of the 1 World Trade Centre in New York and the simultaneous assault on America's military nerve centre, the Pentagon, President George Bush declared the United States to be "at war" with international terrorism. He enjoined America's soldiers, and with them the American people, to "get ready" for military conflict and for further sacrifice. At the memorial service in Washington's National Cathedral for the close to 6,000 victims of the bloodiest terrorist assault in history, the leader of the world's most powerful country declared that this conflict, "begun on the timing and terms of others... will end in a way, and at an hour, of our choosing."

Mr Bush picked his words to send a message of resolve not just to America but to the world. But what does it mean to be at war with terrorism? Who are the enemy? What are the right tools, and what is the best strategy, to fight them with? If this is indeed to be the first war of the 21st century, is victory possible against an enemy that demands neither territory nor any other recognisable war booty, and seeks only the maximum possible destruction with no calculation of restraint? And what might such a victory look like?

Mr Bush's immediate target is clear. This week he called on the Taliban, the rulers of Afghanistan, to hand over Osama bin Laden, the fugitive terrorist leader they have long sheltered-or else. He wanted Mr bin Laden, he said, "dead or alive". Other western intelligence agencies concur with the initial judgment of America's: that all the evidence gathered so far points to $\mathrm{Mr}$ bin Laden as the prime suspect.

But even getting at him, let alone the loosely-knit and widely-dispersed terrorist network over which he presides, will not be easy (see next article). Earlier this week, a high-level Pakistani delegation, given special United Nations dispensation to break the international embargo and travel to Afghanistan to try to talk the Taliban into handing him over, left Kabul emptyhanded. Amid calls for Afghanistan to renew its jihad ("struggle" or "holy war") against America, the country's highestranking Islamic clerics, summoned by their leader, Mullah Muhammad Omar, to respond to the mounting pressure from the outside world, said that $\mathrm{Mr}$ bin Laden should leave voluntarily. Mr Bush is unlikely to wait long before striking back at the man and the organisation he suspects of causing the greatest number of casualties on American territory in a single day since the civil war, and at the country that harbours him. On September 20th, 100 extra American war planes were moved to the Gulf in preparation for action.

In that strict sense, America is not only sounding, but acting, as if it is going to war. Reserves are being called up. Congress has passed a resolution giving the president power to "use all necessary and appropriate force" against any individual, organisation or country that played any role in last week's attacks, and allowing for pre-emptive strikes to prevent any more. It has already appropriated $\$ 20$ billion for that purpose, on top of the $\$ 20$ billion assigned for rescue and clean-up operations at home. Public opinion is overwhelmingly in favour of military action against terrorists, though more nervous of using force against states that sponsor them.

International opinion is a little more varied. Even those countries that back America to the hilt are calling for coolness and deliberation before military action is taken. Others, such as Russia and China, want nothing to be done without the approval of the UN Security Council.

But NATO responded last week by invoking, for the first time in its 52 -year his tory, Article 5 of its founding treaty, which declares the attack on America to be an attack on the alliance as a whole, and enables America to call on its allies for military support. And few would argue that America does not have the legal right, under Article 51 of the UN charter, to strike back at its tormentors. The United States is naturally reserving the right to take unilateral action; but talks are under way with many countries, from America's close al. lies in Europe to Islamic Pakistan and some 
of the countries of Central Asia and even farther-flung Australia, to gather the military support, access to bases and overflight rights that America may need.

Retaliation may indeed be justified and necessary-if only to persuade the world, and especially other would-be terrerist groups, of the strength of America's determination to fight back after such devastating attacks on its territory, its values and its institutions. But the struggle America is preparing to wage will be long, complex and dangerous. President Bush has made it clear that this is not just a war against the terrorists responsible for last week's atrocities, but against terrorism itself.

\section{Needed: allies inside Islam}

That is why this will be unlike any other war America has fought. Mr Bush has called it a "crusade", a word with just the bruising overtones that some Islamic extremists have used in the past to justify their murderous assault on America and all it represents. Yet the president has no intention of declaring war on the Islamic world. On the contrary, he is now hoping for direct help from a number of its governments, from the Middle East to Asia, in isolating and eventually eliminating groups, such as Mr bin Laden's, that use Islam as a cover for their crimes. However, both he and his senior officials have given warning that America will go after not only terrorist groups but also the governments that sponsor or support them.

Apart from Afghanistan itself, America's list of "the usual suspects" in the terrorism business has long included Iran, Iraq, Libya, Syria, North Korea, Sudan and Cuba. Since last week's attacks, the deputy secretary of defence, Paul Wolfowitz, has talked of "ending" states whicn sponsor terrorism. If it refused to hand over Mr bin Laden and his associates, Afghanistan's regime would be one obvious target.

Might Iraq be another? In the past there have been reported links between Iraq and $\mathrm{Mr}$ bin Laden. So far, there is no clear evidence of Iraqi involvement in last week's carnage. If more were to emerge, America would have little compunction about attacking a regime that is thought to be rebuilding its illegal chemical, biological and possibly nuclear weapons.

Yet most of the states on America's listIraq stands out as the exception-have condemned last week's attacks. For the first time in more than 20 years, worshippers in Iran failed to chant "Death to America!" at the start of their Friday prayers. Words of condolence come naturally in the after-
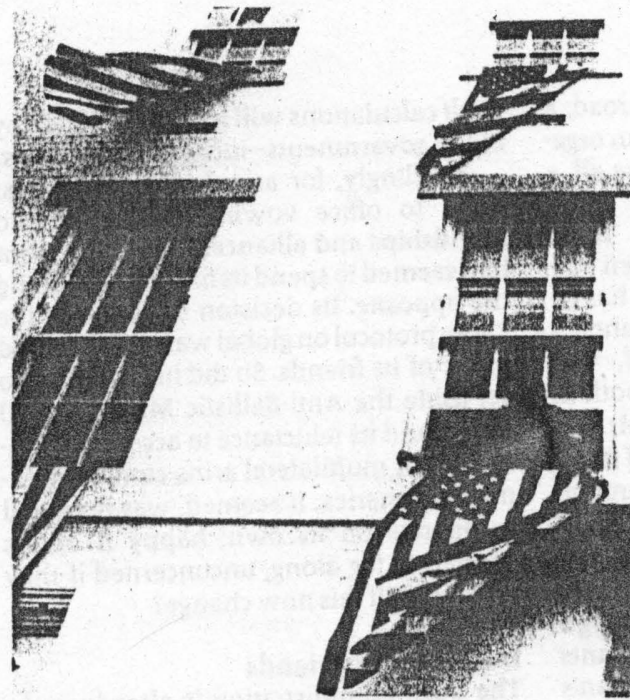

It could be London, Paris, Canberra...

math of ferocious acts of terrorism. Yet this could be a chance for America to find common ground with old foes such as Iran to end some of their official and unofficial support for groups with terrorist connections-a first victory, perhaps, for America's will to prosecute this new war.

Will Mr Bush's chosen tools be diplomacy or force? He will need both. Military pressure-and possible military strikes-on Afghanistan would not just as suage Americans' demands for retaliation, but might help to deter some governments from further aid to Mr bin Laden's group or others bent on terrorism. Yet his senior aides admit that military strikes-even a whole series of them-cannot win a war with an aim as all-embracing as this one. Indeed, unless America is prepared to alienate wide swathes of the moderate Muslim world, by launching military attacks against any country suspected of having terrorists somewhere on its territory, the direct military options available to America may soon come to seem rather limited.

Pinprick missile attacks against terrorist training camps in Afghanistan and a suspected chemical-weapons plant in Sudan, launched by President Bill Clinton in 1998 after attacks on the American embassies in Kenya and Tanzania, did nothing to deter $\mathrm{Mr}$ bin Laden and his followers. Neither have Russia's scorched-earth tactics against rebels (Russia calls them terrorists) in Chechnya, which have reduced that country to rubble. And would the targets be the 1,000 or so operatives thought to be in $\mathrm{Mr}$ bin Laden's al-Qaeda network worldwide, or the wider universe of terror organisations, including Islamic Jihad and Hamas in Palestine? If simply killing terrorists were enough, Israel would by now be the safest country on earth.

Amid all the talk of war, it has been left to Colin Powell, the secretary of state, to spell out the beginnings of a broader strategy. He has called for "a campaign that goes after not just retaliatory satisfaction, but goes after eliminating this threat by ripping it up, by going after its finances, by going after its infrastructure, by making sure we're applying all the intelligence assets we can to finding what they are up to." And the measure of its success? "No more attacks like this against the United States and our interests around the world."

In this campaign, as in the narrower military one that is about to be unleashed, America will need allies. But to qualify as a friend of America's, revulsion and words of moral support will not be enough. $\mathrm{Mr}$ Powell has talked of a "new benchmark": how governments now respond to America's requests for help in the war against terrorism "will be a means by which we measure our relationship with them in the future."

\section{Cold war parallels}

In many ways, the nearest parallel to America's new thinking is the determination to contain communism that marked the cold war. This was an equally allembracing struggle that had military, diplomatic, economic and ideological elements. Of course, the cold war was also a classic military stand-off which ended when the Soviet block finally threw off communism. Islam, by contrast, is here to stay, and many of its adherents are as shocked as the rest of the world at the barbarity of the crimes just committed in its name. Still, as a way of viewing the outside world, the fight against terrorism may now come to represent for America what the cold war did for much of the second half of the 2oth century: a means of ordering defence priorities and national bud. gets at home; a way of organising military, 
political and diplomatic power abroad; a new focus for old institutions and an organising concept for new ones. Above all, a way of telling friend from foe.

Some have understood this more clearly than others. America has been particularly pleased with the support it has received from Pakistan. That country's leader, General Pervez Musharraf, was quick to offer America assistance, both in pressing the Taliban to give up Mr bin Laden and in offering America use of its air space and other support. Pakistan, through its links with Afghanistan, will have a major role if military efforts are made to dislodge the Taliban from power.

By helping America, Pakistan is taking a risk (see page 29). Its own Islamic militants have close connections to Afghanistan's mullahs, and American military action could cause a backlash inside Pakistan. But Mr Musharraf understood that this was the moment he had to choose sides, and has made sterling efforts to induce his people to accept that.

If Pakistan is ever to get out from under its mountain of debt and achieve a degree of political stability, it needs the economic support of the West. Japan has already suggested it may resume some of the aid to Pakistan that was cut off after the Indian and Pakistani nuclear tests in 1998. America may do the same. And at a time when Pakistan's great rival, India, has been seeking a new connection with America, $\mathrm{Mr}$ Musharraf has a much-needed opportunity to strengthen his own American links. Help with the war against terrorism could earn Pakistan some American sympathy in its argument with India over Kashmir. At the least, Pakistan's response to the events of the past week may have corrected what Pakistan saw as a dangerous western tilt towards India. But Pakistan, like other countries, can expect to come under pressure to clamp down on its own extremists.

Other countries will face hard decisions, too. Israel and the Palestinians have been pressed to accept a ceasefire and open talks that could dampen down their months of fighting; America wants nothing to get in the way of its efforts to rally Arab support to the anti-terrorist cause. Saudi Arabia has long supported America's presence in the Gulf, while trying to protect its own regime by funnelling money to fundamentalist groups, including some in Pakistan. This has indirectly helped to finance outfits like Mr bin Laden's. Pressure to end this practice could put Saudi Arabia's stability at risk. But dif- ficult calculations will have to be made by many governments-including America's.

Puzzlingly, for an administration that came to office vowing to nurture old friendships and alliances, Mr Bush's team had seemed to spend its first months doing the opposite. Its decision to abandon the Kyoto protocol on global warming irritated many of its friends. So did its readiness to set aside the Anti-Ballistic Missile (ABM) treaty, and its reluctance to accept the constraints of multilateral arms-control agreements. America, it seemed, was prepared to operate on its own: happy if others wanted to tag along, unconcerned if they did not. Will this now change?

\section{Holding on to friends}

The Bush administration is already making better use of the international tools that are available. Although America will not submit its military plans to the UN Security Council for approval, it has moved quickly to speed payment of its longstanding financial arrears to the organisation, giving its new ambassador, John Negroponte, a cleaner diplomatic slate for gathering support in the fight against terrorism. The strong condemnation of the terrorist attacks by both the Security Council and the General Assembly has been appreciated. Among the UN conventions already on the books or under debate are a number designed specifically to combat terrorism. These include one, adopted in 1999, to help end the financing of terrorist organisations. America is likely to press more countries to put their names to this.

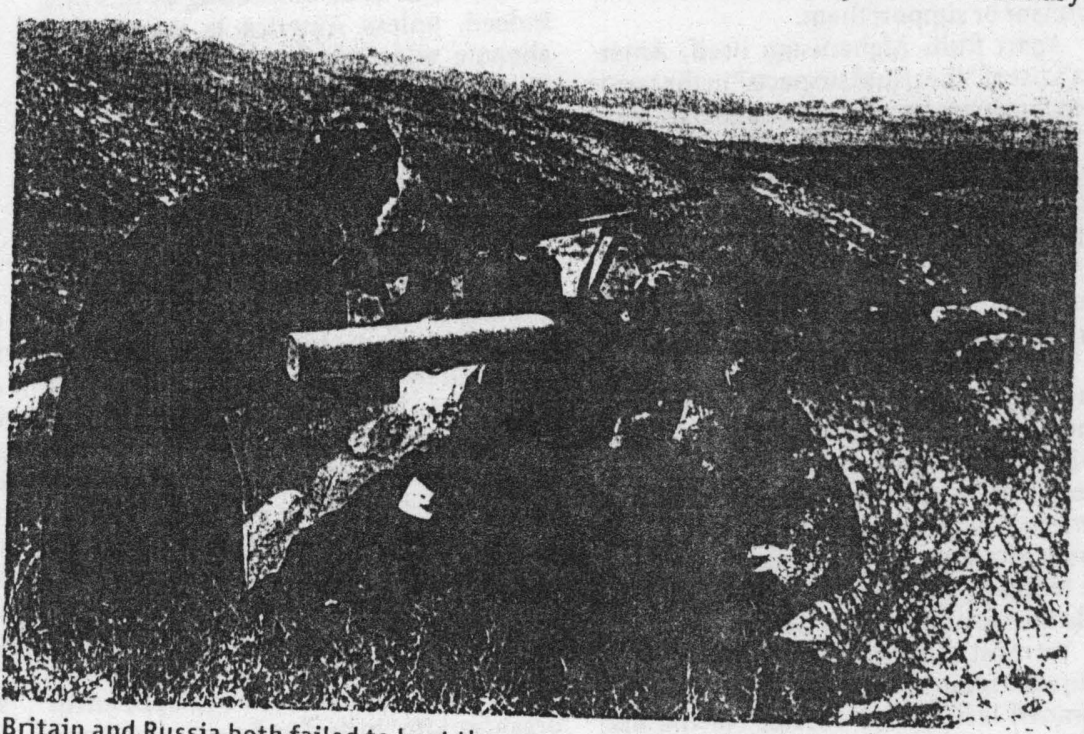

If nothing else, the assaults on the World Trade Centre and the Pentagon have demonstrated to Americans that they can not simply look to their own defences and forget the world outside. An international terrorist onslaught needs an international response. Can America pull together such a coalition, and sustain it? Over the next few weeks there will be more at stake than Afghanistan and Mr bin Laden.

Right now, America seems to have more staunch friends and sympathisers than Mr Bush knows what to do with. France's president, Jacques Chirac, and Britain's prime minister, Tony Blair, were both in Washington to confer with $\mathrm{Mr}$ Bush this week. These are allies who not only posess the most deployable military forces in Europe, should America need them, but also have influence in parts of the world, from Europe to the Middle East and Asia, that will be equally useful if America's diplomats are to turn the coalition of sympathisers into something more useful and enduring.

Yet there is still worry about the possibility of America going it alone. Despite the strong political and emotional support provided by the allies over the past week, a number of European politicians have said that this does not amount to a "blank cheque" for anything America may now wish to do. Both Mr Chirac and Mr Blair will have wanted to impress on Mr Bush this week the need for a measured and proportionate response, and for a readiness to listen to the concerns of allies. The wider and less discriminating America's military 
attacks are, should they come, the harder it will be to keep some of America's European allies on board. Yet, if cracks were to appear in the support for America from its NATO allies, the effects could be disastrous-for both. The worry in Europe is that this danger may be less obvious to the administration in Washington than it is to onlookers in London, Paris or Berlin.

Assuming that these dangers can be avoided, how might the change in America's thinking affect the balance of its relations with the other two big powers, Russia and China? Both have long shared America's concern with the fundamentalist threat emanating from Afghanistan, and have condemned last week's attacks. Yet both have their differences with America. Will this be taken as a time to narrow these, or exploit them?

Russia's reaction has been ambivalent. Its defence minister, Sergei Ivañov, was quick to refuse America access to military bases in Central Asia on the borders with Afghanistan-too quick, given that these bases are in supposedly sovereign countries. Uzbekistan has since sounded more

\section{The military options}

\section{Take your pick}

\section{WASHINGTON, OC}

\section{A tough set of choices}

W ${ }^{\text {HAT }}$ are the ways of fighting such a war? Michael O'Hanlon of the Brookings Institution offers four:

1. Kosovo-style air strikes against Afghanistan. This could be done by aircraft carriers in the Gulf (to where many extra combat aircraft have been sent) and/or stealth bombers flying from America. The combination of precision and heavyweight bombs could almost certainly destroy 2 r bin Laden's camps and the Talibans habdful of military bases. But Mr bin Laden himself might well escape along with inch of his terrorismolanning t itso wisht much of the $T$ liban s rin in w inall rins, rocket propelle or gendes, 2.000 5,000 mortars and stinger misolics thit are deadly

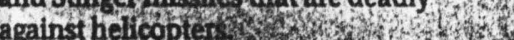
2. Bombing other conntries that help or

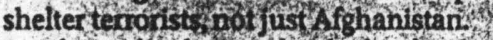
But the wider the attacks, the louder the protests in the Muslim world and elsewhere. The possible exception is Iraq. If Saddam Hussein were found to have been involved in last week's terrorism. ready to accommodate any American requests for help; Tajikistan, more closely under Russia's thumb, has said little.

Yet Russia's diplomats can also see some opportunities for their country in cooperating with America. Russia has long bristled at western criticism of its brutal war in Chechnya, and is clearly hoping that this will now subside if it makes common diplomatic cause with America against Islamic terrorism. It remains to be seen whether Russia will also now temper its support in the Security Council for lifting sanctions on Iraq.

Vladimir Putin, Russia's president, had already agreed to talk to America about new understandings that might amend the to explore anti-missile defences. Although such defences could not have stopped the recent terrorist attacks, America is unlikely to abandon its quest for them. Indeed, its concern about future threats from unpredictably violent countries and people who are attempting to acquire long-range missiles is naturally going to intensify. So too will pressure on Russia to tighten the loop-

attacks on his palaces and his Republican Guard might improve the chances of overthrowing him.

3. Invading Afghanistan. This would be the surest way of destroying the terrorists-if it worked. But it would require bases in either Pakistan or Iran, and preferably the help of their soldiers. Mr bin Laden might slip away. And, as both Britain and Russia can record, Afghanistan is no pushover. "Lice, dirt, blood," is one Russian general's memory. 4. Commando raids plus support for the Afghan resistance. America has 5,000 Green Berets, 2,000 Rangers, 2,200 navy Seals and hundreds of men in the crack Delta Force. Britain has its own efficlent special forces. Other countries might help. This is the likeliest way of dalling or capturing $\mathrm{Mr}$ bin Laden. The ant terrorism allies could also arm and train the anti-Taliban Northern Alliance, even though its leader, Ahmad Masoud, has just been killed. But Mr O'Hanlon reckons all this could take a long time, and cost hundreds of allied lives. holes in its export controls that have repeatedly allowed missile and related technologies to slip through the net.

So far, Russia has been part of the problem. Can it now become part of the solution? Mr Putin may yet be hoping that, in return for Russia's co-operation in the war against terrorism and a readiness to strike a new strategic bargain over nuclear weapons and missile defences, America will heed Russian concerns by delaying or abandoning any plans to bring the Baltic states into an enlarged NA TO.

The Chinese reaction has been even more ambivalent. As expected, China has called formally for America to act only with the approval of the UN Security Council (where China, like Russia, has a veto). Yet it is unlikely to press the matter. It has a keen interest in ending Afghanistan's role as a haven for Islamic terrorists, not least because it sees that as the source of much instability around the region, including in its own Xinjiang province. And it has an interest in improving ties with America after the collision in April between a Chinese fighter and an American surveillance plane off the Chinese coast.

China, too, has its own agenda. This week it pointedly called for America to help in its fight against "separatism"-a dig at continued American support for Taiwan. Despite official promises to the contrary, Chinese firms are as active as ever in supplying illicit technology to dodgy customers who may one day add to the threat the world now faces. America would like more co-operation from China in the fight against terrorism. But few people doubt that, in the longer run, America and China will remain rivals in Asia.

\section{Outward, look}

America has been redefined by disaster three times in the past 75 years. The first was in 1929, when the Wall Street crash began a decade of depression at home and isolationism abroad. That was halted by the second disaster: the Japanese attack on Pearl Harbour. Eventually, once war ended, the country saw 50 years of unparalleled domestic wealth and international engagement. This could be the third shock. There is clearly a risk that America could turn inward, driven by emotional horror at the evil the outside world can do. Yet, to judge by the first rallying of both government and people, almost the reverse is happening. America is seeing this tragedy as a reason to provide renewed leadership, to become engaged abroad, and to look resolutely outward for friends. 
The Economist September 22nd 2001

Osama bin Laden's network

\section{The spider in the web}

\section{A trickier enemy is hard to imagine}

TO MILLIONS of people in the western 1 world, he has come to be viewed as the personification of evil. On the streets of Cairo, in the mountains of northern Pakistan, and even in the air-conditioned luxury of his native Saudi Arabia, he has many admirers, both open and secret.

But for foes and supporters alike, there is much about Osama bin Laden, the man at the centre of a network of Islamist violence spanning 40 countries, that remains enigmatic and contradictory. He was born in the heart of Saudi Arabia's privileged elite, but is now its harshest critic. As a young man, he became a popular figure within that elite because of his prominunt role in the American-backed effort to succour the rebels who were battling Soviet forces in Afghanistan. But for at least the past 11 years-since American troops arrived in his country to wrest control of $\mathrm{Ku}$ wait from the Iraqis, and then stayed on after that war was won-he has regarded the United States and its allies with unqualified hatred.

His own religious roots are in the Sunni branch of Islam, and some of his followers have a history of bitter conflict with followers of Shia Islam, whose biggest stronghold is Iran. But he has insisted that differences within the Islamic world should be set aside for the sake of the broader struggle against western and Jewish interests. American officials say there is clear evidence of tactical co-operation be- tween his organisation, al-Qaeda, the government of Iran, and Iran's proxies in Lebanon, the Hizbullah group. From the early 1990 , members of his group and its Egyp tian allies were being sent to Lebanon to receive training from Hizbullah: an unusual example of Sunni-Shia co-operation in the broader anti-western struggle.

Thousands of would-be Islamist fighters from at least a dozen countries have received training at camps which he set up, at first in Sudan and, since 1996, in Afghanistan. But by no means all the benefciaries of this training are under his control. And, to judge from the evidence that has emerged from three big trials in America over the past decade, many of the people who implement his plans have little idea who their ultimate boss may be. In Chechnya, for example, there is evidence of support (in the form of explosives, logistics and advice) from $\mathrm{Mr}$ bin Laden for the ultra-militant factions. But this tactical support for certain Chechens, according to Mark Galeotti, a British Russia-watcher, does not mean they are under his control.

\section{The money behind him}

$\mathrm{Mr}$ bin Laden was born in Riyadh in 1957, the 17 th of the 52 children of Saudi Arabia's most successful building magnate. His father. Mohammed bin Oud bin Laden, came from southern Yemen in 1932 , when the kingdom's new dynasty was installed, and rose from humble beginnings to become the favoured building contractor to the royal house.

The bin laden group is still the king. dom's biggest construction business, with a turnover of tens of billions of dollars. Its latest peojects include airport facilites in kuala Lumpur, a runway in (airo and a vast new mosque in Nedina. Its recent in vestments have included a marble factory in latly and a shate in lridium, a troubled salellite consortium.

How much of this fortune has tlowed into Mit bin Laden's coffers? According to the State Department's list of terrorist organisations, he is "said to have inherited approximately \$30om." But others who know the Saudi royal house say this is a wild exaggeration. Since the early 1990s, he has been estranged from his family and from the Saudi government, which revoked his citizenship in 1994. The Saudi authorities have frozen his bank accounts and his share of the bin Laden fortune has been confiscated.

Some of the money lost then has, how. ever, been replenished. Former officials of the $\mathrm{CIA}$ and the FBI say Mr bin Laden has been receiving secret donations from rich well-wishers in the Middle East and from Islamic charitable organisations. He may also take a cut from the Taliban's sales of opium. Units of his organisation are believed to raise money through financial and other sorts of crime. For example, Ahmed Ressam, an Algerian who plotted to bomb Los Angeles airport but later co-operated with American authorities, says he was given $\$ 12,000$ of seed-money to set up his operation. When he asked for more cash, he was advised to finance himself by credit-card fraud.

In Sudan, where he established himself in 1991, Mr bin Laden launched several companies. One of these, the Al Shamal Islamic Bank, has a full website with a list of correspondent banking relationships, in cluding institutions in New York, Geneva, Paris and London. He also set up agricultural and construction companies. But these operations, which in the past have built roads in Sudan, were designed primarily to secure the favour of the govern ment rather than to yield high returns, says Vince Cannistraro, a former head of counter-terrorism at the CiA.

A former associate of Mr bin Laden's, Jamal al-Fadl, who fled to America after he was caught embezzling, described a complex operation with three committees, one military, one religious and one financial. Mr bin Laden and his supporters use business fronts and other means to move 
money secretly by wire and computer. Their financial sophistication is such that regulators and investment banks think it possible that they placed advantageous trades in the world's stock and derivative markets shortly before the attack on the World Trade Centre. The shares of three big insurers, France's AXA, Munich Re and Swiss Re, fell sharply in the days before. At the same time, volumes of put options (contracts that allow an investor to profit if shares fall below a specified level) on some airlines and other companies directly affected by the attack jumped beyond normal levels. An investigation is now under way.

What marks out Mr bin Laden from other godfathers of violence against western and Israeli targets is the extraordinary breadth of his connections. Bridging personal rivalries and ideological differences, he is prepared to make tactical alliances with almost any group that shares his aims: the "liberation" of his country and region from American troops, the replacement of pro-western regimes by militant Islamist ones, the defeat of Israel and the restoration of Muslim control over the holy places of Jerusalem.

He has sometimes been described as a Saudi agitator with an Egyptian base. Among the closest partners of his movement-forged in the Pakistani city of Peshawar, which was the home of the anti-Soviet resistance in Afghanistan-are the militant Islamist movements of Egypt. By early 1998, his core group of Afghan veterans had merged with Egyptian Islamic Jihad, a Cairo-based movement which includes the assassins of President Anwar Sadat in 1981. Since 1993 that group has avoided targets inside Egypt, but it bombed the Egyptian embassy in Pakistan and tried to bomb America's embassy in Albania. As a result of the merger, the "consultation council" over which Mr bin Laden presides includes the leaders of the Egyptian Islamic Jihad as well as his old comrades from Afghanistan.

$\mathrm{Mr}$ bin Laden has also co-operated closely with at least one wing of an even larger Egyptian movement, Gamaa Islamiya (the Islamic Group), whose spiritual guide, the blind cleric Sheikh Omar Abdul Rahman, has been in prison in the United States since 1995. This group, which killid 58 tourists in Luxor in 1997, declared a ceasefire in 1999, although this has since been renounced by the imprisoned sheikh.

In February $1998 \mathrm{Mr}$ bin Laden summoned a prominent Egyptian funda-

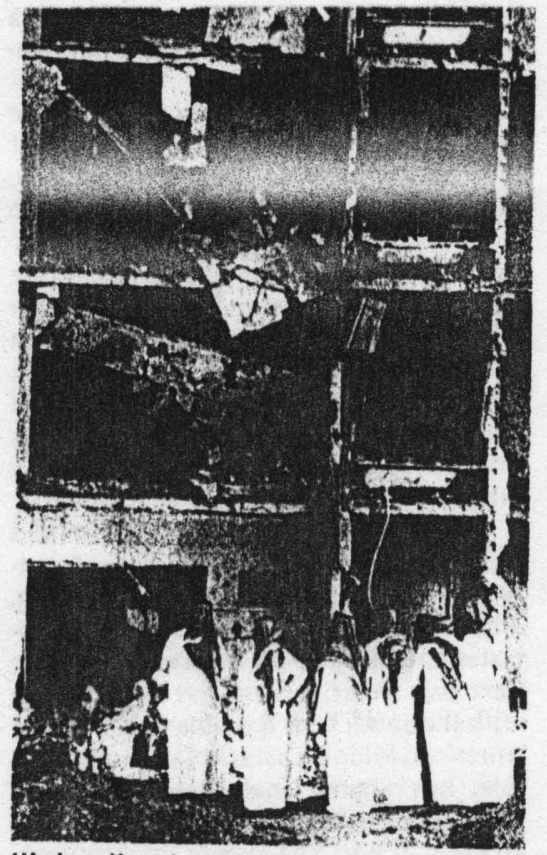

His handiwork

mentalist, together with leaders of three other ultra-radical Islamist groups, to his base in Afghanistan. They agreed to form a new umbrella organisation, the World Front for Jihad Against Jews and Crusaders. The leaders issued a statement asserting that America had, in effect, declared war against God by stationing forces on the holy soil of Saudi Arabia, besieging and bombing Iraq, and supporting Israeli oppression of the Palestinians. The statement concluded with a fatwa demanding that every Muslim comply with "God's order to kill the Americans and plunder their money." This is the imperative that drives Mr bin Laden.

\section{The making of a terrorist}

Unlike many members of the Saudi elite, $\mathrm{Mr}$ bin Laden was never educated in the West, nor even at a western-run college in the Middle East. His only exposure to a cosmopolitan, western way of life was the two years he spent in the hedonistic atmosphere of Beirut after leaving school in 1973. While his brothers studied abroad, he took his degree in engineering in his home city of Jeddah; and he may perhaps have been influenced by the view of conservative clerics that Beirut's plunge into bloody civil war was a divine punishment for its decadent way of life.

Like tens of thousands of idealistic Muslims-and others-from all over the world, he seemed to find his vocation in the battle being waged by the mujahideen, a broad coalition of Islamic fighters divided into at least seven factions, against the Soviet forces that invaded Afghanistan in December 1979 . He was uniquely wellplaced to act as a conduit between the mujahideen and the kingdom because of his family's fortune and his personal contacts with the Saudi elite, including Prince Turki bin Faisal bin Abdelaziz, who was the Saudi intelligence chief for 24 years until his abrupt and unexplained dismissal a few weeks ago.

Shuttling between Peshawar, the Pakistani base for the mujahideen, and Saudi Arabia, Mr bin Laden raised huge sums of money and established a "services office" (maktab al-khidamat) which recruited fighters from all over the world-incluaing the Unired States, where his men operated from an office in Brooklyn. According to American legal documents, the services office had metamorphosed-as early as 1989, the year the Russians left Afghanistan-into al-Qaeda, "the base", which forms the core of Mr bin Laden's network of Islamist violence.

As a supplier of the Afghan rebels, $\mathrm{Mr}$ bin Laden was indefatigable. As well as procuring weapons and humanitarian aid, he obtained bulldozers and engineering equipment which were used to drive tunnels through the mountains of Afghanistan. Although most of his help was logistical and financial, he also saw some combat. In 1986 he was involved in the defence of a small village called Jadji, and in 1989 he was spotted by John Simpson, a British writer and broadcaster, among the forces besieging Jalalabad.

Support for the mujahideen was closely orchestrated between the governments and secret services of the United States, Britain, Pakistan and Saudi Arabia. A privileged recipient of American and Saudi aid (distributed by the Pakistanis) was the militant Islamic leader Gulbuddin Hikmatyar, with whom Mr bin Laden, in turn, was closely associated. The privileged treatment of $\mathrm{Mr}$ Hikmatyar-regarded as power-hungry and fanatical by other rebel groups-was viewed with some bafflement in the expatriate community in Peshawar, and it led to backroom arguments between American officials and their British partners.

Was there any privileged relationship between $\mathrm{Mr}$ bin Laden and the Americans? British officials with knowledge of covert operations in support of the Afghan rebels believed there was such a relation. ship, although this has been vigorously de- 
nied by their American counterparts. In any case, soon after the Soviet withdrawal from Afghanistan in 1989, Mr bin Laden became disillusioned with his erstwhile friends in America, Britain and the Saudi elite. He was dismayed by American support for Dr Sayid Mohammed Najibullah, an Afghan leader whom he viewed as a Russian stooge; and he bitterly opposed the arrival of American troops in Saudi Arabia in August 1990.

Emboldened by the prestige he had ac quired as a powerful friend of the mujahideen, he became increasingly vocal in his criticism of the Saudi leadership-and an embarrassment to his friends and family. He was expelled from Saudi Arabia in 1991 and took refuge in Sudan, where he remained until that country, under international pressure, asked him to leave and return to Afghanistan, his old stamping. ground.

\section{Foot-soldiers' evidence}

The richest sources of publicly available information about Mr bin Laden, his network and methods have been a series of highly publicised trials in the United States over the past decade. Earlier this year, four people were convicted by a New York court for their roles in the August 1998 bombing of the American embassies in Tanzania and Kenya, a double atrocity that cost 224 lives and apparently took five years to plan.

The court was told that one defendant, Wadih el Hage, had been linked with $\mathrm{Mr}$ bin Laden during the Afghan war in the early 1980s; a decade later, he was ordered by the Saudi godfather to bring Stinger anti-aircraft missiles (left over from American supplies to the mujahideen) from Pa $\mathrm{k}$ istan to Sudan by air. Another defendant, a Tanzanian called Khalfan Khamis Mohamed, had played a role in the Dar es Sa. laam bombing but apparently had little knowledge of who was ultimately orchestrating it. As Peter Bergen, the author of a forthcoming book on the bin Laden network, puts it, "This confirms a pattern of foot-soldiers who know very little about the wider plan, and masterminds who are spirited out of the country immediately after, or even before, the attack takes place."

The other court case which provided much information about Islamic terror was that of Ramzi Yousef, who, with half a dozen accomplices, was cosvicted of bombing the World Trade Centre in February 1993. His intention was to topple one tower against the other and release cya- nide gas at the same time. In the event, a bomb went off but killed "only" six people.

While his junior assistants were quickly apprehended, Mr Yousef himself fled the country to Pakistan. Later he moved to the Philippines, where he teamed up with a militant Muslim movement with links to $\mathrm{Mr}$ bin Laden. In the Philippines he conspired to kill President Bill Clinton and Pope John Paul; then, in January 1995 , he plotted to blow up 11 American aircraft in a single day. The plot was thwarted only because of a fire in his Manila apartment; he was arrested a month later in Pakistan.

While it seems clear that Mr Yousef had received support from $\mathrm{Mr}$ bin Laden's network before the February 1993 bombing, and that he co-operated with close associates and allies of $\mathrm{Mr}$ bin Laden over the next two years, his precise relationship with the Saudi boss remains unclear. One American Middle East scholar, Laurie Mylroie, has argued that there are strong grounds for believing that $\mathrm{Mr}$ Yousef was an agent of Iraq. She blames poor co-operation between America's Justice Department and intelligence agencies for the authorities' failure to follow up the evidence.

Whether or not Mr Yousef has an Iraqi connection, his story is a striking example of the grey area in which Mr bin Laden operates. Mr Yousef has a record of support for Sunni Muslim groups which bitterly oppose the Shia branch of Islam; Mr bin Laden, by contrast, believes that all Muslims should work together against their enemies. Yet this did not seem to prevent $\mathrm{Mr}$

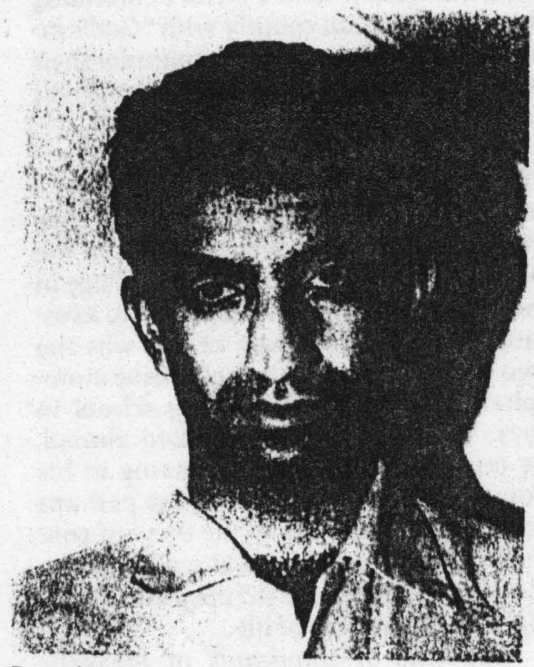

Ramzi Yousef, convicted
Yousef from co-operating with the bin Laden network.

Other tantalising details of the bin Laden apparatus-and the military train ing it offers in Afghanistan-emerged during a separate hearing in New York on the conspiracy by a group of Algerians to set off a suitcase bomb at Los Angeles airport at the turn of the millennium. Ahmed Res. sam, a conspirator who gave evidence for the prosecution disclosed that he had received six months of training at a camp in Afghanistan in 1998, along with volunteers from many other places including Algeria, Jordan, Yemen, Saudi Arabia, France and Chechnya.

The witness said he had been trained in how to blow up the infrastructure of a country-"airports, railroads, large corporations" as well as how to wage urban warfare by blocking roads, storming buildings and assassinating individuals. One of the men convicted in the embassy-bombings trial, Mohamed al-Owhali, had been trained in the same camp, while two other defendants had received instruction at a different training-ground in Afghanistan.

\section{How to get him}

Officials in America and Europe believe that stifling Mr bin Laden's financial network would help to stop more attacks. But that will be difficult. Although it is possible to pinpoint and freeze accounts held in America and Europe, seizing assets held in the Middle East under names not directly related to Mr bin Laden's organisation is far harder. When Mr bin Laden realised that intelligence agencies were pursuing his financial arrangements, he started to rely more heavily on cash, which leaves no trace. His global network may use an internal credit system similar to those employed by the Mafia and Triad gangs, says Magnus Ranstorp, a terrorism expert at the University of St Andrews. Like cash, it leaves no audit trail. "We will never be able to cut off his funds entirely," says Mr Cannistraro; "only restrict them."

The biggest nightmare is that Mr bin Laden and his associates will acquire, or have already acquired, biological, chemical or even nuclear weapons. American legal documents allege that his supporters have been looking for nuclear materials since the early 1990s. Another risk, says bin Laden-watcher Yonah Alexander, is that of devastating cyber-warfare. And even if the man himself is somehow neutralised, plenty of militant Muslims will be ready to struggle on in his name-with or without direct orders from their hero. 


\section{U.S. Military's Pushtu Problems}

The United States faces an important disadvantage if it plans to attack Muslim militants in Afghanistan - the armed forces has no speakers of Pushtu. It is the language of the ruling Taliban and people in the south and east of the country and is also spoken in parts of Pakistan. The army is now recruiting the services of hundreds of Afghan-Americans who do speak the language, say Western diplomats. The military does, however, have several people fluent in Dari, which is a dialect of Persian spoken widely in Afghanistan. The language issue, among other problems, is likely to delay any attack for at least four more weeks, say diplomats in Islamabad. Meanwhile, Pakistani officials speculate that the Americans may attempt to seize an airport deep inside Afghanistan and use it as a base for operations. This could ease pressures on Pakistan and Central Asian nations, where any U.S. military presence would meet widespread local opposition. The most likely candidate is Shindand, south of Herat in western Afghanistan. It is surrounded by desert and would be difficult for the Taliban to defend or wrest back. Military analysts estimate that 20,000 troops would be needed to seize and secure the airport.

\section{No Promises for Pakistan on Kashmir}

United States officials in Washington and Islamabad have firmly told Pakistan that they will not raise the thorny issue of Kashmir with India until any fighting is over. Among other conditions, Pakistani officials had demanded that Washington should help mediate the dispute before Islamabad accepted demands to help the U.S. hit back at Saudi terrorist Osama bin Laden and those sheltering him in Afghanistan. Meanwhile, senior U.S. and Iranian diplomats are scheduled to hold a low-key meeting in Geneva on September 23 to discuss the crisis and the future of Afghanistan, which shares a long border with Iran. Teheran has condemned the terrorist attacks in the U.S., but Iranian officials have expressed serious concern at the possible scale of the U.S. response as it could destabilize the region and increase domestic opposition in Iran to the presence of U.S. forces on their doorstep. Washington needs to reassure Iran because a key component of U.S. strategy will likely be giving support to anti-Taliban Afghan forces led by Ismail Khan close to the border in western Afghanistan. 


\author{
As the United States plots its military response to the September II terrorist attacks, \\ it calls on friends and foes alike for support. In the following articles, the REVIEW looks at \\ the actions and attitudes of Asian nations, and the impact the coming war will have \\ on the region. First, Afghanistan: Ground Zero
}

\section{By Ahmed Rashid/ISLAMABAD}

AS UNITED STATES forces mobilize to attack Osama bin Laden's terrorist networks in Afghanistan in the aftermath of the September II attacks in New York and Washington, the world enters a new era dominated by a global fear of terrorism and the deepening divide between the Muslim world and the West. The total war against bin Laden and Afghanistan's Taliban being planned in the White House will dramatically reshape the political map of South Asia and Central Asia and lead to rapid changes in regional alliances.

Instead of merely dealing with the threat of terrorism, the magnitude of the

U.S. response could unravel the region.

"Bin Laden and the Taliban believe they are about to draw the U.S. into the trap that devoured the Soviet Union, and if we lash out without a political and strategic plan for the region, they could be right," warns Barnett Rubin, a prominent Afghan scholar and Director of the Centre on International Cooperation at New York University.

Clearly the risks are huge. There could also be benefits. In Pakistan, the military could finally delink itself from support to Islamic fundamentalists and the growing culture of so-called jihad, or holy war, undermining the country. Pakistan could rebuild ties with the West and improve relations with India. The Central Asian republics may finally be rid of the militant Islamic opposition move. ments based in Afghanistan and concentrate on improving cconomic and democratic reformsor dissolve into greater authoritarianism and poverty. And in Afghanistan, a U.S.-led alliance could help reconstruct a new govermment which could fimally bring peace after 23 years of war.

On the other hand, as the U.S. offensive is drawn out, Pakistan could unravel and Islamic militants take to the streets, under pressure from the Islamic fundamentalists that are a growing force in the country. Afghanistan could descend into the warlordism that dominated it in the early I990s (and cleared the way for Taliban rule), creating around the world a flood of refugees and angry new recruits for terrorist organizations.

Within hours of the attacks on the Pentagon and World Trade Centre, President Bush said America was at war with international terrorists. "Those who make war on the United States have chosen their own destruction," he said on Sep. tember I5 after declaring a national state of emergency. He warned that the U.S. response would be "a conflict without battlefields or beachheads" and that "the conflict will not be short." He pledged to build an international alliance through Nato and other allies.

The U.S. has identified ig suspected hijackers as belonging to bin Laden's

Al-Qaeda organization, which is based in Afghanistan. As the U.S. mobilized 50,000 reservists and began to ship and airlift men and supplies to its main depot in the region-the island of Diego Gar. cia in the Indian Ocean-it began to seek support from landlocked Afghanistan's neighbours. Pakistan, Russia, China, India, Iran and the Arab world all face a critical moment in their relationships with both the Islamic world and the West. Critical among them, China has already voiced support (see story on page 16), as has India.

The big question was Pakistan. Within 24 hours of the attacks Washington was pounding on Islamabad's door looking for bases and support. Islamabad has spent the past seven years providing mil. itary, political and financial sup. port to the Taliban. A reversal by Pakistani leader Gen. Pervaiz Musharraf would invite an intense backlash from Islamic fundamentalist parties and the officer corps of the military.

Late on September 14, after a seven-hour meeting with his generals, Musharraf summoned U.S. Ambassador Wendy Chamberlin to say his government would give total support to a U.S.-led multinational force to be based in

- Pakistan. The conditions: Pakistani forces would not cross into Afghanistan, and the U.S.-led force would need a UN mandate and must exclude Indian and Israeli involve. ment (though not the use of Indian territory to stage attacks).

Pakistani and Western diplomats told the REVIEW that Islamabad had accepted I8 U.S. demands. Among the most critical will be Pakistan's agreement to share intelligence on bin Laden and the Taliban. It also committed to closing its borders with Afghanistan so that an estimated 3,000 members of Al-Qaeda do not escape into Pakistan.

What Musharraf has agreed to is essentially a policy U-turn. For 20 years the Pakistan military has attempted to bolster Islamic groups to fight its proxy wars in Afghanistan and Kashmirsupport which has rapidly spread the culture of jihad that now poses a threat to its own national security. At present,

3,000-4,000 Pakistani Islamic militants are fighting alongside the Taliban, while thousands more Pakistani and Kashmiri militants train in Afghanistan for the war in Kashmir.

"Reversing this policy will not be easy," admits a retired Pakistani general.

Musharraf has since been lobbying politicians, religious leaders and the media in order to woo a sceptical public. "The present critical situation requires a unified response from the nation," Musharraf said 
on September 16. Pakistan has already enacted stringent security measures to avert terrorist attacks within its borders.

Musharraf will have to do even more. He will need to crack down on Islamic extremists in Pakistan who provide AlQaeda with logistics, communications and other support. He will have to ban Pakistani groups that could pose a threat to U.S. forces, such as Harakat ul. Mujahideen and Jaish-e-Mohammed, which are listed by Washington as terrorist organizations. The largest Pakistani party fighting in Kashmir, Laskar-e-Toiba, is on the U.S. terrorist watchlist. Stopping their activities would lead to an intense political backlash.

A backlash has already begun. Prominent Pakistani Maulana Samiul Haq

heads a string of madrassas - the Islamic religious schools that also serve, in Pakistan, as preparatory academies for jihad-that many Taliban leaders attended in the early 1990s. Haq, who also leads the pro-Taliban fundamentalist

alliance in Pakistan known as the Afghan Defence Council, publicly threatened Musharraf on September 14, saying Musharraf must be "mindful of the sentiments of his under-command."

Qazi Hussain Ahmad, leader of the Jamaat-e-Islami, Pakistan's largest Islamic political party, told a religious meeting on September 15 that "we will oppose the attack on Afghanistan tooth and nail and force the Pakistan govern. ment not to become a party to it." Several retired generals and former chiefs of the Pakistani intelligence service, the ISI, known for their hardline Islamic views, were even more provocative-claiming that the bombings in the U.S. were carried out as part of an Israeli-Jewish conspiracy in league with the U.S. Central Intelli. gence Agency in order to give Israel a free hand to crush the Palestinians and defame Muslims.

The effect of the international crisis is already being felt on the Pakistan economy, which was fragile prior to September II. With the temporary closure of markets, enormous capital flight and rupee value tumbling as banks buy dollars, the country " will soon need emergency financial

support from abroad. Concessions to the U.S. could bring a major write-off of Pakistan's $\$_{3} 8$ billion in foreign debt. On the other hand, an economic meltdown would only serve to strengthen

\section{Pakistan's fundamentalists.}

In contrast to the uproar in Pakistan, India's support for the U.S. has been unam. biguous in the days following the attacks. That's because along with the U.S. and Israel, India is also a target for militants pursuing a global jihad, namely in Kashmir. India has sup. ported Afghanistan's North. ern Alliance, also known as the United Front, in an effort to destabilize the Taliban, and wants Pakistan to stop helping the groups that cross into Kashmir and carry out attacks there. According to The Times of India, the Indian government has offered three air bases as well as port facilities on its Western seaboard for use in a U.S. offensive.

India's main goal is to keep pressure on Pakistan, though not to the point of col-

lapse. "We'd be at the receiving end of the detritus," says Bharat Karnad of the Delhibased Centre for Policy Research.

"The last thing India wants is a failed state on its border," says a senior Indian diplomat. "We want a Pakistan that sees itself coexisting with its neighbours, rather than one using jihad as a tool of state policy."

Meanwhile, Taliban leader Mullah Mohammed Omar threatened that the Taliban would attack any neighbouring country that provided military bases for a U.S. invasion of Afghanistan. "It is not impossible that we would attack such a country under compulsion and the mujahideen would have to enter the territory of such a country," Omar said from the Taliban's base in Kandahar on September 15 .

His invective followed the failure of two days of secret talks between Omar and senior officers of the ISI in Kandahar to persuade Omar to hand over bin Laden. ISI chief Lt.-Gen. Mehmood Ahmed returned on September 17 for further talks. As the Review went to press over I,000 Tilliban officials had gathered in Kabul to debate bin Laden's extradition and under what conditions they would agree to it.

As the threat of a U.S. attack mounts, Omar, bin Laden and Arab and Afghan hardliners around them will stand increasingly isolated. The Taliban, dominated by the Pashtun ethnic group, are deeply factionalized. Moderate Taliban leaders in Kabul have started to send their families out of harm's way to Pakistan. Many of them will desert if they see a credible Pash. tun alternative. That is why U.S. offi-

cials knowledgeable on Afghanistan are advocating that the U.S. help create an anti-Taliban armed force in the belt of southern Afghanistan in which the ethnic Pashtun dominate. Such a force would express its loyalty to former King Zahir Shah, who has stepped up efforts to call a Loyo Jirga, or tribal council, of all Afghans in a bid to set up an alternative government.

"We are looking at a defining moment, if only we will grasp the opportunity," says a senior U.S. official in Washington. "It is especially important that this interna. tional alliance be more than a military enterprise so that it can help shape a postTaliban/bin Laden Afghanistan." Last year Washington provided \$100,000 to Loya Jirga efforts. At the end of September, Nato and the European Union will hold meetings which are expected to endorse this process.

Further destabilizing the Taliban, tens of thousands of refugees have fled Kabul, Kandahar and the eastern city of Jalalabad since the attack on the U.S., according to the United Nations refugee agency. Many are headed for villages within Afghanistan, while others are headed to

the Pakistani and Iranian borders. The "critical" humanitarian situation may soon deteriorate as aid agencies evacuate staff, says the UN. Pakistan is already host to 2 million Afghan refugees, with 1.5 million refugees in Iran.

Meanwhile Russia, Iran and India have stepped up their military support to the anti-Taliban United Front, whose leader, Ahmad Shah Masud, was assas. sinated on September 9 by two suicide bombers who allegedly belonged to AlQaeda. Masud's forces; who control just 10\% of Afghanistan, are presently battling some 25,000 Taliban troops. United Front

leaders have offered their support to the U.S. coalition, and their forces could play a critical role in finding targets and reducing Afghan.civilian casualties.

U.S. forces are also going to need bases in the Central Asian Republics of Uzbekistan, Tajikistan or Turkmenistan, which border Afghanistan. But bases will not be offered without clearance from Moscow, which is playing hard to get. Even though Russian President Vladimir Putin strongly condemned the terrorist 
attacks and pledged support for U.S. air strikes on Afghanistan, Russian officials have said they will not allow U.S. or Nato

forces to be based in the region. Russia appears to be taking a bargaining position from which it can extract concessions from Washington.

For Iran, Afghanistan's western neighbour, the U.S. will have to reassure leaders that its military action will pose no threat. Iran will also want to be consulted about the nature of any future government in Kabul (see Intelligence, page 8). The U.S. is also rapidly mustering Arab support and troops from Saudi Arabia and the Gulf states to join the multinational force-not an easy task with current Arab anger at Washington for coddling Israel.

Enlisting Arab support is critical if Washington is to appease the Islamic world's fear that a war of civilizations between Islam and Christian. ity is about to break out. "Washington needs to demonstrate to ordinary Muslims that this is a global effort against terrorism which Muslim countries support," say's the retired Pakistani general.

Islamabad is also keen to enlist Saudi support as a means to provide political cover at home. On September 15, a high-level Saudi military delegation arrived in Islamabad to discuss military cooperation.
There is no doubt that the U.S. will face major military difficulties in Afghanistan, where the terrain of high mountains and deserts is extreme. There are few obvious targets and overexposure of U.S. forces could lead to a wider back. lash by the fiercely nationalistic Afghans, who in the last two centuries have defeated British and Soviet invaders. The U.S. is unlikely to occupy major portions of Afghan territory, but will need to use ground troops and commandos. Missile strikes alone, which the U.S. carried out in 1998 against bin Laden's camps, are unlikely to succeed.

America's effectiveness will ultimately depend on how Washington sees its military campaign in the region-as merely an attack on terrorism or a broader attempt to restructure Afghanistan, push the peace process between India and Pakistan and help the Central Asian regimes. Emotional and angry demands are being made by many Americans for instant and overpowering retaliation that could devastate the region if the U.S. moves in without a clear-cut political and military strategy. Paul Wolfowitz, the U.S. deputy secretary of defence, spoke ominously of "ending states who sponsor terrorism."

Says Rubin, "The more U.S. action is seen as an act of revenge, the greater the risks of it failing. The more it is seen as meting out justice, the greater support it will muster."

Joanna Slater in Mumbai contributed to this article.

\section{Chinese Organ Screens Web Site}

People's Daily Online, a portal run by the mouthpiece of the Chinese Communist Party, is reporting huge interest in the terrorist attacks in the United States. At its peak the site was hosting as many as 25,000 Netizens at one time. But the Web site's staff told the REvIEw they were deleting two kinds of postingsmessages which cheered the attacks in New York and Washington or that suggested China should carry out their own attacks. Messages that call for China to join the U.S. in going after Osama bin Laden and attacking Afghanistan were also being cut. In the absence of concrete proof that bin Laden was responsible for these acts, the government might be concerned about upsetting the country's substantial Muslim minority. 
ASIAWEEK SEPTEMBER 28200

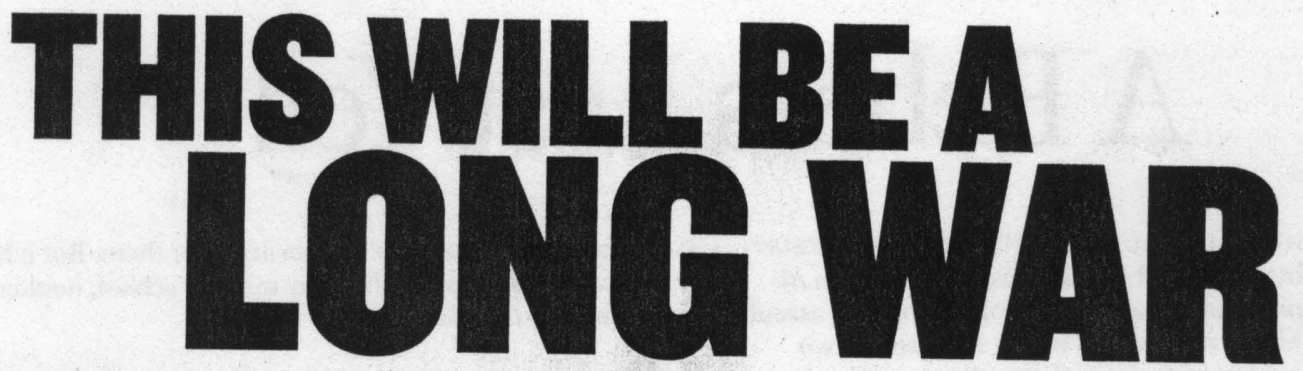

America should beware. Afghanistan has been the graveyard of great armies, from the British in the 19th century to the Soviets in the 1980s by Anthony Paul

7. f the West really is at war with a fundamentalist Muslim army, put aside any notion that this conflict will be short-lived. Not to understand this would be to repeat a mistake many analysts made in 1979, when the Soviet Union invaded Afghanistan. Shortly after the Soviets went in, New York Times correspondent Drew Middleton reported that "one group of military analysts believes that the Russians can finish it in four weeks." But Afghanistan became the Soviet Vietnam. After ro years, and with the number of troops up to more than 100,000, the invaders were forced to withdraw, vanquished by mujahideen (holy warriors) supplied and trained by the U.S., Saudi Arabia, Pakistan and others.

U.S. weapons certainly created a difference, but there was one element that made the Afghans perhaps more formidable than even Vietnam's guerrillas: the fiercely-held tenets of their religion. Afghanistan's mullahs had declared this to be a jihad (holy war). To conduct oneself honorably in such a conflict guarantees immortality. Sayed Naim Majrooh, a young Kabul chemical engineer-turned-guerrilla, explained to me as we sat in 1980 by a campfire outside Kandahar, now Osama bin Laden territory: "If I kill just one Russian and survive, I become a ghazi, the surviving warrior of a jihad. If the Russians kill me, I'm a shahid, a martyr who goes immediately to heaven. Either way, my future is in paradise."

Re-reading the stories I filed to ASIAWEEK from the Afghanistan-Pakistan border in the late I970s and early i 980 s revives for me memories of mujahideen ferocity. Just as significant was their mastery of simple weapons. In an essay lisst week, Stephen King, author of horror novels, noted something similar about the Sept. II hijackers: "This was men armed with nothing but knives and box cutters relying on simple speed to keep people off balance long enough to accomplish their goals. Cost of weaponry? Based on what we know now, less than \$100."

Engineer Majrooh's cousin and fellow mujahid, Sayeed Walid Majrooh, was my eyewitness for a famous incident early in the war in which four illiterate goatherds, the Shahzada brothers, destroyed a Soviet tank almost with their bare hands. Hiding on a narrow mountain road, they rolled boulders to the front and rear of the last tank in a convoy. The tanks II5-mm main armament couldn't get low enough to blast the obstructions. To prevent the tank crew calling for help, one of the brothers attacked the radio aerial with an ax. Another brother rammed his rifle butt against the tank's machine-gun, forcing it to fire uselessly into the air. The other two piled bushes on their prize, set them alight and waited for the external fuel tanks to explode. Cost of weaponry: one rifle, one ax and some matches.

Just as with the U.S. in Vietnam, the Soviet war in Afghanistan in the end came down to ? question of morale. By 1989 , Soviet military and civilian patience

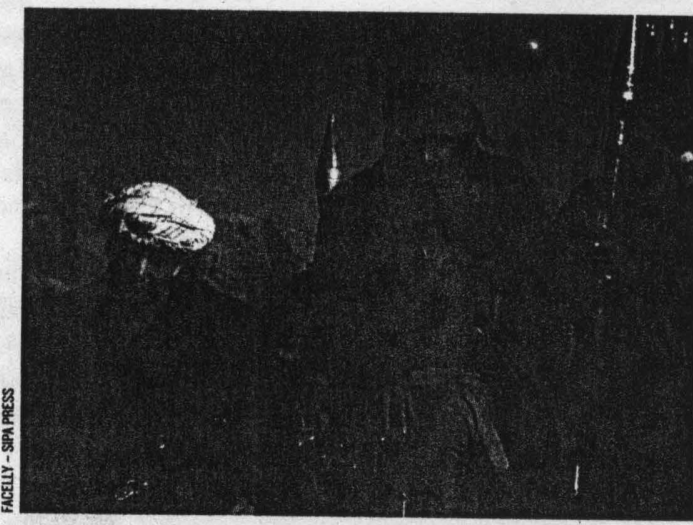

THE WILD BUNCH How ferocious are the Afghans capable of being? Enough to destroy a tank practically with bare hands

was running out and the economy was in disarray. But otherworldly ambitions sustained the mujahideen. Most nations' poets agree with Shakespeare that war's a grim-visag'd thing; not in Afghanistan, where poets seem to celebrate it. In Islamabad I came across an anthology of Igth-century translations that included an instructive ballad, A Pathan Warrior's Farewell:

Now, when our house its mourning wears,

Do not thyself give way to tears:

Instruct our eldest son that I

Was ever anxious thus to die.

For when Death comes the brave are free-

So in thy dreams remember me.

How long will they fight? Washington's military planners should read that Pushtu ballad. $A$ 
NEWSWEEK OCTOBER I, 20 I

\section{A Rebel's Last Yell}

A

HMED SHAH MASSOUD, THE CHARISMATIC RESISTance fighter and head of Afghanistan's Northern Alliance, might have played a key role in any U.S. assault on the Taliban regime. But earlier this month two suicidal assassins posing as journalists-and now suspected of working for Osama bin Laden-murdered Massoud with a bomb hidden in a television camera. Only a few days before, NEWSWEEK's Antonia Francis met with Massoud in a large reception room-the same one in which he was killed-at a compound near the town of Khodja Bahauddin. Excerpts:

Fruncis: Has there been a change in U.S. policy toward the Northern Alliance, and do you want military ald?

Massoud: The Taliban are not a force to be considered invincible. They are distanced from the people now. They are weaker than in the past. Only the assistance given by Pakistan, Osama bin Laden and other extremist groups keeps the Taliban on their feet. With a halt to that asistance, it mould be extremely difficult [for them] to invive. We hope that the future w Theyareweaker than in the past. Only the assistancegiven by Pakistan, Osama binLaden andother extremistgroupskeeps the Taliban on theirfeet." -AHMEd SHaH Massoud
Pakistan could indeed establish an army for them. But it hasn't. Kandahar nor in Kabul.

How would you envisage balancing traditional values with your more modern political visions - especially equality for women?

Of course it's not possible to ignore traditional values, but we the health sector and schools. And they have not established any military school, neither in should take steps to bring change. In the northeastern province of Badakshan, girls go to school and find employment, especially in policy of the Unitid States Will exert pressure on Pakistan and

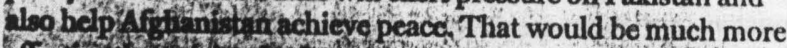

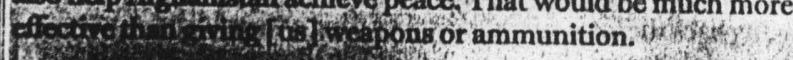

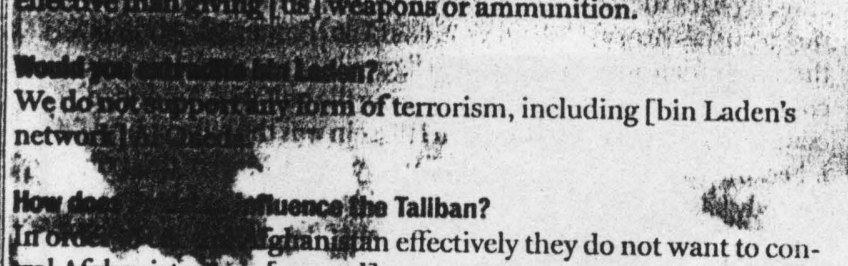
rol Afghanistan is a [normal] state or a government. Instead the imiato reduce fghanistan to a tribal system in which each ethis dependent upon Pakistan. It is again the old method nd rule' h good example: it has been a long time since oen the Inaliban but they still lack [a regular] army.

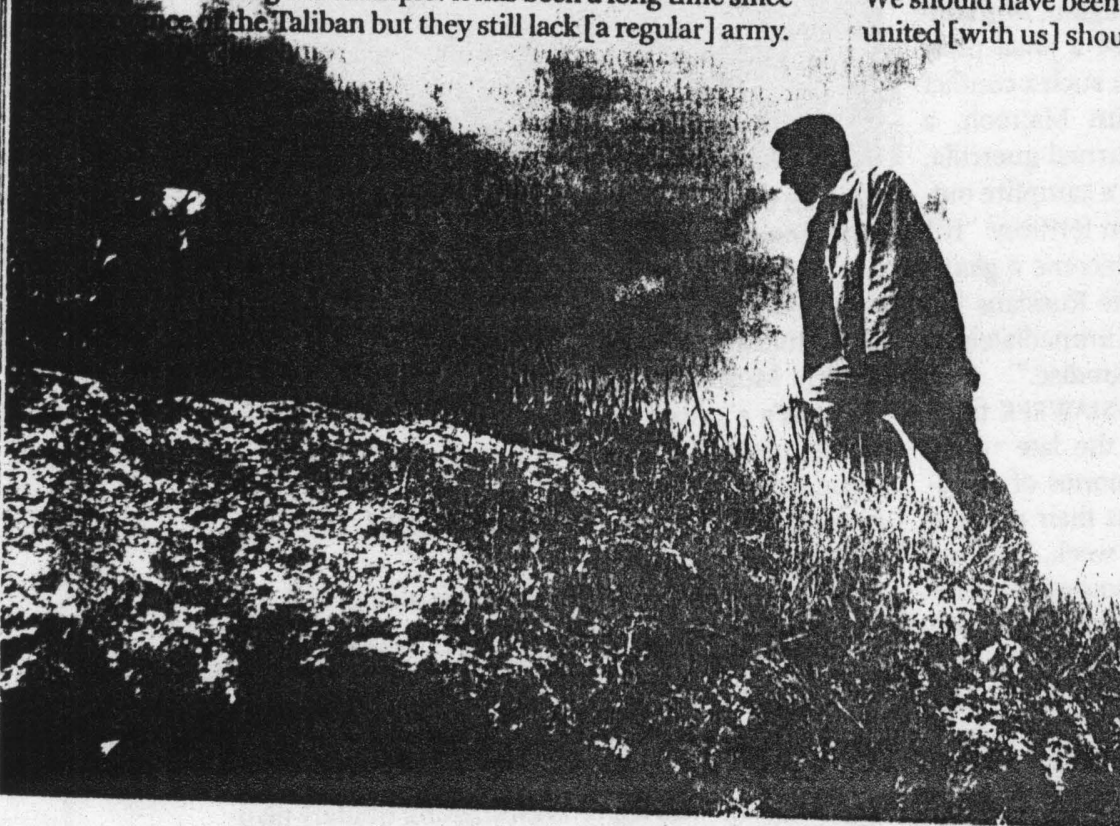
fought the Russians? should leave.
What have you done to demonstrate your own dewocratic values?

We have improved our democratic shura, or council system. Peoplegather and decide what to do. These shuras are composed of different sectors of societyreligious people, elders and the educated. [Military] commanders are not part of these shuras. Our shuras start from the village level and expand to province level. Most of the political affairs are run in consultation with these shura structures.

\section{Are there female representatives?}

No, there are no women in the shuras. We believe in gradual change.

\section{How does your current military strategy compare with when you}

Against the Russians it was the nature of the fighting-the prolongation, continuation, the costliness for the Russians-which forced them to leave. Wisdom should dictate to Pakistani generals that they will have the same fate as the Soviets. So they

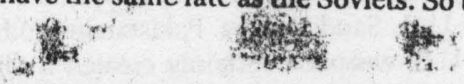

What could your government have done to stop the rise of the Tallban when you were still in powor?

We should have been more united then. The forces that are now united [with us] should have united then. 

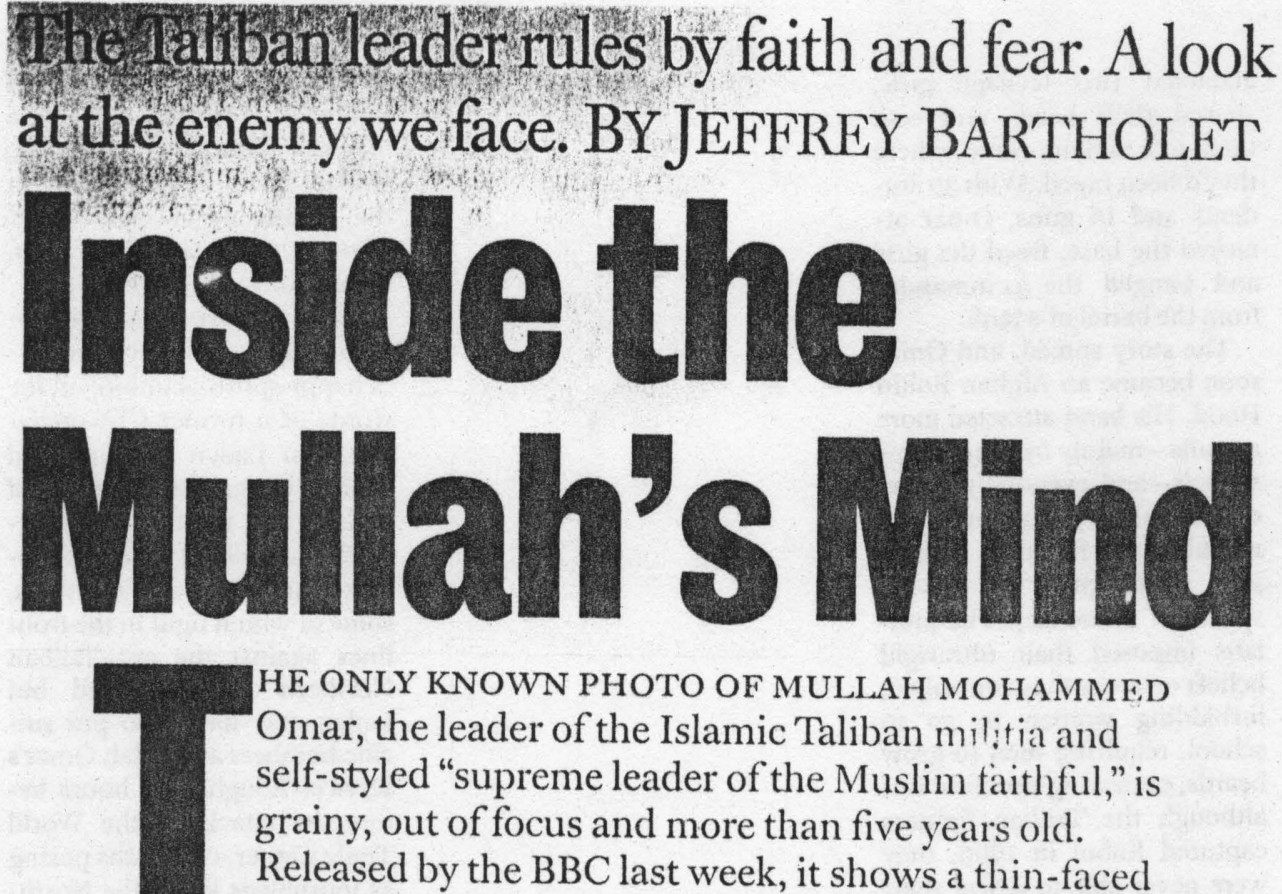
man with a dark beard and oversize black turban during a rally in Kandahar, Afghanistan. It could be just about any Afghan holy warrior. You can't see the scars on Mullah Omar's face, or that his right eye is missing, blown away by a Soviet missile blast. Nor, if

you're hoping for a peek through the one remaining window on his soul, can you get a clear look at his good left eye. Mullah Omar appears instead like an apparitionor a prophet-floating among a blurry, bearded throng of devoted followers.

It's not much to go on. But if Mullah Omar had his way, there would be no such picture at all. He doesn't allow himself to be photographed, believing that "graven images" of human beings are forbidden by Islam. In a land where television is

outlawed, even most $\delta$ fghans have never caught a glimpse of Mullah Omar and don't know what he looks like. Only rarely has he met foreigners. In an interview some years ago with a $\mathrm{BBC}$ journalist, Mullah Omar spoke from behind a curtainthrough a third person-explaining that he had no wish to meet anyone not "helpful" to his cause. Some merchants in the Kabul bazaar like to joke that Mullah Omar doesn't really exist. And, in a sense, that is true: he never finished the Quranic school-

ing required to get the title mullah, but his followers call him that anyway as a sign of respect.

Such is the clusive nature of the enemy that America may soon face in battle. President George W: Bush bluntly warned last week that if the Taliban leaders did not meet a series of nonnegotiable conditionsincluding the handover of Saudi fugitive Osama bin Laden and his comrades in the terror network Al Qaeda-the United States would treat the Taliban just as it would the terrorists. In response, the Taliban made warnings of its own: that American attacks would inflame the anger of Muslims around the world and plunge the region into crisis. "If the L.S. attacks us," Taliban spokesman Mullah Muhmajin told Newswikk by phone, "we will declare jihad against America." War in Afghanistan

seemed all but inevitable. But what kind of war, and against how dangerous an enemy?

That will depend, in part, on how much popular support the Taliban can muster. It wasn't that long ago that its militiamen were regarded by many Afghans as saviors. The movement began in 1994, two years after mujahedin fighters had overthrown the Soviet puppet regime in Kabul. At the time, rilal wartords vied for power, and criminals plagued the countryside. According to a commonly. told take of how the Taliban got started, frantic neighbors called on ()mar one dary, plateding for help: a hecal commander had 
abducted two teenage girls, shared their heads and sent them to a military camp, where they'd been raped. With 30 students and 16 guns, Omar attacked the base, freed the girls and hanged the commander from the barrel of a tank.

The story spread, and Omar soon became an Afghan Robin Hood. His band attracted more recruits-mainly from religious schools-and eventually he received military support from neighboring Pakistan (which sees Afghanistan as a vital sphere of influence). The mullahs imposed their ultrarigid beliefs on areas they controlled, forbidding women to go to school, requiring men to grow beards, outlawing neckties. But although the Taliban fighters captured Kabul in 1996, they were never able to defeat their enemies completely, and gradually they came to alienate their friends.

The Saudis, in particular, cut off much of their support after a heated 1998 meeting between the Saudi intelligence chief, Prince Turki bin Faisal, and Mullah Omar. The prince was haranguing Mullah Omar about bin Laden, according to a Pakistani general who was present. But as Prince Turki spoke, the mullah rudely removed his own turban and

asked an aide to douse him with a bucket of water. "Look, I just cooled myself off so I would not lose my temper," Mullah Omar told his stunned visitor. "You have done very much for us, you Saudis, and now you should never talk to me again."

The Taliban insists that its power really

lies with God and the Afghan people. But the movement now presides over ruin. The country is suffering its worst drought in decades, famine is imminent and U.N. sanctions imposed earlier this year to pressure the Taliban to hand over bin Laden remain in effect. Yet in recent months,

Mullah Omar has implemented several controversial decisions that reflect the political agenda of bin Laden and his Arab-Afghan friemls. These include a new school curriculum emphasizing Arabic, the prosecution of two American and six European aid workers for prose- lytizing and the destruction of the rock-hewn Buddhas of Bamiyan. "Afghanistan is a lijiaked coumery" salys blic krahomshe a scriar fillow at

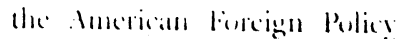
council. "ll anthing. biu latencontrols the Taliban."

(Bher analysts beliene the alationship is more symbiotic . "a halph spiritual whion., in tia words of a tormer (1) operat(ive. Bin Laden has provided Mullah Omar with millions of dollars, and the terrorist's network has trained several thousand Arab-Afghan guerrillas, some of whom fight in the front lines against the anti-Taliban Northern Alliance. And bin Laden may have also put suicide bombers at Mullah Omar's service. Roughly 48 hours before the attack on the World Trade Center, two Arabs posing as journalists killed the Northern Alliance's top general, Ahmed Shah Massoud. The assassins were carrying false Belgian passports and spoke fluent French-an eerily similar MO to the seemingly Westernized fanatics who hijacked planes in the United States.

Terrorists and guerrillas may not pose the most daunting challenge for American forces in Afghanistan, however. "As soon as an American soldier places a foot in Afghanistan, great expectations will rise among the Afghan people," says Olivier Roy, an expert with the Centre National de la Recherche Scientifique in Paris. "They will be looking for food, a political solution to their problems, better roads and health systems." Tough as that scems, providing the simple requirements of life may do more to destroy the 'laliban than all the bullets and bombs the United States and its allies can unleash.

With ROW NORDLAND and IAN MtackiNoN in Islamuabuld, P.zkistan: CAKIA POWER in London DON.ATEIIA L.ORCH in Washington, and OWr. MATTHEWS in Dushanbe, Tajikestan 
NEWSWEEK OCTOBER I, $200 I$

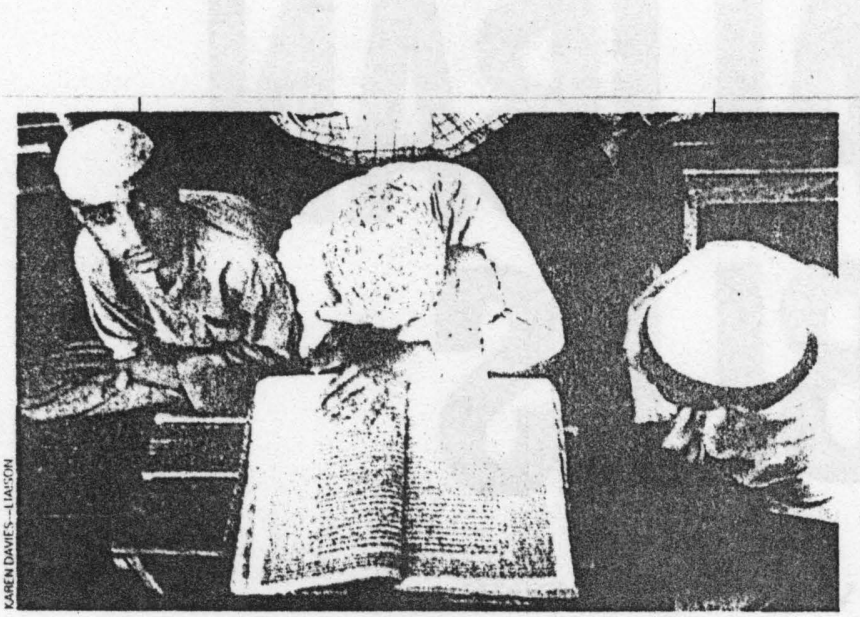

Angry 'Students' of the Faith

They put women in purdah and arrest Christians for teaching their beliefs. Intolerant and suspicious of the outside world, the Taliban movement turns time backward as it rules Afghanistan.

Who they are: The movement formed as a militia in 1994 to quell the chaos that followed Soviet withdrawal. "Taliban" means "students of religion," like those in the photo above.

How they rule: They seized the capital in 1996, establishing an "Islamic emirate." Mullah Mohammed Omar is the "supreme leader of the Muslim faithful."

Where they govern: Kabul is the official capital, but Mullah Omar and his 10-man shura (council) operate in Kandahar, the country's religious center.
What they belleve: Under a rigid form of Islam, women cannot work, and theft is punished by amputation. "Idolatry" is forbidden; two 1,400-yearold statues of Buddha were destroyed. Afghans who convert to Christianity can be executed, and foreign relief workers, including two Americans, are accused of proselytizing.

How they stay in power: Popular at first because they imposed order, they still face armed opposition. Bin Laden's fighters help keep them on top.

\section{T E R R O R I S M \\ Siding With Bin Laden}

$0^{1}$ AMI UL-HAQ, HEAD OF Pakistan's biggest religious school responsible for training many of Afghanistan's Taliban leaders, is considered Osama bin Laden's closest ally in Pakistan. He founded the Afghan Defense Council, which has taken to the streets to protest U.S. retaliation. PERI's Rod Nordland heard him out:

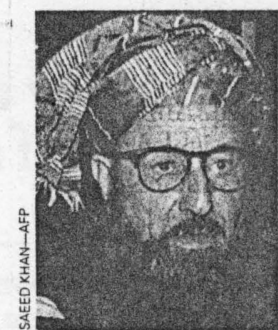

Samiul-Haq
How did you feel when you saw the World Trade Center destroyed? It was a great loss of human life. But America should investigate properly and not

take actions in haste.

\section{Some Muslims even seemed pleased.}

They are suffering from American policies. So, they are happy when Americans are suffering. This is an opportunity for America to reflect on why its policies have caused this.

\section{You know Osama bin Laden. Where is he now?}

Osama has repeatedly said he does not want to add to the problems of the Taliban. He's living in caves. He has no communications. The Americans know this, too. How could a person with no Internet, no telephone, novisitors, commit such an act?

America has declared war on terrorists and their protectors. Are you worried?

So what? We are already in a state of war with you. Attacking Afghanistan will start a fire. Americans found it hard to put out that little fire in Manhattan, they should realize this fire would be much bigger, much stronger and will set all the region aflame.

MALCOLM BEITH with bureau reports 

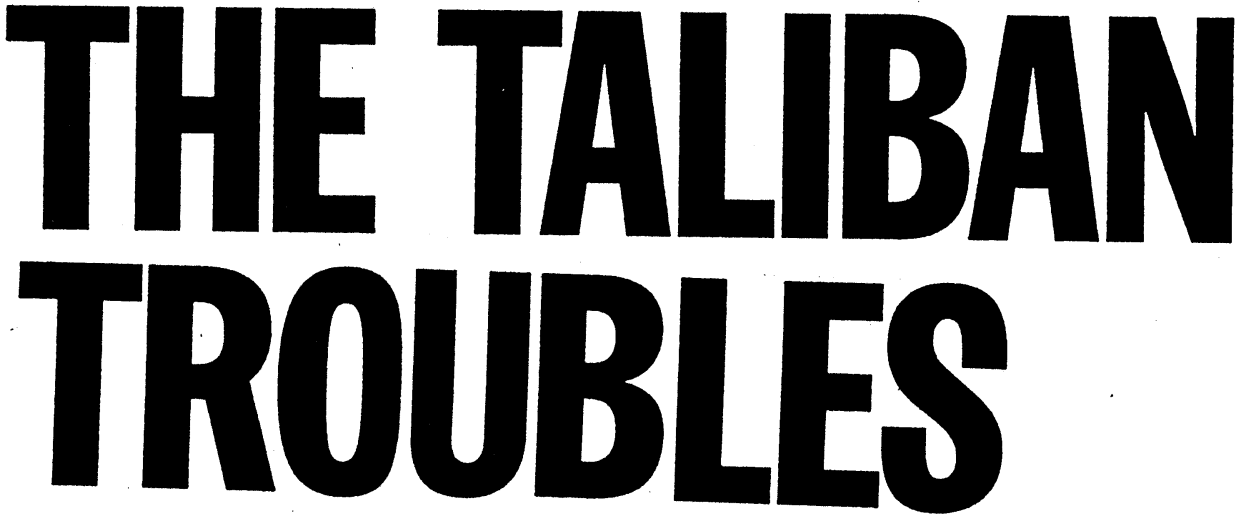

\section{A nation cursed by a violent past now ponders the costs of an even bloodier future}

\section{BY JOHANNA MCGEARY}

N A BLEAK FORTIFIED COMPOUND FEW non-Muslims have ever seen sat a man few non-Muslims have ever met mulling over the future of a wanted man, his own nation and much of the world beyond. Not often in history is anyone given such a moment to affect the world's course, but the Taliban's supreme leader, Mullah Mohammed Omar, is that

man. As American warplanes converged on the region surrounding Afghanistan, he had a stark choice to make. He could call by radio to the Taliban fighters in Osama bin Laden's personal security guard and order them to hand over their "guest" to justice. Or he could refuse and make Afghanistan the fiery center of President Bush's declared war on terror.

At this moment of crisis, the fortyish former village prayer leader was probably

sitting as he often does, cross-legged on the floor, praying and reading the Koran, which has guided him, since the formation of the Taliban in 1994, from scholarly obscurity to spiritual leader of the movement and temporal ruler of the Islamic Emirates of Afghanistan. Yet Omar may find little explicit instruction there for a decision that could equally satisfy his tribal ethics, his puritanical version of Islam and his nation's interests. If he delivers bin Laden to the West, he betrays the man who helped bring him to power and sustains his rule now. If he follows his faith in Islamic jihad or his country's tra-

dition of protecting guests, he condemns Afghanistan to another onslaught in the savage wars that have brought abject misery to its people for the past 22 years. Even if he does hand over bin Laden to
American authorities tomorrow, he has no guarantee that the U.S. will not make his regime pay for its sins of the past.

A TIME reporter who talked to Omar several months ago says he was pondering such dangers. "Did we invite him in?" said Omar of bin Laden. "He was already here. But we don't know how to get rid of him or where to send him." Now Omar's dilemma has reached cataclysmic pro-

portions, and no one knows if he has any real-world grasp of the consequences.

By Saturday, Omar had made up his mind: "No, no, no." He overruled even the tempering recommendation of a 600 man body of senior clerics last Thursday to "encourage" bin Laden to leave Afghanistan "in his own free will" at a time and to a place of his choosing. Now, said the Taliban, Afghanistan is ready for a "showdown of might."

As the U.S. moved steadily toward launching an assault on Afghan territory, Taliban soldiers armed with AKs trundled antiquated rocket launchers into position, while citizens fled to the barren countryside or the Pakistani frontier. No one was sure where the world's most wanted man, Osama bin Laden, might be: in a fortified network of caves tunneling under the eastern mountains, "riding off on a horse," as newspapers in Pakistan reported, or even alone on the run?

If bin Laden is the bull'seye in America's target, the Taliban is the next concentric ring, the masters of a country that has played host not just to the world's most wanted terrorist but also to thousands of jihadis who flock there to learn the tricks of the trade. 
Out of their harsh version of "pure" Islam and to keep themselves in power, the Taliban has made of Afghanistan a mecca of terrorism, a land whose aura of Islam ascendant lures volunteers from a vast pool of Muslims who want to partake of Afghanistan's great victory. Many are drawn not simply to bin Laden and his gang but also to the idea of Talibanizing the Muslim world. The CiA estimates that of tens of thousands of fighters who have graduated from Afghan terror camps, only 3,000 or so are loyal directly to bin Laden. Yet the ties of like mind and mutual interest between bin Laden and Omar, between the cells of al-Qaeda and the Taliban, are so entwined that no quest for freedom from terror can win with the elimination of just one.

No country ever illustrated the law of unintended consequences as well as Afghanistan. The story began in 1979 when the Soviet Union invaded the eternally warring country to prop up a puppet communist regime. Through the prism of the cold war, the U.S. saw a chance to confront its nuclear rival more conventionally on the ground. So the U.S. armed and financed a proxy army. The band of mujahedin, or holy warriors, that the U.S. backed came not just from the fractious,

ethnically diverse Afghan tribes but also from cadres of Muslim volunteers-including Osama bin Laden-who saw resistance against the Soviets as a Godordered defense of Islam. And they won, sending the utterly demrralized Soviet army home ir. 1989.

For the U.S., the ifghan war was over, a last deciding battic on the way to cold war victory. Finished ion was American interest in the shattered nation. Afghanistan's endemic feuding between the dominant Pashtuns and the ethnic minorities had hampered the anti-Soviet fight, and then it demolished what was left of Afghanistan. The country fell into bloody, lawless chaos-political leaders formed fighting brigades; warlords bit off fiefdoms; and rivals shelled one another's villages, routinely robbing and killing civilians. Smuggling and drug trafficking were the only sources of revenue as farmlands turned to dust, cities crumbled into ruin and an estimated 5 million citizens fled the country.

In their misery, many Afghans came to blame "the great American betrayal." They had fought on the front line of

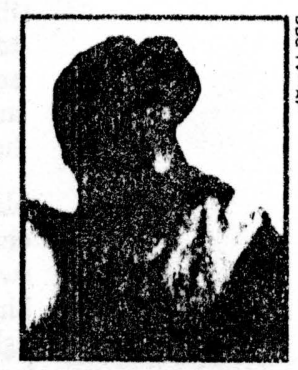

RARELY SEEN Omar allows no photos and never appears in public
America's war; then America had walked away leaving them with a desolated country. The U.S., and the democratic West, did virtually nothing to reconstruct Afghanistan, too busy with post-cold war demands to pay attention to the needs of a landlocked, Texas-size country of 25 million tucked far away in Central Asia.

Then came a day in mid-1994 when Omar, around 35 and preaching at a mosque in his native village of Singhesar, near the religious center of Kandahar, put down his Koran to act. Like so many saints and tyrants before him, Omar says he discovered his destiny in a dream: God was calling him to save his country from the warlords. He had already given his right eye as a young mujahedin to Soviet shrapnel. Now, according to Taliban lore, he gathered together 30 like-minded men to avenge the abduction and rape of two young women; the guilty warlord was captured and killed. A movement was born, in the rare words of Omar, as "a simple band of dedicated youths determined to establish the laws of God on Earth and prepared to sacrifice everything in pursuit of that goal."

The little group, calling itself the Taliban-literally students of Islam, more poetically seekers of knowledge-set out to bring vigilante justice to the city. Its vow was to bring peace, law and order and "pure" Islam to Afghanistan. Led by Omar's extreme interpretations, the Taliban subscribes to a unique extremist model, based on harsh interpretations of Muslim law and a profound belief in never-ending jihad. Its fundamentalist view follows the radical Deobandi branch of Sunni Islam, named for an Indian town housing an influential madrasah, or religious academy, that deems women "biologically, religiously and prophetically" inferior to men. The Taliban laced its faith with the hard customs of Pashtun tradition, like the one that makes hospitality toward guests an irrevocable obligation. And faithlessness must be punished with unprecedented severity in applying Shari'a commands for amputation, stoning and execution.

War-weary Afghans flocked to the Taliban banner. Young men displaced to the wretched confines of refugee camps across the border in Pakistan had spent years being radicalized in the deeply conservative frontier Islamic schools where Pashtu speakers memorized the Koran in Arabic and imbibed the rhetoric of jihad. They went home to rally behind the oneeyed mullah. Pakistan's Haqqania ma- 
drasah, alma mater of many Taliban leaders, awarded its one and only honorary degree to Omar. Other Afghans from the Pashtun south, who knew nothing of the world beyond their ravaged hinterlands, were inspired to join up by the Taliban's steady successes.

Later in 1994, the Pakistani government of Benazir Bhutto needed help setting up trade routes to Central Asia through unruly Afghanistan. A convoy of Pakistani vehicles was hijacked by an Afghan warlord, and Bhutto sent a minister to

ask for the Taliban's help. Omar's men rescued the convoy, opening the door to Pakistani money, arms and military assistance. Now the Taliban could bankroll fighter training, recruit from Pakistan's conservative madrasahs, get weapons and fuel.

The Pakistan connection gave the Taliban the muscle to turn its aspirations for law and order into a quest for national power. The students picked up popular support in 1994 when Kandahar fell to the Taliban with barely a shot fired. Local warlords often surrendered as the now amply armed troops marched toward Kabul, some holding Korans to their foreheads.

Before Omar left Kandahar, he opened the marble vault in the city's most venerated shrine and held up the Respectable Cloak of the Prophet Muhammad, seen publicly only two times previously in more than a millennium. The sight in-

spired Taliben foot soldiers for a final assault against Kabul in 1996.

By then oven the U.S. was quietly encouraging Pakistan and Saudi Arabia to back a movement they hoped might eliminate the heroin trade, open access for a gas pipeline and confine Shi'ite Iran.

Not every Afghan welcomed the Taliban, product of the deeply conservative southeastern region, powered by Pashtun pride. Equally toughened ethnic minorities and religious dissenters loosely linked in the Northern Alliance fought them, especially for control of the cities, the capital and the non-Pashtun north. To this day, the Taliban rules only $90 \%$ of Afghan territory and is still engaged in fierce fighting to capture the rest. So far, however, the alliance's often feuding units do not have the numbers, the ethnic backing or the political skill to constitute a serious opposition.

Stalled at the gates of Kabul, the Taliban found an enthusiastic new benefactor. Osama bin Laden, who had spent some of his family fortune to finance the anti-Soviet mujahedin, needed a new home after Sudan succumbed to U.S.

blandishments to kick him out. In exchange for a haven in Afghanistan's switchback valleys and rugged passes, bin Laden offered the Taliban money and fighters. Afghan and Western sources say he gave $\$ 3$ million that helped push the Taliban into control of the capital and the country in September 1996. It was, according to intelligence reports, one of the last times Omar set foot in Kabul.

The Taliban remains one of the

world's most inscrutable regimes, fanatically loyal to one of the world's most mysterious leaders. The devout Omar, self-declared "Amir-ul-Momineen," or Commander of the Faithful, has lived in seclusion in a Kandahar compound ever since a 1999 bomb killed 40 people near his old mud-brick home in his former village. He permits no photographs and rarely appears in public. He is said to be $1.78 \mathrm{~m}$ tall, heavily bearded and imposing despite his stitched-shut eye. He is thought to confer personally with perhaps

eight or 10 men whom he has known and trusted for years. His whisper-soft voice wields absolute authority. Yet when a $\mathrm{Pa}$ kistani delegation arrived for an audience several weeks ago, Omar greeted its members simply, outside, seated on the gravel.

Omar prefers to rule from the shadows of Kandahar, while his feared Ministry for the Promotion of Virtue and Prevention of Vice enforces Taliban law through religious police with kohlrimmed eyes, wearing black turbans, who crack whips at recalcitrant mosquegoers and banish women to the windowblocked confines of their homes. Life is severely constricted by an endless list of rules creating a variant of Islam never seen before, say Muslim scholars. In a country in which there is no television and only Islamic radio, Omar shows little knowledge of or concern for the outside world. When officials and clerics of the Taliban, under international pressure, debated whether to destroy the 1,500-yearold Bamiyan Buddha statues early this year, Omar is said to have issued the order: Go ahead; it's only breaking stones.

Bin Laden has steadily extended his influence with the Taliban while it lets him turn Afghanistan into a training ground for 


\section{The GuardianWeekly september 20-26 2001}

terror. It was bin Laden, says Ahmed Rashid, longtime reporter and expert on the Taliban, who brought anti-Americanism to the nationalistic Taliban ideology. Intelligence sources say bin Laden's men have infiltrated the Taliban's top ministries, especially Virtue and Vice, where they are said to have argued vigorously for the destruction of the Buddhas. Russia's Foreign Ministry has even reported that bin Laden was unofficially serving as the Taliban's Defense Minister. Bin Laden has allied himself with the Taliban hard-liners; the moderates-and there are some-would prefer to see him vanish over the desert horizon.

Non-Afghans drawn to bin Laden are said to make up a 1,000-strong brigade fighting as part of training on the front line in the Taliban's ongoing war with the Northern Alliance. The soldiers are not just Arab militants from dozens of Middle Eastern countries aspiring to change secular regimes into Taliban-style states but are revolutionaries from Uabekistan and Uighur separatists from China as well. U.S. officials believe that bin Laden masterminded the Sept. 9 assassination of the leading military commander of the Northern Alliance, Ahmed Shah Massoud, the Taliban's chief rival for national power. In

return, bin Laden and the mi':tants are guaranteed sanctuary, plus room to set up camps to train their supporters and help to recruit fresh talent.

Many Muslim scholars say the Taliban brand of Islam falls far outside most interpretations of Koranic writ. And the Taliban's civic reign of repression has made it a pariah even in the Muslim world. Only three nations-Pakistan, Saudi Arabia and United Arab Emirates-accorded the Taliban diplomatic recognition, and the U.A.E. rescinded it last week.

The events of Sept. 11 have uncoupled Pakistan from the Taliban as nothing previously could. Now that bin Laden's activities have forced the U.S. to take a stand against the Taliban, Washington must decide how to eradicate the terrorist threat emanating from a land that has proved to be the graveyard of every previous foreign invader. Afghanistan is a place where warfare is a way of life and fighters use battle toughness and treacherous terrain to compensate for lack of equipment. "Ours is a jihad against those who brought suffering on the Afghim people and violated Islamic teaching," ()mar has said. "The Taliban will tight montil there is no blood in Afghanistan left to be shed." That would wot be just Afghau blood. lut Amenicith tow) Reported by Hammah Bluch and Tim McGirk: Islamabad, Massimo Calabresi and Douglas Waller/Wishington

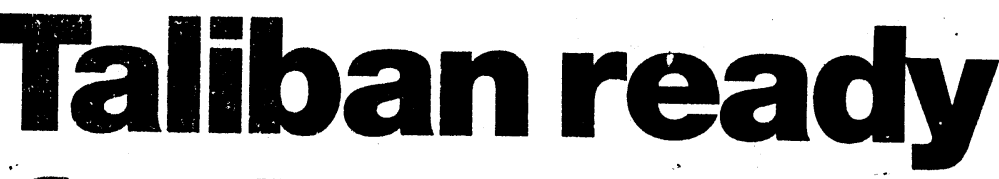
for holy war Afghan rulers defiant as Bush demands they hand over Osama bin Laden

\section{Luke Harding in Islamabad, \\ Ewen MacAskill and \\ Richard Norton-Taylor}

The Thliban's most senior body of clerics is poised to declare a holy war against the United States if a plea from Pakistan this week fails to persuade them to hand over the Saudiborn dissident, Osama bin Laden, wanted for last week's terrorist attacks on New York and Washington.

With fear growing throughout the region that a US assault is imminent, Afghan forces were massing at the Pakistan border near the Khyber Pass, ready to repel US ground forces and to retaliate against Pakistan should it help Washington.

President George Bush, preparing Americans for a nasty war, mobilised reservists and stepped up the rhetoric, declaring that he wanted Bin Laden "dead or alive". Those such as the Taliban who housed them would feel the heat, he said.

The US defence secretary, Donald Rumsfeld, reinforced the point: "This isn't going to be a few cruise missiles flying around for the world to see that something blew up."

Amid signs that action may be only days away, the British Ministry of Defence deployed troops to Kuwait to protect British bases there. SAS and other soldiers on a training exercise in Oman have also been put on standby.

Britain and the US are braced for civilian casualties, and are desperate that such scenes will not turn public opinion against them.

There is already a refugee crisis in the making, with a million Afghans on the move. "It is already a humanitarian disaster," said Yusuf Hassan; of the United Nations High Commissioner for Refugees in Islamabad.

The Afghan clerics, who have been gathering in Kabul at the request of the Taliban's leader, Mullah Mohammad Omar, are expected to declare a war in the event of a US attack, and every American could then be a target.

The threat was heightened in Pakistan, where opinion over whether to support US military action is bringing the country close to civil war.

The leader of one religious party threatened suicide attacks against American interests if US troops are allowed on Pakistani soil.

Mullah Omar emerged from several hours of talks with Pakistani envoys to announce that a grand Islamic council, not he, should decide Bin Laden's fate. The Pakistani delegation had made it clear that Afghanistan faced the prospect of a devastating attack if the Taliban failed to cooperate with the US's key demand.

After flying to meet Mullah Omar at the Taliban's headquarters in Kandahar, the Pakistani delegation made an unscheduled trip to Kabul in a lastditch attempt to influence the clerics' ruling. The council, of 20 senior religious leaders, was expected to conyene in the Afghan capital on Tuesday.

Earlier, the Taliban's spokesman, Abdul Hai Mutmaen, said the two sides had made little progress on Bin Laden. "There was no clear discussion on this particular topic," he said.

The Pakistani foreign minist Abul Sattar, said: "Time is definitely running out."

According to the Pakistani army, the Afghans have mobilised 20,000 to 25,000 fighters at the Khyber Pass. The army also said the Taliban had begun moving Russian-made scud missiles to the border.

Captain Ahmed Baltti, of the Pakistani army, said reinforcements of troops have fanned out along the $1,400 \mathrm{~km}$ western border with Afghanistan in response.

There were reports that the Taliban have already moved most of 
their key military assets out of Kabul and Kandahar, the two most likely targets for US bombing. Senior Taliban officials have sought refuge in the mountains.

The US secretary of state, Colin Powell, said the message that the Taliban had been giving so far was that Bin Laden and his associates were guests in their country. "Well, 't is time for their guests to leave," Mr Powell said. He hinted that the net would be widened to Bin Laden's network in other countries. Bin Laden's organisation al-Qaida is spread throughout the Middle East, North Africa and the Indian subcontinent.

Although the US was continuing to build up its international coalition and succeeded in winning the support of King Fahd of Saudi Arabia, some countries, including Pakistan, are pressing the US to go first to the UN to get international approval for action.

\section{Bin Laden: public enemy No1}

\section{and prime suspect}

\section{Tenuous structure of his group makes Saudi-born terrorist uniquely hard to trap}

\section{Jason Burke}

Peshawar is a dusty, violent city. The air is thick with pollution and shouting. Strangers are greeted with sharp stares. Five times a day the clattering consonants of a badly amplified call to prayer howl over the rooftops, and at night the narrow alleys are silent.

At night scores of young men will be sleeping on thin mattresses or blankets thrown on floors in dozens of hostels and private homes. At dawn the next day they will line up, face Mecca and kneel in prayer. They will be facing Afghanistan and their hero, Osama bin Laden.

They have come from the crowded slums of Pakistan's suithing cities, from the filthy bazaars of Cairo, from the Palestinian refugee camps of Jordan, Gaza or the West Bank. Some will be from wealthy families that have grown rich thanks to Gulf economies fuelled by the West's thirst for oil. Others will be taxi drivers, students, shopkeepers or their sons. Some will have spent time in the West, or have even been born there.

They are there for all the reasons young men have always gone to war. For adventure, for camaraderie, because they believe that it is their duty to their faith and families to defend what they believe to be under attack.

Peshawar has seen it all before. In 1979 Soviet tanks rolled into Afghanistan, and the city, $30 \mathrm{~km}$ from the border in Pakistan, became the centre for the mojahedin resistance. Then the Afghans were heroic allies in the battle against the Evil Empire. They received $\$ 2.8 \mathrm{bn}$ worth of aid in munitions alone over the next 10 years. Now they are the "aiders and abetters of Evil".

Within days of the Soviet invasion hundreds of Muslim men had begun to arrive in the city, ready to fight their war. They fought it and won it. One was a young Saudi graduate, $6 \mathrm{ft}$ $\sin (1.95 \mathrm{~m})$ tall and full of zeal. These days his poster is on the walls of thousands of cafes, bedrooms and offices in the Islamic world. Last week his bright eyes shone from every newspaper and TV set on the planet.

Every morning Bin Laden rises at dawn to pray. He lines up with his Arab bodyguards and close retainers - around a dozen of them, including his eldest son, Mohammed - outside whichever of his bases and homes he spent the night in. He leads the prayers and then the group will spend two hours studying the Koran. It is a routine that, like the breakfast of dry Afghan bread and black tea, is rarely altered.

It is impossible to say where he will be. He could be at the home he built at a disused Soviet airstrip $15 \mathrm{~km}$ east of the southern city of Kandahar. He could be in the city, staying in the home he built and gave as a present to Mullah Omar, the one-eyed cleric who is the spiritual leader of the Taliban militia and effectively ruler of Afghanistan. Omar and Bin Laden fought the Russians together, and are fast friends. He could be at his newly constructed base in the Oruzgan mountains of central Afghanistan, or at his home in the old Soviet collective farm near the village of Hadda, on a fertile ridge $8 \mathrm{~km}$ south of the eastcrn city of Jalalabad.

Most likely he is staying in one of : the dozen or so training camps run by his organisation, al-Qaida (The Base), and other hardline Islamist groups in the mountains that line the frontier with Pakistan. With him will be Mohammed Atef, known as Abu Hafs, his military commander, and Ayman al-Zawahiri, an Egyptian radical who has had an immense influence on Bin Laden in recent years and whose Egypt-based Islamic Jihad group appears to have been a key factor in last week's attack.

The camps were built, some by Bin Laden himself, with the resources of his family's vast construction conglomerate, during the Afghan war to protect the mojahedin from the Russian artillery and helicopter gunships. Many are underground. No one has a clue where he might be least of all the CLA, the Pentagon or the United States state department.

Bin Laden, 44, is no stranger to the role of world's most wanted man. In 1998, after the blasts at the US embassies in Tauzania and Kenya, President Bill Clinton unleashed 75 Tomahawk missiles in a bid to wipe out his Afghan infrastructure. The strikes did nothing but convert Bin Laden into a household name. Later assassination attempts - often orchestrated with the aid of the Saudi government - have been equally unsuccessful. Sanctions on the Taliban have merely hardened their resolve not to betray their honoured guest to their enemies. Bin Laden has remained untouched. 
The past two years have seen the most intensive intelligence effort launched against a single individual. Dozens of satellites monitor every centimetre of eastern Afghanistan. Eavesdropping equipment listens in to his conversations. Super-computers chase details of his banking transactions around the internet.

Until now, especially with the conviction of four men for the African attacks in July, Western security services were relatively pleased with themselves. A series of major terrorist schemes linked to al-Qaida had been headed off. A plan by a Canadian cell to plant a suitcase bomb in Los Angeles airport on Millennium eve

No one has a clue
where he might be
- least of all the
CIA or Pentagon

had been foiled - as were conspiracies to blow up, on the same night, a 400-bed hotel in Amman and several US warships. The USS Cole was hit, it is true, last September, and 17 men died. But all over the world - in Britain, France, Germany, Spain, Italy, India, the Philippines, Bangladesh, Algeria and Jordan supposed Bin Laden operatives had been rounded up, and many tried and imprisoned. So what went wrong?

"What went wrong was we fitted Bin Laden and al-Qaida into existing paradigms of terrorism and terrorist organisation," said one former CIA official. "But that doesn't work. He is something entirely diffe" "ent, entirely new." What security experts are now realising is that al-Qaida is neither a traditional hierarchic organisation with a leader, deputies and a cell structure, nor merely an association of vaguely like-minded, loosely affiliated individuals. It is both and neither at the same time.
Al-Qaida, as FBI reports and witness testimony from the East African bombs trial show, is highly organised and professional. Mohammed Odeh, who helped prepare the Nairobi bomb, and Mohammed Rashid alOwhali, who delivered it, both described their training in detail. AlQaida cells have four members with the leader in charge of intelligence, and the others responsible for logistics, surveillance, ete.

The organisation itself has a series of committees. The most important, the military committee, is headed by Mohammed Atef. He is responsible for suggesting and organising attacks that further Bin Laden's broad strategic aims. Other committees include administration, fundraising and politics. At some periods in its history notably when Bin Laden and his followers were based in Sudan from 1993 to 1996 - members of the group received salaries. At other times funds are handed out. One former Bin Laden operative now in Algeria said that he had received $\$ 1,500$ to pay for his wedding.

Al-Qaida maintains at least four elite training camps in Afghanistan, which teach bomb-making, security, intelligence-gathering, disguise, sabotage and abduction. And the hijacking of buses, trains and planes. For the Nairobi operation the team comprised a mix of long-term sleepers, who had been in Kenya for years, and "cleanskins", who had never been on an operation before. The same structure is now being uncovered in America. At least two of the men who flew American Airlines Flight 11 into the first tower had received American driving licences in 1994. A third, Mohammed Atta was a new arrival.

Communications are vital. Messages are sent by word of mouth to Pakistan, and from there they are emailed. Bin Laden, testimony has shown, had no contact with any of the East African bombers except for al-Owhali, whom he met once, 18 months before the attack. The men were selected, briefed and supervised by senior aides, some from organisations affiliated with but discrete from Bin Laden's.

And this is the key: al-Qaida does not act as a commander, it acts as a facilitator, a co-ordinator, combining disparate elements -. some in Afghanistan, some in a target country, some in other locations - who together can pull off an operation.

Many of the older men will have fought together in the war against the Russians. Many of the younger may have fought for the Taliban. All are united by hatred and fear of the West and admiration for Bin Laden. So when Bin Laden denies he ordered any attacks, he is only being slightly disingenuous. He has provided a figurehead, moral guidance, maybe some cash. And therein lies his, and al-Qaida's, greatest strength.

A "Bin Laden cell" was recently on trial in Jordan. In fact the only link with the Saudi dissident was a signature scrawled on a piece of paper by one defendant, Raed Hijazi, a Palestinian-born American who was a Boston taxi driver. He had attended an al-Qaida-run camp and received basic terrorist training there. When asked to pledge allegiance to Bin Laden, he did so and signed his name. "My client is not an al-Qaida operative," his lawyer said. "He has his own beliefs. He does not follow anyone." Ahmed Ressam, the man

\section{Al-Qaida is not a commander; it acts as facilitator and co-ordinator}

who tried to bomb LA airport; had a similarly tenuous conneetion to alQaida. He admired Bin Laden's thoughts and listened to his advice, but had never had direct contact.

Similarly Ramzi Yousef, who tried to bring down the World Trade Centre eight years ago, had never met Bin Laden. Yousef tried to coondinate the simultaneous hijack of 12 airliners in East Asia. The FBI insists that be spoke to Bin Laden on the satellite phone that the Saudi uses in Afghanistan. But that's all. Bin Laden doesn't give orders to prosecute global war. He doesn't have to.

This summer a tape made by alQaida was circulated in the Middle East. It was full of gory pictures of Israeli troops shooting Palestinian protesters, cut with film of al-Qaida training in Afghanistan. That marked a significant departure for Bin Laden, who previously focused on what he sees as the "invasion and occupation" of his homeland by the 
30,000 US troops who have been stationed in Saudi Arabia si ice the end of the Gulf war. From the tape it seemed that Jerusalem was his target. In the tape he told his brothers it was time to act. They did.

It is too early to know how the attacks on the World Trade Centre were organised. Early indications are that the five teams of between six and 10 operatives were using techniques similar to those taught in the alQaida camps of Afghanistan, as used in Nairobi. There is the same emphasis on planning, and the teams comprised a mix of long-term local residents or "sleepers" and new men.

In all previous al-Qaida-linked attacks the indispensable senior advisers to the attack teams, those closest to Bin Laden himself, flew to safety in the hours before the strike. Investigators will be checking passenger manifests of outgoing flights from the east coast early last Tuesday morning. Many flights come to London, especially those to the Middle East, so British investigators will be examining records of arrivals. Intelligence sources were concerned that, rather than pass through Britain, some of the senior people involved in the attack may have gone to ground in the UK.

Soon, after prayers, a few score of those young men in Peshawar will slip across the fronticr and make their way to the training camps. Most will end up fighting for the Taliban or in Kashmir. Some will be offered the chance to work for Bin Laden and his associates. Their places on the floors of the hostels and guesthouses in Peshawar will be filled again quickly.

When Bin Laden arrived in Afghanistan aged 22, the "emir" of militant Islam was a Palestinian-born academic called Abdallah Azzam. He was assassinated in 1989. It made little difference to Bin Laden and his fellow fighters. They were not following an individual but a cause. They fought their war - ironically with significant American materiel and moral support - to the end. Alongside the Afghans, they won a resounding victory.

Now a new generation of warriors is hungry for another war, and another victory. It seems that they have found the former. Whether they find the latter remains to be seen. The Observer

\section{Moderate leader with pragmatic aspirations for Afghanistan}

\section{Ahmed Shah Masood}

\section{Obituary}

In April 1992, three years after the Russians withdrew from Afghanistan, Ahmed Shah Masood, who has been assassinated in his late $4.0 \mathrm{~s}$, climbed into a Soviet jeep at Bagram airport and led a column of tanks down the road to Kabul.

Three hours later, after a brief stop to pray on the empty road, he entered the capital. Not a shot was fired, although there was heavy fighting immediately before between Masood's coalition force and the troops of Gulbuddin Hekmatyar and the communist interior minister, who were also trying to take the city.

Masood's victory, the result of three years' planning, and the speed of his reaction to the collapse of the Najibullah regime, deserted at the end by its Soviet sponsors, stunned everyone. In particular, ISI, the Pakistan army's intelligence arm, which had supported the Pashtun Hekmatyar throughout the war, and ignored Masood in terms of money and arms, were angry. After all their careful planning, the final prize of the Afghan war had eluded them.

The son of a colonel in King Zaher Shah's army, Ahmed Shah Masood always wanted to be a soldier. After primary school in Herat; he attended the French-run Istiqlal lycee in Kabul. Instead of joining the army, however, he studied engineering at Kabul Polytechnic, where Hekmatyar was also a student.

In 1975 Hekmatyar, an Islamic firebrand, was involved in a coup against President Daoud, who two years earlier had deposed the king, his cousin. With Daoud's proMoscow policies becoming increasingly unpopular, Hekmatyar asked Masood to organise a rebellion in his home valley, the Panjsher, $160 \mathrm{~km}$ northeast of Kabul.

Masood at first declined, but finally agreed, according to one of his brothers, when Hekmatyar taunted

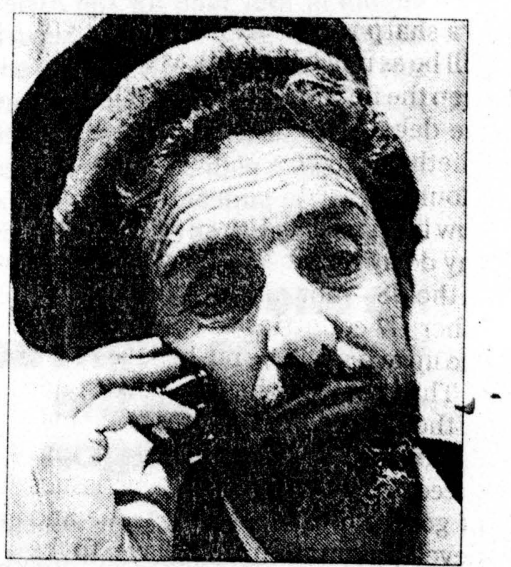

Masood: driven out by the Taliban

him with being a coward. Although the coup succeeded in the Panjsher, it failed nationally, and Masood and Hekmatyar both fled to Pakistan.

There Masood received guerrilla warfare training from ISI, and read Mao Zedong, Che Guevara and a general from the United States whose name, he once told me, he could not remember. In June 1979 he slipped across the border to begin his resistance, at first against the Afghan communists and later against the Soviets, after their invasion the following December.

He had with him only 27 companions, armed with a collection of weapons ranging from two Kalashnikovs and two RPG7s with seven rockets, to five shotguns and nine old-fashioned British .303s. In one abortive operation he was wounded in the leg and suddenly realised, as he said later, that "training, training, training" was the key to success.

By summer 1982, when I made a television documentary about this "potential second Tito", Masood had survived six major Russian offensives. Four years later he had expanded his operations to the north of the country, capturing a key government fort in Takhar province and later taking the provincial capital, Taloqan. 
Masood and his allies now controlled almost the whole of northeast Afghanistan and, by early 1992, when one of Najibullah's northern commanders, General Momen, and the feared Uzbek general, Abdul Rashid Dostum, defected, he knew victory was near.

It came, in fact, with the speed of an avalanche, sweeping Masood to the post of defence minister in the new mojahedin government, of which Burhanuddin Rabbani, the head of Jamiat-i-Islami, was president. But soon things turned sour. Three months later Hekmatyar, supported by ISI, mounted a savage rocket attack on Kabul. One eyewitness counted 60) rockets "before breakfast".

On new year's day 1993 Masood and the government came under ferocious attack from Hekmatyar, his erstwhile ally Dostum, and the Shias. Against all the odds they survived, but the destruction unleashed on Kabul was horrific.

In 1994 the Taliban emerged. At first Masood welcomed them, but, as their ruthless tactics and appetite for power became clear, he changed his mind. In 1995 the Taliban took Herat and soon laid siege to Kabul. By the summer of 1996 Masood knew he had no option but to withdraw. It was a fighting retreat, followed by a brilliant series of counterattacks. But, inexorably, he was driven ever deeper into a corner.

His assassination is a tragic loss for his country. Modern-minded, pragmatic, sensible and moderate, he had much still to offer. He will be remembered mainly for his military resistance against the Soviet Union, but he was also a civilised man in the best Afghan tradition, with a love of poetry. When he left Kabul for the last time in 1996, he took with him a library of 2,000 books.

Sandy Call

Ahmed Shah Masood, soldier and politician, born c1952; died September 152001

\section{Afghans caught in the middle}

IT IS highly improbable that the United States has not factored the risk of civilian casualties into its strategy to smoke out Osama bin Laden from his safe haven in Afghanistan. Even so, the rhetoric of reprisal and shifting geopolitical alignments are giving war-weary Atghans a fresh bout of jitters. Reports indicate that residents of Kabul, fearing major strikes on the capital city, have begun to relocate to rural areas. To make matters worse from their standpoint, neighbouring countries such as $\mathrm{Pa}$ kistan, Iran and Tajikistan are taking measures against a largescale influx of refugees in case of a full-fledged US-led military attack. Clichés like "untold suffering" no longer adequately convey the depths of despair that millions of Afghans find themselves in, trapped as they are between the despotism of homegrown religious militias and the fury of far away victims of terrorism. Exhausted by two decades of internecine warfare and ravaged by a long-running drought, the country has long disappeared from the map of civilisation, and, if forlorn Afghans are to be believed, could disappear from the international map as well. What fate has in store for them, only time will tell.

But regardless of the scale of America's imminent retaliation for the September 11 carnage in New York and Washington, Afghans actually have very little left to lose other than their lives. And it is unlikely that the generals in Pentagon are going to plan their punitive strikes in a manner that entails heavy civilian losses. For one thing, the Bush administration is keenly aware of the misgivings in the Muslim world about the very idea of retaliation, especially in light of US indifference towards Palestinian suffering. Even Pakistan's apparent acquiescence in America's 'war against terrorism' has been obtained under duress, with both religious and secular political parties issuing dire warnings to President Pervez Musharraf. For another, heavy 'collateral damage' could split the multi-national coalition that Bush officials are building up, potentially robbing it of the support of even some European allies. The plight of ordinary Afghans being well known to the world, reports of civilian casualties could quickly turn international public opinion against continuation of the military campaign. However, there does exist a certain risk of ordinary people getting caught in the crossfire given the peculiar military nature of the expected conflict. Western intelligence, agencies have at best a nebulous concept of Osama's organisation, while their armies have no prior operational experience of Afghanistan's treacherous terrain. 
Khalecj Times, Wednesday, September 19, 20(01

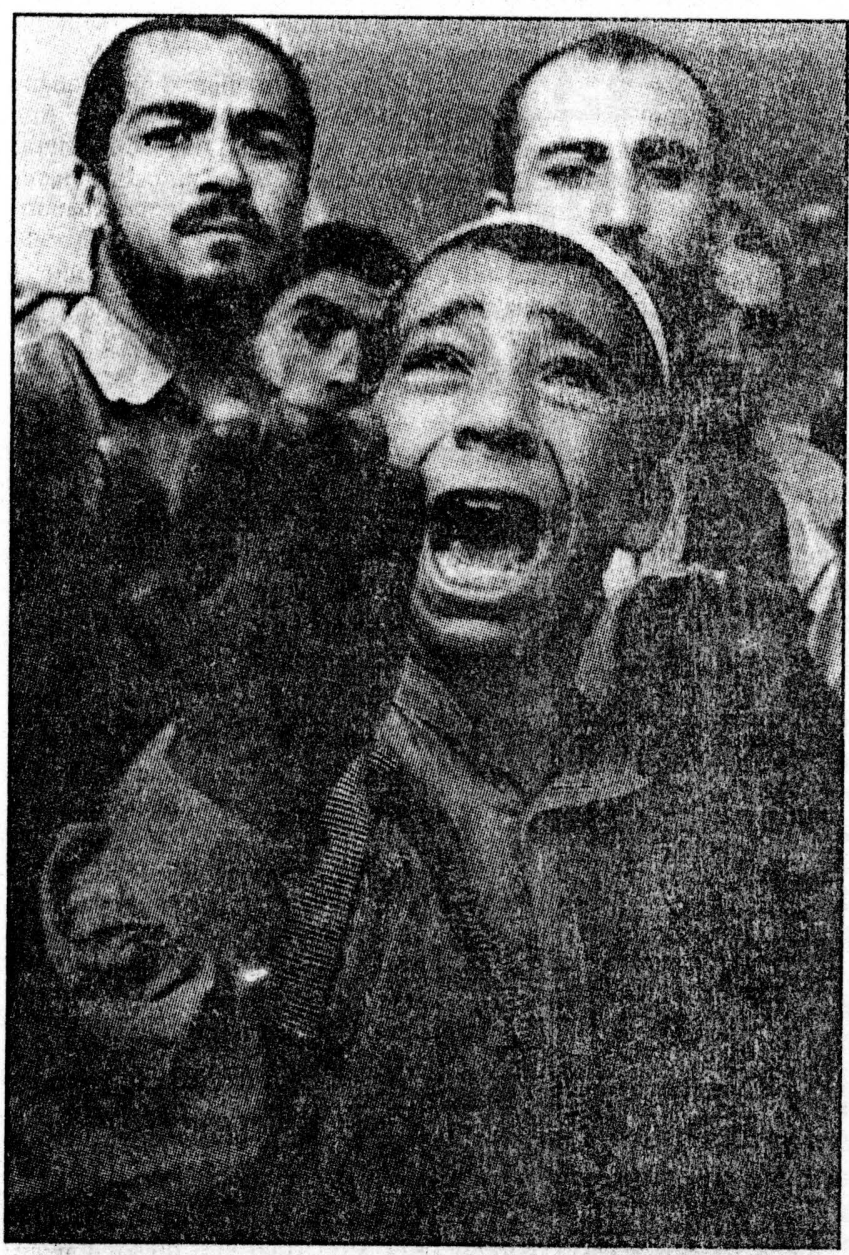

AFGHAN REFUGEES: A young Afghan refugee pleads with Pakistani police to be allowed to go with his mother to the hospital after she fainted in a temporary detention centre in the Pakistani town of Quetta near the Afghan border yesterday, - AP

Khaleej Times, Friday, September 21, 2001

\section{New camp to shelter Afghans in case of war}

QUETTA - Pakistani authorities said yesterday they expected to set up a new camp to handle a flood of refugees if the United States attacked Afghanistan - despite a policy of officially accepting no new refugees.

Expectations are growing that Washington will attack Afghanistan's Taleban rulers for harbouring Osama bin Laden, the prime suspect in last week's attacks on Washington and New York.

"It will be inevitable, Afghans will enter Pakistan when war breaks," said Akhtar Muneer Marwat, district coordinating officer for Quetta, a provincial capital located near one of the main crossing points from Afghanistan.

"But we have decided to put them into a new camp and restrict them to the perimeters of that camp. And more important, they will be unarmed," he said.

Quetta already has an estimated 300,000 Afghan refugees needing shelter - out of some two million already in Pakistan - and as around the city. - Reuters many again distributed in villages
Asylum seekers play soccer unaware of US decisions

AIWO (Nauru) - About 100 mostly Afghan asylum seekers on the tiny Pacilic island of Nauru played soccer and hung out their washing yesterday, ignorant of a possible US-led attack on their homeland.

The Afghans, who landed on Naturu on Wednesday. are among hundreds of unwanted Middle East asylum seekers who have been at sea for about a month after Australia refused to accept them.

When asked through a wire fence whether they knew about the attacks on the World Trade Centre in New York and the Pentagon in Washington or the pending retaliation by Washington, one Afghani man said he knew nothing.

The Afghans' search for asylum began long before last week's attacks on New York and Washington which killed almost 6,000 people. While on board the navy ship they received no news from the outside world and once on Nauru have been placed off-limits.

Yesterday, as some hung out their wet washing and others played soccer on a hot, barren refugee camp, a few managed to speak briefly to reporters near perimeter fences.

"Of course, of course we are leaving (Afghanistan) because of the Taleban. The Taleban forces are a danger in Afghanistan," one man said. - Reuters 
Khaleej Times, Saturday, September 22, 2001

\section{Secret plan for a UN-backed administration in Kabul: report}

LONDON - A secret embassy cable has revealed that the US is planning to overthrow the Taleban in Afghanistan and replace. it with a United Nations-backed administration. The Guardian newspaper reported yesterday.

The broadsheet said the United States was pressing its European allies to agree to a military campaign to depose the radical regime and usher in an interim ruling body.

The Guardian reported it had seen diplomatic cables from the Washington embassy of a key Nato ally reporting that the US was keen to hear allied views on "post-Taleban Afghanistan after the liberation of the country".

The embassy cable showed that the US government was bent on force to overthrow the Taleban because of the support it has given Osama bin Laden, number one supect in the terrorist attacks on the US last week.

The Guardian also said that US was funding and organising for the exiled 86-year-old monarch of Afghanistan, King Zahir Shah, to return to power from exile in Italy and call for a revolution. He was expected to encourage the army of the Northern Alliance opposition to fall in behind him.

"The King plans to call on all the Afghan tribes to rise up against the Taleban" the diplomatic cable reported, according to The Guardian. - DPA

\section{Khaleej Times, Sunday, September 23, 2001}

\section{Afghan mosque imam decries Taleban}

NEW YORK - An imam at the city's largest Afghan mosque gave a fiery sermon against terrorism to followers who chanted "Death to the Taleban".

Hundreds of worshippers, many in traditional garb, then marched several blocks to a police precinct on Friday, some carrying American flags and others placards reading Bin Laden out of Afghanistan" and "Terrorism is against
Islam".

Many said they favor US military action in their homeland. About one-quarter of New York's estimated 20,000 Afghan immigrants pray at the mosque, Masjid Hazrat-I-Abubaker Sádiq, which is tucked into a leafy residential neighbourhood.

The mosque, which had an American flag posted on one of its front windows, lost one of its own in the terrorist attacks on the World Trade Center on September 11. Photos of Salman Hamdani, an emergency medical technician who is missing and presumed dead in the attacks, hung in the mosque's stairwell. - AP

\section{Khaleej Times, Monday, September 24, 2001.}

\section{Former king against attacking civilians}

ROME - Former Afghan king Mohammed Zaher Shah is ready 10 go home if he could be of help 10 his people in the current crisis, he said in an interview published yesterday in the daily $L a$ Repubblica.

"I am ready to go back to my country if that would help my people. But any punishment for terrorist attacks committed by foreigners present in my country should not strike the Afghan people at all," he said, in a reference to feared US reprisals against Afghanistan for sheltering Osama bin Laden, the Saudi-born prime suspect in the terror áttacks on the United States.

He said "people who entered my country thanks to foreign meddling" were responsible for terrorism taking root in Afghanistan, but insisted that the Afghan people were the first victims of terrorism.

"To punish terrorists is just, but you have to understand that the Afghan people are not guilty," he said.

Zahir, 86, who has been living in exile since he was ousted in 1973 by a Soviet-backed coup, was due to have talks with the UN's special representative to Afghanistan, Francesc Vendrell, on the growing crisis in his country.

He was also due to meet a delegation from the country's Northern Alliance, enemies of the
Taleban who rules most of Afghanistan. His private secretary, Zalmai Rassul, said on Saturday that some Afghan commanders had already arrived in Rome and others were expected soon.

He also confirmed that the former monarch was in contact with military and political chiefs from Europe and the' US, buit did not give details.

Mr Rassul said, however, that the question of the return of the monarchy had not been discussed.

"The king is playing the role of coordinator and unifier in the context of a coming together of Afghan chiefs." But he said a return of the former monarch was 'possible.'

This week Zaher Shah appealed to the Afghan people via the $\mathrm{BBC}$ and Voice Of America radio stations, in which he proposed the holding of an emergency Loya Jirga, or chiefs' assembly, in order to elect a head of state and a transitional government.

"I am convinced with your participation and the cooperation of the international community our struggle for the return of peace shall continue until we fulfil our desired goal which is the liberation of our homeland and people." $\mathrm{He}$ also appealed to the people of Afghanistan to continue the fight for peace in cooperation with the international community. - AFP 
Khaleej Times, Tuesday, September 25, 2001

\section{Minister blames Taleban for Afghanistan crisis}

From our correspondent

MUSCAT - Oman's Minister Responsible for Foreign Affairs Yusuf bin Alawi bin Abdallah has held the Taleban responsible for the current situation in Afghanistan, pointing out that Kabul's relations with its neighbouring countries were not what they should be. "The big danger that threatens Afghanistan is the lack of trust ii. its relations with its neighbours. That is the crisis in Afghanistan," he said in a statement on Sunday before his departure for Jeddah to attend an extra-ordinary meeting of AGCC foreign ministers.

$\mathrm{Mr}$ Abdallah said his country did not recognise the Taleban government, therefore it was not obliged in any way towards Taleban or what it did. In reply to a question on whether the US had asked the AGCC states to join an alliance it currently embarks to forge against terrorism, he said the United States, which was the party that was hurt by the events, had sought world support. "What the USA is doing is something that concerns the USA...," he said. He added Afghanistan was the expected target for the United States for known reasons. He explained that those reasons were the inflexibility of the Taleban government, Osama bin Laden's presence there and also the ArabAfghans and what had been said about them in Egypt, Jordan, Algeria and several other Arab countries. "This is the reality and people must consider this reality and its implications," he added.

The Nation TUESDAY, SEPTEMBER 25, 2001

\section{UAE President announces aid for refugees}

\section{By Our Culture Reporter}

ISLAMABAD - President of the United-Arab Emirates, Sheikh Zayed bin Sultan AlNahyan has ordered immediate supply of relief goods for Afghan refugees. Accordingly, Crown Prince of Abu Dhabi and Deputy Supreme Commander of UAE Armed Forces has ordered to mobilize all resources to immediately start emergency' relief operations.

As a follow-up, Sheikh Hamdan bin Zayed Al-Nahyan. Minister of State for Foreign Affairs and President of UAE Red Crescent Society has instructed RCS to urgently coordinate with the International Committee of Red Cross(ICRC) and Red Crescent Societie's Federation to immediately airlift first consignment of relief goods, including foodstuff, medicine, water, tents and blankets to help millions of helpless refugees pouring into Pakistan and other bordering areas of neighbouring countries, consequent to the prevailing critical situation in Afghanistan.

\section{Army fears border clashes with Taliban}

PESHAWAR (AFP) - Pakistan's army fears it may have to engage fleeing Taliban fighters if the United States takes military action against Afghanistan, provincial government sources said Monday, Sources close to the Governor of NWFP warned armed Taliban members may attempt to seek safe haven across the border.

'The threat of violence from Islamists inside Pakistan is not our biggest worry,' a source close to the governor of NWFP told AFP.

Any problems Pakistan has, will likely be along the border with Afghanistan. As you know it is a porous border and the Taliban have a habit of coming and going when they please,' the source said on condition of anonymity.

'Pakistan is a likely destination if they are attacked, which is a potentially explosive scenario.

A military source north of Peshawar added: '(A Pakistani) military engagement with the Taliban is not out of the question. If there is a panic anything can happen, but we are ready to do our job.'

\section{Zahir Shah calls for Loya Jirga}

ROME (AFP) - Former Afghan King, Mohammed Zahir Shah, has called for a special Loya Jirga chiefs' assembly to elect a new head of state and establish a transitional government for Afghanistan.

Now living in Rome, the exiled king broke his silence on the turmoil facing his homeland when he made an appeal for a Loya Jirga during a radio broadcast to the people of Afghanistan on Sunday.

He also offered to meet this week with a delegation from Northern Alliance movement which is opposed to the Taliban regime. A Loya Jirga is a general assembly of chiefs and elders.

Zahir Shah, 86, has said it should be the Loya Jirga which determines Afghanistan's fate in the face of possible strikes from the US-led anti terrorist alliance formed in the wake of the September 11 attacks in New York and Washington. 


\section{Strategic C. Asia focus of new US attention}

\section{By Maura Reynolds}

MOScow - Collectively, sometimes they are called 'the stans.' Individually, as the US prepares for possible military action in their neighbourhood, 'the stans' are suddenly the focus of intense attention in Washington and Moscow.

When the Soviet Union collapsed, five new states arose in Central Asia - Kazakhstan, Uzbekistan, Turkmenistan, Tajikistan and Kyrgyzstan. Should the United States base troops or aircraft in any of them, it would be the first deployment of US forces on the territory of the former Soviet Union.

Three of the 'stans' border Afghanistan. Three struggle with religious insurgencies of their own. Each of the five is ruled by a strongman, whose governance styles range from mildly repressive to downright Stalinist.

And each has its own complicated relationship with Russia, which it must take into account in deciding whether and how to assist a possible US military campaign against Afghanistan, which is said to harbour terror suspect Osama bin Laden.

Since the Sept 11 terrorist attacks, leaders of Russia and the Central Asian republics have expressed sympathy for the US and general support for efforts to locate and punish the perpetrators. But their public statements have wavered, sometimes emphasizing that they have made no commitments, and sometimes emphasizir $g$ their desire to help. Central Asia is predominantly Muslim but politically secular, and all five countries worry about the growth of militant religious activity.
The most worried is Uzbekistan, whose Fergana Valley is home to a large num ber of militants seeking to overthrow the secular government and found a religious state. The Islamic Movement of Uzbekistan, which President Bush made a point of mention ing in his address to the nation on Thursday night, is said to be supported by the Taliban. The movement also is active in Kyrgyzstan and Tajikistan. All three countries are vehemently anti-Taliban.

The two countries best situated to assist possible US military action are Tajikistan and Uzbekistan. Tajikistan has both the region's shakiest government and longest border with Afghanistan. What it can offer most, experts say, is contact with the Northern Alliance, including intelligence information. This was underscored Saturday when the chief of Russia's general staff, Gen Anatoly Kvashnin, met in Tajikistan with the commander of the Northern Alliance.

Uzbekistan, while expressing vehement opposition to religious militants and racking up reported human rights abuses in the process, is highly critical of Russia's continued military presence in the region. It has a short border with Afghanistan, just 90 miles long. But it has a number of prime air bases, including one about 25 miles north of the border town of Termez.

The most inscrutable of the Central Asian countries is Turkmenistan, which has a 500 . mile, largely unguarded border with Afghanistan. It is ruled by president-for-life Saparmurad A. Niyazov, who has turned his country into a North Korea-style isolated state. His gold-plated statue rotates on a pedestal in the centre of the capital, Ashqabad.

Unlike the other Central Asian leaders, who have declared themselves opposed to the Taliban, Niyazov has remained pointedly neutral. The reason, experts say, is that he knows that his border with Afghanistan is largely indefensible.

Any of the countries would want certain things in return for granting airspace, air bases or other assistance to the United States. Because all are impoverished, economic aid and investment likely would be on the list. So would guarantees of financial and logistical assistance with likely refugee flows.

And then there is Russia who jealously guards its prerogatives in the region, which so far Washington has been pains to' honour, even while flirting with Uzbekistan. The biggest constraint on Uzbekistan might not be Russia but fear of the future. In other parts of the world, military campaigns against religious militants have quelled unrest for just a few years before a backlash ensued. If Uzbekistan grants the US access to its air bases, what will be the effect on its own insurgents?

"After the Americans leave, Central Asian leaders will be left to deal with religious fundamentalists," warned Malashenko, "and they will make them remember these days and pay dearly for having helped the infidels fight their Muslim brothers." - Dawn/LAT. WP News Service (c) Los Angeles Times. 
DAWN TUESDAY, SEPTEMBER 25, 2001

\section{Post-Taliban power contenders}

\section{By Tom Heneghan}

ISLAMABAD: Finding a new government for Afghanistan may be almost as hard as disposing of the old one. If Washington's "war on terror" chases the hardline Taliban from Kabul, a new leadership will have to step in quickly to fill the vacuum left after almost three turbulent decades of communism, war and radical Islam.

No obvious successor waits in the wings. The government-inexile and its Northern Alliance have little chance of ruling because it is made up of ethnic minorities. While the name of former king Zahir Shah is being mentioned with greater frequency, Afghan experts believe his age would make his return after nearly 30 years in exile an unlikely candidate.

The next leader is more likely to come from among the ranks of the men who fought the Soviet Union in the 1980 s and have since faded from view. "A lot of the Mujahideen commanders from the 1980 s will probably come back to the fore," said Ahmed Rashid, a Pakistani expert on Afghanistan and the Taliban.

"They have been in semiretirement these past few years, but they will play a very important role." How their influence will play out, though, is unclear. At the best of times, Afghan politics is a snakepit of tribal rivalries, opaque loyalties and dramatic betrayals.

It says much about the bleak state of Afghan politics that the name most frequently mentioned now is ex-king Zahir Shah, 86 , a quiet man who has lived in Roman exile since Afghanistan's troubles began when he was deposed in 1973.

The pro-Moscow leftists who ruled until 1992 were swept away, the Mujahideen then squandered the credit they won for defeating the Soviet Union by waging a futile civil war.

The Taliban swept to power in 1996, at first seen as saviours who would restore peace but then turned many moderate Muslims against them with their extremism. Zahir Shah does not want to return to power, supporters say, but ranks as the only figure the warring Afghans would allow to oversee a tribal assembly to choose a new lead. ership. "We have to empower the Afghan people," said Hamid Karzai, a Pushtun tribal leader from Kandahar who was deputy foreign minister in the Mujahideen government from 1992 to 1994.

"The king has not nominated himself for any job, he only wants to help the Afghan people regain its sovereignty."

Karzai has been working with Zahir Shah and other exile'd leaders for several years to try to organise a Loya Jirga, a tribal assembly of 700 to 1,000 people, that could be held in Kabul as soon as the Taliban are gone and security is guaranteed.

But that is only the method. Who could the new man be?

The most prominent opposition leader now is Burhanuddin Rabbani, 60, who was president when the Taliban seized Kabul in 1996 and is still recognized as such by the United Nations.

His Northern Alliance, forged with other fighting groups across northern Afghanistan, is battling the Taliban and diplomats say it could soon be getting substantial US material aid to launch attacks on Kabul.

But Rabbani has just lost his best commander, the legendary Ahmad Shah Masood, who was mortally wounded by two sui- cide bombers posing as journalists only days before the devastating plane attacks in New York and Washington.

Even if it does eventually win on the battlefield, the Alliance would face an uphill fight governing in Kabul because it is made up of Tajiks, Uzbeks and other minorities.

Among the Pushtuns, the ethnic majority that traditionally rules the country, many former commanders and tribal leaders were sidelined by the Taliban, who are also mostly Pushtun.

Abdul Haq, who staged spectacular rocket attacks on Kabul during the Soviet war until he lost a leg in fighting, commands respect among the Pushtuns and has US support, Rashid saiḍ.

Karzai may have ambitions himself, diplomats say, although he would only confirm he wanted a Loya Jirga to decide.

But another leading Pushtun, radical leader Gulbadin Hekmatyar, could upset the equation with his intransigence. Hekmatyar, one of the most controversial leaders during the Soviet war, fought other rebels more often than he did the Russians and waged a civil war against the first Mujahideen government. His forces rocketed much of Kabul into ruins in 1993. "Hekmatyar was the big spoiler then and he could be the big spoiler now," Rashid said.

Shireen Mazari, director-general of the Institute of Strategic Studies in Islamabad, underlined Islamabad's interest in whatever government emerges in post-Taliban Kabul. "If the end is in sight for (Taliban leader) Mullah Mohammad Omar, then Pakistan has to have a substantial say in the new government in Kabul," she declared last week.-Reuters 


\section{Fridhuffimes Sept 28-Oct 4, 2001}

\section{De-mythologising Afghanistan}

C onspiracy Heorists apart. many commentators have assumed that the United States will bomb Afghanistan into the stone age, thereby provoking a dangerous blowback for America and its Muslim allies like Pakistan. Some argue that it will be "a war without end" in which the tenacious Afghans will defeat America much like the Russains a decade ago and the British a hundred years carlier. Others fear that thousands of innocent Afghaus will perish, triggering widespread anti-American riots in Pakistan that could lead to the overthrow of the moderate Musharraf regime. America's Muslim allies therefore want "credible evidence" of OBL's complicity in order to "neutralize" the rage of their people.

The basic assumption in these scenarios, however, may not be true. Far from exacting revenge for the innocent lives lost in America by launching indiscriminate attacks in Afghanistan, the US strategy may be more calibrated by focusing on OBL, his Al-Qaeda companions and the core Taliban leadership. This much can be gleaned from President Bush's recent statement that the best way to bring those responsible to justice for the September 11 terrorist attacks was "to ask for the cooperation of citizens within Afghanistan who may be tired of having the Taliban in place".

This suggests that the US may seek to ally with the Northem Alliance in

Afghanistan in order to pressurise the Taliban to concede American demands regarding $\mathrm{OBL}$ and $\mathrm{Al}-\mathrm{Q} a e d a$. It would entail beefing up the Northern Alliance and "softening" up the Taliban forces in control of Kabul, Mazar i Sharif and Herat by high-altitude target bombing. This assessment is reinforced by US Defense Secretary Donald Rumsteld who ni cent. ly pointed out that not all Taliban members agree with the their kader's decision to "create a hospitable enviromment for Al Qaeda", adding that certain tribes in the south might be persuaded into joining the anti-Taliban coalition. The recent visit of Britain's foreign secre- taly, Jack Straw, to Iran may also be read in this context.

But an Afghan government led by the Northern Alliance would not be acceptable to Pakistan and create severe strains in the budding US-Pakistan relationship. That is why, perhaps. Presiclent Bush has also said that he is secking "justice" and "isn't into nation-building" - meaning that the US will not go so far als to install a Northem Alliance led government in Kabul hostile to Islamabal. 'This scenario is a far cry firom the crude one assumed by some commentators.

Other assumptions also need to be scrutinized. It is assumed, for example,

that the north-west firontier province is bound to "explode" with insurrectionary outbreaks in favour of the Taliban. But this assumption completely disregards the complex interplay of tribal interests within the Pashtun matrix. For instance, the Atghan Taliban are primarily part of the Ghilzai-Durrani tribal federation of Pashtuns while the main Pashtun tribes which proliferate in Pakistan are the Wazirs, Mahsoods, Mohmands, Afridis, Khattaks, Bangash, Orakzais, Yusutzais, etc. Many among these tribes are in the "pocket" of the federal government in Islamabad and there is no reason to believe that they cannot be dissuaded from supporting the Taliban should a desperate need arise.

Similarly, the premise that the people of Afghanistan are bound to line up behind the Taliban because they love them is questionable. Indeed, the opposite may be truer, since the Taliban have not provided any institutional justice or prosperity to the Afghans. In fact, many of the local commanders who acquiesced in Taliban rule when the Taliban first swept across the country in 1994-95 with the backing of Pakistan may be tempted to switch sides once the writing on the wall is clear and the Pakistani props have been removed.

The assumption that Afghanistan is bound to become a "graveyard" for the Americans because it was such for the British and the Russians before them is also dubious. The Afghan tribes were the "object" of the "great game" in the 19th century and exploited it by switching patrons. In the war against Russia, their powerful patrons were the Americans. Today, however, their sole patron Pakistan has been neutralized while the world powers are forcefully arraigned against them. There is no great game to exploit.

Finally, the argument that the US should provide "credible evidence" of OBL's role in the September 11 attacks in NY may be good for purposes of assuaging public opinion in Muslim states but is a non-starter as far as radical Islam's jehad against America and Israel is concerned. OBL has formally declared such a jehad more than once and Afghanistan under the Taliban has become a veritable base area for all the jehadis of the world. If some jehadis have now attacked America because they perceive it to be their enemy, rightly or wrongly, America has returned the compliment by targeting their base area and leaders in Afghanistan.

That said, the fundamental truth remains as powerful as ever. The United States must strive to remove the root cause of Muslim rage if it seeks to end the scourge of "terrorism". That means it must seek justice for the oppressed peoples of Palestine, Kaşhmir, Chechnya, Kosovo, etc, and end its indiscriminate support for the state terrorism of Israel. 
The News International, Wednesday, September 26, 2001

\section{Sattar warns against helping Afghan groups Says Pakistan favours national reconciliation in Afghanistan; EU terms Islamabad stand courageous}

\begin{abstract}
Umer Farooq
ISLAMABAD: Foreign Minister Abdul Sattar has said that foreign military assistance to any warring group in Afghanistan would be a recipe for disaster.

Addressing a press conference along with four-member delegation of the European Union, the foreign minister said that the reports in the international media about foreign military assistance to groups in Afghanistan is a cause of concern. "Any such move will be a recipe for disaster."

He said that which ever power has tried to impose a puppet government in Afghanistan has always paid a very heavy price for it.

Foreign Minister Abdul Sattar said any decision to favour one side over another in Afghanistan would be a recipe for disaster. "Any decision on the part of any foreign power to give assistance to one side or another would be a recipe for great suffering for the people of Afghanistan," said the foreign minister.

When asked whether he was warning United States, which is preparing for a military strikes against Afghanistan, the foreign minister said that he was not warning anybody. "I was only answering a question in which Pakistan was blamed for creating Taliban."
\end{abstract}

He said that Pakistan favours

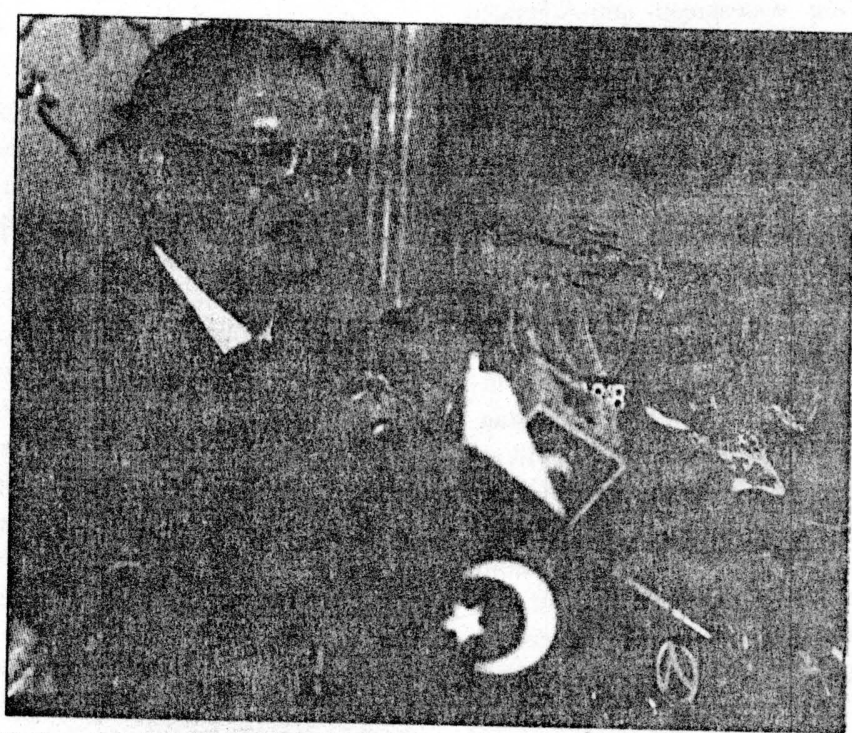

Federal Foreign Minister Abdul Sattar and head of European Union delegation Louis Michael attenively listening to a question from a reporter during their joint press conference.-Sohail Nashir

national reconciliation in the Islamic or Arab world.

Afghanistan as favouring one group would not serve the interest of Afghanistan.

The comments came after a meeting between a top level European Union delegation and Pakistan President General Pervez Musharraf.

It is part of an EU campaign to woo Muslim states into the international coalition to fight terrorism and to assure them that the alAt a news conference, Sattar said that he was concerned over reports that the opposition Northern Alliance in Afghanistan was seeking military assistance to fight the Taliban.

APP adds: Sattar said the Afghans are fiercely protective of their independence. "They never acquiesced to any proxy government in the past. This should be 
kept in mind that those who tried to plant their own leaders in Afghanistan have paid a heavy price for their blunder." "We ourselves learnt a lesson from history, and we did not in the past and not in future will commit this blunder."

He expressed concern over the report that some Afghan groups in Northern Alliance were dsking for foreign military assistance. "We fear any such decision on the part of foreign powers to give assistance to one group or the other is a recipe for great suffering for the people of Afghanistar."

He said Pakistan strongly condemned the September 11 attacks on World Trade Centre in New York and Pentagon in W/ash ington and extended condolence to the US people. He said Pakistan had also announced that it would implement the United Nations Security Council resolutions in this regard. "Pakistan's policy to fight terrorism is cast in the mould of the UN Security Council resolutions."

- Sattar said based on this commitment, "Pakistan can be relied in the efforts to combat terrorism." He said Pakistan was deeply welcomed by the European Union announcement that any equation of fanatical terrar. ism with the Muslim and Arab world was wrong. "Terrorists, are criminals and should be dealt with as criminals." He also appreciated emphasis of the Eutopean Union for a long-term caoperation in fight against terrorism at global level. He said the anti-terrorism campaign should be aimed at eliminating the root cause of tension.

- Sattar also welcomed the decision of the European Union to tesume dialogue with Pakistan. ?We have close and friendly relationship with the European Union." He said European Union is the major trading partner of Pakistan. "We are looking to a further dialogue to iicrease cooperation with the European Union in economic and commercial fields." He also appreciated the "sympathetic and friendly observation made by the European Union with regard to difficult situation Pakistan currently finds itself."
In response to a question, Sattar said because of current difficult situation, Pakistan has withdrawn almost all of its staff from Afghanistan. "We maintain contact with the Taliban government through their embassy in Islamabad."

He quoted President Pervez Musharraf as saying that Pakistan being the only country in contact with the Taliban govern ment, "may serve the role of communication between the world community and Afghanistan."

The European Union Tuesday voiced its full appreciation and support to Pakistan for its "courageous and bold step" to join international coalition against terrorism.

"Rakistan has taken a very courageous stand," Louis Michael, Vice Prime Minister and Foreign Minister of Belgium and Chairman, European Union, said in his opening remarks at a press conference after meetings with President General Pervez Musharraf and official talks in the Foreign Office. "It is a very courageous decision by Pakistan to stand in solidarity with the United States and European Union in fight against terrorism."

He said the EU mission was visiting Pakistan to convey full support from the European Union, Led by Louis Michael, the EU delegation includes Javier Solana, Secretary General of $\mathrm{EU}_{2}$ Josep.Piqul, Foreign Minister Spain and Chris Pattern, Member EU. Michael the European Union leaders last week appreciated the Pakistani position.

He said the EU mission to Pakistan is also aimed at explaining $\mathrm{EU}$ position on anti-terrorism fight. "The EU has expressed full solidarity with the United States aimed at building world alliance against terrorism."

The Belgium Foreign Minister said no country in the world could fight terrorism alone. "Only world together can get rid of this menace." He said there should be no doubt in the international determination to bring to book those responsible for such horrendous crimes and those harbouring the terrorists. "There are no good and no bad terrorists."

He said terrorism is a global challenge demanding global an- swers. He also expressed opposition to any equation of fanatical terrorism to Arab and Muslim world. The EU leader said the support of the Arab and Muslim world is vital to fight out terrorism. He admitted that Pakistan is facing new difficulties in view of the current situation. "Time has come to build new relationship between Pakistan and European Union and to construct longterm partnership between the two."

Answering a question, Chris Patten, the EU's commissioner for external affairs, said the European Union is to provide Pakistan with 20 million euros in emergency aid to help it cope with new influx of Afghan refugees. He said in the light of the August 14 announcement of President Musharraf about roadmap to democracy, the $\mathrm{EU}$ mission would recommend that agreement on initial aid cooperation with Pakistan be signed. "We have assured clear support for every step towards democracy."

He said he would ask EU governments to look sympathetically at Pakistan's demand for greater access to European markets for its large textile sector. Responding to a question, the head of EU mission said, "Pakistan is not only showing solidarity with the United States but also expressing solidarity to defend the humani values."

Chris Patten said Pakistan has made a brave and right choice in siding with international community to combat terrorism.

Talking to $\mathrm{BBC}$ television on Tuesday, Chris Patten said they have been reassured by what Pakistani Ministers have said to them. He said, "We recognise that the President and his colleagues have made a brave and right choice."

To a question, Chris said, "it is such a big potential crisis that as far as we are concerned whatever the costs we will want to be there with the international community in meeting them." To a question, he said we were impressed by what President General Pervez Musharraf said on August 14 about re-establishing democracy. "He laid down a very specific timetable," he added. Chris said, "we said that if you stick to that timetable we have no doubt at all that all member 
states will be happy to sign a cooperation agreement and we will be happy to ratify it."

To a question, he said the events that have unfolded over the last couple of weeks have been appalling beyond one's imagination. Chris said, "there is a real chance for them to take advantage of this adversity and try to open doors and windows which have been closed for too long."

Louis Michael said the European Union appreciates the stance taken by Pakistan government after the horrific events on September 11. Talking to PTV, he said, "we appreciate very much the stance that the President and his team has taken after the awful events."

He said they brought a very important message that there cannot be an equation between Islam and terrorism. "We have to stress that it is very important because there is no question to have a misunderstanding about that," he added.

He said the exchange of ideas between Pakistan and European Union was very good. "It is a positive and deep relationship between Pakistan and European Union," he said addin $\sigma$ they want to create and build a long term partnership between Pakistan and European Union.

Reuters adds: A European Union mission will tell leaders of five Muslim countries this week that the war on terrorism, in- said.

volves the whole world and is not a war on Islam, an EU official said on Tuesday.

"We want to make it absolutely clear that the campaign against terrorism....is a campaign for the whole world. It is not a. question of

America and Europe against Islam, EU External Relations Commissioner Chris Patten told reporters aboard the plane flying the EU mission to Pakistan. Islamabad is the first stop on a five-day tour. "We want to involve as broad a coalition as possible and we think we have...particularly strong relationships. with some countries which will enable us to mobilise that coalition," said Patten, who was joined on the trip by EU foreign policy chief Javier Solana and the foreign ministers of Belgium and Spain, the current and next EU presidents. end.

\section{Riyadh also breaks relations with Kabul}

\section{RIYADH: Saudi Arabia cut all ties ber 11 attacks}

with Afghanistan's Taliban government Tuesday, accusing it of using its land to harbour terrorists

The move leaves Pakistan as the only nation in the world to maintain ties with the Taliban, and leaves Afghanistan's hard-line.Islamic regime ever more isolated in its showdown with the United States over Osama bin Laden.

In a statement carried by the official Saudi news agency, the Saudi government said the Taliban regime "is continuing to use its land to harbour, arm and encourage those criminals who carry out terrorist attacks that frighten the innocent and spread horror and destruction in the world."

The attacks "defame Islam and defame Muslims' reputation in the world," the statement said.

The statement said despite ending all relations with the Afghan government, the Saudi government would continue to stand by the Afghan people.

Saudi Arabia will support "whatever is going to achieve se-" curity, stability and prosperity for the Muslim people, the statement.

Only three nations recognized the Taliban when they seired control in Afghanistan in 1996 epakistan, the United Arab Bmirates and Saudi Arabia,,,+

The Emirates shut the Afghan embassy in Dubai on Saturday, and announced it was severing diplomatic relations with the $T$ al iban. Pakistan withdrew its last diplomats from 16 Kabul, the Afghan capital, over the week-

The Pakistan government has said it will keep relations with Afghanistan, however, calling the Afghan embassy in the Pakistani capital the "window" for the world with the Taliban.

The move by Saudi Arabia marks a major step forward for the United States in its effort to put pressure on and isolate the Taliban, who have refused to hand over bin Laden without proof of his guilt in the Septem-
Following is the text of Saudi announcement released by official Saudi news agency.

The kingdom of Saudi Arabia stood with all of its ability beside the Afghan people while they were struggling for their independence, which gave Afghanistan a special status in the hearts of those who championed the nation's rights of freedom and independence until it regained its independence

"It is unfortunate to see that the Taliban have used that special status for Afghanistan not for

building the ties of brotherhood and for building and development and enforcing the lofty aims which Islam represents, but has tracting, training and recruiting a number of deceived people from different nationalities, especially citizens of the kingdom, in order to carry out criminal acts that violate any faith and creed, besides continuing to reject handing over those criminals to justice.

"In spite of what happened and what is happening, the Taliban government is still continuing to use its land to harbour, arm and encourage those criminals in carrying out terrorist attacks which horrify those who live in peace and the innocent tion in the world.

(It) leads to defaming Islam and defaming Muslims' reputation in the world. Since the Taliban disregard all of the contacts and the attempts that the kingdom has made to convince them to stop harbouring criminals and terrorists and training them and inciting them and making its land a refuge and haven for them, (since) it did not respond to all exerted efforts and attempts in that concern, the last of which is the Pakistan President Gen Pervez Musharraf's call to the Taliban government, the government of the kingdom announces it is cutting all of its relations with the Taliban governmade its land a center for atand spread terror and destruc- 
The News International, Wednesday, September 26, 2001

ment, while affirming that it will continue standing by the Afghan people and will continue its support for everything that will

achieve security, stability and prosperity for Afghanistan." AP

AFP adds: Meanwhile according to another report Saudi Crown Prince Abdullah bin Abdul Aziz reminded US President George W Bush by telephone overnight that the Palestinian issue remains a source of regional instability, SPA news agency reported Tuesday.

"The Palestinian issue, which concerns all Arabs and Muslims, is a source of instability in the region, "the prince warned.

He urged the US administration "and all peace-loving parties in the world" to find a settlement, adding that Bush could contribute through "the efficient role he can play in efforts to establish a comprehensive and fair peacen. in the Middle East.

"The United States wants to re-establish peace in the region," SPA quoted Bush as telling Prince Abdullah.

"The Israeli-Palestinian conflict deeply concerns the administration, which has undertaken serious steps to relaunch the peace process to bring justice for all parties," he said.

Saudi Arabia, Washington's major ally in the crucial Gulf region, has become increasingly critical of US policy in the Middle East and wants any war on ter. rorism directed also against Israel.

It has regularly called on the Bush administration to shoulder its responsibilities to curb Israeli "aggression" against the Palestinians.

\section{Taliban abandon customs post at Torkham}

\section{Ikram Hoti}

TORKHAM: The Taliban Customs authorities at this PakAfghan border seem to have abandoned their post and even food shipments for the desperate Afghan nationals have been blocked.

Truckloads of goods from Peshawar Dry Port have started lining up at the border, with no where to go.

Both the importers and the relevant Pakistani authorities confirmed here that the Afghan Gumruk (Customs) post is not functioning, though it did process papers of some of the fruit exporters at Torkham until Sunday last.

Businessmen in Peshawar told The News that not just the goods in transit, but the entire range of export goods from the NWFP have also ceased to be shipped beyond Torkham.

Ilyas Bilour, former Senator and Chairman Sarhad Chambers of Commerce and Industry (SCCI) told The News that most of the 24 flour mills operating in NWFP have closed down as they are now unable to transport wheat flour to Afghanistan.

He added that the match factories in NWFP and the vegetables business has also suffered substantially as these goods could not be transported.

Almost all of the consignments which enter Afghanistan through the Torkham border post are smuggled back to Pakistan after. clearance by Afghan authorities at Torkham.

The ones that are actually transported beyond the warehouses on Torkham-Jalalabad road are essential items, which the Afghan population uses regularly. With the blockade of transportation and clearance, the Afghan population is left to rough the winter 2001 without fresh supplies of blankets and medicines.

In view of this situation, the importers are now asking the Customs House, Karachi, to waive warehousing charges for the goods in transit, as they cannot get the goods shipped to the authorized destinations. The Dry Port authorities at Peshawar are also expected to soon receive such waiver requests, say sources.

\section{Attacks were to avenge US 'cruelty': Omar}

ISLAMABAD: The attacks on the United States were to avenge US "cruelty" toward Muslim countries, the Taliban supreme leader Mullah Mohammad Omar said Tuesday in a message to the American people.

"The American people must know that the sad events that took place recently were the result of their government's wrong policies," he said in the message, delivered through Pakistan-based private news agency, the Afghan Islamic Press.

"Your government is perpetrating all sorts of atrocities in Muslim countries. Instead of supporting your government's

policies you should urge your government to reconsider their wrong and cruel policies," he said.

"The recent sad event in America was the result of these cruel policies and was meant to avenge this cruelty," he said, without claiming to know who was responsible.

Omar again defended alleged terrorist mastermind Osama bin Laden, named by the United States as the prime suspect for the September 11 attacks.

He reiterated that bin Laden, the Saudi-born dissident who has been living under Taliban protection in Afghanistan since 1996, was incapable of planning the sort of sophisticated suicide hijackings which levelled the World Trade Center and part of the Pentagon two weeks ago.

"You must think of where the attack took place and who was behind it, but Afghanistan is being made the target and preparations are being made to attack Afghanistan," he said.

"What will be the consequences?

"You accept all just or unjust statements from your government but why can't you judge whether Osama bin Laden is involved in this? Can he do this in America?

"It is better for you to consider this seriously and act with wisdom. ${ }^{n}$-AFP

Reuters adds from Dubai: A Taliban defence official said on Tues- 
day the student militia will retaliate against anyone who attacked Afghanistan or helped in the attacks.

"Anyone who attacks or who helps in the attack is our enemy and we will carry out an attack

against them," Mulla Noor Ali, a Defence Ministry official, told Qatar-based al-Jazeera television.

Taliban also said that eight foreign aid workers facing trial on charges of spreading Christianity in the puritanical Muslim country were well and awaiting the arrival of a lawyer from Pakistan.

"They are in Kabul and have no problems," chief justice Maulawi Noor Mohammad Saqib told Reuters. "We are waiting for the arrival of their lawyer. It is up to him when he comes."

The aid workers were last seen by foreign diplomats on September 13, after initial appearances in a Sharia (Islamic justice) court, when the judge gave them permission to engage a lawyer from Pakistan.

It is unclear what sentences they may face if found guilty, but it is believed a final decision on their fate may lie with the Taliban spiritual leader, Mullah Mohammad Omar.

APP/AFP adds: Kabul residents who fled the city for fear of a US attack have begun to return to the capital in the belief that residential areas will not be targeted.

After several days in which the atmosphere in the city has been tense and sombre, the mood on Tuesday seemed to be lighter with more people out and about and more shops open.

"We went to Logar (the province south of Kabul) but we decided to come back," Abdul Haq, a 42-year-old Kabuli told AFP. "At the beginning people believed that the United States would attack Kabul and that residential areas would not be spared but now it does not seem so sure that will happen, "he said.

Ajmal Jamal, 28, said the fact

that the United States had not struck back at Afghanistan in the immediate aftermath of the September 11 attacks on New York and Washington had encouraged optimism that its response would be measured. "It was very good that time has passed in which the US might have thought about (the risk to) civilians and they will not be as angry as they were at the be-

\section{The Frontier Post \\ Wednesday, September 26, 2001}

ginning," he said.

Jamal, who works as a money changer, said he had initially planned to leave the country for Pakistan. He even began moving his family towards the border near the city of Peshawar. But he changed his mind after hearing reports that Pakistan had closed border and was re fusing to let anyone pass through the crossing at Torkham.

People at Torkham were badly treated so I decided to return home," he said. "In the end I decided it would be better to live under rockets here in our own country than in a refugee camp in Peshawar."

Thousands of Kabul residents have left the city for the relative safety of the countryside in the last week as fears a massive US attack was imminent mounted. But those fears appear to have subsided, despite the continuing build-up of US forces in the region, which Kabulis are aware of through the local-language broadcasts of the $\mathrm{BBC}$ and Voice of America.

The local currency, the Afghani, which plunged as low as 79,000 to the dollar last week as an attack appeared imminent, has recovered in the last two days to around 58,000 , although money changers said it was impossible to predict what would happen over the next few hours, far less days.

\section{Aid agencies face problems in Afghanistan}

ISLAMABAD (Agencies): Aid agencies say that they would now face many problems in their relief activities inside Afghanistan. These agencies had withdrawn their staff from Afghanistan in the wake of terrorist strikes in the United States.

A spokesperson of the International Committee of the Red Cross says that 1000 Afghan workers of the committee are undertaking relief works in the field of health in Afghanistan. These workers are supplying medicines and medical equipment to those hospitals which are busy in treating mine blast victims or are preparing for the treatment of injured people in passible fighting.

However, spokesperson said the Red Cross is concerned that medicines and medial equipment would soon diminish. It said that there were stockpiles in Afghanistan but if new stocks were not rushed the old one would soon run out:

She said on their return from Afghanistan, they had material sufficient for three to four weeks of normal supplies. But fighting has broke out between the Northern Alliance and Taliban, adding that ICRC feared that it might not have sufficient medicines for treating the injured people or to be provided to those people who are fleeing towards the Iranian and the Pakistani border and are presently stranded in border areas.

She said their workers could not easily shift medicines to different parts of. Afghanistan. Aid programme was confronting problems in Kabul.

The spokesman said the ICRC wanted to provide flour to bakeries for free distribution of bread among the common people. The World Food Programme also says that it does not have sufficient food to be distributed among these four million people whom it formerly fed. Unicef and the WHO are also forced to reduce their programmes in Afghanistan. 


\section{The Frontier Post}

Wednesday, September 26, 2001

\section{Musharraf tells foreign journalists...} No pressure to snap
relations with Kabul

ISLAMABAD (Online) President General Pervez Musharraf said Tuesday that Pakistan to snap diplomatic ties with Afghanistan.

Talking to foreign journalists here, he said, "you cannot resolve the issue by -isolated Taliban. They have to be in the picture to negotiate"

He welcomed the European Union delegation's visit saying. it would improve Pakistan's relations with the western countries there was no pressure on

He said diplomatic ties with Taliban have been paying as it were a squrce of interaction. "I think a country must have diplomatic ties with them so that there is someone to talk to", he said.

He said remaining in contaet with Taliban was the best resolution of the issue "If Pakistan is the only country having diplomatic links with Taliban it must not abandon it. We also have no world pressure in this regard", he maintäined. $+2, \ldots+$

\section{The Statesman Wednesday, Seperember 26,2001}

\section{Taliban urge OIC to help defuse tension}

ISLAMABAD: Afghanistan ruling Taliban Tuesday backed Pakistan move to convene a special meeting of the Organization of Islamic Conference to review the emerging regional situation.

"We want the OIC involvement to stop the United States from any possible aggression on Afghanistan," Afghan ambassador Abdul Salam Zaeef said.

Pakistan Foreign Minister Abdul Sattar has sent a letter to the OIC Secretary General, calling for holding an emergency meeting to discuss the prevailing situation and adopt a unanimous stand.

Sattar will send letters to his counterparts of Islamic countries to discuss with them Pakistan's quest for the OIC moot. He has already had telephonic talks with Iranian Foreign Minister Kamal Kharazi.

The Taliban Foreign Minister Maulvi Wakil Ahmed Mutawakil Monday wrote to the OIC Secretary General, asking him to take note of American threats to Afghanistan.

Mutawakil drew his attention to the American threats to Afghanistan and urged him to stop the United States from any aggression against Afghanistan.

Mutawakil also invited the OIC chief attention to the violation of Afghanistan air space by American spy plane and described it as a terrorist act. He urged the OIC to use its influence and stop Washington from its threats and any possible attack on Afghanistan.

He said any attack on Islamic country by United States would be disaster for the whole Islamic Ummah. He also referred to the President Bush's statement in which he has stated that the future war will be crusade.

Meanwhile, UN officials and Afghanistan's Ambassador Abdul Salam Zareef met here Tuesday to discuss the issue of disruption of communication links with UN officials inside Afghanistan.

Spokesperson for the United Nations Stephanie Bunker told reporters here that the meeting remained "inconclusive".

According to the United Nations, the Taliban authorities on Friday cut off links between the UN field officials and the outside world and sealed all communication equipment at four locations inside Afghanistan.

She said the Afghan Ambassador has told the UN officials to forward the "concerns" of the world body to the higher authorities in Kabul.

Bunker said the obstruction of communication links had severely hampered humanitarian efforts to assist people of the war-ravaged country.

The spokespersons also told the news briefing that the Taliban authorities took over UN office in Kandahar and asked its officials to leave the premises. Afghan authorities also occupied two NGO offices in Kandahar.

The UNHCR officials, Peter Kessler told the news briefing the UN officials also met Governor NWFP and the Provincial Finance Minister to discuss the recent influx of Afghan refugees.

The meeting was told that the Pakistan-Afghan border will remain closed and only people with valid visa documents will be allowed to cross over.

The UN team identified three sides to set up "Refreshment center to deal with the new entrants where household items including tents, blankets and food will be supplied after the survey. - Agencies 


\section{$K_{\text {HYBER }} M_{A I L}$}

September 26, 2001

\section{Britain signals} overthrow of

\section{Taliban}

LONDON (APP): British Prime Minister Tony Blair hassignalled that his government would welcome the overthrow of the Taliban regime as a consequence of any military operationdesigned to track down. Osama bin Laden.

Mr Blair told the MPs that the government was not formallyaiming to topple the Taliban, but if the regime stood in the way of finding Bin Laden, that obstacle would not be allowed toremain, said a report in the Guardian.

"It has always been our intention and our wish to see ademocratic regime in Afghanistan," the prime minister's spokesmanwas quoted as saying. The collapse of the Taliban regime was apossible consequerice of the military strike being planned by America, Guardian quoted him as saying.

Chris Mullin, the chair of the home affai,s selectcommittee, said he had received reassurance from $\mathrm{Mr}$ Blair thatlong-term thinking was under way about the natuite of the regimethat would follow the Taliban.

\section{The Nation september 26, 2001}

\section{Washington in close}

\section{touch with Opposition US hints at support to Northern Alliance}

WASHINGTON (AFP).- President George W. Bush signalled Tuesday that he might turn to foes of Taliban militia for support in a US-led global war on terrorism sparked by strikes on New York and Washington.

The Taliban have made the decision to harbour terrorists. Now, the mission is to root out terrorists, to find them and bring them to justice, he said at the White House, joined by Japanese Prime Minister Junichiro Koizumi.

One way to do that is to ask for the cooperation of citizens within Afghanistan who may be tired of having the Taliban in place, or tired of having Osama bin Laden, people from foreign soils, in their own land willing to finance this repressive government, said Bush.

The United States has not open$1 y$ said it would send weeapons to foes of the Taliban, and top officials here have said ousting the Islamic militia is not a primary goal of likely military action.

The President's comments came shortly after Pakistan - the last country with diplomatic ties to the
Taliban - warned that pumping cash and arms into opposition forces fighting the Islamic militia would be a recipe for disaster.

Washington has identified Osa-. ma as the suspected mastermind of the September 11 kamikaze plane attacks on the World Trade Center and the Pentagon which claimed nearly 6,800 lives.

US State Department spokesman Richard Boucher had said Monday that the United States was in close touch with many Afghan factions, including the northern opposition forces.

The United States said Monday it was in close touch with many Afghan factions including northern opposition forces battling the ruling Taliban, the protector of Osama bin Laden.

The opposition alliance, a coalition of groups based mainly in a mountainous region north of $\mathrm{Ka}$ bul is the only internal force still battling the Taliban.

State Department spokesman Richard Boucher said he was restricted on what he could say on the issue, but disclosed: We do 
keep in close touch with a variety. of Afghan people throughout the world.

In addition to groups that may operate in Afghanistan, we have a lot of contact with Afghans abroad. We maintain contact with all the Afghan factions.

Defence Secretary Donald Rumsfeld said last week that the United States would seek the support of the Afghan opposition as it hunts Osama bin Laden.

One can say, how much help can they be? Well, they can be a lot of help, Rumsfeld said in an interview on Fox television.

These folks, they know the lay of the land. They know in some cases some targets that are useful. They have some ideas about how to deal with the Taliban, he said. So I think one has to say that they can be useful in a variety of ways.

The opposition, still reeling from the assassination this month of its military chief, Ahmad Shah Masood, has made no secret of its desire for US military help, after years of defeats against the Taliban.

But so far Washington has made no plans public to arm the alliance, a loose coalition of warlords from the Uzbek, Hazara and Tajik ethnic minorities.

AFP adds: President George W. Bush has formally! notified the US

\section{THE PAKISTAN TIMES}

Wednesday September 26, 2001

\section{Russia to take part in operation against Afghanistan}

MOSCOW: Russian President Vladimir Putin is showing his hand for the first time since winning office last year to reveal that he is ready to risk cooperation with Washington to a far greater extent than many had thought.

In a somber Monday night television address that ended two weeks of Kremlin silence, Putin prepared Russia for possible military involvement in Afghanistan - alongside the United States. "Russia is further ready, if necessary - if necessary - to take part in international search and rescue missions," Putin said,
Congress that he has ordered some troops abroad in response to September 11 terror strikes and may need to send more.

The formal notification, made 1973 War Powers Resolution, commander-in-chief's power to undertake military action thout approval from Congress.

After the attacks on Washington ployment of various combatand combat support forces to a number of foreign nations mand areas of operations, Bush said in a letter to Congressional eaders. The two commands covr a geographic area roughly spangrom Egypt to Hawaii, includAfghanistan.

In the future, as we act to prevent and deter terrorism, I may find it necessary to order additionforces into these and other areas of the world, including into foreign nations where US Armed Forces are already located, he said. It is not now possible to predict scope and duration of these essary to counter the terrorist likely that the American campaign against terrorism will be a lengthy one, he wrote in the letter, which the White House released. 
its military campaign in Chechnya, where federal troops have allegedly carried out atrocities, the officials said.

However they stressed that ongoing consultations over US missile defense plans were not part of the current equation in Putin's thinking, as Russia itself one day may want to participate in the lucrative construction of such a system. - By special arrangement

\section{Iran rules out help to US-led alliance}

\section{Khamenei holds Washington responsible for crimes by Israel; says Tehran is neither with US nor terrorism}

TEHRAN: Iranian Supreme Leader Ayatollah Ali Khamenei reacted angrily on Wednesday to US accusations that Iran sponsored terrorism, saying his country would provide no help to the United States in any attack on Afghanistan.

The comments appeared to strike a fatal blow to the efforts of European missions to Tehran trying to secure Iranian help for a USled coalition against Saudi-born Osama bin Laden and his Afghan Taliban hosts.

"Iran will provide no help to America and its allies in an attack on suffering, neighbouring, Muslim Afghanistan," Khamenei told a group of war veterans and their families. Excerpts of his speech were carried on state television.

"You (the United States), who have always caused blows to Iran's interests, how dare you request help (from us) in order to attack the innocent Muslim nation of Afghanistan, which has suffered and which is our neighbour," Khamenei said.

"We do not believe America is sincere enough to lead an international move against terrorism. America has its hands deep in blood for all the crimes committed by the Zionist regime," he added, referring to Israel.

Khamenei, who has the final say in matters of policy, was speaking two days after US Secretary of

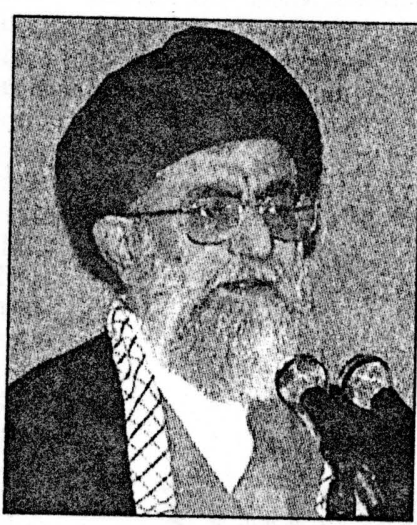

Iranian Supreme Leader Ayatollah Ali Khamenei speaks to family members of Iran-Iraq war soldiers during a ceremony held Wednesday.-AP

State Colin Powell said Iran should halt its support for "terrorism" if it wanted to be a part of a US-led coalition.

"You can't pick your favourite terrorist," Powell told Reuters on Monday in Washington. "If you (Iran) want to be part of this small coalition then you have to change some of the patterns of the past supporting terrorism."

Khamenei made a direct reference to Powell's "arrogant" remarks: "American officials say 'there are no good or bad terrorists', but they themselves have double-standards on terrorism."
"They expect the entire world to help them because their interests demand. Do you ever care about others' interests," he said to chants of "Death to America" and "Death to Israel".

"These are the characteristics that make America so hated in the world."

But Khamenei condemned terrorism, calling for a "serious fight and a holy war to combat terrorism".

Khamenei also rejected America's declaration to the world that nations had to choose between being " with us or terrorism."

"It is not that any one who is with you is against terrorism and those who are against you are for it," he said.

"We are neither with you nor with the terrorists."

Khameniei spoke a day after he chaired an emergency Supreme National Security Council meeting with Khatami, senior ministers and the army top brass. Khatami normally chairs such meetings.

The statement also came after a visit by top EU officials and the first trip to Iran by a British foreign minister since the 1979 Islamic revolution.

The missions had seemed to herald a new era of closer ties between Iran and the West. Many in Europe and the United States saw 
The News International, Thursday, September 27, 2001

Khatami's quick condemnation of the suicide attacks two weeks ago as a sign Iran could be brought 'inside' in an international coalition against "terrorism".

Powell said Khatami's reaction was "positive".

But six days after the attacks, Khamenei weighed in with a warning. The United States' problems would mount if it attacked Afghanistan, he said.

Meanwhile, Khatami and his government were open to diplomatic efforts to forge closer ties. Britain's Jack Straw and the EU delegation came and went. Foreign Minister Kamal Kharrazi even said US retaliation would be justified if there was proof who was to blame.

But one hitch always lurking in the background was Iran's support for Lebanon's Hizbollah and Palestinian militant groups Hamas and Islamic Jihad. This was why Iran remained on Washington's list of state sponsors of "terrorism".

For Iranian authorities, the groups which have carried out numerous attacks on Israeli targets, among them suicide bombings, were engaged in legitimate resistance against what they call Israeli state terrorism against Palestinians.

"When it comes to defining terrorist groups, there is going to be lively debate," EU External Relations Commissioner Chris Patten said in Tehran after meeting Kharrazi on Wednesday. "That debate took place this morning."

Iran said on Wednesday US retaliation for this month's suicide attacks would be justified if there was proof who was to blame, but made clear it would not.help in any strike against Afghanistan.

Foreign Minister Kamal Kharrazi, whose country had previously insisted any US response would have to be under the aegis of the United Nations, said Washington could act if it had evidence.

"If it becomes clear which par- ticular group carried out these attacks in the United States, naturally the United States, based on UN's charter, can take action," Kharrazi told a news conference after talks with a visiting European Union delegation.

"What is important is that it should be proven who carried out those attacks, otherwise attacking a country without any specific target...will lead to the death of innocent people and could cause a second disaster," he said.

Moderate Iranian President Mohammad Khatami on Wednesday branded US President George W Bush "arrogant" for allegedly thinking that he can "distinguish between good and bad on his own , the state news agency IRNA said.

Khatami, who was referring to Bush's recent comments on the September 11 attacks in the United States, said, "A powerful human being can become so arrogant, that he thinks he can distinguish between good or bad on his own."-Reuters/AFP

\section{Northern Alliance's limitations in replacing Taliban government}

\section{Analysis \\ Rahimullah Yusufzal}

PESHAWAR: While the Taliban are fast losing the few friends they had in the world, the opposition Northern Alliance has not only won new supporters such as the US but is also getting fresh supplies of weapons from Russia and elsewhere.

The realignment of forces in and outside Afghanistan could trigger yet another round of bloodletting in that unfortunate country. But the powers determined to overthrow the Taliban regime are willing to bankroll such an effort

even if it means more Afghan deaths, displacement and suffering.

To make matters worse, Washington is also gearing up for punitive strikes on Taliban-ruled Afghanistan. This may not deliver Osama bin Laden to the US but it would certainly contribute to the humanitarian crisis that is unfolding in Afghanistan.
Saudi Arabia and the United Arab Emirates have already cut off diplomatic relations with the Taliban regime. Pakistan is now the only country in the world to have diplomatic ties with the Taliban. Nevertheless, it has withdrawn diplomatic staff from its embassy in Kabul and from consulates in Kandahar, Herat and Jalalabad, primarily due to security reasons. Despite Islamabad's assertions that it would never think of harming the interests of Afghans and Afghanistan, the Taliban and their supporters have been irked by the change in Pakistan's Afghan policy under the US pressure and are no longer willing to trust the Pakistan government.

Isolated and shunned even by erstwhile friends, the Taliban have found that they are unable to reassure their Afghan subjects and stop them from fleeing the cities out of fear of US attack. An appeal by Taliban supreme leader Mulla Mohammad Omar on Wednesday to the people to return home because the threat of a US attack had abated is unlikely to have much of an impact. With the cities emptying fast and most able-bodied men reluctant to fight yet another jihad, the Taliban claim of having signed up 300,000 volunteers appears hollow. However, it is possible that more Afghans would be drawn to the battle once the US ground forces land in Afghanistan. Scared of jet-fighters, gunship helicopters

and long-range missiles, the Afghans would love to flex muscles with invading soldiers in faceto-face encounters.

The Taliban are hopelessly equipped to take on a superpower adversary such as the US. Though it is difficult to gauge the Taliban military machine, the fact remains that they don't have a regular army. The active fighters at their disposal could be anywhere between 35,000 to 50,000 . The number of their jet-fighters, helicopters, transport aircraft, tanks, Stinger and Blowpipe missiles 
The News International, Thursday, September 27, 2001

could be anybody's guess but their maintenance and performance is often a matter of concern. More worrying for the Taliban leaders and military commanders would be to keep in touch with each other in the aftermath of the US strikes because their already poor means of communication are expected to be jammed and rendered non-operational in such a situation. Aware of

their shortcomings, the Taliban have sent out emissaries to try and effect reconciliation with estranged mujahideen commanders and invite them to join the battle against any force that invades Afghanistan.

Mindful of their limitations, the Taliban have left the control of provinces like Khost and districts such as Sarobi to local tribal and Taliban shuras and deployed the surplus fighters in key places including Kandahar, Kabul, Herat and Jalalabad. Kandahari Taliban, until now assigned choicest jobs in other provinces, were reportedly being recalled to their native Kandahar to defend the city. Though late in the day, the people are also being allowed more personal freedoms by the Taliban in a bid to win their support for a military campaign.

Compared to the cashstrapped Taliban, the Northern Alliance may soon end up with more weapons and resources than it can possibly handle. Russian president Vladimir Putin has announced

new military supplies to the Northern Alliance and would be able to prompt Uzbekistan, Tajikistan and Kazakhstan to contribute their bit to strengthen the anti-Taliban coalition.

The US is ready to chip in with substantial assistance to enable the Northern Alliance to put military pressure on the Taliban and, if possible, reclaim Mazar-i-Sharif, Herat, Taloqan and even Kabul. Turkey is also expected to militarily support the Northern Alliance after prime minister Bulent Ecevit gave a statement advocating such assistance by countries opposed to terrorism to oust the Taliban regime.

However, the Northern Alliance due to its composition and fractious nature cannot effect national reconciliation in case it drives out the Taliban from Kabul. Made up mostly of ethnic minorities such as Tajiks, Uzbeks and Hazaras, the Northern Alliance could even loose its only component led by member of the majority Pashtoon tribal confederation.

Ittehad-i-Islami head and former mujahideen leader Prof Sayyaf was said to be unhappy over Northern Alliance's support for possible reprisals by the US against the Taliban. But he may not join the Taliban owing to the bitterness that characterizes their relations.

The Northern Alliance also needs time to recover from the shock of the recent assassination of its most prominent military commander, Ahmad Shah Masood. His replacement, Mohammad Faheem, has been quick to assert himself by paying a visit to Tajikistan for a meeting with Russian military generals to discuss his military needs and future plans.

The strife between Uzbek warlords Rasheed Dostum and Abdul Malik and the rift in the ranks of Shia factions led by Karim Khalili and Ustad Mohaqeq and Sheikh Asef Mohseni and Hussain Anwari also doesn't bode well for the unity and future of the Northern Alliance.

\section{Afghan body backs move for broad-based govt}

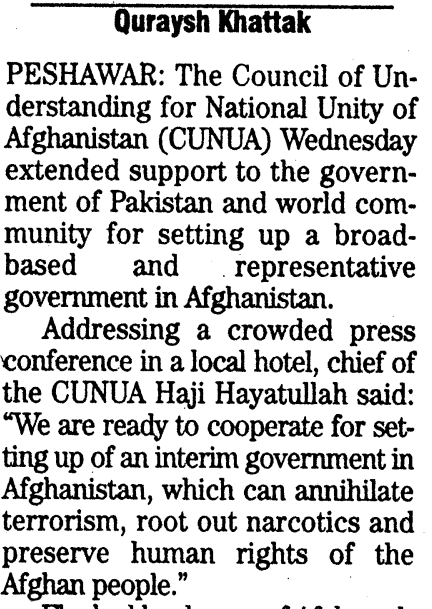

Flanked by dozens of Afghan elders and intellectuals, he appreciated the peace efforts of special envoy of the United Nations secretary general Francis Vendrell. He said former Afghan King Muhammad Zahir Shah had consented to return to Afghanistan and play his role for the reconstruction of the country.

He requested the government of Pakistan to facilitate return of Zahir Shah or of his representative, Afghan elders and politicians to Pakistan. He also sought support of Pakistan and other neighbouring countries for formation of a broadbased government under the lead- ership of the former king.

"We believe that the interim government would work in mutual understanding with all neigh. bouring countries for regional peace and political stability," Hayatullah said. For organization of government, he asked Islamabad to allow formation of a king's party and opening its offices in Pakistan.

He also lauded President Musharraf 's policy against international terrorism and his government willingness to work jointly with the international community for uprooting terrorism. "We hope the present efforts will put and end to the 23 years fighting in Afghanistan," he added. He said that the Afghan peace-loving politicians, tribal elders and aid workers supported government of Pakistan move for peace in the war-battered country. He also recalled for the support of Pakistan government and people against the Soviet invasion of the "heart of Asia".

About attacks on the World Trade Center and Pentagon, Hayatullah said that terrorism was against the teachings of Islam. He also condemned attacks on Muslims in the United States. He asked the people of the United States and other western countries to refrain from retaliatory actions. 
The News International, Thursday, September 27, 2001

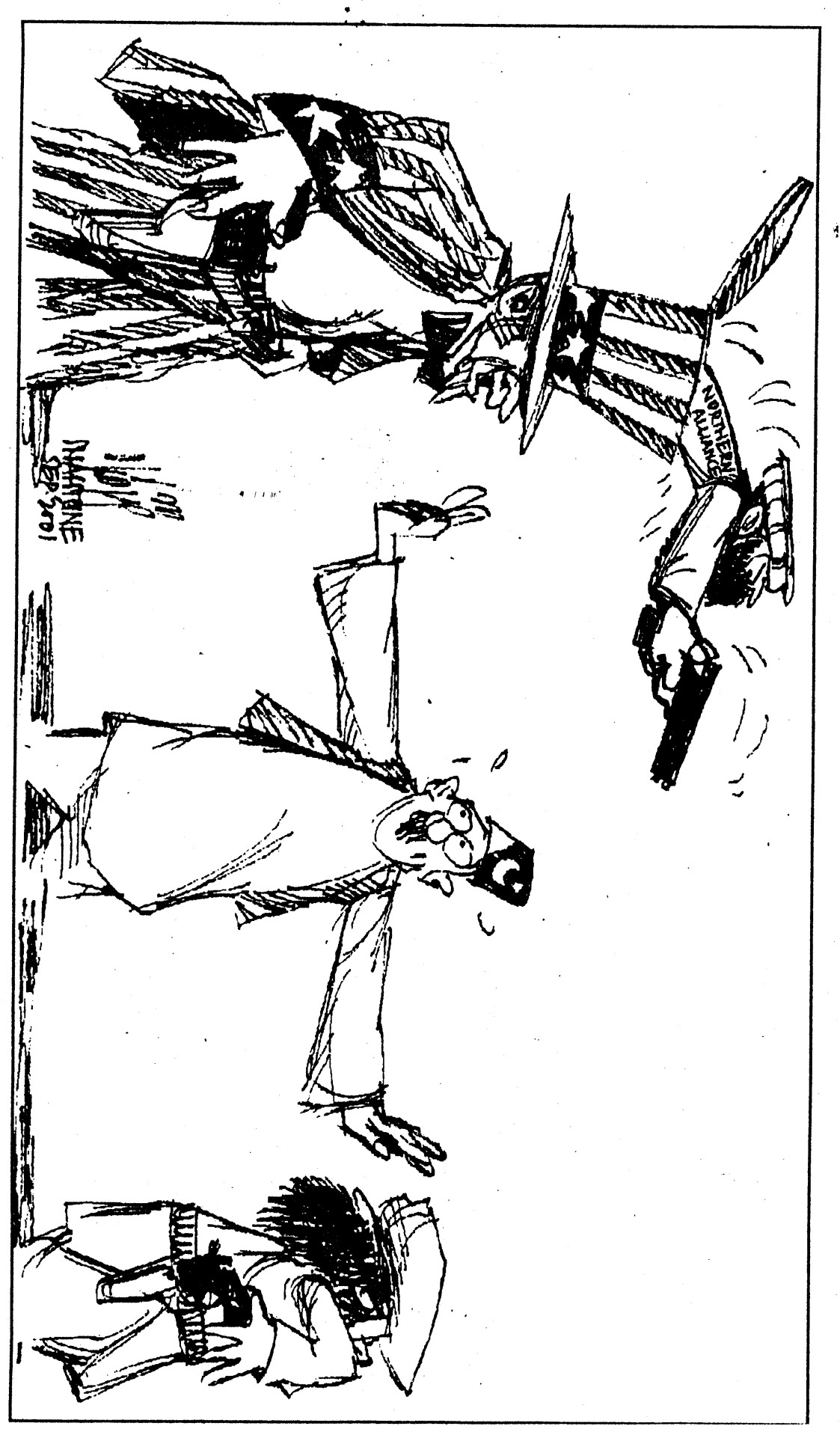




\section{US embassy in Kabul set on fire}

of citizens of the beleaguered Afghan capital pelted stones on the building and chanted slogans in support of Osama bin Laden and Mullah Muhammad Omar and set ablaze a portion of the building. "It took almost half an hour when fire fighters were able to bring the situation under control and extinguish the fire", said director Bakhtar, Abdul Hanan Himat. "Like the stoning of Satan during Haij, we want to stone the greatest Satan of the world", Himat quoted a protester while pelting stones on the deserted embassy building.

The procession started from Pushtunistan Square and marched to Sihat-i-Aama Square, where it converted into a huge public meeting, as according to Fimat, more than 100,000 people took part in the demonstration. This is the second time during a week that the empty building of the US embassy was attacked.

The speakers in their fiery speeches asked the United States to demonstrate restraint because attacking Afghanistan without producing credible proof of its involvement in the suicide attacks on the World Trade Centre and Pentagon, would be against the norms of justice and void of logic.

The US government, the report said, should conduct proper investigation before taking any action against Osama bin Laden or punishing the people of Afghanistan for providing shelter to him. The speakers also announced support to the edict given by religious scholars in Kabul last week to wage jehad if Afghanistan was attacked and said that Afghans would not accept any government to be imposed on them from outside. "They warned of imposing Zahir Shah on the people of Afghanistan and said that every such move would be resisted tooth and nail"; Himat told The News while quoting speakers:

\section{US attack unlikely, says Mulla Omar}

KABUL: Taliban supreme leader Mulla Mohammad Omar said on Wednesday he saw less likelihood of a US attack since Washington had no proof of bin Laden's hand in Sept 11 attack.

Mulla Omar, in a message distributed by the information ministry, also appealed to the thousands of Afghans fleeing toward the border for fear of a US strike against their country to return home.

"There is less possibility of an American attack," Mulla Omar said in the statement. "America has no reason, justification or evidence for attacking... therefore, all those (Afghans) who have been displaced internally or externally are instructed to return to their original place of residence," he said.Reuters 
The News International, Thursday, September 27, 2001

\section{ICC to review Afghanistan's status}

Cur correspondent

ISLAMABAD: Afghanistan's newly-recognised status as an International Gricket Council (ICC) affiliate member is set to be reviewed when the game's governing body meets in Kuala Lumpur, Malaysia on October 15.

An ICC representative, confirmed: "I am sure Afghanistan newly got status will be discussed in the meeting. Nothing can be done until then because the constitution doesn't allow for immediate judgments."

The ICC meeting had originally been scheduled to take place in Lahore, Pakistan, from October 15-19 but was re-arranged following the terrorist attacks in New York and Washington $\Gamma$.

An ICC statement said the switch had been made "in recognition of recent world events and

the uncertainty over the security aspects of international travel to the region".

Afghanistan was only accepted into the ICC fold in June when its Pakistan-backed application to become an affiliated member - the third tier of recognition beneath full members and associate mem. bers - was granted.

It was welcomed into the fold together with a clutch of other un. likely countries including Bahrain, Bhutan, Botswana, Croatia, Indonesia, South Korea, Lesotho, the Maldives and St Helena.

At the time Malcolm Grey, then ICC president, was reported as saying: "Virtually any country that plays cricket, that has a cricketing organisation, will qualify for affil. iate membership."

That situation now looks set to be reviewed following the terrorist attacks in the US, which have been blamed on Osama bin Laden, the millionaire Saudi dissident currently believed to be in hiding in Afghanistan.

The Afghanistan Cricket Federation (ACF) was founded in June 1995 , although cricket has been played there since 1992 . The country has 28 provincial teams, as well as a number of es. tablished senior and junior leagues, and in May its 17-strong national side undertook its inau. gural overseas tour when it journeyed to neighbours Pakistan for four one-day matches against invitation sides.

Returning refugees from Pakistan have played a major role in the sport's growth within Afghanistan and the PCB has also been a vital ally, a fact backed up by its official support for Afghanistan when it sought to become an ICC affiliate member in June. All would-be affiliate members must be proposed by a Testplaying nation.

Former Pakistani Test cricketer Farukh Zaman spent several weeks coaching Afghan cricketers last year - at the request of the ICC - and the PCB also donated a roller to help add to the two pitches currently in the capital Kabul.

\section{The Frontier Post}

Thursday, September 27, 2001

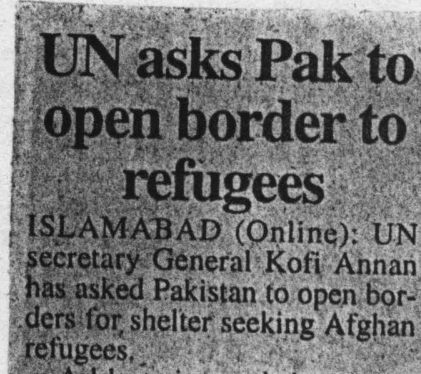

Addressing a joint press conference here Wednesday evening, UN information centre officials in Pakistan have said that Taliban Militia have started enrolling Afghan youths to fight against US in the wake of its anticipated military offensive against Afghanistan.

The UN representatives read out the statement of Koli Annan in the press conference.

Statement said that Kofi Annan appealed to world community to extend all possible assistance to Afghan refugees so that they could not become a burden on the economy of neighbouring countries.

The innocent citizens should not sufter the penalty for the Taliban-sfeps. The whole world is opposed to terrorism in unison therefore concerted efforts are needed to save the life of innocent people in emergent situation, he held:

Replying to a question UN representative said a meeting of Afghan Support Programme is being held today (Thursday) in Germany to review the critical situation facing Afghan citizens, Afghan Forum will also hold its meeting on October 5.6 in Geneva. Iran and Pakistan will take part in the meeting.

The UN representatives said focus of the endeavours on their part is to extend assistance to Afghan refugees under a comprehensive programme. "We are framing a draft 


\section{The Frontier Post}

Thursday, September 27, 2001

focusing on the plans encompassing the period from October 2001 to March 2002 under which we will provide financial and food support to 6 million Afghnis inside Afghanistan", they added.

They said that the refugees camped in neighbouring countries of Afghanistan will be given adequate assistance.

They said that $U_{i v}$ is facing difficulties in establishing contacts with the offices functioning inside Afghanistạn. "Taliban even monitor the contact which we try to make on radio", they complained.
Lack of contact is hindering us to provide assistance to Afghan citizens inside Afghanistan, they observed:

"We are aware of anticipated burden on Pakistan on the influx of refugees but we want that they should be allowed to cross the border on humanitarian grounds", they said.

They noted that Pakistan, which is already sagged under tremendous pressure of Afghan refugees, should be provided assistance as it is beyond its reach to provide food to the largely outnumbering refugees.

\section{Ukraine ready to help Afghan refugees}

ISLAMABAD (Agencies): Ukraine will provide technical help and expertise to Pakistan for generator of Hydel power and development and modernization of its irrigation system, said. Voldimir S. Ponomarenko, Charged Affair of Ukraine in a meeting with Federal Minister for Food, Agriculture and Lives Stock, Khair Mohammad Junejo. here Wednesday.

Ukrainian Charge'd, Affairs who called on the federal Minister, said that his country has the potentials to switch over to the switch over to the production of any kind of equipment needed by Pakistan for its Agriculture and industrial development.

Our doors are open for Pakistan and we would render full cooperation to Pakistan for its economir development, "he said. Valadimir S. Ponomarenko said that Ukraine will provide fertiliz-
$K_{\text {HYBER:M }} \mathbf{M}_{A L L}$

September 27, 2001

\section{Action against}

\section{Afghanistan to breed}

\section{extremism: Imran}

ISLAMABAD (NNI): The

Chief of Pakistan Tehreek-eInsaf (PTI) Imran Khan has called for concrete evidence against Osama Bin Laden as use of brute force alone would not help in eliminating terrorism, on the contrary it would breed extremism and promote more terrorism.

"Without providing credible evidence that provides legitimacy to any military action, resort to force would have grave consequences for the peace and stability of the region and the world"

He was addressing newsmen at the party's Central Secretariat here on Wednesday.

The PTI Chairman said that terrorism is an international issue and could only be addressed if a comprehensive approach is adopted. He called for the setting up of an international court against terrorism, which would define terrorism and distinguish between freedom struggles and terrorism.

He called on the international community to make a serious effort to establish the reasons for growing international terrorism.

Imran said the Afghan people desperately need peace and not more war. Any attempt to hoist a Northern Alliance led government on Afghanistan would backfire 


\section{KHYBER $M_{\text {AIL }}$ Thursday, September 27, 2001}

\section{Influx of fresh Afghan refugees continue in NWFP, Punjab}

Allah Nawaz Khan

DIKHAN: With the reiteration of US attacks on Afghanistan, tens of thousands Afghan Refugees tlocking into Southern part of NWFP and Punjab entering into Pakistan through various known and unknown routes. It has been seen with concern that inllux of Afghan Refugees during this year has been exceeding many fold as compared to the previous years.

they have switched over to modern mode of transportation like trucks and tractor trolleys. Hundreds of vehicles can be seen being off loaded short of DeraDarya Khan Bridge. It has also been reported by the local Live Stock Department that the live stock of these refugees carry many epi- demic diseases like liver fluke, tuberclosis and foot \& mouth infectious diseases. Unfortunately, there is neither any registration nor any monitoring of these unwanted guests on the borders of any where in between. It is not possible for any government agency to arrange any relief or vaccination for these "guests " and their live stock.

Pakistan is already hosting more than three million Afghan Refugees-mostly unregistered and now holding the Pakistan's citizenship. These Ars have not only created law and order situation in many parts of the countries on many occasions but are a constnant burdon on our national economy. The ever increasing number of these Ars has also influnced the local trade and most of the business has slipped away from the hands of local traders and captured by these unwanted guests.

The present inflow of these ARs will further deepen the crisis which need strict precautionary steps to discourage the new inflow. Public of D.I.Khan and Bhakkar has demanded from the Govt: to draw the attention of UNHCR towards thisserious menace andarrange specific camps to confine them into restricyted areas.During past, no relief or emergency food or any other sort of aid has ever been trickled down to thisarea probably because of their far flung locations from their respective provincial capitals.

\section{Masood's assassins plotted in Britain: Time}

LONDON (Agencies): The black flags are still raised in Khawja Bahauddin, more than two weeks after the assassination of Ahmed Shah Masood, the Northern Alliance's commander.

Pictures of his face adorn every vehicle and an atmosphere of sullen anger lingers in the town. Turbanned, bearded warriors idle in the carthen streets, Kalashnikovs slung over their shoulders, and in the far distance comes the irregular murmur of shelllire, reports the limes.

It is a world away from Eritain, yet Britain was where the two suicide bombers who killed Masood on September
9, two days before the attacks on America, began their journey. They had lived in the UK, using it as a secure base in which to research and prepare for their final operation.

Foreign diplomats in Central Asia, British police and UN officials are beginning to look into the background of the assassins, and Afghan opposition forces are expected to release documentary evidence within days concerning their recent movements in Britain.

"All the leads point back to the UK, unfortunately," one foreign diplomat in Dushanbe said.

"The (wo men llew from
London to Pakistan before moving on to Afghanistan. They spoke very good English and from what we know so far both lived in Britain and were members of a fundamentalist organisation with links to Osama bin Laden coordinated by an Egyptian national who is outlawed in his own country."

The precise identities of the two men remain unknown. They are believed to be UK residents of Moroccan origin, who travelled to Afghanistan on stolen Belgian passports. Their operation was. the biggest single blow to the Afghan opposition forces fighting the Taleban. 


\title{
The Nation
}

\author{
SEPTEMBER 27, 2001
}

\section{Taliban replace Khost governor}

From Shamim Shahid

PESHAWAR - in a bid to crush a possible revolt by the supporters and loyalists of former King /alhi Shah, the Taliban authorities have made a major reshuffle and replaced the Governor of Khost Province Gul Agha with Maulvi Abdul Qayum.

In the new reshuffle well-known military commander Jalal-ud-D in Haqani has also been assigned the responsibility to go for early defence measures to foil aggression against Afghanistan. In addition, Maulvi Abdul Haleem hais also been made in charge of internal security.

In the wake of the Taliban's refusal to extradite Osama bin Laden to the United States, the local people, mostly loyal to former King Zahir Shah, are calling for ouster of the 'non-Afghan' Taliban from the region. Khost is near the Pak-Afghan border and North Waziristan Agency of the tribal belt. Earlier, it was headquarter of Paktia province. A majority of the tribesmen from this province are known for their opposition to the Taliban and support and loyalty to former King Zahir Shah.

Though Taliban authorities contradict such an uprising, independent sources from Miranshah, headquarter of North Waziristan Agency, reveal that the King loyalists have succeeded in forcing the Taliban to shift the migrants to other! parts of the country. However, sensing gravity of the situation, the : Taliban authorities went for an early reshuffle.

\section{Food aids to reach in few days UN staff allowed limited links in Herat}

\author{
By Cilocia Zaidi.
}

ISLAMABAD -.. The Taliban administration has allowed the international staff of the United $\mathrm{Na}$ tions to establish limited radio communication with the locai stati in Herat under its own monitoring system.

Stephanic Bunker, the Spolkesperson of United Nations Office for Coordination of Humanitarian Assistance to Afghanistan (UNHOCA), at a Press briefing here on Wednesday, communication could not prove positive results as the messages are being properly conveyed to the staff concerned.

Regarding the food assistance. she informed that food supplies are coming to Afghanistan from different countries. So far, Britain has donated 50 million Pounds to UN agencies and Red Cross for relief assistance for Afghanistan refugees. Australia has also donated 14 million Australian Dollars, Sweden has paid five million dollars," Canada one million dollars, Saudi Arabia five million dollars and $\mathrm{EU}$ has donated four million dollars for the relief activities.

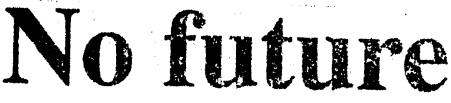
govt can

\section{against Pakistan}

PESHAWAR - Shura-i-Tafahum Milli Afghanistan, an alliance of 55 different bodies and forums, while announcing support to the world community particularly United States and Pakistan against terrorism has suggested early formation of an acceptable interim government in Afghanistan with a view to handle the situation at this crucial stage.

"We believe that problem The problem could be solved couldn't be resolved through war.
Stephanic said that the UN agenemergency and medicines, health services, water and sanitation, shelter, and other non-fiond relief items. crisis has decpened, at the dwindling grip of survival of the refugees is slipping out of hand. The UN agencies fear that if the situation persists and they are unable to move food and oher aid supplies lo the people, starvation may occur.

Stephanie Bunker also said that Afghans are fleeing the country facing great difficulty in crossing the international borders, as all the borders of neighbouring cnuntries of Afghanistan remain elosed.

"UN Secretary General Kofi Annan has called for keeping the international borders neighbouring Afghanistan open to let refugees enter," said Eric Falt, the Director of United Nations Information Center, who was also present on the occasion to brief the journalists about the current situation inside Afghanistan. cies will be noeding assistance in food.

She said that the humanitarian
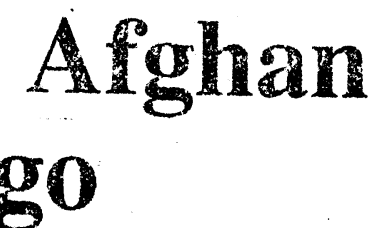

whenever an acceptable government is formed in Afghanistan," President Shura-i-Tafahum Haji Hayat Ullah remarked while addressing a Press conference at a local hotel here on Wednesday. Shura-i-Tafathum Milli expressed satisfaction over the initiatives of UNO Secretary General Special representative for Afghanistan Francis Venderrel for formation of a broad-based government.

Commenting on the reported return of former king Zahir Shah, 
Haji Hayat Ullah said, "we hope present efforts to rescue the help-

less Afghan people from the 23year war of attrition will be fruitful. The peace-loving Afghans, politicians, tribal elders and social workers assure government of Pakistan and President Gen: Pervez Musharraf of their support. We praise the timely decision of Gen. Musharraf about fight against international terrorism and work together with world community for uprooting terrorism," he remarked.

He said that for the last two and half a decades Afghans have been deprived of their just right of self determination and it is the need of hour that an interim government according to wishes and expectations of the people is formed. And formation of such a government is possible only through mutual understanding and consultation. In this respect, he called upon Pakistan to let the Afghan leadership from all over the world, particularly former King Zahir Shah to. assemble here for building up consensus amongst them about the future setup. When diverted attention towards reports pertaining to

Islamabad's opposition to former king Zahir Shah, Haji Hayat Ullah said, "forget the past". Elaborating his point of view, he said, in the light of Pakistan's long assistance and help to Afghans, it would be very difficult for the future governments of Afghanistan to go against Islamabad. He said that there is no more era of cold war. It is an era of international economy and they are hopeful that friendly governments in Kabul and Islamabad could emerge as a powerful economic block in the region. He added that not only former king but almost all of his supporters and followers are very grateful to $\mathrm{Pa}$ kistan for extending hospitality and protection to millions of Afghans.Answering another question, Haji Hayat Ullah said that each and every person is opposing aggression against their motherland. But at the same time he made it clear that they would not support Taliban in any case as they have not only deprived the Afghans of their just right of self determination.

\section{Backing the wrong horse in Afghanistan?}

PAKISTAN has done well to caution the world against the hazards of arming the Northern Alliance. The warning came from Foreign Minister Abdul Sattar, who said Pakistan was concerned about reports that some Afghan groups, including the Northern. Alliance, were asking the US for military assistance. Any decision to arm them, he said, would be a recipe for disaster, plunging the country deeper into factional warfare and adding to the suffering of the Afghan people. Given history and its geographical location, Pakistan knows Afghanistan the way no other country does. For the last two decades especially Pakistan has been closely involved with happenings in Afghanistan, particularly during the Soviet occupation and the Afghan people's epic struggle for freedom. In the post-Soviet period also, Pakistan not only watched but also got involved in the in-fighting among Afghan factions for power. This vicious fratricide has resulted in the deaths of hundreds of thousands of Afghans. Millions have fled their homes and sought refuge in neighbouring countries, mostly in Pakistan. The Northern Alliance came into being after the Taliban captured Kabul and, then, imposed a harsh brand of theocracy on their people. The Northern Alliance since then has waged a relentless struggle to recapture Kabul, in the process causing widespread death and destruction.

The Sept 11 terror attacks in New York and Washington and the American resolve to punish the Taliban government for harbouring Osama bin Laden, 'the prime suspect', seem to have given the Northern Alliance a fresh opportunity for a renewed bid for power. Now they expect the US to give them military help on a massive scale so that they can defeat and, dislodge their idy yer. saries. However, doing so would be a great mistake. The Northern Alliance is seeking power for reasons of self-vindication and for no higher purpose. They think that they were the ones who had waged the jihad against the Soviets and won and, therefore, it is they who are the legitimate rulers of Afghanistan. This view, however, is not shared by all sections of Afghanistan's polyglot population.

A US-supported Northern Alliance back in power would hardly be in a position to bring peace and stability to the country. At present, it is receiving military aid from a number of countries, including India, even though it has no border with that country. What prompted New Delhi to aid the Northern Alliance was Pakistan's close relationship with the Taliban. If the Northern Alliance comes to power, it is unlikely to maintain a neutral posture vis-avis its neighbours, especially Pakistan. This could lead to further instability and bloodshed. The US would, thus, be making a great mistake if it tried to instal the revengeseeking Alliance in power in Kabul.

The best solution for the world community is to have a neutral and peaceful Afghanistan, and this will be possible only when the US regards its campaign less a national retaliatory move and 
The NewS International, Friday, September 28, 2001

\section{Zahir Shah is king of currencies}

more a UN-led international campaign. As Mr Kofi Annan told the UN General Assembly on Monday, any rash action that the world could not understand would be wrong and that only the UN could give global legitimacy to a "long-term struggle against terrorism." The retaliation against the terror attacks, he said, should not make the international community oblivious to its other responsibilities - cooperation and partnership. Placed as Afghanistan is, there is no other solution except that the country should have a broadbased government acceptable to all of Afghanistan's factions and tribes and to all of Afghanistan's neighbours. Any government lacking such a broad-based and neutral

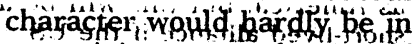
a position to make itself acceptable to the people and have friendly relations with Afghanistan's neighbours. The last thing Afghanistan needs is a partisan and factional government in power in Kabul.

\section{Tribals urge Taliban to expel Arab families 1... Bureau Report "}

PESHAWAR: Taliban authorities are reported to be under extreme pressure from local population over the demands to expel Arab families residing in several provinces of Afghanistan amidst reports that about 50 Arab families have already been evicted from Sarobi district of Khost two days back.

Afghan tribesmen belonging to Mangal, Tanai, Zadran, Ismailkhel and Manduzi in Khost, tribal elders told The News, have forwarded the demand to Taliban administrations in Khost and Paktia to ask the Arabs to move from these provinces. Locals belonging to Tanai tribe informed that the tribal jirga has decided that their support to Taliban government would be conditional to the expulsion of Arabs from the area, as the Afghans could not further US strikes against the unarmed population because of foreigners.

Taliban officials deny the reports saying the situation was under complete control of the government and the local shooras are fully supporting the Islamic Emirate of Afghanistan.

Afghans closing monitoring the situation in the border provinces of Afghanistan believe that reports about eviction of the Arab families could be a tactic to convey the message that resorting to possible air strikes against the population would carry no justification, as the unwanted persons have already been asked to leave the area. Similar reports have been received from Paktia and Nangarhar provinces, where tribesmen have asked the Taliban administration to shift these Arabs to places outside the populated areas and cities to minimize chances of the possible air strikes against them.

Taliban leadership, mindful of the ongoing developments, locals said have sent three different delegations comprised religious scholars, commanders and tribal chieftains to different parts of the country aimed at approaching the local population to seek their support against the onslaught of the Northern Alliance and in the event of the possible US attacks.

A delegation comprising Maulavi Jalaluddin Haqani, Maulavi Arsala, Maulavi Khalilullah, Maulavi Farid and Wahidyar has been sent to meet tribal elders and ulema in Paktia, Paktika and Khost while another delegation led by Maulavi Najibullah Haqani, Kiramatullah Akhunzada and a shi'it leader, Ayatollah Taqadusi has been assigned to meet elders and tribal chieftains in Wardag, Zabul and Ghanzi to ask the people for support of Taliban government. Another delegation is believed to be in Pakistan these days meeting former mujahideen commanders in Kohat to muster their support.
PESHAWAR: Mohammad Zahir Shah may be the ex-king of Afghanistan, but he was still the king of the currencies on Thursday as the war-ravaged country experienced the latest in a string of crises.

Rumours that the ageing former monarch might have a role to play in any change of government in his homeland has boosted the afghani currency, especially the rate for rarely used bills printed during his reign that carry his picture.

"Rates have been improving because people think the king will do something," said money changer Haji Mohammad Rafi.

"There is a 100 percent premium on the Shah money, but it is not used much any more because there are so few bills left," said Rafi, who has been trading money for 14 years in NWFP and trading hub of Peshawar.

The beleaguered currency fell to 78,500 to one US dollar shortly after the attacks on New York and Washington, but had recovered by Wednesday to about 55,000 to 60,000 , near levels it was trading at before the attacks.

Bills that carry the king's picture are rare because none have been printed in decades. And with the biggest denomination note just 1,000 afghanis, the bill is scarcely practical when a stack would be needed to buy just one dollar.

But Khan said dealers were also worried because afghanis are printed in Russia, a throwback to the decade-long Soviet invasion, and are used to fund the opposition Northern Alliance.

The money is smuggled from opposition areas through the north of Pakistan to Peshawar, where the bills - usually in denominations of 5,000 and 10,000 - then enter circulation in Afghanistan.

Rafi said a money transfer system to Afghanistan, which does not have a functioning banking system, was still in place, and he could send money to almost any city in the country.

The money is handed over in Peshawar, and Rafi makes a call to Kabul where the same currency or the equivalent in afghanis or Pakistani rupees is handed over to the recipient - a system known as hawala. He sends about $\$ 3,000$ worth a day, a huge amount considering a teacher in Kabul may be paid only $\$ 8$ a month. - Reuters 


\section{Zahir Shah ready to return: Vendrell}

\section{Naveed Ahmad}

ISLAMABAD: The United Nations Special Representative for Afghanistan, Francesc Vendrell, Thursday said former king Zahir Shah is willing to do his best for the people.

Addressing a press conference, however, he was of the opinion the Taliban movement could play a role in any future government in Afghanistan.

Vendrell, who recently met Zahir Shah in Rome, said the former king is in good health and willing to do his best for the people.

Vendrell said he has seen great support for Zahir Shah inside Afghanistan as well as in areas like Quetta and Peshawar.

When asked about the future role of Taliban he said, "There is a role for everybody in Afghanistan. In due course there must some role for Taliban with the backing of the people. There are Taliban I know that are decent people who had an honest dialogue."

He also noted that help from many countries would require uniting the Afghans and not doing the opposite.

To another question, he said, "The Taliban may control about $90 \%$ of the area but this does not mean that they have $90 \%$ support".
He made it clear that 'the time has come to apply the principal of territorial conquest is not the basis of distribution of power.'

Vendrell, who is also the UN Assistant Secretary General, said the international community has been asking the UN to play a pro-active role before the worst is happened. "The UN in turn requires the cooperation of the member states, so that we could work as the coordinator of various efforts," he explained.

He also called upon the international community to set for itself clear objectives in Afghanistan and move to through a strategy that would achieve these aims.

To a question Vendrell said: "The time of negotiations with Taliban is passed".

He explained: "The secretary general is barred by the resolution of the security council and general assembly. He has condemned terrorism at the same time saying that this must not be seen as an excuse for attacking some country.

He said the Security Council unanimously simply sent one message to the Taliban surrender bin Laden and disassemble its network. He lauded Ahmad Shah Masood as major figure. "His assassination is a national and international tragedy. He had a major role to play," Ven- drell remarked.

Vendrell observed, "The next weeks will be hard for the people of Afghanistan already victims of 22 years of conflict. Now the international community approaches the Afghan people as partners in its struggle towards terrorism.

The security council has joined the secretary general in condemning the terrorist attacks and has unanimously voted to support actions against those responsible as well as against the states who harbour it, he recalled.

Both the UN bodies and the secretary general want a political settlement of Afghanistan and for the establishment of a broad-based and truly representative government, said the UN assistant secretary general.

He also remarked that only such a government would have the capacity to meet the aspirations of the various ethnic and religious groups that comprise the Afghan nation.

Earlier, UNOCHA Spokesperson Stephanie said unlike the rest of Afghanistan, there has been no internal displacement in eastern Afghanistan, and NGOs and United Nations are operating there as normal. "This is the only area where the international staff is not only present but also likely to increase in the coming days," she explained.

\section{Osama delivered Shura edict: Zaeef}

ISLAMABAD: Osama bin Laden has been delivered Ulema Council's decisions after approval by Supreme leader Mulla Mohammad Omar, Taliban Ambassador to Pakistan Mulla Abdul Salam Zaeef said.

The council had proposed to the Taliban leadership to convince Osama to voluntarily leave Afghanistan and choose another place to live.

Zaeef in his press conference a few days ago said Osama had been missing and the council's decisions could not be communicated to him. The US was quick to describe the Taliban claim as laughable.

"Osama has now received the ulema council's recommendations and their endorsement by Amir-ulMomineen (leader of faithful)," Zaeef told NNI in an exclusive in- terview in Islamabad.

Asked about his earlier statement that Osama has been missing, he said, "We have not lost Osama but he is out of sight of the people."

Questioned if Taliban are willing to enter into some sort of compromise on Osama to avert war, the Taliban ambassador said, "No. It has not been tradition of Muslims to compromise."

To a question about the attack on the American embassy in Kabul, he said, "The people are very emotional and angry because the United States is sounding threats to attack Afghanistan. The Taliban security forces tried their best to stop the mob but failed to control the largely attended demonstration."
He claimed that the Kabul antiUS rally was attended by 200,000 people. When asked about the Taliban defence minister statement about the mobilization of fighters, the Taliban envoy said that 300,000 people have voluntarily offered to wage jihad against the United States. "But it is not only 300,000 people, the whole nation is ready for jihad," Zaeef said.

"Every man and woman is ready to wage jihad. All the people are mujahideen. They are soldiers. They are well-trained," he said. The envoy said Taliban do not want war as it will be extra-burden on the Afghans adding that war will add to the difficulties and miseries of the war-weary Afghans. "But if war is imposed on us, we will have to fight back." -NNI 


\section{Afghan govt can't be made from outside}

\section{Pakistan, United States for a broad-based set-up}

\begin{abstract}
Amir Mateen
WASHINGTON: The United States has said it has "very continuous contacts" with Pakistan as both countries agree "that Afghanistan needs a broad-based and representative government,.....and that government can't be made up from the outside."

State Department spokesman said on Thursday that the US shared "the goal with Pakistan of ending the use of Afghanistan as a safe haven for terrorists." The spokesman parried the tongue-incheek question that if Pakistan believed it required a similar broadbased representative government.

He once again clarified that it had never been "our view to make the government - to decide on the government of Afghanistan." US officials also sounded a cautious note about plans to bolster Northern Alliance and acknowledged the seriousness of Islamabad.
\end{abstract}

A State Department official said meaningfully the administration hopes to foster an Afghan opposition front far broader than the Northern Alliance that would also

include dissident commanders within the Taliban movement. "It's a new world for us and the Pakistanis, the Indians and the Afghans. It will require some new thinking, which is still developing," the official said.

He said the US were in touch with a wide variety of Afghan groups and factions that were involved in the situation inside Afghanistan, as well as exiled groups and other interested parties on the subject of Afghanistan. "We have had some contact with the Northern Alliance. We have had contact with former King Zahir Shah in Rome. And we have had contact with others. We keep in touch with various factions inside Afghanistan, as well as people outside the country who care."

The decision for US attack on Afghanistan seems to have been delayed, if not cancelled, as top US officials said on Thursday that "a military strike against Osama bin Laden and his supporters in Afghanistan is not imminent".

Deputy Defence Secretary Paul D. Wolfowitz's statement issued at NATO headquarters in Brussels, released simultaneously in Wash-

ington, was interpreted by local media as a clear indication of the Bush administration backing off from immediate military strikes in Afghanistan.

"I think it can't be stressed enough that everybody who is waiting for military action ... needs to rethink this thing," Wolfitz said while citing the need to gain better intelligence before any strikes against Osama and his alleged camps. "If we need collective action, we will ask for it. We don't anticipate that for the moment," he was quoted as saying.

In the face of scepticism from NATO allies over going to war without establishing evidence against Osama bin Laden, the Bush administration said that military operations would not be the "primary piece" of its campaign.

A Pentagon official told reporters that the United States would ask the alliance for logistical, intelligence and other support, but "the military piece is not the primary piece."

The harsh criticism by NATO allies may have contributed to the postponement decision already being contemplated because of larger consequences of a rash military strike and insufficient intelligence about Osama's whereabouts.

Reports from the meeting of NATO defence ministers suggest
European states pressed for, but did not get, a detailed showing of evidence that would justify any attack on Osama bin Laden's Al Qaeda network in Afghanistan.

After Secretary of State Colin Powell's statement last Sunday that the government would "put before the world, the American people, a persuasive case," NATO allies were frustrated over not getting the much touted white paper.

Rudolf Scharping, the German defence minister, bluntly said he expected the American side to arrive with a "white paper" spelling out the evidence connecting terrorist acts to Al Qaeda.

The New York Times acknowledged that the US allies had been led to expect more. Similar remarks by Defence Secretary Donald $\mathrm{H}$. Rumsfeld indicate that the administration will be taking "a more deliberate approach in launching a military campaign against bin Laden and the Taliban."

After the initial euphoria caused by Bush's aggressive stance adopted in his address the US Congress, the US administration is now talking about needing "time and a coalition." Expectations had been raised by a steady buildup of American troops and aircraft in the Persian Gulf and elsewhere. While hundreds of US warplanes stay alert in the region, the Bush administration is now headed towards a 'go-slow approach'.

The US officials openly confessed about lowering expectations for a major military campaign. "In this campaign, it's worth emphasizing one of the most important things is to acquire more information about an enemy, one of whose principal means of operation is to hide and conceal," Wolfowitz said. "That is one of the reasons why it is not so 
easy to lay out a specific campaign plan and lots of specific actions and why many of the most important things that we are asking for are being done in the intelligence channels."

US officials also said the administration has adopted a methodical approach because it wants to avoid an action that badly misfires, such as the botched attempt to rescue American hostages held by Iran in 1980 .

Another Defence official said that "the military won't play the most important part of the campaign against terrorism. "It isn't exclusively military," he was quoted as saying by ABC TV network. "It isn't even primarily military. Even when military action is taken one of the major objectives of that action will be to get more information" - that is, to gather additional intelligence.

After the delayed policy, US planners on TV networks were found expressing frustration about the unattractive array of military options in war-torn Afghanistan, where destitute refugees were in flight toward the sealed borders of Iran and Pakistan. "The people of Afghanistan are already beginning to suffer the humanitarian consequences from this - just in anticipation of events," a senior Pentagon official said.

The Washington Post reports that Wolfowitz provided an overview of the administration's case against Mr. bin Laden, but did not go into detail, officials said. It said the desire of NATO ministers for more evidence caused tension. The NATO secretary general, Lord Robertson, came to US rescue, asking whether it was even necessary for "an ally to produce evidence."

\section{Ulema team visits Kandahar today}

\section{Shakil Shaikh}

ISLAMABAD: A 10-member Ulema and Mushaikh (religious scholars) delegation from Pakistan will proceed to Kandahar early Friday morning as a "goodwill mission" and to exchange views with Taliban supreme leader Mulla Mohammad Umar and other leaders.

"A special flight will be operated from Islamabad to Kandahar on early Friday," a senior official told The News Thursday.

Some senior officials are also expected to accompany this 10 member Ulema and Mushaikh Mission (UMM), which will convince the Taliban leadership on many counts and to present sug. gestions to resolve the present crisis.

The mission will comprise

Mufti Salimullah, Mufti Taqi Usmani, Mufti Nizamuddin Shamzai, Mufti Mohammad Jamil, Maulana Fazale Rahim, Maulana Abdul Ghani, Qari Mufti Sher Ali Shah, Maulana Mohammad Hassan Jan and Maulana Haji Abdul Rehman.

"They would be exchanging views with Taliban leadership for resolving the crisis in a best possible way," said a senior official. He confirmed that more similar delegations from Pakistan would be sent to Kandahar for talks with Taliban leadership so that the crisis could be resolved.

"I do not see that the Pakistani ulema and mushaikh delegation would be carrying with them a charter of demands to be presented before Mulla Umar, as it is just a goodwill mission for exchanging views with the Taliban leadership," said the senior official.

This is second delegation, following the one official delegation led by Director-General ISI Lt. Gen. Mehmood which visited Kan- dahar and Kabul in the early days of the present crisis, Pakistan is sending to isolated Afghanistan.

Presently, all the countries except Pakistan has broken off its diplomatic ties with Taliban gov-

ernment in Afghanistan, though Pakistan has also withdrawn its diplomatic staff from Afghanistan. Recently, Saudi Arabia and United Arab Emirates have broken off ties with Taliban government, but Pakistan is keeping the world's contact with Taliban open as it is not shutting off the lone window.

Taliban are also under pressure because of Northern Alliance' gains, as these forces are now fully ready to launch attack on Kabul within a week's time.

Earliar reports say that Qazi Hussain Ahmed, Maulana Samiul Haq, and people like Maulana Fazalur Rehman would be going to Kan-

dahar as part of present Pakistani endeavour to resolve the complex crisis. All the three top religious leaders have gone to Karachi Thursday evening flight, and it seems there is no chance of any one of them going to Kandahar this week.

"These top religious parties have not yielded good response from the people, and they are under pressure," said one politician.

Senior officials do not even rule out the possibility of sending a series of other delegations including leaders of religio-political parties. Pakistan has launched these efforts in a bid to sincerely pursue a goal of resolving the crisis peacefully. 


\title{
The Frontier Post
}

\author{
Friday, September 28, 2001:
}

\section{Taliban militia marks five years in power}

ISLAMABAD (Agencies): Afghanistan's ruling Taliban notched up five years in power on Thursday with defiant messages from their leader in the face of an anticipated US-led retaliatory strike.

As Washington kept any military plans under wraps and took its broader anti-terrorism. campaign to the United Nations, Mullah Mohammad Omar warned Afghans of the perils of colliborating with the United States to win power.

Away from the debate about who did what on September 11 , aid agencies in Pakistan and Iran prepared for a fresh exodus of frightened and hungry. Afghan refugees fleeing the combined ravages of war and drought -- and the approach of winter.

Mullah Omar has repeatedly dismissed attempts by Bush's administration to link the Taliban and bin Laden to the suicide hijacking attacks that killed up to 7,000 people.

On Thursday, he warned that any Afghan who used US help to try to take power would face the same fate as collaborators during their country's war against the Soviet Union in the 1980s.

"In case of intervention into Afghanistan, no differ ence will be made between America and Russia and those Afghans. who are brought in by the Americans will be treated like those who were brought in by the communists," he said in a statement.

Five years ago to the day the Taliban swept into Kabul and hanged Najibullah, the former Soviet-installed president, after dragging him from a UN building and hanged him.

The United States and its main ally Britain have told the Taliban they must hand over bin Laden. The Taliban deny any knowledge of his current whereabouts.

"America has no reason, justification or evidence for attacking," Mullah Omar said in a statement on Wednesday, playing down prospects of a US strike and instructing all Afghans who had fled to return to their homes.

In Indonesia, the world's largest Muslim nation, the head of a leading Islamic group said that Washington ran the risk of triggering a war between Islam and Christianity.

$\because$ Proving the evidence is important to distinguishing which is Islam and which is terrorism," Hasyim Muzadi, who leads Indonesia's 40- million strong Nahdlatul Ulama, told media in an interview. After it can be proven, attack the terrorists."

Muzadi, who heads the largest and more moderate of Indonesia's two main Muslim groups, was echoing a view heard from nations and groups across the Muslim world.

In another part of town. the Islamic. Youth Movement, a hardline Indonesian group which says hundreds of its : followers have signed up for a possible war against the United States, warned anyone backing the United States to leave the country.

Outside the heavily guarded US embassy in Jakarta, several hundred protesters from another group burned: the US and Israeli flags in the latest daily outburst of anti-US passions

Aid workers say up to 1.5 million Afghans could flee to Iran and Pakistan, swelling the Afghan refugee. population -- already the world's largest - to around five million.

The UN Office of Humanitarian Assistance: predicts that 7.5 million Afghars inside the country . - out of a population of 20 million - will need outside assistance to survive the? winter. 


\section{The Frontier Post}

Friday, September 28, 2001

\section{NA hails foreign aid, says no to monarchy}

TEHRAN (Agencies): Afghan opposition foreign affairs spokesman Dr Abdullah said there was no question of a retum to the monarchy in Afghanistan and welcomed foreign aid to help end the ruling Taliban militia's hostilities, a newspaper reported Thursday.

"There is no question of a return to the monarchy," Abdullah told the Iranian newspaper in an interview. "We will not oppose outside contributions to end hostilities in Afghanistan if it will entrust the future of the nation to the public," he said.

There is no obstacle to prominent personalities asserting an influence towards the peace effort, but the fate of the nation must be determined by the representatives of the Afghan nation, he said.

According to Abdullah, the Afghan opposition had "contacts with the United States which focus on their imminent attack on terrorist bases" in Afghanistan, which Washington says is harbouring Osama bin Laden.

Abdullah also welcomed the prospect of what the Afghans' call a Loya Jirga if it embraces the concept of confiding the future of the country to the representatives of the country. A Loya Jirga is a general assembly of chiefs and elders.

Afghanistan's Northern Alliance has sent a delegation to Rome to meet with deposed Afghan king Zahir Shah to discuss convening a Loya Jirga with all ethnic groups that would appoint a provisional government.

Zahir Shah, 86, has called for a Loya Jirga chiefs' assembly to elect a new head of state and establish a transitional government for Afghanistan.

The ex-king, interviewed by the Arabic-language daily Asharq al-Awsat, said he supported US military action against the Taliban and that he was prepared to return to Afghanistan to "unify its peo.ple."
In an interview, Zahir Shah said he would view US troops as friendly forces who have no bad intentions and who want to aid iny people to free itself from the yok. of obscurantism and ti Torisni, as was the case in France in thie Second World War.

\section{Zahir Shah backs strike on Taliban}

\section{DUBAI : (Agencies):} Afghanistan's exiled king said in remarks published on Thursday that he would support a foreign military attack to rid his homeland of the ruling Taliban movement, which he described as a foreign occupation power.

He also said that he expected to return to Afghanistan, but not to claim titles or power.

"Afghanistan today is in a situation similar to that of France under occupation. Those who will come to help and liberate us are our friends and they will eventually support a government that will represent the people," Mohammed Zahir Shah told the London-based pan-Arab Ashraq al-Awsat newspaper.

The 86-year-old furmer monarch, who has lived in exile in Italy since 1973, said it was no longer a question of whether he would return to Afghanistan.

\section{The Statesman}

Friday, September 28, 200 t.

Moin rules out joining war against Kabul

KARACHI: Interior Minister Moinuddin Haider Thursday reiterated Pakistan's stance that its forces would not participate in any "ground attack" against Afghanistan, adding that Pakistan would side with the international community against global terrorism.

"We have asked the US to target only those who are involved in terrorist attacks on New York and Washington," he said.

Addressing a seminar here, he said that Pakistan had also asked US to provide proofs against the alleged terrorists hiding in Afghanistan.

He said that Taliban should understand Pakistan's sensitive position in current circumstances, as the Pakistani nation had already suffered a lot because of Afghanistan crisis.

"Afghanistan is our friendly Muslim country. We have done a lot for our Afghan brethren, but now at this critical juncture they should also help us. They should think that we are trying to save the whole Afghan nation," the minister said. - Agencies

\section{Angelina Jolie donates $\$ 1 \mathrm{~m}$ to Afghan refugees \\ GENEVA: US actress} Angelina Jolie, recently appointed goodwill ambassador for the UNHCR, is donating one million dollars to ease the suffering of Afghan refugees, the UNHCR said Thursday.

The contribution of the Acadeny Award-winning actress was the first private donation since the UNHCR launched anappeal on Wednesday for donors to provide 252 million dollars to deal with the growing Afghan refugee crisis. UNHCR head Fuud Lubbers praised Jolie's sense of "humanitarian responsibility" which she exhibited "despite the trauma of recent events in her country." - AFP 


\title{
The Statesman
}

\author{
Friday, September 28, 2001
}

\section{Taliban invite Jackson to lead peace panel to Pakistan}

WASHINGTON:

Jesse Jackson says Afghanistan's ruling Taliban militia has asked him to lead a "peace delegation" to the region.

The civil rights activist said Wednesday he has not decided whether to accept and remains reluctant to do so. But he suggested he is open to making the trip if his involvement could prevent the deaths of innocent Afghan civilians during a U.S. military campaign against terrorism.

"We must weigh what this invitation means. We're not going to be precipitous," Jackson said. "If we can do something to encourage them to dismantle those terrorist bases, to choose to hand over the suspects and release the Christians rather than engage in a long bloody war, we'll encourage them to do so."

Jackson said he spoke with Secretary of State Colin Powell, who repeated the U.S. administration position that it will not negotiate with the Tàliban but did not urge Jackson not to go.

White House spokesman Ari Fleischer declined to comment. "I would just reiterate what the president has said, that he will not engage in any negotiations or discussions" with the Taliban, Fleischer said.

"Either the Taliban government is going to stand alone and take on this world pressure, or they are going to look for some graceful way out," Jackson said. "I hope that appealing to a peace delegation could be a bridge." - AFP

\section{King Zahir most appropriate man to lead Afghans: Vendrell}

\section{UN also sees a role for Taliban in new government}

\section{From Fida Hussain}

ISLAMABAD: The United Nations said Thursday it considered former Afghan king Zahir Shah as the most appropriate person to lead the broad-based interim government in Kabul, for which the world body is seeking help of the member countries.

"We consider the former Afghan monarch as the potential leader in his individual capacity to lead the multi-ethnic interim government in Afghanistan," chief of United Special Mission for Afghanistan (UNSMA), Frances Vendrell, said at UN regular press briefing.

However, he declined to comment whether the UN would extend full-fledged support to the ex-Afghan king but at the same time, vendrell said, "I heard few if none among the Afghans with any grudges against Zahir Shah. He added that in contrast I have heard a large number of Afghan people from time to time who support the ex- Afghan ruler."

Vendrell who has arrived here after his Europe and
America tour said the UN condemned the terrorist attacks in the US and shared concerns with Washington. However, he clarified that in retaliation the civilian must not be targeted.

"Any action sans the cooperation of Afghans will not work. The international community must take Afghans as partners in the likely actions against terrorists believed to be living in Afghanistan. The international community must not leave Afghan citizens down," he replied to a question.

He did not rule out the possibility of political reconciliation in Afghanistan. He opined that the UN secretary general was committed to bring about peace in Afghanistan and he had not lost the hope. In reply to a question he said, "Yes, the ruling Taliban must be a party in the efforts to seek political solution to the Afghan imbroglio." However, he maintained that the present rulers must not enjoy a special status in peace overture.

"Control over vast territory does not make sense of the Taliban militia to get legitimacy for its government in Kabul. People, not territory make a sense in the modern democratic era," he replied to another query.

The head of the UNSMA said he had no information about JC Jackson, whether or not he is in contact with the Taliban officials.

"No, we are still hopeful about reaching a political solution to the Afghan crisis. We are in regular contact with other states joined in the Afghan Support Group and the groups of six plus two countries, the US and Russian Federation," he said.

AFP adds: The United Nations sees a role for the Taliban in any new government arising out of the current crisis facing the country, UN special envoy to Afghanistan Francesc Vendrell said Thursday.

"There is a role for everyone in Afghanistan, but this role must have the backing of the Afghan people," Vendrell told reporters here.

"There are Taliban who are decent people, with whom I have been able to have an exchange of views," he said. 


\title{
The Nation FRIDAY, SEPTEMBER 28, 2001
}

\section{Saudi decision seen dampening Taliban support in Pakistan}

ISLAMABAD (AFP) - Saudi Arabia's decision to snap diplomatic ties with the Taliban is likely to dampen Pakistani religious party support for Afghanistan, analysts said.

'It may have an impact on forces opposed to any action against Afghanistan,' Khalid Mahmood, an analyst with the Institute of Strategic Studies in Islamabad said.

'Quite a few parties in Pakistan have regards for Saudi Arabia. If they dump the Taliban it will weaken the campaign of proTaliban forces.'

Mahmood said he believed the Saudi move would also have a 'psychological and political impact on the climate in the country where religinus forces have been saying it is a war

\section{Afghan Opp hails foreign 'contributions'}

TEHRAN (AFP) - Afghan opposition foreign affairs spokesman Abdullah Abdullah said there was 'no question of a return to the monarchy' in Afghanistan and welcomed foreign aid to help end the ruling Taliban 's 'hostilities,' a newspaper reported Thursday.

'There is no question of a return to the monarchy,' Abdullah told the English-language Iran News paper in an exclusive interview.

'We will not oppose outside contributions to end hostilities in Afghanistan if it will entrust the future of the nation to the public,' he said.

'There "is no obstacle to prominent personalities asserting an influence towards the peace effort, but the fate of the nation must be determined by the representatives of the Afghan nation,' Abdullah said.

According to Abdullah, the Afghan opposition had "contacts with the United States which focus on their imminent attack on terrorist bases' in Afghanistan, which Washington says is harbouring Osama bin Laden, the prime suspect in the September 11 attacks on the United States. between the Islamic world and infidels.' The Saudi decision, on Tuesday, comes after the failure of overt and covert efforts to extradite Osama bin Laden, described by one Saudi diplomat as a 'human monster.'

Officials said it may also give some relief to Pakistan President Pervez Musharraf who has announced unstinted support to the US in its fight against terrorism, despite opposition from radical Islamic groups.

'It means a lot,' a senior Pakistan government official said.

'The religious leaders in Pakistan cannot say we are better Muslims than the Saudis,' the official said on condition of anonymity.

Former foreign secretary Najmuddin Sheikh said with Saudi
Arabia snapping ties, 'moderate voices that may have supported the Taliban will diminish.'

It would have an impact on some parties but it might not have an impact on others who were closely associated with the Taliban, he said. Saudi Arabia enjoys an 'important place in Pakistan and the impact on the general public will be positive' given that they have more clearly identified Osama as a source of terrorism.

He said this would help remove concerns about a lack of evidence against Osama and his alleged involvement.

Political commentator M.A. Niazi said the move would not totally defuse the situation because opposition here to US action was due to domestic political compulsion.

\section{DAWN FRIDAY, SEPTEMBER 28, 2001}

\section{US warned against attacking Afghanistan}

\author{
By Our Correspondent
}

NOWSHERA, Sept 27: Protest demonstrations were held under the aegis of the PakistanAfghanistan Defence Council throughout the Nowshera district against the possible US strikes on Afghanistan.

A big protest rally led by Maulana Anwarul Haq and Maulana Hamidul Haq Haqqani was taken out from the Darul Uloom Haqqania, Akora Khattak.

Addressing the demonstrators, speakers pledged that they would never let the Zionist forces land in the country created in the name of Islam. They said that the Muslims would render sacrifices for the integrity

\section{and solidarity of Pakistan.}

Warning the American government against launching strikes on Afghanistan, they said that more than seven million people of the tribal areas had assured that they would wage Jihad against America if the helpless Muslim nation was attacked.

They said that the nefarious designs of Hindus and Israelis against Pakistan and Afghanistan would be frustrated at all cost. If Pakistan's airspace or soil was provided to the US forces for attacks against Afghanistan, the ulema and religious circles would target the present rulers of the country, they warned. 


\section{United Nations calls for interim}

\section{government}

\section{By M. Arshad Sharif}

ISLAMABAD, Sept 27: The United Nations has called for establishing a broad-based interim coalition government in Afghanistan in accordance with internationally recognised principles of pluralism.

Speaking at a Press conference here on Thursday, personal representative of the UN Secretary General Kofi Anan and Assistant Secretary General United Nations, Francesc Vendrell, said that territorial conquest is not the basis for rule. "Although 90 per cent of Afghanistan's territory is controlled by Taliban, it does not mean that they have 90 per cent support of the people." Majority of the Afghans are hostage in their own country, he said.

Vendrell said that the Security Council and the General Assembly have called for finding a political settlement of the Afghan crisis and estab. lishing a broad-based government there. The efforts of international community aimed at eradicating terrorism can succeed only if a broad-based government, having the capability of addressing the concerns of the global community, is established, he said.

Propounding possible solutions to the Afghan crisis, the UN Assistant Secretary General said that all Afghans should have a role in an interim, broadbased government. "During meetings with the former King Zahir Shah, I found him to be in good health and willing to work for the betterment of his people." UN feels that Zahir Shah has support of great many Afghans and very few speak out against him, Vendrell said, adding, he was the only Afghan ruler who did not harm the

\section{Afghans.}

In response to a question, Francesc Vendrell said that an international coordination, comprising the 6 plus 2 group, Afghan Support Group, UN Security Council and the UN Secretary General are focusing on finding a concerted political solution to Afghanistan's issue. He said that no group can claim legitimacy on the basis of territorial conquests alone unless a Loya Jirga is held.

The international community has been asked to find a proactive solution to the problem. In this connection, UN officials have held a number of meetings with the Russians, Americans and the Pakistanis and alignment of forces both nationally and internationally is on the cards, he said.

Refuting the allegations that the UN Secretary General is biased in favour of the United States, Vendrell said that the secretary general is bound by the wishes of the Security Council but it should not be seen as bias on the part of the Secretary General. He said that the matter of proof against Osama is not a matter of the UN.

Replying to a question about Taliban's latest offer of negotiations, the UN assistant secretary general said he was unaware whether or not Taliban had asked anyone to negotiate. Moreover, he said, "the time for negotiations on the issue of bin Ladin and Al-Qaeda has passed."

In response to another question about a hypothetical postTaliban scenario, Vendrell said that as soon as peace was established in Afghanistan, a massive economic development plan must be implemented to give hope to the Afghan people.

\section{Afghan anti-mine efforts in danger}

\section{By Thalif Deen}

UNITED NATIONS: Efforts to rid Afghanistan of millions of landmines are being disrupted and risk being reversed as the country girds for US military attacks.

Many of the anti-personnel explosive devices date back more than 20 years and are scattered about the harsh terrain in such numbers that Afghanistan is believed to be the most heavily mined country on earth.

Several international groups and countless Afghans have been striving since 1989 under UN auspices to find and remove the landmines. The organisations include the Danish Demining Group, Mine Detection Dog Centre, and HALO Trust.

Working as part of the UN Mine Action Programme in Afghanistan, the world's oldest and largest undertaking of this kind, they have cleared more than 1.6 million explosives from former battlefields, agricultural lands, roads and residential areas.

Mark Hiznay of Human Rights Watch (HRW) says Afghan nationals did most of the actual clearance under the supervision of international advisers. These are now being withdrawn from the country, along with UN personnel and most other international aid workers.

Some 10 million mines were sown during the Soviet occupation of the 1980 s alone. In recent years, the Taliban and its main rival, the Northern Alliance, have accused each other of laying new landmines.

If US ground forces are sent into Afghanistan, the landmines will be among the biggest hazards they face. Martin Barber, head of the UN Mine Action Service, says more than 3,000 Afghan nationals were involved in the daunting task of clearing landmines. They were capable 


\section{THE PAKISTAN TIMES}

Friday, September 28, 2001

of continuing with their work, he said, despite the absence of international staff. Whether they would be permitted to is another matter.

According to UN officials, landmines and unexploded ordnance cover about 724 million square metres of land in Afghanistan. Some 344 million square metres are classified ás high priority land for clearance.

The latest annual "Landmine Monitor Report 2001", published by the International Campaign to Ban Landmines, says that mined areas are still being discovered at the rate of 12 to 14 million square metres per year.

If current funding levels and clearance rates are sustained, it will take seven to 10 years to clear the 344 million square metres of high-priority land, according to a June 2001 socioeconomic survey of Afghanistan sponsored by the World Bank and the UN Development Programme.

The UN mine programme received about $\$ 173$ million for its work between 1991 and 2000. Washington has contributed about $\$ 25$ million since 1993. In addition, the non governmental UN Association of USA has raised some $\$ 620,000$ for its Adopt-a-Minefield Campaign, which covers 22 sites in Afghanistan. Since 1999, the association says, its programme has funded \$35 million worth of mine clearing work in Afghanistan, Cambodia, Croatia, Bosnia-Herzegovina and Mozambique

In 1993, an estimated 600 Afghans were killed or injured by landmines every month. By last year, the rate had fallen to between 150 and 300 per month. Nearly half of the victims died before reaching a medical facility, according to the monitor report. The office of the UN Coordinator for Afghanistan says landmines also have been a major obstacle to the return of refugees and internally displaced persons to their homes. It estimates that the devices have blocked access to about 87,500 houses. Dawn/InterPress Service.

\section{Omar warns US-backed government to face war}

ISLAMABAD: Taliban supreme leader Mullah Mohammad Omar on Thursday warned the United States it would suffer the same fate as the Soviet Union if it tries to impose a puppet government in Afghanistan, the Afghan Islamic Press reported.

"In the event of intervention in Afghanistan there will be no difference between Russia and America," he said in a statement released through the Pakistanbased private news agency.

"The status of Afghans who want to come to power in Afghanistan with the help of American forces will be the same as those Afghans who wanted to come to power with the help of the Russians.

"The Afghans brought by the
Americans would be fought like the communists."

Omar's broadside follows signals from the United States in recent days that it is in favour of a strategy of toppling the Taliban from within, rather than planning a massive attack on Afghanistan.

"We're not interested in making up the future government of Afghanistan; we're interested in getting the Taliban to stop providing safe haven for terrorists and ending the use of Afghanistan by terrorists," said State Department spokesman Richard Boucher.

"If the Taliban doesn't want to do that, they'll obviously suffer the consequences of that failure." - AFP

The News International, Saturday, September 29, 2001

\section{Taliban formally invite Jesse to Afghanistan}

\section{Carter may also join mediation}

\begin{abstract}
Fasihur Rehman Khan
LAHORE: The Afghan government has formally invited Rev Jesse Jackson to mediate between Taliban and the US government and has asked him to visit Afghanistan and meet "high ranking officials" there.
\end{abstract}

It has expressed the need to resolve issues between Afghanistan and America through peaceful means in the current critical situation, emphasising there "is more need for prudence, sagacity and patience to resolve issues", a letter sent by the Afghan Ambassador to Pakistan Mulla Abdus Salam Zaeef to Jackson here Friday night said.

Through the letter, Afghan ambassador has invited Rev Jesse Jackson to visit Afghanistan after a formal approval from the chief of Taliban Mulla Mohammad Omar on Friday.

The letter was faxed by the
Afghan Embassy to Jackson in Chicago USA on Friday night. Contents of the letter acquired by The News are as follows: USA.

"Rev Jesse Jackson, Chicago,

Based on resolve and recommendations of our common friends in the US and Mr Ijazul Haq, son of Shaheed Gen Ziaul Haq, for whom we have high regards.

I am pleased to extend to you invitation to visit Afghanistan and appreciate the peace initiative taken by you. In the current critical situation there is more need for prudence, sagacity and patience to resolve issues between Afghanistan and America through peaceful means. And we welcome your mediation to meet high ranking government officials in Afghanistan. 
The News International, Saturday, September 29, 2001

We believe it is through talks that sustainable solution can be reached. Availing the opportunity I wish you health and success assure of my best consideration.

Regards Mulla Abdus Salam Zaeef, Ambassador of the Isalamic Emirate of Afghanistan Islamabad."

Meanwhile, sources said Afghanistan may release the eight detained international aid workers as a good will gesture in case a non-governmental American delegation headed by Rev Jesse Jackson is able to visit Afghanistan.

Zaeef who was in Kandahar on Friday sought formal approval from Mulla Mohammad Omar. Pakistani politicians and leader of PML-QA Ijaz ul Haq played a key role in convincing Jesse and then the Afghan government to facilitate the visit.

Ijaz could also be part of the delegation which is to visit Afghanistan. Sources said some Pakistani-Americans headed by Dr Murtaza

Arain were actually behind the move to engage Jesse Jackson and other prominent Americans like former United States president Jimmy Carter to mediate in the present crisis and avert a showdown.

\section{Hikmatyar urges UN to save Afghans from US}

ISLAMABAD: Former Afghan foreign minister and chief of Hizb-eIslami Engineer Gulbadin Hikmatyar in a letter to the UN secretary general has urged the world body to save the Afghans from the arrogant approach of the United States.

Drawing attention of the Kofi Annan towards the impending crisis, Hikmatyar said that it seems that the Americans are bent upon attacking our country, paying little heed to the wishes of the international community against start of another war. He said that the views of the people of the US particularly the inhabitants of New York who are quite opposed to invasion of could not make the US government change its stand.

He maintained that statements emanating from Washington have made it clear that this attack is not a retaliatory act rather it is aimed at seeking revenge from those behind the incidents of New York and Washington. He said that he has sensed from the US plan that it wants to occupy and install puppet regime by over-throwing the incumbent government of the Taliban.

He went on to say that it is nothing but a plot by the Americans to cut China's access to Central Asian Republics. He said that American leaders have voiced their support for a campaign to overthrow the Taliban government and install in its like-minded secular government headed by the ousted king.

He warned that with this, the Americans would be repeating the follies likewise the leaders of the former Soviet Union who dispatched their troops to Afghanistan to install Babrak's puppet regime. He said that this folly by the Americans would undoubtedly, lead to a similar devastating war with all the miseries, trails and tribulation that it entails for the Afghans, the people of the region and the whole international community.

"The US has no right to attack our country sacrificing our people at the altar of its battered pride and revengeful ego. If the Americans are really after the people responsible for the incidents in New York and Washington they must put forth tangible and convincing proof against the links of suicide bombers with Osama and Taliban while in other case it has no right to implicate Osama and Taliban government in these suicide attacks," Hikmatyar added.

He said to identify the responsible elements and fight the international terrorism, the matter must be referred to a neutral international commission for investigation and identification of the saboteurs and then any antiterrorist action must be conducted under the supervision of the UN.

He feared that the Americans, on the contrary, want to seize this opportunity and derive maximum benefit form the prevalent atmosphere to launch the War of 21st century a "crusade" against all the opponents in which the Americans are forcing all the nations to blindly follow them or be dubbed as terrorists and wait for punishment.

"To perpetuate its rule of terror and hegemony over the entire world and strengthen its indirect colonisation of other nations controlling their political and economic destiny, USA has started mass mobilisation of its forces, sending warships and aircraft carriers to the region. Is it wise and prudent to blow the war trumpet calling in all the reserves and enlisting volunteers for defence of America just to punish an accused whom the Americans have failed to prove guilty?" He asked.

$\mathrm{He}$ 'said that it is astonishing and puts one in wonder as to what extent the Americans were ill-informed as they had no clue about the suicide attacks

He said, "It is astonishing to see that many countries, oblivious of the nature, objectives and dimensions of the Americans' operations have announced their unconditional support to them. Such countries should have learned a few lessons from the Gulf War experience. Don't they realize that the Americans have ulterior motives of controlling the whole world? Isn't their support tantamount to encouraging America to impose its will on others and punish whoever does not fall in the line with its policies at will? Don't these countries, particularly the neighbours of Afghanistan, realize that once the game is over, they will be left to grapple with the dark legacies of the war on their own, as it has happened in the past? Is it too much to demand from these countries and all the member nations of the UN to act in conformity with the UN charter and in. ternational norms of justice? How do these so-called champions of democracy, justice and equality discriminate against a particular people and participate in a campaign which is aimed at punishing an oppressed nation for sins they have not committed? Is it a campaign to eradicate 
terrorism or to perpetuate it? Hikmatyar questioned.

"We were also astounded to know that the personal envoy of a respectable international personality like Your Excellency acts as an advocate of America's provocative policies in the region, actively supporting the campaign to impose a pro-American puppet regime in Afghanistan and inciting Afghan groups and individuals to participate in the shameful plot of imposing the antiquated monarchy on the Afghans," the Afghan leader remarked.

He went on to say that Vendrel has been actively working for the return of the monarchy since his appointment as Your Excellency's personal envoy. "We don't think that your excellency would have assigned to him the duty of imposing a pro-American puppet regime on the people of Afghanistan and we cannot believe that a man of your state will approve of invading Afghanistan to overthrow a regime and install another through military intervention. Then, the question is that who has assigned this duty to your personal envoy? Doesn't your Excellency agree that your reputation will be seriously compromised if people think that you have been a party to this conspiracy? he claimed.

He said that it is now an open secret that many Afghans were told by Vendrell much before the incidents in New York and Washington, that the Americans were actively pursuing a military plan to overthrow Taliban and install Zahir Khan in their place. He said that for this purpose it used to encourage them that they must participate in the campaign and reserve place for themselves in the future set-up.

He claimed that this fact has also been substantiated by Niaz A Naik, a Pakistani diplomat, in his interview with $\mathrm{BBC}$ a week ago. He added that Naik disclosed that Vendrell had told the participants of a meeting some two months ago that a comprehensive military operation shall be launched be. fore the winter and probably in October by the Americans to replace Taliban with Zahir Shah.

He said that it is imperative that Your Excellency inquires from your personal envoy about the source of his information and the reasons of his active involvement in overthrowing a government at the behest of another country, which is in no way compatible with his duties. "We have a right to know why should your personal envoy support the American plot for imposing a mediaeval and outdated monarchy on the Afghans instead of working for establishment of an interim government acceptable for all Afghans to pave the way for free and fair elections," he said.

He maintained that if the UN, as a respectable forum, wants to play a positive and constructive role in solution of the Afghan crisis, it must distance itself from the provocative and war-mongering policies of America in the region. He said that it should throw all its weight behind establishing a national forum comprising all the peace-loving forces of Afghanistan that strive for restoration of peace and tranquillity in the war torn country through installing an elected government.

He elaborated that the decision of this forum should be defended in all international forums and all the neighbouring countries of Afghanistan and America and Russia should be asked to stop interfering in the internal affairs of Afghanistan, giving the Afghans a chance to iron out their differences without any pressure from outside.

The former Afghan premier said, "It is our earnest hope that the UN under your leadership will act swiftly and decisively to stop the unfolding of a horrible war and the consequent humanitarian crisis in our soil."

Gulbadin Hekmatyar has warned that the United States intended to launch a sudden attack on Afghanistan by showing lesser possibility of its military operations in that country.

The veteran Afghan told Radio Tehran that the Americans had prepared the plan for attacking Afghanistan three months ago. $\mathrm{He}$ added that the United States was continuing to send forces and military equipment to the region and this shows the possibility of a US attack in the coming days.-NNI

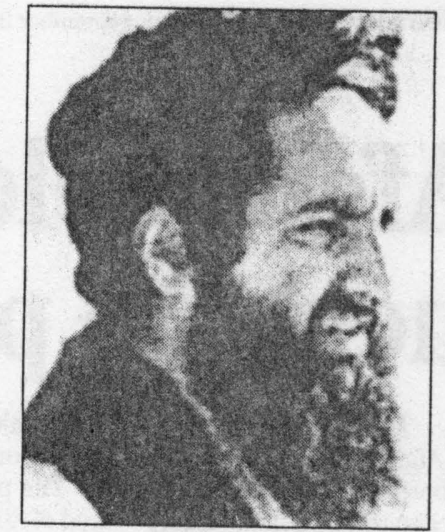

Taliban supreme leader Mulla Mohammad Omar

\section{Rallies held in Nangarhar against US attack threat}

\section{Bureau Report}

PESHAWAR: Protest rallies against the likely US attacks on Afghanistan were held on Friday throughout Nangarhar province.

Reports pouring in from Afghanistan said that speakers condemned terrorist attacks on the United States and showed sympathy with the American people. However, they warned Washington to refrain from attacking their homeland.

In case of attack on Afghanistan, they vowed to lay their lives for defence of the country. They reminded the Americans to look at the history of the Afghans who had humbled two world super powers - the United Kingdom and the Soviet Union - in the past.

They said that Islam was against every sort of terrorism and asked the western world not to blame Muslims for killing of innocent people. 


\section{Afghan elders gather in Quetta to plan new future}

QUETTA: Tribal leaders from southern Afghanistan gathered just over the border in Pakistan on Friday, their aim to write the obituary of Taliban rule and devise a new government for a land ravaged by war and clan rivalry.

"We are here to consult among ourselves and with our Afghan people here to find a way to resolve this matter peacefully," said one elder from Kandahar.

The daring meeting of about 20 elders - all hitherto Taliban allies at the home of a strong supporter of ex-King Zahir Shah was evidence of cracks opening up inside Afghanistan, which is under pressure from the United States to either to hand over Saudi-born fugitive Osama bin Laden or face the wrath of the world's most modern army.

Most of the elders are signatories to peace agreements with the Taliban, but do not necessarily support their hardline Islamic rule or sympathise with their leader Omar. Such treaties among the clans are essential for any government to maintain peace and power in Afghanistan, whose society is composed of a complex structure of tribes and sub-tribes held together by a web of traditions, values and codes of honour.

The elders did not rule out some role for members of the Taliban, although not for the hardline group in its current form or for Mulla Omar, in a future administration. They said their goal was to avoid war and bring lasting peace to a land shattered by more than 20 years of fighting, although they would take part in conflict if that was the only way to bring harmony.

"The people of Afghanistan are tired of 20 years of war, now all they want is peace with or without the Taliban," said Mohammad Akram, 40, a representative of Kandahar's Alkozai tribe. "If America can bring peace the people will welcome them," he said. "We are also ready to fight another war if that war would bring lasting peace."

The meeting took place in the house of Hamid Karzai, the self-exiled leader of the Khilji tribe and loyalist of the king who was deposed in 1973. He also served in the $\mathrm{Mu}$ jahideen government that ruled after Soviet forces left the country in 1992 but was ousted by the Taliban in 1995. Karzai declined to identify his guests, seated on cushions lining the carpeted room, saying the meetings were still at an early stage and could be compromised by too much publicity.

"These are people from different backgrounds, and during the jihad they were with different organisations," he said. Karzai said he believed the 86-year-old former king could play a pivotal role in rebuilding Afghanistan as a rallying point for all tribes to meet for a "Loya Jirga", a traditional grand assembly, that would decide the fate of the country and its future government. The king's supporters and family in Rome say the former monarch is ready to help his country and is probably the only figure with enough prestige to be able to galvanise his warring people behind a new government of national unity.
Such a Loya Jirga would not ignore or keep out the Taliban, he said. "Every Talib is not Mulla Omar, there are several good people in the Taliban, they are good Afghans. A Loya Jirga will not be a Loya Jirga if it does not include everybody. It should be inclusive of all Afghan people," he said.

Some of Karzai's other guests openly vented their anger against the Taliban and their decision to shelter bin Laden, wanted for masterminding the suicide attacks on the World Trade Center and the Pentagon. "People of Afghanistan are happy that the Americans will rescue them from the Taliban and Osama who have killed more Afghans than even the Soviets did," said one tribal elder who said he crossed into western Pakistan from Kandahar last week.

He said people were being forcibly recruited by the Taliban to fight against expected US attacks. "They are picking up young and able men from their homes and sending them to camps near the southern border with Pakistan where they have deployed hundreds of their fighters, tanks and multibarrel rocket launchers," he said.

Many were swiftly deserting. "If they pick up 20 men from a village, by the end of the day 15 will have run away to hide," he said. "I hope Pakistan and America have learnt the lessons after these attacks in America. And if they come into Afghanistan to overthrow the Taliban, I'm confident the people of Afghanistan will welcome them."-Reuters 


\section{US actress announces $\$ 1 \mathrm{~m}$ for Afghan refugees}

Bureau Report

PESHAWAR: American actress and UNHCR Goodwil' Ambassador Angelina Jolie announced one million dollars for Afghan refugees residing in the refugee camps of Pakistan and Iran.

A UNHCR press release on Friday said Angelina Jolie became the first individual donor to respond to the UNHCR's emergency appeal for generating a target of more than $\$ 250$ million to meet the enormous humanitarian needs in and around Afghanistan.

The American actress told UNHCR that she would contribute one million dollar to help Afghan refugees in Pakistan and Iran, which already host more than 3.5 million refugees. During the past year Jolie has also contributed to. UNHCR programmes for refuges in Africa and Asia.
Jolie visited Pakistan in August this year to meet refugees and observe the UNHCR's work and programme for the two million Afghans already seeking refuge there.

Facing a humanitarian crisis of perhaps unprecedented magnitude, UNHCR's \$268 million emergency appeal covers the needs for six months of a possible influx of upto one million refugees into $\mathrm{Pak}$ istan, 400,000 into Iran, 50,000 into Tajlkistan and 50,000 into Turkmenistan. The agency is also doing additional contingency planning to supply aid to 500,000 people inside Afghanistan, if the necessity arises.

The contingency plan involves massive relief efforts, which includes construction and maintenance of refugee camps and delivery of more than 80,000 tents, hundreds of thousands of health and hygiene kits and a huge amount of relief items. Much of it would have to be airlifted to Pakistan and Iran. The UNHCR said it could deploy up to 700 international and local staff to deal with the looming crisis, in addition to more than 500 staff already working in countries neighboring Afghanistan. UNHCR cares for some 22 million refugees and other uprooted people in more than 100 countries of the world.

High commissioner for refugees Ruud Lubbers thanked Jolie and said: "this significant contribution from a young American lady reinforces my belief that despite the trauma of recent events in her country a strong sense of humanitarian responsibility toward innocent civilians suffering in faroff places continues to animate the spirit of caring individuals everywhere."

\section{US troops in Afghanistan}

\section{Gen. Qureshi says: 'We have no knowledge' .}

\section{Amir Mateen}

WASHINGTON: White House officials on Friday confirmed that special US and British commando units were already inside Afghanistan trying to track down Osama ben Ladin.

"They are in the country," a senior official was quoted by the $\mathrm{CNN}$, confirming reports in the USA Today and some Pakistan newspapers that the secret operation had begun.

USA Today claimed that the American special forces are in Afghanistan for two weeks searching for Osama bin Laden.

A more speculative report in The Washington Times says that American commandos are all set for action in Afghanistan. In the event of attack, it says, no more than 40 American commandos will infiltrate Afghanistan at any given time, in an effort to make military strike as simple and secret as possible.

USA Today goes a step ahead by giving the date and place of their landing. It said US commandos arrived in Pakistan on September 13 and began moving into Afghanistan with orders to. capture or kill Osama, or pin him down until the United States can launch air strikes.

The newspaper insists that the forces had landed in Peshawar and Quetta.

Teams of three to five soldiers, supported by Black Hawk MH$60 \mathrm{~K}$ helicopters based outside Afghanistan, began deploying into the country to locate bin Laden, concentrating their searches in caves and underground bunkers in Kandahar, the newspaper said, citing senior US and Pakistani officials.

USA Today said the elite troops were having trouble finding bin Laden and had asked other nations for intelligence help. Quoting US officials, it said several elite military units were involved in the effort to find bin Laden, including the Army's Green Berets, Navy SEALS and the British Army's Special Air Services.

In yet an ther report, The Washington Times says the US military has begun discreetly helping the Northern Alliance in Afghanistan. While the State Department acknowledges that it 
has had contact with the Northern Alliance, The Times quotes unnamed officials claiming that the assistance has come in the form of advice and a discussion of the group's needs on the ground as it conducts an offensive in northern Afghanistan.

It claims that US special-operations troops are now in the region awaiting orders to strike suspected terrorist strongholds. Army special-operations troops began deploying to the Central Asian region shortly after President Bush declared war on international terrorism. It says Uzbekistan and Tajikistan have granted a US request to let commandos launch strikes from the former So- viet republics.

Whatever the case, the administration is involved in a heated debate on whether to arm the alliance. Those in favour argue that aiding Northern Alliance would put added pressure on the Taliban and could also result in toppling them.

Not so fast, say saner elements. They say that, one, the Alliance is not so capable; secondly, they have an equally worse track record of human rights violations and, more importantly, it would require deeper US involvement to impose a non-Pashtun government on Kabul. Finally, it may not be possible without the consent of Pakistan, which is not cooperative on this option.

Officials now say openly that the first US military action is weeks away, unless a chance to capture bin Laden suddenly materializes.

Mr Rumsfeld, who has stressed operational security for his troops moving into the region, declined to discuss a timetable.

"We're not leaping into this. We're moving into it in a measured way," he told reporters.

Shakil Shaikh adds from Islamabad: Pakistan announced Friday that it hi d no knowledge whether elite troops from the US special operation forces had landed inside Afghanistan, as stated by the White House officials in Washington.

"We have no knowledge about it," Pakistan's military spokesman Maj Gen Rashid Qureshi told The News Friday.

\section{Taliban arrest British journalist for illegal entry}

\section{Behroz Khan}

PESHAWAR: Taliban secret police on Friday arrested a British journalist for entering into Afghanistan without proper travelling documents and was shifted to Jalalabad for investigations, Taliban officials said.

The lady, identified as Yvonne Ridely of the Sunday Express, the Taliban officials in Kabul and Jalalabad said, was clad in "burqa" and dressed like Afghan woman, when she was arrested near Dur Baba, close to Pakistani border area. Though, Taliban did not confirm the arrest of two men accompanying the lady, reports reaching Peshawar suggest that she was not alone the time of her arrest and that two Afghans have also been arrested for misguiding the journalist to travel to Afghanistan without visa. The Taliban government has banned issuing visas to forreign journalists after the suicide attacks in the United States.

Reports said that due to closure of the Pak-Afghan border at Torkham, she used the unfrequented routes and walked through the tribal area to enter Afghanistan in a bid to file stories with Afghanistàn dateline. Most of the foreign journalists, who rushed to Peshawar after the US' media published reports about the involvement of Osama bin Laden in the attacks in New York and Washington in the hope that Afghanistan would witness retalia. tory strikes, seems frustrated while filing stories from Pakistan and were desperate to enter Afghanistan.

"Through the illegal entry into Afghanistan, these journalists want to justify their stay in expensive hotels in Pakistan, "remarked an Afghan journalist. Taliban in the past arrested several Pakistani journalists in Kabul and other provinces for entering Afghanistan without visa and were detained for weeks.

Another male foreign journalist, working with a reputed media organisation, was also smuggled into Afghanistan in "Burq 8 " in the midst of the Psteria created by media about the possible US attacks, an act which has been denounced by the Taliban authorities.

However, the authorities failed to arrest him and came to know about the entry of the TV journal- ist only after he crossed over back to Pakistan. Reports say that the Revolutionary Association of the Women of Afghanistan, has smug. gled several female journalists and human rights activists to Afghanistan in the past taking advantage of the traditional women dress, "Burqa" to make films in side houses in Kabul and other parts of the country.

To some extent, the translators, or the latest term used for these people, "fixers" are also partly to be blamed for facilitating illegal entry of these journalists into Afghanistan, just to make some quick bucks.

Not only Afghanistan, but journalists from all over Pakistan have been trying their level best as well to take these journalists, and "others" to restricted areas without legal permission.

The Governor NWFP in a recent meeting with journalists in Peshatwar snubbed many of them for violating the law of the land just for few dollars. And the Governor was justified in his stand to ban entry of foreign journalists even to the tribal areas like Khy. ber Pass, which has been officially declared as a tourist spot. 


\section{The Frontier Post saturday, September 29, 2001}

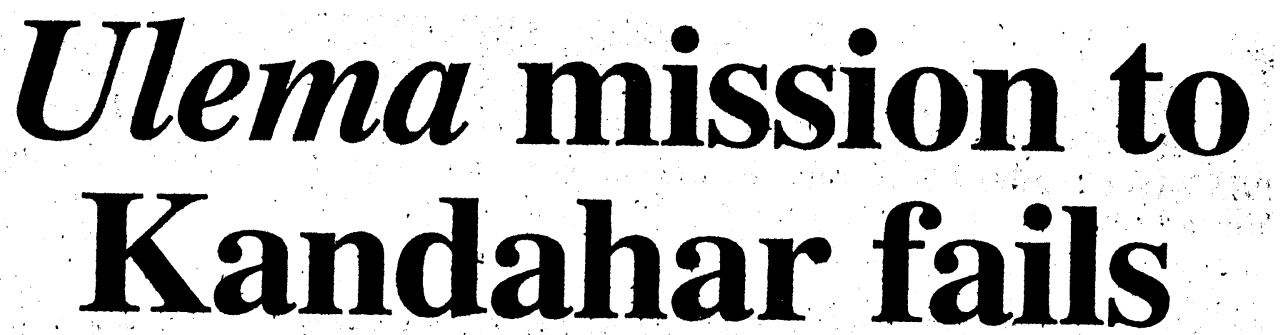

Fakhar-ur-Rehman

ISLAMABAD: A 16-member Pakistani delegation consisting of senior military officials and Ulema, which went to Kandahar on Friday morning to hold talks with the Taliban leadership on the crisis evolving on the issue of extradition of Osama Bin Laden returned empty handed on the same evening....

This was the second effort by the government of Pakistan to convince the Taliban regime to cooperate with the international community in its fight against terrorism. A threemember high-ranking Pakistani delegation had visited Kandaharearlier but failed in its mission.
The delegation held separate meetings with the Foreign Minister Wakil Ahmed Mutawakkil and later with Mulla Omar in Southern city of Kandahar. No official statement was available till the filing of this report.

The meeting which lasted for hours focused on how to avert a looming US allied attack on Afghanistan, which is becoming a certainty because of refusal of Taliban administration to hand over Bin Laden to the US authorities. Sources from Kandahartold The Frontier Post on Friday that the Taliban leader have told the delegation that the Afghan Ulema recommendation was conveyed to
Osama Bin Laden who is staying in Afghanistan as a guest and has been asked to leave the country on his will which is line with the Afghan tradition.

The delegation have also explained the seriousness of the situation and the response that the world community was eager to know.

The delegation was consisting of chief of Inter Services Intelligence Lt Gen Mehmood Ahmed and Mufti Salimulla, Mufti Taqi Usmani, Mufti Nizamuddin Shamzai, Mufti Mohammad Jamil, Maulana Fazale Rahim, Maulana Abdul Ghani, Qari Mufti Sher Ali Shah, Maulana Mohammad Hassan Jan, and Amaulan Haji Abdul Rehman.

\section{Another delegation of Ulema may visit Afghanistan: Qazi}

ISLAMABAD (NNI): Amir Jamaat-e-Islami Qazi Husseain Ahmed has hinted that a delegation of religious leaders may go to Afghanistan for consultation and possible assistance in the current crisis.

In an interview with BBC, after a meeting between him Shah Ahmed Noorani, Maulana Fazlur Rehman, Maulana Samiul $\mathrm{Haq}$ in Islamabad, the JI chief told BBC that they decided to contact the Taliban supreme leader, Mullah Mohammad Omer, and offer him that if he wishes to get assistance.

He said if the Afghan lead- er desired so they were ready to provide this to him. "If he invites us, then the delegation of four members would set out to Afghanistan to meet him," Qazi added.

When told about the failure of previous Pakistani delegations, he said we are not going at the behest of the government.

"At the same time we are not ready to take with us an agenda of anyone or a message of anyone.

If Mullah Omer would invite us and if he would need our consultations to get rid of difficulties, we would certain- ly offer our assistance to him by keeping interests of both Pakistan and Afghanistan in view" he remarked.

Qazi Hussain Ahmed said we have also appealed for National Solidarity Day and Stability of Pakistan. "We have our own stand and we think that if does not suit us to become a partner of any big power for serving its designs. It is the demand of our unity, integrity and selfdetermination to adopt a stand by keeping the interests of Pakistan and aspirations of the people of Pakistan in view" he added. 


\section{The Frontier Post saturday, September 29, 2001}

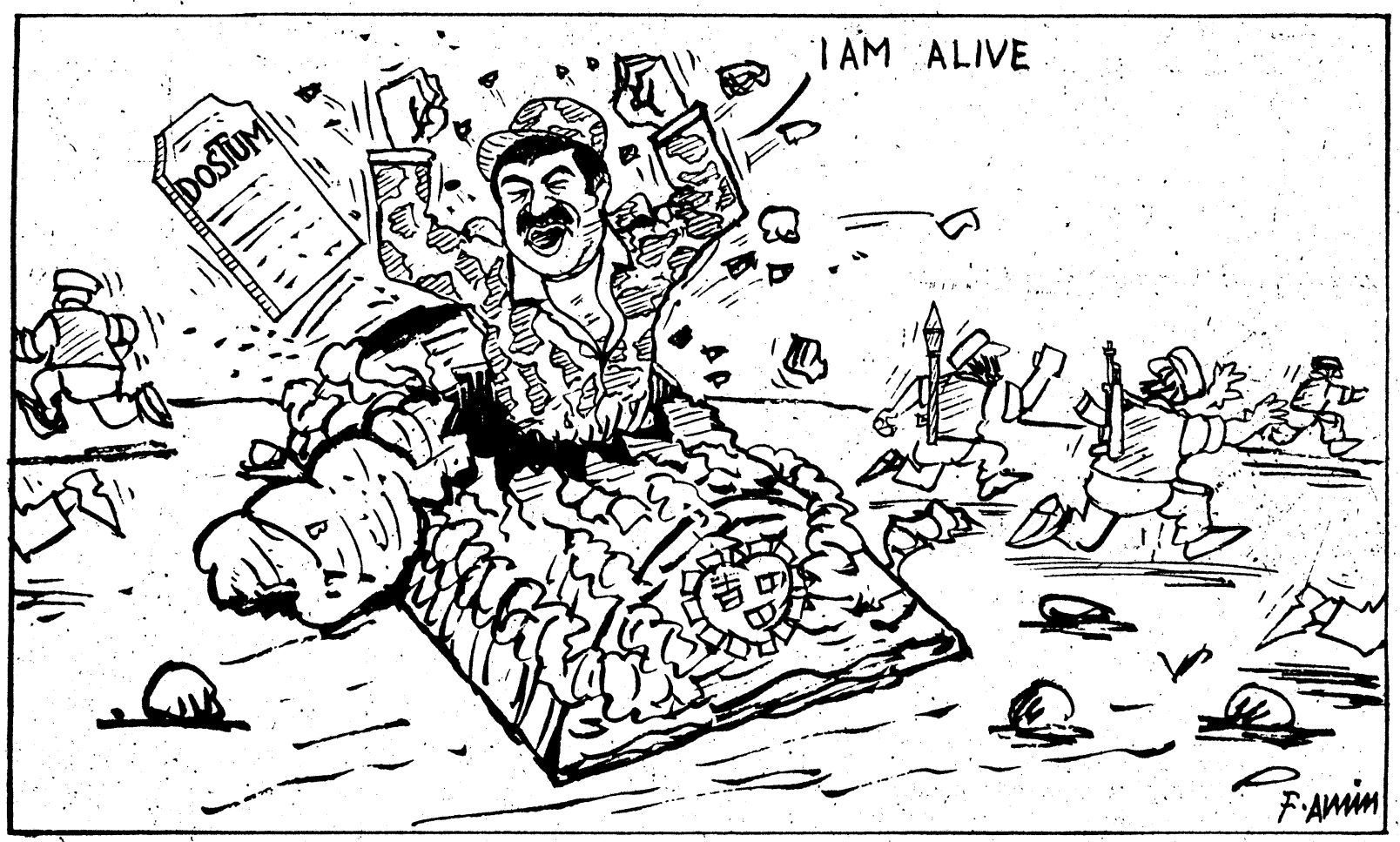

\section{The Statesman Saturday, September 29, 2001}

\section{Putin, Blair confer on Afghanistan \\ MOSCOW: \\ Russian}

President Vladimir Putin and British Prime Minister Tony Blair discussed in their Friday telephone talk the development in Afghanistan and specific steps in cooperation on this issue, the presidential press service said. Putin briefed Blair on his visit to Germany and hoped to further expand partnership between Russia and West European countrics. The two also discussed bilateral issues. - Xinhua

\section{No talks with Taliban: Bush} WASHINGTON:

US

President George W Bush Friday bluntly warned Afghanistan's ruling Taliban they must turn over Osama bin Laden and his network, whom he has blamed for September 11 terror strikes on New York and Washington.

"There is no negotiation with the Taliban. They heard what I said, and now they can act," he said as he met in the Oval Office with Jordan's King Abdullah II.

Bush renewed a series of demands he made of the Islamic militia last week in a rare speech to a joint session of the US Congress in the wake of attacks that left at least 6,000 dead or missing at the World Trade Center and the Pentagon.

"It's not just bin Laden that we expect to see and brought to justice, it's everybody associated with his organisation that's in Afghanistan, and not only those directly associated with him, any terrorist that is housed and fed in Afghanistan needs to be handed over," he said.

"Finally, we expect there to be complete destruction of terrorist camps. That's what I told them. That's what I mean. And we expect them to not only hear what I say, but to do something about it," Bush said. - Agencies 


\section{Foreign aid tied to good governance}

As the horrendous show, security will elude the United States until the marginalized, impoverished and authoritarian countries of the world gain a stake as responsible global citizens in the community of nations.

America's foreign assistance program, its primary foreign policy tool for addressing this long-term challenge, is unprepared for the task at hand.

When Americans are attacked, they rightly expect their leaders to act expeditiously to ensure immediate security. They should also expect their leaders to think about the tools and strategies necessary to ensure America's security over the long term.

The foreign assistance program should be an integral asset in ensuring this long-term security, but it must be more effectively integrated into overall foreign policy. Specifically, policymakers should identify promotion of the particularly, if not uniquely, American values of democratic governance and private sector growth as the primary goal of foreign assistance. These values have proved the surest and most effective path to rising living standards and responsible international behavior.

Policymakers should carefully assess opportunities to purchase the acquiescence of strategic countries by channeling large sums of money to venal and authoritarian governments. Such tactics may appear necessary in pursuit of short-term goals, but they do not constitute a viable long-term foreign policy strategy, since foreign assistance is invariably ineffective in the context of poor governance.

And the supposed security interests served by such tactics frequently prove illusory. For example, Pakistan has received $\$ 60$ billion in foreign assistance in the last four decades, much of it strategically oriented toward ensuring the country's allegiance to U.S. foreign policy objectives. Even after this enormous investment, Washington must still coerce Pakistan - a country with a per capita income of $\$ 470$ and an authoritarian government tottering on the brink of collapse - into cooperating in the struggle against terrorism.

Inevitable short-term strategic uses of foreign assistance must be separated from the essential long-term foreign policy role of foreign assistance in promoting prosperity and freedom. However, just as the urgency of dealing with long-term threats to security has burst upon America's consciousness, the foreign assistance tools at its dis-
J. Bork posal prove sadly lacking The end of the Cold War left the intemational stage open to the effective promotion of democratic govemance and private-sector-led growth. Unfortunately, entrenched interests and the low priority accorded to foreign assistance have degraded the effectiveness of assistance as a foreign policy tool.

This failure is not America's alone. In the last 30 years the developed world has transferred more than a trillion dollars in foreign assistance to the developing world, using a hodgepodge of strategies with few positive results. Throwing foreign assistance dollars at the collapsing governments of the developing world will not serve naticnal interests unless policymakers take the foreign assistance tool seriously and make significant changes in strategy.

Some may object that it is naive to expect the United States to influence the developing world to embrace the economic and political systems that have proved so effective in bringing peace and prosperity to America's own society. Many commentators have characterized the terrorist attacks of Sept. 11 as an intractable assault on American values, and have called for the United States to appease its critics through greater humility.

But the United States cannot compromise on a policy that openly and consistently offers developing countries the opportunity to engage with its proven economic and political systems, gleaning the elements that they find advantageous to their own unique circumstances. Who can doubt that, if appropriately exposed to Western political and economic systems, the vast majority of the developing world would choose freedom, prosperity and stability over authoritarianism, misery and anger?

Communism collapsed in Eastern and Central Europe because people looked over a wall and saw different values that gave them hope for their own futures. Through the opportunities afforded by a carefully crafted foreign assistance program based on democratic governance and private-sector-led growth, the marginalized of the developing world may have the opportunity to tear down walls of oppression and take their rightful place in the global marketplace of goods and ideas.

The writer is a senior associate at the Carnegie Endowment for International Peace 


\section{An Afghan peace}

\section{process set in motion?}

The Bush administration

Patricia Gossman

before some kind of transi-

"replace one regime with another" in Afghanistan. But, like it or not, that is going to it will be 1992 all over again.

There is another option. Afghans inside happen. The question is, what kind of regime?mathe eountry - inchuting'moderate Taliban and:

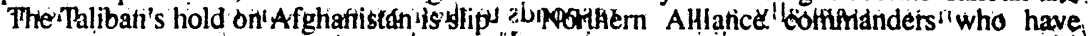

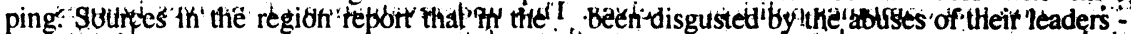

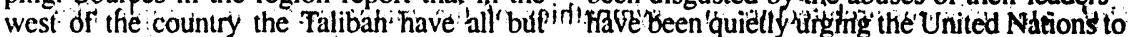
disappeared; checkpoints are deserted, and Taliban fighters are desperately trying to make deals with one side or the other.

Even before the attacks on the United States, there was widespread dissent within the movement, provoked in part by the increasingly centralised and secretive control exerted by Mullah Mohammed Omar and deep resentment about the hold that foreign forces have had over his policies. The anticipated U.S. strike has accelerated this process.

The mood is similar to that which prevailed in from 1994 to 1996, when the Taliban swept into power. If the international community does not act swiftly to take advantage of the moment by supporting Afghans who have initiated a peace process at the ground level, another abusive force could easily come to power.

Gulbuddin Hekmatyar, who has a record of war crimes that rivals the Taliban's and is equally fond of Osama bin Laden, continues to have support within the Pakistani military and intelligence services.

Nor is it enough for the United States to blindly lend its support to the rebel coalition known as the Northern Alliance. Afghans have fled Kabul by the thousands not only out of fear of U.S. airstrikes but out of panic that the group might take power there again.

When I was in Kabul last year, I was told time and again that the only thing people there feared more than the Taliban were the warlords of the Northem Alliance. From 1992 to 1995 , fighting among the factions of the alliance reduced a third of Kabul to rubble and killed more than 50,000 civilians. The top commanders ordered massacres of rival ethnic groups, and their troops engaged in mass rape.

: The years of anarchy laid the groundwork for the emergence of the Taliban and everything that followed. If the Northem Alliance succecds in ousting the Taliban from Kabul take an active role and not leave Afghanistan to political chaos. The United States should support an initiative that has come from inside Afghanistan and is now under consideration in Europe: to achieve fundamental political change in Afghanistan through negotiation with competent local authorities who can begin a transitional process aimed at creating a representative, national administration.

These local authorities include former civilian administrators from many of the different eras of Afghanistan's recent political past, tribal elders, disaffected members of the Taliban and the Northern Alliance, members of local representative councils and other groups recognized as traditional leaders in their communities.

They represent a range of geographic locales and ethnic constituencies. Their own defense forces are prepared to secure and defend territory. Many have links to exiled Afghans, including economists and other technocrats, who have been active in the "Rome process," an initiative focused on the former king, Mohammad Zahir Shah, and aimed at convening an emergency loya jirga (great council) to agree to a constitution and establish a national administration.

This idea has had U.S. support. The process could be greatly strengthened by linking it with local leaders who would be able to facilitate access to members of the loya jirga to enable them to consult more widely, build popular consensus and bring other Afghans into the process.

To deter former warlords from hijacking the process, the United Nations should establish a war crimes tribunal to try suspects accused of grave abuses.

The writer is a consultant on human rights in South Asia and an adjunct professor at Georgetown University 


\section{The Nation SATURDAY, SEPTEMBER 29, 2001}

\section{Osama says Jehad will continue}

KARACHI (AFP) - US atternpts to freeze the bank accounts of Osama bin Laden's al-Qaeda network will have no impact on how it is run, the Saudi millionaire was reported as saying by an Urdu newspaper Friday.

"It will not make any difference," bin Laden was quoted as saying in an interview in the newspape, the veracity of which could not be confirmed.

"By the grace of God, al-Qaeda has more then three different alternative financial networks.

"It is being run around the world by well-educated youth. We do not have a few hundred or a few thousand but hundreds and thousands

of highly educated youth, who were well aware of all these things and know the alternatives."

The newspaper said it had delivered its questions to bin Laden and received written responses through Taliban officials.

Al-Qaeda, which means The Base in Arabic, was top of a list of 27 individuals and organisations identified by the United States this week as being linked to terrorism.

In an executive order, US President George W. Bush ordered a freeze on the assets of all the individuals and groups and instructed authorities to freeze the US assets of any foreign banks not complying with the order.

US officials have described AlQaeda as an umbrella organization for a worldwide network of Islämist extremist groups that was established by bin Laden in the late 1980s.

Osama has denied any role in the terror attacks on the United States and said his holy war against the enemies of Islam would continue even after his death.

"As a Muslim, I will not lie," bin Laden said in the interview, the veracity of which could not be confirmed.

"I was neither aware of these attacks, nor would I support killings of innocent men, women and children."

The United States has identified bin Laden as the chief suspect in the September 11 terrorist attacks on New York and Washington and demanded that the Taliban hand him over or face possible military strikes.

Bin Laden has been living under Taliban protection in Afghanistan since 1996.

In the interview published in Ummat, bin Laden said his proclaimed jihad, or holy war, against "anti-Islamic" countries like the United States and Israel would survive his own death or incarceration. "Jihad will continue even if I am not around,", he said.

Ummat said the interview questions had been delivered to bin Laden and the answers returned through high-ranking Taliban intermediaries.

Elaborating on his denial of any. role in the September 11 attacks, bin Laden suggested they may have been carried out by "armed, militant groups" within the United States.

\section{$\mathrm{ADC}$ to finalise agenda for meeting Taliban}

\section{By Javed Rana}

ISLAMABAD - The leaders of Pak-Afghan Defence Council are expected to gather early next week to continue consultations to thrash out contentious issue as to what specific agenda they will carry along with, for an expected meeting with Taliban leadership to decide the fate of Osama bin Laden, prime suspect for the recent suicidal attacks on USA.

The mainstream leadership have publicly and time and again castigated the government decision to provide specific facilities to USA to attack on Afghanistan. Most of these leaders have announced to provide full-fledged assistance to Taliban government to defend the sovereignty of Afghanistan.

Top religious leaders of Jamaate-Islami, Jamiat Ulema-e-Islam (both factions), Jamiat Ulema-ePakistan (Noorni group) had held meeting in Islamabad on Thursday for deliberations on the subject.
Chief of Jama'at-e-Islami Amir Qazi Hussain Ahmad, and leaders of other religious parties leaders Maulana Shah Ahmad Noorani, Maulana Fazlur Rehman and Maulana Samiul Haq had failed to reach consensus to have an agenda acceptable to each party of the Council.

The failure of the members of ADC apparently forced the government to, arrange "emergency composition" of little known second tier religious leaders and sent them to Kandahar to avert war. 


\section{Haqqani appointed Taliban commander}

By Abdul Sami Paracha

KOHAT, Sept 28: The famous Afghan commander Jalaluddin Haqqani, known for his military prowess, has been appointed commander-in-chief of Taliban armed forces by Mullah Mohammad Omar and asked to establish his base at Khost, the old army headquarters of Afghanistan, bordering the North Waziristan Agency, $260 \mathrm{~km}$ south-west of here, Dawn learnt through confirmed reports reaching here from the area on Friday.

The former Afghan comman. der and trusted companion of Mullah Mohammad Omar, Jalaluddin Haqqani has been given the important post because he possesses the large number of army, about 60,000 men and at least 70 US stringers.

The Taliban have only 43 stringers, according to Afghan official sources. In Afghanistan, various tribes keep the arms with themselves scattered in vast areas for self-defence in case of aggression by rival tribe. They could only be used jointly under an agreement with any force, which is in this case Taliban.

The stringers were first introduced by the US during the Afghanistan-USSR war and supplied in large numbers to the various factions. Some of the

\section{Afghan DPs trying to get NICs}

By Our Correspondent

SWABI, Sept 28: A number of Afghan refugees, living in the Swabi district for the last 22 years, made all efforts to get the Pakistani National Identity Cards (NIC) as Nadra continued its campaign for issuing computerised NICs to Pakistani nationals.

Nadra has deputed its staff in all localities and they are collecting forms for issuing the computerised NICs.

The Nazim and councillors union councils have been authorized to attest the NIC forms and if the application of any person not eligible for getting the NIC was forwarded, the Nazim or councillor concerned and the applicant would have to face the penalty.

Some experts and officials were of the view that those who had already registered themselves might succeed in getting the cards if the Nadra staff, Nazims, councillors and local officials did not act responsibly.

A Nadra official, when contacted, told this scribe that the efforts by Afghan refugees to get the identity cards had not come in their notice and those who wanted to get fresh NICs had to produce their domiciles.

"The domicile is issued by the local administration and if the Afghan refugees have succeeded in getting it issued, the administration will be responsible. The officials concerned have to be careful in issuing the domiciles," he said.

The official said the authority had not demanded domiciles from those whose parents had been registered. stringe $s$ were purchased back by the US from the Afghan commanders through middlemen, mostly Pakistani and Afghan tribal elders.

Most of these anti-aircraft missile-launchers, which can hit their target with 100 per cent accuracy (laser beam tells the shooter to fire) were sold to the US authorities by famous Afghan arms dealer Mullah Abdul Salam Rocketi.

He later died in a shootout with his business partners in 1996 in Kandahar over a money dispute. But some factions preferred to keep them as part of their arsenal, like Haqqani and others.

\section{Opposition team to meet Zahir Shah}

ROME, Sept 28: The Afghan opposition agreed at a meeting here on Friday to create a supreme council and a military council under the authority of ex-king Mohammed Zahir Shah to prepare an attempt to take power from the Taliban, the king's spokesman said.

Members of the Northern Alliance met in Rome earlier in the day and are due to meet the 86-year-old exiled monarch at his home in the Italian capital on Sunday or Monday, the spokesman, Zalmai Rassul, said.

"It has been decided to create a supreme council and a military council under the aegis of the king," Rassul said. "The composition of these two authorities will be decided in the next few days," he added.-AFP 


\section{Taliban capture 5 US commandos: report}

DUBAI/KABUL: A Gulf television station said on Saturday that Afghan security forces had seized members of US special forces in Afghanistan, but the ruling Taliban swiftly denied the report.

Quoting a military source from Osama bin Laden's al Qaeda network, Qatar's al-Jazeera television said the five Americans - two of whom it described as Afghans with US citizenship - were US special forces scouting near the Iranian border with modern weapons and some maps of al Qaeda sites.

Asked about the report, the Taliban's Defence Minister, Mullah Obaidullah Akhund, told Reuters: "It is totally wrong, we deny this news that they have come to our areas."

Kabul's official news agency Bakhtar also issued a denial, saying: "It is not true and has no basis. We contacted the authorities in Kandahar and Nimroz provinces about it and they denied it."

Al-Jazeera said it stood by its report, which it said had been reconfirmed by its correspondent in Islamabad.

"The five were arrested, three Americans and two Afghans, who were trained in the US Special Forces and have US citizenship. The three Americans are also from the US Special Forces," the source told Jazeera's correspondent in Islamabad by telephone.

"They had some modern weapons and some maps of al Qaeda sites," the source was reported as saying. "They were on a reconnaissance mission to know the territory of al Qaeda." He said pictures of the men would be

released soon.

Al-Jazeera, known for its 1998 and 1999 exclusive interviews with bin Laden in Afghanistan, said it was not expecting more on the story from its correspondent.

The Taliban did not rule out the possibility that some foreigners could be in regions held by
anti-Taliban forces north of Kabul and in rugged areas of the northeast near the border with Tajikistan but denied they were in areas under their control. "They could be in the opposition areas. We don't reject that possibility," Akhund said.

Opposition forces led by Burhanuddin Rabbani could neither confirm nor deny the presence in its areas of US or British forces. "Our security sources have not come across such a sign to indicate that they are here. We can neither confirm nor deny the report," Sayed Najibullah Hashimi, a spokesman for the opposition Northern Alliance, told Reuters by satellite telephone.

He did say that some 250 foreign journalists, mostly Western-

ers, were in opposition-held areas. The Taliban have not allowed any western nationals into their territory.

Northern Alliance Foreign Minister Dr Abdullah said he strongly doubted that any British or US special forces were operating in Taliban-held territory in Afghanistan.

The Taliban were "in firm control", he told reporters in the town of Jabal-us-Saraj. "Unless the command and control system of the Taliban is crushed in a way that they lose control of the situation, for me - as an Afghan who has lived in the country for years it is difficult to believe that the special forces could operate or achieve the objectives that they wanted to achieve," he said.Reuters

AFP adds from Doha: Qatar's Al-Jazeera TV stood by its report Saturday that three members of the US "special forces" had been captured in western Afghanistan, countering a denial by Afghanistan's Taliban ruling militia.

Al-Jazeera's correspondent in trol of the areas under their con- the Pakistani border city of Peshawar, Ahmad Zaidan, said in a live broadcast that "three members of the US "special forces" and two Afghans holding US citizenship were captured by the $\mathrm{Al}$ Qaeda organization in Helman, near the border with Iran."

The correspondent attributed his information to "unimpeachable sources." He said "the sources, citing a military official in Al-Qaeda, called Al-Jazeera's office in Peshawar to announce the capture. "The official said the five men, who were on a reconnaissance mission, were in possession of sophisticated weapons and maps of locations of the Al-Qaeda organization."

The correspondent said pictures of the detainees would be published "soon," adding that the two Afghans holding American citizenship had "trained with US special forces."

However, US President George W Bush suggested Friday that covert operations had begun. "I said loud and clear, sometimes people will be able to see what we do on the television screens. At other times, the American people

won't be able to see what we're doing," he told reporters.

"But make no mistake about it, we're in hot pursuit," Bush said, adding: "there is no negotiation with the Taliban." Britain said Saturday it was seeking clarification of the reported capture of US commandos in Afghanistan.

A US administration official, who asked not to be named, told reporter in Washington that the reports that three US commandos and two Afghans with US citizenship have been arrested in western Afghanistan are "inaccurate."

"The report is inaccurate," the US administration official said. Earlier, a US Defense Department spokesman refused to comment on the report. "We're not going to get into the habit of commenting on 'every story that comes out of that region," the spokesman said. "It's a slippery slope once we start getting into that habit."

There have been reports that small teams of US and British commandos have been operating inside Afghanistan for two weeks, but US officials have refused to comment about force deployments in the region. 


\section{Taliban resume trial of 8 aid workers today}

KABUL: The trial of eight foreign aid workers accused of spreading Christianity in Afghanistan will be resumed today (Sunday) after the completion of legal procedures to arrange their defence by a Pakistani lawyer, officials said.

Taliban Chief Justice Noor Mohammad Saqib said the two Americans, two Australians and four Germans would be summoned before the court on Sunday. They have been detained in a Taliban religious police jail since August 5 , along with 16 local staff. The second session of their trial had originally been scheduled for Saturday.

"Both parties - the detainees and the lawyer - will come here to decide about a written undertaking for the continuation of the trial," Saqib told Reuters. The procedures involved ensuring the accused had formally chosen the lawyer, he said.

Saqib said the second session of the trial would now start on Sunday and the lawyer, Atif Ali Kan, was expected to be able to defend the case after reference to the Supreme Court. "If the detainees want to defend the issue themselves they can and if they want the lawyer to do it he can come to the court on their behalf," Saqib said earlier. The lawyer spoke with the Supreme Court authorities on Saturday about the case.

All the accused appeared for the first time before an open pro: ceeding of the court earlier this month and denied the charge of proselytising. While the Taliban say they have seized sufficient evidence to show that they were propagating Christianity, they have not clarified what punishment the defendants face if found guilty.

The Taliban last week moved the foreign workers to what they said was a safer location amid fears of possible strikes by the United States.

The Chief Justice of the Supreme Court told Reuters this week that all eight foreign detainees were well. The status of the Afghan detainees was not known. Another foreigner was in Taliban custody at the weekend.-Reuters

\section{UNSC \\ adopts historic anti-terrorism resolution}

\section{Member states bound to freeze assets of terrorists, prohibit movement; violators to face punitive action}

\section{Azim M Mian}

UNITED NATIONS: In a historic speedy move, the United Nations Security Council adopted a binding resolution obliging all the member nations to freeze assets of terrorists, prohibit their movement, close their training and recruitment camps and take other measures to combat terrorism.

The Security Council resolution is binding under Chapter 7 of

the UN Charter and violator countries can face UN measures up to and including use of force against them.

Some observers say that resolution still lacks the exact definition of a terrorist. It is also not clear if this resolution also applies to Taliban, who have not been allowed to occupy the Afghanistan seat at the United Nations.

Taliban rival Northern Alliance represents Afghanistan at the

\section{United Nations.}

The Resolution also calls for compliance with all other UN Resolutions against terrorism. By inserting one line about compliance of previously adopted such antiterrorism resolutions, US has been able to bring all these resolutions as an obligation of $189 \mathrm{UN}$ member countries under chapter 7 of the UN Charter, according to one UN Observer.

"Linking all such relevant resolutions with this resolution under Chapter 7 has turned them into resolutions with binding obliga- tions under Chapter 7," an observer told The News. …..........

The US envoy to UN, John Negroponte welcomed the unarititious and speedy adoption of US draft and said "it obliges all the UN members to deny financing support and safe haven to terrorists. It will also expand information sharing amiong UN members to combat terrorism and there will be a Security Council mechanism to monitor on a continuous basis. We are very encouraged by Security Council's strong support aand rapid unanimous action."

The compliance of the UNSC resolution popularly named as "Freezing of assets of terrorists" will cause wide ranging changes in the national laws of UN member countries from police, finance, 
passports, travel, formation of voluntary organizations, banking, travel and cross border movement of goods and humans. It will also cause a change in the laws relating to refugees and asylum seekers. It also calls for freezing of the current assets of terrorist groups. Yet this or previously adopted resolutions do not provide any exact definition of a terrorist.

Observers say the US is willing to revise its current policy on Chechnya if Russia completely supports the US strategy against Osama and Taliban in Afghanistan. "Those fighting in Chechnya have some links with Osama bin Laden's group. The US can easily label them as terrorists, if Russia toes the American line on Afghanistan" said an observer.

\section{Afghans need help to oust Taliban, says Zahir Shah}

PARIS: Afghanistan's exiled king said in remarks published on Saturday that Afghans needed foreign help to oust the ruling Taliban movement, but they should be allowed to pick a new leader without outside interference.

Mohammed Zahir Shah, 86, told the French newspaper Le Monde in an interview that the Afghan people were not responsible for the attacks on the United States and confirmed he was ready to return home to help organise the election of a new leader.

"This population must be helped for its liberation, which would in itself guarantee peace and stability in Afghanistan," the former monarch was quoted as saying in Rome, where he has lived in exile since his overthrow in 1973.

Asked whether American officials had asked him to be the focus of a post-Taliban coalition leadership, he said: "We think only the Afghan people in all freedom and without foreign interference must choose their future. This is the basis and the purpose of all the contacts we have made." - Reuters

\section{Russian memo on}

\section{Osama Afghan camps}

ISLAMABAD: Following are excerpts from a memo from Russia to the United Nations Security Council providing information Moscow has on bases and facilities used by Saudi-born militant Osama bin Laden and his associates in Afghanistan.

The memo, obtained by Reuters, was dated March 9, 2001. It did not say when each item was noted or whether each facility was still in use when the memo was written. The memo listed the following 55 camps, offices and residences as part of what it called the "terrorist infrastructure of Osama Bin Laden".

1. A headquarters (150 men) ....in the Bagh-e-Bala restaurant in Kabul.

2. A centre with 300 men ... in the building complex of the former Academy of Social Science in the Afshar district of Kabul.

3. A headquarters in the Hotel Spingar in Jalalabad.

4. A centre in the former headquarters of a subunit of the 25th division in the Zhawar district of Khost province.

5. A centre in the home of the Ismaili leader Said Mansur Naderi in the Kayan ravine in Baghlan province.

6. A camp in the Kishlak-Jadid settlement near the Kandahar airport.

7. A centre in the Al-Farukiya madrassa (religious school) in Khost province.

8. A centre in the headquarters of the former Afghan Ministry of Internal Affairs regiment in the region of the Sardeh-e Ghazni water reservoir in Ghazni province.

9. A camp on the Ghaziabad farm in Nangarhar province.

10. A base on the Hadda farm near Jalalabad.

11. A camp with 30 men under the command of Asadullah in a two-storey building in the village of Zuhira north of Jalalabad.

12. A centre on the former barracks of the Shamsabad regiment near the Afghan-Pakistan border in Nangarhar province.

13. A centre in the Registan

settlement not far from Helmand in the caves next to the Haij-eSahib mausoleum.

14. Valla brigade near Kandahar on the Argandaba side.

15. A new aerodome has been built 20 kilometers south of the Kandahar airport.

16. A centre in the Bogran settlement in Helmand province.

17. An underground centre is being built near Spinbuldak (Shinwar district, Kandahar province). Ten engineers, 500 workers and 30 transport vehicles are involved.

18. A camp near Hajagi water reservoir (Helmand province).

19. A centre in the Rishkor settlement (Kabul province) under the command of Riyaz Basra (600 men). The instructors are Abu Kharas (Libya), Abu Wakil (Tunisia) and Abu Khojam (Egypt).

20 . The barracks of the former Rishkhor division are serving as a base for a Pakistani regiment and more than 7,000 fighters under Maulana Wahezi, Mulla Adel, Mulla Jabbar, Mulla Esrail, Hafez Mohammad, Qari Khaifuz Atar... and from various organisations including Ansar, Harkat-ul-Mujahedin, Jamiyat Ulama-e-Islam and Sephe-Sahab.

21 . There is a carefully protected base north-east of the Messe-Aynak settlement (Logar province) in the village of Sufihaye-Shirallah. In Mess-e-Aynak itself there is a centre for training fighters staffed by 130 men (Egyptians, Sudanese, Yemenis, Iraqis, Czechs and Bulgarians). Not far away is a camp for the families of the fighters.

22. A camp for 200 men near Konjak (Logar province). A centre 
The News on Sunday

September 30, 2001

in the Surhab hills five kilometres south of Mess-e-Aynak settlement.

23. A base near Siyah-kuh between the Sharafghan and Mohammad Aga district.

24. A base in Charasyab near Kabul, used for technical support and repair of weapons. In Charasyab there are several hundred fighters from Arab countries, 50 Filipinos and 50 Uighurs.

25. A centre near Jur in Khost

province.

26. A centre in Shahwalikut in Kandahar province.

27. A centre near Kilagi in Baghlan province.

28. Underground depots in the southeastern part of Mess-eAynak.

29. Darwolat base, where about 500 men are being trained under the command of Abu Hasas Abu Naima and General Abu alSher and Abu Janeba.

30. A centre in Asadabad in Kunar province.

31. A centre in Sad-Kanar asSaraj in Laghman province.

32. A training centre in Chahar-Asyaba (former headquarters of Gulbuddin Hekmatyar) in Kabul province.

33. A headquarters in the Chaunl district of Kandahar.

34. A base of nationals from Arab countries in the Kala-eMoradbak settlment (Shekardar district of Kabul province).

35. A base of nationals under the command of Abulhasan, north of Kabul.

36. A centre in the Band-eAsiyab hills in the Shekardar district of Kabul province.

37. An underground headquarters in the Shekardar district in the Haruti heights, known as the Maidan heights.

38. A training centre for fighters in the Usankot settlement in Shekardar district.

39. The Arab advisers Sheikh Abulhasan and Sheikh Abudaud are active in Kunduz.

40. The eighth division of the Taliban under Mohammad Tarek, a Sudanese, includes, besides Pakistanis and Afghans, Chechens, Tajiks, Uzbeks, Filipinos, Bangladeshis, Kashmiris and nationals from Arab countries.

41. The headquarters of the former 53rd division of Abdul Dostum (in Sheberghan in Jowzjan province) has 60 Chechens involved in military training and instruction.

42. A military training centre for the Islamic Movement of Uzbekistan with 200 men near

Dasht-e-Shur (northwest of MazarI-Sharif). The headquarters is in the house of the son of the Ismaili leader Said Mansur Naderi.

43. There are 300 Chechens receiving military training in the barracks of the former 18th division (in Hairatan).

44. There are 200 Chechens in the Kucha-e-Hazaraha quarter (Kart-e-Saidabad district of MazarI-Sharif).

45. There are 1,000 Chechens and other nationalities in the Horasan district of Mazar-I-Sharif

46. Takhir Yuldashev has his representation in Hairatan (Balkh province), next to the barracks of the former 70th division.

47. Djuma Namangani has 470 men in the Gortepe district of Kunduz.

48. The Islamic Movement of Uzbekistan has a base under the command of Azar on the road to Kol-e-Poshta (80 Uzbeks, four Pakistanis and two Arabs).

49. The Islamic Movement of Uzbekistan has a headquarters ( 15 men) under the leadership of Mohammad Osman, an Uzbek, opposite Fifth Street in the Wazir Akbar Khan district of Kabul.

50. Takhir Yuldashev has an office near the bridge not far from Mesgeri in Mazar-i-Sharif.

51. Takhir Yuldashev has a residence on 15th Street in the Wazir Akbar Khan district of Kabul.

52. Takhir Yuldashev is both Osama bin Laden's deputy and the commander of a regiment made up of Tajiks, Uzbeks and Turkmens. The regimental headquarters is in Jelofantai (Jalalabad).

53. A training centre for Chechens in the Hakrez district of Kandahar province.

54. A Chechen training centre (400 men) near the Red Cross hosital in the Daku settlement (Mirbachakot district of Kandahar province).

55. Takhir Yuldashev and
Djuma Namangani have fighters (500 Pakistanis, 200 nationals from Arab countries and 600 Chechens ) stationed at Hairatan in Balkh province. - Reuters

\section{No US troops on Pak soil: FO}

ISLAMABAD: Pakistan Saturday categorically denied presence of American or any other foreign troops on its soil.

"There are neither any military troops nor any commandos from the United States or any other foreign country present in Pakistan," Foreign Office spokesman Riaz Muhammad Khan said during his daily press briefing.

Pakistani side had shared information of general nature during talks with Americans.

He said the United States had not put before Pakistan any specific plans or contingencies following September 11 terror attacks.

However, he said, Pakistan had stated earlier that it would not commit troops to any such plan.

Responding to a question, Khan said Pakistan had provided the Taliban authorities with a list of 40 persons wanted in criminal cases in Pakistan. However, he said, there has not been any progress on tracing or handing over these persons to Islamabad.

As regards September 11 attacks, he said it had two aspects: one is the United Nations Security Council resolutions calling for the handing over of Osama bin Laden and closure of camps in Afghanistan and the other is that the evidence and determination of who was behind these attacks should be shared internationally.

In response to a question, he

said Russia had appreciated Pakistan's position on the current crisis.

When asked about reports of the presence of any US troops in Pakistan or arrests of some Arab nationals in the country, he said, "there is no basis for either of these two reports."

Asked about the outcome of the visit of ulema delegation to Kandahar, he cited the statement 
issued by the religious scholars on their return from Afghanistan in which they stated that both sides reaffirmed commitment for the security, safety and integrity of both neighbouring countries.

Responding to a question on international fight against terrorism in the context of continuing repression of Israel and India against Palestinians and Kashmiris, the spokesman said, "extremism in a political environment

breeds repression and humiliation."

"In the longer terms in the fight against terrorism, there will have to be a need to address the root causes of extremism and terrorism and injustices have to be rectified." - APP

Reuters adds: Pakistan said on Saturday it planned more talks with Afghanistan's Taliban.

"We will remain positively engaged," a Foreign Ministry spokesman told a news conference next day after a team of Pakistani ulema returned from inconclusive talks with the Taliban's supreme leader, Mullah Mohammad Omar.

But spokesman Khan sidestepped questions on whether the ISI chief accompanying the ulema delegation held a separate discussion with Omar.

AFP adds: Quoting senior US

and Pakistani officials, the daily USA Today reported Friday that American and British special forces had entered Afghan territory on scouting missions.

Pentagon officials were later quoted by CNN as confirming the report, British officials refused to comment.

Elite troops from the America's counter-terrorist unit, Delta Force, its airborne Rangers and Navy SEALS, along with the British Special Air Service (SAS), are reported to be operating out of bases in Pakistan and Central Asia.

Earlier Saturday, Qatar's AlJazeera television reported that the Taliban in western Afghansitan had captured five armed members of US special force, two of Afghan origin.

The Taliban later rejected the report, saying no such arrests had been made.

\section{Pakistan to} continue engaging Taliban: Moin

ISLAMABAD: Interior Minister Moinuddin Haider has said that lack of diplomatic follow-up closed the window of opportunity opened up by Taliban.

Addressing a crowded press conference here on Saturday the Minister said it was a big change in Taliban's stand regarding Osama bin Laden when they asked him to leave Afghanistan after September 11 terrorist attacks in the United States. This opportunity, he said, was "not followed up strongly through diplomatic action."

"But we will continue to engage with Taliban and air our concerns to them," the Interior Minister said.

Moinuddin Haider, who has thrice visited Afghanistan and held meetings with Mulla Omar and other Taliban leaders, told reporters that he has been trying his best to convince the Taliban to listen to what concerns world had about them and what Muslim Ummah expected from them.

"I asked them to be flexible and rethink their policies," Moinuddin said while referring to with Taliban.

Replying to a question, the lnterior Minister said that no Arab national has been arrested in Pakistan. He said, he was also not

aware about presence of any US or British force in Alghanistan.

He said Pakistan is not accepting new refugees but the trickle continues. There is donor fatigue about refugees and Pakistan's economy was not able to sustain and feed any number of refugees.

The minister warned Afghan nationals not to take part in violent protests in Pakistan. He said that government believed in democratic

principals and everyone is allowed to express views, but government will not tolerate violence and killing in the name of protests.

Earlier, the Minister told the foreign and local media about the efforts Pakistan has been making in controlling the menace of drugs and small arms.

The Minister said that due to firm resolve by successive governments to eliminate narcotics, the country had become poppy- free since 1997. "There is no heroin factory in any part of Pakistan and if any journalist discovers one he will get a special present from me," asserted the Interior Minister.

The Minister regretted that donors are not so forthcoming when it comes to rehabilitation of drug addicts. He said according to a survey conducted by UNDCP, there are four to five million drug addicts in Pakistan.

The Minister also told the foreign journalists about the huge citizen database government is preparing after the 1998 Population Census. On the basis of this database all Pakistanis will be issued new identity cards and it will help identify foreign nationals who have acquired Pak IDs through various means. - APP 
The News on Sunday

September 30, 2001

\section{Men guard hills as}

\section{women shop in Kandahar}

KARACHI: In the Afghan Taliban's capital of Kandahar, bearded fighters with Kalashnikovs guard the hilltops while veiled women shop for vegetables, dried fruits and pistachio nuts in the bustling bazaar below.

Taliban forces are clearly on alert against a threatened US attack but the city itself is not on a war footing, said a Pakistani cleric who visited Taliban leaders there on Friday.

"There's no chaos in the streets in Kandahar," said Mufti Mohammad Jameel, who was part of a 10-inember religious delegation that held crisis talks with Taliban leader Mulla Mohammad Omar but did not even raise the issue of the handover of Osama bin Laden.

"Life on the streets went on as usual," said Jameel, who knew the southern Afghan city from previous meetings there with the man the US accuses of harbouring the prime suspect in the suicide attacks on the World Trade Centre and Pentagon.

Jameel said he noticed that anti-aircraft positions on the hills overlooking the crowded city had been reinforced by young fighters with Kalashnikov automatic rifles.

"The restive Taliban are eagerly waiting for their enemy,"
Jameel, who lives in Karachi, told Reuters.

"The Taliban soldiers are living on Kandahari naan bread, onions and water while they keep their eyes peeled on the people down below and the cloudless sky above," he said. "They don't need a commander, they manage their own affairs." Apart from their trademark turbans, beards and guns, he said, Taliban fighters also draped large cloths from their shoulders that they used five times a day as a "janamaz" (prayer mat).

Jameel said he had heard no shooting and seen no movement of artillery or other heavy military equipment during his visit.

"There are no war preparations in Kandahar," he said. There is absolutely no fear on the faces of the Kandaharis." Instead, many in the city went about buying and selling the dried fruits, nuts and vegetables for which Kandahar is famous.

"Women in burqas (full-length veils), holding little children in their arms, were going around buying vegetables," he said.

Noting there were no visible shortages, he said: "I didn't see any long queues outside the ovens that bake naan bread." There were more armed men patrolling the city than he had seen in previous visits, but the atmosphere was not tense.

Even outside the city markets, men spread out cloths on the dusty ground and heaped nuts and dried fruits on them to sell.

On their way to the airport after their talks, Jameel said: "We saw people selling samosas, choley (spicy snacks) and fresh fruit juices to Afghans who were relaxing outside their mud houses and on the roadsides."

The delegation met Mulla Omar and other Taliban leaders at Governor's House, an old stone building in the city. Since it was Friday they first said midday prayers and listened to a sermon by Sher Ali, a Pakistani cleric.

During the talks, Jameel and three other Urdu-speakers needed interpreters to interpret from Mulla Omar's Pashtun.

Jameel heads the foreign af. fairs committee of the World Council to Defend the Finality of Mohammad's Prophethood, a group that combats heresies claiming other prophets followed Islam's highest prophet Mohammad. Muslims recognise thousands of ancient figures as prophets, including Abraham, Moses and Jesus, but Mohammad was the last. - Reuters 


\section{The Statesman Sunday, Seplember 30.2001}

\section{Refugee camp: Bleak end of the road for Afghan widow}

PESHAWAR: Noorbibi is sitting in her only possession, a donated tent in the middle of thousands of similar tattered tents in the poor neighbourhood of a rundown refugee camp.

The widow from Kabul is one of the rare few to cross into Pakistan in recent days, fleeing from war-ravaged Afghanistan ahead of anticipated US attacks if the ruling Taliban refuse to hand over Osama bin Laden, prime suspect in the September 11 attacks on New York and Washington.

Noorbibi is the head of an extended family of 21 , including her three daughters, who used their life savings to take a bus close to the border and then paid smugglers to sneak them across.

The border has been closed by Pakistani officials who fear an influx of one million Afghan refugees, adding to more than two million already in the country -including more than one million in North West Frontier Province, home to several camps like Jalozai.

\section{$K_{\text {HYBER }} M_{A I L}$}

\section{Afghan opposition doubts U.S. forces \\ in Taliban areas}

\section{JABA L-US SARA J,} Afghanistan (Agencies): Northern Alliance Foreign Minister Dr Abdullah said on Saturday he strongly doubted that any British or U.S. special forces were operating in Talibanheld territory in $\wedge$ fohanistan.
But Noorbibi would not be stopped and would pay what it took to reach safety.

"We tried to cross twice but were turned back, then someone named Afridi took us across for 300 rupees $(\$ 4.60)$ a person," she said. "They threatened if we did not pay they would take us back."

"We had to sell our belongings, everything we had," Noorbibi said, motioning around a bare tent that was filled with her daughters, half a dozen grandchildren and nothing else.

The part of the Jalozai camp in which Noorbibi is housed is filled with refugees who have fled over the past year to escape a devastating drought in Afghanistan.

It is visibly less well off than another part of the camp that was set up two decades ago on a driedout riverbed to help refugces from the Soviet invasion of Afghanistan. "This is not a proper place, it is makeshift, it does not have proper water, proper sanitation," said Yusuf Hassan, regional affairs officer for the United Nations High Commissioner for

\section{Refugees.}

Jalozai is full of barefoot children running around with skin discases, and there are freshly dug small graves in the cemetery on the edge of the sprawling camp.

There are no jobs, and many were just sitting in their tents like Noorbibi. "We don't have food, we don't have a house," she said.

The old part of the camp now has mud huts, while the newer part is made up of fly-filled tents that give no protection against temperatures that can soar to 45 degrees Celsuis (113 Fahrenheit) in the summer and slip below freezing in the winter. There has been no rain and winds blow streams of dust through the camp.

Hassan said the next step would be to register Noorbibi and her family so they can be given food rations.

She said she has no idea what will happen to her family now, although eventually she would like to return to Kabul.

"If there are no problems, I would go back. I need peace," she said. - Reuters

September 30, 2001

The Taliban were "in firm control of the areas under their control", he told reporters in the town of Jabal-ns-Saraj.

"Unless the command and control system of the Taliban is crushed in a way that they lose control of the situation, for me -as an Afghan who has lived in the country for years -- it is difficult to believe that the special forces could operate or achiev? the objectives that they wanted to achieve," he said. 


\section{Unscreened refugee influx may cause killer diseases outbreak}

\section{By Waseem Abbasi}

ISLAMABAD - Senior Pakistani health officials have warned of a possible outbreak of infectious diseases in the country as thousands of Afghan refugees fearing attack on Afghanistan continue to pour into Pakistan.

"We fear increased cases of measles, polio, diarrhoea, water-borne diseases and viral infections," Executive Director National Institute of Health (NIH) Dr. Athar Dil told a United Nations' information agency here.

He said the Afghans were pouring in from all sides of the country and were not staying in border areas, but moving to the cities. "We are concerned about overcrowding, lack of facilities and basic amenities, vaccination coverage and spread of any communicable disease," the agency quoting him, added. It is worth-mentioning that Pakistan, along with other neighboring countries of Afghanistan has closed its border to block the influx of thousands of refugees.

\section{Kabul sets up military HQ near Pak border}

TEHRAN (AFP) - Mulla Mohammed Omar, chief of Afghanistan's ruling Taliban militia, ordered Saturday the setting up of the general headquarters at the Khowst military base, some 30 kilometres from the Pakistani border, Iranian radio reported.

The report, quoting sources close to the Taliban, also said Omar had named Molavi Jalaleddin Haqani, a Taliban military commander, as commander-inchief of the militia forces.

Khowst is located in the border province of Paktia, some 140 kilometres southeast of the Afghan capital, Kabul.
Stressing the need for a strong surveillance programme, Dr. Athar said a disease early-warning system had been activated with the help of provincial government in NWFP and Baluchistan which border Afghanistan.

Dr. Athar said that another concern was that the refugees were bringing in tick-infested cattle, thereby facilitating the spread of viral haemorrhagic fever into the country. "This fever causes bleeding from the face and body and can take lives within days," he said.

In order to keep a check on the number of refugees affected by disease, the health officials in the provinces have been asked to keep daily records of new patients, he added.

He said the Afghan children coming into Pakistan would also be immunised.

The UN agency, Integrated Regional Information Network (IRIN), have reported from Peshawar that three main hospitals in the NWFP are "preparing for any eventuality."

"The provincial governments have asked us to submit a disaster plan, as we are close to the Afghan border," Chief Executive of Lady Reading Hospital, Peshawar, Jamil Ahmed Khan, told IRIN.

"Our surgical staff have been directed not to take leave in any case to deal with any casualty in the city" he said. The uncertainty over what may happen next in the region has prompted people in the Federal Capital to stock up on medical supplies. One of the biggest pharmacies in the city reported an increase in sale of medicines.

The officials of Federal Health Ministry have said that the ministry was not planning to place hospitals officially on high alert as there was no need for such a move yet.

"Hospital have their own emergency planning and we are not putting them on alert for the time being. It is far too early to predict what will happen," said a senior official of the Ministry. 


\section{Asia walks fine line in Bush alley}

By Abid Aslam

WASHINGTON: Tajikistan, Turkmenistan, and Uzbekistan have emerged as possible frontline US allies in a war against Afghanistan. The consequences for these countries will be significant and could be severe - as are the questions Washington now faces.

The George W. Bush administration has not yet made clear the kind of presence it intends to establish in the Central Asian countries, what level of support it expects from their govern ments, and what price it is willing to pay in return for their allegiance.

Many of these details may not come to light until after the initial military campaign is over. Enough is known, however, to worry a number of observers.

Tajikistan is embroiled in clan disputes with religious over tones that have persisted even after the completion of a peace process that included the incorporation of Muslims into the government.

In addition, the cash-strapped government in Dushanbe has had to commit resources to containing incursions by Afghanistan-based rebels whose fight against the government of Uzbekistan has spilled over the Tajik border. The focus on security has stalled political reforms and suppressed economic activity.

Some 10,000 Russian troops under Moscow's command are based in Tajikistan and patrol its Afghan border with the mandate to keep rebels and refugees out. Tajikistan also borders China. Moscow and Beijing have said they will contribute in some way to the fight against the Taliban but neither welcomes the prospect of Washington gaining a foothold in Central Asia.

Turkmenistan has offered vague assurances of support to the United States. It commands uninterrupted territory and air space from the Caspian Sea to the Afghan border. At a minimum, say analysts at Stratfor Inc, Washington will want overflight rights. If a ground war is to be launched, however, Turkmenistan could be a valuable staging area; it was from there that Soviet forces entered Afghanistan in 1979.

Uzbekistan has said it is willing to discuss any form of cooperation with Washington. It has a usable air base near the Afghan border and could provide a valuable base for ground infiltrations because the territory immediately across its frontier is controlled by the antiTaliban Northern Alliance.

Former policy, military, and intelligence officials at Stratfor say that despite their ties to Moscow and Beijing - which also dominate regional security pacts - the countries could be won over to Washington's side with military and intelligence assistance, bilateral and multilateral loans and aid, and the promise of state visits or other such symbolic gestures.

It might not be that simple. Washington's war on terrorism could provide legitimacy for political repression, warns Human Rights Watch.

The rights watchdog, in an open letter to Secretary of State Colin Powell, warns that "some governments may cynically take advantage of this cause to justify their own internal crack. downs on perceived political opponents, "separatists" or religious activists, in the expectation that the United States will now be silent."

The risk of such opportunism, the group says, could be greatest in Uzbekistan, where the government of President Islam Karimov in recent years has imprisoned and tortured thousands of non-violent Muslims for worshipping outside state controls. Washington has begun sending military personnel there to prepare a staging area for operations in Afghanistan.

The Islamic Movement of Uzbekistan, accused of exploding car bombs and attacking civilians, was added to the official US list of terrorist organiza. tions on Sept 15, four days after the attacks on New York and the Pentagon.

Uzbekistan and Tajikistan repress even apolitical forms of religious observance and organization as threats to ruling elites, according to the International Crisis Group (ICG), a think tank specializin in conflict resolution. This impulse, it adds, has only been reinforced by Russia, China, and the United States.

Tajikistan and Uzbekistan also are in deep economic trouble and unrest is being fuelled by the growing gap between small elites, who benefit from privatisation and other marketfriendly reforms, and majorities that are being driven to economic desperation. The question could soon become whether the US is sufficiently interested in the region to make major investments not only in military security but also in local economies . and in ways that do not increase disparity and discontent. Dawn/InterPress Service. 


\section{Anti-war protests held in Washington \\ By Our Staff Correspondent}

WASHINGTON, Sept 29: Thousands of peace activists gathered at Freedom Square in downtown Washington on Saturday in what was billed as a rally against war and racism.

The rally represented a fightback against the war-like attitudes that have gripped America since the Sept 11 attacks and which have also led to anti-Arab and anti-Muslim feelings.

Organizers claimed an attendance of over 10,000 in the rally, which was held on the same day as anti-globalization protests planned for the annual World BankıIMF meetings, which were cancelled after the terrorist hits in New York and Washington.

The attacks were condemned by all speakers, but it was underlined, by speaker after speaker, that the answer was not to go to war. 'No War' banners and placards dotted the crowded site of the rally, which was participated in by several coalitions and organizations and by both whites and citizens belonging to ethnic communities.

One banner said" "Bomb them with Butter". The emo tional, youthful gathering reminded many observers of the anti-war rallies that had erupted throughout the US during the time of the Vietnam war.

Speakers expressed solidarity with the victims of the horrif- ic Sept 11 attacks, but recalled the aggression committed by the US in the past against Cuba, Iran, Libya, Panama and other countries.

They said it was always difficult to take a stand for justice and peace, but never harder than in an atmosphere of war such as existed at present, and even harder in view of the terrible destruction and loss of lives that took place on Sept 11.

But the US, the speakers said, should not be guided by a spirit of revenge and it should be understood that a great part of the responsibility was shared by US governments.

Hate attacks against Arabs, Muslims and people of South Asia descent were condemned as manifestations of racism.

Demonstrations are sched. uled to be held also on Sunday.

Agencies add: A handful of protesters briefly clashed with authorities, leading police to use pepper spray to control the crowd, but the group was largely peaceful.

The crowd marched in a park outside Washington's Union Station, near the US Capitol building, behind a five-metrelong banner reading: "Anticapit-alists against war, racism, terrorism, property."

"Destroy imperialism, not Afghanistan," read a flag waved by demonstrators.

"The solution (to terrorism) is to work with the international court system," not war, said
Laura Vild, a 1s-year-old student who traveled six hours by bus along with 40 other students to come to the protest.

"We should use every democratic tool that we have," she said.

A friend of Vild's, who identified herself as Meher but would not give her last name, said she was hiding her face behind a bandana so that her parents would not recognize her. A Muslim of Pakistani origin, she said they were scared for "security reasons."

Richard, 27, who also would not reveal his last name, said he had planned to attend the protests against the World Bank and the International Monetary Fund, which were cancelled when the groups' meetings were called off.

He was carrying a coffin, on which he had written a death toll from the attacks on New York and Washington, but also from the war in East Timor, US strikes against Iraq and the war against drug traffickers in Colombia.

SPAIN: Some 5,000 demonstrators marched through central Barcelona on Saturday, protesting the anticipated US military strikes in Afghanistan.

Dem inst ators at the head of the march carried a banner, saying "No more victims. For peace, stop war" and a globe which said "For the women of Afghanistan, against the
Taliban" militia. 


\section{INDEX ALPHABBETIQUE/ALPHABETICAL INDEX}

(A)

Aid: $4,6,7,8,84,141,183,223,428,518 \ldots$

Aid Worker: $7,16,17,30,48,53,54,58,59,65,85,88,89,90,91$, $92,93,94,107,110,129,130,143,151,160,161,163,168,171,173$, $177,179,183,194,230,307,333,370,379,430,554$.

A.N.P: 308 .

Annan . Kofi: $12,34,353$.

Australia: 2, 10, 12, 15, 28, 29, 31, 36, 37, 39, 40, 76, 77, 78, 81, 82, 102, 108, 111, 113, 134, 150, 153, 154, 155, 156, 204, 205, 206, $273,306,307$.

(B)

Bamyan (Province): $62,161$.

Balkh (Province): 461.

Badakhshan (province): 38 .

Ben Laden Osama: 106, 117, 118, 119, 130, 131, 151, 175, 176, 192, 193, $210,211,214,215,222,224,227,228,232,233,235,242,243,244$, $245,249,250,251,252,253-256,257,258,259,260,261,272,281$, $283,284,287,294,295,296,297,298,300-303,304,308,309,316$, $321-323,325,328,329,330,333,336,338,339,340,341,345,347$, $353,354,355,356,358,362,363,364,368,374,375,377,398,422-$ $424,425,426,448,450,452,453,454,455,459,463,465,468,469$, $475,477,503,504,507,508,528,533,544,551,555,559$.

Bhutto Benazir: 193, 232, 363, 464.

Border (Afghanistan-Pakistan): 231, 275, 280, 324, 336, 344, 464, 510, 517 .

Border (Afghanistan-Tajikistan): 8, 30, 32, 83, 380.

Border (Afghanistan-Iran): $35,330$.

Bombing: $38,136,167,200,201,275,450$.

Bush: 210, 249, 250, 251, 281, 296, 297, 298, 308, 317, 321-323, 394, $397,398,419,420,421,503,548$.

(C)

Carlcatures: $220,234,282,350,384,392,399,458,472,525,548$. Central Asia: 165, 166, 174, 222, 378, 561.

Children (Afghan): 158, 452, 465.

China: $185,320,321,333,344,395,398$.

CIA: $192,303,304,309,450$.

Comments: $7,11,12,13,14,18,22,23,24,41,42-45,46,47,48,49-$ $53,56,57,58,64,65,68,69,70,72-75,78,79,93,94,95,97-101$, $102,103,104,113,114,115,119-124,125,126,127,159,160,165$, $166,186,187,188,189,190,195,196,197,198,199,200,214,215$, $221,225,236,237,238-241,245-249,263,264,300-303,305,306,312$, $313,314,315,335,360,365,366,402,404,405,406,407,408,409$, $410,411,412,413,414,415,416,419,420,421,433-438,439-442$, $443,444,456,457,469,470,478,479,481,482,483,484,485,486$, $487,488,489,490,492,493,494,495-500,501-503,504,505,512$, $513,514,515,516,542,543,555,556,557$. 
Culture: 182,337 .

(D)

Detains: 7, 16, 17, 19, 30, 54, 115, 124, 132, 133, 189, 190.

Demining: 213,540 .

Drugs: $1,25,32,34,39,62,63,83,149,174,231$.

Drought: 24,146 .

Durand line: 144

(E)

East Timor: 37 .

Education: 5, 182 .

E.U: $80,81,141,212,227,398,514$.

Execution: 128,133 .

Explosion: 157, 171, 173, 218, $226,390$.

(F)

E.E.I: 175 .

Fighting: 83, 109, 111, 140, 162, 172.

France: 71, 72, 76, 112, 148, 185, 191, 193, 206, 207, 208.

(G)

Genral Musharaf: 320, 328, 365, 519.

Germany: 382 .

Genral Dostum: 461 .

Ghore (Province): 34, 190.,

Gillani Per Sayed Ahmad: 228.

Greece: 62,190 .

( $\mathrm{H})$

Health: $139,149$.

Hekmatyar: 10, 387, 403, 454, 542 .

Herat (province): 530.

Human rights: $146,149,164,194,424,425,426$.

(I)

I.C.R.C. (the International Committee of the Red Cross): 109, 223, 268, 334,363 .

Interference: $36,112,135$.

Indonesia: $4,164,375$.

India: $229,269,310,318,347,363,379,398,461,466,471$.

Iran: $35,62,146,173,217,229,330,379,388,461,462,522$.

I.S.I. (Inter Service Intelligence): $319,320,325$. 
Jalalabad (Province): 213, 351.

Japan: 345 .

J.U.I: $40,341,464$

\section{(K)}

Kabul: 5, 7, 83, 144, 145, 149, 151, 152, 173, 194, 211, 218, 224, 226, $230,232,283,286,287,333,341,360,376,380,388,394,400,403$, $463,477,509,516,519,526,537,560$.

Kashmir: 377,491 .

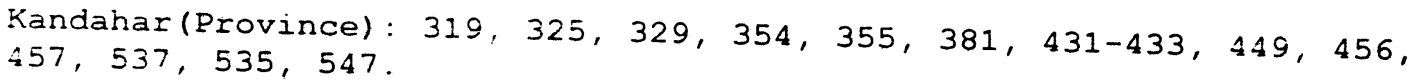

Killing: 1, 61, 85, 111, 163, 173, 213.

Kuwait: $38,424,425,426$.

(I)

Loya Jirga: 130, 131, 134, 146, 510.

(M)

Masood Ahmad Shah: 162, 167, 171, 181, 183, 184, 191, 192, 193, 195, $200,201,202,203,204,206,207,208,209,215,216,217,218,219$, $224,230,232,265,266,268,269,279,280,285,299,300,308,311$, $315,326,328,331,333,340,346,347,363,367,396,451,480,481$, Mulla Omer: $2,66,174,272,281,287,309,319,324,354,358,368$, $381,385,388,391,422-424,455,463,469,475,517,526,541,547$.

(N)

N.G.Os: 61, 109, 145, 148, 231, 266, 267. Newzerland: 15, 28, 29, 34, 37, 55, 56, 80, 81, 87, 105, 116, 117, 150,

Northern Alliance: $38,157,163,181,226,271,279,328,346,359,373$, $388,396,450,451,461,471,476,523,531,537,539,552,558$.
Norway: $8,81,82$.

N.W.F.P. (North West Frontier Province): 9, 29, 147, 157.

(O)

O.I.C: 386,387 . 


\section{(P)}

Pakistan: 3, 148, 158, 185, 195, 216, 227, 268, 271, 275, 278, 282, $286,290,291,292,310,332,336,369,371,386,401,431-433,450$ $452,460,471,473,474,491,530,557$.

Panjsher(Vallay): 162, 184, 276, 326, 382.

Peace prospects: $36,178$.

Picture: $60,67,86,106,110,138,262,265,312,315,327,331,336$, $349,354,357,381,466,480,485,486,489,490,495,508,514$.
P.O.Ws: $177,183,372$.

R.A.W.A: 331,400 .

Rabbani: 224, 286, 316, 328, 373, 379.

Radio Pakistan: 448 .

Refugees (Afghan): 1, 3, 4, 5, 6, 8, 9, 10, 12, 14, 19, 20, 21, 26, 27 $28,29,31,33,34,35,36,37,39,40,41,55,56,63,75,78,85,87$, $95,96,97,105,108,111,116,117,134,136,137,139,143,146,153$, $154,155,158,169,170,172,173,174,175,180,204,205,211,212$ $269,277,306,307,330,345,347,352,371,377,389,400,428,446$, $468,476,477,510,527,528,529,537,545,552,559,560$.

Russia: 161, 175, 195, 227, 273, 337, 342, 352, 353, 356, 378, 461, $467,475,476,521,528,555$.

Sanctions: 138.

Saudi Arabia: 137, 448, 462, 539.

Six Plus Two Groups: 231.

Smuggling: $1,32,34,62,174,231$.

S.N.I: 1, 2, 6, 7, 61, 64, 84, 107, 129, 130, 136, 143, 160, 161, 163, $174,194,266,267,307$.

Sports: $378,527$.

Tajikistan: 224, 271, 281, 326, 380, 451.

Taliban: 1, 2, 3, 32, 35, 62, 66, 85, 88, 135, 136, 144, 151, 171, 173, $175,177,179,184,195,217,229,233,271,273,274,284,294,295$, $307,308,310,317,324,333,337,339,340,346,347,358,362,373$ $374,375,376,381,385,386,396,429,439-442,445,446,450,451$, $454,460,461,464,468,477,491,509,510,519,520,530,532,536$, $538,541,548,551,552,554$.

Takhar(Province): 61, 111, 163, 212.

Terrorism: $353,358,367$. Terrorists: $210,272,273,299,300,353,362,372,375,383,394,419$,
$420,421,451$.

Trading: $142,147,234$.

Turkey: $395,398,404,448$. 
U.A.E: $283,427,428,446,510$

U.K: $71,72,180,231,351,355,454,520,529,546$.

U.N: 4, 10, 26, 27, 28, 29, 40, 58, 59, 84, 109, 130, 131, 138, 141,

$149,152,174,178,180,220,223,227,233,269,276,308,316,321$

$322,323,353,359,364,374,379,390,395,430,431,446,460,474$

$475,509,527,530,540,554$.

U.N.H.C.R: 1, 3, 6, 8, 9, 29, 33, 41, 63, 75, 76, 137, 174, $400,445$.
U.N.I.E.E: 452.

United States of America: 9, 33, 83, 109, 176, 179, 180, 191, 210, 211

$212,213,214,217,220,222,228,229,231,233,242,244,245,249$,

$250,251,252,253-256,257,258,259,266,261,268,269,270,273$,

$271,281,282,283,286,287,288,289,290,291,292,293,294,295$,

$310,332,334,338,339,340,308,309,310,317,321,322,323,328$,

$361,362,363,367,368,369,374,375,344,345,346,347,353,359$,

$390,391,393,393,394,395,397,398,399,377,378,381,383,385$,

$418,422-424,429,430,431,439-442,4451,403,404,416,417$,

$452,459,463,465,467,468,469,475,448,449,450,451$,

$452,459,463,465,467,468,469,475,477,491,507,508,509,511$,

$562,520,522,526,34,539,541,543,545,549,550,553,559,561$,

ilarekistan: 293, 294, 447, 477.

Uridrall Erancais: 533, 538

(W)

W.F.L. (World Food Program): $8,30,135,141,348,359,390,430,474$,
475 .

W.H.O. (World Health Organization): $148,389$.

W. nen (Afghan): 5, 337, 378, 452, 478, 558.

(Z)

7.thir Shah (former king): $130,131,278,367,373,448,454,460,468$, $509,510,524,532,533,537,538,552,555$. 


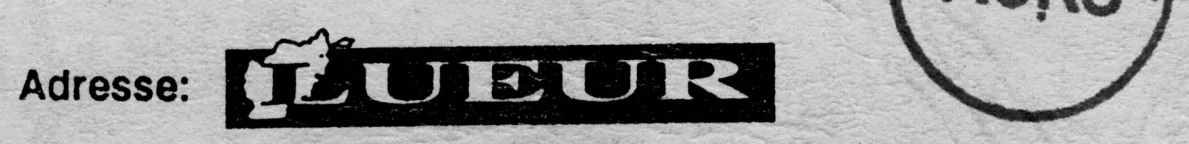

C-27 / 28 Spinzar Plaza, Jamrud Road, Jehangir Abad, Deshawar, DAKISTAN. University D.B. 1460, Deshawar, DAKIST'AN.

Centre Pédagogique $\Lambda$ fahan, Block 17, Zarghuna Watt, Share- Nao, in front of $\Lambda$ gghan Cart Company. D.O. Box. 1644 Kabul, $\Lambda F G H \Lambda N I S T A N$. 